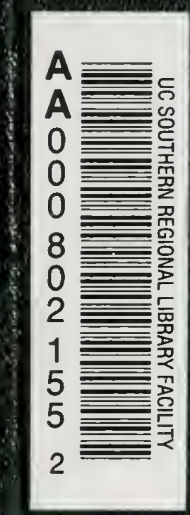

ts 


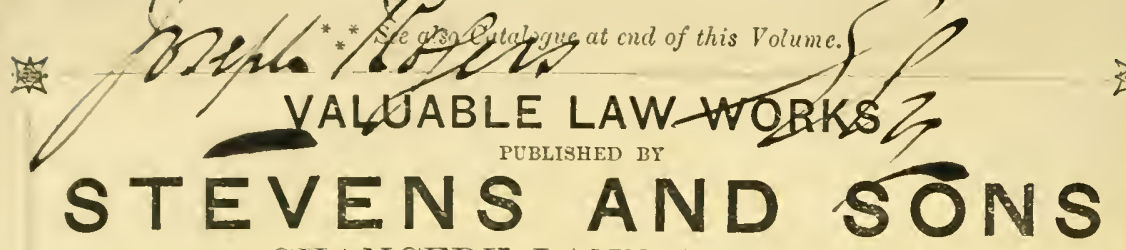

119, CHANCERY LANE, LONDON, W.C. MARCH, 1580 .

Addison or

on the Im

Her Majes

As now

unofession.

ilusto

Haynes' C]

Division 0

'ractition

"student

"Materi:

are flicent

"mplews to

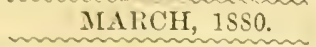

Archbold's

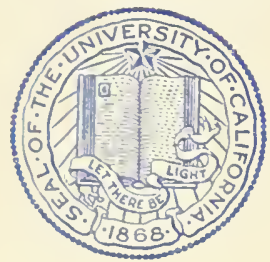

and Exch

have a $\mathrm{Cr}$

2 inls., Si

Chitty's F

Binch, C

Notes co

Fitition.

15. $P$. I

Daniell's

Chancery

tations ar

the High

Chancery

Inn, Exi

Holder o

of Legal

"Mr. I

recent $\mathrm{ch}$

to the for

Scott's Ci

\section{SCHOOL OF LAW \\ LIBRARY}

Courts.-

at.Law,

Price 12 .

"Jis. S

law aud

UNIVERSITY

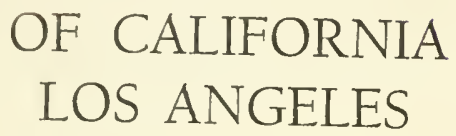

Paley's Law and Practice of Summary Convictions under

'The Summary Jurisdiction Acts, 1818 and 1879. Including Proceedings Preliminary and Sulssequent to Convictions, and the responsibility of Convicting Magistrates and their Officers. With Forms, Sixth Edition. By W. H. MACNAMARA, Esq., Barrister-at-Law. Demy 8in. 1879. Price 1l.4s, cloth.

" Gircat care has evidently been bestowed upon this edition, which is a most efficient guide to the subject of which it treats." -Lrew Times, Novenber 8,1579 .

The Justices' Note Book.-By W. Krox WigraM, Esq., Barrister-at-I,aw, J.P. Middlesex. Rnyal 12mo. 1880. Price 10s. 6d. cloth.

"We have uothing but praise for the book, which is a justices' royal road to knowledge, and ouslit to lesd them to a inore accurate acquaintance with their duties than many of them bave hithertr) [nssessed "-Solicilors' Journal.

"This jy altogether a capital loork. Mr. Wigram is a good lawyer and a good justices' lawyer." - Laer Jisurial.

Templer's Summary Jurisdiction Act, 1879.-Rules and Scluedules of Frorms. With Notes. By FREDERIC GORDON TEMPLER, Esq., Barrister-at-Law. Demy Sin. 1880. P'rice 5s. cloth.

"We think thls edition everything that could be desired."-Sheffeld Post.

* A Catalogue of Modern Law Works, Reports, dec., 8vo, cloth, price Gd., post free. 
Prideaux's Precedents in Conveyancing; with Dissertations on its Law and Practice. Ninth Edition. By FREDERICK PRIDFAUX, late Professor of the Law of Real and Personal Property to the Inns of Court, and JOHN WWHTCOMBE, Esqrs., Barristers-at-Law. 2vols. Royal 8vo. 1879. Price3l. 10s. cloth. "We hare been always accustomed to view 'Prideaux' as the most useful work out on conveyancing. It combines concreness and clearness in its precedents with aptness and comprehensiveuess in its dissertatious and notes, to a degree superior to that of any other work of its kind."-Law Journal.

Williams' Law of Executors and Administrators.-A Treatise on the Law of Executors and Administrators. Eight Edition. By WALTER VAUGHAN WILLIAMS, and ROLAND VAUGHAN WILLIAMS, Esqra., Barristers-at-Law. 2 vols. Royal 8vo. 1879. Price 3l. 16s. cloth.

"A treatise which occupies a unique position and which is recognised by the Bench and the profession as having paramount anthority in the domain of law with which it deals." - Law Journal.

Roscoe's Digest of the Law of Evidence on the Trial of Actions at Nisi Prius. Fourteenth Edition. By JOHN DAY, one of Her Majesty's Counsel, and MAURICE POWELL, Barrister-at-Law. Royal 12mo. 1879. Price 2l. cloth.

(Bound in one thick volume calf or circuit, 5 s., or in two convenient vols. calf or circuit, 9s. net extra.)

Archibald's Forms of Summonses and Orders, with Notes

for use at Judges' Chambers and in the District Registries. By W. F. A. ARCHIBALD, M.A., of the Inner Temple, Barrister-at-Law. Royal 12mo. 1879. Price 12s. 6d. cloth.

"The work is done most thoroughly and yet concisely. The practitioner will find plain directions how to proceed in all the matters connected with a common law action, interpleader, attachment of debts, mandamus, injunction-indeed, the whole jurisdiction of the common law divisions, in the district registries, and at Judges' chambers."-Law Times.

Godefroi's Digest of the Principles of the Law of Trusts and Trustees.-By HENRY GODEFROI, of Lincoln's Inn, Esq., Barrister-at-Law. Joint Author of "Godefroi and Shortt's Law of Railway Companies." Demy 8vo. 1879. Price 1l. 1s, cloth.

"Is a work of great utility to the practitioner."-Law Magazine.

Chalmers' Digest of the Law of Bills of Exchange, Promissory Notes, and Cheques. By M. D. CHALMERS, of the Inner Temple, Esq., Barrister-at-Law. Demy 8vo. 1878. Price 12s. 6d. cloth.

"As a handy book of reference on 2 difficult and important branch of the law, 1 is most ralnable."-Saturday Review.

Cavanagh's Law of I Ioney Securities.-In Three Books. I. Personal Securities. II. Securities on Property. III. Miscellaneous. With an Appendix containing the Crossed Cheques Act, 1876, Locke King's Act and Amending Acts, the Bills of Sale Act, 1878, 'The Factors Acts, 1823 to 1877 . By C. CAVANAGH, B.A., LL.B. (Lond.), of the Middle Temple, Barrister-at-Law. Demy 8vo. 1879. Price 1l. 1s. cloth.

"We know of no work which embraces so much that is of every-day importance, nor do we know of any author who shows more familiarity with his subject. . . It will prove a decided acquisition to the practitioner."-Law Times.

Cordery's Law Relating to Solicitors of the Supreme Court of Judicature, with an Appendix of Statutes and Rules. By A.CORDERY, of the Inner Temple, Esq., Barrister-at-Law. Deniy 8vo. 1878. Price 14s. cloth.

Dixon's Law of the Farm.-A Digest of Cases connected with the Law of the Farm, including the Agricultural Customs of England and Wales. Fourlh Edition. By HENRY PERKINS, Esq., Barrister-at-Law. Demy 8vo. 1879. Price 1l, 6s, cloth.

"The book is now more complete and valuable than erer."-Mark Lane Express.

Wilson's Supreme Court of Judicature Acts, Appellate Jurisdiction Act, 1876, Rules of Court and Forms, with other Acts, Orders, Rules, and Regulations relating to the Supreme Court of Justice, with Practical Notes. Second Edition. By ARTHUR WILSON, of the Inner Temple, Barrister-at-Law. Assisted by HARRY GREEN WOOD, of Lincoln's Inn, Barrister-at-Law, and JOHN BIDDLE, of the Master of the Rolls Chambers. Royal 12mo. 1878. Price 18s. cloth (or limp leather for the pocket. Price 22s. 6d.)

** A Large Paper Edition of the above (for Marginal Notes), Royal $8 v o$. Price 1l.5s. cloth (calf or limp leather, price $30 \mathrm{~s}$.).

"The practitioner will find that it supplies all his wants."-Law Times. 

THE

LAW OF THE FARM. 



\title{
LAW OF THE FARM:
}

WITII

\section{A DIGEST OF CASES,}

ANB INCLUDING THE

AGRICULTURAL CUSTONSS OF ENGLAND AND WALES.

\section{By HENRY HALL DIXON, BARRISTIR-AT-LAW, OF THE MIDLAND CIRCUIT.}

\author{
Jfouth) Evition
}

By HENRY PERKINS, BARRISTER-AT-LAW, OF THE MIDLAND CIRCUIT.

LONDON :

STEVENS AND SONS, 119, CHANCERY LANE,

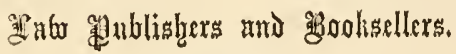




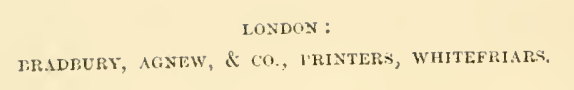

$$
\frac{T}{D / 446+}
$$

15.19 


\section{PREFACE TO THE FOUR'II EDITION.}

I HAVE omitted from this Edition the Coursing Rules, the Smithfield Club and Agricultural Society's Laws, \&c., as not being necessary to a work of this kind.

All cases interesting to Agriculturalists which have been decided up to the present time have been added, and the whole work has been revised.

HENRY PERKINS.

1, New Court, Temple, December, 1878. 



\section{PREFACE TO THE FIRST EDITION.}

THe present work is an attempt to draw together for the first time the principal legal decisions which bear upon the ereryday incidents of a farmer's life. In writing it, I have endeavoured, as much as possible, to prescrre the connection betwecu the cases in each of the branches of the subject, and to show how one gorerned or modified the other. The facts of the leading ones have been fully sketehed ont; and I have also quoted pretty diffusely from the judgments of the Bench. By reference to the Addenda, it will be found that the cases bave been brought down to the end of Trinity Term; and it was for this purpose that the publication of the book was delayed to a very late period of the legal year.

In order to meet the requirements of general readers, the cumbersome case referenees have been kept ont of the text, and confined solely to the conrentional table at the beginning of the work.

'The chapter' on Agricultural Customs, perhaps, calls for some slight notice. I hard originally intended to hare based it almost solely on the Parliamentaly Report of 1848 ; but on putting myself into communication with the gentlemen who went before the Committee of the House of Commons, they almost universally replied, that the principle they then adrocated had made so great an adrance in ten years, that it wonld be absolutely necessary to recast the abstract of their eridence. The customs of Wales, and the other English counties which were not 
examined into by that Committee, have been collected from the best practical sources at my command; and to the gentlemen who hare so ungludgingly lent me their assistance in the getting up of this very arduons chapter, I loeg to tender my most hearty thanks. 'The opening of it wis adopted almost word for word from the Report itself, as I felt it impossible to state the genceal principle in more concise or fairer terms.

I hare thus cudearoured to suplly what always struck me as a want buth in legal and comntry libraries, and I trust that I shall not be foumd to hare laboured in vain.

\section{HENIRY HALI DIXON.}

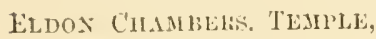

thiy. $7 t h, 18: 8$. 


\section{CONTENTS.}

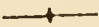

CHAPTER I.

AGRICULTURAL CUSTOMS.

Definition of Tenant right

Arricultural customs in Betfordshire . . . . . . . . . 2

- Berkshire, Bucks, and Cambridgeshire . . . . . . . 3

- Cornwall, Cumberland, and Westmoreland . . . . . . . 4-5

- Derbyshire . . . . . . . . . . . 0

- Derbyshire (North) . . . . . . . . . . . 7

- Deronshire and Dorsetshire . . . . . . . . . 8

- Durham and Northmberland . . . . . . . . . . 9

- Essex and Gloncestershire . . . . . . . . . 10

- Hampshire and Hertforkhire . . . . . . . . . 11

- Hereford and Monmouthshires . . . . . . . . 12

- Huntingdonshirc . . . . . . . . . . . 13

- Kent. . . . . . . 11-15

- Lancashire and Cheshire . . . . . . . . . 16

- Leicestershire . . . . . . . . . 17

- Lincolnshire (North) . . . . . . . . . 18

- Lincolnshire (South) . . . . . . . . . . 19

- Mildlesex . . . . . . . . . . 20

- Norfolk. . . . . . . . . . . . . 21

- Northamptonslire . . . . . . . . . . 21-22

- Northumberland, sce Durham . . . . . . . . -

- Nottinghamshire . . . . . . . 23

- Nottinghamshire (South) . . . . . . . . . 24

- Oxfordshire . . . . . . . . . . . 25

- Rintland and shropshire. . . . . . . . . . 26

— Somersetshire . . . 27

— Staffordshire, Suffolk . . . $2 S$

— Surrej . . . . . . . . . . $29-30$

— Sussex . . . . . . . . . . . . . 31

- Warwickshire . . . . . . . . . 32

- Westmoreland, soc Cumberland . . . . . . . . -

- Isle of Wight, Wiltshire . . . . . . . . . . . 33

— Worcestershire . . . . . 34

- Yorkshire, East Hiding . . . . . . . . . . 3t-35

_. . Nortl ,. . . . . . . . . 36 
Agricultural customs in Yorkshire, West Riding . . . . . . 37

- North Wales . . . . . . . . . . 35

— Soutl .. . . . . . . . . . . . 39-13

The Agricultural Iloldings Act, 1875 . . . . . . . . $43-49$

\section{CHAP'TER II.}

INTERESTS IN LAND.

Definition of interest in land . . . . . . . . ; 50

Igreement for sale of root crops . . . . . . . . . . . id.

- growing hops . . . . . . . . . id.

— growing potatoes . . . . . . . . . . 51-53

- growing fruit and regetables . . . . . . . . . . 54

- growing timber . . . . . . . . . . . . 5

- growing underwood . . . . . . . . . . . . 56

- mowing grass . . . . . . . . . . . . ill.

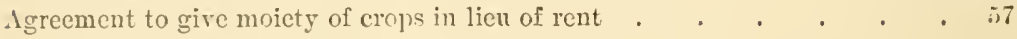

— for salc of growing crop of grass . . . . . . . . 58

- $\quad$ - growing corn and profit of stubble . . . . . . 59

- - growing crops, when it confers interest in land . . . . 60

- - growing crops distinet from letting of land . . . . . id.

- - erops and tillages . . . . . . . . . . 61

- with landlord to accept new tenant . . . . . . . id.

- to suffer another to become tenant for resiane of term . . . . 62

- to surrender interest in land . . . . . . . . . . id

— to occuly loclgings at a yearly rent . . . . . . . . . . 64

- to purchase milk-walk, with possession of premises . . . . id.

- by parol to gire up possession of premises . . . . . . . 6 . . . .

- by tenant to pay landlord for consent to assignment of term . 66

light to take water from well as tenant . . . . . . . . i $i$.

Arrecment by landlord to supply complete furmiture . . . . . id.

- by outgoing tenant to leare fixtures . . . . . . . . . 66

I'arment of legacies out of sale of growing cropls . . . . . . . . (i7

Easement of "grass for a cow" creates no interest in land . . . . . i il.

Indivisible contract for interest in land . . . . . . . . i il.

('ontract by parol to live at boarding-house . . . . . . . . . (is

IIort cagec of tenant's fixtures lias an interest in lanel . . . . . . id.

\section{CHAPTER III.}

\section{EASEMLNTS.}

Definition . . . . . . . . . . . . . 70

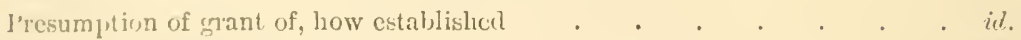

light of way, definition of . . . . . . . . . . . id.

- pastge of water . . . . . . . . . . . . id.

r'laim of right to make drain orer land of another . . . . . . . i $i$.

License to stack hay . . . . . . . . . 71 
PLG:

License to stack coals . . . . . . . . . . . 71

- irrevocable, thougl granted by parol . . . . . . . . id.

- — to enter upon land . . . . . . . . . . . 72

- lefinition as to how determined . . . . . . . . il.

- by parol to put in a liglit cannot be recalled at pleasurc . . . . id.

- to divert water . . . . . . . . . . . 73

Clain to spring of water . . . . . . . . . . . $.7 t$

Verbal license not suflicient to consey easement of drain over land of another $\dot{u}$.

Exclusive right to sewer made under power reserved . • • • $\quad 75$

License to make reservoir for lyc-water and soke . . . . . . id.

Unity of ownership lestroys preseriptire right . . . . . . . 76

- of possession . . . . . . . . . . . . $i d$.

Stopping up windows mima fucic abandonment . . . . . . $\quad$. 77

Obstruction of ancient lights . . . . . . . . . . irl.

Right to use rmming water . . . . . . . . . . ill.

- to dig sinrl, clay, or turves . . . . . . . . . . . 78

- to take water from well . . . . . . . . . irl.

Easement may be claimed ly custom . . . . . . . . . . ill.

Right to take pot water . . . . . . . . . . . id.

— water cattle . . . . . . . . . . . il.

Custom to take piofit in alieno solo barl . . . . . . . . . . . . . 79

light of free miners . . . . . . . . . . . . . . . 50

- owmer of sniface to support of underground strata . . . . . . il.

- to work mines is an incident to grant of mines _ . . . . . 81

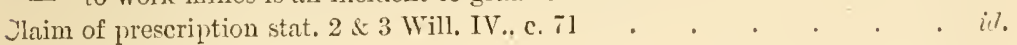

- of right to easements . . . . . . . . . . . . . 82

Plea of forty years' user . . . . . . . . . . . . . . . .

Continuons crjoyment to casement . . . . . . . . . . . . 83

Enjoyment of easement as of right . . . . . . . . . . $i$.

Tight to dig clay for forty jears . . . . . . . . . . . . $8 t$

Proof of user of right of common of pasiure . . . . . . . . id.

Right of conmon of pasture for pigs . . . . . . . . . . . 85

Privilege of washing sand, \&c., dislodged from tin minc . . . . . . 86

Immemorial right of may not lost by non-nser . . . . . . . id.

Presumption of abanclonment not to be made from mere non-user . . . . i . $_{\text {. }}$

Parol agreement for substitution of new way no evidence of abauclonment $\quad 87$

Annexation by vendor of rights comnected with land . . . . . . iel.

Way of necessity . . . . . . . . . . . i.l.

— cannot be pleaded without showing its character . . . . . . $\$ 8$

- effect of unity of possession . . . . . . . . . id.

- law as to. . . . . . . . . . . . . . il.

- definition of . . . . . . . . . . id.

— limited by necessity which created it . . . . . . . . . $\$ 9$

- arises from presumed grant . . . . . . . . i il.

— right of, can only arisc by grant . . . . . . . . . 90

Limited declication of way to the public . . . . . . . . . . . 91

Valid dedication to the public now made . . . . . . . . . id.

Right of way for agricultural purposes . . . . . . . . . id.

- to cart away timber . . . . . . . . . . , 42 
Prescriptive right of way for all manner of enrriages . . . . . . . \$2

Claim of way for eattle and carts how proved . . . . . . . . 93

I'lea of rim? of way for horses, winggons, se. . . . . . . . id.

light of wily for farming purposes does not include all purposes . . . $i d$.

- of roal for tithes. . . . . . . . . . id.

- grantec of an ocenpation way . . . . . . . . . . id.

Obstruction of public footway . . . . . . . . . . . . . . . . . . . . . . .

l'longling up public footpath . . . . . . . . . . . ul.

Erecting gate across public footpatl . . . . . . . . . il.

lierersioner camnot bring action for simple trespass . . . . . . i il.

Injury must be permanent to enable reversioner to maintain action . . 95

Action by reversioner for chaining gate . . . . . . . . $i d$.

Chaining and locking gate miglit damage reversionary estate . . . . id.

Free passage of air to windmill . . . . . . . . . . il.

Prescriptire right to light for windows . . . . . . . . . 96;

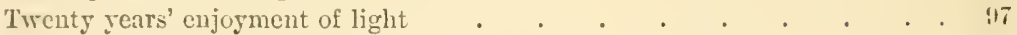

Ancient lights may be altered but not enlarged . . . . . . il.

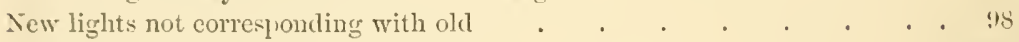

light to lig brick carth . . . . . . . . . . . icl.

C'ustom to dig clay in a copshold not murcasonable . . . . . . . il.

Definition of surface lamage . . . . . . . . . . . . . . . . . . . . .

Support to land from drowned mine . . . . . . . . . . 100)

light of owner to dig minerals on lauds adjoining railway . . . . $\quad \dot{u}$.

Owner of ancicnt house entitled to lateral support of neighbour's land . . id.

Damage to surface of land . . . . . . . . . . ill.

C'ompensation for damage by subsidence of soil . . . . . . . . 101

light acquired by housc after twenty year's' mninterupted enjoyment to laternl support of soil . . . . . . . . . id.

l'rescriptive right to three-fourths of a right of common . . . . . $i d$.

Evidence of existence of highway . . . . . . . . . ill,

- of user and declication . . . . . . . . . . il.

Free right of public to enjoyment of highwry . . . . . . . 112

liight of ormers to enclose part of highway . . . . . . . ill.

- justices to determine lighway . . . . . . . . . il.

Distinction between private and public way . . . . . . . 10:3

Dnty of survegor to protect footways . . . . . . . . ill.

Surveyor of highwnys, liability of, for accident for mon-repair of . . . it.

l'resumption of propertr in prirate way . . . . . . . . il.

liight of was appurtenant to plot . . . . . . . . . lot

Implied grant of way of necessity . . . . . . . . . . id.

When choce of land adjoins highway, half the highway presumably pasises with

the cluse. . . . . . . . . ir.

Map when inadmissible . . . . . . . . . . . id.

Oreler of justices to stop highway implied by non user of highway . . . 10:

l'urrer of Inclosure Commissioncr's to set out private road . . . . icl.

Aprropriation of private way . . . . . . . . . . . id.

light of way under decel of partition . . . . . . . . . . id.

Jerlication of private roarl to public, evidenee of . . . . . . 106

llare tracks mo proof of highwily . . . . . . . . . ill. 
Selling one part of settled estate to pay for making roarls throngh another part

I'longhing up fort-paths, penalty for'

Discharging eaves water on reversioner's land iil.

liule as to going 100 yards tlyrough turnpize-gate

Composition of tolls by lessecs . . . . . . . . . . . it.

Construction of "other thing" in Turnpike Roads $\Lambda$ ct . . . . . ir.

\section{CHAPTER IT.}

\section{TREES AND FLNCES.}

General property in trees aul bushes . . . . . . . . 109

Exception of trees in lease . . . . . . . . . . . i $i l$.

Meaning of "wools and underwoods" . . . . . . . . id.

General demise of land with timber trees . . . . . . . . id.

Covenant not to lop or top trees . . . . . . . . id.

l'roperty in timber . . . . . . . . . . . 110

light to timber when severeal . . . . . . . . . i .

- of lord to fallen rocks . . . . . . . . . i il.

Action of waste for felling timber . . . . . . . . . . id.

light of tenant for life to sell growing timloer without impeachment of waste 111

- of tenant for life to eut ripe timber . . . . . . . . i . $_{\text {. }}$

Tenant for life barred by lapse of time from reeciving proceeds of timber cut

by previous tenant . . . . . . . . . , il.

- permissive waste by . . . . . . . . . . . . . . 112

Prohibition against entting timber . . . . . . . . . $i d$.

Definition of timber . . . . . . . . . . . . . . id

light to repair fences in churehyards . . . . . . . . 113

- to trees in chmrchyards . . . . . . . . . id.

Cutting down ornamental trees by devisce in fee . . . . . . . $i \iota l$.

Claim of right to enter a close and ent down trees . . . . . . . $i \iota l$.

lionghs overhanging lancl a muisanee . . . . . . . . . . 114

T'aking timber for honse-bote . . . . . . . . . . id.

Conversion of timber trees . . . . . . . . . . . . .

Custom of copyholders to fell timber . . . . . . . . . . . il.

Cutting down trees in order to work quarries . . . . . . . 11:;

Trespasser entting timber by collusion with tenant . . . . . . id.

Trustees cannot bring trover for trees felled . . . . . . . i il.

Lessor may loring trover for bark of trees cut . . . . . . . i il.

Interest of lessor ancl lessce in trees . . . . . . . . . . ill.

Lessee has general property in trees not timber . . . . . . . . 116

- may claim dotards if thrown down by tempest . . . . . . id.

Exception of lonshes and thorns necessary for repair of fenees . . . . ill.

Tenants in common of a tree, their rights . . . . . . . il.

Rule as to property in a tree . . . . . . . . . . . 117

Definition of timber trees . . . . . . . . . . . . . . . 118

Saleable underwooks, lareh not . . . . . . . . . . . . . . . . . . . . 119

liating of salealle unterwoots . . . . . . . . , . . il. 
liating of enprolites

Injunction against tenant for life for entting underwool of an insuflicient growth

-1plile-firm lease.

Tight of nurseryman to remove trees . . . . . . . . . 122

Definition of "waste" as applice to trees . . . . . . . . it.

'ntting down willow trees to the butt . . . . . . . . id.

Pollarl willows not timber . . . . . . . . . . . 123

c'utting asl poles . . . . . . . . . . id.

l'enants' rights to dotarels . . . . . . . . . . 124

c'oremant not to grib trees . . . . • . . . . , 125

Tenant no riglht to remore hox elging though planted by himself . . . in.

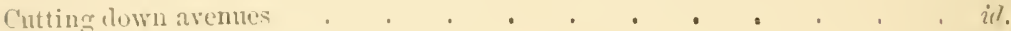

Ornamental timber . . . . . . . . . 126

Procecels of timber which required felling on life estate . . . . . $i \iota l$.

Timber eut for necessary repairs . . . . . . . . . . 127

Entry by lanclloril to cut timber. . . . . . . , . id.

Agrravated trespass by such entry . . . . . . . . . id.

Measure of such damages . . . . . . . . . . . ill.

Fule of standing trees . . . . . . . . . . . . id.

Entire timber contract . . . . . . . . . . . 129

Delivery and acceptance of timber under Statute of Frauds . . . . 130

Property in hedge and ditch . . . . . . . . . . 131

Presumption of ownership of diteh . . . . . , . , . i il.

Diteh considered a fenec under general Enclosure Aet . . . . . 132

Jaw of clitehes . . . . . . . . . . . . id.

Duty of occupier to repair fences . . . . . . . . . . id.

No obligation to fence, when . . . . . . . . . 133

liepairing private roal . . . . . . . . . . . id.

Tiability to repair highway . . . . . . . . . . . 13t

Obligation to fence. . . . . . . . . . id.

Escaje of cattle into field for want of fences . . . . . . . . . . . . . . . . . .

('lipping hedge by one tenant in common . . . . . . . . id.

litlle as to helge-cuttings . . . . . . . . . . . 136

Stealing or injuring trees, sc. . . . . . . . . . . i $d$.

Malicions injury to vegetables, sc. . . . . . . . . . 137

(1)bligation on oceurier to fence clangerons places . . . . . . . . i il.

I,iability of canal company to fence off canal near public footway . . . 138

Injury to horse through bal fence . . . . . . . . i $\mathrm{r}$.

IIorses killecl by fall of haystack . . . . . . . . . . 139

Liarility to maintain fences generally . . . . . . . . $i d$.

- by railway companies . . . . . . . . . . 140

Planting trees adjaccnt to highways . . . . . . . . . 1 . .

I'enalty for riding on footpath . . . . . . . . . . icl.

C'atting heclges by surveyors . . . . . . . . . . 142

I'ower of surveyor to take down fenee . . . . . . . . ill.

I'roperty in waste lanıl aljoining road . . . . . . . . 143

Cattle stliaying on highway . . . . . . . . . . $14 t$

liailway fences . . . . . , . . . , . . ill. 
Their liability as to level crossings . . . . . . . . . 117

Cattle straying on raliway through station yard . . . . . . . 1ts

Liability to maintain fence between railway and highway . . . . 149

Occupation road across railway . . . . . . . . . . . 150

Railway companies not bound to fence one part of premises frum another . , 152

Neglect to fasten railway gate . . . . . . . . . . itl.

Company hound to leave gate on their line slunt. . . . . . . . id.

Sheep killed on railway . . . . . . . . . . . . . . 153

Horse grazing on roadsicle . . . . . . . . . . 15t

\section{CHAPTER $V$.}

DANGEROUS ANIMALS.

Scienter . . . . . . . . . . . . . . 15 . . . . . . .

Keeping savage boar . . . . . . . . . . . ill.

Ferocious dog . . . . . . . . . . . . . 156

Railway company not liable for acts of stray dog on their premises . . . iel.

Habits of dogs dangerous to defendant's knowledge . . . . . i il.

Evidence of $\log s$ being wont to attack men not sufficient to support scicnter

as to shcep . . . . . . . . . . . 157

Sheep worrying . . . . . . . . . . . . . . 158

What is evidenee of scienter for jury . . . . . . . . . 159

Bull ruming at "something red" . . . . . . . . . 160

Caution from owner of $d o g$. . . . . . . . . . . . . . c ill.

Evidence that dog had been bitten hy a mad $\log$. . . . . . id.

Shooting $\log$ when justifiable . . . . . . . . . . 161

Right to keep dogs loose for protection of property . . . . . . i il.

Keeping ferocious bull . . . . . . . . . . . . 162

Obligation of owner of vicious animal . . . . . . . . . . 163

Injury by dog chained up to person lawfully on premises . . . . . i $i$.

Ḱceping wateh-dog in walled garclen . . . . . . . . . 164

Bear tied up by too long ehain . . . . . . . . . . i il.

Lack of caution in person bitten . . . . . . . . . . . 165

Dogs frightening horses . . . . . . . . . . id.

Seicnter" put in issue by plea "not guilty" . . . . . . . 160

Putting scienter in issue . . . . . . . . . . . . . . 167

Depasturing a ricions horse . . . . . . . . . . i $i$.

\section{CHAPTER VI.}

WATER.

Lands formed by alluvion on sea-shore . . . . . . . . $16 \mathrm{~S}$

- gained from the sea . . . . . . . . . . . id.

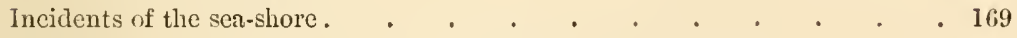

Property in accretions from a non-navigable river . . . . . . id. 
Grant to pass coal muler fore-shore . . . . . . . . . . . . . . . . . . . . . . .

Property an medium filum aque . . . . . . . . . . 170

light of fishing jasses by grant of water . . . . . . . i il.

Elieght diversion of stream . . . . . . . . . . . . . . . . . . . . . . .

light of riparian owners to water . . . . . . . . . . id.

Winer Huwing in a stream is mellici juris . . . . . . . . 172

Aprropriation of ruming water . . . . . . . . . . 173

lifuht to water not in a flowing stream . . . . . . . . 17t

Iaw of right to a spring of water . . . . . . . . . 175

- as io flowing watcl . . . . . . . . . . 176

liight to sink wells . . . . . . . . . . . . . 177

Abstraction of subterimean water . . . . . . . . i il.

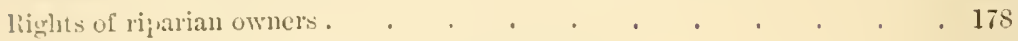

Cutting ofl spring at source . . . . . . . . . . . 179

Law as to artificial water-coursen . . . . . . . . . . . 180

Fluw of water from and into collieries . . . . . . . . $i l$.

Presumptive right to pollute water . . . . . . . . . ill.

light of pollulion subject of grant . . . . . . . . . 181

Pollution of stream to the injury of cattle . . . . . . . id.

Differcuce between drain and water-comse . . . . . . . . . 182

Flow of watcr from drain for agricultural improvements _ . . . . 183

light to artificial watcr-course . . . . . . . . . . 184

Flow of liquicl manure into neighbour's field . . . . . . . . iil.

Enqualificd right of owner to drain . . . . . . . . . il.

lights as to rain-watel . . . . . . . . . . 185

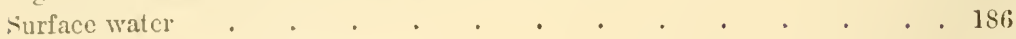

lrrigation ol riparian right . . . . . . . . . . . . . . 187

Diversion of water for irrigation . . . . . . . . . . . . . 189

lights derived from deel . . . . . . . . . . . . . . 190

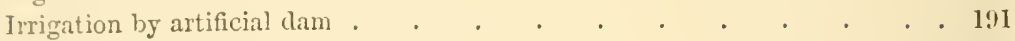

Crossing another's land for purposes of irrigation . . . . . . . . 192

Irrigation by artificial cut . . . . . . . . . . . 193

Injury to reversion by direrting stream . . . . . . . . . 194

Watcr escaping from railway-cuttings into minc _ . . . . . . 196

Working mines uncler water-conse . . . . . . . . . $u$.

Supplying horses from public fountain . . . . . . . . ill.

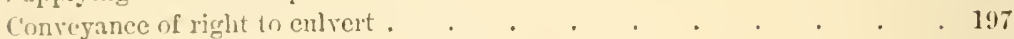

Crmpensation to tenant for life for loss of poul . . , , , . , 19s

\section{CHAP'TER VII.}

SERVANTS.

Iliring on Sunday . . . . . . . . . . • . 199

Contrart may be riulifierl . . . . . . . . . . . . . id.

Temporary illness of servant . . . . . . . . . . id.

Expreser implied largain for service . . . . . . . . $\quad$. $i l$.

l'offreiture of ways by misconduct . . . . : , , , , 200 
Dismissal of servant .

Contract for service for more than a year . . . . . . . . inl.

Hiring by parol . . • • . . . . . . . . 204

Juriscliction of justices as to bailiffs . . . . . . . . . . . . . .

Riglit of servant to quit . . . . . . . . . . . 2?(1);

Contract of service not necessarily for specific time . . . . . . . . $i \iota l$.

Mlonthly servants . . . . . . . . : . . . ill.

Gardener, a menial serrant . . . . . . . . . . . "ul.

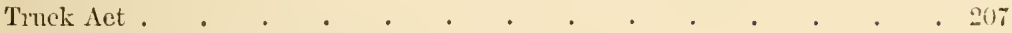

Settlement ho hiring and scrvice . . . . . . . . . . ros

Breach of eontract with shepherd . . . . . . . . . idl.

Bailiff entiticl to notice . . . . . . . . . . . $\dot{c}$. .

Pailiff not a partner . . . . . . . . . . . . cos

Bailiff not anthorised to draw bills or pledge credit of master . . . . il.

Baililt"s power to bind master by contracts . . . . . . . . 210

Master's liability for act of servant . . . . . . . . . 211

Veterinary surgcon liable for negligence of servant . . . . . . . . 213

Liability for letting ont had thatcher . . . . . . . . . it.

Master liable where servant drives his own horse in master's service . . 21t

One man may drive two carts . . . . . . . . . . irl.

Servant killed loy negligence of another . . . . . . . . ill.

No contract by master not to expose servant to rish . . . . . . 215

Master liable for injury to servant . . . . . . . . . il.

Injury to stranger by negligenee of fellow servant . . . . . . . 217

Injury to servant helping servant . . . . . . . . . irl.

Proof of well-defined negligence required . . . . . . . . iel.

Master liable for wilful eonduet of serrant . . . . . . . iil.

Injury to servant by negligence of fellow servant . . . . . . . 218

Injury to servant nsing machine . . . . . . . . . ill.

Injury to servant from minsafe ladder . . . . . . . . . . . 219

Servant going indirect roal . . . . . . . . . . ill.

Serrant using master's cart without leare . . . . . . . . il.

Liability of master defined . . . . . . . . . . 220

General rule of law respecting negligenee . . . . . . . . . 221

Liability of master for debts contracted by servant . . . . . . . 222

Cheating by clairymaid . . . . . . . . . . . 223

Milk-carriers' agreement . . . . . . . . . . . ill.

Larceny by farming scrvants . . . . . . . . . . id.

Fraudulent drover . . . . . . . . . . . . 224

Larceny by drover . . . . . . . . . . . . 225

Enibezzlement by servant . . . . . . . . . . . id.

Fraudulent drover . . . . . . . . . . . . . . 226

Larceny by pig-jobbers . . . . . . . . . . . ill.

Pig-jobber, servant, or bailee . . . . . . . . . . 227 
F.mployment of licensed ilrorey

\section{CHAP'TEL VII.}

\section{CUNVEYACF OF HORSES ANI) CATTLE.}

I.usi on boarch ship

Mortality merning of .

Negligence of owners of ferry

Inilway Clanes C'onsoliclation Act

I.ialibilty of railways at common law

I.iahilits, restriction of, lyy bouking-ticliet

- trimek taking fire

- through gross negligenee

- throngh collision

Construction of couditions on ticket . . . . . . . . . . . . . . . . . .

liajlway and ('anal Traflic Act . . . . . . . . . . 242

Just amil reasonable contract

- what is for the conrt

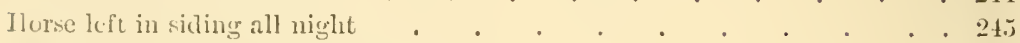

Cattle suffocated in van . . . . . . . . . . . . . 24t;

Injurs to horses placed in eattle-truck . . . . . . . . . . 247

I)

Contract with first railway does not make second railway liable . . . 2:51

Crowling catile withont leave in truck by another . . . . . . . . i il.

liailway must be sued within comty comrt district of principal place of business .

Fstoppel luy false statement of owner

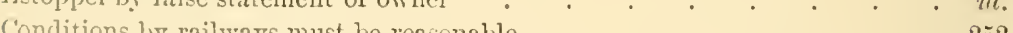

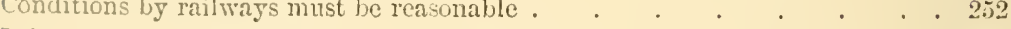

Injury to cow on railway . . . . . . . . . . . . . . $i d$.

- horse sadelled and bridled . . . . . . . . . . $i u$.

Cattle dealers trarel at their own risk . . . . . . . . 253

1)etention of horse by livery-stable keeper . . . . . . . . . id.

Lneasonable conditions . . . . . . . . . . . 25t

Injury to race-liorse, damage limited to $\$: 00$. . . . . . . . idl.

- valuable greyhound . . . . . . . . . . i $i$.

Delay in forwarding pigs . . . . . . . . . . . 25;

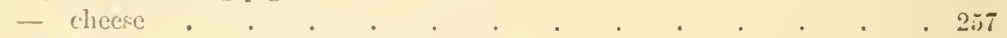

l'ig cace . . . . . . . . . . . . . ill.

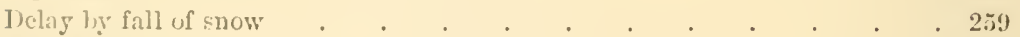

Hire of sacks . . . . . . . . . . . 260

Freat Northern liailway conclitions . . . . . . . . . 261

I'rirate sack compranics . . . . . . . . . . . 263

Giring uotice to eonsignor of consignee's rofusal to receire . . . . i il.

J)elivery of goods within reasonable time . . . . . . . . 204t

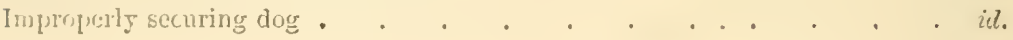




\section{CHAPTER IX.}

\section{DISTRESS.}

Leaving sheep in highway . . . . . . . . . . 266

Things in manual use not distrainable . . . . . . . . $\dot{c}$. . .

Distraining eattle not in locus in quo . . . . . . . . . id.

Demise of a dairy . . . . . . . 267

Escape of a distress . . . . . . . . . . . ill.

Duties of ponnd-keeper . . . . . . . . . . . 268

- liaywarl . . . . . . . . . . 269

Treatment of animals in ponnd . . . . . . . . . . id.

Conviction of persons releasing impoundel animals . . . . . . . 270

Tencler of amends when not too late. . . . . . . . . id.

- of rent. proper person to receise . . . . . . . . 271

— - suficient amends . . . . . . . . . . 272

Onus of estimating amount of damage . $\quad . \quad+\quad . \quad+\quad . \quad 27 \%$

Dedaining cattle after tender . . . . . . . . . . 274

- gools after tender of rent . . . . . . . . . $i$.

Distraining cattle of stranger for rent-charge . . . . . . . 275

- agisting . . . . . . . . . . i ill.

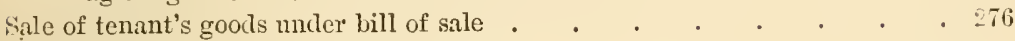

Implied promise by landlord not to stop sale . . . . . . . . ict.

Agreement to take interest on rent in arrear . . . . . . . . $2 \overrightarrow{7}$

Bill of exchange hy tenant to agent . . . . . . . . . il.

Anthority by landiord to distrain . . . . . . . . . 278

Pailiff distraining wrong sheep . . . . . . . . . . itl.

l'ayment of rent under distress not almission of title . . . . . . id.

Trespass maintainable after tender • . . . . . . . . . . 279

Statute of Uses . . . . . . . . . . . . . . . 280

Recovery of rent-charge by distress . . . . . . . . . $i c l$.

Distress not an inseparable incident to rent-service . . . . . . . . 281

- by law . . . . . . . . . . i . . .

- illegal at improper time . . . . . . . . . . ill.

— improper working of . . . . . . . . . . . 282

— after death of tenant . . . . . . . . . . . ill.

— open field sufficient pound for . . . . . . . . . . 283

Inventory taken an impounding . . . . . . . . . . $i$.

Distress, time for making . . . . . . . . . . . 28t

Fraudulent remoral of goods by tenant . . . . . . . . . id.

Duty of distrainer as to goods unsold . . . . . . . . 285

What goods may be distrained . . . . . . . . . . . . id.

Distraining implements of huslandry . . . . . . . . 286

- beasts of plough . . . . . . . . . . . . i il.

- sheep of third person . . . . . . . . . . . 287

Tithes can only pass by deed . . . . . . . . . . $28 S$

Distress illegal after determination of tenaney . . . . . . . id. 
Breach of corenant not to mulerlet

PAGF.

Distress by joint-tenant of rerersion

Aetiou for rent by tenants in common .

i.l.

Inlerlessec's power to distrain

Demise ly a tenunt from year to year. $i i l$.

Inerease of rent does not create new tenamey . 290

Distress un away-going crops

ill.

Nperation of statute of 8 Anne.

1)i-train of growing crops

$i l$.

291

- liay, corr1, in stacks

$i l$.

listress liy grantec of rent-charge . . . . . . . . . . . . . . . 292

s. izure of crops under a $f i . f a$. . . . . . . . . . . i il.

Iaw as to scizure of growing erops . . . . . . . . . . 293

I), mages nominal where erops solit for full value . . . . . . 29t

Cioods sold without apuraisement . . . . . . . . . . id.

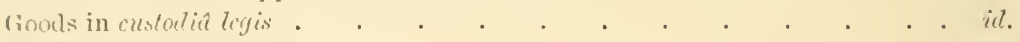

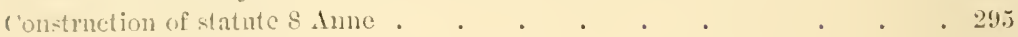

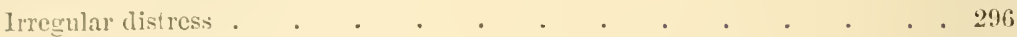

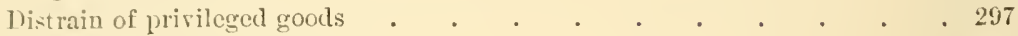

Tomedy for excessive distress . . . . . . . . . . . . il.

Replevin when maintainalsle . . . . . . . . . . . 298

Sale of farming stock taken in excention . . . . . . . . id.

Sale of hay and straw to he consumed on premises . . . . . . u u.

Cnstom of country as to consumption of hay and straw . . . . . . - 29?

Tnensonalule distress . . . . . . . . . . . . . . . 300

Jiscessire distress . . . . . . . . . . . . 301

Implicel warranty of title . . . . . . . . . . . il.

Fon-rlelivery of goods sold at sheriff's sale . . . . . . . . . 302

Second distress when mlawful . . . . . . . . . . il.

Unregistered transfer of growing erop good against excention ereditor • . 303

No interplearler where claim is for rent . . . . . . . . . il.

1)i-tress an affirmation of tenancy . . . . . . . . . id.

Sheriff not entitled to poundage when procecdings set aside . . . . $30 t$

Trespassers al initio . . . . . . . . . . . . ill.

Distress no wairer of breaches of corenant . . . . . . . 30

\section{CHAPTER I.}

IUSDANDRY COVENANTS-CUSTOM OF TIE COUNTRY.

Promise to farm in a lustont-like manner implical . . . . . . 306

Torts which die with the person . . . . . . . . . . . 307

Acts of waste . . . . . . . . . . . . . ill.

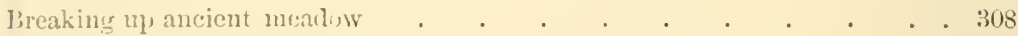

Covenant to manage pasture . . . . . . . . . . ill.

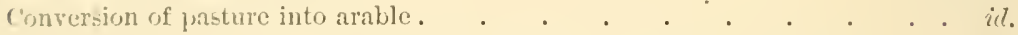

Srowing clover or ermmon grass secd does not make permanent mendow . it.

librht of lessor to suc for waste . . . . . . . . . . . . . 309

light of reversioner to puerent waste . . . . . . . . . il. 
Injunetion to prevent mustarl seed or flax from being sorn _ . . 303

l'lowghing up ancient meadow . . . . . . . . . . . $i d$.

Rights of inemmbent as to glebe land . . . . . . . . . . 310

Breaking up rabbit warren . . . . . . . . . . . id.

Covenant to repair hedges . . . . . . . . . . . . $_{i l}$.

Cutting poles for feneing . . . . . . . . . . . . 311

Parol agreement for lease . . . . . . . . . . . . . . id.

Eneouraging improvements under bad lease . . . . . . . . . 312

Penalties for ploughing up pasture . . . . . . . . . id.

- sowing noxious plants . . . . . . . . . . . 313

Claim for additional rent . . . . . . . . . . . . . 311

Penalty for underletting . . . . . . . . . . . . id.

- cross-eropping . . . . . . . . . . . id.

Covenant to fallow a certain quantity . . . . . . . . . . 315

— spend a certain sum in manure . . . . . . . . . id.

- keep buildings in repair . . . . . . . . . . id.

Oreleropping not waste . . . . . . . . . . . . id.

Custom of the country . . . . . . . . . . . . . . . ill.

Removing lay from farm . . . . . . . . . . . . . . \$16

Allowance for lasting improvenents . . . . . . . . . . . il.

Claim for thatehing . . . . . . . . . . . . 517

Paying for tillages . . . . . . . . . . . . . . ill.

- custom of the country as to . . . . . . . . . . . . 318

Remedy against assignees of reversiun $\quad . \quad$. . . . . . . . $\quad 319$

light of tenant to away-going crop . . . . . . . . . . id.

- to compensation for tillages, \&c. . . . . . . . . . . . 320

Outgoing teuant must give up possession to lanllurd . . . . . . . 321

- _ 's corn may be distrained after expiration of term . . . . . . id.

light of outgoing tenant to away-going elop . . . . . . . . . id.

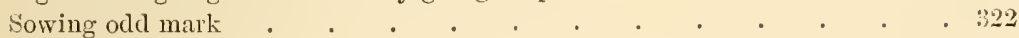

Award when eridenee . . . . . . . . . . . . . . . . $i d$.

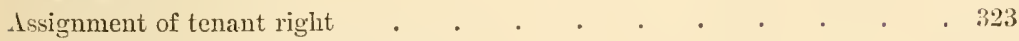

Custom of country exeluded by lease . . . . . . . . . id.

- let in by omission in leaş . . . . . . . . . id.

- to leave mannie . . . . . . . . . . . . . $32 \pm$

Compensation for seeds and labonr . . . . . . . . . . iel.

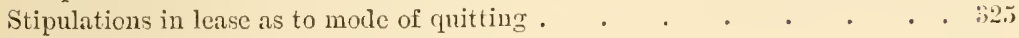

Covenant to consume liay and straw . . . . . . . . . . . . . 326

— not to sell hay . . . . . . . . . . . 327

Consumption of straw by incoming tenant . . . . . . . id.

Covenant not to carty away hay under penilty . . . . . . . . id.

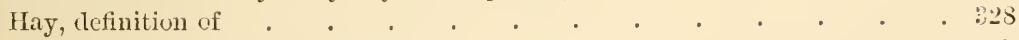

Construction of draining eovenant . . . . . . . . . . . . il.

Compensation to outgoing tenant . . . . . . . . . . . . . $\quad 229$

- for drainage . . . . . . . . . . . . . . . . . $3: 0$

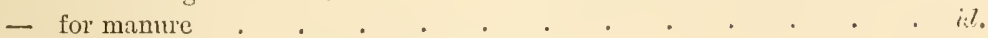

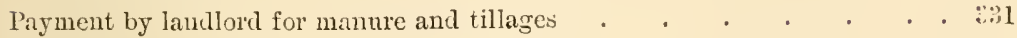

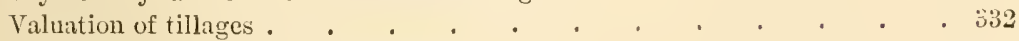

Appraisement stamp when sufticient . . . . . . . . . id. 
Taluer of ecelesiastical property $\quad$. . . . . . . . . . . 333 - when functus officio . . . . . . . . . . . . . ill.

Fair raluation or consuming price . . . . . . . . . . . . . 334

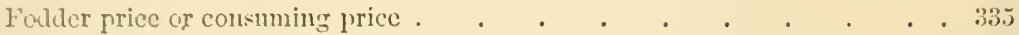

liringing valuc of straw lack in manure . . . . . . . . . . . . . . 336

Meaning of "value" of straw . . . . . . . . . . . 337

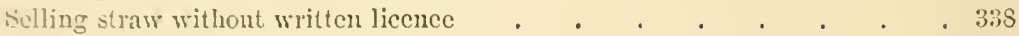

Manure assignable by the tenant . . . . . . . . . . . id.

* Manmre made on farm," definition of . . . . . . . . . . . . . 339

Ri.rlit of outgoing tenant to outstand for manure . . . . . . it.

Curenant to bring manure for hay sold . . . . . . . . id.

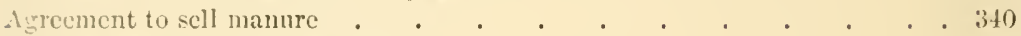

itrect swecpings cxempt from toll . . . . . . . . . . irl.

Lieruslical bones . . . . . . . . . . . . . . . id.

Toll exemptions . . . . . . . . . . . . . . ill.

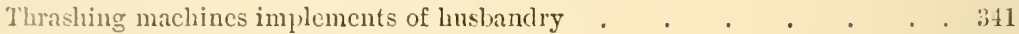

- not liable to pay toll . . . . . . . . . . id.

- may be liable by local act . . . . . . . . . . . . . . . . . . . . .

\section{CHAPTER XI.}

TRESPASS AND GAME.

Tight to bring trespass . . . . . . . . . . . 343

l'uscessory right sufficient to maintain trespass . . . . . . . . inl.

light of churchwardens and orerseers to maintain trespass . . . . id.

- to dig turf and peat. . . . . . . . . . . 34t

l'lea of not gnilty to trespass. . . . . . . . it.

Jicht to glean . . . . . . . . . . . . . irl.

Ilrculass for working an cistray . . . . . . . . . ill.

- breaking a dorecote. . . . . . . . . . itl.

l'jecons suljects of lareeny . . . . . . . . . ill.

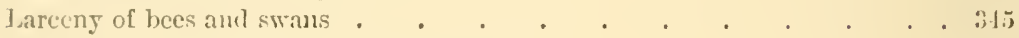

J'ossession, legal possession against trespassers . . . . . . il.

Entry liy lord of manor . . . . . . . . . . . cil.

Inclosure part of holding . . . . . . . . . . . . 8ti;

Incroachments by tenants on waste . . . . . . . . . ill.

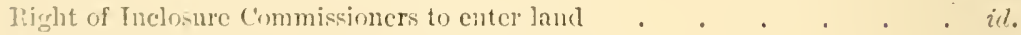

likght to waste lamel . . . . . . . . . . . . it.

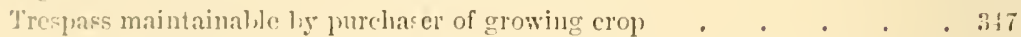

— on subenil . . . . . . . . . . . . . i il.

- clocs not lie for entering a close to retake goods wrongfully bronght

Hlicre. . . . . . . . . in.

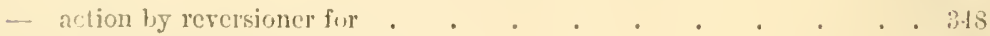

- de brinis resporlalis by auctionecr . . . . . . . . . il.

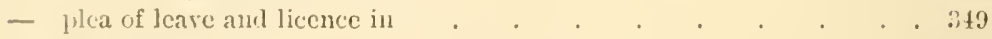

- for horseracingrg . . . . . . . . . . id.

Tre-paseres right of actim for injury . . . . . . . . . id.

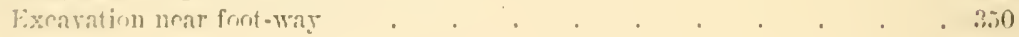




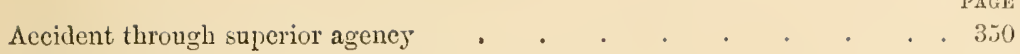

Trespass against surveyor of highways . . . . . . . . . . . . 251

Waterwork company's rights to dig footway . . . . . . . . . . . $_{\text {. }}$.

lights of public company . . . . . . . . . . . . . ill.

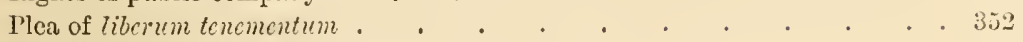

Trespass for continuing building on land $\quad . \quad$. . . . . . . . . . 35:3

— after notice . . . . . . . . . . . . ill.

- certificate of costs in action for . . . . . . . . . . . . . . . . . . . .

Remedy for continnance of nuisance . . . . . . . . . . . . . . . . . . . .

Nuisance by burning bricks near house . . . . . . . . . id.

Reasonable use of right to carry on trade . . . . . . . . . . id.

Placing materials on a private road . . . . . . . . . . . il.

Neasure of clamages for removing soil . . . . . . . . . . . . . . . . . . . . . . . . . .

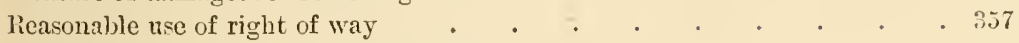

Trespass by breaking locks and ehains . . . . . . . . . id.

Estoppel of tenant from denying landlord's title . . . . . . . id.

Rights of permissire tenant . . . . . . . . . . id.

Furcible entry on common of pasture . . . . . . . . . . . . . . . . . . . . . .

Constrmetion of malicions trespass . . . . . . . . . . . . . id.

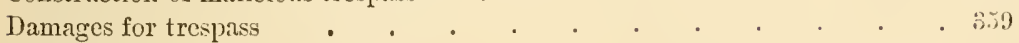

Unlawful entry to remore crops . . . . . . . . . . . . . . id.

Herbage set on fire by sparks from engine . . . . . . . . . id.

Fire cansed by sparkis from railway engine . . . . . . . . . . 360

Fire by spontancons ignition of hay-rick . . . . . . . . . . id.

Carcless burning of weeds . . . . . . . . . . . . . . . . ill.

Laying poisoned corn for poultry . . . . . . . . . . . . . . . . . . . . . . . . . .

Horses frightened by traction-engine . . . . . . . . . . ill.

Troof of negligence necessary to entitle plaintiff to recover . . . . $\quad \dot{u l}$.

Negligent riding on highmay . . . . . . . . . . . . . 362

Nuisance by brick-burning . . . . . . . . . . . . ill.

Carrying on trade in reasonable manncr . . . . . . . . . . . ir.

Brickmaking not a noxions trade . . . . . . . . . . . . . 363

No notice neeessary to trespassers . . . . . . . . . il.

Provisions against trespassers do not apply to fresly pursuit of game . . ill.

lieversioner cannot apprehend trespasser . . . . . . . . . id.

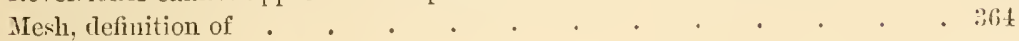

Right to follow fox . . . . . . . . . . . . id.

Law as to hunting trespass . . . . . . . . . . . . . . . . . . . . . . . . .

Ineiting friends to commit trespass . . . . . . . . . . . . 366 ;

Trespass in defiance of notice . . . . . . . . . . . it.

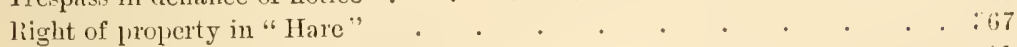

No action lies for involuntary trespasis . . . . . . . . . . il.

Trespass by clog againit master s will . . . . . . . . . . . . lid.

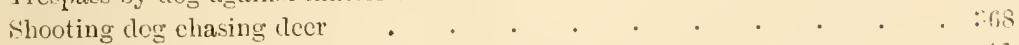

Taking dog damage feasant . . . . . . . . . . . id.

Deputation hy stat. 1 \& 2 Will. IV. tu seize dogs . . . . . id.

l'oacher cannot grive eviclence for himeclf . . . . . . . . . . ill.

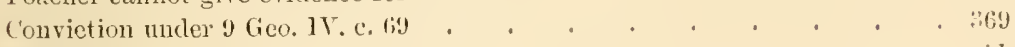

Non-entry of some of poachers cur lemel , . . . . . . . id. 
xxiv

CONTENTS.

PAGE

setting dore on land an entering

Trepan by shooting from highway.

light to kill game exercised for seven years

servant no authority to apprehend poachers

. 369

l'rosecutions miler 1 \& 2 Will. 1Y., s. 32, must be commenced within a rear

lights of anmekecpers to apprehend poachers

()weer of lime need not prove non-permission

Alpreheneling trespasser

loaches damaging fence

Forcible revue from unlawful custody

liability for costs of persons jointly convicted

'taking hares or rabbits by night

(occupier's right to kill lares

Form of authority to kill hares

Taking game on Sunday or Christmas Day .

licasonable time for keeping game after season

light to deal in live pheasants

'lame pheasants subjects of larceny .

'Tame leer in park personal property .

'Trespass for entering fislicry

Conviction for using a trip for game . . . . . . . . . id.

Setting net on waste. . . . . . . . . . . . . 376

shooting hare in turnpike road.

Shooting pheasant on another's land

Frightening grouse with fireworks

I'vacher's found with rabbits on highway

Claim of right to kill game

licking up plicasint on another's lance

Conviction for trespass.

lie-taking rabbits from poacher's

l'roperty in rabbits

light of tenant to kill rabbits .

I labourer taking rabbit by order of farmer .

lieut file assertion of right

MItre vague belief of right

()ousting justices juistliction

ill.

Young pheasants in coop under hens not game

Tame dee in pan k personal property

L. mel of manor's exclusive right to port

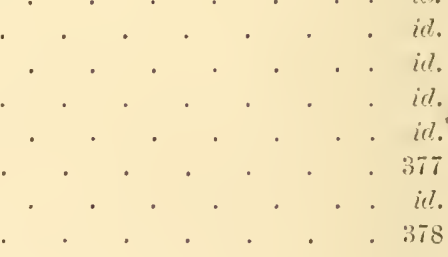

id.

$i d$.

id.

- not entities to shoot over commons . . . . . . . . 3\&3

A- - ci--uscut of land without game

Giant of liberty to sport

die-crvation of game by lessor

tirane of free liberty to sport a license of profit

liatuchire of free warren

- 379

. 380

. $3 \$ 1$

. il.

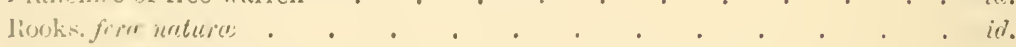

Shouting near decoy . . . . . . . . . . . 38j

Liberty to kill rabbits with ferrets on! 
PAGE

lieservation of all royalties . ..$\quad$. . . . . . 385

light of sporting over eattlegates . . . . . . . . . . 386

Trespassing on land where game reserted to lord of the manor . . . . id.

Right of burgesses to sport muder charter . . . . . . . . . 3s7

Demise of sporting not under seal . . . . . . . . . . id.

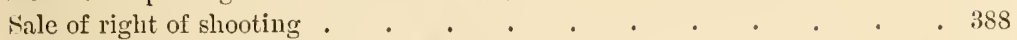

Lease of exelusire rights of sporting . . . . . . . . . . id.

Compensation for clamage by game . . . . . . . . . . . 389

Bequest of money to liberate poachers . . . . . . . . id.

Laying traps for dogs . . . . . . . . . . . il.

Dog lumning against spear . . . . . . . . . . $i d$.

spring-gnus in wood with notice . . . . . . . . . . . . 390

— in walled garden . . . . . . . . . . . id.

- definition of . . . . . . . . . . . . . 391

Aetion for damage by dog lumting game . . . . . . . . i il.

D)amage by game to crops . . . . . . . . . . . id.

thooting rabbits where exclusire right of shooting and sporting let . . . 392

l'ursuit of game . . . . . . . . . . . . in.

l'ersons taken with game on highway . . . . . . . . . . id.

Aprrehension mucler game act . . . . . . . . . . . . 393

\section{CHAPTER XII.}

TITHES.

Talue of rent-charge $. \quad . \quad$. . . . . . . . . 394

Acts relating to tithe . . . . . . . . . . . . id.

Twenty years' pereeption of tithes . . . . . . . . . . id.

liequest of pure personalty to restore tithes voil _ . . . . . . . . . . . . . . .

Land only liable for tithe rent-charge . . . . . . . . . $i$. .

Intention of Tithe Commutation let . . . . . . . . . irl.

light of viear to small tithes . . . . . . . . . . 396

Tithes of beans and peas . . . . . . . . . . . . id.

Apportionment of rent-charge by commissioners . . . . . . il.

Distress muler Tithe Let . . . . . . . . . . . 397

l'rinciple of apportioment . . . . . . . . . id.

Onus of proving lant barren . . . . . . . . . . id.

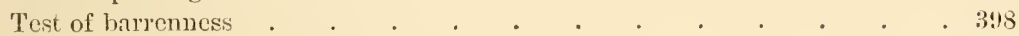

Exemption from tithes . . . . . . . . . . . ill.

Instrument purporting to merge tithes . . . . . . . . id.

Award by 'lithe Commissioner . . . . . . . . . . . . 3999

Confirmerl awarl . . . . . . . . . . . il.

Dispute as to parish bommliny . . . . . . . . . . . . 400

Iode of proceerling to ascertain boundaries . . . . . . . i il.

Appeal against Commissioner's awarl _. . . . . . . . . 401

Actions against Tithe Commissioners . . . . . . . . id.

Amomnt of yearly ralue which entitles an appellant to appeal . . . . id.

T'roper farm modus . . . . . . . . . . . . 402

Death of incumbent within three months of award . . . . . . id. 
Monlus decim maii . . . . . . . . . . . . 102

Aetion for treble ralue of lithes . . . . . . . . . . 103

Expenses incilent to apportionment . . . . . . . . 404

Disqualification loy interest in raluer . . . . . . . . . il.

Asscssment of tithes to poor rate . . . . . . . . . 405

Amexation of portion of tithes to district elureh . . . . . . id.

lient-charge on hepss . . . . . . . . . . il.

- of district church not ratcablc . . . . . . . . . 406;

— not liable to sewers rate . . . . . . . . . id.

- grantce of, liable to income tax . . . . . . . . $i$. . .

Juriscliction of Commissioner of Tithes . . . . . . . . $i$.

Ontgoings include land-tax and rent-charge . . . . . . . 407

Oecupicr of tithe rent-charge to deduet curate's salary from ratcable value . $i d$.

lerpetual pasment to incumbent of new distriet not to be dedueted . . 408

Lessce of tithe rent-charge not entitled to deduct curate's stipend . . . id.

$\Lambda$ scessment of ocempicr of titlie rent-charge . . . . . . . . 109

\section{CILAP'TER XIII.}

LANDLORD AND TENANT.

Lessce for half-year tenant for ycars . . . . . . . . 410

Operative words in lease . . . . . . . . . . . . . . id.

Agreement when operates as lease . . . . . . . . . . e il.

Ienning of words "agree to let" . . . . . . . . . ill.

Fridence of title on a writ of elegit . . . . . . . . . . 411

light to distrain without altormment . . . . . . . . . j jl.

licceipt for reut last cluc . . . . . . . . . . . i t.

Agreement to let agrecment to gire possession . . . . . . . . il.

Contract for sale of agrecment for lease does not imply lessor's power to lease $i$.

Demisc at jearly rent . . . . . . . . . . . 412

New tenaney not ereated by increase of rent . . . . . . . id.

Iereenent not uncler scal . . . . . . . . . . . 413

light to enter for condition broken . . . . . . . . . . ill.

Instrument roid as lease good as agrecment . . . . . . . ill.

Intention of partics as declared ly instrument . . . . . . . 411

Rirlat of tenant to specific performance . . . . . . . . il.

l'arol agrcement fur leace . . . . . . . . . . . 415

Corenant respecting rotation of erops cugraflect on yearly tenney _ . . $i d$.

Xist griving possc sion no breach under a new angecment for a lease . . . 4lli

Expirchl lease . . . . . . . . . . . . it.

Silampon agrechent. . . . . . . . . . . . il.

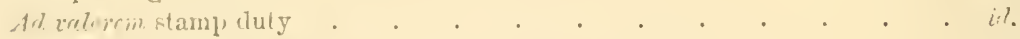

Stamy whers nut necosary . . . . . . . . . . . . 417

Ifcaniug ref "sui,jeret natter" in Stanip det . . . . . . . it.

listrizuel between ]anellowl amel tonant . . . . . . . . 418

Ifoney recorerable from inability to ganat leatec . . . . . . . 119

icparate orders of reference. . . . . . . . . . . it.

Albitrator's between outgoing and incoming tenants . . . . . i il. 
Land to be reasonably fit for purpose for which it is taken . . . . il.

No implied warranty by lessor of house fit for liabitation . . . . . . 125

linterest of reversioner in repair of premises . . . . . . . . il.

Lessee must seek lessor to pay rent . . . . . . . . . . 126

Covenant to repair . . . . . . . . . . irl.

— jicld up in good repair . . . . . . . . . . . 427

Tiule as to kepping premises in repair . . . . . . . . ill.

Meaning of good repair . . . . . . . . . . . 128

light of lessor to enter and examinc . . . . . . . . . ill.

Tenant from year to year not bound to do substantial repairs. . . . id.

Measure of clamages for not keeping in repair . . . . . . . . . . 129

Destruction of rremises by fire. . . . . . . . . . i $u$.

Liability to pay rent for premises burnt down . . . . . . . i il.

Landlord not compelled to spend fire insurance money . . . . . $i l$.

- to rebnild farm-house . . . . . . . . . . . . 130

Compensation for demolition of clwelling-house . . . . . . . i $\mathrm{e}$.

Allowance by Court of Chancery for repairs _ . . . . . . . 431

Action for dilapidations subject to compulsory reference. . . . . . i $i$.

Dilaptations of buildings built on waste . . . . . . . . i il.

Tight of rector to remore hothonses . . . . . . . . . id.

Notice to quit by one joint-tenant . . . . . . . . . . . 432

Who may gire notice to quit . . . . . . . . . id.

Meaning of "old lady day" . . . . . . . . . . . id.

Different times of quitting . . . . . . . . . . . 133

Notice to quit when date of commenecment of tenantry not known . . . i $i$.

Insufficiont notice to rquit . . . . . . . . . . . 434

Lessec for a term of years . . . . . . . . . . . . 435

Tenancy of glebe lands under two ineumbents . . . . . . il.

New vicar right to immediate prossession . . . . . . . . il.

Two years' notice to quit . . . . . . . . . . . . 1:86

Action in comty court by landiorel to evict tenant . . . . . . . 137

Erietion of temant when operating as suspension of rent . . . . . il.

Eriction of tenant from parcel of demised prenises, no answer to action for breach of covenant .

Oceupier's liability to pay rates

Oceupier's power to deduct rates from rent . . . . . . . . . il.

Assessment for land-tax . . . . . . . . . il.

Special agreement hy tenant to pay land-tax . . . . . . . . . . . . . . . . . . . .

Demise of land with power to make bricks. se. . . . . . . . id.

Right of tenant to deduct inenme-tax . . . . . . . . . id. 
Liability of ocempier to pay poor-rate . . . . . . . . 440

light of occhifier to recorer property-tax paicl un behalf of landlord . . . in.

- to decluet properif-tix from rent . . . . . . . . 441

Parish officers need not set out bounclaries of property rated by them . . id.

Emblements, lefinition of . . . . . . . . . . 442

- excentor's right to . . . . . . . . . . id.

- derisec's right! to . . . . . . . . . . . id.

- part of stock on farm . . . . . . . . . . 413

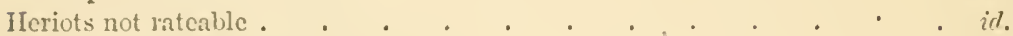

- custom of copylolders, as to . . . . . . . . . . id.

- landlord's right to . . . . . . . . . . . 44

- payment in lieu of . . . . . . . . . . . . . . . . . . .

Action for use and occupation . . . . . . . . . . il.

- will not lic without agreement express or implied . . . . . 446

— - when it will lic . . . . . . . . . . id.

- - may lic where action for rent not maintainab!c . . . . ir.

- - will not lic when title in dispute. . . . . . . id.

Owner-hip anel tenancy, frimê facic cridence of contract . . . . . . $4+7$

Agrecment roid by fraud . . . . . . . . . . . 4ts

Delivery of instrument as an cscrow . . . . . . . . . id.

Receiving rents from nnder-tenant, proof of use and occupation . . . i . $_{\text {. }}$

U se and occupation does not exclude under-letting . . . . . . . . $4+9$

Action for double valuc under statute . . . . . . . . . id.

- rent. . . . . . . . . . . . 450

Holding orer by co-tenant . . . . . . . . . ul.

— after cxpiration of lease . . . . . . . . . . id.

lic-entry on non-payment of rent . . . . . . . . . . t.j1

I'ermission to hold orer after notice to quit . . . . . . . ill.

Actions by tenants in common . . . . . . . . . . 452

licservation of rent in corn . . . . . . . . . . . i il.

drerage price of corn for seren years . . . . . . . . 453

lieversioner liable for permanent unisance . . . . . . . . . ill.

Meaning of one clay's team-mork . . . . . . . . . . ill.

Corenant not to assign or nuder-let . . . . . . . . . . it.

— to repair. . . . . . . . . . . . 15t

- to lcave land stocked with game . . . . . . . . il.

Payment of increased rent sufficient to take case out of Statute of Fraucls . ill.

Farm fixtures. . . . . . . . . . il.

- learling cace on . . . . . . . . . . il.

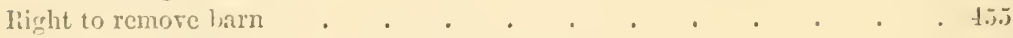

— starel barn. . . . . . . . . id.

— water fenrler. . . . . . . . . . . . 4. . . . . . . . . .

- stardles, thrashing-machine, ant gramaly . . . . . . . . tij

- barn on blocks and patterns . . . . . . . . . 45s

- building where landlorel finds part of timber . . . . . . . 459

- tenant's fixtures after determination of tenancy . . . . . . 160

- pillars of lorick . . . . . . . . . . . ill.

Fixtures, not chattels until sererecl . . . . . . . . . . id.

Trover by tenant for fixtures . . . . . . . . . . 461 
Removal of buildings by tenant after ejectment bronght

Liability of agent for non-fulfilment of agreement . . . . . . it.

Agent's power to let on unisual terms . . . . . . . . 4 4 . . . . . . . .

- act ratified by employer . . . . . . . . . . il.

- represcntation by, that he had anthority to act . . . . . i $\mathbf{l}$.

- guarantec of solvency by . . . . . . . . . . 468

Rights of assiguee of mortgagor . . . . . . . . . i t.

Stean-enginc, grindstones, ctc., fixtures . . . . . . . . 469

Annexation of chattel to frechold . . . . . . . . . ill.

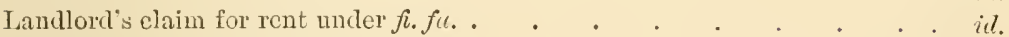

Rights of presumptive heir to rents . . . . . . . . . il.

Feceipt of rent from third party . . . . . . . . . . 470

Holding orer must be continnous to entitle to double value . . . . i $i$.

Ejectment by mortgagor . . . . . . . . . . . cic.

Action by one tenant in common against another . . . . . . icl.

Paying tenant-right to false devisee . . . . . . . . . 471

Enforcing specifie performanee of farming agreement . . . . . $i \iota$.

Lease by incumbent . . . . . . . . . . . . 172

Lessee bound to deliver up lease . . . . . . . . . . . 473

\section{CHAP'TER XIY.}

\section{CONTRACTS AND SALES.}

Parties bound by agreement sent to solicitor to be redueed into form . . 4it

Right of vendor to rezeind contract . . . . . . . . . id.

- purehaser to insist on rendor's personal receipt of moner . . . 475

— - to recorer preliminary expenses . . . . . . . id.

Remuneration to agent . . . . . . . . . . . $i$.

Contract for purchase of land when complete . . . . . . . . 476

Avoidance of contract through fraud . . . . . . . . id.

Contraet as to coal-mines worked ont . . . . . . . . . $i d$.

Sale of close inaccessible except by way orer another close . . . . . $i$.

Auctioneer agent for buyer and seller . . . . . . . . . . . 476

Default by purchaser in eomplying with eonditions of sale . . . . $i d$.

Pight of purchaser to good title . . . . . . . . . . 478

Right of one party to contract to substitute a third party in his place . . iu?. 
Right of anctioncer to commission . . . . . . . . . . . 478

I.argest purchaser entitled to title deeds . . . . . . . . id.

Sile of reputel water-meadow . . . . . . . . . . . 479

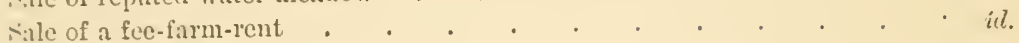

— by sealed tenders . . . . . . . . . . . $i d$.

- printel particulars of, caunot be altered by parol evidence . . . iel.

l'arol evidence when not receivable . . . . . . . . . tio

Sile of . Ware" potatues. . . . . . . . . . . il.

l'arul eridence admissible to explain trade terms . . . . . . . 481

Tracle meaning of ciller . . . . . . . . . . . ill.

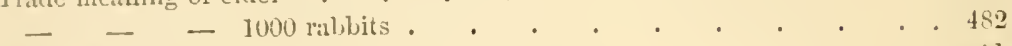

Wiuls of cleseription may be contralieted by parul . . . . . . ill.

liefusal of seller to show in bulk . . . . . . . . . . . icl.

Discharge of surets by variation in contract witlont his consent . . . 483

Grdinary rule of buying by sample . . . . . . . . . . ill.

liulk not equal to sample . . . . . . . . . . . $48 t$

Article sold by sample innst be rejected within reasonable time . . . . 485

Article sold by contract must reasonably answer deseriptiun . . . . i il.

lighlit of purchaser to inspect bulk . . . . . . . . . . . 486

secei not corresponding with warranty . . . . . . . . . ill.

Niecssary to gire notice of this . . . . . . . . . . 487

Application of statute in such cases . . . . . . . . . . . il.

Sale of turnip secl . . . . . . . . . . . . . . c il.

Warranty of Skirring's swedes. . . . . . . . . tss

- $\quad$ - seed wheit . . . . . . . . . . . $i l$.

— - somnd meat . . . . . . . . . . . . 489

('untagions Diseases Animals Act . . . . . . . . . . 490

Alternatise contract must be stated . . . . . . . . i il.

Agrecment to refer enforceable by action . . . . . . . . il.

— - telirer" goods "from time to time" . . . . . . il.

ficcovery of remuneration on a quentum merait . . . . . . . il.

Feller cannot recover price of part of contract _ . . . . . . . . 491

Yon-specification of time for delivery . . . . . . . . . . . . 192

Ircasure of clamages for non-delivery of goods. . . . . . . it.

Ifcaning of "directly" in contract of delivery . . . . . . . . . 493

— - "market raluc". . . . . . . . . . 494

Delivery, what constitutes . . . . . . . . . . . i il.

stack sold, but burnt before paicl for . . . . . . . . .

Sale of specific chattel on eredit . . . . . . . . . . . ill.

Suflicient agreement within Statute of Frands. . . . . . . . 495

- delivery to satisfy statute . . . . . . . . . . . 196

What constitutes delivery, leading case as to . . . . . . . . il.

No actual clelivery necessary in the case of ponderous goods . . . . . 497

Fividence of actual acceptance . . . . . . . . . . 498

liefusing to deliver to bankrupt vendee after sample taken . . . . 499

Urawing samules from bulk after purchase . . . . . . . 500

l'urchascel putting mark on particular article . . . . . . . . i il.

Actual acceptance and receipt of goods . . . . . . . . . . 501

light of rendee to compare goods delivered with sample . . . . . 502 
Name and address of vendee written by himself at bottom of hist of artieles purchased sufficient to satisfy statute . . . . . . . ill.

What acknowledgment takes delst ont of statute . . . . . . . . . . .

II easure of damages for breach of eontract . . . . . . . . . 509

Action for nom-delivery of thrashing machine within certain time . . . 510

Delicery of gools of inferior cinality . . . . . . . . . 511

light of rendee to bring trorer for goods . . . . . . . id.

What suficient evidenee to smport trover . . . . . . . . 512

When trover camnot be brought . . . . . . . . . id.

Orter for clelivery on third person . . . . . . . . . . . 513

Measture of damages in trorer . . . . . . . . . . ill.

Warranty of seed barley . . . . . . . . . . . 51t

Sale of l'emvian guano . . . . . . . . . . . il.

Joint ocerpation of a firm . . . . . . . . . . . . 515

Bill of sale when void against ercditors . . . . . . . id.

- - assignment of, as seeurity for delst . . . . . . . . 516

Devise of farm in trust . . . . . . . . . . . ill.

Drying bark distinct trade from drying corn . . . . . . . 517

Omission of statement in insurance policy . . . . . . . . il.

Law of the market . . . . . . . . . . . $u$.

liights of seller in mblie market . . . . . . . . . 518

Market legally established . . . . . . . . . . . 519

lraul on lessee of market . . . . . . . . . . . it.

Iankruptey of rendees before taking possession of bulk . . . . . 520

Returns of sales of corn . . . . . . . . . . , it.

Corn measures in different markets . . . . . . . . . 521

Abolition of local measures . . . . . . . . . . . . . . 522

Selling by the hobbett . . . . . . . . . . . . id.

Sale of earn by sample . . . . . . . . . . . . . . 523

Weight of hay not to be inereased by water, se. . . . . . . . icl.

Trading by farmer within bankrupt laws . . . . . . . $i l$.

Definition of a trader . . . . . . . . . . . . . . $52 \frac{5}{4}$

- - cowkeeper. . . . . . . . . . . $i l$.

Owner of market liable for nuisance arising therefrom . . . . . 525

Cattle fair not to be held on reereation ground - . . . . . . . $i d$.

Selling horses within limit of market . . . . . . . . . . . . 526

Warranty of seel . . . . . . . . . . . . i

liisk of vendee in absence of express warranty . . . . . . . . . 527

Selling manure not corresponding with warranty . . . . . . il.

Warranty where not implied . . . . . . . . . . id.

No implied warranty that meat fit for food . . . . . . . . 528

Selling bad meat . . . . . . . . . . . . . 523 
Carrier indictible for taking bal meat to market.

Absence of intent to sell bad meat . . . . . . . . . . . . $i_{l} l$.

solling biul cidcr . . . . . . . . . . . . . . il.

- sulphred hops. . . . . . . . . . . . it.

— refusc cake. . . . . . . . . . 530

- sainfoin seel alulterated with bunet . . . . . . . id.

(onviction under Alulteration of Sects Act, 1869 . . . . . . . 531

liecovery of differenee between sale and market price _ . . . . . . 532

Violation of eonsignor's orlers by carrier . . . . . . . . . il.

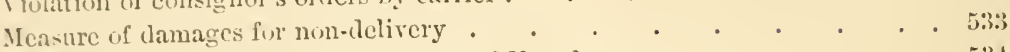

Aceptance of hops within the statute of Frauds . . . . . . . 531

Pelay of delivery camnot be set $u p$ in reduction of damages in breach of warranty

What is suflicient to pass property . . . . . . . . . ill.

Contract for sale of growing turnip secl . . . . . . . . icl.

Ventor liable for false representation of lease . . . . . . . . 5is

Assignment by client to attorney not voit on ground of champerty . . . ill.

Seimure and sale uncler bill of sale . . . . . . . . . il.

The severanee of one part of farm from another by railway an injury to farm 539

Tiailway required to take whole estate . . . . . . . . il.

Mortgage on living $n o$ gromend for reseinding contract of sale of alvowson . il.

Inaceurate particulars of sale . . . . . . . . . . 5 5 5

Right of agent to remmeration when sale goes off $. \quad . \quad . \quad . \quad$. . 5tl

Agent at anction shonld declare himself . . . . . . . . $i$.

\section{CHAPTER XV.}

HORSES AXD CATTLE.

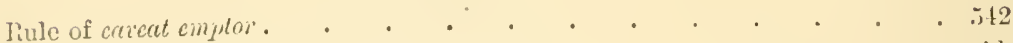

Warranty of somumess . . . . . . . . . . . id.

Distinction between representation and warranty . . . . . . . ill.

"This horec is somul," a warranty . . . . . . . . . ill.

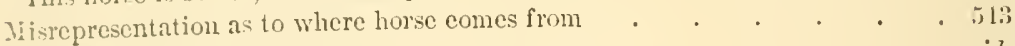

Gicneral rule as to warranty . . . . . . . . . . . iul.

Giving lorse particnlar cliaracter . . . . . . . . . . oft

Warranty of horse being "clever lack" . . . . . . . . . ill.

Enauthorised warranty by servant . . . . . . . . . ists

lieccipt of douccur by agent from seller . . . . . . . . . . 547

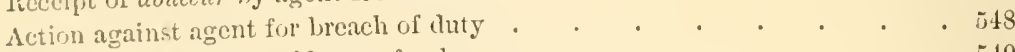

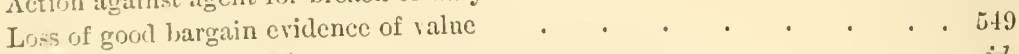

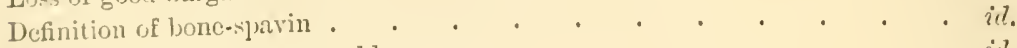

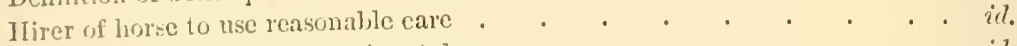

Full dcccription in auctioneer's catalogue. . . . . . . . . id.

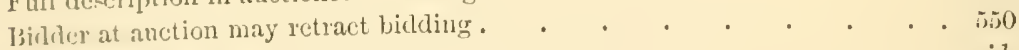

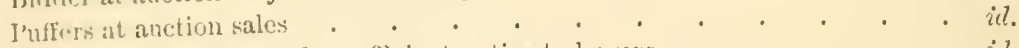

Comlitions of auction sales sufticient notice to buyers . . . . . . $i$.

Horse warranted six years old but actually twelve may be returned . . . 551 
l'rivate warranty incorporated into conditions of sale .

Written warranty

General rule for horse-dealing

Fraudulent representation at time of sale.

Representation must be known to be false

$i \iota l$.

Warranty by servant of horse-dealer .

General rule of selling by servant

Warranty by servant merely entrusted to deliver . . . . . . u.

Rule of master taking back horse which will not stand to warranty given by servant

Principal responsible for agent's frand.

Warranty by veterinary surgeon as agent

Plea of breach of warranty

Stamp on warranty

Partncrship in a horse

Undertaking to give material evidence

Measure of damages in trover for a horse

Warranty that horse "sonnd and quiet in harness" . . . . . . id.

— "good drawer" . . . . . . . . . . . id.

Agreement to return mare if in foal . . . . . . . . . . . . $\quad$. $i d$.

Dealing on Sunday . . . . . . . . . . . . . 562

Covering mares on Sunday . . . . . . . . . . . 563

Farmer not within Sunday Trading Act . . . . . . . . . id.

Positive proof of unsoundness, when necessary . . . . . . . . . id.

Warranty when continuing . . . . . . . . . i $i$.

What constitutes unsomndiess . . . . . . . . . . 564

Warranty of bullocks . . . . . . . . . . id.

Meaning of word "sound" . . . . . . . . . . . . 565

Defect in structure of horse . . . . . . . . . . . . 566

Unusnal convexity in the cornea of eye . . . . . . . . . $i d$.

Hereditary disease in sheep . . . . . . . . . . . . . . 567

Permanent congh unsoundness . . . . . . . . . . . 568

Roaring . . . . . . . . . i . . . . .

Stringhalt . . . . . . . . . . . 569

Laminitis . . . . . . . . . il.

Contraction of hoof . . . . . . . . . . . . $i d$.

Navicnlar joint disease . . . . . . . . . . id.

Chest-foundered . . . . . . . . . . . 570

Cataract . . . . . . . . . . . $i d$.

Affection of nerves in lumbar region . . . . . . . . . . $i d$.

Badness of shape . . . . . . . . . . . . id.

Curby hocks . . . . . . . . . . . $i d$.

Thin-soles . . . . . . . . . . 571

Splint . . . . . . . . . . . $i d$.

Effect of lapse of time on contract . . . . . . . . . . 573

Agreement to take horse back within certain time . . . . . . id.

lieasonable trial . . . . . . . . . . 574

Borrowed horse cannot be used by servant . . . . . . . . . itt

Difference between gratuitous bailee and hirer . . . . . . $i d$.

Doctoring lired horse . . . . . . . . . 575 
Livery-stable keeper no lien for reterinary charges .

"No cure no pay"

Chemist's liability for selling improper lotion

Selling improper sheep-wash

Veterinary surgeon's clain

What constitutes an acceptance

Sale on credit

Complete contract of purcliase from letters.

Liability of auctioneer as agent . . . . . . . . . . id.

Pecorery of keep when warranty broken . . . . . . . . . . 593

Purchaser's duty to return unsound horse . . . . . . . . . id.

Recovery of keep when contract broken . . . . . . . . 594

Question of damages on returning horse . . . . . . . . id.

l'urchaser's duty when warranted horse unsound . . . . . . 595

Right of purchaser to return horse within certain time $\quad . \quad$. . . 596;

Sale by public auction not sale in market overt . . . . . . . . . . . . . . . .

Sale of stolen horses . . . . . . . . . . . id.

Sale of glandered horses . . . . . . . . . . . . . . 598

Conspiracy to cheat in selling horses . . . . . . . . . id.

('onspiring to clefraud by false pretences . . . . . . . . . . 599

()rdinary cheating at fair . . . . . . . . . . i $i l$.

liceovery of stolen goods in trover . . . . . . . . . . 600

Malicious prosceution for sheep-stealing . . . . . . . . id.

Loss of chattels at inn . . . . . . . . . . . . . . 601

Horse injured at liverr-stables . . . . . . . . . . id.

l'lacing gig in street . . . . . . . . . . . . 602

l)ogs in charge of ostler . . . . . . . . . . . till.

heeping swine a nuisance. . . . . . . . . . . ill.

slaughtering horses at kennels . . . . . . . . . . . 603

Cosws poiconerl in pasture . . . . . . . . . . . . tous

— Łg jew clippings . . . . . . . . . . . 604

Acquicsence of owner in erection of injurious works . . . . . $i d$.

Cattle injured by working of mines . . . . . . . . . id.

— by lead works. . . . . . . . . . . . 605

Simptrins of sulphate of learl . . . . . . . . . . 606 


\section{INDEX OF CASES.}

A.

Abhey $v$. Petch, 8 M. \& W., 419-pp. $298,299,300,301$

Abbot 2 . Weekly, 1 Lev., 176-79, 349.

Abington $v$. Lipscombe, 1 Q. B., $776-444$

Ahlest $v$. Pritchard, 1 N. R. C. P., 210-342

Abron $v$. Fussell, 3 F. \& F., 152-549

Ackland $v$. Buller, 1 Ex., 837-401

Acraman $v$. Morrice, 8 C. B., 449-129

Acton v. Blundell, 12 M. \& W., $324-175$, 176

Allams $v$. Great Western Railway Company, 30 L. J. N. S., Ex., 124-251

v. Richards, $2 \mathrm{H}$. Bl., $573-573$

Aldenburgh $v$. Peaple, 6 C. \& P., 212-434

Alcler $v$. Keighley, 15 M. \& W., 117-509

Aldridge $v$. Great Western Railway Company, 3 M. \& G. $515-360$

$v$. Johnsorı, 26 L. J. (N. S.) Q. B., 296-498, 536

Alexander $v$. Combe [Comber], 1 H. Bl., $21-512$

- v. Gibson, 2 Camp., 555-545, 555

Allaway $c$. Wagstaff, 99

AHlay $r$. Great Western Railway Company, 34 L. J. N. S. Q. B., 5-254

Allen $v$. Cameron, 1 C. \& NI, $832-484$

- $v$. Denstone, 8 C. \& P., 760-555

v. Eugland, 3 F. \& F., $49-358$

v. Lake, 18 Q. B., $560-487$

- $v$. Ormond, 8 East, 4-93

Allott (Exor.) $v$. Carr and Scholefield, 27 L. J. (N. S.) C. P., 281 ; Ex. 385516

Alsop v. Yates, 27 L. J. Ex, 156-219

Alston $v$. Scales, 9 Hing., 3 ; 2 M. \& Scott, $5-143$

Anclerson $v$. Blackburn, Veterinarian, vol. 21, p. $469-569$

___ r. Robson, ilid., p. 581-543
Anderson $v$. Radcliffe and Walker, $28 \mathrm{~L}$. J. (N. S.) Q. B., 32-516, 538 584

Angerstein $v$. Handson, 1 Gale, $8 ; 1 \mathrm{C}$. M. \& R. 789 ; 5 Tyr., $383-315$

Anscomb $v$. Shore, 1 Taun., 261; 1 Camp., $285-272,279$

Applebee $v$. Percy, 9 L. R. C. P., 647-157 Appledore ( n r re), Commutation, 8 Q. B., $139-397$

Archer $v$. Horner, 3 L. \& P., 349-206

——. Sadler, 1 F. \& F., 481-359

Arkwright $\because$. Gell, 5 M. \& W., 203 ; 2 Horn \& H., 17-182, 183, 184, 193

Ashmeạd v. Ranger, 1 Ld. Raym., 522-115 Ashworth $v$. Stanwix and Walker, 30 L. J. Q. B., $183-216$

Askew (In re), 20 Law J. (N. S.) ; M. C., 241 ; 2 L. M. \& P., 429-201

Aste $v$ : Montague, 1 F. \& F., 264-222

Attack $v$. Bantell, N. R., January 31, 1863 $-305$

Atterbury $v$. Fairmener, 8 Moore, 32-570

Attorney-General $v$. Chambers, 6 Jurist, $745-168$

S.) Ch., $837-169$

- $v$. Matthias, 27 L. J. (N. S.) Ch., 761-79

$v$. Corporation of South. ampton, 29 L. J. N. S. Ch., $282-525$

$538-316$ $-396^{\circ}$

Atwood v. Emery, 1 C. P. (N. S.), 110493

Anbrey $v$. Fisher, 10 East, $446-11 \mathrm{~s}$

Austin $v$. Manchester, Sheffield, and Lincolnshire Railway Company, 16 Q. B., $600 ; 10$ C. B., $454-236,256$ 
T.

Bach r. Owen, 5 T. R., 409-5s2

Badkin $\imath$. Powell, Cowp., 476-268

Bagge 2: Mawby, S Ex., 6t1-303

Baglehole $r$. Walters, 3 Camp., 154-551

liagnell r. London and North Western Railmay Company, 31 L. J. (N. S.) C. P., $121-196$

Bailey 2: Holford, S Q. B., 1000-375

- 2 . Forrest, 2 C. \& k., 131-571

$\imath$. Forrest, $567-571$

2. Stevens, 31 L. J. (N. S.) 226, C. P. ; 12 C. P., 91 ; 6 Law Rep., 356-114

Baker, IV. (e.r parte), 2 II. \& N., 219 ; 26 Law .T. (N. S.) M. C., 193-201

- $v$. Perkeley, 3 C. \& P., 32-365 r. Holtpzaffell, 4 Taun., 45-429

Paldey 2 . Parker, 3 D. \& R., 220; 2 B. \& C., 37-129, 500

Pillitwin $\because$ Castella. 7 L. R. Ex., 325-157 Ballard $x$. Dyson, 1 Taun., 279-92

Ralston 2. lienstearl, 1 Camp., 463-17t, 175

Bamford $\tau$. Turnley, 31 L. J. (N. S.) Q. I., $286-362$

liandy $v$. Cartwright -463

liankhart $x$. Houghton, Law Times, Narch $12,1859-604$

Banks $c$ Crossland, 10 L. R. (2. B., $97-$ 204

Bannerman $r$. White, 31 L. I. (N. S.) C. P., $28-530$

Barker $r$. Aston, 1 F. \& F., 191-516

- 2 . Daris, 391

$v$. Title Commissioners, 9 MI. \& M., $129 ; 11$ M. \& W., 320-403

— 2 . Richaulson, 4 k. \& Ald., $579-$ 70

Jhirlow $x$. Oshorne, 27 L. J. (N. S.) Ch., $308-479$

biarnes $x$. Harding, 1 C. B. (N. S.) 568411

(Admx.) $v$. Ward, 9 C. B., 392 ; 2 C. \& K., $661-1.37,349$

larnctt $r$. Guildford (Eari), 11 Ex., 19357

Isarraud $\imath$. Archer, $2 \operatorname{Sin}$. 433-479

Barrett $v$. Iarrett, - Hetley, 35-122, 309

- $r$. Stockton and Darlington Railway Company, 3 M. \& G., 953 ; 3 Scott N. I., $803 ; 7$ M. \& G., $270 ; 8$ Scott N. R. $041-274$
Barrington $v$. Turner, 3 Lev., 28-368

larrow $v$. Ashburnham (Lord), 4 L. J. (N. S.), K. B., 146-389

Bartlett $v$. Purnell, 4 Ad. \& E., 792-592

Bartons Hill Coal Company v. Reid-215

Basingstoke (Mayor of) $v$. Lord Bolton, 3 Drew, $50-445$

Bassett $r$. Collis, 2 Camp., 522-568

Bateman $v$. Burge, 6 C. \& P., 391-94

- - Farnsworth, 29 L. J. (N. S.) Ex., $365-303$

Bates $v$. Hudson, 6 D. \& R., 3-57 6

Bathurst (Earl) v. Burden, 2 Br. Ch. Rep., $64-170$

Battishill $v$. Reed, 1 S C. P., 696-84, 354, 355

Battley $x$. Falkner, 3 P. \& Al., 298-487

liaxendale $r$. Eastern Counties Railway Company, 27 L. J. (N. S.) C. P., 137 $-263$ $1859-517$

Paxter $v$. Taylor, 4 B. \& A A., 72; 1 N. \& M., $11-94,95,348$

Baylis $v$. Le Gros, 26 L. J. C. P., 176428

Bayne $r$. Walker, 3 Dow. H. of L., 23:430

Beadon $v$. Trimlett (not reported) -27

Bealey, v. Shaw, 6 East, 208 ; 2 Smith, $321-76,171,172,17 t$

Pearlmore $v$. Treadwoll, 31 L. J. (N. S.) Ch., $592-362$

Beaseley $t$. Clark, 2 Bing. (N. C.), 705; 3) Scott, 258; 2 Hodges, 100 ; 5 Dow. P. C., $50-82,83$

Beaty $r$ Gibbons, 16 East, 116-339

Beaufort (Duke of) $x$ Glynn, $3 \mathrm{Sm}$. \& Gif., $213-476$

Beavan $v$. Delahay, 1 H. B. L., 5-290, 291,321

Beckwith $v$. Shardike, 4 Burr., 209ะ-367

Bedford $v$. Warden and Society of Sutton Coldfield, 27 L. J. (N. S.), C. P. 137 $-396$

Becch $v$. White, 12 Ad. \& E., 668; 4 P. \& D., $399-430$

Peechey $\because$. Sides, 9 B. \& C., $806-364$

Beer $v$. Santer, 10 C. B., 435-329

Beeston $\because$. Collyer, 4 ling., 309-204

-_- $v$. Stuteley, 27 L. J. (N. S.), Cl., $156-419$

- v. Weate, 5 E. \& B., 986-192

Behren $v$. Bremer, 3 C. L. R., 40-419

liell $r$. Wardell (Willis, 202)-349 
Bell $\imath$. Young, 15 C. B., 524-524

Benjamin $v$. Andrews, 27 L. J. (N. S.), Q. B., 448, M. C., 310-519

Benuett $v$. Freland, 28 L. J. (N. S.) Q. B., $48-430$

-._. $v$ : Womeck, 407

Benwell $v$. luus, 26 L. J. (N. S.) Ch., 663 $-223$

Berkeley $v$. Hardy, 5 B. \& C., 355 ; 8 D. \& R., $102-420$

Berridge $v$. Warl, 30 L. I. C. P., 218104

Berriman $v$. Peacock, 2 11. \& Scott, 524; 9 Bing., 38t-109, 136

Berry $v$. Herd, Cro. Car., 242-115

Fersell [Bessell] v. Landsherg, 14 L. J. (N. S.) Q. B., 355-43t

Besant $v$. L. \& S. W. Ry. Co., S C. B., $36 \mathrm{~S}$ $-153$

Best $x$. Oshorne, R. \& M., 296-569

liezozzi $v$. Harris, 1 F. \& F., 92-165

Bcverley $v$. Lincoln Gas Liglit and Coke Company, 6 Ar. \& E., 829-445, 446

ficwick $v$. Whitfield, 3 P. Willians, $268-$ 109

Bexwell $v$. Christie, Cowp., 397-550

Bigg $v$. Whisking, 14 C. B., 195-129

Biggins $x$. Goode, 2 C. \& J., 364; 2 Tyr., $447-294$

Bignall $v$. Clark, 29 L. J. (N. S.) Ex., $257-278$

Binks $v$. S. Y. \& River Don Nav. Co., W. R., Nov. 29, 1862, 138

Binns $v$. Pigott 9 C. \& P., 20S-590

Birch v. Liverpool (Earl of), 9 B. \& C., $392-203$

- $v$. Stephenson, 3 Taun., 469-308, 313

Bird $v$. Baker, 28 L. J. (N. S.) (Q. B., 7435

— $v$. Bond, N. R., Feb. 21, 1863 -114 $v$. G. E. Ry. Co., 34 L. J. (N. S.) C. P., 366-392

- $v$. Higginson, 4 N. \& M., $505-397$

v. Holbrook, 4 Bing., 628 ; 1 M. \& P., $607-350,390$

- 2 . Ralph, 4 B. \& Ad., $826-310$

Bishop v. Wraith, 2 C. L. R., 287-410

Blichford $v$. Preston, 8 T. R., 93 \& 95550

Black v. Baxendale, 1 Ex., 410-264

- $v$. Ellliot, Times, March 3, 1859577

Blackman $v$. Simmons, 3 C. \& P., 138162
Blackmore (Ex parte), 6 Ves., $3-524$

- (Admx.) r. Pristol and Exeter

Railway Company, 27 L. J. (N. S.)

(2. B., 167-219, 575

Blades $v$. Higgs \& Anor. -379

Blagrave $v$. Bristol Water Works Company, 1 If \& N., 369-94

Blake $v$. Gills [Giblus], 5 Russ. $16 n-443$ - $v$. Peters, 31 L. J. (N. S.) Ch., $88 t$ $-112$

Blakemore $v$. Lancashire and Yorkshire Railway Company, 1 F. \& F., 76-258

Blaker $v$. Anscombe, 1 lios. \& P. N. R., $25-115$

Blakey $v$. Dinsdale, Cowp., $664-518$

Blanchard $v$. Bryilges, 4 Arl. \& E., $176-$ 97

Bland $\iota$. Lipseomlse, 4 E. \& B., $713 x-$ 79

Blatelifird $\iota$. Cole, 28 L. J. (N. S.) C. I., $140-450$

Bleaton $v$. Pyke, 5 NT. \& S., 146-69

Blenkinsopr $v$. Clayton, 7 Taun., 597 582

Blewett $v$. Jenkins, 12 C. B., 16-114

- $v$. Tregonning, 3 Ad. \& E., $554-$ 79

Blount $v$. Pcarman, 1 Bing. N. C., $108-$ 416

Blower $r$. G. W. Ry. Co., 7 L. R. C. P., $655-252$

Floxam $x$. Morley, 7 D. \& R., 407-511

Bloxsome $r$. Williams, 3 B. \& C., 232562

Blundell $v$. Howard, 1 M. \& S., 292402

Blythe $v$. Topham, 1 Tioll. Abr., 88 ; Crn. Jac., $158-137,349,350$

Boldero $v$. Brogden, 2 Moo. \& R., 113 564,565

Bond $\iota$. Downton, 2 Ad. \& E., 26-351

- v. Rosling, 30 L. J. (N. S.) Q. I., $227-464$

Boone $v$. Eyre - 332

Bonomi $x$. Backhouse, 27 L. J. (N. S.) Q. B., $378-80,100$

Booth $v$. N. E. Ry, Co., 2 L. R. Ex., 173 $-253,254$

$v$. Macfarlane, 1 I. \& Ad., 904450

Boraston $v$. Green, 16 East, 71-322, 325

Bostock $v$. North Staffordshire Railway Company, $3 \mathrm{Sm}$. \& Gif., 283-351

Boulton $v$. Reynolds -272

Bowen $r$. Jenkins, $6 \mathrm{Ad}$. \& E., 911-352 
Bower ข. Hill, 2 Fing. (X. C.), 339 ; 2 Scott, 535; 1 Hodzes, 334-\$7

Bowers $r$. Lovekin, 6 E. \& B., 554-207 B., $546,556^{2}-312$

Bowrer v. Cook, \& C. B., 236-353, 354

Boydell $2:$ Macllichael, 1 C. M. \& R., 17 : 3 Tyr., 181, $974-460$

loyfielel r. Porter, 13 East, $200-351$

Borle r: Tamlyn, 9 D. \& R., 430 ; 6 F. \& C. $329-134,147$

Bracegirille $\%$. Peacnck. \& Q. B., 17t-352

Eradbury 2 . Wright -40 t

Brady v. Tod $-5+5$

Bragg $r$. Cole, 6 Aloore, $11 t-\mathrm{I} 2 \mathrm{~S}$

Iraisher $v$. Jachson, 6 MI. \& W., $509-$ 463

Braitluaite $v$. Cooksey, 252

Branscombe $v$. Rowcliffe, 6 C. B., 523333

Bramley (appl.) $x$. Chesterton (resp.), 27 Law J. (X. S.) C. P., 23-45I

Brancker $v$. Molyneaux, 1 MI. \& G., 710 $-352$

Brewer $v$. Eaton, 3 Doug., 230-30t

Briddon $"$. Great Northern Railway Co., $\approx 8$ L. J. (X. S.) Ex., $51-259$

Bridge v, The Grand Junction Railway Company, 3 II. \& W., 244-221

Bridges $\tau$. Sinyth, 5 Biug., $410-258$

Fridgland $x$. Sha 1 ter, 5 M. \& W.,:375-519

Briggs $v$. Baker, Olliphant's Law of Jorses, $57-570$

Bright $v$. Swat, 106

2. Walker, 1 C. M. \& R., 211 ; 4 Tyr., 502-70, 83

Brightley $v$. Norton, N. R, Dec. 27, 1562 $-538$

Bringloe $r$. Morrice, 1 Mod., 210-5it

Bristol (Dean \& Chapter) v. Jones \& Oths., 1 l. \& I., 481; 5 Jurist., 956--111

Broadlsent $\because$. Ramshothain, II Ex., 602 ; 25 Law J. (N. S.) lix., 115-176, 178,157

Broadwater 2 . lilot, Holt, $5 \pm \overline{7}-587$

Brock 2 . Copeland, I Fsp., 203-162

Brown $v$. Best, I Wils, I74-171

v. Crump, 1 Marsh, 567; 6 Taun., $300-314$

v. Elkington, 8 .I. \& W., 132-567, 5,0

_- $v$. Giles, 1 C. \& P., $118-367$

r. Glenn, If Q. I3., 25t-281

ข. Hellaby, 1 H. \& N., $729-119$

2. Mallet, 5 C. I3., 599-1fit
Brown $\imath$. Metropolitan Counties Life Assurance Society-2S2

r. Sherill, 2 Ad. \& E., 138 -285

$v$. Robbins-10I

$\imath$. Turner-392

Browe $x$. Powell, 4 Bing., 230-270

Brownlow $r$. Thomlinson, 1 M. \& G., 484 ;

1 Scott, N. R., 428-94, 144

Iruce $x$. Ifelliwell, 29 L. J. (N. S.) Ex., $297-393$

Brucker $i$. Fromont, 6 T. R., 659-212

Brunton $x$. Hall, 1 Q. P., 7!!9-9I

Bryant $r$. Easterson -517

Brydges 2 . Stepluens, 6 Madd. $279-121$

Buchanan $v$. Parnshaw, 2 T. R., $746-5.51$

C. P., 210-438

Buekingham Ry. Co. in re, 539

Bucksby $v$. Coles, 5 Taun., 311-SS

Iutckworth $\because$ Simpson, 1 C. M. \& R., 834; 5 Tyr., 344-426, 45]

Budd $x$. Fairmener, 8 Bing., 48-554

Bull $x$. Sibbs, 8 T. R., 327-448

Bullard $v$. Harrison, 4 M. \& S., 387-89, 94

Bullen $\imath$. Denning, 8 D. \& R., 657 ; 5 B. \& C. $842-121$

Bulling $\imath$. Ellice, 9 Jurist, $936-208$

Burling $x$. Read -358

Bunch $v$. Kennington, 1 Q. B., $679-368$

Burbago $x$. King, 2 Chitt., $246-338$

Bumby v. Lollett, 16 M. \& W., $644-45$ ?, 528

Burnell $r$. Brown, 1 Jac. \& Walker, 16S387,540

Bunt $r$. Hoore, 5 T. R., $329-267$

Iiurton $x$. Ianks, 2 F. \& F., 213-473

Bush $x$. Green, 4 ling. N. C., 41 ; 5 Scott, $259-368$

bushly 2 . Fisher, 3 N. \& MI., 381-2;6

Butcher $i$ Bntcher, 7 I. \& C., 399; 1 M. \& K., $220-345$

Butler $e$. Hunter. 31 1. J., Ex. 214-1 14

Isuttemere 2 . Hayes, 5 גI. \& W., $450 ; 7$ Dow. (P. C.), $45 y-62,63$

13utterfield $v$. Forester, 11 East, 60-221

firwater $\ell$. Riclarison, 1 Ad. \& E., 50 : 3 N. \& M. $7419-551,569$

c.

Caldecentt $r$. Smythios, 7 C. \& $\Gamma$., sos.321

Calerlonion liailway Company r. Sult, 2 Macy. II. L. Calses, 4t!-81 
Calvert $x$. Joliffe, 2 B. \& Acl., 418-295

Callow v. Brouncker, 4 C. \& P., 518203

Camberwell Rent Charge (In $r c$ ), 4 Q. B., $151-280$

Camoys (Lord) v. Scurr, 9 C. \& P., 386574

Canham $v$. Barry, 3 C. L. R., $396-476$

- $v$. Fisk, 2 C. \& J., 126 ; '2 Tyr., $155 ; 1$ Price, P. C., 148-76

Card v. Casc, 5 C. B., 622-166

Carlyon $v$. Lovering, 26 Law J. (N. S.) Ex., $251-86,181$

Carr $\tau$. Lancashire and Yorkshire Railway Company, 7 Ex., 707-239, 249

Carrington $v$. Roots, 2 M. \& W., 248; Mur. \& H., 14-58

- $v$. Taylor, 11 East, 571-385

Carrutlers $v$. Hollis and Church, $8 \mathrm{Ad}$. \& E., $113-266$

Carter $v$. Crick, 28 L. J. (N. S.) Ex., 238 $-528$

- $v$. Toussaint, 5 b. \& Al., $855-495$, 579

Castlemain $x$. Hicks, 1 C. \& M., 266-28:3 Caswell v. Coare, 1 Taun., 566-593

Cattle v. Gamble, 5 Bing. N. C., 46-416 Cave $v$. Coleman, 3 M. \& R., \&-543

Chambers estates ( $I n, r e), 106$

Channon $v$. Patch, 5 B. \& C., $897 ; 8$ D. \& R., $651-124$

Chaplin $v$. Rogers, 1 East, 192-496, 498, 582

Chapman v. Allen, Cro. Car., 271-588,

$-\frac{589}{-} v$. Cripps, 2 F. \& F., $864-106$ v. Gwyther-552

- $v$. Speller, 19 Law J. (N. S.), Q. B., 239-301

Charlewood v. Greig, 3 C. \& K., 46-159

Charter $v$. Grame and Simpson, 13 Q. B., $216-137$

Chase $\iota$. Westmore, 5 MI. \& S., 180-58s

Chasemore $v$. Richards, 2 H. \& N., 165$96,176,177,178$

Chater v. Beckett, 7 T. R., 201-27

Chawler $\tau$. Hopkins, $52 \mathrm{~S}^{-}$

Cheetham $v$. Hampson, 4 T. R., 31S-132

Chenie 2 . Watson, 2 Pcake's Adul. Cas., $123-522$

Cherry $\imath$. Hemming, 4 Fx., 631-495

Chesterman $v$. Lamb, 2 A. \& E., $129 ; 4$ N. \& M., 195--593

Chetham $v$. Williamson, 4 East, 468-75 Chichester (Earl) r. Prestney-387
Chinery v. Kall, 29 L. J. (N. S.), Fx. 180 $-305,532$

Chippendale $v$. Lancashire and Yorkshire Railway Company, 21 Law J. (N. S.), Q. B., 22-235, 248

Christy $v$. Tancred, 7 M. \& W., 127;9 II. \& W., $438 ; 12$ M. \& W., 316 , II. \& Walm., 50-450

Chnreh $v$. Inclosure Commissioners -98

Churchill $v$. Evans, 1 Taun., 529-133, 147

Churehward $v$. Ford, 2 H. \& N., 446; 26 Law J. (N. S.), Ex., 354-445, 447

- $v$. Stndily, 14 East, 219-36

Clare $v$. Maynard, 6 Ad. \& E., $518 ; 7 \mathrm{C}$. \& P., 741-549, 558, 594

Clark $v$. Allatt, 4 C. B., 335-20s

- $v$. Gaskarth, 2 Moore, 491 ; 8 Taun., $431-292$

v. Mumforl, 3 Camp., $37-379$

v. Roystone, 13 M. \& W., 752-329

v. Simythies, 2 F. \& F., 83-541

r. Webster \& Salt, 1 C. \& P., 104161

Clarke $v$. Cogge, Cro. Jac., 170-90

- $v$. Crowder-392

- v. Gray, 6 East, $56 f-313$

- v. Yonge, 5 Beav., 523-399

- $v$. Westrope, 18 C. B., 765--334

Clayton $v$. Corby, 2 Q. B., $813-84$

Clee v. Hall, 7 Cl. \& Fin., $744-396$

Clegg v. Dearden, 12 Q. B., 576-180

Cleghorn $v$. Durrant, Law Times, Junc 26 , $185 \mathrm{~S}-317$

Clement v. Milner, 3 Esp. N. P. C., 95266

Clements $v$. Smith, 30 L. J. (N. S.) M. C., $16-342$

Cleobury $v$. Tattersall, MSS., 1859544

Coates v. Sterens, 2 Moo. \& Rob., 157$564,565,567$

Cobb (Clerk) $v$. Sclby, 2 N. R., $466 ; 6$ Esp., 103-93

Cocker v. Cowper, 1 C. M. \& R., 418 ; 5 Tyг., 103-74

Cocking $\varkappa$ Ward, 1 C. B., 858-62, 64, $65,60^{\circ}$

Coe $x$. Clay, 5 Bing., 440-309, 411

Coke $r$. Cholmondeley, 27 L. J. (N. S.) Ch. $286-431$

Colam v. Hall-603

Colchester $v$. Roberts, 4 MI. \& II., $769-$ 352

Colegrave $v$. Dios Santos, 3 D. \& F., 255 : 2 P. \& C., $76-458,461$ 
Coleman $x$. Foster, 1 II. \& N., 37- 32

Colesworth $x$. Slukes-30.4

Collard $r$. Sonth Eastern Railway Company, 30 L. J. ( . . ..), K.x., 3!!3-5:34

Collen r. Wright, 7 k. \& B., 301-421, $4601,46 \%$

Collins 2 . Jenkius, 4 ling. N. C., $225-$ 559,560

Collis 2 . liotthamley, Weekly Reporter, Dec. 11, 1558-204

('nltheril $r$. l'uncheon, ㄹ D. \& R., 10-561

'noch $i$. Gookhan, 2 (). 13, 580-417

(nok r: Manstnne-490

('ooke 2 . Hlumphrey, Moore, 17\%-455

$--r$. Kitldelien, 1 C. \& K., 561-453

Coombes $r$. Bristol and Exeter Railway Company, 27 L. J. (N. S.) Ex., 269, $401-264,503$

Cooper v. Elston, 7 'T. R., 14-485

- 2. IIubbuck, 31 L. J. Cl., 123-97

- . Shuttleworti, 25 Law .I. (N. S.) Ex., 114-333

- - $r$. Woolfitt, 2 II. \& N., 122- 412

Corby $v$. Hill, 27 L. J. (N. S.) C. P., 318 $-355$

Cormack $v$. Gillis, 7 liast, $480-484$

Cornfoot $x$. Howke, 6 II. \& W., 381-319, 420,556

Cornwell $i$. Saunilers, 32 L. J. M. C., 6377

Cotton $x$. Woorl, 29 L. J. C. P., 333-21\%, 361

Conntess of Cumberland's case, Moore, $\$ 12$ $-125$

Courthorpe $r$. Maplesilen, 10 Ves, 290115

Couston 2 . Chayman-485,

Cowling $v$. IIigginson, 4 M. \& W., 245-93

Cox 2 . Glue, Monseley and Saint, 5 C. B., $533-347$

- 2 . Godsalve, 6 East, 604-443

- 2 . Reid, 13 (2. 13., 558-371

Coxon v. Great Western Railway Company,

29 L. J. (X. S.) Ex. 165-251

'racknell $v$. Davey, 1 F. \& F., 57-423

Cranston $r$. Clarke- 407

C'resswell $v$. Hedges, 31 L. J. (N. S.) 497 Ex. -471

Gripls 2 . Blanks, 9 D. \& R., 480-419

Ciisp r. Gill, 29 Law Times, 82-489

Croft $v$. Alison, 4 H. \& Al., 590-220

Croshy $r$. Warlsworth, 6 liast, 602 ; 2 Smith, $559-52,53,56,57,58,60,347$.

Crouch 2 : Great Western Railway Company, 26 Law J. (N. S.) Ex., 418-26.t
Crouch $x$. Tregonning- 152

Cuckson r. Stones, ㄴ I. J. (N. S.) Q. R., $25-199$

Cuff $v$. Penn, 1 M. \& S., $11-483$

Culling $v$. Tufhat!, Bull N. P., $31-155$, 458

Cumberland r. Bowes [Lady Glamis], 2t L. J. (N. S.), C. P., 46-333

Cumming $x$. Bedlorough, 15 M. \& IT., 138 $-410$

Cummins $v$. Birkett, 27 L. J. (N. S.) Ex. $216-431$

Cupit $x$. Jackson, Macall, 495-2S0

Curtis $r$. Drinkwater, 2 l;. \& All, $169-$ 559

- - $x$. llamnay, 3 E.p., 8.2-575

r. Mills, 5 C. \& P., 4\$9 - 165

$\imath$. Wheeler, M. \& MI., $493 ; 4$ C. \& P., 196-290

Cutter v. Powell, 2- Smith's Lealing Cases, $1-200$

D.

Lalby $x$. Hirst, 3 Minore, 536; 1 B. \& li., $221-329$

Dialton $r$. Whittem, 3 Q. 13, 961; 3 G. \& D., 260-69, 461

Damerell $x$. Protherne, 10 Q. B., 20- 443

Daniel v. Grace, 6 Q. B., $145-440$

- $r$. North, 11 East, 372-70

Dann $x$. Spurrier, 3 li. \& P., 399-43J

Darby $v$. Harris, 1 Q. 1., $\$ 95-285$

Dare $r$. Heathcote, 25 L. J. (N. S.) Ex., $245-93$

Dark $($ I r re $)$ r. linck, S3--322

Davidson $t$. Stanley, 2 M. \& G., 7:21209

Davies $v$. lharon lierwick, 30 L. J. (N. S.) S4, M. C. -206

Davies [Daris] $v$. Connop, 1 Price, 53321

- $x$. Mann, 10 M. \& W., 546-221

- $v$. Unilerwoorl, 2 H. \& N., $570-$ $426^{\circ}$

Davis $c$. Danks, 3 Hx., 435-31s

..- v. Cyde, 4 N. \& M., 462 ; 2 Al. \& E., $623-277$

$\imath$. Jones -465

_ $\bullet$. ()swell, $7 \mathrm{C}$. \& P., S04-560

— $v$ Powell, Willes, 46; 7 Morl., 249 - 256,298

Davy v. Cracknell, 1 F. \& F., 57-14s

- $v$. Gillet, MSS., 1861-530 
Daw $v$. Hole, 15 Law J. (N. S.) Q. 13., 32 $-353$

Dawes $v$. Hawkins, 29 L. J. C. P., 343101

Diawson $v$. Alford, Dyer, 312-286, 287

$-v$. Cropl, I C. I., 961 ; 3 D. \& L., $225-302$

r. Chamney, 5 Q. B.. 15t-601

$-v$. Collis, 10 C. B., 523-484

- 2 . Fitzgerald, 9 L. R., Ex., 7--391

$-v$. Linton, 5 I. \& Al., 521; 1 D.

\& R., 117- 439

- $v$. Midland Railway Co, 8 L. R., Ex. 8-140

1)ityrell $v$. Hoare, 12 Ad. \& E., 356-38t

l) eane $v$. Allalley, 3 Esp., $11-455$

- $v$. Clayton, 7 Taun., 419-389

$-v$. Keat, 3 Camp., 4-575

Dearden $\varepsilon$. Evans, 5 M. \& W., 11; 2 II. \& II., $7-110$

Degg (Adx.) v. Midland Counties Railway, 1 H. \& N., 773-211, 217, 218

Jegge $t$. Tucker, 1 H. \& N., 500-601

Delaney $v$. Fox, 26 Law J. (N. S.) C. P., $248-357,437$

Delapole $r$. Delapole, 17 Ves., $150-126$

Denby $x$. Nloore, I B. \& Al., 123-440, 441

Dendy $v$. Nichol, 27 L. J. (N. S.) C. P., $220-288,451$

v. Simpson, 18 C. B., 831-346

Denne $v$. Light, 26 Law J. (N. S.) Ch., $459-90$

Dennis $v$. Lofft, Weekly Reporter, Feb. 5, $1859-430$

Dent Cummutation ( In re), 8 Q. B., 43 400

Denton 2 . Richmond, 1 C. \& M., 734; 3 Tyr., $630-313$

Derby (Earl) v. Gee \& Others-169

Dering (Ex. parte), 1 De Gex B. C., 398 $-521$

Dickinson $v$. Follett, 1 Moo. \& R., 299570

and 5 C. \& P., 81)-553

$v$. Grand Junction Railway Company, 7 Ex., 282-174, 177, 178, 186

Digby $v$. Atkinson, 4 Camp., 275-451

- $v$. West IIam Board of Health, Weekly Reporter, Mlay 1, 1858-602

Dimech $v$. Corlett, 33 Law Times, $21-$ 478

Dingle $v$. Hare, 29 I. J. (N. S.) C. P., 148 $-527$
Dixon $\because$ Geldard, A. D., 1857--11s

Dolson $v$. Collis, 1 HI. \& N., 81-20:3

Doe dem. $\Lambda \sin r$. Summersett, 1 l). \& Ad., $135-432$

- liaker $v$. Coombes, 9 C. B., $714-345$

liurrett $r$ Kemp, 2 Scott, 9 ; 2 ling., N. C., $102-170$

- Bennelt $v$. Turner, 7 M. \& W., $226-$ 316

Bevis, 7 C. B., 456-482

Bloomfield $v$. Suith, 6 East, 52n435

Cates $v$. Somervile, 9 D. \& R., 100435

Daggett $v$. Snowdon, 2 W. Bl., 1224 $-433$

Davenish $\because$. Moffatt, 15 Q. B., 25\%413

- Davenport $v$. Rhodes, 11 MI. \& W., $600 ; 1$ D. \& I., 292-433

Dixon $v$. Roe, 7 C. B., 134-304

Douglas v. Lock, 2 Ad. \& E., 705 ; 4 N. \& M., $807-90,109,384,443$

IIall $v$. Benson, 4 B. \& Al., 585-4:32 Hertford (Marquis of) $v$. Hunt, 1 II. \& W., 690 ; 2 Gale, $102-423$

$507-432$

Jones $v$. Crouch, 2 Camp., 448-122 Jordan $v$. Ward-435

- Kirloy $v$. Carter, 1 Ry. \& Mloo., 237 $-435$

Kiudersley $v$. Hughes, 7 M. \& W., $130-432,433$

Lewis $v$. Rees, 6 C. \& P., $610-169$

Macartney (Earl) $v$. Crick, 5 Esp., $196-432$

Mann v. Walters, 10 B. \& C., 626 ; 5 M. \& Ry., 357-432

Manvers (Earl) $\imath$. Mizem, 2 Moo. \& R., 56-420, 432

Marlow $v$. Wiggins, 4 Q. B., $367 ; 3$ G. \& D., 504-417

Marsack $v$. Read, 12 East, 57-432

Morgan $v$. Powell, 7 M. \& G., 980410

-_ Monk $x$. Geeckie, 1 C. \& K., 307290,412

Murrell $v$. Nlilward, 3 M. \& W., 325 $-434$

Oldershaw $v$. Breach, 6 Esp., 106435

Philips v. Benjamin, 9 Ad. \& E., $644-410$

Pitt $v$. Laming, 4 Camp., $73-314$ 
Doe dem. Plummer $\iota$. Mainby, 10 (2. 13., $473-434$

Pring $x$. Pearsey, 7 l. \& C., 304; $?$ D. \& R., $005-143$

Rhodes $r$. Robinson, 3 lbing. (X.C.), $67 \%-4: 0,432$

Rigge 2 . Bell, 5 T. R., 471-434

liogers $r$. Price, 19 L. J. (N. S.), C. P., $121-11$;

ข. Rowlands, 9 C. \& P., $734-429$

r. Shaweross, 3 B. \& C., 752-304

r. Slight, 1 Dowl., 163-411

Sicer 1. Lea, 11 Last, 312-432

- 2 . Spiller, 6 Esp., 70-4:32

Strickland 2 . Spence, 6 Last, $120-$ 432

Thomson $\imath$ Amey, 12 Ad. \& E., 476 $-415,451$

Thomas $x$. Fiell, 2 Dow., $542-450$

Tilt $r$. Stratton, 4 ling., $446-435$

Waters $r$. Ifonghton, 1 M. \& Ry., $208-41 \%,+38$

Webly $v$. Dixon, 9 East, 15-435

- Wetherell $\tau$. Bird, 6 C. \& P., 195125

Wimuall $x$. Broad, 2 11. \& (4., 523315

— Wood, 3 F. \& Alel., 724-75

Dolly $x$. Hes, 11 A. \& E., $335-426$

Donellan v. Read, 3 B. \& Ad., 899-495

Donglas $\imath$. Archbutt, 21 L. J. (N. S.) Ch., $271-478$

- $v$. Corbett, 6 E. \& B., 511-600

Dovaston 2 . Payne, 2 H. Bl., 527-135, . $145,148,150,265$

Downshire (Marquis of) $v$. Lady Sandys, 6 Yes. $107-126$

Dowell $\%$. Dew, 12 L. J. (N. S.) Ch., $158-415$

$\vartheta$. Feneral Steam Navigation Co., 5 k. \& 1\%, $2015-2.1$

Draper $x$. Crofts, 15 MI. \& W., $166-450$

Jrant $r$. Hrown, 3 l. \& \& C., $465, ; 5$ D. \& R., $582-417$

Irury $v$. Mrlins, 6 Ves., 325-308

r. De la Fontaine, 1 Taun., 131-502

$r$. Macnanar:t, 25 L. J. (N. S.) (Q.

li., 5-416

Juch $r$. Lratrlyl, Macl., 217-\$16

Durddcn $r$, firarlians of Clutton Union, 1 II. \& $\mathrm{N} ., 62 \bar{\jmath}-179$

Indloy (Loril) $r$. Warl (Lord), Amb, 113; inill $1.1^{\prime}, 31-455$

Duncan $v$. Topham, 8 C. B., 225-493

1) unk r. Hunter, 5 li. \& Al., 322-20!
Dunlop $r$. Dalhousie (Earl of), $\tau$ Bligh

X. S., $422-452$

¿. Waugh, 1 Peake, $167-543$

Durell $x$. Evans, 31 L. I. (N. S.) Ex., 337 $-536$

Durham and Sunderland Railway Company v. Walker, 11 L. J. (N. S.) Ex., 440 $-90$

Dynen $r$. Leach, 26 L. J. (N. S.) Ex., 221 $-219$

E.

Eardley $v$. Price, 2 N. S., 333-206

Eastwood $v$. Kenyon, 11 A. \& E., 438 ; 3 P. \& D., $276-64$

Eaves $v$. Dixon, 2 Taun., 342-563

Edge $v$. Strafford, 1 C. \& J., 391-65

Edmonson $v$. Edmonson, 8 East, 294-66

Edmonds $x$. Eastwood, 27 L. J. (N. S.) Ex., $209-440$

Edwards $v$. Bunbury, 3 Q. B., $885 ; 3$ G. \& D., 229-401

Egerton $v$. Nathews, 6 East, $307-507$

Elias $\tau$. Nightingale, 27 L. J. (N. S.) (Q. B., 195 ; M. C., $151-602$

Elliott $v$. Thomas, 3 M. \& W., 170-129

Ellis $v$. Arnison, 3 D. \& R., 27; 1 B. \& C., $70-131$

— ?. Chinnock, 7 C. \& P.,169-593, 594 v. Loftus Iron Co., 10 L. R. C. P., $10-141$

$x$. London and South Western Rail. Co., 2 H. \& N., 424-150

v. MIortimer, 1 Bos. \& P., 257-574

$\imath$. Taylor-271

- $\imath$. Woodbrilge-103

Elliss $v$. Elliss, 27 L. J. Ex., 516-2 289

Elmore $r$. Stone, 1 Taun. , 460-498, 580, 583

Filton $i$. Jordan, 1 Stark. N. P. C., 12$\rceil-561$

— v. Brogden, 4 Camp., $281-564$

Elwell $v$. Crowther, 31 L. J. (N. S.) Ch., $768-196$

lilwes $r$. Mawe, 3 East, $38-454,458$

limberton $x$. Matthews, 31 L. I. (N. S.) Ex., 139-529

Emblen $c$. Myers, 30 L. J. (N. S.) Ex., 71 $-359$

Embleton $r$. Brown, 30 L. J. (N.S.) M. C., $1-169$

linhrey $\because$. Owen, fo Ex., 353--187, 158, 190,196

Emery $v$, larnett, 27 L. J. (N. S.) C. P., $211 ;--4: 37$ 
Emery $c$. Feake, Vetcrinarian, vol. 29, p. $430-156$

Emmerson $v$. Heelis, 2 Taun., 38-50, 51, 60

Emmett $\imath$. Ricldell, 2 F. \& F., 142-5.38

Empson $v$. Soclen, 4 B. \& Ar., $655 ; 1$ N. $\& \mathrm{M} ., 720-125$

Fssex (Earl of) $v$. Capel, A.D. 1809 (Clitty on Game Laws, 31) - 365

Evans $r$. Birel, 3 Camp., 10-223 v. Botterill, 33 L. J. (N. S.) M. C., $50-376$

v. Elliott, 6 N. \& M., $606 ; 5$ Ad. \& E., $142-279$

v. Evans, 2 Camp., 491-115

v. Matthias, 26 L. J. (N. S.) Q. B., $309-411$

r. Oakley, 1 C. \& K., 125-142

$v$. Roherts, 5 D. \& C., 829 ; 8 D. \& R., $611-50,51,54,56,57,59,60,67$ v. Wright, 27 L. J. (N. S.) Ex., 50 ; 2 H. \& N., 527-285

Every $v$. Smith, 26 L. J. (N. S.) Ex., 344 $-343$

Ewart v. Graham (Bart.), 29 L. J. (N. S.) Ex., 88-382, 383

F.

Fairmener $v$. Budu, 7 Bing., 575-559

Falmouth (Earl) $v$. Thomas, 1 C. \& MI, 89 ; 3 Tyr., 26-61, 306, 588

Farrant $x$. Olmius, 3 B. \& Al., 692-313 $r$. Thomison, 2 D. \& R., 1; 5 l). \& Al., $826 ; 3$ Stark. $130-461$

Faviell $\imath$. Gaskoin, 7 Ex., 273-317

Faweett $v$. Cash, 5 H. \& All., $907-200$ - 2. The York and North Midliand Railway Company, 16 Q. B., 610-144, $147,148,150,152$

Feun 2 . Harrison, 3 T. R., 760-545, 555 Fennell $r$. liiller, 5 B. \& C., $406 ; 8$ D. \& R., 204-56.2

Fentiman $v$. Suith, 4 East, $10 \bar{\tau}-71$

Fenton $r$. Logan, 9 Bing., $676-286$

Ferrier $v$. Peacock, 2 F. \& F., $717-538$

Few v. Perkins-454

Fewings $r$. Tindal, 1 Exeh. 295-206

Fielıl v. Adames, 10 L. J. (N. S.) (2. 13., 2 $-266$

Fielden $v$. 'Tattersall, N. R. Jan, 1863-328

Fielder $r$. Starkin, 1 H. Pl. $17-443$, 5. 2 , 574

Fisber $v$. Burrell, 2 (. B., 239; 8 Ex., $256-398$
Fiteh 2 . Rawling, 2 H. 13l., 399-79, :349

Fitzgerald $v$. Iveson-527

Fitzherbert $v$. Shaw, 1 If. B3., 2.58-455, 461

Fitzmanrice $v$. Bayley, 26 L. J. (N. S.) Q. B., $114 ; 27$ L. J. (N. S.) Q. L. (in Error'), 143-112

Flanders $x$. Runbury, sce 1 C. B., 678401

Fleeming $v$, Snook, 5 Leav., 250-31t

Fleming (Lady) 2 . Simpson, 6 L. J. (N.S.) Q. B., 207-110

Fletcher $v$. Calthorp, 6 (2. 13., S80 -369 $v$ Rylands, 1 J. R. Ex., 265-156 v. Tayleur, 17 C. 13., 21-511

Fliglit $v$. Thomas, 11 Ad. \& E., 688; 10 Ad. \& E., 59 ; 3 P. \& D., $442-84$

Flurean $x$. Thornhill, 2 Sir W. Black, $107 \mathrm{~s}$ $-398$

Folkingham 2 . Croft, 3 Anst., 700-411

Foord $x$. Morles, 1 F. \& F., 496- 207

Forbes $\imath$. Carney, Wallis (Lyne): L. Ch. Rep., 38-312

Ford $\because$ Lacey, 30 L. J. (N. S.) Ex., 352169

v. Tynte, 31 L. J. (N. S.) Ch., $177-$ $38:$

Fortl $v$. Simpson, 13 Q. B., 680-590

Foster $v$. Taylor, 5 B. \& Ad., 887-52:3

--- (appt.) 2 . Smith (resp.), 18 C. B., $156-557$

Fowkes v. Joyce, 2 Vern., 129-275, 276

Franklin $v$. Carter, 1 C. B., $750-440$

Frankum $v$. Falmouth (Earl), 2 Ad. \& E., $452 ; 4$ N. \& M., 330-171

Freemantle $v$. L. \& N. W. Ry. Co., 31 L. J. (N. S.) C. P. 12-360

Freemason $r$. liooman, 2 Keble, 291-446

Freestone $r$. Casswell, 4 L. R. Q. B. 519 $-114$

French $v$. Styring, 2 C. B. (N. S.), $357 ; 26$

L. J. (N. S.) C. P. 181-559

Frend $v$. Tolleshunt knights-409

Frewen $x$. Phillips, 30 L. J. C. P. $356-96$

Frith $x$. Purvis, 5 T. R., 432-279, 283

Frusher $\because$. Lee, 10 MI. \& W., 709-29?

Furley $r$. Wood, 1 Fisp., 197-432

(i).

Galiay $r$ Lloyd, 5 D. \& R., 641; 3 P. \& C., $793-231$

Trage $x$. Aeton, 1 Salk., $326 ; 1$ Com. Ren. $67-27 \%$ 
(rale r. lates, 33 L. I. (N. A.) Ex.-235

(ivllin $x$. L. \& . I. W. Ry. Co., 10 L. R. (2. B., $212-253$

Gilloway $r$. liepworth, 2 C. L. R., $860-$ 419

Galway 2 . Iaker, 5 C'I. \& Fin., 15i-121

- $r$ Cozens-2il

Gimly $x$. Tubber-4.53

Gartiner $x$. Williamson, 2 B. \& Ad., 226$2 \$ 1, .288,296^{\circ}$

Gardner $r$. Chatring Cross Ry. Co., 31 L. J. (天. S.) Ch., 1s1-539

- $\because$ Gront, 2 C. B. (N. S.), $340-$ 500

Gartiud $x$. Jekỵll, 2 Bing., 273; 9 Moore, 511.2- $-443,444$

(iatewarl's Case, 6 Rep. 59 b. $-7 \mathrm{~s}$

liee r. L. \& York. Ry. Co. -534

(iecckie 2 . Monek, 1 C. \& K., 307-290

Gealdes $x$. Tennington, 5 Dow., $159-543$, 553

(ient r. Harrison, 29 L. J. (N. S.) Ch., 68 $-111$

(iesswood (ex purte), 2 C. \& R., 269-201 (irthing r: Morgan, Law Times, May 5, $1857,5 \mathrm{~W}$. R. 586 ; E. T. $185 \%, \mathrm{Q}$. I. -1.58

Hillins $r$. Board of Metropolitan Asylum, 11 Beav., $1-421$

(iibson $x$. Kirk, 10 L. J. (N. S.) Q. B., $967 ; 1$ G. \& D., 252; 1 (Q. 13., $850-446,447$

- $v$. S. E. Ry. Co. -359

Giles $\imath$. Jones, $11 \mathrm{Ex}, 393-523$

- $r$. Spencer, 26 L. J. (N. s.), 237, C. P. -281

— - Tatf Vale Railway Company, 2 E. \& I3., $822-512$

Gill 2. M. S. \& L. Ry. Co., S L. R. Q. H., $156-2.2$

(Himson $v$. Woodfal!, 2 C. \& P., 41-597

(iingell $r$ Glascock, 8 ling., 84 ; 1 M. \& Scott, $125-222$

filaduan $v$. Johnson, 36 L. J. (X. S.) C. P., $153-157$

Glen v. Dungey, 4 Lx., 61 ; 14 M. \& W., $1-448$

Gilenliam 2 . Hantyy, 1 Lr. Rayun, , 739-128

(ilover $i$. Coles, 7 Moore, 231 ; 1 ling., 6 $-292$

- . IIackett, 26 L. J. (X. S.) Ex., $416-418$

(j)ynn $v$. Thomas, 1 Ex., $870-271,272,275$ (iorlts $x$. Rose, 25 L. J. (N. S.) C. B., til491
Golden $x$ : Taylor, 2 F. \& F., 110-164

Golding $r$. Stoeking, 4 L. R. Q. 13., 516-144

Goldsworth $r$. Knight $-46 \mathrm{~S}$

Gooday $x$. Nitchell, Cro. Eliz., 441- $\% 9$

Goode $r$. Jones, 1 Peake, 235-2:29

Gooding $r$. Britnall, 31 L. J. (N. S.) C. P., $4-354$

Goodman $x$. Kennell, 1 II. \& P., 241 ; 3 C. \& P., 167-219

Gompertz $\iota$. Denton, 1 C. \& M., 207-596 Gordon $v$. Woodford, 26 L. J. (N. S.) Ch., $222-111$

$\longrightarrow$ Rolt, 4 Ex, 365-220

- 2 . Harper, 7 T. R., 9 ; 2 Esp., $465-115,45 \mathrm{~S}$

Gorman $v$. Boddy, 2 C. \& K., 145-196

Gorton $r$. Falkner, 4 T. R. 265-286

Gott $v$. Gandy, 2 C. L. R., 392-42S

Grabum $x$. Brown, 16 M. \& W., 831-403

Graham $\imath$. Ewart, 1 H. \& N., $550 ; 11$ Ex., 326-386

v. Musson, 5 Bing. N. C. ti03477,536

$-v$. Peat, 1 East, 246-345

Grant $x$. IIulton, 1 B. \& Al., 134-35S

Grantham $r$. Hawley, Hob., 132-323

(iraves $v$. Teld, 2 N. \& M., $725-442$

Great Northem Railway Company (appts.) v. Morville (resp.), 21 L. J.. (N. ¿.), Q. B., 319-240

ข. Swaf.

field -253

2 C. B. (N. S.), $34 t-260$

Greathe:d v. Morley, 3 M. \& ('., 139-3S2, $356^{\circ}$

Greatrex $\tau$. Hayward, 1 Ex., 291-183, 19:3 Greaves $r$. Ashlin, 3 Camp., 426-480, 492 - $\imath$. Wilson, 27 L. J. (N. S.) Ch., $5 \pm 6$ $-474$

Green $\imath$. Goddard, 1 Salk., 64I-344

- Jenkins, 29 L. J. (N. S.) Ch., $505-$ 472

— ¿. Saddington, Jurist, Aug. 1, 1857 65,68

Greene $v$. Jones, $1 \mathrm{Wm}$. Saun., 299, Note $6-352$

Greenslade $v$. Dower, 7 B. \& C., 634; 1 11. \& R. $640-515$

$-v$. IIalliday, 6 Ping., $379-191$ $4 \mathrm{Tyr}$, 566-314

Greenway $v$. Marshall- 569

$-559$ 
Gregory $v$. Gregory, (G. Cooper, 201 ;) S.C., Jacob, $631-112$

- v. West Midland Rail. Co., 33

L. J. (N. S.) Ex. 155-254

— 2 . Piper, 9 B. \& C., 591 ; 9 М.

\& R., $500-212$

$v$. Wilson -471

Gregg $r$. Coates, 23 Beav., 33-429

Griffith $v$. Young, 12 East, 513-61, 63, 66

Griffiths $v$. Chichester, 7 Ex., 95-278

- v. Hatchard, 1 K. \& Johu. 17478

- $v$. Puleston, 13 MI. \& W., 358321

$v$. Tombs, 7 C. \& P., $810-322$

Griffenhoofe $r$. Danbuz, 4 E. \& B., 230 ;

3 C. L. R., 91 ; 5 E. \& B., $746-395$

Grimoldby $v$. Wells -485

(trimwood $v$. Moss, 7 L. R. C. P., 360305

Grinstead $v$. Narlowe, 4 T. R. $717-78$

Grove $x$. West, 7 T'aun., 39-143

(1) rubb $v$. Brown, Weekly Reporter, Nov. I3, 1858-346

Gulliver 2 . Cosens, I C. R. 788-272, 273

Gundry v. Felthan, 1 T. R., 334-365

trurr $v$. Scudds, 11 Ex, 190-260, 505

(ruy $v$. West, 2 Selw., N. P., 1287-13I

Giulgeon $v$. Bessett, 26 L. J. (N. S.), Q. B., $36-448$

firulab $x$. Inclosure Commissioners-105

II.

IIackett $v$. Overseers of Long Berington408

Halley $i$. Baxendale, 9 Ex., $341-509$, $510,511,514,533,534$

Haigh $v$. London and North Western Railway Company, 1 F. \& F., $646-152$

Haldane $v$. Johnson, 1 C. L. R., $672-$ 426

Hale $v$. Oldroyd, 14 MI. \& W., $789-170$

Hall $v$. City of London Brewery Company, 31 L. J. (N.S), Q. B., 257-463

$v$. Fearnley, 3 Q. B., 919 ; 3 G. \&

D., $10-351$

$v$. Knox, 33 L. J. (N. S.), M. C. 1376

$\imath$. North Eastern Railway Company,

10 L. R. Q. I., $437-253$

$v$. Rogerson, Olliphant's Law of Horses, 56-569

-... vinith [Swift], 6 Scott, 167-171
Hallen $v$. Runder, 3 Tyr., 959 ; 1 C. MI. \& R., $266-66$

Hallifax $v$. Chambers, 7 Dow., 342 ; 4 MI. \& W., $662 ; 1$ H. \& II., 417-306

IIalliwell $v$. Phillips, Jurist, July 10, 1858 $-126$

Hamer \& Strayan v. Knowles-101

Hamerton $v$. Stead, 3 B. \& C., 478 ; 5 D. \& R., 206-2S1, 412

Hamilton $v$. Clanricarde (Earl of), 1 Bro. P. C., $311-420$

Hammack $v$. White, 30 L. J. (N. S.) Cl. $681-362$

Hammersmith Rent Charge $\left(I_{n} \cdot c\right), 4$ Ex., $87-280$

Hammond (Ex parte), 1 De Gex, B. C., $93-524$

Haneock $v$. Southall, 4 D. \& R. 202-603

Hannam e. Nlockett, 4 D. \& R. 518; 2 B. \& C. $934-345,385$

IIanks $v$. Palling, 6 E. \& B., 659-479

Hanson $x$. Armitage, 5 B. \& Al., $557-495$, $496,500,503$

Harcourt v. White, 30 L. J. (N. S.), Ch. 681; 6 Jurist, 1087-112

Harlcastle $v$. Shafto, 1 Anst., 181-312

- $r$. South Yorkshire Railway Company, 28 L. J. (N. S.) Ex., 139350

$-v$. Soutls lorkshire and River Don Company, 4 H. \& N. 67-138

Harden $v$. Hesketh, 28 L. J. (N. S.), Ex., $137-418,469$

Harman v. Reere, 25 Law J. (N. S.) C. P. 257 ; 18 C. 13. $587-505,587,588$

Harmer $x$. Cornelius, 28 L.J. (N. S.), C. P., $85-202$

Harper $v$. Charlesworth, 4 B. \& C., $57 t$; 6 D. \& R., $572-91$

Harris $v$. Hoskins, $34 \mathrm{~L}$. J. (N. S.), M. C. $145-376$

- $\imath$. Mantle, 3 T. R., 306-307

$\imath$. Rydling, 5 MI. \& W., $60-81$

Harrison $v$. Barnby, 5 T. R., 246-289

- $v$. London, Brighton and South Coast Railway Company, 31 L. J. (N. S. ', Q. B. $113-251$

Hart v. Prendergast, 14 M. \& W., 741-509

-v. Sattley, 3 Camp., 523-503

$\imath$. Windsor, $12 \mathrm{MI}$. \& W., $68-425$

Hartley $v$. Burkitt, 4 Bing. N. C., $687-316$

— $v$ Harriman, 1 B. \& Al., 620 ; Holt, 617 ; 2 Stark., 212-157, 158, 160

Harvey $v$. Bridges -378 
Harvey r. Poock, 11 M. \& $\mathbb{W} .740-297$ r. Grablam, 5 Al. \& 1\%, 61; 6 N. \& M., 754: 2 HI. \& II. 146-332

IIaseler $r$. Lemnyne, 2s L. .T. (N. S.) C. P. $103-25.5$

Hatch $r$. II:ale, 15 (1. B., 10-278

Ilawkes $r$. Orton, $5 \mathrm{Ad}$. \& E., 367-423

I Iawkins r. Carbines, 27 Law J. (N. S.) Ex., $44-357$

I Layling $x$. U:key, S kx., 5.3I-35.2

1 [ead $x$. Tiattersall-54!

ILeale 2 . Me.Inrray, 23 liear., 401-411

1Teart $r$. Camplin, 15 Law Times, 437--413

lLeap $x$. Larton, 122 C. B., 27t-461

Hegan $x$. Jolnson, 2 Tamm, 14s-290

Heisch 2 . Carrington, 5 C. \& P., 471$453^{\circ}$

I Lelyear $x$. Hawke, 5 Esp., $71-545,55.5$

1 Lellaby $x$. Prown, 1 H. \& N., T2y-419

Hellyer 2 . Sileox, 19 Law J. (N. S.) Q. l;., $295-447$

IIenchett $x$. Kimpson, 2 Wils., 140-295

IIenilerson $\imath$. Eason, 18 Law J. (N. S.) Q. B., 102; 21 Law J. (N. S.) Q. B., 82 ; 15 Law J. (N.S.) Ch. 457-452

IIerlikenden's Case, 4 liee., $62 b-116$, 125

IIetton $r$. English, 7 E. \& B., 94-515

Iewitt 2 . Sir C. Isham, 7 Kx., $77-127$

Hewlins $v$. Shippam, 7 D. \& R., $783 ; 5$ L. \& C., $221-70,71,73,74$

Hers 2 . Tindall, 30 L. J.(N.S.), Q. B., 362 - 4 its

IIiekman $\imath$. Machin, 28 L. J. (N. S.) Ex. $311-468$

IIiggon 2 . Mortimer, 6 C. \& P., 616-338

Hirgs $r$. Thrale, Olliphant's Law of Horses, $56-570$

Higham $v$. Rabbit, 5 Bing. N. C., 622; 7 Dow., 653 ; 7 Scott, 827-92

Ilighmore 2 . Primrose, 5 M. \& S., 65; 2 Chit., 33.3-64

Hildreth $x$. Adamson, 30 L. J. (N. S.) M. C., 204-197

Ilill 2 . Jialls, 2 II. \& N., 299 ; 27 L. J. (N. S.) Ex., 45, 542, 598

1\%. Isarclay, 18 les., $63-311$

- r. Walker, 2 Peake's Adr. Cas., 2343 ;i)

Hilis, $i$ Shejmard-516

Hinchliffer 1 . Armistead, 9 II. \& W. 1554!) 1

2. Kinnoul (Furl of), is Scott, fi.j), S. C. - 88

Ilinile $r$. I'ollett, 6. .I. \& W., 529-339
IIingeston $x$. Kelly, 1s L. J. Kx., :360199

Ilitehman $x$. Wialton, \& M. \& W., $400-$ 460,461

Ilobby $\imath$. liussell, 1 C. \& K., 716-589

Hockin v. Cooke, 4 T. R , 314-481

Horlges $v$. Lawrence, 18 Jus. P'ea., 347 284

- Litehfield, 1 New Ca., 492-475

Hodgson $\because$. Coates, 2:3 Beav., 33-429

— $~ \imath$. Le Brett, 1 Camp., 233-500 - $v$. Johnson, Jurist, April 2, 1859 $-67$

v. Millanil Railway Company, 33

L. J. (N. S.) (Q. B., 233 ; and 35

L. J. (N. S.) (Q. B., $85-25.1$

Hodsoll $v$. Stallebrass, 8 Dow. (P. C.), $482-163$

Hogan $v$. Sharpe, 7 C. \& P., 755-166

Hogg $r$. Norris, 2 F. \& F. 246-464

Ifolbatch v. Warner, Cro. .Tac., 665-133, 139

Holder $v$. Coates, Moo. \& MI., 112-117

IIolding $r$. Pigott, 7 Bing., 465-325

Hole $v$. Barlow, 27 L. J. (N. S.) C. P., $207-355,362,363$

Ifolland $v$. Hopkins, 2 ls. \& P., 243-5 47 - $\imath$. North Easteru Railway Company, 4 L. R. Ex., 254, and 6 L. R. Lx., $123-253$

Hollingham $v$. Head, 27 L. J. (N. S.) C. P., 241-514

Holloway $v$. Berkeley, 6 B. \& C., 2 ; 9 D. \& R., 83-4.3.

IIolmes $v$. Bellingham, 23 L. J. C. P., 132 $-103$

- 2 . Goring, 2 Bing., $76-88,89$

- $v$. Hoskins, 9 Ex., 753-583

$-v$. Onion, 26 L. J. (N. S.) C. P., $261-213$

- $v$ Wilson, 10 Ad. \& F., 503-353, 354,355

Holt $r$. Daw, 16 Q. B., $990-352$

Holtpzaffell $v$. Baker, 18 Ves., 115-429, 430

Holyclay $x$. Morgan, 28 L. J. (N. S.) (Q. B., $9-566$

Homer $v$. Mellars [Mallars], Law Times, Jan. 16, 1858-513

Honfray $v$. Scrope, 13 Q. B.. 509-402

Honeyman $v$. Marryatt, 6 Cl, 112 ; 21 Beav, $14-471$

IIood (Lord) $\tau$. Kendall, 17 C. B., 260123

IIooker $v$. Wilkes, 2 Stra., $1120-36 s$ 
Hooper v. Clarke-454

-2 . Treff $r y, 1$ Ex., 17-4SS

Hope v. Atkins, I Price, 143-4S?

Hopkins $v$. Tanqueray, 15 C. B., $130-551$

Horn $v$. Thornborongh, 3 Ex., $846-363$

Itorsford $v$. Webster, 1 C. M. \& R., 696276

Hort $v$. Newry (Lord), 1 L. J., K. B., 237 $-543$

Horwood $v$. Powell -107

$$
r \text {. Smith, } 2 \text { T. R., } 750-600
$$

Inoskins $v$. Featherstone, 2 Bro. C. C., 552 $-310$

Honghton $v$. Bankhart, Law Times, March 12. $1859-604$

Hounsell $x$. Smyth (Bart.) 29 L. J. (N. S.), 203, C. P. ; 7 C. B. (N. S.), 731 ; 1 Law Rep., 440-138

Iloward $v$. Castle, 6 T. R., $642-550$

- $v$. Shaw, S M. \& W., 119-4ti, 448

$-v$. Sheward, 2 L. R. C. P., $148-$ 222

Howe $v$. Palmer, 3 B. \& Al., 32I-495, 496,498

Howell $\imath$. Coupland-47t

_- $r$. Richards, 11 East, 633-313

Hudson $v$. Baxendale, 27 L. J. (N. S.) Ex., 93-264

$-\imath$. McCrea, 33 L. J. M. C., 65377

¿. Nicholson, 5 M. \& W., $535-353$

- . Roberts, 6 Ex., 697 ; 20 L. J. Ex., 697-160

ITughes $v$. Buckland, 15 M. \& W., 346363,364

-_ venton, Weekly Reporter, March 12, 1859-40J

__- $\imath$. Great Western Railway Company,

14 C. B., $637-256$

- - $v$. Humphreys, 3 E. \& B., $954-5.22$

- (Ex parte), 23 L. J. (N. S.), M. C., $138-202$

Ifull $v$. Niorell-298

- and Selby Railway Company ( $/$ re,$e$,

8 L. J. (N. S.) Ex., 260-168

- 2 . Vanghan, 6 Pricc, 197-447

IIume $x$. Oldacre, 1 Stark. N. P. C., 351365

IItumihries $x$. lirogden, 12 Q. B., 7899-8n, 81

Hunt $v$. Hecht, S Ex., $81+-502,50.3$

- 2 . Bishop, 8 Ex., $675-413$

llunter $r$ Giblons, 1 H. \& N., 459-356

- $v$ Rice, 15 East, 100-512
Hurst $v$. Hurst, 4 kx., 571-109, 328 , 438

- 2 . Orbell, 8 Ad. \& E., 107-590

Hussey $v$. Hussey, 5 Madd., 44-126

Hutchins $v$. Chambers, 1 Burr., 579-2S6 v. Naughan, 4 Gwill., 1594-398

Hutchinson $e$. Bowker, 5 M. \& W., 235481

C. P., 19 Fx. Ch. - 98

- $v$. York, Newcastle, and Berwick Railway Company, 5 Ex., 343-218

Hutton $v$. Hamboro'-103

v. Warren, T. \& G:, 646 ; I MI. \& W., 466 ; 2 Gale, $71-307,320,324$ Hyatt $r$. Griffiths, 17 Q. B., 505-451 - $x$. Graham, 32 L. J. (N. S.) Ex., 27 $-349$

\section{I.}

Ibletson v. Peat, 34 L. J. (N. S.) Ex., 118 $-376$

Ibbs $v$. Richardson, 1 P. \& D., $61 \mathrm{~S} ; 9 \mathrm{Ad}$. \& E., $849-44 \mathrm{~S}$

Illidge $v$. Goodwin, 5 C. \& P., 190-220

Illott $v$. Wilkes, 3 B. \& Ald., 304-390

Ingram $v$. Barnes, 26 L. J. (N. S.) Q. B., $319 ; 7$ E \& B., I15-20

Inman $v$. Stamp, 1 Stark. N. P., 12-64, 68

Insole $v$. James, 1 H. \& N., 243-I80

Living $x$. Mlotley, 7 Bing., 543-555

Izone $v$. Gorton, 5 Bing. (N. C.) $501-429$

\section{J.}

Jack $v$. Macintyre, 12 Cl. \& Fin., 15l482

Jackson $x$. Cummins, 5 NE. \& T., 342590

- - $v$ Harrison, 2 F. \& F., 2S2-580

- $\imath$. Pesked, 1 M. \& S., 234-95

167

$-v$. Stacey, Holt, 455-91

Jacobs $r$. Latour, 2 MI. \& P. 205 ; 5 Bing., $130-589$

James $\%$ Dods, 2 C. \& MI., 266; 4 Tyr., $101-93$

Janson : Brown, 1 Camp, 41-I6I

Jeffrey $i$. Walton, 1 Stark. N. P. C., $26 \tau$ $-480$ 
Jeffers r. Lutus, 31 L. J. (N. S.) C. P., $261-392$

Tenkins $t$. Betham, 15 C. B., 16s-333 \& Dennis $r$ King, 392

- r. (rreen, 28 L. J. (N. S.) Ch., $\$ 17$ $-4 i \cdot$

¿. Turner, 1 Ld, laym., 109 ; Salk. $66^{\circ}:-15 \%$

Jemner $r$ Clegg, 1 Moo. \& R., 213-2ss

Jenny aud Runniacles $x$. Brook, 2 Q. B., $205 ; 6(2.13 ., 323-116,141$

$r$. Yolland-2s7

Tesse 3 . Gifford, 4 Burr., 214I-87

Joel $r$, Morison, 6 C. \& P., 501-219

Jolnson $r$. Dodgson, 2 A. \& W., 653-496, $506,535,536$

r. Faulkener, 2 G. \& D., 1S4; 2

Q. B., $925-275$

_ 2 . Foldswaine, 3 Anst., $749-307$

- $\imath$. Mlay, 3 Ler., 150-446

- 2 . The Mlidland Railway Company,

4 Ex., $367-232$

- . Upham, $2 S$ L. J. (N. S.) Q. B., $252-2 \div 1$

- . Huddlestone, 4 B. \& C., 922 ;

7 D. \& R., $411-434,450$

— $v$. Usborne, 11 Ad. \& E., 549$4 S 6$

Joliff $v$. Bendell, 1 Ry. \& Moo., 136-567 Jones v. Chapman, 2 Ex., 803-34t

- v. Clark, 2 Bulst., $73-446$

r. Flint, 2 P. \& D., 594 ; 10 Ad. \&

E. , 753-59, 588

v. Gilıbons, 1 C. L. R., $461-490$

— v. Green, 3 Y. \& J., 298-312

ข. Gooday, 8 M. \& W., 146-356

r. Hamp (not reported) -299

v. Jones, 31 L. J. (N. S.) Ex., $406-$ 358

ข. Le David, 4 Gwill., 1594-393

ข. Nixon, 31 L. J. (N. S.) Ex., $504-$ 463

v. Perry, 1 Esp., 482-160

r. Richard, 6 Ad. \& E., 530-58s

v. Tyler, 1 Ad. \& E., 522-602

- $v$. Williams, 2 M. \& W., 326-170, 356

Jordan $v$. Forton, 4 MI. \& W., 155-556, 580

Jordin v. Crump, 8 M. \& W., 78.2-349, 350,390

Judson $v$. Etheridge, 1 C. \& M., $743-$ 583
K.

Kavanagh $v$. Gudge, 7 M. \& G., 316-127

Keats 2 . Carlogan (Farl), 10 C. B., 5.!425,553

Kieeble $r$. Hickeringill, 11 East, $574 n$. 385

lieen $x$. Priest, Law Times, Feb. 12, 18.in $-258,305$

Kielcey $v$. Stupples, 32 L. J. (N. S.) Ex., 6 $-466$

Kelly (App.) $x$. Webb (Resp.), 12 C. B., $283-64$

Kemp $x$. Crewes, 2 Lutw., 1580-275

Kendall $v$. Barker, 11 C. B., 842-453 - v. S. E. Ry. Co, 7 L. R. C. P., $655-252$

Kenyon $v$. Hart, 34 L. J. (N. S.) M. C., $87-376$

Keppell $v$. Bailey, 2 Mylne \& K., 51787

Keymer $v$. Summers, cited 3 T. R., 157SS

Kiddell $\imath$. Burnard, 9 M. \& W., 668-5 42, 564,567

Kidgiil $v$. Moore, 9 C. B., $36 t-7 \overline{7}, 95$

King $v$. Boston, 7 East, 481 n. - 594

v. Price, 2 Chitt., 416-594

Kinglon $v$. Moss, Veterinarian, vol. xxix., $491-212$

Kingsmill $v$. Millard, 11 Ex., 313-3 46

Kinlyside $v$. Thornton, 2 W. Bl., 1111308,309

Rintrea $v$. Preston, 1 H. \& N., 357-411

Kirby $v$. Trotter, 1 F. \& F., 5 $\$ 4-538$

Kirkham $v$. Marter, 2 B. \& Ad., 613; 1 Chitt., 382-561

Knibs $v$. Hall, 1 Esp., N. P. C., $84-27 t$

Knight $v$. Bennett, 3 Bing., 361; 11 Moore, 222-290

v. Cox, 18 C. B., $645-278$

Knowles $v$. Blake, 5 Bing., 499-267, 268

- $v$. Michel, 13 East, 249-63, 128

L.

Ladd v. Thomas, $12 \mathrm{Ad}$. \& E., 117-2i1, 279

Lancaster and Carlisle Railway Company $r$. Heaton, 28 L. J. (N. S.) Q. B., 195 $-404$

Lancaster $v$. Eve, 28 L. J. (N. S.) C. P., $235-469$ 
Langford $v$. Selmes, 3 K. \& John, 220418

Lauglitou $v$. lliggins, 4 H. \& N., 402536

Large v. Pitt, Peake's Add. Cases, $152-$ 88,90

Latham v. Atwood, Cro. Car., 515-442

Lathbury $v$. Earle, 27 Veterinarian, 548603,605

Lathropp $x$. Marsham, 5 Ves., $259-310$

Lattimore 2 . Garrarl, 1 Ex., 809-333

Last $v$. Dinn, 28 L. J. (N. S.) Ex., 94452

Laugher v. Pointer, 5 B. \& C., 517-228

Lawrance $v$. Faux, 2 F. \& F., 435-470

Lawrence $v$. Aberdien, 5 B. \& Al., 107231, 232

\section{$-139$}

144

- $v$. Tolleshunt Knights, 31 L. J.

(N. S.) M. C., 148-508

Lawson $v$. Langley, 4 Ad. \& E., 890-84

Lawton $v$. Lawton, 3 Atk, 13-455

Layton $x$. Hurry, 8 Q. B., S11-270

Leach $v$. Thomas, 7 C. \& P., 327 ; 2 II. \& W., $427-307,428,460$

Leader $v$. Homewood, 27 L. J. (N. S.) C. P., 316-459

Leake's (Sir F.) Case, Dyer, 365 ; 1 Saun., $206-135$

Leame $v$. Bray, 3 East, 593 ; 5 Ksp., 18 155

Learson $v$. Robinson, 2 F. \& F., 351-471

Leath $v$. Vine, 30 L. J. M. C., $207-377$

Lee $v$. Riley, $3 \pm$ L. J. (N. S.) C. H. 212140

$--v$. Risclon, Taun., 189-69

- v. Unwin, 263

v. Bayes and Robinson, 18 C. B., 599 $-597$

-- $v$. Cooke (in Error), 28 L. J. (N. S.) Ex., $337-302$

- $v$. Muggeridge, 5 Taun., 36-64

$-v$. Steplienson, 27 L. J. (N. S.) Q. B., $263-74$

Leeds $v$. Burrows, 12 Fast, 1-332

- v. Cheetham, 1 Siı., 146-429

Legg $v$. Pardoe, 30 L. J. (N. S.) M. U., $108-381$

Legl $v$. Hewitt, 4 East, $154-315$

Leigh $v$. Patersou, 2 MLore, 588-492, 493

- $v$ Heali, 1 B. \& Ad., 622-109

Lemayne $v$. Stanley-535
Lethluridge $v$. Lethbridge, $31 \mathrm{~L} . J .\left(\begin{array}{l}N \\ \text { S.) }\end{array}\right.$ Ch., $737-46: 3$

Lettice $v$. Judkins, 9 L. J. (N. S.) lix., $142-229$

Lewis $v$. Bond-471

- $v$. Cosgrave, 2 Taun., 2-55s

v. Harris, 1 II. Bl., $7 n-290$

$v$. Peake, 7 Taun., 152-558

v. Read, 13 M. \& W., $834-278$

v. Rogers, 1 C. M. \& R., 48-523

Lexington $v$. Clark, 2 Vent., 223-27

Ley $v$. Peter, 27 L. J. (N. S.) Ex., $239-$ 422

Liddard $v$ Káain, 2 Bing., 183 ; 9 Moore, $356-563$

Lidster $v$. Barrow, 9 Ad. \& Ell., 654368

Liebenrood $x$. Vines, 1 Meriv., 15-312

Liford's Case, 11 Rep., $51 b-109,127$

Liggins $v$. lnge, 5 M. \& $1 ., 712$; 7 Bing., $652-73,172,174$

Lilley $v$. Elwin, 11 Q. B., 742-200, 202

Lillie 2 . Legh -471

Lindou $r$. Hooper, Cowp., 414-272, 273, 274

- $v$. Collins, Willes, $429-250$

Line $v$. Stephenson, 5 Bing. (N. C.), 183 411

Limpus v. Gen. Omnibus Co., 32 L. J. Ex., $34-218$

Lindsay $v$. Leigh, 11 Q. B., $455-201$

Lisburne (Earl) v. Davids, 1 L. R. C. P., $259-346$

Littlefield ข. Shee, 2 B. \& Ad., 811-64

Livington $v$. Ralli, 3 C. L. R., $1096-$ 490

Llandaff $v$. Lyndon, 30 L. J. (N. S.), C. P. M. C., $192-526$

Lloyd $v$. Davies, 2 Ex., $103-411$

— $v$. Walkey, 9 C. \& P., 771-602

v. Winton, 2 Wils., $28-280$

Loch $v$. Natthews, W. R., Feb. 14, 1863 $-463$

Loder $v$. Kíkule, 27 L. J. C. P., 27-511

—v. Bartlett, 31 L. J. (N. S.) Ex., 92 $-533$

Logan v. Lemusier, 6 Pr. C., 116-536

London aul North Western Railway Company (apps.) $v$. Dunham (resp.), 18 C. B., $826-2.13$

London and Westminster Loan Conpany $v$. Drake, 69

Lonstale (Earl of) v. Nelson, 2 B. \& C., $311-114$ 
Longmead r: Hollidixy, 20 L. J. Ex., 430 $-140$

Longstatf $r$. Meagoe, 4 N. \& M., $211 ; 2$ Al. \& E., $16 \overline{7}-46 i$

Lord 2 . City of Sydney, 12 Mon, $473-104$ Loring $r$ Warburton, 11 kx., S70 ; 25 L. J. (N. S.) Ex., 125; 28 L. J. (N. S.) Ex., 3l-274

Lorrmer $v$. Smith, 1 B. \& C, $1-482$

louth $\because$. Drummond (eited in Manley Smith's "Law of Master and Servant," 4 S) -208

lowe $v$. Feers, 4 Burr., 2225-110 ข. lioss, 5 kx, $553-445$

Low len $v$. Kay, 6 D. \& R., 20 ; 4 B. \& C., $3-143$

Lowniles $\imath$. Fountain, 11 Ex., 487-336

Lovell $\imath$. Smith, 3 C. P., 120-87

Lumley $\tau$. IIoulgson, 16 East, 99-425

Lueas $v$. Novosilieski, 1 Lip., 296-199

- $v$. Tarleton -296

Luer $\because$. Montlet-485, 529

Lurting $v$. Conn, 1 Ir. Ch. Rep., 23-310

Lyde $v$. Russell, 1 B. \& Ad., 39t-462

Lynclı $v$. Nurlen, 1 Q. B., 37 ; 4 P. \& D., $677-350$

Lyon $x$. Mells, 5 East, 423-234, 236

Lyuns $\imath$. Martin, 8 Ad. \& E., 512-211

M.

Malserley $v$. Shepherd, 10 Bing., $99-497$

MeCance, v. London and N. W. Rail. Co., 31 L. J. (N. S.), 65 ; 34 L. J. (N. S.) Ex., $39-252$

Machell $v$. Ellis, 1 C. \& K., 682-270

Macintosh $v$. Trotter, 3 M. \& W., 184-461

Mackenzie $v$. Cox, 9 C. \& P., 632-602 $r$. Hancoek, Ry. \& Moo., 436-593

II'Kinnon $v$. Penson, 9 Ex., 609 ; and 23

L. J. (N. S.) M. C., 97-103

M'Kone 2 . Woorl, 5 C. \& P., 1-161

Maclanghlin $x$. Pryor, 4 M. \& G., 48-220

Macnianus $v$. Cricket, 1 Hast, 106-211

- $v$. Laneashire and Yorkshire Rnilway Co., Law 'Tiues, Feb. 20,1858; 28 L. J. (N. S.) Ex., 353-247, 254

Mlacnolty $\vartheta$. Fitzherbert, 27 L. J. (N. S.) Ch., $272-4.31$

Marror $v$. Chardwick, 11 Ad. \& L., 571180, 182

Mackiuson 2 Rawlinson, 9 Price, 460-561

Malachy $r$. Soper, 3 ling. (N. C.), $371 ; 3$ Scott, $72: 3-169$
Malins $v$. Freeman-540

Mancliester, Sheffield, and Lineolnshire Rail. Co. (app.) v. Wallis (resp).), 14 C. B., $213-148$

Mann $r$. Lovejoy, Ry. \& $\mathbf{M} \circ 0_{.}, 355-290,415$ Manning $r$. Lunn, 2 C. \& K., 13-279, 439 - v. Wasdale, 5 Ad. \& E., 758-78

Mant $v$. Collins, \& Q. L., 916-456

Margetson $v$. Wright, 1 M. \& Scott, 622 ; 8 Bing., 454 ; 7 Ling., 603 : 5 .I. \& P., $696-571$

Marfell v. South Wales Rail. Co, 29 L. J. (N. S.) C. P., 315; \& C. B., 525-152

Marker $v$. Kenrick, 13 C. L., 188-309

Marlborough (Duke of) $v$. Osborn-453

Marlow 2 '. Thompson, 1 Dow. P. C. (N. S.), • $575-418$

Mar'son $v$. Short, 2 Bing. (N. C.), 111-559

Martin v. Cogan, 1 Hog., 120-308

v. Conlman, 4 L. J. (N. S.) K. B., $37-329$

v. Gilham, 2 N. \& P., $568 ; 7$ A.

\& E., 540-309

$v$. Knollys, S T. R., 145-116

v. Roe, 7 E. \& B., 237-432

$v$. Willace -585

Martindale $v$. Smith, 1 Q. B., 389 ; I $\mathrm{F}$. \& D., $1-495$

Martyn (Adx.) v. Clne, 18 Q. B., 661306,427

Mason v: Hill, 5 B. \& Ad., I ; 3 B. \& Ad., $304 ; 2$ N. \& M., 747-173, 174, 175,176

$-v$. Newland, 9 C. \& P., 575-270

-v. Welbank [Welland], Skin., 238 $-446$

Massey $v$. Goodall, 17 Q. B., $510-337$

Masters $v$. Pollie, 2 Roll. Rep., 141-117

Matson $v$. Cook, 6 Scott, 179; 4 Bing. (N. C.), 392-343

Matheson $v$. Hart, 2 C. L. R., \$14-438

?. Parker, Oliphant, $343-570$

Matthews 2 . Leapingwell, 3 C. L., $912-401$

May $v$. Burdett, 9 Q. B., 121-155, 167

Mnyfield $v$. Wadsley, 3 B. \& C., 357 ; 5 D. $\&$ R., $224-60,67$

Mechelen $v$. Wallace, 2 N. \& P., 22t; 7 Al. \& E., 49; W. \& W. \& D., 40-66

Meddins $v$. Williams, Times, Feb., 1858386

Meggison $x$. Tady Glamis, 7 Ex., 685-296

Mellish v. Motteux, 1 Peake, 115-551

Mennie $x$. Blake, 6 E. \& B., 842-298

Meres $x$. Ansell, 3 Wils., 275-482

Meredith $r$. Megh, 2 E. \& B., 364--503 
Merivale $v$. Exeter Road Trustces, 3 L. R. Q. B., 149-141

Mesnard $v$. Alilrilge, 3 Esp., 271-550

Metcalfe $v$. Lumsden, 1 C. \& K., 309-229

Metropolitan Association for Improviug the Dwellings of the Poor $v$. Petch, 27 L. J. (N. S.) C. P., $330-77$

News $v$. Carr, 1 H. \& N., 481-477

Micklethwait $v$. Micklethwait, 28 L. J. (N. S.) C. P., $121-113,125$

Middleton $v$. Gale, 8 Ad. \& E., $155=377$

Mildred $v$. Weaver-106

Miles v. IIarris-304

- v. Sheward, 8 Eas., 7-462

Millen $v$. Fandrye, Pop., 161-367

Miller $v$. Green, 2 C. \& J., 143 ; 2 Tyr., 1 ; 8 Bing., 92 ; 1 M. \& Scott, $199-$ 291

Mlill $v$. Commissioners of the New Forest, 18 C. B., $60-85$

Millichamp $v$. Johnson, Willis, 202-349

Milligan $v$. Wedge, 12 Ad. \& E., $737-$ 228

Minshall $v$. Lloyd, 2 M. \& W., 450-461

Minshull $v$. Oakes, 27 L. J. (N. S.) Ex., $194-427$

Mitchell v. Crasswaller, 22 L. J. (N. S.) C. P., $100-219$

Mondel $v$. Steele - 536

Monmouthshire Canal Co. v. Harford, 1 C. MI. \& R., 611-82, 83

Mloody $v$. Deau and Chapter of Wells; $1 \mathrm{H}$. \& N., 40-439

Morden v. Porter, 29 L. J. (N. S.) M. C., $226-378$

Morgan v. Abergavenny (Earl), 8 C. B., $768-375,382$

414

Morley $v$. Attenborough-528

v. Pincombe, 2 Ex., 101-2S5

Moore $v$. Plymouth (Lord), 7 Taun., 316394

- v. Rawson, 5 D. \& R., 234 ; 3 B. \& C., $332-77,87$

- v. Webb, 1 C. B. (N. S.), 673-181

Moreten $v$. Porter, 29 L. J. M. C., $213-$ 377,381

Moreton $v$. Harden, 4 B. \& C., 223-216

Morris $v$. Jeffries, 1 Q. B., 261-154

$-v$. Norfolk (Duke of), 9 Sim., $472-$ 403

- v. Morris, 1 Hog., 238-308

- 2 . Nugent, 7 C. \& P., 572-161

Mortimer $v$. Preedy, 3 M. \& W., 602-426
Morton v. Tibbett, 15 Q. B., 428-501, 502,503

Mott $v$. Turnage, $1 \mathrm{~F}$. \& F., $6-413$

Mounsey $v$. Ismay, W. R., Jau. 24, 1563, 349

Mousley $v$. Saint-347

Monseley $v$. Ludlam, 21 L. J. (N. S.) Q. B., $6 t-3 \div 9$

Noxon $v$. Savage, 2 F. \& F., 182-349

Mum v. Fabian-454

Mumford $v$. Oxford and Worcestershire Railway Company, 1 H. \& N., 34- 95

Muncey $v$. Dennis, 1 H. \& N., 216-325

Murgatroyd $v$. Robinson, 26 Law J. (N. S.) Q. B., 233-S6

Murray v. Mann, 2 Ex., 588-556

- $v$. East India Company, 5 B. \& Ald., 204-210

Muskett $v$. Hill, 7 Sc., 855 ; 5 Ling. (N. C.), 694-309

N.

Nargatt v. Nias, 28 L. J. (N. S.) Q. B., $143-2 S 6$

Neale $v$. Cripps, Law Times, Jan. 22, 1559, 115

- $v$. Wyllie, 3 B. \& C., 533-427

Neal $v$. Swind, 2 C. \& J., 377-448

v. Viney, 1 Camp., $471-460$

Nethorpe $v$. Holgate, I Coll., 203-419

Nesbitt $v$. Meyer, 1 Swan, 223-311

Newall (Ex parte), 3 Deac., 333-524

Newcastle (Duke of) $v$. Hundred of Broxtowe, 4 B. \& Ad., $273-430$

Newman $v$. Cardinal, 2 F. \& F., 840-303

Newport (Mayor of) $v$. Saunders, 3 B. \& Ad., $411-518$

Newson v. Smythies, 29 L. J. (N. S.) C. P., 97-331

Newton $v$. Allin, 1 Q. B., 518; 1 G. \& D., $44-437$

- $v$. Harland, 1 Man. \& G., 644378

— $v$. Wilmot, 8 M. \& W., $711-385$

Nicholson $v$. Bower, $2 S$ L. J. (N. S.) Q. E., $97-504$

Nichols $v$. Cbapman-101

- v. Hall -490

Nicklin v. Williams, $10 \mathrm{Ex}$, 259-S0, 100,101

Nicoll v. Greares, 33 L. J. (N. S.) C. P'., 259-201 ข. Goots -530 
Nixon $v$. Freeman, 29 L. J. (N. S.) Ex., $2 \pi 1-25=2$

Nokes $v$. (Gibhons, 20 L. J. (N. S.) Ch., 20S, $433-311$

Norfolk (Duchess of) $z$. Wiseman-3St

Norman 2 . Bell, 2 1). \& Ad., 191-523

- $v$. Phillips, 14 MI. \& W., 277-503

v. Wescomlie, 2 M. \& W., $349-$ 35:2

Forth Listern Railway Company v. Elliot $-100$

landi-100

North r. Smith, 10 C. B., 572-362

Northam $x$. Hurley, I E. \& I., 665-189, 191

Northampton (Mayor of) $v$. Warl, I Wils., 107 ; 2 Strac., $1238-517$

Norton $v$. Iferron, 1 C. \& P., 648-420

Norwood $r$. 1'itt, 29 L. J. (N. S.) Ex., 127 $-358$

Nowlan $r$. Ablett, 2 C. M. \& R., 54-207

Nove 2 , lieed, 1 MI. \& R., 63-131

Nuttall $v$. Staunton, 6 D. \& R., $155 ; 3$ B. s. C., 5I-290, 291

O.

Oastler 1: Pound, N. R., Feb. 14, $1863-$ 536

Ockenden [Ockleden], 6 Henley, 27 L. J. (N. S.) Q. B., $361-477$

Odill:un v. Smith, Cro. Eliz., 589-444

Ongley $x$. Gardiner, 4 MI. \& W., 496-83, 84

()nslow $v$. Eames, 2 Stark, $81-310,568$

Orchitrl $v$. Rackstraw, 9 C. B., 698-576

— $v$. Simpson, 2 C. B. (N. S.), 299 $-494$

Urr $थ$. Fleming, Weekly Reporter, vol. 1, $339-157$

Oshond $v$. Mealows, 31 L. J. (N. S.) M. C., $238-377$

Osluorne $v$. Harrey, I You. \& Coll. (N. C.), $116-124$

- $v$ Wise, 7 C. \& P., $751-88$

Oswald v. Jarl Girey, 24 L. J. (N. S.) Q. 13., $69-419$

Oughton v. Sellings, 1 Is, \& Ad., $241-$ 345

Owens v. Denton, 1 C. MI. \& R., 711522

()wen 2 . Luigh, 3 I. \& $1 \mathrm{l}$, $470-293$

Oxley $c$. Jance, 13 MI. \& W., 209-290
Oxley r: Watts, I T. R., 12-34t

Oxendale $v$. Wetherall, $9 \mathrm{~B}$ \& $\&$ C., 396 ; 4 MI. \& liy., 429-491

Oxford, Worcester and Wolverhampton Railway Co. (in re) (ex parte). Devisees of Milwarl, 29 L. J. (N. S.) Ch., 215 $-539$

P.

Page (Exor.) 2. Pavey, 8 C. \& P., 769$4 \mathrm{~S} 8$

Pain $v$. Coombs, Law Times, May 2 and Oct. $10,1857-311,415,471$

-v. Patrick, 3 Mod., 294-79

Padwick $v$. King, 29 L. J. (N. S.) M. C. $42-381$

$-\imath$. Tyudale, 29 L. J. (N. S.) Q. B., $90-443$

Palmer $x$ Temple -478

_- $\imath$ : The Grand Junction Railway Company, 4 M. \& W., 749-232

Pannell $v$. Nill, 3 C. B., 625-385

Pardington $v$. South Wales Railway Comlany, 1 H. \& N., 392-244, 245, 248

Parish $v$. Slecman, 29 L. J. (N. S.) Ch., $53,97-407$

Parker v. Great Western Railway Company, 7 M. \& G., 253, 7 Scott N. R., S35 274

v. Ibbetson, 26 L. J. (N. S.) C. P., $26-203$

$-v$. Mitchell, 11 Ad. \& E., $788 ; 3$ P. $\& \mathrm{D},, 655-84$

v. Wallis, 5 E. \& P., $21-503$

v. Staniland, 11 East, $362-52$

- . Taswell, 27 L. J. (N. S.) Ch., 812 $-414$

Parkinson v. Lee, 2 East, 322-52S

Parmenter $v$. Webber, 8 Taun., 593 ; 2 Noore, 656-2S9

Parrington $v$. Moore, 2 Ex., 223-364

Parrott $v$. Anderson, 7 Ex., 93-277

Parry $v$. Decre, 2 H. \& W., 395; I N. \& P., 47 ; 5 Ad.\& E., 551-417

Parsons $v$. Sexton, 4 C. B., $899-434$

Partrilge $v$. S'cott, 3 ML. \& W., $220-$ 101

Patrick v. Colerick, 3 M. \& W., 483348

Patteshall $v$. Tranter, 3 Ad. \& F., 103, 4 N. \& M., 649-574

Pattcu $v$. Goulil, 7 Titun., 408-42t 
Patten v. Rea, 26 I. J. (N. S.) C. P., 235; 2 C. B. (N. S.), $606-214$

Payne 2 . Cave, 3 T. R.; 148-550, 592

- v. Haine, 16 M. \& W., $541-427$

v. Rogers, 2 H. Bl., 349-132

v. Shedden, 1 M. \& Rob., 382-87

$v$. Whale, 7 East, $274-595$

Peacock $x$. Harris, 10 East, 104-64

— $v$. Purvis, 5 Moore, 79 ; 2 B. \& B., 362-294, 295

Peake $v$. North Staffordshire Railway Company, 27 L. J. (N. S.) Q. B., $465-243$

Pearee v. Lodge, 12 MLoore, 50-344

Pearson $v$. Speneer, 1 B. \& S., 571, 584-\$9

Peer $v$. Humphreys, 2 Ad. \& E., $495 ; 4$ N. \& MI., $430-597$

Penley $v$. Watts, 16 L. J. (N. S.) Ex., 229 $-127$

Penny $v$. Porter, 2 East, 2-490

Penton $v$. Brown, 1 Sil., $186-284$

- v. Robart, 2 East, 88-455, 460, 461

Perkins $v$. Potts, 2 Chitt., 3.99-332

Perry $v$. Fitzhowe, 15 L. J. (N. S.) Q. B., $239-353$

Petch $v$. Tutin, 15 M. \& W., 110-323

Peter $v$. Knoll, Cro. Eliz., 32-44t

Peters $v$. Blake, 6 L. J. (N. S.) Ch., 157-126

— v. Clarson, 13 L. J. (N. S.) M. C., $153-351$

Peterson v. Ayre, 13 C. B., 363-492

Peyton $v$. Watson, 3 Q. B., 658-403

Phillips $v$. Barlow, 14 L. J. (N. S.) Ch., $35-127$

- $v$. Smith, 14 M. \& W., 589-122 v. Wood, 1 N. \& M., 434-576

Philpotts $v$. Evans, 5 M. \& W., $475-492$

Piekering $v$. Busk, 15 East, 45-554 $-112$

Pieree $v$. Corf -477

- - v. Webb, 3 Pr. Ch. R., 16-316

Pigott v. Bullock, 1 Ves. Jnn., 478-111, 121

- v. Birtles, 1 M. \& W., $441-286.298$ v. Eastern Counties Railway Company, 3 C. B., 229-217

Pike $v$. Eyre, 9 B. \& C., 909 ; 4 M. \& Ry., $661-290$

Pinchon $\%$. Chicott, 3 C. \& P., 236-6t

Pinder $v$. Button, W. R., Nov. 15, 1862526

Pinhorn $v$. Souster-282
Pinnington $v$. Galland, 1 C. L. R., $819-$ 477

Pipe $v$. Fnleher, 28 L. J. Q. F., $12-105$

Pitt $v$. Shew, 4 B. \& Ald., $206-6$ y

Pleasant $v$. Benson, $1+$ East, 234-68

Pluekwell $r$. Wilson, 5 C. \& P., 375-220

Pollitt $v$. Forest, 1 C. \& k., $560 ; 11$ (. B., $949-291$

Pomfret $v$. Rieroft, 1 Saun., $322 c-94$, 109,147

Poole $v$. Bentley, 12 East, 168-414

- $v$. Huskisson, 11 1. \& W., 827-91, 197

v. Longueville, 2 Saun., 290-135, 275,284

$v$. Tunbrikge, 2 M. \& W., 67-426

Porritt $v$. Baker, 10 Ex., 759 ; 1 C. L. R., $432-375$

Portman $v$. Middleton, 27 L. J. (N. S.) C. P., 231-509

Potter $v$. Faulkner, 31 L. J., Q. B., 30217

v. Parry, Weckly Reporter, Jan. 29, 1859-134

Poulter $v$. Killingbeek, 1 E. \& P., 39757,66

Poulton $v$. I Lattimore, 9 B. \& C., $259-$ 436

Pounsett $v$. Fuller, 17 C. B., 660-38s

Pow $v$. Davis, 30 L. J. (N. S.) Q. B., 2.7 $-467$

Powell $v$. Eilmunds, 12 East, 6-480

- $v$. Salisbury, 2 Y. \& J., 391-139

Power $v$. Welles, Cowp. 818-594

Powis $v$. Snith, 5 B. \& Al., 850-289

Powley $v$. Walker, 5 T. R., 373-306

Powys $v$. Blagrave, 24 L. J. (N. S.) Ch., $142-112$

Pownall $v$. Moores, 5 B. \& Al., 416-338

Pratt v. Brett, 2 Maddl., 62-309

-v. Brow1, 8 C. \&. P., 244-340

Preece $v$. Corrie, 5 Bing., 24-289

Price v. Harrison, 29 I. J. (N. S.) C. P., $35-332$

- v. Leyburn, Gow. N. P. C., 109-63

v. Williams, 1 M. \& W., $6-472$

- $v$. Woodhouse, 1 Ex. , 559-297, 444

Prickett $v$. Barger, 1 U. B. (N. S.), 296475

Priestley $v$. Fowler, 3 M. \& T., 1-215, 217

Prince $x$. Lewis, 5 D. \& C., $363 ; 8$ D. \& R., $121-518$

Pritchett $v$. Honeybourne, $1 \mathrm{I}$. \& J., 13.j $-401$ 
Proctor $v$. Hoilgson, 24 L. J. (N. S.) E.s., $195-\$ 9,90$

Protheroe $r$. Watthews, 5 C.\& P., 5\$1-368

Proudlore $r$. 'Twemlow, 1 C. \& MI., 326 ; 3 Tyr., 260-294, 305

Pryce $r$. Burn, 5 Ves., 6\$1-112

Pultener $v$. Shelton, 5 Ves., $147-310$

Tyer $v$. Carter, 20 L. J. (N. S.) Ex., 258 $-74,105$

Pyke $r$. Kiyre, 9 L. \& C., $909-69$

Pym 2 . Camphell-465

Pyne $x$. Dor., 1 T. R., 55-110

\section{Q.}

Quarman $r$. Burnett, 6 M. \& W., $449-$ 213,225

Quayle $r$. Davilson, Law Times, March 5, $1859-516$

R.

Rabbeth [Rabbett] v. Squire, 19 Beav., 70 $-449$

Race $\imath$. Ward, 7 E \& B., 784 ; 4 E. \& B., $702-77,79$

Rackham $v$. Marriott, 1 II. \& N., $234 ; 2$ H. \& N., 196-508, 509

Radnor $v$. Evans - 10S

Ramsden $v$. Hirst [Hurst], 27 L. J. (N. S.) Ch., $482-476$

Ramsbottom $v$. Nortley, 2 M. \& S., 445418

Randall v. Roper, 27 L. J. (N. S.) Q. B., $266-513$

v. Raper -468

Randeau $v$. Wyatt-485

Randell $r$. Trimen- $46 ;$

kankin r. Laty, 29 L. J. (N. S.) Ch., $734-$ 472

Rawstron $v$. Taylor, 11 Ex., 369-178, 184, 197

Rayner $v$. Stone, 2 Eden, 128-310

Jaynor $v$. Childs, 2 F. \& F., 775-251

lead $v$. Fdwards, 34 L. J. (N. S.) C. P., $31-391$

- v. Fairbanks, 22 L. J. (N. S.) C. P., $206 ; 13$ C. 13., $692-560$

- - 2 . King, Times, Jan. 27, 1858-165

lieny $v$. Rawlinson-67

liecre $r$. liecre, 1 J. \& F., 280-199

Regent's Canal Company $x$. Ware, 26 L. J. (N. S.) Ch., $5660-476$
Regina $r$. Almey \& Spcncer, Jurist, Aug. $8,1857-372$

$v$. Aylesford, 29 L. J. (N. S.) M.

C. $83-470$

r. Bedwell, 24 L. J. (N. S.) MI.

C., $17-202$

v. Brooks and Gibson, 2 Cox C. C., $436-370$

v. Bryan, 7 Cox C. C., 599

v. Cheafor, 5 Cox C. C., 367-344

$\imath$. Commissioners of Land Tax for

Tower Division, 1 C. L. R., S28-438

r. Crawley, 3 F. \& F., 109-529

v. Cridland, 27 L. J. (N. S.) M.

C., 28-102, 373, 377, 381

v. Dant, 34 L. J., M.C., 119-167

v. East Mark (Inhabitants of), 3

Cox C. C., $60-91$

v. Edge (not reported)-37I

v. Egerton, R. \& R., 375-515

v. Friend (Clerk), 28 L. J. (N. S.)

II. C., 169-406

$-v$. Freyke, 7 Cox. C. C., 32-340

_ $v$. Garnham, 2 F. \& F., 347-38:2

— Goodbody, 8 C. \& P., 665-226

- $v$. Goodehild, 27 Law J. (N. S.)

MI. C., 233-404, 407, 408, 409

- v. Goodehild and Lamb, 27 L. J.

II. C., 251-406

- $v$. Groves, (elerk), 409

v. Grundell, 9 C. \& P., 365-224

$-v$. Hawkhurst (Inhabitants of) -102

- $v$. Hayward, 1 C. \& K., 518-223

- v. Head, I F. \& F., $350-375$

v. Hey, 1 Den. C. C., 602-226

- v. Hornsea, 23 L. J. (N. S.), M. C.,

$59-169$

- v. Inhabitants of Madeley, 15 Q.

B., $43-400$

- $x$. Jarvis, 3 F. \& F., 108-52?

$r$. Johnson-10:

v. Kenrick, 5 Q. B., 64-598, 599

$v$. Lady Joan Young, 4 Cooke's

Reports, pt. 7, p. S2-345

- Lamb, 27 L. J. (N. S.), M. C., $233-405$

v. Lyon, $1 \mathrm{~F}$. \& F., 54-222

v. Matty, 27 L. J. (N. S.) M. C.,

59

v. Mills, 7 Cox C. C., 263-22.

v. Musson, 27 L. J. (N. S.) (2. B.,

222 ; М. C., $100-169,170$

v. Nickless, 8 C. \& P., 737-369

v. Parker, 33 L. J. (N. S.) M. C.,

$135-392$ 
Regina $v$. Pearson-104

- v. Pratt, 24 L. J. (N. S.) M. C., 113 ; 3 L. R. Q. B., 64-141, 370, 377

$v$. G. Prestney, 3 Cox C. C., 505 $-371$

- v. Privett and Goodhall, 1 Den. C.

C., $193-224$

- v. Sir J. Ramsden, 27 L. J. (N. S.)

M. C., 296-133

v. Read-379

v. U. K. Telegraph Co. Lim., 31

L. J. M, C., $166-102$

$v$. Riley, 3 C. \& K., 116-371

v. Robinson, 28 L. J. (N. S.) M. C.,

$58-345$

$v$. Stevenson, 3 F. \& F., 106-529

v. Stoke-upon-Trent, 5 Q. B., 303

$-199$

$v$. Sylvester-563

$v$. Tithe Commissioners, 12 Q. B., $459-399,401$

- $v$. Inhabitants of Thurlstone, $28 \mathrm{~L}$.

J. (N. S.) ML. C., 106-383

- v. Uezzell, 20 L. J. (N. S.) M. C., $192-369$

v. Waley, 1 F. \& F., 528-370

v. Wall, 2 Cox C. C., 28s-370

369

$-120$

v. Whitaker, 3 Cox C. C., 50--369

$v$. Whiteman, 1 Deers. C. C., 353

$-736$

371

- v. Woods, 27 L. J. (N. S.) Q. B., 433 ; M. C., 289,441

_- v. Wycombe Ry. Co., 29 L. J.(N.S.)

Cl., $462-539$

Reiguolds $v$. Edwards, Willes, 232-89

liex v. Addis, 6 C. \& P., 3ss-270

v. Arlington, 1 M. \& S., 622-208

v. Althorne, 2 B. \& C., 211-208

$v$. Berenger, 3 M. \& S., 73-197

v. Birdbrook, 4 T. R. 245-208

- v. Bishop Hatfield, 2 Bott., 217 208

v. Bradshaw, 7 C. \& P., 233-269

$v$. Buckland Denham, Burr. S. C., 694 $-208$

v. Bucknall-133

v. Doddridge, cited Weekly Reporter,

May $30,1857-599$
Rex $v$. Dodderlíll, 3 M. \& S., 243-208

- v. Empinghan, 2 Bott. 217 ; Burr,

S. C., 791-208

v. Ferrybridge, 2 D. \& R. 634 ; 1 B. \& C., 375-119

v. Flecknow, 1 Burr., 461-134

$v$. Great Yarmouth, 5 M. \& S., 114 $-208$

v. Hampreston, 5 T. R., 205-208

v. Hoseason, 14 Last, 605-209

v. H. Hughes, 1 Ry. \& Moo., 370225,227

ข. King, 2 Chitt., $217-367$

v. Lambeth, 4 M. \& S., 315-20S

v. Lockerley, Burr. Sc., 315-267

$v$. Londonthorpe, 6 T. R., 377-459

$\imath$. Lord Yarborough (in error), 1 Dow. \& C., 178 ; 3 B. \& C., 91 ; 4 D. \& R., $790-168$

v. Macnamee, 1 Ry. \& Moo., 368$225,226,227,228$

v. Minchinhampton, 3 Burr., 1308119

v. Mirfield, 10 East, 219-119, 120

$v$. Narbeth North, 1 P. \& D., 590 ;

9 Ad. \& E., $815-119$

v. Nettleton, 1 Ry. \& Moo., 259225

v. North Nibley, 5 T. R., 21-208

v. Utley, 1 B. \& Acl., 161-456, 459

v. Pease, 1 N. \& MI., 690 ; 4 B. \& Ad., $30-148$

- v. Pershore, 8 B. \& C., 679-208

v. Petrie, 24 L. J. (N. S.) Q. B., $167-91$

v. Pywell, 1 Stark. N. P. C., 402598,599

$v$. St. Nary, Bury St. Edmunds, 4 B. \& Ald., 462-401

v. Stock, 1 Ry. \& Moo., 87-224

$v$. Stone, 1 Kast, $639-374$

$v$. Tolpuddle, 4 T. R., $671-267$

$v$. Trafford, 9 L. J. M.C., 66 ; 1 B.

\& Ad., $874-171$

$v$. Turner, 5 M. \& S., 206-374

v. Turvey, 2 B. \& Al., 520-208

v. Warminster, 6 B. \& C., 77 ; 9 D.

\& R., 70-208

v. Whitnash, 7 B. \& C., 596-199

v. Woodward, 2 Fast P. C., 653-5s7

v. Vanderwal], 2 Burr., 991- 443

Rice $v$. Baxendale, 30 L. J. (N. S.) Ex., $370-533$

Richards $v$. Black, 6 C. B., $437 ; 7$ D. \& L., $325-316$ 
Richarils $\imath$. Frt, 3 N. \& Г., $67-1 \mathrm{~S} 0$ r. Porter, 6 13. \& C., 43i-i, 05 r. Richards, 29 L. J. (X. S.) Ch., $830^{\circ}-46^{\circ}$

Richardson 2 . Trown, 1 Bing., 34t; S Moore, 33s- 55.1

417

P., 75-2.54

Rich $v$. Woolly, 7 Ping., 651-26s, 284

Ricketts 2 . I'irmingh:m Junction liailway Company, 12 C. 13., $160-146,150$

\section{2}

Rivler $\tau$. Smith, 3 T. R., 706-133

Riilge (cx parte) 1 Ves. \& Beam., 360524

Ridgway $v$. Staffurl (Lord), 6 Ex., 40429 s, 301

- 2. Wharton, 3 De G., MI. \& G., 677 , $693-420,474,476,505$

Rigg $v$. Lonstale (Earl) 1 H. \& N., 923 ;

$11 \mathrm{Ex}, 654-356$

Riley $r$. Bazendale, 30 L. J. Ex., S7-215

$-v$. Warden, 2 Ex., 59-207

Rimel v. Sampayo, 1 C. \& P., 254-222

Riseley $v$. Ryle, 11 M. \& W., 16-295

Rivis $r$. Watson, 5 M. \& W., 255-250

Roads $v$. Trumpington, 5 L. R. Q. B., 56 $-120$

Roberts 2 . Parker, 1 C. \& M., 80S-324

- $\imath$. Great Western Railway Company,

27 I. J. (N. S.) C. P., 266-152

v. Smith, 2 H. \& N., 213-219

- $\imath$. Tunstall, 4 Hare, 257. 14 L. J.

Ch., 184--112

Robertson $v$. Gauntlett, 16 M. \& W., 289 $-352$

(apyl.) $v$, Burkett (resp.), Weckly lieporter, Nov. 27, 1858-214

Tolinson 2 . Hintman, 3 \& 4 Ek]', $234-$ 203

2. Purlay, 16 M. \& IT., 11-40t r. liutter, 4 li. \& li., $951-591$

2. Vaughiton, S C. \& P., 252-366

Roden $v$. Eyton, 6 C. L., 427-299, 332

Rorlgers $x$. Parker, 18 (: B., 112-296

Rorlinel $\tau$. Wilen (liart), 1 l. \& F. 542 46,7

Rorlwell $\imath$. Plitlils, 9 II. \& W., 501-51, 54

Iiolfe v. Paterson, 2 lin., I. C., 436-\$12

Rulls $r$. Reck, 22 Selw. ‥ I', 1287-109

Rondear $v$. Wyatt, 2 HI. 131., 63-505
Rooth $v$. North Eastern Railway Company, 2 L. R. Ex., $173-252$

v. Wilson, 1 B. \& Al., 59-138

Roots $\because$. Dormer (Lord), 4 B. \& Ad., 77478

Ross 2 . Smith, 1 B. \& $\Lambda$ d., $907-398$

Routledge $r$. Hislop, 29 L. J. (N. S.) MI. C., $90-205$

Rowbotham $v$. Wilson, 27 L. J. (N. S.) Q. B. $-80,81$

Rowe v. Young, 2 B. \& B., 195, 234-426

Rowlston v. Hardy-386

Rudd $v$. Scott, 2 Scott, N. R., 63I-364

Runlge $v$. Winnell, 12 Bear., 357-443

Rusby $v$. Scarlett, 5 Esp., $76-222$

Ryan 2 . Shileock, 7 Ex., $72-284$

\section{$\mathrm{S}$.}

Sainsbury $v$. Matthews, 4 M. \& IV., 343 51,53

Saffery $v$. Elgood, 3 N. \& M., 346-275

Salisbury (Marquis of) $v$. Gladstone -99

Salkeld (Clerk) $v$. Johnson, 2 C. B., 749398

Salter $v$. Woollams, 2 Mr. \& G., 650-513

Salmon $v$. Ward, 2 C. \& P., 211-5 12

Sampson $v$. Hodinott, I C. B. (N. S.), 590 -1ST, 194

Sanclers $v$. Jameson, 2 C. \& K., 557-485

Sandys $v$. Mayor, \&c., of Beverley, 12 MI. \& W., 568-40t

Sarch $v$. Blackburn, 4 C. \& P., 297-163

Sarl $\imath$. Bourdillon, 1 C. B. (N. S.), 1sS507

Saunders $v$. Baldy, 1 N. R. Q. B., S7375

- v. Kirwan, 30 L. J. (N. S.) C. P., $351-354$

$-r$. Newman, 1 B. \& Al., $258-$ 172,174

$-v$. Tolp, 4 Ex., 390-5.83

Saunderson $v$ Grifiths, 8 D. \& R., 643 ; 5 B. \& C., $909-306$

$-r$. IIanson, 3 C. \& I., $314-$ 440

506

Savage $n$. Connor, 7 Ir. Jur., $161-309$

Scales $v$. Piekering, 6 L. J. C. P., 53-35I

Scarfe v. Morgan, 4 M. \& W., 268- 563 , 590

Schneider $v$. Norris, 2 M. \& S., 2S8-506

Sehwinge $v$, Dowoll-106 
Scorell $v$. Boxall, 1 Y. \& J., 396-56

Scott $v$. Hanson, 1 Russ. \& My. , 128-479

- $\imath$. Henderson-569

Seago $v$. Deane, 4 Bing., 459 ; 1 M. \& P., 227 ; 3 C. \& P., $170-6 t$

Seaman $v$. Price, 2 Bing., $437-66$

Searle $v$. Lindsay, 31 L. J. (N. S.) C. P., $106-217$

Sears $v$. Lyons, 2 Stark., $317-361$

Sellen $v$. Norman, 4 C. P., 80-199

Selsea (Lord) v. Powell, 6 Taun., 297 ; 3 Eag. \& Yo., 714-397, 398

Senior $v$. Armitage, Holt, 197-320

Sewell $v$. Corp, 1 C. \& P., 392-579

Shadwell $v$. Shadwell, 28 L. J. (N. S.) C. P., $275-332$

Sharp $\%$ Waterhouse and Calvert, 27 L. J. (N. S.) Q. B., 70-75

Sharpe $v$. Cummings, 14 L. J. (N. S.) Q. B., $10-452$

Sharrod $v$. London and North Western Railway Company, 4 Ex., 580-144, $145,146,220$

Sharman $v$. Sanders, 13 C. B., $166-207$

Shaw $v$. Robberds, 6 Ad. \& E., 75-517

$v$. York and North Midland Railway Company, 13 Q. B., 347-23!, 239

Sheen $v$. Reekie, 5 M. \& TV., 175-458

Shelton $v$. Livins, 2 C. \& J., $111-479$

Shepherd $v$. Narquis of Londonderry, 21 L. J. (N. S.) Q. B., 304-399

Sheriff $v$. James, 1 Bing., 341-272, 279

Sherwin $v$. Swindall, 12 M. \& W., 783353

Shiels $v$. Great Northern Railway Company, 30 L. J. (N. S.) Q. B., 331-251

Shillitoe $v$. Claridge, 2 Chitt., 425-56s

Shrewsbury (Earl) v. Gould, 2 B. \& Al., $487-314$

Shury $v$. Pigott, Palm., 444; Popham, 166 $-76,87,174,186$

Sibbering $v$. Farl lialcarras, $3 \mathrm{De}$ G. \& Sm., 735 , and 19 L. J. Ch., 252-112

Sidwell $v$. Mason, 2 H. \& N., $306-508$

Sieveking $v$. Dutton, 3 C. B., $331 ; 4 \mathrm{D}$. \& L., 197-484

Silvester $v$. Pierlford, 27 L. J. (N. S.) C. P., $105-396$

Simons $v$. Great Western Railway Company, 18 C. B., 805 ; 2 C. B. (N. S.), $620-$ $243,248,258$

Simmonds $v$. Carr, 1 Camp., 361-563

Simmons $v$. Swift, 5 B. \& C., 857-191

v. Hescltine, Jurist, March 26, $1859-478$
Simmons $v$. Norton, 7 Bing., 640 ; 5 M.

\& P., 645-127, 308, 309

Simpson $x$. Dendy, 8 C. B., 433-104

v. Lamb-538

$-r$. Lewtlıwaite, 3 P. \& Ad., 226

$-3.52$

95

v. Unwin, 3 B. \& Ad, $134-374$

Singleton $v$. Williauson, 31 L. J. (N. S.)

Ex., 287-271

Skeate $v$. Beale, 11 Ad. \& E., 933 ; 3 P.

$\& \mathrm{D}, 597-27 t$

Skerry $v$. Preston, 2 Chit., 245-277

Skipwith $v$. Green, Stra., 610-482

Skrine $v$. Elmore, 2 Camp., 407-55S

Skull $v$. Glenister, 33 L. J. G. P., 185104

Skyring $v$. Greenwood, 4 B. \& C., 281278

Slim $v$. The Great Northern Railway Comprany, 14 C. B., $647-257$

Slocombe $v$. Lyall, 6 Ex., $119-352$

Sloper $v$. Saunders, 29 L. J. (N. S.) Ex., 275 $-567$

Smallman $v$. Pollard, 1 D. \& L., 901 ; 6 II. \& G., 1001-295

Smart $v$. Allison, 21 Veterinarian, 24-569

$-v$. Harling, 15 C. B., 652-64

$v$. Hyde, s M. \& W., 723-551

v. Morton, 4 E. \& B., $47-81$

Sweed \%. Foord, Law Times, February 12, $1859-510$

v. Poor-533

Sinith $v$. Ackroyd, 10 C. B., 164-87

v. Chance, 2 B. \& Al., 753-339

v. Dearlove, 6 C. B., 132-590

v. Eldridge, 2 C. \& R., 855-4 46

r. Fletcher, 7 L. R. Ex., 305-156

v. Goodwin, 2 L. J. (N. S.) K. B., $192-272$

z. (․ E. Ry. Co., L. R. C. P., 4-156

?. IIayward, 7 Acl. \& E., 54t-20t

v. Howard, 3 M. \& G., 25t-411

v. Hudson-520

$v$. Hughes -500

$v$. Humble, 3 C. L. R., 225-438

v. Jeffreys, 15 M. \& W., 561-480

v. Kenrick, 7 C. B., $515-180$

$v$. Kingsford, 3 Scott, 279-206

r. Narrable, 11 M. \& W., 5- 425

$v$. Niller, 1 T. R., $475-343$

v. Neale, 2 C. B. (N. S.), 67-495

v. Parsons, 8 C. \& P., 1!9-461

v. Peat, 2 C. L. R., $421-128$ 
Smith $r$. Pelah, 2 Strange, 126t-15s - 2 . Render, 27 L. J. (N. S.) Ex., 83 $-459$

2. Surman, 4 M. \& R., 455 ; 9 B. S. (.), $561-54,55,56,128,496$ $-r$. Thorne, 18 Q. B., 134-508 r. Wilson, 3 B. \& Al., 72S-482 r. Wright, 30 L. J. (N. S.) Ex. 313 $-2 s 2$

Smout $x$. Ibury-468

Sneesby $r$. Lan. and Yorksh. Ry. Co. -140 Snelling r. IIuntingfield (Lord), 1 C. M. \& R., $30-205$

Somerset (Duke of) $v$. Fogwell, 5 B. \& C., $875-387$

Sonch $r$. Strawbridge, 2 C. B., $\$ 08-66$

Soulsby 2 . Neving, 9 East, $360-470$

Souter $l$. Drake, 5 B. \& Ad., 992-411

Southeote $r$. Stanley, 25 L. J. (N. S.) Ex., $339-356$

Spain $u$. Arnott, 2 Stark., 256-202, 203

Spartali $r$. Benecke, 10 C. B., 212-4S1

Speck $v$. Phillips, 5 M. \& W., $279 ; 7$ Dong., 470-203

Spencer $v$. Parry, 4 L. J. (N. S.) K. B., $186-439$

Spicer $x$. Barnard, 29 L. J. (N. S.) M. C., $176-380,381$

$-v$. Cooper, 1 C. \& D., 52-481, 507

Spieres $r$. Parker, 1 T. R., 144-374

St. Albans (Duke of) $v$. Skipwith, S Beav., $354-310$

Stacey v. Whitehurst, 34 L. J. (N. S.) M. C., $94-376$

Stafford (Marquis) v. Coyney, 7 B. \& C., $257-197$

$-v$. Garlner, 7 L. R. C. P., $212-$ $327-331$

- (Mayor of) $x$. Till, 4 Bing., $75-$ 4.55

Struford (harl of) $r$. Dunhar, 14 M. \& W., 151 ; 12 .I. \& W., $414-403$

Stammers v. Dixon, 7 East, $200-317$

Standen ?. Christmas, 10 (2. B., 135-425, $447,464,468$

Staniforth $\%$ Fox. 7 Jing., 590-411

Stinley $v$. White, 14 East, 332-357

Stannion v. Davis, Salk., 404-602

Startup $v$. Cortazzi, 2 C. M. \& R., 165493

Starcley \%. Alleoek, 16 Q. B., 636-289

Steel $v$. II oruthton, 1 HI. III., $51-344$

Steele v. Nart, 4 B. \& C., 272-482

stevens $v$. Boswell, 28 Veterinarian, 6666.155
Stevens v. Legh, 2 C. L. R., 251-557

Steward v. Coesvelt, 1 C. \& P., 23-553

Stile $v$. Abbot of T'ewkesbury-386

Stockport Waterworks v, Potter, 31 L. J. (N. S.) Ex., 9-363

Stokoe v. Singer, 26 L. J. (N. S.) Q. B., $2.57-77$

Stott $v$. Clegg -107

- $v$. Stott, 16 East, $343-352$

Stradbroke (Lord) $v$. Mulcalyy, 2 Ir. Rep. (N. S.), $406-442$

Stratton v. Pettit, 16 C. B., 420-413

Street $v$. Blay, 2 B. \& Ad., 456-484, 495, 596

Strickland v. Maxwell, 2 C. \& M., 539 ; 4 Tyr., 346-322

Stroud (In re), 19 L. J. (N. S.) C. P., 117 $-412$

Strutt $v$. Rolinson, 3 B. \& Ad., 395-416

Stuart $v$. Crawley, 2 Stark., 323-264

- v. Wilkins, Doug., $19-542$

Studdy $v$. Saunders, 8 D. \& R., 403 ; 5 B. \& C., 628-481

Summersett $v$. Jervis, 3 B. \& B., 2-524

Sutton v. Moody, 2 Salk., 556; 1 Lcl. Raym., 250-367, 379

- v. Temple, 12 M. \& W., 52-424

Swaisland $v$. Dearsley, 30 L. J. (N. S.) Ch., $653-541$

Swatman v. Ambler, 24 L. J. (N. S.) Ex., $185-441$

Swinfen $v$. Bacon, 30 L. J. (N. S.) Ex,, $109-470$

Sylray $?$. White, 1 M. \& W., 435-138

Sylvester $v$. Scattergood, 15 Q. B., $506-$ 600

Symons $v$. Marine Society -67

\section{T.}

Tallot (Earl) $\because$ Hope Scott, 27 L. J. (N. S.) $\mathrm{Cl}_{1}, 273-115$

Talver v. West, Holt N. C. P., 179-4s.5 Tansley $v$. Turner, 2 Scott, 231 ; 2 Bing. N. C., 151; 1 Hodges, 267-130

Tappley $v$. Sheather, W. R., Nov. 15,1862 $-466$

Tarling $v$. Baxter, 9 D. \& R., 272; 6 B. \& C., $360-494$

Tizrrant $v$. Welub, 18 C. B., 797-214

Tasker n. Bullman, $3 \mathrm{kx}, 351-396$

'Tisssell $\because$. Cooper, 9 C. 13., 509-210

Tathan $v$. Hodgson, 6 T. R., 656-231

Taunton $z$. Costar, 7 T. R., $431-322,345$ 
Tawney $v$. Crowther, 3 Bro. C. C., 161420

Taylerson $v$. Peters, 2 N. \& P., 622; 7 Ad. \& E., 110 ; W., W. \& D., 644290

Taylor $v$. Caldwell-475

- v. Carr \& Porter, 31 L. J. (N. S.) MI. C., 111-206

- v. Crowland Gas Co., 11 Ex., 1 \& 24 L. J. (N. S.) Ex., 233-251

- $v$. Henniker, 12 Ad. \& E., 488284

- v. Waters, 7 Taun., 374-71, 74, 302

$-v$. Whitehead, 2 Doug., 475-94

- v. Zamira, 6 Taun., 523-395

Teal $v$. Anty, 4 Moore, 542 ; 2 B. \& B., $99-56$

Tempest $v$. Fitzgerald, 3 B. \& Ald., $680-$ $495,579,582$

Temuleman (app.) v. Haydon (resp.), 12 C. B., 507-220

Tenant $v$. Goldwin, 6 Mod., 314-133, 147

Tennant $v$. Field, 27 Law J. (N. S.) Q. B., $33-283$

Tew $v$. Jones, 13 MI. \& W., 12-449

Tewkesbury (Bailiffs of) $v$. Bucknall, 2 Taun., $120-523$

Thomas $v$. Dering, 1 Keeb., 729-421

$-v$. Evans, 27 L. J. (N. S.) M. C., $172-364$

- v. Fredericks, 10 Q. B., 775-387

$-v$. Harris, 9 Law J. (N. S.) C. B., $308-271,283,284$

v. Morgan, 2 C. M. \& R., $496-$ 166

- v. Packer, 1 H. \& N., $669-451$

- v. Phillips, 7 C. \& P., 573-343

- v. Thomas, 2 C. M. \& R., $34-88$

- - v. Williams, 10 B. \& C., $664-276$

Thompson $v$. Gibson, 7 MI. \& W., $456 ; 8$

M. \& W., 281; 9 Dow. P. C., 717 $354,355,493$

$v$. Patteson, Olliphant, 85-569

Thoruett $v$. Haines, 15 M. \& W., 367550

Thorpe $v$. Eyre, 1 Ad. \& El., 926-323

- $v$. Plowden, 2 Ex., 3S $7-404$

Thrupp $v$. Collett, Jurist, Feb. 12, $1859-$ 209,389

Tickle $v$. Brown, 4 Arl. \& E., 369-82, 83

Tildesley $v$. Clarkson, 31 L. J. (N. S.) Ch., $362-464$

Tinckler $v$. Prentice, 4 Taun., 549-284
Tindall $v$. Powell, Weckly Reporter, August $28,1858-211$

Tomkinson v. Staight, 25 Law J. (N. S.) C. P., 85- 505

Tomlinson (clerk) $v$. Burghey, 1 C. B., 603 $-401$

- $v$. Day, 2 B. \& B., $680-388$

Tooker $v$. Smith, 1 H. \& N., 732-436

Toss [Foss] $v$. Racine, 7 Dow., 53-439

Towne $v$. D'Eynrick, 1 C. L. R., 335446

Townend $v$. Woodruff, 5 Ex., $506-518$

Townsend $v$. Wathen, 9 East, 277-389

Toulmin $v$. Hedley, 2 C. \& K., 157-486

Toymbee $v$. Brown, 3 Ex., 117-403

Trent $v$. Hunt, 29 L. J. (N. S.) Ex. 318470

Tress $v$. Savage, 4 E. \& B., 36-412, 436

Trimmer $v$. Walsh, 32 L. J. (N. S.) Q. B., $20-406$

Truman $v$. Loder, 11 Ad. \& E., 593-210

Truscott $v$. Merchant Taylors Company, 11 Ex., 863 ; 21 L. J. (N. S.) Ex. 17396

Tucker $v$. Newman, 11 Ad. \& E., 40107

Tuff $v$. Warman, 27 L. J. (N. S.) C. P., 322 $-221$

Turberville $v$. Stampe, 1 Ll. Raym., 264 ; 1 Salk., 13-212, 214, 360

Turner $v$. Barnes, 31 L. J. (N. S.) Q.B., $170-283$

v. Hutchinson, 2 F. \& F., 185467

-v. Morgan--392

-v. Robinson, 6 C. \& P., 15 ; 5 B. \& Ad., $789-200,202$

v. Spooner, 30 L. J. Ch., 801-97

v. Wright, 29 L. J. (N. S.) Fx. Ch., 470, 598; 2 Law Rep. 271, 640113

Tuton $v$. Senoria [Sanoner], 27 L. J. (N.S.) Ex., 293-515

Tutton $v$. Darke, 29 L. J. (N. S.) Ex., 2$\rceil 1$ $-282$

Tyler $v$. Bennett, 5 Ad. \& E., 377; 6 Nev. \& M. 826 ; 2 Har. \& W., 272-66

— $v$ Wilkinson, 4 Mason, U. S. R., 397 $-174$

Tyson $v$. Thomas, Miclel. \& Y., $119-$ 522 
I.

Tpton 1 . Greenlecs, 25 Law J. (N. S.) C. P., $4 t-437$

r. Townend, 25 Law J. (N.S.) C. P., $44-437$

Y.

Vaspor 2 . Elwarls, IIolt, 257; 12 Mod. $660 ; 1$ salk., 2 48 ; S C. 13., S12; 19 Law J. (N. S.) C. P., 12-267

Vangh 2 . Menlove, 3 Bing. N. C., 468 ; 4 scott, $244-360$

- 2 . Taff Vale Railway Company, 2S L. J. (N. S.) IX., $11-360$

Venning $r$. Leckie, 13 Last, 7 ; 7 C. \& P., $5: 25-452,459$

Vere $r$. Cawdor (Lord), 11 Fast, 568368

Vertue $v$. Beasley, 1 Moo. \& Rob., 21279

Veysey r. Hoskins, 34 L. J. (X. S.) M. C., $145-376$

Vidler, c.x parte ve Terry, W. R., Dee. 13, $1 £ 62-539$

Viney $\imath$. Chaplin, 27 L. J. (N.S.) Ch., 434 $-475$

Tivian 2 . Champion, 2 Ll. Raym., 1125129

Vowles $r$. Miller, 3 Taun., 13i-132

Voyce 2 . Voyce, Gow.. 201-13.5

Vose Administratrix 2 . Lancashire and Yorkshire Railway Company, 214

W.

Warldington $r$. Rristowe, 2 B. \& P., 452$50,51,5.3$

Trale 2 . Marsh, Lntw., 211-289

Warlhurst $\tau$. Damme, Cro. Jac., 15-36s

Walilo r. Walilo, 7 Sim., $261-127$

Walker 2 . Bentley, 9 Hare, 629-395, 398

- $v$ Giles-282

$\because$ The York and North Mirlland liailway Complany, 2 F. \& B., 750 (5)

Willice $\imath$. Maslaren, 1 M \& R., 5, f -2S?, 152

IV:aller v. Lary-509

Wallis $r$. Harrison, I 2I. \& W., 538; 11 L. J. (X. $\therefore$ ) lix., $110 \ldots-72,90$
Wallis $r$. Littell, 31 L. J. (N. S.) C. P., 100 $-465$

Walmsley $v$. Milne, 29 L. J. (N. S.) C. I., $97-469$

Tansborough $v$. Maton, 4 Ad. \& Ell., 884 $-455,458$

Wanstead Board of Health r. Hill, N. R., Jan. 23, 1863-363

Tarburton $v$. Parke, 2 H. \& N., 6t-8t

Tard $v$. Andrews, 2 Chit., 636-115

- $v$ Robins, 15 M. \& W., 227-180, 192

- $v$. Ward, 7 Ex., S3S- 86

Wardle $r$. Brocklehurst, 29 L. J. (N. S.) Q. B., 145-198

Wardell $\imath$. Usher, 3 Scott N. R., $508-$ 122

Warlow r. IIarrison, $2 S$ L. J. (N. S.) Q. F., $18-591$

Warner $x$. Wellington [Willington], 3 Drew, $523-495$

Warren 2 . Rulall, 29 L. J. (N. S.) Ch., $543-112$

Warton $v$. Flowers, 26 Veterinarian, $143-$ 572

Warwick v. Bruce, 2 M. \& S., 205-52, 53

- v. Collins, 5 M. \& S., 166; 2 M. \& $\mathrm{s}, 349-398$

Washbourne v. Burrows, 1 Ex., 107-55, 60

Waterford (Marquis of) app. $v$. Knight resp., 11 Cl. \& Fin., $653-403$

Waterman $v$. Soper, 1 Ld. Raym., $737-$ 116,117

Waters $\vartheta$. Weigall, 2 Anst., $575-430$

Watherell $v$. Howells, 1 Camp., 227308

Watkins $v$. Major, 10 L. R. C. P., 662377

- ?. Reddin, 2 F. \& F. 629-361

Watson $r$. Denton, 7 C. \& P., Sij-593

r. Lane, 25 L. J. (N. S.; Ex., 102 $-357$ 508

Watts $v$. Ainsworth, 31 L. J. (N. S.) Fix., $448-537$

- $v$. Friend, 10 B. \& C., 446-507, 521

Weale $v$. West Middlecex Waterworks, 1 Jac. \& Walker, :372-518

Wcarer $v$. Llogrl [Floyd], 21 L. J. (N. S.) Q. L., $151-207$

Woljb r. Beavan, 6 MI. \& (i., 1055-347 
Webl $v$. Birl, 31 L. J. C. P. 335, Ex. Cl. $-96$

v. Paternoster, Palnu, $71-71,72,7 t$

v. Plummer, 2 B. \& Al., $746-323$, 324,325

Wecding $v$. Mason, 2 C. B. (N. S.), 382333

Wedlall $v$. Capes, 1 M. \& W., 50-434

Weekly $v$. Wildman, 1 Lu. Raym., 407-78

Weetou $v$. Woodeock, 7 M. \& W., 14-460

Wellington (Duke of) Settled Estates Act $-19 S$

Wells $v$. Head, 4 C. \& P., 568-162

West $r$. Hedges, Barnes, $211-295$

- v. Moure, 8 East, 339-443

- $v$. Nibbs, 4 C. B., 172-279

Western $v$. Russell, 3 V. \& B., 187, 191421

Whaley $v$. Laing, 2 H. \& N., 476-181

Wharton $v$. Naylor, 6 D. \& L., $136 ; 12$ Q. B., 673-294

Wheeler $v$. Overseers of Burmington, 408

Whistler $v$. Paslow, Cro. Jac. 487-109

Whitaker $v$. Barker, 1 C. \& M., 113-316

White $v$. Hill, 6 Q. B., 487-144

- $v$. James, 28 L. J. (N. S.) Cl., 179 $-280$

- $v$. Lesson-105

- $v$. Nicholson, 4 M. \& G., 95; 11

L. J. (N. S.) C. P., 261-462

$-v$. Sayer, Palı., 211-443

- v. Spettigue, 13 M. \& W., 603597,599

- $v$. The Great Western Railway Company, 2 C. B. (N. S.), $7-257$

- N. (In re) v. Wakeley, 28 L. J. (N. S.) Ch., 77-431

Whiteliead v. Benuett, 27 L. J. (N. S.) Ch., $474-363$

Whiteman Ex parte-142

Whittington (Ex parte), 1 Buck, 87-322

Whitty $v$. Lord Dillon, 2 F. \& F. 67-113

Wickliam $v$. Hawker, 7 M. \& IV., 63-90, 384,385

- $v$. Lee, 12 Q. B., 521-450

v. Wickham, 19 Ves., 419-126

Wicks $v$. Macnamara, 27 L. J. (N. S.) Ex., $4[9-221$

Wieler $v$. Schilizzi, 17 C. B., $619-425$

Wiglesworth $v$. Dallison, 1 Doug., 201 319,324

Wilde $v$. Waters, 16 C. B., $637-69$

Wilder v. Speer, 8 A. \& E., 517-270

Wilkins $v$. Wood -306
Willett 2 . Poote, 30 L. J. (N. S.) M. (.., $6-206$

Wilmot $v$. Rose, 3 E. \& B., 562-298

- $v$. Lees -570

Wiley [Wilby] $v$. The West Cornwall Railway Company, 27 L. J. (N. S.) Ex., $181-203$

Williamson $v$. Allison, 2 East, $446-512$ Ex., $176-541$. Barton, 31 L. J. (N. S.)

Williams $v$. Adams-103

$--v$. Kurgess, 10 Ad. \& E., $499 ; 2$

Per. \& D., 422-561

- v. Clo.rgh, 27 L. J. (N. S.), 325

v. Currie, 1 C. I., $841-127$

v. Eyton, 28 L. J. Ex., 146-105

v. Llangeinwen, 31 L. J. (N. S.)

M. C., $51-407$

- v v. Millington, 1 HI. Bl., $81-348$, $5 \$ 7$

- - Moreland, 2 B. \& C., $910 ; 4$

D. \& R , 583-172, 174

? - v. Morris, 8 M. \& W., 488-72

- v. Paul, 6 Bing., 653-562

$-v$. Stiven, 15 L. J. (N. S.) Q. B., $32 \mathrm{I}-2 \mathrm{SS}$

$v$. Williams, 12 East, 209; 15

Ves. Jun., 425-110

Willoughby (app.) ?. Horridge (resp.), 12

C. B., $742-232$

396

Wills $v$. Stradling, 3 Ves., $378-312$

Wilson $v$. Brett, $11 \mathrm{M}$. \& W., 113-57t

- $v$. Fuller, 3 Q. B., $68-420$

- $v$. Greenroyd, Jurist, May 1, 1858

$-344$

$v$. Nackreth, 3 Burr., 1824-34t

$v$. Newberry-604

- $v$. Stevens, M. S. S. -547

Wiltshear $v$. Cotterell, 1 E. \& B., $674-$ 456,458

Winchester (Bishop of) $\imath$. Knight, $2 \mathrm{Ll}$. Raym., 1056 ; 1 P. Williams, 40699,307

Winter $v$. Brockwell, 8 East, 39s-72, 73, 74

Winterbotbam $v$. Ingham, 14 L. J. (N. S.) Q. B., $298-447$

Winterbourne $v$. Morgan, 11 East, 395279

Wintringham Tithes ( $r c$ ) ex parte, Lorl Cariugton, $3+$ L. J. (N. S.) C. P., 271-407 
Wise v. The Great Western Ritilway Company, 1 H. \& N., 63-24t

2. Metcalie, 10 li. \& C., 299 ; 5 M. \& Ry., $235-333$

Wish $v$. Small, 1 Camp., 331 n. -575

Witeher $*$ James Hall, S D. \& R., 22 ; 5 B. \& C., $269-483$

Tithers $v$. Reynolds, 2 B. \& Ad., 892 490

Wittam $r$. Urry, 2 Dowl, 543-309

Womersley $\imath$. Dally, 26 L. J. (N. S.) Ex., $219-319$

Wood 2: Benson, 2 C. \& J., 104-5s8

..- 2. Clarke, 1 C. \& J., 4S4-2S6

— $v$. Hewett, S Q. 13., 913-456, 469

- $v$. Lake, Sayer, 3- 71

- $v$. Lea 3 bitter, 13 M. \& W., S3S-71, 泣, 127

v. Mlarjoribanks, 30 L. J. (N. S.) Cll, $176-540$

v. Manley, 3 P. \& D., 5 ; 11 Ad. \& E., $3.1-302$

ข. Numn, 5 Bing., 10-281

r. Smith, 4 C. \& P., 45 ; 5 M. \& R., $124-543$

ข. Veal, 1 D. \& R., 20 ; 5 B. \& Al., $45+-91$

2. Waud, 3 Ex., 748-176, 182, 184,185

Woodhouse $v$. Swift, 7 C. \& P., 310-125

Woodland $v$. Mantell-44t

Woodley $v$. Brown, 2 ling., 527-521

Woodin $v$. Burford, 2 C. \& M., 39-555

Toorlward $v$. Gyles, 2 V'ern., 119-312

Woolcock v. Dew, 1 F. \& F., 337-427

Wooton $v$. Dawkins, 2 C. B. (N. S.), 312 $-391$

Worth $\imath$. Gilling, 2 L. R. C. P., 1--156
Wortlington $v$. Warrington, 8 C. B., 134 $-475$

- $v$. Grinson-105

Wright $v$. Bird, 1 Price, 20-524 v. Colls, 8 C. B., 150-419

$v$. Dewes, 1 A. \& E., $641 ; 3 \mathrm{~N}$.

\& M., $790-295,296^{\circ}$ v. Howard, 1 Sin. \& Stu., 190

$173,175,176$

- . L. \& S. W. Railway Co., 10 L.

R. Q. B., 298-253

- v. Rattray, 1 East, 37i-88

v. Smith, 470

v. Stavert-68

v. Williams, 1 M. \& W., $77-84$, 1SO, 1 S1

Wrightup $v$. Chamberlain, 7 Scott, $598-$ 558

Wyudham $v$. Way, 4 Taun., 316-121

Y.

Yates $v$. Dunster, $11 \mathrm{Fx}, 15-430$

$v$. Routledge, 29 L. J. (N. S.) Ex., 117-249, 469

v. Pym, 6 Taun., 445-480

Yolland $v$. Priee-286

York, Neweastle, and Berwick Railway Company (app.) v. Crisp and Logan (resps.), 14 C. P., 527-254

Yorke $v$. Greenhiugh, Lord Raym, 868589

Young v. Davis, 23 L. J. (N. S.) M. C., $97-103$

Young $v$. Spencer, 10 B. \& C., 145-348

Ystradinglais $(\mathrm{In} r e)$ Commutation, $8 \mathrm{Q}$. B., $32-400$ 


\section{STATUTES CITED.}

51 Hen. III., st. 4

52 Hen. III., c. 4

21 Hen. VIII., c. 11

25 Hen. VIII., c. 11

32 Hen. VIII., c. 34

2 \& 3 Edw. VI., c. 13

$3 \& 4$ Edw. VI., c. 7

1 Eliz., c. 17

13 Eliz., c. 5

43 Eliz., c. 2

3 Jac. I., c. 12

22 Car. II., c. 6

$$
\text { c. } 8
$$

22 \& 23 Car. I1., c. 9

$$
\text { c. } 25
$$

23 Car. II., c. 24

29 Car. Il., c. $350,52,56,58,59,62$, $63,65,66,67,68,129$, $277,501,504,587$

\section{c. 7}

$199,562,563$

c. 8

409

2 Will. \& Mary, s. 1, c. 5 2 7 1, 282, 285, 291, 292, 293, 332

$7 \& 8$ Will. III., c. 6

404

8 \& 9 Will. III., c. 11

$9 \& 10$ Will. III., c. 36

1 Anne, c. 7

4 Anne, c. 16

5 Anne, c. 14

8 Anne, c. 14

$282,288,291,294,295$,

280,450

230,452

353

85

85

\section{2}

4 Geo. II., c. 21

296,321

470

4 Geo. II., c. 28

c. 29

9 Geo. II., c. 36

$11 \mathrm{Geo}$ II., c. 10

c. 19

20 Geo. II., c. 19
$291,304,450,470$

292

395

446

$279,280,281,283$, $284,291,292,293$, $294,295,296,397$, $425,445,450,51.3$ $201,202,206,209$
201

143

50

121

522,523

438,439

438,439

343

78,132

309

322

518

518

416

55 Geo. III., c. 156

c. $18454,340,416,558,559$

56 Geo. III., c. $50 \quad 292,29 t i, 298,299$

59 Geo. III., c. $95 \quad 340$

1 Geo. IV., c. 56

c. $87 \quad 450,520$

3 Geo. IV., c. $126 \quad 107,141,340,341$

4 Geo. IV., c. $28 \quad 418,449$

c. $34 \quad 200,201,204,205$

c. 95

154

5 Geo. IV., c. 14

396

c. 28

c. 74

6 Geo. IV., c. 16

404

$507,521,523$

7 \& 8 Geo. IV., c. 18

c. $29136,226,227,345$,

$373,599,600$

c. $30 \quad 136,137,358$,

363,372

c. 31

430

9 Geo. IV., c. 14

c. 69

505,587

$369,370,373$,

$376,382,392$

I1 Geo. IV. \& 1 Will. IV., c. $68 \quad 242$

I \& 2 Will. IV., c. $32363,368,369,370$, $371,372,373,374$, $375,376,377$,

$381,386^{\circ}$ 
3 Will. IV., c. 34

1 if 211 ill. IV., c. $3 \%$

$$
\text { c. } 42
$$

$2 \& 3$ Will. IV., c. 71

$3 \& \pm$ Will. IV., e. 4

$$
\text { c. } 27 \quad 345,346,395 \text {, }
$$

4 Hill. IV., ss. 4, 5, 6

$5 \&$ i 11 ill. $11 .$, c. 18

$$
\text { c. } 50
$$

$$
\begin{aligned}
& \text { c. } 53 \\
& \text { c. } 59 \\
& \text { c. } 83 \\
& \text { c. } 74 \\
& \text { c. } 75
\end{aligned}
$$

6 Will. IV., c. 13

ti $\& 7$ Will. IV., c. 71

$$
\begin{array}{r}
395,396,397,399, \\
400,401,403,404, \\
406,453
\end{array}
$$

$230,251,296,394$,

7 Will. IV. \& 1 Vict., c. 69 1 Vict., c. 69 .

1 \& 2 Vict., c. 43

$$
\text { c. } 64
$$

2 \& 3 Vict., c. 62

3 \& \& Vict., c. 24

5 lict., sess. 2, c. 27

5 \& 6 Vict., c. 35

$$
\text { c. } 54
$$

c. 55

c. 97

c. 122

6 is 7 Yict., c. 30

$$
\text { c. } 37
$$

7 \& 8 Vict., c. 29

$$
\text { c. } 76
$$

8 \& $y$ Vict., c. 18

$$
\text { c. } 20
$$

394,399

399,400 s0, 99 399

399,400 353,354 272

440 399

$145,147,150$ 281, 397

525

270

395

373

412,413

$392,475,539$ $146,148,149$, $150,153,232$
S \& 9 Vict., c. 106 c. 118

9 \& 10 Vict., c. 73

c. 93

c. 95

$10 \& 11$ Vict., c. 14

11 \& 12 Viet., c. 29

c. 30

c. 43

c. 63

c. 99

12 \& 13 Vict., c. 45

c. 42

c. 106

13 \& 14 Vict., c. 61

c. 79

c. 94

$14 \& 15$ Vict., c. 25

c. 38

c. 91

c. 199

$16 \& 17$ Vict., c. 62

17 \& 18 Vict., e. 31

c. 36

c. 60

c. 83

c. 124

18 \& 19 Vict., c. 120

c. 121

19 \& 20 Vict., c. 101

c. 97

c. 104

c. 114

$20 \& 21$ Vict., c. 43

c. 157

$23 \& 24$ Tict., c. 93

c. 126

24 \& 25 Vict., c. 70

$$
\text { c. } 96
$$

c. 103

$25 \& 26$ Vict., c. 111 27 \& 28 Vict., c. 101 30 \& 39 Vict., c. 141 $32 \& 33$ Vict., c. 70 38 \& 39 Vict., c. 92
PAGE

$412,413,414,464$

yร, 346

398

219,350

251, 437, 449

602

373

374

201,374

363,602

105

373

$269,270,603$

298, 524, 525

344,602

341

67,395

$293,394,44 \%, 462$

311,312

$52 \mathrm{~S}$

368

598

$242,247,248$,

$249,250,252$

515

270

209,416

431

406

160,425

598

418

405

523

382

567

394

354

361

380

408

376, 392,393

144

204

$4: 10$

$43-49$ 


\section{THE LAW OF THE FARM.}

\section{CHAPTER I.}

\section{AGRICULTURAL CUSTOMS.}

If the Agricultural Holdings Act were universally adopted, the term the "Custom of the Conntry," which has nsually found its way into agricultural leases, wonld cease to exist; but as it seems certain that for the present, at any rate, the Aet above mentioned will not be adopted even by the majority of farmers, it will still be necessary to explain the law of Agricultural Customs.

The claim for remuneration which an ontgoing agricultural tenant has on his landlord for various operations of husbandry, the ordinary return of which he is precluded from receiving by the termination of his tenancy, is termed "Tenant-right," and is governed by the different Customs which have long prevailed in the counties and districts of the United Kingdom. These customs are frequently most conflicting and difficult to define. In many counties they scarcely exist at all; in others it is rather the custom of districts, and in many the custom merely of certain estates. They are imported into leases or agreements for the letting and occupation of land, and nuless the agreement expressly, or by implication, excludes the custom of the country, the landlord and tenant are presumed to contract with reference to it. Tenant-right extends to the crop, which the ontgoing tenant has sown and leaves in the ground, and to remuneration for the preparation of the soil for crops by tillage, for the straw, hay, and occasionally, dung left on the farm, and for growing underrood. Of late ycars, the term has happily been understood in a much wider and more liberal sense, and in many parts of the country a usage has sprung up, which confer's a right on the outgoing tenant to be re-imbursed for certain other expenses incurred by him in cultivation, beyond those of mere ordinary husbandry. Among such expenses are the purchase of food for stock, as well as of certain kinds of manure, and the draining, chalking and 
marling of the soil. If there be no usage to that effect, and no express stipulation, the outgoing tenant can claim no compensation for any of these improrements, howerer short may be the time between their completion and the termination of his ocenpancy. In practice, the compensation agreed to be paid by the landlord to the outgoing tenant, is paid by the incoming one. The cost of the several improvements is found by valuers, who spread the amount orer a certain number of years, within which cach kind of improrement respectively is supposed to repay itself, and dednet the time during which the tenant has enjoyed the benefit of it. It would simplify their calculations if the Hichaelmas entry was unirersal. The customs in England and Wales are as follows:

Belfordshire-The original system in Bedfordshire was a Iady-day hiring, the tenant being entitled to the awaygoing crop ; but in most instances the practice is now changed into the regular Michaelmas hiring. The tenant-at-will receives notice by the 25th of March to quit the next Michaelmas; and is obliged, according to the eustom, generally speaking (though not invariably), to give up his fallows, and a portion of the farmhouse, and a stable for the horses, to the incoming tenant; and the incoming tenant is allowed to come in and sow the seeds himself. The Norfolk system generally prevails, of allowing the outgoing tenant to cultivate the fallows in the usual way, carrying the manure out and sowing the turnips, cutting the hay, and stacking it on the farm. He has to be paid by valuation for the hay and turnips, but he receires nothing for manure, except the cartage, however expensively it may have been made. No exception is made even in the case of oilcake manure. There is no custom that enables the tenant to claim compensation for artificial dressings or drainage, or anything of that kind. In the Duke of Bedford's leases it is stipulated that the tenant should pay six per cent. on the cost of "hollow draining with drainpipe tiles, set upon soles oi flat tiles;" the tenant paying for the carriage of the same. On his Grace's estates, all the dung manure and compost prodneed and made during the last year of the tcnancy, and all unexpended manure whatsoever is left for the ineoming tenant without compensation, and the meonsumed straw, hay, green crops, stubljle, haulm, storer, chaff, and cavings is paid for at a spending price. The incoming tenant is allowed to enter in the Norember of the last year of the term, and as often afterwards as he requires, to prepare a certain portion of the arable land for a fallow; and to enter at sced-time on all the land which shall be sown for a crop of barley or other spring corn, and sow clover or any other grass seeds, to be harrowed in with the grain. He may also enter upon the stubble land, which may have pro- 
duced white straw grain, or pulse, as soon as it is carried off the land at harrest, and prepare and sow it with rye, tares, or any other seeds, or plant it with cabbages or other plants for the spring feeding of cattle or sheep.

Berlishire and Bucks. - The customs are nearly identical in these two counties. Michaelmas is always the time of entry, and there is no other time of quitting. The incoming tenant pays for all acts of husbandry. It is the custom not to allow more than two white straw crops to be taken in succession. Many tenants are allowed to sell wheat straw, but the general principle is that the incoming tenant takes to it at a valnation. The hay is taken to sometimes at a consuming price, sometimes at a market price ; in fact there is no standing custom at all respecting it. The manure of the last two years is usually considered the incoming tenant's property, provided the outgoing tenant had it when he entered. There is no compensation for the purchase of artifieial food or manure, nor for drainage or chalking; or, in fact, for any durable improvements of the land, exeept under special agreements. It is often stipulated that a certain number of sheep shall be kept on the farm during the last year by the outgoing tenant, to September 29th, and folded on those points of the farm the incoming tenant may seleet. After the farm buildings have been put in repair, the general rule is that the tenant is to keep them so, the landlord finding rough materials and the tenant workmauship.

Cambritgeshire.--There are so many varieties of land in this county that it is difficult to define aceurately what custom obtains. In the fens no regular system of eropping prevails, as the variety of seasons sets all regular rotation at defiance; in many instances wheat and bran have been grown alternately for years, while on others, potatoes, rape and mangel-wurzel are alternated with wheat and oats. On the ligh land the old Norfolk fonr-course system is nsnally adopted, viz., wheat, roots, barley, seeds, but in some districts the use of artificial manures has permitted and rendered profitable the introduction of the five-course system, in which case barley is grown after wheat. Where long leases are granted, tenants are usually allowed to crop without restriction, provided the condition of the land is maintained, exeept during the last four years of their tenancy, wherein the four-course system is to be strictly allhered to. It is customary for the outgoing tenant to prepare the fallows and sow the small seeds, and to be paid for these by the incoming tenant. Hay is paid for at a consuming price, and the incoming tenant takes the last year's straw and chaff, but pays for the thrashing, dressing, and delivery, within a reasonable distance. 
In most cases an allowance is made to the outgoing tenant for oil cale and purchased corn, which has been cousumed during the last two years of' his occupation. 'The entries are almost invariably at Michaelmas.

\section{Cheshire-Sse Lancashive.}

Comucll.-Michaclmas is the most general time of entry, but there are some latdy-day holdings, especially in the north and east of the county. The former period, howerer, is considered the most desirable one. The length of holding's varies considerably. In many instances, leascs are granted for terms of seren, fourteen, or twenty-one years, and a rery large number of farms are held at yearly tenancies with, and sometimes without, a written agreement. An outgoing tenant has no allowances whaterer for any unexhausted improvements, except in occasional cases. Draining is generally either performed by the landlord, the tenant paying a yearly per-centage on the outlay, or it is cxecuted by the landlord and tenant jointly, the former perhaps paying for the cutting of the drains, and the latter bcing at the expense of the filling in. Instances of a tenant being allowed for any unexhausted manures are exceedingly rare. In Lady-day holdings the valuation rould comprise the growing wheat crop, and preparations made for the turnip, barley, and oat tillages, \&c. In Michaelmas holdings the matters which come under a valuer's notice are subject to great variation, according to the time at which the incoming tenant commences to do any labour on the farm. Sometimes the outgoing tenant prepares for and tills the root and spring grain crops; and in such cases, if the incoming tenant intends to take them they have to be valued. In others, the greater part of these preparations is performed by the outgoing tenant, but the incoming one puts in the crops, and of course the valuation must be made accordingly. Sometimes farm-yard mauure left in the yards or in heaps in the fields, not used, is paid for, and sometimes it is not; but if carted together in heaps, the labour attendant on it is considered. Hay is usually taken by the incoming tenant at a rahnation. The outgoing tenant allows for the repairs required to gates, fences, \&c., and roofs of thatch; but slated roofs are kept in repair by the landlord.

Cumberland and Westmorcland.-The two principal times of entry are Candlemas (Fubruary 2nd) and Isady-day (March 25th); in some instances the land is entered on at Candlemas, and the buildings at May-day. If the outgoing tenant leaves the farm at Candlemas, he keejis up his regular stock of horses and cattle until the end of the term, and then takes away or sells the remainder of the unconsumed 
restures of the last year's crop, hay and straw. The manure is left for the incoming tenant, free of any charge. In some instances the landlord binds the tenant to consume at least onc-half of the last year's crop of hay and straw, in preference to the mudefined term of "kecping up the usual and regular stock." The outgoing tenant is allowed for rent of the land, taxes, sced, and labour, on all bare or dead fallow in the last year of the term; also the cost-price of clover and grass seeds sown the preceding spring, if kept uninjured. Gates and fences must be left in tenantable repair by the outgoing tenant, or an equicalent in money must be given to the incoming tenant to make good the same. Should the entry be at Lady-day, the tenant is in some cases bound to consume upon the premises at least two-thirds of the last year's crop of hay and straw, and leave the manure for the use of the incoming tenant, free of charge ; and where the entry is on "land at Candlemas, and buildings at May-day," the tenant consumes the whole of the restures upon the premises, and leaves the manure as before stated. Where this is the custom, the outgoing tenant is only entitled to one ploughing and harrowing, seed wheat, carting, and spreading manure, \&c., on dead fallow in the last year. This is the custom on Lord Lonsdale's farms both in Cumberland and Westmoreland, and in fact the universal one in the latter county. The landlord usually drains the land, the tenant paying five per cent. upon the outlay, and carting all the materials free. 'The compensation for uncxhausted improvements must be according to agrecment; and there are rery few, if any, for which an outgoing tenant can claim. There is perhaps, no estate where a portion of the oilcake bill is allowed in the last year; nor is it usual to allow for bones, guano, \&c., except when such manures are put upon the dead fallow for wheat in the last ycar, and the outgoing tenant had no benefit from such manures. The land is chicfly managed under the five and six-course rotation, and the bare or dead fallow constitutes the principal claim that an outgoing tenant has against his successor. Each party chooses a valuer, and in case of disagreement, the trro choose a third, whose decision is final. The value of one acre might be as follows:-Ploughing and harrowing four times at $9 s ., £ 116 s$.; land rent, say $£ 15 s$.; seed wheat, say $£ 15 s$. ;

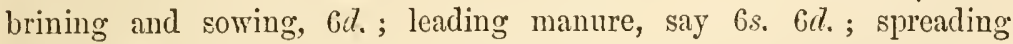

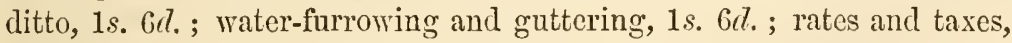
2s. 6d.-total, $£ 418 s$. 6 d. If the land has been limed in that year, the cost of the lime as well as the leading and spreading must be added, and so when guano or bones hare been used. The cost of an acre of fallow wheat chiefly depends upon the value of the land, the market price of seed wheat, and the distance the manmre is to be 
carted. These settlements or arbitrations are always arranged and carried ont by the ontgoing and incoming tenants, and the landlord seldom takes any part in the matter. The land is chiefly managed muler the fire- and six-cour'se rotation ; that is-first year, oats ont of lea; second, potatoes and turnips, or dead fallow; third, wheat or barley, sown with grass seeds; fonrth, pasture, or mown for hay; fifth, pasture ; sixth, pasture. If the five-conrse be adopted, the field rould be in oats, and not in pasture, in the sixth year.

Derbyshire.-The invariable time of entry in this comnty is at Ladyday. 'The offigoing tenant lias no awaygoing crop, and the payments by the incoming tenant to his predceessor are regulated by the usual restrictions and corenants under which the generality of tenant farmers live, and occasionally by custom. The compensation to outgoing tchants for improvements is limited, and frequently discretional with the landlord. 'There is an allowance for mexpended bones, and for other light tillages, snch as grmano, rape-dust, \&c. Gencrally speaking, the tenant by lis conditions is not allowed compensation for draining, but in most cases the landlord finds drain-tiles or pipes, as may be required; and if the landlord or agent gires consent in writing for such drainage to be execnted, the offgoing tenant wonld be allowed compensation, on a seven Jear's' scale. Sometimes when there is no covenant, and the tenant quits on the "custom," draining is allowed for on a ten years' scalc. Of late years there has been an allowance of one-third for oilcake consumed on the farm the previons year, and in some instances half the cost price. Further allowanees ought to be made for cakc consumed, extending over the sccond year, and onefourth or one-sixth of the cost priee would be a compensation, good proofs being produced that snch quantities were consumed. Half-inel drill bones extend over a period of six years on grass lands when pastured; and where crops are taken, over half that time. In some instances where tenants are living under conditions, the whole of the manure made on the farm becomes the landlord's property; and the offgoing tenant has no intcrest in making rich manure. Hence it not unfrequently happens that the whole of one year's hay and straw is left unconsumed, to be taken to at a reduced price. The hay and straw left on the farm are paid for by the award of the arbitrator, subject to tomnage, by which is meant a consuming price, the tenant not being allowed to sell hay or straw off the farm. Leases are the exception, not the rule; and the land is held from year to Juar, with a six-months' notice from either party. 'There is no allowance for buildings of stone or brick erceted by the tenant. Where sheds or 
hovels are built of wood by the tenant, he ean remove them or receive compensation; but there is nothing to compel a landlord to take to such buildings at a vahnation.

Derbystire North.-The gencral time of entry is at Lady-day, and the outgoing tenant has, with a ferv exceptions, no awaygoing crop. Compensation is made to the ontgoing tenant for making clean turnip or summer fallows the year preceding his quitting, by payment of one year's rent and taxes, for dressings, turnip seed and hoeing, labour on manure from the yard, for any purchased manure applied, and for seed wheat and sowing on the summer fallows, deducting from the turnip land two-thirds of the value of the turnip erop if drawn off, and onehalf if eaten on the land. For land having had one crop of corn, since fallowed, and laid down with hay or clover-seeds, the cost price of the seeds and labour of sowing is allowed; and for whent sown upon grass or clover ley, the cost price of the seed and labour of plonghing, harrowing and sowing. For bones, where no crop has been taken, the cost price and labour of carriage and drilling is allowed; where one erop has been taken, two-thirds of the same; and where two crops, one-third. Where land has been pastured, only one-sixth is deducted from the cost price and labour, for each year's pasturage. Turnips are not considered to be a crop. For guano and rape-dust the cost price is allowed where no crop has been taken; after one crop one-third of the value is allowed; and upon land pastured, one year after application, two-thirds of the value; and after tro years, one-third. For monntain or carboniferons lime, the same allowances are made thronghont as for bones. For magnesian lime, the full value of the lime and labour is allowed where no crop has been taken, and one-half after one crop. Where land has been pastured, one-fourth of the cost price and labour is deducted for each year's pasturage. One-fourth of the cost of linseed-cake consumed either in the yard by eattle, or on the land by sheep, during the last year of the tenancy, is generally allowed; and one-eighth of that consumed in the previous year. The tenant by his conditions is mostly allowed compensation for draining, varying from seven to ten years; when it is done by the landlord, five per cent. is generally charged. The manure made from the last year's prodnce, which in former years was left by the ontgoing tenant without any compensation, is now in many instances allowed for, and it is found that the ontgoing tenant having an interest in it, makes better manure than when he was not paid for it under the old system. Hay and straw left rpon the premises are taken to at a valuation not exceeding one-fourth of the quantity of the preceding year's growth. 
Deronshire.-Farms are usually given up at either Lady-day or Michaclmas. In a Lady-day holding, the tenant has no awaygoing crop) ; he gires up ererything when he leares. The incoming tenant generally puts in the wheat and ploughs up the wheat eddish by a prorision to that effect in the lease. If he has no such agreement there is no eustom to gire him a right of entry at all, and he has to compensate the outgoing tenant for seed and labour. The outgoing tenant has no claim for improrements that he has made on his farm, nor for calie, except by special agreement. Where they are tenants-at-will from year to year, the tenant is subject to six months' notice; and whenerer the six-months' notice is given, there is an auction, and the tenant sells off everything, including the manure. There is scarcely any geucral agricultural enstom existing in the county. The tenants are not allowed to sell hay or straw, the corenants restrain them; but they sell reed. A tenant when he is going out nerer sows wheat himself by the eustom of the country, but by agreement. There is no custom as to machinery, thrashing machines, \&c. Cider presses are sometimes the property of the tenant, and he takes them away: if not, he leares them; and it is the same with thrashing machines.

Dorsetstive. - The time of entry upon farms is gencrally Lady-day, On $\triangle$ pril cth the incoming tenant enters the meadows with the land for turnips; on July 6 th all other pasture or down lands, with land of two years' ley for wheat; on October 10th the remainder of the arable lands; and on July 6th of the following rear the remainder of the house, barns, stables, \&c. ITe is allowed stabling and straw for food and litter for a certain number of horses, and the use of the yards for turning up manure: he has also a cottage for the carter and shepherd, with part of the farm-house, and other offices therein. The ontgoing tenant generally takes the following wheat or barley erop, unless there is some special agreement; it is ralued on the ground, and is generally worked off by the outgoing tenant. The manure belongs to the incoming tenant, whether it be made with oilcake, or whether it is mere straw and water, and he usually takes any hay that may be left at a raluation. As a general thing, there is no compensation for improvements to outgoing tenants, and none for artificial manures, chalking, marling, claying, buildingrs, fences, orchards, \&c. Mr. Sturt's "Tenant Security Rules," howerer, provide a seale of compensation to tenants for uncxhausted improvements, extending in the case of liming to the screnth year, and in the case of draining to the eighth year. By rule 15 th, "For conversion of all pasture land into arable, the outgoing tenant is to be allowed $15 \mathrm{~s}$, in the pound for paring and burning before 
the first corn or pulse crop is taken." Leases are not very general in the county. Lord Portman has granted very long ones to lis tenants, half the rent being fixed at a money price, and the other half regulated by the price of barley and wheat, taken on the average of the United Fingdom, as returned by the London Gazette.

Durham and Northumberland.-The customs in Northumberland and Durham are much alike. Some estates are let on an annual tenancy, but the best cultivated and most productive, are let on leases. Fifteen Jear's is a common term of lease, but on large farms, or where much improvement is contemplated, involving a large outlay by the tenant, a term of 21 years is not unusual. The general time of entry is the 13 th of May; but it is stipulated that the outgoing tenant shall preserve uneaten a certain portion of new grass for meadow, and of old meadow land, if there be any, from the end of the preceding October, the incoming tenant finding the grass sceds, or paying for them afterwards. The away-going crop belongs to the ontgoing tenant, by whom it is sown, and he is entitled to reap it, and to retain the stack garth, barns and granaries till the 13th of May ensuing; but it is a better plan, and becoming customary, to bind the ont-going tenant to sell, and the incoming tenant to purehase, the standing crop at harvest, by the valuation of two parties mutually chosen, who shall choose an umpire, leaving the prices to be determined by the market averages of the district at three periods,--November, February, and May, at each of which a payment shall be made. The threshing machine, if a fixed one, is also transferred by valuation in like manner, so that the entering tenant gets possession of the whole of the premises and produce at once. The new tenant has a right to enter into, and plough the stubble land inteuded for fallow or root erops in the ensuing year, after October, and to cart ont manme to it during the winter, but it is better, and frequently stipulated for, that such work shall be done by the out-going tenant, who has little occupation for his dranghts, and that he be paid per acre for doing so, by the incoming tenant. The tenant is bound to the repair of buildings and fences (walls, roofs, and main timber excepted). Tenants are required to insure against firc. Draining is done by the landlord, the tenant carting materials, and paying five per cent. upon the ontlay for labour and pipes. In some cases, as on the estates of Lord Grey, the Greenwich Hospital, and others, compensation is given, on a fixed ratio, for lime and purehased manures applied during the last three rears of the term, in case the tenant leaves the farm. In all cases the manure made upon the premises must be applied to the farm. 
Essex.-The custom of compensation rarics in different localities. The rent upon the fallowed land (and in some cases the tithe and rates) is for the most part allowed to the outgoing tenant. He is also allowed for the plonghing and tillage thereon; for the seed-sowing and cultivation of the turnips, mangolds, or green eattle-crops upon the land under fillow; for the labour thereon, and the dung, either left in heaps, or carted on for the green crops; and for the eloverseeds and grasses, if sorm upon lands fallowed in the preceding year, whether a plant is obtained or not. Hay is ralned at about three-fourths of the market price-being the market valne, less the cost of cutting ont and marketing, and the ralne of a load of manure brought on to the farm. The outgoing tenant folders out his straw and hay of the last year, or the incoming tenant pays the cost of thrashing out the erops, and carts out the grain arising therefrom a distance not excecding ten miles by way of compensation for the straw, \&e. The tenant repairs the buildings, and the landlord finds materials. No compensation is allowed for dritining, or for artificial manure, or oileake, sc., consumed. $\Lambda$ yearly tenant is entitled by custom to the rent, plonghing, and tillages of fallows; to the feeding value of hay and straw ; and to compensation for manure left upon the farm: the principle being that he shall leave the farm in the same way as he entcred. The dung is measured in the heap, and ralned at so much the square yard. All the tenancies commence at New Michaelmas, and the outgoing tenant is entitled to the use of the barns until the Lady-day following, but not of the house, stables, \&c. after Nichachmas-day.

Gloucestershire.-The tenancies are yearly ones, and sometimes cven without a written agreement. They are chicfly from Lady-day, but some few are from Michachmas. The commonest course of cropping is turnips, barley, "scecls" two years (clover, rye-grass, \&.c.), wheat, oats or lyarley. When the "scerls" are ploughed up at one year, the oat or" barley crop after the wheat is omitted: the first is called the six-field system, the other the four-field system. The landlord keeps all the buildings in repair, and, generally speaking, the gates; and the tenant does the hauling for the repairs, finds straw for the thatched buildings, and kecps good all the fences. He cannot sell off either hay, straw, or roots, nor take more than two white-straw crops under the six-ficld system, or one under the four-field system, in succession. On leaving, the tenant is sencrally allowed a barn, yard and field till Midsummer, for fecding off' liss hay, \&e. 'The wheat straw is valned to the incoming tenint at a consuming price, also the hay and other straw if he agrees to take to it. 'The outgoing tenant gencrally does all necessary work on 
the land, snch as plonghing, sowing, \&e., up to a short time before quitting, and is paid for the same by valuation. One-year " seeds" are valued to the incoming tenant, but two-year "seeds" are not. The ontgoing tenant is paid the whole cost of growing the turnip or otler" root crop, inclnding artificial manures. If it be a Lady-day iaking, the root crop belongs to the ontgoing tenant, if a Michaelmas taking, it is left for the ineoming tenant, the outgoing tenant being paid the same in both cases. Dung left in the yards or hanled on to the land belongs to the incoming tenant, who pays for all the labour of preparing or hauling out the same. Sainfoin is paid for aceording to its age, \&e. Vetches grown and fed on the land are paid for-that is, the ploughing, sowing, \&c., but not the seed. All exeeptions to the above payments are made by special agreement. The foregoing customs have been in practice for many years, with seareely any alteration. 'Those in the vale of Gloncestershire differ in many respects as to cropping, selling of hay, straw, \&c.; but the valuations between outgoing and incoming tenants do not differ so much. The Cotswold Hills are the chief corn growing district, the vale being chiefly pasture or small arable farms.

Hampshire.-The usual time of giving up farms is at Michaelmas; and the custom, when the lease is to expire next Michaelmas, generally allows the new tenant to have access some time before Lady-day. He would come on to prepare his turnip crop, and have about June or July a certain portion of land to enter upon to prepare his wheat season; and there is nothing else he would be permitted to do until after harvest. He would first come to prepare his fallow for the ensuing year, and for the wheat a short time before Michaelmas. The dung belongs to the landlord; in fact there is not a single thing the outgoing tenant can claim; he would feed the stock next year on the hay and straw grown in the last year of his tenaney, but he cannot dispose of it; still he may keep the incoming tenant out, and say, I will have the yards and fodder myself, and consume the hay. The incoming teunt has no claim to any hay unless he purchase it by agreement.

IIertfordstive.-The general custom is to enter upon the fallows at Lady-day, commencing tenancy the Michaelmas following. Every tenant is allowed to quit as he entered, if he can prove that entry, unless he be bound by an agreement to the contrary ; if not, the custom is laid down in the regular way, for a certain portion of the fallows to be given up at a certain time. With respect to the straw and manure, he quits as lie enters. The outgoing tenant gives up the farm, and his tenaney ceases 
at Michaclmas; and the incoming tenant has a right of entering at Lady-day, to prepare the wheat stubble for turnips, and the fallow land for turnip or other crops. The incoming tenant has a right to put stock on the fallows, but not on any other part of the farm, and to sow seeds in the growing crops, but he has no power of entry to prepare the clorer-land for wheat till the 29 th of September. The dung usually belongs to the landlord, who has also a claim for dilapidations, which are generally enforeed, such as for dilapidations of premises, and waste upoil the soil. If there is any injury by cross-cropping or neglect of tillage (as when the land is foul with grass, twiteh, \&c.) the landlord has a legal remedy, and frequently recorers compensation upon those gromnls. The tenant has no elaim for compensation for any kind of improvements, and there is no custom that gives him anything.

Herefordshire and Mommouthshire. - The time of entry is chiefly at Candlemas-day, the 2nd of February. The notice to quit is given on or before the previous 1st of Augnst. Yearly tenancies prevail, leases are the exception. The ontgoing tenant on the 2nd of February is entitled to an awaygoing cropl of wheat upon one-third of his arable land; he receives from the incoming tenant the value of the clorer-seeds sown, and of the acts of husbaudry in planting them, viz., sowing and harrowing. The outgoing tenant keeps the dwelling-house and fold-yards, and also one inclosure of grass land near the fold (locally termed a "boozy pasture"), until the 1st of May, with the exception of two rooins in the house for servants, and stable for the horses, which the incoming tenant may claim. The incoming tenant reccires possession of the whole of his occupation, excepting, as before mentioned, on the 2nd of February; he has no acts of husbandry nor mexhausted manures to pay for, and he receires the manure made in the winter by the outgoing tenant's stock without charge. The ontgoing tenant has the right to cut his awaygoing crop of wheat; he has also the porrer to defer thrashing the same to any period previous to the 1st of May after he has harrested his crop, thereby, if so inclined, depriving the incoming tenant of any wheat straw during the first winter. This absurd eustom is to a great extent done away with by special agreements, making it compulsory for the outgoing tenant to sell and the incoming tenant to purchase the wheat crop at a raluation previous to harrest. In the hop districts the poles are generally valned to the incoming tenant; it is of course his interest, but it is not compulsory mpon him to take to them. (Three-fourths of the hops known as the "Woreestershire plantation" are grown in Herefordshire.) No compensation for drain- 
ing is made to the outgoing tenant; but latterly landlords have ineurred all the outlay for draining, the tenant paying a percentage. Cider mills and presses for making cider are generally the property of the landlord, as well as any fixed thrashing machines. The takings in Monmouthshire are generally at Candlemas, as in Herefordshire, and the customs almost the same, with the exception of that of "land share," by virtue of which the incoming tenant claims one-fifth of the outgoing tenant's wheat crop, if on a fallow, and one-third if sown on a clover-ley. 'This custom, which for obvious reasons frequently operates most unjustly, is also common in the lower part of Gloucestershire (West).

Huntingdonshire.-The holdings are for the most part from Lady-day. After a tenant has given or received notice to quit, he is allowed to sow with wheat only such lands as the landlord or his steward may think fit, and in all respects according to his or their direction, or else to allow the incoming tenant to enter on such lands at any time after the 1st day of October. He must also allow the landlord or his incoming tenant to enter on the lands proper to be sown with beans or peas after the 2nd of February, and upon the land proper to be sown with corn or grain or seeds any time after the 1st day of March in the last jear. He is paid for the herbage of the land so entered on, as also for all bones or other artificial manures purchased and used in the production of turnips or colesced in the last year, as well as for claying fen land. For lime, four year's dropping, he is allowed one-fourth of the cost in equal proportions at the end of every year from the time of application of the same, and also for young seeds if sown with the first crop after fallows, and not injured by sheep or cattle. He has also a fair valuation for labour done on dead fallows, in such last year, if the said fallows be on lands unfit for turnips or coleseed; such valuation to be made and determined on by two disinterested persons, one to be chosen by each party, or their umpire, whose determination shall be final. In cases where the outgoing tenant does the secding, or any of it, he is allowed for all seed and labour. The outgoing tenant is allowed oncthird for all linseed cake or other artificial food used in the last year before quitting. Te is also allowed for all carriage on materials for buildings and tiles for draining, and for draining done in the five years previous to quitting, in the following proportions; viz.: For that done within the last year the whole cost; for that done one year, four-fifths; two years, three-fifths; three years, trro-fifths; and four years, one-fifth of the cost, after which no claim will be allorred for underdraining or carriage on building materials. The buildings are made by the landlord, and the tenant keeps them in repair. A great deal of the draining 
is done by the landlord, and the tenant pays interest on the outlay rarring from four to six per cent., but fire per cent. is the most general rate.

Kent.-The rate of eompensation for improrements as between the outgoing and incoming tenant varies considerably in Kent. In the Weald of Kent nearly everything is paid for. In the eastern part of Kent the custom is not quite so extensive; geuerally the dung is not paid for, it is the property of the landlord, and the tenant is paid for labour to it only; but this difference does not exactly oceur where the dirision of the county for other purposes is taken. There is another mode in Mid Kent. In the Weald of Kent, the payments made to the outgoing tenant are for the underwood down to the stubb, the fallows, including rent and taxes and manures, and generally speaking half manmes, but they are in some cases now being bought off by the landlords. Hop poles, liay, straw, ploughings, sceds sown, dressings, young hops planted, seasons, and generally those things are paid for which are considered to be an improvement of the land, and of which the incoming tenant derives the benefit, such as striking up of land to let off the water. If the hop land is also struck up, and laid up round, to take off the water, that is paid for too. Valuers always charge the incoming tenant with it, and in doing so, if it be wood, they allow four sears to run out; if one year is fallow, it goes over another; if one crop is taken, they give three-fourths of the outlay; if two crops, laalf; if three, three-quarters; and if four, nothing is allowed. Draining is generally considered as embraced under the term "custom of the country;" which is a rery common one in the Kent agreements. By the term "custom," is meant rather the mode of raluing; it is rery common in agreements that the tenant shall be "valued out by the custom of the comntry." There is no such thing as chalking, in the Weald of Kent. Sometimes things are done in preparing the grass land for years to come; the seed is occasionally allowed for in those cases. There is scarcely any county in which more is paid for between the outgoing and incoming tenant. Valuers take into account dilapidations, both as to farm buildings and detrimental acts of husbandry, when they are permitted to apply the eustom.

In Mid Kent the allowances are more fuvourable to the outgoing tenant than in East Kent. In the Weald, hay passes from the outgoing to the incoming tenant at what is called a feed price, which prevails throughout the Weald of Kent and Sussex. A feed price is a price between what is termed the foddering or dung price, and the sale price; that is to say, if hay was worth $£ 4$ a ton, it would fetch 50 s. 
The dung is valued in the Weald of Kent and Sussex in the same way, at a feed price, partly according to measure and partly according to quality. If cake or corn have been used, more is paid for the manure so made. The custom in the eastern part of Kent is not to pay for so much; the dung there is principally the property of the landlord. The land is, moreorer, of a better quality, very little fallow is done, and consequently rery little is paid for; the hay is paid for pretty generally in the same way as in the Weald. Mid Kent is better cultivated than the Weald of Kent, and things are paid for higher; hay, and straw, and dung at a market value; and the cnstom is more certain, though it does not embrace such a variety of things as the mode of eultivation in the Weald of Kent requires.

The time of entry in the Tenterden part of the comnty is always at Michaelmas, cither the 29 th of September or the 11 th of October. The outgoing tenant is paid for all tillages of every description. He is paid for hay and straw at a feed price, and for the underwood. In that woody country, he is paid for all drainage, of every description, that is performed with tiles or wood; if with wood, he is paid for four years: with tiles he is allowed to go back ten jears; that is, a certain amount is deducted cach year. Supposing he left at the end of the ninth year he would have $2 s$. to receive, if the first cost was $20 s$. Draining has been much more extensively practised in the conrse of the last few years. All bonght manures are paid for, as also are half-manures; that is, the half part of what the dung wonld have been ralned at, had it been valued the year before. That applies to artificial mamures, but not in the same ratio. The latter are paid for according to their durability ; for instance, guano would be paid one-third of the cost price after one crop off; for bones or lime the ontgoing tenant would be allowed half the sum ; and for carting dung, marl, or mould, there is nothing at all after one crop. Where chalk is used, it is a very permanent job, and the outgoing tenant is paid considerably for it. There is nothing allowed for oilcake except in the shape of the extra price of the manure so made, and the manure made from the straw is put at a different price from the fatting-cake dung. The valuer's value the latter from sight: if there is any difficulty they call for eridence; when they come to value, it is the custom of the country for parties having a farm to produce the invoice of the artificial manures. There was once no allowance for the improvement of buildings, not even for an oast in a hop district, but now it is generally considered that the tenant has a right to be paid for all buildings erected by him with the landlord's consent. The great value of the woods in Kent is for conversion into hop poles; and if near cutting, the incoming tenant has a larger sum to pay for the rood. 
The outgoing tenant receives according to the age of the wood. Every act of husbandry beneficial to the incoming tenant is valued. Labour, rent, and taxes, are allowed for naked fallows, but nothing for any cultiration the tenant has taken one crop from.

In the Hythe part of the county the usual entry is at Michaelmas. The manure is always considered to be the property of the landlord ; and the feeding properties of the straw, as also that of the hay (about tro-thirds of the real value, or the feed price), are the property of the tenant. The incoming tenant has not the right of entry from Michaelmas for the cultiration of tumins or preparation for wheat, mless a previous agreement has been made to that effect with the outgoing tenut. 'Terms of agreement from year to year are entered into, which admit of the incoming tenant entering to prepare for wheat previous to the determination of the late tenancy. 'ilhe outgoing tenant receives no compensation for oilcake or artificial manure. Durable improvements, such as drainage or chalking, are frequently made, but entirely at the hazard of the temant. There is no security of custom or anything else, mnless there is a private agreement, entered into between the landloril and the tenant, that compensation shall be allowed.

It is contrary to the custom of the district to allow anything, either value or labou!, for half-manures. The only allowance made is for labour or any manure from which no erop has been taken, whether it has been earried and spread on the land or is in the mixen. Where fallows are made by the outgoing tenant the last year, he is always allowed the rent and taxes on them from the previous Michaelmas, together with labour of every kind, including labour on manure, made and carried out; and if sown with turnips, the cost of the seed and putting in, se., in fact for everything done to the fallow since the preceding crop was taken off. When the tenant leaves the farm at Michaelnas, he is frepuently permitted by agreement with his landlord to have the usc of the buildings to thrash and prepare the corn for the market.

Lancashire and Cheshire. The customs between the outgoing and incoming tenants in Lancashire are very limited indeed. A tenant professes to quit his land on the 2nd of February, with the excejtion of a pasture field, ealled "the ontlet for the eattle." The house, buildings, and the outlet are given up on the 1st or 12th of May, as the case may be. The tenant leaving his land, therefore, on the 2nd of Fcbruary, has nothing upon it but the wheat crop, and for that he gets half of the wheat crop allowed him by the incoming tenant, if it is after green crops (which it is gencrally): if it is after the summer fallow, he 
gets two-thirds of the wheat crop allowed him, and that is all, with the exeeption of the allowance for elover or grass-seeds which have been sown the previous year. The holdings may be considered as yearly ones from Lady-day. The dung bolongs to the farm, and the incoming tenant makes no payment for the manure he finds upon the premises. Compensation for improvements is rarely given by the landlord to the outgoing tenant. 'The enstoms in Cheshire between outgoing and incoming tenants are similar to those in Lancushire, and the period of entry is the same. The landlord generally pots the buililings into repair when the tenant goes to the place, and he expects the tenant to keep them in repair upon being found materials in the rough. There are various customs upon different estates, but those repairs are generally done by private agrecment, as there is no well-established eustom applicable to buildings. If the tenants put up a thrashing machine they would probably be allowed to remore it, but it is optional with the landlord.

Leicesterstire.-The time of entry is generally Lady-day. The manure, the produce of the farm, belongs to the landlord, and the ontgoing tenant reccives nothing for it miless he paid for it on his entry, which is not a usual occurrence, and it passes to the incoming tenant free of charge. In the absence of any agreement, the custom is as follows: On a summer fallow sown with wheat by the outgoing tenant he rould be allowed for the same, the valuation of the various tillages, the carting and spreading manure, the cost of seed, and one year's rent, rates, and tithes. In the case of a clover ley sown with wheat, half-a-year's rent, rates, and tithes, the cost of seed, plonghing, harrowing, \&c., are allowed; and on bean stubbles, the cost of ploughing, sowing, and sced. When seeds are sown with the preceding spring corn, the cost of the seed only is allowed, and nothing for putting it in. No compensation is given for the culture of the preceding crop of turnips, though eaten on the land, nor for manure nsed in raising the crop, however large it may be. There is no allowance for draining, or any other permanent improvements; nor is anything paid for the consumption of extraneous food by stock, or for use of artificial manures. The above is all which the eustom of the comntry wonld give a tenant; but of late years a more liberal system, by agreement, has been adopted by some landlords. An allowance is made by them for draining done by the tenant within seren years; for instance, he rould receive nothing for what had been done seren years; one-serenth of the cost of that done six years, and so on. In some instances, a portion of the cost of unexhansted artificial manures which have been nsed is 
allowed; but these agreements are by no means general. One-fourth of the oilcake of the last two years is sometimes allowed, if no corn crop has been grown from it. 'There is also a three-pears' allowance for bones on the lighter soils, and a two-year's' one for lime. According to the custom of the comutry a tenant cannot remore or sell off any hay, straw, or vegetable roots, without permission of the landlord; or turn any permanent grass pastures into arable land.

Lincolnshire (.Torth-The Molets).-The usual period for entering upon farms is Lady-day (the cth of April) for arable land, and old Mayday (the 18th of May) for old frature land and buildings. Upon some farms the outgoing tenant is entitled to an array-going crop of corn rarying in quantity, which is usually taken by the incoming tenant at a raluation. The outgoing tenant generally sows all the wheat in the autumn before he quits, and is paid for seed and labour. He generally plonghs once all land in turn to be fallowed, and sometimes he sows the spring corn; and for both of these lie is paid. 'The ontgoing' tenant is also paid the following allowanees by the landlord or his incoming tenant on quitting, riz. : For draining, where the landlord finds the tiles and the tenant puts them in (which is the most usual comrse), the allowance extends orer four year's, one-fourth of the cost being deducted off for each crop taken by the outgoing tenant; for manrling and chalking, the allowance extends orer ten jears; for lime, fire years; for claying sand or peaty soils, five year's ; for bones used within twelre months preceding, tro-thirds if used dry, and one-half if dissulred in acid, and for those used the previous year one-third if used dry, and one-fourth if dissolred in acid; for guano or rape-dust used within twelve months preceding for turnips or other green crops, two-thirds of the cost; for oilcake giren to cattle and sheep, one-third of the cost of that used within twelve months preceding, and one-sixth of that used in the previons year ; and for seeds and clover sown within twelve months of quitting, the whole of the cost of seed and the labour of sowing is allowed, where they have not been stocked after the 1st of November, and up to that time only with sheep and pigs. These allowances are ascertained by two arbitrators, one selected by the ontgoing and the other by the landlord or his incoming tenant, or by an umpire to be appointed by the arbitrators in ease of their disagreement. They are raried upon some few properties by agrcement; but upon a considerable part of the district they are made by custom, and not inserted in the farm agrecments. Formcrly the allowances were confined to acts of husbandry only. The rotation of crops varies on different soils and in different localities, but the four-field course is the 
one most generally followed. There is very little land let npon lease, and the usual tenancies are yearly ones determinable by a six-months' notiee from either party. The necessary farm buildings are generally erected by the landlord, and afterwards kept in repair by the tenant; but in some cases they are put up by the tenants under a special agreement.

Lincolnshire (South). - The usual compensations in South Lincolnshire are for tillages, manure, and draining. The whole of the last year's bill for bones is allowed when only a crop of turnips has been taken; and one-fourth part of the calse bill is allowed, which is ascertained by producing the bill of the last year. In the eastern part of Lincolnshire, where elaying is carried on to a considerable extent, the ontlay is spread over fonr years, and one-fourth is dedueted for every year. On the heath land, when a tenant receives notice to quit, the usual plan, where there is a good understanding between the landlord and tenant, is that the tenant receiving notice applies to the agent to know whether he is to continue to eultivate the land in the way he has been in the habit of doing; and if the agent has confidence in him, and he is not leaving from any fault that the agent or landlord has to find with him, he is told to continue the same manner of eultivation, with the assurance that he will be paid for all acts of husbandry performed between Michaelmas and Lady-day, that is, sowing wheat and ploughing the land ready for the turnip fallows, \&c. He is paid for the herbage upon the land that is sown with wheat seed. If he is not emporrered to go on and farm in the usual manner, the tenant would have no elaim for manure used after the time of his notice, nor for the wheat if sown in opposition to the instruction of the landlord or his agent.

Usually speaking, the tenant farms nuder an agreement that gives the incoming tenant the right of entry after a specified time-after the 10th of October, for sowing wheat; and after the 1st of February, to prepare the land for the spring corn, peas, and beans. After the first of February the incoming tenant may plough up the stubbles on paying for any sheep-keeping there may be. The lease ends on the 5th of April, and the notice to quit is given before the 10th of October. The ontgoing tenant has no rights for acts of husbandry from October to April withont permission from the landlord or bis agent. If there was a hostile feeling between the ontgoing tenant and the landlord, the land is, according to the system, left abandoned as to cultivation from October to the 5th of April, when the incoming tenant can claim to enter. If there is no agreement the latter could not come on even to sow the 
wheat, and the ontgoing tenant could not be compelled to do so after receiving notice to quit. The incoming tenant entering upon the land after the 1st of February would have a right to make use of all the manure that was made upon the farm from the prodnce of the farm, and the ontgoing tenant would be allowed compensation for bones and lime and oilcake, and the other matters. He would have no compensation for acts of husbandry between the 10th of October and the 1st of February; but if he continued to consume oileake, he wonld be entitled to be paid for a proportion of all the cake used up to the 5th of April. The customs as to the allowance for bones and marling, or chalking, have been upheld in a court of law. The draining eustom is that when the landlord finds the tiles, and the tenant only finds the labour, the expense is divided into three ycars. As to the cost of the labour, if the tenant has had three crops he receives nothing for that; if he has only had two crops, he receives one-third; and if one crop, two-thirds. When the tenant has been at the whole expense of the draining, it is divided into seven years in the same way. The custom for drainage is not a customary allowance made by all landlords, but that for bones and manure is customary with all. Five per cent. is charged when the landlord does all the work of drainage, and the landlord invariably puts up the buildings throughout the estate. Draining is now very much done by the Drainage Commissioners, the tenant paying interest on the money expended. The practice of the Iincolnshire valuers is to set off dilapidations in buildings against tenant-right; and that set-off is extended to the state of the farm as to clean husbandry. The fonl state of the fallows would not enter into the calculation unless there had been cross-cropping or gross neglect, and then reductions would be made.

Middlesex.-The entry is generally on September 29, and the holdings are, to a great extent, from year to year. In leases it is almost universally stipulated that the incoming tenant should come on the farm to sow clover seeds in April. If the ontgoing tenant sows them, he is paid for them by the incoming tenant. The latter sometimes takes to the fallows about April, in which case he is allowed stable-room for his liorses. In the ordinary twelve-months' holdings the incoming tenant often makes a similar agreement. The landlord generally finds tiles for draining, and the tenant the labour; but if the former does all, he charges five per cent. In conseqnence of the proximity to the metropolis, hay and straw are always allowed to be sold; but by the custom a load of manure must be brought back for every one of hay and straw that leares the farm. If a tenant pays for the manure on coming in (which is almost always the case), he is paid for it on leaving. The 
incoming tenant is bound to take all the wheat-straw and liay left on the farm at a market price, and the Lenten straw at a consuming price. Tenants under yearly holdings are allowed to sell all their straw at a market price, while those under lease may only sell their wheat-straw; and it is the custom not to sow more than two white-straw erops in succession. The ontgoing tenant is allowed for dressings and halfdressings, but searcely anything for unexhausted inprovements. There is 10 allowance for guano or bones; and in valuing manure, no evidence is called for as to what cake has been used. The tenant-right is, in fact, of a most limited character.

\section{Monmouthshire.-See Herefordshire.}

Norfolk.-On the Holkham estate the leases are for 21 years, and on others for 8,12 , or 16 years. Tenants-at-will are comparatively few. The entry is always on Oetober 11 th. The four-conrse shift is pretty universal, viz., one-fourth turnips or mangold-wurtzels, one-fourth barley, one-fourth grass, and one-fourth wheat; and occasionally, on part of the land sown with mangold-rwurtzel, that crop is followed by wheat instead of barley. The Norfolk covenant applies strictly to root-crops, and not to tillages. For the latter there is no valuation. The root-crop itself is valned at Michaelmas, and is paid for by the incoming tenant, as are also the hay and the manure left in the farm-yard. Latterly it has been the custom to value the hay a little above the consnming price. The incoming tenant either sows the seeds in the last year, or pays the secd-bill of the out-going tenant, who is hound to harrow and roll the land so sown. There is no away-going crop, bnt the incoming tenant takes the straw, chaff, and colder, for which he carries the corn to market. 'This is the practice on the Holkham estate, but on other properties the incoming tenant has generally to pay for the thrashing and dressing of the crop, as well as for carrying it to market. On the Holkham estate the drainage is all done by the landlord, who charges a per-centage; the bnildings are put in good repair by him, and the tenant is expected to keep the walls and louses generally in order: but new roofs are paid for by the landlord.

N'orthamptonshire.-The periods of entry are Michaelmas and Ladyday, but the latter is the most general. At the Michaelmas entry, the custom of the country is to pay for acts of hnsbandry, seed, and labour, and for dead fallows. The ontgoing tenant is entitled to the full value of his turnips, or he may eat them on the land, so that it is eleared by April 5th. Unless the incoming tenant takes his crops, or his hay and 
straw at a valuation, the outgoing one can claim the use of the barns, louses, and yards up to Lady-day to cousume them. With respect to the Lady-day holdings, the ontgoing tenant has not the away-going wheat crop, but is reimbursed by the incoming tenant for the back rent (if on fallow) and for seed and labour, up to the time of his leaving. The manure in all cases belongs to the farm. The buildings are generally made by the landlord, and the tenant is bound to keep and leare them in full repair, as also gates, fences, and water-courses. No compensation is giren at quitting for manures, or mexhansted improvements of any kind. The enstom allows nothing if a tenant builds or drains, but during the last three years an allowance for under-draining has become common in some districts. The landlord most commonly gives the tiles, and the tenant pnts them in at his own expense. In the case of Lady-day holdings, the custom is more universal; but it varies so much in different parts of the connty, and is so undefined, that special anreements are mostly resorted to, to prevent disputes. The farms are in many cases held by the year, but leases are not uncommon.

In the Peterborongh part of the comnty the valuation to an outgoing tenant is generally as follows: On bare summer fallows he is allowed for four ploughings and orders, labour or manure, carting, sowing the wheat or barley (as the ease may be), with one jear's rates and rent; but if the land is in its course for growing tumips or other roots, no rent is allowed. The ontgoing tenant is allowed half-a-year's rent and rates on lands sown with wheat after oats, beans, clover, or vegetables. The manure belongs to the estate; if any carriage is done the labour is paid for; and if artificial manure has been used for the green crop, the whole of the bill and carriage is allowed. Half of the oilcake bill in the last year is allowed; but to prevent imposition the amomnt of the tinee last years' oileake bills is added together, and the outgoing tenant receires onc-sixth. The sowing and seed bill of new seeds is allowed if they are not stocked after Michaelmas. When lime has been used, the tenant is entitled to five years' benefit; and when burnt soil is applice to fallows or green crops, an allowance is made for labour and carriage. All temporary buildings, snch as cow, calf, and waggon hovel, pigrgeries, \&c., if built by the tenant, with the landlord's sanction, are valued and paid for at the time of quitting. IIay and elorer in stack, not consumed, are valued at two-thirds of the market jrice; and all skimming or scarifying of stubbles after harvest at their full value. $\Lambda$ great quantity of drainage (which, if practi(ail)le, is not less than three feet) is done by the aid of Government drainage loans; and when the landlord finds both tiles and labour, he charges five per cent. If the landlord finds tiles, and the tenant labour, 
the latter is allowed at quitting on a fire years' scale. If it has been done only one year he is paid for the whole of the labour and the carriage of tiles; if two jears, four-fifths; and so on. Where the tenant finds both tiles and labour, he is allowed on a seven years' scale. In the fen districts a great deal of claying is done, at a eost of from $£ 2$ to $£ 3$ an acre; and this is also allowed for on a seven year's' scale.

\section{Northumbertand.-See Durham.}

Nottinghamshire.-The time of entry in Nottinghamshire is generally at Lady-day, the 25th of Mareh. At the Lady-day entry, the aets of lusbandry for which the incoming tenant pays, but for which the landlord is liable, are all the labour of making the fallows, one year's rent and taxes on the same, deducting for potatoes and other vegetable crops, according to custom. In most cases the labour only of applying the manure is allowed, the seed and labour on the corn sown, and the full value of purehased tillages. This is followed by the lalftillages, or land in first year's seed, for which the cost price of the seeds and labour is allowed, and the application of all purchased tillages, deducting onc-third as being exhausted by the first grain crop. As regards the last crop, or the one on clover ley, or pea or bean stubbles, seed and labour are generally allowed, with, in some instanees, a proportionate amount of purchased tillages, though chiefly under special agreement. In the fields, as distinguished from the commons in this county, the following crop is allowed, deducting one year's rent and tares. Unexpended tillages are also claimed, and in some instances allowed when the following erop is taken, but this in a great measure depends upon the former application of tillages to the four courses of cropping. One Jear's manure remaining on the premises unconsumed at the time of quitting is the property of the tenant or landlord, according to their agreement. The custom of the comntry does not usually allow anything for drainage, nor for buildings. For bones and other artificial manures, and oileake, there are certain portions allowed. The compensation the outgoing tenant is entitled to for those artificial manures which he has cmployed upon his farm [westem side of Nottingham] is generally one-third; there is an allowance for three crops, deducting a third each crop. Whatever may have been the intervening crop, the expenditure in bones is spread over three jears. Where the manure belongs to the tenant, he would get his compensation in the extra price of the manure; but where the manure belongs to the landlord, they usually allow one-fourth of the oilcake to the tenant. The allowance for the rapecake (which is very 
gencrally used) is the same as for bones. In some cases manure has been lod into the farm, and has been allowed for. The custom in part of South Nottinghamshire would allow it. Probably stable manure led from the town would not be allowed for after the first crop. In some parts of the county an allowance has been made for drainage; for shallow draining (three feet) seren rears, leducting a seventh each year, are allowed, and for deeper draining (ten, twelve, or twenty feet) ten years. The allorrance would not be enforeed as a custom of the country, but only as the custom of certain cstates. In some instances the tiles are given; but generally they are put in under the superintendence of the landlord. In the ordinary farm agrecments, there are gencrally spccial tenant-right agreements with reference to bones, rapecake, and rapedust. In many instances the landlord finds materials for the buildings, in others he does them altogether, and in others he does nothing. 'The houses and barns are generally put up by the landlord; but any increase in the buildings is often made entirely by the tenant. Where the tenants erect buildings themselves, they are constructed on wooden posts so that they may be remored.

Nottinghamstire (South).-By the custom, wheat upon fallow, seed and labour, and the rates and taxes for one year, are paid for ; and in many cases tro-thirds of the fallow crop are allowed to the ontgoing temant. The cntry is at Lady-day, and the ontgoing tenant is paid rates and taxes, which is termed seed and labour raluation. That takes in a year's rates and taxes, besides making the fallows, the seed, and the sowing. The enstoms vary very mnch even in the same villages: it is the practice of each estate rather than the custom of the country. There is not generally any compensation to the ontgoing tenant for improrements by bones, nor by artificial manure; but cake compensation is granted in some instances. In some parts the manure made upon the farm belongs to the tenant, and in others it does not. Sometimes the crop is valned to the incoming tenant; that is termed the open-field enstom. The outgoing crop is taken by valuation, and if not taken, the outgoing tenant would get his crop. In the case of wheat somn upon clover, the ploughing, sced, and labour, and the herhage from Michaclmas to Lady-day are allowed by the custom, and so for all the wheat sown npon pea or bean stubbles. Increased value is put upon the manure when valued if the tenant has purchased oileake. Lime is always paid for by the general custom when no white crops have been taken. There is also an allowance for drainage, of fire or six years njon the labour or tiles that liave lieen used by the tenant, when lie finds both. The grencrul eustom in some districts is for the landlord 
to find the tiles and the tenant the labour, for which he gets an allowance; but the agreements by which the land is held from year to year usually define the allowances which the tenant is to receive on quitting.

Oxfordshire.-The time of entry in Oxfordshire is generally at Michaelmas. The incoming tenant pays the outgoing tenant for the ploughing, manure, seed, hocing, \&c., upon the turnip land, and gencrally takes a portion of the hay at a spending price. He pays for the clover-seed, and other seeds sown with the barley. This applies especially to the district round Chipping Norton. The dung which is made from the last crop belongs to the incoming tenant, in whaterer way it is made. Compensation is very seldom given for any improvements made by the outgoing tenant; it has been given for bones and guano, but generally speaking there is none, and hardly any for draining. 'Tenancies usually commence on New Michaslmas-day. The outgoing tenant may enter on the wheatlands in August, and has half the stable from that date; but at Michaelmas, when the new tenant arrives, the old oceupant gires up only half the house. He retains the other moiety, a portion of the stable, all the barns, sheds, and yards till the following May or June. The outgoing tenant of conrse thrashes and delivers his corn himself. He also spends the "straw, chaff, and caving" in the yards, leaving the manure for the new tenant. The usual corenants are, that the outgoing tenant should be paid for all operations of husbandry performed in the preparation of the ground for root crops or fallors. 'The turnips, \&c., are valued by the number of ploughings, hoeings, and cost of manuring, and not by the worth of the crop. Fallows are similarly paid for, and thus the land is often ploughed in wet weather, and little attempt is made to clean it, as the price depends more upon what has been done than on the manner in which it has been performed. The price allowed for ploughing of course varies on different soils from $8 s$. to $14 s$. an acre. The incoming tenant takes to all, or only half, the hay and wheat-straw at a spending price, and the outgoing tenant retains the rest of the produce. Large sums hare been borrowed from the Government for drainage, and refunded at the rate of $6 \frac{1}{2}$ per cent. for twenty-one ycars. Some landlords make the tenants pay all this charge; while others drain the land themselves, and charge the tenants 5 per cent.; and on some estates it is eustomary for the landlord to find pipes, and the tenant to perform the labour of underdraining. The greater part of the college property is let on leases of twenty-one years, renewable every seren years. The fine is something less than one year's income: and the college has the power of increasing it, and may renew the lease or not, at option. The lessee is supposed 
to kecp the buildings in repair, and is only allowed by the college such timber as grows on the estate. Farm leases are the exception, and not the rule, and almost all the land is held by yearly tenancies, sulject to a six-months' notice to quit.

Rutland.-The time of entry is usually Lady-day. The following scale of allowanees to an outgoing tenant is made on one of the largest estates in the connty.

For Draining.- When the landlord has found tiles and the tenant the labour, the allowance shall be upon a three-years' principle; and when the tenant has found both, upon a five-year's' principle, provided the drainage has been done to the satisfiction of the landlord, and an accomnt rendered every year. For lime on a three-years' principle, iucluding cartage: for bones, or other approved artificial manures used for turnips or other green erops in the preceding year, the whole cost limiterl to 25s. per acre.

For eake, one fourth of the cost price of linseed or cotton cakes consumed by beasts in yards or sheep on seeds or turnips during the two previous years, provided the quantity does not exceed the arerage of the tro preceding years. The tenancies are usually from year to year, terminable at Lady-day by a six-months' notice from either party.

Shropshire.-The period of entry upon farms in Shropshire is on the 25th of March, invariably; never at Michaclmas; and they are held by a rack tenancy from year to year, determinable by a half-ycar's notice given on the 25th of the preceding September. Other leases are comparatively unknown, but on many estates the same farm is held by one family from generation to generation. The ontgoing tenant receives no remuncration from his successor for any improvements he may have made upon the farm, nor for any artifieial manure or food. A great deal of draining has been done of late years; and the landlord either does all except the hauling, and charges the tenant five per cent., or the landlord finds pipes and the tenant lays them at his own expense, under the supervision of a luailiff. 'The soil of the connty varies consiclerably in character and quality. The arable portion consists partly of strong loamy soil, suitable for the growth of wheat and oats, and partly of lighter description of soil, suitable to the turnip and barley system of husbandry. The pasture and meadow lands generally require, and are capable of, much improvement. Within the last few years it has been customary for the landlord in a few districts to aplly bones; the tenant hauling and spreading them, and paying a per-ecntage upon their cost. The wheat crop, on a change of tenancy, is generally divided between 
the outgoing and incoming tenants, in the proportion of one-half to each of that gromm mpon clover-leys, and two-thirds to the ontgoing tenant, and one-third to the incoming tenant, of that grown npon fallows. In a district on the sonthern side of the comnty it is the custom for the outgoing tenant to take the whole of the wheat crop mpon quitting. It is the custom for the outgoing tenant not to depasture the joung clovers after the 2nd of November next previons to quitting, and the meadow lands to be mown the following harvest are usually paid up for from the 2nd February next previons to the time of quitting. The outgoing tenant is allowed the use of a boozy pasture appointed by the landlord for the purpose of consuning thereon any hay or straw unconsumed at the expiration of his tenancy, the Lady-day previously: and his right in this terminates the 1st of May next after he quits. The outgoing tenant has stackyard room for his share of the way-going crop, and the use of a barn to thrash it in, till the 25th of December next after his tenancy ends. He is paid by his successor for the clorer-seeds he has sown the last year previons to his quitting, upon his producing the bills to show that he has purchased the same. He is also paid a fair compensation for any ploughing he may have done for the convenience of his successor.

Somersetstive.-The time of entry about Tamton and westward is Michaelmas, but in other districts generally Iady-day. In the Michaelmas lettings the incoming tenant has no right of entry for cultivation before Michaelmas. He generally gets in to plough the turnip fallows; sometimes by virtue of a provision in the lease. It is only in these lettings that the manmre can be used for potatoes. In the Lady-day lettings there is great difficulty in getting possession of the arable land time enongh to put in spring grain, where there are natural pasture meadows that spring early, and will not bear treading out. The occupation terminates either at Christmas or Canclemas, when the rest of the holding of the farm is from Lady-lay. There is no compensation for purchased manure, or cakes used in the fatting of cattle; or for draining, and any other improvements. In a recent assize case, of Becton v. Trimlett, which was referred to arbitration, there were eleven different customs spoken to, in different parts of the county. Each part of the county has its peculiar custom; and, as the tenants come in they expect to go ont. In some cases they take the offroing crop; but a clause is generally inserted in the leases that seed and labour, and a half-year's rent, shall be charged to the new tenant in lieu of it. The outgoing tenant is often allowed to consume the straw on the premises, or he leaves it to be consumed at a feed price, by the incoming tenant, 
to whom the manure beings, for the use of the furm, in either ease. The principal tenancies are from year to year; but in a great many instances they are for seren jears.

Staffordshire. The period of entry is Lady-day. The incoming temant pars for the grass seeds; he pays also for any tillage that may have been done to the fallows, and he dirides with the outgoing tenant for the wheat erop. He takes half where it is a brush erop, and onethird where it is a fallow erop) ; the incoming tenant also pays for the manure, and for the straw and lay that may be on the farm at the time at the consuming price. In the north, the district on the clay, there are some considerable naked fallows. For wheat fallows, where it has been really a naked fallow during the whole of the summer, the outgoing tenant takes two-thirds of the crop. A brush crop is a crop of wheat that does not follow a naked fallow ; but one, under any other circumstances, after clover, roots, or green crops of any deseription. As regards compensation, the tenants fall back upon the eustom of the district; and those eustoms probably were fixed when nothing was known of artificial food or artificial manure, or drainage. There is no custom to show to allow compensation to the tenant for marling, or for the application of artificial manure of any description. There is, in fuct, no other custom as between incoming and outgoing tenant than the compensation for seeds, straw, and hay. The customs apply chicfly to the light soils of Staffordshire; but there is very little difference in the whole county of Stafford. So various and contradictory are the customs of tenancy, even in the same district, that now the settlement of all such questions are left with experienced arbitrators, who malie as nearly as they can an cquitable adjustment between the parties.

Suffolle-There is no tenant-right in the county, beyond that recognized by the custom of the country, and by the leases or agreements grenerally granted in the neighbourhood. Quite one-third of the comty is holden upon a custom without any written agreement; but in every instance where leases exist, the covenants for entering and quitting the occupation are distinctly laid down, and fully acted up to. The custom of the country varies in different neighbourhoods : but where the understanding is rerbal, the custom which exists in that particular district is considered mutually binding on each party. The outgoing tenant is always paid for the rents and rates incurred on the last year's fallows, and for all reasonable tillage, such as ploughing and harrowing, expended thereon. He is also paid for the muck, hay, and stover made 
in the last year, and for the clorer seeds and the sowing thereof in the preceding spring. In many instanees it is the custom to allow a certain smm for the clover and hean stubbles, but this is generally considered unfair and undesirable. On the light lands they grow all the fallows with root crops; whereas, on the heavy land they grow only a portion. The ontgoing tenant carts the manure for the erop, and is paid both for the muck and eartage. Tares are sometimes grown on a part of the heavy land fallows, in which case the rent and rates are not allowed, and the tillages after the remoral of the crop alone arc paid for. The outgoing tenant is paid for all sheep-folding, provided no after-erop has been taken from the land. If any straw remains mnconverted into manure, the outgoing tenant receires a nominal price for the same, and also for stover or old hay left orer from former years. It is usual to mow but half the pastures of the farm, though in some districts the whole can be mown with impunity, and the custom of the conntry compels it to be paid for at the price per ton which duly appointed valuers may determine. The incoming tenant often finds the clover and the turuip seeds, and does the sowing thereof, but this is a matter of arrangement; and he also pays $3 s$. per acre for the groundage or feed of the young clover. The straw, chaff, and colder of the crop just harvested are the property of the landlord or incoming tenant; and the custom compels his successor to thrash, dress, and deliver the corn of the outgoing tenant. October the 11 th is the day on which the old and new hire ceases and commences.

Surrey. - Where the full custom of the country is spoken of, and the tenant speaks of being paid a full valuation, according to the custom of the country, it means that he is paid for dressings and half-dressings of dung, lime, and sheep foldings; for ploughings and fallows, including the rent and taxes of the same, half-fallows, young seeds, and leys, the underwoods down to the stem, and hay and straw at a feeding price: the hay and straw being at a market price where the half-dressings are not paid for. These valuations are, according to the custom, settled by two valuers, or their umpire. Frand takes place principally in the half-dressings; by which is generally meant, in this county, those manurings from which only one crop of corn has been taken. The "dressing" is dung in the yards, made in the ordinary course of cultivation. Where manure has been put on at a distance of time, it is exceedingly difficult to check both the quantity and quality of the dressings, and very false returns are made of it. In many cases where farms are about to be given up, tenants scatter down an inferior and smaller quantity of manure, and claim for it as dressing; they work, in 
fact, up to a quitting. Having been so imposed upon at starting, they feel justified in playing the same tricks upon their quitting.

Where the tenants have a right to remumeration for dressings and half-dressings, they are paid for the manure, the ralne of which is increased by cake; the ralue of the cake is taken into consideration in the ralue of the manure; but not as a proportion of the cost of the cake. 'lhere is not much diffieulty in ascertaining the value of the manure while it is in the yard; though there is after it has been carried out and mixed with the soil, eren that from which no crop has been taken; and the difficulty is of comrse increased with half-dressings. The landlord, if it is inconvenient to lay out the money on draining, allows at the end of the holding (where the tenant is holding by the ycar') for a certain number of year's a portion of the outlay of drainage, calculated according to the number of years, and according to the quality of the draining.

Draining some few ycars ago was of a very inferior quality to what it is now ; it used to be done with the mole plough, and with bushes; but now that draining is improved in its quality, and tile-draining is carried on cxtensirely, landlords are enlarging the number of years over which those allowances extend. Many of them have made arrangements that for any drainage done within ten or twelve years, the tenant shall be allowed on quitting a valuation in tenths or twelfths, as may be agreed. Naked fallows are not very much practised; but whether they are naked or bearing a green crop, they are equally paid for, the only difference being that the seed is added in the latter case. The landowners have bought up, in many instances, the half-rlressings and half-fallows, as those allowances hare proved so onerous to the incoming tenant, and have a tendency to lower the rents of the farms. In this respect it is, perhaps, the most expensive of all the English counties.

It is the habit, in making a clear fallow, in Surrey, that the plonghing should be repeated four times; and they are very frequently done at improper scasons. It is difficult for an arbitrator to say in October how they were done at the time, though there would be none in giving compensation for the fouluess of the land, which valuers will not consider. 'The system of valuations has grown up and greatly extended in Surrey for a good many years. It originated when prices were higher than they are now; but it has been of gradual growth, and there are still attempts to inerease it. There has been an attempt, since the 'Tithe Commutation Act converted tithes into a rent-charge, to add to the cost of the fallows the tithe rent-charge npon the acres coming for fallow, in addition to the rent and taxes; but the thing is better understood now, and has been very properly resisted. When a tenant entering 
mpon a farm pays for such things with the cognizance of the landlord, he is entitlerl to be paid when he quits. The disadvantage of the Surrey tenant-right is, that the same money is paid for the slovenly as for the good farming, as the raluers never take the bad state of the fillow into account.

Sussex.-The time of entry on farms in Sussex is Michaelmas, and generally the 29th of September in preference to the 10th of October. The customary payments by incoming tenants differ very much in the different districts of the county. 'Taking the boundary on the north as the Sonth Downs, Hampshire on the west, on the east the Adnr, and the sea on the sonth, the customs north of the Downs and east of the Adur differ very much from those in the other parts of the comty. In part of Sussex, west of the rirer Adur, the customary payments by the incoming to the ontgoing tenant are confined rery much to acts of husbandry, the hay at a feeding-off price, and the fodder of the straw. In the Weald the payments are extended to the payment for dressings and half-dressings of dung and lime, and to the payment for fallows and tillage performed on the fallows, and the rent and taxes thereon, and for leys. 'The payment for dressings is for the manures made on the land, and from which no crop has been produced. Half-dressings comprise the dung from which one crop has been prodneed. So with regard to lime, where no crop has been prodnced, or if it be in the heap on the farm, it is paid for at the full cost. If it has produced one straw crop, then it is paid for at half the cost.

On heary land in the Wealds of Sussex, Kent, Hampshire, and Surrey, it is usual to make naked fallows. The tenant has reecired no advantage from the expensive course of plonghing and cleaning into which the field has been put, and therefore it is customary to allow him for that which is a benefit to his successor, and which is no benefit to him. They are also paid in the Weald and east of Sussex for the hedgeroms and underwood, if included in the occupation. When they enter upon a farm, they enter upon the underwood also, and pay to their predecessors in proportion to the mumber of year's' growth of the underwood. The principle of underwood is applied also to the hedges, which are often very wide, and approaching the nature of a copse, or "shaws" as they are termed. They are allowed for the growth up to a certain number of years. By the custom these wonld be valued to the stem, unless there is any special arrangement to the contrary. The buildings are usually maintained by the landlord providing the materials and the tenant applying them. Acts of husbandry on the summer fallows, with the rent and taxes that arise ont of the land, 
having been useless to the tenant, form a large proportion of the valuation of tenant-right to the incoming tenant. The coming-in upon a Sussex firm, where those tillages and half-tillages and rent and taxes are paid, is very heary ; and the tenant-right is very frequently mortgaged. Everything, labour, rent, aul taxes, is paid for nakel fallows, but nothing for any cultiration from which the tenant las taken one crop. If manure is made in a yard used for feeding cattle, the valuer will place a different price upon it from what he wonld do if it was merely a straw-yard in which the cattle had been fed npon straw only. With regard to turuips, the ploughings, sowings, and dressings are taken into the valuation, from the outgoing to the incoming tenant. Rapecake, nitrate of suda, rags, and gmano, are all allowed for, according to their relative ralue. Rapecake is more lasting than rags, and rags than guano. 'There is no compensation for building, as it is considered that buildings erected on the estate become part of the fee of that estate. Stone lime is rery much nsed in Sussex, and is often bronght fiom a great distance, and the ontgoing tenant is allowed half-price for it after one crop.

Wurickstire.-The time of entry upon farms in Warwickshire was formerly Lady-day, but Michaclmas "takes" are now becoming more gencral. The entry being at Lady-day, the ontgoing tenant takes the following erop of wheat, exeept an arrangement is made for payment : the agreements are now generally made so that the ontgoing tenant cannot hold it, but it must be valued to the incoming tenant. By the custom the ontgoing tenant takes the value of it, whether it be in the crop or in money. If a change of tenancy takes place at Miehaelmas, the incoming tenant takes to the wheat sown if it has been regularly fallowed, and in the event of their not agreeing, the ontgoing tenant is at liberty to come upon the land and reap it limself. The manme on the premises belongs to the landlord. If the ontgoing tenant has spent cake upon the feeding of his beasts, he could not claim molel the present custom any compensation. Bones are not much used except on the sandy soils, and the time orer which compensation is allowed for them is redueed to three years. No compensation for improvement of the land is paid by the incoming tenant except for draining. That, according to the custom of many valucrs, only extends over three years; but the time is getting extended. If the landlord dres it all, the tenant pays five per eent.; but very generally the landlord finds the pipes, and the tenant pays for laying them down. 
Tsle of Wight.-The usual period for entering upon farms is at Old Michaelmas, the 11 th of October. A great part of the island is farmed mider leases from ycar to year, or for terms of seven or fourteen jears, and no allowanee is made for artificial mimures or unexhansted improrements. About ten years since a system of allowances similar to that in use in North Lincolnshire was introdnced npon Lord Yarborongh's estates in the island, and it is understood that the same allowances have been adopted upon some other properties. In this agreement provision was male for the entry by the ineoming tenant to portions of the farm at diffurent periods, and the tenancy was also determinable by twelve months' notice. Artificial mamires are not used to any great extent, but the use of them is increasing. 'The landlord finds materials, and the tenant pays the labour of keeping the buildings, gates, and hurdles in repair.

Witstive.-The tenancy ceases in the Warminster part of the county generally at Michaelmas. There are two leases; the pasture-lands are taken at Lady-day, and the arable farms at Michaelmas. On the arable lands the incoming tenant pays the ontgoing tenant for the tillages. If the landlord makes the agreement that the latter is to do the tillages, he is paid for it, such as plonghing for tumips, and anything of that kind ; that is oftener done, horrerer, by the incoming tenant. By the enstom of the country, the incoming tenant has the right of entry to prepare a certain quantity of the land for the turnip erop before Michaelmas. He has also the right to come on in June, generally, to prepare for wheat on the old ley. The manme belongs by the enstom of the country to the incoming tenant. Unless by special agreement the tenant has the right to make those preparations of the land, there would be little or nothing to be paid by the incoming tenant to the ontgoing one. There is nothing paid by the incoming tenant for improvements. The dung belongs to the incoming tenant; eren if the ontgoing tenant had kept a number of beasts upon oileake, he would have no compensation for that; and the same if he has nsed bones. For permanent pastures the tenant receives no compensation. The custom of the incoming tenant entering upon the land to do the acts of husbandry, is the one under which most of the new tenants have entered. They hare paid nothing, but have done the work themselres on entering. The time of entry in the distriets south-rrest, west, and north-rrest of Devizes, is Lady-day. These districts consist of lands, on the Gault, lower green sand, Kimmeridge and Oxford clays, and partially on ontlying portions of forest marble and oolitic formation. The land sonth-east and north-east of Devizes is generally on the 
chalks, with deposits in the larger valleys, and is appropriated to the growth of com and the rearing (and latterly, to some extent, the fattening) of sheep, and is subject to the same customs as the Warminster district. The incoming tenant takes possession of the farm on the 25th of March, by paying for all tillages; there is but a small proportion of arable land in the Devizes neighbourhood: it is generally grazing and dairy land. The tillages are paid for, and the labour of manuring. At present the ontgoing tenants wonld have no compensation if they drained the land themselves. Then draining is done, the nsmal practice is for the landlord to find pipes, and the tenant to do the hating and labour : but as the holdings are from year to year, and no compensation is giren for unexlausted improvements, drainage is not carried to half the extent it otherwise ronld.

Worcesterstire.-There is no definite time for the incoming tenant to cnter upon and quit his farm, but Lady-day is most usual. The offgoing tenant allows his snccessor to commence ploughing the wheat stubbles on the 1st of Jannary previons to quitting, and does not turn stock npon the mowing meadows after Candlemas-day. He is paid for the seed and labour of sowing elover sceds upon his lands bearing the last crop of Lent grain, and leares one-third of the offgoing wheat crop for the landlord or incoming tenant (after the value of the tithe is dedncted), and all the straw. 'There is no compensation for any lind of improvements or mantres, unless specially provided for ; and if any buildings lave been erected by the outgoing tenant, he is not allowed to remore them, although they have been put up with the landlord's permission. All the manure belongs to the landlord, and the offgoing tenant has till the 1st of May, after quitting, the use of the fold-yard, and a boozy pasture adjoining or near, for the purpose of consmming his hay and straw of the last year's growth; and also a room in the house for the servant in attendance npon such stock as are consuming the hay and straw. Since the Tithe Commntation Act agreements have become much more general, and the enstom is but seldom appealed to.

Yorkstire-East Rieling.-There is hardly one single instance of an agricultural lease in this ricling: all are yearly holdings, and these are almost universally from Tady-day. With regard to acts of husbandry, the offigoing tenant is entitled to a waygoing crop, varying from onethird to one-fourtl of the arable according to the description of land he farms. Upon the wold part of the riding they have one-quarter part of the arable land as a waygoing crop; upon the stronger soils 
(Holderness, for instance, and the west side of the wolds, which is called Howdenshire) the waygoing crop averages one-third part of the arable land.

The East Riding of Yorkshire may be described as consisting of three districts, distinct in their surfaces and soils, viz., Holderness, the chalk wolds, and the plain, west of the wolds, which last section contains Howdenshire and the Vale of York. The soil of Holderness is generally stony, that of the western plain stony also, with interventions of sand and gravel. The soil of the wolds is thinner and lighter. These characteristics influence the customs of the waygoing crop. On the stronger soils in former days (in which these customs originated) the three-course system of eropping prevailed, and so it followed that onethird of the arable ras assigned to the ontgoer. In the wolds the Norfolk or four-course system was introdnced upon their inclosure and cultivation, and therefore one-fourth of the arable portion of the farm is the waygoing crop. This crop is either sown after rape, turnips, or sceds, depastured the summcr previous. The ontgoing tenant sows wheat, barley, oats, \&c., as the case may require, and he leares the crop at a valuation, to be taken by the incoming tenant, who has to pay the amount of this valuation, deducting the average rent per acre of the farm upon which the waygoing erop has grown, which is called the onstand, also dedneting the expense for inning and outing, which is reaping, thrashing, delivering, stacking, and cvery other expense attending the bringing the corn to market; as well as one year's parochial taxes for that part of the land upon which the waygoing crop is gromn. The incoming tenant gets the straw and the catage thereof; but he has to allow the offgoing tenant $6 s$. or $7 s$. per acre, or something of that sort, for the eatage of the straw.

Three parts out of four of the dung belong to the land. The outgoing tenant in the absence of corcuants las no compensation for the purchase of artificial manure, or artificial food for stock, nor for draining or chalking the land. The challing and marling is done by the tenant at his own risk. The tenant does nothing but keep the buildings in tenantable repair, and the same with respect to the fences and gates. All the materials belong to the landlord; the painting, the mending of the fences, and the repairing of the gates, belong to the tenant; but if any new gates are wanted, the landlord generally finds them. As to the new roofs, the agreement says the tenant is to keep the buildings in repair; main walls, main timber, and damage by fire and tempest, only excepted. Of late years there has been some compensation introduced into the agreements; it was not so formerly; it is only within the last few years that it has been the custom to feed with oil.. 
cake; since that custom has come in, the practice has been gradually introduced of allowing compensation for a small part of the oilcake that has been used in the last two years. It is very nsual to make allowauce for cake on the wolds, thongh it can hardly be called the custom of the East Riding. If a question should arise upon the quitting of a farm, and reference shonld have to be made to the custom, it wonld hardly allow compensation for the use of cake. Scarcely any compensation clanse has been introduced into the agreements, except as to vileake. Boues are extensirely used, but they are not allowed for, except in the waygoing crop; the tenant has the power of taking the crop where it has been boned the year befure, and he gets his allowance for bones by selecting that part of the farm from which he takes his raygroing crop.

Forkshire-North Riding.-The tenants of a great portion of this extensive riding have no leases. On many estates they are simply tenants from year to year, withont even written agrecments. A customary regulation, that no two white crops are to be grown in succession, that no straw is to be sold off the farm, and that the tenant shall leare as he entered, comprises all the conditions between the parties. There are no stipulations as to tenant-right or mnexhausted improvements; in fact, snch covenants would be almost a dead letter, as changes are rare, and it wonld be easy to point out tenants on many estates whose fathers and grandfathers before them held the same farm, and under the same unwritten agreements. Upon the large properties there is in almost erery case some peculiarity as to the times of entry, modes of cropping, \&c., and hence it would be impossible to give any one general rule. Most freqnently, perhaps, the entry on arable land for fullow or spring crops is on February 2ud (Candlemas day); and on the rest of the arable land at the separation of the awaygoing crop; pasture land on $A_{\text {pril }}$ (ith ; and the dwelling-house, oftices, and meadow land on May 13th. The ontgoing tenant has a right to one-third of the arable land on which to grow an awaygoing crop, and on some estates he pays what is called an onstand for his awaygoing crop, which is oceasionally the average rate per acre of the rent of the farm, but is more frequently a fixed sum of $6 s .8 \%$. per acre. In the latter case the ontegoing tenant has generally the right of eonsuming the straw of his awaygoing crop on the premises. Sometimes, however, the ontgoing tenant pays no onstand for his awaygoing crop, but leares the straw, as soon as it is thrashed, for the nse of the incoming tenant withont fourchase. 'The manure on the farm belongs to the ontgoing tenant u] to February 8th, for his use on his awaygoing crop ; whatever remains 
on the farm, or is made there after Febrnary 8th, belongs to the incoming tenant withont purchase. The Duke of Lceds, since 1848, has inserted a clause in his agreements to the effect that the incoming tenant shonld pay on entry a reasonable price for all manure found on the farm made from the previous year's crop. In taking his awaygoing crop the outgoing tenant is obliged to take it npon-1st, naked fallow; 2nd, turnips half-eaten on ; and, 3rd, clover ley. A great extent of drainage has been effected in this riding within the last fifteen years, partly at the joint expense of landlord and tenant, the former finding tiles, and the latter being at the rest of the expense; and partly by the landlord finding the money, and charging such percentage as may be agreed on; but chicfly under the operation of the drainage loan acts. In the latter case the tenant frequently leads the materials withont charge, and pays as additional rent the Government charge of $6 \frac{1}{2}$ per cent. on the money expended. The ordinary offices on the farm are usually kept up at the landlord's cost, the tenant finding carriage of materials.

Yorkstire-Nest Riding.-The tenant-right is heavier than in Lincolnshire in the tillages and half tillages. They get paid for whatever they liave done in their fallow year, as well as a year's rent and rates and mannre. 'Then they go to a second year, and have half that allowance. 'The tillage is the north-country term for' what is called in the south an allowance for working fallows. That applies to all land alike, for so many ploughings and harrowings in order to clean the land. The West Riding of Yorkshire is the larger portion of Yorkshire, and its system extends partly into Nottinghamshire, and also into part of Derbyshire, though it is a very injurious one to the incoming tenant and to the estate, as regards the awaygoing erops and the half tillages. One-fifth of the farm should be in grass, and the remaining four-fifths are farmed in the four-course shift of husbandry. The allowances are: First course-Summer, turnip, potato, or rape fallows; on these are allowed one year's rent and taxes, the dressings of the fallows, with manure, and all other tillages purchased, dedueting for the vegetable crops, and the seed and labour for the corn sown as a first erop. Second course-Seeds, or pea or bean stnbble, ealled halftillage land, for which are allowed the dressings, half the rent and taxes, half value of manure, three-fourths of bone tillage, one-third of guano or other light artificial tillage, less one-half the amount of last year's deduction for vegetable crop. Third course-Theat on ley, or on pea or bean stubbles; the full value of the crop is allowed, deducting one jear's rent and taxes; horrever, in some instances only the seed 
and labour of the last crop are allowed ; but this depends upon whether the land is "old inclosure," "field," or lands on "the commons of the county." Fourth course-Fallow; here the ploughings and dressings are all allowed ; but if dressed at Michachmas, nothing is allowed in the following spring for mannre made from the stubbles or refuse. The raluation on the premises comprises generally one year's manure, which is lying unspread, and the value of all fodder not consumed on quitting; and the fixtures in the house and buildings aceording to entry. Drainage is permitted and compensated for by special agreement.

\section{NORTH TWALES.}

Tenant-right cannot be said to exist in North Wales. Generally spcaking, all farms and lands are held under a ycarly tenancy, determinable cither upon the part of the landlord or the tenant, by six months notice to quit. The time of entering upon farms -varies in difforent parts of North Wales; but the most general and common eustom is for the ineoming tenant to take possession of the lands upon the 30th of Norember, and of the house, out-buildings, and boozy pasture (being a single field near the house reserved for the purpose of turning the cattle in, for exereise and to water during the winter) upon the first of May. 'The first half-year's rent lecomes payable upon the 25th March interrening between these days, and is therefore somewhat in the nature of a fore-hand rent, of which the tenant has the bencfit upon leaving the farm. In the Island of Anglesea it has been attempted to establish a custom of Tenantright. This has been done by the tenants erecting houses and buildings upon their lands at their own expense, and claiming in consequence either an equitable right for themselves or snceessors to stay upon the farm, or compensation in respect of their improrements. Buildings erected under these circumstances being generally of an inferior character, it has become the practice in some of the agreements used in the Island to restrict the tenants from crecting buildings without the sanction of their landlords. Upon the change of tenancy no division of crops takes place (as in Fingland), betreen the offgoing and incoming tenant, inasmuch as the offgoing tenant has reaped all his crops before the tenancy of the land expires, and the incoming tenant sows in the autumn the crops he is to reap in the ensuing summer, and in respect of which he pays a half-year's rent upon the 25 th of March. Such a thing as an allowance in respect of uncxhausted improvements is almost unkmown in North 
Wales. Agriculture is altogether in a backrard state. Old hedgerows are seldom removed, and artifieial manures are rarely used. Draining is very much required in places, and whatever progress is made in this respeet is principally effeeted either by the landlords themselves, or with the aid of the Drainage Commissioners.

\section{SOUTH IVALES.}

Breconshire.--In this connty the holdings commence almost entirely at Michaelmas. All the land is retained by the ontgoing tenant, with the exception of one field, until St. Andrew's-day (November 30th), when the whole, except such boozy pasture field and the turnips and green crops, are given up to the incoming tenant. The latter are retained by the outgoing tenant till Mareh, when the incoming tenant enters to sow his Lent grain, but, the boozy pasture is given up to the ineoming tenant on the 1st of May. All buildings at the homestead, with the labonrers' eottages, \&e., are retained by the outgoing tenant till the 1st of May, but access to the kitehen and one sleeping-room is granted to the incoming tenant, together with a stable, and a place for his hor'se-gearing. The wheat has to be sown by the 29th September, unless leave for further time has been obtained from the incoming tenant, who is entitled to one-fourth of the produce on fallow, and onehalf from stubble or swarth. In Llanfigan the outgoing tenant has no right to the turnips or green crops after November 30th (unless they are previously taken from the field and stacked), exeept by consent, which is usually given, as is also permission to sow wheat after September 29th.

Curdiyanshire.-The usual period of entry upon farms is Michaelmas, and the holding from year to year. Leases for one or two lives are not uncommon, also for seven, fourteen, or tiventy-one years; but the leases for lives are not so general as they formerly were. The outgoing tenant has nothing to do with the incoming; but each settles his elaim with the landlord. If a landlord gives a tenant notice to quit, he has to pay him for all necessary improrements on buildings, made during the tenaney, and for all draining if properly executed. The outgoing tenant quits the farm at Michaelmas. If he has earted lime on the farm, or left any farmyard manure, or has sown rye-grass and cloversecd, \&c., the new tenant has to pay for them; and also for half the value of the 
lime which has been carted and spread upon the farm during the preceding rear, and prodneed one crop.

Carmenthensture (Eust).-The usual period of entry is at Michaclmas, and the holdings are from year to year. Leases are uneommon, and when granted, rarely execed twenty-one jears, though they run as high as sixty. Where land is to be embanked from the sea, or reclaimed at a great expense, leases have been granted for ninety-nive years. It is not the custom for the outgoing tenant to receire any remuneration from his snecessor for improrements made on the farm; and even if he has expended money on draining or farm buildings, \&c., he is rery rarely remunerated by his landlord. The ontgoing tenant almost inrariably disposes of his crops by public auction, and rery seldom by valuation to the incoming tenant: sometimes the manure is disposed of the same way, unless there happens to he (which is rery seldom) a special agreement to leave it on the land. By the custom, the ontgoing tenant is paid for all the manure that remains unused, also for the lime and manme on summer fallows, as well as for the ploughings and harrowings of the latter, for the elorer and grass-seeds sown with the spring corn, and mostly for part of the manure and lime and the wheat crop, and any ungrazed aftermath.

Carmarthenshire (West).--The entry is generally at Michaelmas, but sometimes at Lady-day. The usual holdings are from year to year. Leases, as a rule, are uncommon; the few granted are chiefly for lives: those for a term of years are rery rare. 'The ontgoing tenant receires some remuneration from his successor for improrements which have been recently made. The landlord allows him remuneration for the nutlay on recently-erected buildings, and draining; but very little of the latter is done. The ineoming tenant has to pay for the manure and lime on the farm; he has also to pay for seeds, clover, and rycgrass, sown the preceding spring by the outgoing tenant. If the latter remores to another farm, he takes the erops with him; if he does not, the usual custom is for him to hare a sale by anction of all his farming stock and crop on the holding which he is about to leave, unless there is a prolibition in his agreement against lis taking away the straw. In the latter case, the landlord of the incoming tenant has to pay for the crop, and two valuers are appointed.

Glamoryanstire.-'The tenure of a seren or fourteen years' lease is fretty common, and the time of entry respectively on the land and louse, in the sonthern districts, are Jady-day and May-day; and in 
the other distriets, Candlemas and May-day. The landlord liceps in repair all the buildings on the farm, the tenant doing the laulage of materials for such repairs, and furnishing good wheat straw for thatching, if required, withont any compensation. If the landlord erects any new buildings, or does any draining, five per cent. is charged on snch outlay. In the eastern distriets (where the holdings are principally from year to year, and if by lease, twenty-one years), a form of lease is becoming rery prevalent, which stipulates that the tenant slall not at any time sow more than one quarter of the arable land with wheat, and one quarter with other straw crops, nor take more than two straw crops from the same land during any four years of tenancy; and also liys down strictly the allowance to the tenant on quitting. All the manme, straw or stubble unconsumed on the farm, is left for the landlord or the incoming tenant without compensation. All the meonsumed hay is left, and a certain number of tons are paid for by the landlord or incoming tenant at a consuming price, and the remainder left on the premises without compensation. In the last year of the tenaney, the tenant is bound to sow one-fourth of the arable land with barley, and to suffer the landlord or the incoming tenant to sow elover or other seeds on the same. He is also bound to sow one-fourth part of the arable land in the same year with turnips. The landlord or the incoming tenant pays for the crop of turnips thus raised, and the value of the same as well as the hay is aseertained, by two valuers, and an umpire if neeessary. It is not usual to make the tenants any allowanecs for improvements, muless there be an agreement to that effect. They cannot elaim remuneration for draining or farm buildings, unless they have been done with the consent of the landlord, and on an understanding that they are to be allowed. It can hardly be said that an established custom prevails between incoming and ontgoing tenants; but it is usually agreed that if the ontgoing tenant has properly fallowed the land, and not taken a crop from it during the last year of his tenancy, the year's rent and taxes, with other ontgoing's, cost of seeds, sowing, \&c., shall be allowed. It is also usual where lime has becn spread on land and only one erop taken, to allow one-half of the value of such lime at the kiln. Where clorer seed has been sown with the barley crop in the last year, the expense of sowing it is allowed, as well as that of ploughing up stubbles, or any necessary act of cultivation conducive to a future crop.

Glamorganstive (Trest).- There is no general enstom as to the period of entry on farms: some commence at Michaelmas, some at Lady-day. Leases are rather the exception; those at present in existence are 
chiefly the remmants of the old system of leases fur three lives, at a nominal or at a rerr low fine. Is the lives fall in, the farms are usually re-let at rack-rent, and subject to a six months' notice to quit. As a rule the tenants make no improrements, and can therefore claim nothing at learing. The old class of tenants with profitable leases merely scem to regard their leases as a security against all modern improrements, and upon the expiration of the lease the premiscs are generally found to be ruinous, and the land in as bad a conclition as possible. The rack-rent tenants naturally expect crerything in the way of draining or building to be done by the landlord; in the rare cases where a tenant lays ont money in improvements, the landlord allows him for them, but there is no custom upon this point. 'The temants have seldom suflicient eapital for the ordinary working expenses and proper stocking of the farm; all improvements by them are, therefore, totally out of the question. The custom is for the outgoing tenant to impoverish the land by a succession of straw crops as long as his landlord will allow him to dlo so, and when the farm is thoroughly run ont, he gives notice to quit. Before leaving, he has a sale of all lis stock, crop and manure, down to the mud in the lanes, which he ustally scrapes up to make the muck heap larger. The sale is by anction, with six or nine months' credit. The only allorrance occasionally made to an outgoing tenant is for the lime, which, by the custom of the country, must be paid full value for, if put on the same year, and half ralue if put on the year previous. However, several large landowners are beginning to establish a better state of things, having determined to let their farms upon yearly agreements, with proper covenants as to cultivation, with a view to prevent the orereropping and sale of manure at the expiration of the tenancy. Some have begnn to purchase all the straw and manure of the outgoing tenant, and make the incoming tenant a present of it on condition that he signs an agrecment. This involves a considerable outlay on the part of the landlord, but if constantly and universally adopted, will end by entirely putting a stop to the creclit sales, which are a most scrious evil, and will in some measure compensate for the want of capital on the part of the incoming tenant, who will find his farm in good condition, and will be merely lound under heavy penalties to leave it as good as he found it.

Pembrokestive.-The general entry on farms is at Michaelmas, and the holdings are mostly by the year. I,eases are not so common as they were some years ago. 'There are a few for lires, and some for seren, fourtecn, and twenty-one years. Any remuncration which the outgoing temant receires from his landlord for building or draining on 
quitting lis furm, is guided entirely by the agreement which is made between them on entry. The incoming tenant pays for the manure left on the farm; sometimes the crops are taken at a valuation, and if they cannot agree, the outgoing tenant thrashes the corn, leaving the straw on the farm. The turnip crops are generally taken by valuation. Where there is a fallow, so much per acre is charged for working it; and that, as well as clover-seeds sown, are paid for by the incoming tenant.

Rachnorstire.-In this county, the smallest in Sonth Wales-so small, indeed, as to hare been styled from the Bench, "that little sheep-walk, which calls itself a county,"-no established tenant-right ean be said to exist, as the customs widely differ, even in neighbonring parishes. A very large portion of the north-mest side of the county consists of open mountain, and is farmed as a sheep-walk. In this district an almost fendal relation exists between landlord and tenant: the landlord is looked upon as the owner of the flocks, ant the tenant receives a certain proportion of the profits in return for his labonr and attendance. In the more cultivated districts the incoming tenant usually takes possession of the land at Lady-day; but the outgoing tenant does not quit the premises till February; he, however, gives up possession of all the land, with the exception of one field sulficient to keep a cow. The country on the east side, in the neighbourhood of Knighton, is very fertile, and the Fferefordshire system of farming is prevalent. In the more remote districts leases are not uncommon, those for lives preponderating over those for a term of years.

\section{TIIE AGRICULTURAL IIOLDINGS ACT.}

This Act, 38 \& 39 Vict. c. 92, was passed for the protection of tenant farmers in England, and with the intention of providing a remedy for a supposed grievance under which the tenant farmers had long laboured.

Leases in this country are no doubt the exception and not the rule, and unless a tenant had a lease he was liable under the old system to be turned out of his oceupation at six months' notice, which notice mould probably expire at Michaclmas, withont receiving any compensation for his unexhausted improrements. These improrements might consist of permanent bnildings, drainage, value of unexhansted manures, etc., and it was argued that no tenant could be expected to 
invest his capital in improrements of this character if he were liable to be turned ont of his occupation at six months' notice without any compensation for the money which he had expended upon his landlord's property. This act came into operation on the 14 th February, 1576, and does not cxtend to either Scotland or Ireland. The th sec. interprets the terms used in the Act: the word "landlord" bears a wide inter]retation, riz., "the person for the time being entitled to possession of land subject to a contract of tenancy, or entitled to receipt of rent reservel by a contract of tenuncy, whaterer be the extent of his interest, and although the lind or lis interest therein is incumbered or charged by himself or his settlor, or otherwise, to any extent; the party to a contract of tenancy under which land is actnaliy occupied heing alone deemed to be the landlord in relation to the actmal occupier: it also includes the agcht authorised in writing to act under this Act generally, or for any special purpose, and the executors, administrators, assigns, lusband, guardian, committee of the estate, or trustees in bankruptey of the landlord. "The interpretation of the "tenant" is not different from that usually held. The 5th sec. gives a list of improrements which are comprised in the Act. They are divided into three classes.

The first comprises :

Drainage of land.

Erection or enlargement of buildings.

Laying down permanent pasture.

Making and planting osier leds.

Making of water meaduws or works of irrigation.

Making of gardens.

Making or improrement of roads or bridges.

Maling or improving of watereourses, ponds, walls, or recervoirs, or of works for supply of water for agricultural or domestic purposes.

liarking of fenees.

Planting of hops.

Planting of orchards.

Reclaiming of waste lands.

Warping of land.

These are called improvements of the first elass, and the tenant is cntitled to compensation up to the end of twenty years from the date of outlay. The amount of the tenant's compensation in this class of improvements is the sum laid out by the tenant on the improrement, with a deduction of a proportionate part thereof for each year while the tenancy endures after the year of tenaney in which the outlay is made, and while the improrement continnes, with this proviso, that where the landlord was not, at the time of the consent given to the execution of 
the improvement, absolute owner of the holding for his own benefit, the amount of the compensation shall not exceed a capital sum, fairly representing the addition which the improvement, as far as it continnes unexhausted at the determination of the tenancy, then makes to the letting value of the holding.

It is most important to notice that a tenant shall not be entitled to compensation in respect of improvements of the first class unless he has received the landlord's consent in writing.

Further a sum reasonably necessary to be expended for the purpose of putting an improvement into tenantable repair or good condition shall be deducted from the amount payable to the tenant.

It will be observed that the words "tenantable repair" or "good eondition" are used synonymously.

The former certainly implies much less than the latter, and it is difficult to see why the words "good condition" were put in as an alternative. A place may be in tenantable repair, but not in good condition, and certainly a place which is in good condition is in tenantable repair.

Improvements of the second class consist of -

Boning with undissolved bones.

Chalking of land.

Clay burning.

Claying of land.

Liming of land.

Marling of land.

Improvements of this class are to be deemed unexhansted for seren yenrs, and the amonnt of compensation shall be the sum properly laid ont by the tenant on the improvement, with a deduction of a proportionate part thereof for each year while the tenancy lasts after the year of tenancy in which the outlay is made, and while the improrement continues unexhausted. A tenant shall not be entitled to compensation in this class muless he has given notice to the landlord in writing of his intention to make the improvement, not more than forty-two or not less than seven days before beginning to excente it, nor where it is executed after the tenant has given or received notice to quit, without the previous consent in writing of the landlord. A distinction is dram between improvements of the first and second class in this respect, that in the former no compensation will be given under this Act unless the consent in writing of the landlord has been first obtained, whereas in the latter, the tenant has power to make the improrements and to demand compensation provided he has given the requisite notice to the landlord unless he, the tenant, be under notice to quit. 
Improvements of the third elass consist of-

Application to land of purehased artificial or other purchased manure.

Consumption on the holding by cattle, sheep or pigs, of cake or other feeding stuff not produeed on the holding.

Improrements of the third class are deemed mexhansted to the end of two years.

It is somewhat remarkable that there is no distinetion between artificial and other manures, it laring been held usually that the former are exhansted in one year, while the farmyard manure is supposed to benefit the land for a much longer period.

The tenant is not entitled to compensation in respect of an improvement in this class where a crop of "corn, potatoes, hay or secd, or" any other exhansting crop" has been taken since the execution of the improvement.

The words "other exhausting crop" are very vague, but would probably include peas, beans, retehes, flax, etc.

By sec. 14 the tenant is not entitled to compensation in respect of an improrement in the third class, consisting in the consumption of cake or other feeding stuff, where, under the custom of the country or an agreement, he is entitled to elaim payment from the landlord or incoming tenant in respect of the additional valne given by that consumption to the manme left on the holding at the determination of the tenancy.

$A$ custom has obtained in some districts to allow the outgoing tenant one lalf the value of corn eonsumed on the holding during the last year of lis tenaney where no crop has becn taken, but it seems that he has the opition of taking advantage of the Act or of seeking compensation under the custom of the country.

Sec. 15 restricts the amount of compensation which can be allotted mder this class to the arerage amount of the tenant's outlay for like purposes during the previons three years of his tenancy, or other less number of ycars for which his tenancy has endured, and the ralue of the manure which would have been made by the consumption of any hay, green crops, ete., sold off within the last two years of the tenancy, except in cases where a proper return has been made in the sliape of manure.

By sec. 16, the landlord may deduct from the tenant's compensation whatever is or may be due during his ocenpation for taxes, rates, the tithe-rent-charge, rent, or landlord's compensation. The landlorl, by sce. 17, may also set off whaterer sum he has contributed towards the improvements.

Secs. 18 and 19 provide for compensation for breach of corenant by either party. 
Sees. $20-44$ provide for the method of precedure for the recovery of claims and connter-claims under the Art.

Firstly, the tenant must give one month's notice to the landlord that he intends to make a claim moler the Aet, and the landlord may at any time after receipt of notice of claim before determination of the tenaney or fourteen days thereafter, give notice of counter-claim. The particnlars of the claim and comnter-claim, as far as they reasonably can, are to be stated in the notices.

It is difficult to see why the words "as far as they reasonably can " are inserted. If a tenant intends to seek compensation under the Act, he onght to keep an aceurate aecomnt in detail of what he has expended in this respect, and the qualification added would seen to encourage parties to make additional demands at the trial.

The landlord and his tenant may settle their differences themselves; if not, they must go to a reference.

If the parties agree, they may appoint jointly a referee: if not, each shall appoint a referee; and the two referees before they enter on the reference shall appoint an umpire: if they fail to appoint within fourteen days the Comnty Court shall appoint an umpire. But in cases where two referees are appointed, either party may, on giving notice to the other in writing, require that the mimpire shall be appointed either by the Inclosure Commissioners or the Connty Court. 'The registrar may, by consent of the parties, exercise the powers of the Comrt.

The same powers are given to the referee, referees, or umpire as are usually given to an arbitrator as regards administering oaths to witnesses, production of docmments, ise.

A single referee must make his award within $t$ wenty-eight days after lis appointment; but two referees have power to extend their time, provided it be done jointly in writing, up to forty-nine days. If two referees fail to make their award within the appointerl time, their anthority ceases, and the matters then stand referred to the umpire, who must make his award within trenty-eight days of his appointment as arbitrator, or within such time as the registrar of the County Court may appoint.

The award is not to arard a sum generally for compensation, but must specify in detail the class moner which each sum is ararded and the amount of each improvement, together with the time at which it was expended.

The costs of the reference are to be paid by the parties in such proportion as the referees or umpire shall direet.

In cases where the amount claimed exceeds $£ 50$ either party may within seren days after delivery of the award, appeal to the Judge of the County Court, on the grounds- 
1. That the award is invalid:

2. That compensation has been ararded in respect of matter's for which the party claiming was not entitled to eompensation : or

3. That compensation his not been awarded in matters for which the party claiming was entitled to compensation, and the Judge may remit the whole or part of the ease to be reheard.

The decision of the Comnty Court Judge shall be final, save that at the request of either party he shall state a special case on a question of law, for the judgment of the High Court of Justice.

Any money agreed or awarded to be paid meler this let siall be recorerable as other money under the ordinary jurisdiction of the County Court.

The County Court has power to appoint a guardian for landlord or tenant in the case of either being an infant or of unsound mind: it may also appoint a person to act as the next friend of a married woman in certain eases.

By sec. 42, a landlord, by an order of the County Court, may charge the holding with the amount of compensation he has paid to the tenant, prorided that, if he be not absolute owner of the holding for his own benefit, no instalment or interest shall be made payable after the time when the improvement in respect whereof compensation is paid, will for the purposes of the Aet be taken to be exlrausted.

By secs. 45-17, the Aet applies to lands belonging to Her Majesty the Qieen, in right of the Crown and the Duchy of Lancaster, and to land belonging to the Duchy of Cornwall.

By sec. 48 , the porrers of this Act cannot be exercised by an archbishop or bishop in respect of lands assigned "or secured as the endowment of a see without the approval in writing of the Ecclesiastical Commissioners.

Nor, by sec. 49, in the ease of an inenmbent of an ecclesiastical bencfice without the written approral of the Gorernors of Queen Anne's Bounty.

Nor, by sec. 50, in the ense of trustees for ecclesiastical or charitable purposes withont the written approral of the Charity Commissioners.

See. 51 is very important, sceing that by it a year's notice to quit is necossary instead of half a year.

Sec. 5.2 legislates for cases in which a landlord gives notice to his tenant to quit with the object of using the land for certain purvoses, viz. :

(1.) Lrection of farm-labourer's' cottages;

(2.) Providing gardens for furm-labourers;

(8.) Allotments for labonrers; 

(4.) Plantations ;
(5.) Mines;
(6.) Brick-earth, gravel, or sand;
(7.) Watercourses or rescrvoirs ;
(8.) Roads, tramways, \&c.

In all these cases the provisions of the Act apply as regards compensation, as on determination of a tenancy of an entire holding, and the tenant will be entitled to a proportionate reduction of rent for the land taken, and also in respect of any depreciation of the value to him of the residue of the holding by the withdrawal of that land or ljy the use to be made thereof.

Sec. 58 relates to fixtures.

By sec. 54, nothing in the Act shall prevent a landlord and tenant from making any agreement they may think fit; but by sec. 55 they may adopt certain parts of the Act, and not the whole.

By sec. 56, this $\Lambda$ ct will apply to all future tenancics, unless the partics agree in uniting that this Act shall not apply to their contract.

And by sec. 57, cither landlord or tenant in any contract of tenancy current at the commencement of the Act might, by giving notice to the other within two months after the commeneement of the Act, viz., Febrnary 14, 1876, become exempt from the provisions of the Act ; and the Act does not apply to holdings of less than two acres.

It will be observed that the adoption of the Act is not compulsory, and that it does not interfere with the freedom of contract between landlord and tenant in any way. It scems, moreorer, that the process of settling a heavy case is both expensive and long: certain it is at any rate that the Act has not at present been adopted to any extent. 


\section{CHAPTER II.}

\section{INTEIESTS IN IAAND.}

Wrere anything is done which substantially amounts to a sale or parting with an interest in land, the contract is for or relating to the sale of an interest in or concerning lands, tenements, or hereditaments, within the meaning of the 29 Car. II. c. 3, s. 4.

The case of Wradington $\mathrm{r}$. Brislowe, where a written agreement was made in November, 1799, for all the hops which should be grown in the ensuing year, upon a given number of acres of land, was long regarded as a leading one on the sulject of root crops, conferring an interest in land. The hops which were the snlject of the contract wore not then in existence; there was nothing but the root of the plant (from which the bine which was to flower and produce the hop, would shoot out in the following spring), and the purchaser was not to have that. However, after the lapse of a quarter of a century, Mr. Justice Bayley, when delivering judgment in Ecans r. Roberts, passed it, among several others of the same elass, under review, and showed that it could not be said to hare been decided on that ground at all. "The question in that case," said his lordship, "was not whether the agreement, which was in writing, was for an interest in land, but whether it onght to have been stamped. It was contended that it was within the exception in 23 Geo. III. c. 58, s. 4, an agreement made for and relating to the sale of goods, wares, and merchandise. All the judges concurred in the judgment that the contract in that ease was not such an agreement; but Chembre J. was the only judge who intimated an opinion that the contract gave the vendee an interest in land. He certainly stated that the contract gave the vendee an interest in the prodnce of the whole of that part of the rendor's farm which consisted of hop grounds." Hence the case hardly deserved to be quoted by Lord ILansfielel C.J., as a precedent strietly in point in Emmerson. ve. Heetis, where the Court of Common Pleas decided that a sale of grouing lumips by public auction no time being stipulated for their removal, and the degree of their maturity not being positively found, was a sale of an interest in land within $29 \mathrm{C}^{\prime} a r$. II. c. 8, s. 4, and must be in writing, "because we do 
not see how it ean be distinguished from the case of hops deeided in this court."

In Emmerson v. Heelis the defendant, by his agent, who was his farming servant, attended at the sale, and being the highest bidder was declared the purchaser of twenty-seren different lots, of fourteen stitches or furrows each, and his name was written in the sale-bill by the auctioneer opposite each particular lot which he had purchased. On this case also Bayley J. thus commented in Evans v. Roberts : "It was not necessary to decide the point upon the Statute of Frauds, because there was another point in favour of the plaintiff, which rendered a decision upon the first question perfectly unnecessary, for the contraet being signed by the auetioneer as the agent of the bnyer was equally binding, whether it was for a sale of goods and chattels or of an interest in land." Parke B. also said in allusion to Waddington v. Bristou'e, in the course of the argument in Roducell v. Phillips, "hops are fructus industriales. That ease would now probably be decided differently. The distinction is pointed out in Scinstury v. Mattheres."

The facts in Exans v. Roberts were as follows: The defendant, on September 25, 1825, agreed by parol with the plaintiff to purehase $a$ cover of potatoes then growing on land of the plaintiff at the price of $£ 5$, and the defendant paid $1 s$. earnest. Some dispute arose as to who should raise the potatoes, and the plaintiff agreed to dig them up, the defendant agreeing to come and take them array before the next Christmas; but in consequence of the price falling from $12 s$. to $8 s$. per sack he refused to stand by his bargain. Garrow B. ruled, in an action of indebitatus assumpsit for a cover of potatoes bargained and sold, that inasmuch as the rendor was to take up the potatoes, it must be considered not as an interest in land within the 4 th, but as merely a contract for the sale and delivery of goods and chattels within the meaning of the 17th section of the Statnte of Frands, and the plaintiff had a verdict for $£ 419 \mathrm{~s}$. The Court of King's Bench refused to enter a nonsuit, and held that this was elearly not an interest in land.

Bayley J. said, "The defendant has no right to any possession of the land; the only thing for which he has bargained is that he shall have the potatoes delivered to him when their growth shall be complete." "In the case of growing potatoes, which are the artificial produce of the land, arising from a particular course of husbandry, they come within the description of emblements, and go, not to the heir, but to the executor, and they may be seized in execution under a writ of fier $i$ fucias. That writ goes against the goods and chattels of the party, and therefore whatever the executor would be entitled to take as goods and 
chattels may be seized by the sheriff. Now the potatoes in this case might, in my opinion, be seized under a writ of fier facias, and whether at the time of the contract they were in a growing state, or in a warehouse, it seems to me that they are to be considered as what the law designates goods and chattels. If that be so, then they are not within the provision of the thth section of the $29 \mathrm{Car}$. II. c. 3 . In the case of Parker r. Stumiland, the potatoes were clearly considered as goods and chattels, and not amounting to an interest in land. I agree that that case is distinguishable from the present, because there the potatoes had ceased to grow. The case of Wareick $\mathrm{r}$. Bruce is distingnishable from this in the same particular; but I think the reasoning of Lord Ellendorough in the latter case is extremely important in assisting us in coming to a right conclusion when forming a judgment as to the effect of that elause of the Statute of Frauds which speaks of an interest in lauds, tenements, or hereditaments. He there says, ' $A$ s to the last objection, if this had been a contract conferring an exchsive right to the land for a time, for the purpose of making a profit of the growing surface, it would be a contract for the sale of an interest in or concerning lands, and would then fall unquestionably within the range of C'rosby r. Hadsicorth. But here is a contract for the sale of potatoes at so much per acre; the potatoes are the subject-matter of the sale, and whether at the time of the sale they were covered with earth in a field or in a box, still it was a sale of a mere chattel. It falls therefore within the case of Parker r. Slaniland, and that disposes of the point on the Statute of Frands.' It does not appear that the other judges in giving judgment made any observations upon that point; but it is elear that my Lord Ellenboroughi's judgment proceeded on the gromnd that if the contract gave to the vendee no right to the land for the purpose of enabling him to make a profit of the growing surface, then it was not to be considered as giving him an interest in the land, but merely in a chattel. Now, trying this case by that test, there is nothing but a contract for the sale and delivery at a future period of that which at a futmre period would be in a perfect state as goods aud chattels."

In P'trker v. Staniland the plaintiff owned a two-acre elose, which was cropped will polaloes, and agreed with the defendant on November 21 st, to sell him the potatoes at $4 s .6 d$. per sack. The defendant was to get them up himself, and to get them immediately, and he employed men on the 25th, 26th, and 27 th of the same month, and got 21, 24, and 39 sacks full. On the 4 th of December he got 7 sacks more, and 14 about Larly-day, the value of which was covered by the money paid into Court. There remained abont three roods of potatoes, which were not dug up, and which were spoilt by the frost; and in an action 
bronght to recover the value of these, the plaintiff had a verdict. It was oljected on behalf of the defendant, that it was an interest in land, and ought to have been in writing ; but Bayley J. overruled the objection, and the Conrt unanimously refused to grant a nonsuit. Beyley J. : "I do not think that this contract passed an interest in the land, within the meaning of the fourth section of the Statute of Frauds. In the cases of Crosby v. Wadsuorth, and Wadlington v. Bristowe, the contracts were made for the growing crops of grass and hops, and therefore the purchasers of the crops had an immediate interest in the land, while the crops were growing to maturity before they were gathered: but here the land was considered as a mere warehouse for the potatoes, till the defendant conld remove them, which he was to immediately, and therefore I do not think the case is within the stalute." And per Ellenborough C. J.: "The lesscc prince vesturce may obtain trespass quare clausum frerit, or ejectment for injuries to his possessory right, but this defendant could not have maintained either; for he had no right to the possession of the close; he had only an easement, a right to come upon the land for the purpose of taking up and carrying away the potatoes; but that gave him no interest in the soil. I am not disposed to cxtend the case of Crosby v. Widdsuorth further, so as to bring such a contract as this within the Statute of Frands, as passing an interest in land."

The defendant in Waruick v. Bruce on the 12 th of October agreed by parol to sell to the plaintiff (an infant) all the potatoes then growing on $3 \frac{1}{2}$ acres of his land, at $£ 25$ an acre, to be dug up by the plaintiff, who paid $£ 40$ under the agreement. 'The latter then dug up and carried away part of the potatoes, but was prevented by the defendant from digging and carrying away the resiclue. It was held that the plaintiff was entitled to recover for this breach of the contract in part executed by him, and which was for his benefit, and that it was not within the fourth section of the statute.

Again, in Sainsbury r. Mattheu's the plaintiff and defendant werc at an inn on the 29th of June, and the latter said he had 100 bags of potatoes to sell at $2 s$. a sack. The plaintiff said he would take them, and it was agreed that he was to have them at that price at digging-up time, and find diggers. When the potatoes were ripe, the plaintiff sent diggers to take them np, but the defendant refused permission. There was some conflicting evidence as to whether the agreement had been previonsly rescinded; but the plaintiff had a verdict for $£ 510$ s., and the Court of Exchequer refused a nonsuit. Parke B. said : "This is a contract for the sale of goods and chattels at a future day, the produce of certain land, and to be taken away at a certain time. It gives no right to the 
land: if a tempest had destroyed the crop in the meantime, and there had been none to deliver, the loss would have clearly fallen upon the defendant. The case is stronger than that of Ei'ans v. Roberts, because here there is only a stipulation to pay so much per sack for the potatoes when delivered: it is only a contract for goods to be sold and delivered." And per Lord Abinger C.B.: "This was not a contract giving an interest in the land: it is only a contract to sell potatoes at so much a sack on a future day, to be taken up at the expense of the rendee; he must give notice to the defendant for that purpose, and cannot come upon the land when he pleases."

In Roduell v. Phillips it was decided that an agreement for the sale of groving fruit and regetables is an agreement for the sale of an interest in land, within the meaning of the Stamp Act, 55 Geo. III. c. 184, sched. part I., title "Conceyance," and if of the valne of $£ 20$, requires a stamp. The memorandum of agreement was as follows:

Memorandum of agreement, this 14th day of July, 1840.

"Thomas Phillips agrees to sell to Mr. Rodicell all the crops of fritit and vergetables of the upper portion of the garden, from the large pear trees for the stm of $£ 30$; and Lionel Rodwell argrees to buy the same at the aforcsaid price, and has paid £1 deposit.

"Witness our hands,

"T.P.

"L.R."

Jord Abinger C.B., said: "There is a great variety of cases, in which a distinction is made between the sale of growing crops and the sale of an interest in land; and it must be admitted that taking the cases altogether, no general rule is laid down in any one of them, that is not contradicted by some other. It is sufficient, however, for us to say, that we think this case ought not to be governed by any of those in which it is decided that a sale of growing crops is a sale of goods and chattels. Growing fruit would not pass to an executor, but to the heir; it could not be taken by a tenant for life, or levied in execution under a writ of feri facias, by the sheriff ; therefore it is distinct from all those cases where the interest would pass not to the heir-at-law, but to some other person. Undoubtedly there is a case, Smith r. Surman, in which it appears that a conlract to sell timber growing was held not to convey any interest in the land; but that was where the parties contracted to sell the timber at so much per foot, and from the nature of that contract it must be taken to have been the same as if the parties had contracted for the sale of timber already felled. In this ease there seems to be no doubt that this was a sale of that species of interest in the produce of 
lands which has not been excepted by the Stamp Act, and that it is not a sale of goods and merehandise."

Smith v. Surman, which Alderson B. alluded to in the course of the argument of Wushbourne v. Burrou's, as "in fact a contract to sell timber as a chattel," was an action to recover $£ 173 s$. $6 u$. for 229 feet of ash timber at $1 s$. $6 \ell$. per foot. The plaintiff, who was the proprietor of a coppice, had given orders to fell some ash trees. When two of the trees had been already felled, the defendant eame to the eoppice, and the plaintiff pointed out to him the remainder, which were numbered from 1 to 14. The defendant said to a bystander he had made a good bargain, and told one of the entters to tell the other men to cross-cut them fair. When they were cut and mcasured, the defendant met the measurer, and on hearing that they were measured, offered to sell him the butts (which he alleged he had bought of the plaintiff), and then said, when this was not acceded to, that he would go to the plaintiff's and convert the tops into building-stuff. He afterwards said that he had bought ten trees only, and that the reason he did not take them was that they were unsound. The timber not having been taken away, the plaintiff"s attorney wrote him to say that the timber he objected to as faulty and unsound, was "very kind and superior, and a superior marketable article," and that he could have no objection to the mode of cross-entting; as it was done agreeably to his own direetion. The defendant wrote in his answer that he bought the timber from Mr. Smith "to be sound and good, which I have some donbts whether it is so or not; but he promised to make it so, and now denies it. When I saw him, he told me I should not have any withont all ; so we agreed on these terms, and I expected him to sell it to somebody else." 'The Court of Queen's Bench held that the contract was not one for the sale of an interest in land within the meaning of the 4 th section, but one for the sale of goods, within the 17 th. Litllelale J., said: "I think that the contract in this case was not a contract for the sale of lands, tenements, or hereditaments, or any interest in or eoncerning the same within the meaning of the 4 th section. Those words in that seetion relate to contracts (for the sale of the fec-simple, or some interest less than the fee), which give the vendee a right to the nse of the land for a specific period. If in this case the contract had been for the sale of the trees, with a specific liberty to the vendee to enter the land to cut them, I think it would not have given him an interest in the land, within the meaning of the statute. 'The object of a party who sells timber is not to give the vendee any interest in his land, but to pass to him an interest in the trees when they become goods and chattels. Here the vendee was to eut the trees himself. His intention elearly was not to give the 
rendor any property in the trees, until they were eut, and ceased to be part of the frechold." And per curiam there was no part acceptance or actual receipt of the goods to satisfy the 17 th section, inasmuch as there was nothing to show that the purchaser had dirested himself of his right to object to the quality of the goods, or that the seller had lost his lien for the price.

Scorrell r. B3oxall, where it was ruled in the Court of Exchequer that the sale of groving undervool to be ent by the purchaser confers an interest in land, was relied on for the defendant in Smilh r. Surman, but was not eommented upon in any of the judgments, which were principally directed to show that the contract was one for the sale of goods, wares, and merchandize, within the 17th section of the statute. Hullock B., in Scorrell r. Boxall, refused to recognize as law the opinion of Treby C.J. and Poucell J. (1 Ld. Raym. 182), that the sale of timber growing upon land may be by parol, because it is lut a bare chattel, and rested his decision on the principle that trees annexed to the frechold are parcel of the inheritance, and pass with it, while corn and other industrial crops go to the executor, and may be seized under a $f i . f a$., which was the distinction on which Litlledale J.'s judgment was based in Erans v. Roberls. His Lordship also relied on Teal r. Auty, where the Court of Common Pleas intimated that the sale of grouing protes or young trees which the defendants had purchased and afterwards ent and carried away, does confer an interest in land. There, however, it was not necessary to incuire whether the original agreement was in writing, as the poles were taken away and the agreement executed, and the plaintiff was nonsuited in consequence of the alisence of proof as to what was strictly due.

C'rosby r. Woulsuorth is among the first of the eases which were decided, under the statute, on the question of grass crops. The plaintiff agreed by parol with the defendant, on June 6, 1804, for the purchase of a standing crop of mowing grass, then growing in a close of the defentant's at Claypole, for $20 \mathrm{gss}$. It was to be mown and made into hay by the plaintiff, but the partics did not absolutely fix upon any time at or which the mowing was to be begun. No carnest was given, and no note or memorandum signed. The defendant, who kept possession of the close, told the plaintiff on the 2 nd of July that he shonld not have the grass, and sold it to another person on the same day for 25.gs. Later in the month, the plaintiff tendered to the defendant $20 \mathrm{gs}$, which the latter refuscd, and then, finding the gate unlocked, entered and cut part of the grass. He was discharged, and the whole of the crop) was taken away by the new purchaser. It was held by the Court of King's Bench that the plaintiff had, under the circumstances, 
such a possession of the close thongh, for a limited purpose, that he might maintain trespass qu. cl. fieg. against any person entering the close, and taking the grass eren with the assent of the owner ; but that this being a contract for the sale of an interest in and conceruing land, it was voidable by the 4 th section of the statnte if not reduced to writing; and might be discharged by parol notice from the owner before any part execution of it. Bayley J. observed npon this case, in Ecans v. Roberts, "The contract was clearly for the sale of an interest in land. There the grass was growing, and the rendee was to mow it, and convert it into hay. He had the whole of the vesture of the land, and had the exchusive possession of the soil from the date of the contract, mutil the period when the grass should be cut and made into hay. Grass growing in a natural state stands on a very different footing from produce which is obtained from the land by artificial means, or by the application of a particular course of husbandry. Grass is the natural growth and produce of the land itself, permanently remaining, not exhausted when once ent, lut constantly growing and renewing. It cannot be seized in execution under a fieri facius, as goods and chattels, and on the death of the omner of the land it goes to the heir, and not to his excentor ol personal representative."

Poulter v. Killingbeck, which was allnded to at the close of the plaintiff's argument in the above case, had no material application in favour of the plaintiff. 'There the plaintiff wished to cultivate some pieces of fen land, and agreed verbally to let them to the defendant without rent, the latter to plough, dress, and sow them for two successive crops, and in lien of rent to allow the plaintiff a moiety of the crops. While the crops of the second year were in the gromnd an appraisement of them was taken fur both parties, and the valne ascertained; and as the $d \in f e n d a n t$ refuced to pay a moiety of the valne, this action was brought. It was held by the Conrt of Common Pleas that the plaintiff might well declare in indetitatus assumpsit for a moiety of the value of the crop sold, withont stating the special agreement, as that was execnted by the appraisement, and the action rose ont of something collateral to it. Buller J. said, "If no appraisement had taken place, the objection to the action in this form might have prevailed. But that circumstance is decisive. With respect to the point made at the trial, on the Statute of Frands, that agreement docs not relate to any interest in land, which remains altogether unaltered by the arrangement concerning the crops." Isord Ellenborough remarked on this point, in Crosby v. Wadsworth, "The contract in Ponller r. Killingbecle, if it had originally concerued an interest in land, after the agreed substitution of pecuniary value for specific prodnce no longer did so ; it was originally 
an agreement to render what should have become a chattel, i. e., part of a serered crop, in that shape, in lien of rent; and hy a subsecuent ayrecment it was changed to money instead of remaining a specific render of produce. So that one wonder's rather how it should ever have been thought an interest in land, than that it should have been decided not to be so."

In Carmington r. Roots the plaintiff had rerbally agreed with the defendant, in May, to buy of him a crop of grass, growing in a four-acre field, at $\$ 510$. per acre, to be cleared by the end of September, and half the price to be paid down before the plaintiff ent any of the grass. 'This condition not haring been complied with, the defendant turned the plaintifl"s loorse and cart ont of the field, and prevented him from cutting or carrying away the grass. It was held by the Court of Exchequer that trespass did not lie, for that this was in substance an action charging the defendant on the contract within section 4 of the Statute of Frands, and that a contract for the sale of an interest in land without a note in writing, may operate as a ticence, so as to excuse the entry of the purchaser on the land, but cannot be made available in any way as a contract.

Perke B. said, "The question is, what the plaintiff means when he avers in his replication, that while the close or crop of grass was the property of the defendant, he agreed to sell and sold to the plaintiff, and the plaintiff agreed to buy and bought of him the crop of grass at a certain price per acre, with liberty to the plaintiff to cut and take away the grass, and to enter upon the close with his horse and cart for that purpose, by rirtue of which he became possessed of the crop of grass. Does he mean an agreement in fact, operating as a licence only? or a binding contract for the sale of the erop, and for him, the plaintiff, to have a right of entry on the land to gather it? I think the latter is the true construction, and that it means a contract which one party conld enforce against the other as a matter of right. If this be so, then supposing the agrcement to be for the sale of chattels, it was not prored by the eridence: if it was an agreement for the sale of an interest in land, it was not binding, by virtue of the 4 th section of the Statute of Frauds. I think the right interpretation of that section is, that an agrecment which cammot be enforeed on either side, is as a contract roid nltogether : no doubt it may hare, as an agreement in fact, some operation in communicating a licence, but such licence would be countermandable; and that appears to be the whole effect of the decision in Ciosbly v. Wradsurorth. 'There, no doubt, the plaintiff might have pleaded at licence; lut the defendant would have replied that it was countermanded, and the plaintiff could not have succeeded on that issue. I 
think, therefore, this is an averment of a binding contract for the sale of the crop, with a right to enter on the land in order to take the crop). That contract being void by the statnte, the action cannot be maintained, and the rule ought to be absolute for a nonsuit."

In Jones v. Ftint the plaintiff" and defendant agreed verbally that the defendant should give $£ 45$ for the crop of grouing corn (wheat and barley) on the plaintiff's land, and the profit of the stubble afteruards; and that plaintiff was to have liberty for his cattle to s'm with the defendant's. Defendant was also to have some potatoes growing on the land, and whatever tay grecss was in the fields, and also to harrest the corn and dig up the potatoes, the plaintiff paying the tithe. It did not distinctly appear whether the sale was by the acre or not; and the crops, \&e., were taken by the defendant in conformity with the agreement. The payment of $£ 5$ and the tender of $£ 3011 s$. 10d. were proved as pleaded; and Bosanquet J., overruling the objection for the defendant that the contract proved was for an interest in land, directed a verdict for the plaintiff on the first issue, never indebted as to all but $£ 3511 \mathrm{~s}$. 10\%., and for the defendant on the second and third. The Conrt of Queen's Bench refused a nonsuit, and held that it did not appear to be the intention of the parties to contract for any interest in land, and the case was therefore not within the 4th sec. of the Statute of Frands, but a sale of goods and chattels as to all but the lay grass; and as to that, a contract for the agistment of defendant's cattle.

Lord Denman C. J. said, "The crops of corn, potatocs, and the after" eatage of stubble and lay grass, were all, except the lay grass, fructus inclustriales; as such they are seizable by the sheriff under a fieri fucicts, and go to the execntor and not to the heir. If they had been ripe at the date of the contract, it may be considered now as quite settled that the contract would have been held to be a contract merely for the sale of goods and chattels. And although they had still to derive nutriment from the land, yet a contract for the sale of them has been determined from this their original character, not to be on that account a contract for the sale of an interest in land. Evans v. Roberts proceeds on this principle. Holroyd J. says, "This is to be considered a contract for the sale of goods and chattels to be delivered at a future period, althongh the vendee might have an incidental right, by virtue of this contract, to some benefit from the land while the potatoes were arriving at maturity, jet I think he luad not an interest in the land within the meaning of this statute.' And Littledcle J. says, 'I think that a sale of any growing produce of the earth (reared by labour and expense) in actual existence at the time of the contract, whether it be in a state of maturity or not, is not to be considered a sale of an interest in or concerning lands within 
the meaning of the 4 th section.' Bayley J. lays down the same principle, and qualifies not the judgment but the dictum of Mansficld C. J. in Emmerson v. Hcelis, which is certainly at rariance with the decision of the Court of King's Bench in Evens r. Roberts. It was a dictum, howerer, unnecessary to the decision. The present case differs from Evans v. Roberts in this, that there the potatoes were to be dug up by the seller; but Hotroyal J. expressly says that eren if they were dug up by the buyer, 'I think he would not have had an interest in the land." "

On the whole the Court considered that the passession of the field remained in the omner after the harvesting, and that it was more reasonable to consider him as agisting the vendce's cattle, than as having his own cattle agisted by him whose interest at the best was of so very limited a natnre; but that if this had been a case in which the parties intended a sale and purchase of the grass to be mowed or fed by the buyer, the defendant's objection must prevail. Without, however, impeaching the authority of Crosty v. Wadsurorth, but deciding on the additional facts in the ease, they thought the introduction of the lay griss into the contract (especially as it might be doubted on all the eridence, which did not state that any clorer or other grass had been sown with the corn, whether anything that could be called a crop of grass was in the ground) did not alter its nature, and that the defendant took no interest in land. Excluding the lay grass, the parties must be taken to have been lealing about goods and chattels, and an easement of the right to enter the land for the purpose of harresting and carrying them away was all that was intended to be granted to the purchaser; and as to the lay grass, it was a mere contract for the agistment of defendant's cattle.

The general prineiple was thus stated by Rolfe B., in Wushtboume r. Burrous: "When," said his Lordship, "a sale of growing crops does, and when it does not confer: an interest in land, is often a question of much nicety; but certainly when the owner of the soil sells what is growing on the land, whether natural produce, as timber, grass, or apples, or fructus imfustriules, as corn, pulse, or the like, on the terins that he is to cut or serer them from the land, and then deliver them to the purchascr, the purchascr acquires no interest in the soil, which in such case is only in the nature of a warehouse for what is to come to him mercly as a personal chattel."

In Mayfictel v. Wadsley, the Court of King's Bench, Litlledule J., thub, was of opinion that where there was a sale of groucing crops distinet from any assignment or lelling of the land, the crops do not constitute part of the inheritance or any interest in land, but are mere chattels, and may be recorered on a declaration for goods bargained 
and sold; or, per Abbot C.J., at least on a declaration stating that the defendant was indebted for the valne of erops sown by the plaintiff on land in his possession, and which the defendant (who had made a part payment on account for such crops, some dead stock, and a farm machine) was allowed to take, and for which he promised to pay.

The case of the Earl of Falmouth v. Thomas, where the pleadings expressly connected the bargain as to the crops and tillages with an interest in land, established that a contract by plaintiff with an incoming tenant to take and pay for growing crops, and the work, labour, and materials expended on making lands ready for tillage, and for which the plaintiff had not as yet derived any benefit, in consideration of plaintiff's letting him a farm for fourteen years, is a contract or sale of an interest in or concerning land, and therefore void if not reduced into writing. At the time when each of those contracts upon which the plaintiff sned were stated to be made, the crops were growing upon the land, the defendant was to have the land as well as the crops, and the work, labour, and materials wore so incorporated with the land as to be inseparable from it. The defendant would not have the benefit of the work, labour, and materials unless he had the land, and hence the Conrt of Exchequer considered that the right to the crops, and the benefit of the work, labour, and materials were both of them an interest in land.

An agreement by a tenant with his landlady, that if she wonld aceent another for her tenant in his place (he being restrained from assigning the lease without her consent) he would pay her $£ 40$ out of $£ 100$ which he was to receive for the good-uill if her consent was obtained, is a contract for an interest in land (Griffith v. Foung). As, however, the defendant had receired the $£ 100$ from the new tenant, who was cognizant of this agrecment, and then refused to pay the $£ 40$ on the ground that "there was no written agreement, and words were but wind," he was held liable to his landlady in an action for money had and received to her use. Lord Ellenborough C.J. said: "I have no doubt it would have been within the statute if the contract were executory ; but when the contract is executed, and money has actually bcen paid by the succeeding tenant to the defendant in trust, to be paid over by him to the plaintifi, shall he now gainsay that he received it for her use? If one agree to receive money for the use of another, upon a consideration executed, however frivolous or void the consideration might have been in respect of the person paying the money, if indeed it were not absolutely immoral or illegal, the person so receiring it cannot be permitted to gainsay his having received it for the nse of that other." Le Blanc J. said : "The consideration is past : Pugh 
is in possession, and has paid this money to the defendant for the rery purpose of his paying it over to the plaintiff: it is clearly, therefore, money received for her use. It would have been a different question if Pugh had not paid the money to the defendant, and the action had been brought against him."

So in Buttemere r. Hayes, the plaintiff being possessed of a messuage and premises for the residue of a certain term of years, made a parol contract with the defendant to relinquish possession to him, and to suffer him to become tenant of the premises for the residue of the term, in considcration of lis paying $£ 10$ towards completing certain repairs of the premises, on the latter being estimated by a surveyor. The defendant lecame tenant, and entered into possession, but refused to pay for such repairs after the surveyor had sent in his report. 'This was held to be an agrecment relating to the sale of an interest in land within 29 Car. I I. c. 3, s. 4, and void for want of being in writing, and the defendant was allowed to avail himself meder non assumprit, of the objection that there was no memorandum or note in writing, \&e., of such contract. Purke B. said: "Perhaps if the declaration had stated an agreement to relinquish the possession merely, it might not have amounted to a contract for an interest in land; but it goes on to allege that the plaintiff was to suffer the defendant to become tenant thereof for the residue of the term. Now, he could not become tenant for the residue of the term except by an assigmment, and that would be a contract for an interest in land within the statute, and ought to be redueed into writing."

This case gorerned the decision of the Court of Common Pleas in Cocking $\mathrm{r}$. Warl, where the contract pointed to a surrender or retingnistement by the plaintiff of an interest in land in favour of the defendant. The facts were as follows: The plaintiff' was about to relinquish a farm, which her deceased husband had oceupied for several years; and the defendant, who occupied an adjoining one, promised to give her $£ 100$ if she would give up possession at Lady-day, and induce her landlord to acept him as a tenant in lieu of her. This arrangement was effected; but after entry the defendant refused to pay the $£ 100$, admitting his liability, and asking for time till he got the valuation of his own farm, which he duly obtained before the trial. It was contended for the defendant that the agreement, if any existed, being for the sale of an interest in land, conld not be proved by parol testimony : while it was insisterl for the plaintiff that the eontract being executed might be proved by parol, and that there was at all events sufficient eridence of an account stated. A rerdict was taken for the plaintiff, damages $\& 100$, leave being reserved to the defendant 
to move to enter a nonsuit, or a verdict for him, if the Court shonld be of opinion that there was not sufficient evidence to sustain the verdict upon the special connt or the accomnt stated. The Court entered the rerdict for the defendant on the first count, but ordered it to stand for the plaintifl" on the second.

Tindal C.J. said: "It was not contended that a contract under" which the plaintiff, in consideration of a sum of money, gave up the tenancy in the land, and procured the defendant to be put in her place, was not a 'sale of an interest in the land' within the meaning of the Statute of Frauds; but the argument before us was, that althongh if this contract had been executory, it must hare been proved by an agreement or memorandum in writing : yet, as it was executed, as the plaintiff had surrendered her tenancy and had procured the defendant to be made tenant instead of herself, the case was not to be held within the statute: and the case of Price v. Leyburn, before Datlas. C.J., was relied on as an anthority to that effect. But as the speeial count in this action is framed npon the very contract itself, to enforce the payment by the defendant of the sum stipulated to be paid as the price of the interest in the land which the plaintiff gave up, and to which the defendant succeeded, we think the contract itself cannot be considered as altogether executed, so long as the defendant's part still remains to be performed. The case appears to us to fall within the principle adverted to by Le Blanc J. in Griffith v. Young; and further, we think the ease of Buttemere v. Hayes is an authority in point, that the present contract, thongh executed on the part of the plaintiff, yet not being executed on the part of the defendant also, is still to be considered as a contract within the Statute of Frauds. The plaintiff, therefore, failing upon the special contract, the remaining question is whether she is in a condition to recover the $£ 100$ under the count upon an account stated. There was distinct evidence in this case that after the plaintiff had given up the possession, and after the defendant had succeded to it through the plaintiff's application to the landlord, the defendant almitted that he owed the $£ 100$ to the plaintiff, and this appears to us to be sufficient evidence to enable the plaintiff to recover on the account stated."

"The objection was that the admission of a debt will only enable a plaintiff to recover as upon an account stated, where the debt itself does not appear to be incapable of being recovered as a debt; and that here the plaintiff conld not recover upon the original contract, inasmuch as it was not evidenced by a writing signed, but in the first place such an exception is contrary to the authority of several decided cases. In Knowles v. Michel the ground of the original debt was a sale to the 
defendant of standing trees, which the defendant afterwards procured to be felled and taken away; and the objection was that the plaintiff conld not recover on the original contract for standing trees, which formed part of the realty; but it was held, nevertheless, that the acknowledgment of the price to be paid for the trees, after they were felled and applied to the nse of the defendant, was sufficient to sustain the connt on the account stated : Lord Etlenborough C.J., saying, that if there were an acknowledgment by the defendant of a debt due to the plaintifi mpon any account, it was sufficient to onable him to recorer on an accomnt stated. And in Highmore v. Primrose the Court of Qneen's Bench held that the proof of the acknowledgment of one item of debt only, was good to support a count upon an accomnt stated; and the former case was there mentioned with approbation, and relied on. In Pinchon $\mathrm{T}$. Chilcolt there was a verbal contract for turnips growing in a field, mpon which it was held the plaintiff could not recorer; yet as the defendint admitted, after some of the turnips were draw, that he owed the plaintiff $£ s$ for them, it was held by Best C.J. at Nisi Prius that he could recover to that amount upon an account stated, and no motion was made to the Court to question the mling. And in Seago v. Deane, a promise to pay a specified sum where the party had the benefit of the contract, though he conld not have been sued upon it, on account of its being a verbal contract only, was held to be good evidence on the account stated. See also Peacock v. Harris. Upon the anthority, therefore, of decided eases, as well as on principle, we think the plaintifr's right to the rerdict on the acconnt stated may be sustained." As to the sufficiency of a consideration arising out of a moral olsligation, see Lee v. Huggeridge, Seago v. Deane, Littlefield v. Shee, and Easturool v. Kemyon.

'The decision of the ease of Cocking $\mathrm{v}$. Ward was also upheld by the Court of Common Pleas in the case of Kelly app., Webb resp., which was an appeal from a decision of the Teeds county court.

It was also held by Lord Ellenborough C.J., in Inman v. Stamp, that an agreement to ocenpy lodgings at a yearly rent, payable in quarterly portions (the occupation to commence on a future day), is an agreement relating to an interest in land.

Sincrit v. Harding was another case of the same class. 'The defendant agreed to purchase a milk-walk in Islington for $\& 80$, inclueding possession of the premises (of which he was tenant from year to year), and plant, cans, and pails. When the contract was entered into the plaintiff' represcuted the custom at between twelre and fourteen barn gallons a day, and the customers as all full-priced ones except two or three. The defendant was not to have had possession for three weeks, but took 
possession at once in conseqnence of the death of plaintiff's wife, paying $£ 515 s, 3 d$. down, and promising to pay the balance when the agreement was ready for exeention. Finding that the plaintiff had misrepresented both the quality of the customers and the quantity of the milk sold, the defendant refused to pay the balanec of the purchase money, £28 14s.9d. Cresswell J. left the ease to the jury on the conflict of evidence, reserving leave to the defendant to move to enter a verdict for him, or a nonsnit, if the Court of Common Pleas shonld think the objection that the contract was void by 29 Car. II., c. 3, s. 4 , for want of a writing, and the plaintiff had a verdict for the balance. The Court, Cressucell J. assentiente, directed a nonsnit, and held that the ycarly tenancy of the premises where he carried on his business, which the plaintiff agreed to assign to the defendant, was elearly an interest in lands within the statute, and eited the anthority of Cocking v. Warl. There the plaintiff annonnced to the defendant that she had not an interest which she conld legally part with to him; but here the plaintiff" expressly agreed to "yield up the possession and occnpation of the premises to the defendant, and to permit him thenceforth to ocenpy the same." If the landlord consented, Harding was to become his tenant; if not, he was to be tenant to Smart for the extent of his interest in the premises. And per Manle. J. : "The only difference between the two cases is, that there was in Cocking v. Ward a stipulation in the agreement that the plaintiff wonld endearour to indnce the landlord to accept the defendant as tenant in lien of himself. The case is a stronger one than Cocking v. Warl, inasmuch as here the plaintiff contracts absolntely to assign, whereas there the contract was to assign subject to the consent of the landlord."

Again in Green v. Saddinglon a parol agreement was made that defendant should. give up possession of premises in Manchester to the plaintiff, who was to pay him $£ 37$, and that the latter was to repay him $£ 10$ in case the town-council of Manchester should at a future time refuse a licence to the plaintiff to use the premises as a slaughter-house. The possession was given up by the defendant, and the plaintiff paid $£ 37$, but the licence was refnsed. The plaintiff was nonsuited by the recorder in the Court of Record in an action to recover the $£ 10$; but it was held by Wightman and Erle JJ. (Crompton J. dubitante) that the contract as far as the land was concerned having been execnted, the contract sned npon was not a contract for an interest in or concerning land within section 4 of $29 \mathrm{Car}$. II., c. 3 , and the rule was made absoInte for a new trial. Erle J. said, "The defendant objects that the whole contract was for a contract or sale of an interest concerning land, and the objection would prevail if the action was for the land or the 
purchase-moner, according to Cocking $\mathrm{r}$. Wart. But the interest in land in this ease has passed, and the purchase-money has been paid. As far as the land is concerned the contract is completely executed, and eannot now be rescinded. In the present action the whole consideration for the promise now sued on was money, riz., £37. The whole of the promise now sued on is for money, viz., $£ 10$. It therefore appears to us not to be within the Statute of Frauds; but, on the contrary, to be within the class of cases where, after the contract directly concerning an interest in land has been executed, the action has been held to be upon a separate promise to be performed after such execution. In Griffith r. Toung, a tenant agreed to pay the landlady $£ 40$ out of $£ 100$ to be received by him from an incoming tenant; this he was to pay to her for consenting to the assignment by him of his term; the assignment was made, and consented to by the plaintiff, and the $£ 100$ was received by the defendant; and in an action by the landlady for $\mathfrak{E} 40$, it was held that the action lay without any writing, the contract concerning the interest in laud having been executed. The same reasoning was applied in Poutter v. Killingbeck, and Secman v. Price. Also the reasoning of Tindal C.J. in Souch r. Strawbridye, that the enactment in section 4 of the Statute of Frands, relating to contracts not to be performed within a year, has no application in an action of indebitatus assumpsit on an executed consideration, applies equally to the present action of indebitatus assumpsit for money had and received, when the defendant seeks to avail himself of the part of the same section relating to land." Crompton J., on the contrary, thought that there was only one indirisible contract.

It was also held in Tyler v. Bennett, that a right to take water from a well by reason of the occupation of a dwelling-house, and for the more convenient occupation thereof, is an interest in land. · Lord Denman C.J. olsserved, "There is no doubt that a right to take water is an interest in land." And per Patteson J.: "In Edmonson r. Edmonson it was not doubted that if the right (to dig turves) had come in question it wonld have been an interest in land, and within the exception."

In Wechelen $v$. Wallace the declaration stated, as the consideration for the defendant's promise, that the plaintiff was to become tenant to the defendant, of the louse and furniture together, at a certain rent, from a given day, if complete furniture were sent into the house in reasonable time, and it was held by the Court of Queen's Bench that the defendant's agreement to send in furniture was an inseparable part of a contract for an interest in land, and that the promise to do so, for neglect of which the defendant was sued, must be in writing. But it was ruled in Hrllen v. Runder that an agreement by an outgoing tenant 
to leave his fixtures (which he had purchased on entering, and might have removed during his tenancy) for the landlord at a valuation, is not the sale of an interest in land within the 4 th sec. of the Statute of Frands, nor ut semble the 17th, which relates to the "sale of goods" above the value of $£ 10$, and the tenant recovered $£ 4010 s$, in indetitatus assumpsit for the price and ralue of fixtures, \&c., bargained and sold, and for fixtures sold and delivered. That case was, in fact, a mere waiver of the tenant's right to remore the fixtures in consideration of the landlord's agreeing to pay for them, according to a valuation to be made afterwards. The plaintiff dil not give the defendant a right to the fixtures before the expiration of the term, but he agreed to waive his right to sever them during the term, and to sell them to her at the end of the term. Parke B. said, "The case bears a strong amalogy to that of a contract by a tenant to give up to his landlord or successor those growing crops to which he is entitled by the common law or custom of the conntry as emblements, and the value of which, after the contract is executed, may certainly be recovered on a count of crops bargained and sold. (See Mayfield v. Wadsley.) We are quite satisfied that this is not a salc of any interest in land, and the judgment of the Court, and particularly of $\mathrm{Mr}$. Justice Littledale in Evans r. Roberts, upon the subject of groming crops, is an authority to the same effect."

Payment of legacies ont of sale of growing crops. - Growing crops are an interest in land within the statute of mortmain (13 \& 14 Vict., c. 94). And per Stuart V.C.: "If growing crops pass under a devise of land, how is it possible to say that the legacies which the testator has given to these charities would be paid out of monies arising from the sale of pure personalty, if they were paid out of the sale of growing crops?" (Symons v. Marine Society.)

Easement of "grass for a cow" creates no interest in land.-A gift by will, dated in 1838 , to J. M. "of the house she lives in, and grass for a cow in G field," part of another estate, passes an estate in fce in the house, but does not create a permanent interest in the land of the other estate. And per Sir J. Romilly M.R.: "The grass for a cow was not necessary for the enjoyment of the house; it passed no interest in the land, but merely gare a personal right to Jane Malcolmson by way of easement to pasture a cow on a field given absolutely to another, as long as she thought fit" (Reay v. Raulinson).

Indivisible contract for interest in land.-In Hodgson v. Johnson (Jurist, $\Lambda$ pril 2, 1859), plaintiff and defendant agreed by word of mouth that plaintiff should become tenant in his stead, of a brick yard, and take the plant upon a valuation, and that defendant should settle with 
the landlord for the rent due, and for plaintiff becoming tenant upon the same terms as defendant. Plaintiff having entered into occupation, and worked the ground, a distress was put in for rent due from defendant to the laudlord; and in an action to recover damages for breach of defendant's promise to pay the rent, it was held by the Conrt of Queen's Bench that the promise in respeet of which the plaintiff smed was part of an indivisible contract for an interest in land within sec. 4 of stat. 29 Car. II. c. 3 , and that therefore plaintiff could not recover. And per Campbell C.J.: "the principle of the decision in Green v. Saldington [see Law of the Farm, 1. 65] is, that there were in that case two separable contracts-not that there was one contract which might be split in two, and that a new consideration was constituted on the part performance of the contract." And per Crompton J.: "I entertain a strong opinion upon Green v. Saddington, where it was thought by the majority of the Court that the contract being exeented as far as regarded the land, and the promise sued on relating wholly to money, the plaintiff might recover. That decision can only be defended on the ground that there were two contracts. In this case it is clear that there is only one, and one part of it eannot be severed from the other."

Contract by parol to live at a boarding-house. - In Wright v. Stavert, where the defendant agreed by parol with plaintiff, who kept a boardinghouse, to pay for the board and lodying of himself and servant, and accommodation for a horse, $£ 200$ a year from a given day, terminable by either party at a quarter's notice-this was held not to be a contract in or concerning land within the Statute of Frauds, and plaintiff could maintain an action for the breach of it. And per Blackburn J.: "In Inman v. Stamp, (1 Stark, N. P. 12), and Edge v. Strafforl, (1 C. \& J., 391), there would have been an actual demise, had the contract been executed giving such a right. In the present case, there was no contract that defendant should become tenant or occupier of any specific room, and therefore there was no intention to pass any interest in that room."

Right of mortgagee of tenant's fixtures to enter and sever them.-The mortyagee of tenant's fixtures has a right or interest in the land, which the tenant who has mortgaged cannot defeat by a subsequent surrender of the lease to his landlord; and if he does so surrender, the mortgagee has a right to enter and sever such fixtures, and may maintain an action against an incoming tenant who has prevented him from exercising such right, and recover the value of the fixtures as severed. And per Curiam: "This doctrine has been fully adopted and acted on in modern cases as in Pleasant v. Benson (14 East, 234), Dd. Bleadon v. 
Pyke (5 M. \& S., 146) and Pyke v. Eyre (9 B. \& C., 909). The question is thus reduced to the inquiry whether the mortgagee's right to sever the fixtures from the freehold is a "right or interest within the meaning of this rule of law, and we are of opinion that it is. Certainly it is an interest of a peculiar nature in many repects, rather partaking of the character of a chattel than of an interest in real estate; but we think it so far connected with the land that it may be considered a right or interest in it, which, if the tenant grants away, he shall not be allowed to defeat his grant by a subsequent voluntary act of surrender" (London \& Westminster Loan Co. v. Drake). The price of fixtures, as such, cannot be recovered under the common count of goods sold and delivered (Lee v. Risdon, 'Taun. 189) ; but it would be otherwise if they had been first removed (Wilde v. Waters, 16 C. B., 637; Dalton v. Whitteen, 3 C. B., 961; Pitt v. Shew, 4 B. \& Ald., 206). 


\section{CHAPTER III.}

\section{EASEMENTS.}

"Terms de la Ley" defines an easement to be a privilege that one neighbour hath of another by charter or preseription, without profit, and it instances "as a way or sink throngh his land, or such like." To establish the presumption of a grant of an easement, it must appear that the enjoyment was with the acquiescence of him who was seised of an estate of inleritance; for a tenant for life or years has no porrer to grant such right, except as against himself (Bright $\mathrm{v}$. Walker), (Daniel r. North) (Barlier r. Richardson). And per Bayley J.; in Ilculins v. Shippam: "A right of way or a right of passage for water (where it does not create an interest in the land) is an incorporeal right, and stands upon the same footing with other incorporeal rights, such as right of common, rents, adrowsons, \&c. It lies not in livery but in grant, and a frechold interest in it cannot be "created or passed (eren if a chattel interest may, which $I$ think it cannot) ollherwise then by cleed."

In this case the action was stopping up a drain, and the declaration claimed the right as a licence and authority granted to the plaintiff's landlords, their heirs and assigns, to make the drain, and hare the foul mater pass from their senllery through it across the defendant's yard. One of the counts claimed it indefinitely, without fixing any limits; others restricted it either to the time the defendant shonld continue possessed of his yard or house, or so long as it should be requisite for the convenient occupation of the plaintiff's house; some stated, as part of the consideration, that defendant's landlords should do some repairs to the defendant's premises; and others did not. It appeared in eridence that the licence to construct and continue the drain was by parol, and it was held that as the right claimed in the declaration was a freehold right, assuming that it was an easement only npon the land of another, and not an interest in land, it conld not be created without deed. Bayley J. said, after clalorately reviewing all the anthorities, "We are of opinion that although a parol licence might be an excuse for a trespass till such licence was countermanded, that a right and title to 
have passage for the watcr, for a freehold interest, recuired a deed to create it; and that as there has been no deed in this ease, the present action, which is founded on a right and title, cannot be supported." In Fentiman v. Smith, where the plaintiff claimed to have passage for water by a tunnel over defendant's land, Lord Ellenborough C.J. laid it down distinctly that "the title to have the water flowing in a tunnel over" the defendant's land conld not pass by parol licence withont deed; and the plaintiff could not be entitled to it as stated in the declaration, by reason of his possession of the mill, but he had it by the licence of the defendant, or by contract with him, and if by licence it was revocable at any time."

Webl v. Paternoster, Wood v. Lake, and Taylor v. Waters, were not cases of frechold interest, and in none of them was the objection taken that the right lay in grant, and therefore could not pass without deed. In Webu v. Paternoster there was a licence to the plaintiff from Sir William Plummer, to lay a stack of hay on his land, for a reasonable time. Afterwards Sir William leased the land, and the lessee turned in his cattle and ate the hay (mise ses avers in e'est acre, queur devoure le cocke de hay). The Court held that such licence was good, and conld not be comntermanded within a reasonable time, but that more than a reasonable time had clapsed, viz., half-a-year, and that therefore the licence was at an end. The question in Wood v. Lake was whether a parol agreement for the liberty to stack coals upon land is good for seven jears, and Lee C.J. and Denison J. thought that it was, as the agreement was only for an easement, and not for an interest in land.

These cases, as well as that of Taylor $\nabla$. Waters (in which the plaintiff, who had purchased a silver opera ticket, was held entitled to a verdict of 28 guineas, as the damage for two years' cxclusion from the opera, where they refused to recognise it), cstablished that a licence to enjoy a beneficial privilege on land may be granted without deed, and notwithstanding the Statute of Frands, without writing. The grounds of the judgment of Gibls C.J., which was here upheld by the Court of Common Pleas, were that the right under the silver ticket was not an interest in land, but a licence irrevocable to permit the plaintiff to enjoy certain privileges thereon; that it was not required by the Statute of Frauds to be in writing, and consequently might be granted without deed. The Conrt of Exchequer, however, in Wood r. Leadbitter, considered Taylor v. Waters " to the last degree unsatisfactory-an observation we have the less hesitation in making, in consequence of its unsoundness having previously been donbted by the Court of King's Bench and Mr. Justice Bayley, in the ease of Hewtins v. Shippam." And per Allerson B.: "Although the older authorities 
speak of incorporeal inheritances, yet there is no doubt but that the principle does not depend on the quality of interest granted or transferred, but on the nature of the subject matter : a right of common, for instance, which is a profit it prendre, or a right of way, which is an easement, or right in the nature of an casement, can no more be granted or conrered for life or for years withont a deed, than in fee simple." (ib.)

It would scem from Williams r. Morris, that there cannot be an irrelocable licence to enter upon land, without its amounting to an interest in land, and such licence can only be granted by deed. And so it was held by the Court of Exchequer in Wood v. Leadbilter, that a right to come and remain for a certain time on the land of another can be granted only by deed; and a parol licence to do so, though money be paid for it, is rerocable at any time without paying back the moncy.

A licence is a thing so eranescent that it cannot be transferred, and it is determined by the assignment of the subject malter, in respect of which the privilege is to be enjoyed (Coteman v. Foster). A parol licence from A. to B., to enjoy an cascment over the land of $A$., is countermandable at any time, while it remains executory (Wallis v. Harrison). And if A. conreys the land to another, the licence is determined at once, without notice to $\mathrm{B}$. of the transfer, and B. is liable in trespass if he afterwards enters upon the land (ib). And per Parke B., "We are not called upon in this ease to consider whether a licence to create or make a railroad, granted by a former owner of the soil, is countermandable after expense has been incurred by the licensee, which was the question in Winler v. Brockuell; for it is not alleged that there has been any expense incurred in consequence of the licence, and therefore it remains executory; and I take it to be clear that a parol executory licence is countermandable at any time, and if the owner of the land grants to another a licence to go over or do any act upon his close, and then conveys away that elose, there is an end to the licence; for it is an authority only with respect to the soil of the grantor, and if the close ceases to be his soil, the authority is instantly gone. Webb $\mathrm{v}$. Patmoster is very distinguishable from this case, for there the licence was executed by putting the stack of hay on the land; the plaintiff there had a sort of interest against the lieensor and his assigns, but a licence executory is a simple authority cxcusing trespassers on the close of the grantor, as long as it is his, and the licence is uncountermanded but ceases the moment the property passes to another." (ib.)

In Winter $\mathrm{v}$. Brockuell it was decided, on the authority of Webb $\mathrm{v}$. Paternoster, that a purol licence to jut a skylight over the defendant's area (which impeded the light and air from coming to the plaintiff's 
dwelling-honse through a window) cannot be recalled at pleasure, after it has been executed at the defendant's expense, at least not without tendering the expenses he had been put to. Bayley J. thus expressly distinguished this ease from Hevolins v. Shippam in his judgment in the latter: "All that the defendant there did he did upon his ou'n land. He claimed no right or easement npon the plaintiff's. The plaintiff claimed a right and easement against him, ly the privilege of light and air throngh a parlour window, and a free passage for the smells of an adjoining honse, throngh defendant's area; and the only point deeided there was, that as the plaintiff had consented to the obstruction of snch his easement, and had allowed the defendant to incur expense in making snch obstruction, he eould not retract that consent without reimbursing the defendant that expense. But that was not the case of the grant of an easement to be exereised upon the grantor's land, but a permission to the grantee to use his own land, in a way in which bnt for an easement of the plaintiff's such grantec would have had a clear right to use it."

Tindal C.J. adopted Winter v. Brockuell as the basis of his judgment in Liggins v. Inge, where the predecessors of the plaintiff, who was entitlea to a flow of water to his mill over the defendant's land, anthorized the latter by a parol licenee to cut down and lower a bank, and to erect a weir upon their own land, the effect of which was to dicert into another channel the water which was requisite for the working of the plaintiff's mill. Subsequently the plaintiff complained to the defendant of the injurions effects of the weir, and brought an action mpon their refusal to remore it and restore the bank to its ancient height; but the Conrt of Common Pleas considered that the operation and effect of the licence after it had been completely excented by the defendants, as sufficient, without holding it to convey any interest in the water, to relieve them from the burthen of restoring to its former state what has been done under the licence, although snch licence was countermanded; and that consequently they were not liable to an action as wrong doers, for persisting in such refusal.

His lordship observed, "This is not a licence to do acts which eonsist in repetition, as to walk in a park, to nse a carriage-way, to fish in the waters of another, or the like, which licence being countermanded the party is but in the same situation as he was before it was granted; but this is a licence to constrnet a work which is attended with expense to the party using the licence; so that after the same is countermanded, the party to whom it was granted may sustain a heary loss. It is a licence to do something that in its own nature seems intended to be permanent and continuing; and it was the fault of the party himself, 
if he meant to rescrie the power of reroking such licence after it was carricd into effect, that he did not exprussly reserve that right when he granted the licence, or limit it as to duration. Indeed, the person who anthorizes the weir to be erected, becomes in some sense a party to the actual erection of it, and camnot afterwards complain of the resnlt of an act which he himself contributed to effect. Upon principle, therefore, we think the licence in the present ease, after it was executed, was not countermandable by the person who gare it, and consequently that the present action cannot be maintained. And upon authority this case appears to be already decided loy that of minter r. Brockuctl, which rests on the judgment in Webb v. Puternoster. We have no reason to donbt the anthority of that ease, confirmed as it has been by the case of Taylor $\mathrm{v}$. Wuters in this Court, and recognized as law in the judgment of Mr. Justice Bayley in the case of Ilextins r. Shippam."

In Cocker r. Couper the plaintiff, a brewer, claimed to be entitled to the benefit of certain water arising from a spring in defendant's close, and flowing through a drain that he had cut, with the rerbal consent of the then tenant and the defendant. It was ruled that he could not recorer, and that a verbal ficence weas not sufficient to confor an easement of having a drain in the land of another, to convey water, and that such licence may be revoked though it has been acted upon. The Court of Exchequer considered "that with regard to the question of licence, the case of Hewlins r. Shippam is decisire, to show that an easement like this cannot be conferred unless by deed, nor has the plaintiff acquired any other title to the water. In order to confer a title by possession, it ought to appear that he has enjoyed it for twenty years, whereas here he had only done so for eightecn. The mere entry into the close of another, and cutting a drain there, and conveying water from a spring rising there, cammot confer a title." Where the owner of *two or more adjoining houses sells one of them, the purchaser of such house is, rillout amy express reservation or grant, entitled to the benefit of all drains from his house, and is, on the other hand, subject to all the drains neccssary for the enjoyment of the adjoining house. Such necessity is to be considered with reference to the time of the conveyance as matters then stood, without alteration, and without reference to whether any other ontlet could be made for the drainage. And per curiam, "It was the defendant's orm fault that he did not ascertain what easements the owner of the adjoining house possessed at the time of the purchase." (Pyrr v. C'artrr.)

A clause in a lease of land from the plaintiff to the defendant reserved to the plaintiff, in Lee v. Stevenson, power to enter upon the demisced land, and to dig and make a covered sewer or watercource 
through it, in order to convey the waste water from the premises of the plaintiff to the river Witham. In pursuance of this power, the plaintiff did make a covered sewer across the demised land, after which the defendant made a drain from his own premises into the plaintiff's sewer, and throngh an opening which he made in it, sent in water, \&c. from his own premises; and it was held by the Court of Queen's Bench that the plaintiff was entitled to recover, as by a grant he had a right to the exclusive use of the sewer which he had made under the power reserved to him. And per Curiam, "A man cannot derogate from his own grant. If the grantec had made a serrer of iron, he would have done no more than he had a right to do under the grant. It is really and substantially the grant of a tube, and from the very nature of the grant, it would appear to be exelnsive. Chetham v. Williamson, and Doe r. Wood are distinguishable. As soon as the minerals were detached they belonged to the person who had the new right, and as the plaintiff had a mere licence to get minerals, he had no right to say that that which had been taken was his; but semble, he would have had a right of action at the moment the minerals were taken away." (ib.)

The discussion of Sharp v. Waterhouse and Calvert, in the Conrt of Qnecu's Bench, was brought to a question upon the construction of the deed, and whether the covenant ran with the land. The decd between Sharp and the defendants recited that the former was seised of three closes, and that the defondants were the proprietors of a mill and dyehonse, from which was prodnced dye-watel and solie, and that defendants had agreed with Sharp for leave to make a reserroir in $L$ close for the reception of such dye-water and soke, in order to filter the same, and also a songh or drain for earrying it away from the reservoir ; and in consideration of the premises, and in consideration of being snpplied by defendants with pure water, and of reeeiving for his own use the sediment which might be found in the reservoir and sough, and of the privilege of using snch dye-water and soke for manuring his lands, Sharp gave licence to defendants to nse the said reservoir and songh, and agreed that he would cleanse the said reservoir, when necessary. There was a covenant by defendants with Sharp, his heirs and assigns, that they would at all times thereafter, at their own expense, supply from their said reservoir, or from some other source, pure water for the cattle of the owners and occupiers for the time being of the three closes, and that it shonld be lawful for Sharp to cleanse the reservoir, and also the sough or drain, and to take the sediment away therefrom for his and their own use and benefit. In an aetiou of eorenant by the devisees of Sharp against defendants for diverting dye-water and soke produced at the mill, it was held, Coleridge J. diss., 
that the deed contained only a lieenee to Sharp to take or use the water and soke, and that a covenant by defendants to send down the dyewater and soke from their mill to the land of Sharp conld not be implied.

In shmy v. Pigott the defendant pleaded that the land over which the water ran to a pool in the plaintiff's close, and the close itself, were both part and pareel of the manor of Markham, and that IIenry VIII. being scised of the said manor in his demesne as of fee, granted the lind orer which the water ran to one under whom the defendant claimed, and the question was whether unity of ownership in the king had extinguished the ensement. The whole Court agreed that the waterconrse was not extinguished; but Doddridye J. said "that a way, if it were a way of convenience, is extinguished, but not a way of necessity." Camham r. Fisk, which was one of case for diverting a watereourse, also tumed on a unity of ownership. Up to 1811 the plaintiff"s garden and an adjoining close, in which a stream took its rise and flowed through the garden, were the property of Mrs. Holford, and in one possession. About that time the plaintiff purchased the garden and continned to use the water till the obstruction complained of. The defendant subsequently purchased the head of water and diverted it. Garrow B. thought that the unity of ounesship destroyed the mescriptive right, and nonsuited the plaintiff, and the Court of Exchequer made a rule for a new trial absolute.

Betyley B. remarked in the course of the argument, "A unity of posscssion merely suspends : a unity of ownership would destroy a title by preseription, but here the plaintiff had enjoyed the water since 1811." II is lordship also secmed to intimate that if the owner of two eloses sell one with a rm of water upon it, the vendor or any other person claiming under him could not obstruct or dirert that water; and in reference to the remarks of the counsel that there were but three ways of acquiring a right to the water, viz., by prescription, which is disposed of by the unity of ownership, actual grant, which was not produced, or a lost grant, he added there was a fourth, by appropriation, and that according to Beculry $r$. Shate, if a man find water running through his land, he may appropriate it, and thus acquire a title to the water. And per Lord Lymallums/ C.P.: " $\Lambda$ s the possession of the garden had been in the plaintiff since 1811, such possession was evidence of a fee which could only pass by grant, and a grant of the land would earry the water. If the conreyance had been producerl, and had been silent as to the water, still the conveyance would have passed the water which flowed orer the land. And are we to assume that the water was excepted out of the conveyanee, merely because the conveyance was not produced?" Jiayley, B. added, "If I luild a house, and having land surrounding it, 
sell the house, I eannot afterwards stop the lights of that house. By selling the house, I sell the easement also. This land is purchased with the water running upon it, and the conveyance passes the land with the easements existing at the time."

Moore v. Ravson is an anthority that stopping up wintous is mimu facie an abandonment, and that it lies on the owner of the dominant tenement to show something from whence to infer an intention of resuming the right within reasonable time. 'This case was relied on for' the defendants in Stokoe r. Singer, where it was held by the Court of Queen's Beneh, that if the plaintiff having accuired the right to the passage of light to his windows blocks them up, and the defendant while they are blocked up purchases the servient tenement and commences building on it, so as to obstruet the windows if open, whereupon the plaintiff reopens them and brings an action for the obstruction, the plaintiff's right to recover depends upon two points : that he did not so close his lights as to lead the defendants to incur expense or loss in the reasonable belief that they had been permanently abandoned; nor so as to manifest an intention of permanently abandoning the right of using them. And per Lord Camplell C.J.: "The question is not what the party stopping up the windors intended, but what he gave others reason to believe that he was going to do. Supposing the facts to be as in Moore v. Raneson, and that in addition the plaintiffs showed by undonbted evidence that the former owner had a bon $\hat{\imath}$ ficle intention of opening a fresh window on a given day, I doubt whether this would entitle the plaintiff to maintain the action."

In an action for an injury to the reversion, by obstructing ancient lights, it was ruled by the Common Pleas, on the authority of Kidgill $\mathrm{r}$. Moore, that it is sufficient for the declaration to show an obstruetion which may cause an injury, especially if it be alleged that by means thereof the plaintiff's reversionary estate was injured; and such declaration is not bad, because the obstruction is one which is eapable of being shown to be only temporary, and not injurious to the reversion. (Metropolitan Association for Improving the Dwellings of the Poor v. Petch.)

Water as it issues from a vell or spring, is not to be considered as the produce of the soil, so as to make the right to take it in alieno solo a profit à prendre. Such right to use running water (under which description the Court of Queen's Bench considered that a spring might farily be ranked) is an easement only, and may be elaimed by custom (Race v. Warll). And per Lord Camplell C.J.: "The reason why a profit it prendre cannot be supported by a custom in an indefinite number of people, is that the subject of the profit ì prendre would in that case be 
liable to be entirely destroycd. The argument in favour of the further reason giren in Gicteucurl's case, viz., that such a custom conld not be realized, applies cqually to many linds of casements by custom. A right to take hy custom part of the soil, like sand or clay, or stones, or the produce of the soil, like grass, or turres, or trees, would clearly be bad, for they all come under the category of profit à prendre, and such a elaim which might leare nothing for the owner of the soil is wholly inconsistent with the right of property in the soil. But the spring of water is supplicd and renewed by nature; it must have flowed from a distance by an underground channel ; and when it issnes from the ground till appropriated for use, it flows onward by the law of graritation. While it remains in the field, where it issues forth, in the absence of any serritude or custom giring a right to others, the owner of the field, and he only, has a right to appropriate it, for no one else can do so without committing a trespass; but when it has left his field he has no more power orer it or interest in it than any other stranger." (ib.)

And where the inhabitants of a township had from time immemorial taken water from a well for domestic purposes, and about fifty year's before action the locus in quo was inclosed under a special inclosure act, incorporating the General Inclosure Act then in force (41 Geo. III. c. 109), but neither in the special act nor in the award of the commissioncrs was any mention made of this well, or of any access to it, it was held by the Court of Qneen's Bench, on a rmle to enter a verdict for' the plaintiff, who had bronght an action against the township for breaking his close, that the right to take water from the well was not extinguished by the inclosure; and that whether the ancient right of access to the well for that purpose was or was not extinguished (and semule it was not) the inhabitants might in other modes legally get access to the well, so that the fifty years' enjoyment de fucto since the inclosure might have a legal origin, and the rerdiet for the defendant was ordered to stand. (ib.)

According to Gateurel's case, and Grinsteal v. Marlou', any mere resement cen be cleimed by custom. The inlabitants of a district may, by custom, have a right to go mpon the soil of another to take or to use water. In Wrekly v. Wildman it was decided that inhabitants may have a right to enter the soil of another to take pot water. Maming v. Wrasdule, where in the first count of the declaration the plaintiff claimed a right as occupicr of an ancient messuage within the parish of St. Ives, to wash and water his cattle in a certain pond, and also to take and use the watcr of the pond for domestic jurposes for the more conrenient use and cnjoyment of the said messuare at all times, at his free will and 
pleasure; and in the second, merely as an inhabitant householder of the parish,-Cdecided that such a privilege is not a profit at prendre, but a mere easement. It may be claimed by reason of the occupation of an ancient messuage, without any limitation as to the quantity of water taken (ib.). And per Coleridge J., the right claimed in each count was an easement. Lord Demman C.J. said, "It is not consistent with ordinary language to call the taking of water a profit a prendre. But assuming it to be so, I cannot see that the declaration here necessarily claims more than enough for the supply of water, for the culinary purposes of the house, and for cattle levant and couchant on the premises. There is therefore no objection arailable on general demurrer." It was said, arguencio in Fitch v. Rauling, that a custom to water cattle at a certain watering-place was an easement, and this was cited in Blevett v. Tregoming, and not disputed. In Pain v. Patrick there is a dictum that a custom alleged by the inhabitants of a vill, or all the parishioners of a parish, for a gateway or watercomrse, is an casement; and in Gooday v. Michell a u'ay to a common fountain is mentioned as an casement, claimable for parishioner's by custom.

There cannot be a custom to take a mofit in alieno soto. And so in Blevett v. Tregonning, 3 Ad. \& E. 554, the Qneen's Bench held an alleged custom to be bad for all the inhabitants occupying lands in a district of Cornwall to enter a close and take therefrom reasonable quantities of sand which had been drifted by the wind from the seashore. The reason was that the drifted sand had become a part of the close, so that the claim was to take a profit in alieno solo. Lord Denman C.J. obserred, "It cannot be said that the inhabitants may take the sand which has drifted at any distance of time, that would place the whole soil at the mercy of any person claiming under the custom." And per Lord Campbell C.J. in Race v. Ward: "As to customary rights claimed by reason of inhabitancy, the distinction has always been between a mere easement and a profit a prendie. A custom for all the inhabitants of a vill to dance on a particular close at all times of the year at their free will for their recreation has been held good, this being a mere easement (Abbott $\mathrm{v}$. Weekly); bnt a custom to take as a profit what is valuable would be very injurious to the owner, and of but little benefit to the inhabitants, and is bad. And so we held in Blancl v. Lipscombe, that to a declaration for keeping and cutering the plaintiff's close, and taking his fish, a custom pleaded for all the inhabitants of the parish to angle and eatch fish in the locus in quo is bad, as this was a mrofit a prendre, and might lead to the destruction of the subject matter to which the alleged custom applied."

It was held by Sir T. P. Wood, V.C. and Bayley J., in T'he Altomey 
General v. Matthics, that the woodwards or foresters of $B$ walk (the soil of which was in the Crown) within the limits of the Forest of Dean, conld nut as such have a right to grant to certain persons called "free mincrs" gales or licences for working stone within B walk, and to tuke gale rents and apply them to their own purposes, without accounting to the ('rown. Independently of statute 1 \& 2 Vict., e. 43 , which extingnished the right and capacities of free miners, no right could ever have hecu established by any custom, however ancient, uniform, ant clear, to the exereise of the custom as now claimed by the defendants, riz., a rightht in one person to enter upon the soil of another', and to carry away portions of it. Such a right cannot be established by mescription, nor by assumption of a lost granl; and a claim which is radically bad in itself cannot be substautiated by any statutes of limitation.

The right of the owner of the surface to the support of the underground strata, moder and near to his land, is one of the ordinary natural rights of property incidental to all land, and not an easement or right acquired by grant or otherwise; and the injury to this right, and not the conseruential damage, is the canse of action. Hence the Statute of Limitations runs from the time of the act which ultimately cansed the damage, although actual damage did not arise till afterwards, and so it was held by Lord Complell C.J., C'olerielge J., and Erle J., Wightman .J., dissentiente, in Bonomi v. Backhouse. And per Curiam: "The check upon mining for the protection of the surface is for the adrantage of the surface, and that adrantage is secured by the decision in Ilumpliries v. lirugent. The surface owner taking that advantage may not unreasonably be held to take it with ordinary legal incidents, and, among others, a liability to be barred by six years from the wrongful act. In case of mining operations, which are a trespass, the statute runs from the trespass, thongh the party may have been ignorant of the act done. The same rule may with equal justice apply to a surface owmer, nutwithstanding he may have been ignorant of the violation of the right to support. 'The right of support which the plaintiffs here claim is a natural right of property to be presumed till, as in Rovetham $v$. Witson, evidence is given to rebut the presumption; and that such a right is not to be considered an easement or a servitude arising from griunt. But the conseqnence does not seem to follow, that the Statute of Limitations cannot begin to run for an injury to such a right till threre has been an actual subsidence of the surface. With regard to the authorities quoted, Nicklin v. Williams is expressly in point, and the decisions relied upon to show that this is an action for consequential damage complete only unon the subsidence of the surface, may be 
distingnished from it," but this judgment was over-rnled (see Law of the Farm, pp. 100, 101). Rowbotham v. Witson was directed to show the qualified right to support by a person who acquired the title to the surface soil, subject to a covenant, under which the owner of the minerals might work them withont liability to an action for damage by the sinking of the surface. Harris v. Riyding, Humphries v. Broyden, Smart v. Morton, and The Caledonian Raituay v. Sprolt, show what are the rights of support both subjacent and adjacent existing, of common right, and upon the construction of ordinary grants and exceptions in conveyances.

The case of Roubotham v. Witson was taken to the House of Lords, who affirmed the decision of the Court of Qneen's Bench, and it was decided that the "right to work mines is an incident to the grant of mines," that though the covenants conld not operate as a release of the general right of a surfice owner to the support of the subjacent soil, it did operate as a grant of the right to work the mines, and thereby injure the surface, provided such injury was not the result of negligence or minkilfulness (8 L. C. 348 ; L. J. 30 Q. B. 49).

In 2 \& 3 IVill. IV., c. 71 (an act for shortening the time of prescription in certain cases), it is enacted by sec. 1, that claims to right of common and other profits a prendie are not to be defeated after 30 years' enjoyment, by showing ouly that they were first taken and enjoyed at any time prior to the commencement of such 30 years; and that after 60 year's' enjoyment the right is to be absolnte, unless the same was taken and cnjoyed by some consent or agreement expressly made or giren for that purpose by deed or writing.

Sec. 2 enacts, "That no claim which may be lawfully made at the common law, by custom, prescription, or grant, to any way or other easement, or to any watercourse, or the use of any water to be enjoyed or derived upon, over, or from any land or water of, \&e., whon such way or other matter as herein last before-mentioned shall have been actually enjoyed by any person claiming right thereto, without interruption, for the full period of 20 years, shall be defeated or destroyed, by showing only that such way or other matter was first enjoyed at any time prior to such period of 20 years; but nevertheless, such claim may be defeated in any other way by which the same is now liable to be defeated: and where such way or other matter as herein last beforementioned shall have been enjoyed as aforesaid for the full period of 40 years, the right thereto shall be deemed absolute and indefeasible, unless it shall appear that the same was enjoyed by some consent or agreement expressly given or made for that purpose, by deed or writing."

Sec. 8 enacts, "That when any land or water upon, orer, or from 
which any such way or other conrenient watercourse or nsed water shall have been or shall be enjored or derived, hath been or shall be held under or by virtue of any term of life or any term of years exceeding three years from the granting thereof, the time of the enjoyment of any such way or other matter, as herein last beforc-mentioned during the continuance of such term, shall be cxcluded in the computation of the said period of 40 years, in ease the claim shall within three years next after the end or sooner determination of such term, be resisted by any person entitled to any rerersion expectant on the determination thercof."

Acording" to Tiikle v. Broum, 4 Ad. \& E. 378, the rrords, "enjoyed by any person claiming right" applied to easements in sec. 2 of this statute, and "cnjorment thereof as of right", in sec. 5, means an enjoyment had not secretly or by stealth, or by tacit sufferance, or by permission asked from time to time, on each occasion or on many, but an cnjoyment had openly, notorionsly, without particular leare at the time by a person claiming to nse, without danger of being treated as a trespasser, as a matter of right, whether the right so claimed shall be strictly legal, as by prescription and adrerse user, or by deed, or shall have been merely lawful, so far as to excuse a trespass. To a plea of 40 or 20 years' enjorment of a way, a licence, if it corer the whole time, must be pleaded; but a parol or other licence giren and acted on dusing the 40 or 20 jears, may be proved nnder a general traverse of the enjorment as of right, and this whether such licence be granted for a single time of using or for a definite period (ib.). And semble that where issue is joincd on the allegation of an interruption acquiesced in, the party alleging the interuption having proved a non-nser during part of the time, may, in order to show that such non-user was not a voluntary forbearance, grire evidence that two years before the non-uscr commenced, the party claiming the ray paid a consideration for being allowed to use it (ib.).

In Becustey r. Clarke, 2 N. C. 705, the Court of Common Pleas upheld the construction put upon the 5th sec. in Tickle r. Broun, and ruled that under a plea denying that the defendant had used the way for 40 years, as of right and without interruption, the plaintiff is at liberty to show the character and description of the nser and enjoyment of the way during any part of the time, as that it was nsed by stealth, or in the alssence of the occupier of the close, and without his knowledge, or that it was mercly a precrious enjoyment by leave and licence, or any other circumstances, which negative that it is a user or enjoyment under a claim of right. Nomouthstire Canal Company $\mathrm{r}$. Harford, in the Court of Exchequer, is another anthority for the same construction 
of the act. So in Ongley v. Gardiner it was decided that the enjoyment of an eascment as of right for 20 years next before the commencement of the snit, within the stat. $2 \& 3$ JVill. IV., c. 71 , means a contimuous cnjoyment, as of right for the twenty years next before the commencement of the suit, of the easement as an easement, without interruption, acquiesced in for a ycar. It is therefore defeated by unity of possession during all or part of the 20 years, and such unity of possession nced not be replied specially under the 5 th section. Ifere the defendant in support of his plea proved that abont 40 year's ago the close now called the Click Head Coppice was a hop-yard, and that at that period hops used to be carried thence over the plaintiff's two closes to the highway, and also that once in every six or seven years hop-poles were carried across them to and from the hop-yard. This use of the premises had, however, long ceased, and the hop-yard was afterwards planted as a coppice, and it appeared that for many years, down to a period of about 15 years before the commencement of the suit, all the three closes had been occupied together : from that period to the commencement of the action the defendant prored a user of the way for all purposes. The plaintiff objected that under these eiremmstances the plea under the statute was not sustained, for that there had not been an enjoyment as of riyll, i.e., adversely to the owner and occupier of the closes, over which the way was claimed, for the full period of 20 years next before the suit.

A verdict was found for the defendants, leare being reserved by Patteson J. to the plaintiff to move to enter a verdict for nominal damages. The Conrt of Exchequer gave the defendant leave to amend by pleading the right immemorially. Parke B. said, "The enjoyment of the easement must be continuous, and the Court has already intimated its opinion to that effect, in the case of The Monmouthshire Company v. Harford. That an enjoyment must be of an easement, as such, is a matter on which we feel no difficulty; and the Court has already put this construction on the act, after some consideration in the case of Bright v. Walker, thongh the precise point was certainly not in judgment. As to the question, whether the proof of unity of possession is admissible under the traverse of the plea, no doubt can be entertained, since the decision of the case of The MIonmouthstire Company v. Harford, and its confirmation by the Court of King's Bench in Tickle v. Brown, and by the Court of Common Pleas in Beasley v. Clarke. The 'simple fact of enjoyment,' referred to in the 5th sec., is an enjoyment 'as of righl,' and proof that there was an occasional unity of possession is as much in denial of that allegation as the occasional asking permission would be." And so it was decided 
by the Conrt of Common Pleas in Battishill v. Read that the enjoyment of an easement as of right, for 20 (or 40) years next before the commencement of the suit, within stat. 2 \& 3 Will. IV., c. 71 , means a contimuous enjoyment, as of right, for 20 (or 40) years next before the commencement of the suit, of the casement as an easement, without interruption, aequiesced in for a year; and snch right is defeated by nnity of possession cluring all or part of the period of enjoyment, thongh such unity of possession has its inception after the completion of the 20 (or 40) years.

In Clayton v. Corby the Queen's Bench considered Ongley v. Gardiner decisive on the point, that mity of possession was receivable in eridence under traverse of the first plea (which pleaded the enjoyment of a right by the defendant to dig clay for 60 years in the locus in quo for the use of the kiln), because it went to show that the enjoyment was not as of right. And in a plea under this statute it is sufficient to allege that the user had existed for 40 years before the commencement of the suit, and it need not lue alleged to have been for 40 years before the act complained of in the declaration (Wright v. Williams); and a replication of a life estate to a plea of enjoyment for 40 years under it, must show that the plaintiff is the person entitled to the reversion expectant on the determination of such life estate (ib.) $\Lambda$ plea of 20 years' enjoyment of a way, under stat. 2 \& 3 Will. IV., c. 71, s. 2, must be supported by user for that period down to the commeneement of the action (Parker v. Mitchell); and proof of user commencing 40 years ago, but discontinued four or five years before the commencement of the action, is insufficient $(i b$.$) . And to support a plea framed on this$ section, of a right of way enjoyed for 40 years, evidence may be given of a user for more than 40 years (Lau'son v. Langley). When an easenent has been enjoyed for 19 years and a fraction, and is then in. terrupted by the owner of the soil, the easement may still be aequired under this statute at the end of the twentieth year; for the interruption to defeat 20 Jears' user must have been acquiesced in or submitted to for a whole year (Flight v. Thomas). And as to pleading 20 years' possession of a mixen, see another case between the same parties (10 Ad. \& El. 59).

Wurburton v. Parke was a case of replevin for taking the plaintiff"s eattle. 'To an avowry, demaye fecesent, plaintifl pleaded in bar, under the aluove statute, a user for 30 yeurs as of right, and also of 60 years as of right, of common of pasture over the locus in quo. At the trial the fact of user by the plaintiff and other oecupiers of his farm was proved; bnt it appeared that S., from whom the plaintiff and defendant derived their title, was for more than 60 years before, and until 
within 30 years, seised in fee of the plaintiff's farm, and during the same period had an estate for life in the land over which the right of common was claimed, but never had actual possession of the dominant tenement except by tenants. More than 30 years before the action he joined a remainderman, in a conveyance of the servient tenement to make a tenant to the precipe for the purpose of suffering a recovery in order to raise money on mortgage; but no recovery was suffered, and S. continued possessed until 28 years before the action, when the property was sold, and all community of title ceased. It was held by the Court of Exchequer that although there was no unity of seisin to extinguish an easement or prevent its existence, the facts precluded an enjoyment as of right within the meaning of the statute.

In MIIl (claimant) v. The Commissioner of the New Forest (objector), an allotment was made of waste land to the claimant under an inclosure act passed in 1810, in respect of which he claimed a right of common of pasture in the waste lands, and a right of common of mast in the time of pannage for all hogs and pigs ringed, levant and couchant, in the open woods of the New Forest, showing an enjoyment for the full period of 30 years as of right, and withont interruption, mentioned in 2 \& 3 Witl. IV., c. 71, s. 1 ; and it was held by the Court of Common Pleas, that the claim might be deleated by showing the commencement of the enjoyment, and that by reason of the statutes $9 \& 10$ Will. III., c. 36 , s. 10 . and 1 Anne, stat. 1, c. 7 , s. 5, the right claimed could not have had any legal origin in a grant from the Crown. Jervis C.J. observed, "The statute $9 \& 10$ Will. III. c. 36 , in effect, says that no right of common shall be created over the New Forest. Lord Tenterden's act clearly was not intended to repeal that, and to permit such a right to be acquired by 30 years' enjoyment. But assuming that Lord Tenterden's act does apply, still the claim cannot be supported. It is not sought to be defeated or destroyed by showing only that the right, profit, or benefit was first taken or enjoyed at any time prior to the period of 30 years; but by showing that it nerer had any legal existence. I do not stop to inquire whether or not there conld be a right of common as appurtenant to common. If it could exist in point of law, it is untrue in point of fact to say that the right existed prior to 1810 , because there was no allotment until after that date. We must, therefore, take it that the enjoyment of the right claimed commenced after the year 1810. Here, then, we have a common inclosed, which could not carry common. There could therefore be no prescription, nor could there be any grant, seeing that the Crown is by the statute incapacitated from making a grant. The effect of the argument on the part of the claimant, is, that you are to get indirectly from the Crown, through the 
laches of its officers, that which the Crossu itself conld not confer directly. I am clearly of opinion that Lord T'enterden's act does not give the chimant the right he claims." And per Cressuell J.: "It scems to be inagined that becanse you cannot defeat a claim which may be lawfully made at the common law, by custom, prescription, or grant, to any right of common or other profit à prendie, by showing only that such right or profit was first taken or enjoyed at any time rrior to the period of 30 years, therefore you camnot clefeat it all. I do not find that stated in Lord T'enterden's act. There is no attempt in this case to defeat the claim by showing only its origin, but by showing that it never conld have had a legal origin."

Under ․․ \& 3 Mill. IV., c. 71, s. 2, the privilege of washing away sand, stone, and rubble, dislodged in the necessary working a tin mine, and of lhaving the same sent down a natural stream, running through the plaintifl's land, may be the subject of a grant, and may be pleaded as a prescriptive right to a declaration elarging the defendants with throwing such stone, sand, and rubble into the stream, and thereby filling up its bed within the plaintiff's land, and causing the water to fluw over it (Cerlyon v. Lovering). Such privileges may also be well pleaded as a loeal custom (ib.). And see Murgatroyd v. Robinson, where it was doubted by the Court of Queen's Bench, whether if a claim lad been sufficiently alleged in the defendant's plea to deposit cinders on the plaintiff's part of the bed of the river Calder, it conld be considered as a ralid elaim to an cascment within the meaning of the same scetion.

An immemorial right of un is not lost by non-user for upuards of 20 years, the user having been discontinued merely by reason of the party's having had a more convenient way (Word r. Ward); and per Alderson I3.: "The presumption of abandonment eaunot be made from the mere filct of non-user; there must be other cireumstances in the ease to raise that presumption. 'Ilie right is acquired by adrerse enjoyment. The non-11scr, therefore, must be the consequence of something which is adverse to the user: Here the owners of the Stubling Pits did not use the way in rucstion, for the simple reason that they had a more easy and convenient means of access to that part of their property. If the owner of that close were now preeluded from recovering the original right, he would be withont any means of access to his property." And pr Palteson J.: "If there be 10 years' enjoyment of a right of way, and then a cessation under a temporary agreement for another 10 years, yet this may be a sufficient enjoyment of the old right for 20 years to makc it indefeasible under Stat. 2 \& 3 Will. IV., c. 71 ; for the agrecment to suspend the enjoyment of the right does not extinguish, nor 
is it inconsistent with the right. So if instead of the direct path from $A$ to $B$, another track over the plaintiff's land from $\Lambda$ to $C$, and thence to $\mathrm{B}$, had been substituted by a parol agreement of the parties, for an indefinite time, yet the user of this substituted line may be considered as substantially an exercise of the old right, and evidence of the continued enjoyment of it." (Payne v. Shedden.) And a parol agreement for the substitution of a new way for an old prescriptive way, and a consequent discontinuance to use the old way, afford no evidence of an abandonment thereof (Lovell $\mathrm{v}$. Smith). But an obstruction, in its nature permanent, which injures a right of way, if acquiesced in for 20 years, becomes eridence of a renunciation and abandonment of the right of way. That is the ground upon which a reversioner is allowed to bring his action for an obstruetion apparently permanent, to lights and other easements, which belong to the premises (Boucer v. Hill); and see Jesse v. Gifford; and Littledale J.'s judgment in Mroore r. Raurson, on the material difference between the mode of acquiring a right of common or of way, and a right to light or air ; the latter of which is acquired by mere occupancy, and the former only by user accompanied with consent of the owner of the land (8 B. \& C. 339).

It is not in the poucer of a vendor to create any rights not connected with the use or enjoyment of the land, and annex them to it; nor ean the owner of land render it subject to a new species of burthen so as to bind it in the hands of an assignee. Cressuell J. said, "This principle is sufficient to dispose of the present case. It would be a novel incident annexed to land that the owner and oceupier should, for purposes wholly imconnected with that land, and merely because he is owner and occupier, have a right of road over other land. And it seems to us that a grant of such privilege or easement can no more be annexed, so as to pass with the land, than a covenant for any collateral matter" (Simith v. Ackroydl); and per Lord Brougfam C. in Keppel v. Bayley: "The covenant (that is such as will ruu with the land) must be of such a nature as 'to inhere in the land,' to use the langnage of some eases; or 'it must concern the demised premises, and the mode of oceupying' them,' as it is laid down in others: 'it must be quodammodo annexed and appurtenant to them,' as one authority has it; or as another says, 'it must both concern the thing demised, and tend to support it, and support the reversioner's estate.' Ineidents of a novel kind cannot be cievised and attached to property, at the fancy or caprice of any owner." "A way of necessity is when there be but one road to a place, and no other way of going" (Willes, 71); and in Shury v. Pigott, a way to church or market is classed under this head. And per Parke B.: "If a way granted by a lease canuot be used, by reason of its passing over' 
the land of third persons, and there is no other way to the lessee's honse, he is entitled to a way of necessity to the nearest public highway br the shortest line across the grantor's land; and the law is that the grantec of a private way is to make it" (Osborn v. Wise). It cannot be pleaded generally, without showing the manner in which the land over which it is elaimed is charged with it (Bullard v. Harrison). A man cannot preseribe for a way or other eascment orer his own soil, for the two rights are perfectly inconsistent, and even a way of necessity cannot be so claimed (Letrge r. Pitl). If the origin of a way of necessity cannot any longer be traced, but the way has been used withont interruption, it must then be claimed as a way cither by grant or preseription, according to the cireumstances of the case. Where the fact is, that there existed at one period a unity of possession, it must then be claimed as a way by grant (Trilliams n. 1 Saund. 323 a). But where there has been no unity of possession, and the way has been used immemorially, it must then be claimed as a way by prescription (Keymer v. Summer). That umity of possession extingnishes a prescriptite right of ray, sce Tright r. Raltray, and Hincheliffe r. Earl of Kimoul. A mnity of possession of the land a quêt and of the land in quê an easement exists, does not extinguish but only suspends the easement, where the party is seised in fee of the one parcel and possessed for the residue of a term of the other (Thomas v. Thomas, 2 C. MI. \& R. 34).

A way of necessity exists after mity of possession of the close to which, and the close orer which, it leads, and after a subsequent severance; hence, if a person purehases close $\Lambda$, with a way of necessity thereto over close B, a stranger's land, and afterwards purchases close B, and then purchases close $C$, arljoining to close $A$, and through which le may enter close $\Lambda$, and then sells close $B$, without a reservation of any way, and then sells close $\Lambda$ and $C$, the purchaser of close $A$ shall nevertheless have the ancient way of necessity to close $A$, over close $B$ (Buclisby v. C'oles).

In Molmes r. Goring, Best C. J. thus stated the law as to a way of necessity: "On the part of the plaintiff the ease has been put on its right ground. If I have four ficlels, and grant away two of them, over which I have been accustomed to pass, the law will presume that I reserve a right of way to those I retain; but what right? the same as existerl before? No: the old right is extinguished, and the new right arises ont of the necessity of the thing. 'The passage which has been cited from $1 \mathrm{Wm}$. Sannders, 323 , note 6 , contains a complete answer to the argument on the part of the defendant: " $\Lambda$ way of necessity, when the nature of it is considered, will be found to be nothing else than a way by grant ; but a grant of no more than the cireumstances which 
raise the implication of necessity, require should pass. If it were otherwise, this inconvenience might follow, that a party might retain a way orer 1000 yards of another's land, when by a subsequent purchase he might reach his destination by passing over 100 yards of his own. A grant, therefore, arising out of the implication of necessity cannot be carried farther than the necessity of the case requires, and this principle consists with all the eases which have been decided. It has been argued that the new grant operates as a prevention of the extinguishment of the old right of way; but there is not a single ease which bears out that proposition, or which does not imply the contrary. Scrjeant Williems says, "Where a man having a close surrounded with his own lands, grants the close to another, the grantee shall have a way to the close over the grantor's land, as incident to the grant : for without it he camnot derive any benefit from the grant. So it is where he grants the land and reserves the close to himself.' What way is it the grantee shatl have? not the old, but a new way limited by the necessity" (2 Bing. 76).

Hence a way of necessity is limited by the necessity uhich created it, and it ceases if at any subsequent period the party entitled to it can approach the place to which it led, by passing over his own land. And where $A$, the owner of a close within a close of B's, had a prescriptive right of way through B's close, to his own, and $2+$ years ago $B$ stopped up the old way and made a new one, which A had used erer since, but it also was stopped up by $B$, it was held in an action by $B$ against $A$ for going over the new way, that A could not justify nsing it as a way of necessity, but that he should have either gone the old way, and thrown down the inclosure, or brought an action against $B$ for stopping up the old way. The new way was only a way of sufferance during the pleasure of both parties; and B by stopping it up determined his pleasure (Reignolds r. Educards). Parke B. thus observed upon Holmes v. Goring, in Proctor v. Hodlyson: "The extent of the anthority of IIolmes v. Goring is, that admitting a grant in general terms, it may be construed to be a grant of a right of way as from time to time may be necessary. I should have thought it means as much a grant for ever, as if expressly inserted in the deed, and it struck me at the time that the Court was wrong." Alderson B. also considered that Holmes v. Goring was open to review in a court of error. And per Purke B.: "All ways of necessity arise from a presumed grant, all the precedents allege a grant; but the lords of the manors are not grantees. Even assuming that escheat is equivalent to a grant, the only ground on which the lord of the manor can claim a way of necessity, is that he has no other way" (10 Exch. 824; 24 L. J. Ex. 195; see also Pearson v. Spencer, 1 B. \& S. 571, 584). 
A right of way of necessity can only arise by grant, express or implied (Proctor V. Houlysone); and no right of way of neecssity can exist, where the title of the parties is by escheat. It must be shown that the party to whom the land wias granted or escheated, supposing escheat were equal to a grant, had no other way (ib). If one sells lands, and afterwards the rundee by reason thereof claims a may orer part of the Ilaintifl's land, there being no other convenient way adjoining, this is a lawful claim because it is a thing of neeessity, otherwise he could have no profit of his land (Clarliev. Cogge). And e converso: "If a man hath four closes lying together, and sells three of them, rescrving the middle close, and hath not any land thereto, but through one of those which he sold, although he reserved not any way, yet he shall have it as reserved unto him by the law, and there is not any extinguishment of a way by haring both lands" (ib.). And per Tord Kenyon C. J.: If 1 grants a close surrounded by his other land to B, the law wonld presume a right of way (Large v. Pitt). In Denne v. Light, the owner of a piece of arable land lying in Ham Common field, surrounded by land belonging to other persons, and to which arable land there was no apparent load or footway, contracted to sell the land, no mention of a right of way being made in the contract. The purchaser required a right of carriage or roadray, and a good title to such way to be shown, in default of which he refused to complete. The rendor filed a bill for specific performance, which was decreed by V. C. Stuct ; but on appeal to the Lords. Justices it was held that such a contract could not be enforeed against the purchaser without proof of a right of way; and unless the plaintiff elected to take an inquiry as to the execution of such right the bill must be dismissed with $£+0$ costs. Among the depositions was the evidenec of one Davis, whose suggestion was, that by non-user or neglect, the owners of the inclosed pieces of land in Ham Common field had lost their right of passing over the neighbouring land, to reach the roadway. It was observed by Tindal C. J. in his judgment in Wallis v. Hurrison, and Durluem and Sunderlend Railuay Compeny v. Wulker, in the Exehequer Chamber, "that a right of way cannot in strictness be made the subject either of exception or reservation; it is neither parcel of the thing granted, nor is it issuing out of the thing granted: the former being essential to the exception, and the latter to the reservation. $\Lambda$ right of way reserved (using that word in a somewhat popular sense) to a lessor, as in the present case, is an easement newly ereated by way of grant from the grantec or lessee, in the same way as a right of sporting or fishing, which lias been lately very inuch considered in Doe dem Louglas v, Lock, and Wickham v. II awker," 7 M. \& W. 63. 
There may be a dedication of a way to the public, for a limiter purpose, as for a foot-way, horse-way, or drift-way; but there cannot be a dedication to a limited part of the public, as to a parish. Such a partial dedication is simply void, and will not operate in law as a dedication to the whole public (Poole v. Huskisson, 11 M. \& W. 827). And per Parke B.: "In order to constitute a valid dedication to the public of a highway, there must be an animus dedicandi, of which the user by the public is evidence and no more: and a single act of interruption by the owner is of much more weight upon a question of intention than many acts of enjoyment." It was decided on the authority of this case in Reg. v. Inhabitants of East Mark, that public user of a road for 50 years is evidence from which a jury may infer a dedication, though it may not be clear in whom the ownership of the soil is invested. In Rex v. Petrie, which the Court of Queen's Bench could not distinguish from the above, it was also held that public user of a road for some time is sufficient mima facie evidence of a dedication to the public by an owner of the freehold, and it is not necessary to show by whom the dedication was made. And per Bayley J. in Harper v. Charlesw'orth, where a public footway over crown land was extinguished by an inclosure act, but for 20 jears after the inclosure took place the public eontinued to use the way, this user ras not evidence of a dedication to the public, as it did not appear to have been with the knowledge of the Crown, who had the right of soil. Wood $\nabla$. Veal is an express anthority to show that the consent of the lessee is not sufficient for that purpose, becanse it cannot bind the owner of the inheritance. It was there held that the owner of the fee when the lease expired had a right to prevent the public from going along the road, notwithstanding it had been used by the public during the term. In Harper v. Clearlesworth, moreover, there was not sufficient evidence to warrant the conclusion that the road was used with the consent of any person in the occupation of the land (4 B. \& C. 574).

A right of way for agricullural purposes is a limited and qualified right of way, and does not necessarily confer a right to use such way for general and universal purposes. Therefore it does not follow that because the defendant proves a right to carry corn and manure over the locus in quo, he has a general and unlimited right to carry lime, or the produce of a quarry over it at all times and for all pnrposes : per Wood, B. (Jackson v. Slacey). Proof of "a free right of way on foot, ancl for horses, oxen, cattle, and sheep," does not confer a right to lead and carry away manure, for leading implies drawing in a carriage, and the plaintiffs themselves admitted that they had no right to "lead" in that sense (Brunton v. Hall). The disturbance complained of in this action, was that a person wheeling manure in a wheelbarrow from the plaintiffs' 
premises, under their direction, was prerented from wheeling it through a certain entry by the defendant. Coleridye J. said, "If a grant had been put in, confessing a right to 'lead manure,' the term would have been construed necording to the usual mode of leading; that is, by drawing in a cart. The rerdiet here if nndisturbed would be evidence in a fnture action of right to lead in that manner." So in Higham v. Rablit, the Court of Common Pleas held that the finding by the jury that the defendant had a limited right of way only for the purpose of carting awiry timber from the wood to the highway, did not support a flen of a general right of way on foot with horses, cattle, carts, waggons, de., at all times of the year at his free will and pleasnre, and that the rules of Hilary Term ( $t$ Will. IV. ss. 4, 5, 6) did not admit of their entering the verdiet distributive for the defendant on it.

Evidence of a prescriptive right of u'ay for all manner of carriages does not necessarily prove a right of way for all manner of cattle, but it is eridence of a drift-way for the jury to consider, together with the other eridence, and the extent of the usage is evidence of a right only commensurable with the nser (Ballard v. Dyson). It was here in evidence that the preceding occupier had been acenstomed to drive fat hogs that way to his slanghter-house; and that the plaintiff had been accustomed to drive a cart, the only carriage which he possessed, usually drawn by a horse, but sometimes by an $0 x$, along the passage in question to the barm, where he liept his eart, but there was then no other way to it. He had lately begun to drive fat oxen that way to the premises, for the purpose of killing them there, but there was no eridence of any other usage than this of the way for the cattle. No deed of grant was produced, and the defendant brought no evidence that he had ever interrupted the ocenpiers of plaintiff's premises in driving eattle there, nor that they had been usually possessed of horned eattle which had not been driven that way, and he admitted that there was sufficient evidence of a right of way for all mamer of carriages. It was contended for the plaintiff' in replevin, that a way for all manner of carriages necessarily included a right of way for all manner of cattle, and therefore proved the prescription. 'The jury found for the defendant, and a new trial was refused. Herth J. said, "This is a prescription for a way for cattle, and a carriage-way is proved. $\Lambda$ carriage-way will comprehend a horsc-way, but not a drift-way. All prescriptions are stricti juris. Some prescriptions are for a way to market, others for a way to church, and in the ancient entries, both in Rastal and Clift, the pleadings are very frarticular in stating these claims. Sometimes there is a carriageway qualified. One claim is remarkable, fugare quadraginte averia. The usage then, in this ease, is evidence of a very different grant from 
that which is claimed, viz., to drive fat oxen, animals dangcrous in their nature, and which there might be very good reason to except ont of a grant of a way through a closely-inhabited neighbourhood." Chambre J. differed from the Court in refusing a new trial, and thought that the driving of hogs was very strong evidence of a grant of a way for cattle. "Suppose," said his lordship, " any new species of cattle is introdnced into this country, shall the grantees of private ways have no passage for them to their lands? Is it to be contended, for instance, that no ancient private way in the lingdom can be used for Spanish sheep? Much of the argument has been built on their being horned cattle. Many heads of kine have no horns, may the grantec drive those?" A claim of a way for cattle and carts may be proved by showing constant use for cattle, and a user for less than 20 years for carts, the claimant not having possessed carts for the whole period (Dare v. Heathcote, 25 L. J. Ex. 245).

In Couling v. Higginson defendant justified his trespass by a plea of user, under $2 \& 3$ Will. IV.c. 71, of a right of way for 20 years as occupier of a close, for hor'ses, waggons, and carriages, at their free will and pleasure. 'The replication traver'sed the right, and it was heldfirstly, that under this issue the plaintiff might show that the defendant had a right of way for horses, carts, waggons, and carriages, for certain purposes only, and not for all, and was not compelled to new assign, and that he might show that the purpose for which the defendant had used the road, and in respect of which the action was brought, was not one of those to which his right extended; and sccondly, that evidence of a user of a road with horses and carriages, for furming purposes, docs not necessarily prove a right of road for all purposes (such, for instance, as leading coal from a mine under defendant's land), but that the extent of the right is a question for the jury, under all circumstances. And Lord Blacdonald C.B. ruled in Cobb (Clerk) v. Selby, that where there was a private road through a farm used by the owner of the land, for agricultural and other purposes, the parson had a right to use it for the purpose of carrying away his tithes, as long as it existed, althongh the owner of the road might shut it up by planting trees, or any other such means. But the farmer acting bonâ fide has a right to alter the line of road for his own convenience, and the tithe-owner must use the road thus substituted (James v. Dods).

One who has a grant of an occupation way, may declare in case against the owner of the land over which the way leads for obstructing it, although it be proved that the public had used the way without denial for the last 12 years (Allen r. Ormond). And per J.ord Denman C.J. at Nisi Prius: "There may be an occupation way and a public highway over the same road, for it does not on becoming a highway cease to be 
an ocenpation way (Brountone v. Tomtinson). A person who preseribes in a que estate for a prirate way eannot justify going out of it on the aljoining land, beense the way is impassable (Bullard r. Marrison). Tuyler $\mathrm{r}$. Whiteheal has settled the distinetion, that the right of going on the adjoining land under snel eireumstances does not extend to private as well as public ways. Howerer, the grantor of a private way may be bound, either by express stipulation or prescription, to repair it. But in an action npon the ease against him for neglecting to do so, it is suflicient to allege generally in the declaration, that he, by reason of his possession of the elose in which the way is, onght to repair it; and the special matter of the obligation shall be given in evidence on the general issue (Pomfret r. Ricroft). Where there was a mblie footucay from one ficld of the plaintiff's to another, and the defendant obstructed the war by coustructing or keeping a reservoir of water on it, whereby the plaintiff and his servants employed in the management of his lands and tending his cattle were obliged to go by a longer route, and their work and labour were necessarily consumed to a greater extent, and the flaintiff was prevented from cmploying them during such excess as he otherwise would have done, it was held that this was sufficient allegation of peculiar damage to sipport an action (Blargrave v. Bristol Waterurorks Company). But it is no ground of action that a person by stopping up on his own land the contiunation of a public footway orer his neighbour's land causes the public to trespass on other parts of his neighbour's land, to his damage, forming a beaten track and wearing off in a permanent manner the griass and herbage from such beaten track (ib.). A man may not plongh up a public footpath across his ficld (2 Rolle Abr. Nusans ? PI.) ; and he must not erect a gate across such footpath (Sir TI. Jones, R. 221). It has also been ruled by Parke J. in Batemen v. Burge, where the plaintiff and defendant owned adjoining lands, and the way had always been a public footway, with a stone wall two feet high across it, that the defendant had no right to remove the stile, and jut up a high fire-bar gate with a step in its place. "If there had becn 20 gates," said his lordship, "across the footway in other places before it, that will not justify you in putting up this one to give people the troulle of getting over it."

A reversioner cennot maintain an action on the case against a shanger for merely mtering upon his lund held by a tenant on lease, though the centry be made in exercise of an alleged right of way, such an aet during the tenancy not being necessarily injurious to the reversion (Baxter v. I'ayf(o) ). Partie J. said: "My notion is that there must be some destruction of the land to enable the reversioner to maintain this action. No case has ever gone so far as to constitute a simple trespass, like 
this, an injury to the revcrsion." IIfalle J. thus remarked on this ease in Kivigill v. Hoor: "My brother Parke does not say that it wonld not be evidence if the party claimed a right of way, and meant to assert it." And per Haule J.: "To entitle the reversioner to maintain this action, must not the two things coneur, viz., an injury of such a nature as will be presumed to be permanent, and the fact of its being evidence against him on a claim of right" (ib.). Cressuell J. also cited Baxter v. Taylor as one in point, as well as Mronford v. Oxford, Worcester and Wolverhampton Railuay Company, in his judgment in Simpson v. Sarage, where it was decided that an action cannot be maintained for an injury to a reversion which is not of a permanent nature, although it makes the reversion of a less marketable value ( 26 L. J.C.P. $50 ; 1$ C.B.N.S. 347 ).

In Kidgill $\nabla$. Moor the declaration in case by a reversioner alleged that the plaintiff was entitled to a right of way for his tenants orer a certain elose of the defendant; and charged that the defendant wrongfully lockerl, chained, shut and fastence, a certain gate standing in and across the way, and wrongfully kept the same so locked, \&e., and thereby obstrueted the way; and that by means of the premises the plaintiff was injured in his reversionary estate. It was held by the Court of Common Pleas, on a motion in arrest of judgment, that the declaration was sufficient, inasmuch as such an obstrnetion might occasion injury to the reversion, and it must be assumed after verdict that evidence to that effeet had been given. Cressuell J. said: "Jackson v. Pesked decides that a delaration of this sort is insufficient unless it eontain an arerment that the acts charged injured the plaintiff's reversionary interest. That ease, however, undoubtedly recognizes the validity of a deelaration which contains snch an averment, and states facts which may or may not amount to such injury of the reversion. Here the declaration alleges certain things to have been done by the defendant, so as to occasion injury to the plaintiff's reversionary interest. I agree with my brother Nlaule that that is an allegation of fact, and that we must take it to have been proved if the facts stated could so operate. It is impossible to say that a gate may not be so fastened as to enure as an injury to the reversion." But qucere per Maule J.: "Could the landlord bring an action alleging an injury to the reversion, where there has been no actual obstruction of the tenant?" (9 C. B. $364 ; 19$ L. J. C. P. 177).

Free passage of air to a windmitl. It was held in error, affirming the decision of the Court of Common Pleas, that a right of free passage of air is not an easement within the meaning of section 2 of the Prescription Aet, 2 \& 3 Will. IV. e. 71 . A grant of a free passage of air to a windmill over the soil of another cannot be presumed from 20 years' use of the 
windmill, for the presnmption of a grant only arises in cases where the owner of the servient tenement had it in his power to prevent the enjoyment, and did not; and it is not practically in the power of an owner of neighbouring land to prechnde the passage of air to a windmill. And per Trightmen J.: "We think, in accordance with the judgment of the Common Plens and Chasemore r. Richards ( 7 H. L. Cas., 349, and 29 I. J.. N.S., Ex., 81) [see Law of the Farm, Pl. 176, 177], that the presumption of a grant from long-continued enjoyment, only arises where the person against whom the right is claimed might lave interrupted or precented the exercise of the subject of the proposed grant. As was observed by Loril Wensleyclate, it was going very far to say a man must go to the expense of putting up a screen to window-lights to prevent a light heing gained by 20 years' enjoyment" (Webb v. Bird). 'The ruling of the Court of Common Pleas was affirmed in the Exchequer Chamber (31 L. J. C. P. 385, Ex. Ch.).

l'rescriptive right to light for windous. - A and B occupied adjoining houses, as tenants to the same landlord, under long leases, which were made on the same dar, and to expire at the same time. B, by building on his own premises, obstructed the access of light to a window in A's house, throngh which the light had passed without interruption for more than 20 years; and it was held by the Court of Exchequer Chamber that A, by the 20 years' user, had acquired a right to the light, and might maintain an action against $B$ for obstructing it, thongh they occupied these premises as tenants and moler the same landlord; and the ubservations of Colerillye J. and Cressuell J., speaking of the 3rd section of the Prescription Act in T'ruscott v. Merchant Taylors' Company (11 Ex., 863; and 21 L. J., N.S., Ex., 173), were cited in support of their vicws. 'The former learned judge obscrved: "The third section secms to simplify and almost new found the mode of acquiring the right to access of light. It founds it on actual enjoyment for the full period of 20 years without interruption, unless that enjoyment is shown to have been by consent or agreement expressly made by deed or writing, thus putting the right on a simple foundation, and with the simplest exception" (Frewen v. Phillips, 30 L. J. C. P. 356 ).

Ancient windou's restored after improper enlargement to their originat size resume their original easement. If ancient windows which look over the land or upon the premises of another are enlarged, and are comIlained of, the Comrt, upon their being restored to their original dimensions, will lestrain the owner of the adjoining property from obscuring such restred windows; and if an owner of land complains of an eascment usurped over his property, and delays his application for relief, a court of equity will not interfere until he has established his right at 
law to an abatement. If the owner of a tenement has windows looking upon the premises of another, he cannot increase their size or number, or claim more extensive rights. Per Sir J. Romilly M.R. (Cooper v. Hubbuck, 31 L. J. Ch. 128).

T'wenty years' enjoyment of light, how calculated. - The period of twenty years' enjoyment, which confers a right to the access of light nnder 2 \& 3 Will. IV. c. 71 , s. 8 , is, by s. 4, the period of tu'enty years next before any suit or action wherein the claim to the right was brought into question; and is not limited to the period of twenty years next before the pending suit or action. Per Erle C.J., Willes J. and Byles J.; Williams J. diss. (ib., 31 L. J. C. P. 223 ).

Ancient rights may be allered, provided they are not made more extensive. -In Turner v. Spooner, the plaintiff was the owner of a house abutting upon a back-yard in the occupation of the defendants, and possessed two ancient lights overlooking such yard, which, for the greater acquirement of light and air, he modernized by removing the old casements, and substituting new ones of a lighter construction, but not extending the aperture occupied by their frames. The defendants then proceeded to erect and glaze with opaque glass a framework close to these improved windows; and a bill was filed for an injunction to restrain such proceedings. It was held by Kindersley V.C. that a party possessed of ancient lights has a right to acquire an increased access of light and air if he can do so without altering the aperture, and this does not create a new easement; that the owner of an ancient light is entitled to use it in any manner he pleases, by obstrueting, opening, or protecting it, or by taking away old window-frames and substituting new ones of a much less size and thickness, so that he does not extend the aperture itself; and that the intrusion upon a neighbour's privacy is not a gromd for interference, either at law or in equity (it., 30 I. J. Ch. 801).

New lights not corresponding with old.-The warehouse of the plaintiffs, which had ancient windows, having been burnt down, was rebnilt by them. In the new warchouse, the windows were placed in different situations and were of different sizes, and altogether occupied more space than the windows of the old building. Some parts of some of the new windows coincided with some parts of the old, but a greater portion of the old and new windows did not coincide. The defendants, who had premises on the other side of the street, raised their own honse, and so obstructed the access of light to the new windows. They could not have obstructed the passage of light to such portions of the windows as were new without at the same time obstructing its passage to such portions of the new windows as were on the sites of the old windows. It was held by the Exchequer Chamber, confirming the judgment of the 
Common l'leas on a special case, that the plaintifls, under these circmmstances, conld not maintain an action against the defendants for obstrueting the passige of light to their warehouse windows, as no one of the existing windows snbstantially corresponded with any of the ancient lights; and per ('hamell B. and Blachbunn J., that it was not necessary in the present case to decide whether there is a right to block up an new window, if it camnot be done withont also ljlocking up an ancient maltered one. And pe" Curium: "We entirely concur in the judgment of Patterson J., in Blunchard v. Brydyes (t Ad. \& E. 176), that lights in respect of which the right of action is sought to be enforced must be substantially the same as the lights which have been gained by user or grant, and that no new light can be substituted without the consent of the owner of the servient tenement" (Hutchinson and Others v. Cupesilie and Others, 31 L. J. C. P. 19 Ex. Ch.).

Right of ligying for brick carth to be taken into considteration under the General Inclosure Act. - Where proceedings were taken under the General Inclosme Act, s \& 9 Vict. c. 118, for the inclosmre of certain land at the instigation of persons who claimed rights of common over the same, and the owner of such land was interested therein in respect of brick-earth which he conld get from it without interfering with the rights of common, it was held that the interest of such ormer in respect of the brick-earth onght to be taken into consideration by the Assistant Commissioner in calculating' the interests of the assenting and dissenting partics, under" sec. 27, notwithstanding all "mines, minerals, stones, and other substrata" had been expressly reserved to such owner by the frovisional order; and the Court granted a prohibition against the Commissioner's proceeding with the inclosure withont the consent of such owner, or taking the value of his interest in the brick-earth into accomnt in reckoning the assents and dissents (Church v. Inclosure Commissioners).

C'nstom lo diy clay in a copylhoth not unreasonable. - A custom in a manor that copyholder's of inheritance may, without licence of the lord, break the surfice and dig and get elay without stint out of their copyhold tenements, for the purpose of making bricks for sale of the manor, is good in law. 'This was decided in error' on a bill of exceptions to the ruling of Siyles J., and the judgment of the Excherper affirmed. It was contended that the custom to take the soil and surface withont stint tends to the destruction of the inheritance, and is mureasonable and roid in law, but per curian: "We are, lowever, mable to draw any soumd distiuction between a custom for copyluolder's to take all the timber or trees, or all the minerals, in their copyholds, and such a custrom to take clay as that in question. It appears to us that the

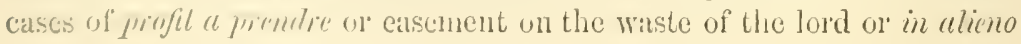


solo, have no application to the present question. A copyholder may, by custom, not only have a possessory but a proprietory right in the trees and minerals in his copylnold tenement. In the case of minerals, the taking them is, in effect, a taking of a portion of the corpus of the copyhold tenement. There appears to be no doubt but that a copyholder of inheritance may not only, by custom, work old mines already opened, but that he may also by custom dig within his tenements for new ones, and, if successful, work them. The case of the Bishop of Winchester v. Knight (2 Ld. Raymond, 1056 ; and 1 P. Williams, 406), [see Lav of the Farm, p. 307] is an authority for the proposition that by custom a copyholder of inheritance may open and work new mines. Gilbert C.P., in his treatise on tenures, p. 327, says that a copyholder of inheritance cannot withont a custom dig for mines; obviously meaning that with a enstom he could. In Scriven on Copyllolds, p. 420, it is said that by custom a copyholder of inheritance may be entitled to the trees and mines in his copyhold. The plaintiff's counsel in his argument did not donbt but that a custom for a eopyholder to have and work quarries and mines might be good, but contended that the surface must be left. But no case was eited to warrant such a conclusion. It may be that the mine or minerals, or a quarry of stone, might oceupy the whole surface of the particnlar copyhold tenement, and that a general right to take stone or mineruls would necessarily involve the taking of the surface. But in the present case there is nothing to show that the taking the clay would necessarily involve the taking of the surface. All the clay might be so situate as to be capable of being got at, as coals or other minerals. But however that may be, we think there is nothing to show that such a custom as that in question is unreasonable or bad in point of law; and we may further observe that it is said, in Scrizen on Copyloolds, p. 26, that a custom is not unreasonable becanse it is prejudicial to or diminishes the lord's cnsualty profit as to escheat. For these reasons, we think the defendant is entitled to our judgment" (Marquis of Salisbury v. Gladstone).

Definition of surface damage.-The words "surface damage" in the Forest of Dean Act ( 1 \& \& Vict. c. 43, s. 68) do not include damage to buildings on the land, by reason of the subsidence occasioned by underground workings. This "surface danage" is damage to the mere surface, injury to the crops, or destriction of the grass, compensation for which ean be ascertained by computation, and determined upon by the gaveller. 'To canse a subsidence of the soil, partially or wholly destroying the future fertility of it, is not a surface damage; it maly be damage to the loase and land, but it is not surface damage (Allaw'ay v. Wagstaff). 
Sumport to lanil from drouned mine.-Although as between conterminous owner's the lateral support of a neighbour's soil ean only be claimed for the surface of the land in its natural state, yet where a person sells laud to another, to be used for an express purpose, he will not be allowed to derogate from his own grant by doing anything on the adjacent soil, which unfits the land sold for the purpose for which it is sold; and it makes no diflerence that the land so sold was taken under compulsory powers; but the purehaser is not entitled to any additional support aflorded by the accidental state in which the adjacent soil happens to be, at the time of the purehase, howerer long it may have been in that state prior to the purchase. Thus where the owner of a drowned mine sold land to a railway company for the purpose of building a bridge, and the land sold derived additional support from the water in the mine, it was held that the railway company were not entitled to restrain him from jumping ont the water, and restoring the mine to a working condition, although the mine had continned in its drowned state, and the works had been abandoned for a period of forty years prior to the purchase (North Eastern Railway Company r. Elliot).

Right of vaituety to support from adjoining lands. - A railway company is entitled to the vertical and lateral support of the adjoining lands of the proprictor from whom the lands or easements required for the railway were purchased; and such proprictor is not at liberty to work the minerals adjoining the railway in such a way as to canse damage to it; and in the alssence of statutory provisions he cannot compel the company to purchase them (North Eastern Raitway Company v. Crostand).

Title of ouner of ancient house to lateral suppiort from auljoining land.- Somble by I1'ood V.C.: "The owner of an ancient house is entitled to the later"al support of his neighbour's land, as well for the house as for the surface of the soil itselt" (Huml r. Peek).

Statule of limilalions in case where damage has been done to the surface by mining.-'The judgment in Bonomi v. Baclihouse, (27 L. J. (N. S.) Q. 13. 378, and that in Nicklin v. Williams (10 Ex. 259), [see Law of the furm, 11). 80, 81, ] on which it was based, were over-1'uled in Error. In the former, the defendant, owner of certain mines in 1849, withdrew the pillars of coal which had been left as supports to roofs in some of the old workings. The consequence was that the roof of the mine fell, the adjacent strutu subsided one after the other in slow suecession, and at last, in 1854 , the support of the intermediate strata having given way, the plaintifl"s land, which was 280 yards off defendant's mines, sank, and the homse on it was injured. 'Tlle plaintifl brought lis action in 1856 . It was ultimatcly held, reversing the 
judgrment of the Queen's Bench in this ease, and Nicklin v. Williums as well, that the Statute of Limitations was no bar to the action, as 110 cause of action arose to the plaintiffs by the mere exeavation by the defendant of the pillar's of plaintiff's coal in his own land, so long as it cansed no damage to the plaintiffs, and that the catse of action first accrued when the plaintiff's received actual slamage.

Compensation for Injury to Buildings by Subsidence of Soil.-When the working of mines, in however careful a manner, has occasioned the subsidence of the land of another, although not immediately adjoining, damages may be recovered in respect of injury to brildings thereon ereeted or enlarged within twenty years, provided their weight did not occasion or contribute to the subsidence; and the action is maintainable for damage to the possession and the reversion (Hamer and Stroyan v. Knoules).

Righl of soit to sumporl for additional weighl of buitlings.-A right to support for additional weight of buildings may be acquired as an easement by tirenty years of minterrupted enjoyment (Partrilge v. Scott, 3 M. \& W. 220), and after twenty years a house acquires a right to the lateral support of soil round it (Lrowne v. Robins).

Three-fourths of a right of common.-A plea of preseriptive right to three-fourths of a light of common of pasture for one cow is had (Nichols v. Chapman).

Evidence of existence of highuay.-In an action of trespass for breaking and entering the plaintiff's land, on an issue raised whether there was a highway over the locus in quo, there was evidence that there had been a highway over the adjacent land, which was then, together with such locus in quo, an open common. There was also evidence that for many year's the highway was obstructed by part of it being included in an enclosure, which had been illegally made on such common; and that during twenty years of that time, the public had deviated a little from the line of way, by going outside such enclosure, and on the locus in quo. At the end of such time, and before the plaintiff became the owner of the locus in quo, the use of such substituted line of way was discontinned by reason of a new road having been laid ont in a different direction by an adjoining land proprietary. Afterwards, the olstrnction to the old road was removed, and the original line of way was reopened to the public. It was held by Erle C.J. and Byles J. (Jitliams J. diss.), that there was no reasonable evidence on the above facts, on which a jury might find that there was, in addition to any other highway, a highway running over the locus in quo (Dares v. Harkins, 29 L. J. C. P. 343).

Evidence of user and dectication.-Although a cul de sac may be a 
lighwar, and although the old doctrine that a highway must lead from one public place to another may not be strictly correct, yet where a road leads to a place which is not public, and which the public entel only hy permission (as where it leads to the gates of a park). the user of the roal by all persons who seek such entry withont eridence of nser for any other purpose, is not a user sufficient to marrant the conclusion of a dedication to the public as a highway and a liability in the parish to repair (lieg. v. Parish of Hauchurst).

For right of mublic to enjoyment of higheay.- Where an ordinary highway runs between fences, one on each side, the right of the passage which the pullic have along it extends mimê facie, and unless there be eridence to the contrary, orer the whole space between the fences; and the public are entitled to the use of the entire space (Reg. v. L.K. Filectric Telegraph Compomy (limited), 31 L. J. II. C. 166).

Enclosing to within fiftern feet of centre of highuay.-The common notion that owners of land on the sicles of a highway may encroach or enclose up to within fifteen feet of the centre is an crror, and the question will always be as to the extent of the highway by uscr: per Erte .J. (Rey. v. Johnson).

Right of Justics to determine whelher road is a highway.-On the hearing of a complaint under 5 \& 6 i litl. IV. e. 50 , sec. 73 , for Jeaving rublesh on a highmas, after notice to remove it, the defendant, who was the owner of the land on both sides of the alleged highway, denied it to be the highray, and as he claimed the soil subject to a private right of way only, he contended that the justices onght not to arjudicate in the matter, on the ground that title to land eame in rucstion; and it was held that the objection was untenable, for that the justices had jurisdiction under the statnte to determine whether the road was a highway or not. And per Wightman. J., the question of title to the land does not properly arise; and per Compton J. "I was struck by the way the point was raised, viz., that the matter of title comes into question, because the appellant claims the land subject only to the easement of a private right of road. As a general rule, no donbt, justices are not to decide on summary convietion, the title to land; and as I saird in lieg. v. Crilland (27 L. J. (N. S.) M. C. 28), this does not depend on any exception in the prarticular statute, so much as on the principle generally applicalole to summary convictions. but in this partirular case, the magistrates were to decide on the - qnestion whather the alleged highway was a highway or not; this in some sort may be saicl to involve a question connected with title to land, but Hhat cronsideration cannot oust them of jurisdiction where they are the tribunal alpribled to decide that rery question, highwaty or no highway. 
The very fomdation of their jurisdiction in the matter depends on this question, and the rery first step is to ascertain whether the locus in quo is a highway. They are not really trying a question as to any title to land; in this case the title to the land was admitted, and the only question was, is the road a highway or not? That is the very thing which, as to any other indiridual, the justices are to try, and why not when the person guilty of the alleged nuisance is the owner of the land? My notion is that if an Act of Parliament gives jurisdiction to justices or other inferior tribnnal over a matter connected with land, there must be a special exception to the Act, in order to oust their jurisdiction, where the title comes in question, as in the County Courts and Malicions Trespass Acts. The appellant seeks to onst the magistrates' jurisdiction, by alleging that the road is not a highway; any other person might set up this defence, and it is a question of user ly the public, and is not founded on title, but arises just as much as to any one of the public, as to the particular owner of the land; and this question of highway is the rery question which the Legislature says the justices are to decide" (IVilliams (appt.) r. Adams).

Distinction between a mivate and a mublic way.- "It appears to me that there is this distinction between a private and a pullic right of way, that the former is not necessarily, as the latter is, over every prent of the land, to which people have access, or along which there is the right of way:" per Cockburn C.J. (Hutton v. Hamboro").

Duty of surveyor to protect foot-causeways ayainst carriages.-The 24 th section of the General Highway Act (5 \& 6 Witl. IV.c. 50), which requires the parish surveyor to secure horse and foot canseways from being passed over by carriages, applies onty to such as are by the side of carriage-ureys; and therefore snch surveyor is not bound by that statute to protect horse and foot-causeways against carriages at the extremities of snch ways (Ellis (appt.) r. Woodbritlye).

Surveyor of highways not liable for accident caused by nonropair of lioacl.-A surveyor of highways appointed under 5 \& 6 Wilt. IV. c. 50 , is not liable to an action for damages resulting from an accident caused by the non-repair of the highway, as was substantially decided in error in LcKimnon v. Ponson (9 Ex. 609, and 23 L. J. (N. S.) M. C. 97) (Young v. Davis).

Piesumption of property on soit of mirate road.-The presumption which prevails in the case of a public highway, that the soil zesque al medium filum trice belongs to the owner of the adjacent land, prevails also in the case of a miute way; provided that there be no other evidence of ownership to rebut such presumption (Hotmes v. Belling 7tam, 29 L. J. C. P. 132). 
Right of uncty alpurtencmt.-A plot of building ground having been convered with a right of way over a new road leading thereto from a high road, it was held by the Court of Common Pleas that if that plot of land is subsequently demised by parol, the right of way passes also, although not specially mentioned (skull $\mathrm{v}$. Glenister, 33 I. J. C. P.185).

Implisd yremt of may of necessity.-Where the owner of a farm severed it by will among his two sons, and the moiety devised to one son was lamilueked, except where it abutted on the moiety devised to the other, ret the will made no mention of any ways whatsoever, it was held by the Exchequer Chamber, aftirming the decision of the Court of Queen's Bench, that some way passed by implication under the will, and that the Count would look at the previous oecupation of the testator's property to see what way was meant by him to pass. Under these eireumstanecs, where the access to the landlocked premises, and to the farm buildings upon them, had been in the testator's lifetime by one particnlar road across the moiety derised to the other son, and the enjoyment of the landlocked premises in the state they were in when devised wis not complete without this particular road, the Court held that this particular roal passed nnder the will, and not merely "a way of necessity ;" and semble, that if a way of necessity only had passed, the way would have been limited by the neeessity (Reg. v. Pearson).

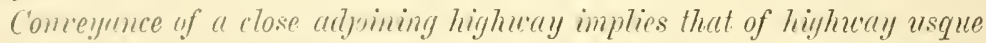
ad molium filmm rive.- Where a close of land adjoins a highwar, the presumption of law is that half of such highway, usque cut medium fitum, prasses with the eonverance of the close; and such presumption is not jebutted by the fact that the close is separated from the highway by a lenee, and is defined in the converance by admeasurement and reference to a plan which did not include such highway, and the eases of Simpson v. Dendy (S C. B. 4:39), and Lond v. the Commissioners of the City of Sydriry (12 Moo. 473), are authorities to that effect (Borridye $\mathrm{r}$. Wirm, :30 L. J. C. P. 21s).

Hap held inadmissitite under certain cirmmstances to prove rights of may. - T' prove that there was a public right of way over certain eloses, jart of a manor, the defendant put in evidence a map used by a deceased steward of the manor at the Manor Courts, for the purpose of defining the copyloolds. In it, there appeared a space marked out by two lines crossing the closes in question, and called Mellow Lane. There were ocempation ways, as well as public highways, marked mpon the map, but there was nothing to distinguish one fiom another, nor was there anything to show that the space marked out as above montioner was a juhlie lighway at all. The map was held inadmissible: che decciscri stewird did not make the map, nor was it proved to 
have been made by any one who had knowledge of the facts (Pipe $\mathrm{v}$. Fulcher, 28 L. J. Q. B. 12).

Order of Justices to stop up a mublic carriage-road under an Inclosure Acl, implicd by long acquiescence.-An award made in 1830, under an Inclosure Act, which emporered the Commissioners to stop up highways, subject nevertheless to the order and concurrence of two justices, directed a certain public highway for carriages to be stopped up. Ever since the arrard (i.e. for 28 years) the road had been stopped up by a gate, and had never been used by the public, with carriages or horses. There had, however, been some user by foot passengers. No proof was given that the requisite order of justices had ever been made. It was held by the Exchequer Chamber, confirming the decision of the Court of Exchequer, that from the non-user of the road for so long a period, the jury might presume that there was such an order (Williams v. Eyton, 28 L. J. Ex. 146).

Power of Inclosure Commissioners lo set out miecte road. - Where a provisional order has been made under the Inclosure Acts, ordering certain land therein described to be allotted to an inclividual, in lieu of his right in the lands to be enclosed, and the order loes not expressly exempt such allotment from having a right of way reserved over it, the Inclosure Commissioners have power, in proceeding with the inclosure, to order the valner to set out a private road over such land, for the use of another landowner; and per Erle C.J., "The words of 11 \& 12 Tict. c. 99, s. 4 , giving the valuer power to set out private roads, are extremely wide, and give the Commissioners jurisdiction in the matter" (Grubb v. Inclosure Commissioners). Afhimed in Error.

Apmopriation of a mivate right of way by Private Estates Act.-A Private Estate Act ( 6 II ill. IV. c. 13) enables tenants for life to grant building leases, and empowers the lessors to lay out, and appropriate any part of the land anthorised to be leased, as for a way, street, square, passage, or sewer, or other conveniences for the general improvement of the estate, and the accommodation of the tenants and occupiers. It was held that extensive private rights of way over such appropriated land might be granted to partienlar lessces, as such appropriation did not coufer a right of user by all the tenants and occupier's (While v. Leeson).

Right of way under deed of partition.-Pyer v. Carter was quite distinguished from Worthington v. Gimson, in which there is no ground for saying that there was any necessity at all for the way claimed. There H. and P. being seised of undivided moieties in the $N$. and $N$. V. estates, entered into a deed of partition, by which the $\mathrm{N}$. V. estate was convered to 1 ., and the $\mathrm{N}$. estate to P. A way had existed for many 
years, leating from a farm on the $\mathrm{N}$. estate, occupied by the plaintiff orer his land, and orer land occupied by the defendant on the N. V. estate. 'The way had been used by the oceupier of the plaintiff's farm before and after the 20th of Jamary, in which month the deed of partition was exeeuted. By the deed, II conreyed his undivided moiety in

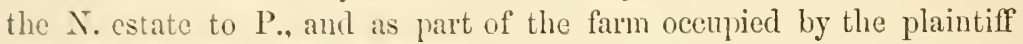
with others, "with their and every of their rights, members, easements, and appurtenances." P. also conreyed his mndivided moiety in the N. V. estate to II. 'I'he plaintiff and his predecessor's nsed the way up to January 1859, when it was obstrueted by the defendant. It was held in an action bronght by the plaintiff in respect of such obstruction, that the way in question did not pass muder words used in the deed of partition, and that the plaintiff could not recover (Worthington v. Ciimson. For Pypr r. Carter, see 26 I. J. Ex. 258).

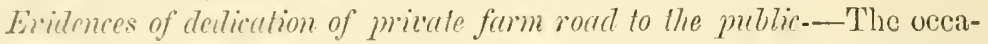
sional user of a farm road by strangers ehicfly for purposes of pleasure is eridence of a public rather than a private way, and may be evidence of a dedication to the public as a highway, but must be well weighed with reference to permission, repair, and all other circumstances tending to show whether the owner ever intended such a dedication, especially if it leads to a place of resort for mere purposes of pleasure : per Er.le C..J. (Jlithed r. W'eater)).

Here tracks in uood not proof of highuay. - The mere use of tracks in a wood by people where they were free to wander about as they pleased, is not necessarily enongh to show a dedication of such tracks to the public as public footways : per Erle C.J., Chapman v. Cripps and Others (-2 F. \& F, S6.t) ; and evidence that in a place of resort for pleasure, as a wood or the like, people have gone abont wherever they pleased, there being no definite enduring trackway in any particular direction, but merely temprary and transitory tracks, not passable in wet weather, rarsing erery season and never proved to be repaired, was held by Irightman J. not to be eridence on which a jury could properly find cither a public highway or a public right of resort for air and exercise, or a preseriptive right of way (Sthwinge v. Dovell).

Charging setflen sstrite with expense of road through anollier part of the rstutes.-The court will not sanction the sale of any part of settled estates, that the purchase-money may be applied in laying out and making roarls through another part of the estates : per liomitly MI.R. ( Th ro Chanber's Settled Estates).

Ploughing up foolpuths.-In Bright v. Shect, which was trier at Taunton Assizes some years sinee, the luxe as to ploughing up footpaths vas thus laik dorn: "In this case, which was an indictment bronght 
by certiorari from the Quarter Sessions, it appeared that there was a public footpath across the lands of the defendant, who had been accustomed to plouglı up the paths, to the great inconvenience of the public. 'The right of way being established by undisputed evidence, the learned judge declared the law to be : That if the public were entitled to a road (or footway) at all, they were entitled to a good one, and that either the parish or the person ocenpying the field, as the custom might be, was bound to keep it in a proper state for the use of the public; that if the road (or path) led from a village to the church, he apprehended the proper persons to repair were the parish officers or way wardens; that it was easy, if the farmer chose, to plough up the field without ploughing up the footpath, and if he did plough it up he was liable to fine and imprisonment for destroying the road (or path); that the King's subjects were not to be put to inconvenience, merely because he would not give himself a little additional trouble in passing the plongh parallel with the path ;" and the defendant was find 40 s.

Discharging urater from eares on to land sutiject of action by reversioner. -Building a roof with eares, which discharge rain-water on to the land, may be injurious to the reversion, and will warrant the jury in finding that the act alleged is an injury of a permanent character to the land. But if the act be done merely with the view to establish an easement on the land, and is not in fact injurions to the reversion, the action will not lie. The action by the reversioner is independent of that by the tenant for damage to his possession. The Prescription Act (2 \& 3 Irill. IT. c. 71 , s. 8), reserves to the recersioner three years for resisting any claim after his estate has come into possession, though the full period of preseription has previously elapsed (Tucker $\mathrm{v}$. Nerman, 11 Ad. \& E. 40).

Rule as to going 100 yards through tum-pize gate. $-A$ person who had here come on to the turn-pike road 20 yards below the gate, and passed 300 yards through it, is liable to pay toll at a toll-gate, on a turnpike road, though he has not travelled 100 yards on the road before coming to the gate, if, after passing through the gate, he uses the road for a space which together with that he has passed over previonsly exceeds in all the distance of 100 yards (Horuood v. Poxell).

Composition for tolls made by lessees are not illegal. (Stott v. Clegg). Construction of "other thing" in Turnpike Roarls Act.-The words "other" thing" in 3 Geo. IV.c. 126 , s. 121 , which imposes a penalty on persons drawing "any timber, stone, or other thing" on a turnpike road otherwise than on a wheeled earriage, were held to apply (Cockturn C..). thri.) only to things ejustem generis, and therefore not to a load of straw. Judgment was therefore for the respondent, and the rierv of 
the magistrates who had dismissed the information mpheld. He had nsed a vehicle on two wheels, so constructed, that when going down lill the front part of the rehicle came into contact with the road, and llonghed it up, acting as a kind of drag, but it was only laden with straw. The Court thonght that this was a sledge, and not a carriage on wheels within the act, as the magistrates had decided; but they ayreed with them that the general worls in the section must be limited to things of the same nature, and calculated to produce the same mischicf as those cummerated, and dismissed the appeal (County Roud Buctrid of Reulnor v. Eicuns). 


\section{CHAPTER IV.}

\section{TREES AND FENCES.}

THE general property in trees is in the landlord, and that in bushes in the tenant, even where they are cut down by a stranger (Berriman $\mathrm{v}$. Peacock). Where trees are excepted in a lease, the land on which they grow is necessarily excepted also, and if therefore the tenant cut down the trees the landlord has trespass for breaking his close, and cutting them down (per Probyn J.; Rolls v. Rock). By Liford's case the soit on which timber trees grow is not excepted by the words "all timber" trees," but only nutriment out of the land sufficient to sustain the vegetative power of the trees. Where, however, there was a lease of the site and demesne of a manor, "exceptis et semper reservatis omnibus boscis subboscis," \&c., it was held that the soil itself was excepted (Whistler v. P(aslow ). Hence it is observed in a note to Pomfret v. Ricroft, "that there is a distinction between an crception of woods and underu'oods, and an exception of all timber trees; for by the former the soil itself on which the woods and underwoods grow is excepted." But it has been held otherwise where the words "woods and underwoods" follow the words "timber and other trees" in the same clause of exception (Leigh v. Heald). "All manner of timber trees and great uoods" are excepted in a lease, and it was held by three judges out of four, that the phrase did not include nnderwood or herbage of the woods (1 Dy. 79 a).

By a general demise of lands on which there are timber trees, withont any exception, the timber trees are demised as well as the lands, and in Doe dem. Douylas v. Lock the Court of Queen's Bench considered that the same rule would hold with regard to the tops of trees likely to prove timber.

Where a declaration, as in Hurst v. Hurst, stated that the defendants corenanted that they "would not lop or top any tree without the assent in writing of the plaintiff, under a penalty of $£ 20$ for each tree which should be so lopped or topped, over and above the actual value of the tree," and the breach laid was that the defendants lopped twenty trees of the value of $£ 80$, without the consent in writing of the plaintiff, and 


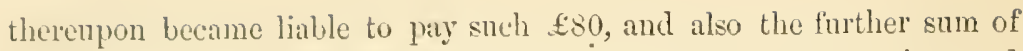
\pm 20 for each tree su hoppel, being the amount of penalties so incurred and forleited; it was held by the Court of Exchequer that assuming the $£ 20$ penalty to be liquidated damages, the plaintiff could not recover it on this breneh, inasmuch as it did not allege that the penalty was not paid. It is a question for the jury whether the cutting done to a tree is a lopping within the meaning of the covemant (Loue v. Peers).

Timber while standing is part of the inheritance : but whenever it is sereved, either by the act of God, as by tempest, or by a trespasser, and by wrong, it belongs to him who has the first estate of inheritance, whether in fee or in tail, who may bring trover for it; and this was so decided upon occasion of the great windfall of timber on the Cavendish estate per Lord Tiulbot C. (Bewiek v. Whitfiele). A tenant in tail after pussibility of issue extinct is entitled to the timber he euts (Filliams $\mathrm{v}$. Williams); but a tenant in tail expectant on the detcrmination of an estate for life, without impeachment of waste, cannot recover in trover for timber which grew upon, and had been severed from the estate, because such an action must be founded on the property of the plaintiff, whereas a tenant for life without impeachment of waste has a right to the trees the moment they are cut down (Pyne v. Dor). The right to trees severed by the tenant of a copylold or customary freehold is mrima facie in the lord, and in general he may maintain trover for them when so serered (Lally Fleming v. Simpson). And so where large masses of rocks had fillen from time to time, and from beyond the time of memory, from some clifts above, which did not belong to the lord of the manor, into the field of a copylholder, which was within the manor, and the copylholder had removed portions of them from his field, and sold them, he was held by the Court of Exchequer to be liable for so doing in an action of trover by the lord, as they had become a portion of the soil, there being no evidence to show that they had fallen since the copyholder was admitted. And per Perke B. : "He may remove them for" the benefit of his argriculture, but it is a different thing if he proceeds to sell; though a eopyholder may cut down trees for pnrposes of repair, the lord may bring trover, if he sells them" (Dewelen v. Evans).

Although no aclion of waste lies where there is an intermediate estate, ret if waste be done by felling timber trees, the lerson entitled at that time to the inheritance in fee or in tail may scize them, or bring an action of trover for the recovery of them. A tenant for life has but a special interest in the trees growing on the land, so long as they are annexed to it; but if he or any one else sever's them from the land, his interest in them is determined thereby, and they become the property of the orner of the inleritance. Lint the words "without impeachmenl of 
uaste" give to the tenant for life the right to fell timber, and also the property of all timber trees felled or blown down, and also of all timber parcel of a building blown down. It has, however, been held (Piyot $r$. Bullock) that a tenant for life withont impeachment of waste cannot maintain trover for timber cut during the existenee of a prior estate; but that it vests immediately in the owner of the inheritance. The power such a tenant for life without impeachment of waste has over his estate, with respect to eutting down timber, must be exercised during his life, and cannot be delegated to any other person, so as to enable sueh person to execute it after his death. 'The tenant for life may cut down timber trees at seasonable times for the reparation of honses or fenees; but he cunnot cut down timber, to build new houses, or to repair those that he himself has improperly suffered to fall into deeay. And where he ents down more timber than is necessary it is waste, though he asserts that he cut it down to employ it on future repairs (Crnise, vol. 1, Tit. III., ch. 1, 2).

Effect of sale of timber by tenant for life to trustees of remainderman.If a tenant for life, without impeachment of waste, sclls for value "all and singular the timber and timber-like trees then growing or being, or which shonld thereafter grow or be, upon settled estates" to trustees, for the benefit of those in remainder, he will be restrctined from either cutting or thinning the timber: per Romilly M. R. (Gordon v. Woodford).

Cutting of timber by tenant for life. - Where timber ripe for cutting is cut by a tenant for lile impeachable for waste, he is entitled to the income of the fund produced by the sale thercof: and the first person taking an estate unimpeachable for waste will, on coming into possession, be entitled to the capital. Where the timber so cut is not ripe for cutting, semble the prodnee belongs immediately to the first person having an estate of inheritance, passing over all the intermediate life estates, whether impeachable for waste or not. But whether it belongs to him or to the first tenant for life unimpeachable for waste, the cutting being a tort, the remedy is by action at law, and not in this court. Therefore under no circumstanees can a tenant for life unimpeachable for waste, be entitled, on coming into possession, to back interest on the produce of timber, whether properly or improperly cat by a previons temant for life, impeachable for waste: per Wrood V.C. (Gent v. H(tritson).

T'enant for life barred by lapse of time from receiving proceeds of timber cut doun by previons tenant.-A tenant for life eut timber in exeess of what he was entitled to ent; nearly 20 years after his death, the succeeding tenant for life filed a bill for an aceomnt, and to make the estate of the deceased tenant for life liable for the timber cut in excess; and 
it was beld by Sir. J. Romilly M.R., that the pluinliff ures becreel by lapse of time, and the bill was cismisset with eosts. Roberls v. Thunstatl (4 11are, 257, 14 L. J. Ch. 181) ; Prye r. Burn (eited by Lord Alconley, 5 Ves. 6s1); Gregory r. Gregory (G. Cooper, 201, s. e., Jacob, 631), were cited for the plaintifls on the question of waste; and Sibbering $\mathrm{v}$. The Earl of Butiaras (3 De G. and Sm., 735, and 19 L. J. Ch. 252); and Pickering r. Lord Stumford (2 Ves. Jun. 272), cited hy the defendants on the question of delay in filing the bill, were thus referred to by II Ho Homr in his judgment. In Piclieriny v. Lord Stamford, the Minster of the Rolls obserred that "the very forbearance to make the demind affords a presmption either that the claimant is conscious it was satiffied, or that he intended to relinquish it. Here the claim is made in respect of timber ent during sixteen years' enjoyment of the property by a tenant for life, who died in March 1838, and all this was at the time within the knowledge of the present plaintiff, who seeks redress in March 1858" (Hatrount v. White).

P'emissive uaste ly tenant for life. - The court in Warren v. Rudall (29 L. J. (N. S.) Ch. 543), quoted Pourys v. Blagrare (24 L. J. (N. S.) Ch. 142), as a proof that the court will not interfere in a case of permissive waste by tenant for life.

Prohibition against timber culting.-Freehold, eopyhoid, and leasehold estates were devised and beqneathed to A. B. in fee simple, subject to a linitation orer, by way of executory derise, in the event of A. B. dying without learing issue male living at his death, with a profibition against his cutling limber, and with a discretion as to the eopyhold and leasehold catates (held upon leases determinable with lives) that such property should be kept "fully estated" with three lives. A. B. died without issue male, and during his life committed varions aets of waste by cutting down timler and allowing the property to become dilapidated. He also onitted to keep the copyholds and leaseholds " fully estated." It was held by Kindersley V.C., that it was eompetent for the testator to impose npon $\mathrm{A}$. B. the olligation not to eut timber, although withont such prohilition he conld have done so ; and also that $\Lambda$. B. was nnder no obligation to repair, and was not liable for permissive waste, but all losses consequent upon his omission to keep the property finlly estated with three lives must be borne by the estate (Blake v. Pelers).

Infinition of "limber" in "reluution.-The defendant having told the plaintill, a land surveyor, that he was tenant for life of an estate, and wanterl to sell every stick of timber on it, gave him an order signed by himself to value it at a certain rate jer eent. The witnesses on both sides agreed that limber ordinarily merent liees of a certain growlh, and the valuation included mere saplings, so that it did not show the valne 
of the timber, and it was held by Cockburn C.J. that there was nothing to show that the word "timber" was not used in its ordinary sense, and that therefore the jury might find the valuation to be valucless (Whitty v. Lor(t Ditton).

Fences and trees in churchyard.-At common law the parishioners are bound to repair the fences of the churchyard, although custom may in particular cases throw the obligation upon either the parson or the owners of particular estates. But the parishioners have no power to cut down trees or mow the grass in the churchyard, withont the consent of the parson, to whom they belong. He can, however, only cut down the trees (unless they are decayed) for the repair of the church or parsonage honse (Holdsworth's Handy Boole of Parish Law', p. 16).

Cutting down ornamental timber or immature trees by devisee in fee.A devisec in fee, subject to an executory devise over, is not impeachable for waste, but the Court will restrain him from committing equitable waste, by cutting down ornamental timber or immature trees: per Woot V.C. This decision was affirmed by Lord Chancellor Campbell. His Lordship stated that he was quite willing with Irood V.C., to accept the clue by which Lord Justice Tumer in Micklethurait v. Micklethwait (1 De Gex. \& Jo. 504, and 26 I. J. Ch. (N. S.) 721,) proposed to solve the difficulty. "If a devisor or settler occupies a mansion-honse, with trees planted or left standing for ornament round or abont it, or keeps such a mansion-house in a state for occupation, and devises or settles it so as to go in a course of succession, he may be reasonably presumed to anticipate that those who are to snceed him will occupy the mansionhouse ; and it camnot be presumed that he meant it to be deprived of that ornament which he himself enjoyed. The tenant for life sans u'aste is as much owner of the timber as the tenant in fee; their legal rights in this respect are identical "(Tumer. v. Wright)."

Claim of right to enter close of another and cut dou'n trees. - To an action of trespass for cutting down and carrying away trees growing in the close of the plaintiff, the defendant pleaded an immemorial enjoyment of a right in one A. B., the owner in fee of a close, and all those whose estate he had, and his and their tenants, to enter on a part or strip of the said close of the plaintiff, and to ent down and convert to their own use the trees growing there, such right being claimed as appurtenant to the close of the said A. B., but the plea did not allege that the timber so taken was not to be nsed in any way in or about the said close of A. B. Averment that the defendant was tenant to A. B. of the said close, and that the trees were cut down by the defendant in exercise of the said right. There were other pleas, which set up the enjoyment of a precisely similar right for 60 years and 30 years respectively; and 
also a plea alleging a grant by deed, which was lost, by the then owner in fee, of the close of the plaintifl to the then owner in fee of the close of the defendant, of the right now elaimed. It was held by the Court of Common Pleas, that all the pleas were bad, as the right claimed being a right in gross conld not pass with the occupation of the land. Semute also that such a right could not pass with the ownership of land; and per Wiltes J., "Except in the case of landlord and tenant, in order that rights orer the land of one may be attached to the land of another, so as to pass with the ownership of the land, they must be such rights as aré bencficial to the omner of the dominant tenement, only so long as he remains orner of that tenement, and to other persons are of no benefit whaterer" (Baitey r. Slevens.)

liough orerhanging Tamel. - It is a nuisance if a man allows the boughs of his trees to grow so that they orerhang his neighbour's land (Earl of Lonsctule v. Netson).

T'aking timber for house-bote.-In a lease for lives of a manor and demesue, the lessee corenanted to repair, and keep the premises in all needful and necessary reparations, having or taking in and upon the demised premises competent and sufficient house-bote for the doing thereof, withont committing waste, and it was held by the Court of Queen's Bench that the covenant was an absolute and not a conditional covenant to repair with a license to take timber for louse-bote (Dean and ('hapter of Bristol v. Jones and ollhers).

Eividence of conversion of tree.--In the case of (Bird v. Bond) A. having sold to B. some growing trees, B. cntered to cut them down, whereupon C., who was on the land as a trespasser, servel B. with a notice not to fell any of the timber. B. having desisted, C. subsequently cut down the tree but did not remove it: It was held by the Court of Exchequer that C. had not been guilty of a conversion of the tree.

C'ustom for copyholders to fell timber without license from Lord. - A custom for copyhold tenants to fell timber or other trees upon their customary lands, and to retain the same for their own use, withont license from the lord, although such timber may not be felled for necessary repairs, was held by the Court of Common Pleas, not to be unreasonable, and such a custom is not the less admissible in evidence because it also professes to entitle the customary tenants to plough up meadow land, and to suffer their houses to decay, which might be a bal custom if pleaded (Blevett app. r. Jenkins resp.).

In Doe dem. Riogers v. Price, a lease contained a demise of land and quarries, with jower to open and work them at a certain rent and royalties, with an exception of the trees on the premises. The lessee covenanted not to commit waste by cutting the trees, \&c., and there 
was a proviso for re-entry in case the lessee should commit any waste by any of the means aforesaid. He, howerer, cut cloun trees which it was necessary to remove in order to work the quarries, and the Court on Common Pleas held that this was not a breach of the covenant working a forfeiture, and that the covenant meant that the lessee was not to cut down the trees excepted so as that the cutting should anonnt to an excess of the rights which it was intended that he should exercise. The case, Courthorpe v. Maplesden, in which the Court of Chancery granted an injunction against a trespasser culting timber by collusion with the tenant, is the strongest case in which it has interfered to restrain waste, and there is no case in which it has interfered to restrain the acts of a mere trespasser ; but semble, if the acts complained of are such flagrant acts of malicious waste as to indicate fraud, that would be a case for interference; per Wool V.C. (Earl Talbot v. Hope Scott). And a party in possession of lands and proceeding to cut timber wastefully, will be restrained by injunction from doing so at the instance of another claiming under a title at law (Neale v. Cripps).

The trustees of an estate fur autre vie cannot bring trover for trees felled on the estate; they have a special property in them while standing, but on severance they belong to the owner of the inheritance (Blaker v. Anscombe). But a lessor has such a possession of timber cut down during the continuance of a lease as to maintain trover for it, for a lessee's interest in the timber determines upon severance (Berry v. Herd), a case which Laurence J. cited in Gordon v. Harper, as decisive npon this point. So he may maintain trover for barl: of trees cut, and for the trees though they be cut into boards, for the principal substance remains. The landlord of a tenant from year to year, thongh there is no reservation of the timber on the premises, may support trespass vi et a'mis against a third person for carrying it away after it has been cut down (Warl v. Andiew's). Lawrence J. decided in Evans v. Evans that the tenant for years could not maintain trespass de bon asp for timber cut down on the demised premises; he had no property or interest whatsoever in the trees after they were severed from the freehold, and they were then in the legal possession of the reversioner, and he alone conld maintain trespass for the asportation. Where the trees are excepted in the Tease, the lessee has no manner of interest whatever in them, and the lessor may have an action for trespass against him if he either fells or damages them (Ashmead v. Ranger, 1 Ld. Raym. 552).

Where there is no exception of them in the lease, both lessor and lessee have an interest in the trees, and therefore if a stranger cuts them down, each of them shall have an action against him to recover their respective loss : the lessee in respect of his loss of their mast and fruit and shade 
for his cattle. A lessec for life or years has only a special interest and property in timber trees so long as they are annexed to the land, and may lop them if the body of the trees is not thereby injured. Therefore if the lessor fells them, the lessee has trespass against him, and will be entitled to recorer damages adequate to the loss of his particular interest, and also for the entry into his land. But the interest in the body of the trees remains in the lessor, as parcel of his inheritance, who may punish the lessec in an action of waste, if he fells or damages any of them. The lessee has a general property in hedges, bushes, and trees which are not timber, and may have them if he cuts them down. So he may claim dotards, which hare no timber in them, if they are thrown down by a tempest, but not trees for which the lessor may have trover (Herlakenden's case). Where the lease of a farm contained the following exception, "except also all and all manner of timber, timber" trees, sc., wood, underwood, topwood, bushes, and thorns, other than such bushes and thorns as shall be necessary for the repairs of the fences; as well as corenants that the lessce would, during the continuance of the term, keep the gates, \&c., and fences belonging to the premises, in a good and proper state of repair, finding all materials except as therein mentioned, the lessor finding rough wood for making such repairs, if growing upon the premises; and that the lessor wonld, during the lease, find and provide, if growing on the premises, sufficient rough timber, stakes, and bushes, for doing such repairs, -it was held in Error, Pollock C.B. dub., that all trees and all bushes, whether forming part of the fences or not, or necessary for repairs or not, were excepted from the demise; and as timber trees, thongh in hedge-rows (and though the body of the tree might form part of the fence), would not probably pass to the tenant, but may be cut down by the landlord, leaving the tenant under the obligation to repair the gap thereby made in the fences ; so in like manner bushes and thorns might be cut down and removed (Jenny and Rumnacles $\mathrm{r}$. Brook).

It was decided in Haterman $\mathrm{v}$. Soper, that if there be two tenants $\mathrm{m}$. common of a tree, and one cuts the whole tree, the other may not have an action for the tree, but for the special damage sustained by the misfeasance of cutting, as where one tenant in common destroys the whole flight of pigeons. And according to Martin $\mathrm{v}$. Knollys, an action on the case in the nature of waste will not lie by one tenant in common against another tenant in common, for catting trees of a proper age and grouth. In this case, the defendant occupied the whole of the land, having a demise from the plaintiff of his moicty. Hecth J. directed a verdict to be taken by the plaintiff for the value of half the trees growing, with leave to move, but the verdict was ordered to be entered for the defen- 
dant by the Court of King's Bench. Lord Kemyon C.J. said, "This verdict has neither principle nor authority for its support. The defendant cannot be in a worse situation by being tenant to the plaintiff of his moiety, than he would have been if the plaintiff had not demised to him, and considered in that point of view this action $e x$ deliclo cannot be supported. If one tenant in common misuse that which he has in common with another, he is answerable to the other in action of misfeasance. But here it does not appear that the defendant committed anything like waste: no injury was done to the inheritance; no timber was improperly felled, the defendant only cut those trees that were fit to be cut. And if he were liable in such an action as this, it would have the effect of enabling one tenant in common to prevent the other's taking the fair profits of their estate. In another form of action the plaintiff will be entitled to recover a moiety of the trees that were cut" (1 Ld. Raym. 737 ; B. N. P. 85 ; 2 Roll. Rep. 255).

The following rule was laid down in Waterman v. Soper as to the property in a tree. If $\Lambda$. plants a tree upon the extremest limits of his land, which in course of time extends its root into the land of B. next adjoining, $\Lambda$. and $B$. are tenants in common of the tree; but if all the root grows into the land of $\mathrm{A}$., though the boughs overshadow the land of $B$., yet the branches follow the root, and the property of the whole is in A. This question was re-opened in Holder v. Coctes. There the plaintiff's and defendant's land adjoined, the former being the higher of the two, and the plaintiff's hedge separated them, standing on the edge of the plaintiff's ground, on the bank or declivity descending to that of the defendant. Tbe trunk of the tree stood in the defendant's land, but some of the lateral or spur roots grew into the land of both parties, and evidence was given on the part of the plaintiff to show that there was no tap root, and that all the principal roots from which the tree derived its main nourishment were those which grew into the plaintiff's land. The defendant, on the contrary, gave evidence that there was a tap root, growing entirely in his land, and that the spur roots grew alike in the lands of both parties; and urged that at all events he was a tenant in common of the tree, and that trespass could not be supported, according to the rule in Waterman $\nabla$. Soper. Littledale J. said that there was another case on the subject, Masters v. Pollie, in which it was considered that if a tree grows in A.'s close, though the roots grow in B.'s, yet the body or main part of the tree being in A.'s soil, all the residue of the tree belongs to him, and he intimated to the jury that he thought this doctrine the preferable one of the trro. His lordship then advised them to ascertain if possible in whose land the tree was first sown or planted. The jury said they conld not tell, and a verdict for the defendant was 
taken by consent (II. \& MI. 112; for Hasters v. Pollie, sce 2 Roll. Rep. 141).

A rery complicated ease of this kind, Dixon $\mathrm{v}$. Gelderd, was tried at the Nestmoreland Summer Assizes, 1857. The tree in question was nearly one hundred years old, and grew in a fence dividing the land of the plaintiff' from the land of the defendant. The fence had always been repaired by the plaintiff, and was admitted to belong to him. It was an old one made up of dry materials, the part near to the tree being what is called a "copped" fence, and the tree in question, a large oak, stood apart from it, rather more to the side of the field belonging to the defendant than to the side of the field belonging to the plaintifl. On the defendant's side of the hedge, elose to it, a short distance from the oak, some ash trees were growing, which, being in the defendant's field and forming no part of the hedge, it was conceded, belonged to him. The cviclence for the plaintiff also went to show that the heart of the tree was a foot nearer the defendant's land than the plaintiff's. There was also, close by the tree, a thorn growing further into the field than the tree, which thorn, when the hedge was repaired, was ahways ent at the bottom and lail back in the hedge. The defence was that the tree was originally planted on the defendant's land, which gave him a right to cut it down, and that supposing it did form part of the fence, if it was originally so planted, the fact of its beconing part of the fence would not alter the ownership. In May, 1857, the plaintiff thought about felling the tree, and spoke to Mr. John Nelson, a carpenter and wood merchant, about it. No bargain was come to, but the price named was $£ 10$. This circumstance reached the ears of the defendant on a Saturday, and he immediately employed two men to cut down and bark the tree as soon as possible after 12 o'clock on Sunday night, and an action of trespass was brought. After a grent deal of contradictory evidence on both sides, the plaintiff had a verdict of $£ 10$.

Timber trees are those which serve for building, or reparation of houses ; such as ouk, ash, and $\mathrm{ctm}$, of the age of 20 years and upwards; but by the curstom of some countries certain trees not usually considered as timber are deemed to be such, being there used for building. Becch, or buck as it was once termed, was admitted in Aubrey v. Fisher to be timler by the custom of the country (Bucks), like oak and ash, and hence the general rule of law, applicable to timber trees, attaches to it so as to gire it the property and privileges of timber at 20 jears' growth. No eridenee was allowed to qualify its character as such, where the trees were more than 20 years old, as for instance that by the custom of the country it was not deemed timber unless it contained 10 feet of solid 
wood. But in Rex v. Minchinhampton, Lord Hansfielel C.J. said, "Beech is certainly not timber by the general law of the land, yet it may be by the particular custom of the place. I do not mean of the county (Gloncester), but that particular part of the country where the trees grow. It is not the use it is put to that makes it either timber or not timber ; its being or not being timber depends upon the custom of the country. And if it be timber by the custom of the country, it must be presumed, and it may be true in fact ' that it was timber before the time of Queen Elizabeth." Mr. White, in a note to his edition of "Cruise's Digest," vol i. 116, says, "Birch trees are considered timber in Yorkshire and Cumberland; beech, cherry, and aspen in Buckinghamshire; beech also in Gloucestershire and Bedfordshire; beech and willow in Hants : in some places, white thorn, holly, black thorn, horse chestnut, lime, yew, crab, and hornbean: in other distriets, pollerts, or other timber trees which have been lopjed, are, contrary to general estimation, also considered timber." Lord King held watnut trees to be timber, and pollards, if their bodies are sound.

Fir and larches planted with oaks, for the purpose of sheltering the latter, and cut from time to time, as the oaks grew larger and recpuired more space, but once cut not growing again, and some of them yielding a profit by sale, were held in Rex v. Inhabitants of Ferrybridye not to be suleuble underwoods within the 43 Eliz. c. 2, the primary object of planting them being to protect the oaks, and not to derive a profit from them per se by salc. And per Bayley J.: "Generally speaking, the term ' underwood' is applied to a species of wood which grows expeditiously and sends up many shoots from one stool, the root remaining perfect from which the shoots are cut, and producing new shoots, and so yielding a succession of profits. It is probable that this is the description of underwood to which the statute of Etizabeth applies. But it is not necessary to decide that, inasmuch as that statute also requires that it should be saleable underwood, and the word saleable in Rex r. Inhatitents of Mirficld has been held to denote such as is intended or destined for sale, in contradistinction to such as is to supply the land with estovers for fuel and other purposes of the estate. It does not, therefore, come within the deseription of saleable underwood, unless the prospect of deriving a profit by sale was the main object of the proprietor when the plantation was made." In Reg. v. Inhabitants of Narberth North, a wood consisting of oak growing from old stools, with a few ash, alder, and beech trees, had not been felled for 50 years, until three years before it was rated. During the last three years, the owner had annually cut the worst shoots, selling the poles by the dozen for colliery purposes and firewood, and the bark by the torl ; the rood was also occasionally 
waste-weeded to improve the plantation, and the waste weedings were allowed to lie on the ground to rot. The Conrt of Queen's Bench confirmed the finding of the sessions, that the rood was not saleable undermood within stat. 48 Etiz. c. 2.

Littledale J. said, "'The first question is whether this wood is underwood? Small wood never likely to be used for timber may be ealled underwood; so may plantations of timber trees not intended for permaneut growth, but to be cut at stated intervals for use as hop-poles, or for other similar purposes. Here the poles were nerer meant for growth as timber, and may therefore be properly ealled nnderwood. Then are they saleable underwoods? A capacity of being sold for profit belongs to all wood; the statute must therefore be taken to mean underwoods cut dom for sale at regular and calculable periods. The question, therefore, becomes one of fact, which the justices at sessions must decide, taking into consideration the mode of managing that sort of property, the time of ertting, and other circumstances." And in Rex $\mathrm{v}$. Inhabitants of Mirfield, the Court of Queen's Bench intimated that the fair mode of rating saleable underuoods would be to rate them yearly at such a sum as a tenant would be willing to give them annually upon a 21 years' lease.

The question whether coprolites were rateable or not was a most important one, and was first raised in the case of Roculs v. The Ocerseers of T'rumpington, 5 L. R. Q. B. 56.

The appellant was rated as oceupier of five acres of land on a gross estimated rental of $£ 43110 \mathrm{~s}$, and a rateable value of $£ 25610 \mathrm{~s}$.

The Court of Queen's Bench, without expressing any opinion as to the amount of the rate, which was a matter not in dispute in the case, decided that as the appellant was in oceupation of the land in respect of which he was rated, he was properly rated.

The Court of Queen's Bench having thus decided that coprolite pits were rateable, another question arose as to the principle on which they were to be rated, and this was decided in the case of Reg. v. Overscers of IVhadelon, 10 L. R. Q. B. 230.

The Assessment Committee rated the appellant in respect of ten acres of coprolite land at a gross rental of $₫ 840$ and a rateable value of $£ 630$. By an agreement with the Earl of Hardwicke, the appellant contracted to pay $\$ 115$ an acre for the coprolite land, and to dig sufficient land to pay the Earl $£ 1000$ per annum at least, such sum to be paid quarterly, whether suffieient land was dug over in any one year to amount to that sum or not.

It was argued on the part of the appellant that he was nerer in bencficial occupation of more than three and a half acres at any one 
time, and that he could not be rated in any one rate for more than that amount.

It was held by Mellor, Lush, and Archibald, JJ. (dissentiente, Cockburn, C.J.) that the appellant ought to be rated in each rate in respect of ten aeres at their enhanced ralue.

A bitl will lie to restrain a tenant for life from cutting doun underuooul aud timber generally of an insufficient growth (Brydlyes v. Stephens); and according to Pigot v. Bullock, he has no property in the underwood till his estate comes into possession, and therefore he cannot have an account of what was cut wrongfully by a preceding tenant. In Galecey v. Baker it was held by the House of Lords, affirming the judgment of the Court below, that a clause in an indenture of lease reserving ont of the demise to the lessor "all wood and underwood, timber and timber trees standing, growing, or being thereon, or at any time thereafter to stand or grow thereon, with full and free liberty of ingress and egress to take and carry away the same," applies only to trees standing when the lease was granted, and not to those afterwards planted by the tenant. Its operation is so restricted by the 23 \& 24 Gco. III. c. 39.

In a Devonshire apple-farm lease, by an exeeption of "all trees, woods, coppice, wood grounds, of what kind or growth soever," apple trees are not exeepted (I'ymlham v. Wray). In Bullen v. Denning it was held by the Court of King's Bench that where in a cider county a lessor demises "all timber and other trees, but not the amnual fruit thereof," apple trees are not within the exception. This was a case of trespass for felling the plaintiff's apple trees, and a rerdict having been found for the plaintiff, the Court made the rule absolute to enter a nonsuit. Littledale, J. said, "The word trees, generally speaking, means wood applicable to buildings, and does not inelude orchard trees. The words 'not the anmual fruit thcreof' may apply either to the prodnce of orchard or to that of timber trees. Those words may therefore be satisfied without holding them to apply to the produce of orchard trees. And as it is doubtful whether it was intended to exeept fruit trees, the words of the exception must be construed favourably for the lessee. I think we are therefore bound to hold that fruit trees do not come within it." Bayley J. also observed in the course of his judgment that "the term firut in legal acceptation is not confined to the produce of those trees which in popular language are called fruit trees, but applies also to the produce of the oak, elm, and walnut trees. In the old books the lessee is stated to have an interest in the trees in respect of the shade for cattle and the fruit thereof. Looking at the nature of the subject-matter of demise, which is land situate in a county where cider is made, and where apples constitute a great part of 
the amunal produce, I think it is not very likely that the lessor would make apple trees the subject of an express exception." A corenant in a lease to deliver up at the end of the term all the trees standing in an orchard at the time of the demise, "iensonable use and arear only cxcepted," is not brokien by removing trees decayed and past bearing from a part of the orchard, which was too crowded (Doe dem Jones r. Crouch). Here nine trees had been ent down, and nine planted, and Lord Ellenberough held that the above was "a reasonable use of the orchard and the trees." A tenemt of a nurser"y yround and gerden may, at the expiration of his tenancy, remoce such trees as are saleable hy him in his trade as a nurseryman, but not such as are only cultivated with a riew to the fruit they yield, and are used by him as a market gardener; and it is entirely a question for the jury, whether they come under one description or the other (Wretell v. Usher).

Alderson B. in Phillips v. Smilh thus defined Wrasle: "The destruction of germens or young plants destined to become trees (Co. Litt. 43), which destroys the futmre timber, is waste; the cutting of apple trees in a garden or orchard, or the eutting down a quickset hedge of thorns (Co. Litt. 53 a), which changes the nature of the thing demised; or the eradicating or unseasonable cutting of white thorns (Vin. Abr. Waste, E), which destroys the future growth, are all acts of waste. On the other hand, those acts are not waste which, as Richardson C.J. in Larrell r. Barrelt says, are not prejudicial to the inheritance, as, in that case, the eutting of sallows, maples, beeches, and thorns, those alleged to be of the age of 33 years, but which were not timber either by the gencral law or particular local custom. So likewise eutting even of oaks or ashes, where they are of seasonable wood, i.e., where they are cut ustially as underwood, and in due course are to grow up again from the stumps, is not waste." It is laid down in Co. Litt. 53 a, that "maste properly is in limber lrees (oak, ash, and elm, and these be timber in all places), either by cuiting of them down, or topping of them, or doing any act whereby the timber may decay. Also in countries where timler is scant, and becches or the like are converted to buildings for the habitations of man or the like, they are all accounted timber : "and that "cutting down of willows, bech, birch, ash, maple, or the like, shemeling in the defonre ent sefeguard of the house, is destruction."

In Phillips r. Smilh, the only acts proved against the lefendant were cutting down for sale screral pollerd willow trees, of a considerable size, whirh grewe on llee side of a brook, but were not shown to be of any service as a support of the bank against the water, nor to be of any protection to the farmhouse, and also some trivial injuries to the fences. The willows were cut close to the ground, leaving the stools or butls, 
from which fresh shoots grew again. It was contended for the defendant, that such cutting down of these trees was not a breach of the implied agreement to cultivate according to good husbandry and in a tenant-like manner, while the plaintiff asserted it was positive waste. Haute J. reserved the point, and the jury having assessed the value of the willows cut down at $£ 64$, gave the defendant leave to move to reduce the damages $(£ 664 s .6 \%$. in all) by that sum. The Court of Exchequer decided that it was not waste, Rolfe B. intimating that he considered that cutting down a fir tree would be waste because it would not grow again. And per curiam, "Applying the principles to be extracted from all the authorities to the present case, we have no difficulty in saying that the cutting of these willows does not amount to waste. They are not timber trees, and when cut down they are not, so far as appears by the evidence, destroyed, but grow up again from their stumps, and produce again their orelinary and usued profit by such growth; therefore neither is the thing demised destroyed, nor is the thing demised changed as to the inheritance, for profit remains, as before, derivable from the reproduction of the wood from the stump of the willow cut down. Nor are the trees in such a situation as to make the cutting of them waste, by reason of what is called collateral respect; as where trees not timber are situated so as to be useful for protection of a housc (Co. Litt. 53 ), and so become, as it were, part of the honse; as in Hob. 219, willows growing within the site of the house. Nor are they willors within view of the manor house, which defend it from the wind, or in a bank to sustain the bank (12 H. 8, 1); or like whitethorns used for the like purpose, or where they stand in a field depastured, and are used for the shade of the beasts depasturing, and so are intended permanently to remain in that particular form, for the advantage of those to whom the inheritance may thereafter come" (14 MI. \& W. 589).

This case was referred to by Jilles J., in his summing up in Viscount Hood v. Kendall, which was an ash-pole case. The defendant held a farm as tenant from year to year, upon a written agreement, by which it was stipulated amongst other things that he should cultivate the farm "in the same way and manner, or as near thereto as cireumstances would admit of, as one Henry Parsons (the outgoing tenant) used, and cultivated the same during his occupation thereof, and in all events according to the rules of good husbandry, used and accustomed in the neighbourhood." In an action against the outgoing tenant, alleging. for breach amongst others, the cutting and carrying away of ash-poles (stch user not beiug as near to the way and manner in which Parsons used and cultivated the farm as circumstances admitted, and being contrary to the rules of good husbandry used and accustomed in the 
neighbourhood), it appeared that the poles in question consisted of shoots growing from old stools, which were seasonable and fit for cutting abont every 17 or 18 years, that by invariable custom they belonged to the landlord in the absence of a special agreement to the contrary; that, whilst Parsons held the farm, these poles had never been in a fit state for cutting; that two tenants who had preceded Parsons in the ocenpation of the farm had cut and sold them as crops, and that Kendall hal, whilst he occupied, paid the rates for the whole furm, including the wool or spinney in which the poles grew. When Parsons became the tenant, the spinncy was ralned as between him and the outgoing tenant at $£ 509 s$. $6 d$.: the valuation describing it is, "' 'T'welve acres of spinney, some of them of three and some of four years' growth; " but there was no evidence that it was valued from Parsons to the defendant's father when he became the tenant (17 C. B. 260).

Hilles J. finally left three questions to the jury, the third being whether the landlord or tenant was entitled to the poles. IIs lordship told them that he thought ash, oak, and elm were primi facie timber trees; that they might assume the character of a crop, and be ent by the tenant, if the usage had for a series of years, and through a suecession of tenancies, been to eut them from time to time, as snch, and allow them to grow up again from the old stumps; and that if there was a custom of the country for the landlord to be entitled to the poles, though of that character, such custom would take away the right of the tenant. And he left it to them to say what was the eharacter of the poles, and whether there was a enstom for the landlord to have them, and whether this case was within the custom. The jury found for the plaintiff as to the poles, damages $£ 7+3 s$. $9 c$., saying that there is a uniersal custom that such poles are not crops, but belong to the landlord, unless there is a special agrecment. His lordship reserved leare to the defendant to move to enter a verdict for him, if the Court should be of opinion that notwithstanding the custom the defendant had a right to the poles. 'The Court of Common Pleas held that it was important to consider on what terms Parsons had held the farm, and that as this question was not left to the jury, there should be a new trial. The case was, however, settled. And where a purchaser of a field entered into possession under the contract, and filled up a pond and stubbed up an osier bed, Knight Bruce V.C. held that these acts did not anount to a waiver of title, but that the purchaser would not be allowed the usual reference for title, unless he paid the purchase-money, and all the interest accrued due on it, into Court within three weeks (Ostorne r. Harvey).

A tenant's right to dotards was fully discussed in Channon r. Palch, 
where a lessor during the term cut down two decayed oak pollards growing upon the demised premises, which were only fit for firewood. The third resolution in Herlakenden's case, that if trees being timber were blou'n dou'n by the wind the lessor shall have them (for they are parcel of his inheritance), and not the tenant for life or tenant for years; but if they be dotards withont any timber in them, the tenant for life or years shall hare them, was held to be an anthority that this action of trespass against the tenant was not maintainable. For if the lessor would have had no right to the trees if they had been severed from the inheritance by the act of God, neither he nor his vendee (the plaintiff), who claimed under him, could have any right to them when they had been severed by his own wrongful act. If these trees had been blown down, they wonld have belonged to the tenant (Countess of Cumberland's case), and the landlord conld not by wrongfully cutting down the trees acquire a right to them, so as to entitle him to maintain trespass against the tenant for taking them away. That would be allowing him to take advantage of his own wrong, for the lessee during the term being entitled to the usufruct of the trees might have maintained an action on the ease against the landlord for wrongfully cutting them down.

Lord Denman C.J. ruled, in Doe dem. Wetheretl v. Bird, that a covenant "not to remove or grub up or destroy" trees, is broken by removing trees from one part of the premises to another; and so it is by taking away trees, even if the lessee plant a greater quantity than he takes away, unless those taken away were dead. In Woodhouse v. Surift evidence was giren to prove that the timber removed was not wholly sound, that a small part of one tree was rotten, and that four other trees were "shaky," which one of the witnesses said amounted to unsoundness. Alderson J. allowed the plaintiff to show that the word "sound" had a techuical meaning in the timber trade, but the case failed upon the facts. A tenant for years of a garden has no right to remove $a$ border of box planted by himself; and Parke J. said it might as well be contended that a tenant could take up hedges (Empson v. Soden).

In Micklethu'rit v. Micklethu'ceit an injunction was granted to restrain the defendant, who was under the testator's will tenant for life, without impeachment for waste, of two estates, Beeston and Taverham Hall, within eight miles of each other, from cutting down trees in the arenue or perk at Beeston. Wool V.C. did not consider the circumstances of the testator pulling down the mansion at Beeston, where he had ceased to reside 33 years before his death, and felling some of the trees, added to the leasing power in the will over all the real estate, except 
the mansion at Tarerham Hall, as well as a power of sale and exchange, sufficient to deprive the timber upon the estate of its ornamental charineter. This ex parte injunction was, however, dissolved by the Lords Justices, who held that timber to be ormamental, so as to entitle it to the protection of the Court against eqnitable waste, must be conneeted with or adjacent to a residenee. Beeston had been wholly dismantled; the wire fence protecting the ornamental garden had been removed to Taverham; the gardens and pleasure-grounds were suffered to grow wild, with the exception of the litehen-garden, which was let to a market-gardener ; and the testator, who was fond of shooting, seemed, after his removal, to have regarded the whole estate merely as a preserre for game.

Where the owner of an estate with residence purchases the adjoining lands with ornamental zrools, the Court will not, from that fact alone, infer that he intended to be left standing for ornament all such trees as he did not in his lifetime eut down; there mnst be some act of dedication, e.g. planting an arenne, entting a vista, ereeting obelisks, \&e.; per Sir W. P. Wood T.C. (Hallinell v. Phillips). A tree or trees may be highly ormamental, and yet not be entitled to the protection of the Court, as being planted or left standing for ornament; bnt saplings and hedgerow trees, or any trees, however ormamental, if planted also for profit, are not within the doetrine (ib.). $\Lambda$ tenant for life sans waste will not be interfered with in the exercise of his legal powers, unless he is proceeding to use those legal powers in a manner inequitable towards those in remainder; and therefore he may fell and sell trees planted for ornament if done in a proper course of husbandry $(i b$.$) , and an injunc-$ tion restraining a tenant for life, without impeachment of waste, from cutting limber growing for ornament or shelter, extends to clumps of furap on "common two miles from the honse which had been planted for ornament (Marquis of Dou'nshire v. Latly Suntys, 6 Ves. 107).

Where an estate was limited to one for life, with a clause of forfeiture and a gift over on his entting timber, and there was on it limber, and other trees, not being in any rookery, or serving for ornament, shelter, or protection to a mansion honse, which required folling, Lord Langdale M.R., on a bill filed for that pmrpose by the tenant for life, anthorized the same to be eut down, and directed a reference to the Master for the purpose, the money arising from the timber in such case to be settled on trusts similar to those on which the estate stood limited (Peters $\mathrm{v}$. Bluke). And see Delupole v. Delapole, Hussey v. Hussey, and Wieliham. v. Wirkham. Where an estate was devised to $A$. for life, impeachable for waste, remainder to $\mathrm{B}$. for life withont impeachment of waste, with remainder to $C$. in fee, and it became necessary in $\Lambda$.'s lifetime to cut 
timber, the proceeds of which were invested and the interest paid to him for life, and on A.'s death B. claimed the proceeds of the timber for his own use, and C. the reversioner in fee, resisted the claim, on the ground that they formed part of the corpus of the estate, it was held by Shadwell V.C., in conformity with Waldo v. Waldo, that B. was entitled to receive the proceeds (Philipps v. Barlow).

In an action of waste for cutting timber, the defendant cannot give in evidence, even in mitigation of damages, that the timber was cut for the murpose of necessary repairs, but tnming ont unfit for the purpose was exchanged for other timber, which was applied to the repairs (Simmons v. Norton). He should have specially pleaded that he cut it for repairs, and he was bound to confine himself to fell such trees as were proper for repairs. And per Bosenquet J., thongh the tenant may fell trees for necessary botes, he must at his own peril sclect such as are fit for the purpose, and employ them accordingly.

Such a clanse in a lease as "all the hedyes, trees, thom bushes, fences, with the lop and top, are respreed to the landlort," was decided in Hmitt v. Sir C. Isham to afford evidence of leave and licence, if the landlord enters and, having cut down some trees, digs sawpits in the land for the purpose of sawing the timber. Here the plaintiff was tenant to the defendant, of a farm under a parol demise, which contained the above stipnlation, on which (althongh he gave evidence that the act was done with plaintiff's permission) the cefendant principally relied. Mamle J. directed the jury that the stipulation in the lease afforded evidence of leave and licence, and the Conrt of Exchequer refised to set aside a verdict for the defendant. And per Purlie B. : "This stipulation conld not operate as a grant or an easement, becanse it is not under seal. It can only operate as a licence from time to - time to enter upon the land (Wood v. Lealbitter, Kavanagh v. Gullye). In Liford's case (11 Rep. 51 乙) it was resolver, "that when the lessol' excepted the trees, and afterwards had an intention to sell them, the law gave him, and them who wonld buy, a power, as incident to the exception, to enter and show the trees to those who wonld have them, for without sight none wonld buy, and withont entry they conld not see them.' So that, according to the authority of that case, whererer trees are excepter from a demise there is by impliention right in the landlord to enter the land, and cut the trees at all reasonable times. If, indeed, he leaves them on the land for an nnreasonable time, he does more than the law authorizes him to do. But here there was no evidence of that."

Williams v. Currie was an aggravated case of liespass on the part of the defeudant, who was landlord to the plaintiff of four grass 
closes (37 acres), which were laid up for hay in April, May, and June. Abont 100 trees (oak, ash, and elm) in the hedge-rows and the close were cut down, and about trenty persons were employed in felling, lopping, and barking the trees, and stacking the fagots and bark, and great damage was done to the hedges. There were three sales-two in May and one in June; and the fagots and bark were not wholly remored till the 28th of September. Evidence was given as to the presumed value of the first and second crop of hay, and it seemed that but for such trespasses they might have yielded $£ 200$. The defendant paid $£ 50$ into Court, and pleaded no damage ultic : bnt the jury gare $£ 250$ more, and the Court refused to grant a new trial, on the ground of excessive damages. Maule J. said: "If we were to hold that the jury in estimating the damages for an unlicensed trespass of this sort are to be restrained to exactly the amount sustained by the plaintiff, it would in effect be placing a wrong-doer upon precisely the same footing as one who enters with the owner's permission." And semble, in actions for tort, the Court will not interfere with the damages found by the jury, unless they appear to be grossly disproportioned to the injury sustained. Holt C.J. also decided "on hearing of counsel several times," in Glenham v. Hanby, that if A. demises ground to B. which was pasture, except the trees, and B. puts in his cattle to feed, which bark the trees, A. has no action for trespass.

In Knoules v. Michel, it was proved that the plaintiff had sole to the defendants some standing trees, which the defendants had afterwards procured to be felled and taken axcay. When the writ was served on Wichel, both defendants admitted they had bonght the trees jointly for 9 guineas; but Michel said he would pay no more than half. On this evidence it was objected that the action was not maintainable, the contract being for standing trees, which were part of the reality. To this it was answered that the acknowledgment of the price to be paid for the trees, made after they were felled and applied to the use of the defendants, was sufficient to support the account stated, thongh there was no other item of account between the parties. The plaintiff was nonsuited; but the Court of King's Bench held that if there were an acknowledgment by the defendant of a debt due on any account, it was sufficient to enable the plaintiff to recover on an account stated, though not for goods sold and delivered. And see Simith v. Surman, cunte, p. 55. In Bragg v. Cole, the defendant agreed to purchase a lot of ash trees for a certain sum, and pay for them according to the conditions of the sale, but afterwards felled and carried away seven of them without making such payment, and refused to pay till the other three had been delivered. It was held that the executors having 
failed to establish the comnt on the special contract might recover the value of trees taken by the defendant as goods sold and delivered, as defendant by such taking had disaffirmed the entirety of the contract. Holroyll J., who tried the case, at first thonght that the plaintifis conld not recover on the counts for trees sold and delivered by the testator in his lifetime, bnt observed that delivery might be satisfied by the rendor's allowing part of the trees to be ent down and carried away by the defendant, and that the contract being for a mere chattel interest was not within the 4 th section of the Statute of Frands (6 B. Moore, 114).

The question of an entire timber contract arose in Bigg r. Th hisking (14 C.B. 195), where the plaintiff and defendant (who was exceedingly illiterate) went to sereral places a few miles distant from each other in one day, and agreed for the purchase and sale of several lots of timber. At the last place, where they dined, the plaintiff, at the request of the defendant, who said he should like him "to mut doun what we have been doing," drew ont and signed a memorandum of the rhole transaction. The defendant received several consignments of timber in London, advancing money for the carriage, which was to be allowed him by the plaintiff. When the residue arrived at the London terminus, the defendant objected that some portion of it was unsound, and the other portion not the timber contracted for, and ultimately he refused to receive it. For the plaintiff the after-dinner memorandum was relied on as binding npon him by reason of his signature, and upon the defendant by reason of his acceptance of part of the timber under it. Cressuell J. ruled, on the anthority of Elliot v. Thomas, that the whole transaction amounted to one entire contract, and that as part of the timber had been - received by the defendant, and money paid on accomt, the provisions of the statute $29 \mathrm{Car}$. II. c. 3, s. 17, were satisfied, and the Court discharged a rule for a new trial. It was clearly one transaction, regard being had to the peculiar nature and situation of the bulky articles which formed the subject of the contract. And per Irilliums J. : "Baldey v. Purlier, and Elliot v. Thomas, govern this case. The transaction amomnted to a joint contract for all the timber" (3 M.\& W. $170)$.

Acraman v. Horrice also turned mon what was a sufficient delivery and accoptance under the statute. The defendant was a timber-merchant, and the action was one of trover for oak timber, which had been purchased of Swift (the bankrupt) by the dcfendant, and marked, measured, and paid for before the date of the fut, but not actmally delivered at the appointed place. The first count alleged a conversion before, and the second, one after the bankruptey of Swift. To this defondant pleaded 
-1st. To the whole declaration, not guilty ; and 2udly and 3rdly, to the first and second counts, that Srift, and the plaintiffs, respectively, were not possessed, \&.e. 'The parties had long dealt together, and when trees were felled the defendant's agent marked and selected what would suit him. Swift then eut off the rejected parts, and at his own expense floated the trunks down the Serern to Chepstow. The timber in this action had been meastired and marked by the defendant's agent, but the rejected portions had not been severed by Swift before the issuing of the fut. After that date the defendant sent some workmen to sever the rejected portions, and carry the rest away, and considered that the measuring and marking of the timber by his agent was a sufficient delivery and acceptance within the Statnte of Frands, and passed the property in it to him. Under Coleridge J.'s direction the jury found for the plaintiff for $£ 95$, the agreed value of the timber so taken, and the Court refused to set the verdict aside.

Wilde C.J. said: "Upon a contract for a sale of goods, so long" as anything remains to be done to them by the seller the property does not pass, and the seller has a right to retain them. In the present case several things remain to be done: the buyer having selected and marked the particular parts of the trees which he wished to purchase, it became the seller's duty to sever those parts from the rest, and to convey them to Chepstow, and there deliver them at the purchaser's wharf. Now that which the buyer does for the purpose of enabling the seller to perform his part of the contract, cannot be considered as an acceptance of the article. The selection and marking must of necessity precede the delivery. What I understand by acceptance is an act done by two parties, one of whom is content to deliver, and the other to receire the subject-matter of the contract. 'The evidence here is, that the seller engaged that he would sever the tops and sidings, and after he had incurred the expenses of severing, he would incur the further expense of conreying the trunks to Chejstorr, and that the buyer undertook to accept the trunks when severed, and delivered to him at Chepstow. 'T'hat is the contract which was proved. This being the state of things, the seller becomes bankrupt, and the buyer anxions to get possession of the timber-which it appears he had paid for-goes to a place where he had no right to go, and takes upon himself to sever and carry away that which does not belong to him. 'The property elearly had not passed to the defendant, and he was gruilty of a trespass and conversion in possessing himself of it in the way he did." Again, in Tanstey r. Thumer the plaintiff sold Jenkins all the ash trees on one Bnckly's lands, where they lad grown, at 1s. $7 \frac{1}{2}$ l. per cubic foot, on credit. Some trees were measured and 
taken array, then all the residue were marked, and the length and girth of each tree were taken; but the total enbic eontents of them was not ascertained. When Jenkins beearue a bankrupt the plaintiff prevented his servants from drawing any more trees, and Jenkins acquiesced. Some time after the plaintiff drew the residue of the trees, which were lying where they had been felled, to his own sawpits, from which the defendant, after notice not to do so, took away two loads. It was held by the Court of Common Pleas, on an action of trespass, that as nothing remained to be done but the adding together of the different measurements, the property passed to the rendec, and that the defendant, as the vendee's assignee, was entitled to the possession of the tress, they having been fully delivered by the vendor, and the vendee not having any right to relinquish the contract, as he was at the time in a state of insolreney.

Where tu'o atjacent fietds are sprarated by a hedye and ditch, tho hedge mima furie belongs to the owner of the field in which the ditch is not. If there are tro ditches, one on each side of the hedge, the ownership of the hedge must be proved by showing acts of ownership. Per Bayley J. in Guy v. West (Som. Ass. 1808). His lordship thus referred to the subject in Noye v. Recel, where the landlord said that he had let the lane jointly to both plaintiff and defendant, as much to one as the other: "I admit that where there are separate owners of adjacent lands, the presumption is that a diteh between those lands belongs to the owner of the hedge; but this is the rule of presumption only, and applies only in cases of separate ownership; and therefore where the lands on each side are the property of the same landlord, as - he may let them as he thinks fit, and confine the rights of his tenants, the onus of making ont that the spot in question was his, was here cast npon the plaintiff. He proved his possession of the close up to the hedge of the lane, but he proved nothing more."

This case deeided that where adjucent lants betong to tu'o dislinct on'ners, the legal presumption is that the ditch which divides them is a part of the soil of him to whom the hedge belongs; and where a road was between those lands, the owner on each side has a right of use ad. medium fitum rice. But semble, that such presumption will not arise where the entire property of such lands is in one landlord, who has let thom out to different tenants; but that it will be incumbent upon either tenant who shall bring trespass against the other to prove his right of exclusive possession of the ditch, or the half of the road next to his close, in order to snstain the action (ib.).

According to Ellis v. Amison, a ditch which had been immemorially the only fence between the commons and adjoining townships, was con- 
silered "fence within the prorisions of the General Enclosure Act, 11 Geo. III. c. 109 (U.K.).

Toules r. Miller, which is a leading case on the lue of ditches, was an aetion by the tenant-in-fee of a close against the tenant-for-years of an adjoining close, for an injury to the plaintiff's reversion. The plaintiff proved that the defendant had a close contignous to a certain close of the plaintiff's, and surromeded by a fence (which the defendant was bound to keep in repair), consisting of a bank and ditch, and that in scouring the ditch the defendant had dug into the hard unmoved virgin soil of the plaintiff's close. The defendant, on the contrary, proved that this fence had been immemorially a bank with a ditch on the outside of it, and not a bank only; and he contended that consecuently he was entitled at common law to have a width of eight feet, as the reasonable width for the base of the bank and the area of his ditch together, which width, measured from the interior line of the base of his bank, he proved that he had not exceeded, admitting that if the fence were a bank only, he was entitled only to four feet. It was therempon contended for the plaintiff that whether the defendant's fence were a bank only, or a bank and a ditch, the action would lic, as the ditch was cut by the defendant's express directions into the soil of the plaintifl's close, so that it was made wider than erer it was before. 'The jury fonnd for the defendant; and a rule nisi, for a new trial, on the ground that the rerdict was against evidence, was discharged. Latrence J. thus stated the rule about ditching: "No man making a ditch can cut into his neighbour's soil, but usually he ents it to the very cxtremity of his own land. He is of course bound to throw the soil which he digs out upon his own land; and often, if he likes it, he plants a hedge on the top of it. Therefore, if he afterwards cuts beyond the edge of the ditch, which is the extremity of his land, he cuts into his ncighbour's land, and is a trespasser. No rule about four feet and eight feet has anything to do with it. He may cnt the ditch as much wider as he will, if he enlarges it into his own land" (3 'Taunt. 138).

An action on the case for not repairing fences, whereby another party is damaged, ean only be maintained against the oecupier, not against the wriner of the fee not in possession, unless the owner was bound to repair (Cherethem v. Ilempson). And per Lord Kenyon C.J.: "It is so notoriously the duty of the actual occupier to repair the fences, and so little the duty of the landlord, that without any agreement to that effect the landlord may maintain an action against his tenant for not so doing, mpon the ground of the injury done to the inheritance." And sce Payne v. Roger's (2 H. Bl. 349).

If two persons are possessed of atjoining closes, neither being under any 
obligution lo fence, each must take care that his cattle do not euter the land of the other. The one cannot clistrain the cattle of the other damaye feasant (Churchitl v. Exans). And per curiam in the case of T'encunt v.Goldecin: "There is a great diversity between a prescription to put a charge mpon a man to repair his fence, and to excuse one from trespass, for snch charge must be by preseription. Every one must use his own, so as therely not to hurt another; and as of common right one is bound to keep his cattle from trespassing on his neighbour, so he is bound to nse anything that is his so as not to hurt another by such nser. Suppose one sells a piece of pasture, lying open to another piece of pasture which the rendor has, the rendee is bound to keep his caltle from ruming into the rendor's piece; so of dung, or anything else."

In an action on the case for not repairing a mivale road leacting through the defendant's elose, it is sufficient for the plaintiff to allege that the defendant as occupier of the close is bound to repair (Rider $\mathrm{v}$. Simith). But if the defendant preseribe in right of his own estate, he must show the estate in right of which he claims the privilege (it).). The Court of King's Bench here were elearly of opinion that the declaration suffieiently charged the defendant by receson of his possession. And jeer Buller J.: "The distinction was between cases where the plaintiff lays a charge upon the right of the defendant, and where the defendant himself preseribes in right of his own estate. In the former case the plaintiff is presumed to be ignorant of the defendant's estate, and cannot therefore plead it ; but in the latter the defendant, knowing his own estate, in right of which he claims a privilege, must set it forth. In Rex v. Buclinall, I.ord Holt C.J., said: "Where a man is obliged to make fences against another, it is enough to say ommes occupatores onght to repair, \&e., because that lays a charge upon the right of another, which it may be he cannot particularly know.' And notwithstanding two out of the three judges were of a different opinion in Holbatch r. Warmer, jet several subsequent cases have been determined on the distinction. In 1 Ventr. 264 an anonymous action on the case against a defendant for not repairing a fence, where the allegation was that the tenculs and occupiers of such a pareel of land adjoining the plaintiff's have time-out-of-mind maintained it, \&c., Holt moved in arrest of judgment "that the prescription is laid in occupiers, and not shown in their estates; and that hath been judged naught in 1 Cro. 155, and 2 Cro. 665.' But the Court said: 'It is true there have been opinions both ways, but 'tis good thus laid, for the plaintiff is a stranger andpresumed ignorant of the estate; but otherwise it is, if the defendant had prescribed.",

It was held by Erle J., and Crompton J., in Reg. v. Sir John Ramsden, 
principally on the authority of Iiex r. Flecknoul, that lhe liubility to repair a highueny, ratione clenesure, is only on the oceupier of the lauds inclosed, and not on the orner. And per Erle J., the liability does not attach where the way is not immemorial, or where the laud inclosed has not been used for prassage before the inelosure. In liex r. Flecknou, the parish was indieted, and plended that Watson, by reason of the tenme of lands inclosed by him, ought to repair, and the prosecutor replied that this land was inclosed nnder an Inclosure Act, and that Watson was allottec of an allotment, and therefore made the inclosure; and it was decided that as Wratson had a lawful right to inclose he incurred no liability to repair by reason of doing so. And semble there is no general rule of law, imposing the obligation on the owner or oceupier of lames abulling on a public roul, to lieep up the fenees. Per Kindersley V.C. (Poller v. Petry).

In Boyle r. Tumlyn the whole subject of the obliyulion to fence was much considered. The plaintiff owned The Deans, and the defendant a close aldjoining it, called Deadmoor, which was scparated from The Deans by a fence with a gate, erected on the defendant's land. They formerly belonged to one Coflin, who thirty year's since sold The Deans to the plaintifl's father, and two years afterwards Deadmoor to the defendant. The gate in the fence was repaired by the tenant of Deadmoor whilst Coffin owned all the lands. In those two years the cattle of Fry, the tenant of Deachoor, trespassed upon The Deans, and the 1laintifl"s father gave Fry notice that unless he repaired the gate he wothl impound his eattle. Fry did repair it, and so did the defendant on a similar request from the plaintiff's father. Lillledale J. thonght that there was some evidence to go to the jury, from which they might presume that there lad been an agreement between the plaintiff"s father and the defendant that the gate should be kiept up by the latter for the Jenefit of the plaintiff, telling them that in point of law the obligation to repair the gate, if any, could only be created by special agreement between the parties, regard being liad to the fact that the land of each party had originally belonged to Coffin. The jury found that the defendant was bound by agreement to repair the gate, a rerdict at which the learned judge, in Banco (who had pointed their attention to the fact, that in no instance had the defendant permitted the plaintiff to do any act upon the defendant's land, and that he might fairly say that he repaired the gate for his own benefit, to prevent lis own cattle from trespassing on the plaintifl's land), expressed his surprise, and leave for a nonsuit having been reserved, a new trial was granted withont costs.

Jireyley .J. remarked that "a man is under no obligation to leepp "up

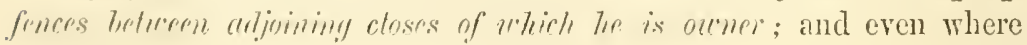


adjoining lands, which have onee belonged to different persons, one of whom was bound to repair the fences between the trro, afterwards become the property of the same person, the pre-existing obligation to repair the fences is destroyed by the unity of ownership. It follows also that where the person who has so become the owner of the entirety, afterwards parts with one of the tro closes, the obliyation to repair the fences will not revive, unless express words are introduced into the deed of conveyance for that purpose." "As the deed of eonveyance from Coffin to Boyle was not produced at the trial, the fair inference is that Coffin did not bind himself by it to keep up the fence between the two closes. I agree if there was proof of any such stipulation it would support the allegation that the defendant 'by reason of his possession' was bound to repair, for then the grant would be evidence only of the liability. Such a right to have fences repaired by the owner of adjoining lands, is in the nature of a grant of a distinct easement, affecting the land of the grantor. The anthorities referred to show that it is usual in such eases to allege that the occupier is "by virtue of his possession' bound to repair" (6 B. \& C. 329).

Wilmot C.J. observed (3 Wils. Anon. 126): "If a man turn his cattle into Blackacre, where he has no right, and they escape and stray into my ficld for want of fences, he cannot excuse himself or justify for his cattle trespassing in my field." See Sir F. Leake's case, and Poote v. Lonyueville (2 Sann. 285 b). In Dor'aston v. Payme, on a plea of bar in avowry for taking cattle damage fcasant, viz., that the cattle escaped from a public highway into the field throngh the defect of the fences, it was held that such plea shonld show that the cattle were prassing on the highuray when they eseaped. And per Eyre C.J.: "A party who would take advantage of fences being out of repair as an excnse for his cattle escaping from a way into the land of another, must show that he was lawfully using the easement when the cattle so escaped." Heath J. added: "The law is that if cattle of one man escape into the land of another, it is no excuse that the fences were ont of repair, if they were trespassers in the place from whence they came. If it be a close, the orner of the cattle must show an interest or a right to put them there. If it be a way, he must show that he was lawfnlly using the way, for the property is in the owner of the soil, subject to an easement for the benefit of the publie" (2 Smith's Lead. Cases).

One tenant in common may sue another for destroying bnt not for clipping a hedye (Voyce v. Voyce). In this action of trespass, the defendants, who were tenants in common with the plaintiff of the hedge and the close of land on which it stood, had grnubed it up ; and Holroyd J. ruled that a tenancy in common could not be given in evidence under 
the plea of liberum tenementum, but that it would have been receivable in evidence as a justifieation, monder the general issne, if the defendants had merely exercised that right of ownership over the subject matter of the tenaney in common, which erery tenant in common may lawfully do, snch as elipping the hedge. As, howerer, in this ease, the hedge itself had been destroyed, the act of destruction rendered it impossible for the plaintifl to exercise his rights as co-tenant in common with the defendants, and therefore it could not be justified. 'The plaintiffs had the rerdiet.

Guaclee J. in Berriman r. Pecteck thus stated the rule with regard to hedlye cullings: "The tenant has a general property in the enttiugs of a hedge, whoever ents it. If by his permission a stranger ents it improperly, so as to damage the fence, that may gire the landlord a ground of action on the case." Here the defendant Peacock oceupied land next a ficld let by the plaintiff to one Wardell for a term of years, and requested the latter to lower a fence between the two properties. Some delay ocenrring, the defendant lopjed the fence himself, but carried the enttings to Wardell, the plaintiff's tenant, who said at the trial, that necording to the custom of the country he believed he was entitled to them. Defendant cut the hedge unskilfully, but the tenant said it was a good job, and the fence the better for it. The action was for trespass de bon asp, and a verdict was found for the plaintifi, with nominal dlamages; but the Court made a rule absolute to enter a nonsuit, and considered that as the tenant adopted the acts of the defendant, no action could lie ly him against Peacock. T'indel C.J. thonght that "it would be orer-refinement to say that becanse a small portion more of a fence has been cut than the tenant is entitled to cut, the landlord has a right to claim it. Here, indeed, the complaint was rather as to the mode than the amount of the eutting; but the question now is, whether the property in the cuttings belonged to the landlord. Now, according to the old anthorities, the general property in trees is in the landlord, and the general property in bushes is in the tenant; althongh if lie excecds his right, as by grubbing up or destroying fences, he may be liable to an action of waste. We should be introdncing a distinction never drawn before, if we were to decide that when a tenant cuts rather more than he onght, the property in bushes so cut passes to the landlord" (9 Bing. 881).

With respect to sleating or injuring lipes and strulbs of different vahes, roots and regetal,les, as well as fences and gates and stiles, see $7 \& 8$ Gro. IV. c. 29, ss. $38-43$, and 7 \& 8 Giro. 1V. c. 30, ss. 19-24. It was held in liry. v. Whilemen, that section 19 of the latter act (The Malicions 'Trespass Act) does not apply to consequential injury, but means injury 
to the tree itself ; and hence where prisoners were indicted for malicionsly damaging trees grouring in a hedige, to an amount exceeding $\mathfrak{L 5}$, and it was proved they had injured trees to the amount of $£ 1$, and that to repair the injury it was necessary to stub up the old hedge, and further, that putting in and protecting a new hedge would cost, including the $£ 1$ for injury to the trees, a sum exceeding $£ 5$, it was held that there was no evidence of injury to the trees to the amount of $£ 5$. The above section makes it felony unlawfully and maliciously to cnt up and destroy tices growing in a yarden, \&ce, if the injury execed $£ 1$.

Section 20 of this act inflicts a fine not exceeding 25 beyond the injury done, for unlawfully and malicionsly cutting up and destroying trees wherever growing, if the injury amomt to 1 s., upon conviction before a justice; section 21 infliets imprisonment or forfeitnre not exceeding $£ 20$ beyond the injury done, for unlawfully and maliciously destroying or damaging with intent to destroy any veyetable production growiun in any garden, \&e., upon like conviction : section 22 inflicts imprisonment for a shorter term or forfeiture (not exeeeding 20s.), as before, for unlawfully and maliciously destroying, damaging with intent to destroy, any cullivated root, plunt, \&e., used for food, medicine, or manufucture growiny in the land not beiny a garden, upon like conviction; and section 24 inflicts, upon conviction before a magistrate, a forfeiture of such sum not exceeding $\mathfrak{f 5}$, as shall appear to the magistrate a reasonable compensation for wilfully or malieionsly committing any damage, injury, or spoil to or upon any real or personal properly, public or private, for which no remedy or muishment is in the act before movided. And sembte, section 24 is inapplicable to damage to growing trees; but neither under that nor any other scetion is a committal or conviction good which states the offence to be wilfully and maliciously cutting up and destroying fruit trees in a garden, or wilfully and malicionsly committing damage, injury, and spoil to real property, to wit, fruit trees, withont a finding as to the amount of damage (Chutrter v. Gicleme (nnd Simpson).

The occunier of land is lound to fence off any hole on it which adjoins or is elose to a public way, and he is mimu furie liable fur any accident which may happen from his negligence in this respect (Barnes v. Ward). One of the first reported cases of this kind was that of Blythe v. Topham, where it was held that if $\mathrm{A}$., seised of a waste adjacent to a highway, digs a pit in the waste within 36 feet of the highway, and the mare of $B$. escapes into the waste and falls into the pit, and dies there, yet $B$. shall not have an aetion against $A$, because the making of the pit in the waste and not in the highway was not any wrong to B., but it was the default of $B$. himself that his mare escaped into the waste. The existence of the pit in the waste adjoining the road was clearly not 
dangerous to the persons or cattle of those who passed along the road, if ordinary caution were employed. Sybbray v. White differed considerably in its facts. The plainteff was possessed of a elose, in which there was an unfeneed shaft, leading to a mine which had been covered np for many years, the top of which gare way under his mare, who fell down and it was lilled. . The defendant denied that the shaft was his, but agreed to pay if a miner's jury of fire shonld find that it was. 'This finding, conpled with his declaration, was held to be admissible in cridence against him in an action for compensation, and a verdict for $\$ 1$ is being returned for the plaintiff, the Cont refused a new trial, and also decided that as the finding of the miner's jury did not on the face of it appear to be an award, it was receivable in evidence withont a stamp) (1 M. \& T. T. 435).

C'unal near public footeruy.-Where a canal had been made in land along which ran an ancient footway, and between the canal and footway was a towing-path nine feet wide, and a strip of grass several feet in breadth, and the public were permitted to pass over the whole interrening space, which was left unguarded and mlighted, it was held by the Court of Queen's Bench that the canal was not so "near to" or" "aljoining" the footway as to be a nuisance or to injose on the proprictors the duty to fence, light, or protect it; and that if a person had gone astray and fallen into the canal, the canal company were not liable, under Lord Camploell's Act, to the representative. And per C'uriam: "We adopt on this subject the law as laid down in Hounsell r. Smyll (7 C.B. N.S. 731), that to throw upon the owner the obligation of fencing an cxearation on land adjoining a public road or way, it ought to be shown that the excavation is 'so near thereto as to be dangerons to persons using the road in the line of the road.' In Herideastle v. South Forkshire and River Dun Compeny (4 H. \& N., $(67)$, it was laid down that the excaration must be so adjoining the public way as that a false step might canse a person using the way to fall into the excavation; and it seems but reasonable that in such a case the owner of the land should be liable. But. where, as here, the excaration is at some distance from the public way, the ease is very different

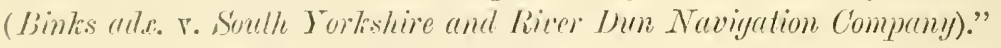

In Rooth v. Hitson, a horse, the property of the plaintiff's brother, was sent over to the plaintifl one erening, who kept it in his stable for a short time, and turned it ont after dark into the close where his cattle usually grazed. On the following morning it was found deced in the drfermlent's close, having fallen from the one to the other. 'The liability to rejair was admitted, and the defence was, that the plaintiff (whose horse it was stated to be in the declaration) had not such a property in 
it as to ontitle him to maintain the action. The jury found for the plaintiff, asd the Conrt of King's Bench refused a new trial, and prer Curiam: "The plaintifl" although receiving the horse as a gratuitous bailee, became accomntable to the owner for any damage to it, if he did not exereise a proper legree of eare, which he had certainly not done here, and such liability was sufficient to enable him to maintain the action. Having an interest in the integrity and safety of the animal, he might sue for a damage done to that interest, and the same possession which would enable him to maintain trespass, wonld enable him to bring case against the defendant for the defects and insufficiences of the fences. He was entitled to the benefit of the field not only for the nse of his own eattle, bnt for patting in the cattle of others; and by the negligence of the defendant in rendering the field unsafe, he is deprived in some degree of the means of exercising his right of nsing that field. Whether, therefore, the damage aecrues to his own cattle, or those of others, he may maintain the action."

Again in Pouell v. Sulisbury, the plaintiff declared against the defendant in case for not repairing his fences, per quod the plaintiff's horses escaped into the defendant's close, and were there killed by the falling of " hery-sturk. 'The damage was held not to be too remote, and the action maintainable. Holbatch $v$. Warner was principally relied npon, which was an action on the case against the defendant, for neglecting to repair his fences, whereby his eattle escaped into the close of the plaintifl, and from thence into the elose of W., who sned the plaintiff and recovered against him in trespass; as well as an anonymons ease, 1 Vent. 261, which was an action on the ease for not repairing fenees, per quod a mare of the plaintifl's went throngh a gap, and fell into a ditch and was drowned. On these cases Hullock B. thus remarked: "In Holbatch v. Wamer the damage was equally remote as in this case, but thore no objection was made npon this ground. In that eited from Ventris npon motion in arrest of judgment, the declaration was held to be good, but no objection like the present was taken. There is no distinction for the purposes of the action between the falling of a hay-stack and the drowning of the cattle in a ditch, for by each the death is occasioned."

Liabitity to maintain fences.-Laurence v. Jentins, 8 L.R. Q.B. 274. This was an action brought in the County Court at Newport, in Monmonthshire, to recover the valne of two cows, which were lilled by eating the cnttings of a yew tree. The defendant ocenpied a close adjoining a close occupied by plaintiff. The defendant sold some trees to one Higgins, who so negligently felled a beech tree that it made a considerable gap in the hedge which divided plaintiff's close from defendant's. 'Two cows of the plaintiff's went throngh the gap in the hedge, 
ate some yew cutimgs which were lying in defendant's close, and died in consequence. 'There was evidence to show that defendant and his predecessor's had repaired the fenee in question for more than forty years, and that for the list nineteen years the fence had been repaired by defentant and his predecessors upon notice by the oceupier for the • time being of the plaintifl"s close. The County Comt judge non-snited the plaintifl, but the Conrt of Qneen's Bench held that the evidence showed a preseriptive obligation on the part of the defendant to maintain the fence so as to keep in the eattle in the plaintiff's close : that the obligation was absolute to keep) up a sufficient fence at all times, the act of God or ris major only excepted, withont any notice of want of repair ; that the damage was not too remote, and that the defendant was therefore liable for the loss of the eows, distinguishing this case from Longmeid r. Holliday, 20 L.J. Ex. 430; and Butler v. Hunter, 31 L.J. Ex. 211. In the case of Dauson v. The Miellenel Pecilueay C'omrany, S L.R. Ex. 8, the plaintiff hired of the oecupier of land adjoining the railway, a stable: he also had permission from the ocenpier to turn his horse into the field during the day-time to graze. Through the defect of the defendant's fence, the horse got on to the railway and was killed : held that the Company were liable to pay plaintifl the valne of the liorse.

In the case of Sncestryy vanceshire and Forkshire Railuay Company, the plaintiff sent a drove of twenty-nine beasts by rail for Wakefield market; arriving at Wakefield on the night before, they were driven at about eleren at night along an occupation road to a field where they were to remain for the night; the road crossed some sidings of defendants' railway ori a level, and while the cattle were crossing the sidings, the defendants' serrants negligently, and withont warning to the persons in charge of the cattle, let some trucks run violently down an incline into the sidings: this separated the cattle into two divisions, and so frightened them that they escaped from the eontrol of the drovers and rushed away. The drovers sueceeded in recorering most of the caltle, but six or seren of them were not discovered till between three and four the next morning, when they were found dead upon anotier part of defendants' line. 'I'heir tracks were traced from the siclings; and it appeared that they had gone along the oecupation road for ahont a quarter of a mile, and liad then got into an orchard and garden belonging to the defendimts, the fences of which were defective, and thence on to the railway, where they were found: held that the damage was not ton remote, and that defendants were liable.

In Lee v. lieley, 84 J.J. X.S. C.P. 212, the plaintiff and defendant occupied arjoining firms, and an occupation road extended from a high- 
way throngh defendant's farm, of which it formed part, into the plaintiff's farm, where it formed part of plaintiff's farm. There was a gate across the occmpation road at the point where the farms adjoined, and it was the duty of defendant to keep this gate in repair. This, however, the lefendant had neglected to do, and in consequence of this neglect, a grey mare of his strayed through the gateway into a field of the plain. tiff's, and inflicted such injuries upon plainiff's hor'se that the latter had to be killed. Held that the defendant was liable for the trespass by his horse, and that it was not necessary for the maintenance of the action that the defendant's horse was vicious and that defendant was aware of the fact. See also Ellis v. The Loftus Iron Company, 10 L.R. C.P. 10 , where the above case is cited.

By section $6 \pm$ of the Highway Aet, 5 \& 6 WVill. IV. c. 50, no tree, bush, or shrub shall be planted in any carriage-uay or cart-uxay, or within 15 feet from the centre thereof, under a penalty of $10 \mathrm{~s}$. if it be not cut down by the owner or occupier of the land within 21 dass after receiving notice from the surveyor. Sections 65 and 66 direct the cutting, pruning, and plashing of hedges, and the pruning and lopping of trees. By the latter section, hedges need only be pruned between the last day of September and the last day of March, and oak trees in hedges are only obliged to be felled (except when the highway requires widening) in April, Nay, or June; and ash, elm, and other timber trees, in December, January, February, or March.

By 3 Geo. IV. c. 126, s. 113, it is enacted "That ditches, \&c., of a sufficient depth shall be made, \&c., and sufficient trucks, tunnels, \&c., shall be made where carriage-ways or footways lead ont of the said turnpike roads into the lands or grounds adjoining thereto by the occupiers of such lands or grounds:" held that the words, "occupiers of the lands adjoining" apply only to the latter part of the section. Hericale v. Exeler Road Trusters, 3 L.R. Q.B. 149.

Section 72 of 5 \& 6 Trill. IV. c. 50 , imposes a penalty npon any one "Who shall wilfully ride upon any footpath or causeway by the side of any road, \&c.:" in the case of Reg. v. Pratt, 3 L.R. Q.B. 64, it was held that this Act was intended to apply only to footpaths or carriage-ways by the side of the road, and not to footpaths generally.

The case of Jemncy and Runnacles v. Brook turned on the construetion of sec. 65. An order was there served on an ouner to cut a hedige, and he did cut some part; but the survesor thonght the order not properly complied with, summoned him before tro justices, and had him fined, and after ten days ent the hedge himself. The Court of Queen's Bench held the order tọ be bad, for not specifying more particularly in what manner and to what extent the hedge was to be cut. 
This was a substantial defeet, and not one of form, and the smrreyol was held liable in trespass for entting the hedge, thongh (as the jury found) he harl not cut more than the order required, and the owner had not ent so much, and though the latter had acquieseed, as was contended, in the goodness of the order by partially obeying it. The surveyor had no power to act execpt in the owner's default, which conld not take place without a ralid order. Lord Demman, C.J. said, "The attention of the ormer nught to be called to the manner in which lie is required to do what is ordered. It is not enongh to call upon him to eause the hedge to be ent, prumed, and plashed, when he may well be in doubt what these words mean, nor to direct him to remore the said obstruction complained of, without pointing ont what the obstruction is, nor whether it is specifically limited to the exclnsion of the sun and wind." On the second trial the rerdict was for the plaintift, and judgment being signed, a writ of error was brought in the Exchequer Chamber, which awarded a renire de novo. It was held, inter alia, that the exclasion of the sm and wind being one of the injuries complained of, the order was bad in part as not stating the extent to which entting, \&e., should take place with reference to that injury. And semble to cut, \&c., so as to prerent the sun and wind from being exeluded, would have been sufficient withont any more precisc order as to the extent of cutting. And per C'miam, the order, though informal, is good in part, and gare anthority to the defendants to ent, pmine, and plash the hedges, so as to remore the actual obstruction to the carriage-war, oceasioned by the branches of the thorns, bushes, and shrubs forming part thereor, but no further.

On the new trial the jury had to inquire whether the defendants did more than this, and assess the damages incurred by the plaintiff if they did. In a parte Whitemarsh the Conrt refued to grant a rule misi for a mandamus, to compel justices to issue their warrant to lery the cxperses of cutting a hedge, purstuant to this section, unless it appears that a demand has been made of the expenses from the person sought to be charged, and that the jnstices were informed of that demand.

T'o juslify a surveyou of highurelys (Elcins r. Oaliley) in laking doun a frner, under the statute 5 \& 6 Witl. IT. e. 50 , s. 69, two things must concur-1st, the fenee must be within 15 feet of the centre of the road; and 2 nu, it must be on the road. Here the two places enelosed never were part of the road, as no carriage ever did or conld go along the steep bank at the pound (where the road was 22 feet wide), or orer the rough, uncren ground at Nichol's (where the road was only 9 feet wide); and Mrunle.J. ruled that if these tro plaees at which the fences were pnt up liad never heen used by the public as a part of the road, the survegor had no right in jull down the fences because they were within 15 feet 
of the centre of the road. Loren v. Kay was also a case on the construction of the 63rd section of the Highway Act, 13 Geo. III. c. 78, which was repealed by the stat. 5 \& 6 Will. IV. c. 50. The langnage of the $63 \mathrm{rd}$ section of the former act, is that if any fonce (taking that as the general word) shall be placed on any highway, the surveyor shall have power to remove it; and the question at the trial was whether the fence was on the plaintiff"s own soil or on the highway, and the jury found that it was on the former. This decided that where the road is not 30 feet wide, the surveyor may not make it so by removing the fences on each side, unless the fence be actually upon the highway. In an action by a reversioner against a surveyor of highways, for cutting away a sinall portion of the soil of a bank or fence adjoining the public road, monder the supposed anthority of 13 Geo. III. c. 78, s. 15, it was held to be no answer that the fence was thereby in fact improved (Alston v. Secules). The jury had to say whether any part of the plaintiff"s fence, which consisted of a bank surmounted by elder bushes, had been ent away. And per Curiam: "The fence is not, as has been contended, to be confined to the mere bushes, but embraces also the substantial part of the enclosure upon which the hedge was supported. The removal of the smallest portion of the soil must in general be esteemed an injury to the land, because it tends to alter the evidence of title."

The presumption of law is, that waste land adjoining the road belongs to the owner of the adjoining enclosed land, whether frechold, leaschold, or copyhold (Doe dem. Pring v. Pearsey); and in Grove v. " West, Gibls C.J. said, "Prima farie the presmmption is that a strip of land lying between a highway and the adjoining close belongs to the orrner of the close, as the presumption also is that the highway itself ad medium fitum vice does. But the presumption is to be confined to that extent; for if the narrow strip be contignous to or communicate with open commons or larger portions of land, the presumption is either done away or considerably narrowed, for the evidence of ownership which applies to the larger portions, applies also to the narrow strip which communicates with them." Holroyd J. remarked on this point, in Doe dem. Priny v. Pearsey, "When a grant of land near to a road is made (even when it is enclosed and separated from the land adjoining), it appears to me that the prime facie presumption is that the land on that side of the fence on which the road is, passes likewise with it. Generally speaking, where an enclosure is made, the party making it erects his bank and digs his ditch on his own ground, or on the outside of the bank. The land which constitutes the ditch in point of law is a part of the close, though it be on the ontside of the bank. And if something further is done for his own conrenience, when that 
which constitntes the fence is dug ont from his land, as, for instance, if a small portion of uninclosed land near a public or private way is left ont of the enclosure, to protect and secmre the ocenpation of that part of the land which is inclosed, that in point of law is a part of the close on which the enclosure is made. But the presmmption that waste land adjoining a road belongs to the owner of the adjoining inclosed land, applies only to eases between the frecholder or copyholder, or those claiming under them, and the lord and those claiming under him ; and does not apply to cases between freeholder and frecholder, where both elaim under the same title (Irhile v. Hill). Where the occupier of a field called 'The Hall Close took down the old fence and added to the field a strip of land adjoining a public road, in an action for a trespass committed npon the strip of land about a year after it lad been so taken in, the declaration described the locus in quo as The Hall Close, and it was held that it was properly described (Brounlon v. Thomtinson, 1 II. \& Gr. 48t).

27 \& 28 Tict. c. 101 , s. 25 , repeals the 7 tth section of the Highray Act, 5 \& 6 Will. IV. c. 50 , and renders the owner liable to a penalty if cattle, horses, sheep, or swine are found lying about a highway "notwithstanding they are under the control of a keeper at the time," Latrence r. Kiny, 3 L. R. Q. B. 345 ; and an owner of cattle is liable to a penalty if his eattle are found straying on the metalled part of a bighway notwithstanding he has a right of pasturage on the sides of it, Golding r. Stocking, 4 I. R. Q. B. 516 ; and Freestone v. C'ussuell, 4 I. R. Q. B. 519.

The question of railurey fences was shightly touched upon in Sharroll r. The London and Torth Western Railway Company, where some sheep got on the railway after dark, in consequence of defect of fences, and were run ovel by an express train. It was held that trespass did not lic against the company, and that if the cattle had a right to be on the railway, the plaintifl's remedy was by action on the case, for cansing the engine to be driven in such a way as to injure that right: but that if the cattle were altogether wrong-doers, there was no neglect or misconduct for which the company were responsible. And per Parlie B., "If the sheep had any excuse for being there, as if they had escaped through defect of fenees which the company should have kept up, they were not wrong-doers, though they had no right to be there ; and their damage is a consequent damage from the wrong of the defendants in letting their fences be incomplete or out of repair, and may be recorered accordingly in an action on the case." This ease was

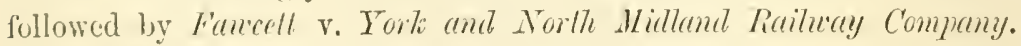
'The plaintiff's horses had leaped orer the fenee of a field, in which 
they had been placed, into a second field, and from that over a broken gate into a third field, all three being the plaintiff's fields, and had strayed through an open gate of the third field into a highway crossed by the railway on a level. The railwas-gate, which was placed as a fence across the highway where it was so crossed by the railway, was also open; and the horses, which had strayed throngh this gate on to the railway, were there killed by one of the company's trains. For the defendants it was contended that the horses were, under the cireumstance, trespassers on the highway, and that the issue taken on the principal plea (that the said horses were not lnufulty in the said highway at the time they so went, strayed, erred, and escaped therefrom, as alleged, \&c.) must be found for them. Wightman J. directed that as against the defendants, who were bound to keep the railwaygate closed, the horses were lawfully on the highway; and a verdict was found for the plaintiff. Leare was given to move to enter the verdict for the defendants in case the Court should be of opinion that the horses were not lawfully on the highway; but a rule nisi for that purpose was discharged by the Court of Queen's Bench.

Patteson J. thus distinguished this case from. Sharrod v. London and North Western Railway Company: "There the sheep got on the line without any default on the part of the company. Here the company did not keep the gate shut." His lordship also thus distingnished it from Dovaston v. Payne: "The cattle there were trespassers mimâ fucie; and it lay on the plaintiff in replevin to excuse their presence in the arowant's field, and show that they were not liable to be distrained. Besides, a person whose ficld adjoins the highway may leave his field open and permit cattle to pass over it; he cannot distrain them if he has suffered them to come there; but he commits no breach of duty by leaving the ficld open. Here there is an obligation cast upon the company by statute to keep the gate shut." His lordship added, "I think there is no doubt in this case. . The original special act of this company provided that the company should keep the gates across the railway, and shonld keep them constantly closed. That enactment, in common with others of the same kind, is altered by stat. 5 \& 6 Fict. c. 55, s. 9 . Now it is to be observed that the words here used are, that the gates shall be such as to "prevent cattle or horses passing along the road from entering upon the railway while the gates are closed;' not to 'prevent cattle lanrfully passing,' \&e. In this declaration the pleader has inserted that word 'Taufully;' and there is an express issue whether the hor'ses were lawfally on the road, across which there was a gate which was left open. It is contended that though there was a highway there, the horses might have been 
distrained by the owner of the soil (I may remark in passing, that I never heard of the owner of soil which was set aside as a highway distraining eattle for trespassing on the hard surface fenced off, and I do not believe he could do it), or at least that under stat. 5 \& 6 Will. IV. e. 50, s. 7.t, they might have been impounded by the surveyors of the highwar. Assuming this to be so, I do not learn that the railway company are in any way made conservators of the highways. By their neglect the gate was open. The question comes to be, then, Were the horses in the road lawfully as against this company? I do not thiuk it was necessary to insert that word 'lawfully', for the act directs that the gates shall be constantly kept elosed; and I think that imposes an obligation to keep them closed, as against everything, whether straying or passing : but at all events the horses were in the road litwinlly as against the company, and consequently the rule must be clischarged."

The facts in Ricketts v. The Birmingham Junction Railuay Company were nearly identical with those in Sharrod v. London and North Trestem Ruituay Company. It was there deeided that the duty imposed upon railway companies by the Railway Clanses Consolidation Act, 1845,8 \& 9 Yict. c. 20 , s. 68 , as to the making and repairing of fences between their railways and the adjoining lands, is not more extensive than that imposed upon ordinary tenants by the common law.

At conmon law the company would only be bound to fence against an auljoining ou'ner, and the question which the judges here decided in the negative was, whether that obligation was extended by the words of the Act. Therefore, where 50 of the plaintiff's sheep escaped from his close, through his own defect of fences, and getting into the intervening cluse of a third party, escaped thence on to the defendants' railway, and were killed by a train, the company were not liable. There was a joinder in demurrer. In delivering judgment for the defendants, Jerris C.J. said, "The admitted facts are these, that the company were bound to make and maintain fences in the terms of the statute; that the plaintifl" was the owner of a close adjoining a close belonging to the Great Northern Railway Company, which abutted npon the defendants' railway ; the fences of which close of the plaintiff; he, the plaintiff, was bound to repair ; and that by defect of his fences, the plaintiff's sheep cscaped into the adjoining close, and thence passed on to the defendants' railway, in ensequence of the want of a fence between it and the close of the Great Torthern Railway Company, and were killed. There is no allegation that the action conld have been avoided, or that the company had by themselves, or their servants, been guilty of any negligence in that respect. It is admitted that the company were bound to repair as 
against the owners of the adjoining lands, bnt it is insisted that the plaintiff under these circumstances is not entitled to recover.

"The rule npon the subject is well laid down in the notes to Pomfiet v. Rieroft: "The general rule of law is, that I an bound to take care that my beasts do not trespass on the land of my neighbonr ; and he is only bound to take care that his cattle do not wander from his land, and trespass on mine (T'encunt v. Golduin; Churchill r. Evans; Boyle v. Tamlyn); and therefore this kind of action will only lic against a person who can be shown to be bound by prescription or special obligation to repair the fences in question for the benefit of the orner or oceupier of the adjoining land. And no man can be bound to repair for the benefit of those who have no right. Therefore the plaintiff cannot recover for the damage occasioned to his cattle by their escape from the adjoining close, through the defect of the defendants' fences, unless the plaintiff had an interest in that close, or a licence from the owner to pat them there.' Applying that rule to the facts of the present case, had the plaintiff any light to have his sheep on the land adjoining the defendants' railway? It is admitted that they were there not by right, nor under any licence from the owner's of the close, but through a breach of duty on the part of the plaintiff himself. It is clear that if the defendants are only liable to repair so as to protect the owners of the adjoining lands, the plaintiff cannot maintain this action. The next question is, in what respect does the statute vary the ordinary common law liability? It seems to me, that, so far from varying the responsibility of the defendants, the statute has most properly taken the common-law rule as the measure of their liability. The 6sth section enacts that the company shall make and maintain 'sufficient posts, rails, hedges, ditehes, momnds, or other fences for separating the land taken for the use of the railway from the aljoining lands not taken, and protecting such land from trespass, or the cattle of the owners or occupiers thereof from straying thereout by reason of the railway.' It seems to me that this liability is not more extensive than the ordinary common-law one. It is said that in adopting this view we shall be conflicting with the decision of the Comrt of Qneen's Bench in Faucett v. York and North Hidland Railuay Compamy. That, horrever, is not so. The Court there held that independently of the common law, the statule 5 \& 6 Tict.c. 55 , s. 9 , imposed upon the company an mqualified and nnlimited obligation to lieep the gates at the end of level-crossings closed against all persons or cattle mpon the highway, whether lawfully there or' not, and that they were liable to an action for an injury arising from a breach of that duty. In the third place it was insisted that even if there was no common-law liability, and the statute imposed on the defendants no additional duty, 
the dangerous nature of the trade carried on by the defendants cast upon them an obligation to adopt more than ordinary precautions."

"Rex r. Pease, howerer, is a distinet authority the other way. The legislature has authorised the formation of the railway, and has done all it thonght necessary to protect the public and the adjoining land-owners, by requiring the company to fence off the land adjoining the railway. For these reasons, it seems to me the defendants are entitled to the judgment of the Court." Irilliums J. added, "The principle of the common law and the authorities on this subject are placed in a very clear point of riew in the case of Dor'aslon v. Payne. Here the plaintiff's shecp, it is conceded, had escaped into an adjoining close through the plaintiff's own default, and were there trespassing. The only question, therefore, is whether the liability throm upon the defendants by the statute is limited to the common-law obligation to fence against the adjoining lands, or is a general liability to fence against the whole world, so as to bring this calse within the principle of Fawcell v. Fork and North Bitlund Ratiuay Company. I am of opinion that the act of parliament creates no such general dity, but only a duty as between the company and the owners of the adjoining lands and those in privity with them, and that a stranger as this plaintiff is cannot found an action upon an alleged breach of that duty." And per Cressuell J.: "The case of Rex v. Pease is a strong authority to show that the legislature haring legalised railways, they are not subject to any liability beyond the ordinary common-law liability, exept where the legislature had thought fit to impose it. It seems to me that the duty or obligation cast upon this company by the $8 \& 9$ Vict. c. 20 , s. 68 , for the protection of the owners or occupier's of the adjoining lands, is co-extensire with, and goes no further than the preseriptive liability of the servient tenant. That being so, sheep trespassing upon a close adjoining the railway are not within the protection."

This case was followed by the Manchester, Sheffelul, and Lincolnshire Rerituculy Company (app.) F. Hallis (resp.), which was an appeal by the Company, the defendants below, against the ruling of the Leicester County Court judge in an action to recover damages for the destruction of two horses belonging to them, which, owing to the alleged negligence af the company's servants in learing open a gate and other openings leadiny on to their reituray, had got upon the line and been killed by a train of the defendants' ruming against them. £35 was elaimed as the value of the horses, and $£ 5$ for expenses incurred in attending on them after the accident. 'The plaintiff's, who were two farmers, residing in 'Torksey, Jincolnshire, had tro horses in a close of their occupation, through which two public highways pass. $\Lambda$ t each end of the close there is a 
gate to prevent the eattle grazing in the close from straying ont of the elose, and these gates are contiguous with and form part of the plaintiff's' fence. It is supposed that one of these gates was left open, and that the horses strayed through it into the highway leading to Torksey. About 100 yards from the gate of the close, is a swing-gate leading into the T'orksey station, which is frequently propped open during the day, but closed and locked at night. On the day in question (January 18th, 1853) the horses strayed into the station, and were tmrned out about six o'cloek in the evening. Before the gate was elosed for the night they got in again, when the defendants' servants accidentally loeked them in. Their footmarlss were traced through the gate to the stationyard, and thenee through an opening in the fence, which had been made by the defondants' servants, by taking down the rails for the purpose of carrying or earting something from or to the railway, and which separates the station-yard from the line of railway, to and upon the railway, where they were killed by a goods train. It seemed that the gate of the close had most probably been left open by travellers along the highway, and eridence was given that the gate into the station-yard was frequently left open, and eattle had been seen to stray through it, and that the defendants, who had kept it shut since the aceident, had often been warned about it. It was contended by the plaintiffs, that the defendants were liable to make good the loss of the horses by reason of the alleged negligenee in permitting the gate of the station to remain - open and the defect in the fenee dividing the station-yard from the line.

The learned judge declined to nonsnit, and put two questions to the jury-first, whether they were of opinion that there had been negligence on the part of the defendants, and that the injury of which the plaintifis complained was to be attributed to their negligenee; and secondly, whether the plaintiffs had been guilty of any negligenee which contributed in any way to the accident. The jury found the first question in the affirmative, and the second in the negative, and gave £35 damages. The Court of Common Pleas allowed the appeal with eosts: and Jervis C.J. thus delivered the judgment of the Court: "After the finding of the jury, we must assume that the cattle of the respondents without any fanlt on their part strayed into the publie road adjoining the railway, and through defect of the appellants' fences got upon the railway and were killed. The question is, whether npon these facts the appellants are liable in this action? We are of opinion they are not. This is not the case of a railway crossing a high way upon a level, with a gate on either side of the railway, but of a highway running alongside of a railway. The only enactment which is applicable to such a case, is the 68th section of the Railway Clauses Consolidation Act, 8 \& 9 rict. c. 20. 
It provides that the company shall make and at all times thereafter maintain the following works, for the accommodation of the owners and occupiers of land adjoining the railway-that is to say, amongst other things, 'suflicient posts, rails, hedges, ditches, mounds, or other fences, for separating the land taken for the use of the railway, from the aljoining lands not taken, and proteeting such lands from trespass, or the cattle of the owners or ocenpiers thereof from straying thereout by reason of the railway, together with all necessary gates made to open towards such adjoining lands, and not towards the railway, and all necessary stiles.' Certainly this section makes a very insufficient prorision for the protection of the public, where a railway runs alongside a public highmay; but, nerertheless, it is clear that it was intended to apply to such a case; for if not, there is no section which casts the obligation to fence upon the company in such cases.

"The highway, therefore, is to be considered adjoining land not taken, and the same construction must be put upon the same words, whether that adjoining land be a public highway or a prixate close. What, then, is the nature of the obligation cast upon the railway company by this section? They are bound to fence so as to keep the eattle of the owners or oceupiers of the adjoining lands not taken from straying thereout. In Ricketts r. Birmingham Junction Reilueay, this Court has already determined that the obligation of the railway company by this section is the same as it would have been at common law, if they had been bound by prescription to repair the fences; in other words, that they were only bound to keep up the fences against the cattle of the owners or ocempiers of the adjoining land. Were, then, the cattle of the respondents at the time they were lilled the cattle of the owners or occupiers of the adjoining land-the highway? We think they were not, and the case of Douaston. v. Payne appears to ns to decide that ruestion."

And smble the 68 th section of the 8 \& 9 Tict. c. 20 , which prorides for the fencing of railways from the adjoining lands, is a substitute for the 10th section of the 5 \& 6 Vict. c. 55.

Fancett v. The Yorto and North Widland Retituay Company was relied on by the plaintifl' in Ellis v. London and South Western Raituay Comfuny. Here the plaintiff had fields on pach side of the defendants' raituren, and an oceupation-way by which his cattle were driven from the ficlds on one side of the railway to those on the other, and along which there was an ancient public footpath, crossing the railway on a level. The defendants erected lofty gates on each side of the railway, and gave cach person who had a right to use the occupation-way a key; but there was no means of the public nsing the footpath, and in 
fuct the defendants were not aware when the gates wore erected that there was any highway. The plaintiff's key was lost, and his men used to fasten the gate by thrusting a piece of wood through the staple. There was some evidence that a boy who drove the plaintiff's cattle through the gates in the evening had left one of them open; and it was also suggested that it might have been left open by some careless person using the footpath. Two of his colts strayed along the occupation road throngh the open gate, and were killed by a train. Cresswell J. told the jury that the defendants were perhaps not obliged to substitute a key for that which the plaintiff had lost, but there was no evidence of notice of the loss, or of any request to be supplied with another; and he asked them whether they thought the plaintiff had been guilty of negligence, telling them if his negligence had contributed to the accident they ought to find for the defendants, who had a verdict. A rule for a new trial, on the ground that the question of negligence on the part of the plaintiff did not arise, inasmuch as the defendants were guilty of a breach of a positive duty in not carrying the railway either over or under the footpath, or providing gates or stiles which might be nsed for passengers, and also that there was a breach of positive duty in not keeping the gates closed, was discharged.

Pollocle C.B. said: "It was a qnestion for the jury, whether the -plaintiff by his own neglect had contributed to the accident. A foot prossenger must seek his remedy for an obstruction of this kind in a court of law, and he has no right to prostrate the fonce, a proceeding which might be productive of the most lamentable consequences, leading not only to the destruction of any cattle which may stray upon the line of railway, but endangering the lives of passengers travelling thereon, as the bodies of snch animals may canse a train to run off the line. Because the defendants have only partially done that which they were empowered to do, it is not therefore illegal quasi ab initio, but they may be compelled to complete it by mandamus." And per Martin B. : "Assuming that there was a public footway, and the gates were improperly erected, the learned judge properly left the question to the jury. In every case of this description the rights and obligations of parties towards each other are correlative. Here the defendants delivered a key of the gate to the plaintiff, which he accepted, and took npon himself the obligation to take care of the gate. Before any obligation could arise on the part of the defendants to take care of the gates, there onght to have been a request from the plaintiff that they shonld do so; and no communication whatever appears to hare been made with reference to the matter" (26 L. J. Exch. 349). 
In Roberts r. The Great Wrestern Ruilurey Company the question was whether a company were hound to fence off one part of their premises from another. The declaration stated that the defendants were possessed of a raitway and station, and yard adjoining, throngh which cattle carried by the railway to the station were obliged to pass in going from the station to a highway, and that by reason of the premises the defendants were bound to maintain good and sufficient fences betreen the ruiluay and the youd, so as to prevent eattle lawfully in the yard from straying on the railwar, with a breach that they did not maintain such funces, whereby the plaintiff"s bull was killed, was held by the Conrt of '('ommon Plens to be insufficient, as there was no such liability to fence as alleged. And per Croweder J. : "I see no ground at all for" lolding the defendants liable, for there has been 110 argument, nor reference to any case, to show that there was any legal liability to maintain a grood and sufficient fence between the railway and the yard. This is a case of not taking proper means to prevent the cattle from straying, and if there were such a duty an action would lie. But the declaration rests on this, that the defendants were bound to maintain fences, and they clearly were not; and as the loss is said to arise from that want of fenees, the defendants are not liable." And per Willes J. : "It is quite consistent with the declaration that the animal was allowed to remain in the yard till it suited the owner to take it on, and that it was not in the charge of the company at all. It may be a question whether in respect of carrying on a dingerous trade the defendants would be liable, but I say nothing as to that."

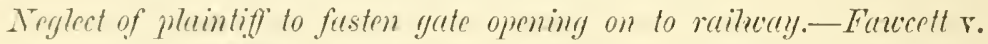
Fork and North Midland Railuray Company (16 Q. B. 610), was cited in IInigh r. London and North Western Railualy Company, where pony strayed on to line and was killed. The evidence was that llaintifl's practice was to fasten gates by a catch by day, and a lock by night only, and that defendants lnew it. The gate might have been blown open by the wind. The Conrt of Qneen's Bench thought that the plaintiff had the means of making the gate secure, and had not nsed them, and confirmed the defendants' verdict.

Company bound to leare gate shut where tramuay adjoins raituay.In Maifell r. South Wules Rreiluay C'ompany, the defendants' railway ran for some distance parallel to a trammay, being separated from it by a fence, also their property, down to a point where the tramway crossed the railway. At this point the defendants had placed gates which conld be shut, so as to separate the tramway from the railway, but which by plaintilf's eridence never were shut. The plaintiff was licensed by refendants, on payment of a certain toll, to use the tramway with 
trucks and horses, one of which, alarmed at an approaching train, swerved from the tramway through one of the open gates on to the railway, and was killed by the engine. It was found that there wis no negligence on plaintiff's part, bat on defendants' in leaving the gate open; and it was held per. Willicms J., and Byles J. (Erle J.C. diss.), that the plaintiff had a right to expect ordinary care and diligenee in liceping the gate shut, and that the defendants were liable for the value of the horse. And per Curiem, the $8 \& 9$ Vict. c. 20 , s. 68, whith imposes on raitway compranies the obligation to fence as against arljoining ouners, does not apmly to cases like the present, where aljoining lemel belonged to company. And per Byles J., "Suppose the defendants to be owners of a meadow, in which there is a deep ehalk pit, fenced round by them to prevent eattle falling in, but with a gate in the fence to be used only by the defendants when they should desire to remove chalk from the pit. Suppose the defendants for reward to take in cattle to agist in that meadow the same question arises, Are the defendants under any obligation to exercise any degree of care in the nse of the gate? It is clear on the authorities, that they are in the supposed case bound to exercise care in the use of the gate, and are responsible if they leave the gate open."

Sheep kilted by a train.-In Besant v. The London and South Western - Reilway Company, the plaintiff was a farmer having land adjoining the defeudant's line, and feeding his sheep on turnips. For this purpose he put them into a fold of which three sides were formed by hurdles, whilst a quickset hedge and a small ditch belonging to the railway made the fourth side. In the night the sheep got throngh the railway hedge on to the line, and 25 of them were killed. Mr. Baron Martin, in summing np, observed that by the Act of Parliament a duty was cast upon the railway company of making, keeping and maintaining a proper fence between the line and the adjoining fields for the words were, "That the company shall at all times make and maintain suffieient posts, rails, hedges, ditches, and mounds, or other fences, for separating the land, for the accommodation of the owners and oceupicrs of the land adjoining the railway, and to prevent the eattle of the owners from straying thereont." The question in this case was whether this was such a fence. If sheep strayed in seareh of food, one would suppose they would go where there was plenty of food, and not upon a barren railway line. Wus there any moof of negligence in the plaintiff in not placing hurdles to protect the sheep from the hedlge, insterul of using the heilye as one fence of the fold? If not, the other defences failed, and the company would be responsible. It was the duty of the company, and not of the plaintiff, to put up a sufficient 
fence for the purpose of preventing the sheep from straying. Why did the sheep stray? Was it not from the fence being insufficient? The jury must try the question as men of common sense. Probably the sheep were alarmed by a dog, for sheep were not straying animals. The jury found a verdict for the plaintiff, damages $£ 30$, in addition to the $£ 20$ paid into court, and a rule for a new trial was refused.

In Jorris r. Jeffries (1 Q. B. 261), horses grazing on a road-side under the charge and control of a man dnly authorized are not liable to be imponnded as "wandering, straying, or lying," under 4 Geo. IV. c. 95, s. 75 . 


\section{CHAP'TER V.}

\section{DANGEROUS ANIMALS.}

Wrokver keeps an animal accnstomed to attack and bite mankind with knowledge that it is so accustomed, is prima fucie liable in an action on the case, at the suit of any person attacked and injured by the animal, without any arerment of negligence or default in the securing or taking care of it. The gist of the action is the keeping the animal after linowledge of its mischievous propensities (May v. Burlett). Bnt per Curiam: "It may be that if the injury was solely occasioned by the wilfulness of the plaintiff, after warning, that may be a gromnd of defence, by plea in confession and aroidance" (ib.). In Lecome v. Bray, Lord Ellenborough C.J. says: "If I put in motion a dangerons thing, as if I let loose a dangerons animal, and leave to hazard what may happen, and mischief ensue to any person, I am answerable in trespass." Lord Holl C.J, also mentioned it as Lord Hate's opinion, that if through negligence the beast go abroad, after the owner has had notice of its mischievons qualities, and kill a man, it is manslanghter in the orncr (Rex v. Huggins, 2 Ld. Raym. 1583).

The argument in Jenkins v. Tumer turned partly on what were the animals which might be the subject of biting, within an owner's cognizance. This was an action on the case against Tumer pro co quod scienter retemuit a certain boar ad mordendum et pereutiendum animatic consuctum, and which percussit et momorlit a mare of the plaintiff's, of which bite she died. The boar had bitten a child before, of which the defendant had notice. It was contended in arrest of judgment, that "the word animalice was too general and uncertain, for it may be they were such animals as, though the boar nsed to bite them, and the defendant knew it, yet it wonld be no offence in the defendant to keep) the boar still ; as if the boar bit frogs and mice, which are animals." Powell J. said, "that if a man has a dog which bites sheep, and the man has notice of it and keeps the dog, and afterwards it bites a mare, an action lies, but the declaration mnst be special." His lordship also added, what certainly admits of considerable dispute, viz., that "there may be a difference between a boar and a $\operatorname{dog}$; for it is the nature of a 
dog to kill animals which are ferce nuturce, as hares, eats, \&e.; but it is not natural to a boar to kill anything ; and therefore in the ease of a dog there might hare becn a question whether the word animalic had been good in the declaration, becanse it might have been intended of some such animals as they naturally bite and kill. But sinee a boar does not naturally kill any, it shall be intended as before is said." And therefore the plaintiff had judgment, as after verdict, the Court intended that animatia were sueh animals as could support the action (1 Ld. Raym, 110).

Ferociuns doy.-To sustain an action against a person for negligently keeping a furocious dog, it is not necessary to show that the dog has bitten another person before it bit the plaintiff: it is sufficient to show that the dog has to the knowledge of the owner shown a savage disposition by attempting to bite (Worth v. Gilling, 2 L. R. C. P. 1).

In Fletcher r. Riylands, 1 I. R. Ex. 265, it was held that one, who, fur his own purposes, brings upon his land, and collects and keeps there, anything likely to do mischief if it escapes, is, primê facie, answerable for all the damage which is the natural consequence of its escape. Sce also Smith v. Fleteler, 7 L. R. Ex. 305.

But in the case of Simith v. Great Eastern Railuay Company, 2 I. R. C. P. 4, where a passenger was bitten by a stray dog at defendants' station, the Court decided in farour of the defendants, on the ground that there was no evidenee of negligence on their part.

The difficulty in Emery r. Peake scemed to be, whether the habits of the dogs had ever reached the defendant's ears. This was a Warwick Assize action against a clergyman for kceping a $\log$ accustomed to bite mankind. His two Skye terriers, while in company with Mrs. Pcake, who was risiting some sick poor, flew on the plaintiff, and bit him in the log and ancle. He exclaimed, "Oh, dear! I am bit!" and the lady expressed her sorrow. The leg bled very much, and became so bad that he conld not work, in eonsequence of the deep sore and wounds so occasioner, and he required medical attendance for tiro months. The defendant refused to see him when he called at the ricarage, and sent him half-a-crown. It was proved that the dogs had often before attacked and bitten people, and that among others the family butcher and his son had been bitten at, and had their trowsers torn, though their boots saved their legs. Both thase witnesses had complained to the servants. Mr. and Mrs. Peake gare the dogs a good character: the former had heard no complaints against his dogs, thongh the latter had heard of the trowser-tearing. Other witnesses also deposed to the peaceable dispositions of ". Mustard" and "Pepper";" but there was a rerdict for the plaintiff, damages $£ 60$. 
In the case of Glatman v. Johnson, 36 L. J. (N. S.) C. P. 153, the plaintiff was bitten by the defendant's dog: the defendant was a milkman, and was assisted in his business by his wife. To establish the scienter a witness was called, who stated that she had made a formal complaint to defendant's wife, for the purpose of its being communieated to the husband, of the dog llaving bitten her nephew, held, that there was evidence of the husband's knowledge of the dog's propensity to bite; and in Balduin v. Castefla, $7 \mathrm{~L}$. R. Ex. 325, that if the owner of a dog appoints a servant to keep it, the servant's knowledge of the dog's ferocity is the knowledge of the master. Sec also Applebee v. Percy, 9 L. R. C. P. 647.

The Court of Queen's Bench decided in Hartley r. Hurriman that evidence of the dogs being accustomed to attack men did not support a scienter that they were accustomed to attack sheep. Here the plaintiff had sent the gardener with his compliments to the defendant, to siny that he feared there would be danger if his dogs often erossed the field where his sheep, which were of a peculiar breed, were feeding. The defendant replied that he kept dog's to defend his house, and would if he pleased keep fifty more. When the gardener took the message lie also told the defendant that he had been attacked by the dogs at the plaintiff's omn door. 'There was other evidence that the dogs had attacked men, and that a voice had once been heard on the defendant's premises calling them off, and also that they had once or twice rum after sheep; but there was no proof that they had ever bitten or harmed any sheep before this event, and it was contended that there was no evidence to support the scienter. Wool B. overmled the objection on the ground that there was evidence of the dogs having attacked different men, and particularly the plaintiff's gardener, to the knowledge of the defendant. The jury found a verdict for the value of the sheep, but the Court made the rule absolute for a new trial. Lord Ellenborongh said: "The plaintiff has, I fear, tied up his complaint by the allegation of the particular habits of those dogs (viz., that 'they were used and accustomed to hunt, chase, bite, worry, and kill sheep and lambs'), and of the defendant's knowledge of those habits. For unless it be inferred that a dog accustomed to attack men is ipso fucto accustomed also to attack sheep, there is no evidence to support this declaration." But semble, that an averment that the dogss were of a ferocious and mischievous disposition wonld be sufficient in an action brought for an injury to plaintiff's sheep, without alleging specifically that they were acenstomed to bite and worry sheep (ib.).

The Court of Session in Scotland held in Orr r. Fleming, by three judges to one, that no scienter need be proved to make the master of a 
dog uho worries sheep liable. The defence was that there was no proof that the foxhound in question had shown any previous disposition to attack sheep, and the Finglish cases were relied on. And per Lord CockTurn: "The law of England allows each dog' to have one worry with impunity." Gettring r. Morgen was a later case of English sheep worrying. Upon the trial of au action in the Monmouth County Court

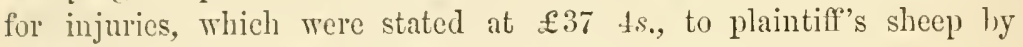
defendant's dogs, it was prored that four year's before the same dog's had, to defendant's knowledge, bitten a child eight years of age, who was passing through defendant's fold in the daytime. It was held by the Court of Quecu's Bench that upon this evidence the judge was justified in giving judgment for the plaintiff, and the judgment was affirmed with costs (5 W. R. 536 ; E. T. 1857, Q. B.).

I.ord Campbell C.J. said, "I am of opinion that our judgment should be giren for the plaintift, eren according to the law of England. Accordjng to the law of Scotland there is no oceasion to show the previons habits of the animal, or the scienter; and when an injury has been done to an innocent person, it certainly seems more reasonable that the loss should fall upon the owner of the animal which has done the mischief, than upon the person injured: but $F$ confine myself now to the law of Fingland, which requires the altegation and proof of a previous bad habit. Finoren to the master. Now in the County Court there is no declaration; but according to Hartley r. Harriman, it would be cnough to allege that the dogs were of a ferocious disposition to the knowledge of the owner. Assuming, then, the declaration to have been in that form, can it be said that there was in this case no evidence in support of that allegation, when it is found that four years before the dogs had bitten a child eight years old, as it was passing through the fold in the daytime? In my opinion that was enough evidence to justify the judge in concluding that the dogs were of a ferocious nature. According to Smith v. Pelah, one instance of previous ferocity is suffieient, and though I would not pronounce judgment of sus. per coll. upon the dog who had so offended, I think he should erer afterwards be cautionsly guarded, and that if he is again guilty of ferocions violence, his master must be answerable fur it." And per Crompton .J.: "I agree that the question is, whether there was such cridence that a jury could airly act upon, in finding for the plaintifi; and I think there was. In ordinary eases one previous act of ferocity is enongh to put the owner on his guard; and if he afterwards permit; his dogs, with knowledge of their vicions disposition, to run albout, with tickets of leare as it were, he must be responsible for any further damage which they may do."

Smille v. Peluh (2 Str. 126.1) was also remarked mon in Chertwood r. 
Greig, where the declaration stated that the defendant wrongfully and injuriously kept a certain dog of a ferocions and mischievous nature, and prone, used, and accustomed to attack, bite, and injure mankind, he well knowing that the dog was such. To this the defendant pleaded not guilty, and that the plaintiff annoyed and irritated the dog, and thereby caused him to bite, which latter plea was traversed by the replication. The plaintiff, who was between five and six years old, and the child of a hairdresser; had put his arms round the neck of the defendant's Danish dog, which had accompanied the servants to the shop on an errand. It was shown that the dog had bitten persons twice before, but only once to the defondant's knowledge. The latter insisted, in an interview with the plaintiff's father, that it was the child's fault, and said, "I want to impress upon you that dogs are uncertain things, and that children should be kept from them." To this the plaintiff replied that, "if they were such uncertain things, they ought to be muzzled;" and Cressuell J. said, "I am inclined to agree with him in that answer." The plaintiff's witnesses had seen the dog run about Clapham Common for years, but had nerer seen him fly at any one. His lordship observed, in summing up, "The question is, was it a sarage dog and accustomed to bite mankind? If you find a dog from time to time biting people under circumstances which could not excite a dog of good temper, you will say whether such a dog is a savage dog or not. There is a case (Smith v. Pelah) which decides that 'if a $d o g$ ' has once bit a man, and the owner having notice thereof lets him go about or lie at his door, an action will lie against him by a person who is bitten, though it happened by such person treading on the dog's toes; for it was owing to the defendant not hanging the $\log$ on the first notice, and the safety of the king's subjects ought not to be endangered.' Our criminal code has been much modified since that time, and that would not now be considered as a proper mode of proceeding. In the present case th master. certainly knew of one instance in which the dog had bitten a person before, and you will say whether, after that, he ought not to have taken more care with respect to it. It is not necessary that the dog shonld run about and show a disposition to snap at and bite everybody; a man of a bad temper is not always in a bad temper. You will say first whether the dog was a savage dog, and if so, whether the defendant knew it." There was a verdict for the plaintiff for $£ 25$ (3 Car. \& K. 46).

The decision of the Court of Exchequer in Hudson v. Roberts turned upon rather a fine point as to what constituted evidence for the jury of a scienter. The plaintiff, who was going on his lawful affairs, and wore a red handkerchief, was attacked and severely injured by a bull which was passing with cows of the defendant's along the highway. After the 
accident occurred, the defendant said to one of the witnesses that he knew $a$ bull would run at anything red, and to another he knew the bull would. The bull had often run at people in red garments, but it was not shown that the defendant knew of these oceurrences. Pollock C.B. considered that if there was any evidence of a scienter the case could not be withdramn from the jury, who found a verdict of $£ 20$ for the plaintiff. The Court discharged a rule to enter a nonsuit, and thought the rerdict a temperate one. Parke B., in delicering judgment, said, "As the circumstance of persons carrying red handkerchiefs is not uncommon, and it is reasonable to expect that in every public street persons so dressed may not unfrequently be met with, we think it was the dnty of the defendant not to suffer such an animal to be driven in the public streets, possessing, as he did, the knowledge that, if it met a person with a red grarment, it was likely to run at and injure him. If there be any evidence of a scienter it could not be withdrawn from the jury" (20 L. J. Ex. 697).

The point in Julge v. Co $x$ was whether a caution from the defendant to the person bitten was sufficient proof that the dog had bitten some one before to the defendant's knowledge. The dog which, as the declaration alleged, the defendant, Mrs. Cox, "knew to be accustomed to bite mankind," was on the premises when she took a ready-furnished house at Harrow, and one of the witnesses stated that she had warned him to take care lest he should be bitten. It wrenched the staple from the tree to which it was tied, and bit the plaintiff and a child subsequently; but there was no eridence of anterior biting. A blot J. intimated that but for the warning given by the defendant lie would have nonsuited the plaintiff, and added, "That in order to warrant a verdict for the plaintiff on such a declaration, they must be satisfied both that the dog had before bitten some person, and that the defendant knew it." He thought sufficient cantion had not been used to secure the dog, and the jury found a rerdict for the plaintiff with $£ 55$ damages. Referring to this case in Harlley v. IIariman, his lordship said, "I left it to the jury in that ease, to say whether the expression proved to have been used by Mrs. Cox, cautioning a person not to go near the dog lest he should be bitten, was not evidence from which they might infer that to her knowledge the dog had previously bitten some person" (1 Stark.285).

Iord Kenyon C.J. admitted, in Jones v. Perry (2 Esp. 482), evidence of a report that the dog had bern bitten by a mad doy previousty, to support the second count of the declaration, which charged the defendant with knowingly keeping a fierce and sarage dog without being properly secured. The dog had been tied up in a cellar loy a rope of such length that he reached the kerh-stone on the opposite side of the street, and tore the plaintiff's child, who was carried to the salt water, but died of 
hydrophobia on its return. His lordship thought it was not a ease for vindictive damages. "Report having said the dog had been bitten by a mad $\log$, it became the dnty of the defendant to be very cireumspect. Whether the dog was mad or not was a matter of snspicion; but it is not sufficient to say, 'I did use a ecrtain precaution.' He ought to use snch as would put it out of the animal's power to do hurt. Here, too, the defendant showed a knowledge that the animal was fieree, unruly, and not safe to be permitted to go abroad, by the precaution he used to tie him up. That precaution has not been sufficient; for a want of it the injury complained of has happened. I am elearly of opinion that the plaintiff should recover." Damages $£ 30$. His lordship also ruled in McKone $\mathrm{v}$. Wood, an action against a party for keeping a dog also accustomed to bite mankind, that it is not essential that the dog should be his, if he harbours or altous it to resort to his memises. Here the dors had bitten two persons before the plaintiff; and when a complaint had been made, the defendant said that the $\log$ (which was seen about the premises both before and after the time when the plaintiff was bitten) belonged to a person who had been his servant and left him.

In Clark v. Webster and Salt, Park J. ruled that the first speeial plea, viz., that the dog was accustomed to attack and bite mankind, and that the defendant and his gamekeeper shot him when he left his owner's waggon, and ran into a field where they were shooting, in order to save themselves, was not supported by evidenec, which only went to show that the dog had once been muzzled, had growled at people as they passed along the road, and pushed down a man who was earrying a pack. The plaintiff had a verdict for $£ 5$, though his lordship animadverted severely on the faet of his ealling seren witnesses to meet the first special plea, by giving eridenee as to the dog's quiet habits. The sceond special plea was to the effect that the defendant and his gamekeeper shot it because it attacked their dogs, and to save the lives of the latter, but nothing turned upon that.

Lord Denman C.J. ruled that to justify shooting another person's $\operatorname{dog}$ it is not sufficient to show that it was of a ferocious disposition and was at large, but it must be actually attacking the party at the time; and that therefore where the plaintiff's dog ran at and bit the defendant's gaiter as he was passing the house, and then ran away, and the defendant shot him at the distance of five yards, he was not justified in doing so (Morris v. Nugent). It was also ruled by Lord Ellenborough C.J. that if defendant justify shooting a dog because it was worrying his fowl, he must move that when he fired the dog was in the rery act, and could not be prevented from effecting his purpose by any other means (Janson v. Brown). And so where it was proved that the owner of 
sheep shot a $\operatorname{dog}^{\circ}$ which had been worrying them, after it had mun tro fields from the spot, Alderson B. held, in an action by the owner of the dog, that the defendant was not justified in shooting it, as it was not shot in protection of his property, though the habits of the dog might be considered in mitigation of damages (Trells r. Head).

In Biock r. Copsetend, where the declaration also stated that the defundant knowingly kept a dog used to bite, Iord Kenyon C.J. decided that nnder the cireumstances the action would not lie, and nonsuited the plaintiff. The defendant's foreman (who was the plaintiff) had gone into the wood-yard after it was shut at night; and the dog, which was rery quiet and gentle, and tied up all day, was let ont to guard the premises, and had bitten him. His lordship considered that the dog had heen projerly let loose, and the injury had arisen from the plaintiff's own fault in incautiously going into the defendant's yard after it had becn shut up). In a previous action (cited 1 Esp. 203) for keeping a mischievous bull that had hurt the plaintiff as he was crossing a field of the defendant's in which it was kept, the defendant's counsel contonded that the plaintiff having gone there of his own head, and having received the injury from his own fault, an action conld not lic. As, howerer, it also appeared in evidence that there was a contest concerning a right of way over this field, wherein the bull was kept, and that the. defendant had permitted sereral persons to go over it as an open way, his lordship r'nled, and the Court of King's Bench concurred in opinion with him, that the plaintiff having gone into the field, supposing that he had a right to go there, and the defendant having permitterl persons to go theie as over a legal way, the defendant should not then be allowed to set up in his defence the right of keeping such an animal there, as in his own close, but that the action was maintainable.

Blarkman r. Simmons (:) C.\& P. 138) was a case of much more modern date, and of the character of the one alluded to by his lordship. The bull was kept on some marsh land near Tottenham, where the inhabitants at a certain season of the year had a right of common for cattle. 'T'he plaintiff, who was a cowkeeper, and had cattle on the marsh, ras driving one of his cows to the bull at a neighbouring farm. There was only a shallow ditch between the field and the marsh, which the defendant's bull crossed and went to the cow. He was struck on the head by the plaintiff, whose stick broke short, and the bull then threw him dorn, and broke tro of his ribs. The defendant had had notice of his having run at a man previously, and at the time of the accident a strap and chain were fastened round the bull's neck, but so loosely as not to prevent his running. It was proved that when the defendant bought the bull he was told that it was rery mischievous, to which he 
replied it rould snit him all the better, as he was troubled by people fishing in his meadow. In reply to an observation that he wonld not surely turn the bull into the meadow without giving notice to the public, he replied, "Let him give notice himself."

Best C.J. remarked in strong terms on the "gross and wicked condnct," of the defendant, and said that if the plaintiff had died it wonld have been " an aggravated species of manslaughter." It was contended for the defendant, that the plaintiff had acted imprudently in attacking the bull, whereas, he ought to have permitted him to go near the cow, and that hence the plaintiff was not injured by the vice of the bull as charged in the declaration. Of such vice it was also urged, that the sight of the strap and chain was sufficient notice to the public. His lordship advised the jury to give considerable damages, and they assessed them at $£ 105$. Hence the ouner of a vicious animal, after notice that he has done an injury, is bound to secure him at all events, and is liable in damages to a party subsecquently injured if the mode he has adopted to secure it proves insufficient. As to prospectire damages see Hodsoll v. Stallebrass. There Littedate J. said: "You may show an injury of a permanent nature beyond the time at which the action is bronght; as in the case of a policy of insurance and other like instances. Then, can prospective damages be given? It appears to me that they may; for this arises from one injury : if they arose from various injuries that would be different. The case of Malachy v. Soper (3 N. C. 371) has been referred to, but that is not an anthority to bind the present case. It is from the consequence of one mnlawful act. You cannot have a fresh action unless there is a fresh mnlawful act done, and fresh damages also sustained as resulting from that act."

The right of any one to recover, who is injured by an animal on ground where he is entitled to be going about his lauful business, was upheld by Tinital C.J. in Sarch v. Blackburn. The plaintiff was a watchman; and the dog which bit him was tied to his kennel by a fouryard chain near a piggery and chicken-house and a cowshed, and just under a board which said in three-inch letters-"BEwARE OF THE DoG." There were three entrances to the house and premises, one of them, more public than the rest, having a spring gate; another, called the middle entrance, across a field; and a third, where the dog was, an cntrance across the cow-yard, and through a private gate and another yard to the house. One of the plaintiff's witnesses said that he had been bitten three years before, as he was passing through a private way to the premises, and that the defendant had rubbed his leg with brandy. He added that the family only used that way, but he had been there before with defendant's son. 
His lordship observed that if a man keeps a log in a garden walked all roumd, any one going in does so at his perit. "Undoubtedly a man has a right to keep a fierce $\log$ for the protection of lis property; but he has no right to put the dog in sucl a situation, in the way of access to his house, that a person innocently coming for a lawful puryose may be injured by it. I think he has no right to place a dog so near to the door of his house, that any person coming to ask for money or on other business might be bitten. And so with respect to a footpath, though it be a mrivate one, a man has no right to put a dog with such a length of chain, that he could bite a person going along it. As to the notice, it does not appear to me that a painted notice is sufficient, unless the party is in snch a situation in life as t. be able to arail himself of it. It does not appear to me that this notice is sufficient so as to bar the action, if the plaintiff' had any right at all to be on the spot, for it seems that he was not able to read. Then was there anything in the appearance of the dog which would lead the plaintiff to suppose that the dog would bite him? It seems that the injury happened in the middle of the day, in July, and that the plaintiff was a person employed as a watcher in the neighbourhood; and as no suspicion has been thrown upon him by the other side, you may presume he was going to the house for a lawful purpose. The only way in which I can leave the question (which I admit is one of considerable nicety) for your consideration, is to leare it to you to say on which side was the negligence on this oceasion. If there was negligence on the part of the plaintiff, he cannot recover for an injury which he has in part brought upon himself; but if there was no negligence on his part, and there was negligence on the part of the defendant, the plaintiff will be entitled to your rerdict." The plaintiff

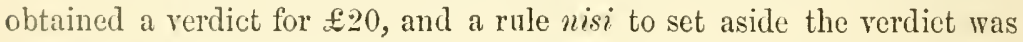
granted, but the case was settled before it came on for argument (МI. \& M. 505).

Again, C'rowder J. ruled, on Besozsi v. Harris, where the defendant owned a bear, which was fastened by a chain six feet long, on a part of his premises accessible to excursionists (one of whom it seized) frequenting his house on the Steep Holms in the Bristol Channel, that a jerson keeping an animal of a fierce nature is bound so to keep it that it shall not commit injury; and when therefore, such an animal does damage, the owner is liable, though it be shown that it never had evinced any fierceness, but evidence of its tameness is received under particular circumstances, in reduction of damages. The evidence was contradictory, as to the lady's knowledge of the bear being there, and there was no notice or caution, written or verbal, to those visiting the premises. 
Curtis v. Mills was a much stronger case than either of the ainove. 'The defendant, who kept a fierce dog so tied up that he contd still reach anyone going from the yard gates to the stable, was being assisted by the plaintiff to carry some planks he had purchased from his master, a wood-merchant, down the yard. 'The dog took no notice of his master as he passed, but severely bit the plaintiff who followed him. It was in evidence that on other occasions the plaintiff had been warned not to go near the dog, though never on the day of the accident; but there was no evidence that the dog had ever bitten a person before. Tindal C.J. held that under these cireumstances the plaintiff was entitled to recover, if the jury thought that he did not, as it u'ere, run himself into the mischinf by his own carelessness and want of cantion; and the plaintiff had a verdict for $£ 20$.

Real v. King was a case of dogs, described "as ferocious and mischievous" in the declaration, attacking "mare of the plaintiff's as he was driving her in a phaeton. On passing the defendant's honse four little wire-haired Skye terriers rushed ont and attacked the mare by barking and snapping at her heels. The animal, according to the plaintiff's account, bore it rer'y well for some time, but at last she took fright, and after plunging and kicking, whilst the plaintiff tried to control her and to drive away her assailants, she fell down and was severely injured. 'The veterinary surgeon's bill was $£ 7$, the repairs to the phacton cost $£ 13$, and eventually the animal was sold at Aldridge's for $£ 33$, and plaintiff now sought compensation for loss and damages. The defence was that the dogs were perfectly mild and harmless; one being totally blind, while in another the senses of seeing aud hearing were considerably impaired. A host of witnesses, amongst whom was a police constable who liad known the dogs for several years, were examined as to character; and some of them who had witnessed the oecurrence, attributed the damage sustained by the plaintiff to the fact that he had endeavoured to whip the first dog, which barked as the vehicle passed by. The defendant also swore that he did not know they were in the habit of attacking horses.

Bramwell B., in summing up, said the jury should find for the plaintiff if they considered the dogs were mischievous, and that the defendant knew it, and that the mischief resulted therefrom. If they were of opinion that they had a mischievous tendency, and the defendant did not know it, or that if they had and he did know it and the mischief was brought abont by some act of the plaintiff, then they must find for the defendant. The jury found a rerdict for the plaintiff, damages $£ 5310 s$; bnt a rule to set aside the verdict on the ground of misdirection, improper reception of evidence, and that the verdict was against 
eridence was made absolute by the Court of Exchequer. Pollock C.B. and Martin B. were of opinion that there was no evidence to go to the jury to show that the dogs were mischierons to the knowledge of the defendant, and that the rule shonld therefore be made absolute. Bramwell B. thonght that the evidence justified the jury in exercising their discretion in arriving at a conclusion of what the four dogs lad done, althongh one might be harmless, and that the rerdict was right; and Chamnel B. considered there was some evidence to be left to the jury, but not sufficient to show that the dogs were mischievons to the knowledge of the defendant.

Not Guilty puts in issue the scienler, and defendant's conditional offer to pay is slight evidence of it (Thomas v. Morgan, 2 C. M. \& R. 496). The declaration here alleged that the defendant "knew that the dogs were of a ferocious and mischicrous disposition, and accustomed to attack, chase, bite, worry, and kill eattle." It was proved that they had killed some of the plaintiff's sheep, as well as the cattle of other people, and that when the defendant was told that his dogs had killed three of the plaintifn's sheep, he promised to settle if it could be proved they had done it. The witness, Protheroe, whose cattle had also been worried (and to whom he oftered satisfaction), deposed that the defendant told him (abont three days after the sheep were worried) that he could not help it, and had ordered his dogs to be kept up. Nitliams J. thought there was not sufficient evidence of the scienter to make the defendant liable, and nonsuited the plaintiff, with leave to move to enter a verdict for $£ 1110 s$, the value of the sheep. The Court discharged the rule, and held that the plea of Not Guilty put in issne the scienter, it being of the substance of the issue, and also that the defendant's conditional offer to pay for the demayge was some slight evidence for the jury of the scienter. Prothcroe's eridence here referred to a time subsequent to the act laid in the declaration, and it was no evidence of it. The offer to pay might have been made from motives of charity in the first instance, and withont any admissive liability at all; and if it had been submitted to the jury the Court felt that it should have been done with such strong observations against its weighing much for the plaintiff; that they declined to disturb the nonsuit. Again in Hogen r. Sharpe, where the declaration stated that the defendant kept a dog "of" a ferocions and mischievous disposition, well knowing him to be so," Lord Abinger C.13. held that the plaintifl must be nonsuited if the defendant never knew the dog to bite any one before, and that he might avail himself of such want of knowledge under the plea of Not Guilty. And in Carel v. C'ase, where a dog belonging to the defendant had chased and killed certain sheep and lambs of the plain- 
tiff's, but there was no evidence that the defendant knew that the don was accustomed to bite sheep, $V$. Willicms J. nonsuited the plaintiff, with leave to move to enter a rerdict for $£ 914 s$, if the Court should be of opinion that the scienter was not put in issue by Not Guilty (5 C. B. 622).

The question here was, as to the effect of the plea of "Not Guilty" in an action for damage done to the plaintiff's sheep by a ferocious dog, as regulated and restricted by the new rules? 'The Court of Common Pleas discharged the rule on the ground that the scienter was clearly put in issue by that plea, and that the plaintiff was bound to prove it; and per Manle J.: "If screral unlawful acts are alleged in the same declaration, Not Guilty will put them all in issue. The eases of ILuy v. Burdett and Jackson v. Smithson, and the general conrse of precedents and anthorities referred to in $M I a y$ r. Burlett prove that the wrongfin act is the keeping of the ferocious dog, knowing its savage disposition, and that an action of this sort may be maintained withont alleging any negligence. The allegation of duty in the defendant to use due and reasonable care and precantion in keeping the animal, is quite immaterial (Brown v. Mallet). The utmost diligence will not excuse him if the dog was of a ferocious disposition, and the defendant knew it. The ground of action is the kecping of a ferocious dog knowing his disposition. Not Guilly cannot put the biting in issue: that is the act of the doy." The decision in May v. Burdelt, as well as that in Jackson v. Simithson, which was argned in the Cont of Exchequer a few days after, and entirely governed by it, are binding anthorities to show that negligence is to be presumed without cxpress averment. The former of these two was the case of a person keeping a monkey which he knew to be accustomed to bite, and which bit the female plaintiff. In Jackson v. Smithson (15 M. \& W. 563), where the defendant "wrongfully and injuriously kept a ran, well knowing he was prone and accustomed to attack, butt, and injure mankind," the plaintiff had a verdict for $£ 10$, and the Court refinsed to arrest the judgment for lack of an express averment that the defendant negligently kept the ram. In reference to Mley v. Burdelt, Alderson B. said: "In truth there is no distinction between the case of an animal which breaks through the tameness of its natnre and is fierce, and known by the owner to be so, and one which is ferce nature (9 Q. B. 101).

Depasturing a vicious horse.-In the case of Rey. v. Dant, the prisoner had turned out upon a common a horse which he knew to be vicions; the horse kicked and killed a littie child which had strayed off the path on to the common, and the prisoner was tried and convicted of manslaughter : held that the conviction was right. 34 L. J. M. C. 119. 


\section{CHAP'TER VI.}

WATER.

Iт was deciled (Rex, mlaintiff in erroi v. Lord Farboroungh) by the Honse of Lords, in concurrence with the unanimous opinion of the judges, that lands formed stowly, gradually, and imperceptibly, by allurion on the sea stiore, belong by general immemorial custom to the owner of the adjoining lands, and not to the Crown. The orner of the shore between high and low water-mark is entitled to sueh parts of the adjoining soil as by the gradual and impereeptible encroachments of the sea have been bronght within those limits; while the owner of the lnnd next adjoining high-water-mark is entitled to all the soil that is added to his land by the imperceptible retiring of the sea; and the same rule holds good for rivers. In re Hull and Selly Railuay, Lord Alinger C.B. referred in his judgment to the case of a $\mathrm{Mr}$. Adam, where a river, containing a salmon fishery belonging to him, was suddenly transferred to the land of his neighbour, who enjoged it with the valuable right attached to it. Afterwards, by another violent effort of nature the river returned to its former chamel; yet in neither case did the owner of the bed of the river lose his right to the soil.

Lands gained fiem the sea.-In The Attomey General r. Chambers, \&c., the Crown claimed to have the medimm line (the boundary of the rights of the Crown on the sea-shore) laid down as it would have existed but for artificial-canses; and it was held on appeal by Lord Chancellor Chermsford that lands impereeptibly gained from the sea by a party's lawful use of his own land, belong to the owner of the land adjoining, unless it can be shown that the operations were intended to produce this gradual acpuisition of the sea-shore. Aud where a party claimed the sea-shore in front of his property, on the ground that he had turned his cattle upon the marsh, and that they had crossed the boundary separating the marsh from the sca-shore, and that he had done this for sixty years without interruption, it was held that where property is of a nature that cannot easily be protected against intrusion, and, if it could, it would not be worth the tronble of prerenting it, mere user is not sufficient to establish a right (ib.). 
Incidents of the sect-shore. - The sea-shore below high water-mark, and without iuhabitants, is an extra-parochial place, having a population less than two hundred persons within the meaning of sec. 6 of 18 \& 19 Vict. c. 121 (Rey. on mroson. of Earl Derby v. Gee and Others). Part of sea-shore between high and low water-mark is within and part of the adjoining county ; so that the justices of the county have juriscliction to take cognizance of offences committed therein, whether land be covered with water or not at the time the offence is committed. And per Cockbum C.J.: "It is elear upon the anthorities, as also upon Rey. v. Mrusson (27 L. J., N. S., Q. B., 222), where it was distinctly held that such part of the sea was within the county, that the justices had jurisdiction to entertain this matter, and that that jurisdiction ought to be excrcised" (Embleton appt. v. Brou'n resp.).

Property in accretions from a non-uacigable river-Accretions from the gradual change of the course of a non-navigable river, where there are no fixed boundaries, will become the property of the owner of the adjoining land (Foid v. Lacey).

But in cases of gradual accretion, the land gained belongs to the proprictor of the adjacent soil. Parke B. held it as settled that encroachments made by a tenant are for the benefit of the landlord, unless it appear clearly, by some act done at the time of the making of the encroachments, that the tenant intended the encroachments for his own benefit, and not to hold them as he held the farm to which the encroachments were adjacent (Doe dem. Lece is v. Rees). This action was one of ejcctment by the lessor of the plaintiff, to recover from the defendant a piece of land encroached from the sea coast by the defendant, while tenant to the lessor of the plaintiff of his farm, which did not extend quite down to the sea shore, till the defendant made the encroachment in question. There is no obligation on a parish to repair a road when it is ueashed areay by the sea (Rey. v. Inkabitants of Hornsea); and per Haule J., "There is no such thing as an absolute right of the public against the act of God and the processes of nature. The repairs to roads which the common law contemplated, were repairs which conld be done by the farmers and their labourers. Here to repair the road, you must begin by restoring the cliff."

A grant by the Crown of "all coals under the commons, waste grounds, or marshes" of a certain manor, was held by Stucert V.C. and Watson B. to pass coal lying under the fore-shore of the estuary of the river Dee, between high and low water-marks, and forming part of such manor (The Attorney-General v. Hamer). If the officers of a parish claim a right to rate a person occupying that part of the sea-shore which lies between high and low water-marks, the onus lies upon them to show 
bs eridence that such part is within the parish, and in the absence of eridence it must be presumed that the land is extra-parochial, and therefore not liable to be rated (Reg. r. Mrusson).

Where, in trespass qu. cl. frey. (Jones v. Irilliems) the plaintiff claimed the whole bed of a lirer florring between his land and the defendant's who contended that each nas entitled ad medium filum aque, it was held, on the principle laid down in Doe v. $K(m)$, that eridence of acts of oumerstip exercised by the phleintiff on the bed and bcenks of the river on the defendant's side, lower down the stream, and where it flowed between the plaintiff's land and a farm adjoining the defendant's land; and also of repairs done by the plaintiff to a fence, which divided that farm from the river, and was in continuation of a fence dividing the defondant's land from the river-was admissilble for the plaintiff. Such acts of omnership in another part of one continuous liedge, and in the whole bed of the river, adjoining the plaintiff's land, are admissible in evidence, on the gronnd that they are such acts as may reasonably lead to the inference that the entire hedge and bed of the river, and conseruently the part in dispnte, belonged to the plaintiff. And per Parke B., "Acts of ownership are not admitted in evidence on the ground of acquiescence; that goes only to the ralue of the evidence; but as showing possession, and so proving title" (2 N. C. 102, Ex. Ch.).

On a grant of a certain weter, the righl of fishing passes to grantee, but not the soil (Co. Litt. 4 b.). An injunction goes to restrain defendants from injuring fish ponds by obstrueting them, and not kceping the sills in reprair (Earl Bathurst v. Burden). 'The right of the flou' of water to a pond was greatly considered in Hale v. Oldroyd, in which the plaintiff alleged a reversionary interest in three closes of land, to wit, three ponds filled with water, one on each close, and a right to the overflow of a certain stream of water from an ancient public well in the defondant's close into the plaintiff's three closes, to water his eattle, which stream the defendant had direrted. The defendant, in addition to his plea of Not grilty, traversed the right of the tenant to such overflow. The 1) laintifl had enjoyed an immemorial right to the overflow of this water into an ancient pond in one of these closes; but more than thirty years lefore, he had made a new pond in each, and the old one had gradually got filled up with rubbish and grass. 'This right in respect to the three ponds was defeated by proof of an ontstanding life estate, under 2 \& 3 IIill. IV. e. 71, s. 7. It was held that he was entitled under this declaration to recover in respect of his right to the orerflow of water to the otel pond (14 M. \& W. 789 ).

Parke B. said, "The use of the old pond was discontinued, only because the plaintiff obtained the same or a greater advantage from 
the use of the three new ones. He did not thereby abandon his right: he only exereised it in a cifferent spot, and a snbstitution of that nature is not an abandonment. He has a right, therefore, under this declaration, to reeorer in respect to the old pond. The right alleged is a right to have the uninterrupted flow of certain surplus water into a pond; and that right is equally proved, whether it be by preseription, or lost grant, or under Lord Tenterden's act. The declaration means no more than this, that the plaintiff has a right to the overflow of water either in one pond or three ponds." And per Rolfe B.: "The declaration means only that the plaintiff has a right to have certain land covered with water, and no abandonment of the right has been proved. If the plaintiff had eren filled up the pond, that would not in itself amount to an abandonment, although, no donbt, it would be evidence of it." If one has anciently calle pomls which are replenished by a rivulet, he may cleanse them, but he camnot change or enlarge them so as to divert the water from its ancient course to the damage of another (Brou'n v. Best). And so a person whose land is occasionally liable to injury by the orerflou of river u'ater, has no right in his mode of protecting himself against that injury to produce injury or damage to his neighbours in respect of the course of the same water (Rex v. Trafford). And the case of (Fronkum v. Earl Falmoulh shows that Not guilty only puts in issue the actual diversion of the water.

A right to water is not destroyed becanse the plaintiff had three years before slightly altered the course of the stream at a point between its exit from the defendant's land, where the obstruction took place, and its citrance upon his orn land; neither is the ancient right lost by desuetude, because more than twenty years before, the stream had ceased to flow to the plaintiff's lane, and had resumed its ancient course only nineteen years before the commencement of the action (Hall v. Sirift). Timdal C.J. observed that it wonld be very dangerons to hold that a party should lose his right in consequence of such an interruption; and that if such were the rule, the aceiclent of a dry season, or eauses orer which the party conld have no control, might deprive him of a right established by the longer course of enjoyment.

The right of lamiouners on the banks of a stream to ampropriate zeater, was first specially considered in Bealey r. Shcue. That case established the principle that the orner of land through which a river runs cannot, by enlarging a channel of certain dimensions through which the water had been nsed to flow before any appropriation of it by another, divert more of it, to the prejudice of any other landowner lower down the river, who had at any time before such enlargement appropriated to himself the surplus water which did not escape by the former channel. 
And per Le Blanc J.: "The true rule is that after the erection of works, and the appropriation by the owner of the land of a certain quantity of the water flowing orer it, if a proprietor of other land afterwards take what remains of the water before unappropriated, the first-mentioned owner, howerer he might before such second appropriation have taken to himself so much more, cannot do so afterwards" (6 East. 215).

'This rule was eited loy Holroyd J., in Samelers v. Neuman, which dccided: That the occupier of a mill may maintain an action for forcing back water aml injuring his mill, althongh he has not enjoyed it precisely in the same state for trenty years. And therefore it was holden to be no defence to such an action, that the occupicr had within a few years erected in his mill a wheel of different dimensions, but requiring les water than the old one, although the declaration stated the plaintiff to he possessed of a mill, without alleging it to be an ancient mill. It was laid down in Hilliems r. IForelend, that flowing water is publici juris, and that an individual can only aequire a right to it by appropriating so much of it as he requires for a beneficial purpose, and that therefore the plaintiff could not recorer damages for the mere erection of a lam higher up the strean, which prevented the water from running smoothly in its usual course, and caused it to run in a different chanmel, and with greater riolence, though it did not, according to the finding of the jury, cause any damage to the banks and premises of the plaintiff. Litfleclele J. said : "Water is of that peeuliar matme that it is not sufficient to allege in a declaration that the defendant prevented the water from flowing to the plaintiff's premises. The plaintiff must state an actual damage accuing fiom the want of the water. The mere right to use the water does not give a party such a property in the new water constantly coming, as to make the diversion or obstruction of the water, per se, gire him any right of action. All the king's subjects have a right to the use of flowing water, provided that in using it they do no injury to the rights already rested in another by the appropriation of the water."

Tindal C'.J. said in his judgment in Liyyins v. Inge, "Wreter flowing in a strem, it is well settled, by the law of Englenel is publici juris. By the Lomen Law, mmning water, light, and air, were consilered as some of those things which had the name of res communes, and which were defined 'things the property of which belong to no person, but the use to all.' And by the law of Englend, the person who first appropurates any part of the water flowing through his land to his own use, has the right to the use of so much as he thus approprriates, against any wher (Braley r. Sheuw). And it secms consistent with the same principle, that the water after it has been so made subservient to 
private uses by appropriation, should again become mublici juris by the mere act of relinquishment. There is nothing unreasonable in holding that a right which is gained by oceupancy should be lost by abandonment. Snppose a person who formerly had a mill upon a stream should pull it down and remove the works, with the intention never to return. Could it be held that the owner of other lands adjoining the stream might not erect a mill and employ the water so relinquished? or that he could be compellable to pull down his mill if the former millowner should afterwards change his determination and wish to re-build bis own?" (7 Bing. 682).

In Mason v. Mill (5 B.\& Ad.), the proposition for which the plaintiff contended was, that the possessor of lemel through which a nutural stieam muns, has a right to the atvantage of that stream flouring in its natural course, and to use it when he pleases, for any purposes of his own, not inconsistent with a similar right in the proprietors of land above and below-that neither can any proprietor above diminish the quantity or injure the quality of the water which would otherwise descend, nor can any proprietor below throw back the water without his licence or grant; -and that whether the loss by diversion of the general benefit of such a stream be or be not such an injury in point of law as to sustain an action without some special damage, yet, as soon as the proprietor of the land has applied it to some purpose of utility, or is prevented from so doing by the diversion, he has a right of action against the person direrting. The defendants, on the contrary, maintained that the right to flowing water is publici juris, and that the first person who can get possession of the stream, and apply it to a useful purpose, has a good title to it against all the world, incluling the proprietor of the lant below, who has no right of action against him, muless such proprietor has already applied the stream to some iseful purpose also, with which the diversion interferes; and in default of his having done so, may altogether deprive him of the benefit of the water.

The Court of Queen's Bench held that the defendants lid not acquire a right by their appropriation, aygainst the use which the plaintiff afterwards sought to make of the water; and hence the proprietor of lands contiguous to a stream may, as soon as he is injured by the diversion of the water from its natural course, maintain an action against the prarty so diverting it ; and it is no answer to the action that the defendant first appropriated the water to his own use, unless he has had trenty years' mndisturbed enjoyment of it in the altered course. Lord Tenterden C.J. rested the decision of the Court mainly on the judgment of Sir John Leach V.C., in Wright v. Howarl: "The right to the use of water" rests on elear and settled principles. Prima facie, the proprietor of 
each bank of a stream is the proprietor of half the land covered by the stream; but there is no property in the water. Every proprietor has an equal right to use the water which flows in the stream, and consequently no promictor can have the right to use the water to the prejudice of any other moprietor. Withont the consent of the other proprietors, who may be affected by his operations, no proprietor can either diminish the quantity of water which would otherwise descend to the proprietors below, or throw the water back upon the proprietors above. Erery propurictor, who claims a right either to throw the water back abore, or to diminish the quantity of water which is to descend below, must, in order to maintain his claim, either prove an actual grant or licence from the proprietors affected by his operations, or must prove an minterrupted enjoyment of twenty years, which term is now adopted on a principle of general convenience, as affording conclusive evidence of a grant. An action will lie at any time within twenty years, when injury happens to arise in consequence of a new purpose of the party to arail himself of his common right."

Lord Demman C.J. (who expressed himself as entirely concurring in Tord T'enterden's judgment), after reviewing Bealey v. Shauw, Saunders v. Newman, Williams v. Horelend, and Liggins v. Inge, thus remarked on those cases in Mason v. Hitl: "None of these dicta, when properly understood with reference to the cases in which they were cited, and the original anthorities in the Roman Law, from which the position that water is mublici juris is deduced, onght to be considered as anthorities that the first occupier, or first person who chooses to appropriate a natural stream to a useful purpose, has a title against the owners of land below, and may deprive him of the benefit of the natural flow of water."

In Dirkinson r. Grand Junction Canal Company (which, with Batslon 5. Bensteal, are the only two cases in the books which support a claim to uater not in a flowiny strecm) the Court of Exchequer decided in faronr of the plaintiffs, the omners of ancient mills, who were entitled to the use of two streams for the working of their mills, against the defendants, who had abstracted subterranean water, which had never reached the streams, but would have done so in its natural course but for the excavation of a woll and pumping from it and whether such water was part of an inderground watereourse, or percolated through the strata, the Court held that the abstraction was equally actionable. And per Pollock C.P.: "We consider it as settled law, that the right to have a stream running in its natural course is not by a presumed grant firom long acruiesecnce on the part of the riparian proprietors above and helow, but is ex jure naluere (Shurey v. Piggot, Tyyler v. Wilkinson), 
and an incident of property as much as the right to have soil itself in its natural state unaltered by the acts of a neighbouring proprietor, who eannot dig so as to deprive it of the support of his land. But in the much-considered case of Acton v. Bhundell, in the Court of Exchequer Chamber, a distinction is made for the first time between underground waters and those which flow on the surface; and it was held that the owner of a piece of land, who has made a well in it, and thereby enjoyed the benefit of under-ground water, but for less than twenty years, has no right of action against a neighbouring proprietor, who, in sinking for and getting coals from his soil in the usual and proper manner, causes the well to become dry. The decision goes no farther. In the present case the water is proved to have been taken from the river after it formed part of its stream, not by the reasonable use of it hy another riparian proprietor, but by the digging of a rell, which is clearly a diversion; and an action will lie at common law against the Company for the injury which has resulted from that unauthorised act to the known right of the mill-owners. And as to the abstraction of the water, which never did form part of the river, but has been prevented from doing so in its natural conrse by the exearation of the well, whether the water was part of an underground water-course, or pereolated through the strata, we are also of opinion that an action wonld lie. The mill-owners were entitled to the benefit of the stream in its natural course ; and they are deprived of part of that benefit if the natural supply of the stream is taken away" (7 Exch. 282).

Lord Etlentorough. C.J. ruled, at Nisi Prius, in Butston v. Bensteat, that after tuenty years uninterrupted enjoyment of a spring of water, an alusolute right to it is gained by the occupier of the close in which it issues abore groume; and the owner of an adjoining close cannot lawfully cut a drain whereby the supply of water to the spring is diminished. In Acton v. Blundell, Tindal C.J. said: "The rule of law which governs the enjoyment of a stream, flowing in its natural course orer the surface of land belonging to different proprietors, is well established; each proprietor of the land has a right to the advantage of the stream flowing in its natural course over his land, to use the same as he pleases, for any purpose of his own, not inconsistent with a similar right in the proprietors of the land above and below; so that neither can any proprietor above diminish the quantity or injure the quality of the water which wonld otherwise naturally descend, nor can any proprietor below throw back the water without the licence or the grant of the proprietor above. The rule is laid down in those precise terms by the Court of King's Bench, in Mason v. Hitl, and substantially is declared by Sir John Leach V.C. in the case of Wright v. Howarl, and such we 
consider a correct exposition of the law. And if the right to the enjoyment of undergromnd springs, or to a well supplied thereloy, is to he gorerned by the same law, then nudoubtedly in this case the defendants conld not justify the sinking of the coal-pits (which laid the mell dry), and the direction of the learned judge Rolfe B. would be wrong. There is, howerer, a marked and substantial difference between the two cases, and they are not to be governed by the same rules of law." The Court then went on expressly to state, that it intimated no opinion whatever as to what the rule of law would be if there had been an mintcrrupted use of the plaintiff's right for more than the last twenty rears. But Purke B. observed, upon Acton v. Bhundell being eited in the argument in Proadlent v. Ramstotham: "That case decided that there is no right to a well unless the water has been used for twenty years. This Court, and I believe all other courts, disapprove of that part of the judgment which denies the natural right to the water." Colerillye J. referred to this dictum with approbation, in Chasemore v. Richarls, in order to show that he was not withont authority when he "ventured to disagrce with what is laid domn in Acton r. Blundell, both as to the natme of the property in subterranean waters, and as to the reasonableness of acquiring a right to use them, as against the landowner in the way of a servitude mpon his land."

The following statement of the law with regard to the right to flowing water in Embrey r. Oren was finally adopted by the Exchequer Chamber in Chasemore v. Richards: "The law as to flowing water is now put on its right footing by a series of cases, beginning with Wright v. Houcard, followed by Hason v. Hill, and ending with that of Wood v. Wrand (? Exch. 773); and is fully settled in the American Courts. The right to have the stream to flow in its natural state without diminution or alteration is an incident to the property, in the land through which it passes; but flowing water is mblici juris, not in the sense that it is bonum eacans, to which the first occupant may acquire an exclusive right, but that it is public and common in this sense only, that all may reasonably use it who have a right of access to it, that none can have any property in the water itself except in the particular portion which he may choose to abstract from the stream and take into his possession, and that during the time of his possession only (JIason v. Hill). But each froprictor of the adjacent land has a right to the usufinct of the stream which flows through it." "The right of each proprictor of the adjacent land to the usufruct of the stream which flows through it is not an absolute right to the flow of all the water in its natnral state; if it were, the argument which has been nsed that every abstraction of it would give a cause of action would be irrefragable; but it is a right 
only to the flow of the water, and the enjoyment of it, subject to the similar rights of all the proprictors of the banks on each side to the reasonable enjoyment of the same gift of Providence."

The right of sinking a well, and thereby interfering with the subterranean supply to a stream, was much considered in Chascmore $\nabla$. Richards, which decided that the owner of a mill on the banks of a river cannot maintain an action against a landowner who sinks a deep well in his own land, and by pumps and steam engine diverts the underground water, which would otherwise have percolater through the soil, and flowed into the river, by which for upwards of sixty years the mill was worked. The plaintiff had a mill, and was entitled to the flow of the stream of the river Wandle. For more than sixty years before the acts complained of, the defendant had not abstracted any of the water from the stream itself, but considerable abstraction had taken plạce from one of the sources of supply to the stream. A large quantity of rain falling in a district of many thousand acres, sank into the upper ground, and then flowed and percolated through the strata to the Wandle, sometimes rising to the surface in springs, and flowing as surface streams into the river; in other instanees finding their whole way underground into the river by drains and courses, so as to supply the river above the mill. The defendant, who conld not reasonably foresee the precise effect, sunk a 74 feet well on a picce of land of his own, in the district, a quarter of a mile from the commencement of the river, intercepted a portion of the water, and supplied 500,000 gallons to Croydon daily. Part of this water was flowing, and finding its way underground through the strata towards the river, and but for its being so intercepted would have reached the river above the plaintiff's mill, and in sufficient quantities to have been of sensible value in and towards the working of it.

The Exchequer Chamber held (Coleridge J. diss.) that no action was maintainable. Cressivell J. in his judgment examined and commented on Dickinson v. Grand Junction Canal Company. His lordship observed: "The owner of a mill on a flowing stream is in the same position as a riparian proprietor; he can have no larger right than that which he has by nature against those above or below him, unless it has been acquired by adverse user. A party, whether mill-owner or riparian owner, suing for abstraction of water, must establish a right either jure naturce or by user, and in the latter case the user must be such as to establish a servitude affecting the land through which the water flows. Every riparian owner is by nature subject to the natural rights of those lower down, which are in the nature of a servitude imposed on the land-a servitude ne facias. Can, then, this servi- 
tude, imposed by nature or by nser, extend to water oozing through land near a flowing stream, which if not intercepted would find its may into that stream ?"

"None of the text-books or decisions in which an attempt has been made to define the rights of riparian ouners to flowing water have extended them beyond some definite aseertained flowing stream, with the exception of Dickinson v. The Grand Junction Canal Company. To extend them further wonld interfere with rights of the landowner, which have never' yet been disputed. 'T'hns a riparian owner cannot divert a flowing stream for any purpose, whether for irrigation or draining his land, or any other, to the prejudice of other riparian owners. But it lats never yet been held, nor was it contended on the aroument of this ease, that a man might not drain his land, and so abstract water oozing through it, although such water wonld have otherwise lave found its way to a flowing stream. Nor has it becn contended that an owner of land situate near a flowing stream may not make a pond for use or ornament, although water would ooze into it which otherwise would have gone into the stream; but he conld not for any of these purposes abstract water from a flowing stream. Again, the orrner of land near a flowing stream has hitherto been supposed to have the right of preventing water from coming into his land from higher ground, provided he does not throw it back upon his neighbours; but he can no longer do that, if water so percolated is to be put upon the same footing as a natural flowing stream; for that he cannot lawfully divert, even for the purpose of preventing injury to his land. But if he may prevent the water from oozing into his land, why should he not allow it to come, and then collect and nse it? And to allow this, wonld be in direct conformity with Ravestron v. Taylor, and Broudbent v. Ramsbothum. The case of Dickinson v. The Grand Junction C'unal Compamy having been eited in argument in Broalbent v. Remsbothem, Porke B. observed, "That ease only decided that if" a person had a right to a stream jure naturce, he had a right to its subterranean course.' If it went beyond that, it appears to have been repudiated by the same Court in both Rausstron v. Taylor and Broadlent v. Reemsbothem, and I think rightly. And adopting the law laid down in these two latter cases, I am of opinion that the action cannot be maintained, and that the judgment of the Conrt below must be confirmed."

This ease of Chascmore r. Richarls was earried to the House of Lords by Writ of Error, but the judgment of the Exchequer Chamber was confirmed.

Hence, the owner of an ancient water-mill on a river has no right of action against an owner of land adjacent who digs a deep well on 
his land, and thereby diverts the underground waters, not knou'n to be formed into a stream, flowing in a defined channel, which otherwise wonld have percolated into the river, although the landowner does not use the water for purposes comnected with the land, but pumps it up and carries it off in pipes to supply persons living in the neighbourhood, many of whom had no right to use the water at all.

The above three cases were the only ones cited in the argument in Dudden v. The Guardians of the Poor of Chutton Union. There the water from a spring flowed in a natural chamel to a stream on which was a mill; the spring u'as cut off at its source by the licence of the ou'ner of the soil in which it rose, and it was held that an action lay against the person so abstracting the water. The plaintiff was the owner of a mill situated on a stream which rises near a place called the Holly Marshes. Prior to 1852, " The Red House Spring," which rose from the earth in a field of Captain Scobell's, after" a short course fell into the stream on which the plaintiff's mill was sitnated. Before 1835, the tenant of the field had slightly altered the course, in which the water after rising from the spring flowed to the stream, and before such altcration the cmrrent from the spring flowed across the adjoining field to the same stream, in a crooked channel or gnlly, where watereresses grew, and trout had been caught in summer, close up to the spring-head. 'The union workhouse is a mile to the north of the spring, and the Guardians in 1852 got a grant from Captain Scobell of the nse of the spring, and caused works to be constructed to supply the workhonse with water from it. A tank was therefore sunk into the earth at the month of the spring, and at a considerable depth, and a line of pipes took the water from thence to the workhouse. The overflowing of the tanks ran throngh the channel to the stream. The jury found a verdict for the plaintiff, leave being reserved for the defendants to move to enter a nonsuit, but the Court discharged the rnle.

Pollock C.B. said: "The real question is, whether there is a natural watercourse, which, but for the acts done by the defendant, would have conveyed water to the stream, and from thence to the mill of the plaintiff. If there is a natmral spring, the water from which flows in a natural channel, it cannot be lawfully diverted by any one, to the injury of the riparian proprietors. When the stream is abore ground, a grant must be presumed not only of the thing itself, but of all things necessary to the complete enjoyment of it. If the channel or course underground is known, as in the case of the river Mole, it cannot be interfered with. It is otherwise when nothing is known as to the sources of supply; in that case, as no right can be acquired against the owner of the land under which the spring exists, he may do as he pleases with 
it ; and if in mining or draining his land he taps a spring, he cannot be made responsible. This was a natural spring, which had acquired a natural channel from its scurce to the river. It is absurd to say that a man might take the water of snch a stream, four fect from the surface." Martin B. added : "I am of the same opinion ; the owners of land adjoining a stream, from its source to the sea, have a natural right to the nse of the water. A river begins at its sonrce where it comes to the surface, and the orner of the land on which it rises cannot monopolize all the water at the source so as to prevent its reaching the lands of other proprietors lower down" (26 L. J. Exch. 146).

It was held by the Court of Queen's Bench in Magor v. Chadwick (11 Ad. \& E. 571) that, in the absence of a special custom, artificial vatercourses are not distinguished in law from natural ones; and that a title may be gained by 20 years' user, as well to the former as to the latter. Therefore, where owners made an adit through their lands to drain the mine, which they afterwards ceased to work, and the owner of a brewery, through whose premises the water flowed for 20 years, after the working had ceased, had during that time nsed it for brewing, he was held to have gained a right to the undisturbed enjoyment of the water, and the mines could not afterwards be worked so as to pollute it. But qucere whether a mirersal practice in the neighbourhood to resume the use of such adit waters for mining purposes after a long interval might not have been set up in answer to the claim of easement, thereby raising the inference that the party claiming used the water, not of right, but only during the accidental disuse of the adit, and with knowledge that the mine-owners reserved to themselres a power to recommence working, and thereby disturbing the waters. And as to the flow of water into or from collieries, see Insole v. James, Smith v. Kenrick, and Clegy v. Dearden (I2 Q. B. 576).

Wright v. Willicems (1 MI. \& W. 77) decided that a claim by an owner of a copper mine to sink pits on his ou'n lands, to fith such pits with iron, and to cover the same with water pumped from the mine, for the purpose of precipitating the copper contained in such water, and aflervards to let off the water impregnated with metallic substances into a watercourse on the land of another, is a claim to a walercourse within the second section of 2 \& 3 Will. IV. c. 71 , and that in a plea under that statute, it is sufficient to allege that the user had existed for 40 years before the commencement of the suit, and it need not be alleged to have been for 40 years before the act complained of in the declaration. The decision in this case was again confirmed by the Court of Exehequer in Hard $\mathrm{v}$. Rolins, and fully approved of and acted upon by the Court of Queen's Bench in Richarils r. Fry. 
Prineipally on the authority of Wright v. Witliems it was held in Carlyon v. Lovering, where the declaration was for urongfully throwing sant, stone, rubble, and other stuff (which became dislodged or severed by the defendant's workmen in the course of working his tin mine, and using the tin and tin ore) into a natural stream of ucater, flowing through the plaintiff's lands, whereby the channel was obstructed, and the water flowed over and npon the lands and destroyed their produce, that there was no reason why such privilege, although injurious to the plaintiff to a great extent, might not be the subject matter of a grant. "The plaintiff," said Watson B., "as a riparian proprietor, has a right to have the waters of this natural stream run through his land in its accustomed purity, withont being polluted by any riparian proprietors or others higher up the stream; but that right he may abandon, by allowing an user to have continued for twenty or forty years; or he may grant the privilcge to an owner higher up the stream, for his advantage, of invading that right to the detriment of the water flowing through the plaintiff's lands. We can see no reason why such a privilege although injurions to the plaintiff to a great cxtent, might not be granted" (1 H. \& N. 784; 32 L. J. Q. B. 231).

Moore v. Webb was an action for polluting a stream and impregnating it with noxious substances, whereby the plaintiff's eattle were unable to drink of the water, and had to be driven to a distance. The defendant pleaded an immemorial right to use the water of the stream for the purposes of his trade as a tanner and fellmonger, and returning it polluted to the stream when so used, and also prescriptive rights for twenty and forty jears respectively. The plaintiff new-assigned "that he sued not only for the grievances in the pleas admitted and attempted to be justified, but for that the defendant committed the grievanees over and above what the defences justified." At the trial the presiding judge directed a verdict to be entered for the defendant on all the issues except the first and second (viz., "Not guilty") ; but the Court of Common Pleas held, that whether the pleas were to be understood as claiming an immemorial or a prescriptive right not limited to the purposes of the tamery, or the more limited right to use the water for the purposes of the business as carried on more than trenty years ago, the verdict was not warranted by the evidence, and also that the new assignment was well pleaded. The rule was made absolute for a new trial.

The declaration in Whatcy $\nabla$. Laing, stated that plaintiffs were possessed of coal mines, and steam-engines and boilers for working the same, and enjoyed the benefit of the waters of a certain canal near the said engines, \&c., to supply the same with water for working the same, \&c., and which said waters then ought to have florred and been without 
the fonling therein mentioned, yet that the defendant fouled the same, s.c. The facts only showed that plaintiffs by permission of a canal company, made a communication from the canal to their own premises, by which water got to those premises, and with which water they fed their boilers; and the defendant fonled the water of the canal, and by the use of it plaintifls' boiler's were injured, defendant having no right or permission to do this from the canal owners. The Exchequer Chamber decided that the declaration disclosed no canse of action, reversing the decision of the Court of Exchequer.

According to all the anthorities from the Digest downwards, there is a difference in point of law between a train and any other vatercourse. Maryor v. Chaturick (11 Ad. \& E. 571) shows that the law of easements in respect of watercourses is generally the same whether they are natural or artificial; but that case is not altogether satisfactory, and inconsistent with Arkeright r. Gell (5 M. \& IV. 203). The latter turned npon the right of the party receiving uater drained from a mine to compel the owners of the mine to continne such discharge; and the court decided that the plaintiffs nerer acquired any right to the artificial waterconrse which supplied their cotton mills, either by the presumption of a grant, or by 2 \& 3 Irill. TV., c. 71 , s. 2, as against the owner of the lower level of the mineral field, or the defendants acting by their anthority.

In Wood v. Wreuel (3 Exch. 748) the Court stated they had again considered that case and were satisfied that the prineiples laid down as gorerning it were correct; and that no action lies for an injury by the diversion of an artificial watercourse, where, from the nature of the case, it was obvions that the enjogment of it depended upon temporary circumstances, and was not of a permanent character, and where the interruption was by the party who stood in the situation of the grantor. The Court added, in reference to Hayor v. Chachwick, "TVe entirely conenr" with Lord Demen C.J., that the proposition--that a watercourse, of whatever antiquity and in whatever degree, enjoyed by numerons persons cannot lie enjoyed so as to confer a right to the use of the water, if proved to have been originally artificial -is quite indefensible;" but, on the other hand, the general proposition "that under all circumstances the right to watereonrses arising from enjoyment, is the same whether they be natural or artificial, cannot possibly be sustained." A riparian proprietor has a right to the natural stream of water flowing through the land in its natural state; and if the water le polluled by a proprietor higher up the stream, so as to occasion damage in lau', though not in furt, to the first-mentioned proprietor, it gives him a good canse of action against the upper proprietor, unless the latter have gained a right by long enjoyment or grant (Wool v. Wroud). Where the owner 
of land through which a stream flows has within 20 years built mills upon its bank, and applied the water of stream to the working of them, he may recover upon an issue raised by a traverse of an allegation that his right to the water was "by reason of the possession of the mills." (ib.) So where water has flowed in an artificial and covered watercourse for more than 60 years from a colliery into an immemorial and natural stream, upon whose banks the plaintiff's nills are situated, the plaintiff in such case has no right for diversion of the water of such artificial watercourse against a party throngh whose land it passes, but who does not claim under, or who is unanthorised by the collicry owners. 'The case, however, would be different if the water were polluted; and the abstraction of water to the amount of five per cent., or its detention so as to occasion sensible inconvenience, will support an action for such injury." ( $i b$.

Greatrex v. Hayleard (22 L. J. Ex. 137), which was governed by the above case, and Arlauright v. Gell, decided that the flow of water from a drain made for the murposes of ayricultural improvements for twenty ycars does not give a right to the neighbour, so as to preclude the proprietor from altering the level of his drain for the improrement of his land. Here the plaintiff's two closes adjoined each other, and were also adjoining to a close in the occupation of the defendant. From the year 1796 till the time of the action (1852), there was a pit partly situate in each of the plaintiff's closes, and during all that time the pit had principally been supplied with water coming from the defendant's close. The water so supplied to the pit ran throngh and by means of an underground songl or drain, which had before 1796 been by the owners or occupiers of the defendant's close laid in, and made to run ont of the same into a ditch of the plaintiff's, which bounded the defendant's close, and from and out of this ditch into the pit. This sough was made for the purpose 01 carrying the water off the defendant's close, and for its better cultivation; and the water from the sough usually flowed in a regular stream, but was subject to occasional interruptions from the sough being temporarily choked up by the roots of trees or otherwise. 'The pit was an open pit, and the water in it had erer been, during the above-mentioned time, used and enjoyed by the occupier's of the plaintiff's two closes for watering and washing cattle and olherwise, openly and without interruption. The sough aided the general surface drainage of the defendant's close, which was of a boggy nature, and the water which passed through the sough did not come from any defined or ascertainable source. In September, 1851, the defendant made alterations in the drainage of his close, by constructing a new sough, and by decpening the course of the old sough, for the purpose of more effectually draining 
and cultivating his close; and by means of the alterations, the water, which had been aceustomed to flow into the plaintiff's pit, flowed into the ditch at a lower level, whereby the plaintiff's pit lost the water which had been aceustomed to flow into it throngh the said songh.

The plaintiff had a rerdiet before Alderson. B. for 40 s., subject to a special rerdict; and the Court, after a very careful consideration, gave judgment for the defendant. It was contended for the plaintiff that, by the minterrupted enjoyment of the flow and use of this water for the time mentioned, the plaintiff had gained a right to its continuance either at common law, by the presumption of a grant, or by virtue of the Prescription Act 2 \& 3 Will. IV. c. 71. Parke B. observed: "The eases of Arkurright r. Gell and Wrod v. Wand are opposed to the plaintiff's claim. The right of a party to an artificial veater-course, as agrainst the party ereating it, must depend upon the character of the matercourse, and the circumstances under which it was created. The watereourse is clearly of a temporary nature only, and is dependent upon the mode which the defendant may adopt in draining his land. This is the precise ease which was put by the Court in Wood v. Wand, where it is said by the Court in their judgment, that 'the flow of water for twenty years from the eaves of a house conld not give a right to the neighbour to iusist that the house should not be pulled down or altered, so as to diminish the quantity of water flowing from the roof. The flow of water from a drain for the purpose of agricultural improvements for twenty years could not give a right to the neighbour so is to prechude the proprietor from altering the level of his drains for the greater improvement of his land. The state of circumstances in such a case slows that one party never intended to give, nor the other to enjoy, the use of the stream as a matter of right.' Alderson B. added: 'In one sense, perhaps, it may be said that the plaintiff has enjoyed the use of this water as of right, because the defendant had not in any way impeded such use; but it is not such a user as of right as will serte his present purpose, for there has been no adverse user. Take the case of a farmer, who under the old system of farming has allowed the liquid manure from his fold-yard to run into a pit in his neighbour's fickl, but upon finding that the manure ean be beneficially applied to his own land has stopped the flow of it into his neighbour's pit, and converted it to his own use ; could it be contended that the fact of his neighbour having used this manure for upwards of twenty years would give the latter the right of requiring its continuance?"

In Iiaustron v. T'aylor (25 L. J. Ex. 33) it was held that the ouner of land has an unqualified right to drain it for agricullural purposes, in 
order to get rid of mere surface water, the supply of the water being casual, and its flow following no regular or definite course ; and a neighbouring proprietor camnot complain that he is thereby deprived of srch water, which would otherwise have come to his land and filled his reservoir. The land of the plaintiff and defendant was contiguous, and just on the outside of the defendant's land there was a wet spongy spot (D), where at most seasons some water rose to the surface, and sufficient collected to flow down the slope of the land. In times of wet there was a great body of water, but scarcely any after a long drought. There was no regularly formed ditch or channel for water, the place where it flowed being constantly trodden-in with eattle. At times there was a drinking place at the corner of the ficld, near (D), but unless it was kept clear it was soon trodden-in with cattle. Near The Slacks farm-house by which it flowed there was a channel cut, which conveyed the water into a trough there, which the water flowed through, and supplied the house. After leaving the trough, the water took no particular direction.

It either flowed over the meadow down the slope of the land, or the tenant of the Slacks made it flow throngh the manure-heap, and then orer the meadow. But whicherer direction was given to the water, so much of it as was not absorbed by the land (and all was not absorbed except in times of drought) ran into an old watercourse of the plaintiff's, which led to a reservoir of the plaintiff's. The water had so flowed for upwards of twenty years, and the defendant, for the purpose of draining his land and of supplying some part of his property with water, diverted this water from the plaintiff's rescrvoir. At another spot $(K)$ on plaintiff's land, as long ago as one conld recollect, water had always risen to the surface. There had generally been a drinking place for cattle formed with stones, and the overflow of the water went down a ditch, and thence into a watercourse, to the plaintiff's reservoir. 'There was also a third point, which is fully referred to in Parke B.'s judgment. Speaking of spot D, his lordship said, "The plaintiff has no right to the rain-water which may flow from that spot to his land ; and what authority is there for saying that spring-water differs from rain-water?" "On the question," his lordship added, "as to the interference of the defendant with the water at the spot 1 , the defendant is entitled to have a rerdict. This is the case of common surface water rising out of spongy or boggy ground, and flowing in no definite channel, although contributing to the supply of the plaintiff's mill. This water having no defined course, and its supnly being merely casual, the defendant is entitled to get rid of it any way he pleases. The same observations apply to the water rising at the point $\mathrm{K}$. This 
water has no defined course, and the supply is not constant, therefore the plaintiff is not entitled to it. The case of Dickinson v. Grand Junction Canal Company does not apply ; and the defendant is entitled to get rid of this also, for the purpose of cultivating his land in any way he pleases.

"With respect to the last and most important part, which relates to the interference with the flow of the water to Lower Gin Bank, we must look to the deed, for the plaintiff's right to that water depends solely upon the deed. By that instrument the defendant conveys to the plaintiff the Gin Bank, together with all ways, waters, watercourses, liberties, pririleges, rights, members, and appurtenances to the same close and piece of land belonging or appertaining. Now this right to this water could not pass independently of the deed, as the plaintiff could hare no right to water in alieno solo. Natural watercourses are like ways of necessity. The right to have a stream running in its natural direction does not depend on a supposed grant, but is jure naturce (Shury v. Pigott). But if the stream is artificial, no such right exists. This is not a natural watercourse; but the plaintiff is entitled to the flow of this water under the conreyance which gives it to him by the terms of the grant. It is necessary to say whether the right passed under the proviso, which, however, throws light upon the grant, and shows that this water was intended to be conreyed. The proviso is for the benefit of the defendant, and gives him the right to apply any water flowing through his land for certain specified purposes; but when he has taken such water, he is bound to return the surplus into its usual channel in the watercourse at a certain place.

"And I am of opinion that the defendant has no right to make any permanent diversion of the water. He may take away the water in buckets, or by any other mode of conveyance, for domestic, agricultural, or manufacturing purposes; but when he has taken what he wants, he is bound to return the surplus into its usual channel at the place mentioned in the plan for the use of the plaintiff, and he cannot divert the water. It seems to me clear, on looking at the proviso, what the defendant grants to the plaintiff by the conveyance; and the defendant is not entitled to more than what is reserved to him in the proviso. $\mathrm{He}$ has permanently diverted the water by placing it under lock and key, and by so doing has deprived the plaintiff of the use of it. I am therefore of opinion that the verdict ought to be entered for the defendant as to the two first causes of action; and as to the third, that the rerdict entered for the plaintiff should stand." Platt B. observed, " $\Delta$ s to the two first points, the defendant is clearly entitled to succed, 
as this was mere surface water ; and the defendant had a right to drain his land, and the plaintiff could not insist upon the defendant maintaining his fields as a mere water-table. With respeet to the third point, the plaintiff is entitled to retain his verdict." And per Martin B.: "The proprietor of the soil has prime facie the right to drain his land; and unless there is some express anthority to show that his motive in so doing affected the question, in my opinion the motire is altogether immaterial."

In some of its points, Broadbent v. Ramsbotham was wholly undistinguishable from, and governed by the Exchequer decision in the alove case. It was here decided that a landowner has a right to appropriate surface water which flows over his land in no definite clummel, although the water is thereby prevented from reaching a watercourse which it previously supplied. Therefore where the plaintiff's mill for more than fifty years had been worked by the stream of a brook which was supplied by the water of a pond filled with rain, a shallow well supplied by subterraneous water, a swamp, and a well formed by a stream springing out of the side of a hill, the waters of all of which occasionally orerflowed and ran down the defendant's land in no definite channel into the brook, the plaintiff had no right as against the defendant to the natural flow of any of the waters. The disputed water in that part of the ease, to which the reasoning in Rau'stron v. Taylor especially applied, was only the overflow of a well, which ran into a ditch (the lowest adjoining ground) made artificially, and for a different purpose, running beside a hedge. After that it was squandered over a swamp made by the feet of cattle treading abont; and not till long after this, what still remained of it found its way, with other water, into what might then be called a definite natural watereourse.

Irrigation is a riparian right, to be exercised subject to the rights of other riparian momietors. The riparian proprietor above might, no doubt, by grant, divest limself of his right to use the stream for the purpose of irrigation; but the mere non-user of the right would not raise a presumption of a grant. Per Witles J. (Sempson v. Hodlinott): Where there is an undue detention of water by the riparian moprietor abov' , it is not necessary in an action to show actual damage to the plaintiff's reversionary interest ; it is enongh to show an obstruetion of his right; and such obstruction of his right being shown, the law will infer damage (ib.). The right of the riparian proprietor is, however, limited to natural streams, and does not attach in the case of artificial cuts or drains (ib., 26 L. J. C. P. 148).

It would seem to be settled in Embrey v. Owen that a riparian pro. 
mietor has within certain bounds a right to use water for the purpose of irrigation. 'The point was raised in Hood $\mathrm{r}$. Wunt, but it became unnecessary to decide it. In Embrey v. Ouen the plaintiff occupied a water grist-mill on the banks of the Rhiew, and the defendant owned land on both sides of that river above the mill. 'The action was brought against her for diverting part of the water of the river, to irrigate certain meadows on the northern bank, in the occupation of her tenant John .Jones. The water was direrted by means of an iron trough or aqneduct, placed near a waste weir, from whence the surplus or waste water was carried into the trough or aqueduct, and by it orer the rirer into the main and floating gutters of the meadow, when required for irrigation. At other times such surplus water was discharged from the trough or aqueduct direct into the bed of the river by means of an iron flap or sluice in the middle side of the trough, so constructed as to be opened for the latter purpose at pleasure. A portion of the water was lost by absorption and evaporation in the process of irrigation, but the working of the plaintiff's mill was not impeded, and all the witnesses agreed that there was no sensible diminution of the stream by reason of the diversion. The verdict was for the defendant on the first issue, as to whether there was any sensible diminution of the natural flow of the water by means of the diversion, which they answered in the negative ; and also for the defendant on the other issues, as to whether the quantities of water absorbed and evaporated in the process of the lefendant's irrigation were small and inappreciable quantities, which they ansirered in the affirmative. Talfourd J. directed that the verdict should be entered on the above issues for the defendant, reserving leave to the plaintiffs to move to enter it for them with nominal damages. A rule misi was accordingly obtained, but the Court decided that the rerdict was properly entered for the defendant on the issues above named.

Parke B. saic in his judgment, "The most important question is that which arises on the plea of Not guilty, the jury having found that no sensible diminution of the natural flow of the stream to the piaintiff's mill was caused by the abstraction of the water. That the working of the mill was not in the least impeded was clear on the eridence, and on that finding we think the rerdict was properly ordered to be entered for the defendant.

"In America, as may be inferred (3 Kent's Com. Leet. 52, 439-446), and as is stated in the judgment of the Court of Exehequer in Wood $\mathrm{v}$. Wand, a very liberal use of the stream for the purposes of irrigation and for carrying on manufactures is permitted. So in France, where every one may use it en bon père de fumille et pour son plus grand ac'antuge, a man may make trenches to conduct the water to irrigate his 
land, if he returns it with no other loss than that which irrigation canses. In Wood v. Wenel it was observed that in England it is not clear that a user to that extent would be permitted; nor do we mean to lay down that it would in every case be deemed a lawful enjoyment the water if it was again returned into the river with no other diminution than that which was caused by the absorption and exaporation attendant on the irrigation of the lands of the adjoining proprietor. This must depend upon the circumstances of eacl case. On the one hand, it conld not be permitted that the owner of a tract of many thousands of acres of porous soil abutting on one part of the stream could be permitted to irrigate them continually by canals and drains, and so canse a serious diminution of the quantity of water, thongh there was no other loss to the natural stream than that arising from the necessary absorption and evaporation of the water employed for that purpose; and on the other hand, one's common sense would be shocked by supposing that a riparian proprietor could not dip a watering-pot into the stream in order to water his garden or allow his family or his cattle to drink it. It is entirely a question of degree, and it is very difficnlt, indeed impossible, to define precisely the limits which separate the reasonable and permitted use of the stream from its wrongful application; but there is often no difficulty in deciding whether a particular case falls within the permitted limits or not." "There has been no injury in fact or in law in this case, and therefore the verdict for the plaintiff should not be disturbed." The rule was discharged, the defendint consenting that on the fourth, seventh, and tenth issues a verdict should be entered for the plaintiff (20 L. J. Ex. 215).

The facts of Northam v. Hurley may be learnt from the judgment of Colerilge J.: "In this case the plaintifl, occupying Fourth Tanner's meadow, complained that the defendant had diverted the channel of a watercourse in 'Third Tanner's meadow ; and in support of his case he relied upon a deed between Sylvanus Fox, owner of Fourth Tanner's meadow, and Edward Fox and others (whose interest in the soil har, however, determined before the execution of the agreement), owners of First, Second, and Third Tanner's meadows, whereby it is stipulated that Edrard Fox and other's should have the use of a certain stream of water for irrigation for ten days in every month, and that at all other times the same stream should be under the control of Sylvanus Fox and his assigns, and should flow in a free and uninterrupted course through a channel therein particularly described, into Fourth Tanner's meadow, with an undertaking that the owner's of First, Second, and Third Tanner's meadows shonld cleanse the channel, and with liberty to Sylranus Fox and his assigns to do so on their default. 
"This deed, in our jndgment, operates as a grant of the easement of the watercourse therein described; and inasnuch as the channel is specified with a right to enter and cleanse it, we are of opinion that Srlranus Fox, and those claiming under him, acquired a right in respect of that channel; and that a change of the chanmel would be an injury to this right. And as the plaintiff claimed under Sylvanus Fox, and the defendant claiming under the orners of the First, Second, and 'Third 'Tanner's meadows had diverted the stream from the specified channel, though without damage to the plaintiff, we think there was a cause of action for injury to the right. Our judgment is founded on the effect of the deed which governs the rights of the present parties; and in so deciding we do not intend at all to limit the salutary principle laid dorm in Embrey r. Owen, to the effect that the superior riparian proprietors may use the stream for all reasonable purposes, while in their land, provided they send it on, without material diminution or alteration, to inferior proprietors. It was further objected that if such was the case the plaintiff conld not recover for it under the present declaration, claiming the right by reason of possession, without mentioning or referring to the deed. But this objection we think untenable. If the easement was granted to the owners of Fourth Tanner's meadow, we think the precedents are clear that it may be deseribed in a declaration as an easement to which the plaintiff is entitled by reason of his possession of that meadow" (22 L. J. Q. B. 183).

The above case, which established that where the rights of the parties are derived from a deed or other instrument, their rights must be ascertained from the instrument alone, and that general doctrines of law are not applicabte, laid down the principle on which Whitehead v. Parks was decided (27 L. J. Ex. 169). In this case, by lease dated 1827, Lord Derby demised to une Woodeock a dwelling-house and fifteen closes of land, and granted all streams of water that might be found in four of those closes, ealled The Clough, The Moorin Clough, The Brow, and The Marleds, excepting out of the demise all timber and other trees, \&e., mines and minerals, \&c., stone, gravel, sand, and clay, \&c., and all streams of water, except those alove granted, then being or thereafter to be found in or upon the premises demised, with power for Lord Derby, his heirs and assigns, and his and their servants and workmen, from time to time "to enter upon the premises, and to crop, fell, search for, s.c., and make marketable all or any of the before-mentioned articles; to make any clay into bricks or tiles on the premises, \&c., and to divert or alter the course of any river, brook, spring, or water, sc." There was a plan annexed to the lease showing a stream of water on the north side of the deinised premises, and flowing through their whole extent 
from east to west, and the four closes were situated on the banks of this stream. There was no other stream on the surface, bnt certain wells were in existence in those closes, and others were subsequently found. It was held by the Court of Exchequer that the wells and all water in the four closes passed by the grant in question to Woodeock, and that neither Lord Derby nor his lessees could work the mines so as to cut off the springs in the closes in question. And per Martin B.: "Lord Derby granted to Woodeock all the water which might be found on the closes in question. Lord Derby cannot derogate from his grant, and the defendant, his lessee, is in the same position. Northam v. Hurley decided for the first time, what appears to me to be clear, viz., that if, upon a question of water rights, there is an agreement by deed, such deed will regulate the rights of the parties" (ib.).

Greenstade v. Halliclay was one of the earliest cases on irrigation. 'The plaintiff owned certain ancient meadow land near a small stream which flowed through defendant's land. For fifty years the tenants of the plaintiff and their predecessors had been accustomed to enter on the dofendant's land, and pen back the water of this stream by placing a row of loose stones across it at a certain point; and when the water was so penned back by this dam or obstruction, a portion of it ran through a small archway along an artificial ent, which passed to some distance over the defendant's land, and so irrigated the plaintiff's meadow. In dry weather the tenants, according to the plaintiff's witnesses, placed a board or fender across the stream, but neither was jermanently fixed till the year before the action, when the plaintiff's tenant placed a board in front of the stones, and fastened it down by two stakes driven into the bed of the stream, on the top of which stakes were crooks embracing the upper edge of the board. Whether this board penned the water higher than the ordinary dam of loose stones, or whether a board had ever been used before, except at a very remote period when the water meadow was in the possession of the defendant's predecessors, did not satisfactorily appear from the evidence. The defendant, however, conceived that the permanency of the dam might establish for the plaintiff a right to a greater extent than he had enjoyed before, and be prejudicial to her own enjoyment of a mill above and water meadows below the dam, and eaused the stakes to be pulled up and the board to be remored; saying to the tenant, at the same time, that until it was prored what quantity of water ought to go, he shonld exercise no right there.

At the trial, Tanton J. seemed to think that the defendant had denied the plaintiff's right in toto, and excluded this declaration as not being admissible evidence. But he told the jury that if the board 
acted on the stream in an unusual manner, and penned the water higher than it ought, the defendant was entitled to pull it down. A verdict for the plaintiff was confirmed by the Court, "on the short ground that the defendant had done more than she ought to hare done." And per Timlal C.J.: "The board in dispute was fastened by stakes, which was not usual; but the defendant, instead of removing the stakes alone, removed the board also. If a party who had a right to a stone weir were to erect buttresses, one who should oppose the erection of the buttresses could not justify demolishing the weir as well as the buttresses." And see also Irard r. Robins (15 M. \& W. 237).

The obstrution of an casement of going across defendant's land to dam up water, and bring it by an artificial cut through the defendant's land to the plaintiff's for irrigation and the use of his cattle, was the subject of Beeston v. Weate (25 L. J. Q. B. 115). The defendant occupied land which was bounded on the sonth by land in the occupation of the plaintiff, called the Cow Pasture. A natural stream ran along the north side of the defendant's land, and there was an artificial watercourse passing from this brook through the defendant's land (crossing a road on the same land) to the land of the plaintiff. According to the evidence this watercourse looked as old, sixty years ago, as at the present time. For more than forty years, and as long back as living memory went, the occupiers of the plaintiff's land had been in the habit of crossing the defendant's land, and of placing sods so as to form a dam, obstructing the course of the water in the natural brook immediately below the point at which the artificial watercourse joined it. The eflect of this was to throw the water into the artificial watercourse, through which it flowed across the defendant's land to the land of the plaintiff, where it supplied a pit or pond. This the occupiers of the plaintiff's land had constantly done to supply their eattle with water, at such times as the lowness of the water in the brook rendered it necessary. When the water was wanted by the occupiers of the defendant's land, as it usually was at certain seasons of the year for the irrigation of that land, the water did not reach the plaintiff's land. 'The water, after being conducted on to the land of the plaintiff, ran off by another arm and rejoined the natural brook. It was not denied that the defendant had done the acts complained of. This evidence being uncontradicted except by an unsuccessful attempt to prove an interruption, Erle J. told the jury that if the occupiers of the plaintiff's land at the proper season had at their will and pleasure turned the water on to their land for the purpose of supplying the cattle with water, the plaintiff was entitled to a verdict. The Court refused a new trial, and held that the jury were warranted in inferring a user as of right by the occupiers of plaintiff's land of the 
easement on the defendant's land; and that for the interruption of such easement plaintill might maintain an action against defendant.

Lord Camplell C.J. said, in delivering judgment: "The defendant's counsel, in argning that the plaintiff onght to have been nonsuited, relied mainly on Arkwright v. Gell, Wood v. Waut, and Greatrex v. Hayvord. We entirely concur in those decisions, thinking that the plaintiff did not in any of them support his allegation as to the easement elaimed. In none of them was there any reasonable ground for infuring that the easement lad been acquired by prescription or grant. But we do not consirler that the eases lay down any such rule as that cnjoyment and acts, which withont the existence of the easement would be tortions and actionable, may not be evidence of the right to the use of water, althongh it flows in an artificial eut. This doctrine would destroy the right to the great majority of mill leats all over the kingdom." "In the eases referred to, regard was had to the water being obtained artificially by the owner of the servient tenement, rather than to the water running through an artificial ent. Here the water in question is part of the water of a stream which has flowed on the surface of the country from the time that onr globe took its present confor'mation. But the strength of the plaintiff's case (distinguishing it from the cases relied upon by the defendant) is, that here the ocenpier of the dominant tenement, for the purpose of letting in the water from the natural current of the river into the artificial cut, and from the artificial cut into his pond in the Cow Pasture, was constantly going upon the servient tenement, with notice to the ocenpier of the servient tenement, and doing acts which, withont the easement, wonld be trespasses. Such has been the practice as far back as living memory goes, and may have been the practice from time immemorial. Yet for these acts no action has been brought, nor has any complaint been made. If you are to presume that they took place by the licence of the occupier of the servient tenement, then by constant user acquiesced in, no easement can be aequired.

"But, if it were not that the occupier of the servient tenement has himself used the water flowing throngh the artificial eut for irrigation, no plausible objection could be made to the easement which the plaintiff claims, and we do not see that the use of the water on the servient tenement takes away from the effect of the use of it for the dominant tenement, regard being had to the positive acts done by the ocenpier of the dominant tenement upon the servient tenement for the purpose of enjoying the easement. Great stress was laid by the defendant's counsel on the often-repeated assertion, that the artificial cut was made for a temporary purpose. The water flowing through the 
(hit has. as far baek as living memory goes, and prohahly much longer, been constantly applied to two purposes-the irrigation of the meadow on one sicle of the ent, and the watering of the eattle pasturing in the meador on the other side of the cut. These purposes cannot be considered temporary in their nature, although there is no certainty that the meadows may not at some remote time become the sites of streets and squares in a town. The defendant's counsel argued strongly against the probability of such a grant, whereby the owner of the servient tenement would have deprived himself of the power of conrerting it to any purpose inconsistent with the easement granted. But it is part of the generally fictitious supposition of a grant that it procecds unon an adequate consideration."

The latest case on the subjeet of irrigation is Sampson v. Hoddinoll, which was an action for an injury to plaintiff's reversion by diverting a stream of vater. Certain tenants of the plaintiff were possessed of certain water meadows, into which meadows he claimed that a portion of the water of certain streams of right ought to have run, for watering the same, and which defendant diverted and obstructed. A rerdict was taken for the plaintiff for $£ 200$ damages, subject to a special case. Judgment was given for the plaintifi in respect only of the diversion of the river Yeo, and for the defendant on the alleged causes of action, which related to the disersion of a stream called the Back Water, and the obstruction and diversion of the Silver Lake spring. The plaintiff had immemorially enjoyed the benefit of irrigating certain of his meadows with the water of the rirer Yeo, subject to the right of the willer at West Mill to detain the water for the use of his mill. The natural flow of the river was prevented by the exercise of the miller's right, but the water was allowed to come down at such times that the plaintiff was enabled to irrigate his meadows effectually. The defendant had, for the purpose of irrigating his own adjacent land, from time to time diverted the water after it had passed the mill, and before it reached the plaintifr's meadows; and although it did not appear that the water which ultimately reached the meadows was sensibly diminished in quantity, yet the effect was that the water was detained by the process of irrigation, and did not arrive until so late in the day that the plaintiff was deprived of the power to use it fully. The water was penned every night at West Mill; and when the defendant was not watering his new water-mead, the water generally came down to the llaintiff's Wyke farm about twelve at noon, and six or seren acres of the plaintiff's water-meads could be watered at a time; but when the dc.fendant was watering his new water-mead the water did not come to the plaintiff's farm until about three o'clock in the afternoon, and then 
only three or four acres of the plaintiff's water-meads eonld be watered at a time; and in winter it was often dark, and therefore too late to pul the water over the plaintiff's meads at all.

There was evidence that in consequence of the defendant's watering his new water-mead in the autumn and winter of 1854 the plaintiff"s tenants could only water some of their meads, and lost some spring feed of the mead; but there was also evidence on the part of the defendant that the hay crop in the Dairyman's Mead was as good as ever; and it was an admitted fact that the defendant irrigated his land properly without exeess or unnecessary waste, and that the mill and wheel were used for agricultural purposes, for threshing, and grinding barley, for the purposes of the defendant's farn only; and if right existed, there was no abuse or excess. The injury to the plaintiff's reversionary interest in his ancient water meadows was stated to be that they were deprived of the first catch or use of the water, the fertilizing sediments or properties of which were deposited on the defendant's new watermead; secondly, that as such new water-mead was very porous upper soil, consisting of a layer of gravel and a subsoil of clay, the whole of the river was insufficient, except in a flood, to water even the plaintiff's ancient meadows; thirdly, that it was penned on this new water-mead so late, that plaintiff's tenants could not watch and attend to the watering of the ancient meadows, as they were prevented by the penning of the water at the West Mill from using it at night. A verdict was taken for the plaintiff for $£ 200$ damages, subject to a special case.

Cressuell J. said, in delivering the judgment of the Conrt, "that all persons having lauds on the margin of a flowing stream have by natnre certain rights to use the water of that stream, whether they exercise those rights or not, and that they may begin to exercise them whenever they will. By usage they may acquire a right to use the water in a mauner not justified by their natural rights; but such acquired right has no operation against the natural rights of a landowner higher up the stream, unless the user by which it was acquired affects the use that he himself has made of the stream or his power to use it, so as to raise the presumption of a grant, and so render the tenement above a servient tenement. If the user of the stream by the plaintiff for irrigation was merely an exereise of his natural right, such user, however long continued, could not render the defendant's tenement a scrvient tenement, or in any way affect the natural rights of the defendant to use the water. If the user by the plaintiff was larger than his natural rights would justify, still there is no eridence of its affecting the defendant's tenement, or the natural nse of the water by the lefeudant, so as to render it a servient tenement. But if the user by 
the defendant has been bejond his natural right, it matters not how much the plaintill has used the water, or whether he has used it at all. In either ease his right has been equally invaded, and the action is maintainable.

"T'he question between the parties is thus reduced to this single point-has the defendant nsed the water as any riparian proprietor may use it, or has he gone beyond that? The general principle of law may be dedueed from the decision of Embrey v. Owen; and the anthorities cited by Parke B., in delivering judgment in that case, is that every proprietor of lands on the banks of a natural stream has the right to use the water, provided he so uses it as not to work any material injury to the rights of other proprietors above or below on the stream. In the present ease it appears to us, on the eridence, that the detention by the defendant, under the eireumstances, of the water of the river Yeo, for the purposes of irrigation, was a use of it which in its eharacter was necessarily injurions to the natural rights of the plaintiff as the proprietor of land lower down the stream. The effect was obviously the same as if the defendant had placed a bar or weir across the river, and by that means had wholly prevented its natural course for a certain number of hours. And it appears to us that there is neither anthority nor principle for contending that such an act can be justified on the ground that it was done for improving the adjacent land of the defendant, whether by irrigation or otherwise." The judgment of the Court of Common Pleas was finally entered for the plaintiff, as to such part of his complaint as related to the river Yeo, and as to the rest of the alleged causes of action, for the defendant (26 L. .J. C. P. 148).

Water escaping from railuay-cuttings into a mine.-A railway company is responsible for injuries sustained by reason of water eseaping from a stream in flood-time, or collected from rain falling on the railway, and flowing along a cutting of the railway, and percolating throngh the substratum into mines beneath, although such mines had not been worked at the time of the formation of the railway; and such damage is the subject of an action, and not the suljject of compensation under the eompensation clauses (Baynell v. London and North-Western Pailuay ('ompany).

Working mines unter water-course. - The owner of frechold lands and his lessee will be restrained from working mines under a watercourse, otherwise than in a manner not likely to prevent the plaintiff from enjoying an uninterrupted flow of water to his works (Eluell $\mathrm{r}$. Croutther).

Supplying Thorses with water from a mublic foumtain.-A local board of 
health, empowered by their private act to supply a town with water at certain rates, supplied an ornamental fountain (which had been presented to the town by one of the inhabitants, and ereeted in one of the public streets) with water for the use of cattle in the cattle market on market days, and for horses, if yoked, when passing to and fro. The board had a fixed charge per horse for water supplied to persons keeping horses, who might choose to have water laid into their stables. The respondent, in order to evade payment of this charge, took his horses fiom his stable to the fountain to drink. Upon a complaint against him for so doing, under the Water Works Clauses Act, 1847, sec. 59, which enacts that "every person who, not having agreed to be supplied with water by the undertakers, shall take any water from any flace containing water belonging to the undertakers other than such as may have been provided for the gratnitous use of the public, shall forfeit," \&c. ; the magistrates being of opinion that the local board had no power to erect a fountain in the public highway except for the gratuitous use of the public, and that therefore the water snpplied to such fountains came within the exception in the above clause, refused to convict. It was held by the Court of Common Pleas that the decision of the magistrate was wrong; for that, whether the fountain were a public nuisance or not, the board were at liberty to supply it with water on their own conditions. And per Wrilliams J.: "It is clear, upon the facts here, that there was no unrestricted dedication to the public at large, and nothing in the act of parliament to work that result. Though there may be a dedieation for a limited purpose to all, there cannot be a dedication to a limited part of the public on the principle which is established in Poote v. Huskisson (11 M. \& W. 827), and The IFarquis of Stafford v. Coyncy ( 7 B. \& C. 257). The consequence is not that a partial dedication will operate as a dedication to all the public, bnt such dedication is simply roid, and no dedication at all. And per Byles B.: "I am not sure that the nse for which this water" is supplied was not a public use. Anybody's cattle and yoke-horses may drink at it; and though the time at which the fountain may be used, and the class of cattle and horses, which may use it are limited, it is not the less for the use of all the public (see Rex v. Berenger, 3 M. \& S. 73). But that by no means justifies the respondent in using the water for other purposes than those to which the use is limited (Hildreth appt. v. Adtamson resp.) - 30 L. J. (N. S.), M. C., 204.

Conveyance of right of contimuance of culvert with farm-By permission of the tenant for life of farms $A$ and $B$, the defendant many years ago made a culvert from a brook, which in its natural course flowed to farm $\mathrm{A}$ for the purpose of getting water for his own premises, and 
for farm B. The culvert which carried off nearly all the water from the brook, commenced in some lands of the defendant, which were bounded by the brook, and then passed through farm B, where a portion of the water was drawn out of it by means of a small pipe for the use of farm B. 'The rest of the water, riz., the larger portion, fluwed on down the cnlvert, which, after traversing farm $B$, ended in other premises of the defendant, where the water was consumed. In September, 1856, the then owners of farms A and B conveyed farm B, in fee to the defendant, together with all waters and water conrses appertaining to the premises or used, ocenpied, or enjoyed with the same. He afterwards conreyed farm $\mathrm{A}$ to the plaintiff, with all waters and water courses. It was held in the Exchequer Chamber affirming the judgment of the Queen's Bench, that as against the owner of farm A the words of the conveyance of farm $B$ were sufficient to convey to the defendant the right to the continuance of the culvert and to the accustomed flow of water down it, and that his right was not limited to the taking so much of the water as had heretofore been used for the purposes of farm B (Wardle v. Brocklehurst).

Condition under which tenant for life received compensalion for loss of pond which urorked his mill.-A pond which supplied a stream by which a flour-mill was worked, was purchased by the Ordnance under the Defence Act, 1842. The water being diverted, the tenant for life of the mill claimed compensation; and before an award was made, he erected a steam engine and suitable buildings for the mill, expending thereon $£ 1,300$. Compensation amounting to $£ 920$ being awarded to him, the Court of Appeal, on a question from the Master of the Rolls, permitted this sum to be paid to the tenant for life, upon the nnderstanding that the erection of the steam engine and buildings was of a substantial and permanent nature (In re Duke of Wellington's Settled Estates $A c t)$. 


\section{CHAPTER VII.}

\section{SERVANTS.}

A contract of hiring made on a Sinday. between a farmer and a libourer for a year, is not "business or work of their ordnary calling" within 29 Car. II. c. 7, s. 1, and is therefore valid (Rex v. Inhabitants of Whitnash). A contract of hiring may be qualified by proof of customary holidays (Reg. v. Stoke-on-Trent); and proof that the plaintiff and other workmen employed by the defendant came reguldarly to receive their wayes from the defendant, whose practice was to pay every week, and that the plaintiff had not been heard to complein of non-peryment, is presumptive evidence of payment (Sellen v. Norman, and see Lucas v. Novosilieski).

In Cuckson v. Stones, the Court of Queen's Bench decided that to a claim for wages on an agreement to serve the defendant during a certain period at a certain weekly sum, it is no answer that the plaintiff was absent from the service of the defendant during the period in respeet of which the wages are claimed by reason of temporctry illness. And per Curiam: "We think that want of ability to serve for a week wonld not of necessity be an ansirer to a claim for a week's wages. In truth, the plaintiff was here ready and willing to serve had he been well, and able to do so, and was only prevented serving during the week by the visitation of God, the contract never having been determined" (ib.).

Long continued service creates no claim for remuneration without a bargain for it, either cxpress or implied from eireumstances, showing an understanding on both sides that there should be payment; and so it was ruled by Martin B. in Reeve v. Reeve (on the anthority of Ifingeston v. Kelly), when the plaintiff had, five years before action, been engaged by his nephew, the defendant, to look after his farm, and to have board, lodging and clothing. The case for the plaintiff (for whom the jury found), was that there was a further bargain for wages at four shillings a-week, but this the defendant denied. A new trial was granted on the ground that the evidence was not sufficient as to a bargain for wages. 
If a yearly servant uromyfully quit, or be dismissed by his master, before the year cxpires, for such miscouduct as will justify the dismissal, the serrant is not entitled to any wages for the time during which lse served (Tumer r. Robinson). The general rule is, that if a master hire a serent without mentioning the time, that is a general hiring, and in point of law a hiring for one whole year ; and a stipulation that there is to be an advance of so much per annum, till the wages reach a certain amount, does not make it the less a contract for a year. In the case of domestic serrants, the rule is well established that the contract may be determined by a month's notice or a month's wages, but that depends upon eustom. Where no such eustom is proved, the contract must be taken to be one for a year (Fuccelt v. Cash).

A general hiring in the case of an agricultural latourer means, in law, a hiring for a year; and therefore the plaintiff in Lilley v. Elucin failed on his first count, which alleged a special contract of hiring, determinable at any time by reasonable notice on either side, and was only supported by proof of a general hiring as to time. And he conld not recover for the time of his actual service on the indebilatus count, as he was bound to give a whole year's service before earning any wages, and he broke his contract by leaving that service before the year's end. In this case nothing was said as to notice of determining the engagement. The defendant, a farmer, hired the plaintiff as a waggoner for ten guineas a-year, payable at its expiration. During the harrest, he rorked in the field generally, and the Court thought it must be taken as part of his contract that he should do so. At that time of the year the practice was to work till eight o'clock in the erening; but he refused to work to that hour, not as being an unreasonable hour, or as not being within the terms of his contract, but because strong beer of good quality was not allowed to him, according to a custom which he alleged to exist; the beer supplied being, as he contended, very bad, and not so good as water. Colcrinlye J. said: "If the discharge was not justifiable, then the plaintifl" was at liberty to treat that discharge as a rescinding of the contract by the defendant, and to adopt that rescinding, and sue for wages pro ratî up to the time of the unjustifiable discharge, and so to retain his verdict on the indebitutus count. We do not think it neessary to go through the anthorities which establish this view of the law ; they will le found collected in Mr. Smith's leading eases in the notes to C'utler v. Ponrll, vol. ii. ca. 1. 'The discharge in this case was not directly by the master, the defendant, but by a magistrate, on the statute 4 Geo. IV. c. 34, on the complaint of the master. But we are of opinion that it is sufficiently the act of the defendant to entitle 
him to a verdict on the third plea (which stated a discharge by the defendaut, for disobedience of orders, in not working during harvest till eight o'clock at night), supposing the alleged misconduct of the plaintiff to be established; and also to entitle him to a verdict on the plea of non assumpsit to the indebitatus count, on the like supposition, because in that case he was never indebted to the plaintilf at all" (11 Q. B. 742).

By sec. 3 of the statute, the magistrates have no juristiction to discharge, unless it shall appear to them that the servant "shall not have fulfilled such contract, or hath been guilty of any other misconduct or misdemeanour." They may issue warrants to apmehend servents ir husbandry, \&c., not entering into service according to their contract, or absenting themselves from it, on complaint by oath, and commis them to the House of Correction for three months' hard labour, or in lieu thereof abate the whole or part of the wages, or discharge the servant. And it was decided by the Court of Queen's Bench, and subsequently by the Court of Exchequer (Pollock C.B. diss. and Martin B. (lub.), that where a party is convicted by a justice of the peace, under this section, for absenting himself from his master's service, the contract is not dissolved; and if, after the expiration of that term, he refuses to return to the service, he may be brought up before the justices and convicted a second time (Ex parte IT. Baker). So, by see. 5, they may order payment of wages due to servants within such time as they may think fit, on complaint made pursuant to 20 Geo. II. c. 19, and 31 Geo. JI. c. 11, which apply to servants in husbandry hired for less than a year.

A conviction under the Masters' and Servants' Act, 4 Geo. IV. c. 34, s. 3, must state on the face of it an offence within the act, and the facts alleged must not be consistent with the innocence of the person charged, otherwise the conviction cannot be supported. And this is so, even since the passing of Jervis's Act, 11 \& 12 Vict. c. 43 , which gives in sec. 17 a general form of conviction applicable to all cases (Ex parte Gessicood).

A huntsman, though hired at yearly wages with the right to receive certain perquisites, is a menial servant, and subject to dismissal at a month's notice, Nicoll v. Greares, 33 L. J. N. S. C. P. 259.

A uarant of commitment issued under 4 Geo. JV. c. 34, s. 3, was held to be bad by Irightmen J., for not stating that the contract was in writing, or that the servant had entered into the service (In re J. Askev") on the authority of Lindsay $\mathrm{v}$. Leigh, which was decided in the Exchequer Chamber, and where the warrant was under the same section, and almost in the same words as in this case. No right of appeal to the Quevter Sessions exists against an order of justices male under sec. 5 of 
this Act, for the payment of an amount ol reekly wages adjudged to be due firom a master to his servant, on a complaint under 20 Geo. II. c. 19, although the justices in making such order may have acted without jurisdietion (lieg. r. Beclurell). In ex parte Hughes, it was decided that tre justices might make an order on the master for payment of a year's veayes to a denirymait, as being a serrant in husbandry, under 20 Geo. II. c. 19. Mary Hughes was hired in the above capacity to serve for a year, and to assist in the harresting of the hay and corn if required. She had also to kecp the house, and to cook for the men-servants and labourers, and to make their beds; and when the master, and sometimes his family, visited the farm, which he did weekly, she cooked for and attended upon them. Mightman J.: "Suppose it were exclusively a dairy farm, would yon say there was no servant in husbandry employed upon it?" And per Lord Cumplell C.J.: "She was employed with a view to the discharge of duties comnected with husbandry, and the domestic duties pertormed by her were ancillary to those she was employed to discharge. A serrant in hushandry may serve intra monia."

Symin r. Amott was an earlier case of the same class as Liley v. Elucin. The plaintiff was a yearly servant to a farmer, and usually breakfasted at five and dined at two. One day, when dimner was ready, he was ordered, to go to the Marsh, which was a mile off, with the horses. He said he had done his dne, and would not go without his dinner, and was sent about his business for the refusal. Lord Ellentorough C.J. rulect that, if the contract was for a year's service, the year must lie completed liffore the servent is entitled to be preid. If the plaintiff persisted in rcfusing to obey orders, he was warranted in turning him away. He night have obtained relief by applying to a magistrate, but he was not bound to pursue that course ; the relation between master and servant, and the laws by which that relation is regulated, existed long befure the statute. There is no contract between the parties except that which the law makes for them ; and it may be hard on the servant, but it would be exceedingly inconvenient if the scrvant were to be permitted to set himself up to control his master in his domestic regulations. A juror was afterwards withdrawn by consent. It was also ruled by the Court of Queen's Bench, in T'umer v. Robinson, in which Syain v. Amott was cited, that where the mime fecie presump,tion was that the plaintifi was hired for a jear, and there was nothing to relnt that presumption, if he violated his duty before the year expired, so as to prevent the refendant from having his services for the whole year, he cinnot recover warges pro ralit.

'The Contrt of Cummon Pleas alsr, in Harmer v. Cormelius, 28 L. J. C. I'. 85 (where it was decided that if a skilled persun undertalie a 
service which requires the exercise of such skill, there is an impliet warranty on his part that he possesses the skill requisite to perform the tusk, and if he does not his employer may dismiss him before the expiration of the period for which he was engaged, withont incurring responsibility) remarked in reference to Spxin v. Arnott, "It appears to us that there is no material difference between a servant who will not and a servant who cannot perform the duty for which he was hired." Parke J. laid down, in Callow v. Brouncker, that to justify a master in dismissing a yearly servant before the expiration of the year, there must be on the part of the servant either moral misconduct, pecuniary or otherwise, wilful disobedience, or habitual negligence; and per Lord Kenyon C.J., in Robinson v. Hindman, that a servant being frequently absent when his master wanted him, and often slecping out at night, would warrant an instant dismissal. Where, as in Speck v. Phillips, the defendant's counsel offered to prove that the defendant had discharged the plaintiff for drunkemmess, it was decided by the Court of Exchequer that the defendant could not give evidence, in mitigation of damages, of circumstances which if pleaded would have been a bar to the action, more especially where money is paid into Court.

Where an action was brought for a wrongful dismissal of a servant, who was hired under a written agreement at a yoarly salary, and a custom to terminate the agreement at a month's notice was pleaded, the jury found that the custom existed but did not apply to the special terms of the contract (or, as Byles J. observed, "in effect found a limited custom "), and it was held by the Court of Common Pleas that it was for the Court to look at the contract, and to see if the custom as found was excluded by it (Parker v. Ibbetson). By the agreement here the plaintiff was to serve the defendant as agent at a yearly salary, with a proviso that the defendant would at the end of the year, if he found the plaintiff had done suflicient business, give him $£ 30$ more; and the Court considered that there was nothing in this agreement inconsistent with a custom in the trade, to terminate the service by either party giving the other a month's notice. And semble per IVilles J. : "A stipulation for a donation to the servant at the ent of the year, under certain circumstances, contained in a written agreement for a yearly hiring, does not exclude either party from setting up a custom to terminate the agrecment at a month's notice" (ib.) (27 L. J. C. P. 236).

A contracl for service for more than a year, but subject to determination within the year on a given event, is within the 4 th section of the Statute of Frands, and must therefore be in urriting (Dobson v. Collis). The Court thought that Birch v. Earl of Liverpool which is an anthority to show that a contruet, which by its generil terms is not to be performed 
within the year, is not taken out of the statute, because it may be ilefeated on a given event, was exactly in point. And per Alderson B.: "The very circumstance that the contract exceeds the year brings it within the statute. If it were not so, contracts for any number of years might be made by parol, provided they contain a defeasance, which might come into opcration before the end of the first year. The reason for the enactment was that there might be no dispute beyond the year as to the terms of the contract. Beeston r. Collyer was the case of a yearly hiring. There was a contract to be performed within the year, and that might lead to another, which the parties might or might not make for a yenr. If they did enter into it after the first or any subsequent year, it was a fresh contract; but when once the contract exeeds the year, the circumstance that it is defeasible will not make it other than a contract for more than a year. See the absurdity of holding otherwise: at the end of two years and a-half, one of the parties might claim a right to put an end to a parol contraet for five years, by giving three months' notice; but the very dispute might be whether or not he had a right to give such notice. That shows that this is a contract within the statute."

In the case of Banks v. Crosstand, 10 L. R. Q. B. 97, by parol hiring on the 11th November, respondent agreed to serṿe appellant for one year from November 23rd. Respondent did not enter his service, and an information was taken out under 30 \& 31 Fict. c. 141, by s. 3 of which nothing in this Act shall apply to any contract of service other than a contract within the meaning of the enaetment of the first schedule of this Act, or some or one of them. By 4 Geo. IV. c. 34 , s. 3 (which is in the schedule), proceedings can be taken against a servant in husbandry who has not entered into his serrice, only if the contract be in writing signed by the parties to it. Held that no proceedings eould be taken against respondent under the Act 1867 ; also that as the contract was not to be performed within the year, and was not in writing; section 4 of the Statute of Frauds would have prevented the enforcing the contract.

By a parol agreement the defendant in Collis v. Botthamley agreed with the plaintiti to serve him for a year from a future day, and that the service thenceforth should continue subject to be determined by three months' notice. After the expiration of the year the defendant quitted the plaintiff's service without notice, and the Court of Exehequer licld that the plaintiff might maintain an action for this breach of their agreement, notwithstanding the Statute of Frauds. And por Watson B.: "After the expiration of the year a fiesh contract arose."

Where $A$ on July zoth made proposals in writing (unsigned) to B to 
enter his service as bailiff for a year, and B took the proposals and went away, and entered into A's service on July 24th, it was held by the Court of Exchequer that this was a contract on the 20th not to be performed within a year from the making thereof, and within the 4th section of the Statute of Frauds (Snelling v. Lord Huntingfield).

A servant in husbandry being hired for a quarter of a year, entered the serrice and was discharged before the end of the quarter; she immediately sted her master in the County Court for discharging her without reasonable cause, and a verdict was given for the defendant. After the quarter had elapsed, she took out a summons before justices against the defendant to recover the quarter's wages. It was held that the qnestion to be decided was essentially the same in the two courts, viz., whether the discharge was wrongful, and that the decision in the County Court was conclusive between the parties. And per Cockinurn C.J.: "It was admitted, and, indeed, conld not be denied successfully, that the question raised by the plaint and particulars in the one case, and the complaint on oath in the other was the same, viz., whether the discharge of the respondent was without just cause. Varying the form of claim, where the claim itself is the same, does not prevent the application of the rule of law to which reference has been made" (Rontledge appt. $\mathrm{r}$. Hislop resp).

Jurisdiction of magistrates does not extend to bailiffs.-A person engaged by the owner of a farm from year to year, subject to a month's notice, and at a salary of $25 s$. per week, to keep the general accounts belonging to such farm, to weigh out the food for the cattle, to set the men to work, to lend a hand to anything if wanted, and in all things to carry out the orders given to him, is not a servant in husbandry within the section 3 of Geo. IV. c. 34 , so as to be liable to conviction under that section for refusing to obey an order given to him by the owner of the farm. The appellant had thrown back a paper at the agent, declaring that he would not give information respecting the herd of Herefords at Cronkhill until a notice which had appeared in the Shrewsbury papers that the appellant was not anthorised to receive money on bchalf of the defendant was cleared up. The appellant had certain information requisite for identifying the calves, \&c., partly in a book and partly in his head ; but per Curiam, Crompton J., and Hill J., "The provisions in the act apply to persons engaged in mamul work, whereas the appellant here was rather a steward or bailiff. The principal thing which he had to do, besides setting the men to work and weighing ont the food for the cattle, was to keep the general accounts, and although he was also to make himself generally useful that was only accessory to his principal work. If we held that he was a servant in husbandry, so as to be liable to be 
convicted in this way, we should have to look into the other question, as to whether he had been guilty of misconduct; but that is unnecessary, as we think he was not a servant in husbandry within the act of parliament" (Laries appt. r. Buron Beruchete resp.).

bumi fiele betiof of sereent thet he may quit his place.-Although if a servant leaves lis employment, or refuses to perform his own contract muler a bonit ficte belief that he has a right to do so, he cannot be conrietel under the statute; yet to entitle the servant to judgment on that groumd on a case stated for the opinion of the Court, the facts must reasonably show that the desertion or neglect complained of was in pursuance of that supposed right, and it is not snfficient that it was merely possible that he acted under it (Jittett appt. v. Boote resp.).

Contracts of service neal not be for any specified time to give magistrates juristiction.-In order to give justices jurisdiction to hear a complaint as to the non-payment of wages, under the 20 Geo. II. c. 19 , s. 1 , it is only necessary that the relation of master and servant should exist between the parties, and the contract of service need not be for any specific time (Alice Taylor appt. v. Carr and Porter resps.).

liccovering a month's wages.-A menial servant, entitled under the hiring to a month's warning or a month's wages, cannot recover a month's wages for having been improperly dismissed without a month's warning on the common intebitatus count for work or' labour, but must declare specially. And per Curiam: "The month's wages are to be paid, not for the bygone services, but for the improper dismissal of the servant. Earlley v. Price (2 N. R. 333) broke in upon the rules of law, perhaps in order to do what happened to be justice in that particular case. Archard v. Hornor (3 C. \& P. 349), which was afterwards confirmed by the Court of Queen's Bench in Simith v. Hayuarl (7 Ad. \& E. 541), and also by this court, governs this case. It is not broken in upon by Sinith v. Kingsford (3 Scott, 279), which was decided on the ground that there was no dissolution of the contract of hiring. The contract in the present case is that the eervice is for the year, but the master is at liberty to dismiss the servant by giving her a month's wages or warning." And yer Aleterson B.: "When we say that the servant is to have a month's warning or a month's wages, it is meant that the payment to be made for the dismissal without warning is to be by way of composition, and that the amount is to be equal to a month's wages" (Fencings v. Tiselul, 1 Exch. 295).

Ciardener only cutitled to a montli's wexyes. $-\Lambda$ gardener with $£ 100$ a year and house, and two apprentices at $£ 15$ a year, is still only a menial servant, and entitled, even after four year's' service, to only a month's warning. And per Abinger C.B., though he did not live in the house, 
or within the curtilage, he lived in the grounds on the domain (Noulun r. Allett, 2 C. M. \& R. 54).

No contract for services. - Where services have been rendered withont any express contract for wages, but with board and lodging and other benefits (here to keep forls, bees, \&c., for her profit, althongh she paid for their lood herself), it was ruled by Martin B. that a contract to pay for such service is not to be implied (Foorl v. Morley).

It is specially provided for by section 20 of the Truck Act, stat. $1 \& 2$ Will. IV. c. 37, that it shall not extend to any domestic servant or servants in husbandry.

It was held by the Exchequer Chamber, in affirmance of the decision of Lord Camplbell C.J. and Coleridye J. (Erle J. diss.), that a labourer or artificer who enters into a contiact to do certain work (as brick-makiny) at. so much per foot, or per thousand, or the like, under which conticuct he ma!y get the worle done by other persons, and is not bound to bestow his own personal labonr, is not within the protection of the statnte, so as to defeat a set-off for goods supplied at a shop in which the employer is interested, in part payment of the wages or money so to be paid uncler the contract (Ingrem v. Barnes). Cresswell J. said : "I ground my judgment on this : that if this were res integra, I should be convinced that the statute applied only to cases where, by the contract, personal service was to be given for wages. That was the view taken in all the cases up to this. It was so held in Riley v. Warden. In Shaman v. Sander's the judges did not, as my brother Erle seems to suppose, proceed merely in deference to the authority of Riley v. Jarden. Each judge expressed his full approbation of that decision. The Chief justice did so; my brother Maule puts it very clearly; and I also expressed my concurrence in it. In Bowers $\mathrm{v}$. Lovekin I find the same doctrine acted upon. The ground of the decision upholding the judgment of the County Court was, as stated by Lord Compbell C.J. in his judgment, that 'it is found as a fact that the defendants were bound to give their personal labour like any other workman. It was an oral contract; and the County Court judge found that such was the contract; and on his finding the judgment proceeded. I think the judgment below right, and the doubt expressed unfounded." And per Chamel B.: "The case seems to me not to be distinguishable from Riley v. Warden and Sharman v. Sanders. But I do not rest wholly on that ground, for I entirely concur in the spirit of those decisions with respect to Bowers v. Lovelin and Weaver v. Lloyd; all I think it necessary to say is, that our decision does not elash with then." The decision in Ritey v. Wrarden was to the effect that a person who takes a contract to execute a certain cutting on a railway, at a certain sum per cubit yard, and 
emplors sereral men under him to assist in doing the work, is not a rockmen or latourer within the true meaning of $1 \& 2$ Will. JV. c. $3 \bar{T}$, althongh he does a portion of the work himself.

"If any portion of the year, hourever short, is excopted, during which the serrant is not under his master's control, whether that exception be express or by necessary implication from the terms used, the hiring cannot be considered a hiring for a ycar so as to confer a settlement, although the contract be for a year's service, subject to such exceptions; thus where a man was hired for a year, with liberty to let himself for the harvest month to any other person (Rex v. Bishop Hatfield, Rex v. Althorme), it was held that he conld not gain a settlement by service under such a hiring; so where the servant agreed for liberty to be absent eleven days (luring the shecp-shearing season (Rex v. Empinylum), or during the sheep-shearing season (Rex v. Arlinyton), or to work shearman's hours and to be at liberty at all other times (Rex v. Bucleland Denham); or as a colt shearman, to work twelve hours each day (Rex v. North Nibley); or where the hiring was for a year from Michaelmas, to go away a month at harrest, and make up the time after Michaelmas (Rex v. Turvey)." And again: "Where the only circumstance from which the intended duration of a contract of hiring and service ean be inferred is the reservation of wages weekly, it must be taken to be a weekly hiring, as where a servant in husbandry was to serve for the weekly wages of $4 s$, board, washing, and lodging, except in the harrest month, when his wrages were to be increased to $10 s$. $6 d$. per week, and then again reduced to $4 s$. (Rex v. Dodderhill); or where the hiring was at $8 s$. a week, and 2 guineas for the harrest, to do anything the gardener should set lim about (Rex r. Lambeth); or when a gardener having asked $£ 20$ a year, his master refused that, but agreed to give him so much a week (Rex $\mathrm{v}$. Iraminster)." But if there is anything in the contract of hiring to show that it was intended to be for a year, the reservation of weekly wages will not control it. (See also Rex v. Birdbrook, Rex v. Hampreston, Rex v. Great Yarmouth, and Rex v. Perstiore, and other cases collected in Mr. Manley Smith's "Law of Master and Servant," pp. 44-47).

Where defendant agreed to take plaintiff, a shepherd, into his service for $50 \mathrm{~s}$. and his board and lodging for five weeks, next ensuing after the 28th Febrnary, but afterwards refused to let him enter his service, flaintiff recovered $£ 5$ damages for such breach of contract (Clark v. Allatt).

It was left by Parke B. to the jury in Louth v. Drummond, at Kingston Spring Assizes, to say what notice a farm bailiff was entitled to; and they said that the master was not justified in giving only a month's notice, and gave a verdict for a year's wages. In Bulling v. Ellice, 
Knight Bruce V.C. held that a farm bailiff who had lived 28 years wilh the Earl of Leicester at $£ 350$ a year, living on the home farm within the park rent-free, the earl paying all rates and taxes, and who was allowed keep for a cow and horse, and to take pupils in agriculture, was a servant who might receive a legacy within the meaning of the will. And so may a gardener and under-gardener, in the exclusive employment of the testator, at weekly wages, but living at their own honses (Thrulp v. Collett). The bailiff cannot be considered as the employer of the labourer's on his master's own farm, within the sense of the words in stat. 20 Geo. II. c. 19, s. 2, though the contract of hiring was made by the bailitf personally; and hence it was held in Rex v. Hoseason to be a most abusive interpretation of the law for a magistrate to sentence one of the servants on his own farm to be "corrected and kept to hard labour for one calendar month" orr a complaint referred to him in his judicial character by his bailiff.

Rey. v. Worlley turned upon the point as to whether a farm bailiff, according to the terms of his agreement, was a servant or a partner. Here the defendant was engaged to "take charge of the glebe land of the liev. J. B. Clarke, his wife undertaking the dairy, and ponltry, \&c., at 15s. a week till Michaelmas, 1850 , and afterwards at a salary of $£ 25$ a year and $a$ third of the clear anmual profit after all expenses of rent and rates, labour, and interest on capital, \&c., are paid on a fair valuation made from Michaelmas to Michaelmas. Three months' notice on either side to be given, at the expiration of which time the cottage to be racated by Samuel Wortley, who oceupies it as bailiff; in addition to his salary." It was held that the defendant was a servant, and not a partner. He was not, however, a menial servant, but a labourer; and the agreement was admissible in evidence, though unstamped, as it fell within the exemption in the Stamp Act as an agreement for the hire of a labourer. And per Lord Camplbell C.J.: "I see no reason for confining the meaning of the word "labourer' to a mere hedger and ditcher." Contracts to serve as artificers, clerks, scrvants either domestic or in husbandry, handicraftsmen, mechanies, gardeners, or labourers are exemipted by sec. 21 of stat. $17 \& 18$ Vict. c. 83.

The builiff of a farminy establishment, through whose hands all payments and receipts pass, has no impried authority to pledge the credit of his emptoyer by drawing and indorsing bills of exchanye in the name of the Tatter. Nor in the absence of all direct evidence of anthority does the nature of the employment of such a bailiff furnish any ground for inferring the existence of such an authority upon slight or on any other than clear and distinct evidence of assent or acquiescence (Duvidson $\mathrm{v}$. Stanley). And per Tindal C.J.: "If banker's could recover on such a 
state of facts as this, every furm agent might pledge the eredit of his employer to an indefinite extent. Here there was no direct anthority; and the case of Murray v. The East India Company establishes that a ymeral anthority to receive and pay does not anthorise the agent to indorse bills of exchange. Here it was nerer shown that the defendant knew or had the means of knowing that his name was used in the manner in which it was used by the bailiff" ( $i b$.$) .$

Lord Demman C.J. thus laid down the law in Truman v. Loder as to a bailif"s pourer to bind his master by his contracts: "Suppose a landed proprietor to send his steward habitually to the neighbouring fuirs and miukets to make sales and purchases for him in matters conneeted with the management of his estate ; that the steward makes all these contracts in his own name, but that he is universally known to have no land of his orn, and to be acting solely for his employer, and by his direction and on his eredit; conld his intention to make himself the owner of articles bonght on one particular occasion in the course of the same dealing deprive the vendor of his recourse against the master? Clearly not." In the ease of Tassell v. Cooper, where the plaintiff, the farming bailiff of Tord De I'Isle (after his employment as such had ceased) received a check of $£ 180$ in payment for wheat belonging to his lordship, which he had sold on his own acconnt while acting as bailiff, and paid it in to his own account with B. and Co., his bankers, who received the cash for it, and gare him credit for the amount; but afterwards, under an indemnity from Lord De L'Isle, refused to honour his drafts; it was held that even assuming that the check had been improperly obtained by the plaintift, still, as between him and his bankers, the amount was recoverable by him as money had and received by them to his use, or as money paid. The plaintiff had been in the habit, in 1844-6, of managing Lord De I'Isle's home farm, and receiving large sums from the sale of the produce on his lordship's account, and paid the varions charges and expenses, and outgoings of the farm as such farm bailiff. He paid into his aceount with the bank, which was sometimes overdrawn, money received on his lordship's account, along with that of himself and others, without any distinguishing mark. The account and the usual pass-book was kept by the company in his name; and till the bank receired Lord De L'Isle's notice, they had no idea that his lordship had any concern with the plaintiff's account with them, or that the plaintiff was his farm bailiff.

On Jannary 11, 18.17, his lordship sent him word, throngh a third party. that he was from that time not to deal any more with his property, but to confine his services to giving orders to the men and to secing that they dirl their work on the furm. On the 19th, however, of the same month he praid in loy check to the 'Tunlridge Branch of the 
Tondon and County Joint Stock Bank $£ 1804 s$. 8l., for wheat he had sold for his lordship in the December previous ; and on January 28th Lord De L'Isle, on learning that he had an account at the bank, served them with a notice to hold "the balance, $£ 1281 \mathrm{~s} .10 \mathrm{l}$., on credit of" the account of Mr. Tassell, the same being formed of money belonging to me," until further correspondence had taken place ; and the plaintifl"s checks were accordingly dishonomred. The Court had no doubt whatever as to the point that, at all events, after the check was converted into money, the bankers (having no notice at the time they obtained money for it that it was not the property of the plaintiff) were indebted to him as for money had and received to his use, or money lent, and became liable to account to him for it whenerer he chose to call for it; but they also seemed to consider that it might be very questionable whether the plaintiff might not fairly have understood the intimation to him that he was "not to deal any more with Lord De L'Isle's property," as prohibiting him from making any more sales, but not from getting in money from persons to whom he had already sold corn, especially as he did not seem to have been asked to render an account of the sales which he had already effeeted. And see Timelall v. Porrell, where a bill for an account against a person who was alleged to have acted as steward to an aged lady up to the date of her decease, was dismissed with costs, there being no eircumstanees of suspicion against the defendant, and no duty to keep accounts having been undertaken, and the edueation and capacity of the defendant, as well as the com'se of dealing between himself and his employers, being inconsistent with the notion of his keeping regular accounts.

It was decided in $M /$ MCamus r. Crickett (1 East, 106) that a master is not Tiable in trespass for the ritful act of his serranl, as by driving his master's carriage against another without the direction or assent of his master (who was not present); but that he is liable to answer for any damage arising to another from the negligence and unskilfuhness of his servant acting in his employ. And per Curiam: "For a wilful act intrinsicatly verong liy a servant, the master is not liable. By a parity of reason he onght not to be, where the act, not wrong in itself, is only so for reasons personal to the servant and his wilful disregard of them. The master's lialjility ought to be limited to that which he may anticipate and gnard against" (Degg (Adx.) v. The Midland Raituray Company). So where a sertant unas guitly of umlarful pounding, it was held in Lyons 5 . Martin. that his master was not liable. The defendant ocenpied land adjoining a highway, and not fenced; and horses of the neighbourhood had, shortly before the act in question, trespassed on the land and been impounded. 'The plaintifl's horse being on the highway was intentionally 
driven from it, by a serrant of the defendant's, into the defendant's ground, and there secured by the same servant and taken to the pound. Coleridge J. thought, as this was not within the seope of a servant's ordinary authority, some direct authority from the master ought to be proved: and this not being done, the plaintiff was nonsuited. The Court refused a new rule, as it was clear the wrongful act conld not be traced to the master. Patteson J. said, "Brucker v. Fromont, and other cases, where the master has been held liable for the consequenees of a lawful act negligently done by his servant, do not apply; here the act was utterly unlawful. A master is liable where his servant causes injury by tloing a laurful act negligently, but not where he wilfully does an illegal one. Every person is to be taken to know the law."

$A$ mester is licelle for an act done by his screant in the consse of exceuting his orders with ordinary care; and therefore where a servant was ordered to lay down a quantity of rubbish near a neighbour's wall, but so that it might not touch the same, and the servant used ordinary care in executing the orders of his master, but some of the rubbish naturally ran against the wall, it was held that the latter might be sued in trespass" Giregory v. Piper, 9 B. \& C. 591). And per Littlellale J.: "Where a servant does work by order of his master, and the latter imposes a restriction in the course of executing his order, which it is difficult for the servant to comply with, and the servant in execution of the order breaks throngh the restriction, the master is liable in trespass. Suppose the case of two persons possessed of contiguous uninclosed land, and that one of them desired his servant to drive his cattle, but not to let them go upon the land of his neighbour, and that the cattle went upon the land of the neighbour, the master would be answerable in trespass, because he has only a right to expect from his servant ordinary, not extraordinary care. If the servant, therefore, in carrying into exeention the orders of his master use ordinary care, and an injury is done to another, the master is liable in trespass. If the injury arise from the want of ordinary care in the serrant, the master will only be liable in case" (ib.). And again in T'urberville v. Stampe, where the defendant's servants kcpt a fire so megligmtly guarded on the heath of their master, which was adjacent to the plaintiff's, that the latter was burnt, the defendant was held liable. Holt C.J. observed: "If my servant throws dirt into the highway, I am indictable. So in this case, if the defendant's servant kindled a fire in the way of husbandry, and proper for his employment, though he had no express command of his master, yet the master shall be liable to an action for damage done to another by the fire, for it shall be intended that the servant had authority from his master, it being for his master's benefit."

In Kington $\mathrm{v}$. Wuss the plaintiff recovered against a velerinary surgeon 
for the loss of a mare which he alleged had been destroyed by the inumoper administration of a dranght by his servant. 'The man, according to the evidence of the plaintiff's servant, had fastened the mare's head to a beam, and poured the draught down ; and the mare coughed and kicked abont, and showed such pain that plaintiff came into the stable and told the man he had killed her. Ten days afterwards she died; but the defendant's witnesses attributed her death to pleuro-pneumonia, and proved that there were tubercles in the left lung in varions stages, as well as a broken abscess and adhesion between the lungs and ribs. Evidence was adduced for the plaintiff to show that the pleuro-pneumonia arose from some foreign substance (in this case the medicine) having gone the wrong way, and got into the air passages. The defendant and his witnesses admitted that it was improper to fix a horse's head when giving medicine; but the man said that he had merely tied the halter to the beam by a slip-knot, and could in a moment set it free by pulling the cord. Lord Campbell C.J. told the jury that if they were of opinion that there had been improper treatment, which had accelerated the death or done any harm whatever to the mare, the jury, in point of law, must find for the plaintiff, which they did, with $£ 5$ damages.

A curious case of liability came before the Court of Common Pleas in Holmes v. Onion. The defendant had hired one Simpkin as a thatcher, but no time was mentioned at which the service was to commence. About a month after this Simpkin hired himself to the plaintiff. Some conversation ensued between the latter and the defendant; and the defendant said, "I must have my wheat cut, and if I give Simpkin up you must pay me as much as I should have had if he were thatching for me." To this the plaintiff assented; and Simpkin did a portion of the thatching very negligently, and left it before it was completed. The defendant then sent another man, at the plaintiff's request, to complete it: sued the plaintiff in the Newmarket County Court, and recovered for the whole work done. An action was then brought by the plaintiff at the Cambridgeshire Spring Assizes against the defendant for the negligent thatching of the stacks; and the defendant had a verdict, leave being reserved by Pollock C.P. to enter the verdict for the plaintiff for $£ 5$, if the Court should think that there was any evidence of a contract between the plaintiff and defendant, so as to make the defendant liable for Simpkin's negligent execution of the work. The Court made the rule absolute.

Cresswell J. said: "The case of Quarman v. Burnett (6 M. \& W. 499) shors that Simpkin would be Onion's servant, and Onion the contracting party. The defendant buys the services of an able thatcher, in order to hire 
him out at a profit, and he does so, and gets the profit; then he should be liable." In reply to the argument of counsel that where the plaintifr' selects his man he takes the risk of his not possessing skill, industry, and good conduet, his lordship added: "Suppose yon send a valuable horse to a smith, and say, "Do not trust this horse to any clumsy hands, but shoe hin yourself, or let your foreman shoe him, and the foreman does shoe him and pierces his foot, is not the smith liable?" And per Cockbuin C.J.: "Althongh where a man sclects a servant, the master may be relieved from responsibility as to incompetency, that will not reliere him from liability as to negligence" (26 L. J. C. P. 261).

If a servent, in this case a general manager, be possessed of a horse and ging of his ortn (which were kept at the defendant's expense), and while nsing them to eollect debts on his master's account with his master's aequiescence, canse a collision and damarge by his negligent driving, the master is liable for the damage (Patten v. Rea). Milles J. observed that the defendant's argument "secmed a contradiction of the doctrine laid down in Turberville v. Stempe." And per Curiam, in an action for damagc done by the negligent driving of the defendant's servant, the proper question to leave to the jury is, whether at the time of the act complained of the servant was driving on his master's business and with his authority (ib.) (1 Ld. Raym. 264).

The 77th see. of Stat. $5 \& 6$ Will. IV. c. 50, provides that a person may act as the driver of tuo carls on a highuray, provided that the carts shall not be drawn by more than one horse each, and the horse of the hinder cart shall be attached by a rein, not exceeding four feet, to the lack of the foremost cart ; and it was held by the Court of Queen's Bench, in Robertson (appel.) v. Burkett (resp.), that the provision was substantially complied with, when a driver seated in the first cart had a rope attached to the head of the last horse passed over the back, and fastened to the body of the first cart about the centre, and the last horse's head drawn close up to the back of the first cart, so that he lad full command of both horses. Erle J. styled the appeal " a pestilent perversion of a useful statute."

Where a servant in the ordinary course of his employment is killed lyy the nergligence of one who is not his mployer, the widow may maintain an action against the latter (Vose Adx. v. The Lancashire and Yorkshire liecileay Company). According to Tarrant v. Webl, a master is not yenerally responsible for an injury to a servant, from the neyligence of a frilou'-serecent; but that rule is sul,ject to this qualification, that the master uses reasonable care in the selection of the servant. And per Irve is C.J. : "The master may be liable where he is personally guilty of necrligence; lunt certainly not where he does his best to get eompetent. 
persons. He is not loond to warrant their eompetency." So if one scrrant overloads a cart, whereby it breaks down and throws plaintifr (another servant), no action lies against the master (Prieslley v. Fou'ter).

The above case was confirmed by the House of Lords in Burtons Hill Coal Company r. Reill, which decided that a master is not liable to his servant for injury done to him by the negligence of a fellowservant employed in the same work, the injury not having arisen from the unfitness of the latter; but to exclude the master's liability, there must not only be common service, but the fellow-servants must be employed in the same work. Where persons in common service are engaged in different departments of labour, the master is liable for an injury committed through negligence by one servant mpon another, unless the risk of such an injury was fairly to be eonsidered as incidental to the particular employment of the injured party ; and the proper test of the latter consideration is, what risk the injured party must have known he was exposed to from the nature of the employment he undertook; and notwithstanding some occasional dicta of judges of the Court of Session, the English and Scotch laws are identical on this subject $(i b$.).

No contract on part of master not to expose servant to great risl.From the mere relation of master and servant, no contract can be implied (in the part of the master to take due and ordinary care not to expose the servant to extraordinary danger and risk in his service. And per Pollock C.B.: "This is an attempt to nullify the decision of the Court in Priestley v. Fouter (3 M. \& W. 1; 7 L. J. N. S. Ex. 42), and to enlarge the case in which persons in the relation of master or employer are to be made responsible for injuries incurred by those in their employment, who are in general much more able to judge of the probability and extent of the risk they run in the service than those who employ them. I think it highly expedient that the rule laid down in Fowler v. Priestley should be maintained and not eaten up by exceptions" (Riley Admx. v. Baxendale, 30 L. J. Ex. 87).

Injury to servant working with master. - When, by the negligenee of the master, an injury is caused to a servant in the course of his employment, the master is liable, although he was employed as a workman at the time, and was working with the servant; and if one member of a partnership is guilty of such an act of negligence, and if it occurs in a matter within the scope of the common undertaking of the partnership, all the partner's will be liable for the injury caused to the servant. And per Curiam: "If the defendant had been simply the fellow workman of the plaintiff, the case would have come within the principle and wonld be quite analogous to Bartonshill Coul Company v. Reid (3 Macq. 
II. I. Ca. 300 ), where it was decided that a servant sustaining an injury from the negligence of a fellow-servant engaged in the same employment, camot recorer against the common master. 'The present case is distinguishable in this important jarticular, that the defendant, althongh engaged jointly in the work of the mine, was also a co-proprietor, and as snch one of the plaintiff's master's; and this takes the case out of the before-mentioned rule, and ealls for the application of a different principle. The doctrine that a servant, on entering the service of an employer, takes on himself, as a risk incidental to the service, the chance of injury arising from the negligence of fellow-servants, has no application in the case of the negligence of an employer. Though the chance of injury from the negligence of fellow-servants may be supposed to cuter into the ealenlation of a servant on undertaking the service, it would be too much to say that the risk of danger from the negligence of a master when engaged with him in their common work enters in like manner into his speculation.

"From the master he is entitled to expect the care and attention which the superior position and presumable sense of the duty of the latter ought to command. The relation of master does not the less subsist becanse by some arrangement between the joint masters one of them takes upon himself the functions of a workman. It is a fallacy to suppose that on that account the character of a master is converted into that of a fellow-labourer. Though engaged with the plaintiff (Ashworth) in a common employment, Walker did not the less remain the master of the plaintiff and the partner of the co-defendant Stanwix. This being so, it follows that Stanwix must be liable in respect of the negligence through which injury has arisen to the plaintiff, as the relation of partner subsisted between Walker and Stanwix; and as the negligence was in a matter within the scope of a common undertaking, we think that Stanwix is equally liable with Walker. That a partner is liable for the negligence of his co-partner when engaged in the business of the partnership is not only elear in prineiple, but it is established by the case of Moreton v. Harden ( 4 B. \& C. 223), in this court, where the proprietors of a stage-coach were held liable with a third for the negligence of the latter, by whom the coach had been driven. Now it has nerer been doubted that for personal negligence "f the master, whereby injury is occasioned to the servant, the master will be liable. Personal negligence is clearly established against Walker; and it being admitted that the defendant Stanwix was his co-proprictor and partner, the latter must be held to be jointly responsille in respect of such negligence, and is therefore lialsle in this action " (Asturorth v. Stanuix and Ifalker, 30 L. J. Q. B. 183). 
Non-liability of master for imjury to servent firom negligence of fellow servant.-The doctrine in Priestley v. Fouter (3 M. \& IV. 1 ; and 7 I. J. N. S. Ex. 42) that a master is not liable for an injury to his servant arising from the negligence of a fellow-servant, movided he has luken alue care to movide proper machinery and competent servants, was upheld in Searle v. Lindsay and Others.

Stranger helping servant.-If a stranger, invited by a servant to assist him in his work, is, while engaged in giving such assistance, injured by the negligence of another servant of the same master in the course of his employment, the stranger cannot hold the master responsible. The stranger, by volunteering his assistance, cannot impose upon the mastel a greater liability than that in which he stands towards his own servant; and if the master takes care that his servants are persons of competent skill and ordinary carefulness, he is not liable for any injury that one of them may receive from the negligence of another. 'This cuse affirmed the authority of Degy v. The Midland Raihiay Company (1 H. \& N. 773, and 26 L. J. N. S. Ex. 171), and the decision of the Queen's Bench was affirmed (Potter v. Faulkner, 31 L. J. Q. B. 30).

Proof of well-defined negligence requived.-In an action for an injury occasioned by a defendant's negligence, e.g., negligent driving, the plaintiff, to warrant the judge in leaving the case to the jury, must give proof of well-dlefined negligence, and not merely some evidence of negligence on the part of the defendant ; and where the evidence given is equally consistent with there having been no negligence on the part of the defendant as with there having been negligence, it is not competent for the judge to leave it to the jury to find either alternative; such evidence must be taken as amounting to no proof of negligence. It had been previously held, in Pigotl v. Eastern Commies Raituay Company (3 C. B., 229), which was referred to in the plaintiff's argument, but not noticed in the judgment, that the fact of the premises being fired by sparks from a passing engine is mimâ facie evidence of negligence, rendering it incumbent on the company to show that some precantions had been adopted by them reasonably calculated to prevent such accidents (Cotton v. Wood, 29 I. J. C. P. 333 ).

Master responsitze for wilful conduct of servant if within scope of his cmployment.-It was held by the Exchequer Chamber (Hightman J. diss. and Crompton J. (Aut.), affirming the judgment of the Court of Exchequer, that a master is responsible for the negligent act of his servant, notwithstanding that it be done wilfully, and contrary to express orders, if it be done within the scope of his employment, and in executing the matter for which he is engaged. Ilere the omnilussdriver of the defendant's had wilfully, and contrasy to express orders 
from his master, pulled across the road to obstrnct the progress of the plantitl"s omnibus, and in so doing injured one of the plaintiff"s omuibus horses. T'he reason he gave was that he wanted to serve the plaintiff"s driver as that person had served him. And per Williams .T.: "If a master employs a servant to drive and manage a earriage, the master is, in my opinion, answerable for any misconduet of the scrvant in driving or managing which can fairly be considered to have resulted from the performance of the funetions entrusted to him, and especially if he was acting for his master's benefit, and not for any purpose of furthering his own interest, or for any motive of his own caprice or inclination" (Limpus v. London General Ommibus Company Limiterl, 32 L. J. Ex. : 1 1).

Alderson B. thus stated, in a similar ease, Hutchinson v. The Tor\%, Neucustle di Bermick Recituray Company, the prineiple applieable to the case of screral scrvants employed by the same master, where injury resulted to one of them fiom the negligence of another. "In such a ease, however," said his lordship, "we are of opinion that the master is not in general responsible when he lias selected persons of competent care and skill. Put the case of a master cmploying A. and B., two of his servants, to drive cattle to market. It is admitted that if by the unskilfulness of A. a stranger is injured, the master is responsible. Not so, if $\mathrm{A}$. by his unskilfulness hurts himself; he cannot treat that as the want of skill of his master. Suppose, then, that by the unskilfulness of A., B., the other servant, is injured while they are jointly engaged in the same service, there we think B. has no elaim on his master. They have both engaged in a common service, the duties of which impose a certain risk on each of them; and in ease of negligence on the part of the other, the party injured knows that the negligence is that of his fellow-servant, and not of his master." In Degy $(A d x$.) v. The Midland Railuay Company, the above rule of lau that a master is not in general responsible to his servant for injury oecasioned by the negligenee of a fellow-scrvant in the course of their common employment, was rerlended to the case of a person who is injured while voluntarily assisting the sercants in their work. The deceased, by thus volunteering his scrvices, could not have greater rights, or impose any greater duty on the defendants, than would have existed had he been a hired servant.

It has also been decided that vinere an injury happens lo a servant white he is in the achual use of an instrument, engine, or machine, of the natwe of uhirh he is as muct audere as his mester, and the use of which is, therefore, the jroximate cause of the injury, lie cannot, at all events if the cridence is consistent with his own nergligence in the nse of it 
heing the real cause, nor in case of his dying from the injury, can his representative under Lord Campbell's Act (9 \& 10 rirt. c. 98 ), recover against his master, there being no evidence that the injury arose throngh the personal negligence of the master (Dynen v. Leach). $\Lambda^{\top}$ or is it any evidence of such personal negligence of the master, that he has in use in his works an engine or machine which is less safe than some other which is in general use (ib.). But it was decided by the Exchequer Chamber that where a master builder personally interferes and directs his workmen to make a scaffolding ont of poles which he knows to be unsound, he is liable to make compensation if the scaffolding gives way, and a workman upon it in his employ, who has had no notice of the unsoundness, is injured thereby (Roberls $\nabla$. Smilh). And see Alsop v. Yates, 27 L. J. Ex. 156.

A declaration that the defendant was possessed of a ladder, mnsafe and mufit for use by any person carrying corn up the same, and the plaintiff was the defendant's servant, yet the defendant, well knowing the premises, wrongfnlly and deceitfully ordered the plaintiff to carry corn up the ladder, and the plaintiff in obedience to the order, and believing the ladder to be proper for the purpose, and not knowing the contrary, did therefore carry corn up it for the defendant; but by reason of its being unsafe and unfit, the plaintiff fell and was injured, was held in Williams v. Clongh, Bramuell B. dub., to be sufficient withont an averment that the plaintiff had no notice that the ladder was unsafe. And semble, the gratuitons lender of an article unfit for use to his knowledge, is not liable to a person whose user of it he has not foreseen, for an injury caused by the unfitness (Blackmore Adlx. v. Bristol \& Exeter Railuay Company).

In Joel v. Morison, Parke B. ruled that if a servant driving his master's cart on his master's business make a detour from the dircet roal for some merpose of his own, his master will be answerable in damages for any injury occasioned by his careless driving while so out of the road. But if a servant take his master's cart without leave, at a time when it is not wanted for the purposes of business, and drive it abont solely for his own purposes, the master will not be answerable for any injury he may do. And this ruling was confirmed by the Court of Common Pleas in the case of Mitchell v. Crasualler, where the defendant's carman, instead of putting up his horse and cart when the day's work was done, without the defendant's leave, drove a fellow-servant in an opposite direction to the mews, and on his way back injured the plaintiff by his negligent driving. 'The defendants, under Not grilty, were allowed to show that the driver was not at that time acting as their servant. The Court of Qneen's Bench upheld the ruling of Parke J. in Goostman v. Keme! 
that if a master sends his servent on an erraml, withoul providing him uith a horse, and the scrvent tulies one and rides it in the doiny of surh errand, and an injury happens in eonscquence, the master is not liable in an action for damages by the party injured. If it were otherwise, every master might be ruined by acts done by his servant without his knowledge or anthority. And Tindal C.J. ruled in Illidge v. Goodtwin, that if a horse and cart are left in the street lyy a servant, without any one to watch them, the owner is liable for any damage done, even thongh it be occasioned by the act of a passer-by in striking the horse. Sce also Croft v. Alison, 4 B. \& Ald. 590.

Mir. Baron Parke observed, in Gordon v. Rolt, "The result of the anthorities is, that if a servent, in the course of his master's employ, drives orer any person, and does a vilful injury, the servant, and not the master, is liable in trespass; if the scrvant, by his negligent driving, causes an injury, the master is liable in case; if the master himself is driving, he is either liable in case for his negligence, or in trespass, because the act was wilful. In Mlaclaughtin v. Pryor, the master, though not actually driving, was present, and directing the driver; therefore there was evidenee that he sanctioned the eonduct of his servant, from which the injury arose." And see his lordship's jndgment in Sharrod v. The London and North Western Raileay Compamy, where some cattle were killed by a railway engine. A person driving a carriage is not bound to keep on the regular side of the road; but if he does not, he must use more care, and keep a better look out, to avoid concussion, than would be necessary if he were on the regular side of the road (Pluckivell v. Witson). And per Menule J.: "It is negligence not to drive an inferior vehicle with such a degree of eare as its inferiority requires, just as it wonld be negligence to drive a high-spirited horse with no more care than a dull one" (Templeman appellant v. Haydlon respondent). This was an appeal against the decision of a Somersetshire county court judge, in an action for negligently driving a horse and cart; the plaintiff having simply jroved the fact of a collision, under circumstances which mignt or inight not anount to negligenee. The defendant proved that the horse, perfectly quiet up to the time, and going slowly, suddenly began to kick rery violently; both shafts broke off, the cart tilted up, and himself and a woman and four dead pigs were thrown into the road, that he himself was rendered insensible, and that the horse, which then ran away, had not sufficient room to pass the plaintiff's horse and gig on the proper side of the road. 'The judge ordered a verdict for the plaintiff', being of opinion that the breaking of the shafts, even morer the circumstances stated by the defendant's witnesses, showed a defect in the cart, which raised a presumption of negligence in the owner, and the appeal was 
dismissed with costs. It is said (Bac. Abr., Tit. "Master and Servant") that if a servant drives his master's cart, and by his negligence suffers the cattle to perish, an action on the case lies against him. In an action of tort for an injury to the person as by careless driving, particutars with be ordered as to the nature and extent of the injuries, or of the claim for compensation on an affidavit (Wicks v. Macnemara).

The general rule of law respecting negligence is, that although there may have been negligence on the part of the plaintiff; yet unless he might by the exercise of ordinary care have avoided the consequences of the defendant's negligence, he is entitled to recover (Davies v. Mann; Bridge v. The Grand Junction Raituray Company; Butterfield v. Forrester). In the first of these three cases, the plaintiff having fettered the forefeet of an ass belonging to him, turned it into a public highway; and at the time in question the ass was grazing on the off-side of a roar about eight yards wide, when the defendant's waggon with a team of three horses coming down a slight descent, at what the witness termed a smartish pace, ran against the ass, knocked it domn, and killed it. It was proved that the driver of the waggon was some little distance behind the horses. Erskine J. told the jury, that though the act of the plaintiff in leaving the donkey on the highway so fettered as to prevent lis getting ont of the way of carriages travelling along it, might be illegal ; still, if the proximate cause of the injury was attributable to the want of proper conduct on the part of the driver, the action was maintainable against the defendant, and his lordship directed them, if they thought the accident might have been avoided by the exercise of ordinary care on the part of the driver, to find for the plaintiff, which they did, with $40 s$. damages. The Court of Exchequer npheld the rnling. Parke B. said: "Although the ass might have been wrongfully there, still the defendant was bound to go along the road at such a pace as would be likely to prevent mischief. Were this not so, a man might justify the driving over goods left on a public highway, or even over a man asleep there, or the pnrposely running against a carriage going on the wrong side of the road." It is deducible from the opinions of the judges in Butterfield v. Forrester, Bridge v. The Grand Junction Canal Company, Davis v. Mann, and Dovell v. The General Steam Nariyation Company, which were all referred to in the judgment of the Exchequer Chamber, which affirmed the decision of the Court of Common Pleas in Tuff $\mathbf{}$. Warman, - that in actions for injuries by collision, thongh the damage is not occasioned entirely by the negligence or improper conduct of the defendant, the plaintiff is still entitled to recorer, if he have not so far contributed to the misfortume by his own negligence or want of ordinary care, that but for such negligence the misfortune could not 
have happened, and if the defendant could by the exercise of ordinary care and caution hare arviled the consequences of the neglect or carelessness of the plaintifl.

Lord Ellenborouyle C.J. ruled, in Rusby r. Searlett, that the master is discharyed from the payment of debts contracted by the servant where the gives the sercant money lieforehand to pay for goods; but not where he authorizes the serrant to take up goods, and afterwards gires him money to par, if the servant embezzles the money. The action here was to recover the price of hay and straw sold and delivered at defendant's stables; but there was no eridence that the plaintiff had ever seen the defendant, ol receired any orders from him. Defendant said he had girels the coachman money to pay the bills, and that he had embezzled it; but it appeared the money was adranced generally, and not with a view to this particular demand; and there was a rerdict for the plaintiff. It was held by Pollock C.B. in Aste v. Montague, that a gentleman weas lietile for corn ordered in his name by a livery-stable keeper, who had been his coachman, and contimed to ueer his livery, not having given notice to the plaintiff of the employment being at an end, Rimel v. Sampayo was relied on for the plaintiff, in which Littledale J. held that if a gentleman's coachman go in his master's livery and hire horses, which his master uses, the master will be bound to pay for the hire of the horses, although lie has agreed with the coachman that he will pay him a large salary to proride horses, unless the lender of the horses had some notice that the coachman hired them on his orn account and not for his master. Where the misoner heul been in the hatit of buying and selling corn for his employprs, and he had been accustomed to employ, for the purpose of payments on their behalf, as well monies which he reccired on their account, as monies which he received from them for that purpose, and had falsely entered the price of some corn which he had purchased and paid for as amounting to a larger rate of $6 d$. a coomb than it really did, and retained the difference, it was held by Wightman J. that there was no case for larceny; but semble that there was a case for the jury of conbezzlement (Reg. v. Lyyon). And in Hourard v. Stherearl (2 L. R. C. P. 148), the Court held that the servant or agent of a horse dealer has implied authority to bind his principal or master by a warranty, even though, unknown to the buyer, he has express order's not to warrant.

In Gingell v. Glascorte, the plaintiff, a hay salesman, sold for the dofendant a load of hay to one Sumuer, and remitted $\& 416 s$. to lim hefore Simncre had paid. In the menntime defendant's serrant, who was sent up to London with the hay, charged by the plaintifl" to deliver it to the purchascr, was imposed on by some cheat, who personated Sumner, and grot the hay. Sumner would not pay, and the defendant would not 
refund, and the case having been referred, the arbitrator decided for the plinitill. The Conrt considered that the servant who made the mistake was at the time acting as the scrvant of the defendant, and the award was confirmed. Evans v. Winifred Birch was a case of supposed cheatiny by a diairymaicl, who was sued for money had and received. She had twenty quarts daily for a milk-walk, and sometimes sold on credit, and sometimes for ready-money. Each morning she accounted with the plaintiff; but there were no written vouchers, and often no third party present: and she was sued for the proceeds of two months' milk. Loird Ellenborough called for "some evidence that the defendant has not paid over the money. If in point of fact she has not, and no negative eridence can be adduced by the plaintiff, I am afraid his only remedy will be by a bill in equity for a discovery and account, though this may be rather an expensive mode of settling a milk score." She, however, acknowledged to $1 s .8 d$. not paid over, and the verdict was for that sum.

A servant carrying out milk at weekly wages, with trade allowances, was restrained by Sir Jolun Romilly M.R. from trating on his ourn account in contravention of an agreement, signed by him, not to carry on the same business, \&c., within the same district (three miles from Charles-street, Grosvenor Square), for two years after ceasing to be employed or leaving the service of his master, his successor, or assigns. His Honour considered that the defendant's being a servant at wages was quite a sufficient consideration to support the agreement, and that it would be a virtual breach of it if he assisted any other milkman (Bencell $v$. Imns). The trade allowances were $5 d$. for every quantity of eight quarts over and above 44 quarts a day he disposed of ; $2 d$. per quart for carrying cream; $4 s$. for every customer he introduced who should continue such customer for two months, and take one quart of milk per day, with an additional $4 s$. for two quarts or more per day which such customer should take (ib.).

The following were general cases of larceny by farming servants, and somewhat peculiar in their facts.

Reg. v. Hayuard. was a case where the prisoner took the straw to the prosecutor's court-yard, and put it down at the stable-door. The prisoner then went to the prosecutor, to ask him to send some one to open the hay-loft, which was over the stable, that the straw might be put in. He then put in part of the straw, and carricl the rest away to a public-honse. 'This carrying away, if done with a felonions intent, was held to be a lareeny, and not an embezzlement, as the delivery of the straw to $A$. was complete when it was put down at the stable-door. And if a servant animo furendi takes his master's hay from his stable 
and puts it into his master's raggon, this is a sufficient asportation (Reg. r. Grundell).

Again, in Rey. v. Primett and Coodhall, the prisoners, a carter and carter's boy, took from the barn-floor, in the thresher's presence, five sacks of unwinnowed oats, and secreted them in a loft, to give to their master's horses, althongh they were not answerable at all for the condition or appearance of the horses. The jury found that they had no intention of applying the oats to their private benefit; but nine of the judges held that, on the authority of previous decisions, this was a larceny, though they doubted if they should have so decided if the matter were res integre. Erle J. and Platt B. thought that the taking was not felonious, as the goods were to be applied to the master's use ; and the former decisions proceeded on the supposition that the prisoners would gain by the taking, which was negatived in this case.

The indictment in Reg. v. Wills was for obtaining money by false pretences. The prisoner had been employed to cut chaff for the prosccutor, and was to be paid $2 d$. per fan for as much as he cut. He made a demand for $10 s .6 d$., and said he had cut 63 fans; but the prosecutor and another witness had seen the prisoner remove 18 fans of cut chaff from an adjoining cliaff-honse, and add them to the heap which he pretended he had cut, thus making the 63 fans for which he charged. Upon the representation that he had cut 63 fans of chaff, and notwithstanding his knowledge of the prisoner's having added the 18 fans, the prosecutor paid him the $10 s$. 6 d., being $3 s$. more than the prisoner was really entitled to for the work actually performed. The Court quashed the conviction. And per Curiam: "The question in these cases is, whether the false representation is the motive operating in the mind of the prosecutor, and inducing him to part with his money. It cannot be said that this was the case here, because he paid the money, although he knew the representation to be false. Unless the money be obtained by the false pretence, it is an attempt only. The prosecutor could not recover hack the money in a civil action, hecause it was paid roluntarily, with a knowledge of all the circumstances."

One of the earliest cases on the subject of ficudulent drovers is Rex $\checkmark$ Stock, which decided that it is larceny for a person hired for the special purpose of driving sheep to a fair, to convert them to his own use, he having the intention so to do at the time of receiving them from the orner. 'The prisoner, who had never been the prosecutor's servant, though he had been occasionally employed to drive sheep, was hired at Bristol fair to drive fifty sheep to Lradford fair for him for $2 s .6 \ell$. per day. He had never had either on this or any other occasion authority 
to sell, but simply to drive them to Bradford ; which he did not do, but sold ten out of the fifty, the next morning after he received them, to a person in quite an opposite direction to Bradford, on a false representation of his authority to do so. The jury found that the prisoner at the time he received the sheep intended to eonvert them to his own use and not to drive them to Bralford, and the judges unanimously decided that he was rightly convicted of felony.

This was followed by Rex v. Bernard Mar Namee, where it was decided unanimously by nine judges, that if a man who is hired to drive cattle sell them, it is laremy; for he has the custody only, not the right to the possession, his possession being the owner's possession, though he is a general drover, at least if he is paid by the day. The prisoner was convicted of stealing 118 sheep. It seems that the prosecutor, who lived fifty miles from Grantham, had employed the drover in his service as a drover off-and-on for nearly five years, but not as a regtilar servant. He was a general drover, and lodged in the town; and agreed with the prosecutor for $3 s$. a day, that being what the former regularly gave drovers. On the $3 r$ of April, 1832, he employed the prisoner to take 169 sheep to Grantham fair, and found him with only 163 sheep on the 8 th ; his exeuse being that he had sold five lame ones, and sent one back. The prosecutor sold 44 at Grantham, and gave the prisoner money and order's to bring the 119 to Smithfield on the 16th, and meet him in London the night before. 'The prisoner had no anthority to sell sheep; but on Monday lie found 118 of them at the market in the hands of different salesmen, who said they had purchased them of one Shelton, who had bought them from the prisoner, who pretended that they were his own. The jury fornd that the prisoner did not intend to steal the sheep at the time he took them into his possession. The case was considered by nine of the judges, and they were unanimously of opinion that as the owner parted with the custody only, not with the possession, the prisoner's possession was the owner's, and that the conriction was therefore right.

In Rex v. Hemry Hughes it was held, in thesame term, that a servant may be found guitty of embezalement, though he is not a general serwernt and employed to receive in a single instane. Here the prosecutor was a farmer, and the prisoner a drover occasionally employed by him. He was engaged to take a corv and calf for him to Marrlebone, and bring baek $£ 16$, and had not any extra reward beyond what was his due for driving and delivering the cattle to the purchaser. From the low situation in life of cattle-drovers they were not likely persons to be entrusted with the receipt of money, and the Recorder (relying principally on Rex v. Neftleton) considered that the receipt in this instance was a mere voluntary act on the part of the prisoner, not at all incident to his 
general character and employment as a drover, and that without any breach of his dutr as such, he might hare declined taking upon himself the burthen or risk attendant on his taking charge of the money. Nine of the judges, howerer, were of opinion that the prisoner was a servant within the meaning of the Act 7 \& 8 Geo. IV. c. 29, s. 47, and that the conviction was right.

The next case on the subject was Reg. r. Wm. Goodlodly. The prisoner was indieted for stealing six oxen from a farmer and grazier, who had known him sereral years, and had employed him once or twice before. He was sent with eight oxen, which were left unsold at St. Ires market, and told that if he could sell them on the road he might, but that those he did not sell were to be taken on to Smithfield to one Mr. Pollett, the prosccutor's salesman. On cross-cxamination the prosecutor said he did not know whether the prisoner drove other eattle on that occasion, though he was at liberty to do so: there is a regnlar charge for drovers; so much per head for eattle triven, and so much for cattle sold. 'Two of the beasts he sold on his way to London, and took the remaining six to Smithfield, where he sold them, and receired the money throngh a Smithfield bank. One of the witnesses for the prosecution said the prisoner was a salesman as well as a drover. Mr. Pollett was called as a witness, and stated that he never received the beasts. He added: "It is the duty of the drover to deliver them to our drover, and next morning to come and see that we have them: it is no part of his duty to sell them in Smithfield. 'The prisoner had twice before delirered the prosecutor's beasts to my drover." The Court held that there was no proof that the prisoner was the scrvant of the prosccutor, and there being no felonions taking in the first instance, the indictment could not be sustained.

The sulject of felonious intenlion was much considered in Regina $\mathrm{v}$. George Hoy, which shook Rex v. Bernard Mac Namee. On September $26,18+8$, the prosecntors, two pig-jobbers at Neweastle, having bought pigs which they thought would suit Goose, a pig-dealer at Lceds, engaged the defendant, a buteher and drover at Newcastle, to go by rail and deliver them to Goose (bringing back the amount in a postoffice order or a check) on showing him a certain paper. No orders of any kind were given him to sell the pigs in case Goose refused to take them. At 6 A.M. on the 27th, he went to the house of Goose, who was not at home. Mr's. Goose, on hearing him, called up a man, to whom she referred him. The latter merely looked out of the window, and sairl, "Is that you?" and then shutting it up retired, as if to bed. Between 6 and 7 that morning the prisoner called np a pork-butcher, sold the pigs to him, absconded with the $\mathbf{E 3 5}$, and said nothing to the 
prosecutors. He had often been employed by them to slaughter and cut up pigs, and had been paid by the job, but never before as a drover. Two pomnds were giren him for expenses, and no arrangement was made as to how he was to be paid, though there was an established custom in the trade to pay them so much per day; and by another trade usage he was at liberty to drive any other person's eattle at the same time, though nothing was expressed to that effect in this case. The prisoner said, in his defence, that he was a partner with the prosecutors; and there was no evidence of an animus furcundi when the pigs were delivered to him. He was found guilty of lareeny ; but the Recorder postponed judgment to take the opinion of the Court, whether, under the circumstances, the prisoner was the servant of the prosecutors, and whether the taking amounted to larceny? The Court thought that it was not proved in this case that the prisoner was a mere servant, and that the conviction was wrong.

Parke B. said, in delivering the judgment: "There are several reported eases bearing upon the question whether a person is a mere scrvant or bailee. There are none precisely like the present, thongh the case of Rex v. Bemarl Mac Name nearly approaches to it. In this case, on the one hand, the cireumstance that the prisoner was paid the expenses of the cattle, and also that the customary mode of payment of his remuneration was by the day, tend to show that he was a mere servant; on the other, the fact of his being a drover by trade, and also of his having the liberty to drive the cattle of any other person by the general usage with respect to drovers, raises an inference that he was not a servant. The learnel Deputy-Recorder felt himself bound by the decision of the judges in Rex v. Henry Hughes, but that case was under the 7 \& 8 Geo. IV.c. 29, s. 47, which makes embezzlement by a servant, or person employed in the eapacity of a servant to receive money, felony; and the learned Recorder of London referred the question to the judges, whether the prisoner fell nuder either description, though if the indictment had been referred to, it was necessary to prove that he was a servant. The judges decided that the prisoner was properly convicted, and consequently that he was a servant or person employed in that capacity, and authorized as such to receive money, so that his receipt would be a discharge to the debtor. This is not exactly the same question. It is, whether the prisoner had the custody of the cattle as a servant to the prosceutor at the time of the receipt of them; and we think he could not be so considered, unless in driving the cattle to market he was his servant, and the prosecutor responsible for any negligent act of his in so driving them. This subject has undergone much discrission of late, and has been placed on its proper footing by 
the ease of Quarman v. Bumett, and other cases: one of which is that of a general drover, who was held, in Milligan v. Wedge, not to be a servant so as to make the owner of the cattle responsible for his negligence. After the full consideration which this subject has undergone, we doubt whether the case of Rex v. Bernard Irac Namee (abore referred to) would now be decided in the same way.

In Milligan v. Wedge, defendant was a butcher, and had bought a bullock in Smithfield-market, which is within the city of London. By the bye-laws of the city, no person not licensed can drive cattle for hire from Smithfield, though the owner may drive them himself. The defendant emplojed a licensed drover to drive the bullock to the defendant's slanghter-honse, which is without the city, and the drover employed a boy to drive it there, with four other bullocks, which were not defendant's, but were bound in the same direction. The five were passing the plaintiff's show-room, which is withont the city in Portland-road, when the defendant's bullock did the mischief complained of. Irilliums J. thought, on the evidence, the boy was not the defendant's servant; and the jury having formd neglect, a verdict was given for defendant on the first plea (that at the time, \&c., the said person driving the bullock "was not employed by him, the said defendant, as his serrant in that behalf, in manner," (Sc.), and for plaintiff on the second (Not guilty). Leave was reserved to more to enter a verdict for the plaintiff on the first plea, but the rnle was discharged. The Court considered they were bound by the decision in Quarman v. Bumett, where the opinions of Abbott C.J. and Litflectale J. in Laugher v. Pointer were acceded to by the Court of Excheqner. The party sued here had not done the act complained of, but had employed another, who ues recognized ly the law as exercising a distinct calliny. The butcher was not bound to drive the beast to the slaughter-honse himself. He employed a drover, who employed a servant; and hence the drover, and not the owner, was liable. It did not even appear that the defendant attended the drover or his servant; and the mischief was done in the course, not of the butcher's business, but the drover's. Coleridge J. said: "The true test is to ascertain the relation between the party charged, and the party actually doing the injury. Unless the relation of master and servant exist between them, the act of the one creates no liability in the other. Apply that here. I make no distinetion between the licensed drover and the boy: suppose the drover to have eommitted the injury himself. 'The thing done is the driving. The owner makes a contract with the drover that he shall drive the beast, and leaves it under his charge; and then the drover does the act. The relation, therefore, of master and seivant does not exist between them " (12 A. \& E. 737). 
A person who is entrusted by the oumer to take catte to a salesman for the market, has no implied authority (in the absence of mroof of a custom to pery the sereant) to receive the procecds of the sale (Lettice v. Judlins). What is a reasonable presumption that a drover has anthority to sell, appears from Iletcalfe v. Lumsden, which was a case of trover for thirteen heifers. The plaintiff bronght the heifers to Morpeth market; but not being able to sell them, entrusted them, withont any direct authority to sell, to a common drover, to take them to some land of defendant's, ordinarily used for that purpose by farmers and cattlejobbers frequenting Morpeth market, to graze till the next market-day. They were brought there on September 6th, and on the next day the drover offered them for sale at a fair price to the defendant, stating that he had anthority from the plaintiff to dispose of them, and absconded with the purchase-money. In a week's time the plaintiff went to demand his cattle, and tendered the money due for agistment; but the defendant refused to give them up, alleging that he had bonght them from the drover. 'The drover had sold cattle for the plaintiff in Morpeth market on former occasions, and had also stood in the market with the cattle in question. It was customary for drover's to sell cattle in the market for their employers; but there was no evidence that the drover had ever sold cattle for the plaintiff except in the market, nor was there any eridence that drovers had by custom an implied anthority to sell cattle on the road.

Rolfe B. said: "An authority to sell may be either express, as when an actual order to sell is giren, or it may arise from ordinary usage, as in the case of a servant in a shop or market, or where the master has been in the habit of sending his servant to sell at a partieular place. Had the defendant purchased the cattle on the 6th of September on the market, he might have been protected; but with regard to the anthority which the drorer had on the 7 th of September, the only evidenee is that he was ordered to take the cattle to depasture, and this, indeed, appears at first to have been the defendant's own opinion. Afterwards, however, on the drover representing to the defendant that he had anthority from the plaintiff to sell, the defendant buys the cattle from him; and who, then, is to suffer by the drover's dishonesty? Clearly the party who was guilty of incaution. The defendant might have ascertained whether the drover had, in fact, anthority to sell or not; but not having done so, and having afterwards refused to give up the cattle to the real owner, on the ground of a purchase from a party who, it turns out, had no authority to sell, he has been guilty of a conversion."

In Goode v. Jones it was settled that there is a privity between the 
ou'ner of cattle anl the satesman's book-liesper, who has received the farmer's money from the salesman and entered it as snch. The plaintiff, a conntry grazier, had sent three oxen by his drover to Smithfield, to be sold by a salesman, who employed the defendant (who was also employed by several other salesmen) as his book-keeper. It was the business of the latter to receire the money from the purchaser, and leep an account of the beasts sold, distinguishing what each beast was sold for, and to whom it belonged. When that is done, the salesman sends an order to the book-keeper, desiring him to pay. In this case the salesman ored the defendant moner, and refused to pay orer the money received for the plaintiff"s enttle till his own debt from the salesinan was satisfied. The salesman became insolvent, and this action was brought. Lord Kenyon C.J. said he was never clearer on a case in his life. By the common law of the land the plaintiff is entitled to receire this money from the defendant, and no cnstom whaterer can deprive him of it. There is not the least similitude between the case of a banker and the present defendant. No privity whatever exists between the banker of a factor and the principal whom he never heard of; but this defendant knew that he was receiving this money for the nse of the plaintiff; he entered his name in his book, and distingnished how much was due to him. The plaintiff had a verdict. 


\section{CHAPTER VIII.}

\section{CONVEYANCE OF HORSES AND CATTLE.}

Very few cascs of injuries to, or losses of, horses and cattle during conveyance from place to place, are to be met with in the books, before the universal establishment of railways. In Latcrence r. Aberdein, two mules, an ox, and five asses were killed, and the remainder received such severe injury from the pitching of the ship, that nearly all of them died. The Court decided that this was a loss by perit of the sec, and that the underwriters were liable on a policy which warranted them "free of mortality and jettison." Best J. said : "The underwriters have only stipulated that they will not be liable for loss by mortality. That word in its ordinary and popular sense signifies death arising from natural canses, and not from violence. I think, therefore, that the underwriters must be taken to have intended to exempt themselves, by this exception, from that species of loss which occurred_in Tatham v. Hodlgson, a loss of which death was the proximate canse, and the perils of the sea the remote canse. Here the injury done to the animals arose directly and immediately from the violence of the tempest; or, in other words, from the perils of the sea. In Tatham v. Hodlyson, the want of provisions was the immediate canse of the death of the slaves; the remote cause was the circumstance of the ship having been driven ont of her course by the perils of the sea, in consequence of which the provisions, which other'wise would have been quite sufficient for the royage, were exhausted."

The construction put by the Court on the word "mortality," in the above case, governed their decision in Gabay v. Lloyct, which was an action of assumpsit on a policy of assurance on three horses, "warranted 'free from jettison or mortality." It was there found, by a special verdict, that in consequence of a storm, the horses broke down their slings, and killed themselves by kicking down the partitions; and that at Lloyd's Coffee-honse, where the policy was effected, a particular usage prevailed with respect to policies on live stock. The Court ordered the postea to be delivered to the plaintiffs, and ruled that as the usage found by the rerdict to prevail at Lloyd's cannot 
possibly affect any other persons than those who frecuent that place, aud are fimiliar witl that nsage, it mould not bind the plajntiffs, who were nut shown to be persons answering that description. Liltledule J., howerer, intimated that he had some douht whether he should have agreed with the rest of the Court, in Luerence r. Aberlein, on the construction of the word "morlulity."

Willonghby anel ollers (appellants) r. Horridge (respondent), was a case of very gross neglingence on the part of the lessees of a ferry, who provided stenm-loats for the conreyance of eattle, passengers, and groods from Liverpool to Birkenhead, and also slips for landing. The plaintiff rode his mare to the Birkenhead ferry, paid $1 s$, led her on board himself, and remained with her till they were alongside the Hoating-stage at Liverpool, when he led her off it along the slip, which had nothing broken in its appearance to attract attention. The company were held liable for the full value of the mare, who sustained a fatal injury, in consequence of such landing-slip (of the dangerous state of which they had been forewarned) giving way, although she was at the time under the control and management of her owner; and the ruling of the County Court judge, that to permit a using of the slip after two accidents, one of them that rery morning, was so careless and eulpable an act, as to make the defendants responsible for the consequences, was confirmed. One of the hand-rails of the slip had been broken in the centre, where a sharp-pointed upright supporter of iron entered it, by a horse a fortnight before; but the rail had been merely tied by a piece of cord, and used as usual. On the very morning before, another horse had fallen against it and broken it ; but in spite of a distinct cantion from the policeman on duty, it was put together agrain, and the plaintiff's mare pressing against the spliced rail, it parted, and the iron upright pierced her so severely, that she had to be destrojed.

The SGth section of the Raturay Clumses C'onsolidalion Art, stat. 8 \& 9 riet. e. 20 , is permissive only, and a railway company who under it clects to earry goods is subject to no greater liability than attaches to carriers at common law ; and therefore such a complany is not bound to carry every description of goods, and between all places on their line, but only such goods, and to and from such places as they have publicly professed to do and have convenience for that purpose (Jolnesom v. The Mirland Sictilua!y ('ompany). The first of a long line of cases in which reilueays endecunied to restrict their common law liability us corriers, by the speriul terms of their booking tickets, was that of fuluer v. Girend function liniturey Compuny. Here the plaintiff', who was a horse-dealer at Northampton, booked nine horses at Liverpool, 
and placed them in three horse-boxes, attended by his son. The engine was thrown off the line near Birmingham, owing to a horse laving strayed on to it, and one of the horses was killed on the spot, and the rest more or less injured. Some labourer's had been working at a culvert, and taken down some part of a fence, and henee the horse had strayed on to the railway. There was contradictory evidence as to whether a ticket had been delirered to the plaintift"s son at the time when the horses were booked at Liverpool, bearing this notice, "This ticket is issued, subject to the ouners undertaking all risks of conveyance whatsocter, as the company will not be responsible for any injury or damages (however cansed) occurring to horses or carriages travelling upon The Grand Junction Line." The declaration alleged that the defendants received from the plaintiff divers horses, to be safely and securely carried and conveyed, which allegation the defendants traversed in their second plea. Two questions of fact were left to the jnry: first, whether the accident was occasioned by the gross negligence of the defendants; and secondly, whether the above ticket, by which the company sought to limit their responsibility, ever came into the possession of the plaintiff's son, or any other person acting for the plaintiff. The jury found gross negligence in the defendants, and that no ticket had been given, and the plaintiff had a verdict for $£ 150$. A rule nisi for a nonsuit was obtained on two grounds--first, that tlie declaration being against the defendants as carriers, it was not supported by evidence which fixed them with negligenee in the non-repair of fences, in their character of railu'ely proprietor; and secondly, that fourteen days' notice had not been given to the defendants before bringing this action. A rule for a new trial was also obtained on the ground of misdirection on the part of the learned judge (Tindal C.J.), in leaving it to the jury to consider whether the ticket ever came into the possession of the plaintiff's agent, instead of leaving to them whether it was not read over, or its contents communicated to him. It was held that the company were not entitled to fourteen days' notice of the action, under section 214 of their act, 3 Will. IV. c. 34 (local and personal), as the action was not brought against them for the omission of some duty imposed upon them by the act; and that not having restricted their liability by any special contract (of which it was to be assumed that there was no evidence in the present case), they werc subject to the liabilities of carriers at common law. At the trial, there was contradictory evidence as to whether a ticket, by which the company songht to limit its liability, had been delivered to the son of the plaintiff (who denied that it had); and the learned judge left it to the jury to say whether it was delivered to him or not. It was held that 
it was no misdirection, in not directing them to find whether it was read over and exylained to him.

The principle of the restriction of liability in the ticket forming part of the contract, was rery fully discussed in the case of Shan v. The Iorto and Sorth Midland Railway Company. The plaintiff was a horsedealer, who had brought nine horses to the York station, to be conreyed by railway to Watford. Three horse-boxes were shown him, to one of which he objected, on the ground that a partition separating one horse-standing from another was insecure. One of the company's scrrants endearoured to remedy the defect, and assured the plaintifi that the partition had been secured; and the horses were placed in the boxes. The plaintitf then paid the fare for their conveyance, and a receipt was giren him for money paid on accomnt of "three horseboxes:" and at the foot of the receipt was the following memorandum:

"M.B. This ticket is issued, subject to the ouner's undertaking all risks of coneryance whatsoever, as the company will not be responsible for any injury or demage (however caused) occurring to horses or carriages white tiacelling, or in loading or unloating."

On the train arriring at Normanton, it was found that one of the horses had killed itself, and that the insecurity of the above-mentioned partition had led to its death. It was objected, for the defendants, that the memorandum constituted the contract, and that the effect of it was to protect the defendants from responsibility, under the cireumstances, and to cntitle them to a verdict on the second and third issues, viz., that the defendants did not receive the horses to be safely and securely carricd and delivered; and that they were carried subject to a certain contract as to plaintiff undertaking the risks of conveyance. Alderson. B., who tried the ease, thought that the special notice did not cxempt the defendants from the obligation to use ordinary care; and also, on the anthority of Lyon v. Wells, that a contract in the terms of the memorandum was subject to an implied exception of injury arising from the insufficiency of the carriage provided by the defendants, and directed a rerdict for the plaintiff. 'The Court held this to be a misdirection, and made a rule for a new trial alssolute. Lord Demman C.J. said, in delivering the judgment of the Court, "It appears to ns clear" that the terms contained in the ticket given to the plaintiff, at the time the horses were received, formed part of the contract for the carriage of the horses, betreen the plaintiff and the defendants, and that the allegration in the declaration that the defendants receired the horses to be sufoly and securety carried by them, which would throw the risks of conveyance upon the defendants, is disproved by the memorandum at the frot of the ticket; and the allegod duty of the defendants, safely 
and securely to carry and convey the horses, wonld not arise upon such a contract. It may be that, notwithstanding the terms of the contract, the plaintiff might have alleged that it was the duty of the defendants to have furnished proper and sufficient carriages, and that the loss happened from a breach of that duty ; lnt the plaintiff has not so declared, but has alleged a duty which does not arise mpon the contract as it appeared in evidence."

The principle thus successfully estublisted in favour of the railuays has been confirmed by a long line of subsequent decisions.

In Chippendale v. The Lancashire and Iorkshire Ratheay Company, the plaintiff's drover brought 12 head of cattle to the Wigan station of the above railway, to go to Bury, a distance of 16 miles. With the aid of the company's servants they were put into a truck, and before that operation was completed the plaintiff himself brought another heifer, which was placed amongst them, and paid $8 s$. for the carriage. He also got a free pass for his drover, and signed a pass-ticket, at the bottom of which was this notice:

"N.D. This ticket is issuch, suljed to the ouncr undertaking all risks of coneryance whaterer, as the compuny will not be responsitule for any injury or damage, hoursocter caused, occurving to live stock of any description tratelliny upon the Lancashive ant Torkshire Raitualy, or in their velicles.

"Tilgian Chippendale.

[Ouner, or on the ouner's behalf, agrees to the above terms]."

On the truck reaching the main line the cattle became alarmed, and three escaped througle a space between the close boardiny at the lower part of the side of the truek, and a rail which ren round the top of the truck; two of the heifers were killed, and the third much injured. The plaintiff"s adrocate in the Wigan County Court, by whose judge the case was stated, contended that the defendants were liable, notwithstanding the special contract, as the truck was ilfectively constructed for the mirpose of conveying caltle, by reason of the space between the top rail of the truek and the close-boarding being too great. 'The learned judge held that the plaintiff having' entered into the special contract as before mentioned had no ground of action, and the defendants were not liable; but having asked their opinion on the point at the request of the plaintiff's alrocate, the jury found that they considered the truck in question was so defectively constructed as to be unfit and unsafe for the purpose of conveying cattle along the line, and that they considered the plaintiff had sustained damages to the amount of $£ 214 s$. 'The judge directed a verdict to be entered for' the defendants, and the Court affirmed the judgment with costs. 
Erle J. said : "I think that the plaintiff entered into a contract by which he undertook not to call upon the company for any damage, such as that which has accrued. I take it that the carriage was fit for the jonrney, and fit for the weight, and that the damage has entirely arisen from the freight being living animals, who made an effort to escape, and so injured themselves. That scems to me to be a risk for which the company peculiarly salid that they would not be responsible. I think that linitation, howerer wide in its terms, being in respect of live stock, is reasonable; for thongh domestic animals might be calried safely, it might almost be impossible to carry wild ones without injury." Colerilye J. thus remarked on Lyon v. Mlells: "The counsel for the appellants allows that to take the ticket literally, would be to cxempt the company in all eases whatever against any risks of conreyance, and against any injury or damage accruing to the animals while travelling, but says that it cannot be construed so literally, and resting on the authority of Lyon r. Molls, seeks to introdnce a qualification that the carriage is to be fit for the journey, or, to borrow a phrase from contracts of insurance, 'sea-worthy.' Now the case of Lyon r. Iells was purely one of construction also. The Court reasoned from the particular exception in the case of want of ordinary care in the master and the crew, that it must be intended that want of ordinary eare in the owner was also excepted; and that it was a want of ordinary care on his part, in not providing a proper vessel. Now the words here do not leave us open to adopt any such gromnd of construction as in that case. The plaintifr had a full opportunity of knowing what the carriage was, for it is found that he saw one of the beasts put into it."

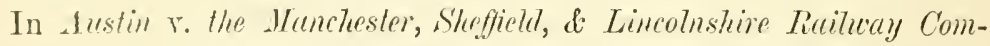
rany, the doctrine of non-liability uess stretchel to its utmost limits. The declaration, which was in ease, contained two connts, and alleged in the second that the delendants were proprictors of a railway and carriages used for the conveyance of horses from New Holland to shoreditch for hire ; and that plaintifl's, at the request of the defendants, delivered to them, and they received, horses to be carried for the plaintills by the defendants in a carriage for reward; and that while the horses were being conveyed in the carriage (which with the locomotive power thereof was under the sole control of the defendants) the whed of the carriage took fire, of which the defendants, at a convenient lime and pluce, had notice, and were requested by plaintiffs not to persist further in carrying the horses in the carriage ; but defendants persisted, and the wheel took fire again for want of due preeaution, and broke, and the carriage was consequently thrown out of its proper posi- 
tion, and the horses were injured. 'The facts of the case were these : Shortly after the train had started, it was discovered that one of the wheels of the truek in which the horses in question stood, was becoming heated for want of grease; and when the train arrived at Boston, the company's servants were requested by the plaintiff's servant to canse the carriage to be removed from the train and another substituted for it; but they declined to do so, alleging that there was not time for it, but they applied water to the wheel, and greased it. When the train reached Peterborongh, the wheel being still on fire, the station-master desired the driver to stop at Whittlesea and grease it again. The driver, however, did not stop, as direeted; and shortly afterwards the wheel broke down, and the truck was broken to pieces, and one of the plaintiff's horses lilled and other's injured. Plea the sixth to second connt alleged that the plaintiffs did not deliver, nor defendants receire the horses to be earried modo et forma. At the trial, before Erle J., it appeared that the horses were placed in trucks at New Holland; and at the time a ticket was signed by the plaintiff Davis, on behalf of the plaintiff Austiu, who could not write. The ticket was indorsed as follows-

"This ticket is issued subject to the oumer's undertakiny to bear all the risk of injury by conveyance and other continyencies; and the oumer is required to see to the efficiency of the carriage before he altours his horses or live stock to be placed therein, the charge being for the use of the raiheray carriages and locomotive power only. The Company will not be responsible for amy alleged defects in their carriages or trucks mess complaint be mate at the time of booling or before the same leate the station; nor for any damages, howerer cansed, to horses, callle, or live slock of any description, liaretling upon their railuary or in their vehicles. I hace examined the carriayes, and am satisfied with theirsufficiency aml safety.

(Signed)

Austin.

(Owner, or on the ouner's behalf)."

Evidence was given in support of the allegations in the declaration. It also appeared that twenty-one horses were sent, and that if the horses had been sent in regular horse-boxes the price of conreyance

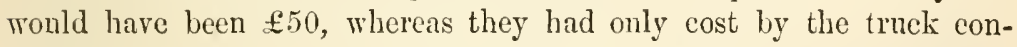

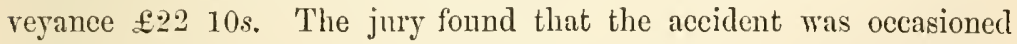
by the fire, and that there was negligence on the part of the company in proceeding with the earriages. The learned jndge directed a verdict to be entered for the defendants on the issue on the sixth plea, reserving leave to move to enter a verdict for the plaintiffs. A verdict was also found for the defendants on issues upon pleas to the first count. Dam- 
ages were assessed contingently ; and a rule nisi was obtained to enter a rerdict for the plaintifls on the issue on the sixtl plea, and for judgment non obstante veredicto, which was not confined to any particular plea. The Court of Queen's Bench held that the traverse taken by the plei was material, and that the rerdict should stand. Erle J. said: "It will be seen that the charge of negligenee arises from the defendants standing in a certain situation, that of bailees. The foundation of the declaration is the bailment. Now negligence is a matter of degree; what is negligence under one baiment is not negligenee under another. The bailment, therefore, should be carefully stated. It may be on the terms that the bailee shall carry safely ; he is then a sort of insurer. It may be on the terms that he shall take such care as the owner would reasonably take; he is then bound to take reasonable care. It may be on the terms that he shall be discharged from all responsibility as to the sufliciency of the means of conveyance; and that is clearly the present case. An ordinary tieket would be simply an engagement for the carriage of the animals; here the ticket contains a contract for the carriage on the terms of conveying for a lower remmeration, but without any liability for accidents arising in the course of the conveyance. The plaintiffs knew the terms. On the face of this record the breach is of a duty, founded on a contract which is traversed, and not proved. Had it been alleged that the damage acerued from the wheel taking fire, and that the defendants undertook that the means of conveyance should liold good, that allegation of responsibility would have been traversed."

$A$ ease was re-tried between the same parties, to reeover damages for the loss of one horse, which was killed in the manner described in the first action; and the declaration alleged that the accitent w'as entirely occasioned by the gross negligence and gross misconduct of the plaintifts, and also contained a comnt in trover. To this the defendants pleaded, first, Not guilty, to the whole declaration; secondly, to the first count, that the injury was oceasioned by conveyance and other contingencies within the true meaning of the ticket; and thirdly, to the first count, that the defects existed in the truck when the horse was placed in it. It was argued for the defendants that the ticket being the contract on which they received the horses, they were by its express terms exempted from all responsibility for damage of whatever kind, and however arising, which horses, sc., might encounter during the journey; while the plaintifls sulmitted that the facts proved exhibited such a degree of gross negligence on the part of the Company's servants as to remove from them the protection of the notice. Jervis C.J. strongly inclined to the latter opinion, and so told the jury, intimating at the same time that the question whether such negligence entitled 
the plaintiffs to a verdict was upon the record. 'The jury found that the servants of the Company had not exercised due care; and they accordingly returned a verdict for the plaintiff, but the rnle for arresting the judgment was made absolnte. Cressuell J. in delivering the judgment said: "The declaration appears to have been drawn with the greatest care, to avoid the objection upon which the decisions in Shaw v. The York and North Midland Railway Company and this case proceeded, and to lead to the supposition that there was some duty cast upon the defendants beyond that which arose out of the special contract made between them and the plaintiffs. But after all the allega. tions as to the usual and known course of business practised and observed by the defendants, the plaintiffs find themselves obliged to aver that their horses were delivered to the defendants to be carried aceording to the usual and well-known course of business so practised and observed, except so far as the same was altered or qualified by certain terms expressed in a note or ticket then by the defendants prepared and produced to the plaintiffs." "The question still turns on the contract, which in express terms exempts the Company from responsibility for damages, hovever cansed, to horses, \&c. In the largest sense, those words might exonerate the Company from responsibility even for damage done wilfully, a sense in which it was not contended that they were used in this contract. But giving them the most limited meaning, they must apply to all risks of whatever kind, and however arising, to be encountered in the course of the journey ; one of which undoubtedly is the risk of a wheel taking fire, owing to neglect to grease it. Whether that is called negligence merely, or gross negligence, or culpable negligence, or whaterer other epithet may be applied to it, we think it is within the exemption from responsibility provided by the contract; and that, such exemption appearing on the face of the declaration, no cause of action is diselosed, and that judgment must be arrested."

This decision in favour of the raitways was referral to and confirmed on the day of its delivery by the Exchequer in Carr v. The Lancashive and Torkshire Railuxy Company, and thus the three Courts were unanimous. The facts of the latter case were as follows: 'The plaintiff delivered to the defendants a horse to be carried from Wakefield to Knottingley, subject to the following conditions at the foot of a certain ticket-

"This ticliet is issued sulfiject to the oumer's underlating all risks of conveyance whatsocver, as the Company will not be responsible for any injury or damage (horcsoever cansed) occurring to live stock of any description travelling upon the Lancashire and Forkshire Railuay, or in their reticles." 
The horse-box was mopelled agamst cerlain trucks, and the horse was so seriously damaged that he died. At the trial, the jury found that the accident was caused by the gross negligence of the defendants, and returned a rerdiet for the plaintify with $£ 87$ damages. A rule misi to arrest the judgment was made absolnte, Plutt P. diss. During the argument, the Court was informed that the Common Pleas had held the declaration in Austin's case insuffieient. After verdict, Purke B. said; "I am of opinion that by entering into this contract, with reference to the sulject-matter, the owner has taken upon himself all risk of conreyance, and that the railmay company are bound merely to find carriages and propelling power. 'The contract appears to me to amount to this: The company say they will not be responsible for any injury or damage, hoverer caused, oecurring to live stock of any deseription travelling upon their railway. This, then, is a contract, by virtue of which the plaintilf' is the party to stand all risk of aceident and injury of eonreyance; and eertainly when we look at the nature of the thing conveyed, there is nothing unreasonable in this arrangement. In the case just decided by the Common Pleas, the language of the contract was slightly different from the present. There the tieket was issued, 'subject to the plaintifl's undertaking to bear all the risk of injury by conveyance and other contingeneies; and the plaintiff was required to see to the efficiency of the earriages, and the defendants were not to be responsible for any damage caused to horses, \&e., travelling upon the railway. In that case the accident was occasioned by the wheels not being properly greased : in the present case, the carriage that contained the plaintiff's horse was driren against another carriage. For the purposes of this decision, the two notices may be considered as in effect the same. It is not for us to fritter away the true sense and meaning of these contracts, merely with a view to make men careful. If any inconrenience should arise from their being entered into, that is not a matter for our interferenee, but it nust be left to the legislatme, who may, if they please, put a stop to this mode which the carricis have adopted of limiting their liability. We are bound to construe the words used according to their proper meaning, and according to the true meaning and intention of the parties, as here expressed. I am of opinion that the defendants are not liable."

The Great Northom Railurey Company (appellants) v. Morville (respondent) was decided within a few days of the above two cases. The plaintiff in it, who was a veterinary surgeon and horse-dealer at Wakefield, had been to Horncastle fair, and on the 14th of August, 1851, lorought a horse he had purehased to the Kirkstead station of the above railway, and signed a horse ticket with this indorsement :- 
"This licket is issued sulject to the ou'ner's undertaking to bear ath the risk of injury by conveyance and other contingencies, and the ou'ner is required to see to the efficiency of the carriuge before he allous his horses or live stuck to be placed therein; the charge being for the use of the raituctuy carriages and locomotive porrer only. The company uill not be responsible for any alleged defects in their carriages or truclis, unless complaint be made at the time of booking or before the same leare the station, nor for any damates, however caused to horses, cuttle, or live stock of amy descrip. tion tra'elling upon their railueay or in their z'ehictes." - "I have cxamined the carriages, and am satisfied with their efficiency and safoty.

$$
\begin{aligned}
& \text { "(Signeel) JoHn Morvilue. } \\
& \text { [Oicner, or on the ou'ner's account.]" }
\end{aligned}
$$

The clerk then handed to the plaintiff what he, the plaintiff, understood to be a duplicate of the ticket signed by him in the book, but which did not contain that part relating to the efficiency of the carriages. The duplicate was not signed by the plaintiff; it was identically the same as the ticket signed in the book, if that ticket had terminated with the word "vehicles." When the train arrived at Knottingley the horse-box containing the plaintiff"s hor'se was detached from the London train and shunted upon the Wakefield line by the serrants of the defendants, in order to be attached to another train proceeding to Wakefield, and in so doing a concussion took place between the horsebox and a truck or carriage on the latter line, which caused the injury that the horse, on the arrival of the train at Wakefield, was found to hare sustained. The judge of the Pontefract County Conrt ordered the rerdict to be entered for the plaintiff, and assessed the damages at $£ 21$. He, however, expressly found that the injury done to the horse had not been caused by any misfeasance, wilful misconduct, or gross negligence on the part of the defendants or their serrants, but was the result of the want of due care only in shunting the horse-box at Knottingley, as ahove stated. The question for the Court of Queen's Bench was, whether the defendants upon the construction of such ticket were protected from their liability to pay for the damage so occrsioned; and Colcrilge and Eire JJ., the only judges present, held they were, and allowed the appeal. Erle J. said: "It is perfectly clear that the defendants undertook to carry the horse upon the terms that they were not to be responsible for damages that might happen to it. The consideration for the plaintiff assenting to the agreement was, the carriage of the horse by the defendants on the payment of the fare. Whether the plaintiff had signed the paper, or whether the clerk had mentioned the terms, or whether the latter had delivered to the plaintiff a ticket 
saying what the terms were, there would have been in each ease good eridence of an agreement betreen the parties. The 4 th section of the Carriers' Act (11 Geo. IV. and 1 Will. IV.c. 68) provides that public notices should no longer be of arail. It used to be a constant question whether knowledge of a public notice was brought home to the party sending the things to be carried: to prevent which question the above proviso was made in the act. But that section does not affect section 6 , by which erery carrier is left free to make a special agreement with the party scuding goods. Assuming the defendants to be common carriers in the widest possible sense, I think that is a special contract under section 6 , and that the defendants are protected by it."

The Raticaly and Canal Traffic Act (17 \& 18 Tict. c. 31) came into operation in July, 1854. It was enacted by section 7 that every railway or canal, or railway and canal company, "shall be liable for the loss of, or for any injury done to any horses, cattle, or other animals, or to any articles, goods, or things, in the receiving, forwarding, or delivering thereof, occasioned by the neglect or default of such company or its serrants, notwithstanding any notice, condition, or declaration made and given by such company contrary thereto or in any wise limiting such liability, every such notice, condition, or declarntion being herelyy declared to be null and roid: Provided aluays that nothing herein contained shall be construed to prevent the said companies from making such conditions with respect to the recoiving, forwarding, and detireving of any of the said animats, articles, goods, or things, as shatl be adjuctged by the Court or jutlye before whom any question retating thereto shall be tried to te just and reasonable." The section further declares that the company are not to be liable beyond a limited amount, to wit, $£ 50$ for a horse, $£ 15$ per head for neat cattle, $£ 2$ per head for sheep or pigs, unless the ralue is declared at the time of the delivery, and an cxtra parment made, proof of the value to lie on the person claiming compensation; and no speeial contract is to be binding unless signed by him, or the person delivering such animals, articles, goods, or things respectively for carriagc.

This section underwent mnch discussion in the Court of Common Pleas in Simons r. The Great Western Raturay Company. It is for the Court to say, wpon the whote matters brought before them, whether or not the "condition" or "special contract" is just and reasonable (ib.). A condition "that no claim for damage will be allowed unless made within three days after the delivery of the goods, nor for loss, unless made within three days of the time that they should be delivered," is just and rensonable (il.); and so is a condition that in the case of 
goods conreyed at special or mileage rate, the company will not be responsible for any loss or damage, hoverer caused (ib.). But a condition that the company will not be accountable for the loss, detention, or damage of any package insufficiently or improperly packed, is unjust and unreasonable (ib.). In The London and North Western Raileay Company (appellants) v. Dumham (respondent), where the respondent had sustained considerable injury, owing to his meat not having been forwarded and delivered in London in time, and the risk note which was signed by him when he delivered the meat at the railway contained this notice-" Hay and straw, furniture, glass, marble, china, castings, and other britte and hazardons articles, de., conveyed at the risk of the ouner's"- the Court held that as the circumstances under which the contract was made, or the nature or reason of the particular risk were not disclosed, they conld not come to any conclusion as to whether or not the contract was "just and reasonable" under the statute.

And per Jervis C.J.: "The result seems to be this: A general notice is roid, but the company may make special contracts with their customers, provided they are just and reasonable, and signed ; and whereas the monopoly created by railway companies compels the public to employ them in the conveyance of their goods, the legislature have thonght fit to impose the further security, that the Court shall see that the condition or special contract is just and reasonable."

In Peate v. The North Staffordshire Railway Company, the Court of Queen's Bench had to decide on the construction of the 7 th section. 'The plaintiff sued for the loss of his goods, which were delivered to the defendants to carry. The defendants pleaded fifthly, that the goods were delivered and receired under and subject to a certain just and reasonable condition, made by the defendants, and assented to by the plaintiffs with respect to the receiving, forwarding, and delivering the said goods (viz., that they would not be responsible for loss or injury to them unless dcclared and insured according to their value), and went on to set out the condition, and to arer that the state of things had arisen, which by that condition exempted them from liability, in respect of the loss of the goods. There was no allegation that the assent of the plaintiff was in writing. The jury, in answer to questions from Ev te J., found that there had been no wilful defanlt or neglect on the part of the defendants, and that there had been no negligence if the goods had been of an ordinary kind, such as granite and not marble chimney-pieces; and on this finding the learned judge held that the condition was reasonable, and directed the verdict to be entered for the defendants, on the fourth and fifth pleas, with leave to move for judgment non obstante veredicto on botlt pleas. The Conrt was divided in opinion. Lord 
Camplell C.J. and Crompton J. considered that "condition" (when assented to) and "special contract" meant in fact the same thing, and that uncler the statute the assent to the condition must be in writing, else the "special contract" constituted by the condition, and the assent thereto, is roid. Erle J., on the other hand, thought that "conditions" are different from "special contracts," and that the railway company may still protect themselres by such "conditions" as the Court may think reasonable; while "special contracts"-direct express bargains between the parties-were alone required to be signed by the parties thereto. According to the majority of the Court (Coleritiye J.also gave judgment) both "condition" and "special contract" are void, unless they fulfil the trro requisites, first of being such as find approval in the sight of the Court or the judge, and secondly of being signed. According to Erle J., "a condition" is sufficient to protect the company if it be reasonable in the opinion of the judge ; and "special contract," whether reasonable or not, or whether thought so or not by the judge, binds the parties if they have signed it.

Among the cases tried since the act were Wise v. The Great Western Raituray Company, and Pardington v. The South Wales Raitway Company. The circumstances of both these cases were peculiar, as in the former there was not only curclessness on the part of the sender, but the raituray officiats had shunted a horse-box to a siding out of the way all night, without eren observing that there was a horse inside; and in the latter the drover, who went fiee with the cattle, did not look at them in the course of the journey.

In Wise v. The Great Western Raituay Company, the horse had been liired from the plaintiff, a job-master residing at Eton, by one Johnson, who sent it from the Newbury station on Saturday, the 31st of Mareh, directed to the plaintiff at Eton. The directions were written on labels, and tied one to the bridle, the other to the saddle. It started by the train from Newbury at 40 minutes past 2, and should have been delivered at the plaintiff's stables at Eton at 5 o'clock the same afternoon. It did not arrive, and the plaintifl had no information whaterer as to its having been sent until the next morning, when Johnson wrote him by post, thus-

\section{"Emborne, March 31.}

"Mr. Wise,-I wrote a letter, intending to send it with the horse, lont forgot to take it down to the station. We send you back the horse to-day, instead of Monday: so in case you require him he will be all ready for liunting on Monday, \&c.

"W. S. Johnson."

On reading this letter, the plaintiff made inquiries respecting the horse 
at the Windsor station, but the parties stated there was no horse at the station, and that none had been sent there. The plaintiff persisted that the horse was there, and it was at length discovered on a siding in the horse-box in which it had come from Newbury, tied up by the head for nearly $2 t$ hours, without food or water, and exposed in an elevated situation to a cold north wind. Johnson had signed the following document:

"IVr. Wise: paid for one horse 12s. 6d.; $9 \frac{3}{4}$ train Newbury to Windsor. Notice: The directors will not be answerable for damage done to any horses conveyed by this railway. - I argree to abide by the above notice. "W. S. Jotrssor."

The plaintiff lived threc-quarters of a milc from the station at Windsor. Sometimes the company sent up horses to his stables, but no regular course of dealing was proved. If a horse was sent, the plaintiff paid the man for bringing it, but in general he sent to the station for his own horses. Pollock C.B. directed the jury to find a verdict for the defendants, reserving leave to the plaintiff to move to enter a verdict for $£ 20$, the Court to be at liberty to amend the pleadings in any way which might be necessary to raise this question. The Court confirmed the ruling, and Pollock C.B. said: "There can be no doubt whatever" that the person who hired the horse was himself the real cause of all the mischief. The railway company may to a certain extent have been blameable; but the person who produced the mischief was the sender of the hor'se, who sent it without having forwarded any letter to inform the plaintiff that it was coming, and withont any groom or person to attend it on its journey. One of the witnesses stated that it was the usual and proper course for an intimation to be sent, and for somebody to come and meet horses sent by train, at the end of the journey. If that had been done, the horse would bave been taken care of, and no mischief would have happened. This action appears to us an attempt to throw upon the railway company, who are ccrtainly not free from blame, the responsibility for an injury which in reality was occasioned by the person who sent the horse; but we think that the mischief was covered by the terms of the note in writing, and that the horse having been accepted under a special contract, by which the railway company were not to be liable for any damage which might be done to it, that any injury which might happen to it, while remaining at the station till somebody came and made an application for it, must be considered as part of the risk of sending it from one place to another." The rule was therefore discharged.

The following were the principal features of Pardington $\mathrm{v}$. The South 
Wates Raitucay Company: On the 11th of March, 1856, one Morgan, a eattle dealer, wishing to send 33 head of eattle, the property of the plaintiff, from Newport to Gloueester, wrote to the superintendent of the Newport station, requesting him to have two or three cattle trucks ready for the following day. When he brought the cattle to the station the superintendent showed him the carriages in which the eattle were to go, which were rans closing with lids, generally used for the conreyance of salt. He made no objection to the vans, and the eattle were plaeed in them, to be forwarded to Gloneester, the lids being open when the train left Newport. The contract ticket was indorsed - "A pass for a drover to ride with his stock will be given for every 10 beasts, 30 calres, 75 pigs, or 100 sheep. All carriage must be prepaid, \&e., and the stock will only be conveyed on the following conditions: The company is to be held free from all rish or responsibility in respect of any loss or damage arising on the loading or untoading, from suffocation, or from being trampled on, bruised, or otherwise injured in transit, from fire, or from any other cause whatsoever. The company is not to be held responsible for carriage or delivery within any certain or clefinite time, nor in time for any particular market." "The form below is to be filled up and signed by the party desiring to send cattle." "And unless this and all the following rules be complied with, the eattle will not go forward."

"Mareh 12, 1856.

"To Messrs. ㄴ.._- the South Wales Railway Company.

"In eonformity to the above regulations with regard to the conveyance of cattle and live stock, I request that two trucks may be ready at the Newport station, in which I may load 33 cattle, to be conveyed from Newport station to Gloucester, on the eonditions above mentioned.

"(Paid)

$£ 2 \quad 5 \quad 0$

"(Signed)

Thomas Mongan, Sender."

'The plaintifl's servant in charge of the cattle reeeived a free pass from the company. He travelled in the same carriage with the guard, and did not get out to look at the eattle during the journey ; but on arriving at Gloneester he heard them make a noise, and found that the lid of one of the vans had beeome elosed, and that out of sixteen oxen in it ten were dead or dying from suffoeation, and four very much injured. Some eridence was given to show that the lid eould not have become closed by the motion of the train, but must have been purposely shut down by the servants of the railway company. Alderson $\mathrm{B}$. asked the jury whether they thought that the eattle were sufloeated during the transit; and the jury having found that they were, his lordship directed 
a verdict to be cntered for the defendants, giving leave to the plaintiff to move to enter a verdict for $£ 135$, if the Court thought the conditions were unreasonable.

The Court refused a rule, and considered that the driver had the means of knowing whether the cattle could travel safely in the carriage provided for them. He had no right to aequiesce in what was done, and take no trouble to look after the cattle on the journey, and then throw the responsibility on the company. And per Bramuell B.; "I think the question of reasonableness does not arise; and that the meaning of the Act 17 \& 18 Vict. c. 31 , s. 7 , is that companies shall be liable for injuries to any cattle oceasioned by the negleet or default of the company or its servants, notwithstanding any notice, condition, or declaration limiting such liability, but that in each case particular bargains may be made. It has been suggested that a railway company might have made any conditions with respect to the carriage of cattle, because they are not compelled to carry them. Assuming that the question of reasonableness does arise, the stipulations in the present case appear to me to be reasonable. 'The company say they do not choose to be liable for accidents occasioned by the negligence of persons who have the care of cattle; and as in the nature of things such accidents are likely to occur, they will not undertake the risk, but allow the owners' servants to travel free in charge of the cattle. If the sender is chissatisfied he should object, or pay something additional for the extra risk." Martin B.: "I am of the same opinion. I am well aware that the case put by the plaintiff"'s counsel seems hard-that where there has been negligence, a person injured by it should not recover. But it is neeessary to companies that they shonld have power to make reasonable provisions for their own protection; and it secms to me especially reasonable that when animals are sent by railway such provisions should be made. If any servant of the company had done the act which cansed this mischief, he would have been responsible. Ilere, howerer, it was apparently a mere accident; besides, there was a written contract for the conveyance of these eattle, dhly signed as provided by the act. People who make such contracts are bound by them." The last case of this kind was MrHams $\mathrm{r}$. The Lancashire and Yorkstive Railucay Company, which was an action to recover dumages for injuries to three horses, which were delivered to the defendants to be conveyed from Lirerpool to York by their railway. The parties agreed upon a written statement of facts, upon which the Court of Exchequer was to give their judgment. It was in substance as follows: The horses were delivered to be forwarded by a cattle truck from Liverpool to York for reward; and the defendants' servant provided a truck which, to all 
external appearance, and so fur as they knew, was sufficient for the purpose. 'The plaintiff signed a ticket, which contained the following memorandum:

"This ticket is issued suljeet lo the oumer's undertaking all risks of conreyance, loading and untoading whatsoever, as the company will not be responsible for any injury or damaye (howsoever cansed) occurring to live stock of any description trarelling upon the Lancastive and Forkshire Raturay, or in their evelicles."

MI'Manus, the owner, or some one on his behalf, agreed to the above terms; and the truck provided proved (as the fact was) to be insufficient for the safe carriage of the horses, and a hole was made in the bottom of it, on the journey, by which the horses were injured. Twopence a mile was charged, being the regular charge for conveyance in open trucks, under tickets in the above form, from the cattle station; whereas 4 d. per mile was the charge for horses forwarded from the passenger station, in horse-boxes under similar tickets.

The jndgment of the Conrt was thus delivered by Hartin B.: "We are of opinion that the cases cited in the argument decided, and must govern, the present case. In Simons $\mathrm{v}$. The Great Western Railucay Company, the Court of Common Pleas held that the 15th clause of the notice of the Great Western Railway Company, viz., that 'goods conreyed at special or mileage rate must be loaded and unloaded by the orners or their agents; and the company will not be responsible for any risk of stowage, loss or damage, hourever caused, nor for discrepancy in the delivery, as to either quantity, number, or weight, nor for the condition of articles so carried, nor for detention or delay in the convering or delivery of them, however cutsed,' was rensonable within 17 \& 18 riet. c. 31, s. 7. In Pardington v. The South Wales Ricituen Company, the Conrt held that a memorandum relating to live animals, that "the company are to be held free from all risk or responsibility, in respect of any loss or damage arising on the loading or unloaling, from suffocation or from being trampled upon, bruised or otherwise injured in transit, from fire, or from any other cause whatsoever,' was reasonable. It seems to us that those notices are not more extensive than the one now in question, and that our judgment must be, that the notice is reasonable. Then if that should be so, the case of C'hippendale v. The Iancashive Raituray Company further furnishes a direct authority that it extends to defects in the trucks, and in that case the notice was the same as the present. 'The jury had found that the truck was unfit and mase for the conveyance of eattle, and that the damage was consequent upon it. Colerilye and 
Erle JJ. held that the notice protected the company. The ease is expressly in point, and we coneur in it. We think one of the risks of conveyance of live cattle is the risk of their breaking the trucks or boxes in which they are conveyed. We are able to decide this case withont referring to the second point made by the defendants, viz., the alleged distinction between the liability of carriers as to the conreyance of horses and live stock, and ordinary goods; but should the question ever arise, we think the observation which fell from Parke B., in Carr v. The Lancastire and Yorkshire Railuay Company, is entitled to much consideration. Our judgment will therefore be for the defendants." The judtyment of the Court below was reversed (Erle J. diss.) in the Exchequer Chamber.

In giving judgment the Court said: "In order to bring the defendants within the protection of the special eontract, it is necessary to construe it as including responsibility for loss occasioned, not only by risks of whaterer kind, directly ineident to the transit, but also for that occasioned by the insufficiency of the carriages provided by the defendants, though occasioned by their own negligence or misconduct. The sufficiency or insuffieiency of the vehicles by which the company are to carry on their business, is a matter, generally speaking, which they and they alone can and ought to have the means of fully asecrtaining; and it would be, we think, not only unreasonable but mischievous if they were to be allowed to absolve themselves from the consequence of neglecting to perform that which scems entirely to belong to them as a duty. It is unreasonable that the eompany should stipulate for exemption from liability from their own negligence however gross, or misconduct howerer flagrant, and this is what the condition nnder consideration professes to do."

"Just and reasonable" condition with respect to a dog under the Traffie Act.-A dog (although not spccifically mentioned in the proviso as to the limit of compensation) is within the 7 th seetion of the Railway and Canal Traffic Act, 1854 (17 \& 18 Tict.c. 31). The plaintiff delivered to the defendants, a railway eompany, a dog, to be carried, and signed this ticket: "Received the annexcd ticket, subject to the following conditions : the company will not be liable in any ease for loss or damage to any horse or other animal above the value of $£ 40$, or any dog above the value of $£ 5$, unless a decluration signed by the owner or his agent at the time of booking shall have been given to them; and by snch declaration the owner shall be bound, the company not being in any event liable to any greater amount than the value declared. The company will in no case be liable for injury to any horse or other animal, or dog, of whatever value, where such injury arises wholly or 
partially from fear or restireness. If the declared value of any horse or other animal execed $£ \neq 10$. or any $\operatorname{dog} £ \check{b}$, the price of conreyanec will, in addition to the regular fare, be after the rate of $2 \frac{1}{2}$ per cent. mpon the declared ralne abore $\& 40$, whaterer may be the amount of snch value, and for whaterer distance the animal is to be carried." The value of the $\log$ was $£ 21$, but the plaintifi made no declaration of its value, and paid only the regular fare 3s. The dog escaped from the train, and was lost withont any negligence on the part of the defendants, and the plaintiff having sned the defendants for the loss, it was held by Cockbum C.J. and Blackburn. J., first that the meaning of this ticket, the whole of which must be read together, was that if the ralue of a $\log$ was above $£ 5$, and its value was not declared, and the cxtra price paid accordingly, the lefendants would not be liable at all eren for loss or injury cansed by their own negligence, and that the condition was therefore within 17 \& 18 Tict. c. 31, s. 7 ; secondly, that this condition was "not just and reasonable," inasmuch as the cxtra charge of $2 \frac{t}{2}$ per cent. (withont proof to the contrary, which it lay on the defendants to gire) appeared excessive and unreasomable; and thirdly, that the condition being roid, althongh there was no negligence on the part of the defendants, the plaintiff was entitled to recover the full ralue of the dog against them as common earricrs. It was held by Irightmen J, that the different elauses of the ticket wore separable; that the first condition meant that the defendants would not be liable beyond £5 for injury, howerer cansed, mless the ralue of the dog were declared, and that this was a reasonable condition, and afforded a good defence beyond $\& 5$, which sum the plaintiff was entitled to recorer. I'he rerdict mas directed to stand for $£ 21$.

Error was thereupon brought by the defendants to reverse the judgment giren by the Court of Quecn's Beuch for the plaintiff on a special case: and it was held (diss. Nitel B.), reversing the decision of the Court below, that the plaintifl was not entitled to recover, Erle C.J. and Keating J. being of opinion that section 7 of $17 \& 18$ Tict. c. 31 , was confined in its application to eases where the loss or injury was occasioned by the neglect or default of the company, and had no Jucaring on snch a case as the present, where the loss arose from pure accident, and that the company were exempt from liability by the terms of their contract. It was held further by Eirle C.J., IT'illiams J., Chammell B3., and Keating J., that assuming that the statute applied to this case, the conditions in the ticlict were reasomable and just, and that they were not to be construed as meaning to exempt or as haring the effect of exempting the company from liability for lass or injury occasioned by wilful misconduct on their part. And per 
Erle C.J., it is for a jury not for the judge to say, whether the percentage charged on the extra value declared in respect of any animal is reasonable (Harrison v. London and Brighton and South Coast liailvaly Compuny).

Contract of carriage with first railuay, and sccond not liatle for accident.- The plaintifi delivered cattle at a station of the Shrewsbury and Hereford Railway Company, to be conveyed to Birmingham, and signed a contract note with that company one of the terms of which was that the company would not be subject to liability for any damage arising on other railways. The eattle were placed on a truck of defenclauts, lying at the station, and were conveyed in it along the Shrewsbury aud Hereford line to Shrewsbury, and then on defendant's line to Birmingham. Between Shrewsbury and Birmingham the cattle were injured by the floor of the truck giving way, and it was held that as the contract of carriage was with the Shrewsbury and Hereford Company for the entire journey, the defendants were not liable (Coxon v. Great Testern Railuary Company).

Crowling cattle withont leave into truck with another ouner's.- Intin B. ruled that an action was maintainable by a person who hired a railway truek to put lis nine cattle in, against another who crammed his two cattic in and serionsly injured the rest. The whole eleven seem to have been bought together, but there was a false representation by the defendant to the railway as to his right to have the truek (Raynor v. Childs).

Railuay company must be sued within county court district of principal place of business.-If a railway company injure a chattel (here a horse) of the plaintiff in County Court district $A$, the company cannot be sned for it in County Court district $\mathrm{B}$, merely because it has a local station in district $B$, at which passengers are booked and goods received for carriage; for a railway company does not carry on its business within the meaning of the statute $9 \& 10$ Tict.c. 95 , s. 60 , at every place where it has a station, but only at the prineipal office, where the directors meet, and the general business of the company is transacted. The case was decided on the anthority of Taylor r. Crouldend Gicts Company (11 Ex. 1, and 24 L.J. (N.S.), Ex. 233), and Adams v. The Great IVestern Railway Company (30 L.J. (N.S.), Ex. 121), Shiels v. Great Northern Raituay Company.

Estopuel by witfully false statement of value of horses at time of contract for their carriage.-It was held by the Court of Exchequer, that the plaintiff having made a wilfully false statement to a railway company, as to the ralue of the three horses (stated to be less than $₫ 10$ each) for the purpose of inducing, and having thereby induced the defendants to 
enter into the contract for their earriage, was not at liberty to show their real ralue, in order to obtain compensation above the amount paid into Court ( $£ 25)$. And semble that the declaration of the value of the lhorses formed no part of the eontract, and that even if it were part, it did not render the contract a conditional contract; and also that the stipulation that the hor'ses should he carried entirely at the owner's risk was not unreasonable and roid within the meaning of the $17 \&$

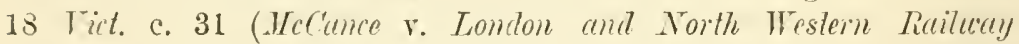
(ompany). This case was confirmed by the Exehequer Chamber, 34 I..J. (X.S.) Ex 39.

The conditions imposed by a railway company on persous sending cattle on their line must be reasonable, and if the conditions are unreasonable, the liability of the company is not removed by the fact that the company under a second condition grants, and the owner of cattle accepts, a free pass for a person who trarels with the cattle. Booth v. Worth Eastern Railucay Company (2 L.R. Ex. 173).

In Gill v. Wanchester, Sheffield, and Lincolnstive Ratiluay Company, (8 I.R. Q.B., 186), the plaintiff delivered a cow at Doncaster station on the Great Northem Railmay to be sent to Sheffield on the defendants' line. The cow arrived safely at Sheffield, but when released from the truek it ran wild, got on to the railway and was killed. The defendants' servant released the cow from the truck against the advice of the plaintitl's servant who was in charge of the cow. The Court having lower to draw inferences of fact, held that the action was rightly brought, inasmuch as the Great Northern became agents of the defendants in making the eontract to carry the cow. Secondiy, that the condition in the contract did not relieve the defendants from liability for negligence on the part of their servants in delivering the cow. Thirdly, (hy Bikekbu"n and Lwsh J.J., Mellor J. diss.), "That the inference to be drawn from the facts was that there was negligence on the part of defendants' porter, and that they were therefore liable to the plaintiff for the loss of the cow. See also Bloner v. Great IFestern Ruiluay Compremy (7 H.R. C.P. 655), Kemdatl v. Surth Western Ruilua!y Company (7 T.R. Ex. 378), and Rooth v. Torth Eastern Railuay Company (․‥R. W.x., 17.8).

In the case of Fendall r. London amd South Wrestrin Paituay Company, the plaintiff delivered a horse sadlled and bridled at Waterloo to be sent to Ewell. The horse was boxed at Waterloo mider the supervision of the plaintiff. To aecident of any lind oceurred to the train and the horse was proved to be a quiet one, but on its arrival at Ewell it was found to be much injured: leeld by Warlm and Bramuell BB., Pigolt B. diss, that the defendants were not liable, as there was no evidenee 
of negligence on their part, and it was to be inferred that the injuries resulted from the action of the horse itself.

In the case of Wright v. London and North Western Raituay Company (10 L.R. Q.B. 298), the plaintiff sent a heifer by defendants' railway to Penritl station. On the arrival of the train at the station, between 8 and 9 p.m., the horse-box in which the heifer had trarelled had to be shunted into a siding to be muloaded. There was only one porter arailable to shmut the horse-box, and the plaintiff', who had travelled by the same train, being desirous of getting his heifer away with as little delay as possible, assisted in shunting the horse-box to the siding from which alone the heifer could be unloaded, and while he was so doing the horse-box was run into by a train which had been negligently allowed to come ont of the siding: and the horse-box was driven against the plaintiff and injured him. There was evidence that it was the practice at Penrith for persons to assist in unloading their cattle, and that on this particnlar occasion the station-master had consented to the plaintiff assisting in the shunting. It was held that the defendants were liable for the injuries sustained by the plaintiff. See also Holmes v. North Eastem Raitucay (Law Rep. 4 Ex. 254, and L.R. 6 Ex. 123); and in the case of Hull v. The North Eustem Railuay (10 L.R. Q.B. 437), where the plaintiff booked some sheep from Angerton on the North British Railway to Newcastle on the North Eastern, it was held that the tieket under which plaintiff travelled meant that he shonld be at his own risk for the whole jomrney, and the defendants were not held liable for injuries sustained by the plaintiff on their line and th:ough their negligence.

A cattle dealer who trarels free of charge at his own risk cannot maintain an action against a railway company on whose line he so travels, for injury incurred either during the actual transit or while leaving the company's premises. Gallin v. London and North Westem Railuecty Company (10 L.R. Q.B. 212).

In the ease of The Great Northem Ratiluay r. Suafficld, the defendant sent a horse from King's Cross to Sandy consigned to himself, the . fare being prepaid. The horse arrived at Sandy at 10 p.m., and there being no one there to receive him, the station-master sent the horse to a livery stable near the station for safe custody. Defendant's servant arrived soon after and demanded the horse; he was referred to the livery stable-keeper, who refused to give up the horse except upon paynent of charges admitted to be reasonable, the serrant refused to pay, and went away without the horse. On the following day the defendant came and demanded the hor'se; plaintiffs' station-master nffered to pay the charges and let the defendant have the horse ; this 
the defendant declined, and the horse remained at the livery stable. The plaintiffs afterwards offered to deliver the horse to defendant at Sandy, but the defendant refused to receive it mnless delivered at his farm and with payment of a sum of money for his expenses and loss of time. The horse remained at the livery stables till November, when the plaintiffs paid the livery stable-keeper's charges and sent the horse to defendant, who received it. The plaintiffs bronght an action to recorer the amount of these charges, and the Court held that the defendant ras liable.

In the ease of Hodrman v. The West IFilland Raitway Company, the plaintiff sent a ralnable racehorse under the eare of a groom to the station of defendants' railway at Woreester to be carried from Woreester to Londou. The horse while being led by the groom came in contact with some sharp-edged girders situate in defendants' yard, and was so injured that it became necessary to kill it. No declaration of value had been made, nor had any ticket been taken, and it was held by the Court, Corlibum O.J. diss, that the plaintiff could not recorer more than £50 (33 L.J. (N.S.) Q.B. 233, and 35 L.J. (N.S.) Q.B. 85).

In the case of Gregory r. The Hest Midland Raituay Compamy, the Court of Exchequer upheld this decision, and decided that an owner is not bound by conditions annexed by a railway company to their cattle tickets which are neither just nor reasonable (83 L.J. (N.S.) Ex. 15\%). I/"Tramus v. The Lancashire and Torkishire Railuay Company (28 L.J. (N.S.) Ex. 358). Attiay r. Great Westem Raitualy Company (31 L.J. (X.S.) Q.B. 5).

In the ease of Richardson v. The North Eastern Ratitury Company (7 I.P. C.P. 75), the plaintiff sent a ralnable greyhound to be carried by the defeudants. In the course of the jomrney it became necessary to transfer the $\log$ from one train to another, and while waiting for this second train it was tied by the strip with which it had been sent by plamtiff to an iron spout on the platform; while so fastened the dog slipped its collar, got on to the line and was killed; held that as the dog was fastened by means furnished by the plaintiff, there was no eridenee of negligence on the part of the company, and judgment was given for them; and in Blouer v. The Great Western Railway Company ( 7 I.R. C.P. 655), when the plaintiff sent a bullock to be conrejed by the defendants, and the bullock, by its own efforts and exertions, escaped from the truck in which it was being carried, and was killed, it was held that the defendants were not liable.

In rengerit of detay in forwarding cattle to market, the decisions hate also bcen ayfrimst the smiters. Of this class of cases was The Tork, Netcastle,

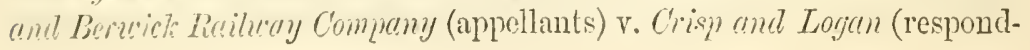


cnts). The respondents were cattle-jobbing partners, and the appellants railway cartiers from Alnwick to Neweastle. Alnwick fortnightly fair is held on a Monday, and a reckly one at Newcastle on a Tuesday, when the market is nominally open from 5 a.m. till 3 p.m., but is practically ended between 10 and 11 a.m. On the 2sth of November, 1858 , the respondents and one Logan brought some sheep and pigs, of a portion of which they were joint owners, to the Alnwick station, in order to offer them for sale at Newcastle early the next morning, and engaged $2 \frac{1}{2}$ trucks for sheep and half a truck for pigs. For this they paid £2 4s. 3d., and certain tickets were given out before half-past three p.m. Evidence was given by the appellants of the ticket having been furnished to Crisp, on the back of which was this, among other conditions-

"That the company be not responsible for the non-telivery of the stock within any certain or reasonable time, nor in time for any particutar market; nor are they requered to forward by amy particular train."

There were no disengaged trucks at this time, as the respondents knew; and after waiting several hours, the station-master franked the respondents to Nerreastle (instead of leaving them to come with the usual cattle-train passes), and assured them that the sheep and cattle would follow the same crening. Logan and a servant were left bohind with the cattlc; and seeing no trucks forthcoming, demanded back their money, which was refused. The former waited fruitlessly for trucks till one in the morning, and then went away, leaving a servant with the cattle, which were put into the coal depôt. At four o'clock the cattle were forced into some filthy waggons, and did not reach Newcastle market till 11 a.m., when the market was orcr. They were so reduced by hunger that some of them died, and the rest were rendered unsaleable up to the time of the trial. Logan proved that whereas he ought to have realized a considerable profit at Neweastle, he had been offered $10 s$. less per head than he had given at Alnwick. The station clerk of the appellants proved that he handed three tickets to Logan, Crisp, and Thompson ; but he admitted that no copy or duplicate was given, nor was it read to any of the respondents or Logan, nor was the attention of any of them directed to the contents or meaning of the tickets.

It was admitted that the tickets were returned to the appellants at Newcastle, lont the latter gave no evidence to explain the delay. The judge of the Alnwick Combty Court did not direct the jury as to the legal eflect of the ticket, but asked them, first, Are the defendants common carriers for hire? secondly, Did they receive the plaintiff's 
cattle as common carriers for hire, or under the special contract set forth in the ticket? and thirdly, Did the station-master further contract that the trucks should be furnished soon? If they found the first question and the first part of the second question in the affirmatire, they were to say what damages the plaintiff had sustained. The following were the terms of the rerdiet for the plaintiff: "The jury find the damages to be $£ 30$; and that the company are common carricrs, and receired the goods without any limitation of their liability by any special contract; and that the only special contract was the subsequent promise of the station-master that the trucks would be realy soon." The court ordered a non-suit to be entered; Jerris C.J. intimating that Austin v. The Manchester, Shefficld, \& Lincolnshive Railucty conld not be orcrivuled, and that it was a mere waste of time to argne against it. His lordship added: "There is clearly a misdirection here. There was no evidence whaterer that the defendants were common carriers of cattle or live stock, or that they had receired the pigs in question as common carriers. The judge should have told the jury distinetly that there was nothing to justify them in finding that the pigs were receired by the company's servants to be carried upon any other terms than those contained in the special contract."

This case was followed by Hughes v. The Great. Thestern Raitucty Company. On the evening of Tuesday the 9th of Norember, 1853, the plaintiff delirered at the company's station at Southall 20 fat pigs, which were intended for the Birmingham market the next Thursday, and was informed that they would go by a train which started at 3 o'clock the next morning. He signed a paper of conditions, part of which were that "The Company is not to be held responsible for the carriage or delivery within any certain or definite time, nor in time for amy partieular market." The pigs were sent by the 3 o'elock a.m. train on the 10th of November, but did not arrive at Birmingham in time for Thursday's market, and so wasted, by want of food, in consequence of having been so long in the trucks, that the plaintiff" sustained great loss. The defendants proved that the goods train which left Southall at 3 a.m. went no further than Dideot, where it onght to have arrived at 7.30 a.m., and that the next goods train for Birmingham, by which the pirs were forwarded, left Didcot at 5.30 p.m., the only other train which passed through Didcot for Birmingham betreen those hours being the express passenger train. It was further insisted that the special contract excluded all question as to reasonable time, and that the pigs were sent within reasonable time, inasmuch as they were sent by the next practicable train. Jenis C.J. referred to Walker $\nabla$. The Tork 
$\&$ North Miellund Railway Company (a well-known case of fish-sending), and being of opinion that the pigs had been forwarded within a reasonable time, and the plaintiff's connsel expressing no dissent, nonsuited the plaintiff. The rnle for a new trial was discharged.

On the anthority of this case Mr. Sergeant Channel nonsuited the plaintiff in White v. The Great Western Railway Company, which was an action against that railway company for negligence in forwarding a quantity of cheese, whereby the plaintiff, a Somersetshire farmer, lost a market at Bishopstoke.

Slim v. The Great Northern Railway Company was a somewhat complicated pig case. The plaintiff had sent two lots, containing together 203 pigs, to the defendant's station at Hitchin, and they were duly delivered in London. Six other pigs of the plaintifl's were conveyed to the statiou by one Lewis, who had 32 pigs of his own going to London. For these latter Lewis procured the proper cattle ticket and consignment note, but negleeted to do so for the plaintiff's six, which he delivered (as he stated) to one Morgan, a servant of the defendants, at the station, who said he wonld take care of them. Plaintiff was cognisant of the course of business at the station, which was, that on the arrival of live stock there, they were comnted by one of the company's servants, who made out and signed what is called a "consignment-note," stating the number of the trucks and cattle, and the name of the consignor and consignee. This "consignment-note" was then signed by the person bringing the stock, and taken to the booking-clerk, who made ont from it a "cattle ticket," which was signed by the consignor"s agent, who on receipt of a duplicate, paid the carriage, the dnplicate ticket being the anthority to receive the cattle on their arrival at their destination. The declaration set ont the special contraet indorsed on the cattle-ticket, which threw the risk of injury, examination of carriages, \&c., upon the plaintiff, and alleged as a breach that the defendants did not carry and deliver the pigss within reasonable time.

There was also a count in trover. The defendants pleaded-fir'st, Not gnilty; and secondly, that the plaintiff did not deliver the pigs, nor did the defendants receive the same to be carried upon the terms and conditions alleged in the first count. It appeared that the payment for the earriage of the cattle was made sometimes at the station at which they were received, and sometimes on their anival at their destination. At the close of the plaintiff"s case the defendant's comscl called upon the learned judge to nonsuit him, insisting that there was no evidence to go to the jury that the defendants had contraeted with the plaintiff on the terms mentioned in the declaration; and that assuming their scrvant MIorgan to have received the pigs in question, he had 
done so without their authority, and in direct violation of his duty and the course of business at the station. Williams J. declined to nonsuit, but left it to the jury to say whether or not Morgan had receiverl the pigs. They found that he had; and his lordship thereupon directed a rerdict for the plaintiff for $£ 14$, the ralue of the six pigs : reserving leare to the defeudants to move to enter a nonsuit, if the Court should think there was no evidence to go to a jury; and also reserring leare to the plaintiff to amend the declaration, if necessary, it being agreed that the only question was whether or not the company had received the pigs to be earried.

'The Court of Common Pleas made the rule absolnte; and held that the count in trover clearly could not be sustained, and that the first comnt, whether in its original state or as proposed to be amended, was not supported by the evidence. Jervis C.J. said: "According to the conrse of business, of which the plaintiff was proved to be perfectly cognizant, it was the sender's duty to get a consignment-note when lie delivered the pigs at the station, and that consignment-note gave him distinct notice that the company would not hold themselves responsible for the pigs, unless the same were signed for as received by their elerk. Knowing this, the plaintiff sent the pigs in question by Lewis; Lewis handed them over to Morgan without more ado, and thus made Morgan his servant for the purpose of doing what was necessary to put the pigs in motion towards their destination. Morgan had no authority to contravene the regulations of the company, and I think they are not bound by his act." In the course of the argument Maule J. observed that "If Morgan had been the master or superintendent of the station, possibly he might have had anthority to do as he did. And it may be that the company are liable if they place a man in a position to hold himself ont as having authority, though he may in some degree have exceeded his duty. Morgan had, it appears, authority to go through some of the preliminary matters to the making of the contract. It is not necessary to show that he had full and perfect anthority. It is enough if there was evidence to go to a jury." The same Court also held in Simons v. The Great Western Raituay Company, that, where the plainfiff was asked by the clerte of the railuay rompany, when the goods were delivered, to sign a paper containing a special contract, and he demurred, in consequence of there not being light enough to read it by, but was told that it was of no importance, and that his signature was a mere matter of form, on the strength of which assurance he signed, the jury were warranted in finding that the goods were not delivered to the company to be carried under the special contract.

It was hold by Liyles J. in Llakemore v. Lancastire and Yorkshire 
Railuay Company that carriers are bound to convey with reasonabte expedition, and if their course of business is inconsistent with that, it is no answer to an action against them for damages arising from delay, that they carricd at the ordinary rate in which they conducted their business. Here the potatoes were placed in the defendant's trucks on a Tuesday afternoon, and ought in due course to have arrived at their destination next day; but did not do so till the Friday, as the line at Wigan was, as was constantly the case, completely blocked up with trucks, for lack of sufficient sidings, the consequence of which was that the potatoes fermented and became rotten and worthless.

However, according to Briddon v. The Great Northem Raitway Company, a carrier of goods and cattle is only bound to carry in a reasonable time, under ordinary circumstances, and is not bound to use extraordinary efforts or incur extra expense in order to surmount obsiructions caused by the act of God, as a fall of snow. It appeared that the plaintiff in this case had receired a ticket at Huntingdon on the terms that the company were not to be liable for any loss or damage arising from any canse whatever during the transit, and that the beasts were put into two cattle-trucks, subsequently attached to a heavy goods train. The line from Nottingham was the defendant's as far as Grantham, from which there was a branch to Nottingham, and on the day in question there was a heavy snowstorm, which obstructed the latter part of the line. The goods train to which the two cattle-trucks were attached was very long, and on arriving at a station on the line to Grantham the train was shunted to a siding, and the engine detached to add to a passenger train which went on its way with this additional power, rendered necessary by a fall of snow on the line beyond Grantham. The plaintiff, who went in the same train with the beasts, remonstrated with the station. master, telling him that the cattle market at Nottingham was the next day. Notwithstanding this, the goods train with the two cattle-trucks attached thereto, was detained at the station thirty hours, during all which time the cattle were deprived of food, and they were not forwarded until next day, too late to save the market. In the meantime all the passenger trains were kept running as usual. To send on the goods train wonld have required additional engines; but it appeared that there was an unlimited supply of engines at Peterborough. The plaintiff's case was that the defendant's servants were bound to obtain additional engines, if necessary, to forward the goods train, or to send on the two cattle-trucks by themselves. For the defendants it was contended that they were not obliged to take either course, nor to use any extraordinary efforts to send on the goods train; but that it was enongh for them to show that by reason of the snow the train could not be reasonably 
sent on with the ordinary engine power. Cockbum C.J. held that the question was whether the delay in forwarding these beasts was owing to the negligence or want of dne expedition on the part of the company's scrvants, or was it the mavoidable result of the state of the line, they doing all that under the circumstances they were bound to do. The jury found for the defendants, and the Court of Exchequer confirmed such fiuding. And per Pollock C.B. : "The contract entered into was to carry the eattle to Nottingham withont delay, and in a reasonable time, under ordinary circumslances. If a snowstorm oceurs, which makes it impossible to carry the cattle except by extraordinary efforts, involving additional expense, the company are not bound to use such means and to ineur such expense."

The suljiect of the Tending of sacks by raitway companies for the conreyance of grain on their lines was considered by the Court of Common Pleas in The Great Northern Raituay Company v. Wyles, in which the plaintiff sought to recover $£ 2011 s$. 5 $l$. for the demurrage of sacks let by them to the defendant. The sacks were hired subject to the following, among other regulations :-

"2. The charges for the use of sacks will be $\frac{1}{2} d$. per sack per journey when discharged at any of the company's stations on the line ; or at their warehouses, or at warehonses or mills connected by rail with the company's line; and $1 d$. per sack when sent to foreign stations.

"3. Demmrage of $\frac{1}{2} \lambda$. per sack per week will be charged after the expiration of fourteen dass, the lire to commence from the time the sacks leare the station to be filled; the time allowed for filling and returning to the station to be seven days.

"10. None of the company's sacks containing grain will be allowed to leave any station (local or foreign) unless a guarantee is first obtained by the clerk in charge, from the consignee, that the grain will be immediately discharged, and the sacks returned the same day, and to the same station."

It was held that the company's claim for demurage arose at the expiration of fourteen days from the hire of the sacks; and that the only person with whom there was any contract for demurrage was the consignor, by rirtne of the 3rd regulation; but that, by the operation of the 1)th regulation, his liability ceased upon the company's permitting the sacks to get into the hands of the consignee, whether with or without a guarantee.

'The Great Northern and other Ruilways have recently issued fresh recrulations with regard to letting ont sacks on hire, and the subject is so imprortant that the new regulations are giren in full. 


\section{The Great Norlhern Railuray Company's Sects are Imt on the} following lems and conditions:-

1. Application for sacks on hire for the purpose of being filled, must be made to the Clerk in charge of the Station from which they are to be consigned for transit when filled, and they must in all cases be returned to that particular station, otherwise the party hiring the sacks subjects himself to the charge of one penny per sack, in addition to any other charge that may be incurred.

2. Parties hiring sacks for the conveyance of grain (or seed) by railway are allowed to have them FOUR DAYS FOR TIIE PURPOSE OF FILLING AND RETURNING to the station whence received, free of charge, subject to the following condition :- -If detained beyond four days, or if returned to the station unnsed, or if returned full and not sent forward by rail, demurrage will be charged at the rate of one halfpenny per sack per week, such demurrage to commence from the date the sacks are taken from the station to be filled, and continue in force till the sacks are returned to the same station.

3. Sacks returned full to the station will be allowed to remain Two DAYS, FREE OF CHARGE, TO WAIT ORDERS. If detained at the station beyond two days, demurrage at the rate of one halfpenny per sack per week will be charged from the time of the receipt of the grain at the station to the date of forwarding.

4. No charge will be made for sacks returned unused if the number be less than twelre, and be part of a larger number obtained for the purpose of being filled, provided they are returned to the station at the same time as the filled sacks are delivered thereat.

5. The charge for SACI HIRE from the sending station is ONE HALFPENNY PER SACK FOR TWELVE DAYS, commencing from the date of the Railway Company's forwarding Invoice; such sacks are only to be used for the same grain during that period. If detained beyond twelve days, an additional one halfpenny per sack per week will be charged, until proof be furnished of their discharge at, or their return to, the station from which they were delivered filled to the consignee. The returned sacks to be addressed to the Great Northern Railway depot, Boston, Lincolnshire.

6. The amounts payable to the Company for hire may be paid by the original sender, or by the transferee of the grain, at the station from which it is to be forwarded; or such amounts as are dne, or may accrue thereon, may be charged forward with the carriage of the grain.

7. On the arrival of the grain at the station to which it is consigned, the consignee will be charged with the demurrage due up to that date, 
and for the hire of the sacks mless previously paid. In the erent of his refusal or objection to pay the same, the Company will hold the consignor or hirer responsible for all amounts of demurrage and hire due and unpaid up to the date of delivery to the consignee. The Great Northern Railway Company therefore recommend the hirers of their sacks to have a clear understanding with the purchaser of the grain at the time of sale as to the charges incurred for the use of such sacks, and to obtain a distinct undertaking for payment of such charges.

8. Consignees and others receiving grain in the Company's sacks, must sign the Full Sack Reeeipt Book, and will be charged demurrage for the sacks at the rate of one halfpenny per sack per week for any period they may detain the sacks beyond that charged for upon the grain by the sending station.

9. In charging for demurrage, parts of a week will be charged as one week. Sundays will not be charged for in calculating any period under a week.

10. Grain brought to a station in other sacks cannot be shot into those belonging to the Great Northern Railway Company, unless an order in writing is sent to the Clerk in charge of the station for the hire of the Great Northern Railway Company's sacks. The party sending such order will be held liable for the Company's charges according to these regulations.

11. Lightermen and carriers of grain applying for and obtaining the Great Northern Railway Company's sacks without a special order from their employers will be held liable for the sacks and the charges thereon.

12. The Great Northern Railway Company's sacks, when obtained from a station for the purpose of being filled, or when emptied after use, must not be sent by merchants or others to the station of any other company, but must in all cases be returned to the same station from which they were received. If this regulation is infringed, one penmy per sack per week will be charged. This rule will not apply when sacks containing grain are sent by the Great Northern Railway Company direct for further transit to the station of another Railway Company in the same town, in which case the usual hire will be charged.

13. The Great Northern Railway Company's sacks are not to be used for any other purpose than for the conveyance of grain by the Great Northern Railway route; parties using them for any other purposes, or for the conveyance of grain by water or road, will be eharged threejence per sack per day the whole time they are in their possession, and in case of damage, loss or misuse of sacks, parties render themselves 
liable to penalties providerl under the Act $7 \& 8$ George 4 th, eap. 80 , section 24.

14. The Clerks in charge at the stations on the Great Northern Railway are not empowered to make any arrangements for use of the Company's sacks contrary to these regulations.

15. In case of parties disregarding or infringing these regnlations the Great Northern Railway Company reserve to themselves the right of refusing to accede to any further application for sacks for or from such parties.

The regulations upon which Private Companies let out sacks are materially different from those of Railway Companies : and this is not to be wondered at, seeing that a Sack Company has no elaim whatever upon the consignee; the hirer of the sacks makes the contract with the lender, and he alone therefore is responsible for any damage which the lender may sustain. Thus it frequently happens that farmers receive a long bill for demurrage upon sacks which they have hired a long time previously, and suppose to have been returned long ago to the Sack Company. These cases are generally tried in County Courts, and are rightly decided in favour of the Sack Companies, so that hirers of sacks should in all cases protect themselves by special contract with the parties to whom they consign their sacks.

In Lee v. Unu'in, which was tried at the York Summer Assizes, the question raised was-how far the plaintiff was entitled to charge the consignees of grain and malt loaded in his sacks, and with whom he had no direct dealings, with demurrage for the extension of the use of his sacks, for a certain number of days beyond those mentioned in his notice? Pollock C.B. ruled that the plaintiff could not by any system of notices make the defendant liable, and that his remedy was against the consignor and not against the consignee.

A railucay company undertaking to carry goods booked through by other means than their line, cannot set up as a defence for damage done to the goods that such contract was ullia vires (Willey $\nabla$. The West Comucall Railuay Company). And if they charge for parcels less than one cwt. a larger rate than for heavy goods, but if such small parcels are packed together or directed to the same consignee the same rate as for heary goods, they cannot be compelled to carry for the lower rate parcels directed to different persons, but delivered to the railway by the same carrier, to be re-delivered by himself at their destination (Baxendale v. The Eastern Counties Ruilway Company).

It has been decided by the Court of Exchequer that there is no general duty imposed by law upon carriers to give notice to the consignor of the refusal by the consignce to receive the goods, but they are merely 
homml to rlo what is reasonable, under the particular circumstances of each case (IIul:on r. Baxemlule). But ner Bramuell B.: "The judgment of the majority of the Court in Crouch v. The Great Western Ratiluay Company scems to show that it is the duty of the carrier to communicate with the consignor" (ib.). And it is no answer to an action against carriers by the owner of goods lost (who was the consignee) that the consignor, after the loss of the goods, claimed compensation, and that the carriers, without notice, and believing him to he the owner, paid compensation to him (Coombs v. Bristol and Exeter Raituay Company, 27 L. J. Ex. 401).

Where the plaintiff sent five bundles of hay-cloths by the defentants, camiers, to be detivered in Bedford on a Thursilay, in order to be ready for the market on Satureley, but did not give notice that they were sent for that purpose. and on that day his clerk proceeded therc, but owing to the non-delivery of the goods till the Monday following, removed them to another place for sale, it was held by the Court of Exchequer, on a motion for a new trial, in an action for non-delivery of the goods within a reasonable time, that the simple expenses so incurred might be given by the jury as damages (Blacto v. Baxenclate).

Lord Ellonborongh C.J. ruled, in Stuart v. Crawley, that when a dog is detivered to a carvier, who gives a receint for it, and is afterwarts lost, the carrier camnot set up as a defence that the dog was not moperly secured viken delireved to him. Here a valuable greghonnd had been delivered to the defendant to carry from London to Harefield Lock. His bookkeeper gare a receipt; and the dog was tied by a cord to a watch-box, but slipped his head from the cord round his neck. The defendant contended that, as the dog had no collar, he was the same as a parcel imperfectly packed, and that the loss should fall on the sender; but lis Lordship said that the cases were notidentical : as in that of the parcel the defect was not visible, whereas here the defendant had the means of secing that the dog was insufficiently secured. 


\section{CHAPTER IX.}

\section{DISTRESS.}

Gilbert thus defines the general principles of distress damage feasant: "A man may distrain beasts damage feasant; but if a man come to distrain, and see the beasts on his ground, and the owner chase them out before the distress be taken, thongh it be of purpose to prevent the distress, yet the owner of the soil cannot distrain them ; and if he doth, the owner of the cattle may rescue them, for the beasts must be damage feasant at the time of the distress; and if they were damage feasant yesterday, and again to-day, they can only be distrained for the damage they are doing when they are distrained. And if many cattle are doing damage, a man cannot take one of them as a distress for the whole damage, but he may distrain one of them for its own damage, and bring an action of trespass for the damage done by the rest." So Lord Coke says (1 Inst. 161 A): "If a man come to distrain for damarye feasant, and see the beasts on his soil, and the owner chase them out on purpose before the distress is taken, the owner of the soil cannot distrain them; and if he doth, the owner of the cattle may rescre them, for the beasts must be damage feasant at the time of the distress." His Lordship also adds (1 Inst. 142 A) : "It is to be understood that for a rent or service the lord cannot distrain in the night, but in the day-time; and so it is of a rent-charge. But for damage feasant one may distrain in the night ; otherwise it may be that the beasts will be gone before he can take them."

And per Witmot C.J.: "If a man turn cattle into Blackacre, where he has no right, and they escape and stray into my field for want of fences, he cannot excnse himself or justify for his cattle trespassing in my field" (3 Will. 12). It was decided in Doreston v. Payne, that a plea in bar of an avowry for taking cattle damage feasant, that the cattle escaped from a public highway into the locus in quo, through the defect of fences, must show that they were passing on the lighluway when they escaped; and that it is not sufficient to state that being in the lighway they escaped. Heath J. said: "The law is as my brother Willicms (Sergeant) stated, that if cattle of one man escape into the 
land of another, it is no excuse that the fences were out of repair if they were trespassers in the place from whence they came. If it be a close, the orrner of the cittle must show an interest or a right to put them there. If it be a way, he must show that he was lawfully using the way ; for the property is in the owner of the soil, subject to an casement for the bencfit of the public.

Carrulkers r. Hollis and Churh was a case of trespass for driving plaintiff's sheep and leaving them in a highuay, by which they were injured. To this it was pleaded that they were wrongfully in defendant's close depasturing, and that defendant drove them into the adjacent highway. The replication was that they escaped into defendant's close from an adjoining close of plaintiff's through a defect in the fence between the two closes, which fence defendant was bound to repair. The rejoinder traversed the escape of the sheep through a defect in the fence, and the issue was found for the plaintiff. It was held that the replication answered the plea. Lord Demman C.J. said: "It is perfectly clear that the least to be expected from a party in the situation of the defendant here, is that he should put back the sheep into the place in which they were before they quitted it in consequence of his neglect."

A horse, harness, and other things in actual manual use, cannot be distrained damage feasant, although they be so in use in doing the damage complained of, because of the tendency to a breach of the peace (Fiell v. Adames). And it is not necessary for the person whose property is distrained to aver that the peace was endangered, nor that the things taken were "in manual" use; but it is safficient to state they were "in the actual possession of the plaintiff, and then under his personal care, and were then being actually used by him" (ib.). A strong ease is put in Bac. Abr. "Distress" (F), where it says, "If a man rides upon my corn, I cannot take his horse damage feasunt."

To support a justification for taking cattle as a distress damage fcasant, if it appear that the party distraining had not actually got into the Tocus in quo before the cattle had got ont of it, the justification cannot be supported (Clement. v. Milner). In this case the cow broke into a ficld of tumips belonging to the defendant, and a woman picking turnips turned her out. The fences (which it appeared the plaintiff was bound to repair) were in a very ruinons state, and the cow returned; the same woman was about to turn her out again, when one of the defendants being in an adjoining field, and seeing her endeavour to turn the cow ont, called out to her to stop, and ran towards the place where the cow was. The woman not having heard him, turned the cow back into the plaintiff's ficld, and she had got some way into the defendant's field before the dofendant came up. He followed the cow into 
the field, and calling the other defendant, his servant, to his assistance, they drove her back into the defendant's field, and from thence to the pound. There was rather contradictory evidence as to the fact whether the defendant had actually got into the field where the trespass was done before the cow had been turned ont of it or not. Lord Eldon C.J. thus put the ease to the jury: If Milner, in the act of coming up in order to distrain the cow, had actually got into the field where the cow was committing the trespass before she had been turned ont of it, the justification that he was owner of the field of turnips where she was trespassing was proved; but if they thought that though he might be approaching it to distrain her, the cow was out of the locus in quo before he got into it, the verdict must be for the plaintiff; and so the jury found it.

Burt v. Moore was a somewhat peculiar case. The plaintiff demised to the defendant the milk of twenty-two cows, provided by the plaintiff, and to be fed at the plaintiff"s expense on certain closes belonging to him, the plaintiff covenanting that the defendant might turn out a mare, and that no other cattle should (except a bull with the cows from April 23rd to November 13th) be fed there. It was held that the separate herbage and feeding of those closes passed to the defendant, and that the defendant might distrain other cattle of the plaintiff's doing damage there. And per Asthuurst J.: "The cases of Rex v. Lockerly and Rex v. Tolpuddle go the full length of deciding the present. In those it was held that a right to the separate herbage gave the party renting it a settlement; and that the sole right to the use of a thing was the same as a right to the thing itself. Such is the present case ; it is the demise of a dairy; of the sole right of enjoyment of certain closes to the exclusion eren of the lessor himself. For as to the circumstance of the bull, that does not derogate from the general and exclusive right granted; on the contrary, the stipulation was inserted for the benefit of the lessee, and not of the lessor, since otherwise the lessee would not have had the advantage of the cows."

The escape of a distress was very much considered in Taspor v. Edwards, which was a case of "trespass quare clausum fregit, and fed his grass with a pig." The pig had been taken damage feasant, and impounded in a common pound, and the Court held that if a distress escapes the person distraining cannot bring trespass, unless he shows that the escape was withont his default. And per Holt C.J. : "If a distress damage feasant dies in pound, or escapes, the party shall not distrain de novo; but if it were for rent, in either case he may distrain de novo." This dictum was quoted by Best C.J. in his judgment in Knowles v. Blake. 
Knoules r. Blutie was a stronger ease than the above, as the callle thed never loen in the pouml. The plaintiff's son having scen the defendant Blake's horses trespassing in his father's field, was in the act of driving them to the pound, when he left them for the purpose of apprising Blake of what had happened. When he was out of sight they strared from the plaintifl's field into the defendant's shrubbery, where they remained half-an-hour: at the end of that time plaintiff's son, haring failed to receive redress, drove them out of the shrubbery into plaintiff's yard, from which they were shortly afterwards rescued by the defendant and his serrant. It was objected that there was no rescue, beeause the distress had been abandoned by the plaintiff's son allowing the cattle to escape and remain in the shrubbery, whence he had no right to remove them. A rerdict was found for the plaintiff, subject to a motion to set it aside, in which judgment was giren for the defendant. Best C.J. said : "Two questions have been raised in this case: upon the first, we all think that the distress was sufficiently made, for no precise act or form is essential to a distress. But distress is a matter of strict right, and if he who distrains damarge feasant permits the eattle to escape, he must look for some other remedy. A mere escape for an instant, indeed, if the distrainor followed him, would not be an abandomment of the distress ; for Lord Coke (Co. Litt. $161 \mathrm{~A}$ ) says: "When a man has taken a distresse, and the cattle distreyned, as he is driving of them to the pound, go into the house of the owner, if he that took the distresse demand them of the owner, and he deliver them not, this is a rescous in law.' But here the plaintiff's son permitted the horses to stray in the defendant's shrubbery for half-an-hour, they were not demanded during that time, and that was an abandonment of the right of freshly following. Lord Coke also says: "If the cattle of themselves after the view go out of the fee, then cannot the lord distreyne them" ", (it.). A plea of recaption on a resene must aver that the recaption was on fresh pursuit (Rich v. Woolley, 7 Bing. 651).

In Bullin v. Povell it was held that brespass vi et armis does not lie aysuinst a pound-lieeper merely for receiving a distress, though the original taking be fortious, but secus if he exceeds his duty, and assents to the trespass. This was a case of trespass by the plaintiff, who was a rumning dustman, agrainst the three defendants, two of whom had detained the 1) laintiff's cart and horses in the street, undor the pretext that they were an estray. Lord Mansfipld C.J. thus defined a ponnd-keeper's duties: "The pound-keeper, who is the third defendant, had no concern in taking or loringing them to the pound. How, then, is he guilty of tresplass? The pound is in the eustody of the law; and the poundkecper is bound to take and kecp whaterer is brought to him at the 
peril of the person who brings it. There is no judgment, no direetion, no written warrant or examination to be had by him. When is the trespass eommitted by him? He does nothing to ratify it. He only takes the cattle, as he is obliged to do, at the peril of the persons who bring them. If wrongfully taken, they are answerable, not he. It would be terrible if a pound-keeper were liable to an action for refusing to take cattle in, and were also liable in another action for not letting them go. If he goes one jot beyond his duty, and assents to the trespass, that may be a different case. When cattle are once impounded he cannot let them go without a replevin, or without the consent of the party. Upon their being released, he is entitled to legal fees. If he is guilty of extortion, there is another remedy. The law thinks him so indifferent a person, that if the pound is broken the pound-keeper cannot bring an action, but it must be brought by the party interested."

And so in Rex v. Bradshav, Coleridge J. defined the duty of a hayucarl: "We may take it that the duty of the hayward is to keep the lanes clear, by impounding stray eattle that he may find there; but that with respect to stray cattle found on private land the hayward is only the private servant of the parties, if they send for him. I should be certainly inclined to ask whether there is any anthority which lays down that a hayward is bound to go into private fields. If there were extensive commons in this parish, I should hold them to fill within the same rule as the lanes. It is true that if these eattle had got to the pound and been resened from it, the defence wonld have been pound. breach, but in some places the offices of hayward and pound-keeper are distinet, and held by separate persons. If the hayward had driven cattle to the pound, which he had found straying in the lanes, I shonld have held that they were in the eustody of the law from the first, and that the resene of them on their way to the pound would be inclictable; but here, till the eattle got to the pound the hayward was merely acting as the servant of Mr. Stone, on whose land the cattle were found, and therefore at that time a reseue of them was no more inclictable than if Mr. Stone had himself been driving them to the pound, and they had been rescued from him; and till those eattle had got to the pound I am of opinion that they could not be considered in the custody of the law, and that the resene of them was therefore not indictable."

The treatment of animats in the pound is fully provided for by 12 \& 13 Vict. c. 92 , ss. 5 \& 6 , which enacts that every one who impounds an animal, "in any pound or receptacle of the like nature," shall provicle it with a sufficient quantity of fit and wholesome food and water, under a penalty of $20 \mathrm{~s}$; and that in ease an animal is left so muprovided for more than twelve successive hours, any one may from time to time enter 
and supply it with food and water, withont being subject to an action of trespass, and recover the reasonable cost of such food and water from the owner of the animal, before it is remored. As it was doubtful whether this latter act gave any remedy to the person impounding for the recovery of the value of the food and water supplied, and ecrtainly gare no porrer to sell the animal, although full provisions for those purposes were giren by 5 \& 6 Writt. IV. c. 59 (repealed), stat. 17 \& 18 Vict. c. 60 was enacted, which provided by scetion 1 that all persons who had impounded animals, \&c., since 12 \& 13 Tict. c. 92, or shonld hereafter impound them, might recover from their owners not exceeding double the ralue of the food and water so already or hereafter to be supplied, and might sell them publicly in the market after the expiration of seven clear days from the time of the impounding, and after having given three dars' public printed notice thereof, and after discharging the value of such food and water, sale expenses, \&ce, hand over the surplus (if any) to the owner.

By section 1 of $6 \& 7$ Vict. c. 30 , persons releasing or attemptiny to relcase cattle impounded, or damaging any pound, \&c., upon conviction before justices are to forfeit $£ 5$, or be imprisoned for not less than fourteen days in defanlt of payment. For decisions on 5 \& 6 Will. IV., c. 59, as to supplying animals in the pound with food and selling them for its valne, see Hachell v. Ellis, Layton v. Harry, and Mason v. Newland. A distrainor cannot work or nse the thing distrained, as he has only the custody of it as a pledge (Bac. Ab. tit. Distr. D). Cows may be milked in the pound, and there is no difference in this respect between those taken for a distress, or in withernam or as estrays. And see the cases collected in Gilbert's "Law of Distress," page 65.

Impounder bound to know state of pound. $-\Lambda$ person who distrains cattle demage feasant is bound, at his peril, to take care that the place in which he impounds them is in a fit and proper state, and is liable for the consequences if it is not (Bignell v. Clark) and (Wilder v. Speer, 8 Ad. \& E. 547.)

Where cattle distrained damage feasant were in a private pound (an onthouse), and the distrainor's wife admitted that they were to be forwarded to a public pound, the tender of amends wels not too late. Here there was abundant evidence that the wife was anthorized to receive such tender. It was not too late, as the cattle were not in the custody of the law (Broume v. Pourelt). And semble prer Best C.J., the poumd of the lord of the manor is the only pound sufficient to make a tender of amends tor) late; and if it were otherwise, the distrainor by impounding on the spot where he takes the eattle, or very near, might exclude the possibility of any tender being made (ib.) (4 Bing. 230). 
But detinne will not lie for goods impounded damarge feasant, where teuder of amends has been made after the impounding, Gatway v. Cozens (1 C.B. 788 ; 14 L.J. (N.S.) C.P. 215), and Singleton v. Wrilliemson.

Tender not too late if made after impounding and before sale.-An action is maintainable upon the equity of the statute 2 Will. \& Mary, stat. 1, c. 5, s. 2, for selling goods seised under a distress for rent, where a tender of the rent and expenses has been made before the sale, and within five days of the seizure, although after impounding; Ellis v. Tuylor is therefore overruled. And per Curiam: "The ease most relied upon by the defendant was that of Ellis v. Taylor (8 M. \& W. 415, and 10 I..J. (N.S.) Ex. 462), in which the Court held, upon the authority of two previous eases, that a tender after impounding a distress for rent was too late. The two cases were Thomas v. Harris (1 M. \& G. 695, 9 L.J. (N.S.) C. P. 308), in which Mr. Jnstice Mraule differed from the other judges; and Ladd v. Thomas (12 Ad. \& E. 117, and 9 L.J. (N.S.) Q. B. 345). Undoubtedly those eases are authorities upon the point. But notwithstanding those decisions, the judges of the Court who heard the argument were mnanimously of opinion that npon the equity of the statute of Will \& Mary, before referred to, an action is maintainable for selling goods distrained for rent after tender of the rent and expenses thongh the tender be made after the impounding." And per Crompton J.: "The Conrt, in Ellis v. Tr(ullor, seems to have assumed that becanse it had been deeided that the defendant could lawfully keep the goods, notwithstanding a tender, if it was after impounding, he had therefore a right to sell. The case of Glyn v. Thomas (11 Ex. 870, \& 25 L.J. (N.S.) Ex. 125) carried the law far enongh against tenants" (Johnson v. Upham).

Proper person to receive teniter of rent.-On distraining for rent, the man left in possession on the premises (being other than the person holding the warrant from the landlord to distrain) has no authority in law to receive the rent. Where, therefore, $W$. execated a warrant of distress, directed to him by the landlord, and left $\mathrm{R}$. on the premises in possession, and the tenant tendered the rent to $R$. who refnsed to receire it, the tenant knowing that $\mathrm{R}$. had not anthority in fact to receive the rent, and that W. had, and that he was within a reasonable and convenient distance of the premises, it was held that the tender was invalid. And per Hill J.: "If it were necessary to decide whether the bailiff employed to make a distress has authority to receive a tender, I shonld say he has, as there onght to be somebody who may be conveniently applied to by the tenant for the purpose of tender. Pillington's Case (Cro. Eliz. 813) decicles that when a bailiff goes with his master, who himself distrains, the bailiff has no authority to receive a tender ; bus 
I should agree with the passage already alluded to in Gillert on Distress, pp. $8:, 83$, that where the bailitl is anthorized to distrain, and distrains without the personal intervention of the landlord, he would be anthorized to receive the rent. But it by no means follows that because a tender may be well made to the bailifl' or broker authorized to distrain, a tender may be made to any person assisting in the distress, and it would be a monstrous proposition to say that the rent might be paid to any irresponsible person who happened to be left by the bailiff in temporary possession of the goods. The ease of Smith v. Gooduin (1 Nev. \& M. 371, and 4 13. \& Ad. 413 ; 2 I.J. (N.S.) K.I. 192) was relied upon for the plaintill as assuming the proposition for which he contended, that the person left in possession had authority to receive the rent; but in that case the rule was refused, on the ground that the tender to the landlord himself was good. The short dictum as to the tender to the man in possession was wholly unnecessary and beside the question (Boulton v. Reynolds, 29 L.J. Q.B. 11).

An action on the case does not lie for detaining cattle distrained damage feasant, where trmiler of suffiriont amends was made after the cattle hat been impounded (Sheriff v. James). It was also held in Anscombe v. Shore that such an action would not lie, and comme semble such an action could not be supported, even if the tender of amends had been made before the impounding, as the proper mode to try the validity of a distress is lyy an action of replerin or trespass. Limelon v. Hooper, which Lord I/ansfield C.J. referred to, in this case, decided that money had and received did not lie to recover back money paid for the release of cattle taken damege feasant, though the distress were wrongful, the proper remedy being trespass and replevin. In Glynn v. Thomas, which was argned in Error from the Exchequer, and where the principle on which Lindon v. Hooper was decided, was expressly in point, Coleridge J. remarked, "Lindon v. Hooper was a case in which the plaintiff's cattle had been distrained demage feasemt, and not for rent in arrear ; and it was acted upon, in the Court of Common Pleas, in the case of Gulliver r. Cosens, in which all the prior authorities were carefully revicwed, and in which it was held that where cattle are distrained demage feasant, an exorbitant sum demanded for the damage, and the owner pays that sum under protest, but makes no tender of a sufticient sum, he cannot recover back the sum so paid as money had and received to his use. And in the same case it was further held, that if he had tendered a sufficient smm before the distress made, his remedy would have been replesin or trespass; if after the distress, but before impounding, detime. The passage cited in that case from that of the Six Carpenters (8 liep. 117) is very important in this, because in it Lord Coke clearly 
puts tender of arrears of rent on the same footing with tender of amenids as applicable respectively to distress for rent in arrear, and distress for damage feresent. In Gullier v. Cosms the Cont assumed the sum demanded for the damage to have been excessive, but laid it down that the plaintiff, being the original wrong-doer, was still bound to tender the sum which he alleger to be sufficient; and in the present case the plaintiff for the same reason was equally bound to make the tender; he was in arrear with his rent, and therefore first in default: by the law he must be taken to know the amount for which he is in arrear, and the landlord when he distrains is not bound to inform him."

The facts of Gulliver v. Cosens were as follow: A flock of sheep, belonging to the plaintiff, having strayed rpon the defendant's land, they were distrained as damage feasunt by the defendant, who refused to restore them exeept upon payment of $£ 215 \mathrm{~s} .9 \mathrm{~d}$., his estimate of the damage. This the plaintiff paid under protest, and brought an action for money had and received. It was urged for the defendant, on the authority of Lindon r. Hooper, that the action was not maintainable, and that where an exorbitant demand was made for compensation, the only remedy was replevin. Alderson B. directed a nonsuit, reserring to the plaintiff leave to enter a verdict for that sum, if the Court should think the action well brought. The actnal damage done by the sheep was estimated by the jury at 5s. The Court discharged the rule; and Tindal C.J. thus laid down the law on the subject:

"The question at issue seems to me to depend on the consideration upon which of the parties has the law cast the omus of estimating the amount of damage done to the owner of the land. 'The party whose sheep have trespassed is in the first instance the wrong-doer; it is therefore upon him that the risk of estimating the amount of damage onght to rest, and not upon the party who has suffered by the trespass. If the owner of the cattle elects to make a tender of sufficient amends before the distress, and the distrainor refuses it, the latter becomes a wrong-doer; but a tender after distress does not entitle the owner to replevy his cattle. The rule of law cannot be more clcarly stated than is done by Lord Colee in the Six Carpenters' case. Tide John Matrerev's case : it is held by the Court that if the lord or his bailiff comes to distrain, and before the distress the tenant tenders the arrears upon the land, there the distress taken for it is tortious. 'The same law for damage feasant, if, before the distress, the tenant tenders sufficient amends; and therewith agree 7 Elw. III. 8 b., in the Master of St. Marl's case; and so is the opinion of Mill to be understood in 13 Hen. IV. 17 b., which opinion is not well abridged in title 'Trespass,' Fitzh. pl. 180. 'Note, reader, this difference, that tender upon the 
land before the distress makes the distress tortions; tender after the distress, and before the impounding, makes the detainer, and not the taking, wrongful; tender after the impounding makes neither the one nor the other wrongful, for then it comes too late, beeause then the cause is put to the trial of the law, to be there determined. Bnt, after the law has determined it, and the arowant has return irreplevisable, yet if the plaintiff' makes him a snflicient tender, he may have an action of detinne for the detainer after ; or he may, upon satisfaction made in Conrt, have a writ for the re-delivery of his goods.'

"It appenrs to me that when the present plaintiff found he was too late to make a tender so as to entitle himself to replery the sheep, and to succeel in an action of replevin, his proper conrse was to make a tender of sufficient amends to cover the damage sustained; and in the erent of the defendant refusing to aceept the sum tendered, and deliver up the sheep, he should have bronght detinne (i.e., upon a tender before the impounding), for they were held by the defendant merely as a pledge. In that ease the hazard of the sufficiency of the tender would fall, as it ought to do, on the owner of the cattle. It has been urged that here a temder was mnecessary, inasmuch as the sum demanded for compensation was exorbitant. That argument, however, as it seems to me, is answered by saying that the risk of determining the real amount of damage is not by law imposed upon the defendant." This I should be dispinsed to holl upon principle, and independently of the authority of Limdon r. Honper, which I am unable to get orer, and which I am not aware has been overruled; and though cases have oceurred in which it has been decided that an excessive demand dispenses with a tender, ret those were cases where the law made it ineumbent on the defemdant correctly to ascertain the amount of his demand. The eases of Barrelt r. The Storkton and Darlington Railu'ay Company and Parker v. The Grat Westem Railuay Compremy range themselves within this class. The cases of Kiribles r. Hull and Slicale v. Becle tollow the doctrine of Limlon r. Hooper. On authority, therefore, as mell as principle, the rerdict for the defendant onght to stand."

And per Maule J.: "The owner of the land is no wrong-doer if he distrains hefore tender marle; nor is he a wrong-doer if he impounds before tender, or after an insufficient tender. Ilere the real question is, whose duty it was to estimate the damage: if the owner of the cattle was bound to make a tender, he was to ascertain the amount at his jeril."

An artion will lie aggainst a lamallort, at the suit of the temanl, for deteiming the goods lation umder a distress, after tender of rent in arrear and rosts, brefor impoundiny (Loring r. Jarburton). And per Culerillye J. : 
"This ease is clearly distinguishable from Clymm r. Thomas ; there it did not appear that the tender was marle hefore imponnding" (it).

The note in Poote v. Lomgurville says, "Agreealle to the opinion of Saunders, the settled distinction secms now to be, that where a stranger's cattle escape into another's land by breaking the fences where there is no defect in them, or if the tenant of the land where the distress is taken is not bonnd to repair the fences thongh there is a defect in them, the cattle may be distrained for rent immediately before they are levant and couchent; but if the cattle escape throngh the defect of fences which the tenant of the land is bound to repair, they cannot be distrained by the landlord for rent, though they have been levant and couchant, unless the owner of the cattle after notice that they are in the land neglects or refuses to drive them away, for the landlord shall not take advantage of his own wrong; and this case of Poole v. Longueville (if cattle escape ont of an adjoining close, and are levant and couchant, adjudged that they may be distrained for rent, though they escape through the defect of fences which the party distraining ought to have repaired) is denied to be law."

Littledale .J. said, in Saffery v. Elgood, which was confirmed in Johmson v. Faulliner, "The cattle of a stanger are distrainable for a rent-charge, unless they are shown to have been placed there by some one who has an interest paramount to the charge." "A rent-charge is a rent with power of distress ; and unless the grantee conld distrain the eattle of a stranger being upon the land, I know not what would be the use of a power of distress; for the land might get into the hands of a stranger. In order to exempt the cattle of a stranger, he onght to show some interest in the land, paramount to that of the grantee of the rent-charge." "In 2 Saund. 290 there is a note which, referring to the case of a stranger's cattle escaping into another's land by breaking the fences, says, 'The lord or grante of a rent-charge, who had nothing to do with the fences, may in such ease distrain the cattle after they have been lowant and couchant, though no notice is given to the owner.' Kemp v. Crexces is there eited. That case may be considered as haring settled the law that a grantee of a rent-charge may distrain the goods of a strar ger being upon the land charged."

Cattle which are upon tand by way of agistment may be distrained for rent (Poll. Alr. 669 ; Cro. Eliz. 549). In Foukes v. Joyce, a grazier's serrant driving a flock of 123 fat sheep to London, was encouraged by an innkeeper's servant to put his sheep into pasture grounds belonging to an inn, at the nsual rate of eightpence per score per night. Before they were loxent and couchant the landlord, Joyee, whose rent was $£ 182$ in arrear, demanded whose they were, and seeming to be angry the 
drorers said they would take out their sheep. At last he said they might stay in for the night; and when the men were gone to the inn he drore the sheep to the pound, where they were kept four or five days, and had to be replevied. It was decided that they were liable to dis tress; bnt the grazier was afterwards relieved in equity, on the ground of frand in Joyce, who was decreed to pay all the costs both in law and equity. Serjeant Irilliams adds, in his note on this case (2 Saund. 290 a), "And it should seem at this day, a court of law would be of opinion that cattle belonging to a drover being jut into a ground with the consent of the occupier, to graze only one night on their way to a fair or market, are not liable to the distress of the laudlord for rent."

In Horsford v. Welster, a tenant's goods, including certain eatage, were sold under a bill of sale; and his landlord (whose agent was the defendant) agreed to let the sale proceed on condition that the arrears of rent for which he liad put in a distress should be paid out of the procecds. It was stated at the time of sale (November), where the defendant attended, that the purchaser should have liberty to consume the grass in the close till February 25, when the tenant's interest in them terminated. The plaintiff purchased the eatage; and as the sale did not cover the arrears, the landlord distrained the plaintifl's cattle, which were eating it off. It was held by Lord Abinger C.B., Bolland B., and Curney B. (Parke B. diss.) that a contract was to be implied on the part of the landlord not to distrain the cattle of snch purchaser. Gumey 13. considered that any other construction of the agreement at the sale "would render the transaction merely a trap for the cattle of any person who purchased the eatage sold under the sanction of the landlord himself." Bollend B. said he was "at first struck with the case of Foukes v. Joyre, which was relied on for the defendant. The point there was, whether the plaintiff had any right to the privilege of having lis cattle unmolested. There was, in fact, no consideration to support the grant of any such privilege; but suppose the landlord there had by agreement taken a portion of the rent from the owner of the cattle, could he afterwards have distrainerl ?"

Whire a tenant, who is shortly about to quil his farm, alvertises for sale by anction his stork, de., upon the farm, his payment of rent already tue and to become due at the expiration of his tenancy to his landlord, who has notice of the intended sale, does not raise an implied promise (no actual promise was proved at the trial) on the part of the landlord not to interfere with or prevent the sale or the remoral of the property, and the tenant cannot recorer damages caused by the hindrance of the sale (Bushby v. Fisher). In Thomas v. Witliams, a tenant of the 
flaintifl"s had engaged the defendant to sell his goods; but on the sale day (August) the plaintiff arrived at the farm with a bailiff and a notice of distress for part of a half-year's rent due on the 25 th of March. The defendant verbally promised that if he would not distrain for the rent due, and let the sale proceed, he would pay him not only the rent due, but the rent that would be due at Michaelmas. It was held that the promise to pay the accruing rent was a promise founcled on a new consideration distinct from the demand which the plaintiff had against his tenant, and therefore void by the 29 Car. II. c. 3, s. 4 ; and that the promise being entire, and in the commencement void in part, was void altogether; and that the plaintiff therefore could not recover from the defendant the rent die on the 25th of Mareh. Lexington v. Clark and Chater v. Beckett were anthorities directly against the plaintiff on the question whether the promise, being void in part, could be held good as to the other part, viz., the arrears due at Ladyday, in respect of which it might have been good if confined to those arrear's.

An agrecment to take interest on rent in arrear does not take away the right of distress (Skerry v. Preston). But per Bayley J., the landlord could not distrain for the interest (ib.). According to Davis v. Gyde, a momissory note given by the tenant to his landlord for rent does not of itself suspend the right of distress until the note is due. Gage v. Acton decided that a debt due on a bond may be set off against rent, because the latter is in the nature of a specialty debt; and in Davis v. Gyde the promissory note being a debt of inferior degree to the rent, the receipt of the note created no extinguishment of the rent. Assuming that the taking of the promissory note might operate as a suspension of the right to distrain, the Court there held that an agreement between the parties to that effect should have been pleaded.

In Parrot and anor. v. Anderson, one Love, a tenant, being indebted to his landlord for rent, gave the agent of the latter a bill of exchunge at foul months for $£ 146$ rent, which he indorsed to a third person, and afterwards paid the rent to the landlord, giving eredit for it in his accounts as if the tenant had paid the money. The lill was dishonoured; and Love having taken the benefit of the Insolvent Act, the defendant, who was the mortgagee of his farm, distrained his goods for rent, including the $£ 146$, and the assignees brought this action for excessive distress. Maule J. thought that the plaintiffs were not entitled to recorer; and it was arranged that they should be nonsuited, leave being reserved to enter a verdict for $£ 80$, if on the facts of the ease the learned judge ought to have directed a verdict for them. After consultation with lyaule J., who reported that he was requested 
to leare the matter to the jury only, if he eould tell them that they must find a rerdict for the plaintiff, the Court refused a rnle. Pollocto C.B. said : "The tenant eannot take advantage of such a payment. Suppose the steward of a lundowner took bills of exchange for rent, and then remitted the amount to the landholder, might he not distrain if the bills were dishononred?" And per Alderson B. : "If the defendant himself had receired the bill of exchange, and it was afterwards dishonoured, could he not have distrained?" Porke B. thought the defendant liable to refund, on the ground that the money was paid by the agent mder a mistake of fact ; and added, "It is a question of lact whether this payment by the agent was a loan to the tenant, or whether the money was advanced by the agent to the landlord. A similar point arose in Griffiths r. Chichester. If the transaction amounted to a discount of the bill by the agent for the tenant, then the rent was paid; but if it was only an advance of the rent by the agent to the landlord, then he was entitled to distrain." The principal acted on in Skyring $v$. Grenurood also applied here.

Where a landlord gies an authority to distrain for rent, he thereby necessarily authorises thie bailiff to receive it if tendered (Hatch v. Hale). In Lewis $\mathrm{r}$. Reet the landlord verbally anthorized his bailiffs, through his agent (Owens), to distrain for rent due to him from his tenant, of a farm called Aberborthen, and a mountain sheep-walk, Penbryn, directing them not to take anything except on the demised premises. The bailitf distrained sheep of another person's (supposing them to be the tenant's) beyond the boundary of the farm; the eattle were sold, and the landlord received the proceeds. It was held that the landlord was not liable in trover for the value of the cattle muless it were found by the jury that he ratified the act of the bailiff's with knowledge of the juregularity, or that he chose, without inquiry, to take the risk upon limself' and adopt the whole of their acts. 'The defendants had first scized abont a dozen sheep which they found on the Penbryn mountain ; and while they wore driving them down, and somewhere very near the boundary of the Penbryn sheep-walk, these were joind by the other shecp (making forty in all), which had been straying upon an adjoining sheep-walk belonging to another farm. Owens received the proceeds of the sale of the sheep, and aceounted for the money to Read, the defendant; but there was no direct evidence that either Owens or Read was infurmed where the sheep were taken, or had any distinct knowledge that the distress was not made on the Penbryn sheep-watk.

P'ayment of rent under a distress is not a conclusive admission of title in the distrainom, but may be rebutted by showing that he never had any titlo (Knight v. Cor). A tender of the rent "under protest" is 
good; but it should be made generally without any condition or qualification being imposed on the receiver (Munning v. Lumn). But tenter of satisfuction to a distrainor is too late after the goods have been inpounded, and this rule applies equally to goods seized for rent as well as to cattle taken demage feasant (Ladd v. Thomas). Pulleson J. suid, "That such a tender cannot arail where cattle have been distrained demage feasant, is shown beyond a doubt by the cases of Sheriff v. Jumes and Anscomb v. Shore. The same doctrine has been laid down as to goods taken for rent in Firth v. Purtis: but that was an act for pound breach; and it was enongh for the decision of the case, that the tenant had no right to take the law into his own hands" (ib.). And per Lord Denman C.J.: "I must say I think continuing in possession after a proper tender is ground for an action of trespass; that Lord Ellenborourfh's doubts on that subject, in Winterbourne v. Morgan, were not well founded; and that Le Blanc J. and Bayley J. took a right view of it" (ib.).

Parke B. ruled, in Tertue v. Beasley, that a tenant tendering his rent and the costs after distress taken, but before it is impounded or removed, mas maintain trespass for a subsequent removal of the distress. His lordship added: "The statute 11 Geo. 2 , c. 19, s. 19, gives the option of proceeding by case or trespass. If the injury had arisen from a mere neglect to do some act (i.e., the mere omission to restore the goods after: acceptance of the rent), case would have been the only proper remedy." 'T'he cause of action here was not the mere retaining possession, but the wrongful removal of the goods after the tender; and hence the Court of Common Pleas did not consider that their decision in West v. Nibls conflicted with it. It was decided in West v. Nibbs, that a landlord who had accepted the rent in arrear and the expenses of the distress after the impounding cannot be treated as a trespasser merely because he retains possession of the goods distrained, although his refusal to deliver them up to the tenant may amount to a conversion, so as to render him liable in trover. And per C'ressuell J., Erans v. Etliot (in which it was held that replevin lay, at common law, for a wrongful detention of goods taken under a lawful distress), " is an authority for the proposition that, where there has been a tender between the taking and the impounding, a detention after the tender is suflicient to satisfy the nsual allegation in a declaration in replevin, that the defendant took, \&c., and detained, \&c.; but yet it does not decide that the mere retaining by the landlord of the goods distrained, after the tenant has gained a right to have them delivered up to him, will render the landlord liable to an action of trespass." And per Wilde C.J., in allusion to Evans v. Elliot: "My present impression certainly is that trespass will 
not lie for the mere detention of the goods; the goods being in the custody of the law, the distrainor is under no legal obligation actively to re-deliver them; the owner must take due means to re-possess himself of them" (ib.).

A rent-charge may be divided by with or by deed operating under the Statute of Liss, so as to make the tenant liable without attornment to several distresses by the devisees, or cestuis que use, and semble since the statute 4 Ame, c. 16, s. 9, a rent-charge may be so divided by a conveyance of any kind (Rivis r. Iratson); and the arrears of a perpetual rent-charge were ordered by a decree of Sir. J. Romilly M.R. in White r. James, to be raised by sale, on the anthority of Cupit v. Jation.

If the half-yearly payment of " rent-charge on land under the Tithe Commutation Act, 6 \& 7 Witl. IV. c. 71, be in arrear, and no sufficient distiess fouml, the owner of the rent-charge may recover such arrear for il period not exceeding two years by assessment and writ of habere facius possessionem, under sec. 8:, although he may not have attenpted to lery the arrear of distress, under sec. 81 , at the end of each or any but the last of the half-years, and although at the end of one or more of such previous half-years there may have been a sufficient distress for the amount then due (In re Cambencell Rent-charge). Paileson. J. said: "There is no rcason to suppose that, althongh a party might distrain for an arrear of two years, the legislature intended that he should not enforce the remedy inder sec. 8:2, unless he attempted to distrain at the end of a single halfyear and no distress were found. The constrnction of both clanses must be the same. In the case of proceedings on a vacaut possession (11 Geo. II. c. 19, s. 16) it never was contended that if the landlord omitted to enforce his remedy at the end of a first year he conld not arail himselt of it afterwards." It was held by the Court of Exchequer (Parle B. diss.), substantially on the authority of the above case, that where under the Tithe Commutation Act the helf-yearly payment of rent-charyes on land shall be in arrear and unpaid for 10 days, and there shall be no sufficient distress on the premises liable to the payment thereof, it shall be lawful for any judge of Her Majesty's courts of record at Westminster to make an order ex parte, without summons or notice, on affidavit of the facts, for a writ to issue to the sherifr to snmmon a jury to assess the arrears of rent-charge, and to return such inquisition to one of the superior courts (In re Hammersmilh Rent-charye). Lloyd v. Wimlon is a clear anthority that a rent-charge is not within 11 Gieo. II. c. 19, s. 22 ; and it was held by the Court of Common Pleas, in Nexnham v. Bever, principally on the anthority of Lindon v. Collins, that the owner of a rent-charge in lieu of tithes, distraining under the 81st section of the 
6 \& 7 Will. IV. c. 71 , and afterwards obtaining judgment in an action of replevin, is not entitled to double costs under 11 Geo.II. c. 19, s. 2\%; and that neither, consequently, is he entitled to "the full and reasonable indemnity as to costs," substituted for donble costs by the 5 \& 6 Fict. c. 97, s.2. And per Haule J.: "The owner of the rent-charge, in distraining for it, may act and demean himself in relation to the distress as any landlord may for arrears of rent reserved on a common lease for yeurs ; that is, he may, withont becoming a trespasser ab initio, conduct himself in a manner not strictly conformable with the proper mode of managing a distress" (ib.).

The right of distress is not so inseparable an incident to a rent service that it cannot be postponed; and therefore where one $A$, a mesue landlord, let premises to an under-tenant by a written agreement which provided, among other things, that no distress should be made till $\mathrm{A}$ had produced the receipt of the superior landlord, and A afterwards distrained for his rent withont prodneing such receipt, it was held by the Court of Common Pleas, in an action by the mnder-tenant against the broker who executed the distress, that $A$ 's right was postponed, and that the defendant was liable as a trespasser (Giles $\mathrm{v}$. Spencer). And the fact that some time after the first agreement, A and his under-tenant (who entered under it) agreed by parol to substitute other premises for those originally taken, to be held on the same terms, constitnted a new contract, and not an alteration of the terins of the first (ib.).

A distiess can only be made by lau', in respect of a fixed ascertained rent reserved ont of land (Gardiner v. Willicmson). It frequently happens that persons enter and occupy at a rent to be fixed in finture. In such cases no distress can be made, but an action may be brought for the rent on a quantum valebat (Hamerton v. Stead). No precise form of words is necessary for a distress ; and where a landlord laid his hand on a lathe, and said, "I will not suffer" this or any of the things to go off the premises till my rent is paid," it was held that the distress was sufficiently commenced to entitle him to the article in question (Wood v. Numn.)

Distress rendered illegal by immoper time of taking it.-In two cases, in one of which the distress was taken at nearly eight o'clock in the evening, when by the almanac the sum set just after seven, and in the other it was taken between two and three o'clock on the morning of a day on which, by the almanac, the sun rose shortly before half-past four, and there was no other evidence upon the point, nor any evidence as to whether in either case it was dark when the distress was taken, but the jury in beth cases found that it was taken between sunset and 
sunrise, it was held that the evidence was sufficient to sustain that finding, and that the distresses therefore were illegal (Tutton v. Jarke; Niron r. Freeman).

Improperly working a distress.-If a distrainor abuses a distress by working it, the owner may interfere and prevent it, and no action can be maintained against him for pound breach or rescue. Here, after three horses of the defendant, who was a butty-collier under the MIessis. Hickuan, tenants to the plaintitl's, of a colliery at a surface rent, and also at a mining rent, had been ineluded in a distress for colliery rent levied on the Messrs. Hickman, and removed to a stable half a mile oft, and notice given that they were impounded there, the plaintiffs' appraiser directed the bailiff's to bring two of them to work in the pit. One of the horses was locked in a movable stable on the pit bank, and the other was about to be let down, when the defendants took forcille possession of both, breaking the lock of such stable, tumed both loose, and then took them away. The plaintiffs got a verdict of $£ 60$ treble damages under stat. 2 Wil. \& Mary, sess. 1, e. 5, with leave reserved to the defendant to enter a verdict for himself on the ground that neither count of the declaration was proved, the rescue being after the impounding, and after the plaintifl's had taken the distress from the pound for an mulawful purpose; and the verdict was entered for the defendant. Aud per Wilde B.: " Here there was a plain, palyable misuse of the distress of the most agrgrarated kind. I think, under the eircumstances, the defendant was perfectly justified in interfering. I think, therefore, the resene is not made out. With regard to the pound breach, it seems to be perfectly plain that directly the distrainor has taken the animals out of the pound for the purpose of using them, it cannot be said that they are any longer muder the protection of the law, nor in any artificial sense can they be considered as being in the pound contrary to the fact." (Smith and Another v. Wright.)

Distress after death of tenant. - T being tenant-at-will at a yearly rent, died leaving rent in arrear ; the next day the lessor distrained on the premises which were then ocempied by 'T's servants; his widow came into oecupation the day after, and subsecpently took ont administration to her husband. It was held that the distress was not justified under 8 Anne, c. 14 , ss. 6,7 , as it was not made "duriny the possession of the tenant from whom the rent became due;" and semble that Wrelker v. Gites (6 C.B., 662 ; 18 L.J. (N.S.), C.P. 323) is still law as to the construction to be jut mon similar deeds, and is not overruled by I'iultern v. Sonster, (8 Ex., 763; 22 J.J. (N.S.), Ex., 266), and Brox'n v. Jetropolitan Counties Life Assurance Saciety (28 L.J. (N.S.), Q.B., 296); and per Mellor J., "Braithuate v. Cookspy (1 H. Bl., 467), is 
distinguishable becanse the tenancy did not cxpire with the death (Turner v. Barnes and others).

An open field is a pound sufficient at law in which to distrain callle taken for rent arrear (Custlemuin v. Hicks) per Colevidge J. Where a bailiff went a little into the field in which the cattle were, and tonching one of them on the side, said, "I distrain these cattle for rent;" and then, after taking a list of them, left them nndisturbed in the field (although he subsequently returned, and then placed them in the charge of another man), without putting any loek or additional fastening on to the gate, and gave notice of distress to the tenant, informing him that if the rent and costs were not paid he would proceed to sell in five days, and adding that the cattle were impounded on the premises, though he did not say where-it was held by the Court of Common Pleas (Maule J. diss.), principally on the anthority of Frith v. Purris, that under these cireumstances the impounding of the cattle was comllete and perfect from the time of giving the notice to the tenant; and consequently a tender of the rent and costs of distraining, \&c., after such incident was too late (Thomas v. Harris). And per Tindal C.J : "Aecording to the best construction which I can put upon 11 Geo. II. c. 19 , s. 10, the impounding of the cattle was complete before the tender was made. A pound, in its strict legal sense, means an enclosed plaec, where eattle are kept mutil rent is paid. The words ' or' otherwise secure the distress,' used in the statute give a greater latitude, and do not render it imperative on the party to seeure them in such pound. For example, cattle grazing in a field, and goods, chattels, or effects placed in a room or other places fit for their reception, may be sail to be impounded."

And so in Tenment v. Field, where a landlord sent a broker to distrain for rent upon the tenant's premises, but he did not lay his lumels upon any of the goods, to indicate an imponndiny, \&c., and by the tenant's wife's request nothing was done but an inventory taken and a man left in possession, with a notice that the broker had "distrained" the goods, the Court of Queen's Bench held that this was an impounding under 11 Geo. II. c. 19, and that the landlord was not bound afterwards to accept a tender of rent. And per Lord Camplell C.J.: "The consent of the parties makes this case like a room being the pound, a man being left in possession. 'This, I think, was equivalent to an actual imponnding ; and looking at the cases and anthorities, 1 an consequently of opinion that there was an imponding before tender." Erle J. said : "I agree with the rest of the Court, becanse the tenant's conduct showed that he agreed to the goods being left where they were. 'The statute shows that there may be an impounding on the premises; but 1 certainly 
eoncul in the observations of Maule J. in Thomas v. Harris, that the rational interpretation of this remedy is to enable the landlord to get what is due for rent and costs, the amount of which there can be no difficulty in ascertaining."

A llistress can only be made betuecn sumrise and sunset; and it was held in Tinkler v. Prentice that in pleading a tender of rent on the land, it must be shown that the tenant was on the land time enough before sunset to have comited the money. A distress must be made on the land from which the rent issnes; but where a farm adjoins a lighway, groods standing on such highway within the middle of it, and on that part next to the demised premises, may be distrained (Hodlyes v. Lau'rence). Where a laudlord distrains for more than is due for rent, an action on the case lies, thongh the goods distrained are of less value than the rent really due; and it is no defence that after distress, and notice thereof, and before the sale, the landlord served a second notice on the tenant stating the arnount really due, and that the distress was taken for that amount only, and would be sold unless that amount was faid (Tuylor v. Hemiker). A landlord cannot break open gates or break cloun enclosures to mulie a distress, but he may open an outer door by turning the key, lifting the latch, or drawing back the bolt (Ryan v. Slitcock). But it was doubted in the same case whecher, if the outer door is broken open, the distress is roid.

The 7 th section of 11 Geo. II. c. 19 gives power to the landlordwhere goods fraudulently carrich away by the tenant, are placed in any "house, barn, or stable," \&c., locked up so as to prevent such guods "from being taken and seized as a distress for arrears of rent"-_" to break open and enter into such honse, barn, and stable," \&c. It was decided in Rich $\mathrm{v}$. Wooley that a plea under this section, justifying the breaking open a lock to distrain eattle which have been frandulently removed to elude a distress for rent, must arer that a constable was present when the lock was broken open. Patteson f. observed npon it, in Brown v. Glenn (which settled that a landlord eannot break open the onter door of a stable, though not within the curtilage, to levy an ordinary distress for rent): "The inference appears to be that the right of the distrainor to break open the door of a stable does not exist irrespectively of that provision." And Lord Campbell C.J. considered that "this statute afforded a clear inference that, irrespective of the matter's therein provided for, the outer door of a barn or stable could not be broken open for the purpose of executing an ordinary distress. 'This doctrine is at least not novel; it was acted upon by Lord Hartwirke; and his decision is cited by Mr. Serjeant Williams, in his note to Poole v, Longuecille. In Penlon v. Brou'n it was decided on 
demurrer that the outer door of an outhouse might he broken open for the purpose of execnting a fieri fucias. 'This, however, is not ineonsistent with our decision; for a distinction may be reasonably made between the powers of an officer acting in execution of legal process, and the powers of a private indiridual who takes the law into his own hand, and for his own purposes. 'There is another well-known distinction, that a landlord cannot distrain at all hours, whereas the sheriff is under no such restriction."

A landlord or baitiff who has distrained, even if not bound (as semb7e he is) to restore goods remaining unsold to the premises on which he distrained them, is at liberty to do so; and his doing so will not be a conversion, even although they are the goods of third parties, and the bailiff has had notice of this from them after the impounding, and has promised to act on the notice, both as to the goods unsold and the surplus proceeds of goods sold: for such a promise does not impose any duty on the bailiff to deliver the goods to the right owner, neither will it sustain an action for money had and received to recover the surplus proceeds of the goods sold (Evans r. Wright).

Where goods distrained for rent in arrear have been removed to a convenient place for sale, and sufficient sold to satisfy the distress, the proper conrse is for the brokel to leave the surplus money with the sheriff, and return the surplus goods to the premises from whence he took them (Evans v. Wright); and, where a broker has distrained for rent the right goods of the tenant, the landlord, having authorised the distress, is liable for any irregularity committed by him in the sale of such distress, although done without his knowledge (Haseler v. Le Moyne).

Things are not distrainale which camnot be restored in the same plight in which they were before the distress, and as Patteson J. observed of fixtures, in Darby v. Harris, the reason would be more apparent in former times, when the landlord was obliged, on distraining, to remove the distress from the premises.

Until 2 IFitl. \& M. $c .5$, no shectes or coeks of corn, loose or in the strare, or hay in any bain or grunary, or in amy hovel, stack, or rick, could by the law be distrcined or otherwise secured for rent; but sec. 3 of that statnte gave the landlord porrer to seize it upon any part of the land or ground. The common law is not taken away by the above statute, and commodities of a perishuble nature, which cannot be restored on a replevin in the same state as that in which they were taken, cannot be made the subject of distress. Hence the curcase of a beast sent to the butcher's (Brown v. Sherill) and the flesh of animals lately slaughtered cannot be distrained (Morley v. Pincombe). Neither can animals ferce 
nakne, though deer may which are put up to fat (Davis v. Porell). Wearing apparel, if in actnal nse, cannot be distrained, nor whatever else is in actnal nse at the time; and goods sent to any place by way of trade, but not to remain there permanently, are within the exception. And so a horse when he goes to be shoed, or takes corn to marlket, is exempt, as well as when a person is actually riding it. Sheep and beasts of plough are privileged by 51 Hen. III. st. 4 , while there is another sufficient distress, unless they are found demage feasent. But an aetion is not maintainable for distraining beasts of the plough when there is no other suflicient subject of distress on the premises beside growing crops (Pigyolt r. Birlles); for the landlord has a right to resort to the subjects of distress which can be made immediately arailable; and beasts of the plough are distrainable for arrears of poor-rate (Hutchins v. Chambers) when there were other things that might have been distrained, and exceeding the valne of the demand. An implement of trade is only privileged if it be in use, and if there be no other distress on the premises (Fenton v. Log(en). Here the threshing machine had been let to hire by the plaintiff to the tenant, on whom the defendant in replevin had distrained. The work for which it was let had been completed on the Saturday, and the distress was made on the next Monday, when there was no other distress on the premises. Gorton v. Futliner was decisire against the plaintiff. And see Lord Lyndhur'st C. B.'s judgment in Wood v. Clurle.

An action of trespass will lie for distraining loots or implements of trade and industry (here a spade and dung fork), though nol in actual use, if there be other sufficient distress on the memises at the time (Nargalt v. Nias). Lord Camplell C.J. thus remarked on Piggotl v. Birtles, Yolland v. Price, Hutchins v. Chambers, Dauson v. Alford, and Fitzherbert's Natura Bretinm, 90, whieh were cited in support of the rule : "On examining the cases cited in the argument, we do not find any which deeides that trespass is not maintainable. The precedent cited from Fitzherbert, is elassed under the head "Writ of Trespass"; and in Comyn's Digest, "Trespass, \&e.," it is laid down that trespass will lie for an unlawful distress of goods, and the same precedent, as in Fitzherbert, is there referred to in support of that position.

Piggott v. Birlles was an action on the case, in which the plaintiff, by one of the comnts in the declaration, complained of the distraining his bensts of the plough, there being other chattels on the premises; and the only matter decided in that case was respecting the distress of beasts of the plongh, that they were distrainalle when there was no other sufficient distress on the premises besiles growing crops. In Inutchins v. Chembers, there were two distresses under the same war- 
rant; under the last distress beasts of the plongh were taken, there leing at the time more than suflieient to answer the demand. The first distress proved insufieient in value, whereupon a sccond distress was made, which was excessive, and in it were also included beasts of the plough. In that ease, there were three qnestions calling for the decision of the Court : first, whether in the last distress beasts of the plough conld be distrained for at all, if there were other things of sufficient value upon the premises; seeondly, whether the second distress under the same warrant was at all justified; and thirdly, whether the seeond distress being excessive, that circumstance alone was not sufficient to maintain the action of trespass. On the first point the Court was of opinion that beasts of the plongh were distrainable moler 43 Eliz. and such like Acts of Parliament, and mpon the second and third questions the Court held, that if a man makes a distress which is iusufficient in the value of the goods, and afterwards on discovering the mistake makes a second seizure, in that case an action of trespass cannot be maintained for taking an excessive distress. With respect to Jenner v. Folland, which was an action on the case, for distraining beasts of the plough, where there were other goods of suffieient valne which ought to have been distrained, the matter in dispute was, whether the value of the other goods was to be judged of at the time the distress was originally made, or whether it was to be aseertained by the subsequent sale; and the Court held that the legality or illegality of the distress was to be determined by the circumstances of the distress at the time it was made. The judgment of Wood B. puts the case very clearly, and there is nothing in that case to show that trespass will not lie if tools of trade are illegally taken. It is true there are precedents for making the illegal distress of tools of trade the sulject of an action on the case; but there are also many anthorities which show that the wrongful taking may be the ground of trespass, and yet the party aggrieved may, if he pleases, waive the trespass and sue in ease. The view that we have taken, that the wrongful scizure of tools of trade is the subject matter of an action of trespass, is fully confirmed in Dauson v. Alford, which shows that it is not necessary for the plaintiff in his deelaration to allege that there were other goods of snffieient value, which might have been distrained, but the defendant must by his plea answer, if he justifies, that no other sufficient distress could be had. The rule must be diseharged."

Where the sheep of a third person on the land of a tenant were distrained by the landlord for rent, when other things arcilable for the distress were npon the premises, in an action against the landlord by the orner of 
the sheep, the Conrt of Exchequer held that the measure of elamages w'as the value of the sheep (Keen v. Priest).

Tithes are an incorporeal hereditument, and can therefore only pass by deed. It was held in Garther v. Willumson, where the tithes of a parish and a homestead were let together by parol agreement, no distinct rent haring been reserved for the homestead, for which there might have been a distress that the distress for rent in arrear was altogether mnlawfnl. And per Purke J.: "It is impossible to say that all the rent in this case is reserved in respect of the laud only; and there can be no distress for rent ensning ont of any incorporeal hereditament. The rent is payable for, thongh it does not issue out of, the tithes."

A distress camnot be mate at common law after the terancy has been determined by notice to quit, thongh the rent may have become due before snch determination; and an avorry for snch a rent must therefore be so framed as to bring it within the 8 Ame, e. 14, s. 6 (Milliams v. Stiven). Here the defendant gave the plaintiff a notice to quit expiring on Feb. 2nd, 1814; and it was contended, on the anthority of Jenner v. Clegg, that the defendant haring by his notice to cuit treated the plaintifl as a tresprasser, conld not afterwards treat him as a tenant. Jemer v. Clegg, a case of replevin, where Parke. J. and Bollanl B. decided that a tenant holding over after notice to quit given by the landlord, is not liable to a distress withont some evidence of a renewal of the tenancy, - was eited. The Conrt, however, held that this ease was not applicable, as the rent there distrained for became ilue after the determination of the tenaney by notice to quit from the landlord. And per Putteson J., "All that. Jenner v. Clegy shows is that the tenancy is at an end when the notice expires." A landlord having treated an occupicr of his land as a trespasser, by serving him with an ejectment, cannot afterwards distrain on him for rent, though the ejectment is directed against the claims of a third person, who comes in and defends in lien of the occupier, and the oecupier is aware of that circumstance, and is never turned out of possession (Briliges v. Smyth).

In Dendy v. Nirhol a tenant broke a covenant not to undertet without. consent. After the breach, the plaintiff brought an action for the rent, and subsequently obtained judgment and received the money. Before he receired the money he bronght an action of ejectment. The Conrt of Common Pleas held that the bringing of the action for the rent and the sulseqnent receipt of the money amounted to a waiver of the forfeiture. Thus a right of re-entry for breach of covenant is waived by the lessor bringing an action for rent accrued due subsequent to the breach.

One joint tenant of the reversion can, by severance, deprive the others 
of their right to distrain for rent already due, and this hardship is an incident to that species of property; all remedy for the rent is not gone, but an action may be clearly bronght in the name of all, as before the severance of the reversion an avowry must have been by all (Stareley v. Allcock). And per Patteson J.: "An anthority is required to show that, by the severance of the reversion, the rent already dne to the six was apportioned." A terre tenant, holding under two tenants in common, cannot pay the whole rent to one after notice from the other not to pay it ; and if he do, the other tenant in common may distrain for his share (Harrison v. Barnby). And per Abbott C.J., in Powis v. Smith, "It is elear that if there be a joint lease by two tenants in common, reserving an entire rent, the two may join in an action brought to recover the same; but if there be a separate reservation to each, there must be separate actions. Here, by the original contract, there was a letting of the whole premises by the two tenants in common at an entire rent; afterwards the rent was severed. It became a question of fact upon the whole evidence, whether the parties thereby meant to enter a new eontract, with a separate reservation of rent to each, or whether they meant to continne the old reservation of rent, each of the plaintiffs receiving his own moiety."

It is a well-known rule that the action for rent by lenants in common is in its nature a joint action, and consequently upon a lease by them the survivors may sue for the whole of the rent, although the reservation be to the lessors according to their respective interests (II allace $\mathrm{v}$. M(actaren). And they can recover an ejectment under the Common Law Proeedure Act (1852), on a joint writ, the whole of the property to which they are entitled (Etliss v. Elliss). A lessee who under-leases for less than his whole estate in the term has a power of distress (Wade v. Marsh), but not where he demises the whole of his interest (Preece $\mathrm{v}$. Corrie). In Parmenter v. Wcbler the lessee of two farms agreed with the plaintiff that he should have them during the leases for the same price, and remain his tenant, with the stipnlation that he should farm according to the tenor of the leases, and incur forfeiture and be paid for the fallows and dung on leaving the farms. The plaintiff took possession, and paid one jear's rent growing due after the date of the agreement to the sub-lessee, who afterwards distrained for the rent in arrear. The Conrt held that the agreement did not operate as an underlease, but as an absolute assignment by the defendant to the plaintiff of all the defendant's iuterest in the farms, and that therefore the defendant, having no reversion left in him, could not legally distrain.

A demise by a tenant from year to year to another also to hold from year to year, is in legal operation a demise from year to year during the con- 
tinuance of the original demise to the intermediate landlord (Pike $\mathrm{V}$ Eyre). According to Curtis v. Wheeler, a tenant from year to year under-letting from year to year has a right to distrain; and per Pollock C.J., the above two "cases show that if a tenant from jear to year" demises for a term of year's, and the original tenancy from year to year" lasts beyond that term, such a demise is not an assigmment, but there is a reversion on which covenant may be maintained." (Oxley v. Jumes).

In Gecckie r. Monk, and D. I. Monk v. Geeckic, Rolfe B. ruled that if, whitst a tenant from year to year is in possession of lands under an agreement reserving a certain rent, he ayjees with lis landlord to pay an increased rent, this will not have the effect of creating a new tenancy. Where the occnpier under an agreement for a lease at a certain rent pays the rent, he becomes tenant from jear to jear on the terms of the agreement, and the landlord may distrain (Mann v. Lovejoy). This was also a case of replevin; and Hegan r. Johnson and Dunk v. Hunter were cited for the plaintiff in support of his position, that if the holding is under a mere agreement for a lease there can be no distress.

In Knight v. Bennett, the plaintiff occupied a farm according to the terms of an oral agreement (which did not fix the rent, but only the time of paring it) for a ten years' lease, which was nerer executed, and paid a certain rent for two years; and the Court held that he was tenant from year to year, and that the lessor might distrain for arrears according to the rate which the plaintiff had paid.

In another case between these parties, it appeared that by agreement, as rrell as by the custom of the comtry, the tenant was to hare the use of the bain and gate-rooms to thrash out his coin and fodder his cattle till the May-day after the expiration of his term. His term expired at Niehaclmas, and he was then restrained by injunction from carrying off the premises corn in the straw. In Janmary his landlord distrained a rick of coru on the premises, and it was held that the distress was ralid.

Bearean r. Delatany decided that a custom that a tenant may leare his ackay-yoing crop in the barns of the farm for a certain time after the lease is expired, and he has quitted the premises, is good; and the fandlord may distrain the corn so left for rent arrear after six months have expired from the determination of the term, notwithstanding the statute 8 Ame, c. 14, ss. 6 \& 7 . And see Lencis v. Harris.

It was lield in Nuttall v. Stannton, where a tenanl by permission of the landlord remained in possession of part of a farm after the erpiration of the tenaney, that the landlord might distrain on that part within six months after the expiration of the tenancy, stat. 8 Amme, c. 14 , ss. 6 \& 7 , not being confined to a tortious holding orer, or to the holding of the whole farm.

And per l'utteson J., in T'aylerson v. P'elers: "To bring a case within 
section 7 of the statute of Anne, the continnance of possession may be either tortious or otherwise. In Nuttall v. Staunton it was by permission, and in Bearan r. Delahay possession was continued under a custom. But to make the statute applicable there must be a keeping as the party's orm, to the exchnsion of other people. That fact is wanting here." In this case a cow and some pigs, of the ralne of $£ 1716$ s., were taken as a distress for rent due from the plaintiff for a farm and buildings. He had receired notice to quit on May 13, 1835, when his time of holding expired. The distress was put in May 22, and between those periods the plaintiff, who still remained, was asked by the incoming tenant, whose term had commenced, when he meant to leare. $\mathrm{He}$ said he did not know; but went away before the distress, leaving the abore animals on the farm. He did not ask permission to do so, nor did he on leaving state his intentions. The new tenant entered, but did not get complete possession till May 22. On that day, and before the distress was put in, he had possession of the whole farm, unless there was a continned possession by the plaintiff. A verdiet ras giren for the defendant; but the Conrt, who solely decided the point whether the distress made after the expiration of the term was justified by statnte $S$ Ame, c. 14 , ss. 6 \& 7 , ordered one to be entered for the plaintiff.

In the case of Pollit v. Forrest the Exchequer Chamber decided that a lessor cannot distrain under an agreement not under seal which gives him power to recover penalties by distress as for rent in arrear, thus reversing the decision of the Court of Qneen's Bench.

It was decided in the Excheqner Chamber, reversing the decision of the Court of King's Bench, that growing crops cannol be taken under the poucer to distrain for the arreas's of an ammily (Willer v. Green).

But in Johnson v. Fanlkmer the Court of Queen's Bench held that hany, conn, and stran', loose or in the stack, or in trusses, may be distrained for arrears by the grantee of a rent-charge, under '2 Will. \& Hary, cess. 1, e. 5, s. 8 , and stat. 4 Geo. II. c. 28 , s. 5 . Lord 1 Yenman C.J. said: "It was contended that this statule did not extend to distresses for such rents as that in question, but only to distresses for rent service properly so called; and Hiller v. Gireen was eited as an authority in favour of the plaintiff. In that ease growing crops had been distrained for arrears of an annuity, granted by a deed, containing a porrer to distrain for arrear's of the ammity, and to dispose of the distress in all respects as distresses for rents rescrved on leases for year's might be disposed of"; and it was held that thongh the powers given by statute 2 Will \& Mary, sess. 1, c. 5, would extend to such a case, the grantee of the ammity could not avail himself of the subseqnent statnte of $11 \mathrm{Gco}$. II. c. 19, introducing a new sulject of distress-the growing crops. 
Without at all impugning the anthority of that case, it is sufficient to obserre that it does not apply to the present. In that ease the party making cognizance relied upon statute 11 Geo. II. c. 19 , which is in terms limited to 'lessors or landlords': in the present, the defendant claims the benefit of the stat. 2 Will. $\&$ Mary, sess. 1 , c. 5 , which is more general. If there were any doubt npon this point, it would be remored by stat. 4 Geo. II. c. 29 , s. 5 , which gires the same powers of distress in cases of rents seck, as in cases of rents under leases, and would therefore entitle the distrainor for such a rent as that in question to all the powers given by the precedent statute, 2 Will. \& Mary, sess. 1, c. 5 , cren if not to those given hy the subsequent statute of 11 Geo.II.c. 19." The grantee of a rent-charge may also take goods of a stranger on the premises charged, as a distress for arrear's (it.).

By 11 Geo. II. c. 19, s. 8, it was made lawful for erery landlord, or person empowerce loy him, to distrain the stock or cattle on their tenants' premises for arrears of rent, and to seize all sorts of corn and grass, hops, roots, fruit, pnlse, or other product whatsoever, which shall be growing, and lay it up when ripe in barns on the premises, or conveniently near them, for the purpose of having it appraised and sold for the satisfaction of the rent. It was held in Clark r. Gaskarth that trees, shrubs, and plants grouing in a mursery ground and planted subsequent to the demisc, camnot be distrained for rent, and that the word "product" in this section applies only to snch products of the land as are subject to the process of becoming and of being cut, gathered, made, and laid up when ripe. By section 9 tenants are to have notice where the "goods and chattels" (which growing crops, according to Glover r. Coles, are considered to be, for the purpose of a replevin) so seized are deposited, and the distress of snch growing erops is to cease, if the rent be paid before it is ripe and cut.

At common law growing crops might be seized and sold under a fieri facias, and were protected from distress by the landilord, unless allowed to remain an unreasonable time upon the land. But, the general right being found to operate in many cases in a manner prejudicial to agriculture, the 56 Geo. III. c. 50 was jassed, in order that the execution of legal process should be so regulated as to be consistent with good husbandry, and the eflect and intent of covenants and agreements. This statute is in some respects restrictive of the rights which the execution creditor would have at common law, but in some respects it extends them. By section 1, no sheriff or other officer is to sell or carry off from any lauds any straw, thrashed or unthrashed, or any straw of crops growing, \&c., chaff, colder, turnips, tares, manure, compost, \&c., hay, grass or grasses, natural or artificial, tares, retehes, roots, or 
vegetables, ice, contrary to the covenant. By section 3 the sheriff may dispose of any crops or produce to any person who shall agrec in writing with snch sheriff, in cases where no covenant or written agreement shall be shown, to use and expend the same on the land in such manner as shall accord with the custom of the country: and in cases where any covenant or written agreement shall be shown, then according to it. By section 6 landlords are not to distrain for rent on crops or prodnce sold subject to such agreement, under the provisions of the act, nor upon any beast whatsoever kept or used upon the land for the purpose of consuming the produce under the provisions of the act, and the agreement directed to be entered into between the sheriff and the purchaser of such produce; nor on any carts or other implements of husbandry which snch purchaser may require. By section 7 the sheriff, \&c., is forbidden under any process whatsoever to sell or dispose of any clover, rye-grass, or any artificial grass or grasses whatsoever, which shall be newly sown, and be growing under any crop of standing corn; but by section $S$ the act does not extend to any straw, turnips, or other articles which the tenant may remove from the farm, consistently with some contract in writing.

The law relating to grouing crops seized under execution was dealt with by section 2 of $14 \& 15$ Tict. c. 25 , which enacts that in case all or any part of the growing crops of the tenant of any farm or lands shall be seized and sold by any sheriff or other officer, by virtue of any writ of fieri facias, or other writ of execntion, such crops so long as the same shall remain on the farms or lands shall, in default of sufficient distress of the goods and chattels of the tenant, be liable to the rent which may accrue and become dne to the landlord, after any such scizure and sale, and to the remedies by distress for recovery of such rent, and that notwithstanding any bargain and sale or assignment which may have been made or execnted of such growing crops by any such sheriff or other officer.

According to Owen v. Leigh, a tenant whose standing corn and grouing crops have been seized as a distress for rent before they were ripe, cannot maintain an action upon the casc under 2 Will. \& Wary, sess. 1, c. 5, s. 2, against the landlord or his bailiff for selling the same before five days or a reasonable timc have elapsed after the seizure. Such sale being wholly roid, the plaintiff sustained no legal damage from it, and las therefore no groind of action in respect of it. And per Abbott C.J. : "It was clearly competent nnder 11 Geo. II. c. 19, s. 8, for the tenant at any time before the corn was ripe to have tendered the rent due, and if after that the landlord had taken the corn, he might have been proceeded against as a trespasser." 
In Proullore r. T'uemlou, where a landlord seized and sold, under distress for rent, growing erops, which were taken away by the purchaser, and it appeared that the crops were sold for the full welue which they lrould have fetchel if sold al the moper time, and the rent proved to be duc, execeded the amount fur which the crops were sold, it was hehl in an action of trover by the tenant that he was entitled to nominal damages onlr. Lord Lymlhurst C.B. said: "One asks naturally, what is the damage the plaintill has sustained? The party making the distress is lawfully in possession, and has a right after a certain time to convert the erops to his own use. He has done that immediately, insteal of waiting till the proper time. Then, is there any rule of positive law which prevents his right to dednet the rent? Before these acts were passed, a party guilty of an irregnlarity in making a distress became a trespasser $" l b$ inilio. So here, reasoning from that, the defendant would lave been a trespasser. Then came the 11 Geo. II. c. 19 , s. 19 , which says that the party shall not be deemed a trespasser al initio, but the party aggriercel shall recover full satisfaction for the damage he has sustained ly an action on the case." By the express terms of this section the party injured by an unlawful act committed after a lawful distress, is only to recover to the amount of the damage he has actually sustained, and hence the measure of damages ras the diflerence between what the crops wonld have been sold for if the sale had been regular, and what they actually sold for, which in this case was proved to be more than their value (it.). Whre yoods distrained for rent are sold withoul an apmercisement, the measure of damages is the value of the goods mimes the rent (Biggins v. Coode). Growing corn sold under a furvifucius cannot be distrained for rent unless the furchaser allow it to remain on the ground an umeasonable time after it is rije (Peacocte r. Puris). Here a stranger became possessed of a crop of growing corn by purchase, at a sale under a $f$. $f a$, on which the landlord was paid a year's rent. The latter, before the corn was ripe, distrained it for rent due subsequently to the sale, and the distress was held ill.

Wharton r. Naylor decided that statute 8 Amme, c. 14, s. 1, malics it unlariful to rmove yoorls taken in execulion, without paying one year's arrears of $\mathrm{rcm}$ to the landlord; but does not invalidale the ereculion itself. Goods, therefore, so taken are in custodiuc leyis, and camnot be distrained on by the landlord for the year's rent; and they are equally in custodin lergis, for this prupose, whether they are in the hands of the sheriff or his rende. The principal question here was whether the growing crop so seized by the sheriff and sold to the plaintifl's could be distrained for antecedent rent, of which the sheriff and the plaintiff had notice, and 
which they neglected to pay. Palleson J. said: "The words of the stat. 8 Amne, e. 14 , s. 1 (which says that no goods shall be liable to be laken by virtue of any execution, unless the party at whose suit the execution is sued out shall, before the removal of such goods from off the premises by virtue of such execution, pay to the landlord of the premises rent not exceding one year), cannot be taken literally. The true construction is given in Riseley v. Ryle, by Parke B. The meaning is that the sheriff shall not remove the goods unless a year's rent shall be first paid. The seizure is lawful mimu facie; but if the goods be removed without payment of the rent, after notice that it is due, such remoral render's the whole proceeding unlawful as regards the landlord, and subjects the sheriff to an action on the ease at his suit. The goods, however, in the meantime, until they are remored, are in custodic legis. A bill of sale of the goods is not a remoral, as was established in the case of simallman $\mathrm{r}$. Pollarl. If indeed the sheriff receives the proceeds under such bill of sale, either from a stranger rendee absolutely, or from the execution creditor construetively, he being an officer of the Cont, will be compelled on motion to pay over a jear's rent to the landiord (West v. Hedlyes, Henchett v. Kimpson, and see (alcert v. Joliffe); but such bill of sale and receipt will not amount to a removal so as to subject him to an action. In the case of growing crops, possibly the sheriff may sell, either for a sum of money to be paid immediately, or for a larger sum to be paid on reaping and removing the crops; and in the latter case he could not be called upon by the landlord by motion to pay his rent until the time came for remoral of the crops. The landlord is in no way injured by this; for, if there had been no exeeution, and he had distrained the erops for his rent, under statute 11 Geo. II. c. 19, s. 8, he could not sell them till they were reaped, and must therefore wait for his money till that time. There seems, therefore, to be no reason why he should be held to be anthorized by the statute of Ame to do that which at common law he could not do, namely, to distrain goods in custoria leyjs, but rather that that act intended to give him protection through the liability of the sheriff, in lien of his right of distress, which is taken away by the seizure under a fieri fucius. This appears to be the reasonable construction of the statute of Anne in regard to goods of any kind seized by the sheriff, and it is more strongly so in regard to growing crops, which, althongh liable to be taken in execution by the cornmon law, were not liable to be distrained for rent until the statute 11 Geo. II. c. $19 . "$

The decision in Peacock v. Purvis was expressly in point, and governed Wright v. Deres, and the Court in fact considered that the only distinction was that the seizure in the former case was in April, and in the 
latter in September. In Wright r. Dex'es, a tenant's growing crops taken in execution and sold and remaining on the premises a reasonable time for the purpose of being reaped, were held not to be distrainable by the landlord for rent become due after the taking in execution. Such erops having been so taken, sold, and left on the premises, and the arrears of rent paid, pursuant to stat. 8 Amme, c. 14, s. 1, the landlord could not distrain them for rent subsequently due, on the ground that the purchaser had not entered into the agreement with the sheriff (to use and expend the prodnce in a jroper manner) directed by stat. 56 Geo. III. c. 50, s. 3. Nor was he entitled to presume, from the absence of such agreement, that the straw of such crops was sold for the purpose of being carried off' the land contrary to scet. 1. The question for the Court was, whether the plaintiff, by virtue of a sale from the sheriff, was entitled to the erops discharged from the landlord's right of distress for rent acerned due subsequently to the sale.

The sulject of an irregular distress was very much considered in Rodyers v. Parker, which settled that 11 Geo. II. e. 19, s. 19, only entitles a tenant to recover in an action for an irregularity in dealing with a distress where artual damage is provel.

A distress was taken for rent, and goods, instead of being retained for the five days, were sold a day too soon, for which the plaintiff brought an action; but no evidenee was given that the plaintiff had sustained any damage thereby, and a verdict for the defendant, under C'ressuell J.'s direction, was upheld by the Court of Exchequer on the authority of Rotlyers v. Parlier, as the 11 Geo. II. c. 19, s. 19, only entitles the tenant to recorer in an action for an irregularity in dealing with a distress where actual damage is proved (Lucas r. Tarleton).

A disliess cem only be by lave in respect of a fired ascertained rent reserved out of the land, and therefore where, as in Gurdner v. Willimmson, a lease of a homestead and tithes was granted at an entire rent, and it was roid as to the tithes, becanse it was not under seal, it was held that a distress for all arrear of rent was altogether unlawful, becanse there was no fixed ecrtain rent reserved in respect of the homestead.

In Morgyison v. Laty Glamis, where the defendant in replevin being the owner of land and also the lessee of the tithe, which had been commuted under $6 \& 7$ Will. IV.c. 71 , agreed by parol to demise to the plaintiff the land "tithe free" at a certain yearly rent of $£ 400$, and then entered and made a distress for one year's rent in arrear, it was submitted by the plaintiff's counsel, on the authority of the above case, that such agreement to demise was meant as a demise both of the tithe and the lands at that entire rent, and since the demise ras not by deel, the tithe did not pass; consequently there was no certain rent 
reserved in respect of the land for which the defendant could distrain. It was, however, held by the Court of Excheqner that although before the commutation such an agreement might have operated as an agreement to demise both tithe and land at that joint rent, yet the agreement being after the commutation, the words " tithe free" were surplusage, since by the 80 th section of that act, if the defendant distrained for the rent-charge, the plaintiff would be entitled to deduct the amount from his rent, and consequently there was a holding at a rent of $£ 400$, as alleged in the avowry.

Where a landlord distrains for lis rent, amongst other things, some privileged gools, he is a trespasser ab mitio only as to the goods which were not distrainable; and if the tenant pay's the amount and costs of distress, upon which the distress is withdramn altogether, the tenant can only recover in trespass, the actual damage sustained by the taking of those particular goods, and not the whole amount paid by him (Harey v. Pocock). It was urged upon the Court in Price v. Woodhouse, that, assuming the right to take a heriot is analogous to a right to distrain, this case put a wrongful seizure on the same footing as a subsequent abuse. But per Purke B. : "If a party having" is right of entry to take one heriot, enters and takes two, does he thereby become a trespasser ab initio, both as to the entry and also as to the seizure? Snppose a landlord enters for the purpose of distraining, and he takes certain distrainable goods, and also some chattels not the subject of a distress, would that make him a trespasser ab initio as to the entry, or only as to the seizure of the chattels? That question was not considered in Hurrey v. Pocock. Here the defendants by their pleas attempt to justify the entry and seizure of one horse as a heriot in respect of one tenement; and the other horse as a heriot in respect of another tenement. Then the construction of each replication is this: Thongh true it is you entered to take a horse as a heriot due for the particular tenement, yet at the same moment you took another horse not due for that tenement. To make the entry good, it must be good with reference to the seizure. That which is mimu fucie au election, is shown to be no ralid election in point of law, and the seizme of the other chattel renders the defendants trespassers $a b$ initio as to the entry, as well as the seizure of the chattels. The defendant may amend his pleas on the usual terms, by stating that Price died seised of two tenements, and that there was a custom to take a heriot in respect of each, and that the horses were seizerl as heriots for those tenements."

The proper remedy for tuking an exressice distess, is case upon the statute of Marlbritlye (52 Hen. III. c. 4); and a landlord is liable to some damages in an action on the case for an excessire distress, where 
the execss consists wholly in seizing growing crops, the probable produce of which is capable of being estimated at the time of the seizure ; but the measure of lamages is not the ralne of the erops, but the inconvenience and expense which the tenant sustains in being deprived of the manigement of them, or which he is put to in proenring sureties to a langer amomt than he would otherwise have been in replerging the crops (Piygott v. Birtles).

In Hemnie r. Blalie the Court of Queen's Bench liad down that "replevin is not maintuinable, mess in a cerse in which there has ben firet a tuling out of the possession of the orrner." If a mare in foal or a cow in ealf be distrained, and it brings forth while in the distrainor's ('nstody, replerin lies for the foal or calf (Bace. $\Delta \mathrm{b}$. tit. Replecin); and if animals force natme have been reclaimed, as deer in a park, an action of replevin will lie for them (Davies r. Poreell).

Section 11 of 56 Geo. III. c. 50, "To reynulete the sale of farming stocto lulen in erecution," chacts that no assignee of any bankrupt or insolvent debtor's estate, or mder any bill of sale, nor any purchaser of the goods, chattels, stock or crop of any person employed in husbandry, on lands let to firm, shall use or dispose of any proluce or dressing of such land in any other manner, and for any other purpose, than such bankrupt, insolvent, or other person so employed in husbandry ought to have ned or disposed of the same if there had been no bankruptcy, assignment, or sale made. The question in Witnot Bart. v. Rose was whether this section gare the plaintiff a right to prohibit the purchaser at an anction of a tenant's crop of hay or straw on the farm, from carrying it off the farm contrary to the terms of the lease. The Court held that it did give such power, and was not confined to purchasers of what has heen taken in cxecntion, and that the monsuit was wrong. And per Lord Camplentl C.J.: " Ridilywny r. Joord stefford is not an anthority on the construction of this section; it was not brought before the Court." The Bankruptey Law Consolidation Act (12 \& 13 Tirt. c. 106), which repeals statnte of (iro. IV. c. 16, and other statutes relating to bankruptey, has a similar enactment in section 111. And see also Mull v. Morell on the construction of this statute.

IThother a lemdlart may amere a condition that they shall be consumed on the jurmises, to the sale of the hany and steren of his tenant which he seizes under a distress, has been the subject of much discussion. In Abbry r. P'ethe the defendant having distrained the hay and straw on the premises of the plaintift, who held a firm under him, sold them subject to a condition, that the purchaser should consume them on the premises; the consequence of which was they produced less than if the sale had been absolute. By the terms of this lease, the plaintiff wats 
bound not to carry off the hay and straw grown on the farm. It was contencled for the plaintiff; that the selling of the goods subject to the above restriction was a wrongful act, and that the plaintift" was entitled to recover under the third count of this action (case for excessive distress) the difference between the price actually obtained, and that which might have been obtained if no such condition had been annexed to the sale. Muule J. was of opinion that no cause of action had been proved, and a rerdict was found for the defendant, with leave to plaintiff to move to enter a verdict for him on the third comnt. The rule was clischarged. Rolfe B. said, "It seems to me that the 56 Geo. III. c. 50 throws some light upon this point, for the srel sect. provides that on an execution against a tenant, the sheriff may dispose of the prodnce of the lanil to any person who shall agree in writing to expend it on the land according to the custom of the country, where no corenant or' written agreement shall be shown otherwise, according to such couencint or written agreement; and the 6 th sect. enacts that the landlord shall not distrain for rent on any such produce which shall have been serered from the soil and sold subject to such agreement." And per Lord Abinger : "When the landlord sells under a distress, he should sell no more than the tenant could himself dispose of."

In Frusher v. Lee the liay and straw were sold under a condition, that they should be consumed upon the land according to the custom of the comntry (Norfolk); and it was alleged that they had in conseqnence fetched inferior prices. Evidence was giren for the defendant to show that such was the custom of the country in the neighlourhood where the land lay; and Abbey v. Peteh was cited as an autlority that the landlord had a right to impose such a condition. Alderson B., in summing up, left it to the jury to say whether, according to the custom of the country, the lity and straw conld not be r'cmoved from the premises; and if so, whether under those circumstances the goods were sold for the best price. 'The jury fornd that such was the custom, but that the goods being sold subject to that condition did not feteh the best price; and upon the whole ense they gave a verdiet for the plaintifi, damages $£ 51$. A rule for misdirection after discussion was discharged by the Court of Exchequer on other points. Parke B. said, "There are two conflicting authorities on this subject. In the ease of Jones $r$. H(cmp), Patteson J. ruled at Nisi Prius that the landlord had no right to annex snch a condition to the sale. Mr. Richards mover for a new trial against that ruling in this Court, on the 25 th of $A$ pril, 1840, and the rule was refused on that point. 'That case was not referred to in Abbey r. Petch. It must therefore still be considered as a disputed question." Alderson B. also expressed himself much inpressed with 
Mr. Kelly's argument at the trial against the decision in Abbey $\mathrm{r}$. Petch, that the landlord may sell it subject to such consuming condition. 'That argument was to the effeet that, if that cuse were law, the land. lord would have the power of authorizing any number of persons to come upon the laud for depasturing the hay and straw during the ocenpation of the tenant.

The facts of Roden v. Eyton were as follows: the plaintiff had been tcnant of a farm, which he quitted at Lady-day, 1847, leaving thereon three ricks of corn, his property. By the agreement moder which he lield the farm, he was bound to consume all the straw, \&c., gromn on the farm upon the premises. The defendant seized the largest rick as a distress for $\& 39$ arrears of a rent-charge, imposed upon the premises under the Tithe Commutation Act, caused it to be ralued by two persons who were not professional appraisers, and sold it upon the terms of the purchasers, leaving the straw on the farm. The agreed value of the straw was $\mathfrak{E}: 0$, and of the wheat when serered from it, $\stackrel{2}{2}$. There was no evidence as to the ralue of the other two ricks. The plaintiff insisted that the defendant had no right to sell the wheat, as he did, apart from the straw; while the defendant contended that the tithe owner was justified in acting upon the condition under which the plaintiff had held the farm, and relied on Abbey r. Peteh. Platt B. acting on that authority directed the jury to find for the defendant, with leare to more to enter a rerdict for the plaintiff on the second count (excessive distress), with nominal damages, if the Conirt shonld be of opinion that the sale onght to have been unconditional. T'he Court refused the rule, and merely decided that the seizure under the circumstances did not constitute an excessive distress. Irilde C.J.said, "It appears the entire value of the rick here seized was $£ 62$, the value of the wheat leing $\& 42$, and that of the straw $\$ 20$, and the claim in respect of which the seizure took place was 239 . 'The value of the other ricks did not appear. 'There being a question whether' the straw conld be legally sold, inasmuch as the tenant was under covenant with his landlord to consume all the hay and straw upon the farm; the tithe owner seized the whole rick (which being an entire thing I think he was justified in doing $)$, and sold the wheat only, leaving the straw npon the land to be enjoyed by whocrer micht be legally entitled to it. Looking at the amount of arrears, and at the value of the rick, I think it is impossible to say the distress was unreasonable." In reference to Abbry r. Petrh his lordship observed, "It ecrtainly does seem to be a startling proposition to say that the distress may be sold sulject to its leeing used upon another man's premises. But how is that case any authority where the straw is not sold at all, but expressly required to be 
Left upon the premises? It being a disputed question whether the straw could be sold or not, the defendant sells that which he has a right to, and leares the rest."

Ridgruay v. Lord Stafford overruled Abbey $\nabla$. Petch. It was in case for excessive distress, the fifth count charging the defendant with selling the pleintiff's hay and manure under improper conditions and restrictions, and for less than the best prices. The plaintiff was tenant to the defendant under a lease, by the covenants of which the plaintiff was bound to consume all the hay and manure on the premises made thereon. The defendant had distrained the hay and manure, and sold it subject to this condition, and the sale had in consequence of this condition not realized the amount it would if it had been absolute. The defendant under Not guitty contended that he was justified in selling the goods on such terms, and leave was reserved to defendant to move to reduce the rerdict from $£ 16615 s$. to $£ 2615 s$. Pollock C.B., in refusing a rule, said, "The question raised on the motion made to rednce this rerdict was this, viz., whether when crops are taken as a distress, upon the farm of a tenant, who is bound by the corenants of his lease to expend such crops upon his farm, the crops ought to be sold with reference to that covenant; and whether if they are so sold, and on that account fetch, as they naturally would, a much lower price than if sold without such a condition, the landlord so seizing and selling them is liable to an action for not selling for the best price. We think that in this case there should be no rule, as we are of opinion that the effect of the decisions upon the subject make the proposition plain." "Ou the whole, therefore, we consider it to be decided that the sale of such produce, if it take place at all, ought to be irrespective of any covenants to expend it upon the premises. A covenant to expend the produce on the land is a covenant that cannot run with a chattel, and it is quite plain that the tenant himself would have the power to sell without such a condition, but would only be liable to his landlord for a breach of corenant. If, therefore, he clearly might send the goods to market, and sell them, the landlord who seizes the property must sell it in the ordinary way, and for the best price."

Where the defendant received a certain sum from the plaintiff for a personal chattel, which both parties knew to hare been brought under an execution, and the plaintiff was presented from taking possession of it by a third party, who claimed meler a superior title, it was held by the Court of Qneen's Bench that under such circumstances there was no implied warranty of title by the defendant, and that the plaintiff could not recover back the price paid by him, as upon a failure of consideration (Chamman v. Speller). The true consideration here was the assign- 


\section{NON-DELIVERT OF GOODS SOLD AT SHERIFF'S SALE.}

ment of the right, whaterer it mas, that the defendant had acquired by his murchase at the sheriff's sale, and that had not failed. But quecere whether the rendor of a persomal ehattel is bound to refund the price if he has no title (ib.).

The run-delivery of youls suld at "t sheritf"s sule was much considered by the Conrt of Queen's Bench, in Wool r. Mantey, where the plaintiff's landlord distrained on him for rent, and seized some hay which was sold on the premises. The conditions of the sale, to which plaintiff was a party, were that the purchasers might let the hay remain on the premises till the next Lady-day, and come on the premises when they liked to remore it. The defendant purchased some hay, and on Jamuary 26th the flaintiff served a notice on him not to commit any trespass on the plaintite's premises; and in spite of a written demand, accompanied with the threat of an action, refused to let him hare it. Accordingly, on March 1st, the defendant broke open the gate and earried the hay away. Frokine J. told the jury that if the plaintiff assented to the conditions of sale at the time of the sale, this amomnted to a licence to enter and take the grods, which licence was not rerocable, and he therefore directed them to find on this issue for the defendant, if they thought the plaintiff' had so assented. 'The Court refused a rule for a new trial. They considered the licence so far executed as to be irrerocable equally with that in Taylei v. Trales's.

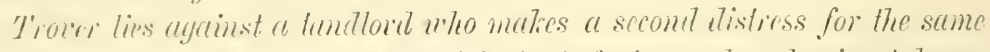

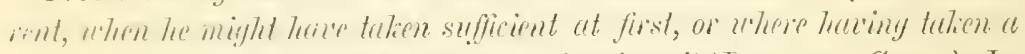

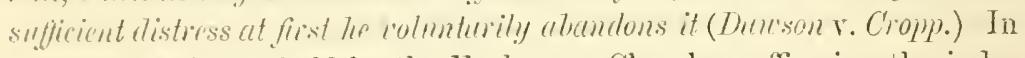
Lere c'ooke it was held by the Exchequer Chamber, affirming the judgment of the Court of lixehequer, that if there is a fair opportanity, and no trigal rause why a distrainer stould not worti out payment by mears of a simyle distiess. it is his duty so to work it out, and he camnot tanfully distruin aygain; but if the purchaser of the goods distrained is prevented from getting them by the wrongful act of the distrainee in converting them to his own use, and has never had an opjortunity of getting them, a sceond distress is lawful.

In this case the defendant (one of the fencral 1)rainage Commiscioncrs) distrained a stack of the plaintifr's standing upon his land; ancl whilst still standing there, it was knocked down to one Leverton at an anction. It was a condition of the ready-moncy sale that purchaser's should remore lots at their orrn expense, take possession, and pay at the fall of the hammer, or with the auctioneer's permission at the close of the sale. Ifter the sale the anctioneer left the stack for the purchaser to take amay; but lie dicl not do so then. Upon his going to the premises four days afterwards with his cart for that pmrpose, the plain- 
tiff, who at the sale had said, "It wonld be one thing to buy the stack, and another to take it array," assaulted him and prevented him from removing it, and kept and converted it. Leverton never paid the price; but the jury fomd that he had nerer had at any time after the sale an opportunity of taking the stack away; and mpon these facts it was held that the distress having been rendered abortive by the wrongful acts of the plaintiff, a second was lawful. Wightman J. thus distinguished it from Bagge v. Mauby: "There the creditor, who subsequently became assignee under the bankruptey, had merely threatened the landlord to hold him accountable if he proceeder with the distress, and the landlord mpon the threat withdrew. If no more than that had been done here, the case wonld have come within the prineiple of that decision; bnt here the plaintiff has converted the distress to his own use, and deprived Leverton of it for erer."

Unregistered transfer of groumy crop yood against exceution creditor.A creditor having agreed with his debtor to take a growing crop in satisfaction, and the detitor having given him a receipt for the amount of the debt as if for money paid on a sale of the crop, and the creditor having taken possession, it was held by Mrightman. J., that the transfer though not registered was good as against an execution ereditor (Nenman v. Ceurdinal).

Interpteader.- There an execution has been levied, and a landord makes a claim upon the sheriff for rent, which the escention creditor has not expressly disputed, whether as regards the amount of rent due (on the construction of the lease), or as regards the liability of the property which lias been seized to distress, the sheriff is not entitled to an interpleader, at all events moless the landlord claims any part of the property; and semble that in no case where the claim is for rent can there be an interpleader (Batrman v. Famsurorth).

Distress an affirnation of tenancy.-A laudlord by distraining for rent affirms the continuance of the tenancy np to the day when the rent so distrained for became due. A tenant inder a lease at a quarterly rent of $£ 80$ payable quarterly, with a clanse for reentry if the rent should be in arrear for 21 days, was in arrear $\mathfrak{s} 60$ for three quartcrs at Michaclmas; for these arrears his landlord on October and took a distress, which on Oetober $16 t_{1}$ realised $£ 27$ 6s., leaving duc $£ 3214$. there being no sufficient distress upon the premises. On Norember 2nd, the landlord (under the Common Law Procedure Act 1552, s. 210) served a writ of ejectment. It was held by the Conrt of Common Pleas, that the landlord had affirmed the continnance of the tenancy mp to Michaclmas, and that as half-a-year's rent was not in arrear at the time the writ was served he conld not recover. And per C'uriam: "The 
statute 4 Geo. II. c. 28, s. 2 , for which the 210 th section of the Common Law Procedure Act is substituted, enables a landlord to proceed under it only in eases where there shall be half-a-year's rent in arrear, and a right to re-enter for the non-payment thereof, i.e. for non-payment of half-a-year's rent, see (Doe dem. Dixon v. Roe, 7 C. B. 134). In the present case, therefore, no right to re-enter in respect of the rent dne for the half-year which ended at Michaelmas conld be relied on, becanse it never was in arrear for 21 days. But it was contended that at all erents a complete title acerned on the 21 st day after the Midsummer rent hecame dne, and Doe v. Shane'ross (3 B. \& C. 752) was cited."

"That case certainly shows that in eases to which the Aet applies, the title accrnes at the time when the demand of the rent onght to have been made at common law. But the statute anthorises the service of the writ 'as often as it shall happen that one half-year's rent shall be in arrear ;' and in the present case, there was no such arrear at the time the writ was served. 'The case therefore is not within the Aet, unless the words 'shall be' onght to be construed 'shall have been.' But there is nothing unreasonable in supposing that the statute meant to confine its operation to eases where the tenant was six months in arrear at the rery time when the landlord had recourse to this statutory remedy. It is not, however, necessary for us to decide this point, becanse we are clearly of opinion that the plaintiff waived any breach of the condition of re-entry, which acerued earlier than Michaelmas, by distraining for the Michaelmas rent. Had the distress been confined to the rent due at Midsummer, it would not have waired the forfeitme for the non-payment of that rent, as appears by the case of Brewer v. Eaton (3 Doug. 230), which was eited for the plaintiffs. But the distinction is plain, that though a distress in respect of rent dne aceruing before the breach of condition is no waiver of it, yet a distress for rent aecruing after such breach, with notice of it, is a waiver of it, becanse such a distress affirms and admits the continuance of the tenancy up to the day when the rent so distrained for became due. If it were otherwise the plaintifls would by this action establish their right to the possession of the demised premises, and to deal with the defendant as a trespasser at a date anterior to Michaelmas, althongh the plaintiff's by their distress have treated the defendant as having been rightfully in possession as tenant up to that date" (Colesu'orth ame Another v. Spokes).

Sheriff not entilled to poundaye.-Where after seizure of goods under writ of execution, but brfore sale, the judgment and subsequent proceedings are set aside for irregularity, and the goods are therefore not sold, the sheriff is not entitled to poundage (Miles v. Marris).

Heasuie of damages in case of trespasser ab initio.-Where a landlord 
distrains for rent actually due in such a manner that he is throughout a trespasser $a b$ initio, and does not merely become such by reason of an irregularity subsequent to entry, the measure of damages in an action of trespass brought against the laudlord by the person so distrained upon is the full ralue of the goods taken, and the jury, in estimating the damages, ought not to make any deduction from such value in respect of the rent which was actually due. And per Blackturn J.: "Where a party sues for a taking of his goods, and the defendant had an interest in the goods, there is very little doubt that the defendant may deduct the value of that interest from the damages of the taking. That was, I think, the principle proceeded on in Proullove v. T'uemlow' (1 Cr. \& Mee. 326) and in Chinery v. Viall (29 L.J. N.S. Ex. 180). Here the landlord was a trespasser $a b$ initio, and did not merely become so by an irregularity after entry so as to be protected by the statute of Geo.II. The case of Keen r. Priest ( 4 H. \& N. 236) is clear against my ruling, and, as I now think, rightly so" (Alluck v. Bantell).

In the case of Grimuood v. Moss (7 L.R. C.P. 360). A lease of a farm contained a condition of re-entry for breaches of covenants which took place before the 24 th June, 1871 ; the lessors brought ejectment on the 21st July in the same year, but the writ did not clain possession as from an antecedent date. After the commencement of the action, but before trial, the lessors distrained for rent due up to 24th June, 1871. Held, that the distress had not waived the brcaches of covenant prior to 24 th June, 1871. 


\section{CHAPTER X.}

\section{HUSBANDRY COYENANTS-CUSTOM OF THE COUNTRY.}

'TuE lan will imply a promise on tenant's part to eultivate his farm in a liusbandlike manner, and according to the eustom of the country in which it is situated, muless the express agreement is inconsistent with the custom. When a custom of the comntry is proved to exist, it is to be considered as applicable to all tenancies in whatever way created, whether verbal or in writing, unless expressly or impliedly exeluded by the written terms themselves (Wilkins v. Irood).

The mere relation of landlord and tenant is a suflieient consideration for the tenant's promise to manage a farm in a good and husbandlike manner, and not to carry away any straw, dung, or compost, \&c., (Pouley r. Iralker). In assumpsit on a promise so to manage it, and according to the custom of the comntry, it is sufficient to allege the breach in the rords of the promise (Earl of Futmouth r. Thomas). And a count stating a contract by the defendant, to use the farm in a husbandlike mamner, is not supported by proof that he had agreed to manage it in a husbandlike manner, to be lept constantly in gretss (Samuderson r. G'riffiths). A breach of a corenant to enltirate according to the custom of the comntry is sufficiently averred, by stating that defendant did not so eultivate, withont specifying instances (Martyn adir. v. $(7 \pi c)$.

Where a declaration stated that the defenclants were tenants to the plaintiff from March, 1835, to Feluruary, 1837, and by reason thereof, it was their duty as such tenants to cultivate the farm in a good substantial manner, according to the custom of the country, the pleas of Not gruily and that the defendants were not tenants, \&e., modo ef forma $\hat{u}$, only put in issue a tenancy in faet, and therefore the defendants could not object to the non-production of a lcase, which was required for the purpose of showing a tenancy inconsistent with the enltivation, according to the custom of the country (IIrallifar v. Chambers). On the eridence it appearcd that there had been a lease, which expired in February, 183f, and that the defendants held orer, and that the action was brought for mismanagement luetween February, 1836, and February, 
1837. And per Cwriam: "If the defendants intended to show that under the terms of a lease they were not bound to manage this farm according to the custom of the country, that should have been pleaded. The declaration merely states that the defendants were tenants, and that a "certain duty derolved upon them in that character; and no point is raised by either of the issues as to the lease, or the terms of the former holding." (ib.)

A tord of the manor, though he may bring a bill for an account of ore dug, or timber cut, by defendant's testator, may not bring one for ploughing up meadow or ancient pasture, or such torts as die with the person (Bishop of Winchester v. Knight). It was laid down in Johinson ๙. Goldsucaine, that irremediable injury is the only ground for the summary interposition of courts of equity, and that the ploughing np of ancient meadow was irreparable waste; but that carrying of the straw and manure which were to have been spent upon the land, was merely a breach of contract. If the breach of a covenant he assigned thus, "that the defendant had not used a farm in a husbandlike manner, but on the contrary has committed great waste, spoil, and destruction," the plaintiff camnot give evidence of the defesdant using the farm in an unhusbandlike manner, if it do not amonnt to waste (Haris $\mathrm{v}$. M(antle). Evidence was offered at the trial to show that the defendant had not managed his farm in a husbandlike manner, as he had not sown any clover or turnips on a certain proportion of it, according to the comrse of husbandry in Woreestershire. Heath J., who tried the case, thought, as the lease was not expired, this was not spoil or destruetion, and nonsuited the plaintiff, and the Court discharged a rule for a new trial without argument. Bufler J. said, on the former words of the breach, the evidence would hare been admissible; yet as the plaintiff had in the subsequent part of it narrowed it to waste, spoil, and destruction, it was not competent to him to give evidence of any other particulars, which did not come within the meaning of those words. And per Purke B.: "It is not waste at common lau', either witful or permissive, to leate the land mentivated. In order to oblige a tenant to farm according to good husbandry, you must either have some express contract, or some implied contract from the custom of the country" (Hutton v. Warren). A breach in an action by a landlord ag'ainst an outgoing temant, that the tenant threatened to commit waste, unless he were paid a certain sum by the incoming tenant, as compensation for plonghings, draggings, grass seeds sown, dung, \&e., and that the latter was thereby compelled to and did pay him that sum, in order to prevent his committing such waste, is bad (Leach v. Thomas). It was ruled at Nisi Prius by Lord Ellenboroung C.J. that it is wete for 
an onlyoing tenant of garden ground to plonyth up strauberry beds in fuil beariny, although when he entercel he paid for them on a valuation to the person who oceupied the premises before him, and although it may hare been usual for stramberry beds to be appraised and paid for, as between ontgoing and incoming tenants (Watherell r. Horcells).

Lord Eldon C.B., granted an injunction to restrain the defendant (the tenant of a farm) firom breaking up meadow for the purpose of building, contrary to the covenants of his lease, which were not to convert any meadow land, with all other nsual corenants showing that it was a tillage farm. A corenant to manage pasture in "lusbandlite mamer. is equiratent to one not to conecrt it into arable (Drury v. Molins). It is clearly established by several anthorities (Co. Litt. 53 a, Dyer 37, Hob. 231) that ploughing mentou land is ureste; and one of the reasons given is, that it alters the eridence of title, a reason which, as Timlal C.J. observed in simmons. v. Norton, "I am not disposed to treat lightly. It is also esteemed waste on another account; viz., that in ancient meadow, years, perbaps ages, must elapse before the sod ean be restored to the state in which it was before plonghing. The law, therefore, considers the conversion of pasture into arable as mima fucie injurions to the landlord on these two gronnds at least." It was uniformly held by Sir W. Jfac.Muhon MI.R. (Ire.) that in fee simple estates a continuance in pasture for 20 rears, during the life of the donor or testator, impresses on land the character of ancient pasture; but that if the period was less than 20 years, the case is open to evidence of intention, but not otherwise. It is not waste to plongh up land held nuder a lease, if the land was not ancient meadow or pasture at the date of the lease (Horris r. Morris). A tenant may not break up ancient meadow or pasture, though the land is mossy and requires tillage, and there is no covenant in the lease against doing so (Heitin r. Coyan). And per Sir WV. Muc Muhon M.R. : "The usnal form of the affidarit required to support an application for such an injunction, is that the land is ancient pasture or meadow, and has not been burned nor tilled for the last 20 years, and it is for the defendant to show that it ought not to be considered ancicnt pasture, by reason of its having been used in tillage previonsly to the date of his lease." Lord Mansfield C.J. ruled in Birch v. Stephenson, that souving clower with the spring corn does not constitute laying dou'n land in permanenl pasture, but it must still be considered in a state of tillage. And per Tindel C..J.: "Merely sowing common grass-secd does not make land old meadow again " (Simmons v. Norton).

Kinlyside v. Thornton decided expressly that a lessor may sue for waste in an action upon the case, although the lease contains a covenant upon which the lessor might maintain an action for the same wrong. 
And per Mutule J. : "Kinlyside v. Thornton (which was expressly recognized in Musketl v. Hill) shows that if waste be committed, the lessor may maintain an action on the case for it, and that it is no answer for the lessee to say that covenant also may be maintained. That case shows that the lessor may have either remedy. The authorities which are said to have shaken that case seem to me to have nothing to do with the matter. All they decide is, that where there is a contract under seal, you camot sue in respect of the same contract, as upon a contract not under seal" (Harker v. Kenrick). An action of waste for not using a firm in a tenant-like manner, is not within the meaning of $46 \mathrm{Geo}$. III. c. 66-Isle of Wight Court of Requests Act-(Wittam v. Ury).

Where a declaration slates a charge of roluntary w'aste, evidence of a permissive uaste is not admissible (Martin v. Gillam). The reversioner or remainderman may apply to Chancery to restrain the tenant in possession from waste, in all cases where it is punishable by law, and an injunction will be granted before the bill is filed. An injunction will be granted on an affidarit of waste to be committed by a tenant for life or years, or to inhibit meadow or other pasture not ploughed within 20 years being ploughed, but not against a lessee who agreed to pay $20 \mathrm{~s}$, an acre per annum increase of rent if he plonghed a meadow ; or to inhibit ancient enclosures being thrown down (Com. Dig. Chan. D 11). The Cout of Chancery will ancerd a perpetual injunction to restrain uruste by ploughiny, buming, breakiny, or souving of Doun lands, the effect of which, though it might be a present adrantage to the appellant for his short term of year's, woulit be a total destruction of all future benefit to arise from the Down, and for want of foldage for the sheep, would greatly damage and imporerish the arable part of the farm ( 4 Bro. Par. Cases, 377). An injunction has been granted where a tenant plonghed up a bowling green (2 Brown's Chan. Rep. 64), and also to prevent the land being sown with mustard-seed, or with any other pernieions crop (Pratt v. Brett), among which flar may perhaps be inclnded (Sarage v. Connor).

On a writ of waste for plonghing ancient mearlow, the defendant was not allowed under the general issne, mul uast, to give evidence that the ploughing was resorted to according to the custom of the comtry, for the purpose of ameliorating the mearlor, and it was held by the Court of Qneen's Bench, that if such matter were a defence at all, it must be pleaded specially (Simmons v. Norton). And per ('urium: "It is ouly where the waste happens by the hand of God, or the like (as if the snrface of the meadow had been destroyed by the eruption of a moss, or enemies had landed and dug it up), that the general issue is the proper plea. The general principle is clearly laid down in Barett v. Barrett; 
and though some exceptions are pointed out, yet with respect to the conversion of meadow into arable, no doubt is raised, but it is extremely doubtful whether such an injunction would now be granted either in the case of mustard seed or flax.

It camnot be llecided as a general moposition, without any exception, that the comersion of ancient meadou into arable is to be trated as waste, and hence the Court will not restrain an incumbent from ploughing up meadow infected with moss and weeds for the pnupose of laying it down again in grass when properly eleanod (Duke of St. Albons r. Skiquith). And qucere, whether a patron is in any case entitled to an injunction to restrain the incumbent from ploughing up ancient meadows, as in that case the course of hushandry enltiration must remain the same to all time (ib.). In Moskins v. Featherstone, where the Cont had previously interfered to stay the conrersion of glebe meadow into pasture, the bill was filed, not against the incumbent, but against the widow of an incumbent who was doiug the acts complained of during a racancy. Nergled to cultivete the glebe tand in a hushandlitie mamnos, is not a ditapialation for which an incumbenl can recover against the cxcentors of a prerious incumbent, as no such contract to cultivate it can be implied between him and his sncessor; there must be something of demolition to support im action for dilapidations (Birl v. Ralphe). And per Patteson J.: "The authorities show that such an action is maintainable, where the buildings, hedges, and fences belonging to the benefice are left in a state of decay, or where there has been a felling of timber, otherwise than for repairs or finel" (ik.).

Te break up a rabbil uctren for potato gromeds, unless it be a marren ly charter or prescription, is not waste at common law, and the Court will grant no injunction (Luiting v. Comm). Here the warren was demised simply as land, but the Master of the Rolls iutimated that if a lease was marle of a rabbit waren as a rabbit warren, the tenant might jurlars be considered as precluded from plonghing it mp. An injunction was grantel to restrain tenauts from year to year under notice to quit, as in the case of a lessee for a longer term, from cutting and doing damage to hedge-rows, and from remoring the crops, manure, \&e., cxcept according to the custom of the country (Onslour v. Eames), and sce Pultenry v. Shellon, and Lathrom v. Harsh.

In finymer v. Stome a demurrer to a bitl by a landlord for a specific jerformunce of rocenants rontained in a lease which had expired, to rejatip herderes and mansion-lyouse, to accomnt for loppings, toppings, and liederes which the defendant laad cut on the premises, or to account for the fodder or dung which he had removed, or to set up landmarks, stones and fences, was allowed; common covenants in hushandry not 
being the subject of equitable jurisdiction, of which a specifie performance will be granted. Lord Chaneellor Honley said, "How can a master judge of repairs in husbandry? What is a proper ditch or fence in one place may not be so in another." Where a tenant has committed breaches of covenant by waste, treating the land in an muhusbandlike manner, se., and been guilty of various breaches of covenant for which the lessor had a right of re-entry, he is not entitled to a specific performance of an agreement for a lease (Hill v. Barclay). And in Nesbitt v. Meyer specific performance was refused of an agreement to grant a lease for a term expired before the hearing of the cause, as the acts of waste, which were confined to the cutting down of 70 or 80 poles of the value of $£ 3$ in order to repair the fences, rrould not entitle the plaintiff, in an action on the corenants to be inserted in the lease, to more than nominal damages.

Where upon a parol agreement for a lease (the land, the rent, and the terms of years being certain) the tenant was let into possession, and the landlord received a sum of money from him for the stock on the farm, Sir J. Stucart T.C. decreed that the tenant was entitled to a specific performance of the agreement (Pain v. Combes). But if under an agreement for a lease the tenant files his bill for specific performance, and gross acts of waste and gross breaches of covenant are proved against fime, the Court will not grant a lease, the only effect of which would be to compel the landlord immediately to sue the tenant for breach of the covenants; but where the alleged acts of waste and breaches of covenant are explained or contradicted on the other side, the Court will not take such doubtful questions into consideration, as a reason for refusing a decree for specific performanec (ib.). A Court of Equity will not interfore generally to restrain an action of ejectment brought ageinst a lessee for breaches of corencent in the Tease, except for breaches in nonpayment of rent (Nokes v. Gitibons). And where a lessee covenanted to make certain drains, it is not an equitable ground of interference that he employed persons to make the drains, but that they did not do the work properly (ib.). It is laid down (Prec. Chan. 561) that where a man on a promise of a lease to be made to him, lays out money on improvements, he shall oblige the lessor afterwards to execute the lease, because it was executed on the part of the lessee; besides, that the lessor shall not take advantage of his own fraud, and run away with the improvements made by another: if no such expense had been on the lossee's part, a bare promise of the lease though accompanied with possession, as where a lessee by parol agreed to take a lease for a term of years certain, and continued in possession on the credit thereof, there being no writing to make out this agreement, it is directly within 
the Statnte of Frands, and will not be enforced. See also Wills r. Stratling. And per Lo:d Mactonald C.B.: "The condnet of a landlord in permitting and encouraging improrements under sanction of a lease, which he knew to be bad, may perhaps in equity give the lessee a claim against him for a new lease, though it does not at law amount to a confirmation or renewal of the old" (Harilcustle v. Shafto).

A tenant under agrement to manage amel quit the premises, ayrceably to the manner in which the same had been manuged and quitted by the former. tenants, is not bound by the terms upon which they held, withont notice of the existence and purport of the lease, and if he have no such notice he is only bound by the mode in which the landlord shall have permitted the former tenants to manage the farm, thongh they may hare been legally bound by stricter agreements (Lirbemrood v. Tines). Lorel Ellon C. said : "With regard to the question what is the custom of the country, that is one which has no place where there is a written agreement" (ib.).

In a lease for years of land, where the lessee corenants not to plongh pasture Tand, and if he does, then to pay after the rate of 20 s. per armum for erery acre plougherl, no injunction will be granted against the tenant's plonghing, for the parties themselves have agreed to the damage, and set a price for ploughing (Woolucard v. Giyles); nor will the ('onrt relieve the lessee against the penalty if he plonghs (ib.); and so in Forles r. C'urney. Where a farm was let subject to certain yearly payments, independent of the rent, in case the tenant should not crop, mannre, and manage it, in manner, specified and corenanted in the lease; and also in case the tenant during the last three jears of the term shonld som more than 70 acres of clover in one year, the additional rent of $£ 10$ an acre, for every acre above 70 acres for the residne of the term-it was leeld that the additional rents were in the nature of lirguidated damages, and not of penalties ; and therefore on a bill filed by the landlord for a discorery of breaches of the covenants in aid of an action at law, a plea that the discovery might subject the teuant to penalties was overmled (Jomes v. Cirren). And per Alerander C.B : "Since the case of Rentfe r. Patrison, it has always been understood in all eases between the landlord and tenant, whether the term used has been 'penalty;' or 'liquidated damages,' or 'additional rent,' or any other similar expression, that it shonld not be considered as a penalty in rorder to protect the defendant from answering, but as stipnlated danages or adlitional rent, and as entitling the plaintiff to a discovery of the transaction."

In Boures v. Wiron, the remlendem of the lodese, on which covenant was bronglit, was "rickling and paying therefore" to the lessor "the jearly 
rent or sum of $£ 100$," "to be paid by two equal half-yearly days of payment in the year," "and also yieldiny and paying unto" the lessor" on the said days, " "further yecorly rent or sum according to the rate of" $£ 20$ an acre, for converting grazing land into tillage without lieence, and also, "yieldiny and praying over" and above the stiul rent hereinbefore resered, according to the rate of $£ 20$ per acre," "for sowing any rape, woad, or potatoes, or above half an acre at one time of flax or hemp, or from which he or they shall have, get, or take more than three crops of corn or grain, in any one comrse of tillage, or from which shall be taken a second or other crop of wheat, withont making a clean summer fallow," \&c. Four breaches were assigned, and the defendants conteuded that it was the intention of the parties, that on the specified acts or defaults taking place, a penal snm should be paid, not an additional rent continuing to the end of the term. The Court, however, held that the intention of the parties undonbtedly was that efch of these sums should become payuble continually as additional rent, if the act or defanlt upon which they arose was once committed, and that the accidental onission of the term "further rent" in one of the clanses, while "yielding and paying" ran thronghout, left enough to show the necessary construction. And per Lord Ellenboromgh. C.J.: "In the ease of a corenant in a lease not to plough ancient meadow or the like, followed by a proviso that in case the same shonld be plonghed by the tenant thereof he should pay a certain increased rent for the same, it would certainly be in the option of the lessor to declare as for a breach of covenant not to flongh, or he may declare at once for a breach of corenant in not paying the stipulated satisfaction for snch ploughing" (Clerke v. Groly). And see Birch v. Stephenson; IIovell v. Richerds; and Denton v. Rirlemond.

In Farent v. Olmins, which was a case of covenant by lessor against lessee on al lefse reserving an inereased yearly rent of $\$ 50$ for ereply acre of rertain lends. comerted into tillerye, Abbott C.J. said, "If the argument that the Conrt ought not to disturb such a verdiet, hacause it is consistent with justice, were to prevail, it wonld encourage jurors to commit a breach of duty, by finding verdicts contrary to law, and would enable them to set aside the contracts of mankind. There certainly is nothing unreasonable in a landlord stipulating that partienlar lands shall not be converted into tillage at all, and that in ease that be done a large sum shall be paid by way of stipnlated damages. In this case there is an express contract for stipulated damages, and the jury have given a rerdict for arbitrary lamages." The increased rent to which the plaintiff was entitled, for the land converted into tillage, was $£ 1,550$; whereas the jury, contrary to the direction of Rirhaids 
C.B., who told them to find for that sum and half a year's rent for the land not laid dorrn for grass, returned their verdict for $£ 1,100$; and when requested to reconsider it, and specify low much was for repairs, (according to the corenants of the lease), and how much for the land, they stated that they found $£ 500$ for the repairs, and $£ 600$ for the injury done to the land. The rule for a new trial was made absolute, on the gromnd that they were bond to gire the increased rent. At the following assizes, Abrott C.J. refused to receive evidence that the actual damage to the land was less than the sum elaimed as increased rent; and the plaintiff recovered the increased rent.

The allitional rent was claimed in Gremslate v. Tapscolt.under peculiar cireumstances. There the lease contained a stipulation that for erery acre, and so in proportion for a less quantity of the land, which the lessec should suffer to be oceupied by any other person, without the conscnt of the landlord, an additional rent should be paid. The tenant undertook to use, necupy, dress, and manure the land accorling to the custom of the comntry; ami without the consent of the lamilord, sufferent othere nersons to use small portions of the land for sir monthe at a time, for the purpose of recising a potato crop. It was proved to be the custom of Somersetshire for the farmers to pursue that comrse, and after the potatoes were taken out, and the land delivered up in October, wheat was somn. The Court considered Lord Ellenborongh's decision in Doe dem. Pilt v. Laminy to be unsatisfictory, and held that the landlord was held entitled to the additional rent, this being an oceupation of land "lyy any other person." And per Pailie B.: "Such an occupation as this for 12 montlis would have conferred a settlement, and the party in occupation would be the only person entitled to maintain trespass for an injury donc to the possession."

A corenant in a furming lease not to sore any of the lands demised "with whent moire than onre in four years, nor with more than twe srops of any limet of yrein ullutsoever, during the same period of four years," was lichl to aplly to any four years of the term, however taken, and not to each sucessive four years from the commencement (Fleminy v. Shook). And in sterevstury (Earl of) v. Could, where a lessee covenanted that he wonld "at all times ame secsons of burning lime" supply the lessor and his Staffordshire tenants with lime at a stipulated price for the improrement of their lands and repair of their houses; it was held that this was an implied covenant also that he would burn lime at all such feasons, and that it was not a good defence to plead that there was no lime burned on the premises, ont of which the lessor conld be suppliced.

In Bron:n r. Crump, a declaration which stated that in consideration 
that the defendant hal become tenant to the plaintinf of a farm, the former umderlook to matie not less than thity acres of fullow', and to spend $£ 60$ worth of manure ammeally, and to keep the buildings in repair, being allowed timber in the rough, was held bad on general demurrer, those obligations not arising out of the bare relation of landlord and tenant. Gibbs C.J. said, "The doctrine which I have often heard Mr. Justice Buller lay down is, that every tenant, where there is no particular agreement, dispensing with that engagement, is bound to cultivate his farm in a hushandlike manner, and to consume the produce on it ; this is an engagement which arises out of the letting, and which the tenant camot dispense with, unless by special agreement; but it does not follow that a tenant shall be bound to have a certain portion of land every year in a certain tillage."

In an action against a tenant, on promises that he urould occumy the farm in a good and husbandlite manner, according to the custom of the comtry, the allegation that a tenant has treated his estate contrary to good husbandry and the enstom of the country (Cheshire) is proved by showing that he had treated it contrary to the prevalent course of good husbandry in his neighbourhood, as by tilling half of his farm at once, when no other farmer tilled more than a third, and sowing nearly half of that with wheat (Legh v. Hevitt). But evidence of a breach of corenant by mismanagement in overeropping or by deviating from the usual rotation of crops, is inadmissible in ejectment by landlord against tenant, where particulars of breaches delivered are for selling hay and straw off the land, removing manure, and non-cultication (Doe dem. Wimall r. Broal). And per Ceriam: "Orercropping does not come within the ordinary meaning of the term 'non-cultivation,' which means leaving the land to go to waste" (ib.).

In Angerstein r. Hemdson the declaration stated that the defendent undertook to cultivate and manage the form und lands aceording to the course of yood hushandry and the custom of the country where the farm was situcte, and then averred that according to the conrse of good hisbandry and the custom of the country, the defendant onght to have had about one-half only of the arable land in corn, one-fourth in seeds, and the remaining fourtl part in turnips or fallow. That was an averment of the custom; and the breach alleged was that the defendant had more than one-half of the arable lands in corn, had not one-fourth in sceds, and less than one-fonrth in fallow or tumips. The defendant trarersed the cnstom in the same terms as it was alleged in the declaration, and the jury found that the custom was not as the plaintiff alleged, but that there was a different custom; and that the farm had been cultivated contrary to the course of good husbandry in the neigh- 
bomlioud. The Court held that the plaintifl had tied himself up to the precise custom as alleged in the decluration, and having failed to prove it was not entitled to recover.

Where the declaration. as in Harfley r. Burkth, charged the defendant, as tenant to the plaintiff, with carrying array in an untenantable mamer, and contrary to the custom of the comintry, seiveral loals of hay off the farm without bringing luek and spentiny on the pecmises an equal mumber of loculs of dumy, the plea that there was not any such eustom of the country (which the plaintift contended was bad as amounting to the general issue) was helel to be good. 'There was a covenant in Richards r. Btack to spend the grem crops on the lands, or to bring back for every sucli ton of green arop sold ofl, a ton of good stable manure within three months. 'The plaintiff set ont the first part only, and assigned for hreach that the defendant carried away fourtecn acres of turnips without converting the same into manure and spreading it on the demised premises. It was objected that there was a material rariance betreen the corenant in the declaration and that contained in the lease, and the Court considered that the judge was right in refusing to amend, and that the covenant being an altemative one, the plaintiff should have negatived the bringing back, within the time limited, an equiralent in manure.

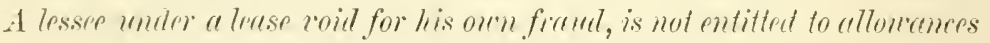
for lesting improrements (Pipre v. Webl). But where, as in AttorneyGement r. Prefymen, an order was made in al suit that the master of a charity should be at liberty to let a farm to the old tenant for twentyone real's at a rent of $\$ 800$ a-rear, and the lease had been approved of ; but before it had been exeented by the master, an offer was made of an increased rent of $\$ 220$, the tenant in the meanwhile having laid ont $£:, 92512 s .1 \%$. in artificial manures and improvements on the faith of such future lease; the Jaster of the liolls held that the offer of such an increase of rent as $£ 220$ could not be refused (supported as it was ly the raluation of four land-agents and surreyors), but that the old tenant was entitled to be sared harmless, and have an allowance for his outlay, if he did not make fresh proposals for a lease on the same terms. In Whitulier r. Berlier a bargain was made between the defentant and the plaintiff that the latter should take the farm for fourteen years, and pay $\$$ :) at coming in for tillages, and receive compernsetion at quitfing

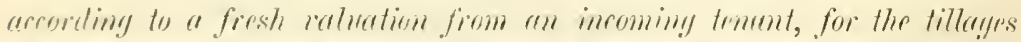

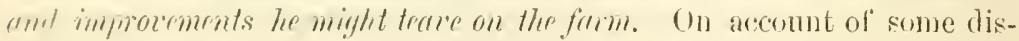
pute, the tenant, withont making any new bargain as to the tillages and improvements, said he wonld quit at the end of the year, and the Jandlord said he might, and the Court considered that as such quitting: 
was not a quitting under the terms of the tenancy, but in reality a running away, the landlord was entitled to possession, without making him any compensation for the tillages and improrements he left on the farm.

In Cleghom r. Durrant, the tenant of a farm contemplating taking a lease and penting negotietions for the same, beiny desirous of currying out certain thatching and draining improcements, and anxions as to repayment of them, wrote thus to her landlord- "I should feel obliged if you would send us a rough draft of the agreement at your earliest conveniance, as I do not feel comfortable to proceed with the vecessary improvements of thatching the barn and draining the land, \&c., without some little assurance from you that we are acting safely." The landlord replied as follows-" I will send you a copy of the lease next week, and trust you will make yourself comfortable as to the thatching of the barn and the draining, \&c.; I will pay for the thatching and draining if we do not come to terms; but as the covenants will not be unnsual, I trust there will be no necessity for that." The tenant, who was uuder notice from the litndlord to quit at the end of the half-year, declined continuing tenant of the farm nnder the terms of the new lease, an event for which no provision had been made in the correspondence, and the landlord, on the determination of the tenaney, bronght his action for the half-year's rent. The tenant pleaded by way of set-off; the money she had paid for thatching and draining, and paid into Court the balance of the landlord's claim; and it was held by the Court of Common Pleas, on the interpretation of the correspondence, that the defendant was entitled to set-off against plaintiff's claim for rent, the money she had expended on the said improvements.

The question of the atstom of the country as to paying for lillages betueen the out-going and in-coming tenant, was very much considered by the Court of Exchequer in F'aviell v. Gaskoin, which was an action in assumpsit to recover the amount of the usual valuation paid by an incoming tenant for fallows, half fallows, dressings, \&e. 'The defendant's testator being in possession of an estate, of part of which he was the owner, and another part Crown lands, on a lease which was to expire on the 10th of October, 1849, contracted with the plaintiff to sell to him his part of the estate, and demised to him the Crown lands for one year from the 29th of September, 1848. 'The plaintiff agreed to keep all the Crown lease covenants, and the testator agreed that in case he could get a further lease from the Crown for fourteen years, he would grant to the plaintiff a lease for thirteen years, subjeet to the same covenants. On February 2 nd, 1849 , the plaintiff signed a memorandum agreeing to take (with others) the Crown lands, "subject to the same rents, corenants, and obligations in all respects," as were contained and 
provided for in the leases, by which the testator held or should hold the same. The plaintiff, on taking possession in the course of that month, paid to the defendant's testator, aceording to the custom of the country, the amount of the raluation, $£ 2,23319 s$, for fallows, dressings, \&e., as well of the other lands as of the Crown lands, which latter only amounted to $£ 240$. By the terms of the Crown lease, the custom of the country as between landlord and out-going tenant was excluded. At the desire of the phintiff the Crown lease was not renewed, and the plaintitr gave np possession of the Crown lands on the 10th of October, 1849 , when he claimed as out-going tenant to be paid for fallows and dressings, \&c., aceording to the custom of the country. The defendant objected first that the custom of the country was excluded by the terms of the contraet, and secondly that, if not, the enstom did not include a case where the term was detemined by the expiration of the landlord's interest.

It was also objected that there was no obligation on a landlord to pay according to the eustom of the comtry. Jervis C.J. left it to the jury to say whether the custom for a landlord to pay the out-going tenant was proved; and the jury having found in the aflirmative, his Lordship, directed a rerdict for the plaintifl, reserving leave for the defendants to move to enter a verdict for them, if the Conrt sinould be of opinion that on the construction of the documents the enstom of the country was excludul by the agreement between the parties. The rule was discharged, and the Court held, first, that the custom of the country was not excluded hy the arreement; and that where such a custom exists there is an implied contract on the part of the landlord, that if there be no incoming tenant, lie will pay the out-going tenant according to the eustom; but semble that such a eustom does not apply to eases where the term is put an end to lyy the determination of the landlord's interest.

Parle B. said: "The plitintiff" was to indemnify the testator as to all covenants which lie had entered into with the Crown. The latter receircel the amount of viluation from the plaintiff as in-eoming tenant, and is bound to pas him. The agreement does not cxelude the custom of the country. It merely contemplates a lease which would expire on the 2sth of September, 1ऽ19, so that the time of quitting is not the same as under the Crown lease. The obligation created by taking this particular property literally turns out to be nothing more than a demise for a year, and the custom of the country applies to that." And pre Aldrerson I3. : "The plaintiff" agrees to take the whole of the lands, and he stipulates that he will sare harmless his landlord from all corenants cntered into betreen the latter and the Crown. But there is nothing 
in such an agreement inconsistent with the custom of the country." Martin B. added: "I am of the same opinion. With respect to the second point, the meaning of such a contract is this, that at the time the tenancy commences the landlord and tenant enter into a special contract, the one to receive and the other to pay the value of the tillages, to be repaid by the landlord at the expiration of the term. That is as much a part of the terms of the tenancy as if it were contained in the lease itself. It is true that in ninety-nine cases of a hundred a new tenant comes in and takes the tillages for his own profit, and so becomes a debtor to the out-going tcnant; but still the landlord is liable upon his special contract; and the in-coming tenant is liable in inclebitutus assumpsit by reason of his taking the benefit of what was left. Then as to the other point, the truth is the rerdiet is conclusive. The agreement does not exclude the custom of the country. That Mr. Clode's (the testator's) intentions were is not material: it may be that he never wonld have entered into this agreement if he had known its effect; but the jury have found that the custom of the comntry existed."

According to Tromerstey v. Dally, assigners of the reversion may be sued by an out-goiny tenant, on a contract or custom of the country, by which he is entitled to receive, on the termination of his tenancy by notice from the landlord, reasonable allowance for the value of labour bestored on the land, and the benefit of which he loses by such termination of his tenancy, although he has paid all the rent to the original landlord, and received notice from him, the assignees having renewed the notice after the conveyance to them, and possession having been given to them. And a stipulation in a contract of tenancy, that the tenant shall kecp a certain proportion of the land demised for grass, and pay so much per acre for any deficiency below such proportion, is extinguished by severance of the reversion; and tenants in common, assignees of the reversion on a lease, may join in sning, and be jointly sued on covenants thereon (it.).

The rule of lau" as to importing into the terms of the tenancy "the custom of the country," dors not admit of eivitence of the usage of a particular estate, or the property of a particular individuat, however extensive it may be, it not being shown that the teuant was aware of it (Iromersley r. Dally). The Conrts have always inclined farourably to the introduction of those regulations in the mode of cultivation which custom and usage hare established in each district to be the most beneficial to all parties. Hence a custom that tenants, whether by parol or by deed, shall have the arcay-yoing crop after the expiration of their term, was upheld in Miglesurorth $\mathrm{r}$. Dallison, which was aflimed on a mrit of crror. 
This was an action of trespass for mowing, carrying away, and converting to the defendant's own use, the corn of the plaintiff on Hibaldstow Lers, in the county of Lincoln. Dallison pleaded liberum tenementum, and the other defendant justified as his servant. To this the plaintiff replied that there was a laudable eustom within the parish of Hibaldstow, that erery tenant and farmer of lands within it, whose term expired on the 1st of May in any year, had a right to take his aucay-going crop; and the custom was found in the words of the replication. A motion was made to arrest judgment, on the ground that such a eustom might be good in respect to parol leases, but could have no legal existenee in the cases of leases ly deed, but the Court of King's Bench diseharged the rule. Lord Hansfielet C.J. said, "We have thought of this case, and are all of opinion that the custom is good. It is just ; for he who sows ought to reap, and it is for the benefit and cncouragement of agriculture. It is, indeed, against the general rule of law concerning emblements, which are not allowed to tenants who know when their term is to cease, becanse, it is held to be their fault or folly to have sown when they knew that their interest would expire before they could reap. But the enstom of a particular place may rectify what otherwise would be imprudence and folly. 'The lease being by deed does not vary the case. The custom does not alter' or contradict the agreement in the lease ; it only sujeradds a right which is consequential to the taking, as a heriot may be due by custom, although not mentioned in the grant or lease."

The question subsequently eame nnder the consideration of the Court of King's Bench, in the case of Senior v. Armitaye, where a custom for the tenant of a farm in a particular distrirt to provide nork and Tebour, tillage, souring, and all materials for cultivation in his areay-yoing year, and for the landtord to make him a reasonable compensation for the same, was held to operate notwithstanding the farm is held under a written agreement, unless it can be collected expressly or impliedly from such agreement that the partics did not mean to be governed by the custom. Puik B. observed, in Ilullon v. Warren, that from his perusal of Mr. Jnstice Bayley's manuseript notes of the case, Mr. Holt had stated it too strongly when he said that the Court lield the custom to be operative, unless the agreement in express lerms "exchuded it," and that their decision was to the effect that, "though there was a written contract between landlord and tenant the custom of the country would still be binding, if not inconsistent with the terms of such written contract; and that not only all common law obligations, but those imposed by custom, were in full force where the contract dil not rary them." The castom in Senior. v. Armitery prevailed only in the neighbourhood 
of the plaintiff's estates; and there was no doubt about its existence, as the defendant had, on the evidence, paid the amount of a former valuation under it to the tenant of this very farm.

When the tenancy of a farm expires, the tenant must give up the possession of the whole of it to the landtord, crops, and everything else, unless there be a custom of the country for the tenant to hold over any part, or to take any of the erops; and the proof of the custom lies on the tenant-per Parke B. (Catdecott v. Smyllies). But it, was held by the Court of Exchequer in Griffiths v. Puleston, that where it appeared that by the custom of the country as between outgoing and incoming farm tenants, the former was entilled to a way-going share of the crop of uheat soun by him in the last year of his tenuney, and that he cut the whole of such crop, and kept the fences of the field in repair till the whole crop was ent and earried away, he had under such cireumstances the possession, in law, of the field until the crop was carried away; and that therefore the vendee of his share of the crop had a good defence, under not possessed, to an action by the new tenant for breaking and entering: the close in which the erop grew, for the purpose of carrying it away. Parke B. said, "The outyoing tenant remains in possession unlil all is done which he has a right to do in respect of the crop, not merely until the cutting. The case of Bevan v. Delahay is a strong anthority to show that his interest amounts to a possession, and not merely to an easement. In that case there was a custom for the tenant to leace his way-yoiny crops in the barns and olher buildings of the farm for a certain time after his lease had expired and he had quitted the premises; and it was held that the landlord might distrain the corn so left after the expiration of six months from the determination of the term (notwithstanding 8 Ame, c. 14 , ss. 6 and 7). The obligation on the outgoing tenant to repair the fences is strongly confirmatory of this view of the case."

It was held by the Court of Exchequer that trover lies at the suit of a landlord for corn cut and carried axay by an outgoing tenant after the expiration of his term, though sown by him before that time, under the notion of being entitled to an away-going crop (Dacies v. Comop). Here the plaintiff, at the expiration of the defendant's term in Candlemas, 1813, had let the same lands to another by parol, reserving the land on which the wheat was sown, and on which, therefore, the new tenant did not enter. On the 25th of August, 1813, the plaintiff sent his reapers to cut it; but the defendant, who had sown a third part of the arable land with wheat, conceiving, as he said, that he was entitled to a way-going crop, came and turned them out, and then cut and carried away the whole. The court decided that the plaintiff had such a possession as enabled him to maintain trorer, principally on the anthority 
of Taunton v. Costur, where it was held that a tenant holding orer after the expiration of his term cannot distrain the landlord's cattle, which were put on the premises by way of taking possession. "Taking this," said Thomson C.B., "to be a crop growing upon the land, whether cut by the defendant or a stranger not being in possession, the moment it was severed it became the property of the landlord."

The Comrt of King's Bench held, in Boraston v. Green, that the incoming tenant hat nol such a possession as cnabled him to maintain trourer against the outgoing tenant, who had committed a breach of the custom of the comntry in not leaving one-third of the way-yoing wheat crop sou'n upon a clocer trush.

Where, by a clanse in a lease, it was agreed that in case the lenant should duty observe and perform the sereral covenants and ayreements, \&c. (one being for the payment of rent), and should peaceably (quit, \&c., on notice, \&c., he should be entitled to a way-going crop, which was to be left for the landlord or his incoming tenant at a valuation, it was held by the Com't of Excheqner that this clause did not give the tenant the right of possession as against the landlord after the determination of the tenancy, but that the tenant at most conld only go on the land for the purposes of a way-going crop, and conld not exclude the landlord (Strickland v. Mamedl). By the enstom of Herefordshire, an offgoing tenant is entitled to crop one-third of the arable land of the farm with wheat, which is called his odd mark, and to cut and carry it away after the tenancy has expired (Giriffths r. Tombs). And per Parke B., "A parol permission by the landlord to the outgoing tenant to sow more than his strict odd mark will be good as against the landlord himself, and therefore as against the incoming tenant." If " lease containing a covenant that the lessee, "at the expiration or other sooner determiuation of the term," shall take the offgoing cropl, is detemined by the order of the Lord Chancellor in Banliruptey, under the 49 Geo. III. c. 121, s. 19, the assignees are entitlcd to the offgoing crop ( In ire Darli). And if a lease is determinable upon notice at the will of the lessor or lessee, and the lessee covenants to leave, at quitting, the hay, straw, \&c., on the premises, the bankiruntcy of the lessee and the election of his assignees not to lake to the lease have the same effect with reference to the corenant as thongh the lessee had quitted npon notice (Ex parte Whitlington).

Where a tenant held from Lady-day in a county in which the enstom of waygoing crops prevailed on the regular expiration of a Lady-day tenancy, but the tenancy was delermined on June 1st, by an aucard made on reference of a dispute betueen landlord and tenant, it was held that the arard (which did not of itself change the property) was admissible in 
evidence on the part of the landlord, on an issue between the landlord and an execution creditor of the tenant, whether the crops on the land at a certain time were the property of the party so found to have been tenant, but that the custom had no operation in the case of a tenancy so determined (Thorpe v. Eyrc).

In Petch v. Tutin, where the leseanl of a farm, being indebted to his Tandlord, assigned to him by deed, amony other Ihings, "all the tenantright and inlerest yet to come and mexpired of him the said S. Petch in and to the said farm and premises, it was considered that the future crops must fall within the meaning of the wor'ds "tenant-right yet to come and unexpired." And per Alderson B.: "It is impossible to give effect to the whole deed withont holding that the 'tenant right' ineludes the way-going crop. As to the question whether it may pass by such deed, Grantham v. Hawley (where it was held that a party who has the interest in the land 'may grant all fruits that may arise upon it after', and the property shall pass as soon as the fruits are extant') is decisive."

The question us to whelluer the lemes of a lease exchule the cuslom of the rountiy, where the allourane clamed is not mentioned among others in such lease, was much considered in Webl v. Plummer. Here there was a lease of a Sonthdown farm, with a corenant to spend all the produce on the premises, and to fold a flock of sheep, under a penalty of $₫ 3$ cach time they were folded off the premises, or any other than the usual part of the farm; and also, in the last year of the term, to carry ont the manure on parts of the fallowed farm pointed out by the lessor, the lessor paying for the fallowing such land and carrying ont the dung, but nothing for the dung itself, and paying for grass on the ground and thrashing the corn. The claim was for an allorme for foldage, which the ontgoing tenant was entitled, by the custom of the country, to receive from the incoming tenant; but the Court of King's Bench held that, as there was an express provision for some payment on quitting for the things corenanted to be done, and an omission of foldage, the customary obligation to pay for the latter was excluded.

Bayley J. thus laid down the rule applicable to snch cases: "JVhere there is a written agreement betreen the parties, it is naturatly to be expected that it will contain all the terms of their bargain ; Int if it is entively silent as to the terms of quittiny, it may let in the custom of the country as to that particular. If, however, it specifies any of these terms, we must then go by the lease alone. The custom of the country applies to those cases only where the specifie terms are unknown; and it is founded npon this principle, that justice requires that a party shonld quit upon the same terms as he entered. If, therefore, the party when he entered upon the 
farm paid for a way-going crop, or for foldage, manure, fallowing, or tillage, then if the lease be wholly silent as to the terms upon which he is to quit, the custom may be introduced, and he may be entitled to receire for a way-going crop. foldage, \&e. Upon this ground Semior v. Armituye. was determined; for the lease there was wholly silent as to the terms of quitting, and the claim there was different from the present, being a claim for labour done by the ontgoing tenant, from which he conld not himself derive any benefit. Here, too, there is a specific contract to fold the flock upon the premises under a penalty. My judgment, howerer, is formded particnlarly on the last stipulation in the lease, by which the tenant is prohibited from carrying off the manure, and by which the incoming tenant is directed to make certain payments to lim; and if a lease speaks distinctly of the allowances to be made on quitting, it seems to me to exclude all others which are not named." And per Holroyll J., "The covenant in the lease that the tenant will fold his flock which he shall kecp, \&c., is linding on him to keep a flock and fold it on the usual parts of the demised premises." Best J. added that, "In Wigglesworth v. Dallison there were no sufficient circumstances to exclude the custom. Here the parties have made some stipulation as to the terms of quitting; and if they had intended that this or any other payment should be also made, they would have introduced them into the lease."

Parlie B. also observed on the latter point, in Hutton v. Warren, "No doubt could exist, in $W e b b$ v. Plummer, but that the language of the lease was equivalent to a stipnlation that the lessor should pay for the things mentioned, and no more." In Roberts v. Burker the principal question aces whether the words in the lease expressly binding the tenant to leare the mamure in the fold, to be expended on the land by the defendant (the landlord) or his subsequent tenant, withont making any mention of parment for it, ercluded the custom of the country for an outgoing tenant to leare and be pariel for such mamme; and the Court held that they did exclude it, and refused to engraft the custom to pay for the manure upon the engagement to leare it for the use of the sneceeding tenant.

All these cases were reviewed by the Court of Excherper in Hutton v. Wraren, where, by the custom of Iincolnshire, a tement was bound to

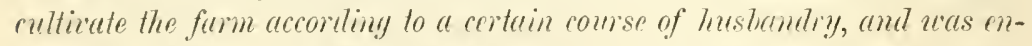
titled on quitling to a frir alloweance from the lendlord or incoming tenant for serds und labou bestowed on the arable land during the last year of the tenancy, and was obliged to leave the manme on the land if the landlord chose to purchase it. By the terms of the lease (in this instance original lease, which had long since rum out, between the fathers 
of the plaintifl and defendant, of the glebe land tithes), the tenant was bound to spend three-fourths of the hay and straw arising from the glebe lands, in the shape of manure npon them, and to leave the residue of such mannre for his successor or the landlord, on being paid a reasonable price for it. The defendant contended that the effect of the latter stipulation was to exclude the custom of the country as to the allowances for seed and labour on quitting, as the plaintiff must be considered to hold under the terms of the original lease, in which no mention was made of them. The plaintiff had sown the arable land for which the compensation was claimed after his notice to quit, in consequence of the defendant's insisting that he was bound to keep the farm in due course. It was decided that, in the absence of evidence to the contrary, the plaintifl' held under the defendant on the same terms as he had held by lease originally under his father, so far as those terms were applicable to a tenancy from year to year' and as the custom of the country as to cultivation and the terms of quitting with respect to allowances for seed and labour were clearly applicable to a tenancy from year to year, and as the custom was by implication imported into the lease, the plaintiff and defendant were bound by it after the lease expired.

Holdiny v. Pigott, which was an action by an outgoing against an incoming tenant, differed from Webt v. Plummer, in this, that there were no express stipulations in the lease as to the mode of quitting which could exclucle the custom, and hence the outgoing tenant was held to be cntitled to his way-going crop of one-half of the wheat sown after a crop of turnips, according to the custom of the country, though the terms of his holding were that wheat-land should be summer fallowed. The Court considered that Boraston v. Green, both in its decision and the reasons given by Lord Ellenborongh and Mr. Justice Buyley, went strongly to the principle that the laudlord would have his remedy by action for breach of covenant, and the tenant the wheat nnder the custom; and that if that was the conclusion, in case the landlord had taken to the premises at the expiration of the term, it must be cqually so at least where there is a new incoming tenant. Here the landlord laid no claim at all to the crop, and did not even insist upon damages for the breach of covenant; but the tenant, who was not entitled to those damages, set up the breach of covenant made with his landlord as a ground for diresting the outgoing tenant of the property in the coris, which he claimed under the custom.

The principles of the decision in Muncey r. Dennis are to be found in Holding v. Pigott. It was to the effect that, as under the custom of the comntry the tenant would have been entitled to be paid for the straw and manure on leaving, the covenant that the tencent should consume 
with stock on the furm all the hay, stran, and clower groun thereon, and containing as it did no provisions as to straw unconsumed on quitting, was not inconsistent with the custom of the country, and that therefore the plaintiff' was entitled to be paid for it. The action was brought to recorer 1310 s. from the incoming tenant, according to the custom of the comntry, for the ralue of straw left by the plaintiff, the outgoing tenant, at Michaclmas, 1854 , on quitting the occupation of two pieces of land, leased by one Flanders to the plaintifr. 'The lease containcd corenants by the plaintiff that he would cultirate the farm according to the custom of the country, and that "he should with the last wheat crop lay domn the same witlı 20lbs. weight of good clover-seed per acre, and continue the same so laid down for feeding, not to exceed three grounds belonging to the farms; and should and would during all the said term consume with stock on the said farm, all the hay, straw, and clover grom thereon, which manne should be nsed on the said farm: and that the said smith Flanders, his heirs and assigns, should and would allow the said Ellis Muncey to occupy half the rooms in the honse and the barn-yards and granary until Midsummer day after the expiration of the said term, if necessary, to end the cropping of the said Ellis Anncey grown on the said premises thereby demised." The defendant objected that cridence of the custom of the country (Cambridgeshire) was inadmissible; but the under-sheriff decided that he wonld admit it. 'The custom was proved to be that when an incoming tenant pays for' straw and manure, he is paich when he goes ont: when the dung belongs to the landlord, the incoming tenant pays for the thrashing, dressing, and carting to market, and lias for that the straw, cliafl, and colder; but when the dung belongs to the tenant, then the straw is ralued by the tron at a consmming price.

Gn taking possession of the furm, the plaintiff had paid for the hay, straw, and manne according to the former ralnation, and on his leaving the farm the straw was ralued by a person named by the de.cndant, who adnitted that le agreed to the rilnation "if it was lawful." "Ending the croppiug" was explained by one of plaintiff's witnesses to mean the harvesting and thrashing ont of the eorn, and so turning it into straw; but not consuming the straw. 'The plaintift' lad a rerdict for the amount claimed; and a rule for a new trial on the gronnd that the lease excluded the custom of the commtry was discharged. Pollock C.B. said: "The defendant's contention was that by the lense the plaintiff was bound to consume all the straw, and not to loive any, and that therefire he could have no right to be paid for any which lie did leare. But we think this is not the meaning of the clause. 'The meaning is that no straw shall be removed off the pre- 
mises. If the defendant's construction is right, the tenant breaks his covenant by leaving any straw, and therefore as the right of onstand does not apply to the consumption of the straw, he must keep his straw and cattle so nicely adjusted, that the last stalk is finished by the 11th of October, 1851, including that produced at the previons harvest, or he will be liable to an action, although it is certain that the consuming of the straw is a benefit to the consumer, and that it would be a gain to the succeeding tenant to have the straw left gratis for him, rather than the manure, its produce."

A covenant in a farming lease, that the lessee "shall not nor will during the last year of the term sell or remore from the lands demised, any of the hay, straw, and fodder which shail arise and grow thereon," prohibits the lessee from removing any of the hay or straw during the last year of the term, at whatever period of the term it nay have grown (Gale v. Bates, 33 L.J. N.S. Exch. 235).

An ontgoing tenant, on quitting his farm at Michaelmas, gave up to the incoming tenant, and the incoming tenant exercised it, the right he had under the lease of converting the straw on the farm into manure with his cattle from Michaelmas to Lady-day. 'The incoming tenant's cattle, in the process of so converting the straw into manure, ate a portion of strar calculated at one third of the bulk; the outgoing tenant is entitled to be paid for this by the incoming tenant (Stafford $\mathrm{v}$. Gardner, 7 L.R. C.P. 242 ).

Effect of covenant not to carry aray hay and stran", de., under a penalty.-On a covenant in a farming lease, that the lessee would not sell or carry away from the demised premises any hay, straw, or manure, which shonld be grown or produced thereon, withont the consent of the lessor first had and obtained, under the increased rent of $£ 10$ for every ton so sold or carried aray, and so in proportion for any greater or less quantity, but that the lessee would eat and consume the hay and straw with his cattle ; the breach alleged was that the lessee, withont the consent of the lessor, did sell a large quantity of hay and straw grown and produced on the demised premises, to wit, \&c. It was held by the Court of Exchequer, that the covenant was one covenant, which gave the lessee the right to sell the hay, \&c., on payment of the increased rent, and that therefore the breach was not well assigned. And per Bremuell B., "The expression is first, that he should not sell or carry away from the demised premises any mannre, and so forth, but it is said moler an increased rent of $₫ 10$. That is to say, he shall not do it, except on liability to pay a rent. I think that is the fair meaning of it. If you do it, you may do it on a liability to pay rent. If that is the trme constrnction of the document, he covenants to pay an increased 
rent. There is no absolnte covenant that he will not do it. If that is the true construction of the document, then undoubtedly the declaration onght to have alleged that inereased rent, and though the time for payment arrived, that it had not been paid. ** It seems to me that Hurst r. Hurst ( $t$ Ex. 571, 19 L.J. (X.S.) Ex. 401) was well recided on principle, and that it is distingmishable from this case. In Hurst r. Hurst the Court says the meaning of the covenant is, "You shall not lop the trees; further, if you do you shall pay $£ 20 . "$ If the corenantee think fit to arail himself of it, then the consequence is there may be a good breach of the original covenant : therefore the declaration is a good one. But the Court came to that conclusion on the ground that there were two corenants there; one an absolute one-not to eut the trees, and the other an absolute one-to pay liquidated damages if he did so. But we deeide this case on the ground that this is not so here. 'There is no covenant that the defendant will not remore the manure, but a covenant that he will not do it without paying $£ 10$; in fact, there is only one covenant, which is a complex covenant that he shall pay $£ 10$ if he remove it. It seems to me in this case, the plaintiff can only recorer the agreed $\& 10$, that he is not cntitled to claim unliquidated damages, and consequently he ought in the declaration to have shown he is entitled to $£ 10$ per ton, and made a good breach as to its non-payment; and in that case the declaration would be good; not having done so, it is bad, and is distinguishable from Hurst v. Hurst on the ground I have named."

"Hay" in farming lease includes hary not fit for fodder.-Where it was covenauter in a farming lease that an additional rent of $£ 10$ per ton shonld be payable "if hay, straw, or other dry fodder" should be sold and taken off' from the farm, and hay had been taken off by the defendant which was not fit for food, it was held by the Court of Exchequer that such damaged hay was still within the meaning of the corenant, which implied that everything grown on the farm should remain and be used there (Fielden. v. Tutlersall).

Construction of drainage covemanl in lectse.-An agricultural lease contained a covenant on the part of the lessor, his heirs, \&c., that he and they would "drain with proper drain-tiles, one rood apart, ten acres of the land now in rye grass, at his and their costs, except the curriage of the said drain-pijes, which is to be borne and paid by the lessee; and will drain the remainder of the lands hereby demised, in mamer aforesenil, upon being paid a further yearly rent of $£ 5$ for every $\mathfrak{1 0 0}$ so expended." It was lield by the Court of Common Bench, that the words "in manner aforesaid" referred only to the mode of lerforming the work, viz., placing the drain-tiles one rood apart; and 
consequently that the tenant was not chargeable with the expense of carriage of the drain-pipes beyond the first ten acres (Becr appt. v. Senter respt.).

A usang for a lamullow to pany a sum in compensation to the offyoing tenant, for the tabour and expense bestou'ed by him upon tilling, fallowing, ant manuring the arable and meatow lant, according to the course of good husbandry, the advantage of which the tenant could not otherwise reap, is a reasonable nsage ; and snch practice being a mere usage of the neighbourhood (Bradford) is not a custom strictly speaking, and need not be immemorial (Dallyy v. Mirst). And, in faet, where an ontgoing tenant does the necessary ploughing, and sows the land in the ordinary and proper course of husbandry, and leares manure for the benefit of the landlord, which is accepted by him, the law, without allegation or proof of the custom of the country, will imply an assumpsit on the part of the landlord to pay the tenant the value of such labour and manure, and the plaintiff is not deprived of that right by reason of his having held over after the expiration of the term (Martin v. Coulman).

This minciple of compensation by a landlord to his outgoing tenant was cxtended by Coleridge and Er.le J.J. to the case of drainage, in Mousley $\mathrm{v}$ Ludlem, where their Lordships held that it is not an unreasonable custom that a tenant who is bound to use and cultivate his farm according to the rnles of good husbandry and the custom of the country, should be entitled on quitting to charge the landlord with a certain portion of the expense of the necessary drainage done without his consent or knowledge. This was a Connty Court action by au ontgoing yearly tenant to reeover $£ 50$ from his landlord, for haring giren up to him his farm at his request with the appurtenances, and the benefit and advantage of work done, manure, soughing tiles, and other materials expended and bestored by the plaintiff in and about the cultivation and improvements thereof, together with stone posts, grass, herbage, crops, chattels, and effects then growing and being thereon. The plaintiff had been a searly tenant to the defendant in Derbyshire, on condition that he should use the farm in a good and tenantable manner, according to the rules of good husbandry and the custom of the conntry, and the valuation of his tenant-right inclnded charges under each of the alove heads. For draining, which had been done two years, he charged the landlord with five-sevenths of the cost, and for that which had only been done one, with six-sevenths. This draining was done withont the defendant's consent, and his witnesses stated, in contradiction of the plaintiff's, that where it was done without snch consent, the custom of the country that the offgoing tenant, in addition to compensation for crops, \&c., shonld be paid for the expense of drainage and 
tiles, did not apply. No question mas raised as to the propriety of the drainage. The defendant merely contested the right of the plaintiff to charge him for drainage dome without his knowledge. The jury beliered the plaintiff's witnesses, and found for him with damages.

It was contended lor the defendant, among other things, that the julge ought to have directed the jury that the alleged custom under which the plaintiff charged the landlord with the expense of draining, could not be supported in lars. Coleridge J. considered that it was involved in the alleged custom that the tenant is to farm according to the rules of good husbandry, especially as certain lands absolutely require drainage to make then bear. His Lordship added, "The finding must be taken with reference to the terms upon which the tenant held the fin'm. We must assume that the jury have found that this draining is according to the rules of good husbandry. It seems to me that it is not an unreasonable custom that a tenant, who is bound to use a farm in a good and tenantable mamner, and according to the rules of good husbandry, should be at liberty on quitting the farm to charge his landlord with a portion of the expenses of draining the land that requires draining, according to good husbandry, though the drainage be done without his landlord's knowledge or consent." Erfe J. added: "I think that the finding of the jury fairly means that the eustom is that the drainage must be according to the rules of good husbandry. If a tenant contracts to hold accorling to the custom of the country, the risage of the conntry becomes part of the contract. It would not be an unreasonable contract between landlord and tenant that the tenant shonld be at liberty to put in such drainage as was necessary, and that the landlord should pay a portion of the expense. If it be not unrensonable as a contract, I do not see how it is unreasonable as a custom." 'The appeal was dismissed, with eosts.

In Clarte v. lioystone the declaration stated that the plaintiff was prsecsset of a farm on which he latd laid eertain manure, and in con-

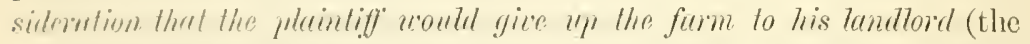

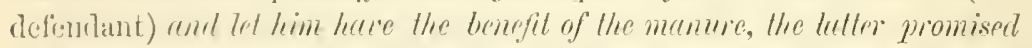
(1) July him so much money as he deserved to have, arrorliny to the rustom of the countiy. Breach-nonpayment of the value of the manure. In the memorandum of agrecment betreen them, and signed by hollh"lie it remembered that the above closes of" land have been only elipped or mown once, and since manured with eight loads of rotten manure per acre, which the tenant agrees when given up by lim to leave in the same state, or allow a valuation to be made." This agreement having leecn prover l,y the plaintifi; it was contended for the defendant that there was a rariance between the allegation in the first count and the 
proof adduced in support of it, and that the count was not proved. Pollock C.B. was of that opinion; and the jury having found for the plaintiff, gave the defendant leave to enter a verdict on the first count (the two others were for use and occupation to recover the rent), and the Court made the rnle absolnte, on the ground that the written agreement exclnded the enstom of the country, as being ineonsistent with it, and that therefore there was a variance between the declaration and the proof. Alderson B. said: "It appear's to me that the reasonable and natural construction of the agrecment is that the party is to pay nothing down, but that he is to do something when he goes out of possession, or to pay for the deterioration of the property if he does not; and that this stipulation being inconsistent with the custom of the country, the contract must prevail, and the cnstom of the country must be excluded."

In Stafford r. Gardner (7 L.R. C.P. 242) the plaintiff was tenant of a farm with a right to the use of a certain part of the premises without payment until the 25th March next after the expiration of the term for threshing and spending the last year's cropl, and by the custom of the country, he was entitled at the expiration of the term to be paid by the landlord or incoming tenant for certain tillages. He gave up the farm to the defendant as incoming tenant at Michaelmas, 1870, and ralners were appointed by both parties and duly made their valuation. After the defendant had entered into possession, but before 25th Mareh, 1871, the landlord gare him notice that rent was dne from the plaintiff, and requested him to pay the amount of the valuation, which was less than the rent dne, to him, the landlord, and not to the plaintiff. This the defendant did, and the plaintiff bronght an netion to recover the amount dne for the tillages: he was non-suited, and the Court of Common Pleas confirmed the non-suit.

Payment by landlord for mame and tillages, de.-In Nereson v. Smithies, the plaintiff covenanted with the dofendant, lis landlord, to deliver up possession of a certain farm and land on a day named, and that in the meantime he would cultivate the land aceording to the custom of the country, and that upon the delivering up of the land be wonld surrender and yield up a certain agreement to be cancelled, and all his mexpired term and interest in the farm, and wonld afterwards, on request, execute any farther desd for effectually surrendering the term ; and the defendant covenanted that if the plaintiff did on the day named deliver up possession, and did and should in the meantime cultivate the land, according to the custom of the country, and also did and should weth and truly obsrre, perform and keep all and singular other the covenants and agreements thereinbefore contained, and on his part to be 
performed, he, the defendant, would upon the delivery up of possession of the said land, on the day spceified, so cultivated as aforesaid, and on such performance of such other cocenants aforesciul, pay the plaintiff for the manure, tillages, hay, (lover, and all other things then upon the land, as were usually paid for betreen an outgoing and incoming tenant. It was held by the Court of Common Pleas, on the authority of Boone r. Eigre (1 H. 13. 273 n), that the delirery up of the agrecment was not a condition precelent to the payment for manure, sc."

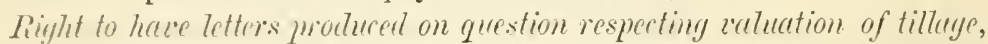
dr.-In Price r. Harrixon, the declaration stated an agreement between the plinintif and defendant, that the plantilf should lease to the defendant a furm, and that defendant should forthwith, after making the agreement, pay to the plaintiff the amount of certain tillages on the farm, at a valuation; and the breach arerred was the non-payment of the raluation. The defendant on an affidarit stating that during the treaty for the farm, he had written letters to the plaintiff, which were in the plaintiff"s possession. but of which the defendant had no copies, and that he believed it wers on surh letters that the plaintiff retied to establish such ayreement, and that he had a just ground to defend the action, and that it was necessary for the purpose of his pleading that he should inspect the letters, obtained an order from a Judge at Chambers to inspect them. It was held, on cause being shown against a rule to rescind the order, that the defendant was entitled to inspection ret common lare. And per. Williams J., "It did not follow in Shaducell r. Shatuell (28 L.J. (N.S.) C.P. 275), that a writing must be necessarily produced to prove the agreement referred to ; but here the declaration could not be proved by parol evidence only. The plea there might have been supported by a release by parol, a writing was not necessary ; and it also appeared to me that there was only a surmise that the defendant intended to rely on some document supposed to exist."

Ithere persons are appointed umber an agrement merely to value the grods and repairs of " farm, an appraisement stamp upon the written valuation is sufficient without an award stamp (Leeds r. Burrou's), although in fact the appraisement is in the nature of an award (Perkins v. Pott.s). And per I'ilde C.o.: " "Theo sicom apmraisers' in statute 2 Will \& Hary, sess. 1, c. 5, s. 2, must be persons reasonably competent, but need not be professional appraiscrs" (Rodon r. Eyton). Where an agreement in writing relating to an interest in land contains also stipulations for the mode in which the straw and manure upon the premises was to be ralued, the Court of King's Bench held that the agreement was entire, and that the mode of reluetion could nut be validly altered by a subsequent parol agreement between the parties (Harrey r. Giab- 
ham). There may possibly be (though qucere) an abandoument of the entire agreement by parol, but at all events there can be no such partial abandonment (il.). It was decided in Cooper v. Shuthev'orth, that an agreement to settle risputes between two parties, as to the amount to be paid by one of them in respect of the value of the goods belonging to or work done by the other of them, by a reference to tu'o valuers, one to be appointed by each party, does not import any undertaking by the former that the valner whom he may appoint shall act in the valuation, nor any liability for his not acting. The party is only bound to appoint a valuer on his part, and if the person appointed does not act, the other party is remitted to his original canse of action, and may revolse his submission, or may possibly, if the valuer has undertaken to act and failed in his duty, have a right of action against him ; but has no right of action against the party who appointed him. And see Latfimore v. Garrart.

One who holds himself out as a valuer of ecclesiastical property, though he is not bound to possess a precise and accurate knowledge of the law (as laid down in Wrise $r$. Metcalfe) respecting the valuation of the dilapidations as between outgoing and incuming incumbents, is bound to bring to the performance of the duty he undertakes a knowledge of the general rules applicable to the subject, and of the broad distinction which exists between the cases of a valuation as between an incoming and outgoing tencut, and an incoming and outgoing incumbent (Jenkins v. Betham).

In Branscombe v. Roucliffe, the Court of Common Pleas upheld the valuer, and declined to decide in a case where the defendant had refused to abide by a valuation, whether he was right or wrong in only allowing one ploughing on a part of the land where there had been a crop of turnips, one portion only of which had come to maturity, and had been consumed by the plaintiff; while he allowed three in respect of another portion, which had not arrived at maturity, and had been plonghed in ; besides other charges for "working out and turning stroyle," and spreading lime, which the defendant contended was out of the scope of the agreement of reference. The second oljection in Cumberland $\mathrm{r}$. Bowes was, that there was no such valuation as entitled the plaintiff to recover, because the valuation delivered out by the umpire did not pursue his anthority, and the latter was functus officio when he altered it. On this Maule J. observed: "The umpire was not functus; he had not valued at all till he gare out the perfect valuation. If a man does not communicate the value of a specific thing which he is employed to value, he does not value it at all." When it was urged by the defendant's counsel, that by this ruling every objection in the case of an 
award which is bad for excess would be cured, his lordship added: "Not so. The arard is bad, not because the arbitrator has exceeded lis anthority, lout because he has not done that which the parties lad required him to do."

The diflieulty here arose from the substitution in the draft lease, "of fair raluation" for "consuming price." The action was brought by an ontgoing tenant of a Herts farm against his landlady, to recorer compensation for certain hay, straw, and manure, left by him on the farm, and the defendant pleaded-first, that the umpire did not duly value, and sceondly, payment into Court of $£ 520$. The farm was taken by the plaintiff, subject, amongst others, to these corenants contained in a draft lease, under which plaintifl's father had held: first, to house the produce on the farm, and to thrash, feed, and fodder the same thereon, and not to sell or dispose of any part thereof, except as after-menlioned; secondly, that he should be at liberty to sell and dispose of his hay and wheat straw (except that of the last year's prodnce), bringing back immediatcly for erery load of hay and straw so disposed of, two loads of good rotten dung; or other equivalent manure; and thirdly, that he should, on the determination of his tenancy, leave all the hay, straw, and mamure arising dnring the last year of his tenancy, for the use of his landlord or the incoming tenant, being paid for the hay and wheat straw at a fair raluation. These latter words were substituted in the draft lease for "consuming price." When the plaintiff gave mp his farm at Michaelmas, $185:$, a dispute arose between him and the defendant as to the valuation of the hay and straw left loy him, the plaintiff insisting that he was entitled to be paid for them at a "fair valnation," and not a "consuming price," as was contended by the defendant. Talners were appointed on each side, and then, as they could not agree, an umpire, who ralned the hay, straw, Sc., left on the premises, at f.7.t 1$]$ s. $3 d$. , sent in the following certificate: "I certify that I have valued the alove at a markctable price in its present situation." This umpire was the only witness called at the trial, and stated that he did not valne at a "consuming price" or at "a marliet price," but at a fair valnation." After delivering" ont his valuation, he discorerel that he had improperly included in it a small quantity of old hay, worth $£ 2$, and the jury returned a verdict for $t$ w p plaintiff for $£ 25211 \mathrm{~s}$. 3 $\mathrm{d}$., being the difference between the sum paid into Court, and the amount of the valuation when so altered.

I.eave was rescrved to the defendant to move to enter a nonsuit or for a new trial, lont the court discharged the rnle.

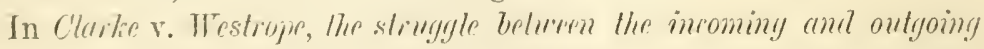
trnants was whether the former should pay the latter for the straw at a 
"fodder mice" or "a consuminy mice." The plaintiff entered in 1818 on the ocenpation of Morden Heath, a farm of Lord Hardwicke's, muder a written agreement made between his lordship's steward on his behalf and the plaintiff's father and brother, at the commencement of a fourteen years' lease in 1839 . By clause 4, the latter agreed "to pay $£ 5$ for every load of fodder, straw, haulm, dung, or turuips which shall be sold or carried off the premises, and the same sum for every load of hay or wheat-straw sold or carried off the premises, for which there shall not be two loads of good dung or other mamne (at the option of the landlord) to be spent on the premises. Clanse 15 was to the effect that they agreed "to pmrchase all the liny, sainfoin, and tares now in the yard, also all the dung and manure nou on the premises, also all the straw from the crops now stacked or abont to be stacked in the yard, paying a fair price for the same, to be ascertained by valners on both sides. Lord Hardwicke also engaged in a supplementary agreement, when the tenant quitted the farm "to purchase all hay, sainfoin, and tares in the yard the prodnce of the farm" ("all dumg and manure on the premises" struck out), "also all straw from the crops of the previons harrest that may be on the premises, paying a fair price for the same, to be ascertained by valuers." The plaintifl quitted the farm at Miehnelmas, 1853 , and two valners were appointed to value between him and the incoming tenant. On the subject of the tillages, the foldings, the fixtures, and some other matters, they agreed. The market valne of the strar at the time was admitted to be 25. . per ton, but the plaintifl's valuer estimated it at a "consuming price," or two-thirds of the market valne, while the defendant's valner estimated it at a fodder" or browsage price, being one-half of the market value. On this point they failed to agree, and as the negociations respecting a referee went off, the valuation came to nothing, and an action was bronght. It was proved that according to the custom of the conntry, the ineoming tenant, in the absenee of a special agreement, nsually paid the ontgoing tenant for the straw at a consuming price; but that if the ontgoing tenant was bound to consume all the manure on the farm, the allowance in respect of straw as between him and the incoming tenant wonld be only at fodder price.

The defendant insisted that, firstly, plaintiff" conld not maintain his action, as there had been no valuation pursuant to an agreement of May 30th, 1853 ; and secondly, that the terms of the contract under which plaintiff had entered on the farm precluded any claim on his part to be paid more than a fodder price for the straw on quitting it. The above agreement was to the effect that the defendant would pay the plaintiff for all the cultivation done upon the fallows, for the carriage 
and labour of dung, and the folding of sheep on the farm, such valuation to be made before September 29th, 1853. In answer to the questions put them by Williams J. on the trial, the jury found that it was agreed between the parties, that the valuatiou of the straw should be made on the same terms as that of the other matters mentioned in the agreement; that supposing the ontgoing tenant entitled to the manure, the straw was to be paid for at two-thirds of the market price, but if he was not, at one-half of the market price; and that when there was no special agreement to the contrary the tenant was entitled to go out as he came in. It was agreed that the Court should decide by whose fanlt the valuation went ofl. A verdict was accordingly entered for the plaintifl for $£ 3112 s$. 1d., being the whole amount claimed in the particulars on the higher valuation, less $£ 2512 s$. 8 $d$. for price and value of work, seeds, \&c., supplied by the plaintiff, and leave was reserved to the defendant to move to enter a nonsuit on the first point, or to reduce the damages on the second to $\$ 215$, the amount agreed to be due upon the valuation at the lower price. The Court of Common Pleas held upon the first point, that as inasmuch the valuation went off, and the straw had been consumed by the beasts of the defendant, so that a valuation had become impossible, an action would lie, in order to have the ralue assessed by a jury ; and on the second, that such an action would only lie to recover the value of the straw at the lower valuation, on the ground that the terms upon which the valuation as between outgoing and ineoming tenant was to be made, were contained in a written agreenent, which provided only that the outgoing tenant should be paid for the straw on the premises, and not for the lung, and according to the elear and established rule in these cases, he was entitled to be paid for the straw only at a fodder price. And per Cresswell J.: "The ground of the Court's decision on the second point is, that there is an express stipulation that the tenant shall pay for the manure on going in, but no stipulation that he shall be paid for it on going ont." Aceordingly the verdict was ordered to stand for $£ 215$.

In Loumdes $\nabla$. Fountain a farming agreement contained among others this elause-" No hay or strew to be soled off" the seid laml, without consent of the landlord or his agent, except the value of the straw so sold off be returned in manme on the said land," and the Court of Exchequer was equally divided as to whether "culue" was to be construed as a mannie or money value. 'The defendants took possession of the land as assignees of one Boreham, under the agreement, in April, 1854 , and continued to oceupy it until Lady-day, 1855, when the flaintiff determined the tenancy by notice to quit. During their tenancy the defendants sold all the straw off the land, elaiming to do 
so for the benefit of the creditors of Boreham, and did not return any manure on to the land. The splling mice of the straw was $\& 1$ per ton, but its value, if spent in manure, about $7 \mathrm{~s}$. per ton. The defendants contended that according to the true construction of the agreement, they were only liable in damages for the value of the straw if spent in manure, and it was urged for the plaintiffs that the measure of damage was the selling price of the straw. Alderson B. was of that opinion, and there was a verdict for the plaintiff, with damages so calculated, leave being reserved to the defendants to move to reduce the damages, if the Court should be of opinion that the learned Judge had erroneously construed the agreement. Parke B. said: "The difficulty arises from the use of the word 'value.' If the word had been 'price' instead of 'valne,' then all the hay or straw sold off must have been expended in the purchase of manure, and a much larger quantity of manure would have been returned than the hay and straw conld have produced, if it had not been sold off. My brother Alderson retains his opinion, and my brother Platt concurs with him. They think that the term 'value' means the value of the straw itself, and that that is to be laid out in the purchase of manure, and spent upon the land. If, indeed, this were in the nature of a penal clause, there wonld be reasonable ground for concluding that the word 'value' meant the market value of the hay or straw, because that would be required to be brought back in order to prevent the tenant from carrying off the hay or straw at all. The Lord Chief Baron and myself think that this is not a penal clause, and that it mercly meant to keep the parties in statu quo. You may sell the hay and straw off the land, but you shall do no injury to the farm. You shall buy back a quantity of manure equal to that which the hay or straw if left on the land would have produced. There being a difference of opinion, no rule will be granted." Pollock C.B. in the course of the argument thus pointed out the special hardship of construing "value" as money value: "Some person might want the straw and be willing to give for it a price beyond its farm value, or it may be that there is a greater quantity than the tenant has occasion for, so that it would be more profitable to sell it, and return its value in manure; but if the tenant is merely at liberty to take the price for which it sells, and bring back that in manure, he would receive no benefit." And it is submitted that the view of the Chief Baron and Baron Parke is the most in accordance with public feeling, and most likely to be upheld if the question is re-opened.

A nice point also arose in Massey v. Goodull, where the declaration alleged that the defendant had become tenant from year to year to the plaintiff on certain conditions and stipulations, one of which was that 
he "should not sell any strau", de., or manure grouch or produced on the scid farm, without the written licence" of the plaintiff, under certain penatties, which were to be recoverable by distress or otherwise as additional rent, at the rate of $£ 7$ for every load of hay and $£ 5$ for every load of straw, \&e. To this allegation of a positive and unqualified stipulation, that the defendant should not sell straw grown upon the farm, it was assigned as a breach that the tenant did sell ten loads of straw grown on the farm during the tenancy, and did not pay the £50 penalty for which the action was brought. 'The defendant pleaded that the straw was sold after the determination of the tenancy; and it was held by Lord Camplell C.J. and Patteson J., on demurrer, that the breach was well assigned, and came within the express words and intention of the agreement, and that it was immaterial whether the straw alleged to have been sold by the defendant was sold by him before or after the determination of the tenancy, provided it was straw grown on the farm during the tenancy. Lord Campbell said: "If the stipulation were confined to sales during the continuance of the tenaney, there would be nothing to prevent the tenant during the last year from hoarding up all the produce of the farm, spending no part of the manure on the farm, and the day after the tenancy determined, selling it all, leaving the farm ruined and exhausted. I do not think that such a construction would make the agreement reasonable as between landlord and tenant." Jndgment was given for the plaintiff. Erle J., however, thought that, looking at the stipulations as set out, which did not include any provision that the landlord shonld take the unconsumed prodnce at the end of the term, the tenant was entitled to use it as his own after the tenancy expired, and need not leave it as manure for the landlord, without any remuneration.

Mamure is assignable by the tenant, though he thereby subjects himself to an action for bad husbandry (Burbago v. King). A covenant by a lessee that he will sufficiently muck and manure the land with turo sufficient sels of muck, within the space of six of the last years of the term, the last set of muck to be laid upon the premises within three years of the expiration of the term, is satisfied by the tenant laying on two sets of muck within the last three years of the term (Pounall v. Moores). Abbot C.J. said: "The object of the last-mentioned stipnlation was that all the benefit of the manure should not be exhausted during the lessee's holding, but should at least partially continne at the expiration of the term. But the lessce has nowhere restricted himself from laying on both the sets of manure within the last three years, if he should think proper, and we cannot by construction bind him beyond the terms of his covenant." Parke B. ruled in Miggon v. Mortimer that if a tenant 
during his tenancy remove a dung-heap, and at the time of so doing dig into and remove virgin soil, the latter becomes by operation of law the personal property of the landlord, and is so completely revested in him as to enable him to bring trespass de bonis asportatis and à fortiori trover.

Where at the sale of the defendant's stock the tenant of an adjoining farm bought two cows, and by the defendant's permission left them in a shippon in the defendant's farm-yard for some weeks, bringing provender from his own farm to feed them, it was held that their manure was manure made on the form, and that the removal of it by the cows' owner to spread on his own farm was a breach of a condition in the defendant's lease, "to put and spread all the manure and compost then collected in the midden-stead or any other part of the farm on the meadow land, and not to sell, cart, or convey away any dung, compost, or manure from the said farm" (Hinclle v. Pollett).

Where the outgoing tenant is bound by his covenant not to carry away the dung, his property, off the premises, but to sell it to the incoming tenant at a valuation, he has a right of on-stand on the form for it, till he can sell it to the incoming tenant; and as the possession and property must remain in him in the meantime, he may maintain trespass against the incoming tenant for taking it before it is valued (Beaty v. Gibbons).

In Smith v. Chance, which was an action of assumpsit for hay sold and delivered, one of the terms on which the plaintiff held the land was that he would consume the hay on the premises, or for every load of hay removed would bring two waygon-loads of Worcester muk, and spread the same. When the plaintiff quitted, part of a rick of hay was left standing, which he sold to the defendant, but, without mentioning the muck agreement. The new tenant, in consequence of some dispute with the plaintiff as to terms, would not let the defendant carry away the hay till he had bought the manure. At the end of a month, permission was given; and as the hay had been spoiled in the meanwhile, by exposure to the weather, the defendant refinsed to take or pay for it. The jury found for the plaintiff, but the Court of Queen's Bench ordered a new trial, on the ground that although by the agreement the plaintiff was not bound, while in possession of the land, to bring on the manure till after the hay had been removed, still, after the expiration of the plaintiff's tenaney, the then succeeding tenant might make the bringing on of the dung a condition precedent to carrying off the hay.

The following mamure agreement was held by the Court of Exchequer to be a contract relating to the sale of goods, wares, or merchandize 
within the exemption in the Stamp $\Lambda$ et 55 Geo. III. c. 184, schedule part 1, title "Agreement."

Agreement between Mr. Wm. Gurr and Mr. Scudds :-

"I dou aggree (sic passim) to take all the mannure at $4 \pi$. each horse, a week for 45 horses by the year ; and to keep it cleared away erery week; and likewise to let the few Gardners have a few loads at the same price, and serve them; and to let me have during the jear 6) loads of straw at $£ 19 s$. per load : began the year $23 \mathrm{July}, 1852$, and ends 28 . July, 1855.

"WM. GURr."

A horse and cart cmployed by a dust contractor in conveying street sucepings (found in this ease to be manure) to a place of deposit, partly for the contractor's own use as manure, but principally for the purpose of sale as manmre, was held in Reg. v. Freylie, to be within the following exemptions in a local turnpike act (59 Geo. III., c. 95, s. 25): "For" any horse or other cattle or carriage employed in carrying or conveying (among other things) manure employed in husbandry for manuring or improving the land." Lord Campbell C.J. said: "I am of opinion that this exemption was properly claimed; and this exemption being for the benefit of agriculture, that is as much affected by this case being excmpted from liability to toll, as by the case where the manure is being actually conveyed by the farmer to be laid on his own land." II is lordship also ruled that a cart carrying gnano to a place of deposit to be sold again was within the exemptions ( $i b$.).

Gurney B. had previously ruled in Pratt v. Broun that uncrushed bomes which are taken throngh a turnpike to a farm, to be there crushed, and part of them there used as manure, and the residne to be afterwards sold, and to be nsed for manure at other farms, are exempt from toll under 3 Geo. IV., c. 126 , s. 32 , and 5 \& 6 Will. IV., c. 18, s. 1. By scetion 1 of the latter act "no toll shall be demanded or taken on any tumpike road for or in respect of any horse, beast, cattle, or carriage when employed in carrying or conveying only dung, soil, compost, or manure for land (sare and except lime), and the necessary implements nsed for filling the manure, and the cloth that may have been used in corering any hay, elorer, or straw which may have been conreyed." Int by sec. 2 of this aet it is provided that "nothing herein contained shall extend or be construed to extend so as to exempt any waggon, cart, or other carriage laden with dung or manure for manuring land, or any horse or other beast drawing the same from any toll imposed in respect thereof, by virtue of any local act or acts now passed, whereby such toll has been imposed for the maintenance of the 
roads therein respectively mentioned." As the non-exemption of lime was felt to be a hardship by agrienlturists, the statnte 13 \& 14 Tict. c. $79, \mathrm{~s} .3$, empowered the trustees or commissioners of any turnpike road, notwithstanding any loeal act, and without the consent of those who have lent money on the credit of the tolls, to reduce or wholly take off, if they think fit, tolls on lime used for the improvement of land.

It was enacted by sec. 4 of stat. 14 \& 15 「rict. e. 38, that the words "implements of lutsbandry," in 3 Geo. IV., c. 126, s. 36, should be deemed to include thrashing-machines; and it was held by the Court of Queen's Bench in Reg. v. Matty that horses employed in conveying a steam-engine, which is intended to be used as the motive power of a thrashing-machine, which accompanies it, are exempt from toll. The steam-engine in this case was drawn by horses, and was following a thrashing-machine also drawn by horses, and both were going along a turnpike-road to a farm, to be employed in thrashing corm. The thrashing-machine was allowed to pass through the turnpike-gate free of toll, but toll was taken for the steam-engine, and the toll-keeper was afterwards convicted for improperly taking such toll, and his eonviction was affirmed by the Worcester June Quarter Sessions, subject to a case for the Court of Queen's Bench, which affirmed the conviction.

Lord Camplell C.J. said: "Looking at statute 3 Geo. IV. c. 126, I should rather think that a thrashing-machine is an implement of husbandry within the meaning' of that act, were it not for the particular' words 'ploughs or harrows,' which precede that expression; and may therefore narrow its meaning. But stat. $14 \& 15$ Vict. e. 38 , s. 4, having expressly enacted that implements of husbandry shall be deemed to include thrashing-machines, that point is settled; and the question is whether this steam-engine, which was to be used for the thrashingmachine, and for no other purpose, is to be considered as part of the thrashing-machine. I think that it is. Both the machines belonged to the same man, were travelling together, and if the same horses had. dragged the whole machine together, it is not doubted that the exemption would exist as to the whole. Suppose, for convenience, that the thrashing-machine had been divided into two carts, both would have been entitled to be exempted from toll; and it can make no difference that the thrashing-machine and the steam-engine were in like manner separated. I think fiuther, that if the steam-engine had been travelling by itself for the sole purpose of working the thrashing-machine, in such case the exemption would arise. We here distinguish between horses or animal power, which eannot be an implement within Dr. Johnson's definition of the word, and a steam-engine, which is within the 
definition. If spades were employed for husbandry, the eart carrying them would be exempt from toll; but not so if the spades were intended to be sent out to California, or to be nsed for some purpose foreign to husbandry." Bnt Coleridye and Crompton JJ. scemed to doubt whether, if a person kept a steam-enyine to go about to different thrashing-machines, it would be exempt.

Where a person sent by a horse and eart thrashed barley, which had grown upon his farm, to the mill for the purpose of having it brought back as meal to be consumed by pigs on the farm, it was held that the horse and cart were exempt from toll, on the ground that meal came within the words 'fodder for cattle' (Clements v. Smith).

'Thrashing-machines, thongh exempt from toll by General Turnpike Act, may be made liable to a toll by a local act. 14 \& 15 T'ict. c. 38, s. 4 (Ablest v. Pritchard, 1 N.R. C.P. 210). 


\section{CHAPTER XI.}

TRESPASS AND GAIIE.

To entitle a man to bring trespass, he must at the time when the act was done which constitutes the trespass, either have the actual possession in him of the thing which is the object of the trespass, or else he must have a constructive possession, in respect of the right being actually rested in him (Sinith v. Willer).

Where A. commissioned her brother to buy her a cow, and a fortnight afterwards he bought her one, but as it was being driver home, and before she had assented to the purchase, the cow was taken by the defendant; it was held by Lord Denman C.J. that A. had such a property in the cow as would enable her to maintain trespass; the evidence here showed a property in the plaintiff at her election; and by bringing the action she had elected to take to the bargain and to make the cow hers (Thomas v. Plitips).

The plaintiffs, churchuardens and overseers of a parish, who inclosed parcel of a waste under statute 39 Geo. III. c. 12, and 1 \& 2 Will. IV. c. 42, were held to have a sufficient possession to maiutain trespass against an inhabitant of the parish, who destroyed their fence, withont establishing any right of common, notwithstanding they failed to show the consent of the lord of the manor to their inclosure (Matson $\nabla$. Cook). A possessory right, sufficient to sustain trespass, may be resorted to, even after it has appeared that the plaintiff has in fact no legal title; and when the locus in quo is the soil of a street, and the only actual possession he sets up is by his recent commencement of a building upon the locus in quo, the pulling down of the incomplete walls of which was the trespass complained of, and which were pulled down on the suggestion that they constituted a nuisance to the highway (Every v. Smith). The defendants, who were highway commissioners, pleaded Not possessed, and justified in abatement of a nuisance on the highway, but did not justify under the owner of the soil. And per Bramuell B.: "They not having justified under the owner of the soil, that would be a trespass, at the snit of the partics in actual possession" (ib.). 
The Conrt of King's Bench held that where a person has an exclusive right to dlig turf and peat, or a right to a sole and separate pasture, for a time, trespass lies by him, though he has not the absolnte right to the soil (Hilson v. Wacketh). Bnt per Wilmot J.: "If this was only a right of common of turbary, trespass would not lie" (ib.). In Pearce r. Lodge, which was an action of trespass for taking and carrying away furze, the defendant pleaded the general issue, and several special pleas, in which he claimed a right to estovers from a common. It was held by the Court of Common Pleas that under the general issue he might give eridence of an exclusive right of possession, and that persons who had a right of common were eompetent witnesses for the defendant, to prove that he was entitled to the exclusive possession of the land from which the furze was taken.

In an action for a trespass to land, the plea of Not guilty operates as a denial that the defendant committed the trespass alleged in the place mentioned; but not as a denial of the plaintiff"s possession, or right of possession of that place, which, if intended to be denied, must be traversed specially (Reg. Gen. H.T. 1853, Pl., r. 16). In such action a regular jndgment may be set aside upon an affidarit of a defence on the merits, or that there was no probability of the plaintiff's recovering more than $£ 5$, or obtaining the judge's certificate under stat. 13 \& 14 Vict. c. 61 (Witson r. Greemroyd). Under a plea to trespass upon land, that the close is not the close of the plaintiff, the defendant may show a lauful right to the possession of the close either in himself or in some other persen under whose anthority he claims to have acted (Jones v. Chapman).

No person has at common law a right to gleen in the harvest field (Steel r. Houghton). Neither have the poor of a parish legally settled (as such) any such right (ib.).

In the case of a trespass in lau merely, without actual force, the owner of the close, dc., must first request the trespasser to depart before he can justify laying his hand on him for the purpose of remoring him ; and even if he refuse, he ean only justify so much foree as is necessary to remove him (Green v. Godldarl): but if the trespasser usc force, then the owner may oppose force to force (ib.). 'Trespass lies for u:orking an sstray, though the original taking be admitted to be unlawful (Oxtry v. Watts).

'Trespass will lie for breaking a kovecote. Pigeons kept in an ortinary dovecole, having liberty of ingress or egress at all times by means of holes at the top, may be the subjects of larceny (Rey. v. Cheafor); and pre Curiom: "It has been mistakenly supposed that Parke B., in Lalin's casce, decided that pigeons were not the subject of larceny except strietly confined; there is no question that they are, even though they are 
allowed the liberty of going to enjoy the air when they please (ib.) In Comyn's Digest (Bims B.) it is said that ' deer in a park, conies in a warren, and doves in a dove-house go with the inheritance to the heir.' A man may prescribe to have a game of sucans within his manor, and may prescribe that his swans may swim in the manor of another. A swan may be an estray, and cygnets belong equally to the owner of the cock and the hen, and shall be divided betwixt them " (Reg. v. Latly Joan Young). The punishment for stealing a swan used to be that it should be tied up by the neck, and the offender should pile wheat on it till it was covered. And per Bayley J. : "Bees are property, and the subject of larceny" (Hannam v. Mlockett). But dogs are not the subject of larceny at common law, and therefore not chattels within statute $7 \& 8$ Geo. IV. c. 29 , s. 53 (Reg. v. Robinson).

Any possession is legal possession as against an evil-doer (Gralect v. Peat; Oughton v. Seppings). A pariy who has the legal title to land, having entered, may maintain trespass against a person wrongfully in possession at the time of entry, and continning in such possession afterwards (Butrher v. Butcher). And per Buyley J. : "Tumton v. Costar is an authority to show that a party wrongfully holding possession of land cannot treat the rightful owner, who enters on the land, as a trespasser. I think that a party having a right to the land, acquires by entry the lawful possession of it, and may maintain trespass against any person who being in possession at the time of his entry wrongfully continnes on the land." And per Lord Tenterden C.J. : "It is not necessary that the party who makes the entry should declare that he enters to take possession; it is sufficient, if he does any act, to show his intention. Here his servants plonghed the land: it is manifest, therefore, that he intended to take possession."

Since $3 \& 4$ Will. IV. c. 27, a mere entry by a lord of the manor (where, as possession had commenced adversely more than twenty years before, and nothing had occurred to interrupt or put an end to it, ejectment was too late) is not enough to bar the tenant's right, unless accompanied by circumstances which would restore the possession of the land to the lord (Doe dem. Baker v. Coombes). Here the defendant, nore than twenty years ago, without permission of the lord, inclosed a small portion of the waste of a manor, on which he built himself a hut. In 1835, the encroachment having been presented at the lord's court, the then lord of the manor, accompanied by his steward, went to the premises, Coombes' family being there, and stating that he took possession, directed that a stone should be taken out of the wall of the hnt, and that a portion of the fence should be removed. All this was done in the absence of Coombes, and the lord and the steward then retired 
without doing anything more. It was held by the Conrt of Common Pleas that the acts so done by the lord did not amount to a dispossession of Coombes, and a resumption of possession by the lord, so as to entitle the latter to maintain ejectment within twenty years from that time.

Cressucll J. said: "Pritchard, the lord, when he intended to resume possession of the land in question, in 1835 , from a feeling of kindness to the ineroacher, abstained from doing enough to resume his rights. It is clear that he was out of possession, and that there was no tenancy at will before the jear 1835 . The defendant was there as a trespasser. The 10 th and 11 th seetions of $3 \& 4$ Will. IV. e. 27 , must be looked at together. The latter throws light upon the former: it enacts that ' No eontinual or other claim npon or near any land shall preserve any right of making an entry or distress, or of bringing an aetion.' That section treats the making an entry as something more than merely being on the land, and elaiming it. The 10 th section seems to require something more than merely formally going on the land. The making an entry amounts to nothing, unless something is done to divest the possession ont of the tenant, and revest it in fact in the lord. We are bound by the plain words of the statute." And see Doe dem. Bennet v. T'umer.

And where a tenant encloses land, whether adjacent to, or distant from the demised fremises, and whether the land be part of a waste, or belong to the landlord or a third person, it is a presumption of fact that the inclosure is part of the holding, nnless the tenant during the term does some aet diselaiming his landlord's title (Kingsmill v. Millard).

Incroachments by tenant on waste are presumably for the benefit of the landlord (Earl of Lisburne v. David Davids, 1 L.R. C.P. 259).

The 8 \& 9 Tict. c. 118 , s. 123, which gives a right to the Inclosure Commissioners or their valuer to enter land to be inclosed or dealt with under the Act, extends to land over which there is a right of common, and which by an order for inclosure is to be retained by the owner, freed from the right of eommon (Givbl v. Broun).

Upon a question whother a piece of waste land lying between a highway and the plaintiff's inclosed land, belonged to the plaintiff, or to the lord of the manor, it was held in an action for breaking and entering the close of the plaintiff, that grants by the lord of other slips of waste land on either side of the same road, abutting on inclosed lands of the lord himself and of other persons, were admissible for the purpose of showing that the locus in quo was part of the waste of the manor without showing continuity (Jenily v. Simpson).

One who has contracted with the ouner of a close for the purchase of a 
growing crop of grass there, for the purpose of being moun and made into hay by the iendee, has such an exchisive possession of the close, though for a limited purpose, that he may maintain trespass quare clausum fregit against any person entering the close, and taking the grass even with the assent of the owner (Crosby v. Wutlsworth). Where A. is seised in fee of a close, upon which the burgesses of $B$. have a right during a certain portion of the year, to depasture their cattle, and have during that period exclusive possession of the close, A. may maintain trespass against a party who during that period commits a trespass in the subsoil by digging holes, but not against one who during that period merely rides over the close (Cox v. Glue, and Mousley v, Saint). With respect to the latter point Iraule J. said, "You might as well contend that a man who owns a stratum of coal a thousand fathoms deep, can bring trespass against another for walking over the surface of the land. That is this case, differing only in degree." And per Curiam: "The word 'close' in a declaration in trespass inchudes the subsoil as well as the surface "(it.) The possession of the surfuce may be in one person, and the possession of and the right to the subsoil, in another; and such rights may be derived by grant ; or may be inferred from a long and uniform course of enjoyment, which will be supposed to correspond with the interest created by some grant" (ib.) In Comyn's Digest Common $(H)$ it is said that a commoner cannot maintain trespass for damage to the soil or grass ; for he has no interest but to take the pasture by the mouths of his cattle. One person may hold the prima tonsura of land as copyhold, and another may have the soil and every other beneficial enjogment of it as freehold ; and as the word close imports in the abstract the interest in the soil, if the defendant in trespass (who by his plea alleged the plaintiff's close to be copyhold, holden under a certain manor of Hatfield Peverell, and justified the trespass therein under a grant from the lord, and by command of the copyholder') only make ont that he has a partial interest in the land, such as the right primce tonsurce, the issue must be found against him (Stammers v. Dixon).

Trespass does not lie for the occupier of land against a party, who enters to reteke goods wrongfully brought into the close by the plaintiff (2 Roll. Abr. 565, 1. 54); and in trespass for breaking and entering a yard, the defendant was allowed to plead that he entered for the purpose of viewing a mare then in the stable in the yard, which had recently been stolen from him (Webb v. Beavan). A plea to a declaration in trespass for breaking and entering the plaintiff's close, that the defendant being possessed of certain goods, the plaintiff, without his leave and against his will, took the goods and placed them on the close in the declaration mentioned, wherefore the defendant made fresh 
pursuit, and entered to retake the goods, is a good plea and a good justification of the eutry on the plaintiff's close (Patrick v. Colerick).

A recersioner cannol maintain an action against a stranger for acts of trespass on the land unattended with any other injury to the reversion than as being committed in assertion of the claim of a right of way (Baxter r. Taylor). And per Parke J.: "No injury has been done to the reversion. MIy notion is that there must be some destruction of the land to enable the reversioner to maintain this action. No case has ever grone so far as to constitute a simple trespass like this an injury to the reversion. The case of Ioung $\mathrm{v}$. Spencer is distinguishable from the present. The words of Lord Tenterien C.J. in that case are to be consilered with reference to the subject-matter of decision; and he is there stating what in his opinion are acts of waste." (ib.)

An auctioncer put into possession of fixtures (spouting) attached to the freehold, for the purpose of selling them, the purchaser being bound to detach and remore them, has not such a possession as will support trespass de bonis asportatis for their wrongful removal (Dacis v. Danks). And ner Parke B.: "There is no doubt as to the law, that an anctioneer has a special property as bailee in goods and chattels which are put into his possession for the purpose of sale, whether such goods and chattels be in his own rooms or in the house of another person. The case of Williams $v$. Millington is a decision to that effect. On the ground that he is a bailee, he may maintain trespass de bonis asporlatis, or trover, for such chattels. But is he bailee of the roof of the house which is part of the freehold? He cannot be considered to have such a possession of the house and fixtures as would entitle him to maintain an action of trespass quare clausum freyit against a party, for an injury to them; and that is conceded to be so by the plaintiff's counsel. He was only authorized at the time of his employment to sell the right of detaching and removing the fixtures, and he had no possession of them as materials, and he was not in possession of the freehold. But it was said that on their severance they were bailed to him. That depends upon the cuestion, whether or not the real owner of the fixtures ever intended that the plaintiff should hare possession of them after they were detached. The evidence is that the lots were to be sold as fixtures, which the purchaser was to detach and remove. The evidence, therefore, is opposed to the plaintiff's view of the question. 'The present action, therefore, so far' as it respects those fixtures, is no more maintainable than an action of quare cleusum freyit would be, if bronght for the removal of growing crops by an anctioneer who has been directed to sell them." 
Plea of lecue and licence in tresposs.--In trespass, a plea of leave and licence means leave and licence in fart, and a licence in law must be specially pleaded, and semble it may be pleaded to part of a count if severable and distinct: per Cockburn C.J. (Moxon v. Sarage.)

Lenve and licence.-T'o a declaration in trespass, and for breaking open a gate and lock, the defendant pleaded as an equitable defence, that disputes having arisen between the plaintiff and the defendaut and other persons about a right of way, an agreement in writing was entered into between the plaintiff and the defendant and the said other persons, that without prejudice on either side to the question of right, a way over the locus in quo should remain open for the passage of the defendant and the said other persons, until the plaintiff's solicitor and the defendant should come to a definite understanding as to the course to be pursued in deciding the question in dispute; that all things happened necessary, \&c., and that the alleged trespasses were committed in the use by the defendant of the said way, because the said gate had been wrongfully and contrary to the said agreement placed across it. It was held by the Court of Exchequer-1st, that the plea did not amount to a plea of leave and licence at common law, as the locking of the gate was a revocation of the licence to use the way; and 2 ndly, that it was not good as an equitable plea, the circminstances disclosed not being such as would in equity entitle the defendant to have the plaintiff' restrained by an unconditional injunction from prosecuting the action (Hycle v. Gratum).

Reasonableness of a horse-racing eustom.-To an action of trespass quetre elausum fiegit, the defendant pleaded that from time immemorial, on Ascension Day, horse races had been held, and of right onght to be held on land in a certain extra-parochial place, and that there was a custom for the freemen of the town of $\mathrm{C}$ to enter on the close for the purpose of horse-racing; and it was held on a demurrer to the plea and the authority of Fitch v. Peavlings and others (2 H. Bl. C. B. 393) and Abbott v. Weekly (1 Levinz, 176) that the custom was good and reasonable. The Court of Exchequer distinguished this case from Millichamp v. Johnson and Bell v. Wardell (Willis, 202), becanse the right to go on the land in question was limited to a few days abont the time of Ascension Day or Holy Thursday, whereas in these cases the custom to enter on land for the purpose of playing any rural sports or games was held bad, as being too general and uncertain (Mounsey v. Ismay).

A trespasser may have a right of action for an injury sustained whilst in the act of trespassing (Bumes Adlx. v. Ward). And per Maule J.: "With respect to the case of Btyth v. Topham, and Alderson B.'s dictum in Jordin v. Crump, it must be observed that in those instances 
the existence of the pit in the waste or field adjoining the road is not said to hare been dangerous to the persons or cattle of those who passed along the road, if ordinary caution were employed. In the present case, the jury expressly found the way to have existed immemorially, and they must be taken to have found that the state of the area made the way dangerous for those passing along it, and that the decensed was using ordinary caution in the exercise of the right of way, at the time the accident happened. With regard to the objection that the deceased was a trespasser on the defendant's land at the time the injury was sustained, it by no means follows from this cireumstance that the action cannot be maintained. A trespasser is liable to an action for the injury which he does, but he does not forfeit his right of action for an injury sustained. Thus in the ease of Birl v. Holbrook, the plaintiff was a trespasser (and indeed a voluntary one), but he was held entitled to mantain an action for an injury sustained, in consequence of the wrongful act of the defendant, without any want of ordinary cantion on the part of the plaintiff, though it would not have oceurred if the plaintill had not trespassed on the defendant's land. This decision was approved of in Lynch v. Nurden, and also in Jordin v. Crump, in which the Court of Exchequer, thongh expressing a doubt whether the act of the defendant in setting a spring-gun was illegal, agreed that if it was, the fact of the plaintiff being a trespasser would be $n$ answer to the action." (it).)

It was decided by the Court of Exchequer in Hardrastle Adx. v. South Yorkstive Raituray \& River Don Company, in accordance with the principle of the case of Blyth $\mathrm{v}$. Topham, that when the owner of land makes upon it an excarction, adjoining a public way, so that a person walking upon it might, by making a false step, or being affected with a sudden giddiness, or by the sudden starting of a horse, be thrown into the excaration, the party making the excavation is liable for the consequences; but it is otherwise when the excavation is made at some distance from the way, and the person falling into it would be a trespasser upon the land of the party making the excavation before he reached it. And semble, the proper and true test of legal liability in such cases is whether the excavition is substantially adjoining the way, and these principles apply to actions brought under stat. $9 \& 10$ Vict. c. 93.

The authorities show that if an acrident, such as the defendunt driving his cart and horse against the prlaintiff, resulted entirely from a superior ugency, that is a defence, and may be proved under the general issue; but a defence stating that there was no negligence on the part of the defendant, and that the plaintiff slipyed from the kerb-stone just as the 
cart was passing, and so got his leg under the wheel, cannot be proved under that issue (Hall v. Fearnley).

It was decided by the Court of Common Pleas, on the anthority of Boyfield v. Porter, that tiespass does not lie against a surveyor of high. ways for entering lands and cutting drains under the powers of the Highway Act, without tendering amends for the injury done (Peters v. Clarson). The justices at Special Sessions are the only persons to ascertain and settle the amount of damages to be paid, and the surveyor is not bound to have the amount of damages ascertained within twentyone days of his committing the injury. (ib.)

Where a water-work company were empowered by Act of Parliament "to dig and break up the soil, \&c., of any of the roads, highways, footways, \&c.," and by a subsequent clause it was provided that they should not enter upon the private lands and grounds of any person without the consent of their owner, \&c., the Court of Common Pleas held that a footuay across a field was not within the meaning of the Act (Scales $\mathbf{v}$. Pickering).

The ou'nership acquired in land by a mublic company, under their compulsory powers for the purpose of their works, is a qualified ownership, to be restricted to the purposes expressed in the act, those purposes being the essence of the contract; and therefore the landowner in Bostock v. North Staffordshire Railway Company, whose comfort and enjoyment of the remainder of his estate is affected by the company applying the ownership for other purposes not contemplated by the act, had a perpetual injunction granted to her by Stuert V. C. to restrain the use of the land for such purposes. Part of the plaintiff's estate had been taken by the company to form a reservoir to supply their canal, and for no other purpose; whereas they had persisted in holding a "grand fête or regatta" on the lake. The legal right of the plaintiff had been affirmed (Erle J. diss.) in a case which was argued before the Court of Queen's Bench.

Where there were several adjacent closes called $H$, and the plea to a declaration for seizing pigs was, that defendant was possessed of a close named H, in which the pigs were eating, \&c., and were taken damage feasant; and the replication was that the defendant was not possessed of the said close in the said plea mentioned, in which the pigs were alleged to be eating, \&c. ; and issue was taken thereon-it was held that the defendant was bound to show that he was possessed of a close, in which the pigs were eating, \&c., and that it was not enough for him to show his possession of a close named H (Bond v. Downton). But a plea, justifying an alleged trespass as committed in exercise of a right of way, is sufficiently certain, as to the premises in respect of 
which the way is claimed, if it describe them as "a close in the parish," se., "and comty," \&e., "called B, with certain lands thereunto adjoining; and another close called M, and divers, to wit two, other closes next adjoining thereunto;" claiming a way from B to M and back for the better nse, occinpation, \&c., of B and the said lands adjoining thereto, and of $\mathrm{M}$ and the said adjoining closes respectively (Holt r. Date).

And per loord Camplell C.J.: "It appear's with sufficient certainty that there is bnt one way in question; and the termini are specifically described by name, as well as of the two closes in respeet of which it is clitimed. The other lands and closes in respect of which it is claimed are stated to be aljoining to those that are expressly named; and if they had been described by name, or by metes and bounds, the plaintill wonld have derired little advantage from such particularity, as the defendant was not bound to prove his right in respect of any but the two closes named as the termini, and wonld have been entitled to the verdict if he had proved his right in respect of them, thongh he had failed as to all the others, as appears from Rickelts v. Saluey."

"In Stott v. Sloll the defendant justified nnder a right of way in respect of a certain messnage, and divers (to wit, 50) acres of land. In Simpson v. Lexthuccite the defendant claimed the right of way in respect of 100 acres of land contiguons and next adjoining to one of the cluses in which, \&c. In Colchester v. Roberts the defendant justified nuder a claim of a right of way in respect of a messuage, and divers (to wit, three) closes of land near to the close in which, \&c. There is, therefore, abundant authority in the precedents for such a mode of pleading, and no case was cited in point to show that such a form is objectionable."

In trespass quare clausum fiegit, the defendant is entitled to plead liberum tenementum, together with a plea denying that the close-in which, \&c., is the plaintiff's (Stocombe v. Lyall). And per Parke B.: "They do not necessarily relate to the same subject-matter of defence. Under the plea that the close is not the plaintiff"s, he must prove himself in possession, and that is sufficient until the defendant shows a better title; bnt the plea of liberum tenementum sets up the title of the defendunt. Under the denial that the close is the plaintiff's, both possession and title may be in issue, which is not the case with liberum tenementum." (ib.) As to new assignment see Braceyirtle v. Peacock, liobertson r. Gecuntlell, Bowen v. Jenkin, Normen v. Hescombe, Brancker v. Holynecuex, and Hayting v. Oakey, and the review of the older authorities laid down in the note to the ease of Grecne v. Junes. 
Trespass is the proper remedy for uronyfully continuing a building on plaintiff's land, for the erection of which plaintiff has already recovered compensation; and a recovery, with satisfaction for erecting it, docs not operate as a purchase of the right to continue such erection. And hence where, as in Holnes v. Wilson, the trustees of a turnpike road built buttresses to support it on the land of the plaintiff, who sued them and their workmen in trespass for such erection, and accepted money paid into Court in full satisfaction of the trespass, it was held by the Court of Queen's Bench, that after notice to defendants to remove the buttresses, and a refusal to do so, the plaintiff might bring another action of trespass against them for keeping and continuing the buttresses on the land, to which the former recovery was no bar. And per Lord Demman C.J.: "The former and the present action are for different trespasses. The former was for erecting the buttresses. This action is for continning the buttresses so erected. The continued use of the buttresses for the support of the road under such eircumstances was a fresh trespass." And so in Bou'yer v. Cook, where the defendant was sued in trespass for placing stumps and stakes on the plaintiff"s land, and paid into Court 40s., which the plaintiff took out in satisfaction of that trespass; and the plaintiff afterwards gave the defendant notice, that nnless he removed the stumps and stakes, a further action would be brought against him ; it was held that the leaving the stumps and stakes on the land was $a$ new trespass, and that the plaintiff was entitled to full costs in an action for their continuance after the notice, thongh he recovered less than 40s. Parle B. had refused to certify that the trespass was wilful and malicions under the $3 \& 4$ rict.c. 24 , s. 2, and said that the proper mode of obtaining such costs was by entering a suggestion on the record, under the 3rd section, that the trespass was committed after notice.

And per Curiam: "In Sherwin v. Su'indall, the judge clearly had power to certify as he did under $3 \& 4$ Vict. e. 24 , s. 2 . In Daw v. Hole the attention of the Court of Queen's Bench does not seem to have been called to the effect of the $8 \& 9 \mathrm{~W}$ ill. III. c. 11, in connection with the $22 \& 23$ Car. II. c. 9 : they appear to have thought that the costs are given only where the judge certifies, not adverting to the circumstance of the only statute depriving the plaintiff of costs in these cases having been repealed. The next question is-was the trespass in this case committed after notice? That depends npon whether or not the continnance of the stmmps and stakes on the plaintiff's land, after the notice to remove them, was a new trespass. The cases of Hudson v. Nickolson and Ifolmes v. Witson clcarly show that it was. 
Ancl per Cressuell J.: "Primî facie, the plaintiff having recovered damages is entitled to costs; if he is not, it must be by virtue of some statutory enactment. It has been very properly admitted that the only statute that can have the effect of depriving the plaintiff of costs in this case, is the $3 \& 4$ Fict. c. 24. The 2 nd section of that statute cnacts, that if the plaintiff, in any action of trespass, or of trespass on the ease, shall recorcr less damages than $40 s$, he shall be entitled to no costs, unless the judge shall certify on the back of the record that the action was really brought to try a right, or that the trespass or gricrance was wilful and malicious. Then comes the ard section, which provides that nothing in that act shall extend to deprive any plaintifl of costs in any action for a trespass over any lands, \&c., in respect of which a notice not to trespass thereon shall have been previonsly giren to the defendant. If this 3rd section had enacted that the plaintiff should not be deprived of ensts, if it shonld appear at the trial that a previons notice not to trespass had been given, there might have been gromul for contending that the judge must certify to entitle the plaintiff to costs. But the notice is not required to appear at the trial. The proper course clearly is to suggest the fact upon the record, learing the defendant to traverse it, if so adriscd."

The certificate to deprive the plaintiff of costs under $23 \& 24$ Ticl. c. 126 , s. 34 , where in an action for a wrong he recovers less than $£ 5$, must negatice not ouly the trespass being wilful and malicions, but also the fact that the action was bronght to try a right, and that it was not fit to be bronght. And per Williams J.: "The case of Saunders r. Kirman" (30 L. J. (N. S.) C.P. 351) applies to the negative that the trespass was wilful and malicions, and the decision there is quite correet, inasmuch as if the certificate negatives the trespass being either wilful or malicious, it necessarily negatives its being both wilful and malicious (Gooding v. Brimull).

It is now perfectly settled that a man may be guilty of a misance in erreting, or contimuing a building on the leond of another. And it was so held by the Court of Qneen's Bench in Holmes v. Wilson, by the Court of Exchequer in Thompson v. Gilison, and by the Court of Common Pleas in Borryer v. Cook, and Battishill v. Reed. And per T. Williems.J.: "Where an action has been brought for erecting and leaving a building on the plaintifl"s land, a fresh action will lie for continuing it there; and action after action may be brought till it is removed. Whether this case falls within the principle of INolmes v. Wilson, I will not undertake to say; but assuming that it does, Iolmos v. Witson has been followed by Thompson v. Gribson; and Thompson v. Gibson and Linuyer v. Cook have established that 
fresh actions may be bronght as long as the nu'sance is continued" (Battishill v. Reell). And per Jeriti C.J.: "It was for the jury to say what damages the plaintiff" was entitled to ; but as a principle of computation, the diminution in the saleable value of the premises was not the true criterion. Every day that the defendant continues the nuisance he renders himself liable to another action. I think the jury did right to give, as they generally do, nominal damages only in the first action ; and if the defendant persists in continuing the nuisance, then they may give such damages as will compel him to abate it, but not as was insisted here, the difference between the original value of the premises and their present diminished value" $\left(i b_{*}\right)$. And per V. Williams J. : "Where the action is for a nuisance in the defendant's own land, he may always discontinue it; but where it is for a trespass, in respect of an act done in the plaintiff's land, he cannot enter to remove it without committing another trespass (ib.). The rule suggested in Holmes v. Wilson, and Thompson v. Gibson, is adopted by Professor Sedgwick (see Sedgwick on Damages, 2nd edit. p. 144), where it is said, 'Every continuance of a nuisance is held to be a fresh one, and therefore a fresh action will lie,"

In an action for a nuisance by the burning of bricks near the house of the plaintiff, the Court of Common Pleas decided (confirming the ruling by Byles J.) that the jndge may properly direet the jury that the plaintiff was not bound to show that the brick-burning was injurious to health ; but that if it rendered the enjoyment of his life and property substantially uncomfortable, he was entitled to recover ; and that the jury ought to takc into consideration, as an element of the inquiry, whether the brick-burning was carried on in a proper and convenient place for that purpose (Hole v. Barlou').

The Court rested their judgment on Com. Dig. "Nuisance," C, where it is said, "An action does not lie for the reasonable nse of any right, althongh it be to the annoyance of another; as if a butcher, brewer, dc., use his trade in a convenient place, though it be to the annoyance of his neighbour." Willes $J$. said, "Comyn lays it down that every person has a right to fresh air ; but that right must be limited by this, that those matters which must be done in ordinary life may be done." Hence a work of reasonable necessity cannot be made the foundation of an action for a nuisance, which is a limitation of the doctrine in Aldred's case, 9 Rep., $57 "$ (ib.).

In Coiby v. Hill the facts were these : The defendant being about to build, laid his materials (having received leave so to do) on a private road leading to a connty lunatic asylum, along which persons bad been accustomed to pass by leave of the owners, and were likely to continue 
to pass, so as to obstruct the road and make it dangerous to per'sons using it, and gave no notice by signal or otherwise. It was held by the Conrt of Common Pleas that the defendant was liable to an action by the plaintiff for the injury sustained by his horse, and semble it was not necessary to aver in the deelaration that the materials were so placed by the defendant without the permission of the owners and oceupiers of the soil, as such allegation would raise an immaterial issue. And per Hilles J.: "A statement of the facts was sufficient to show that the plaintifl had a remedy, because the defendant had no right to set a trap for the plaintiff. A person coming on lands by licence has a right to suppose that the person who gives the licence, and much more a person who is a wrong-doer, will not do anything which will cause him an injury. In this ease I do not think that the defendant has shown a licence to place the materials in the way he did." And per Williams J. : "Suppose you have a piece of land, and give your neighbour leave to put his harrou's upron it, and just before dusk he fuls them the wrong way upururls, and your friend comes to dine with you, and is damaged thereby, will he not have a right of action against that man ?" On the counsel objecting that according to Southcole v. Stanley he had not, his Lordship observed, "The exception is the case of Souflucote v. Slanley, and that case stands entirely on the relation of lost and guest, and is founded on the proposition that a man who becomes a guest cannot complain of the want of good appointments in the house in which he is a ginest."

In trespass for cutting into the plaintiff's close, and carrying away the soil, the proper mectsure of damayes is the value to the plaintiff of the land removed, not the expense of restoring it to its original condition (.Jones v. Gooday). To a plea of the Statute of Limitations in an action of trespass, or trespass on the case, the plaintiff will not be allowed to reply as an equitable answer nnder sec. 85 of the Common Law Procedure Act, 1854, that the trespasses, \&e., were under-ground, and had been fraudulently concealed from the plaintiff till within six years before suit (Hunter v. Gibbons).

With respect to giviny acts of ownership in evidence in an action of trespass, Purke B. observed in Jones v. Williams, "I ordinary cases to prove his title to a close, the claimant may give in evidence any acts of ownership in any part of the same inclosure ; for the ownership of one part causes a reasonahle inference that the other belongs to the same jerson; though it by no means follows as a necessary consequence, for different persons may have balks of land in the same inclosure; but this is a fart to be submitted to the jury. So I aplrehend the same rule is alplicalole to a wood, which is nut inclused by any fence; if you 
prove the cutting of timber in one part. $\mathrm{I}$ take that to he eridence to go to a jury to prove a right in the whole wood, althongh there shonld be no fence or distinet boundary surrounding the whole; and the case of Stanley v. White, I conceive, is to be explained on this principle; there was a continuous belt of trees, and acts of ownership on one part were held to be admissible to prove that the plaintiff was the owner of another part, on which the trespass was eommitted. So I should apply the same reasoning to a continuous hedge, though no doubt the defendant might rebut the inference that the whole belonged to the same person, by showing acts of ownership on his part along the same fence."

Where premises are demised or conveyed " with right of way thereto," it may he a question for the jury what is a reasonable use of snch right. And so in Hankins v. Carbines, which was an action in trespass for breaking locks and chains, and the defendant justified under an alleged right of way through a gateway, across which the chain was fixed, and the right of way was expressed to be "through the gateway" of the plaintiff (which gateway led to other premises of the plaintiff), and at the time of the lease earts could come in to load and unload, and turn round and go out again, but throngh alterations of the premises conld not now do so withont slightly trenching upon the plaintiff's premises, the Court of Excheqner held that in the reasonable use of the right of way the defendants had a right to do this; and that what was a reasonable user was for the jury.

It was decided by the Court of Common Pleas in Delaney v. Fox, that the rule by which a tenant is estopped from denying the title of the landlord who let him into possession, is applicable in an action of trespass as well as an ejectment, thus qualifying Pollock C.B.'s dietum in JVatson v. Lane, that the doctrine which prevents a party from denying his landlord's title is peculiar to ejectment. On the termination of a lease, the landlord cannot maintain trespass before entry. And so the enstomary heir of a copyhold tenement eannot maintain trespass withont entry; but after entry there is a relation back to the astual title, as against a wrong-doer, and he may maintain an action for trespasses committed prior to his entry (Barnett v. Earl of Guillford).

Mere permissive tenant has no right to sue a claimant under ouner for forcible cntry.- Where the plaintiff used land as a garden for more than 20 years, under permission from the owner to do so in order to keep it from trespassers, the owner from time to time coming on to the land, and giving directions as to the entting of trees, \&ce, it was held by Erle C.J., that he had not got a title so as to enable him to sne a elaimant under the owner for forcible entry. The learned judge observed, "It may be taken that the plaintiff had a beneficial oceupation for more than 20 
veirs, and if that will give him a title I will give him leave to move; but in my opinion every time Cox the owner put his foot on the land, it was so far in his possession that the statute wonld begin to run from the time he was last on it. Mr. Bovill moved in the Common Pleas, and took nothing (Allen r. Enyland).

Forcible cntiy in exercise of right of common of pasture.-To an action of trespass for breaking and entering, and pulling down, and destroying the plaintifl's house, whilst he and his family were therein, and assaulting the plaintiff, and by so pulling it down endangering the lives and injuring the persons of the plaintiff and his family, and ejecting them therefrom, and taking the materials of the house; the defendant as to the breaking and entering and pulling down and destroying the house, and taking the materials, justified in the exercise of a right of common of pasture orer the land, on which the plea alleged the house was wrongfully ereeted, so that without pulling it down the defendant conld not enjoy the right of common of pasture. It was held by the majority of the Conrt of Exchequer that the ease was governed by Perry v. Fitzhoure (8 Q. B. 757,15 L. J. (N. S.), Q. B. 239), which is an authority that a house cannot be pulled down, a man being in it, and that the plea did not answer the action. The Court intimated that it was doubtful whether if the case had been before them for the first time they would have coneurred in the judgment pronounced by the Court of Qucen's Bench in Perry v. Fitzhoue, but that as the question was of no importance to the parties in the canse, except as to the question of costs, it was better to abide by that decision. And per Ifilde B., "Burting v. Read (11 Q. B. 890 , and 19 1. J. (N.S.), Q. B. 291 ), and Perry v. Fitshouce estabblish a clear distinction between a man entering on his own land, and an entry to aluate a mere infringement of a right of common" (Jones $\mathrm{v}$. Jones).

Construction of the Maticious Trespass Act.-The ocenpier of land found a man (employed ly the owner) felling trees on to the land in such a way as to damage growing barley; and after again and again desiring him to desist gave him into custody for wilfully damaging the barley. In an action of trespass, the man recovered $£ 20$; and the judge having declined to certify for costs, a suggestion was entered to deprive him of costs, on the ground that the defendant was acting in pursuance of the Nalicious Trespass Act $(7 \& 8$ Geo. IV., c. 30, s. 22). Blackburn J. on the trial of the suggestion having left it to the jury to say whether the defendant really and reasonably believed he was acting aceording to $l_{\omega}$, and they found in the aflirmative, it was held that whether the question was for the judge or the jury the verdict was right, and semble that it was right?y left to the jury (Norwood v. Pitt). 
Estimating tamages for trespass or negligent act.- In an action for a wrong, whether arising ont of trespass or a negligent act, the jury in estimating the damages may take into consideration all the circumstances attending the committal of the wrong. In an action for wrongfully and injurionsly pulling down a building adjoining the plaintiff's stable in a negligent and improper mamner, and with such a want of proper care, that by reason thereof a piece of timber fell upon the plaintiff's stable and destroyed the roof, and by reason of the defendant's negligence, carelessness, and muskilfulness, part of the building fell upon and injured the plaintiff's hor'se, and evidence was given showing that the defendant had acted wilfully and with the object of forcing the plaintifi to give up possession of the stable, it was held by the Court of Fxchequer that the jury were properly directed, that if they thought the defendant had acted with a high hand wilfully, and with the object of getting the plaintiff" out of possession, the damages might be higher than if the injury was the result of pure negligence. And por Bramuell B., "Suppose a man was to put an offensive mixen on his own lands, opposite his neighbour's window, so as to be a nuisance, and for the mere purpose of annoyance, do you conceive that the damage could be limited to a mere pecuniary compensation in such a case as that it may be said the act is wilful as it is here?" And per Channel B., "My brother Bramwell has obscrved that in an action of trespass, that is in some action of tort, you may give evidence of damage beyond the actual injury sustained, in conseqnence of insulting eircumstances connected with the trespass; and I can see no reason why that should be limited to one kind of action of tort, by trespass, and should not extend to an action which, in substance, is for negligence committed under circumstances which might have supported an action of trespass" (Emblen v. Mlyers).

Entry untauful on day when plaintiff has whole of day to remov'e crops.--In trespass for entering land and breaking gates (the interest of the plaintiff under a contract for growing crops expiring on the day of which the entry was made by the defendant, who was entitled to the property), it was held by Wightman J. that as the plaintiff was entitled to the whole of the day to remove his crops, the entry was unlawful, but the damages must be nominal, and an amendment to include the crops in the declaration was refused (Areher v. Sa:lter).

In an action against a railway company for carelessly letting sparles fly from their engines, so as to set the herbuge, de., on fire, Wutson B. ruled that it is not necessary to prove any specific negligence, and that the compensation in such a case shonld be measured, as in that of an nuwilling vendor (Gibson v. South Eastern Railuay Company). 
But a railway eompany anthorised by the Legislature to nse locomotive engines is not responsible for lamage by fire oceasioned by the sparks from an engine, provided they have taken erery precaution which science can sngrgest to prevent injury from fire, and are not guilty of negligence in the management of the engine (Taughan $\mathrm{r}$. Taff Vale Railuray (mmpany), 29 L. J. N. S. Ex. 247, see also Fremuntle v. London and Sorth IT estern Ratideay Company.

It is a question of fuct for a jury, and not of law for a jullye, whether the furmer in setting his stucts of beans where it was ptaced, or the railuay company who iynited it by the spartes which flew from their engine, hat bren the most negligent (Aldrillye v. Great Western Railway Company). In Rex: v. Pease it was held that no indictment for a nuisance lay against a railway which ran five yards from a highway, for frightening horses.

According to T'aughan v. Wenlove, an action lies against a party for so megligently constructing a hay-rick on the extremity of his land, that in consequence of its spontuneous ignition his neighbour's house is burnt dor'n. At the trial it appeared that the riek in question had been made by the defendant near the boundary of his own premises; that the hay was in such a state when put together as to give rise to diseussions on the probability of fire ; that though there were eonflicting opinions on the subject, yet during a period of five weeks the defendant was repeatedly warned of his peril ; that his stock was insured; and that upon one oceasion being advised to take the rick down, to avoid all danger, he said " he wonld ehance it." He made an aperture or chimney in the rick; but in spite, or perhaps in consequence, of this precaution, the rick at length burst into flames, which communicated to the defendant's barn and stables, and thence to the plaintiff's cottages, which were entirely destroyed. The pleas were Not guilty, and that there was no negligence; and the ruling of Patteson J., who told the jury that the question for them to consider was, whether the fire had been occasioned by gross negligence on the part of the defendant; adding that he was bound to proceed with such reasonable caution as a prudent man would have exercised under such circnmstances-was mpheld by the Court of Common Pleas, and a new trial refused after a verdict for the plaintiff.

In 'Tubertill v. Stcump, which applied very closely to the present case in principle, it was decided that if an occupier burns weeds so near to the boumlary of his oun land that damaye ensues to the property of his nerighbour, he is liable to an action for the amount of injury done, muless the accident were vccasioned by a sudden blast which he could not foresee. 
Sectrs r. Lyons was an action of trespass for brecking the plaintifr's rlose and layjing poisoned butey upon it to destroy his poultry. The defendant had strewn it both on the plaintifl's premises and his own, into which the fowls sometimes escaped, and several of them had died in consequence. In summing up Abbott C.J. told the jury that "It had always been held that for trespass and entry into the honse or lands of the plaintiff, a jury might consider not only the pecuniary damage sustained by the plaintiff, but also the intention with which the act had been done, whether for insult or injury;" and added, "that they were not confined in this case to the mere damage resulting from throwing poisoned barley on the land of the plaintiff, but might censider also the object with which it was thrown, taking care at the same time to guard their feelings against the impression likely to have been made by the defendant's conduct." The plaintiff had a verdict for $£ 50$.

Horses frightened by traction engine on highucay.-It was held by Erle C.J., that a plaintiff has a right to recover against the owner of a traction engine used on a highway under $24 \& 25$ Tict. c. 70 , if he knew from his men or other persons, or from the nature of the engine itself, that the engine was calculated by its noise and appearance to frighten horses. The defendant has clearly no right to make a profit at the expense of the security of the public (Watkins $\mathbf{v}$. Reddin).

Evidence of negligence necessary to entitle plaintiff to recover.-In an action for an injury occasioned by defendant's negligent driving, the plaintiff to warrant the judge in leaving the case to the jury, must give proof of well-defined negligence on the part of the defendant; and where the evidence giren is equally consistent with there having been no negligence on the part of the defendant, as with there having been negligence, it is not competent for the judge to leave it to the jury to find either alternative; such evidence must be taken as amounting to no proof of negligence. Foot-passengers, in crossing a highway, are bound to take due caution to avoid vehicles; and the drivers of vehicles are bound to take due caution to avoid foot-passengers. And per Pollock C.B. : "To sustain an action for an injury cansed by the negligent driving of the defendant, the injury must have been caused by the negligence of the defendant only, without the negligence of the plaintiff contribnting in any way to the accident" (Cotton v. Wood, 13 C. \& K., 81). 'The mere happening of an aceident is not sufficient evidence of negligence to be left to the jury, but the plaintiff must give some affirmative evidence of negligence on the part of the defendant. Where, therefore, it was shown that the defendant was riding a 
horse at a walk, when the animal became restive, and rushing on to the parement knoeked down and killed the husband of the plaintiff, but the witnesses for the plaintill' also proved that the defentant was doing his best to prevent the accident, it was held that this was no proof of negligence; that taking the evidence of the witnesses for the plaintiff altogecher, it was clear that the defendant was carried on to the pavement against his will, and that there was therefore nothing to turn the scale of evidence against the defendant, and to show that he was responsible for the consequences of the accident, but qucre whether on an indictment for manslaughter the same presumption would be made in farour of a prisoner as for the defendant in an action for death cansed by negligence (Hammack r. White).

Negligence in viding alony a public highuay.-The plaintiff was driving a waggon with three horses along a highway, walking in the usual way at the head of the leading horse, on his proper side of the road. The defendant and his groom were riding at a foot's-pace (meeting the waggon on the wrong side) when, just as he passed the plaintiff, the groom touched his horse with a spur and he kicked out, and struck the plaintiff. It was held by the Court of Common Bench that the act of using the spur when so near to the plaintitf, was such an improper act on the part of the groom as to justify the jury in finding the defendant to have been guilty of negligenee (North $\mathrm{v}$. Simith).

Nuisunce by brick-burning. - Where a man by an aet on his own land, such as burning loricks, cances so much amnoyance to another in the enjoyment of a neighbouring tenement as to amonut mima facie to a canse of action, it is no answer that the act was done in a proper and convenient spot, and was a reasonable use of the land. The fitness of the locality does not prevent the carrying on of an offensive thongh lawful trade from being an actionable nuisance, but whenerer, taking all the cireumstances into consideration, including the nature and extent of the plaintifl"s enjoyment before the acts complained of, the annoyance is sufficiently great to amount to a nnisance, an action will lie whatever the locality may be, and the decision of the Queen's Bench was overruled by Erle C.J., Williams J., Bramuell, B., Keating J., and Wilde B.; Pollock C.B. diss. 'Thus Hole v. Burlow is overruled, the case upon which the Qneen's Bench grounded their judgment (Bamford v. Tumley). Without expressly overruling Hole v. Barlow, Stuart V.S., had decided to the same eflect in Beardmore v. Treaduell.

Onus on defendant lo show that trade is carried on in a reasonable and proper manner.-The carrying on a lawful trade in the usual manner is not necessarily the carrying it on in a reasonable and proper manner, and where to an action for carying on a trade in such a 
manner as to canse injury to the plaintiff, the defendant relies for a defence upou the fact of the trade being earried on in a reasonable and proper manner, the onus of proving that it is so carricd on is on the defendant, and not on the plaintiff of showing that it is not so carried on, and the case does not come within the principle enunciated in Hote v. Burlow (4 C. B. (N. S.) 437, 27 L. J. (N. S.), C. P. 207), (The Stockport Waterworks Company v. Potter and Others).

In Wanstead Local Board of Health (appt.) v. Hill (resp.) it was decided by the Court of Common Pleas that briek-making is not an offensive or noxious trade or business within sec. 64 of the Public Irealth Act (11 \& 12 Vict. c. 63).

No notice is required by the $1 \& 2$ Will. IV. c. 32, nnder which trespassers may be punished if in pursuit of game, on eonviction before a justice of the peace. Notice for an ordinary trespass must be served either verbally or in writing, and should come from the tenant of the particular parcel of land on which the trespass is committed. Gamekeepers or other persons deputed to do so may serve a notice, but they must name the occupier as giving them orders. The form of notice should be as follows :

"To A. B., residing at , in the parish of county of . I do hereby give yjure notice not to come into or upon any of the lands or woods occupied by me in the parish of and commonly linoun as the furm or w'oods of ; and in case of your so doing I shall proceed against you as a wilful trespasser.

"Witness my hand this day of , 18 . A. D."

The provisions against trespassers in the above act do rot apply to amy person huinting or coursing upon any lands with hounds or greyhounds, and being in fresh pursuit of any deer, hare, or fox already started upon any other land.

A person who canses the apprehension of another for a maticious trespass to property, of which the former is the reversioner only, is cntitled to notice of action nnder the Malicious Trespass Aet, 7 \& 8 Geo. IV. c. 30 (which repeals 1 Geo. IV. c. 56), if he eauses such apprehension under the bona fide belief that he is acting in pursnance of the statute (Horn v. Thornlorongh). And per Parke B. : "The defendaut was entitled to notice of action provided he bona fide believed that he was acting in pursuance of the statute; or according to the cases in the Cunrt of Queen's Bench, if he bona fide so believed, and had reasonable ground for that belief. It was decided by the case of Huyhes v. Bucklaml, that the protection afforded by the statute is not to be 
strietly confined to the owner of the property injurer, but is extended to all persons who have a bona fide belief that they fill the character mentioned in the statute, and act bonu fide under that belief. MIost of the authorities were considered in Huyhes v. Buckland, where the serrants of the owner of a fishery, bona fide believing the plaintiff to be fishing within the boundary of their master's fishery, caused him to be apprehented, although in fact he was not within the boundary. The same rule was laid dorm in Beechey v. Sides and Rudd v. Sirott; and there is no doubt that those decisions are correct, for no benefit would be conferred by the statue if it were to be confined to those persons only who have the legal power to arrest. The only apparent difficulty in the present case arose ont of Parrington v. Moore, to which reference was made in the conrse of the argument; but that ease, on a closcr inspection, has no bearing whatever mpon the present. The only question there was, whether the defendant was justified in arresting the plaintiff, who was mima facie a trespasser, but who, it appeared, had acted under the bona fide belief that he had a right to do what he did : and the Court there held that the defendant was not warranted in arresting him. That distingnishes that case from the present, and leares us to the other authorities, and the later case of Hughes v. Buckland leaves no doubt upon the matter. These observations do not apply to justices, as in such ease the protection is only given nominatim to those who actually fill that character; and the same with respect to certain eases of trustees and commissioners; but by the present Act, this protection is granted to every person who, when he commits the trespass complained of, acts under the bonc fide belief that he is acting in pursuance of the statute."

In Thomas (appt.) v. Ei'ans (resp.), the appellant was convicted for fishing for salmon with a net, the meshes of which were less than $2 \frac{1}{2}$ inches broad. The nct in question had its meshes $1 \frac{1}{2}$ inches broad from knot to knot. Statute 1 Eliz. c. 17, s. 3, enacts that no one shall take fish as therein mentioned, "but only with net or trammel, whereof the mesh shall be $2 \frac{1}{2}$ inches broad," and does not describe what is the meaning of the word "mesh"; while stat. 3 Jac. I. c. 12, s. 2, which speaks of" a mesh of 3 inches, describes it as " $1 \frac{1}{2}$ inches from knot to knot." 'The Court of Queen's Bench held that the convietion was right; and that the meaning of the word "mesh" in stat. 1 Eliz. e. 17, s. : 3 , is that cvery space between the threads of the net should be $2 \frac{1}{2}$ inclies from one thread to the opposite thread, and that the superficial area which bounded each mesh should be $2 \frac{1}{2}$ inches at least.

It has been held that a person may justify trespass in following a fox with hounts over the groumls of another, if he do no more than is neces- 
sary to kill the fox (Gundry v. Feltham). So in Popham (162) it was adjudged that a man may start a fox on his own, and hunt him into another man's land, because it is "a noysom creature to the commonwealth."

But in the case of the Earl of Essex v. Capel, Lord Ellenborongh C.J. denied the anthority of Gundiy v. Feltham, and ruled that persons lunting for their own amusement over the lands of another are trespassers, and may be warned off; and the plaintiff will have full costs, though the jury do not give 40s. damages. His Lordship said: "The defendant stated, in his plea, that the trespass was not committed for the purpose of diversion and amusement of the chase merely, bnt as the only way and means of killing and destroying the fox. Now if you were to put it upon this question, which was the principal motive? Cam any man of common sense hesitate in saying that the principal motive and inducement was, not the killing of vermin, but the enjoyment of the sport and diversion of the chase. And we cannot make a new law to suit the pleasures and amusements of those gentlemen who choose to hunt for their own diversion. 'These pleasures are to be taken only where there is the consent of those who are likely to be injured by them, and they must be necessarily subservient to the consent of others. There may be such a public nuisance by a noxious animal as may justify the running him to his earth, but then you cannot justify the digging for him afterwards. That has been ascertained and settled by the law. But even if an animal may be pursued with dogs, it does not follow that fifty or sixty people have a right to follow the dogs, and trespass on other people's lands." His Lordship also ruled in Hume v. Oldacre, which was an action of trespass a rainst the huntsman of the Berkeley Hunt, that damages might be recovered, not only for the mischicf immediately occasioned by the defendant himself, but also for that done by the concourse of people who accompanied him.

The rule as to hunting trespasses was made still more stringent in Baker v. Berkeley, where the plaintiff had $£ 100$ damages. The defendant had received notice not to trespass on the plaintill"s land. Some time after, his field went, and did damage to the amount of $£ 23$, while he rode along a road to avoid it. The stag ran into a barn followed by six couple of hounds, where it was worried; and the defendant, who was not allowed to go into the barn to rescue it, gave the plaintiff a blow. Lord Tenterden C.J. ruled "that if a gentleman sends ont his hounds and servants, and invites other gentlemen to hunt with him, although he does not himself go on the lands of another, but those other gentlemen do, he is answerable for the trespass they may 
commit in so doing, unless he distinctly desires them not to go on thoselands ; and if (as in the present case) he does not so desire them, he is answerable, in point of law, for the damage that they do. With regard to the defendant's attempt to go into the plaintiff's barn, it is clear that the plaintiff had a right to refuse any person's going into it, if he chose to do so. Whether it might be discreet in him is another thing; but undoulitedly he had a right to say that they should not go into his barn, and if they did so they are trespassers."

And so it was ruled by Laurence J., in the case of Hill v. Watler, that where a person goes out sporting with his friends, and wilfully leads them on to another's land, he is equally guilty of a trespass, although he may remain off the land whilst his friends go on it, as if he had entered himself or sent his dog. Here the defendant Walker and several other gentlemen being out sporting, attended by the other defendant (Walker's servant), two of the party went into the Withy Bed, and shot several times, the rest remaining in the adjoining highroad. As the pheasants rose very fast, the defendant ordered his servant to go and fetch his dog out, which was done, The two shooters swore that they only entered the Withy Bed, and that the defendants held the horses outside, and did not eren let Walker's dogs enter. On cross-examination, it appeared that Walker having had notice to keep off the land, before the party eame to the Withy Bed, told the shooters that he would show them where plenty of game was to be found; and he took them to the plaintiff"s close, and pointed that out as the place. But per Alilerson B. : "If I give a man leave to go on " field over which I have no right, and he gocs, that will not make me a trespasser; but if I desire him to go and do it, and then he does it, that is a doing of it by my anthority, which is quite a different thing, and I should be liable as a joint trespasser. An order to go on land, in spite of the owner, is a great deal more than leave and licence, it is an authority" (Robinson v. I'cunglion).

And the Court of Queen's Bench also held in Merest v. - that $£ 500$ were not excessive damages for a trespass in sporting, perserered in defianes of notire, and accompanied with offensive language. The defendant (who had been sporting) left his carriage on the road, and told the plaintiff, with an oath, that he would shoot with his party in spite of lis notice; fired sereral times at the birds, which the plaintiff found, and proposed to borrow shot of him when he had exhausted his own belt, besides threatening, in his capacity of magistrate, to commit him, and defying him to bring an action. Horth .J. cited a ease where \pm tof was given for merely knocking a man's hat off. And it is no reason for changing the ermue, in an indictment for a supposed con- 
spiracy to destroy fores and olher vermin, that the gentry of the county (Cheshirc) in which the indictment was found are addicted to fox-hunting (Rex v. King).

In the case of Sutton v. Moody, it was said by Holt C.J. that "If $A$. start a hare in the ground of B., and hunt and kill it there, the property contimes all the while in B.; but if $A$. start a hare in the ground of B., and hunt it into the ground of C., and kill it there, the property is in $A$. the hunter; but $A$. is liable to an action of trespass for hunting in the grounds as well of $B$, as of $C$." The latter part of this dictum was relied upon for the plaintiff in Churchuard v. Studdy, which was an action of trespass for carrying away a dead hare. The plaintiff had part management of the hounds, and was hunting them, when they started a hare in a third person's grounds, aud followed her into defendant's grounds, where she was seized, quite spent, by one of the dogs between the legs of a labotrer, who took her up alive; and she was killed by the defendant. The plaintiff demanded the hare; and the labourer said he had taken it up not for his own use, but in aid of the hunters ; but the defendant refused to give it up. Iord Ellenborough C.J. considered "that the plaintiff, through the ageney of his dogs, had reduced the hare into his possession: that makes an end of the question, even though the labourer had first taken hold of it before it was actually eanght by the plaintiff's dogs; yet it now appears that he took it for the benefit of the hunters, as an associate of them, which is the same as if it had been taken by one of the dogs. If, indeed, he had taken it up for the defendant before it was caught by the dogs, that would have been different; or even if he had taken it as an indifferent person in the nature of a stake-holder."

No action in general lies for an incoluntary trespass ; and it is laid down in 2 Roll. Ab. $566 \mathrm{pl}$. 1, that if eattle in passage on the highway eat herbs or corn raptim et sparsim against the will of the owner, it will exeuse the trespass. So in Millen v. Frandrye, where sheep trespassed on a neighbour's land, and he drove them out with a dog, it was'held that trespass could not be brought. If a person goes along a footpath, and his $\operatorname{dog}$ happens to escape from him, and run into a paddock, and pull down a deer against his will, it is no trespass (Berlicuth v. Shardike). And per Parke J., a dog jumping into a field without the consent of its master is not a trespass for which an action will lie (Brown $\mathrm{v}$. Giles). A plea to an action for trespass for killing the plaintiff's dog cannot justify the act by stating that the lord of the manor was possessed of a close, and that the defendant, as his gamekeeper, killed the dog, when running after hares in that close, for the preservation of the hares; such plea not even stating that it was necrssary to kill the dog 
for the prescrration of the hares, nor that it was the dog of an mnqualified person (Tere v. Lord Caudor). But it was held by Taunton J., in Protheroe r. Matheu's, which his Lordship (who mentioned Wadhurst v. Damme and Burrington v. Turner as being in point) considered to be very distinguishable from Tere v. Lord Candor, that the servant of the ourner of an ancirnt park may justify shooting a doy that is chasing the decr, although the dog may not have been chasing deer at the moment whem he was shot, if the chasing of the deer and the shooting of the dog were all one and the same transaction, but that if the ehasing was at an end, and the dog would not have recommeneed, the plaintiff ought to have a rerdict, which he had for one furthing.

There it was replied, in an action of trespass for taking plaintiff's $\mathrm{dog}$ as a distress elamage feasent in a close, that the dog, when taken, was in the actual possession of, and under the eare of, and being used by the plaintiff's son and servant, it was held by the Court of Queen's Bench that the averments in the replication were insufficient as applied to a dog, to show such user of it as exempted it from seizure (Bunch v. Kennington). And per Patteson J.: "The arerments in the replication would be satisfied by proof that the dog was wihin sound of Bunch's whistle, and that Bunch was out of sight."

A yamekerper aulhorised to seize the dogs of mquatified persons sporting on a manor, by deputation given before stat. 1 \& 2 Will. IV. c. 32, and not renerred, eamnot justify seizing the dogs of uneertificated persons committing such trespass, since the passing of the Act (Lidster v. Burrou'). Nor is he entitled to notice of action under sec. 47 of the statute, on the ground that he bon $\hat{\iota}$ fide supposed himself to be acting in pursuance of the statnte (it.). 'The Court of Queen's Bench considered themselves bound by the ease of Bush v. Green, where the Court of Cummon Pleas held that a gamekeeper acting under a deputation granted and registered previously to the 1st of November, 1831, when the Act $1 \& 2$ Witl. IV. c. 32 , came in force, was not entitled to notice of action, or to give all matters in evidence under the general issue. And per Abbot C.J., The 2 nd section of $22 \& 23$ Cur. II. c. 25 (which was one of the twenty-seven game acts repealed by the above) contains no prohilition against keeping or using hounds, and therefore the gamekeeper of a lord of the manor is not authorized by his deputation to seize them (Grent v. Hulton). And in Hooker v. Willes, it was held that a hound was not within the statute of 5 Amue, c. 14.

The rlarge of teking game withoul a rertifisate under 1 \& 2 Will. IV. c. 32 , s. $2: 3$, is a criminal proceeding for an offence punishable on summary conviction, within 14 \& 15 Fict. c. 99, s. 3, and therefore $t$ person so rluargal wus levtel by the Court of (uneen's Bench as not competent 
to give evidence for limself (Cuttell, appellant, v. Treson, respondent). Aud per Cromptom. J.: "It has been said that if an action of trespass were brought the defendant might be a witness, but that is not the same thing; the action is for damages to the plaintiff and to the land, but this proceeding is a punishment for taking game, and the penalty goes to the poor. A gain, eonsider the absurdity of putting a poacher into the box and compelling him to answer so as to criminate himself" (ib.)

Stat. 9 Geo. IV. c. 69, s. 1, gives a summary comviction if any person "shall by night unlawfully enter or be in " any land, whether open or enclosed, with any gun, net, \&e., "for the purpose of taking or destroying game or rabbits;" but the eonvietion under see. 1, in Fletcher v. Calthrop, setting forth that one Fletcher did by night " mnlawfully enter certain enelosed land" "with a net for the purpose of taking game, to wit partridges and pheasants contrary to the form," \&c., was held bad for not stating the intent to be to take game there. But in the case of Reg. v. Western, 1 L. R. C. C. 122, it was held that an information under this statute is good thongh it does not allege that the entry was for the purpose of taking game there.

In Reg. v. Whitaker, it was held by seven judges out of twelve, Parke B., Patteson J., Rolfe B., Cressuell J., and Platt B. diss., that under the 9 th section of 9 Geo. IV. c. 69, if several persons are indicted for entering enclosed land by night, armed for the murpose of taking game, it is not necessury to prove that atl entered the enclosed lame; it is enough if some are proved to have entered the land, and the rest are shown to have been engaged with them in a common object, and to have been near enough to render assistance. Senuliny on a log, to drive hares into a net set in the fence, was ruled by Patteson. J. not to be an entering of the land within this section (Reg. v. Nickless). If persons to the number of three or more are together in one party armed by night in any land for the purpose of destroying game there, and the land consists of several eloses, and one of such persons be in one elose, and another in a different elose of the land, they may be convieted under the above section; and the conviction will not be affeeted by the circamstance that one of the eloses is an enclosed field, and another an open waste, and that each is in the oecupation of different tenants (Reg. v. Uezzell). And per Parke B.: "The words 'open or inclosed' lands were inserted to prevent parties from supposing that they might destroy game on waste land with impunity" (ib.).

To constitute the offence of tiespassing upon land in search or pursuit of game under 1 \& 2 Will. IV. c. 32 , s. 30 (which enacts that if any person slatl commit any trespass by entering or being in the daytime upon any land in seareh of or pursuit of game, or woodcoeks, snipes, 
quails, landrails, or conies, such person shall on conviction thereof before a justice of the peace, forfeit and pay a sum of money not exceeding $£ 5$, together with the costs of the conriction), there must be a bodily "entering or being" of the person upon the land, npon which the trespass is alleged to have taken place: and there may be a trespass within the act, thouylh at the time the person be upon a highway. Where, therefore, the appellant, whilst on a highway carrying a gun, waved his dog into a cover on one side of it, and flushed a pheasant, at which he fired as it crossed the highway, it was held that he was properly convicted under the above statute, of a trespass in search of game, upon land in the possession and occupation of one George Bowyer, who was lord of the manor, and the owner of the land on both sides of the highway (Reg. v. Prutt).

Evidence that a party has exercised the right of killing game for seven year's upon land, is mima facie evidence of the right under 1 \& 2 Will. IV. c. 32, s. 36, which makes it lawful for any person having the right of killing the game mpon any land, by virtue of any reservation or otherwise, or for the occupier of such land (whether there shall or shall not be any such right by reservation or otherwise), or for any gamekeeper or servant of either of them, or for any officer of Her Majesty's forest, park, chase, or warren, or for any person acting by the order and in aid of any of the said several persons, to seize game (if not immediately given up on demand) recently killed, found in the possession of any person upon such land, by day or by night, in search or pursuit of game (Rey. v. Wall). Under the stat. 9 Geo. IV.c. 69, s. 2, the servant of a person being neither the owner nor occupier of the wood, nor the lord of the manor, but having only permission to preserve the game there, has no authority to apprehend poachers (Rex v. Addis). Section 4 of this statute requires prosccutions under it to be commenced within a yrar, and the provision is complied with if the information is laid before the magistrates, and the prisoners are apprehended within the year, although the indietment is not preferred till after the year has elapsed (Riry. v. Brooks \& Gibson).

A person having only a right of shooting over land, has no right to empower keepers to apprehend trespassers in search of game; and on their resisting with no greater violence than is used by the keepers, they will not be liable for an assault; but if the trespass is in the night they may be indicted for night-poaching (Reg. v. Wood) 1 F. \& F. 470 ; and a ganekeeper appointed by a person who had only permission to Shoot, trying to take a gun from a poacher, and in the scuffle causing a zan to go off which killed a poacher, was held by Lord Campbell C.J. guilty of manslaughter (Reg. v. Waley) F. \& F. 528. 
It was held by the Court of Criminal Appeal that it is not necesscery on the part of the prosecution to ralt the occupier or the ouner of the land to prove that the persons charged were not upon the land by their permission (Reg. $\mathrm{v}$. Wood). This case was reserved by Bramwell B., in consequence of a decision of Martin B., in Reg. v. Edge, to the effect that in a case of night poaching, the landlord or occupier of the land, whicherer was entitled to the game, ought to be called to show that the prisoner was not on the land by their permission. Jervis C.J. said: "There must hare been something more in that case. If men are on land at night armed and doing violence, is the occupier to be called to deny that he had allowed them a day's shooting?" And it is sufficient to allege in the indictment, that the land is land "of and belonging to J." without stating it to be in the occupation of J. (Reg. v. Riley).

In Cox v. Reid \& Another, the defendant, Reid, who rented some land in Surrey, discovered the plaintiff shooting on the land, and warned him off. The latter handed his game-certificate (which the defendant designated as "all humbing," on account of some seeming insufficiency in the plaintiff's description), when asked for his address, but refused to give up his gun or quit the premises, and the defendant with the assistance of his gamekeeper, the other defendant, took ax ay his gun, removed him by force into a lane, and detained him there (after a scuffle, in which he was thrown down and injured) till a policeman came. Ultimately he was not given into charge, but summoned for trespass, and convicted. He then brought an action of trespass for assanlting and wounding, \&c., to which the defendants pleaded Not guilty by statute, relying on 1 \& 2 Will. IV. c. 32, s. 31, and Parke B. left it to the jury to say, whether or not the defendants at the time of the alleged assault and imprisonment acted under the belief that they had authority under the prorisions of that section, and if so, whether they had reasonable grounds for so believing. The jury found that the defendants had no right to take away the gun, but the defendants thought they were acting in pursuance of the statute ; and his lordship then directed a nonsuit, on the ground that the plaintiff had not given a month's notice of trial in compliance with sec. 47. It was held that the question of reasonable or not reasonable belief in this case was a question simply whether there was such bona fides as entitled the defendants to notice of action, and that the case was properly left to the jury, and that the defendants were entitled to notice whether the trespass was justifiable under the statute or not.

Reg. v. George Prestney, which was an indictment for felonious autting and wounding, turned upon the construction of the same section. The prosecutor found the prisoner in a field of his, with another man, 
ferreting rabbits. His dog had slightly damaged the hedge in two or three places, by breaking throngh it. The defendant ran away, and was caught after a struggrle, and would not tell his name. It was submitted that the charge could not be snstained for more than a mere assanlt, as the apprehension and detainer of the prisoner were both unlawful, for that by stat. 1 \& 2 Witl. IV. c. 32, s. 31, before apprehending the prisoner, the prosecutor was bound to ask his Christian name, surname, and place of abode, and also to require him to quit the land. Parke B. held that damage done to a fence by a poacher's log in pursuit of game is not a "malicious" injury within the meaning of stat. 7 \& 8 Gro. IV. e. 30, s. 23 ; and that to justify the apprehension of an offender under 1 \& 2 Will. IV. c. 32 , s. 31 , it is only necessary that he should have been made to understand by the person authorised under that section, that he is required to tell his Christian name, sumame, and place of atiode, and that he should have refused to comply with such requisition, and that it is not necessary that he should have been required both to quit the land and also to tell his name. 'The prisoner was found guilty upon the first count, which alleged an intent to prevent his lawful apprehension and detainer.

The forcible rescue of a person from unlauful custody is illegal. And so it was held in Reg. v. Almey and Spencer, where the prisoners were charged with feloniously assanlting and wounding one James Rayson, a gamekeeper, who saw them with one Kenney and four others beating for game. Kenney had a gun, and on being asked his name refused to give it, and was taken into custody, and the gamekeeper was wounded by the prisoners in their attempt to rescue him. It was contended for the prisoners that the apprehension was unlawful, inasmuch as before the apprehension Kenney had only refused to give his name, and had not refused to go off the land, and that the prisoners were therefore justified in using violence to effect his rescue. But Erle J. (after consulting Cressuell J.) considered that Kenney himself might perhaps have lawfully resisted his apprehension, but that the prisoners had no right to take part in that resistance, and overruled the oljection.

A conviction of sereral persons for trespassing in pnersuit of yame in the daytime, under 1 \& 2 ITit7. IV., c. 32, s. 30, was drawn up, including them all in one conviction, and adjudicating "each of them ;" the said C, B, W, and S, so making default, to be imprisoned for one month, unless the said several sums and the costs and charges of conveying each of them the said $C, B, W$, and $S$, so making default to the said gaol, shall be sooner paid." It was held by the Court of Queen's Bench that the conviction was bad, as it made each defendant liable 
to be imprisoned until he had paid the penalty, and the expense of conveying, not only himself, but the other persons convicted, and that this was not a case in which to exercise the power of amendment under $12 \& 13$ Vict., c. 45 , s. 7 (Reg. v. Critland). And semble, where to an information for an offence under $1 \& 2$ Will. IV. c. 32, s. 39, the defendants bona fide claimed a right to enter upon the tand under an authority from $S$, who was alleged to be the owner of the land, and asked for an adjournment, as they were not then prepared with evidence, which was refused; this was such a bonâ file claim of right as put an end to the jurisdiction of the justices (ib.)

By statute 7 \& 8 Geo. IV. c. 29, s. 30, to take or kill any hare or rabbit in the night time, in any uarren or ground lawfully used for the keeping or breeding of the same, is a misdemeanour; and to take and kill them in any warren or ground in the daytime, or at any time to set any snare or engine for the taking them, is punishable upon summary couviction by fine, not exceeding $£ 5$. But nothing in this act affects any person taking or killing in the daytime any rabbits on any sea-bank or river-bank in the comnty of Lincoln, so far as the tide shall extend, or within one furlong of the bank. Statnte 7 \& 8 rict. c. 29, s. 1 , recites statute 9 Geo. IV.c. 69 , s. 1 , and extends the provisions of that act to any person by night unlaw fully taking or destroying any game or rabbits on the public road, highway, or path, or the sides thereof, or at the openings, outlets, or gates from any such land into any such public road, highway, or path, in the like manner as upon any land open or inclosed. Night-time in both of these acts means some time between the expiration of the first hour after sunset and the beginning of the last hour before sumise.

By section 1 of statute 11 \& 12 rict. c. 29 (which did not disturb the existing agreements for the reservation of game), persons in the actual occupation of inclosed ground, or any owner thereof, who has the right of killing game thereon, by himself or by any person directed or authorised by him in writing so to do according to the form given in the schedule of the act, muly take, kill or destroy hares thereon with. out a game cerfificate. Section 2 provides that the authority so to take, kill, and destroy hares, which holds good till February 1st in the year following that in which it is granted, shall, when granted, be limited to one person at the same time in any one parish; that such authority shall be sent to the Clerk of the Petty Sessions, who shall register it; and if it be revoked, notice must be given to him of the same. Section 4 allows an uncertificated person to join in coursing and hunting ; and sections 5 and 6 render it illegat to lay amy poison on the ground, whether open or enclosed, or on the highway, or for 
any person to use any fire-arms or guns of any description by night, for the purpose of killing any game or hares. The above act applies only to England and Wales, but 11 \& 12 Tict. c. 30, extends it to Scotland. The form giren in the schedule of the former act is as follows :-

"I, A B, do anthorize C D to kill hares on ['my lands,' or 'the lands occupied by me,' as the case may be] within the —_ of [here insert the name of the parish or other place, as the case may be]. Dated this — day of —-, A.D. 18-.

"Witness, E F."

"By the 1 \& 2 Will. IV. c. 32, s. 3, the penalty for killing or taking game on Sunday or Christmas Day is a sum not exceeding five pounds, to be recovered before two justices with eosts. And to kill or take any partridge between the 1st of February and the 1st of September; or any pheasant between the 1st of February and the 1st of October; or any black game, except in Somerset or Devon, or in the New Forest, between the 10th of December and the 20th of August; or in Somerset or Deron or the New Forest, between the 10th of December and the 1st of September; or any grouse, commonly called red game, betreen the 10th of December and the 12th of Angust; or any bustard, between the 1st of March and the 1st of September, is an offence punishable upon conviction before two justices with a penalty not exceeding $£ 1$ for any head of game, with costs. It is no offence to hare in possession after the 1 st of February partridges and pheasants within a reasonable time, as on the 9th February (Simpson v. Unwin). And now under s. 4 of the $1 \& 2$ Witl. IV. c. 32, it is illegal, and punishable with a forfeiture not exceeding $£ 1$ for each head of game for a dealer to buy, sell, or have game, after ten days from the dates above specified, and after forty days for any other person. The onus of proving the rightful possession lies upon the kefendant. And by sec. 42 any exception in his favour must now be made good by witnesses on his behalf. Uncontradicted or unexplained possession is a fact sufficient to warrant a conviction. Under some statutes the exception must be negatived by the prosecutor in his information (Spires v. Parker; R. v. Tumer; and see R. v. Stone). By 11 \& 12 Vict. c. 43 , s. 14, if the information or complaint in any ease shall negative any exemption, execption, \&e., in the statute, the prosecutor or complainant need not prove the negative, but the defendant may prove the aflirmative, if he would have the advantage of the same."-Serjeant Woolrych on the Game Laws, P. 135. 
A contract by a licensed dealer in game to deliver pleeusants in good feather on request, followed by a request to deliver them more than ten days from the time (February 1) when it is unlawful to kill them is good, notwithstanding that statute $1 \& 2$ Will. IV.c. 32, s. 4, prohibits the sale of birds of game at that period, becanse that section applies to dead game only (Porritt v. Baker). And per Purke B. : "There is nothing in the statnte to prevent the defendants selling and delivering live pheasants out of season, since they can either bny pheasants from a person who keeps them in a mew, or can keep them in a mew of their own" (ib.) And it was ruled by Lord Campbell C.J., in Reg. v. Head, that pheasants which have been reared under hens in coops, throngh the bars of which they could pass, and which had at the time of the robbery been hatehed a month, and could fly thirty rods, and answer to the keeper's whistle at night, were as much the subject of larceny as the hens themselves.

Deer in a park (though an ancient and legal park) may be so tamed. and reclaimed fiom their natural wild state as to pass to executors as personal properly; and so it was held by the Court of Common Pleats, in Morgan v. Abergarenny, where the executors sucessfully bronght trover against the heir.

But it is laid down in Paslet v. Gray, that where a man, having fishes in a pond, made his execntors, and died, and defendant as executor takes fishes, plaintifl as heir brings trespass rightly; for they are as profits of the freehold, which the executor shall not have, but the heir, or he who hath the water. Trespass lies for breaking and entering the seceral fishery of A. on the soil of B. (Bailey v. Holford); but the words "sole and exclusive fishery" are not equivalent to "several" fishery (ib.).

In the case of Samulers v. Baldy, 1 N. R. Q. B. 87, an information was laid by the appellant, under 1 \& 2 Will. IV. c. 32 , s. 23 , against the respondent, charging him with having, on the 13th of March, 1865, nsed a trap for the purpose of taking game, he not having a game certificate. The 1 \& 2 Will. IV. c. 32, s. 3, forbids the taking game during certain intervals of the year, and the justices dismissed the information on the ground that as no certificate would authorize persons to take or kill game at the period mentioned, the respondent could not be said not to be authorized for want of a certificate, and therefore could not be legally convieted upon an information which charged him with using an instrument for the purpose of taking game without a certificate, when no game certificate could be obtained which would anthorize his act. The Court, however, deciled that the respondent onght to have been convicted. 
In the cases of Teysey v. Hoskins and Harris v. Hoskins, 34 L. J. (N. C.) M. C. 145 , the appellants were found with a net for the purpose of taking game on land which liad a hedge on either side and a metalled road through it, but the land on each side of the road was waste, and varying in cxtent; it was held that this land was neither open nor inclosed within the meaning of the 9 Gro. IV. e. 69, s. 1 .

In the case of Stucey v. Whitelurst, 34 L. J. (N. S.) M. C. 94, Whitehurst and another person were driving along a turnjike road when the other person got out of the conveyance, entered a field, shot a hare, and handed it to Whitehurst, who then drove away, it was held that Whitehurst could be fonnd guilty of aiding and abetting to commit the offence of trespass in pursuit of gamc.

In Krmyon v. Hurt, 34 L. J. (N.S.) M. C. 87 , the respondent was shooting on his own land when a pheasant rose and flew orer the land of another person; the respondent fired at and killed the bird, which fell upon the other person's land. The respondent went with his dog, and picked up the pheasant and took it away. He was afterwards summoned for "trespassing in search of game," but the justices dismissed the case, and the Court held that they were right.

In Ibbotson v. Pect, to a declaration alleging that the defendant, with intent to frighten away grouse from plaintiff's land, fired and exploded rockets and fireworks, so as to be a nuisance, the defendant pleaded that he committed the acts complained of in order to prevent the plaintiff from shooting grouse which had been cnticed by the plaintiff from defendant's land, and from enticing other grouse from defendant's land, it was held that the plea was no answer to the action, and judgment was given for the plaintiff' (34 L. J., (N. S.) Exch. 118).

In the case of Hall v. Knox, a constable saw a person with a gun in his liand, on a public footway, in the act of picking up a rabbit which was thrown over the hedge by another person; it was held that to sustain a conviction under the Prevention of Poaching Aet, 25 \& 26 Tit. c. 114, s. 2, an actual search was not necessary (Hull v. Knox, 33 L. J. ( N. S.) M. C. 1), and in Eecans v. Botterill and Others, 33 L. J. (N. S.) M. C. 50, where the defendants were found on the highway at 6 a.m., with a bag containing a hare and rabbits, and with nets and stakes, it was held that they could be convicted of having obtained the game by having leeen unlanfully on land in pursuit of game, without direct proof that any of the defendants had been upon any land, or had used any of the nets.

It is not sufficient to oust the jurisdiction of justices in regard to a charge of trespass in pursuit of game, nuder $1 \& 2$ Will. IV. c. 32, s. 30, that there is an honest claim of right, if such claim is absurd and im- 
possible in point of law. Game statutes are not mere criminal statutes, but are statutes passed for the purpose of protecting the peculiar right of those entitled to shoot game (Watkins v. Major, 10 L. R. C. P. 662 ; see Morden v. Porter, 29 L. J. M. C. 213 ; Leatt v. Vine, 30 L. J. M. C. 207 ; Cornucell v. Saunders, 32 L. J. II. C. 6 ; Hudson v. H.Crea, 33 L. J. M. C. 65).

Picking up pheasant shot in another's land a trespass. - A person who in his own land shoots a pheasant in the land of another, and goes on to such land to pick the bird up, commits a trespass of entering land in pursnit of game within the meaning of $1 \& 2$ Will. IV. c. 32 , s. 30 , the shooting and picking up of the bird being one transaction, but qucre whether entering land for the purpose of picking up dead game is a trespass within that Act. And per Byles J.: "If it were necessary for us to decide on this occasion, that dead game is within the statute, I should have desired time to consider. But I agree that the pur'suit commenced with the shot, and terminated with the picking up. There was a pursuit and a trespass. It would be highly inconvenient to have to inquire in every case whether the bird had breathed its last or not when picked up" (Osbond appt. v. Meadows resp.).

Not essential to conviction for trespass in pursuit of game, that there should have been an intention to commit such trespass. - It is not necessary that a conviction under $1 \& 2$ Will. IV. c. 32 , s. 30 , for a trespass in pursuit of game, should be on the information of the owner or occupier of land, or of a party interested in the game, and on this point Middleton v. Gale (S Ad.\& E. 155) is decisive, and semble per Willicms, J. and Willes J., dubitante Keating J., that it is not necessary, in order to support a conviction under the above section, that the defendant should have intended to commit or have been conscious that he was committing a trespass. And per Williums J. : "The dictum of Erle J. in Reg. v. Cridland (7 E. \& B. 858, 27 L. J. (N. S.) M. C. 28) is relied on by the defendant's counsel; but that case is wholly distinguishable, for it only decides that where the entry is made under a boni ficle claim of right, no proceedings can be maintained against the person so entering upon the land. But that is upon a principle not peculiar to this case, but applicable to all cases, that no conviction can take place for an act done under a bonct fide claim of right to do it. In the case of Reg. v. Pratt (24 L. J. (N. S.) M. C. 113), where the defendant was convicted of a trespass, although he never left the high road, the whole discussion was whether there was a trespass on another man's land; no one thought of suggesting that the defendant would not be liable if he had thonght that he had a right to shoot on the high road. With regard to the hardship of thus deciuing, I confess I caunot see it. If a person goes 
on to land to enjoy the dirersion of shooting, he must take care that he has the leare of the person justified to give him leave; if he chooses to risk it, he must suffer the penalty if it is enforced against him" (Morden, appt. v. Porter, respt.).

Retaking rabbits from poachers.-If A. wrongfully, after request to give it up, detain a chattel from B., the owner entitled to possession, B. has the possession in law, and A.'s wrongful detention against B.'s request is 110 possession, but is the same violation of the right of property as the taking the chattel out of the actual possession of B., and B. (or his servants acting under his command) is justified in using force sufficient to defend his right and retake the chattel. This was a declaration for assault and battery, and the plea was that the plaintiff became the holder thereof, and had wrongfully in his possession dead rabbits belonging to E., and being about to carry them away, the defendants as servants of E., and by his command, requested the plaintiff to refrain, which he refused to do, and thereupon defendants as servants of E., and by his command, gently laid their hands on the plaintiff, and took the rabbits from him, using no more force than was necessary. This was held a good plea, although it did not allege how the plaintiff took the property of E. And per Curiam: "It has been decided that the owner of land entitled to the possession may enter thereon and use foree sufficient to remove a wrong-doer therefrom. In respect of land as well as chattels, the wrong-doers have argued that they ought to be allowed to keep what they are wrongfully holding, and that the owner cannot use force to defend his property, but must bring lis action lest the peace should be endangered if force was justified; see Nercton v. Hartand (1 Man. \& G. 644). But in respect of land, the argument has been overruled in Harley v. Brilges (14 M. \& W. 437, 14 L. J. (N. S.) Ex. 384). Here Parke B. says: "Where a breach of the peace is committed by a freeholder, who, in order to get possession of his land, assaults a person wrongfully holding possession of it against his will, although the freeholder may be responsible to the public for a forcible entry, he is not liable to the other party, and I cannot see how it is possible to doubt that it is a perfectly good justification to say, that the plaintiff was in possession of the land against the will of the defendant, who was owner, and that he entered upon it accordingly, eren though in so doing a breach of the peace was committed.' In our opinion, all that is so said of the right of property in land applies in principle to the right of property in a chattel, and supports the present justification. If the owner was compelled by law to seek redress ly action for a violation of his right of property, the remedy would be often worsc than the mischief, and the law would aggrarate the mischicf 
instead of redressing it ; and on these grounds, onr judgment is for the defendants" (Blades v. Higgs and Another, 34 L. J. (N. S.) C. P. 286).

'The decision of the Court of Common Pleas and Exchequer Chamber' was upheld by the House of Lords.

Rabbits the property of the person on whose lands they are started and killed.-If rabbits be started and killed on the land of another, they are the property of the person on whose land they are killed, but the Court were not prepared to decide whether there would be any distinction if the rabbits were driven off the land of one person on to another; and per Willes J.: "It is impossible to get over the case of Lord Lonsdale v. Rigg (1 H. \& N. 923, and 26 L. J. (N. S.) Ex. 196). It will be well when this case is further considered, if it should ever be so, to compare the dictum of Lord Holt in Sulton v. Moody, with the passage in the Institutes of Justinian, where it is laid down that wild animals: 'Simul atque ab aliquo capta fuerint jure gentium statum illius esse incipiunt quod enim ante nullins est, id naturali ratione oceupanti conceditur. Nec interest feras, bestias et volncres utrum in suo fundo quisque capiat an in alieno.' The same rule has been adopted in all countries professedly governed by the Roman civil law." Here the defendants, servants of the Marquis of Exeter, claimed the bags with rabbits in them ont of the luggage-van, and emptying ont the rabbits returned the bags (Blades v. Higgs and Another). This decision was affirmed in the Exchequer Chamber, on the ground that Lord Lonsdale v. Rigg had settled the question.

Reg. v. Paul Read. This was a case stated by the Vice-Chairman of the Berkshire Quarter Sessions. The prisoner was indicted at the Berks Epiphany Sessions, December 31, 1877, for stealing 18 rabbits the property of Mr. Smith, his master. The evidence showed that the prisoner was the gamekeeper of Smith, and was employed to look after a wood in which the game and rabbits and rights of sporting had been granted to Smith by the owner. The prisoner was not at liberty to take or kill rabbits in the wood for his own use, but he took and killed and removed 18 wild rabbits from the wood, and had bargained to sell them when they were seized in the possession of the purchaser's agent, the capture, killing, removing, and selling being part of one continuous act. The counsel for the prisoner asked the Conrt to stop the case because there was not any evidence to go to the jury that the rabbits had ever as subjects of larceny been in the possession of Smith, and that, therefore, the prisoner could not be guilty of stealing or embezzling them. The counsel for the prosecution insisted that when the rabbits were captured and killed by the prisoner, they were by that act reduced into the possession of his master and became subjects of larce:yy or embezzlement. The 
case was left to the jury, the Conrt telling them that the criminal oflence of the prisoner-if any-was embezzlement and not larceny, and that if in their opinion, the prisoner, being the servant of Smith, captured and killed the rabbits, although against the orders of his master, they so eame into the possession of the prisoner for and on behalf of his master, and the prisoner converting them to his own use was guilty of embezzlement. 'The jury found the prisoner guilty of embezzlement, and he was sentenced to four months' imprisonment, with hard labour. But the Court reserved for the opinion of the Superior Conrt the question whether the prisoner by capturing and killing the rabbits against his master's orders did so bring them into the possession of his master that he could by appropriating them to himself be guilty of embezzling them. The enactment on which the question turned is one of the Common Law Consolidation Aets-24 \& 25 Vic. cap. 96, sec. 68-as to larceny or embezzlement by servants :-

"Whosoever being a servant, or being employed for the purpose or in the capacity of a servant, shall fraudulently embezzle any chattel, money, or valuable security which shall be delivered to, or received, or taken into possession by him, for or in the name, or on the account of his master or employer, shall be deemed to have feloniously stolen the same from his master, although it was not received into his possession otherwise than by the actual possession of his servant."

'The Court held that the prisoner could not be convicted of embezzlement, because the killing and taking away were one continuous act. The conviction was therefore quashed, but the Court expressed no opinion as to whether the prisoner might have been convicted of larceny.

Tenant killing rabbits where "game" reserved to landlord.-Spicer \& Others (appts.) v. Barnard (resp.) decided that where a tenant oceupies land under a lease, which reserved to the landlord the exelusive liberty to shoot, hunt, fish, and sport over the laud, the tenant may lawfully employ his servants to kill rabbits on the land. This was a case stated by Justices in Petty Session. When the appellants were called on to plead, their solicitor handed in a written notice, by which they denied that they had committed any trespass, but admitted that they were at the place by direction of Jesse Spicer (who proved the fact), the occupier of the land, in search of rabbits, under a bona fide claim of right, but, if such right were disputed, they submitted that the magistrates had no jurisdiction to decide on the hearing of an information for a penalty, but must leave the landlord to his aetion at law. The justices convicted the alpellants, on the gromd that they appeared to have been guilty of the oflence, and that the defence set up by them 
amounted not to a boni fule claim of right or title, so as to oust the jurisdiction of the justices, bnt merely to a plea of leave and licence of the occupier of the land, and that such plea was no defence under sec. 30 of $1 \& 2$ Will. IV. c. 32.

Labourer taking rabbit by order of farmer whose lease made no mention of rabbits in its yame reservation.-A labourer employed upon a farm, the right of sporting over which was reserved to the landlord, was authorized by the temant to go and kill a rabbit for his wife, who had been confined; and the justices having found that he killed the rabbit as the servant of the tenant, and by his order, it was held, on the authority of Spicer v. Barnard (28 L. J. (N.S.) M. C. 176), that the labourer was not liable to be proceeded against under $1 \& 2$ Will. IV. c. 32 , s. 30 , for a trespass in pursuit of coneys. Hawkins, his master, had succeeded one Christmas as tenant on the terms generally of Christmas's lease, of which there had been no assignment, and had constantly killed rabbits on the land in his occupation. The original lease between Christmas and Padwick contained no mention of rabbits in its reservation of game, and in the agreement between Hawkins and Padwick there was this exception in reference to game- "excepting that the said H. J. Hawkins shall have permission to sport over the said farm and lands" (Padwick, appt. v. King, resp.).

Bonâ fule assertion of right under Game Act. - The jurisdiction of the justices to convict summarily under 1 \& 2 Will. IV. c. 32, s. 30, for trespass in pursuit of game is onsted when a question of right to be on the land is bona fide raised between the complainant and defendant, according to Reg. v. Critland (7 E. \& B. 853, 27 L. J. (N.S.) M. C. 28) and Morden v. Porter (7 C. B. (N.S.) 641, and 29 L. J. (N.S.) M. C. 226),-Legg, appt. v. Pardoe, resp.

Ifere vague belief of righl not suffcient to oust jurisdiction of magistrates under Game Act.-A person charged under stat. $1 \& 2$ Will. IV.c. 32, s. 30 , with trespassing in pursuit of game in the daytime on land in the occupation of a tenant to A., set up a claim of right to shoot over the land on the ground that he and every one who chose had always shot there till some recent acts of interruption, and declared his readiness to try the right with $A$. It was held by the Court of Qneen's Bench that the mere assertion of such a general right in himself and every one else, though he really believed it, withont showing any such claim of right as would be a defence to an action of trespass, did not onst the jurisdiction of the magistrates to convict under the statute in question.

Ousting justices' jurisliction.-In a prosecution for a trespass in pursuit of game under $1 \& 2$ Will. IV.c. 32 , s. 30 , the defendant cannot oust the jurisdiction of the justices by disputing the title of the person 
who is alleged in the information to be in occupation of the land in question. In order to do that, he must make a bonê fide claim of title on behalf of himself or of those nnder whom he elaims. The justices are to consider whether the oceupation is proved as alleged in the information. It was held by Cockturn C.J., Blackturn J., and Mellor J., that if there was any evidence before the justices proving the occupation as laid, they would be justified in deciding that the information was proved; and that a superior conrt ought not, upon a case granted by them under 20 \& 21 Vic. c. 43 , to interfere with their decision. It was shown on the evidence on behalf of the lord and in support of the prosecntion that the appellant was beating for game with a $\operatorname{dog}^{\circ}$ and a gun on the day in question in a part of the parish of Slow cum Quny called Quy Fen, and that he asked a witness not to say anything about it, and that Quy Fen was within the manor of Slow cum Quy, the bounds of which were coterminous with the parish. The appellant gare evidence to prove that he had been in the habit of shooting orer Quy Fen for forty years, and that the inhabitant householders had paid a tax raised for the draining of Quy Fen.

Young pheasants still under protection of hen in coop by day are not game.-It was held by Pollock C.B. and Williams J. that a prisoner cannot be conricted under 9 Geo. IV. c. 69 , s. 9, for entering land by night, armed for the purpose of taking game, when his object is to steal young pheasants which had been hatched by a hen, and had not yet become wild. Although they roosted on trees near the coops, they were still under the care and protection of the hen, and therefore were Dr. Vernon's property, and not game, which is not the subject of property, and the prisoner was convicted of a common assault (Reg. v. G(trnhum).

Tame deer in park personal mroperty.-Tame deer in a park are personal property, and the Court will not interfere to restrain waste in not keeping up the herd (Ford v. Tymte, in which case Morgan v. Lord Abrigarenny, 8 C. B. 768 , was cited).

Lord of Manor's exclusice right to sport over allotments.-Eurart $\mathrm{v}$. Grahum (Bart.) was confirmed with costs in the House of Lords (29 L. J. (N.S.) Ex. 88). It was a proceeding by way of writ of error, brought for the purpose of reversing a decision of the Court of Exchequer Chamber, partly affirming and partly reversing a judgment of the Court of Exchequer, pronounced on a special case stated for the opinion of that Court. Lord Wensleydale adhered to his Exchequer decision, that there was a reservation of the de fucto right: he only doubted whether this case could be distinguished from Greethead v. Morley (3 M. \& G. 139, and 10 L. J. (N. S.) C. P. 246); but if it could not, he was prepared to say that ease was wrongly decided. 
Hence the lord still possesses the exclusive right of hunting, shooting, \&e., over the allotments.

Lord of Hanor not entitled to shool over allotments of Common.-In Bruce v. Hellivell, an Inclosure Act, after directing one-sixteenth of the common land to be allotted to the Lord of the Manor as a compensation for his right to the soil, and the residue (with certain exceptions) among the commoners, contained a proviso that nothing in the act should defeat, lessen, or prejudice the right, title, or interest of the lord to the mines and minerals in or under the said commons, or to any seignories or royalties incident and belonging to the manor, the same being thereby reserved to the lord, with full power for him at all times to hold and enjoy all rents, fines, dnties, customs, and services, and all courts and perquisites, and liberty of hunting, conrsing, fishing, and fowling within and throughout the said manor; and all goods and chattels of felons, treasure trove, waifs, estrays, forfeitures, royalties, jurisdictions, purchases, and privileges whatsoever to the said manor incident or appertaining (other than and except such right as could or might be claimed by him as owner of the soil and inheritance of the said commons) in as full ample and beneficial manner to all intents and purposes as if the said act had not been passed. As owner of the soil of the commons, the lord had before the act the free and exclusive right and liberty of sporting and killing game thereon, but there was no right of free share or free warren within the manor. It was held that the lord retained no right to shoot over the allotments. And per Bramwell B. : "Eu'art v. Graham is distinguishable from this case, inasmuch as the words in it were that the lord was to have the right of shooting, fowling, coursing, and so forth over the allotted lands. It might be that that right had been conferred upon him nnder some mistake as to its previous existence; but whether it was conferred upon him owing to that mistake or not, the answer is that it was conferred upon him. It might have been conferred upon him under a mistake, namely, under the misapprehension which my brother Martin referred to as to the rights of lords of manors. Whatever be the origin of it, there it was."

In Reg. v. Inhabitants of Thurlstone, a tenant occupied land under an agreement with his landlord, that he was to have no right to the game upon it. He was assessed to the poor-rate on the land walued with the game, and on appeal before the West Riding Magistrates it was agreed that the proper assessment should be, if for the land only, without a right to the game, $£ 115 \mathrm{~s} .8 \mathrm{~d}$. ; and if with the game, $£ 2619 \mathrm{~s} .8 \mathrm{~d}$.; and the Court of Queen's Bench held that he ought to be assessed only for the lower amonnt. 
Where, as in Duyrell r. Hodre, estates, hereditaments, and premises were demised to $\mathrm{R}$. for life, with power to the tenant for life to make any lease of the same, or any part or parts thereof, for 21 years, reserving the most improved yearly rent, with a condition for re-entry on non-payment, so that there should be no elause giring the lessee power to commit waste, and so as the rent shonld be incident to and go along with the reversion, it was held by the Court of Queen's Bench that this poure alil not anthorize a luse of pait of the lame, with liberty to sport orer the rest; and where defendant in trespass justifies, in a right which he claims under the estate of tenant for life, simply as such, he must arer the continnance of the life.

Any one may lease or convey his land, and reserve to himself the right of entering to kill game without being subject to being sued as a trespasser; but an exception to a deed, made A.D. 1655, of the free liberty of hunting and harking, will not extend to shooting feathered game with a gun, because guns, not being in common use, conld not have been in the contemplation of the parties (Hoore v. Lord Plymonth); and semble that the liberty of hawking and hunting for the grantee, his friends and serrants, is a tenement, and entailable (ib.). The grant to a person, his heirs and assigns, of "frec liberty, with servents or otherwise, to come into and upon lands, and there to hawk, hunt, fish, and fowl," is a grant of a license of profit, and not of a mere personal licence of plecusure; and therefore it anthorizes the grantee, his heirs and assigns, to hawk, hunt, \&c., by his servants in his absence (Wickham v. Hawker). Such a liberty is therefore a profit a prentre within the Prescription Act 2 \& 3 Will. IV. c. 71, s. 2 (ib.). And per Curiam, "What relates in a lease to the privilege of hawking, hunting, fishing and fowling is not either a reservation or an exception in point of law ; it is only a privilege or right granted to the lessor, though words of reservation and exception are used." (Doe drm. Dongles v. Lock). It is also decided by the case of the Thuchess of Norfolk v. Wiseman (Year Book, 12 Hen. VIII. $25)$, that if there be a personal licence of plecasure, it extends only to the indiridual, and it cannot be exereised with or by servants; but if there is a licence of profit, and not for pleasure, it may.

The franchise of free uarren is of very great antiquity, and very singular in its nature. It gives a property in wild animals; and that property may le claimed in the land of another, to the exchusion of the owner of" the land. And "no one can make a park, chase, or warren without the king's licence" (2 Inst. 109).

As rooks are birds ferce naturce, not known as a regular article of food, causing no expense to keep, and not protected either by common law or statute, the owner of a rookery ean have no property in them, or 
show any right to have them resort thither, and therefore he cannot maintain an action against any one for firing guns near it and causing them to desert (Hannam v. Mockelt).

This case differed from Keeble v. Hickeringill, where it was decider that an action on the case lies for discharging guns near the decoy of another, with design to demnify the owner by frightening away the witdfowl resorting thereto, and by which the wild-fowl are frightened away and the owner damnified. In the first place, wild-fowl are protected by $25 \mathrm{Hen}$. VIII. c. 11 (A.D. 1533-34), which forbids every one except a forty-shilling freeholder to take wild-fowl, to wit, "ducks, mallards, widgeons, teals, wild-geese, and divers other kind of wild-fowl," and only permits them the use of a spaniel and a longbow for that purpose. The statute of $3 \& 4 E d m$. VI. c. 7 , which repeals that of 25 Hen. VIII., takes notice of wild-fowl, and hath the general word vill-foul, without coming to particulars. They also constitute a known article of food; and a person keeping a decoy, spends money and employs skill in taking that which is of use to the public. It is consequently a profitable mode of employing his land, and is considered by Lord Holt C. J. as a description of trade. Currington v. Taylor was governed by Keeble v. Hickeringill; and it was there held that as the defendant, being out shooting wild-fowl on part of an open salt-water creek called The Blackwater, on the Essex shore, first fired his fowling-piece about a quarter of a mile from the plaintiff's decoy, when 200 or 300 wild-fowl came ont, and afterwards, approaching nearer, fired at wild-fowl on the wing at the distance of 200 yards from the decoy, where he killed several widgeons, and caused 400 or 500 wild-fowl to fly from the decoy, thongh he did not fire into it, this was evidence of a wilful disturbance of the decoy, for which an action on the case would lie.

Where a demise was made of a mansion-house and land, with the sole licence of shooting and sporting over all other the lands of the lessor, "subject to the liberty for each tenant on his farm to kill rabbits thereon with ferrets only;" this exception as to killing rabbits extends not only to farms existing at the time of the demise, but also to other lands, as plantations, subsequently let as farms (Terton r. Jilmot). A demise of lands, excepting and reserving all royalties, with a clause for the lessor to be allowed to prosecute actions against persons trespassing for the purpose of hunting, \&c., does not amount to a grant by the lessee of a liberty for the lessor to enter for the purpose of pursning, killing, and taking birds of warren (Pamell v. Mill). And per Coltman J.: "The present case is distinguishable from that of Wicklatm v. Hauker; as in that case the clause excepting and reserving 
the liberty to hunt, \&.e., could not by possibility operate as an exception or reservation. In the present case it is not so, for a royalty may by law be appurtenant to land as in this rery case of warren; a man may have warren in his own laud, or in that of another man by prescription (Bro. Abr. tit. Wirren, pl. 2). And in the case of Boutston v. Hordly, it is said a warren is not parcel, nor any member of a manor ; thongh it may be appertaining, but that is, by prescription. Aud it is said in Dyer, page 30, n (209), and in the 'Year Book,' in Stite v. Abbot of Tenclistury (T. 8 II. 7, fo. 4), that a man may have warren in the land of another as appendant to his manor ; and if the manor is granted cum pertinentiis, the warren will pass." (ib.)

It was decided in error from the Court of Exehequer (which had been equally divided on the point) that the customary right of pasture in a manor or cattleyates gires the on'uers no right to possession of the soil; but the ownership of it remains in the lord of the manor, subject to the right of several pasture npon it by the cattlegate owners, and therefore the lord may maintain trespass against a eattlegate owner for sporting over it without his permission (Rigg v. Earl of Lonsdale.) And it was held by the Court of Common Pleas, in Greathead v. Morley, that the right of sporting over the allotments of the moor or common in question was not reserved to the lord of the manor by the saving clause in the Inclosure Act, " with free waren, and liberty of hunting, hawking, fishing and forling," the object of that clause being to reserve to the lord all those manorial rights which he possessed before the inclosure, as lord, except the right to the soil ; the power of a lord to sport over a waste within his manor being not a licence or liberty, but a mode of enjoyment of his own property.

The appellant in Meddins v. Williams had been convicted under stat. 1 \& 2 Tritl. IV. c. 32, s. 32, for trespassing upon certain land inclosed mader an Inclosure Act, in company with five or more persons. It appeared that the appellant had the consent of the allottce of tine inclosed land, but not of Sir Watkin W. Wynn, who was the lord of the manor, to whom the right of taking game was said to be reserved. It was contended, in support of the conviction, upon the authority of Gratecm v. Eururt, that the right to take the game was elearly in the lord of the manor, and that althongh the apjellant had the consent of the allottee, he was nerertheless a trespasser within the Act. Lord Camplell C. J. said, "It was clear, after the decision in that case, that the right to take game in the locus in quo was exclusively in the lord of the manor. The question was a nice and difficnlt one, but the Court was bound by that decision. The lord of the manor was not entitled to the right ratione soli, lut it was confinmed to him in the hands of the 
allottee. It was impossible for language to be better calculated to secure this than that nsed in the 12 th section, which enacted that when the game was reserved to another person than the ocenpier, the latter shonld be liable to a penalty for giving permission to kill game on the land so occupied by him. The rest of the judges concurred, and the conviction was affirmed, with costs.

Under an ancient churter, granling to the mayor, aldermen, and burgesses of a borough the right to sport oier lands within the liberties thercof, individual burgesses, in the absence of all evidence of the exercise of the right, are not entitled to enter a field within the liberties, but in the occupation of a third party, to kill rabhits with a dog or ferret, or for any other kind of sporting. Coleridge and Wightman J.J. referred, in support of their judgment, to the authority of The Mayor of Colchester v. Prestney, where (argued June 23, 1857, but not reported) the right of individual burgesses to dredge for oysters was attempted to be made out; but the Court of Queen's Bench held that the right was in the corporation, but not in the individual corporators.

A demise in uriting, but not umier seal, of a messuage, amd full and exclusive licence and leate for the lessee, his friends, gamelcepers, de., to hunt, hauk, course, shoot, and sport on, over, and wpon a manor of the lessor, and to fish in the ponds and waters thereof, from August to February following, at an entire rent, is altogether void (Bird v. Higginson). And so it was ruled, in The Duke of Somerset v. Fognuell, that where a sulject is ouner of a several fishery in a navigable river, where the tide flows and reflows, granted to him (as must be presumed) before Magna Charta by the description of "seperatem piscariam," that is, an incorporeal, and not a territorial hereditament, and a term for years in it cannot be ereated without deed. But in Thomas r. Fredericks, where a written agreement not under seal w'as declared on, by which plaintiff agreed to let land to defendant with right of sporting, defendant to make satisfaction to plaintiff's tenants for damage done by game on their farms, the amount to be ascertained by valuers and an umpire; and defendant neither made satisfaction nor appointed a valner; it was decided that, thongh the right to shoot did not poss umler this contruct, being an incorporeal hereditament, jet the agreement to make compensation was valid, and good ground for an action, defendant having had the full benefit of such agreement.

If a purchaser after the detivery of the abstract, on the face of which part of the estate appears to be suljiect to a right of sporting, not mentioned in the particulars of sale, enters into possession, he waives that objection (Burnell v. Broun). Where a vendor fails to make a good title pur- 
sumt to his contract, the purchaser (in the alssence of fraud or misrepresentation on the jart of the rendor) is not entitled to damages for the loss of his haryain. Thus in Pounsett v. Fuller, the defendant agreed to sell to the plaintiff shooting on a certain manor, and it was afterwards discorered that the defendant had a mere equitable title, in faet, a mere agreement from the owner of the manor to let the shonting to him for four years, he supplying his house with game. 'The plaintiff brought an action for the breach of the contract; but it was held that he was entitled only to recover nominal damages, and the expenses incurred in the investigation of the defendant's title, but not damages for the loss of his bargain, or expenses ineurred in obtaining shooting elsewhere, or in fruitless endeavours to substitute a new contract on the failure of the original hargain. The Conrt of Common Pleas thonght the ease fell within Fhoreat v. Thormhill, which decided that where a man mndertakes to sell an estate, the bargain is to be understood as being subject to this qualification or condition, viz., that he has a good title to convey ; and in the judgment it is said to result from that, that the vendec, where the bargain goes off by reason of the vendor's inability to perform the condition, gets no damages beyond the mere expenses of investigating a title which turns ont to be bad.

In Tumitison r. Day, the defendant took a mansion-house and farm from the plaintiff under an agreement, by which the plaintiff agreed, among other things, that the defendant should have the exchusive right of sporting orer the manor in which the farm lay, and shond ocenpy the

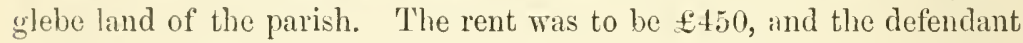
ocenpied the farm for some time; but the agreement, although acknowledged and recognised, was never signed by the defendant. The chief inducement of the latter to take the farm was the promised privilege of an exclusive right to sport ; but it tmmed out that the plaintiff (not being the owner of all the lands in the manor, and not having free warren) had no power to grant any such privilege; and the defendant was, in fact, warned off by the several ocenpiers within the manor. 'The plaintiff also failed in procuring the glebe for the defendant's occupation, and for this he offered to make a proportionate abatement of the rent. The defendant was sued in Use and Oceupation for $£ 450$, one year's rent, as reserved by the agreement, and paid $£ 350$ into Court, and had a verdict, the jury considering that to be the annual value of the land, independently of the glebe and the privilege of sporting. The Court of Common Pleas held that it was elearly the province of the jury to ascertain, independently of any agreement, what the defendant onght to pay, and that an eviction of part of the subject matter of the demise (namely, of the exclusive privilege of sporting) 
having been clearly proved in the present instance, the rule for a new trial must be discharged.

The minciple of compensation for damage by game was upheld in Barrow v. Ashburnham, where evidence was given of a conversation letween the plaintiff who subsecuently became the tenant, and the steward of the defendant, in which the former said, "I have no objection to take the farm, if the game is destroyed; I don't care so much about the birds, as the hares and rabijits." To this the steward replied: "Why, you are a man who keep no dog: and use no gun, and you ought not to be annoyed with hares and rabbits; you must let the keepers know, and they must kill them." The plaintiff rejoined, "Then upon these terms I will take the farm." This conversation was held by the Court of Queen's Bench to infer a contract on the part of the landlord to kill the hares and rabbits; and that the landlord was liable to damages (in this case $\mathfrak{E} 150$ ) committed by the hares and rabbits on the tenant's farm.

A bequest of money $(£ 5,000)$ to be applied in purchasing the discharge of persons, who, at the time of the testator's decease, or within five years afterwards, should be committed to mison for non-payment of fines, fees, and expenses under the game lau's, was held by Sir J. Romilly M.C. to be invalid, as contrary to public policy (Thrupp v. Collett).

The sulject of laying traps for logs was first considered in Tounsend v. Wathen. Here the defendant owned a large wood within 150 yards of the plaintiff's house, which was intersected with public highways and paths. In the blind tracks, traps large enough to catch sheep or deer were laid and baited with fresh or stinking flesh. But no notice was given of the traps being set. Besides this, paunches rubbed with aniseed had been dragged by the gamekeeper at a circle round the traps, to draw animals to them, for which defendant recompensed the keeper, at the rate of $2 \mathrm{~s}$. $6 \mathrm{~d}$. for every fox and badger, and 1s. for every dog. Some of these traps were set so near the plaintiff's house that the baiting and aniseed might be scented by the dogs there. It was held by the Court of Qneen's Bench that an action on the case lay.

In Deane v. Clayton, where the plaintiff had a verdict for $₫ 15$, subject to a point which Dallas J. reserved, on the authority of Tounsend $\mathrm{v}$. Wathen, the Court of Queen's Bench was divided in opinion as to whether, if plaintiff's dog started off the unfenced public footpath through defendant's u'ood, and ran against spikes placed in the hare-paths (of which the notice was given), the plaintiff was entitled to compensation for his $£ 50$ pointer if he chased a hare and was killed. Park and Burrough J.J. held that he was, and Gibls C.J. and Dallas J. that he was not. The Court of Exchequer adopted the ruling of the latter tro 
judges, in Jorlin v. Crump. The question here was whether the plaintilf was entitled to compensation for the death of or an injury done to his log, who by reason of his own natural instinct, and against the will of his master, ran off' the path, after a rabbit which crossed it, against ccrtain dog-spears, which were set by the defendant in his wood, and of which the plaintifl admitted he had notice. The Court considered that this was a stronger ease than Deane v. Clayton, and said that if a man chose to walk with his dog along a footpath through ground on which the latter might commit a trespass, he knew the risk he was ruming.

Per Alderson J.: "Illolt v. Wilkes was decided previously to the passing of the 7 \& 8 Geo. IV.c. 18, and was the case of a party trespassing in a wood, with notice that spriny-yuns were set there; but the Court of Queen's Bench held that he was not entitled to recover against the owner of the wood for damage done him thereby, it having been his nwn fault to go where spring-guns were set, for with that knowledge on his part spring-guns ceased to be secret engines of mischief. The case was similar to that of a trespasser endeavouring to climb a wall, who shonld hurt himself by coming in contact in the dark with spikes, or broken glass stuck upon it, in a case where it appeared that he had a previous opportunity of observing in broad daylight that such means of mischicf were placed on the wall. The other was the case of Bird $\mathrm{v}$. Hollrook, which was decided after the prassing of the statute $7 \& 8$ Geo. IV.c. 18. That was a case where the defendant, for the protection of his property, set a spring-yun in a wulleul garden, not only without giving notice, but where it appeared by the evidence that he had purposely abstained from giving any, in order that the thief (as he said) unight be detected. The plaintiff' was in search of a stray pea-hen; and laving trespassed in the garden, the springr-gun went off, and injured him serercly. On this the Court of Common Pleas held that he was entitled to maintain an action against the defendant; but the reason of this decision was that settiny sminu-guns without a notice was, even independently of the statute, an unluuful act. The correctness of this position may perhaps be questioned; but if it be sound, the decision in that case was right. Our judgment, however, in the present case proceeds on the ground that to set dog-spears in this wood was a perfectly legal act on the part of the defendant." The setting of dog-spears is not in itself an illegal act, nor is it rendered such by the stat. $7 \& 8$ Geo. IV. c. 18, s. 1, which prohibits the setting or placing of man-traps or other engines caleulated to destroy human life, or inflict grievous bodily harm, with intent that or whereby the same may destroy hunan life ur inflict orricrous bodily harm. 
But it was decided by the Courts of Queen's Bench (where a rule had been moved for by mistake) and Common Pleas, in Wootton v. Dawkins, that an engine intended to give alarm by loud explosion is not "a springgun" within the meaning of that section, and that a trespasser, though in a degree injured thereby, cannot recover for such injury at common law; nor in the absence of cvidence that it was caused by a spring-gun or other engine " calculated to inflict grievous bodily harm," under the statute. Here the plaintiff, having obtained permission during the daylight to go into the defendant's garden to look for a lost bantam, climbed over the wall into it by a ladder, without permission, at night ; and whilst groping among the bushes, came in contact with a wire, which caused sometting, the nature of which was not in evidence, to explode with a loud noise, knocking him down and slightly injuring his face and eyes.

In Read v. Edwards, 34 I. J. (N. S.) C. P. 31, the plaintiff brought an action against the defendant for damages sustained by him in respect of a dog which was in the habit of hunting game in plaintiff's woods, and thereby cansing damage to the plaintiff, and the Court held that such action was maintainable.

In the case of Baiker v. Davis, the appellant shot game on land which he occupied as tenant. Before the commencement of the tenancy, the landlord had granted the right of shooting to a Mr. Garnett, by deed. The tenant, the appellant in the case, was summoned and convicted before justices, on the evidence of Mr. Garnett, that he had the exclusive right of shooting on the land in question, that he preserved the game, and had given no permission to the tenant to shoot. It was held that upon this evidence the justices ought not to hare convicted, as there was not sufficient evidence that the right of shooting was in Garnett, withont the production of the deed (34 L. J. (N. S.) M. C. 141).

In the case of Dawson v. Fitzyerald, 9 L. R. Ex. 7, the defendant hired of the plaintiff the right of shooting over certain lands upon the terms, amongst others, that the defeudant during his tenancy would only keep such a number of hares and rabbits as would do no injury to the woods or plantations on the estate, or the growing crops of the tenants, and if such damage or injury did result to the crops of the tenants or the trees of the plaintiff, then the defendant should pay the plaintiff or the tenants a fair and reasonable compensation for such injury. It appeared that injury was done to the trees and crops; and to an action brought for compensation for such injury, the defendant pleaded that " one of the terms of the tenancy was, that in case of any such injury, the defendant would pay a fair and reasonable compensation, the amount of such compensation, in case of difference, to be referred to two arbitra- 
tors or an mmpire ; that a difference arose, and that no arbitrators or umpire were appointed, and no award made." Held, on demurrer, that this was a good plea.

To snstain an indictment muder the 9 Geo. IV. c. 69 , s. 4 , it must be proved that proceedings were commenced within twelve months from the time of the offence, and the warrant under which the prisoners are apprehended is not sufficient evidence : the information also must be proved (Rey. r. Purker, 33 L. J. (N. S.) M. C. 135).

In the case of Jeffiyes v. Ev'uns, 34 L. J. (N. S.) C.P. 261 , the plaintiff hired of the defendiunt the exclusive right of "shooting" and sporting orer and taking the game, rabbits, and wild forvl upon" a farm of which one Rees was tenant, the defendant having in his lease to Rees reserred this exclusive right to bimself. Rees shot a quantity of rabbits and grubbed up a large extent of gorse, and the plaintiff brought an action against the defendant in consequence of these acts of Rees. It was held that Rees had no right to shoot the rablits, and that his act was a wrongful one, for which defendant was not liable, but that Rees had a right to grub up the gorse in the reasonable course of husbandry, and that there was no implied covenant with the plaintiff that this should not be done, and that defendant was therefore not liable for such act of Rices.

A person who has a right of shooting orer land the property of another by an agreement not under seal has not snch an interest as to entitle him to compensation from a railway company under the Lands Clauses Consolidation Act, 8 \& 9 Vict. c. 18, s. 68 , in respect of the shooting being diminished in value by the company taking a portion of such land for the purposes of coustructing a railway (Birl v. Great (Eastem Railuay (34 L. J. (N. S.) C. P. 366).

Pursuit of game under $25 \& 26$ Tict., c. 114, s. 2. Under the 2 nd section of the new Game Act, empowering constables to stop and search persons suspected of poaching, and on finding game, or instruments for taking game upon them, to summon them before justices, the justices may convict withont direct proof that the persons charged have gone upon anj land in pursuit of game, circumstantial evidence that they must have done so being sufficient (Brown \& Others v. Turner).

In order to justify a conviction under $25 \& 26$ Vict. e. 114 , s. 2 , it is necessary that game or instruments for taking game should be found on the accused on a highway; it is not sufficient that the accused should le seen on a highway and game found on him elsewhere (Clarke $v$. Cromder, 4 L. I. C. P. 638 ; see also T'umer v. Morgan, 10 L. R. C. 1'. 587).

In Jenkins \& Demis r. King, 7. T. R. Q. B. 478, the appellants were 
convicted under the $25 \& 26$ Vict. c. 114 , s. 2 , of having used a net for unlawfully taking game ; they were met at about half-past nine at night on the highway by a policeman, one of the appellants had a game-net under his arm, and a lurcher dog accompanied them ; nothing else was found upon them, but the net was wet, and the policeman had shortly before heard the yapping of a dog as if in pursuit of game, held that the conviction was right. 


\section{CHAP'TER XII.}

TITHES.

The value of the rent charge, charged upon any land in lien of tithes by the apportionment, is reckoned as if one-third of it were invested in wheat, one-third in barley, and one-third in oats, at certain fixed prices, which were declared by 7 Will. IV. and 1 Vict. c. 69 , s. 7 , to be $7 \mathrm{~s} .0 \frac{1}{4} \mathrm{~d}$. for a bushel of wheat, $3 \mathrm{~s} .11 \frac{1}{2} \mathrm{~d}$. for a bushel of barley, and 2s. 9d. for a bushel of oats; and by 6 \& 7 Will. IV.c. 71 , s. 56 , the average is settled each January from the returus of the seren previous years, ending on the Thursday next before the preceding Christmas-day. The sum in question is payable half-yearly, and issues out of the lands, and is liable to rates, charges, and assessmeuts in all respects as tithes were. And by $14 \& 15$ Fict. c. 25 , s. 4 , if any ocenpying tenant of land shall quit, leaving such tithe rent-charge unpaid, and the tithe-owner shall give or have given notice of proceeding by distress on the land for its recovery, the landlord or the succecding tenant or occupier may pay it, and recorer the sum and expenses as if it were a debt by simple contract due from such first-named tenant or occupier.

The several Acts of Parliament for the commutation of tithes in England and Wales were lately extended by the 23 \& 24 Vict. c. 93. According to the new law, corn rents under local acts may be converted into rent-charges, which rent-charges are to be appointed by the commissioners with power to appeal to a court of law. Tithes commuted for a sum or rate per head of cattle may be converted into a rent-charge. "Whenerer a sum or rate per head shall be in arrear, the arrears shall he recoverable by distress and impounding of any cattle, stock, goods, or chattels belonging to the person in respect of whose cattle or stock such sum or rate per head is in arrear, wherever the same may be found." The commissioners have access to the books of the comptroller of corn returns, and are to be furnished by him with such information as they nay rernire for the purpose of any award of rent-charge in lieu of corn rents.

I'urmty years' perception of tithes does not give a title or right to them; 
and stat. $3 \& 4$ Will. IV. c. 27 cannot be applied to the case of tithes; in the same way as it has been held to operate as a parliamentary conveyance of land (Bumbury v. Fuller).

$A$ bequest of mure personaliy to a charity, the object of which is the purchase and restoration of the church of impropriate tithes, was held by the Lords Justices, confirming the judgment of Sir J. Romilly M.R. to be void under the Mortmain Act (stat. $9 \mathrm{Geo}$. II. c. 36), notwithstanding stat. 6 \& 7 Vici. c. 37, s. 25 , and stat. 13 \& 14 Tict.c. 94, s. 23 (Denton v. Lord John Manners).

The 6 \& 7 Will. c. 71 , creates no personal liability upon the owner of lands charged with the tithe-rent. In Griffenhoofe v. Daubuz the declaration alleged that the plaintiff was tenant of a farm to defendant for a term of years, after the expiration of which there becane due and payable from defendant to the Ecclesiastical Commissioners money in respect of a tithe commutation rent, charged on the farm and the land, which defendant, as owner of the farm, and entitled to the rents and profits, was liable to have paid, and ought to have paid. Defendant having neglected to pay it, the commissioners distrained for it a stack of wheat of plaintiff then lawfully on the farm and land, and afterwards sold it, and defendant, thongh requested had not indemnified plaintiff. The defendant pleaded that he was not liable to pay, nor ought to have paid, and it was held by the Court of Queen's Bench that the issue onght to be found for him, as stat. $6 \& 7$ Will. IV. c. 71, s. 67 , provides that nothing in the statnte contained shall be taken to render any person whatsoever personally liable to the payment of any such rentcharge ; the land only is liable. The commutation rent-charge, as thus settled, is simply a prayment issuing ont of the land, and by sec. 80 may be deducted from the rent. The plaintiff had covenanted to pay such rent-charge, and here endeavoured to charge the defendant with it on the ground of personal liability, which is not created by the act. This judgment was affirmed in the Exchequer Chamber, where Taylor v. Zamira was cited for the defendant as an anthority that the defendant was bound to indemnify him.

The intention of the Tithe Commutation Acts is, that the lands on which the apportionment of the tithe in each parish is cust, and these lands only, shall be liable in respect of the tithe payable for any lands in the parish; and that lands on which no apportionment is cast, shall not be liable to tithe ; and lands which on the agreement and apportionment under the Tithe Commutation Acts (confirmed by the Tithe Commissioners) are treated as free from tithe, cannot be afterwards made subject to it (Walker v. Bentley). A lessee of tithes is liable on his covenant to pay rent, notwithstanding the tithes have been commuted 
for a rent-charge, his remedy being by the surrender of his lease under the 88 th section of 6 \& 7 Will. IV. c. 71 (Tasker r. Bulliman).

Where there is evidence that a vicarage was endoued with small tithes, the ricar's right to them is established against all lands in the parish, as to which no particular discharge is proved, although no small tithes hare erer been paid (Clee v. Hall). By the common law the rector has a right to all such tithes as the vicar is not proved to be entitled to, and the title of the vicar must rest either on direet proof of an endowment, or on an endowment to be inferred by prescription or usage (AtlorneyGeneral. v. Hard). Tithes of beans and peas have been held to be comprised in the description of tithes of corn ( $i b$.).

Where an enclosure act enacted that it should be lawful for the commissioner to apportion the rent-charge in lieu of tithes upon such portion, as he should think fit, of the lands of A. B., the Court of Queen's Bench held that it was not necessary for him to specify in his award the lands on which the rent was to be charged (Hillonghby v. Willoughby). The abore case principally governed the decision of the Court of Common Pleas in Sitiester v. Bedford, and Bedford v. The Warden and Society of Sutton Coldfield. By a local enclosure act (5 Geo. IV. c. 14) tithes were abolished, and yearly rents imposed in lieu thereof, which yearly rents it declared should be eharged on the land, and should be paid at the rectory-house. The rector, "in addition to all present powers for recovery of tithes and eompositions," was to have " the same powers and remedies for recovering the said yearly rents," when in arrear, "as by common law or statute are provided and given to landlords for the recovery of rack-rent." Provision was made for the apportionment of the rent-charge in case of the division of the lands, which apportioned part was " to be recovered from the lands or hereditaments so charged therewith, or from the owners thereof, in such and the same manner as the whole of the yearly corn rents" were thereby inade recoverable. The commissioner was to determine what yearly sums, according to the aggregate annual amount, were equivalent to the tithes of each proprietor's old enelosed lands within the parish, which said yearly sums were to be charged upon the old enclosed lands of the respective proprietors as yearly rents payalle thereout. The Court of Common I'leas held firstly, per totam Curium, that the statute did not authorise an action by the rector against the owner of inclosed lands in his parish for the non-payment of such rent-charge; that a distress for the aggregate amount of a rent-eharge imposed upon lands accinired before and sulssequently to the act, was illegal ; and secondly (C'orlimm C..J. Miss.) that a distress on the ocenpier for the amount of the whole rent-charge on all the lands in the parish belonging to the 
same proprictor, thongh comprising lands not in the ocenpation of such ocenpier, was a legal one.

The person entitled to the rent-rharge ine licu of tithes, who distiains meder the Tithe Act, 6 \& 7 Will. IV. c. 71 , s. 81, is not entitled to indemnity in lieu of donble costs under $5 \& 6$ Vict. c. 97, s. 2, if such person avows under 11 Geo. II. c. 19, s. 22, and the plaintiff discontinues his action of replevin (Newnhem v. Berer).

The principle upon which an apportionment shoutd be made was considered In re Applettore Commutation, where the valuer made an apportionment which was objected to by landowners in the parish, and such objectors were heard first by the assistant commissioners, who received evidence for and against the objections, and then by the Tithe Commissioners, according to sec. 61. The tithes of corn and grain in the parish of Appledore (part of which was woodland) were payable to the rector, and moduses for all other tithes to the vicar, and a rentcharge, in lieu of such tithes and modnses, had been awarded under sec. 36 of 6 \& 7 Will. IV. c. 71 . Sir J. E. Honeywood, a landowner, held ancient pasture land of the Dean and Chapter of Canterbury, by lease, which forbade him to plongh the land without their licence in writing, for which he had never applied or purposed applying, bat lands of the Dean and Chapter within the same district had been plonghed within living memory. The valuer in apportioning the rentcharge under secs. 33 \& 34 , "pon Sir John Honeywood's pasture lands, assessed them with the ricar's rent-charge according to the modus, and added a small portion of rent-charge, 1s. per acre, to be paid to the rector, as part of the gross rent-charge awarded to him, where it seemed that the productive quality of the land admitted of its being arable, and that there was a reasonable probability of its being tilled; but he made no additional assessment on the woodland, not considering that a reasonable probability existed of that land becoming arable. The commissioners confirmed the principle of the apportionment, and the Court of Queen's Bench decided that a prohibition did not lie, as the possibility of the land reverting to a different state of cniture must be taken into account in the apportionment; and the commissioners must make the best average they can.

The onus of proving that the land is barren, in an action for not setting out tithes, is on the defendant (Lord Selsect r. Pouell). The seven years during which heath or waste ground which has lain barren, and paid no tithes by reason of the barrenness, but which is afterwards improved and converted into arable ground or meadow, is exempt from tithe by 2 \& 3 Edw. VI. c. 13, s. 5 , begin to run from the time when some act has been done to make the land more productive than before 
(Ross r. Smith). In Mutchins r. Manghan, eited by Eyre C.P. in Jones r. Le Darit, it was held that land which from its exposed situation would not grow enrn withont the expense of ereeting stone walls to protect it from the sererity of the climate, is exempt. Land which is of a good natural quality is not to be considered as "barren" within 2 \& : Eilu. TI. c. 1:3, but shall pay tithe immediately, althongh the expense attending the breaking it up and liming it exeeds the return made to the farmer in the several first jears of cultivating it (Wururick v. Collins). The proper test of barrenness within this statute is, whether the land requires extraosdinary expense either in manure or labour to bring it into a proper state of enlture (Lord Selsea v. Porrefl.

'The enjoyment of land produeing titheable matters, withont payment of tithe for the period prescribed by $2 \& 3$ Will. IV. c. 100 (an Act for shortening the time required in elaims of modus decimanti, or exemption from or discharge of tithes), if adrerse and as of right, creates $a$ valid and indefeasible exemption from and discharge of tithes. But the nonparment of tithes of a particular thing for such period, in respect of lands for which tithes or other titheable produce have been paid within the statutable period, does not operate as an exemption from the payment of the tithes of that particular thing (Salkeld (elerk) v. Johnson). 'The legislature by stat. 5 \& 6 Will. IV. c. 75 , did away with the distinction in regard to turnips, expressly proriding that turnips severed and eaten on the ground should be titheable in the same manner only as if eaten without being severed. And the Court of Queen's Bench decided in Fisher r. Burrel that milk drawn from the cow by hand, and giren to the ealf before it beeomes titheable, is exempt from tithe, as well as milk sucked by the calf.

The enactment of the Tithe Commutation Amendment Act $(9 \& 10$ Tirt. c. 78, s. 19), that every instiment purporting to merge any lithes, and made with the consent of the Tithe Commissioners, shall be absolutely confirmed and made valid both at law and in equity in all respects, is not limited to eases in which the person executing the instrument has a title to the tithe, but operates as well where such person has no estate in the tithe, as where his estate is insufficient to eflect the merger (IFalker v. Bentley). The intention of the legislature was to preclude all questions of merger of tithe in all eases where declarations of mererel had been made with the consent of the Tithe Commissioners, leaving the parties affected by an erroneons declaration to their remedy against the party making it ; and such being the intention, the merger is effeeted, although the sanetion of the commissioners has been erroneously given (ib.).

A commissioner has by bis award under the Tithe Commutation Act 
6 \& 7 Witl. IV. c. 71) to fix the amount of rent-charge mayable in lien of tithe, and, for that purpose, to decide mpon the titheability of lands; but he has no jurisdiction to decide thereby who is the party entitled to receive the rent-charge (Eduards v. Bunbury). And on a feigned issue under sec. 46 , the landowner cannot deny that the lands were subject to the payment of tithe to B., for the purpose of raising the question of title, as betwcen B. and a third party (ib.).

The awarl to be made by Tithe Commissioners nnder $6 \&$ \& Will. IV. c. 71, is for the purpose only of settling disputes betucen tithe-owner and land-owner, and not of deciding questions of title between rival claimants of tithe. Hence where tithes of agistment were claimed by both rector and vicar, and the latter called upon them to determine snch claims before making their award, it was held on a return to a mandamus that the commissioners were not bound so to determine, the difference not being one within sec. 45 , by which the making of the award was hindered; but they would do rightly in awarding rent-charge for the tithes, including that of agistment, to the parties respectively in possession, leaving them to litigate the title subseqnently, as they might do under sect. 72 , notwithstanding the award, and that no statement appearing as to the receipt of agistment tithe by any party, the commissioners might properly consider the rector as the person in actual possession within sect. 12 (Reg. v. Tithe Coimnissioners). The confirmed aucard, under the Tithe Commutation Acts ( 6 \& 7 Will. IV. c. 71 , amended, \&c., by 7 Will. IV. and 1 Vict. c. $69 ; 1$ \& 2 Vict. c. $64 ; 2 \& 3$ Vict. c. 62 ; and $5 \& 6$ Vict. c. 54 ), thongh final as between the tithe-owners and tithe-payers, does not exclude from farther investigation a case between the tithe-owners themselves, in which there was, before the award, a just title to tithes, which by accident and mistake was not brought forward until after the award was made. 'Thus where by an award made with the concurrence of A., the patron, the whole rent-charge was made payable to B., the rector, A. being at the time entitled to one-half of the corn tithes, but ignorant of his rights, he was held entitled to relief in equity as against B. (Clarke v. Yonge). But where at the time of the making an award of a rentcharge in lieu of certain tithes under the act, a suit in equity was pending for an acconnt of the same tithes, in which the question was as to the title of the claimant to receive the tithes, the Conrt of Queen's Bench held that the validity of the award was not thereby affected, such suit not being one "touching the right to any tithes," and "whereby the making of the award shall be hindered," within the meaning of the 45 th section of the $6 \& 7$ Witl. IV. c. 71 (Shepherd $\mathrm{v}$. Marquis of Londonderry). 
Stat. 6 \& 7 Will. IV.c. 71 , s. 45, empowering the Tithe Commissioners to decide any question touching "the boumdary of any lanils," does not anthorize them to settle by their arvard a dispute as to the boumlary of parishes (In re Ystralginlais Commutation). Nor can they do so under the powers granted by stat. 7 Will. IV. and 1 Fict. c. 69 , $\mathrm{s.} 2$, eren at the request of two-thirds in ralue of the landowners, if the boundary of the parishes be also a boundary between counties; for by stat. 2 \& 3 rict. c. 62 , s. 37, this and the two prior acts are incorporated; and sect. 34 of stat. 2 \& 3 Vict. c. 62 forbids the commissioners to adjudicate on a boundary which divides counties as well as parishes (ib.). And quere whether a parochial agreement for a commutation rent-charge can legally be made and confirmed under stat. 6 \& 7 Will. IV. c. 71 , ss. 17,27 , \&c., while a dispnte exists as to the boundary of the parish (ib.). The award of an Assistant 'Tithe Commissioner, employed to settle the boundaries of a township on request of the landowners, under 7 Witl. IV. and 1 Tict. c. 69, s. 2, should state the district to be one of which the tithes are "to be commuted," and the request to have been signed "at a parochial meeting called for" that purpose," "according to the provisions of " stat. 6 \& 7 Witt. IV. c. 71 , s. 17, referred to by 7 Will. IV. and 1 Vict. c. 69 , s. 2 (In re Dent Commutation). An award under the latter section can be made only where the tithes are "to be commuted," and there is no jurisdiction under it, if the tithes have been commuted already (ib.). And in a case under it, the commissioners may ascertain the existing boundary of a parish, though it be also that of a county, or of a copyhold in a manor, the lord of which does not consent to the inquiry $(i b$.$) . The interpre-$ tation clause, see. 12 of $6 \& 7$ Vill. IV. c. 71 , with which 7 Will. IV. and 1 Tirt. c. 69 , is incorporated, enacts that the word "parish" shall inchude "township" (ib.).

By stat. 2 \& 3 Tirt. c. 62 , s. 34 , which defines the mode of proceeding to ascertain boundaries, the commissioners are empowered "to ascertain, adjust, set-out, and define the ancient boundaries," "or draw and define a new line of boundary as they may see fit"; and the boundary line so ascertained or newly defined "shall thenceforward be the boundary line of and between such parishes." Whether they ascertain old or set out new boundaries, the word "thenceforward" applies; and the reasonable construction is, that the award in this respect is to be conclusive from thenceforward only, leaving past transactions and the state of things on which they depended to be asecrtained as under the former law (Reg. v. Intubitants of Hadetey):

An aucard by the T'ithe Commissioners nuder 1 rict. c. 69, and $2 \& 3$ Tict. c. 62, as to the boundary of a parish, is not conclusive as to what 
was the boundary prior to the time when the aurard was made (it.); and see Rex v. St. Mary, Burry St. Edmumuls. $\Lambda$ dispnte as to the title to tithes between the rector and the vicar is not "a difference whereby the making of the award is hindered" under 6 \& 7 Will. IV., c. 71, s. 45, and which the commissioners are bound to decide before making their award; and an aucarl of a rent-charye in lieu of certain tithes to which it states that the rector is entitled, does not conclnsively vest the title to those tithes in the rector, and the viear may notwithstanding try his right to the substituted rent-charge (Reg. v. Tithe Commissioners). Where on a hearing before the Assistant 'Tithe Commissioner, appointed to ascertain the amount of a commutation rent-charge, under statnte 6 \& 7 Will. IV. c. 71, a landowner denied the right of B., an alleged tithe-owner, to rectorial tithe of his lands, asserting that they were tithe free, and the Assistant Tithe Commissioner decided that B. was owner of the rectory, and as rector entitled to the said tithe-it was held by the Court of Queen's Bench, on a feigned issue under section 46 , that the landowner could not deny that the lands were subject to the payment of tithe to $\mathrm{B}$. for the purpose of raising the question as between B. and a third party (Edwards v. Bumbury).

As to actions against Tithe Commissioners, \&c., under 6 \& 7 Will. IV. c. 71 , s. 94 , see Ackland v. Buller. By the Tithe Commutation Act, 6 \& 7 Will. IV. c. 71 , s. 46 , any person claiming an interest in lands or tithes who shall be dissatisfied with any decision of the commissioners (deciding upon an amount above $£ 20$ ) may, within three months after notice to him of the decision, bring an action by feigned issue to disputo the decision. Where, in proceedings before a Tithe Commissioner under 6 \& 7 Will. IV.c. 71 , s. 45 , several moduses are set up in respeet of distinct farms, and the annual value of the payment to be made in respect of each farm is less than $£ 20$, his decision is final under section 46, notwithstanding the whole is in the hands of the same proprietor, and the aggregate jearly value exceeds $£ 20$ (Tomlinson, clerk, v. Burghey).

The yearly value of the payment to be made under the award by the individual aprellant must exceed $£ 20$, to entitle him to appeal (Flanders v. Bunbury and Hattheus v. Lcapinguelt). And smuble, that in estimating such value he is not entitled to take into account lands held by him as tenant in eommon with another person who is no party to the appeal (it.). The "payment to be made or withholden according to such decision," is the difference between the modus claimed and the asserted value of the tithes in kind, payable under the award (ib.) Reputation is not admissible evidence of a furm modus (Pritchett v. Honcybourne). And in an action by a rector for tithes, where the 
question is, whether a modus exists of a certain sum of money for a particular farm in a township within the parish, the plaintiff may inquire whether other farms in the same township are not subject to the same parment for the pulpose of showing that such payments cannot be a farin modus (Bhundell r. Howard).

A modus and its incidents were thus described by Kindersley V.C., in Chapmeys r. Buchan: "A proper farm morlus is a modus payable in lien of the tithes in kind of a particular parcel of ground. A modus decimandi properly means a particular mode or manner of tithing, which custom or prescription has substituted for the ordinary common law mode of rendering tithes in kind. A modus, indeed, can only exist by rirtue of a enstom or prescription ; but it is a enstom not creating, but modifying and altering, the original common law liability to pay tithe. Whenerer there is a valid modus, the law presumes that at some period before the time of legal memory tithes were payable in kind in the ordinary common law manner, and that by some ancient composition, or agrecment, or practice, dating before the time of legal memory, some other manner of tithing became substituted for it, which was at the time a fair and reasonable equivalent for the tithe payable by the common law. The mochus does not create the liability to tithe, so as that if there were no modus there wonld be no liability to tithe; on the contrary, the existence of a moclus pre-supposes the original liability to tithe; so that if there were no modus, tithes would be payable in kind, according to the common law. The term modus decimandi is therefore properly applicable to those things only which are titheable at common law, and not to things which de communi jure are not liable to tithe at all. Whenerer tithe is payable for a thing which de communi jure is not liable to tithe, this can only be by virtue of a special custom which creates the original liability to tithe; so that, if there were no custom, there could be no liability to tithe. And the same custom which creates the liability to tithe must also preseribe what is payable for the tithe, and how its amount is to be ascertaincd, and in what manner the tithe is to be rendered or paid."

If the incumbent ayainst whom an axard is made in farour of a moches dies within the there months, having had notice in writing of the decision without having brought an action to dispute it, his successor cannot do so after the three months have expired; and if he does, the Conrt will set the proceedings aside on motion (Homfray, clerk, v. Scrope). A claim of modus decimandi from time inmemorial may be pleaded, notwithstanding the statute $2 \& 3$ Will. IV. c. 100, and may be proved by the same evidence as would have been sufficient before the statute; but such claim will be liable to be defeated by showing payment of tithes 
in kind at any time within legal memory (Earl of Stamfort v. Dunbar) Where a sum of money has been expressly paid and received during the whole statutable period mentioned in $2 \& 3$ Will. IV. c. 100, s. 1, as a modus or composition for the tithe only, such payment renders the molus valid and indefeasible, althongh the abandonment by the rector of certain rights of common originally formed part of the consideration for the payment (Toymbee v. Brown).

In order to take the payment of a modus for the statutable period out of the operation of this section, by virtue of the concluding part of it, it must be made by a consent or agreement in writing for the payment of that very modus, during all or some part of that time, and that by a person who could otherwise have objected to the payment; for by the words of the statute, the payment for the statutable period must be made by consent in writing expressly given for that purpose (ib.).

It was held by the Exchequer Chamber, in Barker v. The Tithe Commissioners confirming the judgment of the Court of Exchequer, that where a claim of a modus or other exemption from tithe is preferred before the Tithe Commissioners, under 6 \& 7 Jitl. IV. c. 71, who decide against the claim set up, the party is not prectuded from setting up another claim to a different modus on the same lands, unless the commissioners have made their final award under the act, even thongh a feigned issue delivered under the 46 th section be pending to try the validity of the first modus.

In an action of debt on $2 \& 3$ Edtw. VI. c. 13, s. 1, for treble value of tithes carried an'ay before setting out the same, the defendant should not plead several pleas of nil debet by statute as to several parts of the lands on which the titheable matters were produced, but should plead one plea of nit debet by the statnte to the whole (Graburn v. Broun). And he will be obliged to give a particular of all grounds of exemption, modus, \&c., intended to be insisted on at the trial (ib.). Statute $5 \& 6$ Will. IV. c. 74 , s. 1 , extends to the prohibition of actions of debt for treble value under $2 \& 3 E d w$. VI. c. 13, s. 1, for not setting out tithes where the annual value is less than $£ 10$ (Peyton $\mathrm{v}$. Watson). As the account for tithes is merely incidental to the rector's legal title, a court of equity cannot interpose in his favour until he has established his right at law (Marquis of Waterford, appel. จ. Knight, clerk, respt.). A court of equity will compel discovery and production of documents in aid of proceedings at law to try a disputed right under the Tithe Commutation Act, notwithstanding special provisions are contained in that act for those purposes (Morris v. Ducke of Norfolk). A defendant is entitled to judgment, as in case of a nonsuit, where the plaintiff has allowed two assizes to elapse withont proceeding to trial, after issue joined on a 
feigned issue, under the Tithe Commntation Act, 6 \& 7 Will. IV. c. 71 , s. 46 (Santys v. Mayor, \&e., of Bevertey). Error does not lie on a judgment of a superior court upon a feigned issue brought under such section (Thorpe r. Plouden). Since $5 \& 6$ Will. IV. c. 74, if any tithe, oblation, or composition not excepted in $7 \& 8$ Iritl. III. c. 6 , or exceeding $£ 10$ yearly value, due from any one person, is in arrear, it must be proceeded for before two justices. And if the title of the claimant, or liability of the party sought to be charged is undisputed, two years' arrears may be there recorered; whereas, if such title or liability is denied vir' $\hat{\imath}$ voce before the justices, or at any time in writing, the claimant may proceed by suit in equity, and lecover six years' arrears (Robinson, clerk, v. Purday).

E.rpenses incurred by the employment of an attompy by the landowners of a parish to conduct the procedings torrards a commutation of the tithes of the parish, under $6 \& 7$ JVitt. IV. c. 71 , are not "expenses of or incident to making the apportionment" within the 75 th section of that aet, and the attorney may therefore recorer the amount of his bill for such services in an action against the landowners who were parties to employing him (Hinchcliffe v. Armistead, clerk).

Disqualification by interest in a valuer was the subject of The Lancaster and Curlisle Railway Company v. Heaton. Here, under a local tithe commutation act (5 Geo. IV. c. 28), on application made to the quarter sessions, that court was to appoint "one or more fit and proper jersons not interested in the said tithes or dues" to value the lands in a certain tomnship, with a view to the apportionment between different landowners of the corn rent-charge substituted in lien of the viearial tithes; and the sessions appointed as valuer a shareholder in a railway which passed through the township in question. No steps were taken to set aside the order of sessions; but afterwards the collection of the rent-charge, as asscssed on the valuation, was resisted. The Court of Queen's Bench held, in an aetion of replevin, that even if the valuer appointed was an interested person within the meaning of the local act, the sessions had jurisdiction to make the appointment, and that, at all events, the validity of that order could not be questioned in that way; but semble, that he was not disqnalified by interest.

And where the person appointed to act as tithe valuer was required before acting to take and smbseribe an oath in the words following :"I, A. B., lo sucear fuithfully to expcute the poueers, \&e., so help me God," it was held by the Court of Queen's Bench that a person who bad subscribed an oath in which the words "So help me God" were admitted, had substantially complied with the statute $(i b$.$) .$

It was decided by the Court of Queen's Bench, in Reg. v. Goodchild 
and Reg. v. Lamb (Colevidge J. diss.), that in assessing a commutation rent-charge of a benefice to the poor's-rate, deductions are to be allowed in respect of the expenses of collection, including law expenses, and losses by ultimate non-payment; but no allowance is to be made for the personal services of the incumbent, in diseharging the duties of his cure. The principle of such assessment is, that the rent-charge is to be assessed, like all other property, according to what it might be reasonably expected to let for from year to year; but beyond allowances for the expenses of collection, law expenses, and bad debts, a deduction by way of tenant's profits is not necessarily to be made. 'The poor's-rate is to be deducted, and this thongh the composition, before commutation, had been calculated on the principle of being paid free from poor's-rate, and the rent-charge had been fixed with an addition in respect of this circumstance. Tenants' property-tax is to be deducted, but not landlord's property-tax or land tax. First-fruits and tenths (and other ecclesiastical dues, if any, of the same character) are to be deducted in the proportion which the rent-charge bears to the whole anni proventus of the living. An allowance is also to be mate of any sum contributed by the incumbent towards a district chapel in the parish, if not a mere voluntary contribution; and a reasonable allowance is also to be made for the curate's stipend, where the curate is not employed as the mere substitute of the incumbent, but is required by law, in addition to the incumbent from the population or value of the living, or where, if not required by law, the wants of the parish make his services necessary in addition to those of the incumbent properly discharged.

The pouer given by stat. 1 \& 2 Will. IV. c. 45, s. 21, to amex a part of the tithes or other ammal revenues belonging to a rectory or vicarage to a district church within the parish, authorises the annexation of part of an annual payment in lieu of tithes (Hughes v. Denton); and althongh by $19 \& 20$ Vict. c. 104 , s. 14 , certain districts are made separate parishes for ecclesiastical purposes, they still remain districts only for other purposes; so that a district to which this section is applicable, is still capable of receiving, as such, an annexation of a portion of the annual revenues of the principal chureh, under stat. $1 \& 2$ Will. IV. c. 45, s. 21 (ib.).

Rent-charge on hops.-Under the Tithe Commutation Act, after a commntation of the tithes of a parish, an allotment being made under an inclosure act "of common and waste land," and part of the land so enclosed being turned into a hop-ground, it was held by Cockburn C.J., Blackbum J., and Mellor. J., that as the tithe on the land in question had been extinguished, it had been commuted, and that it was not material that it had never been tithed, for it was titheable, and the 
commutation was in respect of liability to tithe, not of actual payment of tithes, and therefore they gave judgment for the defendant. But per Wightman J., there was no commutation of tithes in respect of this land, there being, in fact, nothing to commute, tithes having nerer been paid in respect thereof (Trimmer v. Walsh).

Liability of rent-charge to poor-rates. - The incumbent of a district parish, ereated under the New Parishes Acts, 1843 and 1856, is not liable to poor-rates, in respect of a yearly rent-charge, payable out of the tithe rent-charge of one of the parishes out of which the district parish is ereated (Reg. on prosecution of Tolleshunt Kmights, resps. v. Rer. W. H. Friend, appt.).

A commutation tithe rent-charge is liable to a general rate and lighting-rate levied under Metropolitan Act (18 \& 19 Vict. c. 120, s. 161). Semble that a commutation tithe rent-charge is not liable by law to contribute to a sewers rate (Reg. v. Goodchild and Lamb).

Grantee of rent-charge liable for income-tax.-The grantee of a rentcharge is the person bound to pay the income-tax due upon such rent-charge (Festing v. Taylor).

Juristiction of commissioner.-By a private Act of Parliament passed in 1762 , for carrying into effect an agreement between the landowner and rector for the commutation of tithes on certain lands in the parish of $\mathrm{W}$., it was declared that certain rents therein specified should be vested in the rector, in lieu of and as full compensation for all tithes of corn, grain, hay, wool, lambs, and all other tithes whatsoever, except as after mentioned, arising from all or any of the lands in the said parish, sare and except marriage, churching, and burial-fees, "providing that nothing in the act should prejudice the right of the said rector or his successors to any marriage, churching, or burial-fees, nor the right or tithe and customary stocking" in certain specified lands, "the modus in the groves and ancient closes adjoining to the town, and all other petty and personal tithes not herein mentioned and relinquished, all which the said rector reserves, and they are hereby reserved to him and his successors in full right and in as ample manner as they have always been enjoyed. The assistant tithe commissioners having decided that the caid lands called "ancient closes" were not exempt from tithes; it was held on motion for a prohibition, that the tithes of the "ancient closes" were not eommuted or extinguished by the private act of 1762 , and therefore the jurisdiction of the commissioners was not taken away by sec. 90 of the 'Tithe Commutation Act, $6 \& 7$ Witt. IV. c. 71 . Semble that even if the tithes of wool and lamb were not included in the modus reserver to the rector, and were therefore extinguished by the act of 1762, such practical extinguishment of tithes arising out of the lands 
would not satisfy section 90 , so as to deprive the commmissioners of jurisdiction (Re Wintringham Tithes ex parte Lord Carrington).

"Ontgoings" include land-tax and commutation rent-charge.-On the construction of an agreement between landlord and tenant for the lease of a farm for a term of years at a yearly rent of $£ 40$, payable quarterly, "free of all outgoings." It was held by Stuart T.C. that the word "outgoings" did not include the land-tax and tithe commutation rent-charge. The decision was reversed by Lord Chancellor Campbell, who observed: "Mr. Hobhouse, for the plaintiff, mainly relied upon Cranston v. Clarke (Sayer 78), but this authority was outweighed by the other authorities which had been cited, particularly Bradbury v. Wright (2 Dong. 624), and Bemett v. Wromeck (7 B. \& C. 629, and 6 L. J. (N. S.) Q. B. 175). The certificate must, therefore, be varied by making the rent payable free of land-tax and tithe commutation rent-charge (Parish v. Sleeman).

Occupier of tithe rent-charge compelled or voluntarily appointing curate may deduct satary from rateable value of rent-churge. - Where two parishes, each separately supporting its own poor, and having each its own church, have been immemorially united as one ecclesiastical benefice, and in order to the due performance of the clerical duties of his two parishes the incumbent necessarily requires the assistance of a curatein assessing his tithe commutation rent-charge in one of the parishes to the poor-rate the incumbent is entitled to a dednction in respect of the salary which he pays to the curate. The Court thought that the case was not distinguishable from Reg. v. Goodchild (1 El. B. \& E. 1, \& 27 I. J. (N. S.) M. C. 233), which decides that if a rector being entitled to a tithe rent-charge is assessed to the poor-rate as occupier of the rentcharge, and if he can be compelled to appoint a curate, or if acting under a proper sense of religious duty he voluntarily appoints a curate, the salary of the curate ought to be deducted in estimating the rateable value of the rent-charge; the distinction put being such a case, in which " the incumbent is non-resident, or, being resident, from sickness, infirmity, or any less creditable cause," employs a cur'ate to perform his duty. 'That decision, therefore, decides the present case in farour of the appellant. It is conceded that the bishop conld interfere and compel the appointment of a curate; and even were it not so, it cannot be disputed that, owing to the area of the two parishes, it is impossible that the proper number of services could be performed by the incumbent without assistance; and therefore the case comes within one or other of the alternatives in which, according to Rey. v. Goodchild, the curate's salary ought to be deducted (Iritliams, appt. v. Overseers of Llangeinwen resps.). 
Perpetual payment to incumbent of new district not to be deducted in assessing tithe rent-charge to poor-rate.-The rector of a parish, who pursuant to the statutes in that behalf, has charged the tithe rentcharge with the perpetual payment of an annual sum towards the stipend of the incumbent for the time being of a new ecclesiastical district, formed, under the statutes, of part of the parish, is not entitled to hare the sum so charged deducted in assessing the tithe rent-charge to the poor-rate.

And per Curiam: "It is true that it has been held in the case of Reg. r. Goodchild that an incumbent entitled to rent-charge, who employs a curate either because he is compellable by the bishop to do so, or becanse the magnitude of the ease properly requires it, is entitled to hare the stipend of such curate dedueted from the assessable value of the tithe rent-charge. But we are of opinion (as indeed we intimated in the recent ease of Itheler, appt. v. Overseers of Burmington (31 L. J (N. S.) M. C. 57) that the principle of the decision in Reg. v. Goodchild ought to be carried no further. We think it onght not to be applied to a case where the owner of the tithe rent-charge voluntarily parts with a portion by creating a rent-charge on it to endow another minister. Certain lands in the parishes of Long Bevington and Foston in the county of Lincoln were enclosed under a local act, and the commissioners allotted eertain lands to the rector, which were subject to a corn-rent payable to the vicar "clear of all parochial taxes, rates, dues, and assessments whatever: " it was held by the Court of Common Pleas that the oceupiers of the land charged with the payment of the cornrent, were not entitled to have the amount of such eorn-rent deducted in estimating the net aunual value of their property, liable to the poor rate nuder 24 \& 25 Trict. e. 103, s. 15. (Hackett v. the Churchuardens and Overseers of Long Berington, 33 L. J. (N. S.) M. C. 137. Laurence, appt. $\mathrm{v}$. Oimserers of Tolleshunt Knights, resps.).

Lessere of tithe remt-charge not entilled to deduct stipend to curate.The lay impropriators of the tithes of the parish of $\mathrm{B}$. granted a lease of their tithe rent-charge, at a nominal rent, to the appellant for twentyone years, if he should so long remain the vicar of the adjoining parish of W., he covenanting to serre the cure of B. either by himself or a curate. In order to the proper discharge of the dnties of the two parishes, it was necessary to employ a cmrate for B., and it was held that in asscssing the appellant to the poor-rate of B., as occupier of the tithe rent-charge, he was not entitled to any deruction in respect of the stipend which he paid the curate. And per Blackburn J.: "If the facts were that the parishes of Wolford and Burmington were one benefice, and that Mr. Wheeler was compolled to employ a eurate to assist him 
in the proper discharge of the duties of the two churehes, then he conld claim exemption within the prineiple laid down in Reg. v. Goodchild (1 E. B. \& E. 1, and 27 L. J. (N. S.) M. C. 233). But on the facts as they appear in the ease, the tithes or tithe rent-charge of Burmington are held by Mr. Wheeler, not as having been instituted to the vicarage of Wolford, but because he has become lessee of them from Merton College. He has become lessee, and he pays rent in services instead of money. If he paid in money, he conld not deduct the amount. It is enough to say that this is the case of a lessee of a tithe rent-charge, and not at all a case to which Reg. v. Goodchild applies (IVheeler, appt. v. Overseers of Burmington, resps.).

Assessment of occupier of tithe rent-charge.-The Archbishop of Canterbury, being owner of the impropriate rectory and tithe rent-charge of the parish of $\mathrm{H}$., and of a piece of land thereunto appertaining, granted (under the Augmentation Acts 29 Car. II. c. 8, and 1 \& 2 Will. IV. c. 45) to the perpetual curate for the time being of an annual rent of $£ 40$, to be charged upon and yearly issuing ont of the said rectory, tithe rent-charge and land; and he afterwards leased the same to G. for 21 years, G. yielding and paying yearly to the archbishop $\& 913 s$, and also $£ 616 s$. for redeemed land-tax, and to the perpetual curate for the time being of $\mathrm{T}$. the said sum of $£ 40$. It was held that, in assessing $\mathrm{G}$. to the poor-rate of $\mathrm{H}$., as occupier of the tithe rent-charge, $\mathrm{G}$. was not entitled to any deduetion in respect of the jearly payment of $£ 40$, such payment being so much rent paid for his occupation of the tithe rentcharge, and not a charge upon him as occupying tenant, nor so mulch tithe rent-charge withdrawn from his occipation. And per Blackburn J : "The person rated ought to be rated according to the value of the rateable property which he occupies, and the rateable value is the rent at which the same might be reasonably expected to be let for from year to year. What does the appellant oceupy? He ocenpies the whole of the property comprised in the lease, viz., the tithe rent-charge and the lalfacre of land. That the eurate of Thannington is not the occupier in respect of the $£ 40$ is shown by Frend v. Tolleshunt Knights (28 L. J. (N. S.) MI. C. 169). That seems to me a sound decision, and it shows that the party charging, or his assignee or tenant must occupy the whole hereditament though charged" (Reg. v. W. J. Groves, clerk). 


\section{CHAP'TER XIII. \\ IANDLORD AND TENANT.}

A lessep even for half-a-year is considered a tenant for ycars, a year being the shortest term which the law notices. In the absence of any evidence to the contrary, the tenancy under a written agreement for the hire of a farm at a yearly rental, from year to year, must be taken to begin from the day on which that agreement professes to have been executed; and that question is for the judge and not for the jury (Bishop v. Wraith). "Demise, grant, and to farm-let," are the nsual words in a lease ; but whatever' words amount to a grant are sufficient to malse a lease (Co. Litt. 45 ; 2 Black. Com. 318). It was decided in Doe dem. Morgan v. Pou'ell, that whether an instrument is to operate as a lease or an agreement depends upon the intention to be collected from it, and from the nature and condition of the subject-matter, withnut reference to the extrinsic circumstances or subseqnent acts. And per Tindal C.J. : "The mere use of the words ' $I$ agree to let.' does not make the instrument an agreement only, provided the rest of the words show an intention to create an actual demise, but they throw a doubt upon the intention."

In Doe dem. Philips v. Benjamin, the plaintiff entered into an agreement, of December 13th, 1834, with the defendant, who was his yearly tenant, in the middle of a half-year, whereby he agreed to let the premises to him for fourteen years, determinable upon notice at the end of seven years, at a certain rent, a lease to be drawn upon the usual terms, upon which the defendant agreed to take them, and it was held that this constituled a lease. And per Curiam: "The words "agree to let" have long been held the same as words of actual letting. It is said here that the agreement for a future lease is inconsistent with a present demisc ; and it would have been as well if that distinction had been upheld from the first : but it has been long settled that that circumstance alone will not reduce what wonld otherwise be a present demise to a mere agrecment. As to the provision that the lease shall contain the usual corenauts, Mrensfield C.J. certanly held in Morgan v. Bissell that such a description of the intended lease was uncertain and incon- 
sistent with the supposition of a present demise; but in later cases a different opinion has prevailed. As to the construction, Staniforth v. Fo $x$ is a case very near this in words and in principle."

Upon an inquisition on a writ of elegit, proof of possession or receipt of the rent of the land by the party is prima facie evidence of the title, and where a jury, notwithstanding such evidence, found that the party had no lands, the Court of Common Pleas set aside the finding, and directed the sheriff to take a new inquisition (Barnes v. Harding). A tenant by elegit has a right to distrain without attornment (Lloyd v. Davies). An attornment by a tenant of land to a receiver appointed by Chancery to collect the rents, and payment of rent to such receiver, create a tenancy by estoppel between the tenant and receiver, but do not enure to enable the person who is found nltimately to have the legal title to the land to treat the tenant as his tenant, and to distrain for rent (Evans v. Matthias). Where a mortyagee gave notice to the tenants of the mortgaged property not to pay their rents to the mortgagor, but to himself, it was held by Sir J. Romilly M.R. that he was liable to the mortgagor for any consequential loss, as it is his duty either to take possession himself or to leave the mortgagor in possession (Heale v. M'Murray). If a lease is in the hands of a tenant, and it appears that no counterpart can be found, the Conrt will permit the landlord to inspect and take a copy of it (Doe dem. v. Slight).

The terms of a lease may be proved by oral admissions (Smith v. Howad); and if a landlord gives a receipt for rent last due, it is presumable that all former rent has been paid (Gilb. Ev. 157).

He who agrees to let agrees to give possession, and not merely to give the chance of a law-suit; and if he fails to do so, the lessee may recover damages against him, and need not bring ejectment (Coe v. Clay). On an agreement for a lease "with all usual and reasonable covenants," $a$ covenant not to underlease or assign is implied where the custom is not generally against it (Folkingham v. Croft). In the Exchequer Chamber, on error from the Court of Common Pleas, it was held that the word "demise" in a lease implies a curenant for title and a covenant for quiet enjoyment; but both branches of such implied covenant are restrained by an express covenant for quiet enjoyment (Line v. Stephenson). In every contract for the sale of an existing lease there is an implied undertaking by the seller (if the contrary be not expressed) to make out the lessor's title to demise; and without showing such title, the seller cannot maintain an action at law against the buyer for refusing to complete the purchase (Souter v. Druke). But, on a contract for the sale of an agreement for a lease it is not an implied condition that the lessor has power to grant the lease (Kintrea v. Preston). Alderson B. thus 
pointed out the distinetion : "In every contract for the sale of a lease the agreement is to sell an interest in the land; that is not so in the ease of the sale of an agreement. The question is one which depends upon the words of the eontract. It has been decided that the grant of a lease means the grant of an absolute right of enjoyment for a certain number of years; and there is therefore on the sale of a lease an implied term that the vendor shall show the lessor's title. Here there is merely the purchase of an agreement. Whatever benefit the agreement gave to the plaintiff the defendant is entitled to. It is ntterly uncertain what the terms of the agreement between the plaintiff and E. C. his landlady are; but any right which the defendant may have to eall for Iroof of the lessor's title rests npon that agreement, and must be the right which the plaintiff had against E. C., and which by the contract is transferred to the defendant." And per Littledale J.: "Where parties enter under a mere agreement for a future lease they are tenants at will; and if rent is paid under the agreement they become tenants from year to year, determinable on the execution of the lease contracted for, that being the primary contract. But if no rent is paid, still before the execution of a lease the relation of landlord and tenant exists, the parties having entered with a view to a lease and not a purchase" (Hamerton r. Stcal).

Although it may be that where an actual demise is male generally at a yearly rent, and nothing is said as to the duration of the term, a tenancy from year to year woutl be implied; yet where, from the terms of an agreement for a lease, coupled with surrounding eireumstances, it is ambiguous what term is intended to be eonreyed, such agreement is roid for uncertainty. And so it was held by the Exchequer Chamber in Fitzmanice v. Bayley. By increasing the amount of rent payable by a temant from year to year, a nex tenancy is not necessarily created; much must depend upon what was said at the time the additional sum was agreed to be paid (Doe dem. Honk v. Geckie). The Court of Common Pleas considered that the umpire was right in refusing to admit evidence to show that by the custom of the trade of brickmaking, brick land is always let for a longer period than from year to year (In re Stroud).

The argument in Tress v. Sarage turned upon the effect of 7 \& 8 Vict. c. 76 . There the plaintiff and defendant, after stat. 8 \& 9 T'ict. e. 106 came into operation, executed a written instrument not under seal, on December 17th, 1850, by which 'Tress agreed to let, and Savage to hire land for a term exceeding three years, at a rent payable monthly, from Jecember 25th of that year. Savage entered, and it was afterwards orally agrcerl that the rent should be paid quarterly. 'The Court of Quncen's Lench held that stat. 8 \& 9 Vict. c. 106 , s. 3, though rendering 
the lease void, as not being by deed, still made it void only as a lease, and did not prevent it from indicating the terms on which Savage held as tenant from year to year ; and that, consequently, Savage's tenancy might be determined, during the term, by a half-year's notice, but the end of the term expired withont notice. Coleridge J. said, "By sec. 4 of $7 \& 8$ Vict. c. 76 , no lease in writing of any freehold land 'shall be valid as a lease,' 'unless the same shall be made by deed; but any agreement in writing to let' 'any such land shall be valid and take effect as an agreement to execute a lease;' 'and the person who shall be in possession of the land in pursuance of any agreement to let, may, from payment of rent or other circumstances, be construed to be a tenant from year to year.'

"Under this section Doe dem. Davenish v. Moffat was decided. There the defendant took possession of land under the terms of a written agreement not under seul, which, before stat. 7 \& 8 rict. c. 76 , came into operation, would have operated as a demise for three years; and it was held that he became tenant from year to year, subject to the terms of the agreement; and that the consequence of this was, that at the end of the three years the tenancy expired without any notice to quit. That statute is repealed by stat. 8 \& 9 Vict. c. 106 ; sec. 3 of which substitntes, for sec. 4 of the repealed act, an enactment somewhat differently expressed, and makes a lease required by law to be in writing, of tenements or hereditaments, "void at law, unless made by deed."

The right to enter for condition broken is not included in the 8 \& 9 Vict. c. 106 , s. 6 , which enacts that a right of entry may be disposed of by deed (IIunt v. Bishop). And per Cressuell J.: "A lease in writing, not by deed, void under stat. 8 \& 9 Vict. c. 106, does not require a stamp" (Mott v. Turnage).

By sec. 3 of statute $8 \& 9$ Tict. c. 106 , which repealed the statute $7 \& 8$ Vict. c. 76 , it is enacted "That a lease required by law to be in writing of any tenements or hereditaments made after the 1st day of October, 1845, shall be void at law unless made by deed." The effect of this statute is, that an instrument which purports to let premises for a period of more than thee years, and which therefore is void as a lease in not being sealed, is still good as an agreement, and the tenant who enters under it becomes tenant from year to year according to its terms, so far as those terms are applicable to a tenancy from jear to year (Heard $\mathrm{v}$. Campline.

The question in Stratton v. Pettit was whether the instrument set forth in the declaration was a lease or an agreement. Aud per Jervis C.J.: "The rule to be collected from all the cases is, that the intention of the parties, as dectared by the uorls of the instiument, must govern the con- 
struction (per Lord Ellenborough C.J. in Poole v. Bentley). And the Court will, if possible, put such a construction upon it as will effectuate the intention of the parties rather than defeat it. 'The question then, is, what was the intention of the parties when this instrument was made? Doubtless they intended to make an instrument which should have some operation; but did they intend to make a lease, or an agreement? If the former they have not done what they intended, because the lease is roid by the statute. The intention of the parties must be collected from the instrument itself. The rule is well explained by Laurence J. in Morgan v. Bissell: "Where there is an instrument by which it appears that one party is to give possession and the other to take it, that is a lease, unless it can be collected from the instrument itself that it is an agreement only for a lease to be afterwards made.' But it is unnecessary to refer to the cases which are all collected by Sir Robert Comyn in his nseful book upon Landlord and Tenant. It is adnitted that before the statute this instrument would have been held to be a lease; and if the true rule be that the intention of the parties as declared by the words of the instrument must govern the construction, it is clear that the parties intended this instrument to operate as a lease. It is roid as a lease, and the defendant is therefore entitled to our judgment" (ib.).

In Parker v. Tasuell, by an agreement in writing, a landlord agreed to let a tenant certain lands for ten years at a fixed rent. The tenant, howerer, was to perform eertain acts as "leading," or carrying materials for building and draining, which were to be done by the landlord; and there were stipulations that new hedges were to be made and planted by the landlord, and that "gates, buildings, \&c.," were to be left in repair; also that the landlord reserved to himself all customary rights and reservations, such as liberty to cut and plant timber, search for and work " mines and minerals," \&c. The agreement was signed by both parties ; and Stucrt V.C. held that, inasmuch as the subject-matters, the term and the rent, were certain, the uncertainties as to the subsidiary part of the lease, even in the use of the expression "\&c.," were not sufficient to prevent the tenant from having specific performance of the agreement, and that the 3rd section of the 8 \& : Ficl. e. 106, which enacts that every lease required by law to be in writing shall be void at law unless made by deed, did not exclude the jurisdiction of the Court in this case. It was held by Lord C'lirlmsford Ch. on appeal, that such agrcement, though void at law, under $8 \& 9$ Vict. c. 106, as a lease, was valid as an agreement, and specific performance of it was decreed, and also that the insertion of "Sc.," on some of the terms of the agreement did not produce such uncertainty as to render the agreement incapable 
of specific performance, where the property, the rent, and the other material points on the lease were sufficiently described and ascertained.

A parol agreement for a lease, evidenced by a momorandum stating terms and rent, under which the tenant took possession, was decreed, on appeal from Stuart V.C. to the Lord Chief Justices, to be specifically performed, although it was uncertain whether the tenant had not committed a breach of some of the proposed covenants; but in case the defendant should bring an action for such breaches, the plaintiff in equity was not to be at liberty to plead that the deed was not executed until after it purported to be (Pain v. Coombs). It was decided by Lord Lyndhurst Ch., confirming the decree of huight-Bruce V.C., that an agreement for a lease may be assigned; and where a landlord enters into an agreement to lease a farm to $\mathrm{B}$., who assigns the agreement to C., the landlord is entitled to have the personal liability of $B$. for the performance of the covenants of the lease to be granted to C., in pursuance of the covenant (Doucll v. Dew). And where an agreement was entered into by a landlord with a tenant in possession of a farm, under a lease, to reneve the lease upon its expiration, which us executed by the landlord only, and not by the tenant, such agreement was not mudum pactum, and the tenant, who continued some time in possession of the farm under it, after the expiration of the lease, might enforce it against the landlord (ib.). Knight-Bruce V.C., in the conrse of his observations in the same case on evidence adduced in equity as to the annual value of a farm, and the repairs of farm buildings, and the cultivatiou of a farm according to covenants in a lease, and the waiver of forfeiture of a lease by a landlord, said, "It has been a very old principle of law to disregard umimportant matters of u'aste; for if according to a liberal interpretation of strict covenants, a tenant was to be ejected for a foul turnip-field, an unhinged gate, a broken shutter, or small matters of that description, which frequently occur on the best-managed farms, there wonld scarcely be a lease in existence throughout the kingdom. It is necessary that in these cases juries and judges should make a reasonable allowance, and not put too strict and precise an interpretation on such covenants."

According to Doe dem. Thomson v. Amey, where a party is let into possession, and pays rent under an agreement for a future lease for years, which is to contain a covenant against taking successive crops of corn, and a conlition of re-entry for breach of covenants, it was held that he thereby became a yearly tenant, subject to the above terms and condition. Patteson J. said, "In IIam v. Lovejoy, though the facts differed from those of the present case, yet in principle the ruling of $A b b$ ot C.J. is in favour of the plaintiff. It is said that a covenant respecting the rotation of crops canuot be engrafted on a jeariy tenancy; but I see no 
reason why it should not. The tenant in possession under such circumstances is bound to cultivate the lind as if he were going to continue in possession as long as the lease itself would have lasted. It is argued that the tenancy arises by operation ol law upon the payment of rent, and that the law implies no particular mode of cropping, nor any condition of re-entry. But the terms upon which the tenant holds are in truth a conclusion of law from the facts of the case, and the terms of the articles of agreement; and $I$ see no reason why a condition of re-entry should not be as applicable to this tenancy as the other terms expressed in the articles" (ib.).

In the case of a mere agreement for a lease, it is no breach that possession is not given: and it was so decided in Drury r. Macnamara. By an agreement in writing the plaintiff agreed to take of the defendant a farm at a yearly rent, the plaintiff paying all rates, taxes, \&c., "the tenancy to commence from the 29th of September next, for a term of eight years, subject to a lease " to be drawn up by defendant's solicitor. 'The plaintiff bronght an action for not giving possession before or on the 29 th of September, and averred that he had laid out a large sum of money on implements to cultivate the farm ; but it was held no breach of the agreement that the defendant would not give him possession on that day, or at any time subsequently. The instrument in writing here did not operate as a lease, or so as to give an interest in land.

An expired lease, which was produced in an action brought for not farming land in compliance with its covenants, was held by the Court of Queen's Bench not to be "a schedule, inventory, or catalogue," containing the conditions or regulations for managing a farm within 55 Geo. III. c. 184, Sched. pt. 1 (Strutt v. Robinson). In Cattle v. Gamble, the agreement was for the purcluase of the herbage of a close for five months at the price of $£ 45, £ 10$ to be paid down, and a joint promissory note to be given for the residue, payable within five months; and on a trial of assumpsit for use and occupation of the land and eatage of the grass, brought to recover the residue of the purchase-money, it was held that the contract was sufficiently stamped with a $£ 1$ stamp, as it fell under the head in the schedule in 55 Geo. III. c. 156 of "comeyance, whether grant, disposition, lease, \&c., or of any other kind or description on the sale of any lands or tenements where the purchase or consideration shall not amount to £50."

By 17 \& 18 Tirt. c. 83 , s. 23 , the ad-ralorem stamp duty on a lease is to be rempulated by the considcrations expressed on the fuce of the deed (Duck v. Bradyll). In Blouml v. Pearman the lease contained a demise of two separate farms, with two labendums diflering from each other in duration ; a reservation of two distinct rents, one in respect of each 
farm and separate corenants, some applying to one farm and some to the other. The lessec entered on the whole at the same time, and it was held that one ad-valorem stamp, calculated on the united amounts of the two rents, was sufficient. So an agreement containing a demise of land at a certain rent, and of other land at the same as was then paid for it by a tenant, but not describing the amount, is well stamped by one ad-valorem stamp, calculated upon the whole amount of rent to be paid for all the lands, the tenant's rent being proved by witnesses (Parry $\mathrm{v}$. Deere).

Where A. entered into a written agreement with $\mathrm{B}$., for the hire of a piece of land for the purpose of making bricks, and C. afterwards made an offer in writing to let another piece of land to A., upon the terms contained in the agreement between $\mathrm{A}$. and B., which offer A., at a subsequent period, verbally accepted; in an action by $\mathrm{C}$. for a brcach of some of the terms of this contract, it was held by the Court of Queen's Bench that the uritten offer by C. was admissible in cvidence without being stamped (Drant v. Brown). The alteration of an agreement stipulating to give up the holding and occupation of a farm, by the addition of the words "house and premises," after that agreement has been completed, is not such an alteration as will render the affixing of a new stamp necessary, house and premises being included within the meaning of the term "farm" (Doe dem. Waters v. Houyhton).

The "subject matter" of an ayreement to take land, within the meaning of the Stump Act, is the right of occupation, measured by the total amount of rent to be paid for the whole period of such occupation. An agreement in the following form-“ I, J. T., do hereby agree with W. M. to retake of him two acres of land, \&c., from the 10th of October, 1840, at which time my tenancy thereor expires, until the 25 th of March, 1841, for the sum of $£ 10$," with a promise by J. 'T. to allow W. M. to plant fruit trees, and to deliver up possession at the end of the time; and signed by J. T., but not by W. M. - was held by the Conrt of Queen's Bench in Doe dem. Marlow v. Wiggins to be neither a lease nor an agreement, in which the matter was of the value of $£ 20$, and therefore to require no stamp.

And per Patteson J.: "If this document is a lease no doubt it requires a stamp. But it cannot be so, because there is no person demising, no lessor. I do not say that it is not binding on the party who executed it, but simply that it is no lease. Richardson v. Gifford does not determine that. The Court in that case gave no opinion that the instrument was a lease, and merely determined that the covenantor was bound by it as an agreement. Cooch v. Goodmun is a very peculiar case, and the Court there also gave no opinion whether the instrument operated 
as a lease, or passed any interest, and it eventually went off on another point. There are, then, no authorities to show that an instrument execnted by the teuant only can be a demise. It is therefore an agreement. And the remaining question is, whether it requires a stamp, as being respecting a snbject-matter above the valne of $£ 20$. I think it does not; the subject-matter, I think, is measured by the whole amount of rent to be paid, not by the total value of the land in respect of which it is to be paid ; and here the right of occupation is only for half-a-year, and the rent \&10. Reliance was placed in the argument on the exception exempting leases at rack rent, under $£ 5$ per annum; but that, I think, is to be explained by considering the subject-matter as the whole rent to be paid, which for a term of years might well exceed $£ 20$, although under $£ 5$ per annum. I think, therefore, that the decision of Williams J. in Mav-low v. Thompson was right."

The following document-

"August 2nd, according to Mr. Hacketf's request, the land at Blackfordby, under Mr. Elstead, I will be bound for till next Ladyday.

Signed, "J. GLOVER."

which was tendered in evidence in an action by Glover against Hackett for money paid to Mr. Elstead, was held on the authority of Ramsbottom r. Morfley to be a guarantee, and to require an agreement stamp (Glover v. Hackelt). But queve whether under $19 \& 20$ Vict. c. 97 (the Mercantile Law Amendment Aet) the document by itself was one which would satisfy the Statute of Frauds (ib.).

The doctrine of estoppel between landlord and tmant is founded upon the principle that a lessee having aceepted a lease may not plead to the action of his lessor nit habuit in tenementis. But the lessee may plead to such an action, that the lessor had an interest at the date of the lease, but that such interest had determined before the alleged cause of action arose. Therefore if a termor affect to grant a lease for a term exceeding his own term in duration, and to reserve an annual rent, that would operate as an assignment of his term, and there would be no estoppel between him and the person to whom he made such assignment; and accordingly, it would be doubtful whether the assignor would have any remedies for recovering the rent (Lemyford r. Selmes). The stat. 4 Geo. IV. c. 28 , does not give power to distrain for such a rent (ib.).

By an agreement in uriting $A$. agreed to demise to B. certain premises, which were then in lease to $C$., and $B$. undertook to procure a surrender of the rxisting lease from $\mathrm{C}$., and to accept the new lease. C. haring afterwards refused to surrender, A. filed a bill against B. for specific performance with a modification; and it was lield on demurrer by Wood V.C., 
who distinguished the case from Nethorpe v. Holgate, which was cited in support of the bill, that the bill eould not be sustained (Beeston $\nabla$. Stutely). And where an agreement recited that the defendant had, as he was advised, legally put an end to a lease of a furm by virtue of a power in it to that effect, in case of the tenant's bankruptcy, and that the lease to the plaintiff (who was admitted into possession and paid $£ 250$, or half of the bonus agreed on for the lease so to be granted) should commence on a day certain, if the defendant conld then legally make it, or as soon as he was in a situation to do so ; and the defendant after the plaintiff had oceupied the farm two years was unable to grant the lease, owing to his former tenant's commission of bankruptcy being superseded, it was held that the granting of the lease being the consideration for the bonus, the plaintiff conld recover back his $£ 250$, as money paid on a consideration that had failed, althongh he had had such beneficial occupation (Wright v. Colls).

An action by $A$. against $B$, and a cross action by B. against A., were referred by separate order's of reference made under the 3rd section of the Common Law Procedure Act, 1854. The latter action contained counts for not using a farm in a tenant-like manner, and for goods sold; and the defendant pleaded to the first count a denial of the tenancy upon the terms alleged, and performance of the agreement; and to the last count -never indebted, payment and set-off. The arbitrator made his award on one piece of paper, awarding for the plaintiff in the first action, and that in the second action there was nothing due or payable from the defendant to the plaintiff, and he ordered that the costs of the award should be paid by B.; but the Conrt of Exehequer remitted the award to him that he might make two awards, and find the issues specifically (Hellaby v. Brown, Broun v. Hellaby). A usage for arbitrators appointed to determine, as between outgoing and incoming tenants of a farm, the vatue of the awaygoing crop, and the deductions for want of repairs of the farm buildings and fences, to make their award, on inspection of their crops and premises, without notice to the parties and without evidence, may be good; but no usage can justify the arbitrators in hearing one party and his witnesses only, in the absence of and without notice to the other party (Oswald $\mathbf{v}$. Earl Grey). Behren v. Bremer, which confirmed Galloway v. Keyworth settled that there is no impropriety in arbitrators employing an attorney to prepare their award, and that there is not any necessary impropriety in their employing the plaintiff's attorney for that purpose.

An authority to an ayent, to execute an indenture under seal, must also be under seal. A deed inter partes can only be available between the parties thereto ; therefore where in eovenant upon an indenture of lease it appeared that the landlord by writing, not under seal, anthorised his attorney to execute the lease for and on his (landlord's) behalf, and the 
attorney sealed and sigued the lease in his own name, the landlord cannot maintain covenant against the tenant npon the indenture, althongh the eorenants were expressly stated to have been made by the tenant to and with the landlord (Berkeley v. Hardy). If' a man describe himself in the beginning of an agreement to grant a lease, as making it on behalf of another, but in a subseqnent part say that he will execute the lease, Best C.J. held that he is personally liable (Norton v. Herron). An ayreement for a lectse made with an agent, who acts under a power of attorney, and a lease executed by such agent in pursuance of the agreement, effectually binds the principal (Hamilton v. Clanricarde (Earl); and see Comjoot v. Fouke, and Wilson v. Fuller.) According to Doe dem. Rhoules v. liobinson, " notice to quit given by the agent of an agent is not sufficient withont eridence of an authority to give notice, or of a recognition by the principal. Doe dem. Matm r. Walters is an authority that an agent to receive rents has no implied anthority to give notice to quit, and where notice to quit is given by an agent, the authority of such agent must be complete a half year before the expiration of the notice, or at least before the day of the demise laid in a declaration in ejectment brought in respect of such notice.

If contracting parties agree on the terms of a lease, of which there is sufficient eridence, but contemplate in addition a more formal document, it becomes a question of intention merely whether they intend it as a memorial of the terms already agreed on, or as the instrument by which alone they meant to be bound. And where, as in Ridyway v. Wharton, R., the sublessee of the property, applied to W., the owner, for a lease to himself, when the original lease expired, and W. referred him to his agent, C., and certain interviews and correspondence between them resulted in the specification of eertain terms, which were sent as instructions by C. to W.'s sulicitor, to prepare a lease, and both $\mathrm{W}$. (the defendant) and C. denied that the one had given, or the other had received authority to conclude a binding agreement, though some evidence on the part of the plaintiff went to show the terms for the intended lease had been finally settled, so as to constitute an agreement, it was held by Lord Cranu'orth Ch., Lord Brougham, and Lord Wensleydale, \&c., Lord St. Leonards diss. (affirming the decree of the Jord Chancellor in the Court below, though on different grounds), that there was no concluded binding agreement. And see this case (in which Tuumy v. Croutluer was observed on) for general observations on the conduct of contracting parties, and the evidence necessary to enable the Court safely to decree specific performance of an agreement. And per lord St. Leonards: "As to the case of T'unney v. Crowther, it is not at all material whether Lord 'Thurlow was right in construing the words to amount to an acceptance of the agreement. It is an anthority for this 


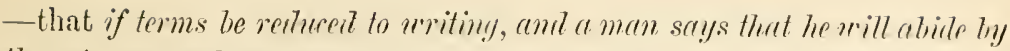
those terms, and witl sign lipe ayremnent, allhough he thos not sigm, he is bouml by that argrement. There are besides several eases (Wrstern v. Roussell, Thomes v. Dering, and Gibbins v. The Boart of the Metropotitan Asylum) in which a single note written by one party to a solicitor to draw an agreement, independently of the agreement, has been held perfectly valid" (ib.).

In Collen v. Wright, the defendant signed the following written agreement :

"Terms for letting a farm on Sohem Fen, containing, \&e. Term $12 \frac{1}{2}$ years from Lady-day last; rent $£ 350$, to be paid quarterly ; landlord to pay the tithe rent-charge and drainage taxes; landlord to put buildings, gates, and posts in repair ; and tenant afterwards to keep them in repair, being allowed rough timber; tenant to pay for the muck and straw upon the farm by valuation. All the other conditions to be the same as in the lease under which J. H. B. now holds the said farm. Landlord to allow tenant $£ 25$ of the first halfyear's rent. We agree to the above conditions, this 21 st day of April, 1853.

$$
\begin{aligned}
& \text { "Robert Wright, agent to W. D. G., Esq. } \\
& \text { "John Collen." }
\end{aligned}
$$

It was further agreed between Collen and Wright that an agreement, stating in detail the terms referred to in the above agreement, shonld be prepared withont delay, and be signed by the parties; and on 22 nd April, 1853, Collen, on the faith of the signature of the said agreement by Wright, as abore set forth, took possession of the farm. Both Collen and Wright believed that the latter had authority from Gardner, the owner, to let the farm. On 1st June, 1853, a valnation of the straw and muck was made in accordanee with the agreement, and the amount was paid to Gardner's credit at his bankers', and Collen expended a considerable sum on the eultivation and improvement of the farm before the September of that year. About the middle of November he received notice that Gardner refused to sign the lease, on the ground that Wright (against whose executors the action was brought) was not anthorised to let the farm for $12 \frac{1}{2}$ years, or on the terms set forth in the agreement. Collen then filed a bill against Gardner for specific performance, and after he had put in his answer, denying Wright's anthority, Collen gave notice to Wright of the suit and ground of defence, and that he would proceed with such suit at his expense unless he gave him notice not further to proceed; and that he would bring an action against him for damages, in the event either of the bill being dismissed 
on the ground of defence set up, or of his requiring him not further to proceed. Wright answered repudiating his liability to Collen, and the bill was dismissed on the ground of defence set up. On a case stating the above circumstances, with liberty to the Court to draw inferences of fact, the Court of Qneen's Bench held that Collen was entitled to maintain an action against Wright's executors, as for a breach of promise, that Wright had the authority, and that he might recorer in such action damages for the expenses of the Chancery proceedings, it not appearing that he had instituted them incautiously, and they being therefore damages naturally resulting from the misrepresentation made by Wright. This ruling was confirmed by the Exchequer Chamber (Cockbum C.J. diss.).

In Ley v. Peter, in which the action was brought to recorer possession of an undirided third of a piece of land called Barn Meadow, the defendant's grandfather had been owner of two undirided thirds of such meadow, and held the other third under a lease, which expired in 1818. The father of defendant and defendant succeeded in their turns; and at the time the action was brought, the defendant ras orner of the two-thirds, and occuvied the whole, no rent having been paid since 1818. The only evidence relied upon for the plaintiff was a letter of the land-agent who managed the defendant's property, written within twenty years of the action being brought, in which he said the defendant "would no doubt accept a lease of Ley's one-third at a fair rack rent." It was held, after a verdict for the plaintiff in ejectment for the one-third, by the Court of Exchequer, first, that this was not an acknouledgment of title within 3 \& 4 Jill. IV., c. 4, s. 14, as not being signed by the person in possession, but only by an agent; and secondly (Jartin B. diss.), that the land-agent had no authority by virtue of his employment as such to write such a letter ; and thirdly, that the letter was no eridence of a tenancy at the will of the plaintiff.

Where a tenant from year to year, having no anthority from his landlord to let in a new tenant, falsely represented to the plaintiff that he had, and thereby induced him to pay $£ 100$ for allowing him to enter into possession, and also to take the stock at a valuation; but the landlord refusing to accept him as tenant, he had to leare after a year's occupation, and it was left doubtful on the evidence, whether, on the whole, the plaintiff had become a loser or a gainer ; and the defendant had paid the first half of the year's rent to the landlord; the jury, in an action for the false representation, were directed by Wightman J. that they were at liberty, finding for the plaintiff, to give a sum less than the $£ 100$, or eren nominal damages; and in a cross action by the defendant against the plaintiff in that action for half-a-year's rent, they 
were directed by his lordship to find for the plaintiff on a count for money paid (Craclinell v. Dary).

The question as to when a lessor can be said to demy an entrance on to his farm to the new tenant was discussed in Hanlies v. Orton. The plaintiff in the autumn of 1832 entered upon 98 acres of the arable land, and sowed them with wheat, and on April 6th, 1833, he went to the farm, which still continued in the defendant's occupation, and stated that he was come to take possession according to the lense. Some further conversation followed, and according to the plaintiff, he at that time demanded possession of the premises not yet given up to him, and the defendant refused it. The plaintiff never obtained possession. He ceased to ocenpy the 98 acres, and the defendant reaped the wheat. Lord Abinger C.B. considered that the plaintiff had not clearly shown any actual demand and refusal of possession, and that there onght to be a nonsuit. The plaintiff's counsel contended that there was a constructive eviction, as the plaintiff must be taken (and was in effect admitted by the pleadings) to have entered on the whole of the premises when he entered on the 98 acres, and the defendant on April 6th kept him out of the farm. His lordship then left it to the jury whether or not the plaintiff had gone to the farm on April 6th, with a bona ficte intent to take possession, and whether the defendant had seriuusly expressed and shown by his conduct an intention that he shonld not have it. The jury found for the defendant, and the Court refused a new trial.

Doe dem. Marquis of Hertford v. Hunt was the case of a tenant refusing to show his farm. He had required that his rent might be ' reduced from $£ 520$ to $£ 400$; the landlord refused, and he gave a notice to quit at Michaelmas, 1834. It was afterwards agreed that he should continue to hold on for a year at a reduced rent, the notice continuing in force until Michaehmas, 1835. Before that time arrived he made an offer of $£ 420$, and received an answer from the plaintifr's agent stating that "The Marquis of Hertford has directed me to inform you, that he could only consent to accept your offer of $£ 120$ for the farm, for the year from Michaelmas next to Michaelmas, 1836 , subject to the existing covenants, provided I could not find a tenant for it at the rent it appeared to me to be worth by the 1 st of August; and subject as well to the express understanding that the notice yon had given to quit your farm at Michaelmas next should be admitted between you not to be withdrawn, but to be carried over to Michaelmas, 1836 . The Marquis also directed me to advertise your farm to be let, in the Ipswich paper, and I shall sond the adrertisement for insertion in the next paper." 
The adrertisement that the farm was to be let at next Michaelmas accordingly appeared. On the 9 th of July, 1835, the defendant signed the following memorandum: "MIr. Hunt has explained that his offer for the farm was $£ 400$ only, and sulject to this correction he assents to the terms proposed in MIr. W.'s (the agent's) letter.-J. Hunt." A Mr. Catlin made an appliention for the farm, but the defendant refused to allow him to see it, and he made no offer ; and in consequence of the defendant's refusal to leare at Michaelmas, 1835 , this action of ejectment was brought. It was contended for the defendant, that under this agreement the tenancy continued till Michaelmas, 1836, but Gazelee J. refused to nonsuit the plaintiff. A rule to enter a nonsuit was discharged, and the Court held that it was a necessarily implied condition of the agreement that the tenant should allow persons applying for the farm to go over it to inspect it, and that the tenant having before the 1st of August refused to perform that condition, the contract was put an end to.

The word "demise" does not carry with it amy implied undertaking that the lanu shall be reasonably fit for the murpose for which it is taken; the law merely annexes to it a condition that the party demising has a good title to the premises, and that the lessee shall not be evicted during the term (Sulton v. Temple). Here the defendant took the eatage of a field in the parish of Skirbeck from the plaintiff. It consisted of 24 acres of eddish, and the agreement was signed on September $8,18 \pm 2$, for $£ 40$, half to be paid at Boston Mart, on the 12 th of December, and the rest on the 6 th of April. The defendant stocked the eddish with 15 beasts, four of which died on Oetoher 2 nd, from the poisonous effects of old refuse paint, which lay open in a manure heap in the field. The plaintiff was informed of this, but took no steps to remore the manure, and the defendant fenced it off, and turned in more beasts, four of whom died from the poison above mentioned in a fortnight. The defendant deelined any longer to stock the eddish, and told the plaintiff she might do what she pleased with it, but she did not resume possession till after the 6th of April. There was no evidence to show that the plaintiff was aware of the state of the eddish when she let it. Hence it was contended that the defendant conld not be made liable, inasmuch as the eddish being wholly unfit for the purpose of which it was taken, viz., the food of beasts, the defendant could not be said to have had any beneficial use or enjoyment of it.

I.ord Abinger C.B. left it to the jury, who found that the beasts were poisoned by the paint, and a verdict under his lordship's direction was entered for the plaintiff for $£ 12$, that bcing a ratealsle proportion of the rent for the time that the defendant actually occupied, leave being 
reserved to the defendant to move to enter a verdict for him, and to the plaintiff to move to increase the damages to $\mathfrak{2} 26$. Cross rules were obtained accordingly. The rule for a nonsuit was discharged, and that to increase the damages made absolute. Lord Abinger C.P. said : "I take the rnle of law to be, that if a person contract for the use and oceupation of land for a specified time, and at a specified rent, he is bound by that bargain, even though he took it for a particular purpose, and that purpose be not attained."

In Hart v. Windsor, which virtually overthrew Smith v. Marrable, Parke B. said : "It appears to us to be clear on the old authorities, that theie is no implied warranty on a Tease of a house or of land, that it is, or shall be, reasonably fit for habitation or cultivation. The implied contract relates only to the estate, not to the condition of the property." So in Keats v. Earl of Catogan, it was held that there is no implied duty in the onener of a house, which is in a minous and unsafe condition, to inform a proposed tenant that it is unfit for habitation, and no action will lie against him for an omission to do so, in the absence of express warranty or active deceit.

Stat. $32 \mathrm{Hen}$. VIII. c. 34, applies to leases by deed only; and where a lease is not under seal, the assignee of the reversion cannot maintain assumpsit against the lessee for breach of his contract with the assignor to repair (Standen v. Cliristmas). And there is no implied contract to use demised premises in a tenant-like manner, where the tenant has expressly contracted to repair (ib.). Where a lease for a term certain was granted by writing, not under seal, which contained an undertaking on behalf of the lessor and his assigns for quiet enjoyment, his assignees may maintain assumpsit for use and occupation; for the lessor haring granted for himself and his assigns the permission of any person who might become assignee of the reversion during the lease was virtually included, so that the occupation became in point of law permissive on the part of the assignee as soon as his interest accrued (ib.). And per Curiam: "The occupation being in point of law by the permission of the plaintiff, the action is maintainable in its present form, by virtne of the statute 11 Geo. II. c. 19, s. 14. In most of the cases referred to on the argument, the tenancy was from year to year. It is obvious that the assignee of the reversion has then the power of determining the tenancy by notice; and if he refrains from doing so the occupation may well be said to be by his permission. In Lumley r. Fodgson the tenancy was from year to year, and a notice to quit had actually been given, but not persevered in. The action was for a year and a half's rent; the last year's rent all accrued after the expiration of the notice to quit; and the occupation during that time was clearly by the per- 
mission of the plaintiff; the first half-year not so; and the same qnestion might late arisen as in the present ease, but it was not made. In Jortimer v. Presdy the Court felt the same difficulty as arises here; but the point was not expressly determined. 'The ease of Buckuorth v. Simpson was also mpon a tenancy from year to year ; so was the ease of Dolby v. Mes, which, however, turned nuon the defendant being estopped by his own acts of recognition. No case appears yet to have been determined, where an alsolute lease in writing, not nnder seal, for a fixed term of rears having been granted, and the landlord having assigned his reversion, it has been held that the assignee can maintain an action of assumpsit for use and occupation. We are, however, of opinion for the reasons already given, that he can " (ib.).

To an action on a covenant in a lease to pay the rent reserved quarterly, it is no ansuer that the defendant was on the demised premises on the quarler-day, ready to pay the lessor, but that the latter did not eome to receire it (Haldane v. Johnson). And per Nartin B. : "The covenant is a corenant to pay a sum of money to the lessor upon a particular day, no place being mentioned for payment, either expressly or by implieation. In such a case it is clearly laid down, in both Rowe v. Young, in the House of Iurils, and the judgment of the Judges there, and Poole v. Tumbridge, that it is the duty of the covenantor to seek out on the appointed day the person to be paid, and tender the money; and in Poote v. Tumbridge, it was stated by Purke B., as the conclusion from the authorities, that 'Nothing can discharge a covenant to pay on a certain day, but actual tender or payment on that day, although if the party afterwards choose to receive the money,' it is a payment to be 'plearled in the way of accord and satisfaction.' And this is in exact conformity with the rule laid down in Sheppard's 'Touchstone,' p. 378, that where an obligor is to pay a sum of money or do a like thing to the obligee on a day certain, bnt no place is set down where it shall be done, it must be done to the person of the obligee, wheresoever he may be, if he be infra quatuor maria" (ib.).

Where A., vie tenant, covenanted with the landlord, B., to lieep certain memises in repair, but allowed them to become dilapidated, and the cost of repair would amount to $£ 40$, and B. had covenanted with C. (the ground-landlord) duly to pay rent, which he had fuiled to pay, so that B.'s reversion might have been forfeited and of no value, the Court of Exchequer held, in an action by 13 . against $A$., that the damages should be what it would cost to put the premines in repair, not what might be the value of B.'s reversionary interest an the premises (Daties v. Underwoorl). And where a lease and under-lease each contained a covenant, to repair and kerp in repair, differing however in substance and in terms, 
the Court of Exchequer held that the measure of damages in an action by the lessee against the under-lessee on his eovenant, was the sum it would cost to put the premises into repail ; and that the plaintiff was not entitled to recover as special damage in such an action the damages and costs recovered in a former action, brought against him by his lessor, for breach of the eorenant in the lease (Pmley r. Watts). But quere would the plaintiff have been entitled to reeover them if the covenants had been identical (ib.). And see Neule v. Wyllie.

A covenant to yield up in repair at the end of a term, vuns with the land, and binds an assignee, though not named (Martyn Adx. v. Clue). Defendant, who was the assignec of the lessee, pleaded, among other pleas, as to suffering the premises to be ruinous and out of repair, and so leaving them, that the lessor did not at any time from the assignment till the expiration of the term provide on the premises any rough timber whatever. It was held by the Court of Common Pleas on demurrer to this plea, that it was sufficient on this record to aver that the lessor was always ready and willing to furnish timber, withont stating that he actually did furnish; and that the plea was also bad, for that the condition precedent to the defendant's obligation to repair was sufficiently performed, if he was ready and willing to supply timber when required (ib.). In a covenant by a lessee, not naming assigns, to repair and yield up in repair all buildings and erections, an assignee is liable in respect of the non-repair of buildings erected during the term (Minshull v. Oakes). Willes J. held in Woolcock v. Dew, that by a covenant in a lease of a farm and cottages to keep, support, and maintain the premises in good repair, the lessee or assignee is bonond to keep the cottuges in situ, and to repair them if ruinous, or at least to replace them as nearly as might be in the position in which they were when demised, and is held liable, having pulled them down, for their value as they stood, without reference to the result of their removal as regarded the general improvement of the farm.

The rule as to keeping premises in repair was specially laid down in Payne v. Haine. The defendant on becoming tenant to the plaintiff of a farm and ontbuildings agreed "to keep the same, and at the expiration of the tenancy to deliver up the same, in good repair, order, and condition." At the trial the plaintiff proved bad repair of the thatch on the outbuildings, as also of the gates, while the defendant songht to prove that the gates had fallen to pieces from age alone, and the thatch was better when he left than when he entered the farm. Platt B. told the jury to consider the state of the premises when the defendant entered, adding that it was enough if the defendant left them in as good plight as he found them, and that he was not bound on quitting the 
firm to replace the matters demised hy learing new instead of old, or oak instead of apple-tree posts. A rerdict was therempon found for the defendant, and the Court (Plalt B. assen.) made the rule absolute for a new trial, on the ground of misdirection. Parke B. said: "If at the time of the demise the premises were old and in bad repair, the lessee was bound to put them in good repair, as old premises; for he cannot 'keep' them in good repair without putting them into it. He might have contracted to keep them in the state in which they were at the time of the demise. 'This is a contract to keep the premises in good repair as old premises; but that eannot justify the keeping them in bad repair, because they happened to be in that state when the defendant took them. The eases all show that the age and class of the premises, with their general condition as to repair, may be estimated in order to measure the extent of the repairs to be done." Rolfe B. added, "The term 'good repair' is to be construed with reference to the subjectmatter, and must differ, as that may be a palace or a cottage; but to 'keep in good repair' presupposes the putting into it, and means that during the whole term the premises shall be in good repair."

In Baylis v. Le Gros the lease contained a corenant by the lessee to repair and keep in repair the premises; and further, that it should be taniful for the lessor once, or oftener in every year to enter the premises and examine their condition, and if necessary give the lessee notice in writing to repair, with a proviso that if the lessee should not perform the covenants, it should be lawful for the lessor to re-enter. It was held that these were independent covenants, and that the lessor had a right to re-enter, as for a forfeiture, upon finding the premises out of repair, thongh he had not given notice to the lessee to put them in repair. The lessor, on examining the premises, found the defendant, who was not the original lessee, in possession, and entering into an agreement with him continned him as tenant. It was held that this was a sufficient re-entry to onst the original lessee from further enjoyment.

It was ruled by Palteson (..J., in Leach v. Thomas, that a tenant from ypar to year is not bound to do substential repairs, but only to kepp the premises uind and uaterlight. The landlord of premises let from year to year is not bound to keep them in repair in the absenee of an express contract for that purpose; nor is he liable to damage arising to his tenant from the want of repair (Gott v. Genly). Where a tenant prid a sum of money to his landlord for breaches of eovenant to repair, committed during the ocenpation of his assignee and his assignee's snccessor, he can recover damages against his assignee for the money paid for the non-repair during the assignee's occupation, withont showing an apportionment (Smith v. Prat). The measure of damages for a breach 
of contract to repair during the existence of the term, is the difference between the price for which the reversion would sell if the covenant were unbroken, from that for which it would sell if the covenant were broken (ib.). And per Parke B. : "The measure of damages as laid down in some of the eases, and by my brother Colcrilge in Doe v. Rowlands, is too low. The true measure is to be ascertained by eonsidering what would be the loss to the reversion, if it were sold at the time of the commencement of the action" (ib.). And in Viviun v. Champion, Lord Holt C.J. says: "If the premises were out of repair in the ancestor's time, yet if the lessee suffers them to continue out of repair in the time of the heir, that is a damage to the heir, and he shall have an action; and in these actions there ought to be very good damages; and it has been always pratised so before me, and everybody else that I ever knew. We always inquire in these cases what it will cost to put the premises in repair, and give so much damages; and the plaintiff onght in justice to apply the damages to the repair of the premises."

A testator directed his trustees to allow A. B. to occupy a mill, \&e., so long as he should think proper so to do, he nevertheless keeping the premises iu good and tenantable repair, and paying a rent of $£ 100$. A. B. accepted the gift, but the premises were afteruards totally destroyed by accidental fire, and it was held that A. B. was bound to reinstate them, or pay a sulficient sum for that purpose, and was liable for the rent in the meanwhile, and that he conld not escape from the liability to rebuild by declining any longer to retain them (Gregy $\mathrm{v}$. Coates; Hodlyson v. Coates).

It was decided in Betker v. Holtpaaffell that the landlord of a house demised under a written agreement not under seal, may recover against the tenant in occupation and use and occupation for the rent accruing after the premises are burnt doun. And so in Izon v. Gorton, where there was no written agreement, but a mere tenancy from year to year (which until it is determined by a notice to quit, is, as to its legal character and consequenees the same as a term for years); for in order to enable a tenant to aroid his lease there must be a default on the part of the landlord (ib.). In Holtpzaffell v. Baker, where the plaintiff offered to surrender his term, praying relief from the previous action, Lord Elcton Ch. held that he was entitled to no relief, although the agreement contained an engagement by the tenant to repair the premises, and keep them in repair, " reasonable use and wear and damage by fire excepted."

A tenunt hes no equity to compel his landlord to expend money received from an insurance office on the demised premises being burnt doun, in rebuilding the premises, or to restrain the landlord from suing for the rent until the premises are rebuilt (Leeds v. Cheetham). An attempt 
was made in Demis v. Lofft, on the anthority of an observation in Lord St. Lconard's " Hand Book," p. 101, to overthrow the doctrine established in this case and Holtpzaffell v. Baker. The defendant was sued for the use and occupation of a farm-house, some of the buildings of which had been accidentally destroyed by fire. He placed an equitable plea on the record to the eflect that the landlord had insured the buildings in question (which were of a description much to enhance the value of the premises), and having received the sum insured, had not expended the same on rebuilding the premises. This plea was demurred to, and the Court of Queen's Bench, without calling the plaintiff, gave judgment against the defendant, remarking that the law of Scotland as to this point was different from that of England, in which it is no excuse fur noppayment of rent that the landlord has insured and receired the money, if he has entered into no corenant to lay it out on the premises.

Where a farm-house uas bumt by accident, it was held by the House of Lords, reversing the judgment of the Court of Session, that the landlord is not bound to rebuild if there was no written agreement (Bayne v. Walker). If a landlord is bonud in law or equity to repair in certain cases, and the tenant in one of those cases owing to a sudden tempest is obliged to make those repairs to prevent further mischief, and then an action is brought against him for the rent, equity will not interpose, because the tenant is entitled to charge the landlord with the repairs, and may set-off in an action for rent the money advanced by him for repairs, as money paid to the nse of the landlord (Waters $v$. Irreigall).

The plaintiff in Tates v. Dunster (in which Beech v. White and Bennet r. Ireland were cited) being the assignee of a lease, which contained a corenant to repair, underlet the premises to the defendant, upon the terms that he should "maintain them in as good a state as they would be when repaired by him." Shortly after the defendant took possession, the premises, which were old and dilapidated, were destroyed by fire. The jury found that the cost of rebuilding them would be $£ 1,635$, but

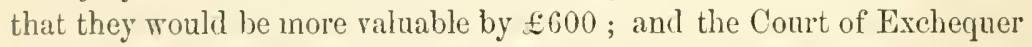
held that the defendant was only bound to put the premises in the same state as they urould have been if he had repaired them before the fire, and conseruently he was liable to pay as damages $£ 1,035$ only.

In 'The Duke of Neuccaslle v. The Inundrrl of Broxtoure, it was held that in assessing compensation for the demolition of a clwelling-house under statute 7 \& 8 Geo. IV. c. 31 , the jury onglit to consider what sum will be necessary to repair the injury and replace the house in the state in which it was at the time when the outrage was commitled, and not 
whether the plaintiff was likely to make it his residence, or whether it was suitable for such residence.

In Mrcnolty v. Fitzherberl, where an agreement had been approved by the Court for letting a farm, the farm-house and buildings of which being in a dilapilated state, were to be put into substantial repair by the reccicer, Sir J. Romilly M.R. made an order with very great hesitation, on the petition of the tenant for life, that the $£ 220$ which had been expended (out of $£ 550$ ) on repairs of a permanent character, should be allowed out of the corpus of certain stock, in Court, limited on the same trusts, and of which the petitioner was allowed interest for her life.

In Coke v. Cholmondley, a testator direeted his trustees, out of the rents and profits of his estate, to keep the manor-housc and messuages in good repair, and, if necessary, to rebuild any farm buildings from time to time. The buildings being in a dilapidated state at the testator's death, a question arose between the tenants for life and those in remainder as to the construction of the will in this respect; and it was held by Kindersley V.C. that the manor-honse and messuages must be repaired out of the annual rents and profits ; that the rebuilding applied to farm-houses, and then only in case of their being incapable of repair, or in case of the expense of rebuilding being no greater-regard being had to the nature, age, dimension, and structure-than the cost of putting them into good repair.

An action for dilapilutions when money is paid into Court, and the question in dispute is only as to the amount of the damages, may be a matter of account, and the subject of a compulsory reference within the meaning of the Common Law Procedure Act, 1854, 17 \& 18 Vict.c. 124 (In re Cummins v. Birkett).

A tenant under a lease which contained a covenant to repair, and leave in good repair, all buildings and erections then standing or to be erected during the term, built a farm-house, partly on the land demised, and partly on the waste adjoining belonging to the lessor. On the decease of the tenant a claim was made by the landlord for dilapidations, and Sir J. Romilly M.R. held that his aequiescence in the act of the tenant prevented his dispossessing him of the premises built on the waste, and that it mnst be assumed by implication that the covenant to repair extended to the whole building, and that the landlord was entitled, in a suit for the administration of the tenant's estate, to establish a claim for dilapidatious (Tn re Newbery White v. Wakely).

Where a rector mut un in the garden of the rectory, apart from the house, hot-houses, 70 feet long and between 10 and 20 feet high, consisting of a frame and glass work, resting on brick walls about 2 feet high, and embedded in mortar on these walls, he or his executors in a reasonable 
time after his death are entitled to remore them without ineurring any liability for either dilapidations or waste, provided the garden is restored to its former condition (Martin v. Roe).

A notice to quit, signed by one of several joint tenants, purporting to be given on behalf of them all, is sufficient to determine a tenaney from year to year as to all (Doe dem. Astin v. Summersett).

And so a notice to quit given by a person meriously authorized by one of sereral lessors, joint tenants, determines the tenancy as to all (Doe dem. Kindersley v. Huyhes). A receiver appointed by the Count of Chancery, with a general anthority to let the lands to tenants firom year to year, has also anthority to determine such tenancies by a regular notice to quit (Doe r. Read). But per Parle J., a mere reccirer of rents, as such, has no authority to determine a tenancy (Doe dem. Mann $\nabla$. Walters). And per Patteson J., an agent to receive and let has authority to determine a tenancy (Doe v. Mizem) ; but a notice to quit given by an agent of an ayent is not sufficient withont evidence of an authority to give notice, or a recognition by the prineipal (Doe v. Robinson). Lord Ellenborough C.J. ruled that notice to quit may be given to a tenant by parol; and where there are two tenants of premises held in common, notice to one is sufficient (Doe dem. Hacartney, Lord, v. Crick). And, again, if a notice to quit is directed to a tenant by a urony Christian name, and he keeps it, it is a waiver of the misdirection, and the lessor may recover on it, if there was no other tenaut of the name (Doe v. Spiller).

On a parol demise of rent, to take place from the following "Lady Day," cridence of the custom of the country uras admitted, to show that "Old Lady I)ay" was meant (Doe dem. Hall v. Benson). And see Joe v. Hopkinson, decided on the anthority of this case ; and Furley ऽ. Wood, where Lord Kenyon C.J. admitted proof of the custom of the country that a general holding in Kent from "Michaelmas" meant Old Michaelmas Day. In Loe dem. Spirer v. Lea, where the letting was by deed, the Court allowed of no extrinsic evidence to explain the time of holding stated therein; and ruled that since the new style (Jan. 1, 1752 ) to hold "from the Feast of St. Nichael" meant New Michaelmas, and that, considering the tenant's year to end at New Michaelmas, the notice to quit at Old Michaelmas, though given hall-a-year before New Ilichaelmas, was bad; for the notice inust be to quit at the end of the tenant's year, and if it might be given to quit twelve days afterwards, it might as well be at any other time.

In the case of Dor dem. Stricklund v. Spenre, there was an agreement by a tenant of a lar'm "to enter on the tillage land at Candlemas last, and on the house and all the other premises at Lady Doy following, and that when he left the farm he should quit the same, according to the 
limes of entry as aforesciid"; and the rent was reserved half-yearly at Michaelmas and Lady Day. It was held that a notice to quit delivered half-a-year before Lady Day, but less than half-a-year before Candlemas, was good, the taking being in substance from Lady Day, with a privilege for the incoming tenant to enter on the arable land at Candlemas for the sake of the plonghing, \&c. Lord Eltenborough C.J. said : "The case Doe dem. Daggett v. Snoudon has decided that the notice to quit shall refer to the substantial day of entry of the tenant, thongh he may have before entered on the arable land for the benefit of plonghing and preparing it, and that the incoming tenant may have the privilege of entering upon it for the same purpose, antecedent to the time of notice."

In Doe dem. Daremport v. Rhodes, a tenant held a farm, the lands, with the exception of a sufficient outlet of boozy pasture, from the 2 ml of February, and the house with such pasture from the 1st of May, 1835, then next, for one year, and afterwards from year to year, as long as both parties should please. On Aug. 1st, 1842, a notice was served on the defendants to quit the farm on the 2 nd of Feb. then next, or at such other time or times as their terancy shonld expire next after the expiration of half-a-year from the delivery of the notice. It was contended for the defendants that this notice was not snfficient to entitle the lessor of the plaintiff to recover the honse, onthonildings, and outlet, as to which the term wonld not expire until the 1st of May following. Williams J. reserved the point, and the plaintiff had a general verdict. The Conrt did not pronounce a definite opinion upon the question, and the plaintiff was held entitled to a general verdiet, if he proved his title to recover any part of that for which he had declared.

In Doe dem. Kindersley v. Hughes, the actual period of the commencement of the tenancy uas not shorn; but it was proved to be the nsage of the estate that the tenants should enter upon the lands on the 2 nd of February, and upon the house and outbnildings on the 1st of May. On the 16th of February, 18s8, a notice to quit was served upon the defendants by the agent of the trustees, "to quit and deliver up the farm, lands, and premises which you hold under them at the end of your present year's holding thereof"; and it was held that this was a good notice to determine the tenancy in the spring of 1839 , it not being shown, on the part of the tenant, that the land was not the principal subject of the holding. The defendants contended that the notice to quit was insufficient on the face of it, inasmuch as it was to quit at the end of the defendant's present year's bolding, i.e., in May, 1838, for which it was too late; and that it could not operate to determine the tenancy at the end of a subsequent year. 
Where a tenant from year to year gave his landlond, who accepted it, a uritten notice to quit at Midsummer, and then, on discovering that his tenaney did not expire till Christmas, sent another notice accordingly, and refused to quit the premises until the latter date, the Court of Exchequer held, on an ejectment being lrought, that the tenancy was not determined by notice, inasmuch as it was not good as a notice to quit, and conld not operate as a surrender by a note in writing within the Statute of Frands, the first being to take effect in fuluro (Doe dem. Murell v. Miluard). The ease of Aldenburgh v. Peaple was much shaken by the decision of the Court of Exchequer in Wedtull r. Capes ; for although the precise point is not there determined, yet it is clear that the Court were of opinion that the instrument could not operate as a surrender in futuro. Bersell v. Lansbery, where it was held by the Court of Queen's Bench that a rerbal acquiescence by the landlord on receiving from a tenant from year to year a verbal notice to quit determining within the six months is not sufficient, and does not operate as a surrender of the term, fell directly within the authority of Johnstone v. Hudillestone.

In Doe dem. Plumer v. Mainby, the premises were demised under a written agreement dated August 4th, 1845, " the tenaney to be from year to year from Michaelmas next," at the rent of $£ 55$, payable halfyearly, "except the last latf year, which portion of rent shall be paid on or before the first of August in that year, and to be deemed then due for all legal remedies for recovering rent in arrear" : tenaut "to allow the landlord or incoming tenant in the last year to enter on 1st May, to make fallows and carry out the manure"; for which compensation was to be paid, \&c.: "tenant to have the use of the barns for stacking and thrashing the crops of the last year till the 1st day of May after the tenancy." Defendant came into possession, and on the 26 th of March, 1846, he was served with a notice to quit at Michaelmas, 1846. It was contended on his behalf, that, taking all the terms of the agreement together, they necessarily imported that the tenancy was to last beyond the first year; but under the direction of Wilde C.J., a rerdiet was returned for the plaintiff. The Court of Qneen's Bench refused a rule for a new trial on the ground of misdireetion.

If a landlord lease for seven years by parol, and agrees that the tenant shall enter at Iady Day and quit at Candlemas, though the lease be roid by the Statnte of Frands as to the duration of the term, the tenant holds under the terms of the lease in other respeets, and therefore the landlord can only put an end to the tenancy at Candlemas (Doe dem. livigge v. Bell).

It was decided by the Court of Qucen's Bench in Bird v. Baker, 
that a lease, dated January 19, 1851, of certain premises to hold from December 25th, 1849, for and during the full term of fourteen years then next ensuing, containing a proviso that either the lessor or lessee may determine the lease at the expiration of the first seven years, by six months' notice to quit, is a lease determinable at the expiration of seven years from December 25th, 1849, on due notice being given.

Where a tenant entered under an ayreoment for a seven years' lease, which was never executed, it was held by the Court of Common Pleas that he was not entitled to notice to quit at the end of seven years. Within the seven years he could not have been turned out without notice; but at the end of the seven years the contract itself gives him sufficient notice (Doe dem. Titt v. Stratton). 'The point is, in effect, decided in Doe dem. Bloomfield v. Smith, and Due dem. Oldershauv v. Breach.

If a lease be granted for scien, fourteen, or twenty-one years the lessee has the option at which of the above periods the lease shall determine (Dann v. Spurrier). The Court of King's Bench fully acknowledged the authority of this decision of the Court of Common Pleas in Doe dem. Webb v. Dixon; and held that, under a lease for fonrteen or seven years, the lessee only bas the option of determining it at the end of the first seven years, every doubtful grant being construed in favour of the grantee.

Where a tenant for life makes a lease for years to commence on a certain day, and dies (before the expiration of the lease) in the middle of a year, and the remainderman receives rent from the lessee (who continues in possession, but not under a fresh lease) for two years together on the days of payment mentioned in the lease, this is evidence from which an agreement may be presumed between the remainderman and the lessee, that the lessee should continue to hold from the day and according to the terms of the original demise, so that notice to quit cnding on that day is proper (Doe dem. Jordan v. Ward).

A person who held glebe lands as tenant to one incumbent, and continues in passcssion under his suecessor, without disturbance, must be presumed to hold as a tenant to the latter, and cannot be dispossessed without notice to quit (Doe dem. Cates v. Somerville). But Littledale J. held, in Doe dem. Kirby v. Carter, that the incumbent of a living may sustain cjectment against parties in possession of the glebe lands, though the current year of a tenancy from year to year created by his jredecessor is unexpired, as such new vicar had a right to immediate possession, notwithstanding the tenancy recognised by his predecessor. Here the plaintiff gave in evidence a notice to quit from the preceding vicar, which had expired previous to the date of demise, and the defendant 
endearoured to show that his tenaney did not expire at the time to which the notice had relation. The letters of institution reciting the cession of his predecessol were snfficient mima facie of the cession being duly made, especially as it was acted on, and a rule for a new trial on the ground of misdirection was refnsed.

In Tooker $r$. Smith an ayreement for a lease contained a stipulation that the tenancy shonld continue untit after two years' notice to quit had been given. The tenant oceupied the farm, paid rent for some years, but no lease was executed, and the Court of Exehequer held that it could not he implied that the stipulation as to the two years' notice to quit was one of the terms ander which the tenant held. The farm was to be managed aceording to the four or five-conrse system-i.e., with respect to the five-course, not less than two-fifths of the arable land to be always in sown grass and a two-year's' ley, so as to be in proper preparation for wheat, \&c.; and with respect to the four-conrse, not less than one-fourth of the arable land to be always in sown grass, \&e. The one party to give the other two-years' notice in writing of his intention to put an end to the tenaney; sneh notice to be given on or before the 29th day of September, and to expire on the 29th day of September, which should happen next before the expiration of two full year's after such notice should have been given. The agreement containing these terms, and signed by one Pearson for the plaintiff, and loy the defendant, was prodnced. It was not under seal, and when first produced was nnstamped, lut was subsequently stamped as an agreement. Possession had been taken by the defendant under the agreement, who oecupied the farm, and paid rent for it for some years, till his tenancy was determined by a two-years' notice, expiring Michaelmas, 1856. 'The plaintiff averred that the farm had not been cultivated according to the four or five-course system, but that large quantities of the arable land had been kept in wheat; and the defendant pleaded, intrr alia, that he never held the farm on the terms mentioned in the deelaration. Martin B. ruled that the contract in the declaration was not proved, and nonsnited the plaintiff.

His Lordship, on a motion for a new trial, referred to Tress v. Sarage, where Colevidye J. pointed ont that the tenancy to be implied was a yearly tenaney, determinable by six months' notice to quit; and added, "There is nothing inconsistent with a yearly tenancy in stipulations for the cultivation of lands upon any system the parties may ehoose to agree 11]nn. It is a fallacy to assume that the term as to the four-eomrse system of hushandry cannot be implied. It is nothing more than an agrecment, that during each year that the tenancy shall contime, a certain course of euItivation shall be pursued." And per Pollock C.B. : "A 
tenant holding upon the terms of an agreement for a lease was formerly considered to be merely a tenant-at-will, but the Conrts have since held that if rent is paid a tenancy from year to year shall be presumed.' Leave was given to amend the declaration within three weeks, by striking out so much of it as related to the two-years' notice to quit, on payment of costs; otherwise the rnle to be discharged.

In a plaint in the County Court for the recovery of premises by a landTord against his tenant, the Conrt is not, under stat. 9 \& 10 rict. c. 95 , s. 58 , necessarily deprived of its jurisdiction, by the judge being satistied from the evidence that there is a bon $\hat{\imath}$ fide claim of title to the premises by a third person, who has not only given notice to his teriant not to pay rent, but who has succeeded in obtaining possession from him. It is the duty of the judge, before he declines to try such cause, to ascertain whether the person so claiming title has obtained possession under circumstances which would amount to an action by title paramount; for if the tenant voluntarily gave up the premises, the canse conld have been tried without the judge having to determine any question of title (Emery v. Barnett).

To constitute an exiction of a tenant by his landlord, which will operate as a suspension of rent, it is not necessary that there should be an actual physical expulsion from any part of the premises ; but any aet of a permanent character done by the landlord, or by his procurement, with the intention to deprive the tenant of the enjoyment of the premises as demised, or any part of them, will operate as such eviction, and the existence of the intention is a question for the jury (Upton v. Greenless, and Upton v. Tox'nemd). Payment by a tenant of rent to a person other than the person who let him into possession, under a threat of expulsion, does not amount to a constructive eviction, so as to affect the estoppel ; and semble, that there cannot be a constructive eviction for that purpose (Delaney v. Fox).

It is no ansuer to a declaration in covenant by a landlord against a tenant for not repairing, converting meadow-land inlo tillage, depasturing orchards with other than specified cattle, cutting trees, and underletting par't of demised premises without his consent, that before any of the alleged breaches, and during the continuance of the term, he was evicted from an outhouse, garden, and court-yard, parcel of the demised premises, by authority of the landlord (Nexton v. Allin). And per Curiam: "The tenant can never be allowed to say that he is no tenant, because he has been evicted at the very moment when he is underletting the land which he has been put in possession of by the landlord, in direct contravention of the covenants that he has entered into, the breach of which is admitted upon the record" (ib.). And where lands have been demised until 
Michaelmas and no longer, the tenant to have the use of a part of the premises until the following Laddy-day, the lessor may maintain ejectment for the other part, during the perior between Michaelmas and Lady-day (Doe dem. Waters r. Houghton).

Where a lessee corenanted that he "urould pay all tares, charges, rates, tithes, or rent-elearges in lien of tithe, dues, and duties whutsoever, as then were or should at any time thereafter during that demise be taxed, charged, assessed, or imposed upon the said demised mremises," the corcuant is not confined to rates payable by the landlord, but means all rates then imposed on the lessee in respect of his oceupation, and all future rates which might be imposed on the land itself (Hurst $\mathrm{v}$. Hurst).

It was held by the Court of Common Plas in Matheson v. Hart that rates charged by act of partiament uron lund, but which the occupiers are to pay, retaining the same out of their rent, and not paying more than the rent which shall from time to time become due from them, and leviable by distress on the occupier neglecting to pay them, are, if left unpaid by outgoing teuants (in the absence of any remedy either against the owcors or against occupiers who may have left the rates unpaid, or of any provision for a different course) leviable on the present occupier, to the amount of any rent becoming due on any current reservation. And if a rate be separately assessed in different disiricts, and lands not within the juristiction of the act are included in the assessment but omitted from the rate for which a warrant is issued, the warrant is not thereby rendered invalid (ib.). The tenaut under a lease, reserving rent, to be paid without deduction, except for land-tax and scwers'-rate, cannot dednct the tax or rate on the value of the demised premises, but on the amount of the rent reserved; and it is immaterial in this respect whether the value of the demised premises has been augmented abore the rent by erections or improvements prior to or after the lease (Smith v. Humble).

The lanu-tax in earh parish or place assessed by the commissioners is a fixed quota, established lig slutule 38 Geo. III. c. 60, and not a proportion of the whole sum charged on the division, to be assessed equally thronghout the same, under statute 38 Geo. III. c. 5 (Reg. v. The Commissioners of Land-Tax for the Touer Division). Where by a contract for the sale of land, the lend is described as "lemel-tux redeemed," the rendor is bound to give reasonable evidence that the land-tax has been redeemed, or that, if purchased, it is in his power to transfer or release it; and ordinarily the proper evidence of this wonld be the certificate of the commissioners or a copy of the register (Buchanan v. Poppleton). 
The land-tax is a "partianentary tar" within the merening of an ayrecment to pay rent "and all taxes parliementary and parochiat" (Namminy v. Lumn). It was settled in Moody v. Dean and Chapter of We/ts, that the owner of lands charged with a fee farm-rent, payable to a purchaser from the Crown, under statutes 22 Car. II. c. 6, and 23 Car. II. c. 24 , having redeemed the land-tax chargeable on the lands, ont of which the fee farm-rent issues, is entitled under the land-tax acts to deduct $4 s$. in the pound from the rent so payable. Alderson B. said: "It is clear that according to the true construction of the acts this deduction must be allowed. What was the sitnation of the parties when the $38 \mathrm{Geo}$. III. c. 60 passed? All the country was originally rated equally at $4 \mathrm{~s}$. in the pound. The variation in the rate has arisen from change of eireumstances - one part of the eomntry prospered, another has dechined. The tax has thus become unequal. There was no real difference in the proportion when the tax was assessed, thongh there was a difference in the mode of assessment. Fee farm-rents and payments to the Crown were subject to a fixed payment of $4 \mathrm{~s}$. in the pound. The whole tax was paid by the party in possession of the land. He then dedncted a proportion, from the owner, of the rent; and there seems to me no reason why he shonld not still do so."

If by the stipulations eontained in a lease the tenant is to pay the land-tax, which he left unpaid during his tenaney, and which the succeeding tenant paid, and the landlord repaid him, it was held that as the tenant's liability only arose from the special agreement, the landlord conld not recover the sums so paid in an action for money paid but must declare on the special agreement (Spencer v. Parry). And per Lord Denman C.J.: "The special agreement in this ease creates the liability of the defendant, which the act of parliament did in Dawson v. Linton" (ib.). A land-tax collector has no authority under a warrant of the commissioners to break open an outer door unless a constable is present; and he cannot defend himself under 38 Gco. III. c. 5, s. 17 (Toss v. Racine).

A lease demising a parcel of land, with liberty to take clay, \&e., and make bricks, contained three reservations, viz., an annual sum of $£ 1710 \mathrm{~s}$. for surface rent, a royalty or brick-rent of $£ 100$ by the year, and a sum of $2 \mathrm{~s}$. for every thousand of bricks made in one year over a million. Each sum was declared by the lease to be free of all deductions except for landlord's moperty and income tax. The tenant claimed to deduct from his landlord property or income-tax on each, and the Court of Exche quer held that he was entitled to make the deduction, the two first payments being rent, and the third, if not rent, still a payment with reference to which the parties had agreed that the deduction should be 
made (Filnomds v. Easlurood). And semble per Warlin B., Tralson B., and Chamell B., that the landlord was assessable to income-tax in respect of the $2 \mathrm{~s}$. payable for each thonsand orer a million bricks made on the demised premises in the course of a year under $5 \& 6$ Vict. c. 35. s. 1, and that the deduction was properly made under Schedule A, No. 3 (ib.). And per Channell B.: "The case of Daniel v. Grace is an authority that the right of distress attaches in respect of the reservation of $2 s$. per thousand on the bricks made orer a million" (ib.). IIis lordship thus explained the distinction between the schedules: "No doubt Schedule $A$ imposes the tax in respect of the property in land; Schedule B in respect of its occupation; Schedule C in respect of profits derived from land; but Schedule D is more general in its terms, and of wider effect than any of the preceding, and was, in my opinion, intended to impose the tax in respect of every sort of property, occupation, ol profit, in or from land not embraced by any of the other schedules" (ib.).

The poor rate is entirely charged mon the occupier, and is a personal charye in respect of the land. 'The property tax is assessed on the occupier, and he has a right to deduct it from his next payment of rent, and if he does not do so, he cannot recover it back from his landlord, either as money paid, or money had and received to his use (Cumming v. Beclborough). And per Alderson B. : "Money had and receired could not lie, because it is not shown that the rent was overpaid at all. It either is a voluntary payment, or it is no payment at all "(ib). And per Manle J.: "Without unduly straining the words of the act, the deduction may be claimed ont of the next payment, though made under legal process" (Franklinv. Carter). And semble per Lord Tenterden C. J.: "If a tenant pays taxes which he alleges ought to have been paid by his landlord, and afterwards pays rent for two years subsequently without making any deduction, he cannot recorer the amount in an action against the landlord" (Saunderson v. Hanson). And semble that a broker, who, when receiving rent under a distress, deducts a sum purporting to be for land-tax, is not to be considered as allowing the land-tax, so as to aflect the landlord's right, but as merely from not knowing how to act, consenting to receive the money without the sum deducted (it.). The landlords are compelled by the statutes 5 \& 6 Vict. c. 35 , ss. 103-105 to allow the deduction under a penalty.

Denby 5 . Moore decided that an occupier of lamls having, during a course of twelve years, paid to the collector of tares the landlord's propertytas, and the full rent as it became due to the landlord, could not recover back fiom the latter any part of the properly-lace so paid, as money had 
and received to his use. It was his own voluntary act, as he must have known he had a right to dednet it from each rent.

Suatman v. Ambler settled that a tenant has a right to deduct from his rent the amount of property-tax assessel upon, and paid by him in respect of his landlord, although the landlord is not in fact liable to be asscssed, and has beforc the payment claimed exemption, and that exemption has been subsequently allowed. Parke B. said: "The question here was whether the defendant was entitled to deduct certain property-tax paid by him-not to set it off. It was in effect settled by Denby v. Moore that a claim of this nature cannot be set off, because in paying over the property-tax a tenant cannot be considered as having done anything more than paying part of the rent, and he camnot set off that. The plaintiff is in fact the representative of the Eau Brink Commissioners, and we have now to decide whether the defendants are entitled to deduct certain payments they bave made on account of the property-tax since the commencement of their lease of the tolls, which they held at different detached periods between 1\$37-50. We do not see any reason why they shonld not be entitled to dednct the money, not to recover it by way of a cross action, but to deduct it from the unpaid rent. They nerer paid the rent in full. There appears to us to be no reason why they should not be entitled to dednct every sum they had paid on account of their landlords down to that time. It was the business of the landlords here to get relieved from the assessment, which they neglected to do in the first instance, but which they finally effected; but the tenants in the meantime being assessed and compelled to pay, have a right to make every deduction."

By a case reserved from the Quarter Sessions, on an appeal against a rate for the parish of $\mathrm{H}$., W. was found to be the occuipier of a farm situate partly in $\mathrm{H}$. for 195 acres and partly in $\mathrm{C}$. for the residue, and it was held by the Conlt of Queen's Bench that he was liable to be rated in H., although the boundaries of such land could not be ascertained. And per Curiam: "It does not seem necessary that the parish officers should be able to point out which is the land rated" (Reginc v. Wools). 'The occupier of a farm, of which a certain number of acres are in parish A., and the residne in parish B., is properly rated to the poor rate of parish A., as the occupier of the number of acres in that parish, althouyh the specific acres in cither parish are not known (ib.). And per Lord Campbell C. J. : "It is not necessary for the parish officers to set out the particular boundaries of the land, in respect of which they rate an occupier" (ib.).

Emblements can only be claimed in respect of crops which grow by the industry and manurance of man, and which ordinarily repay the labour 
by which ther are proluced within the year in which the labour is bestowed, thongh in extraordinary seasons they may be delayed beyond that period; and a tenant entitled to emblements ean hare only one erop of the thing sown, i.e., the crop growing at the time of the determination of his tenaney, although such crop may not compensate him for industry and manuranee bestowed (Graces v. Well). Emblements exteud not only to corn sorm, but to roots, hemp, flax, or any other anuual profit, but not to young fruit-trees, or young oaks, ashes, elms, \&e., because they yield no present ammal profit. Hops which grow from ancient roots were held, in Latham $v$. Alucool, to be "like emblements, because they are such things as grow by the manurance and indnstry of the owner, by the making of hills and the setting of poles." That labour and expense, without which they would not grow at all, scems to have been deemed equivalent to the sowing and planting of other regetables. Cruise's Digest, v. 1, p. 710, 3rd ecl., observes that this determination was probably on account of the great expense of cultivating the ancient roots. On this Lord Denman C. J. remarked, in Grures v. Weld, "Latham v. Atwood decides that hops, so far as relates to their anmual product only, are only emblements; but it by no means proves that the person who planted the young hops would have been entitled to the first crop whenever produced."

If the lessee of a tenant for life sou's the laml, and dies bofore harrest, his executors shall have the emblements or profits of the crop. But now by $14 \& 15$ Vict. c. 25 , s. 1, as regards tenants at rack-rent holding furms or lands under landlords entitled for life or any other uncertain interest, and the lease or tenancy determines by the death or cesser of the estate of the landlord, the tenant shall, instead of claims to emblements, continue to hold until the expiration of the then current year of his tenancy ; the succeeding landlord to be entitled to recover a fair proportion of the rent for this period, and all the benefits, terms, and restrictions, \&c., to apply between the latter and the preceding landlord; and no notice to quit is necessary to determine such holding or occupation. And see Stradbroke (Lord) v. Mulcaly, for a decision on this section of the statute.

It is stated in Sheppard's Touchstone (Preston), p. 472, that "as betueen an execulor and devisee, the emblements belong to the devisee, unless they are expressly bequeathed." And so in Cooper v. Woolfit, where a testator devised to W. certain lands called the "Clay-pits," and bequeathed to $\mathrm{C}$. and $\mathrm{W}$. all his moneys, \&c., personal estates and effects whatsoever and wheresover, not therein specifically bequeathed, but did not make a specific bequest of crops growing on the land, it was held that the d: visee was entitled to the emblements growing upon 
it at the the time of the testator"s decease. "Cox v. Goclsulie and ITest $\mathrm{v}$. Noore prove that emblements are part of the stock and will pass under the description of "the stock on a farm" "; per Lord Gifford MI. R. (Blake v. Gills). And in Rudge v. Wimnell, Lord Langdale M. R. also ruled that devise of real estate in the occupation of the testator in trust for A., with a bequest of "all his live and dead stock, \&c., and all his personal estate whatsoever and wheresoever" to $\mathrm{B}$. passes the cmblements $\mathrm{n} n$ the real estate to $\mathrm{B}$.

At the death of a tenant of the manor, it was the custom to appraise his effects, and the best chattel was declared due to the lord, and styled a heriot. Heriots, like quit-rents and gromud-rents, are not rateable to the poor (Rex v. Tandericall). They may be proved by parol to be due on the death of a tenant, though not expressed in the lease (White $\mathrm{v}$. Sayer.) As a custom may be valid for a heriot on the death of every free tenant holding for a less estate than fee-simple, it follows that it may be valid in respect of a tenement of frec lands, held in fee-simple of a manor, as the nature of that estate is not inconsistent with such a custom; and therefore to prove such a custom, presentments of the deaths of other tenants of other free tenements held in fee of the manor, and the seizure of heriots thereupon, are admissible (Damerell $\mathrm{v}$. Protheroe). And quere whether the ancient lease having reserved as a heriot the best beast of the lessee (being one of the lives), his executors, administrators, assigns, or such person as should be in possession of the tremises, and entitled to the same by virtue of the lease, a lease reserving only the best beast of the lessee (being one of the lives) be good; but a lease is not bad under the power, which reserves the best beast of the person or persons who for the time being shall be tenant or tenants in possession of the premises (Doe dem. Douglas v. Lock).

Where, from an entry on the rolls of a manor, it appeared that it was presented, in 1778 , to be the custom "that every copyhold tenant that holdeth copyhold lands upon death or alienation ought to pay a heriot," the custom had been in accordance with the entry, but there was no instance shown of an alienation of joint tenants, or of a claim of a heriot from each of several joint tenants on alienation, it was held that without proof of a special custom (of which there was none) one heriot only was due on a joint alienation of several joint tenants (Padrvick v. Tyndale).

But Holloway v. Berkeley decided that when a copyhold tenement holden by heriot custom becomes the property of several as tenants in common, the lord is entitled to a heriot from each of them; but if the several portions are re-uuited, in one person, one heriot only is payable. So in Carland v. Jekyll, it was held that a copyhold property which when in 
the hands of a single owner pars bnt one heriot, but pays several if dirided among several owners, shall again pay but one heriot if it again becomes united in the person of a single owner.

It was held, in Abington v. Lizscomb, that trover did not lie, where the lamellord had marked and demanded seven heriots instead of five. In March, 1838, the defendant's father died, seised of certain customary frecholds, on which heriots were payable to the plaintiff as lord of the manor of Penshnrst Halemote, on the death of the tenant. The customary heriot was the best living beast or a stated money payment. The tenements were seven; they had originally been only five, but two had been divided, and the several parts had passed into different hands, and the whole had become re-united in the possession of the defendant's father. Seren heriots were accordingly claimed, one for each tenement by the bailiff of the manor ; but it was admitted in the argumerit that according to the rule in Gerlend r. Jekgll only five were dne. 'The bailifl claimed to mark seven beasts, a day or two after the death of the defendant's father, and with the consent of the defendant. marked four horses in the ficld, one in the stables, and two cows in the yard. This was in March; and when he went to claim them in December, the defendant said he should refer it to his attorney and not deliver them up. It was nrged for the defendant that the refusal did not under the circumstances show a conversion; and there was no refusal of five, but only a refusal of seven, and that in fact the only conrersion was a refusal to give ap the seven unlawfully claimed. The defence in point of fact was an assignment made by the father shortly before his death, which the plaintiff contended was void by stat. 13 Elis. c. 5, s. 2. The jury found that there had been such an assignment with a view to evade payment of the heriot; and returned a verdict of $£ 105$ for the plaintiff, leave being given to move to reduce the damages if the plaintiff was entitled to recover, but not for so many as seven heriots, or to enter a nonsuit if the Conrt should be of opinion that the above statute did not apply, or that the evidence did not show a conversion. The Court held that that there was no conversion, and a rule for entering a nonsuit was made absolnte, on the grounds put by Lord Demmen C. J., that "the demand had reference to a seizure actually made of seven beasts, when the plaintiff had only a right to seize five. Supposing it then to be clear that the demand and refusal amounted to a conversion of five, still it is left uncertain which five lo lawfully reized. If he is entitled to the best beast as an heriot, he must form a judrment and exercise an option as to which is best. This is clear from Woolland v. Mantell, P'eler v. Knoll, and Odiham v. Smith." And sce Price v. Wooulhouse. 
In the case of The Manor of Basingstoke v. Lord Bolton there was a bill by the lord of a manor against the tenant, alleging immemorial payments, as rent, or in the nature of rent, on the death of each tenant by his successors, in respect of thirty-eight different estates. The payments were in lieu of heriots and reliefs. It appeared by the evidence that the heriots were more probably heriot custom than heriot service, and that the relief was by eustom, and not by common right or by reservation. Some of them had been paid by the execntors of the deceased; it was not shown that the tenant was in possession of all the lands alleged to be liable; and only the aggregate amount of rent was known, not the proportion due to each estate; and Kindersley V.-C. heid that under these circumstances the lord had no equity against the successors of the deceased tenant, although it appeared that in consequence of the description and identity of the lands being lost he conld not enforce any claim at law. Commissioners of enclosure have no powers, in exchanging freehold lands subject to heriots and reliefs, to make the lands allotted so subject (ib.).

The action for use and occupation existed before statute 11 Geo. II., c. 19, but until the passing of that act the plaintiff was nonsuited if a demise was proved. Except in that particnlar the statnte did not make the action maintainable in eases where it could not lave been maintained before (Churchuarl v. Ford.). According to the words of section 14 of the statute it may be maintained "where the agreement is not by deed." Some agreement seems to be implied as the foundation; though it is well established that it need not amount to a formal demise, or even be express. And per Patteson J. : "Corporations aggregate may maintain actions on executed parol contracts. In The Dean and Chapter of Rochester v. Pierce, Lord Ellenborongh C.J., first at Nisi Prins, and the Court of Queen's Bench afterwards, held that they might sue in debt for use and occupation of their lands ; and the Court of Common Pleas, in The Mayor of Stafford v. Till, held the same as to assumpsit. This establishes that where a benefit has been enjoyed, such as the ocenpation of their land by their permission, the law will imply a promise to make them compensation, which promise they are capable of accepting, and upon which they may maintain an action" (Beverley v. The Lincoln Gas Light and Coke Company).

An action under the statute will not lie where there has not been an actual entry by the lessee (Love v. Ross). "Before the statute an action for use and occupation might be maintained, unless an actual demise were shown; proof of which was held (though not uniformly, to be fatal to the action, either on the ground of its showing a real contract, or because the demise having passed an interest, the defendant conlu not 
be said to oceupy by the plitintiff's permission. In some instances an exeeption was allowed, where an express promise conld be proved or intended. The alteration introduced by the statute was, that proof of a demise muless by deed was no longer fatal to the action; but the terms of the demise might be used as evidence of the quantum of damages (6 A. \& E. 839 n.)." Deb/ for nse and ocenpation lies at common law, where there is an express demise at a certain rent, not by deed (Gibson v. Kirk). After referring to the above note, in which all the principal cases are collected, Lord Demman C.J. added : "The Court in Deverley r. The Lincoln Gas-light and Coul Company observed that an action for use and oceupation is established by 11 Gco. II., c. 10, which expression must not be taken as meaning that it was introduced by the act, but only that it was estublisheu, even in cases where there was an express demise at a certain rent, though not under seal. Yet no instance of indelitatus assumpsit for use and occupation will be found before that act, nor any founded upon a quantum meruit; they are all for some fixed sum. So debt for rent was at all times maintainable, whether the demise was by deed, or by writing not under seal, or by word of mouth; both which latter are, of course, included in the expression 'parol demise, so frequently met with in our books (it.)."

Although an action for use and occupation requires some agreement express or impliad, to pay for the occupation, yet there may be a liability for use and occupation where no action for rent could be maintained; and therefore if a party enter nuder an agreement for a demise at a certain rent- the rent not to commence until the repairs are completed by the landlord, the agreement being silent as to the terms of the present oceupation-the entry and oceupation before the repairs are cxecuted may be evidence to go to the jury of an implied agreement to fray in the meanwhile what the premises were worth. And even if the tenant leave before the repairs are executed, the question will be whether there was such an implied agreement; and if there were, he will be liable for a reasonable compensation for his vecupation (Smith v. Eldridge). And see Jolmison v. May; Fremason v. Booman; Mason v. Welbante; and Jones v. Clurk. And as to the distinction between an action for rent and an action for use and occupation, see Toune v. If Eymrick, where the Court of Common Pleas held in an action for the "use" of a house, that an actual or constructive oceupation must be proved, and that the fact of the defendant giving directions on the premises to workmen whom the landlord sent in to do repairs, was no evidence of an entry to take possession, which is necessary to charge a farty in this form of action.

Vos amt orrmpation urill not lie if a title is in dispute. Where a lease 
for a term certain was granted by writing not under seal, which contained an undertaking on behalf of the lessor and his assigns for quiet enjoyment, it was held that his assignee might maintain assumpsit for use and occupation; for the lessor having granted for himself and his assigus, the permission of any person who might become assignee of the reversion during the lease was virtually included, so that the occupation became in point of law permissive on the part of the assiguee as soon as his interest acerued (Standen v. Christmas). An action for nse and occupation is one of contract, and is founded on the relation of landlord and tenant; it therefore requires evidence of an occupation by the permission of, and under a contract with, the plaintiff; and thongh the title on the part of the plaintiff and oceupation by the defendant may, in the absence of any other evidence, be a prima facie case from which such a contract may be inferred, yet where the letting has been by another party, the plaintiff will not be allowed to l'e'over' and so where he fails to prove title or actual contract with himself (Churchward v. Ford). And where the letting has been by another party, mere notice by plaintiff (even though he has the title) to pay the rent to him will not convert the occupation into an occupation by his permission and under a contract with him; for such notice, unless assented to by the tenant, does not create a new contract, and can only enable the party to bring ejectment to recover possession of the premises (ib.).

And per Pollock C. B.: "There are cases-Hull v. Vanghan; Howard v. Shaw; and Winterbotham v. Ingham - which show that ownership in the plaintiff and tenancy in the defendant are mrima facie evidence of such an implied contract as will sustain the action. If indeed yon show positively that there was no contract, it will be a different question; but if nothing else appears than the plaintiff's ownership and the defendant's tenancy, there is a mima facie evidence of an implied contract sufficient to sustain the action. It was so laid down in Hellyer v. Sillcox." And per Bramuell B.: "In exery case a contract must be shown, in order to enable the plaintiff to recover (Gibson v. Kirk). Now here, instead of this being shown, the contrary is shown; for it is shown that the defendant did not occupy by permission of the plaintiff, under any contract with the plaintiff, but by the permission of Mrs. Foss, under a contract with her. It would not only be contrary to all the principles of law and reason, but would lead to gross injustice, if a tenant should be held liable to one party as landlord on a contract made with another. It is not found as a fact that Mrs. Foss let the premises as agent of the plaintiff. In Hellyer v. Sillcox the Conrt of Qneen's Bench thought that the oceupation was by permission of the plaintiff. In Standen v. Christmas there hiul not 
only been a notiee to pay rent to the plaintiff, but the defendant had afterwards paid rent to him ; and the Court were in error in saying that to give an action for use and ocenpation, the relation of landlord and tenant need not subsist between the parties. The word "landlord" implies not the mere londstip or ownership of the soil, but the relationship to a lenant.

Lis am occupation are not maintainable where the express agreement is void by receson of frand. But the plaintiff having paid the rent to the superior landlord, Wightman J. directed a verdict for the plaintiff on the count for money paid. And per Wightman J.: "The frand destroring the express agreement between the parties, there can be no implied contract; and use and occupation are not maintainable withont a contract" (Da'y v. Cracknell); and it is some reillence to go to the jury in support of a connt for use and occupation that a fixed payment has been made for many years in respect of the land in question by the defendant to the plaintiff, the defendant abstaining from all $\mathrm{ex}$ planation of the origin or grounds of that payment, which it seemed he was able to give (Hardon v. Heskett).

Where the circumstances warrant an inferene in fact, that it was agreent by both plaintiff and defendunt at the time of the execulion of the instrumonl, that it should not operate as a Tease until the payment of the balance of an agreed sum for fixtures, though no express words of delivery as an escrow were nsed, it did not operate as a deed till then; and therefore the defendant was held to be tenant from year to year under the terms in the instrument, and not tenant under a deed, and an action for use and oceupation lies against him or the assignee of his interest (Gudyen т. Besset).

If $A$. aygres to let lands to $B$., who permits $C$. to occupy them, A. may recover the rent in an action against $B$. for use and occupation (Bull $v$. Sibls).

Receiving the rents and profits from an under-tenant, is proof of use and oecupation by the person receiving them (Neal v. Sucind); and a lessee, whose underlesse holds over ayainst his will after the expiration of the term, is liable in this action for the period of the holding over, but not for a whole jear's rent (Ibbs v. Richardson). Where there is a paiol drmise to two parties joinlly, and one enters in respect of both, the other, who is not proved to have entered at all, is equally liable to an action for use and occupation (Glen v. Dungey).

Where a parly is let into possession of land under a contract 10 purclease, which afterwards goes off, he is liabte to an action for use and occupation. at the suit of the vendor, for the period during which he continues in possession after the contract went off (How aid $r$. Shaw). If he had 
entered under an agreement for a lease, lie wonld have lieen a tenant-atwill until it was granted. Ant per Alderson B. : "While the defendant was in possession muder the contract for sale he was a tenant-at-will, under a distinct stipulation that he should be rent-free; therefore for that time no action for use and occupation can be bronght against him ; but when that contract is at an end he is a tenant-at-will simply; therefore from that time he is to pay for the occupation (ib.). If a remlor remains in possession willout any agreement after the conveyance is executed, such oceupation does not of itself entitle the vendee to sue him in use and occupation, as there is no evidence of a holding by permission of the plaintiff; but he is a wrong-doer, and may be turned out by ejectment, and is liable in trespass for mesne profits (Tew $\mathrm{v}$. Jones).

In Cripps v. Blank, a person having a title to land sued the defendant, who had received possession from a third person, and it was held that the conditional promise of the defendant about two years before the trial, when the plaintiff lecame owner of the land, and asked hime either to give up possession of it or pay for it- "I do not consider the land as yours; but prove your right, and I will pay for it"-would not support assumpsit for use and occupation. At the trial the learned judge was of opinion that the action would not lie in the absence of proof of an unqualified attornment, and direeted a nonsuit, which the Court upheld. Bayley J. said: "The general rule certainly is, that if $A$. receives possession of land from $B$, he cannot dismute the title of the latter in an action for use and occupation; but where he receives possession from another person, he may dispute the title of the party suing as landlord. Here the defendant did not receive possession from the plaintiff, and therefore the evidence produced could not support use and occupation."

According to Rabbeth v. Squire, the words "use and occupation" in a will do not exclude under-letting. There a testator desired that his two sons might have "the use and occupation" of certain lands, they paying a stated rent, and that in default of payment, or if they converted the arable land into tillage, they should no longer hare "possession" thereof ; and it was held by Sir J. Romitly M.R. that personal use and occupation was not enjoined, and that they might nnderlet the property.

Atthongh a demise be for a time certain, a landlord must make a demand of possession, and give notice in uriting, in order to recover double value under statute 4 Geo. II. c. 28 , s. 1 . An action for double value lies in the County Courts established under statute $9 \& 10$ Vict. c. 95 ; and per Coleridlye J.: "There is no donbt that debt for use and occupation 
and for donble ralne are distinct eanses of action within that statute' (Wickham r. Lee). Double rent is giren by statute 11 Geo. Il. c. 19, s. 18, which was enacted to meet the diffienlty which landlords had with tenants who had porer to determine their own leases, and refused to give up possession pursuant to their notice, when the landlord had agreed with another tenant for the same (Jolinstone v. Huddlestone). A tenant who after having given notice to quit holds over for a year, paying double rent, accorling to stat. 11 Geo. II. c. 19, s. 18, may quit at the end of such year without fiesh notice (Booth v. Macfarlane). Patteson J. held that if a landlord allows his tenant to hold over above a year without taking any step to recover the premises, he is not entitled to the benefit of 1 Geo. IV. c. 87 , s. 1 , which "enables landlords more speedily to recorer possession of lands and tenements unlawfully held over by tenants" (Doe dem. Thomas v. Field).

It is only the lessor or the person who stands in the situation of landlord, and not any one who derives a title from the lessor, who can, under 4 Gco. II. c. 28, s. 1, sue a tenant for double value when there has been a holdiny over after determination of the tenancy; and therefore where A. B., who had let certain premises to the defendant, under a letting which expired on the 25th March, 1858, and had required the defendant, by notice in writing, to deliver up possession on that day, afterwards, but before the end of such tenancy demised the premises to the plaintiff from such 25th of March, 1858, and the defendant held over without paying rent to or otherwise recognising the plaintiff as landlord, it was held that the plaintiff was not the proper person to sue the defendant for double valne under such statute (Blatchford $\mathrm{v}$. Cole).

Where there is a demise to tu'o co-tenants for a term, and one holds over after the expiration of the term without the other's assent, the other is not liable for rent becoming due during such holding over (Dreper v. Crofts). But in Christy v. Tancred-one co-tenant, who assented to the other's holding over after the expiration of the term, was held equally liable with him in use and occupation, so long as the latter continued actually to occupy, but no longer.

A tenant holding over after the expiration of a lease for years may be taken to hold upon any of the terms of such former lease as are consistent with a yearly tmancy, and whether he does so hold or not is a question for the jury on the facts proved; and a covenant in a lease for years ending at Michaelmas that the tenant shall and may retain and sow 40 acres of wheat on the 213 acres of arable land demised, at the seed-time next after the end of the term, and have the on-stand thereof till the harrest then next following, with the use of the premises for thrashing, 
\&c., till a day named, is a term which may be made incident to a tenancy from year to year (Hyatt v. Griffiths).

It was decided in Thomas v. Packer that a proviso in a lease for recutry on nonpayment of rent, is a condition which attaches to a yearly tenancy created by the tenant holding over and paying rent after the expiration of the lease. In Digby v. Atkinson it was held that a covenant to insure was applicable to a new yearly holding. And in Doe dem. Thomson v. Amey, it was held that where a party is let into possession, and pays rent under an agreement for a future lease, which is to contain a covenant against taking successive crops of corn, and a condition of re-entry for breach of covenant, he thereby becomes a yearly tenant subject to that condition. And a right of re-entry for breach of covenant in a lease is uaved by the lessor bringing an action for rent accrued due subsequent to the breach (Dendy v. Nicholl).

The Court of Common Pleas have held in Bramley (appel.) v. Chesterton (resp.) that if a landlord, after giving a yearly tenant notice to quit at the end of his year, afterwards agrees to let the premises to $A$. from the end of the year, and informs the tenant he has done so, who nevertheless holds on the premises for another quarter, and is ejecter, the landlord is not prevented by the receipt of rent from the tenant for such extra quarter from bringing an action against him for the damages occasioned by his holding over, and may recover in that action as damages the amount of the ordinary damages which he has had to pay in an action brought against him by A. for not giving him possession at the time agreed on, and also the costs of such action.

Where A. demised to B. certain lands and premises for one year certain, and then from year to year, so long as the partics should think proper, with power to determine it on giving notice to quit, and the lease contained various terms and conditions as to the management of the land and repairing the buildings, and on the lessee's death his execntors entered into the occupation of the premises, and continued to occupy and paid rent, the latter were held to be chargeable in their personal character upon the terms contuined in the original demise, their continuing to occupy, and the landlord's abstaining from giving notice to quit, raising an implied promise on their parts to abide by the terms of the original contract (Bucku'orth v. Simpson). And per Parke B.: "If the tenant assigns, and the landlord do not give notice to quit, the assignee must be taken to hold on the same terms. That contract the law will imply; otherwise the consequence would be that no action could be bronght on the original demise when there is an occupation from year to year, and the tenant assigns, for there is no 
contract whaterer unless the original contract is transferred by operation of law" (ib.).

Tenants-in-common may join in suing for use and occupation a tenant holding under them; and payment of rent to an agent "on behalf of the family" is evidence of such holding (Last v. Dimn). An action for rent by trants-in-common is in its nature a joint action, and consequently the survivors naty sue for the whole, though the reservation be to the lessors according to their respective interests (Wallace v. Muclaren). And it was decided by the Conrt of Exchequer Chamber, in Henderson v. Eason, that if one of turo tenants-in-common solely occupy land, farm it at his own cost, and take the prodnce for his own benefit, his co-tenant cannot maintain an action of account against the former nnder 4 Amne, c. 16, s. 27 , as his bailiff, by reason of the former having received more than comes to his just share and proportion; the statute applies to eases where rent or payment in money or in kind, due in respect of the premises, is receired from a third party by one co-tenant, who retains for his own use the whole or more than his proportional share.

Where it appeared in evidence that A. and B. had taken some pasturage pointly, and that each had tmmed his eattle upon it (how many was not shown), and that A. paid the whole rent, it was held by Patteson $\mathrm{J}$, in making a rule absolute for a new trial, in an action against B. for half the sum so paid by A., that the jury were not warranted in finding that the share of each was a moiety (Sharpe v. Cmmminys). "If they took the catage together," said his Lordship, "I think it must be taken that there was a partnership, and this case does not come within the rule in Venning v. Leckie, inasmuch as it was not a payment before, but in consequence of the partnership. Suppose they had taken a farm together, can there be any doubt that there would have been a partnership then, and that the plaintiff could not have recovered a payment like this?"

The reservation of a rent in corn means the legal quarter of eight gallons to the bushel. Curn purchased in open market may by the law of Scotlind be recorered from the buyer to satisfy rent in arrear of the current year, the corn being part of the prodnce of that year of the land rented; and this decision was affirmed by the Ilouse of Lords (Junlop v. Juthousio).

Where in a lease of land for 21 years from the 25th of March, 1848 , it was corenanted that the lessee should pay a stipulated sum for the first year, with a proviso that the rent for each subsequent year of the term steould be relluced or increased according to "the arerage mice of wheat in amy one year of the said term," such arerage " to be taken 
and ascertained from the then current year's averages which were taken in the month of January in every year under and by virtue of the Tithe Commutation Act, 6 \& 7 Will. IV. c. 71, s. 56," which is the result of the sales "during seven years ending on the Thursday next before Christmas-day then next preceding"-it was held that the rent must be computed according to such septemial arerage so published in each year, and not, as the defendant contended, according to the average price in any one year of the term (Kendall v. Barker).

A nuisance of a permanent character having been created on land in the occupation of a tenant from year to year, the reversioner is liable for damage caused by it, if it be shown that since the creation of the nuisance, and before the damage, he might have detcrmined the tenancy and did not, such continuing of the tenancy being equivalent to a reletting; and it is no defence that he had no notice or knowledge of the existence of the nuisance. (Gauly v. Tubber, 33 L. J. (N. S.) Q. B., p. 151.

In the Duke of Marlborough v. Osborn, 33 L. J. (N. S.) Q. B., p. 148, it was held that a clause in the lease " the tenant to perform each year" for the Duke of Marlborough, at the rate of one day's team-work, with two horses for every $£ 50$ of rent when required (except at hay and corn harrest) without being paid for the same," extends to other than agricultural work, such as hauling coals; but it does not oblige the tenant to find a cart, plongh, or other vehicle or machine necessary for the performance of the work.

In the case of Crouch v. Tregoming, 7 L. R. Ex. 88 , plaintiff took a farm under lease for seven, fourteen, or twenty-one years from 1858. The lease contained a covenant not to assign or under-let without the written consent of the landlord. The plaintiff, however, sold all his interest in the farm to the defendant by a memorandum of agreement, dated March 10th, 1869, and the defendant entered into occupation in the following May. This agreement was not under seal; nothing said in it about payment of rent, and the landlord's license was not obtained. The defendant paid the rent to the landlord's agent in plaintiff's name, and the receipts were also made ont in lis name. In March, 1870, the defendant gave the landlord notice to quit at Michaelmas, 1870, and he left the far'm at that time. The farm remained empty from Michaelmas, 1870 , to March, 1871, and the plaintiff having paid this half-year's rent to the landlord songht to recover the amount from the defendant.

It was held, however, that he was not entitled to recover, there not laving been any promise to indemnify the plaintiff against rent accruing after the defendant's occupatiou had ceased, nor any such relation of landlord and tenant existing between the parties as wonld entitle the 
plaintiff to the repayment by the defendant either as rent or compensation for use and occupation of the sum paid to the landlord by the plaintifl.

In the case of Few v. Perkins, 2 L. R. Ex. 92, an indenture of lease, with a clause for re-entry, contained a gencral covenant on the part of the lessee to the premises demised in repair, and a further covenant that he would, within three months after notice from the landlord, do all repairs specified in the notice. The demised premises being out of repair, the landlord gare the lessee notice to repair in accordance with the corenants of the lease. Before the expiration of three months ejectment was bronght, and it was held that the notice was not a waiver of the forfeiture incurred by the breach of the general corenant to repair, and that the action was maintainable.

In the case of Hooper v. Clark, 2 L. R. Q. B. 200, one Campbell demised the cxclusive right and license to take and kill game on certain land, with the use of a cottage, to the defendant for a term, and defendant covenanted to leave the land as well stocked with game at the end of the term as it was at the time of the demise. Campbell assigned his reversion in the land and hereditaments to the plaintiff, who brought an action at the end of the term against the defendant for a breach of corenant, and it was held that the plaintiff, as assignee of the reversion, could sue upon the corenant on the demise, was not a mere license, but the grant of an incorporeal hereditament.

The case of Mum v. Fabian, though referring to a house, may, nevertheless, be considered important to occupiers of land : a landlord verbally agreed with his tenant to grant him a lease for twenty-one years at an increased rent, but died before the lease was executed. Before his death, however, the tenant had paid a quarter's rent at the increased rate : held, that this payment of rent constituted a sufficient part performance to take the case out of the Statute of Frauds, and specific performance was decreed. Mum v. Fabian, 1 L. R. Ch. 35.

The leading case on fixtures is Elu'es v. Maw. About fiftecn years before the expiration of his lease the defendant erected upon his farm, at his own expense, a substantial bectst-7ouse, a carpenter's shop, a fuel-house, a cart-house, a mmp-house, and foll-yard. The buildings were of brick and mortar, and tiled, and the foundations of them nearly one foot and a half deep in the ground. The carpenter's shop was closed in, and the other buildings were open to the front, and supported by brick pillars. The fold-yard wall was of brick and mortar, and its foundation was in the ground. 'Jlue defendant, previous to the expiration of his lease, pulled down the crections, dug up the foundations, and carricd away the matcrials, leaving the premises in the same 
state as when he cntered upon them. These erections were necessary and convenient for the occupation of the farm, which could not well be managed without them. A verdict was found for the plaintiff for $\mathfrak{E} 60$, and the question submitted to the Court of King's Bench was whether the defendant had a right to take away these erections. The defendant relied on the cases of Dean v. Allalley, where the tenant was held entitled to remove Dutch barns ; Lord Dudley v. Lord Ward; Penton v. Robart; Lawton v. Lauton ; Culling v. Tuffnal (where the barn's weight sank it into the ground, though the foundations were not dug); and Gould J.'s opinion in Fitzherbert v. Shaw, as to what would have been the right of the tenant as to the taking away a shed built on brickwork, and some posts and rails which he had erected, if he had done so during the term. The Court of King's Bench confirmed the finding of the jury, and decided that the defendant had no right to remove these erections. Lord Ellenborough C.J. said: "The general rule in the first-mentioned case on the subject, as between heir and executor (Year Book, 17 Eelw. II. p. 518, and Co. Litt. 53, Cooke v. Humplirey, \&c.) is that where a lessce having annexed anything to the freehold during bis term, afterwards takes it away, it is waste. This rule at a very early period had several exceptions attempted to be, and at last effectually, engrafted upon it, in favour of trade, and those vessels and uteusils which are immediately subservient to the purposes of trade. But no adjudged case has yet gone the length of establishing that buildings subservient to the purposes of agriculture, as distinguished from those of trade, have been removable by an exccutor of the tenant for life, nor by the tenant himself who built them during his term."

In Culling v. Tuffnal, decided by Lord Ch. J. Treby at Nisi Prius, the barn was only battens and blocks of timber, lying upon the ground, but not fixed in or to the ground, and the tenant therefore, without even any custom of the country, had a right to remore them.

In Wanstrough v. Maton the plaintiffs beld some land as tenants to the defendant, for a term of years determinable on lives. On the expiration of the last life the plaintiffs quitted possession, and the defendant demised the land to a new tenant, who entered. When the plaintiffs quitted they left on the land a stavel barn which they had erected, and for which the action was brought. It consisted of wood resting on, but not fastened by mortar or otherwise, to the caps or blocks of stone (called stavels or staddles) fixed into the ground or let into brickwork, the brickwork being built on and let into the ground in those parts where the ground was lowest, for the purpose of making an eren fonndation for the barn to rest upon. The wooden barn could be taken away without injury to the rest. It is usual, in the part of the 
country (Salisbury) where the barn stood, for the tenants who have built such barns to remove them on quitting, or to have them valued to the incoming tenant. The plaintiffs, after the new tenants had entered, demanded the burn of the defendant off the premises. The defendant said they should not have it till they had agreed with him as to another matter in dispnte; and they afterwards sent men to bring it array; but the defendant being then on the premises, ordered the men to quit the ground, and locked the gates after them. The defendant's comsel applied for a nonsuit, on the grounds, first, that the barn was a fixture for which trover would not lie, and secondly, that no conversion was proved. Liberty was given to move to enter a nonsuit on both points, but the Court of Queen's Bench refused a rule to show cause on the point of the conversion, but granted it on the other.

In discharging it they observed, if they were to decide it was a fixture they should be overruling the decision in Rex v. Otley, where it was clecicled that the wooden windmill resling by its ou'n weight on a brick foundation was not ammexed to the freehold. That, too, was a strong ease, for the mill and ground had been demised together by the same person to the pauper, vet it was held that the mill did not eonstitute a part of the tenement so as to make up the annual value of $£ 10$.

In Wood $\mathrm{r}$. Hewett, the question for the Conrt of Queen's Bench was, whether the water fender or hatch resting on masomy and brickurork fixed into the bank of the mill stream, on the soil of the defendant (who was tenant from year to year of the close adjoining the mill stream) became his property as a necessary consequence of its position. It had been placed there 43 years before, at the time of a former occupier of the close, under whom the defendant claimed. Abont nine years before this action, repairs had been done to the masonry, with assistance from the plaintiff"; and soon afterwards the plaintiff remored the fender and put in a new one, but without the consent of the tenant for life, who, when he knew what had been done, threatened to bring an action. The Court held, on the authority of Rex v. Otley and Mant v. Collins, that where such chattel has been annexed by its owner to another's freehold, but may be severed without injury to the freehold, it is not necessarily to be inferred from the annexation that such ehattel becomes the property of the freeholder. Whether in a particular case it has become so or not, may be a question on the evidence; and a jury may infer, from nser or other circumstances, an agreement that when the chattel was annexed the original owner should have liberty to take it away again.

Wiltsheur v. Collrell was an action for an injury to the reversionary 
estate of the plaintiff in premises occupied by a tenant of the name of May, by removing some staddles, a thrashing-machine, and a granary. Plaintiff had purchased the premises in question from the devisees in trust of one Thomas Cottrell deceased, the father of the defendant, and they had been conveyed to the plaintiff by a deed, to which the defendant was a party, as one of the derisees. Immediately after the conveyance the plaintiff demised the premises to May, and after such demise the erections in question had been removed from them. The deed which the defendant had executed conveyed the land and all fixtures to the plaintiff in fee, and it appeared that the erections had been put on the land by the defendant's father, who had subsequently become owner in fee, and under whose will the title had come to the defendant. The staddles were erections for the support of a rick : they were stone pillars mortared into a foundation of brick and mortar, which was let into the earth : stone caps were mortared on to them at the top; and on these the ricks rested. The thrashing-machine was placed inside one of the barns (the machinery for the hor'se being on the outside), aud there fixed by screws and bolts to four posts which were let into the earth. The granary consisted of a wooden shed tiled over, and rested by its mere weight upon a wooden frame supported by staddles similar to the first-named. Evidence had been given at the trial to show that by the custom of the country an out-going tenant had the right to remore such things at the expiration of his tenancy, and it was further contended that he was entitled to do so by the general law of the land. This the plaintiff denied, and contended that even if it were so, the language of the conveyance took away the right.

A verdict was taken for the plaintiff for $£ 30$, the parties agreeing that the staddles and thrashing-machine should be estimated at $£ 10$, and the granary at $£ 20$, and leave was reserved to enter a verdict for the defendant, or reduce the amount of damages. The Court of Queen's Bench held that the defendant being a party to the conveyance, could not set up any right to remove any of the articles as fixtures removable by an agricultural tenant at the expiration of his term. The land and everything attached to the land passed by the deed, and there was no tenant-right to remove them. The real rnestion therefore was, whether all or any of the articles passed by the conveyance under the words "and all fixtures"; and it was held that the staddles and the thrashing-machine clearly did, and that as they were really attached to and part of the land, their removal was clearly an injury to the reversionary estate, as a removal of so much of the land, so as to make the first count applicable. The question as to the granary was a different one, as it was provecl that that was not attached except by its weight 
to the staddles, and that by sufficient power it might have been lifted from the staddles without disturbing them. Hence it was decided that the granary was a mere chattel, and wonld not be a fixture in the ordinary sense of the word, though it might pass by that word, if from the rest of the conveyance an intention appeared of comprehending farm machinery in general; but that even then the plaintiff conld not recover igniinst the defendant for carrying it away, either as for an injury to the reversion in land, the chattel not being part of such reversion, or, according to Gordon v. Harper, in trover (the sccond count), as the possession of the chattels for the term was in May, the tenant at the time of remoral. The Court, however, intimated that, considering this article was put up so long ago by a party who beeame owner of the freehold, it seemed to have been always demised with the freehold, and remembering the larger meaning of which Baron Parke had shown the word "fixtures" to be capable, they might have held that it passed as a chattel, if either comt could have been supported on that supposition.

The "larger meaning" was given to fixtures by Parke B. in Sheen v. Reckie, where he says, "It does not necessarily follow that the word 'fixtures' must import things affixed to the freehold, nor has the rord necessarily acquired that legal sense. It is a very modern word, and is generally understood to comprehend any article which a tenant has the power of removing, as appears from the case of Colegrave v. Dios Santos; but eren this is not its necessary meaning; it only means something fixed to another ; and every article in this declaration (stores, shelres, closets, cupboards, \&e.) may be a purely morable chattel, and the fit subject for an action of trover. For instance, they might be affixed to a barn, or other structure so supported, as that it might itself be the subject of this form of action." Coleridge J., in delivering the judgment of the Court in Hittsherer v. Cothell, thus summed np the anthorities on which a granary of this description was considered a mere chattel, and neither as a part of the land, or so affixed to the freehold as that its severance would give a cause of action for injury to the reversionary estate in the land, the suljject of the first count: "In Culling v. Tupfnal, a bam erected on pattens and blocks of u'ood, but not itself fixed in or to the ground, was held to be removable. T'he eustom of the comtry was relied on in that case, as making such erections removable liy an outgoing tenant; but Lord Ellentroromgh, in the great case of Ellures v. Hau, in referring to Culling v. Thufinal, treats the barn as laving been clearly removable without any custom, hecause it ures not. a fisture al all, as not hoing fixed in or to the ground. In IJanshrongh v. Juton it was decided that a barn resting by its mere weight on a 
brick foundation was not a fixture, but a mere chattel, for which trover might be bronght. Mr. Justice Patteson referred to that case in Rex v. Ottey, where it was held that a vindmill resting by mere weight on a foundation of brick was not a part of the freehold so as to contribute to the value of the tenement; and in Rex $\mathrm{v}$. Londonthorpe it was held that a windmill not attached to the ground, but constructed on cross traces laid upon brick pillars, but not attached or fixed thereto, was a mere chattel."

If a landlord sumplies timber to erect a buitding, and the tenant so uses the timber together with some which he has himself supplied, he cainnot remove the building on quitting the occupation of the land (Simith v. Render.) The defendant had been tenant to the owner of the field, and obtained permission from his landlord to cut down some timber that was on the field, for the purpose of erecting a cattle-house. The building consisted of six posts, driven four feet into the ground, and a number of smaller posts driven to the depth of eighteen inches or two feet; and this erection was completed except the tiling, and was in a condition to have the timber of the roof put on, and so stood in the field. In this state of things the landlord sold the reversion to another person, and the tenant not wishing to remain a tenant to the new owner of the property, gave him a notice to quit, and before that notice had expired pulled down the builling he had ereeted, and carried away the timber, and insisted that the materials belonged to him. It was contended on his behalf before the Court of Exchequer that the building did not become a fixture until it was completed, and that the tenant had a right to remove any materials which had been inserted in the foundation; and it was insisted that he had passed no conclusive portion of the building materials to the owner of the land, or to the landlord, or annexed them to the land, till the thing was completed.

But per Curiam (which confirmed the rnling of Hartin B.) : "We think that if a person takes from his landlord timber for the purpose of erecting a honse, and does use that timber in it, althongh he may add something to it, yet nevertheless, in point of fact, the true question as between the tenant and the reversioner to the fixture does not arise, whatever might be the case in the event of a man partially erecting a building from materials entirely his own. In this case it is obvious that the original owner of the land never meant this timber to be applied otherwise than to this house ; and if he sold it and the house to the snccessor, the defendant had no right whatever to pull down the building and remove that timber."

The Court of Common Pleas decided in Leater v. Homeu'ood, that the right of a tenant to sever tenants' fixtures from the freehold, cannot 
be exercised after the landlord has re-entered, and all tonancy of any kind has been mut an end to ; and it makes no difference that the tenant has not evinced an intention to abandon his right to such fixtures. And per Curiam: "The law as to the limit of time within which a tenant is allowed to serer from the freehold the fixtures which are usually called 'tenant's fixtures,' is by no means elearly settled. According to the older anthorities, the rule was that he must sever them during the term. Bnt in Penton v. Robart it appears to hare been considered that the sererance might be made even after the expiration of the tenant's interest, if 'he has not quitted possession. However, in Weeton v. Wroodcock, the mle was laid down that the tenant's right continues only during his original term, and such further period of possession by him, as he holds the premises under a right still to consider himself a tenant. It is perhaps not easy to understand fully the exact meaning of this rmle, and whether or not it justifies a tenant who has remained in possession after the end of his term, and so become a tenant on sufferance, in serering the fixtures during the time he continues in possession as such tenant."

Patteson J. held in Leach v. Thomas, that an ontgoing tenant has no right to remove some small pillars of brick and mortar built on a dairy floor to hold pans, although such pillars are not let into the ground. "They-had," his lordship said, " beeome, I think, part of the freehold, and could not be legally removed, and it is not necessary for that purpose that they should have been let into the ground."

In Neal v. Timey, by a written agreement between the plaintiffs and the defendant, the defendant was to accept of the assignment of the lease of a farm from the plaintiffs, and to take the fixtures in the farmhonse and growing crops at a valuation. He was afterwards let into possession of the fixtmres, and the crops which were valned to him, but the lease was never assigned. Lord Eltenborough C.J. held that indebilatus assumpsit would not lie for the price of the firtures and crops, and that the plaintifl's only remedy was by a special action on the agreement. His lordship considered the agreement an entire one, and that fixtures wre not chattels until severanec from the realty. Boydell v. $1 /$. Hichcel decided that a tenant has during the term a sufficient interest in the fistures to enable him to maintain trover against a third party who wrongfully removes them, although at the end of the term he may be bound to leave them for the use of the landlord. And according to Iritrhan $\mathrm{r}$. Wafton, the mortgagee of the tenant may declare in case as rercrsioner against the assignee of the tenant, for the remoral of fixtmes from the premises, whereby they were dilapidated and injured; and he is also entitled, during the term, to recover in trover against 
such assignee the value of all the fixtures, whether landlord's or tenant's, which were affixed to the premises before the execution of the mortgage, although there was a covenant in the original lease to the mortgagor, to yield up to the lessor, at the termination of the term, "all fixtures and things to the premises, belonging to or to belong."

But it was decided in Mackintosh v. Trotter, on the authority of Minshall v. Lloysl, that a lessee even during his term camot maintain trover for fixtures attached to the freehold, and not yet removed by the murchaser. And per Parke B.: "The principle of law, as settled in Minshall. v. Lloyd is that whatsoever is planted in the soil belongs to the soil-quiequid plantetur solo, solo cedit-that the tenant has the right to remore fixtures of this nature during his term, or during what may, for this purpose, be considered as an excrescence of the term ; but they are not goods and chattels at all, but parcel of the freehold, and as such not recoverable in trover." And even during the continnance of the term a landlord may bring trover for machinery annexed to the mill, and which was unlawfully serered from it (Farrant v. Thompson). Trover also lies by the tenant for fixtures which the landlord has severed from the freehold and distrained for rent (Dation v. Whittem). And per Parlie B. : "By a conveyance, whether to a purchaser or to a mortgagee, fixtures annexed to a freehold will pass, mless there be some words in the deed to exclude them. Coleyrare v. Dios Santos is an authority to that effect in the case of a purchaser, and Longstaff v. Mearge in the case of a mortgagee" (Hitchman v. Walton).

The purchaser of lands, dr., having brought an ejectment against the tenant from year to year, the parties entering into an agreement that judtyment shall be signed for the plaintiff, with a stay of execution till a given period, the tenant eannot in the interval remove buildings, de., from the premises which he himself had erected during his term, and before the action u'as brought (Fitzherbert v. Shau'). This case was considered to be completely in point in Hetop v. Barton, where Penton v. Robart was remarked on by Jervis C.J., who said, "There is a view of this case which gets rid of the discrepancy between Penton v. Robcrt and some of the other cases. The tenants here disclaimed; they became trespassers. The Courts," added his lordship, "seem to have taken three separate views of the rule-first, that fixtures go at the expiration of the term to the landlord, unless the tenant has during the term exercised his right to remove them; secondly, as in Penton v. Robart, that the tenant may remove the fixtures notwithstanding the term has expired, if he remains in possession of the premises; and thirdly, that his right to remove fixtures after his term has expired, is subject to this further qualification, viz., that the tenant continues to hold the premises under a right 
still to consider himself as tenant." The Court gave no opinion as to any of these positions, but remarked in reference to the statement in Amos and Ferrard on Fixtures, p. 88 (and eited by Lord Tonterden C.J. in Lyde v. Rnssell) to the effect that a tenant must use his privilege in remoring fixtures during the continuance of his term, for if he forbear to do so within this period, the law presumes that he voluntarily relinquishes his claim in favonr of his landlord:--" Is there any authority for what is said there abont the volmutary relinquishment? May not the rule be this-that the fixtures are the landlord's, subject to the tenant's right to remove them during the term? Suppose the landlord to be a tenant for life, could the tenant, on lis death, remove the fixtures?"

Where by an agreement dated August 21, the defendant agreed to take certain premises at a certain rate, "to commence on the 29th of September," the landlord to take the fixtures at the end of the tenancy, provided they are in the same condition then as they now are; and the defendant agreed "to leare the premises in the same state as they now are ;" the Court of Common Pleas held that "now" might be taken as referring to the commencement of the tenancy; and that a breach "that the defendant did not leave the premises in the same state as at the commencement of the tenancy" was properly assigned (White v. Nicholson).

The lue of fixtures is now put on a regular footing by 14 \& 15 Tict. c. 25. By section 3 of that Act it is enacted, "That if any tenant of a farm or lands shall, after the passing of this Act (24th of July, 1851), with the consent in uriting of the landlord for the time being, at his own cost and expense, erect any farm buildings, either detached or otherwise, or put up any other building, engine, or machinery, either for agricultural purposes or for the purposes of trade and agriculture (which shall not have been erected or put up in pursuance of some obligation in that behalf), then all such buildings, engines, and machinery slatl be the property of the tenant, and shall be removable by him, notwithstanding the same may consist of separate buildings, or that the same, or any part thereof, may be built in or permanently fixed to the soil, so as the tenant making any such removal do not in anywise injure the land or buildings belonging to the landlord, or otherwise put the same in like plight or condition, or as good as the same were in before the erection of anything so removed: Provided, nevertheless, that no tenant shall, under the provision last aforesaid, be entitled to remove any such matter or thing as aforesaid, without first giving to the landlord or his agrent one month's previous notice in writing of his intention so to do; and thereupon it shall be lawful for the landlord, or his agent on his 
authority, to elect to purchase the matters and things so proposed to be removed, or any of them, and the right to remove the same shall thereby cease, and the same shall belong to the landlord, and the value thereof shall be ascertained and determined by two referees, one to be chosen by each party, or by an umpire to be named by such referees, and shall be paid or allowed in account by the landlord who shall have so elected to purchase the same.

Contract for quiet enjoyment.-It was held by the Court of Qneen's. Bench in Hall v. City of London Brewery Company (limited) confirming Bandy v. Cartwright (8 Ex. 913, 22 L. J. (N. S.) Ex. 285), that there is a contract for quiet enjoyment implied in a demise of tenement, but not for good title. A similar promise is not implied in an agreement to give a lease containing such covenant, and further act must be done before the promise arises (Brashier v. Jackson).

Implied agreement for quiet enjoyment. - On a parol tenancy from year to year, it was held by the Queen's Bench that there is no implied agreement for quiet enjoyment beyond the duration of the lessor's interest, and if he is himself a termor, and the tenant was aware of this, the latter, in case of eviction on the expiration of his landlord's term, can maintain no action against him for such eviction (Penfold v. Abbott).

Meaning of "premises."-Where a testator by his will empowered his trustees to permit the person entitled for life or any greater estate in the S. property to occupy the mansion, gardens, and "premises" rent free, and the home-farm had no farm-house, and the farm-buildings and farms were occupied by the testator at the time of his death, it was held by the Lords Justices that the "premises" meant premises in immediate connection with the house, and did not inchde the home-farm (Lethbriclge v. Lethbridge).

Tenancy at will.- When a tenant at will is warned to quit, and afterwards has leave given him to remain on part of the property, this permission commences a new tenancy from the date of which the Statute of Limitation runs (Loch v. Mattherrs).

Demise of three years certain.-A demise by deed for the term of three years, "determinable on a six months" previous notice to quit by either lessor or lessee, otherwise to continue from year to year until the term shall cease by notice to quit at the usual times," is a demise for three year's certain, and the tenancy cannot be determined sooner than by a six months' notice, ending with the third year (Jones v. Nixon).

Action upon agreement for lease.-An agreement not under seal between two persons, by which one agrees to let, and the other to take, certain premises for the term of seven years, and by which it is agreed 
that a gond and sufficient lease of the premises shall be prepared, may be grood as an agreement; so that an action may lie upon it for not nceepting the lease when prepared, although it would be void as a lease in consequenee of s \& 9 J'ict. e. 106, s. 3. And per Blackburn J., the Act of Parliament does not say that the agreement, by which the parties agreed that a lease should be granted, should be void. I do not lnow that there is anything illegal in such an agreement, so that it shonld be roid. The words of the statute merely mean that it shall create no estate and pass no interest" (Bond $\mathrm{v}$. Rosting).

Document roid as a lease requires agreement stemp.- Where a doeument roid as a lease is tendered in evidence to show the terms of a collateral agreement, it requires a stamp as an agreement : per Byles J. (Golden v. Tuylor).

An entry at Old Wichaelmas camot be implied.-In Hogg v. Norris and Berrington it became neeessary to prove a notice to quit, and one was put in served on both defendants on 5th of April to quit at Michaelnas. To make this a sufficient six months' notice, evidence was tendered of the custom of the conntry to quit at Old Michaclmas Day (Oet. 11), and not at New Michaelmas (Sept. 29); but per Erle C.J. : "That evidence is inadmissible; the eustom of the country cannot be set up against the legal presumption, that Michaelmas means any other day than September 29. It must be shown by direct evidenee that this is an Old Michaelmas tenaney.

Effect of contract to repair.-There is no implied contract to use premises in a tenant-like manner where tenant has expressly contracted to repair (Standen v. Christmas).

Tenant in residence not bound to accept agreement for lecase when house is found seriously defertive.-A tenant under an agreement to take a lease of a louse is not bound to aceept it (although he has entered into residence) if the honse upon a competent survey is found defeetive and finished in such a manner, that it is likely to subject the tenant under the covenant to repair to an unusually large annual ontlay to maintain it: per Romilly M.R. (Tildestey v. Clarkson).

Evidence of oral agreement that writlen agreement shall become void in a certain event. - The declaration stated that the defendant agreed to transfer a farm held by him under Iord Sydney to the plaintiff, on the terms and conditions nnder which the same was held by Lord Sydney, and to sell the stock at a certain price, and alleged a breach of that agreement. The defendant pleaded non chsumpsit, and a contemporaneous oral agreement, that in the event of Lord Sydney not consenting to the transfer, the above agreement was to be null and roid, and that Lord Sydney had refused his consent. 'The prineipal agreement was in 
writing, and the plaintiff paid to the defendant $£ 100$, a part of the consideration money, and sold with the defendant's consent a small portion of the stock; but when Lord Sydney refused his consent, the defendant tendered back the $£ 100$, which the plaintiff refused to aecept. It was held by the Conrt of Common Pleas that the evidence of the contemporaneous oral agreement was rightly received; for that under the cirenmstances the inference of fact was that the oral arrangement was intended to suspend the written agreement, and not as a defeasance of it; and that it was not necessary for the plaintiff to produce or cause to be produced at the trial the lease from Lord Sydney to the defendant, referred to in the declaration. And per Curiam: "In Pym $v$ : Camplell (6 El. and Bl. 370, 25 L. J. (N. S.), Q. B. 277), and Davis v. Jones (17 C.B. 625 ; 25 L. J. (N. S.), C. P. 91), it was decided that an oral agreement to the same effect as that relied upon by the defendant might be admitted without infringing the rule that a contemporaneous oral agreement is not admissible to vary or contradict a written agreenent. It is in analogy with the delivery of a deed as an escrow; it neither varies nor contradicts the writing, but suspends the commencement of the obligation. The evidence shows that the defendant introdnced the oral agreement for his benefit, and has treated the written agreement as suspended, having always retained possession of his farm. Also, the subject matter of the two agreements is strong to show that the oral suspended the written agreement from the beginning, and was not in defeasance of it, for the written agreement was to assign, but the possibility of assigning was supposed to depend on Lord Sydney's consent, and the oral agreement that the written agreement should be void if he did not consent, is in its nature a condition precedent. The defendant in effect says, if I have the power to act, I will agree; but if I have no power to act, I will make no agreement at all (Wallis v. Littell).

Valuation agreement.-S. being possessed of a leasehold farm, entered into an agreement with T., whereby after reciting that T. had lent him a certain sum of money and agreed to make him further advances, it was agreed that the said sum, and such sums as shonld be further advanced, should be repaid on the day mentioned, but if S. should not then repay the same, $\mathrm{S}$. agreed to assign the farm to $\mathrm{T}$. for the residue of the term withont any further consideration, together with the furniture and stock at a valuation, and 'T. agreed to pay the amount of such raluation, dedncting therefrom the money adranced. The valuation was afterwards made, and the plaintiff entered into possession, but the defendant refused to receive the balance of the money, alleging that the agreement was for a mortgage and not for a sale, and T. filed a bill for specific performances. 'The Master of the Rolls considered that the 
agrecment was for a mortgage of the said farm, and made a foreclosure deree, and directed an aceount accordingly ; but the Lord Chancellor held, on appeal, that the relation of seller and purchaser was constituted by the agreement, and that the plaintiff was entitled to specific performauce (Tappley v. Shouther).

Costs abidiny event of reference.- Where an action for alleged breaches of corenant in a farming lease, in which the plaintiff claimed $£ 100$ damages, was, after pleas but before issue joined, by a Judge's order and by consent, referred to arbitration, "the costs of the reference to abide the event," and the arbitrators found in favour of the defendant on all the alleged breaches, with the exception of one, on which they awarded $16 \mathrm{~s}$. damages to the plaintiff', it was held by the Court of Exchequer that the event of the reference was in favour of the defendant, and that the plaintiff was not entitled to his costs (Kelcey v. Stupples).

Liability of agent for non-fulfilment of agreement.-The defendant, bonu fice believing he had authority, verbally agreed on behalf of the owners to let the plaintiff a lonse for seven years; and the plaintiff was let into possession by the defendant, and began repairing the premises. The owners had not given the defendant authority, and they informed the plaintiff of this, and brought ejectment against him ; the plaintiff consulted the defendant, who persisted that he had authority, and advised the plaintiff to defend the action, and a verdict passed against him. The plaintiff having bronght an action against the defendant for his breach of warranty of anthority, it was held that the plaintiff could not recorer the costs of defending the ejectment, as they were not the consequence of the defendant's breach of warranty, inasmuch as if the defendant had had anthority, the plaintiff could not have succeeded in the ejectment by reason of the agrcement being verbal only, and consequently creating no more than a tenaney at will. And per Cockbum C.J.: "The plaintiff's remedy, if any, was by groing to a Court of Equity, and eompelling the landlords to execute the necessary documents to complete his title, and if he had been defeated in that application in consequence of the defendant's authority leing negatived, the defendant might have been justly charged with the costs, as the consequences naturally following from the breach of warranty." And per Crompton J.: "This action is brought on the principle established by Collen v. Wright (7 E. \& B. 301, and 26 L. J. (N. S.), Q. B. 147, and in Error 8 E. \& B. 647, and 27 L. J. (N. S.), (2. 13. 215), in this Court and in the Excheqner Chamber, that an agent who holds himself ont as anthorised to contract for another, warrants lais anthority and is liable for the damages flowing from the breach of 
such warranty, and the question is whether my Brother Blacklum was right in holding that the damages in the shape of the costs of the ejectment, did not naturally flow from the breach of the defendant's warranty. I think that he was right; the ejectment would have been wrongly defended whether the defendant had authority or not." And semble per Blackburn J.: "The mere fact of the tenant having laid out money on the premises, with the sanction of the landlord, does not create at law any tenancy other than a tenancy at will " (Pow v. Davis).

Agent camnot let on umusual terms without cognisance of ouner.-A farm bailiff or agent who used to let farms upon the ordinary terms, and received the rents, \&c., was held by Blackburn J., to have no authority in law to let upon unusual terms mnknown to the owner; and the question was left to the jury as one of fact, wliether he had express anthority or had been held out by the defendant as having had it (Tumer v. Hutchinson).

Ratification of agent's bargain by employer.-An agent to receive rents and manage property, having without actual authority agreed that his employer should take the stock, \&c., of an outgoing tenant at a valuation, and the valuation included eatage of fields, in which the employer's cattle were afterwards placed by his servants, and with his knoucledge, such conduct of the employer was held by Byles J., to be a ratification of the whole valuation (Rodmel v. Eden, Bart.)

Wrong information to tenant by receiver as to length of term.-The receiver of an estate in which the plaintiff had an equitable interest under a settlement, vesting it in trustees, let defendant into possession under an agreement with himself in writing in which he deseribed himself as agreeing on hehalf of the estate to let for a term of years, whereas the plaintiff would only sanction a jearly letting. A correspondence ensued between him and the defendant, in which the latter intimated that as he could not get a lease, he should leave as soon as he could, and he did leave before he had been six months in possession. He was held not liable to the plaintiff in trespass or use and oceupation, and semble not at all (Stoper v. Sannders).

Representation by agent that he had authority to contract.-In an action against an agent on the implied waarranty, that he had authority to contract with the plaintiff, the plaintiff is entitled to recover, as special damage, the costs of an unsuecessful action against the alleged principal on the contract (Randell v. Trimen, 25 L. J. (N. S.), C. P. 307), or of an unsuccessful suit for specific performance, (Collen v. Wright), and the liability to pay such eosts is, if properly charged in the declaration, sufficient to sustain the claim for special damage (Rumtell $\mathrm{v}$. 
Ruprer, 27 T. .J. (N. S.), Q. B. 266). In Ramlell v. Trimen, the defendant was clearly liable for his misrepresentation as to his being anthorised to order stone in the name of the clergyman who was the head of the Werneth Chnrch Committee, even though he were honestly mistaken. In Smoul v. Ibury (10 M. \& W. 1), there was no representation at all and no assumption of authority by the defendant, and the plaintiff was misled by a cireumstance equally withont the knowledge and beyond the control of both parties. The plaintiff, like the defendant, did not know that the defendant's husband was dead in foreign parts, and the defendant was therefore not liable for goods supplied to her after his death, but before information of his death had been receired.

Guarantee of solvency of tenant by house-agent. - Where a house-agent is employed to let a house, and charges 5 per cent. commission on letting it, it is a question for the jury whether he undertakes to use reasonable care to ascertain that the person to whom he lets it is in solvent circumstances (Heys v. Tindall).

Assignee of mortgayor letling tenant into prossession.-The assignee of a mortgagor, who has let a tenant into possession after the mortgage, can sue such tenant for use and occupation, notwithstanding notice from the mortgagee to pay rent. A mortgagor in possession agreed to grant a lease to the defendant with the privity of the mortgagees, who, however, were no party to the agreement; the defendant was let into possession under the agreement, and paid rent to the mortgagor. The mortgagor then assigned to the plaintiff, who sued the defendant, after notice to him from the mortgagees to pay them the rent, for use and ocenpation, and it was held that the action was maintainable; and per Martin B.: "The doctrine that a tenant shall not be allowed to deny the title of his landlord is sound, and ought to be supjorted. It compels persons to perform their contracts until something: has taken place, which in justice ought to put an end to them. The dictum in Gouldsworth v. Kriyfht (11 M. \& W. 385), supposed to be contrary to that doctrine, was merely the expression of an opinion and not duly considered." And per Bramuell B.: "The sole question is whether the mere notice was sufficient to terminate the estoppel arising by tenancy? We think it was not. That the assignee of a reversion on a parol tenancy can sne for the rent has been held in Standen v. C'hristmas (10 Q. B. 135, 16 L. J. Q. B. 265)," (Hickman v. Machin).

Fixtures.-MI. being owner of certain land and premises, mortgaged them in fee, but still continued in possession of the mortgaged premises, on which, sulseqnently to such mortgage, he put up and used for the purposes of his trade a steam engine and boiler, also a hay-cntter and 
corn-crusher, and grinding-stones. All these articles cxcept the grindingstones were screwed, or otherwise firmly fixed to the several buildings to which they were attached, but still in such a manner as to be removable without damage to buildings or themselves, and the upper millstone lay in the usual way on the lower. The steam-engine and boiler were nsed for supplying with water certain baths on the premises; the haycutter was attached to a building adjoining the stable to improve its usefulness as a stable, and the malt-mill and grinding-mill were to add to value of premises. In an action by the assignees in bankruptcy of M. it was held by the Court of Common Pleas, Willes J. dub., that the articles were fixtures, and that although they were trade fixtures as well as annexed to the freehold after the mortgage, they enured to the benefit of the mortgagee, and did not pass to the assignees of the mortgagor (Walmisley v. Mitne).

Annexation of chattel to another's frechold.-The mere annexation of a chattel by its owner to the freehold of another, does not necessarily make it the property of the freeholder; but in each case it may be a question whether the owner of the chattel has lost his property in it (Wood v. Hewitt, which governed Lancastor v. Eve).

Landlord's claim for rent under a fi. fa.-The sheriff on a levy under a fi. fa. is liable to the landlord's claim for rent under 8 Ame, c. 14, while the goods remain in his hands, even after sale, and the claim may be made by a mortgagee to whom the mortgagor has attorned as tenant for rent payable in advance althongh no interest has become due. And per Chamel B.: "As long as the goods are in the sheriff's hands, the landlord's claim attaches; and even if he has sold and received the money, the claim attaches to the proceeds in his hands" (Trates $\mathrm{v}$. Routledge).

Presumptive proof that payments were made as rent-charge for common land.-In an action by overseers, for nse and occupation, and for rent of parish lands, evidence that the defendant and his ancestors had for upwards of a century, up to the last ten years, paid rent for the land as "common lands" (he refusing to prodnce the deeds under which he professed to hold), is evidence sufficient to go to the jury, in the absence of any evidence that the payments were made by way of chief rent or rent-charge (Harding v. Hesketh).

Right of presumptive lieir to rents up to birth of posthumous son.-The right of a presumptive heir to the rents which accrue due between the death of an ancestor and the birth of a posthumons heir, extends to all rents which have acerued due in the interval, and whether actually received or not, and whether in respect of fee simple or entailed estates (Richards v. Richards). 
Tenants in ancient demesne liable to pay counly rates.-Tenants of land in ancient demesne are not by reason of their tenure exempted from liability to pay comnty rates (Rey. v. Inhabitants of Aylesford).

Reccipt of rent from third parly evidence of survender by operation of lau:.-It was held by Blackburn J., in Law'rance r. Fuux, that receipts for rent receired by a landlord from a third party were held evidence of a surrender by operation of law, putting an end to the liability of the former tenant.

The holding over to entille to double rahu must be contumacious.-B., a tenant to S., after the death of $\mathrm{S}$. aceepted a fresh term from his devisee. He aftermards found that the heir-at-law of $\mathrm{S}$. disputed the will, and from the circumstances of the case, he reasonably and bon $\hat{a}$ ficle believed that the derisee had no title, and that the land belonged to the heir-atlaw. B. thereupon refused to pay rent to the devisee, who gare him notice to quit. As B. did not quit at the expiration of his term, the devisee, who had made ont her title to be good, brought an action against B., under statnte 4 Geo. II. c. 28 , s. 1 , for donble value. It was held by the Court of Exchequer that to enable a landlord to recorer double value under $4 G e o$. II. c. 21 , the holding over must be contumacions. A holding orer under a mistaken belief that a third person who claimed the reversion is entitled, is not sufficient to support the action, even although the tcnant was let into possession by the landlord, and the third per'son does not claim throngh, but adversely to him. 'This was decided on the judicial construction given to the statute in Wright v. Smith (5 Esp. 203), and Soulsby v. Neving (9 East. 310). This decision was affirmed in the Exchequer Chamber, which considered that the action was not maintainable, and that to come within the statute the holding over must be with the couscionsness on the part of the teuant that he has no right to retain possession (Swinfen v. Bacon).

Ejectmont ly morlyagor. $-\Lambda$ mortgagor before mortgage let a farm to $P$. as tenant from year to ycar. After the mortgage, P. let the defendant into possession in his stead, and informed the mortgagor of the fact, and the mortgagor subsequently receired rent from the hands of the defendant. It was held that the tenant's term was still in P., there being no effectual surrender, and conseqnently that the mortgagee could not maintain ejectment against the delendant without a notice to quit. Aud per Marlin B. : "There can be $n$ o assignment of a term cscept by deed, and there cannot be a surrender by operation of law withrut the assent of all parties" (Trem/ v. ITunt).

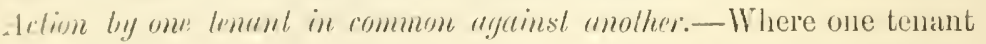
in common brings an action against his co-tenant, and the declaration talies 110 notice of the plaintiff"s limited interest, but alleges an expul- 
sion or total destruction, the defendant may pay money into court in respect of the damage to the plaintiff's share; and as to the residue, plead liberum tenementum, or traverse the plaintiff's property (Cressucelt v. Hedlyes).

Taking farm and paying tenant-right to false devisee.-A defendant who had taken a farm withont any agreement, but by arrangement for a yearly tenancy, he paying the usual tenant-right, which ineluded a valuation for dung for which $£ 62$ was paid to the person in possession and claiming as devisee under a will, was held by Williams J. liable in trover when the will was set aside to the plaintiff, who took out letters of administration, as the personalty vested in him by relation (Learson v. Robinson).

Enforcing specific performance of farming agreement.-An agreenent for a farming lease was entered into in Oetober, 1855, for twelve years. In Febrnary, 1859, the landlord gave notice to quit, on the ground of the lands not being farmed according to the agreement. In November, 1859 , the tenant paid the balance of rent up to the previous Michaclmas, the receipt expressing that it was withont prejudice to any question. In December, 1859, an action of ejectment was commenced, and thereupon the temant filed a bill for sprecific performance of the agreement, and to restrain the action; the evidence as to the tcnant's farming was conflicting. A decree was made by one of the ViceChancellors for specific performance of the agreement; the lease to be dated in October, 1855, and the tenant to admit in any action for breach of covenant that the lease was execnted at that date, and an injunction to restrain the action was granted, and on appeal this deeree was confirmed. And per Lord Chancellor Campbell, affirming Stuct V.-C.'s decree: "The eases of Gregory v. Wilson (9 Hare, 683, \& 22 L. J. (N. S.) Ch. 159) and Lewis v. Bond (18 Beav. 85) are mell decided; and I mean entirely to be bound by the doctrines there laid down. If there has been a breach of the agreement, and if there has been what would have amonnted to a breach of the covenants which ought to have been introdnced into the lease had the lease been granted, which would have worked a forfeiture, and that is clearly made ont, then there is an answer to the bill, and specific performance shonld not be deerecd. But if that is not made out, then $I$ think the proper course to be adopted is that which was adopted in the two cases that have been referred to, of Pain v. Coombs (1 De Gex \& Jo. 34) and Lillie v. Legh (3 De Gex \& Jo. 204), which is to decree specific performances, and to dircet that the lease should bear date at the date of the agrcement, giving the landlord the opportunity, if he thinks fit, of bringing an ejectment for the forfeiture, and so to recorer possession 
of the premises." His lordship added : "There is considerable difference of opinion as to the four-course system and what constitutes a breach of it, particularly with regard to fallow; what would be a breach of the corenant that they should lay fallow one year; whether a green crop is allowed, and what green crop is allowed" (Rankin v. Lay).

The stat. 5 Trict. sess. 2 , c. 27 , for better cnabling incumbents of ecclesiastical benefices to demise the lands belonging to their benefices upon farming leases, does not abridge any right of leasing formerly cnjoyed by the incumbent, and so it was held in full Court of Appeal (Green v. Jenkins).

Letting by incumbent.-An agreement to let a farm less a stated number of acres will be supported in equity, thongh the lands to be excepted were not specified. A rector agreed to let a farm, except 37 acres, with liberty to plant not more than 10 acres of ground. The tenant took possession; but before the lease was exeented, disputes arose respecting the lands to be taken by the rector; and on a bill filed against the tenant for a specific performance of the agreement, it was held by Sir J. Romilly M.R. that the rector had a right to select the lands to be reserved, as the lease had not been executed; but that had it been executed, the rector conld not have taken any lands without the concurrence of the tenant. It was held also that the right of selcetion must be exercised so as not to prevent the useful occupation of the rest of the farm; and with these declarations, a decree was made for a specific performance of the agreement (Jenkins v. Green).

If a farmer contracts with a rector for a lease of glebe lands the Court will not assume that both parties had an enabling statute present in their minds, and modify the express terms of the agreement to make it conform to the provisions of the statute. Where an agreement had been made by a rector to grant a lease of glebe lands at a rent to be paid half-yearly, the Court will not vary the agreement in accordance with the provisions of 5 Vict. sess. 2, c. 27 , and direct the rent to be paid quarterly. A decree was made for the specific performance of a lease of glebe lands. The decree was duly enrolled; it was, however, subsequently found that the agreement and the statute enabling incumbents to grant leases of their glebe land did not conform. It was held by Sir. J. Romilly M.R., notwithstanding the prerious proceedings, that the bill must be dismissed, but withont costs (ib. Ch. 280). And glebe lands which have been usually let on lease hy incumbents are not within the 5 Vict. sess. 2, e. 27 (ib. Ch. 822). If an incumbent contract to let lands belonging to the benefice for a term 
of years, his resignation of the living during the term is a breach of his eontract (Price v. Williams).

"Lessee of a farm bound to deliver lease to tenant who took it off their hands." On a contract by a letter of the defendant, assented to by the plaintiffs, to take a farm off their hands provided he was accepted by their landlord on the covenants to the lease, it was held by Blackburn J. that they were bound to procure and deliver to him the lease; and it having been deposited as security for a loan, and they not having procured it, the plaintiff's were nou-suited (Burton $\& A n$ other v. Banks.) 


\section{CHAP'TER XIV.}

\section{CONTRACTS AND SALES.}

If parties enter into an agreement, they are not the less bound by it because they send it to a solicitor to reduce it into form ; but the presumption is, if they send it without having previously arranged to that eflect, that they do not mean to bind themselves until it is reduced into form (Ridyuray v. Whaton). When an offer in writing is mate by the owner to sell an estate on specified terms, and this is mnconditionally accepted, there is a binding contract which neither party can vary ; but the owner is entitled, at any time before his offer has been definitely accepted, to add any new terms to his proposal, and if those are refused the treaty is at an end. And so it was decided by the Honse of Lords, in Honeyman r. Harryat, confirming the decision of the Master of the Rolls. 'Thus where a person proposing to sell an estate receives an offer, and his estate-agent answers, "Il has authorized us to accept the offer, subject to the terms of a contract being arranged between his solicitor and yourself," the answer does not constitute a complete contract; and the vendor is at liberty to add other terms, and on their non-acceptance to break off the treaty $(i b$.$) .$

A vendor has duties inseparable from that character which he is bound to perform, and cannot aroid by restrictive conditions of sale; and hence he is not justificd in rescinding a contract under a restrictive condition of sule reserving that pourer, when he has not answered the purchaser's requisitions, or made an attempt to answer the objections to the title. I'er Sir.J. Lomilly M.R. (Greaces v. Witson).

Where there is a contract with respect to a particular thing, and that thing camnot be delivered owing to it perishing without any default in the seller, the delivery is exensed. In the case of Howell and Coupland, 9 I. R. Q. B. 462, the defendant in the month of March entered into an agreenent to deliver to the plaintiff in September or October 200 tons of Tiegrent potatoes. The refendant planted in fact sixty-eight acres of land with potatoes, and this in an average year would have been amply Euflicient to produce 200 tons of potatoes; but a blight attacked the crop, and the defendant was only alle to deliver eighty tons. The 
plaintiff therempon bronght an action for the non-delivery of the 120 tons, but the Court held that he was not entitled to recover becanse performance of the contract became impossible from the perishing of the thing withont defanlt in the contractor: See Taylor v. Caluluell, 32 L. J. Q. B. 166.

It was decided in Viney v. Chaplin by the Lord Chancellor and Lord Justices, confirming the opinion of Kindersley V.-C., that there is no general rule that, in every case of a nurchase, the purchaser can insist upon the vendor personally receiviny the purchase-money; but the vendor is not entitled to refuse upon the reasonable request of the purchaser, where the special circumstances would suggest such a step; and in every case where the vendor does not attend personally to receive the money, the purchaser can require the written authority of the vendor for the receipt of the money by an agent. The vendor's soticitor is not cntitled to receive the purchase-money by virtue of his office, and neither he nor any other person merely because he has possession of the deed of conveyance with receipt endorsed, executed by the vendor (ib.). Where a purchaser requires the vendor to execute the conveyance in the presence of the purchaser or his solicitor, the onus of justifying the refusal is on the vendor ( $i b$.).

The purchaser cannot recover expenses incurred previously to entering into the contract; nor the expense of a survey of the estate made before he knows the title; nor the expense of a conveyance drawn in anticipation; nor the extra costs of a suit for specific performance brought by the venclor; nor losses on the resale of stock prepared for the firm (Hodlyes v. Litchfield); and where a lessee with pourer to alter and immove had an option to purchase, and after laying out money in improvements elected to purchase, and the title proved bad, he was held entitled only to damages for the breach of contract, but not for the expense of improvements (Worthington $\mathrm{v}$. Wrerrington).

Where an agent employed for an agiced commission to sell land at a given price succeds in finding a purchuser at such stipulated price, but the principal, from whatever cause, declines to scll, and rescinds the agent's anthority, the latter is entitled to sue for a reasonable remuncration for his work and labour, and is not bound to resort to a special action for the wrongful withdrawal of the authority (Prickett v. Badyer). In such a case, a contract to pay what is reasonable is implied by the law ; and it is not a question for the jury. And semble per lrilles J., that under such circumstances the proper measure of thamages would be the entire amomut of the commission agreed for (ib.).

$A$ contract for the purchase of lame by a company under 8 \& 9 Tict. c. 18 , is complete when notice to take the land has been served, and the 
value has been fixed by an arbitrator appointed by the owner and the company ; and such a contract will be enforced in cquity, notwithstanding the special prorisions contained in the act relating to compulsory purehases (Reyent's Canal Company v. W'are). And if an ouner of land compelled to sell delays the completion of the purchase, interest will stop upon an appropriation of the purchase-woney, with notice that it is unemployed (ib.). It is not the course of the Court, when it entertains jurisdiction in specific performance, to permit an action at law to proceel for the same subject-matter (The Duke of Beaufort v. Glymi). And per Lord St. Teonarels, it is no objection to the specific performance of an agreement that collateral circumstances necessarily arising out of the agreement are not mentioned in it (Ridguay $\mathrm{v}$. Jharton).

1 contract may be aroided by a false and fraudulent representation, though not relating directly to the nature or character of its subjectmatter, if it is so closely connected with the contract, as that the party sued upon it would not, but for the representation, have entered into it, and was induced to enter into it to the knowledge of the other party by such representation. And hence in an action for not giving up possession of a farm, under an agreement to assign it to the plaintiff, a plea that the plaintiff held it on lease containing a corenant not to part with, assign, or underlet withont the landlord's consent (the covenant being accompanied with a proviso for re-entry in case of breach), and that the plaintiff falsely and fraudulently represented to the defendant that the plaintiff had provided a respectable tenant, whom the landlord would accept, and thereby induced the defendant to enter into the arrreement-was held on demurrer by the Court of Common Pleas to be good (Canham v. Barry).

Kinderstry V.-C. held that where coal mines are viorlecd under an agrement which provides that when the workings shall have finally ceased, the pits shall be filled in, and the ground restored to cultivation, the cessation of the works and the filling up of the pits, and the restoration of the land, does not prevent a re-working of the mines under the agreement (Remsden v. Hirst). An objection to the title on the ground of such right to re-work is valid, and a purchaser is entitled to compensation, to be estimated by taking all the cireumstances into consideration (ib.).

An ouner in fee sold and coniryed tu'o closes, $A$ and $B$, by instruments executed on the same day to different purchasers. A was separated from the highway hy $\mathrm{B}$, over which, previous to the sale, the tenant of $\mathrm{A}$ used a way, which was the shortest from $A$ to the highway. Another more circuitous way existed, which had been, long before the sale, 
specially granted to the occupiers of two closes lying beyond A, and except by one of these ways the occupicr of A could not reach the highway. The Court of Exchequer held that if the conveyance of $A$ was exeeuted first, there was a way (the shortest) by implied grant; and if last, by implied reservation (Pimnington v. Galland).

Where, as in Mews v. Carr, the plaintiff put up for sale by publie auction a quantity of timber, several lots of which were unsold, and a fow days afterwards the defendant ealled upon the anctioneer, and selected from the catalogue two of the unsold lots, which he agreed to purchase, and the latter then wrote, in the defendant's presence, his name in the catalogue opposite these lots, it was held by the Conrt of Exchequer that the auctioncer was not the agent of the defendant so as to bind him by signing his name, and that there was no sufficient note or memorandum of the bargain to satisfy the 17th section. Bramerll B. said: "The observations of the Court, in Graham r. Musson, must not be misunderstood. There the Court said that if the travelter had signed the defendant's name, and had not expressed any dissent, that would have been a reeognition of agency. Here the auctioneer signed the defendant's name, not purporting to act for him, but as the person who sold the goods. It is now established that an auctioneer at the time of the sale is agent for both buyer and seller; but as soon as the sate is over, the reason for the rule faits, and he is certainly not the agent of the buyer, unless he has some authority to act on his part."

The mere entry by an anctioneer's clerk of the price at which a lot is knocked down is not sufficient to satisfy the 19th section of the Statute of Frauds. Pierce v. Corf, 9 L. R. Q. B. 210.

In Ockenden v. Henly, one of the conditions of a sale by auetion was, "If the purchaser shall fail to comply with the conditions, the deposit shall be actually forfeited to the vendor, who shall be at liberty to re-sell, and any deficiency upon re-sale, together with the expenses, shall be made good by the defaulter, and on non-payment shall be recoverable as liquidated damages, but any increase of price at the second sale shall bclong to the vendor." Default having been made by a purchaser at the anction, and the property re-sold at a reduced price, it was held, by the Court of Queen's Bench, that the vendor conld recover from the defaulter, in addition to the deposit, only so much of the difference between the two prices, and of the expenses of re-sale, as the deposit did not cover.

And per Lord Campbell C.J.: " We think the difference between the balance of the purchase-money on the first sale, and the amount of the purchasc-money obtained on the seeond sale, or in other words the 
deposit, althongh forfeited so far as to prevent the purchaser from ever recovering it back, as without a forleiture he might have done (Pulmer r. Temple), still is to be brought by the seller into account, if he seeks to recorer as for a deficiency on the re-sale." His lordship added that lie had consulted Lord St. Leonerels on the point, and that he quite coincided with the Court on the point.

As between vendor and purchaser, a lille dependent on a question of fact, which it is impossible to consider as reasonably certain, is not a good or sufficient title; and therefore it was held by the Court of Common Pleas, that an intended purchaser, who by the conditions of sale is to have a good title made out, may, npon such an insufficient title being oflered to him, recover lack his deposit money and expenses, in an action against the intended vendor' (Simmons v. Heseltine).

It was held by the Privy Council in Dimech $v$. Corlett that one perty to a contract cannot, withoul the privity or consent of the other party, substitute a third person in his place, on simply guarantecing the solvency of such third person; and the only exceptions are in the cases of negotiable and transferable instruments. And where a contract concludes with a penalty, the intention of the parties is the sole guide as to its effect, and this intention is determined not merely by the term "penalty" or. "liquidated damages," but the Court will look at the whole document (ib.).

Where certain property was assigned to $B$., an anctioneer, upon trust for sale, and to apply the moneys arising therefrom in payment of the expenses of the deed of assignment, and of effecting such sale, "including the usual anctioneer's commission," and upon further trust; it was held by the Lord Chief Justice that B. was entitled, in taking the accomnts between himself and the assignor, to be allowed the usual charges for commission made by him as auctionecr (Douglass r. Archbull). On a sale by auction of land in lots, the murchaser of the lot largest in value, in the absence of any conditions respecting them, is cntutled to the custorly of the litle-deeds relating to all the property ; but if there be a condition that the purchaser of the "largest lot" shall have them, that must mean largest in superficial area (Griffiths v. Halchard). Where scveral lots (growing crops) are knocked domn to a bidder at an auction, and his name marked against them in the catalogne, a distinct contract arises for each lot; and a memorandum signed afterwards by the bidiler, stating that he agrees to become the purchaser of the screral lots set against his name, does not require a stamp, though the aggregate exceed $£ 20$ in value, no single lot being of that price (lioots v. Lord Dormer).

If tam generelly remuted to be mater-meadow is sold by the assignees 
of a bantrupt by the Atescription of uneommonly rich water-meaduw whereas in liact it is very imperfectly watered, this is not suctu a misrepresentation as will aroid the sale (Scott v. Manson). And where an estate consisting of fen land, and so described in the particulars of sale, was charged by a local but public act of parliament with drainage and embanking taxes, of which the purchaser had no express notice, it was held that he was not entitled to compensation for those taxes (Barraud v. Archer). A point of this kind arose in Hanks v. Palling, where the defendant purchased at a public auction a lot comprehending a frechold messuage and a fee farm rent of $21 s$. By the conditions of the sale, no evidence was to be required of the receipt or payment, or existence of the fee farm rent other than that declared by a certain conveyance, "nor should any objection be taken to the title in consequence of the nonpayment or non-receipt," thereof. It was discovered that, in fact, the rent had not been paid or received for 20 years before the sale; and the purchaser therefore contended that it was extinguished mder 3 \& 4 Will. IV. c. 27, s. 34 , and had ceased to exist at the time of the sale; but it was held by the Court of Queen's Bench that he was not entitled to repudiate the contract on this ground, but must be considered to have purchased under the conditions of the sale, the chance of the rent being obtainable. The Court did not feel enlled upon to give an opinion upon the point whether, after the expiration of the 20 years, there was an absolute bar. The purchaser made an objection which was excluded by the conditions of sale, and an agreement to purchase a rent under the circumstances, taking the risk of it not having been paid, was perfectly valid.

A sate by scaled tenders is in effect the same as a sale by anctionper Lord Cranuorth Ch. (Barlow v. Ostorne). It was established, in Shetion v. Livius, that the printed particulars under which a sale by auclion proceeds cannot be varied by parol evidence of the verbal statement of the auclioneer at the time of the sate, either as to the parcels or quality of the subject-matter of the sale; and it makes no difference that the question arises on a sub-sale of the same subject-matter by the purchaser. Here the lot 6 in question was described as "ten acres of spring wheat on further hill"; and at the bottom of the handbill was this memorandum - "The keep of all the fields, until Old. Michaclmas Day, will be sold with the crops, except St. George's Field (lot 15)." The plaintiff bought lot 6 for $£ 7$ 15s. per acre, and the auctioneer made an entry in his sale-book at the bottom of the description of lot 6 . The description and minute then stood as follows: "Tot 6 . Ten acres of spring wheat on further hill, Mr. Shelton, $£ 715 s . "$ Shortly afterwards, a little conversation cnsued between the plaintiff and the defen- 
dant, and the latter requested the anctioneer to put him down as the purchaser of lot 6, and he accurdingly inserted ("Mr. L.") after the words "Mr. Shelton" in the minute. The wheat proved not to be spring wheat, but red Lammas wheat, which, though sown in the spring, is more liable to blight and mildew. The defendant had offered to sell the crop to a third person, and had paid the plaintiff a $£ 35$ s. deposit; but as the erop became damaged with mildew, he refused to complete the bargain. In an action for the price, parol evidence was offered to prove that the anctioneer had explained, in defendant's presence, at the time of the sale, that the wheat in question was not spring wheat, and that the keep of the field with respect to this lot was not to be sold. To this it was objected for the defendant, that as a written instriment was signed by the anctioneer, the accredited agent of both parties, at the time of the sale, with the purchaser's name, its terms conld not be varied by parol, and it could alone be looked at to ascertain what was the contract between the parties. The Court of Exchequer conld not see anything in the distiuction which was taken betreen the case of Shelton as buyer and Livins as bnyer, and confirmed the nonsuit.

The general rule is that parol cridence is not receivable which goes to vary and limit the written contract between the parties. Thus where the printed conditions of sale of timber growing in a close did not state anything of the quantity, parol evidence that the anctioneer at the time of sale warranted a cortain quantity is not admissible as varying the mritten contract (Powell v. Edmunds). The case of Greaves v. Ashlin is also decisive that parol midence is not admissible with respect to trrms which appear on the fare of the contract. In Jeffrey v. Walton the memorandum was clearly imperfect, and some evidence was necessarily required to show the other parts of the agreement.

In Simith r. Jeffryes, the Court of Exchequer considered that the plaintiff, who sued in assumpsit for the non-delivery of sixty tons of "Ware potatoes," at $£ 5$ per ton, according to a written agreement, had no right to show that he had in fact contracted for the sale of a particular kind of Ware potatoes, viz., "Pegent's Wares," while those offered by the defendant were of an inferior lind, or "Kidney Wares." There were three qualities of potatnes in that part of Kent where the contract was made-Wares, Middlings, and Chats-of which the Wares were the largest and best. The plaintiff had a rerdict, but the Court granted a new trial for improper reception of evidence. Again, on a uraranty of mime sinyel bacon, evidence was held not admissible of a practice in the bacon trade to receive bacon to a certain degree tainted as prime singerl bacon (Tates r. Pym). And so parol evidence 
is inadmissible to explain that on a contract to sell wool "to he paid for by eash in one month, less 5 per cent. discomt," the ventor has a lien on it for payment by usage of the trade (Sportuli v. Benecke, Godts v. Rose).

Parol evidence is, however, admissible to explain trade terms. And ver Parke B., in Hutchinson v. Bouker, where parol evidence was admitted for the purpose of showing that there were two descriplions of larley in the same market, one "fine" (which was the heavier of the two) and one "good." "The law I take to be this: that it is the duty of the Court to construe all written instruments : if there are pecnliar expressions used in it which have in particular places or trades a known meaning attached to them, it is for the jury to say what the meaning of these expressions was, but for the Court to decide what the meaning of the contract was. It was right, therefore, to leave it to the jury to say whether there was a peculiar meaning attached to the word 'fine' in the corn-market; and the jury having found what it was, the question whether there was a complete acceptance by the written documents is a question for the judge." And an agreement to sell oats at so much per bushel must be taken to mean the legal standard bushel, and will not be supported by evidence to sell by some other bushel (Hockin v. Cooke).

In Studdly v. Saumders parol evidence was admitted to show that cider in Devonshire (which diminishes in quantity in the course of manufacture at the average of six or eight gallons per hogshead) mcans apple-juice as soon as it is squeezed from the apples, without undergoing further preparation. And so again, in Spicer v. Cooper, to explain the wording of a hop-contract, where one of the items in the written eontract signed by the defendant, was to the effect that the defendant had sold the plaintiff " 18 pockets of Kent hops at 100 s." The declaration stated that he had sold the pockets at $£ 5$ per crt., bnt failed to deliver them according to promise, and Non assumpsit was pleaded. It appeared that a pocket of hops contained more than one cwt., and that the defendant had proposed to deliver the hops at $100 \mathrm{~s}$. for such pocket; but it was held that the plaintiff was justified in showing by parol evidence, that by the usage of the hop trade a contract so worded was understood to mean $£ 5$ per cwt. Plaintiff had a verdict, and a rule for a nonsuit was refused. Lord Denman C. J. said, "In this case the contract was either simply 'at i00s.' in which case evidence was admissible to explain in what sense such words are nsed in the trade, or it is a perfect contract at ' $100 s$. per poeket,' in which case evidence is admissible as to the sense in which the trade understand the word 'pocket' so used. Thercfore in either view of the case there should be "no rule." 
And where the defendant, as in Smith r. Iritson, demised a rablit warren to the plainditts. and covenanted that they shond lerte 10,000 rebbits on the waren at the expiration of the term, and receive payment for those and any more than that number at the rate of $\mathfrak{E} 60$ per thousanl, the question arose as to whether by the Suffolk custom the word "thousand" meant 1:00 as applied to rabbits. Two indifferent persons estimated the rabbits at 1600 dozen, and hence the defendant paid into Court a sufficient sum to pay for 16,000 rabbits, and contended that thousaml meant one mundred dozen, while the plaintifis contended that he ought to play for 19,200. Under the direction of Garrow B. the jury found for the defendant, and the Court of King's Bench refused a new trial. Lord Tenterden C. J. said, "There is no act of parliament which says 1000 rabbits shall denote ten hundred, each hundred consisting of five score; and that being so, we must suppose the term thousend to have been nsed by the parties in the sense in which it is usually understood in the place where the contract was made, when applied to the subject of rabbits ; and parol evidence was atmissible to show what that sense was."

Here worls of description in a deed of conveyance not operating by way of estoppel, may be contradicted by parol ; thus the lessee of land described as "meadow," may prove it to have been arable in an action by the lessor for ploughing it up (Stipwith v. Green); or he may.show that land described as containing 500 acres does not in fact contain so many ( $S . C$. as reported Bac. Ab. Pleas I., 11) ; or contains many more (.Jack v. Mc Intyre). Pastura bosci may be explained, by usage and later admittances, to mean the soil and wood itself (Doe v. Beviss).

A dect takes effect from the delivery, and not from the date; therefore parol evidence was allowed to show that a lease dated on Lady Day 1788 , and purporting to commesce on Lady Day last past, was in fact executed after the date, and that the term therefore commenced on Lady Day 1783, and not 1782 (Steele v. Mart). But where it was agreed in writing that A., for certain considerations, should have the prouluce of Boreham mealou, it was held that he could not prove that it was at the same time agreed by parol that he should have both Milcroft and Borelian meadow (Ileres v. Ansell). And see Hope v. Atkins.

According to Lorymer v. Simith, a refusal to show in bulle, justifies a jurcleaser in rescinding a sule, aren after bought and sold notes have bcen exchanyed. 'The contract here made was for 1400 and 700 bushels of wheat, at 9s. Gd., on Sept. 11th, "Jankers' bill if required"; and on Sept. 19th, according to the usage of the place, the plaintiff went to the defendant's warchonse to inspect it in bulk, in order to see if it 
corresponded with the sample. The 700 -bushel parcel was shown lim, but the other of 1400 was not there. Plaintiff oflered to send a loarl to him for his inspection, or to send for a bushel at that time; but declined to show the whole, as he did not choose to let defendant into his connections. Under these circmmstances, the latter relused to have the wheat, although he receired a message a few days after, that the whole 1400 bushels were in his loft, ready for inspection and delivery, on a bankers' bill being given for the price. It was held by the Court of Queen's Bench that, under these circumstances, the contract was rescinded, and that the seller, having refused to show the wheat when required, conld not afterwards insist upon the performance by the buyer.

A variation made in a contract without the surety's consent discharges him, atthough his riste u'as not thereby increased. And so it was held by the Court of Queen's Bench, in Witcher v. .Fames Hall. The agrcement here was to the effect that one Joseph Hall was to have thirty corrs for' the dairy year, at $£ 710$ s. a cow per annum to be paid quarterly in advance, beginning from 4th of February, 1824. On that day only ten cows had calved, but the plaintiff in March added two ; and what with deaths, slips, and takings away with the consent of. Joseph IIall, the latter had, on the average, only twenty-eight cows. All these deviations were made without the knowledge of the defendant, who laad agreed to pay the rent in consideration that plaintiff performed his agreement. Plaintiff got a verdict for the rent of as many cows as Joseph Hall actually had, but a rule for a nonsuit was made absolute. The Court (Littledale lliss.) held that the rent was an entire, and not a divisible contract; and that the defendant was a mere surety, and plaintiff in an action against him must prove a literal performance of the contract.

Where the defendant agreed by a written contract to purchase of the plaintiffs 300 hogs of bacon, to be delivered at fixed times and in specified quantities, and after a part of the bacon had been delivered requested the plaintiffs as the sale was dull not to press the delivery of the residue, to which they assented--this request was held by the Court of Queen's Bench, in Cuff r. Pemn, to be only a parol dispensation of the performance of the original contract, in respect to the times of delivery, and therefore not affected by the Statute of Frands, and the defendant was held liable for not accepting the residue within a reasonable time afterwards.

The ordinary rule of buying by sample was thus laid down by Cresswell J. in Cook v. Riddetien: "Under ordinary circumstances a person who buys goods by sample may return them if they do not answer the sample, but he must do this within a reasonable time; and if after 
objecting to the goods he still retains them, he is bound to pay for them, making such a dednction as he may be entitled to by reason of their reduced value." 'The case of "sele of specific goods, with a warremty that they were equal to the semple, was considered in Cormerte v. Gillis (where the plaintifl" was a secdsman, and the defendant a gardener), and much more recently in Dau'son v. Collis. In the latter case a plea that the defendants male the promise in respect of 31 pockets of hops bargained and sold by the plaintiff to the defendants; and that at the time of the promise the plaintiff produced and showed defendants a sample, and promised to deliver hops equal thereto, \&c., but that the hops were not equal to the sample, and that therefore they refused to acept them, was held bad on special demurrer, as amounting to non assumpsit. Jereis C.J. said, "This plea is no answer to the action. I am inclined to think, according to the principle of Street v. Blay, that on the sale of a specific article (as alleged, in this plea) the buyer has no right to repudiate the article if it does not correspond with the sample, but that his proper remedy is to briug a cross action on the warranty, or to set up the breach in reduction of damages. But it is unnecessary here to express any opinion upon that point, because if proof of the warranty on the part of the plaintiff be a necessary condition of his recovering, there is no promise on the part of the defendant to pay, unless the specific article corresponds with the sample, and that is a defence under non assumpsit. The case of Parsons v. Sexton is expressly in point, except that ther'e was no delivery of the steam-engine."

And per Manle J.: "It seems to me that the principle of s'treet $\nabla$. Blay ought to be extended, and that the just and convenient thing is, that the vendee should have an action for the breach of the warranty, or that he should give it in evidence in reduction of damages, as in Allen r. Cameron and several other cases" (it.). But where, as in Sirecking v. Dullon, the defendant pleaded to a count upon a contract by him to receive a certain quantity of wool of merchantable quality from the plaintiffs at a certain price, that at the time of making the contract the plaintiffs produced a sample, and momised him thet the lnalk was equal in quantity and destription thereto, but that the wool when tendered ras foumel to be of an inferior quality, wherefore he refused to aceept itthe Court of Common Pleas held that the plea was not bad on special demurrer, as amounting to non assumplsil, inasmuch as the contract therein set up was not necessarily incompatible with the contract declared on. And prer Manle. J.: "If issue were taken on the tender, the plaintiffs wonld fail, unless they proved a tender of wool of the quality and description ordered" (ili.).

A custom of the Lierpool corn mathel, that when corn is sold by 
sample, if the buyer does not on the dery it is sold excmine the buth and reject it, he cannot afterwarts reject it, or refuse to pay the whote mice, was held by Rolfe B. to be a reasonable one (Sunders v. Jumeson). And semble that an article sold by sample cannot in any case be rejected as not corresponding with the sample, except within a reasonable time (it.). The detivery of a sample, if considered to be part of a thing sold, was ruled by the Court of King's Bench, on the anthority of Randean v. Myalt, to be a sufficient acceptance; but otherwise where it is a sample merely, and forms no part of the bulk (Cooper v. Elston). And so it was held by Gibbs C.J. in the case of a sample of trefoil (Talver v. West).

In the case of Grimoldlyy v. Wells, plaintiff sold by sample to defendant four quarters of tares, which were placed in defendant's barn by his servant. When the defendant saw them, he said they were not as good as sample, and wrote to the plaintiff to that effect, and that he world not have them. It was found, as a fict, that the tares were not as good as sample. Held that the defendant had a right to reject them, and was not bound to send them back, or place them in neutral custody (Couston v. Chapmani, L. R. 2 H. L. Sc. 250 ; cited Luey v. Mouflet, 29 L. J. Ex. 110).

Wieler v. Schilizai is an authority that upon a sale (not by sample, and without warranty) of merchandise, which the buyer has no op? ortumity of inspecting, it is an implied condition that the article shall fairly and reasonably answer the description in the contract. Here the plaintiff agreed to buy of the defendant a cargo of "Calentta linseed tale quale," but on its arrival he oljected to its quality, complaining that it had such a large admixture of other seeds as not to be "Calcutta linseed." It was proved that no seed comes to market without some admixture, the average generally being two or three per cent., but according to the plaintiff's witnesses the linseed in ruestion had fifteen per cent. of tares, rape, and mustard, and was not linseed at all within the meaning of the contract. The defendant's witnesses said it was inferior, but still answered the description in the contract, and that the plaintiff had sold it as and for "linseed" to crushers, who had sold it made up as "linseed-calse." Jervis C.J. put it to the jury to say whether the article delivered reasonably answered the description of Calcntta linseed, that is, linseed with a reasonable amount of adnlteration only. A verdict was found for the plaintiff, and the Court of Common Pleas refused to disturb it. Willes J. said, "The jury have in substance found that the linseed in question was so mixed with seeds of a different and inferior description, as to have lost its distinctive character, and prevent its passing in the market by the commercial name of 'Calcutta linscel.' 'The purchaser had a right to expect not a perfect article, but an article which would be sale- 
able in the market as 'Calcutta linseed.' If he got an article so adulternted as not reasonably to answer that description, he did not get what he bargained for. As if a man buys an article as gold, which ereryone knows requires a certain amount of alloy, he cannot be said to get gold if he gets an article so depreciated in quality as to eonsist of gold only to the extent of one earat."

In T'oulmin r. Hettey, which was a ease of the same class, Cressuell J. ruled that where a party buys a specific cargo of guano, expected by a partiender ship, and warranted to be of a particular quality, he has a right on the arrival of the ship to inspect such eargo before it is delivered to him, in order to ascertain whether the warranty has been complied with, and if it has not, he may reject the cargo altogether; but if the cango he once delivered to him, he has no right to return it on the ground that it does not correspond with the warranty.

The defendant in Hooper v. I'reffiry asked the plaintiffs to find him a - rustomer for his burk; and one was found who agreed to purchase it, if equal to the scmepte. It was shipped, and the defendant sent the plaintifis the inroice, and requested them to aceept a bill of exchange for the price, which they did on the offer of a del credere commission. The bark not being equal to the sample, the eustomer refused to accept it, and the plaintiffs were called on to pay the bill when dne. It was nrged for the defendant that there was no privity between him and the plaintiffs, but the Court of Exchequer held that they were entitled to recover the amount of the bill in an action for money paid to the defendant's use. Aud see Johnstone v. Usborne and IIeisch v. Carrington.

The first of the leading cases upon seed not ansucring its varranty was that of Poullon v. Lallimore, where the action was brought to recover the value of eight quarters of sainfoin seed, sold by the plaintiff to the defendant at $£ 3$ per quarter, and warranted good new growing sced. It was proved that soon after it was bonght it was examined and tasted by a man of good skill, who said it was bad growing seed. This opinion was not communieated to the plaintiff, but part of the seed was sown and the rest sold to two witnesses, who proved it was worthless, anl said they would not pay for it. 'The plaintiff eontended that as the defendant had adopted the contract in part by selling and sowing the soed, he was bound to adopt it altogrether, and eonld not insist on the breach of warranty as a defence to the action. The jury found for the defendant, on the ground that the secd did not eorrespond with the warranty, which was the only question at the trial. The Court of King's Bench discharged a rule to enter a verdict for the plaintiff for the value of the seed, and held that as the plaintifl gave an express warranty that it was good growing seed, the defendant might without 
returning it show that it did not correspond with the warranty, and that the buyer was not bound to trust the assertions of third pirties, and return the seed on the assumption that it was bad seed, but was at, liberty to test its capabilities by sowing. In such cases of warranty the vendee is entitled, although he do not return the seeds to the vendor, or give notice of their defective quality, to bring an action for breach of the warranty, or if an action be brought against him by the vendor for the price, to prove the breach of the warranty either in diminution of damages, or in auswer to the action, if the groods be of no value.

And per Littledale J.: "The not giving notice raises a strong mesumption that the article at the time of the sale corresponded with the uaranty. But if that be clearly established, the seller will be liable to an action brought for breach of his contract, notwithstanding any length of time which may have elapsed since the sale."

The application of the Statule of Limitations to such cases was comsidered in Battley v. Faulkner, where the plaintiffs bought certain wheat from the defendants early in 1810, as spring wheat, and sold it to one Shepard, who sowed it, and discovering in the autumn that it was wholly unproductive, gave the plaintiffs notice that he held them responsible for the loss of the erop. This the plaintiffs communicated to the defendants, as well as the fact that in June, 1811, he was abont to assess damages against them in the Court of Session. Nothing more passed between the partics till 1818, when the suit in Scotland was completed, and the plaintiffs paid Shepard his damages and costs, and commeneed the present action of assumpsit, alleging as special damage the damages so recovered. Abbott C.J., on finding that there was no promise to take the ease out of the Statnte of Limitations, nonsuited the plaintiff. The Conrt of Queen's Bench confirmed this ruliug, on the gromnd that though such special damage had occurrect within six years before the commencement of the action, yet that the breach of contract, which in assumpsit was the gist of the action, having occurred and become known to the plaintiff more than six years before that period, he was guilty of negligence, and the statnte might well be pleaded.

The gist of the action in Allen v. Lake was that the seed proveal to be of a different kind to what it was sold for. One of the plaintiffs, in company with Reed, the defendant's agent, saw six acres of the defendant's turnips in bloom, and agreed to buy the seed produced by them. On Augnst :ird the produce, fourteen quarters, was delivered to the plaintiff, and the following sold-note-

"MIr. 'T. C. REED,

Aurg. 5, f Sold to Messrs. Beck \& Co., for Mr. C. Lake, 14 qrs.

1850. (Stiming's Sicede at 17s. per bushel," 
and an inroice was sent shortly afterwards. In a few days another parecl of turnip seed was sold by Reed to the plaintiffs, Reed stating it to be of the "same stock" as the former, and calling it Skirving's Sicedes. No bought or sold note was given on this occasion, and the in roice deseribed the seed as $24 \frac{1}{4}$ quarters of turnips. In May, 1851, samples of both parcels were sown; the crop partly failed, and of those plants which made their appearance, the greater part were not of the description of turnip called Skiming's, bnt of a spurious and inferior kind. The defendant contended that the sold note did not amount to a warranty, but merely contained a representation that the first parcel of seed ras Slitiviny's Sucdes, and also that there was no evidence for the jury that the seeond parcel had been warranted to be Skirving's Sincles, the invoice describing the seed merely as $24 \frac{1}{4}$ quarters of turnips. Lord Camplell C.J. overruled both objections, and the jury found for the plaintiff for the value of the seed, with leave reserved to move to reduce the damages by the value of the second parcel, if the Court thought there was no evidence for the jury of that parcel having: been sold under the warranty of its being Skivving's Sicedes, and the Court of Queen's Bench refused to disturb the verdict. Lord Campbell C.J. said: "As regards the first parcel, I adhere to the opinion which I expressed at the.trial, that the statement in the sold note amounted to a warranty that the seed was Skirving's Sucedes. I also agree with the rest of the Court, in thinking, with respect to the second parcel, that there was evidence for the jury of the defendant having warranted them also to be Sliriviny's Suceles. It is clear that the invoices did not form the contract. There was a previous verbal contract for the sale of the second parcel; and the defendant's agent having stated that the second parcel was of the same stock as the first, that statement became part of the contract."

In Puge (Exor.) v. Parey the plaintiff sued defendant on a breach of earranty on the sale of old cone wheat, and the declaralion contained a sperial count, which stated a waranty llut the wheat would grow, and a breach that it would not grow, and that the plaintiff was deprived ol" great gains from the corn and straw. The declaration also contained counts for money had and received, and on an account stated, and the particulars of demand were for the price of the wheat, but expressly linited to the inlrbilatus counts. It was oljected for the defendant that the particular's tied down the plaintifl to $\$ 619 \mathrm{~s}$. Gel., the price of the sced; but Palleson J. considered that the particulars only applied to the common counts, to which they were expressly limited, and that this dirl not prevent the plaintifl" from giving evidence of what the value of the crops might have been, with a view to his damages on the first count. 
The question as to when an action on an implied werranly of the soundness of meat will lie, was settled by the Court of Exchequer in Bumby v. Bollett. The plaintiff and defendant were both farmers, and the latter bought the earcase of a pig at a butcher's in the public shambles in Lincoln market, but having other business, left it till it was more convenient to take it away. Before he returned, the plaintiff came to the same stall and offered to buy the pig; he was told it was the defendant's, and a bargain was struck for $£ 618 s .6 d$. Next day the meat was found to be quite rotten, and measly (the season had been remarkably unfarourable for meat), and the action was brought on an implied warranty of soundness. The defence was caveat emptor; but Patteson J. inclined to think that the law implied such a warranty as that mentioned in the declaration, "that the said carcase was in a sound and wholesome condition, and fit for human consumption." A verdict for the amount was found for the plaintiff, subject to a motion to enter a nonsuit, and the Court made the rule absolute.

The jury negatived all fraud in the defendant, who was not a butcher or a dealer in meat. He had not exposed it publicly for sale, but had simply bought it for his own use, and left it till it shonld be delivered; but when he sold it to the plaintiff there was a reasonable presumption for the consideration of the jury that he knew it was to be used for human food. 'The sole point for consideration was, whether an ordinary individual, not clothed with any character of general dealer in provisions, who bona fide sells meat for human consumption, must be taken to sell them with an implied warranty of soundness. This was not the case of a butcher or taverner or farmer killing or exposing to sale meat in open market, who may be reasonably taken as impliedly warranting the meat to be sound. It was put for the plaintifi, that by reason of food being the subject of sale, this was an exception to the general rule, so as to make the seller responsible on account of the common good, though no care could have discorered the latent defect; but the defendant was not dealing in the way of a common trade, and was not punishable in the least for what he did. He merely transferred his bargain to the plaintiff. Lord Hale's note in Fitzherbert's "Natnra Brevium," p. 94, says that "There is diversity between selling corrupt wines as merchandize; for there an action on the case does not lie without warranty ; otherwise if it be for a tarerner or victualler, if it mejudice amy." And the Court of Exchequer held that the defendant fell within the reason of the former part of Lord Hale's distinction; and that there being no evidence of a warranty or of any fraud, he was not liable. And where the plaintiff, a butcher, sold the defendant meat, and the latter after taking it home subsequently called at the shop, and 
said before sereral enstomers, "I intended to have dealt with you, but I shall not do so, for you changed the lamb which I bounght of you for a course piece of multon," it was held by the Court of Exchequer in Crisp $\checkmark$. Gill that an action for slander did not lie, as the communication so made was a privileged one.

Contagions Diseases Animals $\Lambda$ ct, 32 \& 33 Vict. c. 70, s. 75 : in order to convict a person for being in possession of a diseased animal under this Act, it must be prored that he was arare of the fact that the animal was diseased. Nichols r. Hall, 8 L. R. C. P. 322.

Allemative contracts must be stated accordiny to the fact; and where a contract was made for the purchase of 100 bags of wheat, 40 or 50 of which were to be delivered on one market day, and the remainder on the next market day, it was held that the plaintiff could not declare as upon an absolute contract for the delivery of 40 bags on the first day, though 40 bags were then in fact delivered, bnt the contract must be stated in the alternative according to the original terms (Penny v. Porter). And if a contract to deliver soil be declared upon as a contract to deliver soil or breeze, the variance will be fatal if it appears that soil and breeze are different things (Cookv. Manstone).

An agrecment contuined in a contract for the purchase of a cargo of wheal, to vefor to arbitration any difference that might arise between the parties as to the contract, is enforeeable by action; and a dispute as to the amount of compensation to be paid to the plaintiff in respect of deficiency of cargo, is a "difference" within the meaning of such agreement (Licimyton v. Ralli).

1 contract to deliver goods to purchaser "from lime lo lime as required," does not lapse at the expiration of a reasonable time from the date of the contract; and the vendor must, to determine it, request the purchaser to require the goods, and if the latter does not do so within a reasonable time from such request, the contract lapses (Jones v. Gilibons).

Whire no entire sum has been agreed upon, it is generally presumed that it wers the intention of the contracting parties that the remuneratim shouth licep pece with the consideration, and be recoverable toties quealies by an action on a quenlum mevut. And this doctrine seems to be countenanced by Writhers v. Reynolds, which was an action of assumpsit for not delivering straw according to the following agreement :

"John Reynolds nndertakes to supply Joseph Withers with wheat-straw relivered at his premises till the 24th .June, 1830, at the sum of 3is. per load of "36 trusses, to be delivered at the rate of three loads 
in a fortnight ; and the said J. W. agrees to pay the said J. R. $33 s$. per load, for each load so delivered from this day, till the 24 th June, 1830 , according to the terms of this agreement."

When the straw had been supplied for some time, the defendant asked for payment, and received $11 \mathrm{gs}$. payment for all the straw, except the last load, as the plaintiff said he shonld always keep one load in hand. The defendant said he shonld send no more straw unless it was paid for on delivery, and no more was accordingly sent ; and it was submitted on his behalf at the trial that there must be a nonsuit, as the plaintiff on his own showing had not performed his own part of the contract, which was in effect to pay for each load on delivery. It was held by the Court of Queen's Bench that according to the true effect of the agreement each load was to be paid for on delivery, and that on the plaintiff"s refusal to pay for them, the defendant was not bound to send any more, and the Court directed a nonsuit.

Patteson J. said, "If the plaintiff had merely failed to pay for any particular load, that of itself might not have been an excuse to the defendant for delivering no more straw ; but the plaintiff here expressly refuses to pay for the loads as delivered; the defendant, therefore, is not liable for ceasing to perform his part of the contract." Tannton J. expressly founded his decision upon the special wording of the contract "for each load, \&c.," which he considered to import that each load shall be paid for on delivery. On this $\mathrm{Mr}$. Smith renarks in his "Leading Cases," vol. II., p. 19, that if this case were decided on any other ground, it would be contrary to the opinion expressed by Parke J. in Oxendule v. IVetherall, viz., that " Jj7ere there is an entive contract to deliver a large quantity of goods, consisting of distinct parcels, within a special time, and the seller delivers part, he camot before the expiration of that time bring an action to recoier the mite of that part detivered, because the purchaser' may, if the vendor fail to complete his contract, return the part delivered. But if he retain the part delivered after the seller has failed in performing his contract, the latter may recover the value of goods which lie has so delivered." Here the plaintiff had delivered to the defendant 180 bushels of wheat, and the question on the evidence was, whether the contract was for 250 knshels, or so much as the plaintiff conld spare. 'The jury found that it was an entire contract, and Bayley J. ruled that notwithstanding the non-performance of part of the contract by the rendor, if the purchaser retains the part which has been delivered after the time for completing the delivery has expired, he is liable for the price of that part. 'The Court of Queen's Bench refused a rule for' a nonsuit, and Lord Tenlerden C.J. observed that, "If the rule contended for were 
to prevail, it wonld follow that if there had been a contract for 250 bushels, and 249 had been del:rered to and retained by the defendant, the vendor could never recover for the 249 , becanse he had not delivered the whole."

Where a written contract for the sale of goods specifaed no time for detivering thrm, Lord Ellenboroungl C.J. held in Greares v. Ashlin (which was an action for non-delivery) that it was not competent for the defendant to give parol eridence that it was a condition of sale that the goods shonld be taken away immediately, or that by the usage of trade where goods are sold to be delivered at a distant day the time is always mentioned in the written contract, and that although the purchaser (who had here received a delivery order) neglected after notice to carry them away, the seller had not on that account a right to re-sell them, and the plaintiff had a rerdict for the difference per quarter between oats at $45 s .6 \%$, the price at which he bonght the oats, and 51s. or that for which they were re-sold. And so it was held by the Court of Common Pleas in Peterson v. Ayre, that the measure of damages in the case of a breach of contract to cleliver goods at a specified time, is the difference wetween the contract price and the market price at the time of the breach of contract, or the price for which the rendee had sold; but that the latter caunot recorer as special damage the loss of anticipated profit to be made by his vendees. This was an action of assumpit for the breach of a contract of delivery of "from 80 to 120 tons of best oblong fiesh-made Flensburg linseed-cakes, at $£ 610$ s. cost and freight to a safe port on the East coast of Great Britain, or $£ 613 s$. to a safe port in the Channel." In consequence of an undne delay in the shipment, which was to have taken place at "the first open water after the end of January," at Flensburg, the plaintiff declined to receive the cakes, and bronght this action to recover $₫ 2710 s$, the difierence between the price at which he had bonght and that at which he had sold the 110 tons, and also $£ 13710$ s. claimed from him as damages by his rendec, but only recovered the former.

Again in Plilpotts r. Evans, where a certain miller (defendant) conlracted for the purchase of ulteat "to be delivered at $B-$ as soon as ressels could be mocured for the carriage thereof; " amel subsequently (the markent having fallen) grave the seller notice that he rould not accept it if it vere dolicred, the wheat being then in transitu, it was held by the Conrt of Exchequer, on the anthority of Leigh v. Palerson, in an action for not accepting the wheat, that the proper measure of damages was the differenee between the contract price and the market price on the day when the wheat was tendered to him for aceepitance at Birmingham and refused, and not on the day when the notice was received by the seller. 
In Leigh v. Palerson the defendant contracted to deliver tallow to the plaintifl" "in cll next December" at 62s. per ewt. The dofendants in October tried to compromise and be off their bargain (as they had sold the tallow for 71 s.), but the plaintiff insisted on holding them to it, and the Court considered that tallow having risen in priee, the plaintiff was entitled to recover damages according to the market price $(81 s$.) on the last day on which the contract would have been performed, nanely, the 31 st of December, as he had not acquiesced in its being reseinded when the defendants refused to perform it,-and not aceording to the (71s.) October price. And in Stertup v. Cortazzi, which was a case of delively of Odessa linseed (100 chetwerts $=73$ cuarters), payment of the difference between the contract price (36s. per quarter) and the value of the linseed (48s.) at the time when the eargo onght to have been delivered in due course, was that to which the plaintiffs were entitled. The defendant had paid 47s. into Conrt, being the price at the time of the notice of non-completion. It had risen to $56 s$, at the time of the trial, and the plaintiff contended that the damages should be calculated according to that price; but per Lord Abinger C. B. this was not a case resembling contracts for the replacing of stock, where the damages are estimated at the price of the funds.

A contract to be performed "direclly," means to be performed not "within a reasonable time," but "speedity," or at least " as early as practicable." Thus, in Duncan v. Topham, on February 18 the plaintiff wrute to the defendant, offering to supply him with linseed cake at $£ 1015 \mathrm{~s}$. per ton, and on the 19 th the defendant replied, "I can takc 5 tons at $£ 1010 s$, but it must be put on board directly." On the $22 n d$ thie plaintiff again wrote: "I shall ship yon 5 tons best cakes to-morvou" ;" and it was held by the Court of Common Pleas that the correspondence did not prove a contract on the part of the defendant to accept cake " to be delivered within a reasonable time," and a new trial was ordered, after a verclict for the plaintiff. Cresswell J. said: "It is true, as it appears from T'hompson v. Gibson, that 'directly' does not mean instanter, and it may be subject to a similar limitation here; but the expression 'within a reasonable time,' certainly is larger than is warranted by the tcrms of the contract." And per Curiam, a contract is complete upon the posting by one party of a letter addressed to the other accepting the terins offered by the tatler, notwithstanting such letter never reaches its destination. A contract by a manufacturer to furnish certain specified goods "as soon as possible," means within a reasonable time, regard being had to the manufacturer's ability to produce them, and the orders he may already have in hand (Attwood v. Emery).

Where by a written contract the plaintiffs agreed with the defendant 
to make him a canvas tent covering, the canvas to be equal to pattern, and of the market ratue of $11 \%$. per yard, and the making to be charged at 5il. prer yord, and it was agreed that if the marlirt velue of the canvas shonld be less than that, the amount (i.r., the difference) should be deducted, the Court of Common Pleas held that the "market value" must be taken to mean the price of the commodity in the market as between the manufacturer and an ordinary purchaser; and that those worls were not to receive a different interpretation because a person requiring a large quantity might have purchased the canvas at a lower rate (Orchard v. Simpson).

What constitutes a delivery of bark came before the King's Bench for decision in Simmons v. Sivift. Here the owner of a stack of bark entered into a contract to sell it at a certain price per ton, and the purchaser agreed to take and pay for it on a certain day specified, and a part was afterwards weighed and delivered to him. It was held that the property in the residne did not rest in the purchaser until it had been weighed, that boing necessary to ascertain the amount to be paid, and that even if it had rested, the seller conld not before such weighing maintain an action for goods sold and delivered.

But where, as in Tarling v. Baxter, the defendant agreed to sell plaintiff a stack of hay for $£ 145$ on the 4 th of February, to be paid for in one month, and to stand for three on the defendant's premises, plaintiff stipulating that it should not be cut till it was paid for, and the plaintiff accepted a bill for the amount on the Sth of January, and on the 20th of that month the stack was accidentally burnt, the Court held that the plaintiff could not recover back the price, as there was a contract for an immediate sale, by which the property in the hay vested immediately in the plaintiff. Littledale J. said: "Here was an absolute agreement on the 4th of January for the sale and purchase of the hay, to be paid for in a month. According to the seller's contract-note, the buyer might lave cut and removed the hay immediately. By the buyer's contract it was stipulated that he should not cut the hay until it was paid for. Bnt the property in the hay liad already passed to him loy the first contract of sale, and all that he did afterwards was to waive his right to the immediate possession. Then the property having passed to the buyer, the loss must fall "pon him."

The sale of a specific chattel on credit, thouyh that credit may be limited to a definite period, transfers the moperty in the goods to the vendee, giving the vendor a right of action for the mice, and a tien on the goods, if they remain in his possession, till that mice be paid. But defanlt of payment does not rescind the contract; and such was the doctrine cited by Jolroyn J. from Com. J)ig. Agreement в 3 in Tarliny v. Luxter, which 
governeal the decision of the same Conrt in Murtintole v. Smith. Here the defendant on $\Lambda$ pril 2.81 sold six oat stacks for 185, standing on his own gronnd, to the plaintiff, with liberty to leare them there till the middle of Angust, and to defer payment for twelve weeks from the date of the agreement. In the beginning of July the defendant told the plaintiff that if he did not pay on the 16th of the month he would consider the contract at an end. Plaintiff did not pay on that day, but asked for time, which the defendant refused to give; adding, that now the plaintiff should not have the stacks, as he had failed to come to time. Two or three days after, the money was tendered, but not accepted; and on the 14th of August the plaintiff serred a written notice on the defendant, repeating his tender, and stating his intention to remore the stacks at ten o'elock next morning, and requesting admittance to the field for that pupose. He again made an actnal tender, and required the defendant not to sell the stacks, which he did. Trover was accordingly brought, and Alderson $\mathrm{B}$. directed a verdict for the 1)laintiff, giving leave to more to enter a verdict for the defendant on the second issue, that the plaintiff was not possessed of the goods and

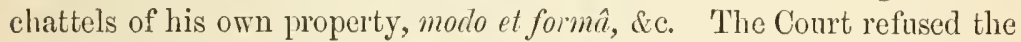
rule, and decided that the vendor had no right to treat the sale as at an end, and re-invest the property in himself by reason of the defendant's failure to pay the price at the appointed time, and that the vendor's right to detain the thing sold against the purchaser must be considered as a right of lien till the price is paid, not a right to rescind the bargain ; and here the lien was gone by tender of the price.

According to Smith v. Nrale (which confirmed the jndgment of Kinderstey V.C. in Warner v. Willington), a uritten proposal, containing the terms of a proposed contract, signed by the defendunt, and assenterl to by the plaintiff by word of mouth, is a sufficient agreement within the 4th scetion of the Statute of Frauls. Bnt an agreement whereby all that is to be done by the plaintiff, constituting one entire consideration for the defendant's promise, is capable of being performed within a year, and no part of what the plaintiff is to do constitnting such consideration is intended to be postponed until after the expiration of the year, is not within the 4 th section of the statnte, notwithstanding the performance on the part of the defendant is or may be extended beyond that period (ib.). And see Donellan v. Read; and the judgment of Lord Wensleydale in Cherry v. Homing.

And per Paike J. : "In the older cases the Court did not advert to the words of the statnte; but the later cases (Hox'e v. Pulmer; Hanson v. Armitage; Carter v. Toussaint; Tempest v. Fitzgerald) have established that unless there has been such at dealing on the part of the pur- 


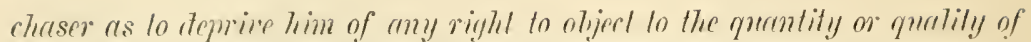
the yools, or to deprive lhe selter of his right of lim, there cammot he any part acceptance to satisfy the 4 th section of the statute," (Smith v. Surman).

A somewhat nice question as to what was a delivery to salisfy the 17th section of the Stalute of Frauds arose in Gorman v. Boddy. The defendant gare the plaintifl a written order for ten firkins of butter, which he directed to be sent to him by a certain conveyance. Instead of ten firkins trelve were sent, and the defendant refused to receire them. The carrier said that his general practice was never to deliver part only of a parcel of goods. The twelve firkins were never in defondant's shop; but while they stood in the street he drew a sample from a firkin, and said that it was inferior. The carrier then put the goods into his cart, and sent them back by railway; and an action was bronght for gonds sold and •delivered. In summing up, Ciressuell J. said: "At that time the possession of the goods was in the carrier, and he might perhaps maintain trespass against the defendant for doing as he did. But that will not help you. How ean you make ont that these goods were delivered to the defendant? They were sold; but I do not think that you have proved a delivery. The defendant never got the butter, there was therefore no actual delivery to him ; nor was there any delivery to the carrier, as the defendant's agent. I do not see that the carrier was his agent to receive more than ten firkins. The delivery of the ten firkins, therefore, to the carrier, with two others, as one parcel, was a delivery in respect of which the earrier was not the defendant's agent; and it thus appears that there was no delivery of the goods to the defendant at all, and conseqnently there could be no acceptance thercof by him, so as to satisfy the 17th section of the Statute of Frauds." The plaintiff was nonsuited. Respeeting the delivery to a carrier, it was observed by Parke B. in Jolnson v. Dodyson, that "such dclivery may be a divery to the defendant; but the acceptance of the carrier is not an acceptance by him. The old cases in which it had been said that a receipt by a carrice was an acceptance to satisfy the statute, were overruled by Houre v. Palmer; and Hanson v. Armilage." And pes Lord Abinger C.B. : "If", to take the strongest case, the purchaser sent his own serrant for the goods, and when they were brought sent them back as not answering the contract, le could not be said to aceept them" (ib.).

Chaplin v. Rogers is a leading case as to what constilutes a delivery. The parties were in the plaintifl's farm-yard, and the defendant, after objecting to the quality of a stack of hay (particularly the inside part) in the yarl, agreed to take it at $2 s$. $6 d$. per ewt. Soon after, he sent a 
farmer to look at it, and his opinion was mfarourable. In the course of two months a farmer called Loft agrecd with the defendant to purchase some of the hay still standiug untonched in the plaintitf's yard; and the defendant told Loft to go there, and ask what condition it was in, saying he had only agreed for it if it were good. The plaintiff having informed Loft it was in a good state, the latter agreed to give the defendant $3 s .9 l$. per cwt. for it, the defendant having told him that he had agreed to give the plaintiff $3 s$. 6d. for it. Loft brought away 36 cwt., but withont the knowledge, and against the direction, of the defendant. The evidence as to the quality of the hay, when the stack was afterwards cnt, was eontradictory. It was objected for the defendant that the contract of sale was fraudulent and roid by the Statute of Frauds, being for the sale of a commodity no part of which was delivered, and of which there was no acceptance by the defendant; but Hothem B. left it to the jury to decide whether the sale had been fraudulent, and whether, under the eiremmstances, there had been an acceptance by the defendant; and they found for the plaintiff on both points, and gave him $£ 50$ damages, being the valne of the hay at the price agreed for. A rule for a new trial, on the grounds that the learned judge had left that as a question of fact to the jury which he himself onght to have decided as an objection in point of law arising on the Statute of Frauds, and that the evidence did not warrant the verdict, was discharged. Lord Kenyon C.J. said : "I do not mean to disturb the settled construction of the statute, that in order to take a contract for the sale of goods of this value ont of it there must be either a part delivery of the thing or a part payment of the consideration, or the agreement must be rednced to writing in the mannor therein specified. But I am not satisfied in this case that the jnry have not done rightly in finding the fact of a delivery. Ithere goods are ponderous, and incapable, as here, of being handed over from one to another, there needed not be an actual delivery; but it may be done by that which is tantamount, such as the delivery of the key of a warehouse in which the goods are lodged, or by delivery of other indicic of property. Now here the defendant dealt with this commodity afterwards as if it were in his actual possession, for he sold part of it to another person. Therefore, as mpon the whole justice has been donc, the verdiet onght to stand."

This case was relied on for the plaintiff in Maberley v. Shepparit, where the defendant emplojed plaintiff to construct a waggon, and while the vehicle was in the plaintift's yard, infinished, bonght ironwork and a tilt of a man, who assisted plaintifl"s workmen to fix it. It was contended that the defendant must be thus taken to have exer- 
cised acts of ormership orer the maggon, and that the exercise of such acts ras tantamount to a delivery; but these things haring been done before the waggon was finished, and there being no proof of actual delivery, the Court of Common Pleas held that the plaintiff was rightly nonsuited in an action for goods sold and delivered. They thought that "the act proved at the trial was by no means so strong and unequivocal as that which took place in Chaplin v. Rogers, where the purchaser sold part of the hay to a stranger, who actually took it away."

In Horre r. Palmer the Court of Queen's Bench took a similar view of Chaplin v. Rogers, when it was relied on as an authority for the plaintiff. There the grower of some tares in Essex sent his nephew with a sample to Romford market, where the defendant agreed to buy 12 bushels at $£ 1$ per bushel, and to send to plaintiff"s farm to take them away. He declined taking the sample, saying he had seen the tares on the plaintiff's premises, and that he had no immediate use for them, and therefore requested that they might remain there until he wanted to sow them, which was agreed to. Accordingly, on the nephew's return, the tares were measured and set apart in the granary, with instructions that the defendant was to have them when he called. 'The Court did not consider that this was an acceptance by the defendant, so as to take the case out of the 17 th section of the Statute of Frands. Bayley J. said: "The two cases cited are distinguishable from this. In Chaplain v. Rogers the jury thonght that there was sufficient avidence to draw the conchusion of an actual acceptance, inasmurh as the rendee had dealt with the hay as his own; and in Etmore v. Stone the buyer directed expense to be incurred, and the directing of that expense was considered evidence of an acceptance on his part. That case goes as far as any case ought to go, and I think we ought not to go one step beyond it. There is this distinction between that case and this, that there an expense was incurred on account and by direction of the buycr, here there is none; but I must say, however, that I doubt the authority of that decision." Although the defendant in Hou'e v. Pulmer professed to have already seen and approved of the tares in bulk when he made the bargain, the circumstances from which the acceptance was inferred in Aldridge v. Johnson were of a much stronger character.

This was a speeial ease stated in detinue for the recorery of a quantity of barley, with a count in trover. There was an agreement between the plaintiff' and one Knight for the exchange of 200 quarters, part of a quantity of barley in bulk on Knight's premises, for a number of bullocks, plaintiff to send his sacks to be filled from the bulk, and on 
delivery of the barley to pay Knight £23, the difference between the price of the bullocks and the corn. Plaintiff sent the bullocks to Knight, who sold them, and also sent 200 half-quarter sacks to be filled, ordering them to be sent home loy the railway. Knight fillect 155 of the sacks from such bulk, but never detivered them at the ratheray station; and subsequently becoming a bankwut, the corn which hat been filled was pul back again to the bulk whence it had been taken. It was held by the Court of Qneen's Bench, that the sacks having been sent and filled by Knight, the property in that part passed to the plaintiff, althongh they had never left Kuight's premises, as plaintifl' having examined the grain, and approved of it, the contract was complete when the separation was made by Knight.

Lord Campbell C.J. observed that the argument as to the property in the whole 200 quarters having passed to the plaintiff, thongh it was part of a larger bulk, derived from the bargain between the parties and the fact of the bullocks being sent to Knight, was untenable; because it is well settled that where there is a purchase of a part of a larger quantity of goods in bulk, the property does not pass to the vendee until separation. "No part of the property in bulk," said his Lordship, "ever passed to the plaintiff; becanse until there was a separation the whole bulk belonged to the bankrupt, and what part rested in the purchaser could not be ascertained. Nothing can be clearer than that when a part of groods in bulk is purchased, until separation and appropriation by the rendor, and assent given by the purehaser, there is no transfer of the property; therefore as to the 155 sacks, I think there must be judgment for the plaintiff ; and as to the remainder, our judgment must be for the defendant. Looking at the bargain, and what was done under it, when the barley was put into the sacks the property in it was appropriated and vested in the plaintiff, becuuse there uus a prior assent by the plaintiff. He examined the goods, apmroved of them, and sent his sacks to be filled; and if any subsequent assont were necessary, I think that would be supplied by the orders given to send the goods by railu'uy. Nothing remained to be done by the vendor ; he had appropriated a part with the consent of the vendee, just as much as if the vendee had sent boxes, and when they were filled, the keys had been forwarded to the vendee; in such a case it could not be disputed that the property would vest in the purchaser. Then as to the alleged conversion, I see no difficulty; for the goods being in the plaintiff, he has done nothing to divert it, nor anything which can be complained of. It was a wrongful act of the bankrupt's to take the corn out of the sacks, and then to bring the property into his hands again. By doing this he has converted the plaintiff"s property, and therefore the defendants, 
as his assignees, are liable, they haring claimed it as the property of the baukrupt."

Where goods are sold by sample, the handing over the samples to the buyer does not, in the absence of evidence of a usage or custom to the contrary, amount to a delivery and aceeptance of part of the things sold, so as to take the case out of the 17th section of the Statute of Frands; but it is otherwise where the buyer draus sumples from the bulk after he has murchased the goods. The latter was the case in Gaicher r. Grout, which was an action for a breach of contract to deliver $24 \frac{1}{2}$ tons of sacks and bags, which the defendant had agreed to sell to the plaintiff at $£ 11$ per ton. A rerbal contract was proved in the terms alleged in the declaration, but there was no contract in writing or any part acceptance. The plaintiff relied, in order to take the case out of the Statute of Frands, on a part delivery and acceptance, which was supported by the following eridence: Four days after the sale the plaintiff went to the defendant's warehouse, and asked for samples of the sacks and bags, which were given to him by the defendant's foreman, and which he promised to pay for when the bulk (which was all there at the time) was taken away. The samples so given to the plaintiff were, by the defendant's order, weighed and entered; and the jury found that they were delivered and accepted as part of the bulk, and gave the plaintiff a rerdict for $£ 40$, which the Court of Common Pleas refinsed to disturb. Hodlyson v. Le Brett and Anderson v. Scoll are authorities to show that if a person selects and puts a mark on a particular article, intending to take possession of it as his own property, that is evidence for the jury of an acceptance. buldey r. Parker only decides that, under the cireumstances, there was no acceptance and receipt. It is an anthority to show that the selecting particular articles does not amount to a receipt within the statute, but is merely an agreement that the property in the specific articles shall pass. At common law, the property would pass by the contract of bargain and sale; but in order to satisfy the statute, there must be either a part payment or an acceptance and receipt of goods. In Henson v. Armitage there was no acceptance by the buyer of the goods.

In the case of Smith v. Hughes, 6 L. R. Q. B. 597, the plaintiff showed the defendant a sample of oats; the defendant took the sample away with him, and afterwards wrote to the plaintiff to the effect that he would take the oats. According to the defendant's version of the story, the plaintifl had said they were "old" oats; this, however, the plaintiff denicd. The oats, in fact, were new, and the defendant refused to take thens. Held that the defendant was bound by his contract. 
The whole tenor of the decision of the Court of Qneen's Pench, in Morton v. Tibbett (which was contrary to some previons dicta, thongh not to any actual decision), was to the effect that the arceptance mint actual receint of goorls, which make a written memorumbum unneressur!y under the 17th section of the Statute of Frands, are not such an ncceptance and receipt as with prestude the murchaser from qusstioning the quantity or quality of the goods, or in any way dismuting the fart of the performance of the contract by the vendor; and that the effect of such statutory acceptance and receipt is merely to dispense with the necessity of a written memorandum of the contract. 'The action was to recover the price of 50 quarters of wheat, which the plaintiff sold to the defendant by a sample, and which the latter took away with him. On the 26th of August (next day) the wheat was given to a general carrier and lighterman, Edgeley, who was sent by the defendant, to take it by water from March to Wisbeach; and on that day the defendant sold the wheat at a profit, by his sample, to one Hampson, at Wisbeach market. The wheat reached Wisbeach on the 28th, and was tendered by Edgeley to Hampson on the 29th; but he refused to take it, on the ground that it did not correspond with the sample; and notice of this refusal was given to the defendant, who had never seen or examined the wheat by proxy ; and on the 30th of Angust he wrote to the plaintiff, repudiating his contract, on the same grounds. The defendant objected that, as there was no memorandum in writing of the bargain, there was no evidence of acceptance and reccipt to satisfy the 17 th section of the Statute of Frauds. Poltocle C.B. orerruled this objection ; and a rerdict was found for the plaintiff, with leave to more to enter a nonsuit, if the Court should think either that there was no evidence of acceptance or receipt, or no such evidence as justified the verdict.

The Court held that there was evidence to warrant a jury in finding acceptance and actual reccipt by the defendant within the meaning of stat. 29 Cur. II. c. 3, s. 17. Lord Camplell C.J. said, in the course of his very elaborate judgment, "As the Act of Parliament expressly makes the acceptance and actual receipt of any part of the goods sold sufficient, it must be open to the buyer to object, at all events, to the quantity and quality of the residue; and even where there is a sale by sample, that the residue offered does not correspond with the sample. We are, therefore, of opinion that whether or not a delivery of the goods sold to a carrier or any agent of the buyer is sufficient, still theie may be an acceptance or receipt within the meaning of the act without the buyper having examined the goods or done anything to prechute him from contending that they do not correspond with the contract. The accept- 
ance to let in parol evidence of the contract appears to us to be a diffireut acceptance from that which affords conclusive eridence of the contract having been fulfilled. We are, therefore, of opinion in this case that, although the defendant had done nothing which would have precluded him from objecting tnat the wheat delirered to Edgeley was not according to the contract, there was evidence to justify the jury in fincling that the defendant accepted and receired it."

A rule nisi on the anthority of Morton r. Tibletts mas discharged in Hunt r. Hecht, which decided that there can be no acceptance and actual reccipt of goouts within the 17 the section, unless the ventee has an opmortunily of jutying whether the goods sent correspond with the oriler: and herire that although there may be a recript there need not neessurity be an acceptance. The defendant in this action for goods sold and delivered went to the plaintiff's warehouse to buy bones, and inspected a heap of ox and cow bones, and others of an inferior kind. He objected to the latter, and rerbally agreed to buy a quantity of the other bones to be separated from the rest, and to contain not more than 15 per cent. of cow bones, giving directions as to where they were to be sent, and the mode of making the sacks. The plaintiff sent 50 bags (leg bones marked "os A," and the bullocks "Os B"), and according to a request contained in a letter of February 7 , filled up the shipping note, and delivered them at the wharf on 9th of February. On the following day the defendant examined the bones, and refused to accept them, as not being what he had bargained for. Martin $\mathrm{B}$. thought there was no cvidence of acceptance and receipt to satisfy the 17 th section of the Statute of Frauds, and nonsuited the plaintiff, reserving leare for him to move to enter a rerdict for that amount. Allerson B. said, in discharging the rule, "If a person agrees to buy a fuantity of goods, to be taken from the bulk, he does not purchase the particular part bargained for, until it is separated from the rest, and he camnot be said to accept that which he knows nothing of, otherwise it would make him the acceptor of whaterer the rendor chose to send him, whereas he has a light to see whether in his judgment the goods sent correspond with the order. 'The statute requires an acceptance and actual receipt of the goods; here there has been a delivery, but no accepitance."

Martin B. thus remarked on Morton v. Tibuelts: "There are rarious authorities to show that for the purpose of an acceptance within the statute the rendee must have had the opportunity of exercising his jurlgment with respect to the article sent. Morlon v. Tibbetts has been cited as an authority to the contrary; but in reality that case deciles no more than this-that whore the purchaser of gools takes mon himself to 
exercise a dominion oxer them, and deals with them in a mannes inconsistent with the riglet of moperty being in the vemdor, that is evidence to justify the jury in finding that the vendee has accepted the goods, and actuatly received the same. Hanson v. Amitage and Norman v. Philtips are express anthorities that a wharfinger or a carrier is not the ayent of a vendee, so as to bind him by acceptance of the goods. In Meredith v. Megh, Lord Campbell C.J. expressly overmled Hart v. Suttley, where Chambre J. ruled that if goods are ordered verbally, the delivery to a carrier who has been used to deliver goods between the parties is sufficient to bind the contract, according to the 17th section of the Statute of Frands. Of Horton v. Tibbetts his Lordship also remarked in that judgment, "The vendee there resold the wheat at a profit, and altered its destination in the carrier's hands (by sending it to another wharf), and that was held to be evidence of an acceptance and receipt."

In Coombes v. Bristol and Excter Raituay Company, the plaintiff agreed with one Avery by a verbal contract for the purchase of goous exceeding $£ 10$ in value, to be sent to the plaintiff by the Bristol and Excter Railuay. The goods were sent by snch railway by Avery, addressed to the plaintiff, and rere lost during their conveyanee. It was held by the Court of Exchequer that the plaintiff could not sne the railway company, because the contract being verbal there had been nothing to ratify the 17 th section of the Statute of Frands, the delivery to the railway company being no delivery to the purchaser; that the property had therefore not passed, and Avery, not the plaintiff, was the party to sue. Martin B. said, "I adhere to what I am reported to have said in Hunt v. Hecht, that there is no acceptance unless the purchaser has exereised his option, or has done something that has deprived him of his option. There was nothing to prevent the vendee rejecting the goods if they had been delivered to him on the ground that there had been no contract to satisfy the 17th section of the Statute of Frauds."

A curious point as to what constitutes an acceplance of seed arose in Parker v. Wallis. The plaintiff, a farmer, made in June a verbal contract with the defendants, at Bury market, for the sale of turnip-seed exceeding $£ 10$. It was harvested and thrashed in Jnly, and on the 24 th of that month 20 sacks of it mere sent to the defendants. Plaintiff and one of the defendants again met at Bury market, and the latter said he had just had a message that the seed was out of condition, which the plaintiff denicd. Soon afterwards the defendants wrote to plaintiff, rejecting the seed, and in one of the letters informed him that "the 20 sacks which you anthorised us to receive for you and lay out thin, in consequence of its being hot and mouldy," would be returned. 
On the trial the ahove facts being proved by the plaintiff, who gave eridence that he dicl not request them to spread it ont thin, and that the seed was not hot and monldy. ITighlman J. directed a nonsuit, with leare to enter a rerdiet, if there was any evidence of an acceptance of any part of the tnruip-seed to satisfy the Statute of Frands. It was held by Lord Campltell C.J. and tike and Cromplon JJ.; Wightman J. dise., that there being eridence to go to the jury that the seed was spread out thin, neither because it was out of condition, nor by plaintiff's authority, there was evidence that it was spread out thin as an act of acceptance, and that therefore the nonsuit was wrong. Still as the eridence was slight the Court merely directed a new trial, and did not feel justified in entering a rerdict for the plaintifl. But per Lrle J. : "If" the sced was hot and monldy, it would be a very proper thing to spread it out thin and air it, so as to prevent it from perishing. I should be very unwilling to say that if perishable property is delivered out of condition, the vendee who rejects it must suffer it to perish or take to it as owner."

In Nicholson v. Bouer, wheal purchased by sample was consigned from Peterborough to Messr's. Pavitt, millers, at a railway station in London. When it arrired on May 4 they received notice that it had been warehoused at the company's warehouse, and entered in the company's books in their names. 'The company, as usual, allowed the consignees to use the warehonse 14 days, without charge. On Saturday, May 9, Messr's. Paritt's carman brought a bulk sample to them from the station, which they examined and found it equal to the sample, but said, "Don't carl the wheat to the mith at present." That afternoon Messis. Pavitt found themselves in difficulties, and on the Monday morning stopped payment. On that day they gave the vendor an order for the wheat, which he took to the railway station. On a feigned issue to try whether the wheat was the property of the assignees of Messrs. Pavitt or the vendor, it was held by the Court of Queen's Bench that, allowing the transitus was ended, there was no binding contract here without an acceptance, and there was no valid acceptance of the wheat by Messrs. P'avitt within sect. 17 of stat. 29 Car. II. c. 3. And somble per Lord Cumplell C.J., there was no valid stoppage in lransilu, for the transitus was cnded. And per Hill J., the question whether there has been an acceptance of part or not, under the 17 th section of the statute, is a question as to the intention of the buyer to be manifested by outward act: a part aeceptance is not sufficient always. And per Erle J., unless the defendant conld have sued the bankrupt in an action for goods sold and delivered there was not an acceptance.

In wrder to satixfy the I7th section of the Slatule of Frants, on a sale 
of yools for $£ 10$ or more, there must he pither a uritiny or a part payment, or a delivery and accuptance of the goods so sold. A contract for the sale of goods at that price is within the 17 th section, notwithstanding it inchudes other matter to which that section does not apply (Harman v. Recie); and the bare acceptance by the vendee as owner is sufficient to satisfy that section, although the vendee immediately after accepting them states that he does so on terms different from those on which the vendor delivered them (Tomkinson v. Staight). And per Curiam: "In an action for the price, the fact of the contract of sale having been established by the acceptance, parol evidence of its terms is admissible" $(i b$.$) . And so, where by an agrcement in writing signed by the$ party to be charged, something not expressed on the face of it is agreed to be done, and what is to be done is included in another writing, parol evidence may be admitted to show what the other witing is, so that the two documents together may constitute a binding agreement within the statute (Ridguray v. Wharton).

The Statute of Frauls was extended by 9 Geo. IV. c. 14, which was framed to meet the difficulty which arose in Rondean v. Wyutt, and the cases which were decided on its authority. Section 7 of the latter statute enacted that "The provisions of the Statute of Frauds shall extend to all contracts for the sale of goods to the value of $£ 10$ or upwards, notwithstanding the goods may be intended to be delivered at some future time, or may not at the time of such contract be actnally made, procured, or provided, or fit or ready for delivery, or some act may be requisite for the making or completing thereof, or rendering the same fit for delivery." And per curiam: "The effect of such a section is to substitute for the words ' for the price of $£ 10$ ' in the 17 th section of the Statute of Frands, the words ' of the value of $\mathbb{E 1 0}$ ', (Harman v. Reere). The effect of the new statute was thus remarked on by Martin B. in Gurr v. Scudels: "Reference has been made to various decisions under the Statute of Frands, and certainly great efforts were formerly made to take cases ont of the 17 th section of that Act. These cases remained the law, until it was amended by the 9 Geo. IV.c. 14, s. 7. According to the present law, however, if the result of the agreement be that the seller transfers the article as goods to the buyer, it is ntterly immaterial whether the goods were existing at the time of the agreement or not, and the case falls within the exemption in the Stamp Act."

When a note or memorandum in writing is sufficient to satisfy the Statute of Frauds was much considered in Richards v. Porter. 'The plaintiffs sent to the defendant (January 25 th) an invoice (in which the purties were duly described as seller and purchaser) of five pockets of 
hops, and delirered them to a carrier to be conveyed to Derby. The defendaut on February 27th wrote to the plaintiff-"The hops I bonght of you on the 23rd of January are not yet arrived. I received the inroice : the last were longer on the road than they ought to have been; howerer, if they do not arrive in a few days I must get some elserwere." It was held by the Conrt of Queen's Bench that the inroice and this letter, eren taken together, did not constitute a note in writing of the contract to satisfy the 17 th section of the Statute of Frands.

In the case of Johnson v. Dodlyson, the traveller of the plaintiffs, hop-merchants in London, agreed with the defendant at Leeds for the sale to him, by sample, of a quantity of hops. The defendant wrote in his own book, which he kept, the following memorandum :-

"Leeds, 19th Octoher, 1836 , sold John Dodgson 27 pockets Playsted, 1836, Sussex at 1038 , the bulk to answer the sample; four pockets Selme, Beckley's at $95 \mathrm{~s}$. ; samples and inroice to be sent per Rockingham eoach ; payment in bankers' at two months."

This was signed by the traveller on behalf of the plaintiffs, and on the same day the defendant wrote the latter, requesting them to deliver the hops to a third party. The bulk samples and invoice were sent to the defendant by coach, pursuant to the contract ; but he returned them as not answering to the samples by which he bought, but the jury found that they did. It was contended for the defendant that there was no sufficient memorandum of the contract in writing to satisfy the Statute of Frauds, the entry in the defendant's book not being signed by lim, and his subsequent letter not referring in sufficiently express terms to the entry as that it might be connected with it; but the Court of Exchequer deeided that the inemorandum was sufficient. Parke B. said, "The defendant's name was contained in it, in his own handwriting, and it was signed by the plaintiff; the point is in effect decided by Situmderson v. Jackson and Schncider v. Norris. There the bills of pareels were held to be a sufficient memorandum in writing, it being proved that they were recognized by being handed over to the other party. Here the entry was written by the defendant himself, and required by him to be signed by the plaintiff's agent. That is amply sufficient to show that he meant it to be a memorandum of contract between the parties. If the question tmined on the reeognition by the subequent, letter, I own I should have had considerable donbt whether it referred sufficiently to the conluact : it refers to the subject-matter, but not to the specific contract. But it is unnecessary to give any 
opinion upon that, because on the former point $I$ think there is a snfficient note in writing."

Again, in Watts v. Friend, a verbal agreement between the plaintiff and defendant, that the former should fumish the latter will a quantity of twmin-seed, which the defendant was to sow on his ou'n land, and sell and deliver the whole of the seed produced to the plaintiff at $£ 11$ s. the Winchester bushel, was held by the Court of Queen's Bench to be within the 17 th section. It was substantially a contract for goods and ehattels, as the thing agreed to be delivered would at the time of delivery be a personal chattel. The case therefore eame within the above section, and the contract being verbal only, and for goods of more than $£ 10$ value, was not binding. And per Curiam: "It wonld independently of that have been void by 5 Geo. IV.c. 74 , whieh renders invalid contracts of sale made by the Winchester bushel." The seed produced was 240 bushels, and worth at that time not less than $£ 110$ s. a bushel. Upon this ease the learned editors remark: "It wonld seem that the case would not have been within the 17 th seetion if the valne of the seed produced at the rate agreed for had been less than $£ 10$; and therefore whether it would be within it or not, was uneertain at the time when the agreement was made. Now it has been held that eases depending upon contingencies which may or may not happen within the year, are not within the fourth seetion of the statute, even although the event does not in fact happen within the year. It seems, therefore, that the 17 th section is in this respect to receive a different construetion from the 4 th" (ib.).

Where, as in Sarl v. Bourctitlon, the defendant u'ent into the plaintiff's shop, and agreed to prerchase certain goods in the aygregate exceeding the value of $£ 10$, and the several articles with their respective prices were entered in the plaintiff's "order-book," on the flyleaf at the beginning of which were written the names of the plaintiffs; and the defendant wrote his name and address at the foot of the entry, for the purpose of verifying the bargain-this was held by the Court of Common Pleas to be a sufficient signature of the contract by both parties to satisfy the 17th section of the statute. Cressuell J. said, "The memorandum stated all that was to be done by the person charged, viz., the defendant; and according to Egerton $v$. Mutthew's that is sufficient to satisfy the 17 th section, though not to make a ralid agreement in eases within the 4th. Moreover, the difficulty which may arise as to the sufficieney of the preeise candlestick supplied to fulfil the contract, is not greater than that of identity, which even in an agreement under the 4th section may be left to parol evidence. Thus in Spicer v. Cooper it was held that 'Sold 14 pockels Fent hops at 100s.' might be explained to mean 
100 s. per cwt. ; and it was not even argned that the apparent ambignity as to the price cansed by the omission of any statement of the quantity for which the $100 \mathrm{~s}$. was to be paid, rendered the note or memorandum insuflicient to satisfy the 17 th section."

A contract for the sate of stueres in a mining company, contueted upon the cost-book minciple, was held by the Conrt of Exchequer (Purke B. diss.) not to be one for the sale of land, or any interest in it within section 4 of the Statute of Frands ; but per Curiam, it is not a contract for the sale of goods, wares, or merchandizes within section 17 of the same statute (IIatson v. Spratley).

The question as to what acknowledyment will take a debt out of the Stutute of Limitations has been the subject of a very recent Excheqner Chamber decision in Rackluem v. Marriott. In this ease the debtor, in answer to an application for payment of a debt, wrote as follows : "I do not wish to arail myself of the Statute of Limitations to refuse the layment of the debt. I have not the means of payment, and must crave a continnance of your indulgence. My situation as a clerk does not afford me the means of laying by a shilling, but in time I may reap the benefit of my services in angmentation of salary that may enable me to propose some satisfactory arrangement. I am much obliged to you for your forbearance." The Exchequer Chamber, confirming the judgment of the Court of Exchequer, decided that the letter contained no sufficient acknowledgment or promise to take the case out of the statnte. Cockutrn C.J. said : "Here the defendant merely expresses a hope that circumstances will enal,le him, not to pay, but to propose a satisfactory arrangement, and he says that he will not avail himself of the statute. That does not amount to a promise to pay, but is rather holding ont an inducement to the plaintiff to let lim alone, and trust to his sense of honour. There is here an acknowledgment of a debt, but not an acknowledgment compled with a promise to pay either on demand or at a future period which has elapsed, or on a condition which has leen fulfilled. An acknowledgment without a promise is not sufficient to take a case out of the Statute of Limitations. Looking to the current of anthorities, and more especially to the last case, Smith v. Thorne, and being of opinion that the principle is applicable to the present case, we think that the acknowledgment must amount to a promise to pay cither on request or at a future period, or on a condition. Here there is a mere expression of hoje to make some satisfactory arrangement, not an acknowledgment coupled with a promise to pay."

In Siduell v. Mason the letter was as follows: "I have received your liill. It does not specify sufficiently to which cottages the work is done; for instance (specifying some of the items), I do not know 
where all this is done, and I shall feel obliged if you will more prarticularly explain. It is my wish to settle your account immediately, but being at a distance I wish everything very explicit and correct. I have asked $H$. to mark the agreements and send them to me, and I will return them by the first post, with instructions to pay if correct." 'The Court of Exchequer held that this was a sufficient acknowledgment to take the case out of the Statute of Limitations; and Pollock C.B. observed, with respect to the Exchequer Chamber decision in Rackham v. Marriott, that there was considerable doubt in the minds of several members of the Court, whether the acknowledgment was not sufficient, and that he considered it an extreme case. And per Mortin B. : "Rackham v. Marriott and Hart v. Prendergast are cases where the acknow ledgment was coupled with a hope, and not a promise to pay. It was said that the amount of the debt must be ascertained; but the contrary doctrine is established in Waller v. Lacy, and other cases."

In the case of Alder v. Keighley the Court of Exchequer laid it down as a clear rulc, "that the amount which wouthl have been received, if the contract had been kepl, is the measure of damayes if the contract is broken." The rule was cited by the same Conrt in their judgment in Halley $\mathrm{v}$. Buxendale, in which they held that where two parties had made a contract, which one of them has broken, the damages which the other party onght to receive in respect of such breach of contract should be such as may fairly and reasonably be considered either arising naturally (i. e., according to the usual course of things, from such breach of contract itself), or' such as may reasonably be supposed to have been in the contemplation of both parties at the time they made the contract as the probable result of the breach of it.

The Court of Common Pleas decided in Portman v. Middleton that the correct rule of the recovery of damages is laid down in Hadley v. Baxendale, and therefore a party cannot recover as damages for a breach of contract, compensation which he has had to pay for a breach of contract by himself, consequent upon the nonfulfilment of the defendant's contract, unless such compensation can recsonulbly be supposed to be in the contemplation of the parties at the time they male the contract. There the plaintiff contracted with one Sheaf to supply him with a fire-box for a thrashing machine by a certain day, and then entered into a contract with the defendant, by which he was to deliver one to him on a certain day in order that he might perform his contract with Sheaf. The defendant delivered an insufficient fire-box, and sheaf bronght an action against the plaintiff, which was settled by him for $£ 25$ odd. The plaintiff also gave $£ 8$ for a proper fire-box. In an action by the plaintiff against the defendant for breach of the agreement, the jury 
gave the plaintiff a rerdict, and as damages they gave $£ 12$ for the price of the fire-box paid by the plaintiff to the defendant, $£ 8$ for the price of a fire-box bonght by the plaintiff instead of the insufficient one supplied by the defendlant, and $£: 0$ for the damages and costs which the plaintiff had been obliged to pay to Sheaf. Upon a rule to reduce the damages, it was held that as the damages and costs paid by the plaintiff to Sheaf could not have been in contemplation of the parties at the time of the contract, they could not be recovered from the defendant. And per Curiam: "I'le action being brought to recover the sum of $£ 12$, it wonld be a monstrous conclusion to arrive at, that the breach of the contract for not furnishing the fire-box for $£ 12$ did give rise to the additional damage of $£ 20$."

In Sineed v. Foord, which was an action in a contract to sell and drtiver a throshing machine, the plaintiff had inquired of the defendant, who was also a farmer and an agent for the sale of thrashing machines, when he conld have a thrashing machine of a certain power delivered. A correspondence took place, in which the defendant said he could let the plaintiff have one in a month, and afterwards in three weeks, and plaintiff then wrote--." I will take a seven-horse engine, with the latest improvements, if you can let me have it in three weeks; " to which the defendant replied that he would let plaintiff have the machine at the time named. It was further intimated to defendant, that if the machine was not delivered by the 14th of Angust, plaintiff would be under the necessity of hiring one. The defendant did not deliver the machine as promised, and the plaintiff, expecting from day to day from defendant's promises that it would be delivered, abstained from hiring one, when heary rain coming his corn was damaged to a very considerable extent, and the jury had given him damages for deterioration in the value of corn and straw, for expenses of carting and stacking, for expenses of kiln-drying, and for loss in consequence of the fall in the market price.

A rule nisi having been obtained to enter a nonsuit or to rednce the damages, the verdict was ordered to stand for $£ 300$. And per Lord C'complell C.J.: "Here was an express contract to deliver the machine on the 14th of August; it was not delivered on that day, and not until long after, and the question is whether, under the circumstances, the plaintiff is entitled to recover for the damage he has admittedly sustained. Te must refer to the case of Hadloy v. Barendale, where the rule on this subject is correctly laid down; and that rule is, that the plaintiff under snch cireumstances as these is entitled to recover either such damages as may fairly and reasonably be considered as arising naturally, and in the usual course of things, from such breach 
of contract, or such as may reasonably be supposed to liave been in the contemplation of both the parties at the time they made the contract, as the probable result of the breach of it. That is the principle laid down by Pothier, the Code Napoleon, and Chancellor Kent, and that is the abstract rule laid down in Hadley v. Barendale. I do not say how far it is supported by the facts of that case, but that rule is laid down, and it is well laid down. Then are these losses naturally arising out of the breach of the contract, or such as might have been foreseen by the parties? The facts of this case clearly show that they are. The damage done to the wheat and the cost of kiln-diying were the natural consequence of the defendant's breach of contract, and the proper measure of damages; but the maiket price is variable, and it w'us just as possible that it might ha'e been higher as that it fell. I think, therefore, on that head of damages the plaintiff is not entitled to recover."

In the case of Fletcher v. Tayleur the law as to the measure of damages was thus laid down by Willes J.: "It certainly is very desirable that these matters should be based upon certain and intelligible principles, and that the measure of damages for the breach of a eontract for the delivery of a chattel shonld be governed by a similar rule to that which prevails in the case of a breach of contract for the payment of money. No matter what the amount of inconvenience sustained by the plaintiff in the case of nompayment of money, the measure of damages is the interest of the money only; and it might be a conrenient rule if, as suggested by my lord, the measure of damages in such a case as this was held by analogy to be the average profit made by the use of such a chattel."

In an action for the breach of a contract by delivering goods of a quatity inferior to that contracted for, the proper measure of damages is the difference between the value of goods of the quality contracted for at the time of the delivery, and the value of the goods then actually delivered, or their value as ascertained by a re-sale within a reasonable time; and the facts of the goods having been previously paid for cannot be taken into consideration in estimating the damages (Loder v. Kckulé).

The merchaser of goods sold upon credit cannot maintain tiover for them without paying the price ; for though he aequires the right of property by the purchase, he can only acquire the right of possession by the payment, and in order to maintain trover he must have both (Bloxtm v. Morley). So where the plaintiff' had agreed to buy sheep of the defendant, at Lewes fair, and to take them away at a certain hour, but no earnest money was paid, and no sheep delivered, and the sheep, in consequence of his 
not keeping his appointment, were sold to another person, the operation of the Statute of Frands prevented the plaintiff from bringing trover (Alexander $\mathrm{r}$. Combe). What was sufficient evidence of a conversion to support trorer was much discussed on a bill of exceptions in Giles r. T'aff Vale Railuay Company, which was to recorer quicks and plants from a railway company. 'The plaintiff was a contractor planting hedges for deferrdants at one of their stations, and was the owner of live thorn plants, which had been by leave of one Fisher (called in the bill of exceptions the general superintendent of the company) placed in a piece of ground belonging to the defendants, and close to the station. Plaintiff demanded these thorns from the station-master, and was referred to Fisher ; and Fisher, professing to act for the defendants, refused to let the plaintiff remove them. Seven out of nine judges construed the bill of exceptions as meaning that the thorns had been carried as merchandise on the line, and left in the grom of the defendant with their roots covered, as a mode of warehousing them, for a reasonable time, in such a manner that they might remain alive; but they all held thit Fisher had anthority to refuse, and therefore confirmed Wightman J.'s ruling at the trial, that there was sufficient evidence of a conversion by the defendants.

There is a differene betueen property awedred to be transferred by the ouner to another, and property which is actually transforred by the contract of the ouner through the medium of his ayent; and in the former case, while the award is still unratified, trover cannot be brought. Such was the case in Hhonter v. Rice, where, under a submission to an arbitrator of all matter's in difference between landlord and tenant; the arbitrator awarded, inter aliu, that a stack of hay shonld be delivered up by him to the landlord by a certain day, upon the tenant being paid or allowed a certain sum in satisfaction. The question here was, whether the property in the hay was transferred from one Sharpe, who was tenant to Hunter, of certain land on which the hay was stacked, by force of an award, without the assent or delivery of Sharpe, to the plaintiff. Hunter brought an ejectment for waste, and the whole matter was referred to an arbitrator, and the submission was made a rule of Court. On a balance being struck, pursnant to the award, it scemed that Hunter orred Sharpe $£ 18$, which sum was tendered and refused. Sharpe also refused to quit or to execute the award, but was evicted, and then placed in custorly under an attachment for nonperformance of the atrard. Sharpe's wife sold the hay off the premises, and the defendant was employed to carry it away. It was onjected that trover did not lie, there being no property in the plaintiff nor conversion by the delcndant; but the plaintiff was permitted to take a 
verdict. The Court made a rnle for a nonsnit absolute. Lord Eflonborough C.J. said: "In the present case there is no other remedy for" the plaintifl but to proceed against Sharpe upon the award. If indeed Sharpe had accepted the money tendered, that would have been a ratification of the award, and an assent on his part to the transfer of the property; but without that I cannot conceive that the property was transferred by the mere force of the award."

An order for delivery made by the seller to the buycr of a rick of hay on a third person, who has consented to let it remain on his land; is a sufficient delivery as between such seller and buyer, the latter having undertaken to carry it aucay himself; and according to Sulter v. Woollams such third person is clearly liable in trover if he refuses permission to remove the hay, as on the sale the property in the hay passed to the rendee, and if any accident occurred the loss wonld have fallen upon him.

In the above case Messis. J. and R. Aldrilge distrained for rent on some growing grass, which was subsequently made into two ricks of hay on the premises, under 11 Geo. II. c. 19, s. 8, and the defendants as anctioneers advertised the ricks for sale by auction in two lots; the hay, by the written consent of $H$. Jackson, the distrainee, to remain from the day of the sale, July 24 th, till the 28 th of September. This memorandum of consent was indorsed on the conditions of sale, and read by the auctioneer at the commencement of the sale; and the plaintiff bought one of the ricks for $£ 30$, and paid the money. He went next weck to the premises to remove it, bnt was not allowed to do so. He accordingly brought an action of assumpsit against the anctioneers. A rerdict was found for the plaintiff, both on non-assumpsit, and "that the defendant did deliver to the plaintiff possession of the last-mentioned rick of hay" issues; but the Court of Common Pleas made the rule absolute for a non-suit, as the contract, on the part of the defendants with the plaintiff, was merely that they would give him a ful legal authority to remove, which they had fulfilled by procuring and incorporating into their articles of sale the written agrecment from Jackson, who had attorned to the sale."

The measure of tamages in trover where an offer to return the chattels lias been made after writ issued, is the value of the chattels at the time of the conversion, and not the difference in their ralne betreen the time of the conversion and the offer to return (Homer v. Mellars).

In Randall $\nabla$. Roper, which was an action bronght by a purchaser on a breach of u'arranty on a sale of goods, pridence given lyy sub-purchasers who had bought portions of the goods with a similar warranty, that they hat made claims against the purchaser for breach of warranty, is admissible. 
as the natmral and probalile resnlt of the breach of the original contrart, and notwithstanding that none of the elaims have been satisfied. This action was for a breach of marranty on the sale of 30 quarters of Chevalier seed barles. The plaintiff, the purchaser, had sold portions of the barley, with the same warranty that he had received from several sub-purehasers, who had surn the barley, and snbsequently made claims to the plaintiff for the damage they had sererally sustained by the badness of the barler. At the trial before the mnder-sherifr of Essex, the sub-purchasers gare eridcnee of the loss which they had sustained, and the plaintifl oltained a rerdict for $\mathfrak{2} 261 \mathrm{7s}$. 6d., while the damage prored, independently of these witnesses, was $£ 15$. A rule to reduce the damages to $£ 15$, on the ground that the contingent damages were not the natural and probable result of the breach of the original contract, and that the plaintill had snstained no actual loss on his re-sales, because the proof only amounted to claims against him (the test of certainty in damages being whether they are liquidated or unliquidated, as in this case, and not estimable by a jury), was refused by the Court of Queen's Bench.

Erle J. said: "The question is, what amount of damages the plaintiffs are entitled to recorer? The defendant sold the barley as Cheralier sced barley, and from such a contract the natural and ordinars consequence mould be that it wonld be sold as the same, and on being somn, an inferior crop would come up. The natural amount of damages would be the difference between the value of the inferior crop and of that which would have come up if Cheralier seed barley had been sown, which would have been within the decision in Hadley v. Baxendale. Then it is said that the sub-purchasers hare merely claimed the money from the plaintiffs, but have not brought any action, and that non constat, the claim may ever be enforced. But where a legal liability to pay is incurred by a man, and a claim is made in respect of it, he can recover the amount he is so liable to pay from the person by whose Jreach of contract he has incurred the liability; and for this purpose tlice is no difference letween a liquidated sum and a sum which is unliquidated, but which he is liable to pay."

'The question in IIollingham v. Head was, whether in an action for goods sold and drtireved, it is competent to the defendent to show that the ptaintiff has entered into contrats of a particular form, for the purpose of conrincing the jury that his contract with the jlaintiff was in the same form. In this case "rival guano" had been supplied to the defendant, a farmer. The defence was that the guano in question was sold on the rondition that if it was not equal in ruality to Pernvian guano the defcudant was not to pay for it. The price of the "rival guano" was 
$\mathcal{E} 7$ per ton, while that of the Peruvian was $\mathfrak{E} 14$, and the improhability of such a contract being made by the plaintiff was eommented upon liy his connsel. The plaintiff was called, and in cross-examination was asked, "Did you not sell portions of the 'rival guano' to other parties on the same terms?" meaning the special agreement as to quality, above referred to. Witlirms J., however, thought that such a question might be put for the purpose only of testing the credit or memory of the witness, and that it could not be offered as independent evidence for the defence, that similar contracts to that insisted on had been made with other parties. It was proposed to put similar questions to the defendant, but the learned judge also refused his permission. A verdict having been found for the plaintiff, the Court of Common Pleas refused a rule for a new trial, on the ground of improper rejection of evidence, and considered the case of Reg. r. Egerton quite distinguishable. And per Bytes J.: "It may be that the plaintif? might have been asked whether he had ever made such contracts befure, by way of testing his memory or credit. But as evidence offered by the defendant, it was totally inadmissible, and to hold otherwise would be contrary to every principle and to universal practice" (ib.).

A joint interest and occupation of a farm by two persons is not a patnership, so as to convey to each an implied authority to binut the other, by the acceptance of bills of exchange, for payments in respect of the farm (Greenslade v. Dower). And where, as in Wish v. Simall, the plaintiff purchased two bullocks, and put them to feed on the lands of one Woof, on an agreement that the profit above $£ 20$ to be made by the re-sale after they had been fatted should be divided equally between the plaintiff and Woof ; and it was objected in an action for the price, that Woof should have been joined in the action; Thompson B. thought that he and Wish were merely partners in the profits, and that this was a mode of paying. Woof for the pasture, and the Court of Quecn's Bench refused a rule for a nonsuit.

Under stat. $17 \& 18$ Vict. c. 36 , s. 1 , a bill of sale is void against creditors untess a description of the residence and occupation of the person granting it be fited along with the bill of sate. It is not sufficient that the bill of sale which is filed itself contains a deseription of his residence and occupation (Hetton v. Enyfis/1). The same statute requires that the description of the residence and ocrupation of the attesting uitness to a bill of sale shall be given, though the bill of sale be not made by a person in execution (Tuton v. Senoria). The defect of registration under the Bills of Sales Act does not avoid a bill of sale as between the parties. Where a bill of sale assigned certuin horses as a security, and also sueh other horses as might be substituted for them in the business of the 
assignor, prorided the names and descriptions of such substituted horses were indorsed, it was held by Colerilige. I. that the indorsements did not require an additional stamp, being only for the purpose of identification. The son of the assignor claiming them, all the eircumstances were left to the jury on the question of property, althongh the son swore he had merchasel them, the business appearing to have been the assignor's (Barker r. Aston). It was ruled by Williams J. that the Bills of Sales Act only renders bills of sule voil for ulefect of myistration, not as between the parties, but as against creditors (Hills $\mathrm{v}$. Sheppard).

An aswigmment by bill of sale, as security, for a debt (due for money lent and work done as an attorney) to an attorney from his client, of the sulject matter of a snit, during its pendency, in this case an unexpired term in a farm, together with the erops growing on it, is not roid on the ground of champerty (Amlerson v. Ratefiffe amel Walker). When on the face of an assigmment of personally it is plain that it was intended to operate as a continuing security, and to apply to property afterwards nequired, and substitnted for that which was originally assigned, it will, if the words are eapable of such a coustruction, be so applied. And where in such a case the deed was found capable of such a constrnction, although rather in the indirect form of a power of attorney, than in the way of direct conreyance, it was construed to extend to stock and grouing crops on a farm not occupied by the assignor at the time of the execution of the deed (Allott (Exor.) v. Cary and Scholfield).

The teslator in Quayle v. Daridson, devised a farm to lits u'ife, and after her theath to D., "in trust for D.'s son beiny brought up to work the furm," provided if D. have no male issne, then to other persons. D. had no child at the date of the will, but after the testator's death had a son. It was held by the judicial committee of the Privy Council, that 1).'s son did not take any beneficial interest nnder the will, the words "in trust for D.'s son being brought up, \&c.," being a mere recommendation or expression of hope or confidence; but quere if D.'s son lad been burn before the date of the will whether he would have taken an interest.

A tenant farmer bequeathed his houschold goods, \&e., "together with all his live and dead farming stock, implements, and all other his household and furming eflects," to his wife for life, or so long as she should continne his widow. ITe directed also that after his decease :n inventory shomld be taken of his said porsonal estate, but he gave 310 direction as to any valuation being marle. After his death an inventory of his personal estate generally was made for the purpose of the probate dnty, lut no inventory was signed as directed by the will. 'The widow married again, and the legatees in remainder claimed that 
the widow and her husband may be charged with the value of the following articles included in the inventory: growing turmips, fallows, labonr, seeds, and manmre, wheat, \&c., oxen, shcep, and pigs, some of which the tenant was bound to consume on the premises, and others not. It was held that, as the testator had not directed a valnation, the legatees in remainder could not eall for an account of farming effects of a consumable nature specifically bequeathed, which had been actually consumed by the tenant for life in the ordinary course of husbandry (Bryant v. Easterson).

In the case of Shaw v. Robberds, the plaintiff insured premises against fire by the description of a granary, \&ce, and "a kiln for drying corn in use" communicating therewith. By the third condition of insurance the policy was to be forfeited, unless the buildings were accurately described, and the trades carried on therein specified; and by the sixth, if any alteration were made in the building or covering, or the risk of fire increased, the alteration, \&c., was to be notified and allowed by indorsement on the policy, otherwise the insurance to lse roid. The plaintiff carried on no trade in the kiln except drying corn; but in 1832 the bark from a vessel which had sumk near Lymn was dried gratuitonsly, and no notice was given. No greater fire was made; but in the course of drying, the bark in the kiln took fire, and the other premises were burnt down. The jury found that drying bark u'as a distinct trade from drying corn, and more hazardons, and that insurance oflices charge a higher premium for a bark kiln, and a rule was made absolute to enter a verdict for the plaintiff.

Omission of statement in fire instrance policy.-A fire insurance policy contained a condition that it shonld be roid "unless the nature and material structure of the buildings and property insured, and of all buildings which contain any part of the property iusured, be fully and accurately described, and unless the trades earried on in such buildings be correctly shown, or if any alteration or addition be made in or to any buildings insured or in which any insured property be contained by which the risk of fire is increased." The policy stated that a steam engine was erected on the premises, which was used for the purpose of raising goods; machinery had also been erected for grinding corn for horses, which was driven by the engine, and the Conrt of Exchequer held that the omission to state this fact, did not violate the condition (Baxendale v. Hurdingham).

The law of the market was thus laid down by the Court of King's Bench in the Mayor of Northampton $\nabla$. Ward: "By law every man has, of common right, a liberty of coning into auy public market to buy and sell without paying any toll, if it be not due by custom or 
preseription ; but if he requires any particular easement or conrenience, as it stall in the marliet, he must have the licence of the owner of the soil for that purpose, if there be no particular sum fixed by the custom of the market for stallage. If there be a fixed sum or duty by custom, that cannot be cxeeded, but still he must agree with the owner of the soil." And it was held in The Mayor of Neuport v. Samucers, that assumpsit may be maintained by the owner of a market for stallage, as for use and occupation of premises, and that without showing any contract, in fact, between him and the oceupier of the stall. And per Lord Tenterden C.J. : "Tolls may be recovered in assumpsit, and no proof is required of anything like a contract by the party against whom the claim is made. Evidence is given of the right to receire them, and that is always deemed sufficient. Stallage is not distinguishable from tolls in that respect. The party entitled to stallage may waive the tort."

I person who erposes goods for sale in a public market has a right to ocrupy the soil with baskets necessary and proper for containing the goods (Tounchel r. Woodruff) ; and per Alderson B.: "Ereeting a stall is rery different from plaeing goods in baskets on the ground for sale" (ib.) But if any one is refused at a fair or market the accommodation to which he is entitled, a court of equity cannot interfere by injunction (Weale v. West Mielllesex Water Works). Blakey v. Dinsdale seems to establish that, in order to maintain an action for selting yoods near to, but out of the limits of the market, it is incumbent on the plaintiff to prove that the defendant did so ficuululenfly, in order to aroid the toll ; and the distress of goods thus fraudulently sold was illegal. But the proprietor of a market caunot bring an action for toll against a person who sells ont of the limits, unless he shows that he first a]prised him that there was room in the market, to which he might resort.

This was the sulustance of the decision of the Court of Qneen's Bench, in the celchrated Corent-garden case of Prince v. Lexis.

King Charles II., ly letter's patent, granted to William Earl of Bedford, his heirs and assigns, leave to hold a market within specifierl limits within the parish of St. Paul's, Corent-garden, on every day in the week (except sunday and the Feast of Nativity) for the buying and selling of all kinds of fruits, flowers, roots, and herbs whatsoever. By is Goo. III. c. 71, reciting these letters patent, \&c., the owners of the inarket were anthorized to take from the sefler the tolls then usualiy taken or enllerted within the market. The plaintill's were the lessees of the market muler the l)uke of Bedford, and the deliendant resided in James-strect, about 7 ) or 80 yards withont the linits of the market. Betwecin the hours of six and eight on the 1th of January, 18:5, a 
waggon loaded with greens was drawn up before his door, and he sold them there. There was evidence to show that during some part of the time he was sclling there was room in the market for his cart; but the plaintiffs dicl not apprise him of the fact, when they demanded toll. It appeared that part of the space in the market was let out to yearly tenants for the sale of different articles, not being fruits, flowers, or regetables, and that in fact there were china shops, old iron shops, and some public-houses-in short, two-thirds of the market was occupied with covered buildings. Tolls had freqnently been collected in Jamesstreet; and in consequence of so much of the market-place being appropriated to other purposes, the remaining space was on ordinary occasions fully occupied. Abbott C.J. (without adverting to the fact that during part of the time while the defendant was selling his vegetables there was room for his cart in the market) was of opinion that the lessees of the market were not entitled to maintain this action unless they gave up the whole space for the use of those who attended the market from day to day to sell those commodities to the sale of which the market was devoted. The plaintiffs were non-suited, with liberty reserved to move to enter a verdict; but the Court of Qncen's Bench discharged the rule. As it was proved that the market was generally occupied, they held that it lay upon the plaintifls to show that the defendant knew that on the morning in question there was space for his cart in it, and that they had given notice to him to that effect.

A market which hat existed de facto for more then twenty years, and for which tolls had been taken as for a legal market, but which the jury found had no legal origin, is not a market "legally established" within the 50 Gco. I1I. c. 41 , s. 5, and a hawker trading therein without a licence may be arrested and taken before a magistrate (Benjumin v. Andieus). To aroid the penalty the market must be one created by grant, and not merely a market de facto (ib.).

The circumstances whirh constitute a fiaud on the lessee of a market were illustrated in Brilgland v. Shapter. Ilere the plaintiffs were the lessees of Sir John St. Aubyn, of a market called Deromport Narket, within the borough of Devonport, under a written agreement not under seal. The defendant, a cattle-jobber at Ugborongh, had on several market-days brought sheep to the premises of a public-house 40 yards beyond the limits of the market, where he left them while he went into the market in search of customers, whom he brought back to the public-honse, and there bargained with them for the sale of the sheep, and refuscel to pay any tulls in respect of such sales. J3y a private act the market was enlirged into one for cattle, \&c.; and Sir 
John St. Aubrn was emporrered to let the erections, buildings, \&c., on the ground whereon the market should be held, and to demand and take certain tolls of and from any person or persons bringing any goods or articles to the market. There was also a clause providing that if the owner should demise or lease the market or the site thereof, the lessee should be sulject to such exceptions or restrictions as might be expressly contained in the lease, and take and enjoy the rent and tolls authorised to be taken by the act, as the owner would be entitled to do if the lease had not been made. At the trial it was contended for the defendant that the market, being an incorporeal hereditament, could only be leased by deed; and that the defendant had not been gnilty of any disturbance of the market for which he was liable in this action, the right to toll being only in respect of articles brought to the market. Gurney B. overruled these objections, and a verdict was found for the plaintiff with nominal damages, leave being reserved to the defendant to more to enter a nonsuit or a verdiet in his favour. The Court of Exchequer discharged the rule, and held that the lessee of the market under a parol demise had a right to take tolls, and that this was a fraud on the market, for which case would lie by the lessee of the market.

In Smith v. Hulson the defendant, a farmer in Norfolk, sold John Willden $48 \frac{1}{2}$ qrs. barley to be delivered to Willden's order on the Great Eastern Railway: the barley was duly delivered at Swaffham Station on the 7th November, 1863. Willden became bankrupt on the 9th Norember, and on the 11th November, and before the bankrupt had given any directions about the corn, the defendant gave a rerbal notice to the station master at Swaffham not to deliver the corn into the possession of the bankirupt or his assignees or any other person without defundant's consent in writing, but to deliver the same to him or his order, and subsequently on the same day gave a written notice to the station master to the same effeet. At the time these notices were given, the corn was still on the platform of the goods shed at the station. The bankrupt had given no order respecting it, nor had he examined the bulk to sce whether it corresponded with the sample, nor had he given notice to the defendant whether he declined or accepted the corn. It was held by the court that the plaintiffs, the assignees in bankruptey, were not entitled to the corn, 34 I. J. (N. S.) Q. B. 145.

Returns of sales of com, under 1 \& 2 Gico. IV. c. 87, are not conclusive evirience, if evidence at all, to show the parties to whom the corn was delisered; for it is no part of the duty of a corn-factor to mention this in the retum (Woolley v. Brom'n). It was enacted by $22 \mathrm{Car}$. II. c. 8, s. 2, that no one should sell corn except by the eight-gallon Jinchester 
measure; and semble, since 5 Geo. IV. c. 74, an agreement to sell by the Winchester bushel, not containing any declaration of the proportion which that measure bears to the imperial bushel, is void (Witls v. Friend). By this act the imperial standard bushel of eight gallons or solbs. avoirdupois was substituted. For heaped measure (potatoes, lime, and fruit, \&c.) the same standard was adopted for the bushel, with the proviso that the bottom of the ressel should be plain and even, and $19 \frac{1}{2}$ inches from outside to ontside. "In Mark Lane, however, wheat (taking it only as an illustration, though as great a diversity exists as to barley and other products) is nominally sold by the contents of the imperial bushel without reference to weight. Measure is in fact found to be so much affected by quality and other circumstances that practically an average estimate of the weight of the imperial bushel has been formed, and 62lbs. is generally taken as equal to and representing the imperial bushel.

"In the markets of Birmingham, Warwick, Walsali, Stratford, Alcester, Worcester, Evesham, Kidderminster, Bromsgrove, Gloucester, 'Tewkesbury, Hereford, Ledbury, and generally throngh the counties of Warwick, Worcester, Gloucester, and Hereford, wheat is sold by the bushel of 62lbs.; whilst at Monmonth, Abergavenny, and in Monmonthshire generally, it is sold by the bushel of 80lbs. At Nantwich, Shrewsbury, Market Drayton, and Wellington, it is sold by the bushel of 75lbs. In Wolverhampton and Stafford $721 \mathrm{bs}$. is reckoned to the bushel. In Manchester English wheat is sold by the bushel of colbs., and American wheat by the bushel of 70lbs. At Liverpool, Bideford, and Torrington, a bushel of wheat means 70lbs.; at Aberystwith, 65lbs. ; at Carmarthen and Haverfordwest, $641 \mathrm{lbs}$; at Hull and Boston, and Lincolnshire generally, 63lbs. ; and at Wakefield, Doncaster, and Leeds, 60lbs. At Aylesbury, Cirencester, Dorking, Farnham, Petworth, Uxbridge, Midhurst, Oxford, Robert's Bridge, Chichester, Brighton, Linfield, and East Grinstead, wheat is sold by the load of five quarters ; at Hitchin, by the load of five bushels; at Pontefract, by the load of three, and at Bedford by the load of five bushels. At Ulrerstone wheat is sold by the load of 144 quarts; at Bridgnorth, by the bag of 11 scores; at Much Wenlock, by the bag of 11 scores and 4lbs.; at Ludlow, by the bag of 11 scores and 10lbs.; at Leominster, by the bag of 12 scores; at Whitehaven, by weight of 14 stone; at Nottingham and Grantham, at 36 stone; at Malton and at Scarborough, by the weight of 40 stone; at Swansea, by the sack of three bushels; at Barnard Castle, Darlington, and Morpeth, by the boll ; at Beccles, by the coomb ; at Preston and Garstang, by the windle of 220 lbs.; at Denbigh, by the hobbett of 16slbs. 
In Suffolk nearly all grain is sold by the coomb of 4 bushels, and in Cambridgeshire by the quarter of $s$ bushels. These are but samples of the miniresal confusion on the sulject, the custom, however, of selling all grain by weight is rastly on the increase, and will probably become general, the standard weights per imperial bushel being, for wheat, 63lbs.; for barley, 5clbs. ; and for oats, $421 \mathrm{los}$.

Stat. ¿े \& 6 Mill. IY., e. 63, s. 6, abolishes all "local or customary measures, and imposes a penally on crery person who shall sell by amy desumination, or measure other than one of the imperial measures, or some multiple or atiquol part thereof." But it was held by the Court of Queen's Beuch in Hheghes v. Ihumphrey that this applies only to sale by measure of capacity, and not to sale by weight estimated in pounds; and that, therefore, it does not extend to sale by any local term designating a given number of pounds weight.

Huyhes v. Humplereys was a case of sate by the hobbelt, which is a measure of the Llanrwst market, and contains four Welsh pecks, each of them 42lbs. in weight; it therefore contains 168lbs.; while an ordimary sack contains six Welsh pecks, or 252lbs. The sale was made by sample, at Rhyl, in Flintshire, at so much per hobbett, and the wheat was delirered in sacks of the ordinary kind. Filliems J. directed a rerdict to be entered for the defendant on the third issue under $5 \& 6$ Mill. IT., c. 68, and the Court of Queen's Bench ordered it to be entered for the plaintiff. And per Lord Camproll C.J.: "If this was really a sale by measure of capacity it would be contrary to the Act. And the question therefore comes to be, Was it a sale by measure or a sale by weight in pounds? Now, according to the evidence, when jon buy ly hobbett you buy not dimensions but avoirdupois pounds, and the contract is not fulfilled unless that weight is marle; it is therefore a sale of so many times $168 \mathrm{lbs}$., which is a sale by weight, and no infringcment of the statute 5 \& 6 Wrill. IV., c. 63 , or of any other act." Er.l J olserved: "It is clearly a sale by the pound, the hobbett being a given inultiple of a pound."

In Ouens v. Denton a sale by the hobbett was held illegal, it being there assumed that the hobbett was a measure of eapacity. And so in Tyson v. Thomes it was held that an action could not be maintained "upon a contract to sell by the hobbrtl, it appraring on the evidence that "hoblett ronsisted of four perks of 21 legal pnarts earh, and not, as in

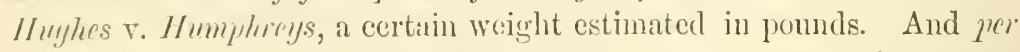
Lord Semyon, C.J., in Chenie v. Watson: "The contents of measues rinc onty be proved by prorluction in opmen Courl." It was in evidence there, that the romend strike fressed the corne down, and left more in the Jushel than the flat strike. 'The provisions of 36 Geo. Ill., c. 88, 
ss. 2 \& 3 , which repuire the lontter-packing vessel to be branded under a penalty with the name or the names. in full of the cooper and seller, the exact weight or tare thereof, indirectly prohibits any sale of butter in vessels not properly marked, and therefore the contract of sale for a number of firkins of butter not so marked is void, and the plaintiff cannot recover, and the clause may be nsed against him as a defence to an action. The Court of Queen's Bench in Foster v. Tuylor directed a nonsuit, and said that it was rightly held at the trial that the onus lay at all events on the defendant to prove that the plaintiff had not complied with the statute.

And semble by the Court of Exchequer Chamber that the 15 th section of 5 Geo. IV., c. 74 , is not repealed by 5 \& 6 Will. IV., c. 53 , and consequently that contracts by loeal weight may be lawfully made if the proportion to the standard is expressed; though it is otherwise with respect to measures, all local measures being abolished by 5 \& 6 Will. IV., c. 63 , s. 6 (Giles 5. Jones).

The seller of corn by sample in a market is benefited by the marliet, as well as the seller of corn wohich is pitched there in bulls and sold; and if he refuses to pay the same toll which is paid by the seller of corn in bulk, an action on the case lies against him for the injury done to the market in selling by sample (The Bailiffs of T'eutiesbury v. Bricknall). Where a toll hat been customarily taken by the collector mutting his hand into the saek and lifting out a hendful, and placing it in a bowl held near the month of the suck, and that functionary varied from his ordinary mode by sweeping instead of lifting such toll, it was held, by the Court of King's Bench in Norman r. Bell, that trover lay against him for the excess. It is now provided by 5 Geo. IV., c. 74, s. 9, that where articles are sold by stricken, not heaped measure, "they shall be stricken with a round stick or roller, straight, and of the same diameter from end to end."

By 19 \& 20 Vit., c. 114, s. 1, no water, sand, carth, or other matter is to be zut into a bundle or truss of hay or straw intended for sale within the eities of London and T'estminster or within 30 miles thereof, to increase the weight, imder a penalty not exceeding $£ 10$. By section 2, salesmen, \&c., are to furnish the lunyers with a ticket stating the number of trusses sold, and the name and address of the owner. This Act and 36 Geo. HI., c. 88 , are to be construed together.

An assignment for the benefit of credlitors by a trater and farmer, of alt her "effects, stock, books and book delits," conveys the cattle on the farm (Levis v. Roygers, Exor.). A farmer who is in the habit of buying half as many more sticep as was necessary to stock his farm, and of selling the surplus at a profit, is a trader within the bankrupt laws as a sheep- 
salesman (E.r parle Nenall). And so if he buys horses unfit for farming, and resells them, and arows his intention to take out a licence, and become a horse-dealer, these ficts were held in Wright v. Birl to be critence of tratling. I colonel of a regiment who sills horses occasionally at Tattersalls (Err parte Blackmore), or a person who keeps houmds, buiging dead horses and selliny the stins and bones (Stammerselt v. Jarris), are not liable as traders. But a farmer making lime fiom a lime-pit, opened and worked before the commencement of his term, and sclling the surphus beyond what he required for manure, is not a trader within the bankrupt laws (Ex parte Ridge). And so where the defendant in Patten r. Gould bonyht sixty ping in the course of the year, fel them on his stubles, and resold some at the end of a weck; and also bought 200 bushels of ray grass to sell, which he mixed with seed he raised on the farm, and resold at a profit-it was held that neither of these acts made him a "trader" within the scope of the bankruptey laws. Borrough J. observed, that in a year like 1816, when so much wheat was beaten down with rain and tempest, it was most profitable to stock a farm with pigs.

The anthorities on the subject were much considered in Bell and Anor., Assignees, v. Young. The case stated by the arbitrator for the opinion of the Court of Common Pleas found that H. M. Hainland, a farmer", who was under covenant with his landlord "to consume the whole of the turnips and other roots upon the premises," liept cou's as part of his slock on the farm, $\dot{m}$ orter that he might sell mith throngh his man at the neightbouring tou'n, to chance and regutur eustomers, besides making butter for sale of the surplus mitk, and that his keeping cows to this extent was a good, proper, and husbandlike way of managing the firm as he did, and that cows in fact were the most profitable stock he could keep. The Court held that he was clearly not a corkeeper within the meaning of the Bankrupt Act, 12 \& 13 T ict., c. 106, s. 65. Their decision was governed by Ex purle Dering, where a farmer in the Isle of 'Thanct occupying two firms (a considerable portion of which was soun with comarysect, the manure for which was all purchascd), containing togrether 200 acres, and bound to fodder his straw ant green crops on them, kept five cows, four of which were Alderneys, and seven horses, and no other stock; and it was lield that his selling the milk of the cows regularly to a retail dealer in Margate, who pail for it on an arerage 30 . a-weck, did not render him sulject to the bankrupt laws as a cowkecper. Er parte Inemmond was similar in principle to the above. Here a tenant of 180 acres under a farming lease, which ohliged him to fetlow

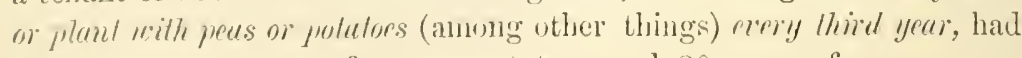
on lis farm 12 acres of young potatoes, and 20 acres of green peas, 
growing in open fields every year, and consigned the prodnce for table consumption to London salesmen, to whom he allowed snch commission as was usually allowed by market gardeners; and it was held that he was not a narket gardener within the 5 \& 6 Vict., c. 12\%, s. 10. And see 12 \& 1 .) Vict., c. 106 , s. 144, as to non-liability of bankrupt for rent accruing after issuing of fiat or filing of petition of adjudication of bankintey against him.

Owner of market liable for nuisance from the droppings.-The owner of a market allowed sheep to be penned there, and he found the hurdles for the pens, and derived a profit in addition from the toll on the sheep, whose droppings created a nuisance on the part where they were penned. It was held by the Court of Common Pleas that the appellant, the owner of the market, was liable to an order for the removal of the nuisance mnder section 12 of the Nnisances Remoral Act (18 \& 19 Tict. s. 121), as being the person within the meaning of that section, "by whose act, default, permission, or sufferance" the nuisance arose.

Cattle fair not to be held on picce of ground put by for recreation biy Corporation.- Where by an Act of Parliament a corporation were directed to canse a piece of land to be drained and levelled, and kept in proper condition for purposes of public recreation, the Court restrained the corporation by injunction from permitting a cattle fair to be held on such piece of ground. (Attorney General v. Corporation of Southampton.)

Selling horse within limits of market.-By a local act for establishing a market, power was given to the proprietors of the market to take tolls on horses brought into the market place; and by one of its clauses it was enacted that every person who should sell at any place within the limits of the act (other than in the market-place, or in his own drelling-honse, or in any shop attached to or being part of any dwelling-house) any article in respect of which tolls were by the act anthorised to be taken, other than eggs, butter, and fruits, shonld forfeit a sum not exceeding 40 s, provided that nothing therein should restrain any person from crying or selling from door to door within the limits of the act any such article as aforesaid, provided such person should have first paid for such articles the regular market tolls, and provided such articles should first have been brought into the market for inspection there. It was held that a horse was an article within the meaning of such clanse, and that a sale of horses within the limits of the act by a licensed auctioneer in a yard which formed part of the drelling-house and premises of a third person subjected the anctioneer to a penalty of $40 \mathrm{~s}$., the place of sale not being within the exception 
contained in such clanse (Llumeluff and ('onlon Districl Murkert Company appits. r. Jimnton resp.)

Harranting tumip sed to lie rape sect.-An action by seed merchant lies against seed brokers for falscly warranting turnip seed to be rape sced, although it was sold by sample, and was of greater vilne than turnip seed, the pluntifr haring sustained actual loss and injury in lis business, from having resold it as rape seed, and haring to compensate his enstomers. (Lovegrove v. Fislerr.)

Warranty of seel.-In Pinder appt. r. Button resp., the action was for damages sustained by the appellant having contracted to sell to the respondent a quantity of mangold-wurzel seed warranted to be of good growing stock, and having delirered seed not according to such warranty. The memorandum signed by appellant was merely, "Sold Mr. Button half a ton of yellow mangold wurzel seed, at $9 \mathrm{~d}$. a lb., for the latter end of the year." Respondent was allowed to give parol evidence that appellant said the seed was to be sown by himself, and be of "good growing stock." Sereral of respondent's customers were called to prore that the seed was "unproductive and worth nothing," and there was some evidence, although the appellant denied it, that the seed when delivered by the appellant was kiln.dried, and therefore injured. It was admitted that the season of 1860 , when the bargain was made, was rery wet and unfarourable, and also that there was no fraud. For the appellant, it was contended that there was no warranty, and no evidence of the quality or unproductiveness of the secd. 'The learned judge of the Lincoln County Court ruled "that there was necessarily an implied warranty that the seed wonld grow," and gre a $\$ 50$ verdict for the respondent; and The Court of Queen's Jencl gare judgment for the appellant. And per Cockburn C.J.; "It dues not appear that the seed delivered was dead or bad, or had wholly lost its character as seed, but only that it had a defective germinative or reproductive power. We are not called on to decide whether on a rencral contract for seed there is an implied warranty that it is growing sced. 'This is not such a contract; it is a special contract for such seed as the appellant should raise from seed 'of a good growing stock.' It is not denied that the seed he delirered was fairly raised from snch seed "of a crool growing stock ;" and there being an express warranty, there can l,e no warranty implied beyond it. It was agreed that the appellant should sow a certain quantity of mangold wurzel seed on his own land of ' a good growing stock;' and shonld sell the respondent the seed raised therefrom. 'There is nothing to show that he has not done so ; and if so, the only warranty he gave has been complied with. The judgment of the County Court, thercfore, was wrong, and this appeal must be allowed." 
Riste of vente in absenre of express warranty. - $\mathrm{\Lambda lthongh}$ a vendor is informed of the purpose for which a material is required, yet if the rendee inspects it, its unsoundness or mufitness for the purpose, in the absence of any express warranty, is no defence to an action for the full price; per Cockburn C.J. (Fitrgerald v. Ireson), 4 II. \& N. 412, 28 I. J. Exch. 238.

Damayes for selling manure not corresponding with warranty.-TV., being agent to sell for two distinet principals, $H$. and defendant, both dealers in manure, contracted with plaintiff to take back manure which as agent for $\mathrm{H}$. he had supplied to plaintiff, on condition that plaintiff wonld take certain other manure which defendant dealt in instead, and which W. warranted, it being, as the jury found, usual to sell such manure with a warranty. Defendant executed the order for the latter manure, and received payment from plaintiff; who was also a dealer in manure, and, as defendant knew, purchased to sell again. Plaintilf having resold the manure to different purchasers, was threatened with an action by one of them for loss sustained by reason of the manure being, as was proved, of an inferior quality, and plaintiff made good the loss, but no complaints were made by the other purchasers. It was held, first, that defendant was liable to plaintiff in an action on the warranty given by W.; secondly, that the differenee between the value of the manure supplied and its value if it had been according to the warranty was a correct measure of damages. And scmble, that the loss which the plaintiff made good to his vendee was damage naturally arising from defendant's breach of contract, and for which he was liable to the plaintiff; and that if the two contracts made by W. with plaintiff were to be considered as only one, plaintiff had sufficient interest in it to maintain the action. The jury gave the ordinary measure of damagesi. e., difference between the actual value and the value guaranteed (Dingle v. Hare).

Where uarranty not implied.-The sale of an article not by sample, but by a particular description, does not necessarily import a warranty, if all the circumstances show that it was understood as a mere expression of opinion or belief; and words having a known natural meaning can have a particular meaning attached to them, as prevailing in a certain trade, only by clear evidence, as a matter of fact, of their general use and acceptation in such meaning. The defendant, a corn dealer, sold to the plaintitr, also a corn dealer, barley by sample, which he called "seed barley," but which he had himself just purchased by sample, not laving seen the bulk, and, as the plaintiff knew, being ignorant of what sort it was. It turned out to be an inferior kind of barley, and different from ordinary seed barley. There was no evidence 
that in the corn trade the words "seed barley" had acruired a particnlar meaning, thongh there was eridence that it had in the locality such a meaning. It was leeld that there was no evidence of a warranty, nor of a contract for anything clse than what the words naturally imported, viz., barley seed which would grow; and such barley having been delirered, that there was no canse of action. The rnle to set aside the nonsuit was discharged. And per Martin B. : "There was no warranty. A warranty is an absolute engagement that the article sold is of a particular quality or kind, and will answer a particular purpose. Here there was a mere expression of opinion or belief. The defendant had negotiated for a quantity of barley, which he believed to be 'seed barley,' and sold, as he had bonght, by sample; saying that he believed it to be seed barley, but did not know what sort it was. Assuming, even, that the words 'seed barley' meant what the plaintiff maintains, still, if it was understood that there was a purchase of the article which was shou'n, it wonld be the same if any other name had been given to it. If we conld see that 'seed barley' was an article well known and commonly sold as such, then it might be that the sale of barley by that name might import a warranty. But it was not so here. And as to the damage, even if there was a breach of warranty, it would only be nominal, for the plaintiff brought his loss npon himself by warranting the barley as "Chevalier' or a certain particular quality." (Curter v. ('icki.)

No implied warranty that meat fit for food.-There is no implied warranty that an article exposed for sale as human food is fit for that purpose; and if a meat salesman in Newgate market exposes a carcase for sale which, in consequence of some latent defect of which he is ignorant, is unfit for human food, he is not liable to a penalty under section 52 of 14 \& 15 Tict. c. 91 for selling it, nor, in the absence of any fraud on his part, will an action on the case for deceit lie against him; nor will an action to recover the price lie by a purchaser, who, believing it to be fit for human food, has purchased it to sell to retail customer's. And per C'rriam: "The undoubted general law is that, in the alssence of all fraud, if a specific article is sold, the buyer having an opportunity to examine it and selecting it, the rule of Careat emptor applies, (Chaneter v. Hopkins, 4 M. \& W. 399, 8 L. J. (N. S.) Ex. 14, I'arlinson v. Lee, 2 East 314, and Morley v. Attenborough, 8 Ex. 500, and 18 T. J. (N. S.) Ex. 148), and the plaintiff has to establish that in the case of a salesman dealing with a retail bnyer there is an exception to the general rule, and that there is an implied warranty that the meat is fit for the purpose for which probably it is bonght. None of the cases cited dceide this ease, although in liumby v. Bollett (16 II. \& W. 
646, 17 L. J. (N. S.) Ex. 190), all the law is examined and collected, and the matter was much discussed. We are of opinion that a salesman offering for sale a carcase with a defect of which he is not only ignorant, but has not any means of knowledge (the defect being latent), is not liable to any punishment, and does not, as a matter of law, completely warrant that the carcase is fit for human food, and is not bound to refund the price of it should it turn out not to be so" (Emberton v. Matthews).

Selling bad meat.-A meat salesman can be indicted and convicted at common law for knouingly sending or exposing meat for sale in a public market as fit for human food, which in fact was not so, and the defendant was imprisoned for six months: per Willes J. (Reg. v. Ster'enson).

Carrying bad meat.-A carrier can be indicted and convicted at common law for knouingly bringing to market meat unfit for human food: per Gurney R. (Rey. v. Jarvis).

Absence of intent to sell bad meat for food.- A person is not indictable for sending to a meat salesman meat he knows to be unfit for human food, if he does not intend (as appeared in this case, from the evidence of a bone-boiler called by the defendant) that it is to be sold for human food: per Willes J. (Reg. v. Crauley).

Sending bad cider to eustomer.-A cider merchant at Cheltenham sold to the defendant, a publican in Loudon (to be delivered to him there), a hogshead of cider warranted "good" and "prime." A hogshead being delivered, it was tapped, and found unfit for use. The defendant at once wrote to the plaintiff that the little he had sold was complained of, and that if it continued to be so he should have to return it. No notice was taken of this letter for about a month, during which period the defendant was trying to sell it, and found it unsaleable. He then wrote to the plaintiff, proposing to return the logshead, but the plaintiff refused to assent to this, and sued the defendant for the price. The defendant paid into court the value of the part he had used, and was held not to be liable for the residue, and scmble for none (Lucy v. Mouffet).

Selling sulphured hops. - The defendant, a hop merchant, entered into a contract with the plaintiff, who was a hop grower, for the purchase of hops by sample. Inasmuch as the defendant could not sell hops to his customers if sulphur had been used in their growth, he inquired of the plaintiff at the time of making such contract if sulphur had been so used, and the plaintiff stated that it had not, and thereupon the contract was made. The plaintiff knew of the objection by hop merchants to sulphured hops, and the defendant would not hare bought the hops if he had been aware that sulphur had been used, as it was admitted it 
lad been in 5 acres out of 300 , and the sulphured hops mixed with the unsulphnred afterwards. It was held by the Court of Common Pleas that the contract was conditional on sulphur not having been used in the growth of the hops; and that if sulphur had been so used, the defendant was at liberty to reject the hops, although they corresponded with the sample by which they had been sold. And per Byles J.: " The case of Nichol v. Godts (10 Ex. 191, and 23 L. J. (N. S.) Ex. 314) comes very near to the present one. Although that was the sale of an ascertained article, foreign refined rape-oil, which corresponded with the sample, the Court held that the vendee might return it on its not answering to the description by which it was sold" (Bamnerman v. IIthite).

Selling refuse cake.-It was held by Pollock C.B., in Jackson v. Harrison, that seed-crushers who sold the refuse cake when the oil had been expressed from the linseed to farmers for oilcake, but without any description as cattle food, or any express or actual warranty as such, and without, so fur as appeared, anything being said as to its use, or any intimation that it was bought for that purpose, are not liable on an implied warranty that it was good for cattle food, when the cows died (from its mechanical, and not chemical action) after enting it.

Adulterated seed.-In Davy v. Gillett, which was tried in the Common Pleas at Westminster, the verdict turned on the amount of burnet seed among the $5 \frac{1}{2}$ qrs. of sainfoin sold by the defendant to the plaintiff, without a sample or a warranty.

It was allowed by the skilled witnesses on both sides that you would expect to meet with burnet in every sainfoin sample; but according to the testimony of the witnesses, and Prof. Buckmann especially, who thonglit it was a crop of burnet, the per-eentage in the seed purchased by the plaintiff was very great. The seed was duly dilled in with barley in the February of 1858 , and fed with sheep that autumn, mown in 1859 , fed again in 1860 , and then ploughed up as being perfectly useless, instead of running out its five or six years; and at the end of that time the plaintiff applied to the defendant for compensation, and wished for an arljitration by a mutual friend, who fixed the claim for compensation at a most moderate figure. 'The defendant declined all such overtures, and principally relied on the claim being a stale one, in consequence of the lapse of time, and on the fact that the plaintiff, instead of merely rumning his lambs over the sainfoin after the barley was cut, had folded sheep on it, who had eaten the very heart out of it, and laid the foundation for lob and other weeds among the plants next spring.

'The general tenor of his evidence went to show that no sainfoin samples were now free from a rery great admixture of buruct, and that 
no purehaser could expect it. In shape the two sceds are very distinguishable, as the sainfoin is oral and the burnet has four angles; and while the former costs $2 s$. $2 \frac{1}{2} d$. a lb., the latter costs only $1 s$. The seedsmen's theories were very various. One had seen more than one part in five burnet; another thought a fourth or a fifth a fair sample, but had never seen less than a fourth, and did not expect, on an average, to get less than a sixth in it; while some said an eighth or a tenth. A great Strand dealer "would not gire a fourth burnet if he knew it. I should not have done you justice if I did." In fact, he went so far as to say he wonld not sell it if it was in that state, but would clean it. Another eminent dealer said that he might send three or four per cent. out in his samples, hut certainly not more than five; and has for twenty years past only recommended milled sced, i.e., set loose from the shell. He added, there " has not bcen much more burnet of late years, but there has been much more noise made about it. If I was asked for pure sainfoin, I would not sell it all ; if I was asked for the best, I'd send the best I had." He, however, thus qualified the last remark on cross-examination: "I should not do you justice if you paid me the best price and I sent you one-fourth burnet." The plaintiff as it happened, had paid the top price, $52 s$., in 1858 , and hence this witness virtually settled the question against the defendant who called him. Mr. Justice Keating asked the jury to consider was it such seed as would answer to the agreement between the parties, or was it such as might be reasonably sold for sainfoin seed. The jury, after a very short consultation, found for the plaintiff for the $£ 416 s$. 9d. claimed. On the count charging fraud there was a verdict for the defendant, as there was not the smallest ground for attributing to him anything of the kind. 'The seed was proved to have come to him direct from Mr. Forshaw, a very aged and infirm farmer in the neighbourhood (whose health alone prevented him from travelling up to speak to the fact), and had been passed on at once to the plaintiff.

Conviction under the Adulteration of Sceds Act, 1869.-At the Lord Major's Court on Nov. 26, 1877, one 'I. S. was charged with laving sold killed seeds with intent to defraud. By this Act, killing or dyeing seeds, and the sale of snch, is prohibited. 'The enstom appears to have been to buy charlock-seed, and to kill it by artificial means, to prevent it from growing, as thereby the fraud would be discovered. This dried or killed seed is then mixed with turnip or other similar seeds, and the whole is sold as good seed. The ralue of turnip-seed is about $80 \mathrm{~s}$. a bushel; that of charloek-seed $3 s .6 d$. In this case the defendant was charged with killing and afterwards selling 28 bushels of killed charlock-

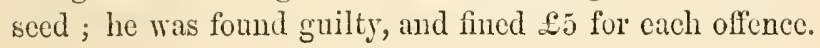


Recovering difference between sale and market price where sheep not delirered. - The plaintiff haring contracted with the defendant to buy of him a lot of 48 sheep at 538 . a head (less than the market price at the time), to be paid for on delivery, took away five, for which he paid in a day or two, and agreed to take the rest in a fortnight. Within that time, before any application for the remainder, the defendant sent them away and re-sold them. The rendee then within a fortnight applied for 19 "to make half the sheep at half the time," offering to pas for them, and finding that they were re-sold, sued the vendor on the contract and also in trover. It was held that he was not entitled on either count to recover the full valne, but only the difference between the price he was to have paid for them and the market price when he was entitled to them, and the rule was made absolute to reduce the damages on the second count from $£ 11819 \mathrm{~s}$. to £5. And per Curiam: "It is to be understood that though in a case like this the plaintiff may not recorer more than this, it is possible that if a stranger had converted the goods, the plaintiff would have been entitled as against him, to recorer the whole value of the amount or proceeds. That might depend upon whether the plaintiff would be liable to the seller for the contract price; but probably in such a case, he would be, for there the seller wonld be in no default; and if he could not delirer the goods, owing to the wrongful act of a third party, it may be that he could recover the whole price, and that the rendee would be entitled to recover the whole from the stranger" (Chinery v. Viall).

Violation of consignor's orders to carrier as to delivery.-Although the consignor of goods directs a carrier to deliver them to the consignee at a particular place, the carrier may deliver them whererer he and the consignee agree. 'The plaintiff having sold corn by sample to be delivered to the purchaser at his mill at $\mathrm{B} \longrightarrow$, sent the corn by the defendants' railway, carriers paying the freight to $\mathrm{B}$ - station, and an extra sum for cartage from $\mathrm{B}-$ - to the mill. In pursuance of general orders previously given by the consignee to the defendants, but not communicated to the plaintiff, the defendants left the wheat at their station at 13., and advised the consignee of its arrival, who examined it, but left it there for two months, and afterwards refused to take it. The wheat was deteriorated in quality during that time. It was held that the defendants were not liable to an action by the plaintiff for not delivering at the mill, as the non-delivery there was pursuant to the orders of the consignee, and that it made no difference in this respect that the plaintiff conld not recover the price of the wheat from the purchaser, in consequence of there being no acceptance of the wheat within the meaning of the Statute of Frauds; and scmble the rights of the 
plaintiff and the purchaser were not affected by the non-delivery at the mill (London and North Western Railway Company ampts. v. Bartlett respt.)

Consignee sues for missing goods at place of destination.--Where goods are sent by a carrier, the consignee is entitled to recover their value at the place to which they are consigned, as distinguished from the place at which they were delivered to the carrier (Rice and Another appts. v. Barendale respt.).

Damages in action for non-delivery, measure of.-In an action against carriers for the non-delivery, according to contract, of goods of a marketable kind intended for sale, the jury may give as damages the difference between the market value on the day the goods ought to hav'e been brought to market, and the day on which they afterwards were, although no notice be given to the carriers that the goods were intended for market; for such damages are the natural and immediate consequence of the defendant's act. There is no difference in the application of this rule, between a delay occasioned by the detention of goods in the hands of the carrier, and delay necessary for the purpose of restoring goods to a marketable state, when delivered by the carrier in a damaged condition.

Here the plaintiff sent hops in bags from Kent to London by the defendants' railway, for the purpose of delivery to the vendee, a hop dealer. The hops were detained by the defendants several days, and received some damage by water, and the vendee refused to accept them. The plaintiff dried the hops, and when fit for sale the price had fallen in value. Independently of that, the stained portion of the hops deteriorated the marketable value of the whole, although for the purpose of brewing the value of the bulk was unaffected. It was held by the Court of Exchequer that the plaintiff was entitled to recover, as damages from the defendants, the difference in price of the amount of deterioration in market valne, and was not confined to the value of the parts actually damaged, although the defendants had no notice that the hops were sent for the purpose of sale and not for use. And per Channell B.: "I think that the doctrine laid down in Hadley v. Barendale (9 Ex. 341, 23 L. J. (N.S.) Ex. 179), by this Court does not apply to this case, and I also agree in the decision of the Court of Queen's Bench in the case of Smeed v. Poor (28 L. J. (N. S.) Q. B. 178), which seems to me to be perfectly distinguishable from this case : in each of the above cases the damages were consequential, but here there was a strict diminution in vahe. In Smeed v. Poor the Court admitted that the plaintiff was entitled to recover compensation for all heads of damage directly resulting from the non-delivery of the thrashing- 
machine: lint what was attempted to be recovered there, and what the Court held was not reasonable, was in my opinion not at all necessarily consequential damage from the non-delivery of the thrashing-machine. Here the hops were delivered in a damaged condition, and I agree in the statement that there is no difference between their being delivered in a damaged condition for the pnrpose of this enquiry, and their having been kept in the defendants' own premises, as from the facts found by the jury, for all purposes, it is precisely the same as if they had been in the defendants' possession, and not in the plaintiff's. At the time they became available to the plaintiff as goods for sale, the market had fallen from the defendants not performing their contract; if there is, therefore, any case where that can be treated as damage, this is a case of that description. This seems to me to be the test by which you must endearour to ascertain the damages; if you cannot resort to this test, I own I do not know to what test you can resort. I am therefore of opinion that the rule in this ease should be discharged" (Collard v. South Eastern Railuay Company).

The measure of damages for non-delivery of goods by a carrier, as laid down in Hadley v. Baxendale, was approved of by the Court in Gee v. Lancashire and Yorkshire Raitway Company (30 L. J. (N. S.) Ex. 11).

Acceplance of hops.-Plaintiff, a hop grorrer, sent samples of hops to his factor ; and defendants, hop merchants, agreed with plaintiff at the factor's premises to purchase some. The fact $\mathrm{r}$ made out a bousht note, and delivered it to defendants together with the sample. At defendants' request the date of the note was altered to give them longer time for payment. In an action for not accepting the hops, this was held not a sufficient note or memorandum to bind defendants to the bargain within sec. 17 of the Statute of Frauds. The declaration was in assumpsit for refusing to receive hops. The plaintiff accompanied the defendants to the factors, and after bargaining for the sale of the hops at $£ 1616 s$. per cwt., the sold note was then given to the plaintiff, and the bought note was, with the sample, delivered to the defendants. In the sold note, the date was October 19th, but 19th was crossed out and 20th substituted at defendants' request, the custom in the hop trade being to pay on the Saturday week after the purchase, so that if the sale had been completed, the payment wonld have taken place on November 3rd, the defendants obtaining thereby a week longer for payment. On October $23 \mathrm{rd}$, the hops were sent to the factor according to usage, to be weighed. 'The plaintiff was present, as was also one of the defendants during some portion of the weighing. One of Messrs. Noakes's warchousemen weighed for the plaintiff, and one of the defendants' men 
acted for them. A dispute having arisen about the weighing, and as to the condition of the hops, the defendants refused to take them at all. In consequence of the badness of the hop season in England, English hops became suddenly almost unsaleable, and on November 3rd they were not worth more than $£ s$ per ewt., although the bargain had been made on October 19 th at $£ 1616 s$. per cwt. It was contended on the defendants' behalf, that this being a contract for the sale of goods above $£ 10$, there was no note or memorandum in writing made by the party to be charged with the contract or by his agent thereunto lawfully authorised, so as to satisfy the 17 th section of the Statute of Frauds, and a verdict for $£ 420$ was taken for the plaintiff, leave being reserved to the defendants to move to enter a nonsuit. It was contended that Noakes the factor was as much the agent of the defendants as the plaintiff, just as a stock or sharebroker or an auctioneer would be between a vendor and purchaser, that he made ont the usual bought and sold notes, and handed the bought note to the defendant, that the defendants expressly directed him to alter the date, and that there was evidence for the jury that Noakes was acting as the defendants' agent.

In the Exchequer Chamber, the decision of the Court of Exchequer was reversed, and it was held that there was evidence from which a jury might find, that Noakes was the agent of the defendants as well as of the plaintiff to draw up a record of the contract between them, and that if he were, the writing by him of "Messrs. Evans" was a signature binding on the defendants within the 17 th section of the Statute of Frauds; and per Byles J.: "It seems to me that there was evidence sufficient to sanction a verdict for the plaintiff. It is plain that the signature, though not at the foot of the document, but at the beginning, is abundantly suflicient. Then in the first place, was the plaintiff bound by what Noakes did? The Messrs. Noakes were employed by him as factors ; there was therefore, no doubt, more evidence against him than against the defendants. But the defendant and the plaintiff knew what Noakes was doing. What does the defendant do? Next of all he sees a duplicate written by the hand of the agent, and he knows it is a counterpart of that which was binding on the plaintiff', he knew what was delivered ont to him was a sale note in duplicate, and accepts and keeps it. The evidence of what the defendant did both before and after Noakes had written the memorandum, shows that Noakes was authorised by the defendant; and the case comes directly within the terms of Lord Abinger's judgment in Johnson v. Dodyson (5 Taun. 786)." And per Keating J.: "There is abundance of authority from Lemayne v. Stanley (3 Lev. 1), downwards, that the name appearing on the face of the document is a sufficient signing 
within the statute." And per Mellor J.: "I agree with my brothers Crompton and Blackburn that Graham v. Marson (5 Bing. N. C. 603, and 8 L. J. (N. S.) C. P. 324), is not inconsistent with Jolinson r. Dollgson (2 M. \& W. 653, and 6 L. J. Ex. 185). In the former case the circumstances failed to raise the question of authority which is raised here" (Durrell v. Eirans).

Delay in delivery of goouls may not be set up in reduction of damages on breach of uctrranty. - In an action for goods sold and delivered, or in an action upon a guarantee of the payment of the price of such gcods, it is not competent for the defendant to set up in reduction of damages, the fact that the goods were delivered by the vendor to the vendee, after the stipulated time in the breach of the agreement between them. And per Mellor J.: "There is a manifest distinction between the principle of Mondel v. Steele (8 M. \& W. 858, 871), and the endeavour to set off damages arising from delay or similar causes" (Oastler and Another v. Pound).

Putting, oil into plaintiff's bottles by defendant passes the property in it.-There was an agreement between the plaintiff and C., for the sale to the plaintiff of all the oil produced from the whole erop of peppermint grown on his farm in the year 1858, and C., after having had the oil weighed, according to contract, and put into the bottles, which the plaintiff had scut to him for that purpose, sold it to the defendant. It was held by the Court of Exchequer, on the authority of Aldritge. $\mathrm{v}$. Johnson (5 W. R. 703), and Logan v. Le Mesurier (6 Pr. C. 116), that the bottles having been sent by the plaintiff and filled up by C. or his agent, the property in the oil had passed to the plaintiff, and that he could maintain an action of trover against the defendant (Langton v. Higgins).

Contract for hornip seed to satisfy Statute of Frauds. - The plaintiff, a seed merchant in Kent, wrote to the defendants, seedsmen in London, offering to sell the seed of growing turnips; to which the defendants replied, asking the quantities and price for white globe turnip seed. The plaintiff answered that all he conld offer at present was the produce of fire acres at $18 s$. $6 d$. per bushel delivered at the Bricklayers Arms Station. 'The defendants offered to take two or three acres at $16 s$. $6 \ell$. The plaintiff wrote saying he could not accept less than $18 s$, his contract price with London honses. The defendants then wrote the following letter, dated March 21st: "In reply to your favour of this morning, we beg to say, as our neighbours are giving you 18s. per bushel for white globe turnip, we as a beginning with you will take the produce of three acres at that price, to be delivered, as soon as harvested, free of carriage to London station. Let us know what other 
sorts yon may have to offer, as also wurzel seed of sorts for 1861 harrest. Waiting your reply, we remain, \&c." 'The plaintiff verbally told the defendants he accepted the offer. The defendants having refused to receive the seed, it was held by the Court of Exchequer, confirming Wightman J.'s ruling on the trial, that there was a binding contract in writing within the 17th section of the Statute of Frands, although the plaintiff never replied in writing to the defendants' last letter. The plaintiff gave evidence to the effect that he did not reply by letter to the defendants' letter of March 21st, but that being in London on March 25th he called at the defendants' shop, and had some conversation with Ainsworth one of the defendants on the subject of other seeds, in the course of which he said: "I think we have some transaction with yon?" and the plaintiff replied, "Yes, a contract for three acres of white globe." Ainsworth, on the other hand, stated that he said to the plaintiff when he called, "I believe we have been writing to you abont some turnip seed ?" and the plaintiff said, "Yes, but I cannot accept your offer ;" and that acting upon that the defendants bought turnip seed elsewhere at a higher price. It appeared that the market had fallen considerably hetween March and August. IVightman J. left it to the jury to say whether the plaintiff at the interview rejected or accepted the terms of the letter of March 21st, reserving leave to the defendants to move on the question of whether there was any contract in writing to satisfy the 17 th section of the Statute of Frauds. The jury fornd that the contract was accepted, and the verdict was entered for the plaintiff. And per Wilde B.: "The single question is whether the letter of 21 st of March is a sufficient memorandum within the Statute of Frauds? If it is a contract to buy three acres of turnip seed at $18 \mathrm{~s}$. per bushel, then the point is not arguable. I think it is a contract. I will only say in reference to the words 'waiting your reply,' that if they are to be regarded as making only a proposal, then there is not a contract, but I do not give that effect to the words. The letter makes enquiries as to other sorts of turnip seeds, and also as to wurzel seed, and the defendants wait for a reply as to that part of the letter" (Watts v. Ainsicorth).

No contract where sale conditional on answer by return of post which u'as not sent.-A letter making an offer for a horse, adding, "Send a reply by return of post," was held by Byles J. to be conditional, and not to constitute a contract in the absence of a reply; and the subject of the letter having been sent to, but not actually received by the defendant, it was also held there was no delivery to him. The offer having received no answer, and being conditional on return of post, the 
plaintiff could not recorer or gools bargained and sold, and there not haring been a delirery proved, the piaintiff conld not recover on goods sold and delirered, and the verdict for the defendant was confirmed by the Queen's Bench (Kirlyy v. Trotter). And in Emmott v. Riddell, a proposal on one side, not answered by the other nutil after a delay of some months, and then not assented to, but some months afterwards neceded to, was held by Martin B. to be no evidence of a contract.

Vendor liable for fulse representation of length of lease even when vendee hal means of knov'ledye.-The mere possession by a purchaser of the means of knowledge, does not prevent the vendor's liability for a false representation; and the rendor having sold a lease as of a longer term, he knowing it to be a shorter, was held liable thongh he had sent a draft conveyance reciting the lease, the recital not haring been referred to by the purchaser, and the plaintiff's verdict was upheld by the Queen's Bench (Ferrier v. Peacock).

Assignment by bill of sale to attorney from client not void on ground of champerty.-Anderson v. Radeliffe and Walleer was affirmed in error, and per Curiam: "The Court of Queen's Bench which decided Simpson v. Lamb (7 E. \& B. 84, 26 L. J. (N. S.) Q. B. 121) distinguished this case from that, on the ground that here there was not an absolute purehase, but only a seeurity for eosts already due."

Seizure and sale under a bill of sale.-On a bill of sale with eovenant for payment of the money at a distant day "or at sueh other day or time" as the creditor, the assignee, might appoint by notice in writing, it was held by the Court of Queen's Bench that reasonable notice was required, and the assignee having made a demand of payment in halfan-hour, and in default of payment seized and sold, he was liable to an action of trespass, but that the damage must be estimated with reference to the probability of the debtor's having been able to obtain the money had reasonable notice been given; and semble per Crompton J. that a reasonable notice meals not merely such time as might be necessary for him to get the money, supposing him to have had it ready, but time to raise it, supposing that he had it not (Brighlley v. Norton).

Portion of bankrupt's farm produce sold and placed separate does not pass to assignees. - Whare, aceording to the custom of some parts of Eingland, the sold produce of a farm is stacked apart from the unsold produce thereof, with liberty for the purehaser to remove such sold produce from time to time as he may require it, and at the date of the bankruptcy of the seller a portion only of such sold produce has been removed, it was held that the purchaser was entitled to the benefit of the unremoved portion, and that the same did not pass to the assignees of the seller as being in his order and disposition, within the meaning of 
the 125th section of the Bankrupt Law Consolidation Act, 1819 (Ex parte Vidter and Another re T'erry).

Railieay dividing one part of farm fiom another.-A railway passed throngh a farm, and divided it, so that the buildings conld not be conveniently used for one part of the farm. This was held by Romilly M.R. to be an injury within the meaning of $8 \& 9$ Vict. c. 18 , s. 69 , which required the substitution of other buildings, and that the compensation paid for the damage might be applied in the erection of new buildings upon that part of the farm which required them. It was also held on the anthority of In re Buckingham Railu'ay Company (14 Jur. 1065), that the application for the sanction of the Conrt was not within $8 \& 9$ Vict. c. 18 , s. 80 , and that the railway company was not liable to pay the costs, but that the costs, exclusive of those of the railway company, must be paid ont of the fund in Court (In re Oxford, Worcester, and Wolverhampton Railu'ay Company ex parte the Devisces of Mitucad).

When railuay company obliged to take house and premises.-A railway company under the compulsory power's of the Land Clanses Consolidation Act cannot take a portion of a garden and orchard essential to the enjoyment of a mansion and premises; they must take the entire house and curtilage ; and therefore where a mansion and premises were surrounded by a brick wall, and a railway company took a portion of the garden and orchard, and divided one part of the premises from another, and destroyed all the internal communication, it was held that the company were bound to take the whole estate. And a company may abandon a notice giren with the intention of taking lands under the compulsory powers conferred upon them : such notice, without some act to obtain possessson, is not a contract binding on the company: per Romilly M.R. (Reg. v. Wycombe Railecay Company).

Requiring company to take all the premises they cut through.-A land owner having receired notice from a railway company to treat for the sale of a part of his premises, does not by offering to sell that part at a price named by him preclude himself, if the company decline the offer, from requiring them to take the whole under the $92 \mathrm{nd}$ section of the Lands Clauses Consolidation Act: per Wood V.C. (Gardner v. Charing Cross Railicay Company).

Mortgage on living sold no ground for rescinding contract.-An advowson was sold, and after the sale the purchaser found that there was a mortgage on the living for money advanced to build a new parsonagehouse. It was held by the House of Lords on appeal from Stuart V.C. and the Lord Justices that this did not form a ground for rescinding the sale of the adiouson, or for allowing to the purchaser a deduction from the amount of the purchase money. And per Lord Campbell: "No misrepre- 
sentation on the part of the vendor was alleged; but it was said he did not communicate the fact of this charge on the living; that could not affect the sale of the adrowson, the value of which it did not diminish but lather increased, for the living was more valuable for having a good parsonage-honse on the land, than if the house was bad or there was none. The ease of Burnell v. Brown (1 J.\& W. 68) did not apply; for there the right of sporting over the land did affect the value of the land, which was the thiug sold. This was a ease where the maxim Caveat emptor applied; and the purchaser not having made himself acquainted with all the facts, which he might easily have done, had no title now to ask for compensation." And per Cramworth Lord: "Before the law was altered as to titles, I question much whether, if the vendor of an adrowson knew that there was a modus affecting a particular farm, he was bound to say a word abont it " (Edwards Wood v. Marjoribanles and Others).

Inaccurate particulars of sale.-If particulars inaccurately describe premises to be sold by anction, the Court will refuse to direct a specific performance of the contract, though the error might have been ascertained on a minute inspection of the particulars and eonditions of sale; and the evidence of an anctioneer is admissible to state what took place at the auction. In the disputed lot (which was deseribed as "an undivided moiety in freehold plantation, \&e."), the particular's said, "the apportioned rent of this lot is $£ 16$ per annum," whereas it was only $£ 8$, but the error was patent on such particulars. And per Sir J. Romilly M.R.: "I regret I cannot make a decree for specific performance, because the defendant has oceasioned this suit by refusing the offer made to put an end to the contract. In ease of mistake, the principle upon which the Court proceeds is, that if it appears upon the evidence that there was in the description of the property a mistake, which a person might bon $\hat{a}$ fide make, and he swears positively that he did make such mistake, the evidence not being contradicted, this Court cannot enforce the specific performance of the contract against him. If there is no ground for the mistake, if no man with his senses about him could have misapprehended the description or character of the parcels, then it is not sufficient for lim to say that he made a mistake or he did not understand what he was about. It is quite different from Mulins $\mathrm{v}$. Freeman (2 Keen, 25 ; S. C. 6 L. J. (N. S.) Ch. 133), where a man bought one lot by mistake for another, and as soon as the auction was over, stated that he had inade the error, and refused to sign the contract. Still the statement here is contained in the lot, and grammatically it applies to the apportioned rent of the lot, and the lot is an mndivided moicty, and I cannot say upon that statement that it is not possible a 
person may have been bona fide deceived in the matter, and he swears he was so deceived" (Sucaistand v. Dearstey).

Right of agent to remuneration where sale goes off.-In the absence of any express contract, auctioneer's are entitled to reasonable remuneration for sales by private contract, effected through their instrumentality, even although by the act or default of the rendor the contract is rescinded; and it is for the jury whether the same commission as on sales by auction is reasonable; and semble that apart from express contract, they would be entitled to the expenses of abortive attempts at sale, bnt it would not be reasonable that the anctioneer should charge not only expenses and a fixed fee, but also commission : per Cockburn C.J. (Clark v. Smythies).

Agent should declare himself at an auction.-A party bidding at an auction, and giving his own name simply to the auctioneer, must be understood to be the contracting party, and onght to be held liable as such ; if he is bidding only as agent, and wishes to protect himself from being treated as the contracting party, he onght to say so (IVilliamson v. Barton). 


\section{CHAPTER XV.}

\section{HORSES AND CATTLE.}

When there is no uaranty the rnle "Caveat emptor" applies to sales; and except there be deccit, either by fraudulent conceatment or a fraudulent misremesentation, no action for unsoundness lies by the rendee against the vendor, upon the sale of a horse or other animal (Hill v. Balls). It was formerly a current notion that a sound price was tantamount to a warranty of solndness. Lord Mansfield C.J., hotrever (A.D. 1778), ruled in Stuart v. Wilkins that there must be an express warranty of soundness, which extends to all faults, known or unknown to the seller, in order to maintain an action. If a seller warrant a horse sound, he does it at his peril if the horse was not sound at the time of the sale, whether he knew it or not (1 Lofft. 146). Bnt per Erskine J.: "Where there is evidence of a warranty, the fairness of the price paid is a cireumstanee tending to eonfirm that evidence" (Kiddell r. Bumard). It need not be averred, nor if arerred proved, that the defendant knew of the msoundness (Titliamson v. Allison).

In Salmon v. Ward, Brst C.J. laid down the distinction betuecen a rempesentation and a varranty. No direct evidence had been giren of anything that passed at the time when the contract was made; but some letters were put in, one of them written by the plaintiff, which contained these words, "Yon will remember that you represented the horse to me as a five-year-old, \&c.; " and one from the plaintiff, in which the defendant in answer, stated, inter alia, "The horse is as I represented it." On this his Lordship observed: "The question is whether I and the jury can collect that a warranty took place. I quite agree that there is a difference between a warranty and a representation ; lecause a representation must be known to be false. No particular words are necessary to eonstitute a warranty. If it were so, there would be inore tricks in horse cases than there are at present. If a man says, 'This liorse is somnd,' that is a warranty. If the jury found that the representation alluded to in the letters occurred at the time of the sale, and without any qualification, then I an of opinion that it is a 
warranty. If it occurred before, or if it was qualified, then it must be taken to be a representation, and not a warranty."

Lord Eldon Ch., in Geddes v. Pennington, held that if the horse answered the warranty at the time of sale, a misrepresentation as to the place from which it was procured does not suffice to set aside the sale, though it might be a material consideration with respect to costs ; and the judgment of the Scotch Court of Session, where three out of five judges held that the accident was not owing to vice in the horse, but lack of skill in the driver, was affirmed by the House of Lords, without costs on either side.

On a motion for a nonsuit in Cave v. Coleman, the Court of Queen's Bench held that the simple words, "You may depend upon it that the horse is perfectly quict and free from vice," spoken by the defendant in the course of deating, and before the bargain u'as complete, was sufficient to support an averment of varranty, although the word "warrant" was not used. In Dunlop v. Waugh, where a horse sold as an eight-yearold proved to be fourteen, but the defendant showed the written pedigree at the sale, and said that he knew no more, as the mark was out of his mouth, Lord Kenyon C.J. ruled that this clearly was no warranty, as the defendant told all he knew, and ontered into no express undertaking that the horse was of the age stated in the pedigree. So in Anderson v. Robson, which was an action for the price of a horse which had thrown a spavin, and evidence as to warranty went to show that plaintiff' had merely said, on defendant's making inquiry, that the horse was "sound as far as he linew", and he had not previously discovered anything the matter with him, Cressuell J. held that there was no warranty, and the plaintiff had a verdict. This casc differed materially from Wood v. Smith, where, although the defendant at the time of the sale said, "The mare is sound to the best of my knowledge, but I never warrant; I would not even warrant myself," it was prored that he knew her to be unsound at the time: and hence the Court of Queen's Bench refused a nonsuit. Bayley J. observed: "The general rule is that whatever a person represents at the time of a sale is a varranty. But the party may either gire a general warranty, or he may qualify that warranty. By a general warranty a person warrants at all events; but here the defendant gives a qualified warranty, as he only warrants the mare sound for all he knows. This is a qualified warranty, and the purchaser may maintain assumpsit on it, if he can show that the horse was unsound to the knowledge of the seller."

It was ruled by the Court of Queen's Bench in Hort v. Lord Neury that, although a person may discluim against making a wearanty of a horse, yet if he give him a character for a particular quality, as by saying 
that he is quiet in harness, and do it in such a manner as reasonably to make an impression on the mind of the buyer that he is generally quiet in harness, he will be bound by that representation; and if it is not true, an action will lie to recover back the price of the horse. And per Curiam: "In this case the defendant, knowing that the witness had been requested to speak to him to give a character of the horse, asserts that he is quiet in harness. That description of the horse is carried on to the plaintiff, who, relying upon it, buys him. Would any man of common sense, to whom that communication was made, understand that the defendant meant to convey an impression that the horse was generally quiet in harness, or only that he was quiet the last time he drove him?"

"Wranty of horse being "a clever hack" does not imply that it is sound.-Cleobury v. Tattersall was brought to recover from the defendants, the well-known proprietors of the horse establishment at Hyde Park Corner, the sum of $£ 43$, upon an alleged warranty of a horse, purchased by the plaintiff at one of their public sales. It appeared that the plaintiff, a solieitor, was on the 11th May looking over the list of horses entered for sale the following day at Tattersall's. He saw a horse, described in the catalogue as " a bay gelding, a clever hack and hunter," and on the following day he went to the sale, purchased the animal for 21 guineas, and rode it home to his residence at Bayswater, when it "blundered" and stumbled twice during the journey; and on the day after he sent it to $\mathrm{Mr}$. Field, the veterinary surgeon, who examined it, and gave a certificate that it was lame in both its fore-legs. It was then returned to Messrs. Tattersall's, who refused to receive it, on the ground that no warranty of soundness had been given, and that the horse really was what it was described to be-" a clever hack and good humter." Witnesses were called to prove that the horse was in an unsound state. Blackburn J. said that as a point of law he must certainly rule that the description of the horse as "a clever hack" did not amount to a warranty of soundness; the only question for the jury was whether, apon all the facts, they considered the horse entitled to be described as "a clever hack." The jury considered that, from the description, the plaintiff had a right to expect something different, and they returned a verdict in his farour. A rerdict was then taken for the plaintiff, but judgment was stayed, the learned judge giving the defendants leave to move to enter a nonsuit, in the event of the Court being of opinion that he was wrong in law in his ruling with regard to the contract. 'The defendants did not carry the point into a higher court; and we understand from them that the horse has gone well both as hack and hunter since. 
Unauthorised warranty by servant.-In Brady v. Tod (30 L.J. (N.S.) 223 C.P.), it was decided that the servant of a private owner entrusted on one particnlar occasion, not at a fair or other public mart, to sell and deliver a horse, is not therefore by law anthorised to bind his master by a warranty; but the bnyer who takes a warranty in such a case takes it at the risk of being able to prove that the servant had his master's authority to give it. The defendant was not a horse-dealer, but a tradesman residing in London, who also had a farm in Essex, which was managed by his bailiff Greig; and the latter, by the defendant's anthority, sold the horse in question to the plaintiff, and, as the jury found, with a warranty that it was sound and quiet in harness; but it was also proved that the defendant gave no authority to Greig to give any warranty. The horse having turned out vicions in harness, the plaintiff brought this action and recovered, leave being reserved to the defendant to enter a nonsnit. And per Erle C.J.: "Upon this rule to set aside the verdict for the plaintiff, and enter it for the defendant, on the plea denying the warranty of a horse, the question has been, whether the warranty by the defendant was proved. The jury have found that Greig in selling the horse for the defendant warranted it to be sound and quiet in harness. The defendant stated, and it must on this motion be taken to be true, that he did not give authority to Greig to give any warranty.

"The relevant facts are, that the plaintiff applied to the defendant, who is not a dealer in horses, but a tradesman with a farm, to sell the horse ; that the defendant sent his farm-bailiff Greig with the horse to the plaintiff, and authorised him to sell it for 30 guineas. The plaintiff contends that an authority to sell and deliver imports an authority to him to warrant. The subject has been frequently mentioned by judges and text writers, but we cannot find that the point has been ever decided. It is therefore necessary to consider it on principle. The general rule that the act of an agent does not bind his principal, unless it was within the authority given to him, is clear; but the plaintiff contended that the circumstances created an authority in the agent to warrant on rarious grounds; among others, he referred to eases where the agent has by law a general authority to bind his principal, though as between themselves there was no authority, such as partners, masters of ships, and managers of trading business; and stress was laid on the expressions of several judges, that the servant of a horse-dealer or a livery-stable keeper can bind his master by a warranty, though as between themselves there was an order not to warrant. See Helyear v. Hawle (5 Esp. 72), Alexander v. Gitson (2 Camp. 555), and Fenn v. Harrison (3 T. R. 759). We understand those judges to refer to a 
general agent employed for a principal to carry on his business, that is the business of horse-dealing, in which case there wonld be by law the authority here contended for.

"But the facts of the present case do not bring the defendant within this rule, as he was not shown to carry on any trade of dealing in horses. It was also, conteuded that a special agent without any express anthority in fact might have an authority by law to bind his principal; as where a principal holds out that the agent has such authority, and induces a party to deal with him on the faith that it is so. In such a case, the principal is concluded from denying this anthority as against the party, who believed what was held out, and acted on it (Pickering r. Busk, 15 East, 38). But the facts do not bring the defendant within this rule. The main reliance was placed on the argument that an authority to sell is by implication an authority to do all that in the usual course of a sale is required to be answered, and that therefore the defendant by implication gave to Greig an authority to answer that question, and to bind him by his answer. It was a part of this argument, that an agent authorised to sell and deliver a horse is held out to the buyer as having anthority to warrant. But on this point also the plaintiff has in our judgment failed.

"We are aware that the question of warranty frequently arises upon the sule of horses, but we are also aware that sales may be made without any warranty or even inquiry about warranty. If we laid down for the first time that the servant of a prirate owner entrusted to sell and deliver a horse on one particular occasion is therefore by law authorised to bind his master by a warranty, we should establish a precedent of dangerous consequence. For the liability created by a warranty extending to unknown as well as known defects is greater than is expected by persons incxperienced in law; and as everything said by the seller in the bargaining may be evidence of warranty to the effect of what he said, an unguarded conversation with an illiterate man sent to deliver a horse may be found to have created a liability, which would be a surprise equally to the servant and the master. We therefore hold that a buyer taking a warranty from such an agent as was employed in this case, takes it at the risk of being able to prove that he had the principal's authority, and if there was no authority in fact, the law from the circumstances does not in our opinion create it.

"When the facts raise the question, it will be time enough to decide the liability created by such a servant as a foreman alleged to be a general agent, or such a special agent as a person entrusted with the sale of a horse in a fair or other public mart where stranger meets stranger, and the usual course of business is for the person in posses- 
sion of the horse and appearing to be the owner to have all the powers of an owner, in respect of the sale; the anthority may, under such circumstances as are last referred to, be implied, thongh the circumstances of the present case do not ereate the same inference. It is unnecessary to add, that if the seller should repudiate the warranty made by his agent, it follows that the sale would be void, there being no question raised upon this point."

Limitation of particular of horses sold.-Under a particular specifying horses sold by the plaintiff to the defendant, the plaintiff cannot recover the price of horses sold by the defendant for the plaintiff as his agent (Holland v. Hopkins).

Receipt of douceur by agent from seller.-Witson v. Stevens was an action against $\mathrm{MTr}$. Stevens, a veterinary surgeon, for having kept for an unreasonable time a horse which he had been employed by the plaintiff to sell, and for having, when employed by the plaintiff to examine and purchase a horse for him, bought an unsound horse, and received a bribe of $£ 5$ from the seller for the same. The plaintiff, Mr. Wilson, was recommended to the defendant as a man in whom he might safely confide to purchase horses for him, and it was agreed that Mr. Stevens should charge $£ 22 s$. for each of such purehases. Sereral dealings took place, some satisfactory, some otherwise, before the purchases of the horses which were the snbject of this action. The charge was two-fold, and related to two horses. A horse was bought of Mr. Rice, for the plaintiff, for $£ 105$. After some time, not being quite pleased with it, Mr. Wilson sent it to the defendant for sale. It was kept by Mr. Stevens for 113 nights without being sold, Mr. Wilson being absent almost the whole of that time in Scotland. On his return, finding it still in the stables, he took it away, and sent it to Lawrence's stables, by whom it was sold in a very few days, for $£ 60$. Mr. Stevens brought an action against Mr. Wilson for the keep and eare of this horse, which Mr. Wilson resisted. It was tried at Guildhall, when it appeared that no legal defence conld be offered, and a verdict was given for the plaintiff.

In the course of this trial, it came out that Mr. Stevens had receired $£ 10$ from Mr. Rice for selling this horse to the plaintiff; and thereupon Baron Martin told the jury that an agent had no right to take a single farthing from the party with whom he was dealing; that it was a disgraceful and dangerous transaction; and, although they could not reach it in that action, Mr. Wilson had another remedy; and he directed them to deduct the $£ 10$ so received from the amount claimed by the plaintiff. Upon this Mr. Wilson made further inquiries, and henee the present action. Mr. Sterens had previously bought for 
him another horse from a dealer named Sewell. At the time of the purchase, when trying it, Mr. Wilson was not quite satisfied with the horse's morements, and especially with the contracted shape of the feet, but Mr. Sterens said it was nothing, that the horse was sound and right; and, relying upon that advice, Mr. Wilson bought it for $£ 90$. It soon turned ont to be a screw, and fell, and broke both its knees, and three veterinary surgeons certified that it was unsound, with contracted feet and discased eyes of long standing. It was also sent to the defendant himself for examination; and, not remembering that it was the very one he had put upon Mr. Wilson, he also gave a certificate, which was read, that it was lame and unsound, with diseased eyes, and that these defects were of long standing. The horse was sent to Gower's and sold for $£ 51$, Sewell himself being the buyer.

An action was brought against Sewell on his warranty; and thereupon Sewell paid the whole difference between the sum he received for the horse, and that at which it had been sold, together with the costs. Mr. Wilson then discovered that, for putting this horse upon him, Mr. Stevens had receired from Sewell the sum of $£ 5$. The present action was brought for the breach of duty by Stevens in that, having been employed and paid by Mr. Wilson to use his professional skill in the choice of a sound horse for him, he had either negligently or ignorantly bought an unsound one, and for having taken a bribe of $£ 5$ for so doing. Mr. Stevens had received $£ 10$ for one horse, and $£ 5$ for another, at the same time charging Mr. Wilson, as his professional adviser, for luying these horses. Mr. Ficld's examination (he being ill) was read, where he stated that, from the condition of the horse when he saw it, it must have been in a diseased state five months before, such as any man of ordinary professional skill ought to have detected, and Mr. Mavor and another gentleman gave evidence to the same effect.

For the defence, it was contended that, as to the first charge, there was proof that every possible endeavour was made to sell the horse; and, as to the second, that it was not proved that the unsoundness had actually existed at the time of the purchase, or could have been then discovered, and also that it was not proved that the horse seen by the veterinary surgeons was actually Sewell's horse, and that the $£ 5$ was not a bribe paid at the time, but a present made to Mr. Stevens afterwards for his trouble. Witnesses were then called to prove this, and among them the defendant himself, who armitted the receipt of the $£ 10$ from Pice and the $£ 5$ from Sewell, but added that he had returned the latter after the action had been settled by Sewell; and he also said that he did not helieve the horse for which he gave the certificate was the same lorse he had bought for Mr. Wilson. Baron Martin told the jury 
that upon the first charge they would exercise their own judgment whether there was any proof that defendant had not made reasonable endearours to sell the horse. If they thonght he had, he would be entitled to their verdict on the first count. But the other, on which the plaintiff mainly relied, was a much more serious matter, and he would tell them at once that an agent, employed and paid to act for a purchaser of anything, has no right whatever to receive a single farthing from the seller. It was a transaction perfectly unjustifiable, and which the plaintiff had acted most properly in bringing under the consideration of a jury. He then went through the evidence, and left it to them to say if they had any doubt that the horse seen by the veterinary surgeons was the same horse, remembering that Sewell had actually admitted it to be so by paying the loss upon it; and that if so satisfied, they would give the plaintiff a verdict upon the second eount, with such damages as they thought proper; and the damages to which he would be entitled would be the inconvenience and cost he had reasonably been put to, and which he had not recovered from Sewell, including the $£ 22 s$. which the defendant had received for the services he had failed to render. The jury returned a verdict for the defendant on the first count, and for the plaintiff on the second count, damages £5. His Lordship immediately certified for costs and for the special jury, and observed to the jury: Gentlemen, this was a very proper action to bring, and a very proper verdict. It is just what I would have given myself.

Loss of good bargain evidence of value.-Although no damages can be recovered for the loss of a good bargain, the bargain would be evidence of the value of the horse supposing him to be sound (Clare v. Maynard).

Definition of bone spavin.- "Bone spavin is a bony deposit on articnlating surfaces of joint. 'The term 'spavin' really means the lameness and not the disease. In splint espccially, and in spavin, traces may disappear and disease exist."

Responsibility of hirer of horse.-As between the lender and hirer of horses, the hirer, in the absence of any cnstom in the trade, is only bound to use reasonable care, to employ a competent coachman (Abron v. Fussell).

In the case of Head v. Tattersall, 7 L. R. Ex. 7, the plaintiff bonght of the defendant, an auctioneer, a horse described in the catalogue as liaving been hunted with the Bicester and Duke of Grafton's hounds. The contract of sale contained a condition that "horses net answering the description must be returned before 5 o'clock on the following Wednesday evening," the sale having taken place on Monday. The horse had not in fact been hunted with either pack of hounds as 
described, and the plaintiff was told this before he had taken the horse away by a groom who had had charge of the horse. The plaintiff nevertheless took the horse away. On the road to the plaintiff's premises, and while under the charge of plaintiff's servant, the horse took fright, ran away, and was injured. The plaintiff thereupon returned the horse as not answering the description before the Wednesday erening, and brought an action to recover the value given. The jury found that the plaintiff was induced to buy the horse by the warranty, and that the injury sustained by the horse was not in any way eaused by the negligence of the plaintiff's servant, and a verdict was entered for the plaintitf for the value of the horse. This rerdict was upheld by the Court of Exchequer.

A bidder at a sale by anction, under the usual conditions that the highest bidder shall be the purchaser, may retract his bidding before the hammer falls, as until then his offer is not assented to by the anctioneer as the agent of the rendor (Payne v. Care). Where a sale is on these conditions, and a horse is bid up by a muffer (here a servant of the owner, who bid the horse up to 23 guineas after a bona fide bidder had bid 12 guineas), it was settled in Crouder v. Austin that the rendor bas not an action for the price against the last bidder, to whom it was knocked down for 29 guineas. Best C.J. said that "such puffing was a gross fraud, and that a seller had a right to hare one person to bid for him at a sale, but must declare it in the conditions. Here defendant was entitled to have the horse at the next bidding to that of the only fair bidder." A rule nisi to set aside the nonsuit was discharged without argument, Parke J. observing that "the opinion of Lord Mansfield in Bexuell r. Christie is not a mere dictum, but a long elaborate judgment; and he was followed by Lord Kenyon C.J. in a case of Blachford v. Preston; and in Houcard v. Castle. And it is now fully settled that the vendor may employ one person to prevent a sale at an uncier-value, provided it be not stated in the particulars or advertisements that the sale is "without reserve." But the employment of a single puffer when the sale is "without reserve" will avoid it at law (1'hornett v. Haines).

The conditions of sule by auction minted, and posted up under the auctioneer's box, in a Repository, compled with his declaration that the conditions are as usual, constitute, according to Llesnard v. Aldridge, a sufficient notice of them to purchasers. In that case, where a horse was bought on Wednesday with a warranty of soundness, and one condition was that all horses purchased there, in case of any unsoundness being discovered, should be returned before the evening of the second day after the sale, the returu of a horse on Saturday was decided to be 
too late, and the purchaser was deemed to have been cognizant of the conditions, though they were not read over before the sale by the anctioneer. And so in Smart v. Hyde, where a mare was sold under a somewhat similar condition, at Lucas's Repository, and the defendant pleaded to a declaration on a warranty of soundness that the sale took place subject to that condition, and that the same was arreed to by the parties, and that the notice and certificate of unsoundness were not given within the time limited (i.e., before noon of the day after the sale), the plea was held good, and not amounting to the general issue. It adinits the contract and promise; but shows it to have been made subject to certain rules, which had not been complied with. That was clearly not a denial of the contract, as alleged in the declaration.

In Buchanan v. Parnshaw a horse, warranted six years old and sound, was discovered ten days afterwards to be twelve years old. The Court of King's Bench held that the condition of sale- "That the purchaser of any horse warranted sound, who shonld conceive the same to be nnsound, should return him within two days, otherwise he should be deemed sound "-must be confined solely to the unsoundness; and that, as regarded that, it was a wise and reasonable one; but that, as the age of the horse was not open to the same difficulty, he ought to have been taken back, and therefore the buyer might maintain an action against the seller. And the buyer's right to recover was held not to be affected by his having sold the horse, after offering him to the defendant (ib.). The unsoundness in Bywater v. Richardson was of a nature not likely to be discorered (especially as he was shown on a bark ride at Lucas's Repository) in the twenty-four hours, within which the buyer had the option of returning the horse; but still the Court of King's Bench upheld the condition as not unreasonable, although it would have been inoperative if the facts had shown any fraud or artifice in the seller. In contracts of this nature, where a horse is "sold with all faults," there is no fraud unless the seller by positive means renders it impossible for the purchaser to detect latent faults; and the dictum of Lord Kenyon C.J. in Mellish v. Motterx, that the seller is bound to disclose snch of the latter as have come to his knowledge, was expressly overruled by Lord Ellenborough C.J., in Baglehole v. Walters, which Lord Denman relied upon in Byuter v. Richardson.

The question as to uhether a private warranty could be incorporated into the conditions of sale at Tattersall's, where the well-known course of business is, that horses sold there are not warranted unless a statement to that effect is made in the catalogue, was very much discussed in Hopkins v. Tanqueray, which was an action for alleged breach of warranty. The defendant, in that case, had sent his horse California to 
Tattersall's, and he was advertised to be sold there on Monday (May 30, 1853). On the previons Sunday the defendant saw the plaintiff, whom he knew, knceling down in the stall to examine his horse's legs, and said to him, "You need not examine his legs; you have nothing to look for; I assure yon lie is perfectly sound in every respect." To this plaintiff replied, "If you say so, I am perfectly satisficd ;" and immediately got up. Next day the plaintiff, having, as he said, "nade up his mind on the 29th of Nay to buy him, relying on defendant's positive assurance that he was sound," bonght the horse for 280 gnineas. The horse broke down at his trainer's, and was sold for 144 guineas, and it was sought to recover in this action the difference between that sum and the price he was originally sold at. It was contended, among other points for the defendant, that the conversation was not equiralent to a warranty, but a mere representation of opinion and belicf, which, in the absence of fraud, gave no ground for an action; and further, that it was no part of the contract under which the horse was sold on the Monday; and that the representation could not be incorporated into such contract, it having been made on a Sunday. All idea of frand was disclaimed.

Talfourd J. thought there was not any evidence of warranty, but declined to nonsuit ; and the jury found, in reply to his lordship's questions-(1) That a warranty was embodied in the contract of sale and (2) (thongh as to this the evidence was conflicting) that Californid was unsound at the time of sale; and gave a verdict for the plaintiff of $£ 14216 s$. The Court of Common Pleas held that there was no evidence of a warranty, express or implied, to go to the jury ; as the conversation on the Sunday was a mere representation of what the plaintiff bon $\hat{\imath}$ fide believed to be the fact, and formed no part of the contract of sale on the next day. Cressuell J., however, intimated his opinion that if such representation had been made at the time of sale, so as to form part of the contract, it might have amounted to a warranty. Maule J. said in the course of the argument: "Assuming that the defendant privately warranted his horse to the plaintiff before the sale, a very serions question would arise, whether such a warranty conld be enforced. Bona fule bidders, to whom the horse was not warranted, might thus be induced to offer a higher price, supposing the plaintiff to be bidding on the same footing as themselves. That sort of donbledealing could hardly have been intended by either of these gentlemen. Each would, in effect, be taking the chance of an arlvantage at the expense of third persons." And per Jere'is C.J. : "It might be a ground for setting aside a sale between the seller and a thirl person."

In the case of Chapman v. Guyther (1 N.R. Q.B., 463) the plaintiff 
bought of the defendant two horses and the following memorandum was sigued by defendant at the time of sale :

"June 5th, 1865.

"Mr. Chapman bought of Mr. G. Gryther, a brown horse six years old, warranted sound, for $£ 180$ : also a bay horse five year's old for $£ 90$. Warranted sound.

"Warranted sound for one month.

"George Gwyther.

"George Gwyther."

It was held that the latter words limited the duration of the warranty. The general rule for horse-dealing was thus laid down by Maule J. in Keates v. Earl Cadoyan: "If a horse-dealer contracts to sell a gentleinan a horse fit to carry him, and he sells him one which he knows to be unfit for the purpose, he does not perform his contract. But if a man buys a horse generally, the seller will not be responsible, althongh knowing that his customer wanted the horse for his own riding, he sells him one which will not carry him." If there has been a parol agreement, which is afterwards reduced by the parties into writing, that writing must alone be looked to, to ascertain the terms of the contract; but where, as in Allen v. Pink, the plaintiff merely received the following memorandum from the seller:-

"Bought of G. Pink a horse for the sum of $£ 72 s$. $6 d$.

"G. Pink,"

and brought an action to recover back the price he had paid for the horse, which proved nuruly and vicious in harness, he was allowed to give parol evidence of a warranty given him by the defendant at the time of the sale, to the effect that he was a quiet worker, and would go well in spare harness. A fraudulent representation at the time of sale invalidates the varranty; though it does not relate to any point included. in it; and in Steucard v. Coesielt, where the written warranty was simply to the effect that the horse was "sound, and free from vice," Burrough B. almitted, as general evidence of fraud, that the horse was represented at the time of sale as five off, whereas he was only rising five. But Geddes v. Pennington is an authority to show that if the warranty is answered, a mere trivial misrepresentation as to the place from which the horse was procured wonld not suffice to set aside the sale. A representution must be knoun to be false; and hence where, as in Dickenson v. Gaqp, the receipt ran thus :- 
"Sept. 7. Received of Robert Dickenson $£ 100$ for a bay gelding got by Cheshire Cheese, and warranted sound,"

and according to the evidence on an action of breach of warranty of breed, the gelding was not got by Cheshire Cheese, but the defendant believed it was, Dallas C.J. considered it to be a representation merely, and that the warranty was confined to the soundness.

The warranty in Richardson v. Brou'n, ran thus :-

"To be sold, a black gelding, five years old. Has been constantly driven in the plough. Warranted."

The plaintiff proved him sound, and got a verdict for the price; and a rule for a nonsuit on the ground that the warranty referred to the horse's previous employment, which the plaintiff onght to have proved, was refused by the Court of Common Pleas, and the warranty was held to apply to the soundness only. Both these cases were referred to, as being directly in point by Tindal C.J. in his jndgment in Budd v. Fairmener, which was an action to recover the expense of keeping a grey colt for a year, which, as plaintiff contended, had been warranted to him by defendant as a four-year-old when it was only three. The receipt was to this effect :-

"Received, Augnst 4, 1830, of MIr. Budd, ten pounds for a grey forryear-old colt, warranted sound in every respect.

"John Fairuener."

Tindall C.J. directed a nonsuit, and said, "The first part of the receipt contains a representation, and the latter part a warranty. In the case of a representation, to render liable the party making it, the facts stated must be untrne to his knowledge; but in the case of warranty, he is liable, whether they are within his knowledge or not." 'The Court of Common Plens discharged a rule nisi for setting aside the nonsuit, and Alderson J. said: "A wetranty must be complied with, whether it is material or not; but it is otheruise as to a representation. As at present advised, if the word werranted had been the last word, I should have held that it extended to the whole. But here I think it is confined to the soundness only."

"If the servent of a horse-deater with express directions not to warrant do warrent, the master is bound; because the servant having a general authority to sell is in a condition to warrant, and the mister has not notified to the workl that the general authority is circumseribed"per Bayley J. (Pickering v. Busk). And the rule is the same as regards 
the servant of a livery stable-keeper-per Ashurst J. (Fenn v. Harrison); but if the owner of a horse were to send a stranger to a fair with express directions not to warrant the horse, and the latter acted contrary to the orders, the purchiser could only have recourse to the person who actually sold the horse, and the owner would not be liable on the warranty, because the servant was not aeting within the scope of his employment (ib).

It was expressly laid down by Lord Ellenborongh C.J., in Alexander v. Gibson, where the defendant's servant su'ore that he was expressly forbidden by his master to give a uarranty, and denied that he had given one, while another witness said that he had warranted the horse "sound all over;" that if a servant is authorized to sell a horse and receive the stipulated price, he is impliedly anthorized to give a warranty of soundness which will bind his master, and that it is enough to prove that he gave it, without calling him or showing that he had any special authority to do so. His lordship ruled, in Helyear v. Hawke, that what a servant has said respecting the horse at the time of the actual sale, as part of the transaction of selling, is evidence against the principal, but not what he may have said at another time; and further, that being entrnsted to do all that he can to effectuate the sale, he binds his master even if he exceeds his authority. And see Irving v. Motley. Erskine J. also declined to receive evidence in Allen v. Denstone, that defendant's son said on the day of the sale, in answer to a question about the price, that he would warrant the horse all right except being a whistler, as it was a mere conrersation with a stranger, and not a statement made in the course of the bargain. His lordship said: "It might have been admissible if it had been shown that, in offering the horse for sale, the defendant's son had offered to give a warranty, as that would have been a statement accompanying an act done in the course of his agency;" and after a verdict for the defendant, the Court of Common Pleas refused a new trial.

The general rule in selling a horse by a servant or agent is thus stated in Oliphant's Lau of Horses, 2nd ed., page 105: "The master or owner is bound by a warranty given by his servant or agent at the time of sale, without his consent, and even against his express direction; and the only exception is the case of the agent of a person, who is neither a horse-dealer, or stable-keeper, warranting a horse in spite of the express orders of the owner to the contrary; and then if the principal is unwilling to stand by it, he should at onee offer to rescind the contract."

The case of a warranty by a servant who was mercly entrusted to deliver a horse was fully considered by the Court of Exchequer in Woodin v. Bufford, which decided that a warranty of a person, in this ease a 
serrant, who is merely authorized to deliver a horse, does not bind the principal; and that in an action on the warranty, the seller is not bound by the statements or receipt of the serrant, as no express authority to give the warranty was shown. Bayley J. said: "What is said by a servant is not eridence against the master, mless he has some authority given him to make the representation; and the question here is whether there is reasonable ground for inferring such authority. It is quite clear that before the time when the horse was delivered to the plaintiff, and the receipt was given, there had been a bargain between the defendant and the plaintiff, and all that the servant was directed to do was to take the horse to the plaintiff and receive the money. It seems to me that, althongh a warranty given by a person entrusted to sell mima facie biuds the principal, yet the warranty of a person entrusted merely to deliver is not primâ facie binding on the principal, but an express authority must be shown, which was not doue here." Jordan v. Norton is also an authority to show that where an agent is merely instructed to receive and pay for a horse if a certain uaranty is given, and he brings it home without one, the principal may repudiate his act, and return it within a recisonable time.

The rule of law as to a master taking back a horse, and returning the money if he will not stand to a uraranty improperly given by his servant, was thus touched upon by Lord Abinger C.B., in Cornfoot v. Fouke. "Put," said his lordship, "the ordinary case of a servant employed to sell a horse, but expressly forbidden to warrant him sound: is it contended that the buyer, indnced by the warranty to give ten times the price which he would have given for an unsound horse, when he discovers the horse to be unsound, is not entitled to rescind the contract? 'This would be to say that though the principal is not bound by the false representation of an agent, yet he is entitled to take ad-. vantage of that false representation for the purpose of obtaining a contract beneficial to himself which he conld not have obtained without it."

If an agent is guilty of fraud in transacting his mincinal's business, the principal is responsible; and where a principal claims the purchasemoney by virtue of a contract made for him by his agent, which was defeasible by reason of frand, and is put an end to by the rendee, the agent holds the purchase-money as received to the use of the rendee. 'This was the tenor of the decision in Muray r. Mam, which was an action hy a livery-stalle keeper for the keep of a horse, to which the defendant pleaded a set-off for money received by the plaintifl' for his nse. The defendant har sent the horse to the livery-stables of the plaintiff, where it stood for some time, and was sold for $£ 125$, with a warranty 
that it was sound and free from vice. The purchaser returned the horse in three weeks as unsonnd, and got back from the plaintiff the $£ 125$, the amount which the defendant sought to set-off, on the ground that it was received for his use by the plaintiff. 'The jury found for the plaintiff, and the Court of Exchequer refused a new trial.

This case governed the decision of the Court of Queen's Bench in Stevens v. Legh, where an auctioncer was sued for the purchase-money of a horse, which he had returned to the vendee after the fraudulent misrepresentations which he had been employed by the plaintiff to make had been discovered. The plaintiff, a horse-dealer in Bristol, had here instructed the defendant to sell a horse for him, representing to him that it was a useful horse, \&c., and accustomed to harness work, but that he was not to warrant it. The defendant sold it and represented it as such ; and the purchaser afterwards rescinded the contraet, on the ground of fraud, as the horse proved worthless, and gave the defendant notice not to pay over the purchase-money to the plaintiff; and it was held by the Court that these facts afforded the defendant a good defence, and they refused to disturb the verdict.

The ease of Foster appt. v. Rev. W. Smith resp., which was one of money had and received for the price of a mare sold by defendant to plaintiff, and afterwards returned, was very complicated, from the conflict of evidence as to whether the agent had really warranted the mare, and on whose account he received her when she was returued. The plaintiff had purchased the mare from Sparrow, a veterinary surgeon at Cambridge, for $£ 44$; and stated that at the time of sale he said to Sparrow, "I suppose she is all right," and received, as a reply, "If there is anything not right, she is not yours; she belongs to the Rev. Mr. Smith, of Drayton, who is not the man to do anything wrong." This Sparrow denied, in his examination; and said that he told plaintiff the defendant never warranted, it was his habit never to do so, but that he (S.) believed the mare to be perfectly sound, and that if he misrepresented her he would take her back. Sparrow paid over the £44 to the defendant, who acknowledged to having received it; and in about nine weeks the mare was retmrned to Sparrow, whose evidence was to the effect that he got her then to try and sell for the plaintiff, while the latter said that he got her for the defendant; but there was no evidence that the defendant had assented to or knew of the return of the mare, or taken any part in these transactions.

The defendant said he had employed Sparrow to sell eight horses for lim before in the course of fifteen years, and had over and over again repeated to him that he never would warrant a horse, and he was not 
to do it for him, but he gare no particular orders about this mare. The judge of the County Court left these questions to the jury: 1, Was the mare sound or unsound at the time of sale? 2, Was there a warranty giren by Sparrow to the plaintiff? 3, Was the warranty given by the defendant's authority? and 4, When the mare was sent back to Sparrow, was she receired by him for the plaintiff or defendant? The jury found that the mare was unsound; that a warranty was given, but not by defendant's anthority, and that she was received by Sparrow on the defendant's account; and the judge, considering the finding to be ambiguons, ordered the verdiet to be entered for the defendant. The Court of Common Pleas directed a new trial with costs (which are always granted to the successful party on an appeal from the County Court); and per Jerris C.J.: "The proper question for the jury was whether it was part of the contract that the mare should be returned if she proved to be unsound. If so, and she were returned, there would be a failure of consideration, and the plaintiff would be entitled to recorer back the price." The case went down again, and the plaintiff had a rerdict.

In an action on a bill given for the price of a horse sold under a warranty, the breach of the waranly is an answer to plaintiff's demand, if the defendant has lendered the horse back, though the plaintiff did not accept it (Levis v. Cosgruie). Where the buyer of a horse with a warranty resells with a warranty a horse which proves unsound, and being sued thereon offers his vendor the option of defending, but in consequence of receiving no anstrer defends it himself, and fails, he may recover these costs from his rendor as part of the damage occasioned by his breach of warranty (Lewis v. Peake); but he cannot recover such costs, if he conld have discovered the breach of warranty by a reasonable examination before the resale (JVightup v. Chamberlain). In Clare v. Maynard, however, where the rendee, who had purchased a horse for $£ 45$ with a warranty of soundness, and sold it to Mr. Collins for $£ 55$, was obliged to repay the latter his money, and take the horse back, in consequence of its proving unsound, the Court of Queen's Bench, on a motion for a new trial, laid down that a claim of compensation for a good bargain could not be allowed as damages in an action.

A uaranty need not have an agreement-stamp, and comes within the exception in the schedule of 55 Geo. III. c. 184, as it is "a memorandum letter of agreement relative to the sale of any goods, wares, and merchandize;" and it was held by Lord Ellenborough C.J. that a receipt for the price of a horse containing a warranty of sonndness may also be read in evidence, to prove the warranty, without an agreementstamp (Skrine v. Elmore). But the fact of a receipt containing a 
warranty is not always conclusive evidence ; and it was held not to be so where the warranty was introduced into the receipt by an afterthought of the defendant's coachman, and signed by the plaintiff, who was merely a marksman (Fairmaner v. Budd).

The following "memorandum of agreement between William Short and William Brooke-which is, the horse to be $£ 34$, William Brooke to have half at $£ 17$, and to pay half the horse's expenses being with Job Marson from his arriving at Malton, Feb. 1, 1831, \&c.," and duly signed by the parties, was decided on the authority of Venning v. Leckie to be an agreement for an undivided moiety of a horse within the above exception in 55 Geo. III. c. 184, and not to require a stamp (Marson v. Short). The question of partnership in a horse was very much discussed in French v. Styring, where the plaintiff and defendant, being partners in a horse (Census), agreed that the plaintiff should have the entire management of it, and that the expense of the keep, training, and running him should be borne, and his winnings should be shared by both equally. The horse won nothing ; and the plaintiff having paid the whole of the expenses, it was held that even if a partnership existed between the plaintiff and the defendant in the management and running of the horse, half the sum expended by the plaintiff was in the nature of an advance by him of capital on behalf of the defendant, and which he was entitled to recover from the defendant. And semble per Cockburn C.J., that the agreement constituted a partnership between the plaintiff and the defendant; and per Willes $J$., that it was rather an agreement between two tenants in common (who had acquired a title to the horse at different times and by different contracts) as to the management of their common property, than a partnership.

In an action on a warranty (Collins v. Jenkins), a letter written by plaintiff's attorney in Middlesex, apprising the defendant of the breach of the warranty, and that the horse was standing at livery at the defendant's expense, coupled with an admission in Middlesex by defendant's agent of the receipt of such letter, was held sufficient to satisfy an undertaking to give material evidence of some matter in issue arising in that county. Tindal C.J. said: "It appears to me that this case is determined by that of Cutis v. Drinkwater. The letter written by the plaintiff's attorney was material to a point in issue, since its object was to increase the damages. The proof that such a letter was written in the county of Middlesex, coupled with the admission by defendant's agent in the same county of its haring been received, was according to the principle of that case a compliance with the plaintiff's undertaking.

In Greenway v. Titchmarsh, where the venue hal been changed from 
Middlesex to Herts on the ordinary affidavit, and brought back again, the question was whether the horse had been bought by a person named Gront on his own account or as agent for the plaintifi. Grout had bought the horse of the defendant at Biggleswade Fair (Feb. 13, 1840) with a warranty, and told him at Royston Fair, on March 4th, that the horse was unsound, and he must take him back. On March 5, the plaintifl's attorney wrote in Middlesex a letter, posted in London, telling defendant of the unsoundness, and saying that, unless the price was returned, the horse would be sold, and he wonld become liable for the difference. After this the horse stayed for some days at Grout's, in Surrey, and food and stabling were paid for by the defendant at Enfield, in Middlesex. On Mareh 11th, the horse was sold by the plaintiff; and in an action for the difference between the two sales and the expenses of the keep and resale, it was held, on the point being reserred, that payment in Middlesex of the keep of the horse after notice of unsoundness was sufficient to satisfy the undertaking, as such evidence was material to the damages. And per Parke B.: "The case of Collins v. Jenkins shows that the evidence to be given under an mndertaking like the present is not confined to the mere issue in the canse, but includes also the question of damages, which are to be considered for this purpose as a matter in issue between the parties. Here part of the amount claimed and recovered by the plaintiff was paid in Middlesex, and that payment was good evidence on the question whether the sum claimed was a reasonable amount or not. If the case had stood merely on the letter, there would have been considerable doubt."

It was observed by Jervis C.J., in Read v. Fairbanks, that "in ordinary cases of trover for a horse, the plaintiff recovers the value of the horse, and not what it might have earned besides." Manle J. mentioned a case of trover for a cow, where the value not only of the cow, but also of her milk, was claimed; and added, "I rather think that the value of the thing at the time of the conversion is all that can be recorered." And again, on the question of damages, his lordship said: "Althongh it be true that in trover the owner may recover for the conversion of the improved chattel, it does not follow that he is entitled to recover the improved value as damages. The proper amount of damages is the amount of pecuniary loss which the plaintiffs have been put to by the defendant's conduct. My brother Parke has said that a plaintiff may recover special damages in trover. That was where money had been necessarily laid out in consequence of a conversion (ib.)." The case alluded to by the learned judge was that of Daris v. Osucell, which was one of trover for a pony value $£ 15$, and the special damage alleged in the declaration was that after the conversion of the pony by the defend- 
ants the plaintiff was obliged to hire other horses instead. Parke B. ruled that special damage may be recovered in trover if it is laid in the declaration, but that where no such special damage is laid the valne of the article at the time of the conversion is the measure of damages. At his lordship's recommendation, however, it was agreed that the plaintiff should have the expense of the hire of other horses, less the keep of his own pony during the time, and the plaintiff abated some part of his demand, and consented to a verdict of $£ 25$. A rule to show cause why, on defendant delivering up to plaintiff a horse for which he had brought trover, and paying his costs, all further proceedings should not be stayed on an affidavit that the animal was not in a worse state than when he came into the possession of the defendant, but in an improved condition, was discharged, on cause shown, with costs (Makinson v. Rawlinson).

Where A had wrongfully, and without the licence of $B$, ridden his horse, and so caused his death, a promise by a third person to pay the damages thereby sustained, in consideration that $B$ would not bring an action against $A$, is a collateral promise within the Statute of Frauds, and must be in writing (Kirkham v. Marter). But an agreement to sell a mare on condition that if she prove in foal she should be returned to the iendor on the prayment of a certain sum, is not a distinct agreement for the resale of the mare within the scope of the statute, but a mere qualification of the original contract of sale which was executed, and need not be in writing (Tilliams v. Burgess).

A uaranty that a horse is "sound and quiet in harness" was ruled by Lord Abinger C.B., in Smith v. Parsons, to be supported by proof that the defendaut verbally warranted the horse to be "perfectly sound and quiet in all respects," as the latter phrase includes the going quiet in harness. A somewhat similar case, of Coltherd v. Puncheon, had been decided previonsly in the Queen's Bench, where the plaintiff had a rerdict on a warranty that the horse was "a good drawer, and would pull quietly in hamess." The defendant moved to set it aside, on the ground that being "a good drawer" (which appeared by the evidence) and "pulling quietly in harness" were not convertible terms. The Court, however, held that they were, "becanse no horse can be said to be a good drawer if he will not pull quietly in harness; and therefore proof that he is merely a good puller will not satisfy the warranty. The word 'good' must mean 'good in all particulars." "

Where the plaintiff declared that in consideration of his re-delivery to the defendant of an unsound horse, the defendant promised to deliver to him another horse which should be worth $£ 80$, and be a young horse, and a breach was assigned in both those respects, it was held no 
variance, though it was proved that the defendant also promised that the horse was sound (Miles v. Shourard).

It was ruled by the Court of Common Pleas with regret in Drury v. De la Fontuine, that where neither the vendor nor his agent in the sale of a horse were working within their ordinary calling on a Sunday, the sale must be held good. 'The plaintiff was a banker, who had sent his horse for sale to the repository of one Hull, a horse-anctioneer, who was not therefore acting within his ordinary calling when he sold the horse to the defendant by private contract. In Blorsome v. Williams, the defendant was a coach-proprietor and dealer in horses; and the plaintift's son verbally agreed one Sunday, as he was trarelling on his coach, to buy a horse from him for $39 \mathrm{gs}$, on a warranty that it was sound and rising seven. No earnest was given ; and on the next Tuesday the price was paid, and the horse, which proved to be unsound and serenteen, was delivered. There was no proof that the plaintiff or his son knew that the defendant was a horse-dealer; and Park, J. overruled the objection of the latter, that the contract being made on a Sunday came within the $29 \mathrm{Car}$. II. c. 7, s. 2. The Court upheld the rerdict for the price of the horse, on the ground that this was not a sale on a Sunday; and that if it was so, it did not appear that the plaintiff was priry to the fact of this being the defendant's ordinary employment; and that as the defendant was the only person acting illegally, it did not lie in his mouth to make the objection on the statute, and thereby take advantage of his own wrong.

The bargain in Williams v. Paul, where the plaintiff, a drover, sold three cows and a heifer to defray his expenses during a journey from Sussex to Wales, was made on a Saturday night, subject to the defendant's approval next morning. 'The four were approved of and left, but were not paid for at the end of the three months, as agreed on; and Bayley J. considered that the defendant having kept the beasts, and subsequently promised to pay, was liable for the value upon a quantum mervit, though not for the price agreed upon by the bargain completed on Sunday. On these grounds, although the Court considered that it was a Sunday contract, because the bargain on Saturday was incomplete till the beasts were inspected, they refused to enter a nonsuit.

'The oljection under the statute in Fennell v. Rieller was of a novel kind. The plaintiffs were horse-dealers, and objected that the statute did not apply, as their contract with the defendant, an innkeeper, who had given them a warranty, was made within his own yarl with closed grates, and in the presence of the parties and their servants only; and under the direction of Park J., they had a verdict. The Court, however, considered that the ease was strictly within the scope of the words 
of the statute "exercising himself in the duties of piety and true religion publicly and pricutely," and made the rule absolute for a new trial. But where a farmer kept a stallion, and covered mares with it on a Sunday, the contract was not held void under the statute, as it was not done in the "exereise of his ordinary calling"; but even if it were, the contract having been executed, he had a lien on the mare if the covering fees were not paid (Scarfe v. Morgan). Bnt qucere whether the statute 29 Car. II. c. 7 avoids a previous parol contract for the sale of goods, where the delivery and acceptance take place on a Sunday (Beaumont v. Brengeri).

A farmer is not within the Sunday Trading Act, 29 Car. II. c. 7, s. 1, Queen v. Silvester 33 L.J. (N.S.) M.C. 79. The appellant, a farmer, was convicted and fined for haymaking on Sunday, but the Court of Queen's Bench on appeal quashed the conviction.

It is not sufficient, on a trial of waranty, for the plaintiff to give such evidence as to induce suspicion that the horse is unsound; if he only throws the soundness into doubt he cannot recover, he must positively prove the horse unsound at the time of sale. And hence in Eares v. Dixon, where the horse died a few days after the sale, and on dissection reterinary surgeons gave it as their opinion that inflammation of the lungs might lead to mortification in three days, and that if the inflam. mation had existed at the time of the sale there would have been thick breathing, and the plaintiff had a rerdict on the warranty, the Court directed a nonsuit. A warranty only refers to the state of a thing at the lime of sale; but it may, as in Lidlard $\mathrm{r}$. Kain, become a continuing warranty. There defendant remarked at the time of sale that one of the pair of horses he purchased had a cough and nose-running, and said in reply to the plaintiff's assurance that he would be well in a week, that he would not take him unless the plaintiff would let him stand in his stable for a fortnight. To this the latter assented, and said, "I will deliver both the horses at the end of the fortnight, sound and free from blemish." At the end of that time one still had a cough, and the other a swollen leg, and was lame and blemished from a kick in the stable. The jury found for the defendant in an action for the price, and the Court refused to disturb the verdict. The plaintiff had agreed to deliver up both borses at the end of the fortnight, sound and free from blemish; and the warranty, therefore did not apply to a mere unsoundness at the time of sale, but was a continuing warranty to the end of the fortnight. And where, as in Simmonds v. Carr, an agent for the sale of horses sold a horse of the defendant's and another of a third person's to the plaintiff at the same time, at an entire price of $90 \mathrm{gs}$. , and warranted both to be sound, Lord Ellenborough C.J. held 
that the plaintiff had no action of assumpsit against the defendant for the unsoundness of the horse which belonged to him, declaring as upon a sale of one horse, since the contract concerning the two was entire.

The doctrine as to whet constilutes unsoundness was very carly laid down by Ellenborough C.J. in Elton v. Brogden, where the defendant allowed that the hor'se was lame at the time of the sale, but said that such lameness was only temporary, and that he was now quite sound. His lordship said, "I have always held, and now hold, that a warranty of soundness is broken if the animal at the time of the sale lad any infirmity upon him which rendered him less fit for present service. It is not necessary that the disorder should be permanent or incurable. Whilst a horse has a cough I say he is unsound, although that may be either temporary or' may prove mortal. 'The hor'se in question having been lame at the time of the sale when he was warranted to be sound, his condition sulusequently is no defence to the action." In Elton v. Jordan, where a witness for the defendant admitted that he had banduged one of the horse's forelegs because it was weaker than the other, his lordship repeated this definition. It was, however, laid down by Coleridge J. in Boldero v. Brogden, that if a horse were sold with any ailment on him which might be reasonably expected to give way to slight medical treatment, and to leave behind it no seeds of future disease, he was not unsound within the meaning of a warranty. This decision, and one to the contrary effect by Parke B. in Coates v. Sterens, were both bronght under review in Kiddell v. Bumarl in the Court of Exchequer, and the question finally settled.

The above was an action of assumpsit to recorer back the money for three bullocks which had bcen warranted sound. Adam Bryant, a man in the plaintiff's employ, had purchased them for him at Lew Down fair, in Devon, for $£ 40$, a fair price if they had been sound. At the time of the sale Bryant had complained of the badness of their colour; and the defendant said, "I will warrant them sound." It was also proved by witnesses that all three appeared more or less unsound at the time of sale, and two of them after a resale turned out to be so; and the plaintiff had to pay $£ 20$ as compensation to the purchaser, while the other died on its road to Leicestershire. Eighty-three bullocks of the plaintiff's had been taken by his drover from Devonshire to Northampton by stages of fourteen and fifteen miles per day, and all with the exception of these three stood the journey well. Erskine J. said, "The third question is, were the cattle unsound at the time of sale? The plaintiff must prove that the beasts had some disease or seeds of disease at the time of the sale, which rendered them in some degree unfit or less 
fit for ordinary use. Thus it is in the ease of horses, so with respect to oxen. The defendant warrants that they have no disease which wonld prevent them from being fattened, and made fit for sale to a buteher, or render them disqualified for travelling: One of the beasts died on the road from unsoundness. Did the unsoundness eome on by any aecidental cireumstances after the sale, as taking cold or drinking cold water? if so, that is not such unsoundness as to affect this verdict; or were the symptoms referable to antecedent disease? if so, the ease is made out as to that animal. For the other two bullocks, you have it in evidence that the butcher who bought them observed their bad condition, and it is also said that they were unsound at the time of the sale on Lew Down. The question is, are you satisfied that these beasts had the disease upon them at the time of the sale?" The jury returned a verdict of $£ 25$ for the plaintiff, and a rule to show cause on the ground of misdireetion was refused.

Parke B. said, "I think no rule ought to be granted in this case. In the ease which has been referred to, of Coates v. Stevens, I am reported and correctly reported to have said to the jury 'I have always considered that a man who buys a horse warranted sound must be taken as buying for immediate use, and he has a right to expect one capable of that use, and of being immediately put to any fair work the owner chooses. The rule as to unsoundness is, that if at the time of the sale the horse has amy disease which either actually does diminish the natural usefulness of the animal; so as to make him less capable of work of any description, or which in its natural mogress will diminish the natural usefulness of the animal; or if the horse lats cither from disease or accident undergone any alteration of structure that cither actually does at the time or in its oritinary effects will diminish the natural usefutness of the horse, such horse is unsound. If the congh actually existed at the time of sale as a disease so as actually to diminish the natural usefulness of the horse at that time, and to make him then less capable of immediate work, he was then unsound: or if you think the cough, which in fact did afterwards diminish the usefulness of the horse, existed at all at the time of the sale, you will find for the plaintiff. I am not now delivering an opinion formed on the moment on a new subject ; it is the result of a full and previous consideration.'

"This is the rule I have ever acted on, in cases of unsoundness, although in so doing I must differ from the eontrary doetrine laid down by Coleritlye J. in the ease of Boldero v. Brogden, which has been referred to. In short the word 'sound' means what it expresses, namely, that the animat is free from disease at the time he is warranted to be sound. If, indeed, the disease were not in ordinary cases of a 
nature to impede the natural usefulness of the animal for the purpose for which he is used-as, for instance, if a horse had a slight pimple on his skin, it wonld not amount to an unsoundness; but cren if such a thing as a pimple were on some part of the body where it might have that eflect, as, for instance, on a part which would prevent the putting a saddle or bridle on the animal, it would be different. An argument has, however, been adduced from the slightness of the disease and the ficility of the cure ; but if we once let in considerations of that kind, where are we to draw the line? A horse may have a cold which may be cured in a day, or a fever which may be cured in a week or month, and it would be difficult to say where to stop. Of course, if the disease be shight the unsoundness is proportionably so, and so also ought to be the damages; but in the question of law I think that the direction of the judge in this case was perfectly correct, and that this verdict ought not to be disturbed. Were this matter presented to us now for the first time, we might deem it proper to grant a rule; but the matter has been, we think, settled by previous cases, and the opinion which we now express is the result of deliberate consideration." Alderson B. said, "I an of the same opinion. The word 'sound' means sound, and the only qualification of which it is susceptible arises from the purpose for which the warranty is given. If, for instance, a horse is purchased to be used in a given way, the word 'sound' means that the animal is useful for that purpose, and 'unsound' means that he at the time is affected with something which will have the effect of impending that use. If the disease be one easily cured, that will only go in mitigation of damages. It is, however, right to make to the defence of unsoundness the addition my Brother Parke has made, namely, that the disqualifieation may arise either from disease or accident; and the doctrine laid down by him on this subject, both to-day and in the case of Coates v. Stevens, is not new law, and is found to be recugnized by Lord Ellenborough and other judges in a series of cases."

According to Holyday v. ILorgan, any defect in the structure of a horse, whether congenital or arising from subsequent disense or accident, that diminishes his natural usefuhess and renders him less than reasonably fit for present use, is unsoundness; and couvexity in the formation of the cornea of the eye of a horse, making him shortsighted, and so inducing a habit of shying, is such a defect. At the trial in the Lord Mayor's Court of London, before the Common Serjeant, it appeared that the defendant sold the horse to the plaintiff with an express warranty of somndness. It was found to sliy going through the strects, and a velerinury surgeon gave evidence that it had an unusual concexity 
in the cornea of the eye which cansed shortsightedness, and that the habit of shying might arise from this; but that there was no disease in the eye, the peculiar formation being congenital. His honour directed the jury that if they thought that the habit of shying arose from a defect of vision caused by natural malformation of the eye, this was unsoundness. The jury found a verdict for the plaintiff, leave being reserved to move to enter it for the defendant, or for a new trial under stat. 20 \& 21 Vict. c. 157, s. 10, and the Court of Queen's Bench confirmed their finding. And per Lord Camplell C.J.: "The direction of the Common Serjeant was wholly unexceptionable, being in effect that if the shying arose from malformation of the eye, that was unsoundness, although the defect was congenital. Althongh in the authorities cited (Kildell v. Burnard, Coates v. Stevens, Barley v. Forrest, and Brown v. Etkington) for the defendant, the cases of supervening disease and accident are alone mentioned, yet it is not from thence to be assumed that the learned judges wonld have said, that if a congenital defect had been found to exist, there would not have been a breach of the warranty of soundness, the defect being such as to prevent the animal from performing that which might reasonably be expected from him. Suppose a horse to be born blind or with a contracted foot, surely that would be a breach of warranty of soundness, althongh the deficiency or defect existed before the animal was foaled. Then as to the point that this was such a defect as the purchaser was bound to take notice of ; there being an express warranty, he was not bound to examine so closely as to ascertain whether the cornea were so formed as to produce short sight; the most prudent man conld not be expected to do that. The plaintiff had a right to rely on the warranty, and that I think was broken."

It wonld also seem, from the decision of Abbott C.J., in Joliff v. Bendell, that the purchaser of sheep or cattle may have his action when they prov'e to hav'e some hereditary disease in them which prevents them from thriving. This was a case of assumpsit on a sheep warranty, the first count of which stated the sheep to be sound, and the second fiee from goggles. The sheep, 100 in number, were sold on the 12 th of Angust, 1823. At the time of the sale they were apparently sound, and continned so till the middle of the next October, when one or two of them were seized with goggles, which exhibited itself in giddiness, swelling of the eyes, and hanging of the head. They grew weaker and weaker, and generally died in abont a week or ten days after the seizure, and on dissection, water was found in the head or brain. Abont 50 had died, and 50 continned well mp to the time of the trial. There was no contagion, other sheep with which they were fed and kept 
haring continued healthy. Witness stated that it was an hereditary disease, arising from breeding "in and in, or from relations"-that sheep so disordered would thrire and seem to be in sound health generally until two or three years old-that there was no means of discorering by the appearance or otherwise that sheep were so affectedthat it was generally fatal, and no cure or prevention known for it, and was reputed amongst farmers an unsoundness. The evidence for the defendant went to show that the sheep were of a pedigree frec from "breeding in and in," and that others of the same sort and older were perfectly sound. The warranty was proved without dispute, and the sheep rere all of the same breed. For the defendant it was contended that the sheep having been thriving and healthy at the time and for two months after the sale, must be considered as sound at that time; that, inasmuch as there were no previous symptoms to connect the disense of which they died with their former state of health, there was nothing to show that the disease existed at the time of the sale; and that an hereditary liability to a particular disorder was of too uncertain a natmre to be capable of proof, and could not be legally considered as an unsoundness existing at the time stipulated for in the warranty. Abbott C.J. left it to the jury to say whether at the time of the sale the sheep had existing in their blood or constitution the disease of which they afterwards died, or whether it had arisen from any subseqnent canse. The verdict was for the plaintiff for $£ 120$, the value of the sheep which had died, and the defendant agreed to take back the remainder.

It was laid down by Lord Ellenborough C.J., in Shillitoe v. Claridlye, that if a horse has a cough of a permanent nature, he is unsound, and "such has, I believe, always been the understanding both in the profession and amongst reterinary surgeons. On the counsel (subsequently Mr. Justice Williams) remarking that "at present at least twothirds of the horses in London have conghs," his lordship rejoined, "Be it so ; but still it is a breach of the warranty." Tord Mansfield C.J. held that rouring was not necessarily an unsoundness; and in Betsett v. Collis a somewhat strained distinction was drawn by Lord Ellenborough C.J. between roaring which proceeded merely from a bad habit, producing a noise offensive to the ear, and that which is the result of any disease or organic infirmity. However, in a later case of Onslou' v. Eames, after hearing the evictence of Mr. Field, V.S., to the effect that roaring is occasioned by the circumstance of the neck of the winlpipe being too narrow for accelerated respiration, and that the disorder is often produced by sore throat or other topical inflammation, and incommodes him when pushed to his full speed, his lordship said, 
"If a horse be affected by any malady which renders him less serviceable for a permanency, I have no cloubt that it is an unsoundness. I do not go by the noise, but by the disorder." Subsequently, in Best $\mathrm{v}$. Osbome, Best C.J. ruled that the plaintiff had not done enongh in showing a horse to be a roarer, and that "to prove a breach of warranty he must go on to show that the roaring was symptomatic of disease." Roaring is now considered in practice to be an unsoundness.

In both Thompson v. Palleson and Niglett, and Scott v. Henderson stringhalt was considered an unsonndness. In the latter trial Professor Diek mentioned that a horse's leg usually clears the ground at least five inches in stepping, whereas a stringhalt would cause it to be raised at least one-third more. The defendant in Anderson v. Blackburn consented to a rerdict against him, as he had evidently mistaken stringhalt action, or "a catching gait with all the legs," which is rery peculiar to all Arab horses, as this one was for stringhalt. According to Professor Spooner, it most frequently attacks horses whose erusts and laminæ are weak and very obliquely placed. Laminitis was considered by Wilde C.J. in Smart v. Allison to be an unsoundness, as it alters the structure of the feet to such an extent as to cause lameness. Here the off forefoot was especially impaired, and the disease was marked by the usnal symptoms (flat soles and ridges on the hoofs below the coronets), and had evidently been in existence some time. For the defence it was unsuccessfully urged that the horse had been flatfooted and ribbed in the hoof from his birth, but had never been lame but once from the effects of a thorn, and that then, if he had been suffering from laminitis, he could not have beeu hunted for two seasons. Professor Spooner, who was called for the plaintiff" to prove the alleged unsonndness, said that "Laminitis, usually styled 'ferer of the feet,' commences with acute inflammation of the laminæ, substances which lie between the coffinbone and exterior hoof, protecting the latter from being pressed by the former. If the inflammation be so acute as to occasion a disunion of the sensitive from the horny laminx, the coffinbone falls down upon the sole, producing a deformity of the hoof, and the horse beeomes incurably lame. If it does not proceed to that length chronic inflammation supervenes, the coronet of the hoof throws out ridges, the horn at the toe thickens, and the sole or space within the frog beeomes so flattened as to touch the gronnd and make the horse liable to lameness after a hard day's work or travelling on the road." Hall v. Rogerson was a case of the same class. A contraction of the hoof causing lameness (Grecnuay $\mathrm{v}$. Marshall), and a naricular-joint disease, which is an inflammation of a joint on the inside of the hoof, and a peculiar incident of contracted feet, are also an unsoundness (Byucaler v. Richardson); and sce 
Matther's v. Parker. A chest-foundered horse is unsound (Alterbury r. Fuirmaner), and so is one suffering from caturact (Higgs v. Thate), or opacity of the crystalline lens (brigys v. Baker).

An affection of the neres in the lumbar region was held in Witmot $\mathrm{v}$. Lees to be an unsoundness. The large nerves so affected take their origin from the spinal marrow as it passes throngh the loins, and hence there is no proper nervous connection between the hind quarters and the brain. The discase betrays itself very little when the horse is in action, but is especially apparent when he moves in the stall by the jerking npwards of the near hind limb, and an inability to move sideways, which canse him to fail and drop several inches on the near side. Three reterinary surgeons "could see nothing the matter" with this horse, and his groom swore that he had aequired the habit of dropping his hind legs from his occasionally clipping him over the legs with a pitchfork to make him elear the bedding. Under the direetion of Colevidge J. there was a verdiet for the defendant for the difference between the price given for the horse and the sum he sold for when under dispute.

It was expressly laid down by Alderson J., in Dickinson v Follett, that "a horse camnot be considered unsound in law merely from badness of shape. As long as he is uninjured he must be considered sound. When the injury is produced by the badness of his action it constitutes an unsoundness." The evidence here was eontradictory as to whether the unsoundness existed at the time of the sale, and a veterinary surgeon who was ealled for the defendant said that the horse was so illformed from turning ont one of its fore-legs, that it was incapable of doing work to any extent without cutting so as to produce lameness. The law laid down by the learned judge was expressly in point for the defendant in Broun v. Elkington, where it appenred that the plaintiff had objected to the horse's curby hocks at the time of the sale, but bought him for $£ 60$ on receiving a general warranty of soundness. He sprang a curb a fortnight after, in his third day with homds. Veterinary surgeons gave their testimony for the plaintiff to the effect that curby hocks indicate a peculiar form of the hock, which was considered to render the horse more liable to throw ont a eurb, but did not of itself occasion lameness, and that the horse had curby hocks at the time of sale. Iord Abinger C.B. told the jury that a defect in the formation of the horse which had not occasioned lameness at the time of sale, though it might render the animal more liable to be lame at some fiture time, was no breach of the warranty. 'The Court of Excherpuer refused a new trial for inisclirection, which was moved for on the sround that a malformation, the natural consequenee of which was 
lameness, amounted to an unsoundness; and Alderson B. observed that, "The law as laid down by me in Dickinson v. Follelt has not been questioned in any subsequent case."

Cresswell J. also ruled in accordance with this doctrine in Bailey $\mathrm{v}$ Forrest, where it was contended for the defendant that the mere fuct of a horse being thin-soled did not of itself make him unsound, and that the plaintiff' could not recover on the warranty, although the horse fell lame shortly after the sale. "The plaintiff," said his lordship, "must prove that the horse was unsound at the time of the sale, or he cannot recover. Mere defective formation not producing lameness at the time of sale, does not, in my opinion, constitute unsoundness."

The subject of splints was rery mneh considered in Margelson $\mathrm{v}$. Wright. Here the plaintiff, an attorney, being desirous of possessing a race-horse, went to examine the defendant's stallion Sampson, who, in addition to being a erib-hiter, had a splint on the off fore-leg, and had broken down in training. In consequence of these defects the plaintiff purchased him for only $£ 90$, a French veterinary surgeon having redueed the splint and given a plausible recipe for its future treatment. Defendant would not give a warranty that he would stand training, and hence a sale memorandum was ultimately signed stating the amount and time of payment, that plaintiff was to give the defendant $£ 10$ for each of the first five races the horse won in 1830 , and concluding thus-"And the said Mr. Wright does hereby warrant the said horse to be sound, wind and limb, at this time." In the course of six months the horse broke down in training, and an action was commenced on the warranty. Purke J. told the jury that the parties, by the insertion of the words " at this time," probably intended to exclude a warranty of the hor'se's standing training ; and that the question for them to consider was, whether at the time of the warranty the animal was sound for ordinary purposes, as to go on the road or the like, the express warranty rendering the defendant responsible for the consequences of the splint, though the defect was visible.

The Court of Common Pleas granted a new trial, as they thought that the jury might hare been misled by the direction, which wonld have been less subject to misapprehension if it had been left to them to consider whether the horse was at the time of the bargain sound in wind and limb, saving those manifest defects contemplated by the parties. At the second trial the plaintiff brought forward evidence as to the nature and eonsequence of various kinds of splints, and proved not only that they may or may not be the efficient cause of lameness, according to their size or to the position they occupy ; but that Sampson's splint was in a very bad position, as it pressed on one of the 
siners, and produced inflammation and eonsequent lameness whenever the horse worked. Faughan B. requested the jury to tell him distinctly whether in their judgment the horse was sound; or if unsomnd, whether the unsoundness arose from the splint. They said "that although the lorse exhibited no symptoms of lameness when the contract was made, he had upon him the seeds of unsoundness, arising from the splint;" and they accordingly found for the plaintifr.

On a motion for a new trial, the Court of Common Pleas ordered the postea to be delivered to the plaintiff. Tindal C.J. said: "The jury drawing their attention to the particular splint to which the eridence related, appear to us to have intended that this individual splint, though it did not at the moment produce lameness, was at the time of the contract of that sort and in that situation as to contain, in their language, the seeds of unsounduess that is the efficient canse of subsequent lameness. If the lameness complained of had proceeded from a new or different splint, or from the old splint taking a new direction in its growth so as to affect a sinew, not having pressed on one before, such. a lameness wonld not have been within the warranty, for it would not hare constituted a present unsoundness at the time of the warranty made. But the jury find that the very splint in question is the efficient cause of lameness; and it appears by the fresh evidence that some splints canse lameness and that others do not, and that the conscquences of a splint cannot be apparent at the time like the loss of an eye or any visible blemish or defect to a common observer. We therefore think that by the terms of a written warranty the parties meant that this was not a splint at that time which wonld be the canse of future lameness, and that the jury have found it was. We therefore think that the warranty was broken."

In Warton r. Flourers the horse had a splint on the near frout leg at the time of the sale, but after some examination a warranty of soundness was given. At the end of ten days the horse went lame, and on examination of his feet and legs by Professor Spooner, who had the shoes taken off, that gentleman gave it as his opinion that the lameness proceerler from the splint, and was of some months' standing. Mr. Webb, T.S., who was sent to look at the horse by the defendant, maintained that the horse wanted shoeing, and that his lameness was caused by the growth of his loofs, by which his heels were let down and his naricular joint bruised on the pavement. The defendant, on henring this, refused to take him back, and bronght evidence on the trial to show that he had worked 18 miles a-day with the splint in the Epping Coach before the plaintif had him, and done a potato mer- 
chant's work for three months after his resale by the plaintiff, and yet had never gone lame. Jertis C.J. put it to the jury that if the lameness was produced by the splint the plaintiff was entitled to recover; but if on the other hand they were of opinion that $\mathrm{Mr}$. Webb was right in supposing the lameness to be caused by want of shoeing, they must find for the defendant. The plaintiff had a verdict for $£ 326$ s. 9 d., being the difference between the original price and the net proceeds of the sale, and for keep during the time he had him.

According to the rule laid down in Fielder v. Starkin, no length of time elapsed after the sale will alter the nature of a contract originally false, Hough the not giving notice is a strong mesumption against the buyer that the horse had not at the sale the fault complained of. Here the mare was found soon after the sale to he a roarer, in addition to having a thorough-pin, and a swelled hock from kicking; but the plaintiff kept her three months, and tried to eure her. He then resold her, and she was returned unsound, and defendant refused to receive her back at the end of six months, as the plaintiff (who got the verdict) had often met him during that time, and never mentioned the matter. On her way back to the plaintiff's stables, after this refusal, she died, and reterinary surgeons thought she had been unsound for a twelremonth.

A verdict for the plaintiff, with $30 \mathrm{gs}$. damages, was confirmed; and on the authority of this ease a new trial was moved for, after a verdict for the defendant, in Adams v. Richards, which was an action on the warranty of a pair of brown coach-horses, to be "perfectly sound, free from blemish, and in no manner vicious, and if on the trial they should have any of the above-mentioned faults to be taken back and purchasemoney returned." Soon after the sale one of them turned vicious and restive, and there was evidence that he was so at the sale. 'The plaintiff told the defendant of this, but still kept the horse for a time, in the hopes that he would improve by use. The defendant took his horse back for a time, lending him another to make up the pair, and then sent him the vicious one back with the assurance that it was quite quiet now. On this point, however, the plaintiff differed with him, returned the pair at the end of nearly seren months, and sued defendant for his money. The Court said that they fully assented to the doctrine in Fielder v. Starkin (that where a horse has been sold warranted sound, which, it can be clearly proved, was unsound at the time of sale, the seller is liable to an action on the warranty, without either the horse being retumed or notice given of the unsoundness). Still when there uas an agreement to take a horse back, if on trial he should be found faulty, though it were accompanied with an express warranty, it was 
incumbent on the purchaser to returu the horse as soon as the funlts were discovered, unless the seller by any subsequent misrepresentation induced the purchaser to prolong the trial. A trial means a reasonable trial: but here nearly seven months had elapsed after the horse was known to be restive, and before the return, and therefore the verdiet for the defendant was right. Forty years after it was urged on the argument in Patteshatl v. Tranter, where the horse was discovered to be paralyzed in the spine shortly after the sale, and the plaintiff gave no notice for nine months, but put him into physic and cut his tail, that Fieleler v. Starkin had been overruled, or at least qualified by other decisions in the interim; but Lord Demman C.J. said, with the assent of Littledale, Patteson, and Colerillge J.J.: "We think that Fielder v. Starkin is not overruled." And the nousuit was set aside and a new trial ordered.

When a certain time for trial is fixed upon, the person granting it cannot break off the negotiation till it is concluded. And so in Ellis v. Mortimer, where the defendant told the plaintiff, when only a fortnight out of the month was expired, that he liked the horse but not the price, and was requested to send the horse home, but did not do so till three or four days before the close of the month, the plaintiff could not maintain an aetion against him for the price.

A borroued horse camot be used by a servant (Bringloe v. Morrice), which was the case of a master and servant riding by turns to York. But a man may met his servant on a hired horse (ib.); and if he is about to buy a horse he is not limited to trying its paces himself, but has a right to put his groom or a competent horseman on it for the purpose of a trial, and provided they do nothing more than is necessary, even if the horse runs away and injures itself or is killed, he is not liable (Camoys (Lord) v. Scurr). If a person rides a horse gratuitously for another at the oumer's request, in oriler to show him for sale, he is bound to use sueh skill and care as a person conversant with horses might be reasonably expected to use, and if he does not, he is equally liable with a borrower for injury done to the horse while ridden by him. Hence in Wilson v. Bretl, where the defendant, a skilled horseman, took a horse for inspretion into a cricket-field, where it slipped several times owing to the nature of the firtd, and broke its knees, the Court of Exchequer refused to set aside a verdict for the plaintiff, and considered that the proper question for the jury was that put by liolfe B., whether the defendant did or did not use such skill and management in choosing his ground and handling his horse as he really possessed. And per Rolfe 13. : "The distinction between this case and that of a borrower is that a gratuitous bailee is only bound to exereise such skill as he possesses, 
whereas a hirer or borrower may reasonably be taken to represent to the party who lets, or from whom he borrows, that he is a person of competent skill." But per Colerielge J. : Would it not be monstrous to hold that if the owner of a horse, knowing it to be vicions and uninanageable, should lend it to one who is ignorant of its bad quality, and conceal this from him, and the rider-nsing ordinary care and skill-is thrown from it and injured, he should not be responsible?" (Blackmore (adx.) v. The Bristol and Exeter Railecay Company).

The defendant in Curtis v. Hannay had learnt the day after the sale that the horse had defective eyes at the time he bought him, but leept him seven weeks before he returned him, and said nothing. During that time he gave him medicine and blistered him for a funcied defect in the feet, which produced a thrush and lameness. The latter was only temporary, and the horse got better, and those remedies did not affect the eyes. Under these circumstances Lord Eldon C.B. said that the question was, "Would the horse, when returned to the seller, be diminished in value by this doctoring? If he would, the defendant should pay the price, and bring his action against the seller for any defect in the warranty existing at the time of the sale. Me took it to be clear law that if a person purchases a horse which is warranted, and it afterwards turns out that the horse was unsound at the time of the warranty, the buyer might if he pleased keep the horse and bring an action on the warranty in which case he would have a right to recover the difference between the value of a sound horse and one with such defects as existed at the time of the warranty; or he might return the horse, and bring an action to recover the full money paid; but in the latter case the seller had a right to expect that the horse should be returned in the same state he was when sold, and not by any means diminished in value." The jury found for the full price, as they seemed to think that a future purchaser would think less of the horse if he heard that he had been blistered and doctored.

If a horse is taken ill on a joumey, without any fantt in the hirer, the oumer lias to pay the expense of its cure; lut if the hirer takes upon himself to mescribe medicines, and the horse dies, he is liable for the price of it. And so it was ruled in Dean v. Keate, where the defendant gare the horse some medicine, mild in itself, and then drove him very quick in rough weather, producing thereby inflammation of the intestines, which he treated with opium and ginger, and then when he found the horse dying in great pain sent for the farrier too late. Lord Ellentorongh C.J. said, had he called in a farrier he would not have been liable for the medicines he administered; but when he prescribed himself, he assumed a new degree of responsibility, and in preseribing so improperly 
he did not use that degree of care which might be expected from a prudent man towards his own horse, and thongh acting bonk fide, was liable to the owner for gross negligence.

It was decided in Orehurd $r$. Rackstran, that where a horse is standing at livery, and the livery-stable keeper at the ouner's request employs a veterinary suryeon, he has no lien on the horse for the latter's charge. In this case the horse was blistered for splints, and on its being demanded the defendant claimed a lien of $£ 2313 \mathrm{~s}$. including his charge for the standing of the horse and the hire of a chaise, and $30 \mathrm{~s}$. for payment to the veterinary surgeon. Maule J. told the jury that the defendant was not entitled to claim a lien upon the horse, either in respect of the char'ge for its keep, or of the surgeon's charge for blistering, and accordingly a verdict was found in trover: for the plaintiff-damages $30 \mathrm{gs}$, being the ralue of the horse. The Court of Common Pleas confirmed this ruling. Wilde C.J. said, "Suppose the reterinary surgeon had treated the horse unskilfully and damaged it, who would have been responsible to the owner, the livery-stable keeper or the veterinary surgeon? Clearly not the former. The veterinary surgeon had $n o$ lien for his bill, and the livery-staule keeper none for the keep of the horse." Cressuell J. added, "There is no rule of law giving a livery-stable keeper a lien for money expended upon a horse standing at livery at the request of the owner. The case, therefore, does not fall within the rule of law which confers a lien upon one who expends his money or his labour upon a chattel of another."

Bates v. Hudson was a case of "no cure no pay." The plaintiff proved that he had been employed by the defendant to cure a ftock of 350 sheep and 147 lambs of the scab, at so much per head for each sort. General evidence was given that the plaintiff had performed his contract; but the defendant proved that the plaintilf at the time he undertook the task did not expect to be paid unless he cured all the flock, whereas he had failed in at least forty cases. Alexcender C.B. held that if the plaintiff agreed to cure all the sheep, at all erents that was an entire contract, and he could not recover if some of the flock were not cured. 'I'he jury found that the complaint had been checked but not subdued, and a verdict was entered for the defendant, which the Court of King's Bench refused to disturb.

'The question of the liability for the damage where a highly improper application for a horse is furmisled was fully considered in Phillips v. Wood. 'The defendant was a chemist and druggist, and the first count stated that he had agreed to sell the plaintiff a quantity of ointment, ruasonably fit to be applied as a blister to horses with puffed legs ; and that though it was defendant's duty to sell him such ointment, he suld 
him some which was totally unfit, and by the application of which his mare was made useless. It appeared on the trial before Littledule J., that the paintiff, thinking his mare required blistering, agreed with his father that the latter should take her, have her blistered and properly treated, and send her to grass in his own field. The father, who was to be paid for the keep of the mare, bought from the defendant the blistering ointment, which was applied by a man employed by himself, to all four legs at once. The jury found that the plaintiff had not been guilty of negligence, and gave him $£ 32$ damages. A new trial was moved for on the ground that the contract was not properly stated in the declaration, and also that the plaintiff himself was guilty of negligence, as he had applied the ointment too severely. The Court of King"s Bench refused the rule, and thought that the contract was described according to its legal effect. It was quite clear in law that this was the son's contract. By the terms of the agreement between the father and the son, the latter was liable for the price; and if it had been a eredit transaction the chemist might have recovered from the son, for the father purchased in the character of his agent. The Court by no means assented to the proposition that the plaintiff was bound to show that he himself is not chargeable with negligence before he could impute it to the delendant. That formed no part of the issue he was bound to prove.

Black v. Elliot was a very important action to recover damages for the defendant's negligence and want of skill in selling a sheep wash to the plaintiff, which poisoned his sheep. The plaintiff was a large farmer at New Heaton, in Northumberland, and he had recently purchased the stock and taken a farm of abovt 1,000 acres at Burton, in addition to his own. In July, 1858, he saw an advertisement in the "Berwick Advertiser" headed "Important to farmers," and greatly recommending the defendant's "Celebrated sheep wash," for the destruction of tick, lice, and vermin in sheep. Accordingly, on the 7th of August, the plaintiff being at Berwick, ordered sufficient of this sheep wash to wash 700 sheep. The wash was sold in powders; and the defendant's shopman told him he would require 14 of these powders-one powder being sufficient for 50 sheep. The plaintiff ordered 15 powders, and they were sent to his Burton farm. 'I'he direction on the powders was that each powder was to be mixed with three or four gallons of boiling water, and that then this mixture, with $4 \mathrm{lbs}$. of soft soap, was to be diluted with 45 gallons of cold water, and this would make a wash for 50 sheep, in which they were to be dipped. The direction was implicitly followed, and on a Saturday in Angust 869 sheep were dipped in this wash-60 of thom being dipped in it much diluted, as they had 
been washed before. The sheep rere brought from a considerable distance to the sheds, and they were turned back into the sheds, and sent back to their pasture at intervals during the day, and all appeared to go on well. On the Sunday, however, one of these sheep died. On the Monday several more died, and many were seen to be ill-foaming at the mouth aud shaking, their heads, and lying down.

On the Tuesday a great number died; mole still on the Wednesday ; until, in the course of a few days, 850 of the sheep had died, 19 only surviring, and these 19 were part of the 60 which had been dipped in the rery dilnted mixture. It was also fonnd that the hands and arms of the shepherds which had been dipped in the liquor beeame sore, and mortified and sloughed, and they were ill for some time from it.

It was suggested that the sheep had been allowed to eat the herbage on which they stood after they were washed, and that a shower of rain had rashed off them much of the mixture, and saturated the herbage of the field where they were placed, and thus poisoned them.

On the sheep all dying in this manner, Mr. Black had one of the powders analyzed, and it was admitted that it contained $11 \mathrm{lb}$. of arsenic, $1 \frac{1}{4} 1$ b. of soda ash, and 2oz. of sulphmr, each powder weighing 21b. 10oz. The sheep were dissected and found to have been poisoned. They were all much swollen and black. The plaintiff then saw the defendant, who went over to his farm. The defendant said then it was a bad job, that his powders had never poisoned any sheep before, and he knew he was responsible. The defendant then sold the skins of the sheep to a skimer who joined them on the road for $2 s$. each, and the carcases were buried. The plaintiff claimed $₫ 1,737$ as the value of his sheep. The defendant, however, afterwards resisted this demand, and set up as a defence the improper mixing and dilnting of his powders, contending that the solution made was stronger than it ought to have been according to his directions.

Those that had the disease had a frothy mucous about the brow, nose, and montl, the eye was very dull, and evident pain in the bowels, the breathing was most laborious, the head was swollen, and thrown back. The urinary discharge was black and bloody. The skin was of a black and blne appenrance, and the wool falling off in large patches, particularly on the back and across the loins. Professor Dick, of Edinburgh, Dr. 'Thompson, and other scientific witnesses, were called to prove that the sheep, on dissection, exhibitel traces of arsenic in their intestines, and as much as six grains was fonnd in a sheep, which was quite sufficient to account for the death. The quantity of arsenic in each porrder sold by the defendant for the washing of each sheep amounted to 195 grains. Willes J. summod np at considerable 
length: "With regard to the question of compensation, assuming that they found for the plaintiff, it would" (his Lordship said) "be a matter for consideration whether they should find a verdict in respect of the 700 sheep, for which the packages were sold, or whether in respect of the whole. He observed that, although the damages were laid at $£ 1,700$, he thought if the jury found for the plaintiff, $£ 1,400$ wonld be sufficient to cover the loss. The decision must be founded on whether this was a 'reasonable, fit, and proper' composition to be used, according to the directions on the package, for dipping sheep. If they, turning the matter over in their minds, thought that the result conld not be reasonably attributed to any other cause than the impropar composition, then they onght to find their rerdict for the plaintiff. But if the plaintiff had not made that out to their satisfaction, then they onght to return their verdict for the defendant." The jury returned a verdiet for the plaintiff, damages $£ 1,400$.

Where there is no contract a vetcrinary surgeon must go upon a quantum meruit (Seucell v. Corr?); and in the same case Best C.J. refused to receive in evidence, as coming from a body not known to the law, a certificate of the Royal Veterinary College of attendance at lectures. It was held by Lord Ellentorough C.J. that, under a general count for work, labour, and materials, a furrier may recoier for attendances and medicines administered in the cure of a horse (Clark $\mathrm{v}$. Mumford).

What constitutes an acceptance was very much considered in Elmore 5 . Stone, which was an action by a livery-stable keeper to recover the price of a pair of carriage horses for which he had asked the defendant $180 \mathrm{gs}$. The defendant declined at the time to give that, but afterwarls sent to say that "the horses were his; but as he had neither servant nor stable, the plaintiff must keep them at livery for him," and the latter accordingly removed them out of his sale stable into another. Mansficld C.J. thought there was a sufficient delivery, but reserved the point, and the jury found for the plaintiff. The Cunt of King's Bench discharged the rule for a nonsuit, as they considered that the horses were completely the horses of the defendant, and that when they stood at the plaintiff's stables they were in effect in the defendant's possession.

The case of Carter v. Toussaint was also $a$ sale on creclit; and as in Tempest $\nabla$. Fitzgerald, the purchaser had exercised tarious acts of ounership over the horse. The facts were as follows: The plaintiffs, who were farriers, sold the defendant, by a verbal contract, which specified no time of payment, a race-horse for $£ 30$. It required firing at the time, which was done in the presence and with the consent of the defendant, who agreed with the plaintiffs to keep the horse for 21 days, free 
of charge. At the end of that time, plaintiffs' servant, by direction of the defendant, took the horse to grass in Kimpton Park, and entered it (simply becanse the defendant wished to conceal from his friends the fact of his having a race-horse) as one of the plaintiffs'. Eventually defendant refused to take the horse, and under Abbott C.J.'s direction a rerdict was found for the plaintiffs ; and the Court of King's Bench made the rule absolute for a nonsuit. Bayley J. said : "The Statute of Frands is a remelial law, and we onght not to endeavour to strain the words in order to take a particular ease out of the statute. In the 17 th scetion it is provided that in the ease of a sale of goods above the value of $£ 10$ the buyer must accept and actually receive part of the goods so sold. There can be no acceptance or actual receipt by the buyer unless there be a change of possession; and unless the seller dirests himself of the possession of the goods, though but for a moment, the property remains in him. Here the plaintifl's had a lien on the horse, and were not compellable to part with the possession till the price was paid. Then the question is, was there anything to deprive them of that right? It is said that the horse was fired, but after that he still remained in their possession, and then he was sent under the care of their servant to Kimpton Park. But that was no act of delivery to dispossess them of the horse. At Kimpton Park he was entered in the name of one of the plaintiffs, and they therefore still retained a control over him. How can it be said that the horse was in the possession of the defendant when he had no right to compel a delivery to him. For he could not, on tendering the keep, maintain trover against the park-keeper, because the possession had not passed from the vendors to him. The case of Elmore v. Stone is distinguishable. There the original owner of the horse had stables in which he kept horses as owner, and others where he kept them as lirery-stable kecper; and the Cuurt considered that by changing the horse from the one to the other he had divested himself of the possession, and given up his lien. But there is no circumstance of that sort here."

The principal question in Jordan v. Norton was uhther there ever was a complete contract of mirchase, the terms of uhich had to be gathered from letlers. 'The plaintifl' and defendant lived thirty miles apart, and on October $16,183 \overline{7}$, at the request of the latter, a mare was sent to a pullic-house half-way between their residences, for the defendant to try; but as he woukd only offer $20 \mathrm{gs}$. for her, the plaintifl's groom took her back. Next day plaintiff wrote and offered him the mare at $20 \mathrm{gs}$, and defendant replied-

"I will take the mare at $20 \mathrm{gs.}$, of course warranted; but as you say 
you have another horse that I shall buy, the same expense will bring the two up; therefore, as the mare lays out, turn her out with my mare. I will mect you at West Wycombe which day you like, and pay you at once.

"W. Norton."

This and three other appointments were broken ; and in answer to a remonstrance from the plaintiff, defendant wrote thus-

"Oetober 26.

"Of course I mean to have the mare; and if you had read my note properly it would have saved you a great deal of trouble. My son will be at World's End on Monday, when he will take the mare and pay you. If you want to go elsewhere, send anybody with a receipt, and the money shall be paid-only say in the receipt, sound and quiet in harness."

On Oetober 27th plaintiff wrote-

"I send the mare as desired; she is warranted sound and quiet in double hamess. I never put her in single harness, as I never wanted it."

The mare was accordingly sent, and left with the landlord at the World's End, where the defendant's son took her away without any receipt or warranty, and rode her home to the defendant's. In a touple of day's her legs swelled, and she was sent home as unsound; but plaintiff would not receive her, and she was turned out of the yard, and wandered no one knew where. The defendant's son and the person who took her back spoke to her unsoundness, and the former said that his father had been angry with him for bringiug her back without a receipt. The jury found that the defendant had not accepted the mare, and that the son had no anthority to bring her home without, and gave a verdict accordingly. A rule to enter it for the plaintiff for $£ 21$ was disebarged. And per Curiam: "The correspondence amounts altogether merely to this - that the defendant agrees to give $20 \mathrm{gs}$. for the mare if there is a warranty of her being sound and quiet in harness generally, but to this the plaintiff has not assented, and thus the parties never contracted ad idem. There is nothing in the parol evidence of the acts or conduct of the parties to supply the deficiency in the contract. 'The defendant is not bound loy his son's conduct at the World's End, as he gave him only a limited 
authority, and told plaintiff that his son would only receive the mare if he sent a warranty that the mare was sound and quiet in harness. 'There was not a complete contract in writing by which both parties were bound, no sufficient delivery to defendant, and no acceptance."

In Bach r. Orren, the plaintiff, one May morning, A.D. 1792, agreed to give the defendant a colt for defendant's mare, and pay $2 \mathrm{gs}$. to boot on December 17th, plaintiff to keep the colt till September 29th. The defendant, aceordingly, pait a halfpenmy to bind the bargain, but would not either receire the colt nor deliver the mare, and it was held that the plaintiff might liave an action against him, alleging a demand on him for his mare, but withont alleging any delivery or offer to deliver his own colt ; for payment of earnest money, however small, had vested plaintiff's eolt in the defendant. But where, as in Blenkinsop v. Clayton, the plaintiff sent his horse with his servant to a fair to sell, and the latter, on receiving the defendant's offer of $£ 45$ for the horse, took out a shilling, diew the ellye aross the defendant's yalm, and put it into his pocket aygain without making a transfer of the shilling even for a moment, and then the defendant returned in half-an-hour to the plaintiff's stable, and on the plea of some supposed unsoundness, which was urged by a chapman to whom he wished to sell it, refused to take the horse; the Court of Common Pleas held that the Statute of Frands was not satisfied, and after a verdict for the plaintiff granted a new trial. 'The case they said was very different from that of a haystack, as in Chaplin v. Rogers, for there nothing more conld be done to confer a possession.

There was this distinction between Blenkinsop v. Clayton and Tempest v. Fitzgerald-that in the former the contract was not for ready money, but the horse was to be delivered within an hour, and the defendant treated it as his oun by offering it for sale; whereas, in the latter the express contract was for ready money, and the payment of the price was an act concurrent with the delivery of the horse. 'The facts in Tomprest v. Fitzgercld were as follows: In Angust, 1817, the defendant, who was plaintifl"s visitor, agreed to purchase a horse for 45 guineas, and fetch it about September 27th, as he returned from Doncaster Races. It was understood to be a ready-money bargain, and the plaintiff proposed to put the horse into physic, and have it ready for the hinting season. On Septemler 20 th defendant returned, ordered his horse ont of the stable, saw his groom gallop and leaphim, and gave directions about haltering him. He then asked the plaintiff's son to keep him another weck, and said he would call in seven days when the races were over, and left orders to have the horse sweated. On the 27 th he returned, and found that the horse had died; and on his refusal 
to accept, an action was brought, which ended in a verdict for the plaintiff. The Court of Queen's Bench, however, considered that there was no acceptance of the horse within the 17 th section of the Statute of Frauts, and granted a new trial. Abbott C.J. said: "The defendant had no right of property in the horse till the price was paid, and conld not then exercise any right of ownership. If he had at that time ridden away with the horse the plaintiff might have maintained trover." And per Bayley J.: "This was a ready-money bargain, and the purchaser could have no right to take away the horse until he had paid the price. If the argument on the part of the plaintiff were to prevail, the defendant might have maintained an action for the horse without paying the price, which would be contrary to the express terms of the contract."

The above case governed the decision in Hotmes v. Hoskins. There the defendant was a butcher, and verbally promised, one Salurday, to buy 15 head of cattle in plaintiff's field, for $£ 190$. Finding he had not got his cheque-book, he told the plaintiff to eall at his house for payment in the evening. It was arranged that the cattle should stay in the plaintiff's field till the next Tuesday. The defendant was out when the plaintiff called in the evening, but he sent a message to request the loan of some of plaintiff's hay from the rick to feed the cattle, and fed them with it till the next Wednesday. He afterwards refused to pay for the cattle, as he said he had offered too much. Martin B. thought there was no evidence of an acceptance and receipt under the 17th section of the Statute of Frands, and nonsuited the plain tifl, with leave to move to enter a verdict for $£ 190$, if the Court thought the eridence sufficient. The Court of Exchequer upheld the learned judge's ruling. Parke B. said, "In order to satisfy the statute, there must be an acceptance and an actual or constructive delivery. Now in this case there was no actual delivery, and therefore to entitle the plaintiff to recover there must be such a dealing with the cattle by the defendant as oumer that the plaintiff would lose his lien. But it is clear that the plaintiff never meant to part with his cattle until the price was paid, and there is no gromud for holding that the mere giving permission to feed the cattle changed the possession. In this ease there has been no actual receipt, for the defendant never had the cattle; and the only question is, whether the act of feeding the cattle with the plaintiff's assent is an exercise of such an act of ornership as to amount to an acceptance and constructive delivery. I think that it's not. Elmore v. Stone was relied on for the plaintiff; but that ease is very different from the present; for there, when the vendor assented to the purchaser's request, there was an acceptance by which the former lost his lien."

Scumclers v. Topp was another case of the same class. The defendant 
went with plaintiff to his farm, and selected from a flock 45 couples of exces and lambs, which he agreed to buy at 40 s. a conple, also a stag sheep and dry ewe at $40 \mathrm{~s}$. each. These he directed plaiutiff's shepherd to send to his furm at Wimbuurve in the course of the day. They were accordingly sent along with two comples of ewes and lambs (which he bought from plaintiff without inspection at another of his farms) to Wimbourne, and left in his field. The defendant did not see them there, but after the lapse of two days sent his man to drive them 14 miles to his residence, and said, after counting them on their arrival, "It's all right ;" adding, with respect to the two couple, "They do not match very well with those I have got." The next day the defendant wrote to complain that the plaintiff had not sent the same sheep he bonght, and that unless $£ 2$ was deducted he would not take them, and they were accordingly sent back. The defendant contended that the bargain for the 45 couples and the trro couples was one transaction, and void by the 17th section of the Statute of Frauds, as there had been no part payment or aceeptance. The jury found that there was a distinct bargain for the 45 couples only, and the verdict was entered for the plaintiff, with leave for the defendant to move to enter a nonsuit, if the Court thought there was no evidence of acceptance to satisfy the statute.

The Court of Exchequer decided that the plaintiff was entitled to retain his verdict for the 45 couples, as there was clearly evidence of an aceeptance after delivery, though they doubted, but did not consider it necessary to decide the point, whether under the statute there conld be an aeceptance before delivery. Alderson $\mathrm{B}$. said that he "did not agree with the case of Anderson v. Scott, which, I think, required fuller consideration." His lorship added: " Tere there was evidence of an acceptance by the inspection and separation of the sheep at the time uhen they w'ere in the vendor's possession, and very slight evidence of the acceptance of the sheep when receiced would be sufficicnt to show an acceptance coupled with the receipt, because they were previously selected by the vendee himself. It is only a question of degree. In truth the previous selection of the sheep is very material to show the nature of the acceptance when the sheep were received. The defendant says, 'It is all right.' If he had never seen the sheep, and there had been no previous acceptance, his saying 'It is all right' would have had no effeet; but when he had previously examined and selceted the sheep, it was for the jury to say whether he did not mean, "These are the sheep which I selected.' Suppose, in the case of a remarkable animal, for instance a horse with peculiar spots, the rendee had said, 'All right,' there could be no doubt he would mean, 'This is the horse I bouglit.' That 
shows the whole question is one of degree only; and the previons fact of selection may well be used as a circumstance from which the jury might properly infer an acceptance at the time of the receipt."

Where the contract for the sale of a horse is not to be performed within a year, the agreement itself, or some memorandum or note of it, must be in writing, and be signed by the party to be charged, or his agent, within the 4 th section of the Statute of Frauds.

If the price is under $£ 10$, and the seller stutes what he astes for his horse, and a buyer says he will yive it, the bargain is struck, and neither of them is at liberty to be off, provided that immediate possession of the horse or the money be tendered by either side.

Where a horse is bonght for any price or consideralion under the value of $£ 10$, and there is not an actual payment and delicery at the time of sale, and the contract is to be performed within a yeur, the bargain may be bound by any of the following five methods: 1st, an agreement to detiver the horse on a certain day, a day also being agreed upon for payment of the price, and, in default, the buyer may have an action for the horse, or the seller for his money ; 2 ndly, the payment of the whote price, and then if the seller do not deliver the horse the buyer may sue him, and recorer it ; srdly, part payment of the purchase-money, and then the buyer may sue for and recover the horse, or the seller may sne for the residue of the price; 4thly, an earnest may be given, and even the smallest sum is sufficient, and in such case the remedies are reciprocal ; 5thly, an actual delivery of the horse, and even if there be none of the purchase-money paid, no earnest given, or no day set for payment, the seller may at any time sue the buyer, and recorer his money (Oliphant's Law of Horses, 2 nd ed., 1. 4).

In Martin v. Wallace, a complete verbal baryain hat been made for the sale of the horse in question by the plaintiff to the tlefendant for more than ¿210; and before there had been an actual delivery of the horse, the plaintiff asked the defendant to lend him it to use for a short time, as he had two or three journeys to make. Defendunt assented, telling him to take care of him; and the horse remained a fortnight with the plaintiff, not as vendor, bnt as borrower, during which he threw him down and broke his knees. On the day fixed for the return of the horse, plaintiff sent him to the defendant who said lre had been injured in the interval, and would not receive him. There was no part payment, and no memorandum in writing. It was objected that there was no evidence to go to the jury of any acceptance and actual receipt of the horse, but Lord Camplell C.J. would not stop the case. Defendant then gave evidence that by the original verbal bargain the horse was not to be delivered for a month; and that plaintiff retaincd possession, not as a borrower, 
but by virtue of the original bargain. His lordship accordingly left the question to the jury, "whether the rerbal contract for the sale of the horse was complete before there was any agreement about the horse being returned by the plaintiff, and the horse was lent to the plaintiff by the defendant as his owner; or, whether the retainer of the horse was part of the bargain?" The jury found the contract to be complete before the permission to keep the horse was given to the plaintiff, and that the horse was lent by the defendant as his owner. A verdiet was directed for the plaintiff, with leave to move to enter a verdiet for the defendant, or a nonsuit, on the ground that there was no evidence of a sufficient acceptance of the horse in question within the 17th section of the Statute of Frands.

The Court of Queen's Bench discharged the rule. Erle J. said: "The question is whether the buyer has accepted the horse, and actually received it. All that passed has been merely by word of mouth. There has been nothing which, aceording to the language of many cases, amounts to manual delivery. The statute for many years was very much praised. I believe that the person who inserted the words had no notion what he meant by 'aceeptanee.' 'That opinion I found on the everlasting discussion which has gone on, as if possession according to law could mean only manual prehension. It may mean that, or it may mean handing over to a servant; but the question is whether there has been an exercise of the right inconsistent with any supposition but that of ownership; whether there is an actual sale and an act which is inconsistent with anything but ownership? When you apply that here, you have the finding of the jury that there was an actual sale, and that the purchaser was assumed to be in actual possession. He permitted the other party to retain the horse. All, indeed, passed by word of month; but to my mind it is a most decisire case of possession, and one in which the rendor had lost his claim to lieu."

Iord Camplell C.J. added: "I agree with the rest of the Court, while the Statute of Frauds remains we are bound to give effect to it, and shall do so ; but we are doing so here. 'There has been an acceptance and receipt of the chattel on the fincling of the jury, which is quite justified by the evidence. 'The vendor became the bailee of the horse, and held by the authority of the vendee. The case is within the exception of section 17. I must say that, giving, as I do, full effect to the statute while it remains, I shall rejoice when it is gone. In my opinion it does much more harm than goud. It promotes frand, rather than prevents it, and introduces distinctions which I must confess are not productive of justice." 
The statute was further extended by 9 Geo. IV. c. 14, s. 7, by which it is enacted that, "the provisions of the Statute of Frauds shath extend to all contracts for the sale of goods to the value of $£ 10$ or upucards, notwithstanding the goods may be intended to be delivered at some future time, or may not at the time of such contract be actually made, procured, or provided, or fit or ready for delivery, or some act may be requisite for the making or completing thereof, or rendering the same fit for delivery." It is now well settled that the 17 th section of $29 \mathrm{Car}$. II. c. 3 , and the 7 th section of 9 Geo. IV. c. 14 (Lord Tenterden's Act) are to be read together. The effect of the last-mentioned enactment, therefore, is to substitute "value" for "price" in the 17th section of former statute, and to adopt a nniform rule in all cases. A contract for the sale of goods of the value of $£ 10$ or upwards is not the less within such 17th section, because it embraces something, viz., agistment to which the statute does not extend. Hence, as in Harman v. Reere, where it was agreed by parol between $A$. and B. that the former should sell the latter a mare and foal, and should at his own expense keep them until a certain day, and that A. should also for a given time keep a mare and foal belonging to $B$., and that in consideration of all this $B$. should fetch away A.'s mare and foal on the day named, and pay him $£ 30$, it was held by the Court of Common Pleas that this, so far as it related to the sale of A.'s mare, was a contract within the 17 th section of the Statute of Frands, and roid for want of writing, no point having been made at the trial as to the value.

Where cattle were alleged in the indictment to be the property of a person who, it appeared in evidence, was merely the agister, and not the actual ouner, the Judges, in Rex $\nabla$. Wooducted, held it to be sufficient. He may also maintain trespass against any one who takes the beasts (2 Roll. Abr. 551). And so where a horse is sold at a repository, the auctioneer may maintain trespass or an indictment for larceny in his own name, if it be stolen before delivery; and such special property also entitles him to maintain an action for goods sold and delivered against the buyer, though the sale was at the house of such third person, and the goods were known to be his property (Wiltiams v. Millington). The general liability of an ayister was considered in Broadwater $\nabla$. Blot. 'The defendant, a farmer, had received the plaintiff's horse to agist, but it strayed ont of the field with several more of defendant's horses, and was lost; while the others were merely impounded. The defendant had advertised, and offered to bear half of plaintiff's expenses. It did not appear that the loss of the horse was occasioned by the defect of the fences, or that he had strayed through the gates at the time that the witnesses spoke to their being open; but evidence was 
given of general bad condition of fences on the farm, and negligence as to leaving gates open. Gibbs C.J. said: "All the defendant is obliged to observe is reasomable care. He does not insure, and is not answerable for the wantomess or mischief of others. If the horse had been taken from his premises, or had been lost by aceidents which he could not guard against, he would not be responsible. I admit that particular negligenee must be proved, by occasion of which the horse was lost; or gross general negligence, to which the loss may be ascribed in ignorance of the special circumstance which oceasioned it. If there were a want of due care and diligence generally, the defendant will be liable. The question is, were the defendant's fences in an improper state at the time the lorse ras taken in to agist? Did he apply such a degree of care and diligence to the custody of the horse as the plaintiff, who entrusted the horse to him, had a right to expect? I shall leave it, to the jury "-who found for the value of the horse.

Where a tenant of one Rev. IIugh Smith relied on the preseriptive right of his landlord to have for himself and his tenants, \&c., oceupiers of the messnage and farm of Blaenmerin, "the sole and exchsive right of pasture and feeding of sheep and lambs," on the locus in quo, as to the said messuages and farm aplertaining, it was held by the Court of Queen's Bench, confirming the ruling of Coleridge J., that this did not entitle him to take in the sheep and lambs of other persons upon tack to pasture thereon, for that by the terms of the grant some interest in the pasture was reserved to the lord, and the alore practice was prejudicial to such interest (Jones $\mathrm{v}$. Richard).

As regards compensution for agistment in Harman v. Reere, it was suggested, per Curiam: "Could not the plaintiff" sue the defendant for" the six weeks' agistment of the mare and foal on the principle suggested by Bayley 13. in Wood v. Benson and Earl of Falmouth v. Thlomas? 'It by no means follows that, because you cannot sustain a contract on the whole, you camnot sustain it in part, provided your declaration be so framed as to mect the proof of that part of the contract which is good.'" A contract for agistment is, according to Jones v. Flint, not a contract for an interest in land. 'The question as to whether agisted cattle are the subject of lien was first decided in Chapman v. Allen, where five kine were put to pasturage at twelve-pence a-week each. 'The Court said that it "was not like to the case of an inne-keeper or tailor"; they may retain the horse or garment delivered to them until they be satisfied; lut not when one receives horses or kine, or other cattell, to pasturage, paying for them a weckly summe, unless there be such agreement between them."

Lord Lillenborough C.J. thus remarked on this ease in C'hase v. Ir'st- 
more: "It does not appear to have been decided on the gronnd snpposed, but rather on the ground that a person taking in cattle to agist conld not detain them until the price be paid ; or if he conld in general do so, yet that in the particular case the defendant was guilty of a conversion as against the plaintiff, who was a purchaser of the cattle, by having delivered them over to a third person, on receiving from such third person the amount of his demand."

And in Hobby v. Russell (exor. de son tort of John Smith), where it was in evidence that the defendant, after the death of John Smith, obtained possession of a pair of new boots, a cow and calf, a barren cow, a pony-mare and colt, and a hackney mare, which had been his property; and that at the time of his death the cow and calf were agisted with Mr. E. Jones, and that the defendant paid Mr. E. Jones for their agistment, in order to obtain possession of them, Cressucell J. rnled that the defendant was not entitled to any allowance in respect of what he paid Mr. E. Jones, as the latter had no lien on the cattle for their agistment; and the Court of Exchequer refused a rule for a new trial.

The cases on the subject were also allnded to at some length by Lord Lyndhurst C.B., in his jndgment in Judson v. Etheridye, where to a count in detinne defendant pleaded that the plaintiff had delivered the horse to him to be stabled and taken care of, and fed and kept by him for the plaintiff for reward, and that $£ 10$ became due to him from the plaintiff as a reasonable reward, and so justified the detainer for that sum; but on general demurrer the plea was held bad. Lord Lyndhurst C.B. said: "Upon this plea, the question is whether, on the state of facts disclosed, the defendant has or has not a lien upon the horse. I am of opinion that he has no lien. The present case is distinguishable from the cases of workmon, and artificers, and persons carrying on a particular trade, who have been beld to have a lien by the valne of labour performed in the conrse of their trade upon chattels bailed to them. The decisions on the subject seem all one way. In Chapman v. Alten, it was decided that a person receiving cattle to agist had no lien. In Iorke r. Greenhaugh, it was held, not merely by C.J. Holt, but by the whole Court, in their decision, that a livery-stable keeper had no lien." Bolland B., who acknowledged that, according to Jacobs v. Latour, a trainer has a lien, added: "The doctrine might perhaps be extended further, so as to embrace the case of a breaker, into whose hands a young horse is placed to be broken in. The breaker makes it a different animal. The chattel is improved by the application of his labour and skill. In the present case it does not appear that anything was to be done to the animal, to improve it or render 
it a different animal, by the application of the skill and labour of the bailee."

In Jackson $\mathbf{v}$. Cummins and Others, which was a case of trespass for cntering an outhouse of the plaintifl's, and seizing and driving away 10 cows which had been depastured on the defendant's land, the jury found that there was no such agreement, that the defendant should retain and keep possession of the cows nntil the amonut dne for pasturage was paid, and gave their rerdict for the plaintiff, Parke B. reserving leave to the defendant to move to enter a nonsuit, if the Court were of opinion that a lien existed at common law for the agistment of cattle, but the rule was discharged.

It was ruled by Parke B, in Bims v. Pigolt, that an imnkeeper hus no lien on a horse for its keep, unless it be brought by a guest; but he can only retain it for its own keep, not for that of others the property of the same person. And see Smith v. Dearlore. Speaking of a lien on a racehorse, in Forth v. Simpson, Palleson J. said: "An innkeeper's lien stands on a different principle; he has a lien on the guest's horse, because the law obliges him to take it in. My brother Parke's view of a trainer's lien, as stated by him in Jackson v. Cummins, exactly supports our decision, which is also quite consistent with his observation in the same case, that where a horse is to be trained for a specified race the trainer may have a lien for his charges until the hor'se is given up." The judgment of Erle J. in this ease shows that an ordinary lrainer has no lien on the horses under his charge. His lordship said: "A trainer of racehorses has the benefit of one general principle, that the person exercising care and skill in the improvement of a chattel is entitled to a lien on such chattel for his charges in respect of his care and skill; but there is another general prineiple, that in order to complete a right of lien there must be a continuing right of possession, and this principle defeats the claim of lien in the present case. It is quite clear, upon the evidence, that the owner was entitled to have his horses re-delivered to lim for the purpose of running at any races he pleased, and this is quite inconsistent with the trainer's right of continuing possession." Hence it would seem that if a case arose under the "half-profits" principle which has sprung up of late years, whereby the owner sends his horse to a trainer and stipulates that he is to train and keep him frec of expense, and rum him where he likes, and to give the owner half his winnings, that the trainer would lave a lien.

Subject to the above qualification, which was made by the Court of Queen's Bench in Forth v. Simpson, and which seems to have struck Aldersom B, in Scarfe v. Morgen, the general rule of lim was thus explained by Parlie B. in the latter case: "The artificer to whom goods 
are delivered for the purpose of being worked 1 into form; or the farrier, by whose skill the animal is cured of a disease ; or the horsebreaker, by whose skill he is rendered manageable, have liens on the chattels in respect of their charges; all such specific liens being consistent with the principles of natural equity are faroured by the law, which is construed liberally in such cases. This being the principle, let us see whether this case falls within it; and we think it does. The object is, that the mare may be made more valuable by being in foal. She is delivered to the defendant, that she may by his skill and labour, and the use of his stallion for that object, be made so ; and we think, therefore, that it is a case which falls within the principle of those eited in argument." Here the mare had been sent more than once to the defendant's, who was a farmer, to be eovered by his stallion; but as $11 \mathrm{~s}$. for the last service was not paid, defendant refused to deliver up the mare until the $11 \mathrm{~s}$. (which was not tendered) and $£ 97 \mathrm{~s} .4 \frac{1}{2} d$. which included the fee for covering other mares of plaintiff's and some poor-rates, was paid. In an action for trover, to which "Not guilty" and "The mare was, and is, not the property of the plaintiff" were pleaded, Parke B. direeted a verdict for $£ 25$, reserving leave to the defendant to enter a nonsuit on three points. It was held (1) that the defendant had a specific lien for covering the mare, as she might be made more valuable by proving in foal ; $(2)$, that the claim of defendant to retain the mare for his general balance was not a waiver of his lien for his charge on the particular occasion, and did not dispense with the necessity of a tender of that sum ; and (3), that even if the covering of mares with his stallion was done within the exercise of his ordinary calling, on a Sunday, that still, it having been executed, the lien attached.

The question as to whether an auctioneer has a lien on a horse for lis commission and charges was very much considered in Robinson v. Rutter, and it was decided that he lrad a lien.

It was decided by the Court of Queen's Bench, in Warlow v. Hamson, that althongh at a sale by auction, the auctioneer may, after a bidding has been accepted, become the ayent of the bidder for the purpose of signing a memorandum of the argreement, he is not an aggnt for the bidder at all till the bidding is accepted; and until the hammer is knocked down both the bidder and the vendor are free, and may retract if they choose to do so. Hence, where the owner of a mare sent her to the defendant with instruetions to sell her by anction without reserve, and the plaintiff was the highest bona fide bidder, but the mare was knocked down to the owner, who made a higher bid, it was held that the plaintiff could not maintain an action against the 
defendant, on the ground that he was his agent, and was bound to complete the contract on his behalf. The defendant was in partnership as anctioneer with one Brotherton, who kept a horse repository at Birmingham. Among the lols advertised to be sold on June 24th, 1858 , were "Boxes 8,9 \& 10 , the three following horses, the property of a gentleman, without reserve." “No. 2.4, 'Janet Pride,' a brown mare without white, five years old, by Iago out of Stormy Petrel," \&c. "There were printed conditions of sale, of which the first nas: "The highest bidder to be the buyer, and if any dispute arises between two or more bidders, before the lot is returned into the stables, the lot so disputed shall be put up again and resold, or the auctioneer may declare the purchaser." The plaintiff attended at the sale, and when 'Janet Pride' was put up he bid for her $60 \mathrm{gs}$. ; almost immediately after the owner bid $61 \mathrm{gs}$., and as the plaintiff was informed that it was the owner who made that bid, he abstained from making any further bil, and the mare was knocked down. The plaintiff then went to the office of the defendant, and elaimed the mare as being his property, but the defendant refused to give her up, and allowed the owner to take possession of her. 'The jury returned a verdict for the plaintiff, and leave was reserved to the defendant to move for a rule to show canse, why the verdict should not be set aside and a verdict entered for him, or why a nonsuit should not be entered. The Court made the rule, which gave the plaintiff the choice of either of these courses, absolnte. The counsel for the defendant relied upon Payne r. Care and Bartlett v. Pwrell.

And per Cwram: "Payne v. Cace has been considered good law for nearly seventy years. That case decided that a bidding at an auction, instead of being a conditional purchase, is a mere offer; that the auctioneer is the agent of the vendor ; that the assent of both parties is necessary to the contract; that this assent is signified by knocking down the hammer, and that till then either party may retract. This is quite inconsistent with the notion of a conditional purchase by a bidding, and with the notion of there being any personal promise by the auctioneer to the bidiler, that the bidding of an intending purchaser shall absolutely be accepted by the vendor. The rendor himself and the bidder being respectively free till the hammer is knocked down, the auctionecr cannot possibly be previously bound. $\Lambda$ this anction, the mare was never knocked down to the plaintiff, and the relation of principal and agent hetween him and the defendant never had commencel. We are not called upon to say urhether there is amy or what remedy on the conditions of sale against the vendor, who violates the condition that the article shall be bonit fide sold without 
resere? but we are clear that the bidder has no remedy against the anctioneer, whose anthority to accept the offer of the bidder has been determined by the vendor, before the hammer has been knocked down." This case has been taken into a Court of Error.

It was settled by the Court of Queen's Bench, in Casu'ell v. Coare, that unless the plaintiff had previously tendered the horse, he cannot recorer for the keep, becanse it was not the defendant's fault that the plaintiff kept him; and a rule was made absolute to reduce a £30 10s. verdict (which included $10 \mathrm{gs}$. for keep) to $£ 20$, the plaintiff undertaking to deliver back the horse, whose warranty was broken, free of all expense. And per Lillledale J., in Mackenzie v. Hancock, where the defendant, after due notice, refuses to receive a horse back, the plaintiff may recover the keep for as long a time as may be reasonably occupied in endeavouring to sell the horse to the best advantage. In Ellis v. Chimock, where a horse warranted "sound, free from vice, and quiet in harness" was sold on Nay 7 th, and refused when tendered back on May 30 th, the same rule was acted upon by Colcridge J., and the plaintiff recorered the amount of its expenses at a livery-stable from the latter period up to Reading Fair (July 25th). Again, in Chesterman v. Lamb, where the defendant had notice at the end of a fortnight (July 11th) that the horse was unsound, and on September 16 th it was sold, the whole of the horse's expenses at livery from July 26th were allowed. Lord Denman C.J. said: "The question whether the horse has been kept an umreasonable time before the resale is a question for the jury ; "but the two reports of the case differ as to whether the $₫ 917 \mathrm{~s}$. claimed for keep, included keep from the time the notice of unsounduess was giren, or merely the liverystable charges.

The law upon the subject is thns laid down in "Selwyn's Nisi Prius," Sth edition, vol. i., p. 657: As soon as the unsounctuess is discovered, the buyger should immentiately tender the horse to the seller; and if he refuses to take him back, sell the horse as soon as possible for the best price that can be procured, for the purchaser is entitled to recorer for the keep of the horse for such time only as would be required to sell him to the best advantage." It may be inferred, from the language of Tindul C.J., in Wratson v. Denton, that the expenses of lieep up to the time of the offer to return an unsound horse may be recovered as damages. Ilis lordship said: "You will give as damages the difference between the price paid and the real value of the horse, and damages for the exponse which the plaintiff was put to hy selling him that which was of no nse to him for a certain time, at least to the time when he offered the horse to the defendant." 
In Ellis r. Chimnock, keep between may 7 th and May joth was not asked for; but Coleridye. J. in his summing up, expressly said: ". All the plaintiff is allowed to do is to keep it for a reasonable time, till he can fairly sell it, and for that time he ought to be allowed for liceping it."

Where in an action for the keep of a horse (King v. Price) it appeared that the defondant rescinded the contract entered into by lis wife for the sale of the horse some time after the contract was made, he was taken to have rescinded it from the day it was entered into; and as the horse was kept by the plaintiff in the intermediate time, and was receired back by the defendant in improved condition, a verdict for the value of such keep was confirmed by the Court of Queen's Bench.

The question of damages, on returning a horse, was considered by Lord Denman C.J. in Clare r. Mcaynarl, where the plaintiff bought the horse from the defendant at Northallerton Fair for $£ 45$, warranted sound, and sold it with a similar warranty to Mr. Collins for $£ 55$, which the plaintiff had been obliged to repay, along with $£ 33 s$. for expenses. The horse was sold by auction for $£ 1714 s$, and the plaintiff recovered $£ 276 s$. (the difference between that and $£ 45$ ), the expense of bringing the horse to London, the keep of the horse from the time of the purchase to the time of sale by anction, and $£ 18 s$. $6 \mathrm{~d}$. part of an attorney's charge for service of notice on defendant in Yorkshire (who had not answered two letters on the subject) that the horse would be sold by auction. His lordship disallowed $£ 10$ 10s. repaid to Mr. Collins, as well as $£ 1$ s. for an examination at the Royal Veterinary College, $£ 1$ s. for counsel's opinion, and the attorney's charges for two letters to the defendant, and for preparing a case for counsel. A new trial was moved for, on the ground that the plaintiff should get the $£ 10$ extra, not as the value of the good bargain he had lost, but as a remuneration for the capital he had expended and the labour he had bestcwed on the lorse to increase its value. The Court of Queen's Bench, however, refused the rule, saying it was in substance a claim of compensation for a good bargain, which could not be allowed as damages in an action.

Where a horse was bought with a warranty of soumdness, and turned out not to be so, but only 3ys. out of 12gs. had been paid by the defenctant, Iord Kimyon C.J., on its being proved in an action for the $9 \mathrm{gss}$., that the horse at the time of the sale was only worth $£ 111$ s. 6 cl., and had since leen sold for only $30 \mathrm{~s}$, held that the plaintiff could only recover the value, and nonsuited the plaintiff (King v. Boston). It was laicl down in Pourer v. Wetles, that where the contract is still open an action for money had and received will not lic. 'The plaintiff had given 
á mare of his own and $20 \mathrm{gs}$. for a horse of deferdant's, which, on discovering that it was unsound, he sent back with a letter, and put both letter and halter into defendant's hands, who refused to take them, and turned the messenger out of his yard when he asked for the plaintiffs $20 \mathrm{gs}$. and mare back again. There should have been a special declaration on the warranty, and trover did not lie for the mare, as the exchange had been effected, and the property transferred thereby. But where, as in Payne v. Whale, in reply to an action for money had and received, the defendant admitted the warranty, but denied the unsoundness and refused to take back the horse or return the money, adding that if the horse were unsound he would do so, and the horse was proved to be a roarer and unsound, Lord Ellenborough C.J. thought that such special promise to rescind the contract and return the money if the horse were unsound took this out of the general rule, and suffered the plaintiff to have a verdict for the amount.

The course which a purchaser is to mursue, when a warranted horse his proved unsound, was very fully laid down by the Court of Queen's Bench in Street $\mathrm{v}$. Blay. The action was in assumpsit for a horse sold and delivered with a warranty by plaintiff, on Feb. 2nd, 1830, for $£ 43$, to defendant, a horse dealer, who sold him to Bailey, one of his customers, the same day, at a $£ 2$ profit. This new purchaser kept him a day and parted with him in exchange to one Osborne, who kept him a day and sold him again to the defendant for $£ 30$. No warranty was giren except on the first sale, and the defendant sent the horse back lame to the plaintiff's premises, saying that he was unsound, on February 9th; but the latter would not receive him, and brought his action.

The defendant had a verdict, and Lord Tenterden C.J. reserved the question for the Court, whether or not the defendant, after having sold the horse, could, upon becoming possessed of him again, return him to the plaintiff and refuse payment of the price, by reason of the original unsoundness. The Court of Queen's Bench made a rule absolute for a new trial, or to enter a verdict for a reduced sum in lien of damages, as the defendant had a clear right of action against the plaintiff for breach of warranty. They held that there was no authority to show that a purchaser may return a warranted article where he has done more than was consistent with the purpose of trial, as exercising dominion of an owner over it, by selling and parting with the property to another, and that supposing it were competent for the defendant to return the horse after having accepted it and taken it into his possession, if he had never parted with it to another, he conld not do so after in resale at a profit. He could not require the original vendor to take it 
back again, nor by reason of the unsoundness resist an action by the rendor for the price, but might give the breach of warranty in evidence in rednction of damages. And semble, the purchaser of a spreific warranted articte, having once acichted it, can in no instanes returin the chattel and recorer the mice as money paid on a consideration which has fuited. He must sue on the uarranty unless there has been a condition in the contract anthorising the return, or the vendor has received back the chattet, and thereby consented to rescind the contract, or has been guilty of a framl, which destroys the contrart altogether. But where the contract is cxecutory only whon the chattel is received, as where goods are ordered of a manufacturer, and he contracts to supply them of a certain quality or fit for a certain purpose, the rendee may rescind the contract, if the groods do not answer the warranty, provided he has not kept them a longer time than was necessary for the purpose of trial, or exereised the dominion of an owner orer them by selling them. The authority of this case was fully acknowledged in the following year by the Court of Exchequer, in Gompertz v. Denton, where they expressly decided that the purchaser of a horke can recover for a breach of rarranty in an action of damages only, and cannot sue on the indebitulus counts, as on a fiilure of the original consideration, unless under the circumstances pointed out above; and Lord Lymdlhurst C.B. said: "The case of Street v. Blay seems to heve been very much considered."

It was also settled, in Hurst v. Orbell, that where a horse has been bought and the price paid, but the purchaser, by the terms of the agreement, has the option of returning the horse within a certain time allowing a certain sum for the use of it, the residue of the price may be recoiered by him after the horse has been returned or tendered in an action for money hed and received. Here the plaintiff had agreed to buy a pair of horses for $£ 80$ from the defendant, $£ 10$ to be allowed by him ont of the $£ 80$ if he returned the horses within the month, and he was to pay $\mathcal{L} 80$ if he liept them over that time. Dufendant gare the following receipt:

"£s0. Received of - Hurst, Esq., eighty pounds, for two grey horses, warranted sound and quict in harness. Ten pounds more if the hol'ses are kept.

\section{" Hentry Orbell."}

The plaintiff returned the horses within a month. The objection that the action should have heen on the special contract, or that the plaintiff shonld have ploved his readiness to pay the $£ 10$ before attempting to recover back any part of the $\mathfrak{L} 80$ as money had and received to his 
use, was held to be much "too refined." The defendant merely held the $£ 70$ to the use of the party who shonld be entitled at the time when the option was to be determined.

It was ruled by the Court of Common Pleas, in Lee v. Bayes amd Robinson, that the sate by public auction at a horse repository ont of the City of London is not a sale in market ocert, according to the statutes $2 \& 3 P h . \& M$. e. 7 , and 31 Eliz. c. 12 ; and also on the authority of White v. Spettigue (which overrules Gimson v. Woodfull and Peer v. Humphreys), that the obligation which the law imposes on a plaintiff to prosecute the party who has stolen his goods, does not apply where the action is against a third party imocent of the felony. The facts of the case, which were rery intricate, were as follows:

'The plaintiff's horse had leen stolen out of the Essex marshes, and the defendant Bayes bonght it on commission, by public auction, at Rea's Horse Repository, Nov. 27, 1855, throngh the agency of one Proctor, for $£ 85 s$. His customer did not like it, and it was sent back again to Robinson's Repository in Little Britain, where it was claimed by the plaintiff. Bayes told the plaintiff where he had bought the horse, but he refinsed to give it up, and Robinson and his clerk refused to do so without his anthority. A police officer was procured, and Lee gave Bayes in charge for stealing the horse. The inspector refised to take the charge, but sent a constable with the parties to Rea's Repository, where the anetioneer satisfied the plaintiff that the horse had been bought there. Lee, Bayes, and the constable then went back to Robinson's, when Bayes, Robinson's son, and the foreman refused to give up the horse, in spite of the offer of an indemnity to Robinson; but on the 7 th of December, Robinson's attorney offered by letter to give it up, on an indemnity being given to himself and Bayes. The action was brought for a wrongful conversion and detainer. The defendants maintained that as the horse was sold at a public anction, the plaintiff conld not recover, but that at all events he was bound first to prosecute the thief to conviction, and that there was no evidence of a joint conversion. The jury found that Bayes had purchased the horse bonk fide, and returned a verdict for the plaintiff, damages $£ 30$, to be rednced to $£ 5$ if the horse was returned. Willes J. said : "Here the defendants had notice that the hor'se belonged to Lee; and althongh what passed on the first oceasion when the horse was demanded was merely a reference to Bayes, as the party who had deposited it as orner, on the second occasion there was an absolute and unqualified refusal to acknowledge Lee's title and an assertion of the title of Bayes, which clearly was evidence of a conversion. The letter of the 7th of December, though written after the commeneement of the action, may serve to throw light 
on the previons transaction." The Court held that there was evidence of a joint conversion, and discharged a rule to enter a nonsnit or a verdict for the defendant.

The 16 \& 17 Tict. c. 62 (which was eontinued by 19 \& 20 Tict.e. 101), inflicts by sec. 1 a $£ 20$ penalty on anyone "bringing or attempting to bring for sale any horse or other animal into any market, fair, or other open or public place, where animals are commonly exposed for sale, knowing such horse or other animal to be affected with or labouring muler the disctese called glanders," or "turning, kecping, or depasturing any horse or other animal infected with or labouring under such disease in or mpon any forest, chase, wood, moor, marsh, heath, common, waste land, open field, road side, or other undivided or uninclosed land." A question arose, in Hill v. Balls, on the meaning of "public place" in this act. The declaration stated that the defendant was possessed of a glandered horse, and knowing it had such disease cansed it to be sold by auction at a Horse Repository, and the plaintiff believing it to be healthy bought it at the sale and paid for it. It was ntterly worthless from disease, and the plaintiff not only paid a veterinary surgeon to examine it, but it mortally infeeted another horse of his in the same stable, and the plaintiff paid a large sum of money in endeavouring to cure the infeeted horse. It was held that no canse of action was disclosed, since the declaration not being founded on any fraudnlent misrepresentation or breach of warranty did not show that the defendant lial committed an illegal act, for although by the statute the bringing or attempting to bring for sale a horse "into any market, fair, or any other open or public place," knowing it to be infected with the glanders, is made an offence, yet a horse repository is not necessarily a "public place" within the meaning of the statnte, and it was not stated to be such a place.

The subjoct of a conspiracy to cheat was considered in Rex v. Pyucell. The defendant Pywell advertised the sale of horses, which he undertook to warrant. General Maclean, on application at his stables, saw another of the defendants, who said he had lived with the owner of the horse, knew it well, and would warrant it sound. The horse was bought with a warranty for $50 \mathrm{gss}$. , and tmmed out worthless before the week for returning was expired. Lord Ellenborongh C.J. stoplyed the case, and said "that if this was to be considered an indictable offence, then instcad of all the actions which had been brought .on warrantics, the defendants onght to have been indicted as cheats, and that no indictment could be maintained in a case like this, withont evidence of a concert between the parties to cffectuate a fraul."

This case mas followed by liey. v. Fenrick, which was an indictment 
found at the Middlesex Sessions, and removed by certimatri, at the instance of the defendants. It churyed the two defendents with conspiring to cheat and defraul one Featherstonhaugh by false pretences as to the sale of turo horses, and the verdict of guilty was confirmed by the Comrt. In his elaborate judgment on the law of false pretences, in Reg. v. Bryan, Erle J.thus explained the difference between the two foregoing cases: "Although in the case of Rex r. Pyzell it was held not indictable to praise the quatity of a horse, knowing it not to be worthy of the praise put on him, yet in the case of Reg. v. Kenrick, as far as I understand the case, for I was connsel for the man, the fact which bronght that case within the definition was the fact that Kenrick averred that these horses had been the property of a lady deceased, were now the property of her sister, and had never been the property of a horse dealer, and were quiet and proper to drive. The purchaser wanted those horses for a woman of his family; the substance of the contract was, that they were the property of a lady, who had driven the horses, and it was a false assertion of a definite existing fact; 'they are the property of the sister now' when they were the property of another person : 'they never were the property of a horse dealer,' whereas they were the property of a horse dealer, and had run away and produced a fatal accident. The case of Rey. v. Kenrick was not the warranting a horse sound, as in the case of Rex v. Doddridge, but it was the affirming of a false fact, which the party knew to be false, and on that ground the conviction proceeded."

His lordship also observed: "In the ordinary case of a man coming up) to the seller of a horse at a fuir, and saying, "Allow me to try that horse,' and he rides away and sells it, if the jury are of opinion that he got possession animo furandi, it is a larceny. But if he were to profess to the seller of the horse, 'I like the horse, and I will pay you next Monday,' and the seller says, 'I agree to that,' although the jury find that he did that animo furandi, unquestionably that was not indictable before stat. $7 \& 8$ Geo. IV. c. 29 , s. 53 , which seems to make persons responsible in a criminal court, where there was a contract of sale; but yet it fell within the same category of criminal intention, as the cases I have adverted to, where the possession was obtained animo furandi. Looking at all the cases which have been decided there, those that seem to have been the subject of the greatest comment, appear to me to fall within the principle, that where the substance of the contract is falsely represented, and by reason of that the money is obtained, the indictment is good" (ib.).

According to White r. Spettigue, an action of trover is maintainable to recorer the value of goods which have been stolen from the plaintiff, and 
which the defendant has innocently purchased, although no steps have been taken to bring the thief to justice.

Goouls which have been stolen may be recovered in trover from the purchaser of them in market orert, upon a conversion by him, subsequent to the conriction of the felon, withont any order of restitution having been male; for the effect of the $7 \& 8 G e$. IV. c. 29, s. 57 , is to revest the preperty in stolen goods in the original ormer upou conviction of the felon (Syliester v. Scatteryood). And per Lord Camplell C.J.: "It is admitted that the sale in market overt would be no answer to the action if an order of restitution had been made. We have now to determine what is the cousequence of such an order being wanting. The plaintift must rely on the statute, as at common law the property is permanently changed by the sale in market overt, and looking at the statute we must take it, that on the conviction of the thief the property revests. The stat. $21 \mathrm{Hen}$. VIII. c. 11 restored the party to his goods, and that conld not be that he had merely a right to retake them under a writ of restitution. The present act provides that ' the property shall be restored.' I think both the statutes must be taken to have the same meaning, and their object cannot be effectnally carried out unless we suppose the right of property to be restored to the owner on conviction, without any order being made. At the same time, it is much to be regretted whenerer an order is not made so as to obviate the necessity of an action; but it is not a condition precedent, and this action is well brought. The dictum of Buller J. in Horrood v. Smith, that the property of the plaintiff begins after the conviction of the felon, accords with our riew, and is decisire of the case."

Douglus v. Corbett was a somewhat remarkable action for maticious mosecution for slecep-stealing. The plaintiff was a small farmer, and in October, 1855, sold seven sheep. The purchaser took them to Southam fair, where defendant, a sheep-farmer, claimed six as belonginc to a parcel of ten stolen from him in September, 1855. Plaintiff said the whole seven were part of a lot of 17 he had had for months, and he had still four of the lot left at his farm, which defendant might see. Defendant went to plaintifl's farm with his shepherd and a policeman, and his shephord claimed one of the four as belonging to the ton. 'The plaintiff' came up while the shepherd was in the act of leading it away, and after an angry discussion said it was one of the 17 that he had bought at Banbury fair, and the defendant said it was one of ten stolen from his field in September. Good, a neighbour of plaintiff's, on being appealed to by the plaintiff, said it was not one of the same breed as the 17 he got from Banbury fair, and defendant drove the four away. Plaintiff sued him in the County Conrt, and 
defendant laid an information before a magistrate for felony. The plaintiff at first did not give satisfactory proof that he had purchased sheep at all, and was committed for trial, but acquitted. In the present trial it appeared on the balance of testimony that the sheep was really one of the 17 purchased by the plaintiff at Banbury in June, and could not have been stolen from defendant in September; but still there were many facts to lead to the conclnsion that the sheep was not one of the 17 , but one of the ten. Defendant, as it appeared, laid an information merely on the advice of his attorney, as being the shortest way to stop proceedings in the County Court.

Bramuell J. told the jury that the question of malice was for them, but expressed a strong opinion that they onght not on this evidence to find it. He told them, that as to the question of reasonable and probable canse, there seemed no doubt that defendant bonâ ficle believed it was one of his stolen sheep, and asked the jury to find as a fact "whether defendant had reasonable ground for that belief?" The jury found he had; and his Lordship rnled that there was reasonable and probable cause for instituting the prosecntion, and that therefore the question of malice became immaterial, and directed a verdict for defendant. A rule nisi for a new trial for misdirection was discharged (Erle J. diss.).

When chattels have been deposited in a public inn, and there lost or injured, the prima facie presumption is that the loss or damage was occasioned by the negligence of the innkeeper or his servants. Bnt this presumption may be rebutted; and if the jury find in favour of the innkeeper as to negligence, he is entitled to succeed on a plea of Not guilty. Thus in Dauson v. Chammey, where the plaintiff gave his horse on a Penrith market day to an ostler, at the Bell and Bullock, who placed him in the stall with a kicking horse which injured him, the Court held that as the defendant in his answer convinced the jury that there had been all due care taken, and he got a verdict on the first issue Not gnilty, that proof took away the ground of action, according to all the authorities, and a rule for a new trial was refnsed.

In Degge v. Tucker the declaration stated that the plaintiff, at defendant's request, delivered to defendant, then being a livery-stable keeper, a horse of the plaintiff, to be by him taken dne and proper care of, and to be kept in a separate stall in the defendant's stable, for rerrard to be paid by the plaintiff in that behalf; and that the defendant accepted the care and custody of the said horse npon such terms; yet he would not take due or proper or any care thereof, or keep it in a separate stall, and by means of the premises the horse was so kicked by 
the other horses that it heeame of no vahue to the plaintiff. 'The defendant pleaded "Not guilty;" and at the trial a verdict was found for the

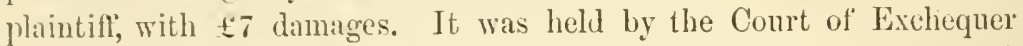
that the cause of action was founded on contract, and not on tort, and therefore the plaintifl' was deprived of costs by the County Court Act, 13 \& 14 Tict. c. 61, s. 11 . In Stamian v. Davis, an innkeeper was held liable for an injury lone to a horse which was taken out of the inn and immoderately ritden and whipped, thongh it did not appear by whom. And an innkeeper on a matket-day placing a gig belonging to a gnest in the open street, according to the usual custom, is liable if the gig be stolen (Jones v. T'yler).

In Mackenzie v. Cox, there dogs were taken care of by the ostler of the defendant, a stable-keeper, who was paid to buy them food, and keep them in the defendant's stable with the plaintiff's horse. The plaintiff asked if the dogs rould be safe, and the defendant said he never lost anything, and referred him to the ostler. The missing dog was locked up, and stolen between twelve and one o'clock at night, the door having lueen opened, as it was thought, by a false kej. Information of the loss mas given at once. The declaration stated that the defendant received the dogs to be kept, fed, and taken care of for reward, which the second plea traversed. Guney B. put it to the jury, whether the defendant received the dogs, and whether he had been negligent, both of which points the defendant called witnesses to disprove; and his lordship held that even if a person does take goods into his possession for reward, he is not answerable for their loss if he takes reasonable care of them; and that it was for the jury to say whether locking these dogs into a stable was not taking reasonable care of them, and that if a dog-stealer came in the night and stole the dog, the defendant was not answerable for the loss. 'The verdict was for the defendant on both issues.

The keeping of suine so as to be a muisance, is an offence within 11 \& 12 Tict. c. C3, s. 59 (Digly v. Hest Ham Boarl of Health). Under a local act following closely the words of the Markets and Fairs Clauses Act, 10 \& 11 Vict. c. 14, s. 19, it is no offence to stanghter cattle elsenthere than in a public stanghter-house, unless there be an intention to sell the carcase as human food (Elius v. Nightingale). Lloyel v. Walkey was an action for negligence in not properly seruring a cour of the defendant's in a stanyhter-house, and the declaration stated that by means thereof the cow "ran at, butted at, gored, killud and destroyed a cow of the plaintiff:" Plea, a payment of 30 s. into Court, and "that the flaintiff had not sustained damages to a greater amount than the said sum of 30 s. in respect of the earses of action in the decluration mentioned." lieplication that lie had. It was then proposed to give in evidenee for 
the defendant, that the plaintiff's cow was not killed by the defendant's cow, but that after being so hurt it was killed by a butcher. Colevidye J. declined to receive slich evidence as to the killing by the butcher, as the contrary was admitted by the defendant's plea. Where the declaration stated that the defendant struck the plaintife's cow divers blows, by reason whereof she died, and it appeared that the defendant having beaten the plaintiff's corv unmercifully, the plaintiff mercifully put it to death, it was objected for the defendant that this was a variance, as the animal might not have died from the defendant's blows; but the Court considered that the objection was cured by the verdict, and refused a rule to enter a nonsuit (Hancock v. Southall).

In the case of Colam r. Hall (6 L. R. Q. B. 206), the respondent was huntsman of the Old Berkeley Hunt at Chorley Wood, and, on the 19th Narch, 1870, a horse was sent there to be slaughtered for the hounds ; the horse, however, was not immediately slanghtered, bnt was lent to another person for the purpose of being worked, and was, in fact, put to work. It was held that the respondent was gnilty of an offence under sect. 9 of the $12 \& 13$ Vict. c. 92 , which imposes a penalty on any person who, having the management of any place for the purpose of slanghtering horses or other cattle not intended for butcher's meat, shall use or permit to be used any horse or cattle brought to such place for the purpose of being slaughtered.

The case of cows being poisoned in their pasture was the subject of Lathbury v. Earle. The plaintiff was a large dairy farmer at Stratton, and the defendant a railway contractor, who was engaged in making a railway through the plaintiff's farm. 'The wood for the line was pickled with creosote and oil of tar, and the defendant had a tank fol this purpose near the plaintiff's farm. When the pathway was laid down, the stuff in the tank was pumped out into a culvert, which passed under the canal and to a watercourse going through the plaintiff's field where the cattle were watered. This was in the autumn of 1852, and in April 1853, when the cattle were turned out, their mouths in five days became burnt and black, and their hocks affected. On a request being made, the defendant cleaned out the watercourse, the length of the plaintiff's field, but not the culvert under the canal, and promised compensation, and plaintiff put the cows into a field he had saved for mowing. At the end of a mojuh the cows were put back, but did not recover till after calving. 'I e er fell off so much in their milk that the deficiency was calculated at 7000 quarts at $\tau d$. per gallon, for the first three months, the loss being $£ 182$ odd, as they ought to have given during May, June, and July 16 quarts a-day, and for the next four months $£ 204$, calculating the milk at 10 quarts a-day. Besides this, 
his loss on the hay was $£ 10$, but $£ 30$ was deducted for cheese he had made, and milk used on the premises. It was attempted to show that lis cows were affected with the "mouth discase," but he denied that they had the ruming and blisters in the mouth consequent upon it; and Professor Spooner stated that the effect of creosote was to suspend the secretions of the body, especially the secretions of milk, and stated that none of the symptons from which the cows were deseribed to have suffered were analogous to those of "mouth disease." lt was attempted to show for the defence that other cattle drank of the stream, and were uninjurcd, but the plaintiff had a verdict for $£ 2668 s$.

In the case of Iritson v. Nexthry (7 L. R. Q. B. 31), the declaration stated that the defendant was posscssed of yew trees, the elippings of which he knew to be poisonous, and that it was the duty of the defendant to prevent the clippings from being placed on land not occupied by him; that the defendant took so little care of the clippings that they were placed on land not ocenpied by him, wherely the horses of the plaintiff were poisoned: held that the declaration disclosed no facts from which a duty could be inferred in the defendant to take care of the clippings.

Where the occupier of land acquiesces in the crection of works (here copper smelting furnaces) of a nature to do injury, but which appear not to be, in fact, injurious to the adjoining land, there is no implied acquiescence in the natural extension of those works in the ordinary course of operations ; and Sir J. Romilly M.R., in Bankhart v. Houghton, would not restrain the party agrieved from proceeding at law to obtain compensation by damages for the injury sustained; and semble that this Court rould not in such case interfere by injunction to restrain the continuance of the works, but would leave the parties to their remerly at law.

Houghton r. Bunkhart, on a motion for injunction, was under the following circumstances: In the year 1853 the plaintiff became tenant of ccrtain farm lands in Glamorganshire, near which there were some copper mines, known as the "Red Jacket Mines," and opened for working in 1819. Shortly after the plaintiff obtained possession of his farms the proprielors of the Red. Juclist Nines considerably increased their furnaces, and in the course of time the ptaintiff's horses, shcep, cou's, dc., bergan, as he allerged, to grou ill and die, so much so that in 1854 the plaintiff lost no less than between 200 and 300 sheep alone. In 1856 the plaintiff, having previously suspected that the copper fumes from the furnaces poisond lis cattle, submitted one of his dead horses to Mr. Herajuth for examination, when that gentleman at once pronounced the beast to have died from alorbing copper fumes. Plain- 
tiff, upon this, and upon the smoke from the new and large furmaces not being discontinued, commeneed an action against the proprietors of the mines, and obtained $£ 450$ damages against them. 'T'he proprietors moved the Rolls Court, in Deecmber, 1858, for an injunction to restrain the plaintiff proceeding on this verdict, on the ground that he had permitted the nuisance lie complained of; and the Court, in January, 1859, dismissed such motion with costs. While the latter part of these proceedings were going on, the defendants to the present suit began to erect certain new copper works, ealled the "Briton-ferry Works" in the vicinity of the "Red Jacket" works and the plaintifl"s farm; so that, what with the copper fumes and smoke of both these mines working together, the plaintiff alleged his condition to be all but intolerable. His Honour, after hearing the evidence on both sides, granted an injunction to restrain the proprietor's of the Briton-ferry Mines from permitting smoke to issue from their works so as to produce any damage to the land and property of the plaintiff, and directed an issue at law to try the fact whether the smoke from the defendants' furnaces did injuriously affect the plaintiff's farm or not.

Sterens v. Boswell was a similar case to Lathbury v. Earle. The plaintiff had a duiry farm, on which he kept thirty or forly cous near certain lead works, which hal a blasting and three calcining furnaces, and in 1851-53 four cows, forty-eight lambs, and six eolts died, poisoned with sulphate of lead, which was found in their insides, as well as in the hay, the hedges, and the weeds on the farm. It was also deteeted in the milk after it had passed through the cow; though it did not affect vegetation, but only animal life. On examination, the eareases had oxide of lead in the mucous membrane, as well as in the lungs and liver in great black patches. There was also a black streak round the gums; and one pig's kidneys were bare of fat. It was urged by the counsel for the defence that the land on the farm was of a poisonous nature, and had been for centuries, and that the smeiting works had nothing to do with it. A juror was withdrawn, and the plaintifl was to receive $£ 500$ damages, and the defendants to purchase the furm at full value. The nearest point of the farm which was thus injured by the lead fumes was half a mile from the works, and the most distant a mile; and the white smoke from the blast furnace gave a small proportion of oxide of lead, and the remainder of carbonate and sulphate of lead.

Professor Herapath described the effect as " a stunted growth, and leanness, shortness of breathing, paralysis of the extremities (particnlarly the hinder ones), the flexor muscles of the forelegs affected so that the beasts stand on their toes, swelling of the knees, but no constipa- 
tion or colic, as in the human race. In a few days death followed. If the injured beasts were removed to another farm they never throve. In the young the symptoms were more conspicuous and the mortality greater. Lambs were yeaned paralytic; when three weeks old they could not stand, although they had made great efforts to do so: in attempts to feed out of a bottle they were nearly suffocated from paralysis of the glottis, and twenty-one died early ont of twenty-three. Colts also died; and those that lived conld not be trotted 150 yards without distressed breathing. Pigs confined to the stye were not injured; but if allowed to roam were soon affected. The milk of cows and sheep was rednced in quality and quantity; and cheese made from the former had less fat in it. I find in the milk of both minute traces of lead. It will be observed that of the symptoms, those of emaciation, paralysis, and the blue line in the gum of the lower jaw, are similar to those of the human subject, that constipation and colic are absent, and that we get two new ones-shortness of breath, and swelled knees." 


\section{INDEX.}

\section{ABANDONMENT,}

not presumed from mere fact of non tser, 86

stopping up windows primû facie, 77

parol agreement for substitution of new way, no evidence of, 87

permanent obstruction, evidence of, 87

\section{ACCEPTANCE,}

meaning of, 586

what constitutes, 579

after delivery, 584

to satisfy statute, 586

verbal promise does not constitute, 583

by vendee dealing with goods purchased, 498

by vendee selecting and marking a particular article, 500

rendee may after acceptance dispute quality of goods, 502

of turnip seed, 503

what sufficient to satisfy 17 th section of statute, 503

actual, and receipt of goods, 501

where goods lost in transitu, 503

and delivery of timber, 130

\section{ACCIDENT,}

to horse through bad fence, $13 \mathrm{~s}$

by fall of haystack, $i b$.

to cattle straying on railway, 148

to pony through neglect to fastell gates, 152

to sheep through defectire railway fence, 153

\section{ACCOUNT STATED,}

what sufficient evidence to sustain verdict upon, 63

\section{ACKNOWLEDGMENT,}

of title, 422

what takes debt out of statute, 504

ADDITIONAL RENT,

for ploughing up pasture, 312

for underletting, 314

ADULTERATION ACT, conviction under, 5.31

selling adulterated sainfoin seed, 530 
AGENT,

right of, to sue for remuneration when authority rescinded, 475

auctioneer agent for both buyer and seller, 477

anthority to execnte lease, 419

notice to quit by, 120

letting by, without authority, 421

power to let on unusual terms, $t 67$

act ratified by employer, $i l$.

representation that he had authority to act, $i b$.

guarantce of solvency by, 168

authority of, to bind principal, 546

receipt of douceur by, $5 \pm 7$

warranty by reterinary surgeon as agent, 557

\section{AGISTMENT,}

agreement to agist eattle, 60

general liability of agister, $5 \$ 7$

compensation for, 588

contraet for, not an interest in land, $i b$.

does not ereate a lien, 589

\section{AGREEMENT,}

for sale of growing erops, 50

growing timber, 55

growing underwood, 56

growing grass, 5s

crops and tillage, 60

with landlord to accept new tenant, 61

to occupy lodgings at yearly rent, $6 t$

by parul to deliver up possession, 65

by landlord to supply complete furniture, 66

by ontgoing tenant to leave fixtures, $i b$.

parol, for lease, 311

when operates as lease, 410

to let, agreement to give possession, 411

contract for sale of, 411

agreement not under seal, $\$ 13$

instrument roid as lease, good as, 113

parnl, for lease, 415

not giving possession under a new one, for lease, 416

stamp on, 416

subject matter of, within stamp act, 417

terms of, reducerl to writing, coupled with promise of party to sign, bind party

so promising, 121

$\triangle$ GRICULTULAL IIOLDINGS $\triangle C^{\prime T}, 43-49$

AGRICULTURAL P'URPOSHS,

right of way for, !1

\section{ALTITION,}

Ianis formed by, on seashore, 168 
ANCIENT LIGHTS,

obstruction of, 77

may be altered, not enlarged, 97

new lights not corresponding with, 97

\section{ANCIENT MEADOW,}

ploughing up, for building purposes, 308

conversion of, into arable land, 310

\section{APPLE FARM LEASE,}

apple-trees not excepted in, 121

\section{APPLE-TREES,}

not within the exception "other trees" in cider count $y, 121$

APPRAISEMENT,

necessary before indebitatus assumpsit will lie by landlord for moicty of crops in lieu of rent, 57

goods sold without, 294

stamp when sufficient without award stamp, 332

\section{APPRAISERS,}

sworn appraisers in stat. 2 Will. \& Mary, Sess. 1, c. 5, need not be professional, 332

\section{APPREHENSION,}

of trespassers, when justifiable, 364

\section{ARBITRATORS,}

hearing one party in absence of the other without notice, 419

may employ attorney to draw award, 419

\section{ASSIGNMENT,}

by tenant of lease, 61

when agreement to underlet amounts to an, 289

demise by yearly tenant for a term of years not an, 290

of tenant right by tenant to landlord, 323

of agreement fur a lease, 415

by bill of sale to attorney not roid on ground of champerty, 538

\section{ASSIGNEE,}

when entitled to away-going crop, 322

electing not to take to lease, what effect on corenants by lessce to leave hay, straw, \&c., 322

bound by covenant to repair, 427

of reversion, rights of, 425

\section{AUCTION,}

purchaser of largest ralne entitled to deecls, 478

printed particulars of, cannot be altered by parol evidence of terbal statement of auctioneer, 479

bidding by "puffers" at, 5.50

bidder at, may retract bidding, 550

conditions of sale sufficient notice to bidders, 550 


\section{AUCTIONEER.}

agent for burer and seller, 477

right of, to commission, 478

description in catalogue, 549

auctioneer's lien. 591

not agent for bidder till bidding accepted, 591

liability of, 592

\section{ATERAGE}

price of eorn of seven years, 153

AWARD

admissible in eridence on part of landlord, 322

stamp when not necessary, 332

when unratified, trover will not lie, 512

AWAY-GOLNG CROP,

award admissible in evidence on part of landlord on issue between him and

execution creditor of tenant, 322

right of tenant to, 320

custom of country as to, 321

BAILEE,

action by gratuitous bailee for horse killed through defective fences, $13 \mathrm{~S}$ negligence of, under different bailments, $232-260$

BAIIIFF,

has authority to receive tender, 271

authority to distrain equivalent to authority to receive rent, 278

distrain of wrong sheep by, 278

ratification of acts of, by landlord, 278

BAILIFF (FARM),

jurisdiction of justices as to, 205

entitled to notice to quit, 208

not a partner, 209

not authorised to draw bills or pledge credit of master, 209

authority to bind master by contracts, 210

\section{BANKRLPTCY IAWS,}

farmer ordinarily not within them as a trader, 523

when farmer within them as a trader, 524

farmer keeping clairy cows not within them, 524

non-liability of bankrupt for rent accruing after filing of petition, 525

BARGAINED AND SOLD (GOODS),

where growing crops are sold distinct from the land, 60

for value of fixtures left by agrecment for landlord, 67

\section{BATK,}

lessor may bring trover for bark of trees cut during lease, 115

tenant not liable for cattle barking trees, 128

what constitutes delivery of, $49 t$ 
BARK-continued.

drying bark distinct trade from drying corn, 517

Fire Insurance Company not liable for fire resulting from drying bark, 517

BARLEY,

warranty of seed, 514

sale of, to bankrupt, 520

meaning of seed barley, 528

IEAR,

tied up by too long chain, 164

BEASTS OF PLOUGH,

distrain of, 286

BEES,

subject of larceny, 344

BEQUEST,

of money for liberation of poachers, invalid, 389

BILL OF SALE. (Sce SALE.)

\section{BILLS OF EXCHANGE,}

given by tenant to agent and dishonoured, 277

joint occupants of farm cannot bind each other by them, 515

BONES,

uncrushed, exempt from toll, 340

\section{BOUNDARIES,}

liability of land to be rated where boundaries cannot be ascertaincd, 141

BULK,

refusal of seller to show, 482

not equal to sample, 484

right of purchaser to inspect, 486

drawing samples from, after purchase, 500

BULL

running at "red," 160

keeping ferocious, 162

\section{BULLOCK;}

warranty of soundness of, 564

BUSHES,

general property in, 109

exception of, for repair of fences, 116

\section{CARRIERS,}

liability of railway, at Common Law, 232

restriction of liability by booking ticket, 233

construction of conditions on ticket, 241

Railway and Canal Traffic Act, 242

just and reasonable contract by, 242 
CARRIERS-continucd.

dogs within Traffic Act, 247

conditions by railways must be reasonable, 252

responsible for delay, 255

delivery of goods by, within reasonable timc, 264

CARTS,

claim of way for carts and cattle, 93

CATARACT,

unsoundness in horse, $5 \pi 0$

CATTLE,

claim of way for cattle and carts, 93

injury to cattle on railway, 235

suffocated in railway van, 246

crowding cattle in truck, 251

cattle dealers trarel at own risk, 253

injured by working of mines, 604

by lead works, 606

CAVEAT EHPTOR,

rnle of, $5+2$

CHAMPERTY, assignment by elient to attorney not void on ground of, 538

CHEST-FOUNDERED

horse unsound, 570

CIDER.

trade meaning of, 481

selling bad, 529

CLOSE,

definition of, 347

hirer of grass in close has right of action against one who breaks the soil, 347

CLOVER,

sown does not constitute permanent pasture, 308

compensation for sowing, 324

COAI,

grant to pass under fore-shore, 169

COLILISION,

injury to cattle through, 210

COMMON,

proof of user of right of common, $8 t$

right of common of pasture for pigs, $8: 5$

forcible entry on common of pasture, 358

lord of manor not entitled to shoot on, 38.3

CUNSIGNEE,

notice of refusal by consignee to receive goods need uot be sent by carricr to consignor, 263 


\section{CONSIGNOR.}

cannot require notice from carricr of consignee's refusal to receive goods, 263

CONSUMING PRICE,

definition of, 334

relative valuc of, .335

\section{CONTRACT,}

for purchase of growing timber, $5 \tilde{j}$

indivisible contract for interest in land, 67

by parol to live at boarding house, $6 \mathrm{~s}$

entire timber contract, 129

of hiring, may be qualified by proof of customary holiclays, 199

for service for more than one year, 203

of service not necessarily for specific tinc, 206

under Pailway and Canal Traflic Act, 242

just and reasonable, 242

with first railway does not make sccond railway liable, 251

conditions on railway tickets must be reasonal,e, 252

unreasonable conditions, 254

with sack contractors, 260

for sale of agreement for lease does not imply lessor's power to lease, 411

for quiet enjoyment, 463

for purchase of land when complete, 476

as to coal mines worked out, $4 \pi ; 6$

discharge of surety by variation in contract, 483

articles sold by contract must reasonably answer description, 485

alternative contract must be stated, 490

seller cannot recover price of part of contract, 4.91

meaning of "directly" in contract of delivery, 493

to furnish turnip seed, 507

for sale of growing turnip seed, 536

complete contract of purchase of horse from letters, 580

giving halfpenny to bind contract, 581

\section{CONVICTION,}

of poaching under 9 Geo. IV. c. 69,369

for using trap for game, 375

for trespass, 375

\section{COPROLITES,}

proper mode of rating, 120

\section{COPYHOLDER,}

liable in trover for removing timber, 110

may cut trees for repairs, 110

\section{CORN RENT,}

reservation of, 452

how estimated, 453

\section{CORNEA,}

unusual convexity in, unsoundness. 566 


\section{CORN MEASURES,}

in different markets, 521

\section{CORN SALES,}

returns of, 520

\section{COTEXANT,}

not to lop or top trees, 109

not to grub up trees. 125

breac' of, not to underlet, 288

to farm in a busbandlike-manner, 306

to manage pasture, 308

to repair heages, 310

to fallow a eertain quantity, 315

to keep buildings in repair. 315

to spend money in manure, 315

to consume hay and straw, 326

not to sell hay, 327

to bring manure for has sold, 339

as to rotation of erops, $\$ 15$

to repair, 426

to yield up in good repair, 427

not to assign or ander-let, 453

to repair, $45 t$

to leave land stocked with game, 4.5

cows,

poisoned in pasture, 603

poisoned by yew elippings, $60 \mathrm{t}$

\section{CURBY HOCKS,}

in horse, 570

\section{CUSTODIẦ LEGIS,}

goods in, 291

\section{CUSTOMS (AGRICULTURAL),}

Bedfordshire, 2

Berkshire, 3

Buckinghamshire, 3

Cambridgeshire, 3

Cheshire, 16

Cornwall, 4

Cumberland, 5

Derbyshire, 6

North, 7

Devonshire, 8

Dorsetshire, 8

Durham, 3

Essex, 10

Gloueestershire, 10 
CUSTOMS-continued.

Hampshire, 11

Hereford, 12

Hertfordshire, 11

Kent, 14

Lancashire, 16

Leicestershire, 17

Lincolnshire, North, 18

Sonth, 15

Middlesex, 20

Monmontl, 12

Norfolk, 21

Northamptonshire, 22

Northumberland, 9

Nottinghamshire, 23

South, 21

Oxfordshire, 25

Putland, 26

Shropshire, 26

Somersetshire, 27

Staffordshire, 28

Suffolk, 28

Surrey, 29

Sussex, 31

Wales, North, $3 \mathrm{~s}$

South, 39-43

Warwickshire, 32

Westmoreland, j

Wight, Isle of, 33

Wiltshire, 33

Worcesterslire, 34

Yorkshire, East Riding, 35

North Riding, 36

West Riding, 37

CUSTOM,

to take profit in alieno solo, is

to dig clay in copyhold, 98

of copyholders to fell timber, 114

of country as to consumption of hay and straw, 293

of the country generally, 315

as to paying for tillages, 317

of country excluded by lease, 323

let in by omission in lease, 323

to leare manure, $32 \frac{1}{t}$

DAIRY,

demise of, 267

DAMAGE,

by game to crops, 391

compensation for, 389 
D.MAGE-continued.

to surface of land, 100

to horse through bad fence, 138

to horses by fall of haystack, 139

to cattle by polltition of stream, 181

D.A.KA GE FE.LSANT,

dog taken, 368

DAMAGES, MEASURE OF,

for aggrarated trespass. 127

nominal where crops sold for fnll value, 294

for removing soil, 356

for trespass, 359

for not keeping buildings in repair, 429

for non-chelivery of goots, 492

for breach of contract, 509

in trover, 513

for non-delivery, 533

in trover for a horse, 560

question of damages on returning horse, 594

how estimated for irregular distress, 273

for detaining cattle after tender, 274

for distraining eattle of stranger, 275

for distraining wrong sheep, 278

DANGEROUS ANIMALS,

scienter, 155

savage boar, 155

savage dog, 156

ferocions bull, 162

bear tied up by too long chain, $16 t$

depasturing vicious horse, 167

DECOY,

penalty for shooting near, 385

DEDICATION,

of way to prabic, 91

valid derlication of, how marle, ?1

evidence of user and dedication, 101

of private roart to the palblic, 16 ;

UEED,

works of deseription in deed may be contradicted by parol evidence, 482 takes effect from the delivery and not the date, 182

DEER,

in park personal property, 382

DEIAY,

by railway in forwarding ligs, 25;

forwarding cheeses, 257

by fall of snow, 259 


\section{DELIVERY,}

and acceptance of timber within Statute of Frands, 130

non-delivery of goods sold by sheriff, 302

of instrument as an escrow, 448

what constitutes, 494

sufficient to satisfy statute, 496

actual, not neeessary in the case of ponderous goods, 497

leading case on, 496

non-delivery of thrashing machine within certain time, 510

of goods of inferior quality, 511

order for delivery on third person, 513

delay of delivery cannot be set up in reduction of damages in breach of warranty, 536

what sufficient to pass property, 536

DEMISE,

general demise of land with timber trees, 109

at yearly rent, 412

meaning of, 424

of land with power to make bricks, 439

for three years eertain, 463

\section{DILAPIDATIONS,}

when action maintainable for by incumbent, 310

what knowledge neeessary in valuer of ecclesiastical dilapidations, 333

action for dilapidations subject of compulsory reference, 431

of buildings built partly on waste, 431

\section{DISTRESS,}

general principles of, 265

of sheep in highway, 266

of things in manual use illegal, 266

of cattle not in locus in quo, 266

escape of, 267

duties of pound-keeper, 268

duties of hayward, 269

tender of amends when not too late, 270

tender of rent, proper persons to receive, 271

tender of rent sufficient amends, 272

detaining cattle after tender of rent, 274

detaining goods, 274

of cattle of stranger for rent-charge, 275

of eattle, assisting, 275

authority by landlord to distrain, 278

of wrong sheep by bailiff, 278

payment of rent under distress no admission of title, 278

trespass maintainable after tender, 279

for recovery of rent-charge, 280

Statute of Uses, 280

not an inseparable incident to rent-service, 281

by law, 281 
DISTRESS-continued.

illegal at improper time, 281

improper working of, 282

after death of tenant, 282

open field suffieient pound for, 283

fact of inventory being taken an impounding, 283

time for making, $28 t$

fraudulent removal of goods by tenant. $2 S 4$

duty of distrainor as to goods unsold, 28.;

what goods may be distrained, 285

of implements of hnshandry, 286

of beasts of plough, 286

of sheep of third person. 287

illegal after determination of tenancy, 288

by joint-tenant of reversion, 289

by under-lessee, 289

on away-going crop, 290

Statute 8 Anne, 290

of growing crops, 291

of hay and corn in stacks, 291

by grantec of rent-charge, 292

of crops under a $f . f a ., 292$

of growing crops, law as to, 293

irregular, 296

of privileged goods, 297

excessive, remedy for, 297

and sale of farming stock, 298

of hay and straw to be consumed on the premises, 295

unreasonable, 300

excessive, 301

second distress when unlawful, 302

affirmation of tenancy, 303

right of sheriff to poundage, 304

no waiver of breaches of covenant, 305

\section{DITCH,}

property in, $1: 31$

presumption of ownership in, 1.1

considered a fence under Enclosure Act, 132

law as to ditehes, 132

DOG,

scienter as to ferocity, 15.5

keeping savage dog, 156

railway company not liable for acts of stray dog on their premises, 156

dog dangerous to owner's knowledge, 156

evidence of dogs being wont to attack men not sufficient to support scicnter as to shcep, 157

sheep, worrying, 1:8

what is evidence of scienter for jury, 1.59 
DOG-continued.

caution from owner of $\mathrm{dog}, 160$

evidence of dog having been bitten by mad dog, 160

shooting dog when justifiable, $\mathbf{1 6 1}$

right to keep dogs loose for protection of property, 161

injury by dog chained up to person legally on premises, 133

keeping watch-dog in walled garden, 164

dogs frightening horses, 165

dogs within Traffic Aet, 249

injury to valuable greyhonnd on railway, 254

inproperly securing dog on railway. 264

trespass by dog against master's will, 367

shooting dog chasing deer, 368

taking dog clamage feasant, 368

deputation by Stat. $1 \& 2$ Will. IV, to seize $\operatorname{dogs}, 368$

sending dog on land an entering, 369

laying traps for $\operatorname{dog} s, 389$

DOG SPEARS,

injury to dog from, 390

DOTARD,

lessee may claim if thrown down by tempest. 116

tenant's rights to, 124

\section{DOUBLE VALUE,}

action for, under Statute, 149

\section{DRAIN,}

claim of right to make drain over another's land, 70

verbal licence not sufficient to convey easement of drain over land of another, 74

difference between drain and watercourse, 182

flow of water from drain for agricultural improvements, 183

right to artificial watercourse, 184

nnqualified right of owner to drain, 184

rights as to rain water, 185

rights as to surface water, 186

action will not lie against surveyor of highway for cutting drains under power of Highway Act, 351

DRAINAGE,

compensation to out-going tenant for, 329

DRAINING,

construction of draining corenant, 328

\section{DRIVING,}

liability of master where servant drires his own horse in master's service, $21 t$ two carts, 214

servant killed by negligent driving, 214

servant going indirect road, 219

servant driving master's cart without leare, 219 


\section{I)RIYING-continued.}

liability of master defined, 220

general rule as to negligence, 221

what is negligence in driving, 220

running over ass tethered in highway, 221

person driving not bound to keep on right side of road, 220

\section{DROVERS,}

larceny of sheep by drover, 224

fraudulent drovers, 225

not general servants, 225

may be found guilty of embezzlement, 225

general drover not a serrant so as to make owner of cattle liable for his negligence, 228

drover has no implied authority to sell, 229

reasonable presumption that drover has authority to sell, 229

drover's cattle agisting for one night not liable to be distrained, 276

\section{FASEMENT,}

of grass for a cow creates no interest in land, 67

definition of, 70

presumption of grant of, how established, 70

to stack hay, 71

to stack coals, 71

easement of drain over land of another cannot be conveyed by verbal licence, 74 unity of ownership destroys preseriptive rights, 76

may be clained by custom, 78

right of owner to support of underground strata not an easement, 80

right to take pot water, 78

to water cattle, 78

distinction between profit $\dot{a}$ prendre and a mere easement, 79

claim of prescription under Stat, 2 \& 3 Will. IV., c. 71, 81

claim of right to easements, 82

plea of forty years' user, 82

continuous enjoyment of easement, 83

enjoyment as of right, 83

easement of common of pasture, 84

rights of way, 86

\section{EJECTMENT,}

may be bronght by lessec of prime vesture for injuries to his possessory right, $\tilde{5} 3$

action of, against lessee for breaches of covenant, 311

evidence of cross-cropping, when inarmissible in action of ejectment, 315

too late after twenty years' aciverse possession, 345

tenant estopped from denying title of landlord who let him into possession, 355

incumbent may sustain ejectment against tenaut during eurrent year, 435

ejectment from part of premises, 437

eviction of trnant, when operating as suspension of rent, 437

\section{EL.MI}

is timber when twenty years old, 118 


\section{EMBEZZLEMENT,}

by servant, 222

by drover of catîle, $22 \pi$

\section{EMBLEMENTS,}

growing potatoes come within description of, 51

value of, may be recovered on account of crops bargained and sold, 67

definition of, 442

executor's right to, 442

devisee's right to, 442

part of stock of farm, 443

\section{ENCROACHMENTS,}

by the sea, 168

made by tenant are for bencfit of landlord, 169

from non-uavigable river, 169

\section{ENTRY,}

by person who has legal title to the land, 345

by lord of manor when not enongh to bar tenant's right, 345

under 3 \& 4 Will. IV. c. 27,346

to retake goods wrongfully taken, 347

on termiuation of lease, landlorl cannot maintain trespass before entry, 357 permissive tenant cannot sue claimant under owner for forcible entry, 357

forcible entry in exercise of right of common of pasture, 358

unlawful on day when plaintiff has whole of day to remove crops, 359

customary heir of copyhold tenement cannot maintain trespass without entry, but after entry may maintain action for trespasses committed prior to his entry, 357

times of entry on farms, 433

\section{ESCHEAT,}

right of way of necessity cannot cxist where title is by escheat, 90

when escheat equal to grant, 90

\section{ESCROW,}

execution of an instrument may amount to an escrow without express words of delivery, 448

\section{ESTOPPEL,}

tenancy created by estoppel between tenant and recciver appointed by Chancery, 411

doctrine of estoppel between landlord and tenant, 418

no estoppel between assignce and termor who grants lease cxcceding his own term, 418

constructive eviction so as to affect estoppel, 437

mere words of description in a deed of conveyance not operating by way of estoppel may be contradicted by parol, 482

\section{ESTRAY,}

trespass lies for working estray, $34 t$

swan is an estray, 340 


\section{EVICTION,}

action for in County Court, 437

of tenant, when operating as suspension of rent, 437

of tenant from parcel of demised premises no answer to action for breach of covenant, $43 i$

constructive so as to affect estoppel, 437

\section{EXCHANGE (BILL OF)}

giren by tenant to agent, $2 \pi 7$

joint tenants of farm cannot bind each other by bills of cxchange, 515

\section{EXPEDITION,}

railway companics must convey with reasonable expedition, $\mathbf{2 5 9}$

\section{FALSE PRETENCES,}

obtaining money by, for cutting chaff, 224

\section{FARM,}

contract to farm in a husbandlike-manner, 306

mere relation of landlord and tenant, sufficient consideration to farm in a husbandlike-manner, 306

removing hay from, 316

manure made on, definition of, 339

refusal of entrance by lessor to new tenant, 423

refusal of tenant to show farm, 423

landlord not compelled to rebuild farm buildings, 429

different times of quitting farms, 433

farm fixtures, $45 t$

\section{FARMER}

not within Sunday Trading Act, 563

\section{FENCES}

in churchyard, whose duty to repair, 113

tenant's right to bushes and thorns for repair of fences, 116

ditch considered a fence under General Enclosure Act, 132

duty of occupier to repair fences, 132

when no obligation to fence, 133

when obligation to fence, 134

escape of cattle for want of fences, 135

obligation on occupier to fence dangerous places, 137

liability of canal company to fence, 138

injury to horse through bad fenec, 138

general liability to maintain fenees, 139

liability of railway companies to fence, 143

power of surveyor to take down fence, 142

railway fences, 144

obligation of company to fence, 146

liability to maintain fence between railway and highway; 149

railway companies not bound to fence one part of prenises from another, 152

damarce to fence by poacher not malicious injury, 372 


\section{FERRY,}

negligence of owners of, 232

\section{FIERI FACIAS,}

growing potatoes may be seized under, $\mathbf{5 1}$

growing fruit cannot be seized under, 54

corn and other industrial crops may be seized under, 56

growing grass cannot be seized under: 57

what may be seized under, 59

onter-door of out-house may be broken under, 285

seizure of crops under, 292

landlord's claim for rent under, 469

FIRE,

injury to horses through axle of carriage taking fire, 287

herbage set on fire by sparks from engine, 359

caused by sparks from railway engine, 360

by spontaneous ignition of hayrick, 360

by careless burning of weeds, 360

destruction of farm premises by, 429

liability to pay rent for premises burnt down, 42 ?

landlord not compelled to spend insurance money, 129

farm-house destroyed by fire, 430

FISH,

right of fishing passes by grant of water, 170

trespass for entering fishery, 370

definition of mesh in Salmon Act, 364

\section{FIXTURES,}

agreement by ontgoing tenant to leave fixtures not an interest in land, 67 mortgagee of tenants' fixtures has no interest in land, 68

farm fixtures, 454

leading case on, 4 ist

right to remove barn, 455

stavel barn, 455

water-fender, 456

staddles, thrashing machine and granary, 457

barn on blocks, 458

building where landlord finds part of timber, 459

tenants' fixtures after determination of tenancy, 460

brick pillars, 460

trover by tenant for, 461

removal of, by tenant after ejectment brought, 461

leaving fixtures in same condition, 462

law of fixtures nnder 14 \& 15 Vict. c. 25,462

steam-engine and grindstones fixtures, 469

FLAX,

injunction to prevent the sowing of, 309

penalty for sowing, 313

FODDER,

price or consuming price. 33 .; 
FOLDAGE, claim for, by outgoing tenant, 323

\section{FOOTPATH,}

obstruction of, 94

penalty for ploughing up, $9 t$

erecting gate across, 94

\section{FORCIBLE}

entry in common of pasture, 358

\section{FORFEITURE,}

cutting down trees to work quarries does not work forfeiture, 115

waiver of, by receipt of rent, 288

re-cntry by lessor, as for a forfeiture, on finding premises out of repair, 428

FOX,

trespass lies for hunting over another's land, 364

\section{FRAUD,}

use and occupation will not lie wherc agreement void by reason of, 448

contract void through, 476

on lessee of market, 519

by misrepresentation in warranty of horse, 553

principal liable for agent's, 556

effect of, on contract, 557

FRAUDS (S'TATUTE OF),

fact of auctioneer signing purchaser's name is not a memorandum to satisfy

17 th section, 477

entry by auctioneer's elerk not sufficient to satisfy 19 th section, 477

written proposal signed by one party, and orally agreed to by the other, sufficient, 495

what is part acceptance to satisfy 4 th section, 496

delivery to satisfy 17 th section, 496

acceptance by carrier not sufficient, 496

actual delivery, when not necessary, 497

actual acceptanice, under, 498

delivery and acceptance of samples so as to satisfy 17 th section, 500

acceptance and actual receipt, 501

no acceptance and actual receipt, unless vendce lras opportunitics of secing goods, 502

acceptance within 17 th scetion, 503

there must be a writing, or a part payment, or a delivery and acceptance, to satisfy 17 th section, 50 \%

extension of Statute by 9 Geo. IV. c. 14,505

when note or inemorandum sufficient to satisfy, 50.5

verbal agreement to grow wheat not binding, 507

name and adriress of rendec written by himself at bottom of list of articles purchased, sufficient to satisfy 17th section. 507

contract for sale of mining shares not sale of land within th section, nor sale of goods within 17th section, o0s 
FRAUDS (STATUTE OF)-continued.

promise by a third party to pay contingent damages within statute, 561

what constitutes acceptance within statute, 579

satisfied by half-penny deposit, 580

money must actually pass, 582

feeding cattle with owner's consent, not sufficient evidence of accpitance, 583 acceptance after delivery to satisfy statute, 584

contract for sale of horse not to be performed within a year within 4th section, 585

acceptance within statute by borrower of horse, 586

extension of statute by 9 Geo. IV. c. 14, 587

FREEHOLD INTEREST,

in right and title to a passage for water passes by deed only, 71

FREE MINERS,

their rights, 80

FREE WARREN,

franchise of, 384

birds of, 385

FRUCTUS INDUSTRIALES,

hops are, 51

definition of, 59

FRUITS,

sale of growing fruit an interest in land, st

growing fruit passes to heir, 54

cannot be taken by tenant for life, 54

nor levied under a $f . f a ., 54$

penalty for wilful damage to fruit trees, 137

\section{FURNITURE,}

agreement by landlord to supply complete furniture, must be in writing, 66;

FURZE,

planted for ornament, protected under term ornamental timber, 126;

GALES,

grants of, by foresters, 80

GAME,

no notice to trespassers in pursuit of, necessary, 363

right of property in, 367

taking, without certificate, 368

summary conviction for being in pursuit of, at night, 369

trespass in pursuit of, by shooting from highway, 370

right to kill, excrcised for seven years, 370

right of keepers to apprehend persons in search of, 370

prosecutions under 1 \& 2 Will. IV., s. 32, must be commenced within a year, 370

law as to apprchension of persons in pursuit of game, 371

taking game on Sunday or Christmas day, 374 
G.AME-continued.

reasonable time for keeping game after season, 574

elaim of right to kill game, 376

Joung pheasants under coops not game, 382

assessment of land without game, 383

reservation of game by lessor, 384

trespassing on land where game reserved to lord of manor, 386

compensation for damage by game, 389

action fur dlamage by dog hunting game, 391

damage by game to crops, 391 .

pursuit of game, 392

persons taken with game on highway, 392

GAME-DEALER,

right to sell live pheasants, 375

\section{GAMEKEEPER,}

anthority of, to seize dogs, $36 \mathrm{~S}$

to take game from poachers, 370

rights of, to apprehend ponchers, 370

forcible rescue of poacher from custody of gamekeeper, 372

\section{GATE,}

crecting gate across footpath, 91

action by reversioner for fastening gate, 9;

obligation of railway companies as to gates, 145

of occupation road across railway, 150

neglect to fasten gate over railway, 152

railway company bound to keep their gate shut, 159

trespass for breaking, 257

\section{GLANDERS,}

penalty for selling glandered horse, 599

\section{GLEAN,}

poor have no legal right to, 344

\section{GLEBE,}

rights of incumbent as to, 310

tenaney of glebe lands under two sncessive inemmbents, 135

right of incumbent to immediate possession of, 435

\section{GOGGIES,}

shcep affected with, 567

GRANT,

privilege of washing sand, sce, from a mine down natural stream subject of grant, 86

right to work mines an incident to grant of mines. 81

way of necessity arises from presumed grant. 89

right of way ean only arise by grant, 90

of an occupation way, 93

implied grant of way of nccessity, 101 
GRANT-continued.

to pass coal under fore shore, 169

right of fishing passes by grant of water, 170

right of polluting stream subjeet of grant, 181

GRASS,

purchase of standing crop of, 56

purchase of mowing grass, 58

cannot be seized under a $f$ i. $f a ., 57$

sowing grass seed does not make permanent meadow, :308

GROUSE,

frightening, with fire-works, 376

\section{GROWING CROPS,}

agreement for sale of, when it confers an interest in land, 60

agreement of sale of, distinct from letting land, 60

distrain of, 291

seizure of, under a fi. $f a ., 292$

law as to scizure of, 293

unregistered transfer of, good against execution creditor, 303

GUN,

laken away from trespasser, 371

free liberty to hunt and liawk, granted by deed in 1655, will not extend to shooting with a gun, 384

HARES,

sending on a dog to drive hares into a net, 369

property in, 367

taking hares by night, 373

occupier's right to kill hares, 373

form of authority to kill hares, $3 \pi t$

$\mathrm{HAY}$,

distrain of, 291

sale of, to be consumed on premises, 298

custom of colntry as to consumption of, 299

removing hay from farm, 316

covenant to consume, 326

not to sell, 327

penalty for carrying away, 327

definition of, 328

weight of, not to be increased by water, 523

HAXSTACK,

licence to stack hay on land, 71

horse killed by fall of, 139

fire caused by spontaneons ignition of, 360

left on land by outgoing tenant, 339

sold but burnt before paid for, $49 t$

HAYWARD,

duties of, 269 
HEDGES,

property in, 131

primî facie, belong to owner on whose side ditch is, 131

clipping hedge by one tenant in common, 135

rule as to hedge cuttings, 136

powers of surveyors to ent hedges, 142

incumbents' duty to maintain, 310

specific corenant to repair, 310

cows poisoned by clippings from yew hedge, 604

\section{HEFIOT,}

- definition of, $4+3$

not rateable, 443

custom of copyholders as to, 443

landlord's right to, 444

payment in lieu of, 444

\section{IIGHWAY,}

evidence of existence of, 101

use and dedication of, 101

free right of public to enjoyment of, 102

right of owners to enclose part of, 102

right of Justices to determine, 102

surveyor of, liability of, for accident through non-repair of, 103

where close joins highway, half highway passes with close, 104

order of Justices to stop highway, 105

mere tracks no proof of, 106

liability to repair, 134

obligation to fence, $13+$

planting trees adjacent to highway, I+1

cattle straying on, 144

liability of railways to maintain fence between railway and highway, $I 49$

trespass against surveyor of, 351

negligent riding on, 362

trespass by shooting from, 370

persons taken with game on, 392

\section{HIRING (see SERVANTS).}

\section{HOBBETT,}

sale of wheat by, 522

\section{HOLDING OVER,}

opcration of stat. 8 Anne, c. 14, 291-296

by co-tenant, 450

after expiration of lease, 450

permissive, after notice to quit, 451

inust be continuous to entitle to double value, 470

IOLIDAYS,

centract for hiring may be qualificd by proof of customary, 199 
HOOF,

contraction of, in horse unsoundness, 569

HOPS,

sale of growing, 50

sale of sulphured, 529

acceptance of, within Statute of Frauds, 534

\section{HORSES,}

injured through bad fence, $13 \mathrm{~s}$

killed by fall of haystack, 139

depasturing a vicions horse, 167

servant driving his own horse in master's service, 214

injured on railway, 234

left in siding all night, 245

injury to, when saddled and bridled, 252

detention of, by livery stable keeper, 253

race-horse injured, damage limited to $£ 50,254$

frightened by traction-engine, 361

warranty of, $542,543,544$

hirer of, to use reasonable care, $5 \pm 9$

warranted six years old, 551

partnership in, 559

rirling horse without licence of owner, 561

war'ranted "sound and quiet in harness," 561

good drawer, 561

diseases and unsoundness in, 566-571

agreement to take back within certain time, 573

reasonable trial of, 574

borrowing, before actual delivery, 585

lien on race-horses, 590

auctioneer's lien on, 591

purchaser's duty to return unsound, 595

right to return within certain timc, 596

sale of stolen, 597

sale of glandered, 598

injured at livery stables. 601

slaughtered at kennels, 603

HORSE-DEALER,

warranty by servant of, 554

HORSE-DEALING,

general rule of, 553

HUNTING,

right to follow fox, 36 5

law as to trespass by, 366

HUNTSMIAN,

though hired at yearly wages a servant, 201 


\section{HUSBANDLIKE MANNER,}

promise to farm in, implied, 306

mere relation of landlord and tenant insuflicient consideration for promise to

farm in, 306

\section{HUSBANDRY,}

corenants, 306

\section{IGNITION,}

spontancous, of hayrick, 360

\section{MPROVEMENTS,}

encouraging, under lease known to be bat, 312

allowance for lasting, 316

compensation to outgoing tenant for drainage, 330

for manure, 330

\section{INCLOSURE COMMISIONERS,}

power of, to set ont private road, 105

their rights to enter land, 346

\section{INCUMBENT,}

may break up ancient meadow, 309

cannot recover against previous incumbent for not cultivating land in husband-

like manner, 310

what knowledge necessary in valuers between outgoing and incoming, 333

death of, within three months of award, 402

removal of hothouse by late incumbent's executor, 431

tenancy of glebe lands under two incumbents, 435

new incumbent a right to immediate possession of glebe, 435

\section{INJUNCTION,}

against tenant for life for cutting underwood of insufficient growth, 121

to prevent the cutting down arenues, 125

ornamental timber, 126

to prevent breaking up meadow for building, 308

lerpetual, to restrain breaking np, down lands, 309

not granted to restrain turning rabbit warren into potato ground, 310

granted to restrain tenant from year to year from (lamaging hedge-rows, 310

to prevent mustard or flax being sown, 309

not granted to prevent incumbent from breaking up meadow, 310

\section{INJURY,}

to trees, 13;

to vegetables, 137

to horse through bad fence, 138

by (Ing chained np to person lawfully on premises, 16.3

to reversion by diverting stream, 194

to stranger by negligence of fellow-servant, 217

to servant helping servant, 217

to servant by negligence of fellow-servant, 218

to servant using machine, 218 
INJURT-continued.

to servant from unsafe ladder, 219

to horses on railway, 234

to cattle, 237,240

to horses in cattle truck, 247

to cow on railway, 252

to race-horse, 254

valuable greylound, 25.

\section{INNKEEPER,}

has no lien on a horse for its keep, unless brought by a guest, 590

liable for loss of goods deposited in his loouse, 601

not liable for damage to horse where due care taken, $60 \mathrm{I}$

liable for horse being immoderately whipped, 602

liable for loss of gig placed in open street on market day, 602

\section{INSURANCE,}

meaning of mortality in policy, 231

landlord not compelled to spend money from policy, 429

consequence of omission of statement in policy, 517

\section{INTEREST'S IN LAND,}

definition of, 50

agreement for sale of, 50

growing hops, 50

potatoes, 51.53

fruit and regetables, $5+$

timber, 5.5

underwood, 56

grass, 56

erops when it confers an interest in land, (0)

with landlord to aceept new tenant, 01

to surrender, 62

by tenant to pay landlord for consent to assignment of term, 66

easement of "grass for a cow," does not create, 67

mortgagee of tenants" fixtures has, 68

\section{IRREGULAR DISTRESS,}

of things in manual use, 266

of cattle not in locus in quo, 266

of wrong sheep, 278

after determination of tenancy, 288

where actual damage resulted, 296

of privileged goods, 297

\section{IRRIGATION,}

rights of riparian owner as to, 187

diversion of water for, 189

by artificial dam, 191

crossing another's land for purposes of, 192

by artificial cut. 193 
KEEP,

recorery of, in case of horse returned for broken warranty, 593

recorery of, when contract broken, 594

LABOURER,

general hiring of agricultural, 200

taking rabbit by order of farmer, 381

L.IDDER,

injury to scrvant from use of unsafe, 219

I.AMINITIS,

unsoundness in horse, 569

I.AND,

interests in, $50-68$

licence to enter upon, 72

L.ANDLORD,

agreement with, to accept new tenant, 61

by tenant to pay, for consent to assignment of term, 66

by to supply complete furniture, 66

outgoing tenant must give up possession to, 321

payment by, for manure and tillages, 331

estoppel of tenant from denying the title of, 357

estoppel between landlord and tenant, 418

not compelled to spend fire insurance money, 429

not compelled to rebuild farm-house, 430

action in County Court by, to evict tenant, 437

right of occupier to recover property-tax paid on behalf of landlord, 440

his right to heriots, 444

claim to rent under $f i . f a ., 469$

implied promise by, not to stop sale, 276

authority by, to distrain, 278

\section{LARCENY,}

by farming servants, 223

by drover, 22.5

hy pig-joblers, 226

of bees and swans, 345

pigeons, subjects of, $34 t$

LEASE,

operative words in, 410

arrieement, when operates as, 110

contract for sale of agreement for lease does not imply lessor's power to, 411

instrument voil as lease, good as agrcement, 413

parol agreement for, 415

not giving possession, no breach under a new agreement for, 416

expired, 416

money recoverable from inability to grant, $\$ 19$

hinding agreement for, 420

holding orer after expiration of, 4.50 
LEASE-continued.

lessee bound to deliver up, 473

vendor liable for false representation of, 538

LEAVE AND LICENCE, plea of it by landlord to entering land and cutting timber, 121

\section{LIBERUM TENEMENTUM,}

tenancy in common cannot be given in evidence under plea of, 136

plea of, 352

\section{LICENCE}

to stack hay, 71

to stack coals, 71

irrevocable, though granted by parol, 71

to enter upon land, 72

definition as to, how determined, 72

by parol to put in a light, cannot be recalled, 72

to divert water, 73

verbal, not sufficient to convey easement of drain over land of another, 74 to make reservoir for dye-water and soke, 75

LIEN,

none in case of agistment, 589

livery-stable kecper has no, $\mathbf{5} 89$

innkeeper has no lien, except in case of guest, 590

general rule of, 590

on race horses, 590

auctioneer's, 591

LIMITATIONS (STATUTE OF), application in cases of warranty, 487

what sufficient acknowledgment to take debt out of, 508

LINSEED CAKE,

warranty of, 485

\section{LIVERY-STABLE KEEPER}

has no lien on horses, 589

\section{LODGINGS,}

hire of, at a yearly rent an interest in land, 64

LORD OF MANOR,

right of, to fallen rocks, 110

entry by, 345

his exclusive right to sport, 382

not entitled to shoot orer commons, 383

his rights as to pound, 270

LUMBAR,

affection of nerves in lumbar region, unsoundness in horse, $5 \% 0$

MALICIOUS PROSECUTION

for sheep stealing, 600 


\section{MANSLAUGHTER,}

in the owner of a dangerons animal, 15.j

by keeping dangerous bull at large, 163

by depasturing a vieious horse, 167

\section{MANURE,}

flow of liquid manure into neighbonr's field, ist

eorenant to spend a eertain sum in, 315

compensation for, 330

payment by landlord for, 331

bringing value of st raw back in manure, 330

" made on farm," definition of, 339

assiguable by the tenant, $33 \mathrm{~s}$

right of outgoing tenant to on-stand for, 339

eovenant to bring manure for hay sold, 339

agreement to sell mannre, 340

exempt from toll, 340

selling manure not corresponding with warranty, 527

\section{MARKET,}

pigs too late for. 2.55

definition of " market ralue," 194

law of the, 517

rights of seller in public market, 518

legally establishel, 519

fraud on lessee of, 519

owner of, liable for nuisances arising therefrom, 525

selling horses within limit of, 526

carrier indictable for taking bad meat to, 529

recovery of difference between sale and market price, 532

sale by public anetion, not sale in market orert, 597

\section{MASTER. (See SERvaNT.)}

\section{MEADOT,}

lord of manor eannot bring bill for meadow broken up by defendant's testator. 307

injumetion against breaking 11 meadow for building purposes, 308

ploughing $" 1$, aneient meadow, 309

rights of incumbents as to, 310

permanent meadow not made by sowing elover and grass seed, 308

II E.IT,

warranty of sound, 189

sclling bad, 529

no implied warranty that meat fit for fond, 528

carrier inclictable for taking load meat to market, riz?

absenee of intent to sell bat meat, 529

\section{MIEIICINE,}

inproper alministration of, by reterinary's servant, 218

giving medieine to bired loorse, 5is

chemist's liability for selling improper medicine, 577 
MESH,

definition of, 364

MILK-CARRIER'S

agrecment, 223

MILK.WALK,

agreement to purchase, with possession of premises, 64

\section{MILKING}

cows in pound, 270

MINES,

right to work, is an incislent to grant of, 81

privilege of washing sand dislodged from tin-mine, 86

MODUS,

proper farm, 402

decimandi, 102

MORTALITY,

meaning of, in insurance policy, 231

MORTMAIN ACT,

bequest of pure personalty to a charity to pureliase and restore to church impropriate tithes roid under, 395

\section{NAVICULAR}

disease of joint in horse unsoundness, 569

\section{NECESSITY (WAY OF),}

cannot be pleaded without showing its character, 88

effect of unity of possession, 88

law as to, 88

definition, of, $\$ 9$

limited by necessity which created it, 89

arises from presumed grant, 89

right of, can only arise by grant, 90

implied grant of, 104

\section{NERVES,}

affection of, in lumbar region, 570

NET,

definition of mesh of, 364

NIGHT,

poaching, 369

entering land at, armed, 369

taking or killing hares or rabbits by, 373

definition of, 373

\section{NON-DELIYERY}

of goods sold at sheriff's sale, 302 
NON-USER (OF WAY),

supported by what eviclence, 82

immemorial right of way not lost by, 86

presumption of abandonment not to be made from, 86

\section{NOT GUILTY,}

puts in issue "scienter," 165

effect of plea of, in action for damage done to plaintiff's sheep, 167

plea of, in action for obstructing flow of water, 170

plea of, puts in issue the fact that the driver was not defendant's servant at time of accident, 219

NOTICE TO QUIT,

by one joint-tenant, 432

who may gire, 432

when date of eommencement of tenaney not known, 433

insufficient, 434

two rears, 436

permission to hold orer after, 451

may be given by parol, 432

given by agent's agent, 432

\section{NOTICE TO TRESPASSERS}

not necessary, 363

\section{NURSERYMAN,}

rights of, to remove trees, 122

trees, shrubs, and plants, planted in a nursery-ground subsequent to demise cannot be seized, 292

\section{OBSTRUCTION}

of ancient lights, 77

of public footway, 94

by erecting gate across footpath, 94

\section{OCCUPATION}

road across railway, 150

\section{OCCUPIER,}

duty of, to repair fences, 132

obligation on, to fenee dangerous places, 137

right of, to kill hares, 373

liability of, to pay rates, 438

power of, to deduct rates from rent, 438

right of, to recover property-tax pair on behalf of landlord, 110

\section{ODD MARK,}

meaning of, 322

right of tenant to remove, 322

\section{ONSTAND,}

right of outgoing cuant to, 339 
ORNAMENTAL TIMBER,

right of devisee in fee to cut down, 113

definition of, 126

may extend to furze, 126

rights of tenaut for life as to, 126

OVERCROPPING,

not waste, 315

not within meaning of non-cultivation, 315

\section{OWNER,}

of savage animal, liability of, 155

caution from owner of dog, 160

obligation of owner of vicious animal, 163

rights of riparian, 178

unqualified right of owner to drain, 189

of land need not prove non-permission, 371

right of, to dig minerals on lands adjoining railway, 100

of ancient house entitled to lateral support of neighbour's land, 100

rights of, to enclose part of highway, 101

of market liable for nuisance arising therefrom, 525

rights of, to support of underground strata, 80

OWNERSHIP,

unity of, destroys prescriptive right, 76

presumption of ownership of ditch, 131

and tenancy, primâ facie evidence of contract, 447

\section{PAROL,}

hiring by, 204

agreement for lease, 415

\section{PAROL EVIDENCE,}

evidence of oral agreement, 464

when not receivable, tso

admissible to explain trade terms, 481

words of description may be contradicted by, 482

PARTNERSHIP

in a horse, 559

PASTURE,

covenant to manage, 308

breaking up, 308

sowing clover or grass does not make permanent, 308

ploughing up ancient, 309

rights of incumbents to break up, 310

penalties for ploughing up, 312

\section{PENALTY}

for ploughing up footpath, 106

for riding on footpath, 141

for ploughing up pasture, 312

for sowing noxious plants, 313 
PENALTY-continued.

for underletting, 314

for cross-cropping, 314

\section{PHEASANTS,}

right to deal in live, 375

tame, are subject of larceny, 375

young birls in coop under hens not game, 382

trespass by shooting, from highway, 370

\section{PIGEONS,}

subjects of larceny, 344

\section{PI,OUGH,}

beasts of, distrain of, 286

\section{PLOUGHING}

up public footpath, 94

up footpath, penalty for, 106

up ancient meadow, 309

right of incumbent to, 310

up pasture, penalty for, 312

\section{POACHER,}

cannot give evidence for himself, $36 \mathrm{~s}$

non-entry of some of poachers on land, 369

right of gamekeeper to apprehend, 370

damaging fence not malicions, 372

forcible rescue of, from unlawful custody, 372

found with rabbits on highway, 376

\section{POLCHING,}

with dogs, 367

conviction for, under 9 Geo. IV., c. 69,369

hares or rabbits by night, 373

game on Sunday or Christmas Day, 374

in pursuit of game, 392

a plorehension of persons, under Game Act, 393

POISON,

cows poisoned in pasturc, 603

cattle poisoned by cating yew clippings. 604

acquiescence of owner in erection of poisomous works, 604

cattle poisoned by lead works, $60 \mathrm{~J}$

symptoms of sulphate of leat, 606

P'OLES,

cutting ash poles by tenant, 124

POND,

compensation to tenant for life for loss of, 198

POOR RATE,

rating of saleable underwoods, 119

rating of esprolites, 120

nssessment of tithes to, 405 


\section{POSSESSION,}

unity of, destroys a title by preseription, 76

duty of outgoing tenant to give up possession to landlord, 321

legal possession against trespassers, 345

not giving possession no breach under a new agreement for a lcase, 416

new incumbent has right to immediate possession of glebe, 435

POTATOES,

sale of growing, $51-53$

sale of "ware," 480

POUND,

duties of kceper of, 268

treatment of animals in, 269

conviction of persons releasing animals from, 270

open field a sufficient, 283

POUNDAGE,

sheriff not entitled to, when proceedings set aside, 304

PRESCRIPTION,

unity of ownership destroys title by, 76

elaim of Stat. $2 \& 3$ Will. IV., c. 71, 81.

right of way by, for earriages, 92

- right to light for windows by, 96

right to three-fuurths of a right of common by, 101

\section{PRESUMPTION}

of abandonment not to be made from mere non-user, 80

of property in private way, 103

of ownership of ditch, 131

of right to pollute water, 180

\section{PRINCIPAL}

responsible for agent's framd, $5 \% 6$

PRIVATE,

distinction between private and public way, 103

presumption of property in private way, 103

appropriation of private way, 105

dedieation of private road to publie, 106

warranty incorporated into conditions of sale, 551

PROFIT A PRENDRE,

right to take water from a well not, 77

what is, $78-81$

- liberty to sport is a, 384

\section{PUFFERS}

at auction sales, 550

QTANTUU MERUTT, recovery of remuneration on, 490

veterinary surgeon recovers on it, where no contract, 579 


\section{QLITTING,}

different times of, 433

\section{RABBITS,}

taking by night, 373

poacher found with, on highwas, 376

retaking them from poacher, $37 \mathrm{~s}$

property in, 379

right of tenant to kill, 380

labourer taking, by order of farmer, 381

liberty to kill, with ferrets only, 385

shooting, where exclusive right of shooting let, 392

trade meaning of 1000 rabbits, 482

\section{PACE-COURSE,}

claim of right by custom to use, 349

RACE-HORSE,

injury to, damage limited to $£ 50,254$

\section{PAIIWAYS,}

liability to maintain fences, 140

obligation as to gates, 145

obligation to fence, 146

their liability as to level crossings, 147

cattle straying on, throngh station yard, $14 \mathrm{~S}$

liability to maintain fence between railway and highway, 149

occupation road across, 150

not bound to fence one part of premises from another, 152

neglect to fasten gate, 152

bound to leave their gates shut, 152

sleep killed on, 153

water escaping from cutting into mine, 196

Railway Clauses Consolidation Act, 232

their liability at common law, 232

restriction of their liability by booking ticket, 233

injury to horses, 234

cattle, 235

through truck taking fire, 237

negligence, 238

collision, 240

construction of conditions on ticket, 241

Railway and Canal Traffic Act, 242

just and reasonable contract by, 244

injury to horse left in siding, 245

cattle suffocated in van, 246

horses placed in cattle truck, 247

cattle through being crowded, 251

contract with first railway does not make second railway liable, 251

must be sued within County Court district of principal place of business, 251

their conditions must be reasonable, 252 
RAILWAYS-eontinued.

injury to cow, 252

horse saldled and bridled, 252

eattle dealers on, travel at their own risk, 253

unreasonable conditions, 254

injury to racehorse, 254

valuable greyhound, 254

delay in forwarding pigs, $25 \%$

cheese, 257

by fall of snow, 259

sack conditions of Great Northern, 261

giving notice to consignor of consignee's refusal to receive, 263

delivery of goods by, within reasonable time, 264

injury to dog throngh being improperly secured, 264

fire by sparks from locomotive, 360

horses frightened by, 361

RATES,

rating of saleable underwoods, 119

rating of coprolites, 120

assessment of tithe to poor rate, 405

rent-charge of district church not rateable, 406

rent-charge not liable to sewers rate, 406

occupier of tithe rent-charge may deduct curate's salary from rateable value, 407 assessment of occupier of tithe rent-charge, 409

occupier's liability to pay rates, 438

RENT,

tender of, proper person to receive, 271

tender of, sufficient amends, 272

detaining goods after tender of, 274

agreement to take interest on rent in arrear. 277

authority by landlord to distrain for, $27 \mathrm{~s}$

payment of, under distress no admission of title, 278

action for, by tenants in common, 289

underlessee's power to distrain, 289

increase of, does not create new tenancy, 290

where claim is for, there can be no interpleader, 303

distress for, an affirmation of tenancy, 303

receipt of, prima facie evidenee of title, 411

an actual demise at yearly rent, implies a tenancy from year to Jear, 412

new tenancy not created by mere increase of rent, 412

power to distrain for, under Stat. 4 Geo. IV., c. 28, 418

lessee must seek lessor to tender rent, 426

eviction of tenaut when operating as suspension of rent, 437

occupier's power to deduct rates from rent, 438

right of occupier to deduct property-tax from rent, 441

receiving rents from an under-tenant-proof of use and oceupation, 418

re-entry on non-payment of, 451

reservation of, in corn, 452 
RENT-continued.

landlord's elaim for. uneler fi. fa., 469

rights of presumptive heir to. 169

receipt of, from third party, 760

RENT-CHARGE,

distraining cattle of stranger for, 275

recovery of, by distress, 280

distress by grantee of, 292

value of, 394

land only liable for tithe rent-eharge. 395

apportionment of, by commissioners, 396

on hops, 40j

of district chureh, not rateable, 406

not liable to sewers rate, 406

grantee of, liable to income-tax, 406

outgoings include land-tax and rent-charge, $\mathbf{4 0 7}$

occupier of, to deduct curate's salary from rateable ralne, $\mathbf{4 0 7}$

lessee of tithe rent-charge not entitled to dednet carate's stipend, 108 assessment of occupier of tithe rent-charge, 409

REPAIRS,

liability of surreyors for neglecting to repair highways, 103

right to repair fences in churehyards, 113

right to cut timber for necessary repairs, 127

duty of occupier to repair fences, 132

of private roau, 133

liability to repair highway, $13 t$

covenant to repair hedges, 310

to keep buildings in repair, 315

interest of reversioner in repair of premises, 425

corenant to repair, 426

to vield $11 p$ in good repair, 427

rule as to keeping premises in repair, 127

meaning of good repair, 428

tenant from year to year not bound to do substantial repairs, 428

measure of damages for not keeping in repair, 429

allowance by Conrt of Chaneery for repairs, 431

covenant to repair, 454

\section{REPIEVIN}

lies after tender male of sufficient sum before distress, $2 \pi 2$

only remedy where exorbitant demand marle for compensation, 273

lies for wrongful cletention of goods after tender, $\mathbf{2 7 9}$

when maintainable, 299

REP'RESENTATION,

tenant underletting by false, 422

distinction between it and warranty, 542

fraudulent at time of sale, 5is3

must be known to be false, 55.33

agent's, that he had power to act, 467 
INDEX.

\section{RESCUE}

of impounded cattle, $26 \pi, 26 \mathrm{~s}$

\section{RESERVATION}

of game by lessor, 384

of all royalties, 38.5

\section{TESERVOIR.}

licence to make, for ilye-water anil soke, $\%$

\section{REVERSION.}

injury to, by blocking up ancient lights, 77

right of reversioner to bring action for obstruction to easements. 87

assignees of, may be sned by ontgoing tenant on a contract or custom of the country, 319

injury to, by diverting stream, 194

distress by joint-tenants of, 288

\section{REVERSIONER,}

cannot bring action for simple trespass, $9 \dot{t}$

injury must be permanent to enable him to bring action, 95

action by, for chaining gate, 95

discharging eaves' water on land of, 107

legal possession of timber in, 110

right of, to bring action against surveyor of highways for cutting fence, 143

right of, to prevent waste, 309

action by, for trespass, $34 \mathrm{~s}$

cannot apprehend trespasser, 363

interest of, in repair of premises, 425

RIDING,

penalty for riding on foot-path, 141

horse without licence of owner, 561

RIPARIAN,

right of riparian owners to water, 171

rights of riparian owners generally, $17 \mathrm{~s}$

riparian or irrigation right, $18 \pi$

RIVER,

property in accretions from a non-navigable, 169

property in, ad medium filum aquec, 170

ROCKS,

right of lord of manor to fallen, 110

ROOKERY,

action not maintainable for firing a gun near, 385

ROOKS,

ferce nature, and not protected by either Common Law or Statute, 394

ROYALTIES,

reservation of, what included in, 385 
SACKS,

hire of, 260

conditions of Great Northern Railway as to, 261

private sack companies, 263

liability of consignor of grain as to hiring, 263

liabilities of hirers of, 263

SALE,

agreement for, of growing roots. hops and potatoes, 50

of fruit and regetables, 54

of growing timber and underwood, 55, 56

of growing crops, 59,60

of tillages, 61

of scized crops for full valne, 294

of farming stock taken in execution, $29 \mathrm{~s}$

of hay and straw to be consumed on the premises, 298

non-delivery of goods sold at sheriffs', 302

of a close inaccessible except by way over another close, 476

default of, by purchaser in complying with conditions of, 477

of reputed water-meadow, 479

of a fee-farm rent, 479

by sealed tenders, 479

printed particulars of, cannot be parol evidence, 479

of "Ware" potatoes, 480

of turnip seed, 487

of specific chattel on credit, 494

of Perusian guano, 514

of corn by sample, 523

of bad meat, 529

of bad cider, 529

of sulphured hops, 529

of refuse cake, $\tilde{\jmath} 30$

of sain-foin seed adulterated with burnet, 530

recovery of difference between salc and market price, 532

inaccurate particulars of, 540

right of agent to remuneration when sale goes off, 541

fruadulent representation at time of, 533

by servant, 555

on credit, 579

of improper sheep-wash, 577

by public auction, not sale in market overt, 5.97

of stolen liorses, 597

of glandered horses, 598

conspiracy to cheat by sale of horses, 598

SALE, BILL OF,

sale of tenants' goods under, 276

of goods not a removal, 295

when void against creclitors, 51;

assignment of, as security for debt, 516

seizure and sale under, 538 


\section{SALESMAN,}

drover no implied authority to receive money from, 229

his book-keeper liable for cattle sold, 230

SAMPLE,

ordinary rule of buying by, 483

bulk, not equal to, 484

article sold by, must be rejected within reasonable time, 481

right of purchaser to draw samples from bulk after purchase, 500

refusing to deliver to bankrupt vendee after sample taken, 499

right of vendee to compare goods delivered with sample, 502

SCIENTER,

gist of action for keeping dangerous animals, 155,156

evidence of dogs being wont to attack men not sufficient to support scicnter as to sheep, 157

what is evidence of, for jury, 159

put in issue by plea of not guilty, 166, 167

\section{SEA-SHORE,}

rights as to land formed by alluvion on, 168

incidents of, 168

no right to take land from another's close, which had drifted from sea-shore, 79

\section{SEED,}

sowing clover or grass seed docs not make permanent pasture, 308

sale of turnip, 487

acceptance of, what constitutes, 503

contract to furnish turnip seed, 507

warranty of seed barley, 514

warranty of, 526

sale of sainfoin seed adulterated with burnet, 530

conviction under Adulteration of Seeds Act 1869, 531

contract for sale of growing turnip seed, 536

\section{SERVANTS,}

hiring of, on Sunday, 199

temporary illness of, 199

express or implied bargain for service, 199

forfeiture of wages for misconduct, 200

general hiring of agricultural labourer, 200

jurisdiction of magistrates to discharge, 201

Master and Servants Act, conviction nuder, 201

huntsman a servant, 201

dismissal of, 203

contract for service for more than a year, 203

hiring by parol, 204

right of servant to quit, 206

monthly servants, 206 ;

gardener, a menial servant, 206

Truck Act, 207 


\section{SERTINTSE-continued.}

master's liability for act of, 211

veterinary surgeon liable for negligence of, 213

master liable where servant drives his own horse in master's service, 214

serrant killed by negligence of another, 214

no contract by master not to expose servant to risk, 215

master liable for injury to scrrant, 215

injury to stranger by negligence of, 217

injury to serrant liclping servant, 217

master liable for wilful conduct of, 217

injury to servant through negligence of fellow-scrvant, 218

injury to serrant using machine, 218

from unsafe laduer, 219

servant going indirect road, 219

using master's cart without leave, 219

liability of master as to, defined, 220

liability of master for debts contracted by, 222

larceny by farm-servants, 223

embezzlement by servant, 225

unauthorised warranty of horse by, 54.5

warranty by horse-dealers, 554

general rule of selling by, 555

warranty by servant merely entrusted to deliver, 555

rule of master taking back horse which will not answer warranty given by, $\tilde{5} 56$

borrowed horse must not be used by, 574

\section{SETTLEIENT,}

by hiring and service, 208

SHAPL,

badness of, in horse so as to cause unsoundness, 570

SHEEP,

evidence of dogs being wont to attack men, not sufficient to support scicnter as to, 157

dogs given to worrying, 158

killed on railway through defective fences, 153

right to shoot dogs engaged in worrying, 162

of thirel person, distrain of, 287

distrain of wrong sheep by bailiff, 278

sale of shcep affected with goggles, 567

joisoned by deleterious sheej-wash, 577

SHEEP-STEALING,

case of malicious prosecution for, 600

SIIEPHEIRD,

brcach of contract with, 208

SHIP,

injury of cattle on board, 231

mraning of mortality in policy of assurance, 231

rlcall of slaves caused by want of provisions on buard, 231 


\section{SHOOTING,}

dog, when justifiable, 161

dog, chasing deer, $36 \mathrm{~s}$

trespass by shooting from highway, 370

hare in turnpike road, 376

pheasant on another's land, 376

no penalty for shooting near rookery, $38 \dot{1}$

near decoy, 385

sale of right of, $38 s$

rabbits where exclusive right of sporting let, 392

\section{SLAUGHTER-HOUSE,}

right to slaughter cattle elsewhere than in a public slaughter-house, 602

action for negligence in not securing cow in, 602

penalty for using horse sent to kennels to be slaughtered, 603

SNOW,

delay on railway by fall of, 259

SOII,

compensation for damage to buildings through subsidence of soil by working mines, 101

right acquired by house after twenty years uninterruptel enjoyment to lateral support of, 101

right of seller in market to occupy soil with stalls, \&c., 518

SOLO ALIENO,

custom to take profit in, bad, 79

SOUND,

"this horse is sound," a warranty, 542

meaning of word as applied to horses, \&c., 565

SOUNDNESS,

warranty of, as to horses, 542

SOWING,

clover or grass seed does not make permanent pasture, $30 \mathrm{~s}$

injunction to prevent sowing mustard seed or flax, 309

penalties for sorving noxious plants, 313

SPARKS,

herbage burned by sparks from engine, 359

fire caused by sparks from, 360

SPAVIN,

definition of, 549

SPECIAL, CONTRACT,

may be made by railway companies with their customers, 243

SPECIFIC PERFORMANCE, enforcing specific performance of farming agrcement, 171

SPLINT,

(in horses), 571 
SPORTING,

lorl of manor's exclusive right of, 352

grant of liberty of, 384

right of, over cattle gates, 386

demise of, not under seal, $3 \& 7$

lease of exclusire right of, $3 \mathrm{ss}$

shooting rabbits where cxclusive right let, 392

SPRING GUXS,

set in wood with notice, 390

in walled garden, 390

detinition of, 391

STACK,

horsc killed by fall of, 139

firel by sparks from l'ailway, 360

fired by spontaneous ignition, 360

sold but burnt beforc paid for, 494

STALLS,

law of market as to oceupation of, 517,518

STAMPS,

appraisement, when sufficient, 332

on agreements, 416

ad ralorem stamp duty, 416

when not necessary, 417

meaning of subject matter in "Stamp Act," 417

agreement requiring stamp, 464

warranty does not require stamp, ̃̃s

STATUTE OF FRAUDS (see FraUdS).

STRAW,

sale of. to be consumed on premises, 298

custom of country as to consumption of, 299

covenant to consume. 326

consumption of, by incoming tenant, 327

bringing of value of straw back in manure, 330

meaning of "value" of, 337

selling straw without written licenec, 338

STRAWBERRY·BEDS,

waste to plough up, 308

STRIYGHALT,

unsoundness in horse, 569

SUNDAY,

hire of lalowurers on, 199

Leror:-r]e:sling on, legality of, 5010

Inares ervered on, 56;is

farmer not within Sunday Trading Aet, 563 


\section{SURFACE,}

definition of surface damage, 99

damage to surface of land, 100

surface water, 186

SWANS,

subjects of larceny, 345

SWINE,

late for market through delay on railway, 257

kept so as to be a nuisance, 602

\section{TAXES,}

grantee of rent-charge, liable to income-tax, 406

right of tenant to deduct income-tax from rent, 439

outgoings include land-tax, 407

assessment for land-tax, 438

special agreement by tenant to pay land-tax, 439

right of occupier to recover property-tax on behalf of landlord, 440

right of occupier to deduct property-tax from rent, 441

TENANT,

agreement with landlord to accept new tenant, 61

agreement to suffer another to become tenant for residne of term, 62

agreement by tenant to pay landlord for consent to assignment of term, 66

right to take water from well, 66

mortgagee of tenant's fixtures has an interest in land, 68

right of tenant for life to sell growing timber, 111

to cut ripe timber, 111

for life, barred by lapse of time from receiving proceeds of timber cut by previous tenant, 111

for life, permissive waste by, 112

tenants in common of a tree, their rights, 116

tenant's right to dotards, 124

has no right to remove box edgings though planted by himself, 125

sale of tenant's goods under bill of sale, 276

bill of exchange by tenant to agent, 277

distress after death of, 282

fraudulent removal of goods by, 284

demise by a tenant from year to year, 289

increase of rent does not necessarily create new tenancy, 290

distress an affirmation of tenancy, 303

right of tenant to away-going crop, 319

to compensation for tillages, 320

outgoing tenant must give up possession to landlord, 321

outgoing tenant's corn may be distrained after expiration of term, 321

right of outgoing tenant to away-going crop, 321

assignment of tenant-right, 323

compensation to outgoing tenant, 329

for drainage and manure, 330

right of outgoing tenant to onstand for manure, 339

estoppel of tenant from deuying landlord's title, 357 
TEISNT-continued.

rights of permissive tenant, 357

itssee for half-year, tenant for ycars, 410

new tenaney not created by increase of rent, 412

right of tenant to speeific performance, $\mathbf{4 1 4}$

estoppel between landlord and tenant, $\$ 18$

arbitrators between outgoing and ineoming tenant, 419

refusal of entrance by lessor to new temant, 423

refusal of tenant to show farm. $\$ 23$

tenant from year to year not bound to do substantial repairs, 428

notice to quit when date of commencement of tenancy unknown, 433

tenaney of glebe lands under two incumbents, 435

action in County Court by landlord to evict tenant, 437

eriction of tenant when operating as suspension of rent, 437

from pareel of demised premises, no answer to action for breach of corenant, 437

special agreement by tenant, to pay land tax, 439

right of tenant to deduct income-tax, 439

ownership and tenancy, primâ fucie evidence of contract, 447

holding over by co-tenant, 450

tenant's right to remove barn, 455

starel barn, 4505

water fender, 456

staddles, thrashing-machine and granary, 457

barn on blocks, 458

building when landlord finds materials, 459

fixture after determination of tenancy, 460

pillars of brick, 460

trover by tenant for fixtures. 461

removal of buildings, after ejectment bronght, 461

leaving fixtures in same condition, 462

contract for quiet enjoyment by, 463

not bonnd to take house serionsly defective, 464

paying tenant-right to false devisee, 171

trespass by tenants on waste, 346

TENANTS-IN-COMMON,

rights of, as to timber, 116

clipping edge by one, 135

action for rent by, 289

action by, 452

action by one, against another, 170

TENANT-RIGHT, 1

\section{TENDER,}

of amends when not too late, 270

of rent, proper person to receive, 271

of sufficient amends, 272

detaining cattle after, 274

detaining gonds after tender of rent, 274

trespass maintainable after, 273 
THATCHER,

liability for letting out incompetent, 213

THRASHING-MACHINES, implements of husbandry, 341

exempt from toll, except liable by local act, 342

action for non-delivery of, within certain time, 510

TILLAGES,

agreement for sale of crops and tillages an interest in land, 61 payment by landlord for, 331

valuation of, 332

TIMBER,

sale of growing, 55

right of way to cart away, 92

general demise of land with, 109

property in, 110

right to, when severed, 110

action of waste for felling, 110

right of tenant for life to sell growing timber, 111

definition of timber, 112

to cut ripe timber, 111

taking timber for house-bote, 114

conversion of timber trees, 114

custom of copy-holders to fell, 114

definition of timber trees, 118

pollard willows not, 123

ornamental timber, 126

proceeds of timber, which required felling on life estate, 126

entry by landlord to cut, 127

entire timber contract, 127

delivery and acceptance of, under Statute of Frauds, 130

right of tenant to remove building when landlord finds part of, 459

TITHES,

right of road for, 93

can only pass by deed, 288

Acts relating to, 394

20 years' perception of, 394 .

bequest of pure personalty to restore tithes roid, 395

land only liable for, 395

intention of Tithe Commutation Act, 395

right of vicar to small tithes, 396

of beans and peas, 396

distress under Tithes Act, 397

exemption from, 398

award by Tithe Commissioner, 399

actions against Tithe Commissioners, 401

action for treble value of, 403

expenses incident to apportionment of, 404 


\section{TITHES-continucd.}

assessment of to poor-rate, 405

annexation of portion of, to district church, 405

jurisdiction of Commissioner of, 406

right of oceupier of, to deduet curate's salary from rateable value of, $\mathbf{4 0 7}, 108$

assessment of oceupier of, 409

TITLE-DEEDS,

largest purchaser entitled to, 478

TOP,

corenant not to lop or top trees, 109

rule as to tops of hedges, 136

TRADE TERMS,

parol eridence, admissible to explain, 481

TRAPS,

laying, for dogs, 389

TREES,

general property in, 109

cxception of, in lease, 109

corcnant not to lop or top, 109

right to, in ehurchyards, 113

cutting down ornamental trees by devisee in fee, 113

claim of right to enter a close and cut down, 113

cutting down trees in order to work quarries, 115

trustees cannot bring trover for trees felled, 115

lessor may bring trover for bark of trecs cut, 115

interest of lessor and lessee in, 115

lessee's general property in trees not timber, 116

tenants in common of a tree, their rights, 116

rule as to property in, 117

definition of timber trees, 118

right of nurseryman to remore trees, 122

definition of waste as applicd to, 122

covenant not to grub, 125

cutting down willow trees to the butt, 122

rule of standing trees, 127

stealing or injuring trees, 136

TRESPASS,

trespasser cutting timber by collusion with tenant, 115

aggravated trespass by landlord, meisure of damages for, 127

maintainable after tender of rent duc, 279

trespassers $a b$ initio in the matter of a distress, 304

right to bring, 343

posscssory right sufficient to maintain, 313

right of churchwardens and overseers to maintain, 343

plea of not guilty to, 344

for working an estray, 344

for breaking a dovecote, 341 
TRESPASS-continned.

possession, legal possession against trespassers, 345

maintainable by purchaser of growing crops, 317

on subsoil, 347

does not lie for entering a close to retake goods wrongfully brought there, 347 action by reversioner for, 348

de bonis asportatis by auctioneer, 348

plea of leave and licence in, 349

for horse-racing, 349

trespasser's right of action for injury, 349

against surveyor of highways, 351

for continuing building on land, 353

after notice, 353

certificate of costs in action for, 351

by breaking locks and chains, 357

construction of malicious trespass, 358

damages for, 359

no notice necessary to trespassers, 363

provisions against trespassers do not apply to fresh pursuit of game, 363

reversioner cannot apprehend trespasser, 363

law as to hunting trespass, 365

inciting friends to commit, 366

in defiance of notice, 366

no action lies for involuntary trespass, 367

by dog against master's will, 367

by shooting from highway, 370

right to apprehend trespasser, 371

for entering fishery, 375

conviction for trespass, 377

trespassing on land where game reserved to lord of the manor, $38 ;$

TRIAL,

of loorse, what is reasonable, 574

TRUCK ACT, 207

TURBARY.

trespass does not lic for mere right of eommon of, $3 \mathrm{tt}$

\section{TURNIP SEED,}

sale of, 487

warranty of Skirving's swedes, 488

contract to furnish, 507

contract for sale of, 536

\section{TURNPIKES.}

construction of " other thing" in Turnpike Roals Act, 107

exemptions from toll, $340,341,342$

\section{TURVES.}

right to dig, an interest in land, 66

right to dig them a profit à prendre, 78

exclusive right to dig, gives right to bring trespass, 344 
LNDERGROTNT.

right of owner of surface to underground strata, 81

UXDER-IESSEF.

power of. to distrain, 289

LNUERLETTING, penalty for, 314

not excluded by words " use and occupation," $\$$ t?

covenant not to underlet, 453

UNDERWOD,

sale of growing, an interest in land, 56

meaning of "woods and underwoods." 109

larch not saleable miderwoods, 119

rating of saleable underwoods, 119

injunction granted against tenant for life eutting underwood of insufficient growtls, 121

UNITY OF OWNERSHIP, destroys prescriptive right, 76 destroys obligation to repair fences, 135

\section{LNITY OF POSSESSION,}

suspeuds title by prescription, 76

defeats easement, $8: 3$

effect of, on way of necessity, 88

UNSOCNDNESS,

positive proof of, when necessary, 563

what constitutes, 504

permanent cough, 568

roaring, 568

stringhalt, 569

laminitis, 569

contraction of hoof, 569

navicular joint-disease, 569

chest.foundered, 570

cataraet, $5 \pi 0$

affection of nerres in lumbar region, 570

badness of shape not, iz70

curby-hocks, 570

thin soles. 571

Ellint, 571

purchaser's duty to return unsound horse, 593

purehaser's duty when warranted horse proves unsound, 595

USE AND OCCUPATION,

action for, 445

implied arreement to pay for, 446

when it will lie. 446

may lic where action for rent not maintainable, 446

will not lie when title in dispunte, $\$ 16$

does not inclurle underletting. 419 
USER.

plea of 40 years', 82

immemorial right of way not lost by non-user, 86

presumption of abandonment not to be made from mere non-nser, 86 proof of user of right of common of pasture, $s t$

of way for agricultural puposes, 91

YALUATION,

of tillages, 332

what stamp sufficient for, 332

fair valuation or eonsuming price, 334

of rent-charge, 394

agreement, 465

agreement to bring value of straw back in manure, 3.35

meaning of "value of straw," 336

right of outgoing tenant for onstand for manure sold at a valuation, 339

VALUER,

of ecelesiastical property, amount of knowle:lge required in, 333

duties of, 333

disqualifieation of, by interest, $40 t$

\section{VEGETABLES,}

agreement for sale of, an interest in lani, 54

VENDEE,

right of way of, to lands purchased, 90

refusal of, to complete purehase for want of way to land purchased, 90

right of, to insist on vendor's personal reeeipt of money, 1.75

right of, to recover preliminary expenses, 47 ;

\section{VENDOR,}

annexation by, of rights eonnected with land, 87

right of, to reseind contraet, 474

right of reudee to insist on vendor's personal receipt of money, 475

right of vendor, to recover preliminary expenses, 475

refusal of, to show in bulk, 482

eannot reeover price of part of contract, 191

rights of, in public market, 518

liable for false representation of lease, 538

\section{VETERINARY}

surgeon liable for negligenee of his servant, 213

warranty by veterinary surgeon as agent, 5.57

livery-stable keeper no lien for veterinary eharges, 576

claim by veterinary surgeon, $\tilde{579}$

WAGES,

forfeiture of, by miseonduct, 200

presumptive evidence of payment of, 199

elaim for, during temporary illness, 199

WAIVER,

filling up bond by purchaser before parment no waiver of title, 124 


\section{WARRANTY,}

by skilled person that he possesses skill requisite to perform the task which lie undertakes, 203

sale of seed not corresponding with, 4 s

notice necessary that article does not correspond with. 487

application of Statute of Limitations in such cases, 487

of Skirving's swedes, 458

seed wheat, 488

sounil meat, 459

seed barley, 514

seed, 526

where not implied, $\tilde{5} 27$

not implied, that meat fit for food, $52 \mathrm{~S}$

of soundness in horse, 542

distinction between warranty and representation, 542

"this horse is sound," a warranty, 542

general rule as to, 543

of horse being elever hack, 544

unauthorised warranty by servant, 545

horse warranted 6 years old, but actually 12, may be returned, 551

private warranty incorporated into conditions of sale, 551

written warranty, 552

general rule as to, 553

by servant of horse-dealer, 554

by stranger, 555

by servant, merely entrusted to deliver, 555

rule of master taking back horse which will not stand to warranty giren by servant, 556

by veterinary surgeon as agent, 557

plea of breach of warranty, 5.58

stamp on warranty, 558

that horse "sound and quiet in harness," 561

" good drawer," 561

when continuing, 563

гесотеry of keep when warranty broken, 593

purchaser's duty when warranted horse proves unsound, 595

WARREN,

breaking up rabbit warren, when not waste at eommon law, 310

penalty for taking rabbits by night in, 373

franchise of free warren, 384

WATER,

right of way of passage of, 70

licence to divert, 73

claim to spring of, 74

right to use muniug, 77

right to take from well, 78

riglit to take pot water, 78

right to water cattlo, 78 
WATER-continued.

discharging eaves' water on reversioner's land, 107

right of fishing passes by grant of, 170

right of riparian owners to, 171

flowing in a stream is publici juris, 172

appropriation of running water, 173

right to water not in a flowing stream, 174

law of right to a spring of water, 175

law as to flowing water, 176

abstraction of subterranean water, 177

law as to artificial water courses, 180

flow of water from and into collieries, 150

right of polluting water, subject of grant, 181

presumptive right to pollute, 180

difference between drain and water-course, 182

flow of, from drain for agricultural improvements, 183

right to artificial water-course, 181

rights as to rain water, 185

surface water, 186

diversion of, for irrigation, 189

escaping from railway cuttings into mine, 196

working mines under water-course, 196

supplying horses with, from public fountain, 197

compensation to tenant for life for loss of, 198.

WASTE,

action of, for felling timber, 110

right of tenant for life to sell severed timber without impcachment of, 111

permissive, by tenant for life, 112

when action for, will not lie by one tenant in common against another, 116

acts of, 307

by ploughing up ancient meaclow, 308

by breaking up rabbit warren, 310

right of lessor to sue for, 309

right of reversioner to prevent, 309

by ploughing up pasture, 312

by sowing noxious plants, 313

overcropping not, 315

inclosure of, by churchwardens and overscers, 343

encroachments by tenants on, presumably for benefit of landlord, 346

claim to waste land, by lord of manor, 346

dilapidations of buildings built on, 431

property in waste land adjoining road, 143

WAY,

right of, definition of, 70

plea of 40 years' user of, 82

continuous enjoyment of right of, 83

plea of one year's enjoyment of way uncler stat. $2 \& 3$ Will. IV., c. 71, s. 2,84

immemorial right of way not lost by non-user, 86 


\section{WAY-continued.}

presumption of abandonment not to be made from non-user, 86

parol agreement for substitution of new way no evidence of abandonment, 87 of necessity, 87

cannot be pleaded without showing its character, $\$ S$

effect of unity of possession of, 88

law as to, 88

definition of, 88

limited by necessity which created it, 89

arises from presumed grant, 89

right of, can only arise by grant, 90

limited dedication of way to the public, 91

ralid dedication of, to the public, how made, 91

right of, for agricultural purposes, 91

to cart away timber, 92

prescriptive right of, for earriages, 92

claim of, for cattle and carts, how proved, 93

plea of right of, for horses, waggons, Sc., 93

right of, for farming purposes does not include all purposes, 93

for tithes, 93

grantee of an occupation way, 93

obstruction of public footway, 94

distinction between private and public way, 103

presumption of property in private way, 103

right of, appurtenant to plot, $10 t$

implied grant of way of necessity, 104

power of Inclosure Commissioner's to set out private road, 105

appropriation of private way, 105

right of way under deed of partition, 105

dedieation of prisate road to public, 106

selling one part of settled estate to pay for making roads through another part,

106

excavation near footway, 350

reasonable use of right of way, 357

\section{WEIGHTS AND MEASURES}

in different markets, 521

abulition of local measures, 522

sale by the hobluett, 522

WEIL,

right to take water from, 78

claim to spring of water, 74

right to take water from a well not a profit a prendre, 79

law of right to a spring, 175

right to sink wells, 177

right to cut off spring at source, 179

abstraction of subterranean water by sinking well, 177

WIID-FOWL,

penalty for shouting, near decoy, 38j 
WINCHESTER BUSHEL

an illegal measure, 521

WINDOWS,

stopping mp, prima farie abandonment, 77

obstruction of ancient, 77

prescriptive right to light for, 96

twenty years' enjoyment of light, 97

ancient lights may be altered, not enlarged, 97

new lights not corresponding with old, 98

WOODS,

meaning of, 109

rating of, 119

WOODWARDS,

their right to grant licences to frec miners, 80

WORRYING

of sheep by dogs, 157, 158

THE END. 



\section{A OATALOGUE \\ L A W W O R K S, \\ PUBLISHED BY}

\section{STEVENS AND SONS,}

119, CHANCERY LANE, LONDON, W.C.

(Formerly of Bell Yard, Lincoln's Inn).

Law Books Purchased or Valued.

Acts of Parliament. - Public and Local Acts firom an early date, may be had of the Publishers of this Catalogne, who have also on sale the largest collection of Private Acts, relating to Estates, Enclosures, Ricilways, Roadls, \&e., \&e.

ACTION AT LAW.-Foulkes' Elementary View of the Proceedings in an Action.-Founded on "Sнith"'s Action at LAw." By W. D. I. FOULKES, Esq., Barrister-atLaw. Second Edition. 12mo. 1879.

"The student will find in 'Smith's Action' a manual, by the study of which he may easily acquire a general knowledge of the mode of procedure in the various stages of an action in the several divisions of the High Cuurt of Justice."-Law Times.

Peel.-Vide "Chancery."

Prentice's Proceedings in an Action in the Queen's Bench, Common Pleas, and Exchequer Divisions of the High Court of Justice. Second Edition. By SAMUEL PRENTICE, Esq., one of Her Majesty's Counsel. Royal $12 \mathrm{mo.}$

"The book can be safely recommended to students and practitioners"-Lozo Timcs.

Smith's Action.--Vide "Foulkes."

ADMIRALTY.-BOyd.-Vide "Shipping."

Lovvndes.-Marsden.-Vide "Collisions."

Pritchard's Admiralty Digest.-With Notes from Text Writers, and the Scotch, Irish, and American Reports. Second Edition. By ROBERT A. PRITCHARD, D.C.I., Barrister-at-I $\mathrm{aw}$, and WILLIAM TARN PRITCHARD. With Notes of Cases from French Maritime Law. By ALGERNON JONES, Avocat à la Cour Impériale de Paris. 2 vols. Royal 8vo. 1865.

$3 l$.

Roscoe's Treatise on the Jurisdiction and Practice of the Admiralty Division of the High Court of Justice, and on Appeals therefrom, \&c. With an Appendix containing Statutes, Rules as to Fees and Costs, Forms, Precedents of Pleadings and Bills of Costs. By EDWARD S'TANLEY ROSCOE, E:q., Barrister-at-Law, and Northern Circuit. Demy 8vo. 1878.

" Ir. Roscoe has performed his task well, supplying in the most convenient share a clcar digest of the law and practice of the Admiraity Courts." - Liveryool Courier.

* * All standard Lew Works are keyt in Stock, in lave calf and other bindings. [No. 3.] 
AGENCY.-Petgrave's Principal and Agent.-A Manual of the Law of Principal and Agent. By E. C. PETGRAVE, Solicitor. $12 \mathrm{mo}$. $155 \%$.

7s. $6 d$.

Petglave's Code of the Lavv of Principal and Agent, with a Preface. By E. C. PETGRAVE, Solicitor. Demy 12mo. 1876.

Net, 2 s.

Rogers.- Viile "Elections."

Russell's Treatise on Mercantile Agency.-Second Edition. Sro. 1873.

AGRICULTURAL LAW.-Addison's Practical Guide to the Agricultural Holdings (England) Act, 1875 (38 \& 39 Vic. c. 92), and Treatise thereon, showing the Alterations in the Law, and containing many useful Hints and Suggestions as to the carrying out of the Provisions of the Act; with Handy Forms and a Carefully Prepared Index. Designed chiefly for the use of Agricultural Landlords and Tenants. By ALBERT ADDISON, Solicitor of the Supreme Court of Judicature. 12mo. 1876. Net, 2s. 6 d.

Cooke on Agricultural Lavv.-The Law and Practice of Agricultural Tenancies, with Numerous Precedents of Tenancy Agreements and Farming Leases, \&c., \&c. By G. WINGROVE COOKE, Esq., Barrister-at-Law. Svo. 1851.

188.

Dixon's Farm.- Fide "Farm."

ARBITRATION.-Russell's Treatise on the Duty and Power of an Arbitrator, and the Law of Submissions and Award's; with an Appendix of Forms, and of the Statutes relating to Arbitration. By FRANCIS RUSSELL, Esq., M.A., Barrister-at-Law. Fifth Edition. Royal 8 ro. 1878

MRTICLED CLERKS.-Butlin's New and Complete Examination Guide and Introduction to the Law; for the use of Articled Clerks and those who contemplate entering the legal profession, comprising Courses of Reading for the Preliminary and Intermediate Examinations and for Honours, or a Pass at the Final, with Statute, Case, and Judicature (Time) Tables, Sets of Examination Papers, \&c., \&c. By JOHN FRANCIS LUTLIN, Solicitor, \&c. 8vo. 1877.

"A sensible and useful guide for the legal tyro."-Solicitors' Jounnal.

"In supplying law students with materials for prcparing themselves for examination, Yr. Butlin, we think, has distanced all competitors. The volume before us contains hints on reading, a very neat summary of law, which the best read practitioner need nat despise. There are time tables under the Judicature Act, and an excellent tabular arrangcment of leading cases, which will be found of great service... Tuition of this kind will do much to remove obstacles which present themselves to commencing etudents, and when examinations are over the book is one which may be usefully kept close at hand, and will well repay 'noting up." "-Law Times.

Rubinstein and Ward's Articled Clerks' Handbook.-Being a Concise and Practical Guide to all the Steps Necessary for Entering into Articles of Clerkship, passing the Preliminary, Intermediate and Final Examinations, obtaining Admission and Certificate to Practise, with Notes of Cases affecting Articled Clerk, Suggestions as to Mode of Reading and Books to be read during Articles. Second Edition. By J. S. RUBINSTEIN and S. WAPD, Solicitors. $12 \mathrm{mo} .1878$.

"No articled clerk should be without it."-Law Times.

"We think it omits nothing which it ought to contain."-Lavo Joumal.

Wharton's Articled Clerk's Manual.-A Manual for Articled Clerks : being a comprehensive Guide to their successful Examination, Admission, and Practice as Attorneys and Solicitors of the Superior Courts. Ninth Edition. Greatly enlarged. By C. H. $\triangle$ NDERSON. Royal 12mo. 1864. $18 \mathrm{~s}$. * * All standard Law Works arc kept in Stock, in law calf and other bindings. 
ARTICLES OF ASSOCIATION.-Palmer.-Vide "Conveyancing." ATTORNEYS.-COrdery.-Vide "Sulicitors."

Pulling's Law of Attorneys, General and Special, Attorneys-at-Law, Solicitors, Notaries, Proctors, Conveyancers, Scriveners, Land Agents, House Agents, \&c., and the Offices and Appointments usually held by them, \&c. By ALEXANDER PULLING, Serjeant-at-Law. Third Edition. 8vo. $1862.18 \mathrm{~s}$.

"It is a laborious work, a careful work, the work of a lawyer, and, beyond comparison the best that has ever been produced upon this subject."-Law Times.

Smith.-The Lavvyer and his Profession.-A Series of Letters to a Solicitor commencing Business. By J. OR'ON SMITH. $12 \mathrm{mo} .1860 . \quad 4 s$.

AVERAGE.-Hopkins' Hand-Book on Average.-Third Edition. 8vo. 1868. 188.

Lowndes' Law of General Average.-English and Foreign. Third Edition. By RICHARD LOWNDES, Author of "The Admiralty Law of Collisions at Sea." Royal 8vo. 1878. 21s.

BALLOT.-FitzGerald's Ballot Act.-With an INrroduction. Forming a Guide to the Procedure at Parliamentary and Municipal Elections. Second Edition. Enlarged, and containing the Municipal Elections Act, 1875, and the Parliamentary Elections (Returning Officers) Act, 1875. By GERALD A. R. FITZGERALD, Mr. A., of Lincoln's Inn, Esq., Barrister-at-Law. Fcap. 8vo. 1876. 5s. $6 d$. "A useful guide to all coucerned in Parliamentary and IInicipal Elections."-Lais Magazine.

"We should strongly advise any person connected with electious, whether aeting as candidate, agent, or in any other capacity, to become possessed of this manual."

BANKING.-Walker's Treatise on Banking Lavv. Iir. cluding the Crossed Checks Act, 1876, with dissertations thereon, also references to some American Cases, and full Index. By J. DOUGLAS WALKER, Esq., Barrister-at-Law. Demy 8ro. $1877 . \quad 14 \mathrm{~s}$.

"The work has been carefully written, and will supply the want of a compact sunsmary of Banking Law."-Solicitors' Journal.

"Persons who are interested in banking law may be guided out of many a difficulty by consulting Ir. Walker's volume."-Law Times.

BANKRUPTCY.-Bedford's Final Examination Guide to Bankruptey.-Third Edition. $12 \mathrm{mo}$. $1877 . \quad 6 s$.

Haynes.-Vide "Leading Cases."

Lynch's Tabular Analysis of Proceedings in Bankruptcy, for the use of Students for the Incorporated Law Society's Examinations. Second Fdition. 8vo. 1874. Net, $1 s$.

Scott's Costs in Bankruptey.-Vide "Costs."

Smith's Manual of Bankruptcy.-A Manual relating to Bankruptcy, Insolvency, and Imprisonment for Debt ; comprising the New Statute Law verbatim, in a consolidated and readable form. With the Rules, a Copious Index, and a Supplement of Decisions. By JOSIAH W. SMITH, B.C.L., Q.C. 12mo. 1873. * * The Supplement may be had separately, net, $2 s .6 d$.

Williams' Law and Practice in Bankruptey: comprising the Bankruptcy Act, the Debtors Act, and the Bankruptcy Tepeal and Insolvent Court Act of 1869, and the Rules and Forms made under those Acts. Second Edition. By ROLAND VAUGHAN WILLIAMS, of Lincoln's Inn, Esq., and WALTER VAUGHAN TVILLIAMS, of the Inner Temple, Esq., assisted by Francis Hallert Fiaddastle, of the Inner Temple, Esq., Barristers-atLaw. 8уo. 1876.

" Williams on Bankruptcy' is quite satisfactory."-Law Magazine.

" It would be difficult to speak in terms of undue praise of the present work."

* * All standard Law Works are Kept in Stock, in law calf and other bindings. 
BAR, GUIDE TO THE.-Shearwood.-Vide"Examination Guides." BILLS OF EXCHANGE.-Chalmers' Digest of the Lav of Bills of Exchange, Promissory Notes, and Cheques. ByM.D. CHALMERS, of the Inner Temple, Esq. Barrister-at-Law. Demy Svo. 1878.

12s. $6 \mathrm{cl}$.

* * This work is in the form of the Indian Codes, besides the English Cases it is noted up "with reference to the French Law and the German Cade, and on doubtful points to the more recent $A$ merican Decisions; it also contains a table of overruled or doubtcd eases.

"Mr. Chalmers has cono wisely in casting his book into its present form, and the plan, thus well conceired, has been most effectually eartied out. As a handy book of reference on a difficult and important branch of the law, it is most valuable, and it is nerfectly plaiu that no pains bave been spared to render it complete in every respect. The index is copions and woll arranged."-Saturday Reviero.

"The book is mot only well planned, but well executed . . . . . for the rising generations and for men of business this digest will be a gift of no small value."-Pall Mat Gazelle.

Chitty on Bills of Exchange and Promissory Notes, with references to the lavv of Scotland, France and America.-Eleventh Edition. By JOHN A. RUSSELL, Esq., I.L.B., one of Her Majesty's Counsel, and Judge of County Courts. Demy 8vo, 1878.

17. $8 s$.

Eddis' Rule of Ex parte Waring. By A. C. EDDIS, B. A., of Lincoln's Inn, Barrister-at-Law. Post 8vo. 1876. Net, 2s.6d.

BILLS OF SALE.-Cavanagh.-Tide "Noney Securities."

Millar's Bills of Sale.-A Treatise on Bills of Sale, with an Appendix containing the Acts for the Registration of Bills of Sale Precedents, \&c. (being the Fourth Edition of Millar and Collier's Treatise on Bills of Sale). By F. C. J. MILLAR, of the Inner Temple, Esq., Barrister-at-Law. 12mo. 1877.

"The original work is brought down to date, and the latest cases are referred to and considered. The value of the work is enhanced thronghont by careful annotation." -Lavo Magazine.

BOOK-KEEPING.-Bedford's Intermediate Examination Guide to Book-keeping.-Second Edition. 12mo. 1875. $N e t, 2 s .6 d$.

CANAL TRAFFIC ACT.-Lely's Railway and Canal Traffic Act, 1873.-And other Railway and Canal Statutes; with the General Orders, Forms, and 'Table of Fees. Post 8 vo. 1873. 8s.

CARRIERS.-Browne on Carriers. - A Treatise on the Law of Carriers of Goods and Passengers by Land and Water. With Jieferences to the most recent American Decisions. By J. H. BALFOUR BIOWVNE, of the Mirdle Temple, Esq., Barrister-atLaw, Registrar to the Railway Commission. 8vo. $1873.18 \mathrm{~s}$.

CHANCERY, and Vide " EQUITY."

Daniell's Chancery Practice. - Sixth Edition, by IEONARD FIELD and EDIVARD CLENNELI, DUNN, Barristers-at-Law; assisted by W. H. UPJOHN, Student and Iolt Scholar of Gray"s Inn, \&c., \&c., Editor of "Daniell's Forms, Ttird Edition." 2 vols. 8vo.

(In meparation.)

Daniell's Forms and Precedents of Proceedings in the Chancery Division of the High Court of Justice and on Appeal therefrom; with Dissertations and Notes, forming a complete guide to the practice of the ('hancery Division of the High Court and of the Courts of Appeal. Being the 'Third Edition of "Daniell's Chancery Torms." Byy WIILIAM JENRY UPJOHN, Esq., Student and Holt Scholar of Gray's Inn, Exhibitioner in Jurisprudence aud Roman

** All standard Law II"orks are kcpt in Stoek, in law calf and other bindings. 
CHANCERY.-Contimued.

Law in the University of London, Holder of the First, Senior Str. dentship in Jurisprudence, Roman Law and International Law awarded by the Conncil of Legal Education in Hilary Term, 1879. In one thick vol. Demy 8vo. 1879. $2 l .2 s$.

"Mr. Upjohn has restored the volume of Chancery Forms to the place it held lefore the recent changes, as a trustworthy and complete collection of precedents. It has all the old merits; nothing is omitted as too trivial or commomplace ; the solicitor's elerk finds how to indorse a brief, and how, when necessary, to give notice of aetion : and the index to the forms is full and perspicuous." - Solicitors' Journal.

"It will be as useful a work to practitioners at Westminster is it will be to those in Lincoln's Inn."-Laio Times.

Haynes' Chancery Practice.-The Practice of the Chancery Division of the High Court of Justice and on Appeal therefrom, for the use of Practitioners and students. - By JOHN F. HAYNES, LL.D. Author of the "Student's Leauling Cases," \&c. Demy 8vo. 1879.

$11.5 \mathrm{~s}$.

"Materiais for enabling the practitioner himself to obtain the information he may require are placed before him in a convenient and aecessible fol $\mathrm{m}$. The arrangement of the work appear's t, be good."-Lavo Magazine and Reviev, February, 1850.

Morgan's Chancery Acts and Orders.-The Statutes, General Orders, and Rules of Court relating to the Practice, Pleading, and Jurisdiction of the Supreme Court of Judicature, particularly with reference to the Chancery Division, and the Actions assigned thereto. With copious Notes. Fifth Edition. Carefully revised and adapted to the new Practice by GEORGE OSBORNE MORGAN, M.P., one of Her Majesty's Counsel, and CHALONER W. CHU'IE, of Lincoln's Inn, Barrister-at-Law, and late Fellow of Magdalen College, Oxford. Demy 8vo. 1876. 11.10s. " This edition of Mr. Morgan's treatise must, we believe, be the most popular with the profession."-Lav Times.

Morgan and Davey's Chancery Costs. - Vide "Costs."

Peel's Chancery Actions.-A Concise Treatise on the Practice and Procedure in Chancery Actions.-By SYDNEY PEEL, of the Middle Temple, Esq., Barrister-at-Law. Demy 8vo. 1878. Ts. 6d. "To Chancery practitioners of both branches the volume will doubtless prove very useful."-Law Times.

CHANCERY PALATINE OF LANCASTER.-SnOW and Winstanley's Chancery Practice.-The Statutes, Consolidated and General Orders and Rules of Court relating to the Practice, Pleading and Jurisdiction of the Court of Chancery, of the Comnty Palatine of Lancaster. With Copious Notes of all practice cases to the end of the year 1879, Time Table and 'Tables of Costs and Forms. By THOMAS SNOW. M.A., and HERBERT IVINSTANLEY, Esqrs., Barristers-at-Law. Royal 8vo. 1880. (Nearly readly.)

CIVIL LAW.-BOWyer's Commentaries on the Modern Civil Law.-By Sir GEORGE BOWYER, D.C.L., Royal 8vo. 1848.

Bowyer's Introduction to the Study and Use of the Civil Law.-By Sir GEORGE BOWYER, D.C.I. Royal 8vo. 1874 .

$5 s$.

Cumin's Manual of Civil l_aw, containing a 'Translation of, and Commentary on, the Fragments of the XII. Tables, and the Insiitutes of Justinian; the Text of the Institutes of Gaius and Justinian arranged in parallel columns; and the Text of the Fragments of Ulpian, \&c. By P. CUMIN, M.A., Barrister-at-Law. Second Edition. Medium 8vo. 1865. * All standard Law Works are kept in Stock, in law calf and other bindings. 
CIVIL LAW.-Continued.

Voet Commentarius ad Pandectas, Translated into English.-Part I. The Contract of Sale. (Book xviii.) By SIR ROLAND KNYVET WILSON, Bart., of Tincoln's Inn, Barrister-at-I Law. Royal Sro. 1876. Net 11.1 s.

COLLISIONS.-LOWndes' Adnuiralty Law of Collisions at Sea.-Svo. 1867. $7 s$. fid.

Marsden on Maritime Collision.-A Treatise on the J.aw relating to Collisions between Ships, Compulsory Pilotage, and the liule of the Roal at Sea. With a Summary of English and American Decisions therem, references to Foreign Law, and en Appendix containing the Intermational Regnlations (of 1863 and 1850) for preventing Collisions at Sca ; the Thames, Mersey, and other local Tules of Tavigation; and Extracts from the Merehant Shipping Acts. By REGINA\}D G. MLARSDEN, Esq., Barrister-at-Law.

(In the press.)

COLONIAL LAW.-Clark's Colonial Law.-A Summary of Colonial Law and Practice of Appeals from the Plantations. 8vo. 1534 .

1l. $4 s$.

COMMENTARIES ON THE LAWS OF ENGLAND.-BedfOrd.Fidle "Examination Guides."

Broom and Hadley's Corrimentaries on the Laws of England.-By HERBERT BROOM, LL.D., of the Inner Temple, Barrister-at-Law ; and EDWARD A. HADI.EY, MI.A., of Lincoln's Inn, Barrister-at-Law; late Fellow of Trinity Coll, Cambridge. 4 vols. 8vo. $1869 . \quad 3 l .3 s$.

"Messrs. Broom and Hadley have been unsparing in their editorial labours. There are abundant reference notes, so that the diligent student can consult the authorities if he is so disposed. Nothing that could bo done to make the work useful and handy has been left uudone."-Law Journal.

Dickson's Analysis of Blackstone's Commentaries. - In ('barts for the use of Sturlents. By FREDElifCK S. DICKSON. 4 to.

$10 s .6 \mathrm{cl}$.

C.OMMERCIAL LAV.-LEvi.- Vidc" International Law."

COMMON LAW.-Archbold's Practice of the Queen's Bench, Common Pleas and Exchequer Divisions of the High Court of Justice in Actions, etc., in which they have a common jurisdiction.-Thirteenth Edition. By SAMUEJ, PRENTICL, Esq., one of Her Majesty's Counsel. 2 vols. Demy 8 ro. 1879. 37. 3s. Archibald.-Vide "Judges' Chambers Practice."

Chitty.—Vide "Forms." Foulkes.—Vide "Action."

Fisher.-Vide "Digests." Prentice.-Vide "Action."

Smith's Manual of Common Law.-For Practitioners and Students. A Mlannal of Common Law, comprising the fundamental principles and the points most ustally occurring in daily life and practice. By JOSIAH W. SMITH, B.C.L., Q.C. Jighth Edition. $12 \mathrm{mo}$. 1S78. $14 \mathrm{~s}$.

COMMONS AND INCLOSUFES.-Chamber' Digest of the Law relating to Commons and Open Spaces, including T'ublic P'arks and Recreation ('romnds, with various official locuments; precedents of by-laws and regulations. The Statutes in full and lirief notes of leading cases. By GEOHGE T. UHADBTRS, of the Inner Temple, Lisq., J barrister-at-Law. Imperial 8\%. $1877 . \quad 6 s .6 d$. Cooke on Inclosures. - Vith Forms as suttled by the Inclosure Commissioners. By G. WINGROVE COOKE, Esq., Jarrister-at-Law. Fourth Edition. 12mo. 1864. 16s.

" All standard Law Works are kept in Stock, in law calf and other bindings. 


\section{COMPANY LAW.-Finlason's Report of the} Twycross v. Grant. 8vo. 1877.

Case of Net, $2 s .6 d$.

Palmer.-Vide "Conveyancing."

Palmer's Shareholders' and Directors' Com. panion.-A Manual of every-day Law and Practice for Promoters, Shareholders, Directors, Secretaries, Creditors and Solicitors of Companies, under the Companies'Acts, 1862, 1867, and 1877. Second Edition. By FRANCIS B. PAIMMER, Esq., Barrister-at. Law, Author of "Company Precedents." 12mo, 1880. Net, 2s. 6c". Thring.-Vide "Joint Stocks."

CONTINGENT REMAINDERS.-An Epitome of Fearne on Contingent Remainders and Executory Devises. Intended for the Use of Students. By W. M. C. Post 8vo. 1878.

6s. $6 d$.

"An acquaintance with Fearne is indispensable to a student who desires to be thoroughly grounded in the common law relating to real property. Such student will find a jerusal of this epitome of great value to him." - Law Journal.

CONSTITUTIONAL LAW.-BOWyer's Commentaries on the Constitutional Law of England.-By Sir GEO. BOWYER, D.C.L. Second Edition. Royal 8vo. 1846. 1l. $2 s$. Haynes.-Vidle "Teading Cases."

CONTRACTS.-Addison on Contracts.-Being a Treatise on the Law of Contracts. By C. G. ADDISON, Esq., Author of the "Law of Torts." Seventh Edition. By L. W. CAVE, Esq., one of Her Majesty's Counsel, Recorder of Lincoln. Royal 8vo. 1875 .

$17.18 \mathrm{~s}$.

"At present this is by far the best book upon the Law of Contract possessed by the Profession, and it is a tlioroughly practical book."-Law Times.

Leake on Cuntracts.-An Elementary Digest of the Law of Contracts (being a new edition of "The Elements of the Law of Contracts"). By STEPHEN MAR'IN JEAKE, Barrister-atLaw. 1 vol. Demy 8 vo. 1878.

1l. 18 s.

Pollock's Principles of Contract at Law and in Equity ; being a Treatise on the General Principles relating to the Validity of Agreements, with a special view to the comparison of Law and Equity, and with references to the Indian Contract Act, and occasionally to American and Foreign Law. Second Edition. By FLEDERICK POLLOCK, of Lincoln's Inn, Esq.. Barrister-atLaw. Demy 8vo. 1878.

11. 6 s.

The Lord Chief Justice in his judgment in Iftropolitan Railuay Company v. Brogden and other's, said, "The Law is well put by MTr. Frederick Pollock in his very able and learned work on Contracts." -The Times.

"For the purposes of the student there is no book equal to Mr. Pollock's."--The Economist.

"He bas succeeded in writing a book on Contracts which the working lawyer will find as useful for reference as any of its predecessors, and which at the same time will gire the siudent what he will seek for iu vain elsewliere, a complete rationale of the law, Law Magazine and Review.

"We see nothing to qualify in the praise we bestowed on the first edition. The chapters on unlawful and impossible agreements are models of full and clear treatment." - Solicitors Journal.

Smith's Lav of Contracts.-By the late.J. W. SIITH, Esq., Author of "Leading Cases," \&c. Seventh Edition. Iy VINCENT T. THOMPSON, Esq., Barrister-at-Law. Demy 8vo. 1878.

1l. 1 s.

"We know of few books equally likely to benefit tlie student, or marked by such distinguished qualities of lucidity, order, and accurncy as the work before us. "- Solicitor's' Journal, December 2S, 1578.

* * All standard Law Works are kept in Stock, in law calf and other bindings. 
CONVICTIONS.--Paley's Lav and Practice of Summary Convictions under the Summary Jurisdiction Acts, 1848 and 1879; including Proceedings preliminary and subsequent to Convictions, and the responsibility of convieting Magistrates and their Officers, witl Forms. Sixth Elition. liy W. H. MACNAMAli, Esq., Barrister-at-Jaw. Demy Sro. 1879.

11. 4 s.

Stone.-Fide" Petty Scssions."

Tenmpler.- Vide "Summary Convictions."

Wigram.-Iride "Justice of the Peace."

CONVEYANCING.-Dart.-. Vide "Vendors and Purchasers."

Greenwood's Manual of Conveyancing.-A Manual of the Practice of Conveyancing, showing the present Practice relating to the daily routine of Conveyancing in Solicitors' Offices. To which are added Concise Common Forms and Precedents in Conveyancing; Conditions of Sale, Conveyances, and all other Assurances in constant use. Fifth Edition. By H. N.CAPEL, B.A., LL.B., Solicitor. Demy svo. $1877 . \quad 15 s$.

"A carelul study of these pages would probably arm a diligent clerk with as unjch useful kncwledge as he might otherwise take years of desultory questioning and observing to acquire." - Solicitors' Journal.

The youns solicitor will find this work almost invaluable, while the members of the higher brauch of the profession may refer to it with advantage. We have not met with any book that furuistics so simple a guide to the manugement of business eatrusted to articled elerks."

Haynes.-Vide "Iscading Cases."

Martin's Student's Conveyancer.-A Manual on the Principles of Modern Conveyancing, illustrated and enforced by a Collection of Precedents, accompanied by detailed Remarks. Part I. Purchase Deeds. By 'IHOMIAS FREDERIC MARTIN, Solicitor. Demy Svo. 1877 .

"It should be placed in the hands of every student."

Palmer's Company Precedents.-Conveyancing and other Forms and I'recelents relating to Companies' incorporated under the Companies' $\Lambda$ cts, 1862 and 1867. Arranged as follows :Agreements, Memoranda of Assotiation, Articles of Association, Resolutions, Notices, C'ertificates, Provisional Urders of Board of 'Trade, Debentures, Ricconstruction, Amalgamation, P'etitions, Orders. With Copious Notes. By FRANC'IS BEAUFURT' PALMER, of the Inner 'Temple, Isq., Barrister-at-Law. Demy 8vo. 1877. 1l. $5 s$.

"There bad never, to our knowledge, been any attempt to collect and edit a body of Forms aud Precedents exclusively relating to the formation, working and wanding-up of companics. This task Mr. Palmer bas taken in hand, and we are giad to say with much success. . The information contained in the 650 pages of the volume is rendereal casily accessible by a oool and full index. Tre author has evidently not been sparing of labonr, nud the fruits of bis cxertions are now before the legal professiun in a work of great practical utility."-law Jfagazine.

"To those concerned in getting up companics, the assistance giren by Mr. Palmer must oe very valual,?e, because he does not confine himself to bare precedents, but liy intelligent aud learuvi commentary lights $u p$, as it were, each step that he takes. The volume befire us is a ct, therefore a book of precerlents merely, bint, in a greater or less legree, a treatise un certaiu portions of the Companies' Acts of $1860^{\circ}$ and 1567 . There is an cliborate index, aub the work is one which nust cummend itself to the profession."Jaw Timss.

"The lrecedents are as a rule excecdingly well drafted, and allapted to companies for almost every conceivabie object. So especially are the forms of memoranda aud articles of association; and these will be found extremely serviceable to the conveyancer. . . All the notes have been elaborated with a thoroughly scientifie knowledge of the jrinciples of company law, as well is with copious referonces to the eases substantiating the priuciples. . We venure to predict that his notes will be found of great ntility iu guiling opinions on many complicated questions of law and practice." - Law Journal.

* * All standard Law Works are kert in Stock, in law calf and other bindings. 
CONVEYANCING.-Continued.

Prideaux's Precedents in Conveyancing.-With Dissertations on its Law and Practice. Ninth Edition. By FREDERICK PRII)EAUX, late Professor of the Law of Real and Personal Property to the Inns of Conrt, and JOHN WHITCOMIBE, Esqrs., Barristers-at-Law. 2 vols. Royal 8vo. 1879. 3l. $10 s$.

"We have been always accustomed to view 'Prideaux' as the most useful work out on conveyancing. It combines conciscness and clearness in its precedents with aptness and comprehensiveness in its dissertations and notes, to a degree superi r to that of any other work of its kind."--Law Joumal, February 8, 1879.

"Prideaux has become an indispensable past of the couveyancer's library.

The new edition has been edited with a care and accuracy of which we can hardly speak too highly. The care and completeness with which car hardy speak been revised leaves us hardly any room for criticism." - Solicitor's' Journal.

"The volumes are now somethiug more than a mere collection of precedents; they contain most valuable dissertations oli the law and practice with reference to conveyancing These dissertations are followed by the precedents on each subject dealt with, and are in themselves condensed treatises, embodyiug all the latest case and statute law . . Having regard to the wide general knowledge required of all lawyers in the present day, such $a$ work as this must prove highly acceptable to the whole Profession."-Laz Times.

COPYRICHT.-Phillips' Lav of Copyright.-The Law of Copyright in Works of Literature and Art, and in the Application of Designs. With the Statutes relating thereto. By CHARLES PALMER PHILLIPS, of Lincoln's Inn, Esq., Barrister-at-Law. 8vo. 1863.

$12 s$.

CORONERS.-Jervis on the Office and Duties of Coroners.-With Forms and Precedents. Fourth Edition.

(In preparation.)

cosTS.-Morgan and Davey's Treatise on Costs in Chancery.-By GEORGE OSBORNE MORGAN, M.P., one of Her Majesty's Counsel, late Stowell Fellow of University College, Oxford, and Eldon Scholar; and HORACE DAVEY, M.A., one of Her Majesty's Counsel, late Fellow of University College, Oxford, and Eldon Scholar. With an Appendix, containing Forms and Precedents of Bills of Costs. 8vo. 1865. Il. $1 \mathrm{~s}$.

Scott's Costs in the High Court of Justice and other Courts. Fourth Edition. By JOHN SCOTT, of the Inner 'Temple, Esq., Barrister-at-Law, Kieporter of the Common Pleas Division. Demy 8vo. $1880 . \quad 17.6 \mathrm{~s}$.

"Mr. Scott's introductory notes are very useful, and the work is now a compendiurn on the law and practice regarding costs, as well as a bock of precedents."-Law Times, Jamuary 3,1850

Scott's Costs in Bankruptey and Liquidation under the Bankruptey Act, 1869. Poyal $12 \mathrm{mo}$. 1873.

net $3 s$.

Summerhays and Toogood's Precedents of Bills of Costs in the Chancery, Queen's Bench, Common Pleas, Exchequer, Probate and Divorce Divisions of the High Court of Justice, in Conveyancing, Bankruptcy, the Crown Office, Lunacy, Arbitration under the Lands Clauses Consolidation Act, the Mayor's Court, London; the County Courts, the Privy Council, and on Passing Residuary and Succession Accounts ; with Scales of Allow. ances and Court Fees, the Law Society's Scale of Commission in Conveyancing ; Forms of Affidavits of Increase, and Objections to Taxation. By WM. FRANK SUMMERHAYS, Solicitor, and THORNTON TOOGOOD. Third Edition, Enlarged. Royal 8vo. 1879.

1l. $1 s$.

"In the volume before us we have a very complete manual of taxation. The work is beautifully printed and arranged, and each item catches the eye instantly."-Law Journal.

** All standard Law Works are kept in Stock, in law calf and other bindings. 
COSTS.-Continued.

Webster's Parliamentary Costs. - Private Bills Flection Petitions, $\Lambda$ ppeals, House of Lords. By EDWWARD WEBS'TER, Esq., of the 'Taxing and Examiners' Office. Third Edition. Post Svo. 1867. 20 s. cOUNTY COURTS.- The Consolidated County Court Orders and Rules, 1875, with Fornes and Scales of Costs and Fees, as issued by the Lord Chancellor and Committee of County Court Judges. Authorised Edition. Super-royal 8vo. $1875 . \quad$ Tet, 3s.

Pitt-Levvis' County Court Practice.-A Complete Practice of the County Courts, including Admiralty and Bankruptcy, embodying the Act, Rules, Forms and Costs, with Table of Cases and Full Index. By G. PITT-LEWIS, of the Middle Temple and Western Circuit, Esq., Barrister-at-Law, sometime Holder of the Studentships of the Four Inns of Court, assisted by H. A. DE COLYAR, of the Middle Temple, Lisq., Barrister-at-Law, Author of "A Treatise on the Law of Guarantecs."

(In the press.)

CRIMINAL LAW,-Arehbold's Fleading and Evidence in Criminal Cases. - With the Statutes, Precedents of Indictments, \&c., and the Evidence necessary to support them. By JOHN JERVIS, Esq. (late Lord Chief Justice of Her Majesty's Court of Common Pleas). Nineteenth Edition, including the Practice in Criminal Proceedings by Indictment. By WILLIAM BRUCE, of the Middle Temple, Esq., Barrister-at-Law, and Stipendiary Magistrate for the Borough of Leeds. Royal $12 \mathrm{mo}$. 1878.

11. $11 s .6 d$.

Cole on Criminal Informations and Quo War. ranto.-By IV. T. COLE, Esq., Barrister-at-Law. 12mo. 1843. 12s.

Greaves' Criminal Lav Consolidation and Amendment Acts of the 24 \& 25 Vict.-With Notes, Observations, and Forms for Summary Proceedings. By CHALLES SPRENGEL GREAVES, Esq, one of Her Majesty's Counsel, who prepared the Bills and attended the Select Committees of both Houses of Parliament to which the Bills were referred. Second Edition. Post 8vo. 1862.

Haynes.- Tidle "Leading Cases."

Roscoe's Digest of the Lav of Evidence in Criminal Cases.-Ninth Edition. By HORACE SMITH, Esq., Barrister-at-Law. Royal 12mo. 1878.

1l. $11 s, 6 d$.

Russell's Treatise on Crimes and Misdemeanors.-Fifth Edition. By SAMUEL PRENTICE, Esq., one of Her Majesty's Counsel. 3 vols. Royal 8vo. 1877. 5l.15s.6d.

This treatise is se much more ecriens tlian any other upon all the subjects contained in it, that it affords by far the best means of acquiriug a knowledge of the Criminal Law in general, or of any offence in particular; so that it will be found peculiarly useful as well to those who wish to obtaiu a complote knowledge of that law, as to those who desire to be informed on any portion of it as occasion may require.

"Whit better Digest of Criminal Law could we possibly hope for than 'Russell on Crimez?" "-Sir James Fitzjames Stephen's Speech on Codification.

"No more trustworthy anthority, or more cxhaustive expositor than 'Russell' can be consulted."-Law Mhagazine and Rebriew.

"Alterations have been made in the arrangement of the work whieh without interfering with the genera! plan are sufficient to show that great care and thought have been bestowel. ... Wo are amazed at the patience, industry ard skill which are exbibited in the collection and arrangement of all this mass of learriug." - "

CROSSED CHEQUES ACT.-Cavanagh.-Vide "Money Securitics."

Walker.-Tide. "Danking."

* * All standerd Lav Works are kept in Stock, in law culf and other öindings. 
DECREES.-Seton.-Vide "Equity."

DIARY,-Lawyer's Companion (The), Dialry, and Law Directory for 1880.-For the use of the Legal Profession, Public Companies, Justices, Merchants, Estate Agents, Auctioneers, \&c., \&c. Edited by JOHN THOMPSON, of the Inner Temple, Esq., Barrister-at-Law; and contains a Digest of Recent Cases on Costs ; Monthly Diary of County, Local Government, and Parish Business; Oaths in Supreme Court; Summary of Legislation of 1878; Alphabetical Index to the Practical Statutes; a Copious Table of Stamp Duties; Legal Time, Interest, Discount, Income, Wages and other Tables; Probate, Jegacy and Succession Duties; and a variety of matters of practical utility. Published Annually. Thirty-fourth Issue.

(Now ready.)

The work also contains the most complete List published of Town and Country Solicitors, with date of admission and appointments, and is issued in the following forms, octavo size, strongly bound in cloth:- s. $d$.

1. Two days on a page, plain . . . . . . $\quad 50$

2. The above, Interleaved for Attendances $: \quad: \quad: 70$

3. Two days on a page, ruled, with or without money columns $\quad 56$

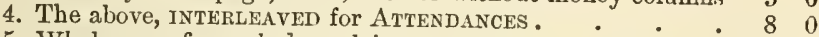

5. Whole page for each day, plain . $\quad . \quad \therefore \quad \cdot \quad 76$

6. The above, interleaved for Attendances : $\quad \cdot \quad \cdot 96$

7. Whole page for each day, ruled, with or without money columns . • • • • • . 86

8. The above, INTERLEAVED for ATTENDANCES : $: \quad \cdot 106$

9. Three days on a page, ruled blue lines, without money columns .

The Diary contains memoranda of Legal Business throughout the 10 "An cxcellent work."-The Times.

"A pnblication which has long ago secured to itself the favour of the profession, and which, as heretofore, justifies by its contents the title assumed by it." - Lazo Journal.

"Contains all the information whicl could be looked for in such a work, and gives it in a most convenient form and very completely. Wo may unhesitatingly recommend tho
work to our readers." - Solicitors' Joumal.

"The "Lawyer's Companion and Diary' is a book that ought to be in the possession of every lawyer, and of every man of business."

"The 'Lawyer's Companion' is, indeed, what it is called, for it combines everytling required for reference in the lawyer's office."-Lano Times.

"It is a book without which no Jawyer's library or office can bc complcte." -Irish Post.

"This work has attained to a completencss which is beyond all praisc."-dforning

DICTIONARY.-Wharton's Law Lexicon.-A Dictionary of Jurisprudence, explaining the Teshnical Words and Phrases employed in the several Departments of Einglish Law ; including the varions Legal Terms used in Commcrcial 'I'ransactions. 'Together with an Explanatory as well as Literal Translation of the Latin Maxima contained in the Writings of the Ancient and Modern Commentators. Sixth Edition. Enlarged and revised in accordance with the Judicature Acts, by J. SHIRESS WILL, of the Middle 'l'emple, Esq., Barrister-at-Law. Super royal 8vo. $1875 . \quad 2 \%$. $2 s$.

"As a work of reference for the library, the handsome and elaborate edition of " II harton's Law Lexicon' which Mr. Shiress Will has produced, must sujersede all forwer issues of that well-known work."-Law Magazine and Review.

"No law library is complete without a law dictionary or law lexicon. To the practi. tioner it is always useful to have at hawd a book where, in a small compass, lie can find an explanation of terms of intrequenf occurrence, or obtain a reference to statutes on most subjects, or to books wherein particular subjects aro treated of at full length. To the
student it is almost indispensable."-Law Times.

* * All etandard Law Works are kept in Stock, in law calf and other bindings. 
DIGESTS.-Bedford.- Fide "Examination Guides."

Cliamber"s-Tide "Public Health."

Chitty's Equity Index.-Chitty's Index to all the Reported Cases, and Statutes, in or relating to the Principles, Pleading, and Practice of Equity and Bankruptcy, in the several Courts of Equity in Fingland and Ireland, the Privy Council, and the House of Lords, from the earliest period. Third Edition. By J. MACAULAY, Esq., Barrister-at-Law. 4 vols. Royal Svo. $1853 . \quad 7 l .7 \mathrm{~s}$.

Fisher's Digest of the Reported Cases determined in the House of Tords and Privy Council, and in the Courts of Common Iaw, Divorce, Probate, Aduiralty and Bankruptcy, from Michaelmas Term, 1756, to Hilary T'erm, 1870; with References to the Statutes and Tules of Court. Founded on the Analytical Digest hy Harrison, and adapted to the present practice of the Law. By T. A. FISHER, Esq., Judge of the County Courts of Bristol and of Wells. Five large volumes, royal Svo. 1870.

\section{(Continued Annually.)}

12l. 12s.

" Irr. Fisher's Digest is a wonderful work. It is a miracle of human industry." $-M T$. Junice Willes.

"I think it would he very difficult to improve upon Mr. Fisher's 'Common Law Digcet." "-Sir Jamcs Fitzjames Stephen, on Codification.

Leake.-Vide "Real Property" and "Contracts."

Notanda Digest in Lavv, Equity, Bankruptey, Admiralty, Divorce, and Probate Cases.-13y H. TUDOR BODDAM, of the Inner Temple, and HARRY GREENWOOD, of Lincoln's Inn, Esip's., Barristers-at-Law. The Notanda Digest, from the commencement, October, 1862, to December, 1876. In 2 rolumes, half-bound. Net, $3 l .10 \mathrm{~s}$ Ditto, Third Series, 1873 to 1876 inelusive, half-bound. Nct, 1l. 11s. $6 \mathrm{~d}$. Ditto, Fourth Series, for the years 1877,1878 , and 1879, with Inclex. Each, net, 1l. Is.

Ditto, ditto, for 1880, Plain Copy and Two Indexes, or Adhesive Copy for insertion in Text-Books (without Index). Annual Subseription, payable in advance.

Net, 21s.

** The numbers are issued regularly every alternate month. Each number will contain a coneise analysis of every case reported in the Law Reports, Law Journal, Wekhly Reporter, Law Times, and the Irish Law Reports, up to and including the cases eontained in the parts for the eurrent month, with referenees to Text-books, Statutes, and the Law Reports Consolidated Digest. An alphabetical INDEX of the subjects contained IN EACH NUMBER will form a new feature in this series.

Pollock.-Vide "Partnership."

Roscoe's.-Vide "Criminal Law" and "Nisi Prius."

DISCOVERY.-Hare's Treatise on the Discovery of Evidence.-Second Iidition. Arlapted to the Procedure in the High Court of Justice, with Addenda, containing all the Reported Cases to the end of 1876 . By SHERLOCK HARE, Barrister-at-

Law. Post 8vo. 1877. $12 s$.

"The book is a useful contribution to our text-books on practice."-Solicitors" Journal.

"We have read his work with considerable attention an 1 interest, and we can speak in terms of corditl praise of the manner in which the wew procedure has been worked into the old material. . . . All the sections and orders of the new legislation are referred $t_{0}$ in the text, a synopsis of recent cases is given, and a good index completes the volume."-Law Times.

Seton.-Vide "Iquity."

* All standard Law Works are kept in Stock, in law calf and other. Lindings. 
DISTRICT REGISTRIES.-Archibald.-Vide "Judges' Chambers Practice."

DIVORCE.-Browne's Treatise on the Principles and Practice of the Court for Divorce and Matrimonial Causes:-With the Statutes, Rules. Fees and Forms relating thereto. Fourth Edition. By GEORGE BROTVNE, Esq., 13.A., of the Inner Temple, Barrister-at-Law, Recorder of Ludlow.

Haynes.- T'ide "Leading Cases."

DOMICIL.-Dicey on the Law of Domicil as a branch of the Law of England, stated in the form of Rules.-By A. V. DIUEY, B.C.L., Barrister-at-Law. Author of "Rules for the Selection of Parties to an Action." Demy Svo. 1879.

$18 s$.

"The practitioner will find the hook a thoroughly exact and trustworthy summary of the present state of the law."-The Spectator, August 9til, 1879.

Phillimore's (Sir R.) Law of Donicil.-8vo. 1847. $9 s$.

OUTCH LAW.-Vanderlinden's Institutes of the Lavs of Holland.-8vo. 1828.

11. $18 s$,

EASEMENTS.-Goddard's Treatise on the Law of Easements.-By JOHN LEYBOURN GODDARD, of the Middle 'Temple, Esq., Barrister-at-Law. Second Edition. Demy 8vo. 1877.

$16 s$.

"The book is invaluable: where the cases are silent the author has taken pains to ascertain what the law would be if brought into question."-Law Journal.

"Nowhere has the suhject been treated so exhaustively, and, we may add. so scientifcally, as by Mr. Goddard. We recommend it to the most careful study of the law student as well as to the library of the practitioner."-Law Times.

ECCLESIASTICAL. - Finlason's Folkestone Ritual Case.-The Judgment of the J'ldicial Committee in the Folkestone Titual Case, with an Historical Introduction and brief Notes. By IV. F. FINLASON, of the Middle Temple, Esq., Barrister-at-Law. 8vo. 1877. Net, 2s. $6 d$.

Phillimore's (Sir R.) Ecclesiastical Lav.-The Ecclesiastical Law of the Church of England. With Supplement, containing the Statutes and Decisions to end of 1875 . By Sir ROBER'T PHILLIMORE, D.C.I., Official Principal of the Arches Court of Canterbury; Member of Her Majesty's Most Honourable Privy Council. 2 vols. 8vo. 1873-76. 3l. 7 s. $6 d$. ** The Supplement may be had separately, price $4 s .6 d$. , sewed.

ELECTIONS.-Browne (G. Lathom.)-Vide "Registration."

FitzGerald.-Vide "Tallot."

Rogers on Elections, Registration, and Election A gency.-With an Appendix of Statutes and Forms. 'T'welfth Edition. By F. S. P. WOLFERSTAN, of the Inner 'Temple, Esq., Barrister-at-Law. $12 \mathrm{mo.} 1876 . \quad 10.108$.

"The book maintains its reputation as a well arranged magazine of all the authorities on the subject."-Law Journal.

"Mr. Wolferstau has added a new chapter on Election Agency, which contains a care$\mathrm{ful}$ and valuable digest of the decisions and dicta on this thorny subject." - Solicitors" Journal.

ENGLAND, LAWS OF.-BOWyer.-Vide "Constitutional Law." Broom and Hadley.-Vide "Commentaries."

Syms' Code of English Lavw (Principles and Practice) for handy reference in a Solicitor's office. By T. I. SYMS, Solicitor. $12 \mathrm{mo}$. 1870 .

$16 s$.

All standard Law Works are kept in Stock, in law calf and other Vindings. 
EQUITY, and ride CHANCERY.

Seton's Forms of Decrees, Judgments, and Orders in the High Court of Justice and Courts of Appeal, having especial reference to the Chancery Division, with Practical Notes. Fourth Fdition. By R. H. LEACH, Esq., Senior Registrar of the Chancery Division ; F. G. A. WILLIAIIS, of the Inner Temple, Esq. ; and the late H. W. MAY, Esq.; succeeled by JAMLES EAST'WICK, of Lincoln's Inn, Esq., Barristersat-Law. 2 vols. in 3 parts. Royal 8 ro. 1877-79. 4l. 10s. * * Vol. II., Parts 1 and 2, may be had separately, to complete sets, price cach 11.10 s.

"Of all the editions of 'Setou' this is the best.-Solicitors' Journal.

"We cin hardly speak too highly of the industry and intelligenee whiels have been bestowed on the preparation of the notes."-Solicitors' Journal.

"Now the book is before us complete; and we advisedly sas complete, beeause it has sc:ureely ever been our fortune to see a more complete law book than this. Extellsive in sphere, and exhunstive in treatise, comprehensive in matter, vet apposite in details, it presents all the features of an exeellent work . . The index, extending aser 278 pages, is a model of comprehensiveness and aecuraey."-Law Journal

Smith's Manual of Equity Jurisprudence.A Mannal of Equity Jurisprudence for Practitioners and Students, founded on the Works of Story, Spence, and other writers, and on more than a thousand subsequent cases, comprising the Fundamental Principles and the points of Equity usually occurring in General Practice. By JOSIAH IV. SMIT'T, B.C.L., Q.C. Twelfth Edition. $12 \mathrm{mo} .1878$.

12s. $6 d$.

"There is no disguising the truth; the proper mode to use this book is to learn its pages by heart."-Lav Magazine and Reviev.

"It will be found as useful to the praetitioner as to the student." - Solicitors' Journal.

EXAMINATION GUIDES.-Bedford's Guide to the Preliminary Examination for Solicitors.-Fourth Edition. 12mo. 1874.

$N e t, 3 s$.

Bedford's Preliminary.-Containing the Questions and Answers of the Preliminary Examinations. Edited by E. H. BEDFORD, Solicitor (No. 15, May, 1871, to No. 48, July, 1879). (Discontinued).

Seved, net, each, Is.

Bedford's Digest of the Preliminary Examination Questions on English and Latin, Grammar, Geography, History, French Grammar, and Arithmetic, with the Answers. 8 vo. 1875 .

Bedford's Preliminary Guide to Latin Grammar.-12mo. 1872 . Net, $3 s$.

Bedford's Intermediate Examination Guide to Bookkeeping.-Second Edition. 12mo. 1875. Net, $2 s .6 d$.

Bedford's Intermediate.-Containing the Questions and Answers at the Intermediate Examinations. Edited by E. H. BEDFORD. Nos. 1 (Hilary, 1869) to 34 (Hilary, 1877). 6d. each. Nos. 35 (Easter, 1877) to 43 (Trinity, 1879). (Discontinucel).

1s. each, $N e t$.

Bedford's Student's Guide to Stephen's New Commentaries on the Laws of England. Demy 8vo. 1879.

"Ifere is a book which will be of the greatest serviee to students. It reduees the 'Cornmentaries' to the form of question and answer... We must also giro the author credit, not only for his selection of questions, but for his answers thereto. These are models of fulness and conciseness, and lucky wili be the candidate who ean hand in a paper of answers luearing a close resemblance to those in the work before us,"-Law Journa!.

Bedford's Student's Guide to Smith on Contracts. Demy 8vo. 1879. 3s. 6d. * All standard Law Works are kept in Slock, in law calf and other bindings. 
EXAMINATION GUIDES.-Continued.

Bedford's Final.-Containing the Questions and Answers at the Final Examinations. Edited by E. H. BEDFORD. Nos. 1 (Easter, 1869) to 33 (Easter, 1 1877). 6d. each. Nos. 34 (Trinity, 1877) to 42 (Trinity, 1879). 1s. each, Net. (Discontinued.)

Bedford's Final Examination Digest : containing a Digest of the Final Examination Questions in matters of Law and Procedure determined by the Chancery, Queen's Bench, Common Pleas, and Fxchequer Divisions of the High Court of Justice, and on the Law of Real and Personal Property and the Practice of Conveyancing. In 1 vol. 8vo. 1879.

$16 s$.

"Will furnish students with a large armoury of werpons with which to meet the attacks of the examiners of the Incorporated Law Socicty."-Law Times, Nov. S, 1879.

Bedford's Final Examination Guide to Bankruptey.-Third Edition. 12mo. $1877 . \quad 6 s$.

Bedford's Outline of an Action in the Chancery Division. 12mo. $1878 . \quad$ Net, 2s. 6cl.

Butlin.-Vide "Articled Clerks."

Dickson's Analysis of Blackstone's Commentaries.-In Charts for the use of Students. By FREDERICK S. DICKSON. 4to.

Haynes.--Vide "Leading Cases."

10s. $6 \mathrm{~d}$.

Rubinstein and Ward.-Vide "Articled Clerks."

Shearvood's Student's Guide to the Bar, the Solicitor's Intermediate and Final and the Universities Law Examinations.-With Suggestions as to the books usually read, and the passages therein to which attention should be paid. IY JOSEPH A. SHEARWOOD, B.A., Esq., Barrister-at-law, Author of "A Concise Abridgment of the Law of Real Property," \&c. Demy 8vo. 1879.

5s. 6 d.

"A work which will be very acceptable to candidates for the various examinations, any student of arerage intelligence who conscientiously follows the path and obeys the instructions given him by the author, need not feal to present himself as a candidate for any of the examinations to which this book is intended as a guide." -Lazo Jouinal.

EXECUTORS.-Williams' Law of Executors and Administrators. - By the Rt. Hon. Sir EDIVARD VAUGHAN WILLIAMS, late one of the Judges of Her Majesty's Court of Common Pleas. Eighth Edition. By WAL'TER VAUGHAN WILTIAMS and ROLAND VAUGHAN WILLIAMS, Isqrs., Barristers-at-Law. 2 vols. Royal 8vo. $1879 . \quad 3 l .16 s$. "A trcatise which occupies a unique position and which is recognised by the Bench and the profession as having paramount athoricy in the domain of law with which it deals."-Law Jourial.

EXECUTORY DEVISES.-Fearne.-Fide "Contingent Remainders." FACTORY ACTS.-Noteutt's Law relating to Factories and Workshops, with Introduction and Explanatory Notes. Second Edition. Comprising the Factory and Workshop Act, 1878, and the Orders of the Secretary of State made thereunder. By GEO.JARVIS NOTCUTT, Solicitor, formerly of the Middle Temple, Esq., Burrister-at-Law. 12mo. 1879. 9 s.

"The task of elucidating the provisions of the statute is done in a manner that leaves nothing to be desired."-Birmingham Daily Gazette.

FARM, LAW OF.-Addison ; Cooke.-Vide "Agricultural Law."

Dixon's Law of the Farm -A Digest of Cases connected with the Law of the Farm, and including the Agricultural Custonns of EnglandandWales. Fourth Edition. By HENRY PERKINS, Esq., Barrister-at-Law and Midland Circuit. Demy 8ะ\%. 1879. 11.6s "It is impossible not to be struck with the extraordinary research that must have been used in the compilation of such a book as this."-Law Journal.

* * All standard Law Works are kent in Stock, in law calf and other bindings. 
FINAL EXAMINATION DIGEST.-Bedford.- Fide "Examination Guides."

FIXTURES.-Amos and Ferard on Fixtlures.-..Second Edition. Royal 8vo. 1847.

16 s.

FOREIGN JUDGMENTS.-Piggott's Foleign Judaments, their effect in the English Courts, the English Doctrine, Defences, Judgments in Rem, Status.-liy F. 'T. PIGGOT'T, M.A., LL.M., of the Middle Royal Sro. 1879.

"A useful and well-timed rolume."

"Mr. Piggott writes under strong conviction, but he is always caleful to rest his arguments on autlinrity, and thereby adds considerably to the value of his haudy volume." Law Jaguzine and Review, August and November numbers, Isi9.

“ M. Priggott donne al l'étude de l'une des questions les plus complexes du droit inter. national prisé une furme tout nouvelle: il applique dans toute sa rigueur la métlode des sciences exactes, et ne recnle pas devant l'emploi des formules aloćbríiups. C'étrit lit une tentative périlleuse dont le succes pouvait sembler douteux; mais il suffit d'indiquer la marclie suivie et les résultats obtenus oar l'auteur pour cumprendre l'importance et le wérite de cette publication." -Journal du Droit International Privé, 1 is 79.

FORMS.-Archibald.-Vide "Judges' Chambers Practice."

Chitty's Forms of Practical Proceedings in the Queen's Bench, Common Pleas and Ex. chequer Divisions of the High Court of Justice: with Notes containing the Stututes, Rules and Practice relating thereto. Eleventh Edition. By THOS. WILLES CHITTY, Esqr. Demy 8vo. $1879 . \quad 1 \% .18$.

Daniell's Forms and Precedents of Proceedings in the Chancery Division of the High Court of Justice and on Appeal therefrom; with Dissertations and Notes, forming a complete guide to the Practice of the Chancery Division of the High Court and of the Courts of Appeal. Being the Third Edition of "Daniell's Chancery Forms." By WILLIAM HENRY UPJOHN, Esq., Student and Holt Scholar of Gray's Inn, Exhibitioner in Jurisprudence and Roman Law in the University of I.ondon, Holder of the First Senior Studentship in Jurisprudence, Roman Law and International Law, awarded by the Council of Legal Education in Hilary 'Term 1879. In one thick vol. Demy 8vo, 1879. $27.2 s$.

"Mr. Upjobn has restored the volume of Chancery Forms to the place it held before the recent changes, as a trustworthy and complete collection of piecedents." - Solicitors' Journal.

"We have had this work in practical use for some wceks, and so careful is the noting up of the suthorities, so clearly and colcisely are the notes expressed, that we have found It of as much value as the ordinarr text books on the Judicature Acts. . . It will be as useful a work to practitioners at Westminster as it will be to those in Lincoln s Inn. 'The labour entailed in the compilation must have been severe, and we renture to predict a complete success for this uew edition of an old friend."-Law Times.

GAS WORKS.-Palmer.-Fide "Conveyancing."

HICHWAYS.-Baker's Law of Highways. By 'THOMAS BAKER, of the Inner 'Temple, Esq., Barrister-at-Law. (In the press.) Chambers' Law relating to Highways and Bridges, being the Statutes in full and brief Notes of 700 I,eading Cases; to which is added the Law relating to the Lighting of Rural Parishes under the Lighting Act, 1833. By GEO. F. CHAMBERS, Esq., Barrister-at-Iaw. Imperial 8vo. 1878. Highways; including the General Highway Acts for England and Wales, and other Statutes, with copions Notes of the Decisions thereon; with Forms. 'Third Edition. With Supplement by C. MANLEY SMITH, Esq., one of the Masters of the Queen's Bench. 12mo. 1865 .

158 . * * All standard Law Horks are kept in Stcck, in law calf and other bindings. 
INCLOSURES.-Vide "Commons."

INDIAN LAW.-Norton's Leading Cases on the Hindu Lavv of Inheritance.-2 vols. Royal 8vo. 1870-71.

INJUNCTIONS.-Seton.-Vide "Equity."

Net, 2l. 10s.

INSURANCE.-A Anould on the Law of Marine Insurance.-Fifth Edition. By DAVID MACLACHLAN, Esq., Barrister-at-Law. 2 vols. Royal 8vo. 1877.

"As a text book, "Arnould" is now all the practitioner can want, and we congratulate the editor upon the skill with which he has incorporated the new decisions."-Law Times.

Hopkins' Manual of Marine Insurance.-8vo. 1867.

$18 s$.

INTERNATIONAL LAW.-Amos' Lectures on International Law.-Delivered in the Middle Temple Hall to the Students of the Inns of Court, by SHELDON AMOS, M.A., Professor of Jurisprudence (including International Law) to the Inns of Court, \&c. Royal 8vo. 1874.

Dicey.-Vide "Domicil."

Kent's International Lavv. - Kent's Commentary on International Law. Edited by J. T. ABDY, LL.D., Judge of County Courts. Second Edition. Revised and brought down to the present time. Crown 8vo. 1878.

$10 s, 6 d$.

"Altogether Dr. Abdy has performed his task in a manner worthy of his reputation. His book will be useful not only to Lawyers aud Law Students, for whom it was primarily intended, but also for laymen. It is well worth the study of every member of an enlightened and civilized community."-Solicitors' Journal.

Levi's International Commercial Law.-Being the Principles of Mercantile Law of the following and other Countries -viz. : England, Ireland, Scotland, British India, British Colonies, Austria, Belgium, Brazil, Buenos Ayres, Denmark, France, Germany, Greece, Hans Towns, Italy, Netherlands, Norway, Portugal, Prussia, Russia, Spain, Sweden, Switzerland, United States, and Würtemberg. By LEONE LEVI, Esq., F.S.A., F.S.S., Barrister-at-Law, \&c. Second Edition. 2 vols. Royal 8vo. $1863 . \quad 1 l .15 s$.

Vattel's Law of Nations.-By JOSEPH CHITTY, Esq. Royal 8vo. 1834.

Wheaton's Elements of International Lavv; Second English Edition. Edited with Notes and Appendix of Statutes and Treaties, bringing the work down to the present time. By A. C. BOYD, Esq., LL.B., J.P., Barrister-at-Law. A uthor of "The Merchant Shipping Laws." Demy 8vo. $1880 . \quad 1 l .10 s$.

"Mr. Boyd, the latest editor, has added many useful notes; he has inzerted in the Appendix public documents of permaneut value, and there is the prospect that, as edited by Mr. Boyd, Mr Wheaton's volume will enter on a new lease of life. . . . It is all the more important that their works (Kent and Wheaton) should be edited by intelligent and impartial Englishmen, such as Dr. Abdy, the editor of Kent, and Mr. Boyd."-The Times.

"Both the plan and execution of the work before us deserves commendation. IIr. Boyd gives prominence to the labours of others. The text of Wheaton is presented without alteration, and Mr. Dana's numbering of the sections is preserved. Mr. Boyd's notes, which are numerous, original, and copious, are conveniently interspersed thruughout the text; but they are in a distinct type, aud therefore the reader always knows whether he is reading wheaton or Boyd. The lndex, which could not have been compiled without much thought and labour makes the book handy for reference, and, consequently, valuable to public writers, who iu these days have frequently to refer to International Law." - Law Journal.

"Students who require a knowledge of Wheaton's text will find Mr. Boyd's volume very convenient." - Law Magazine.

Wildman's International Lavv.-Institutes of International Law, in Time of Peace and Time of War. By RICHARD WILDMAN, Barrister-at-Law. 2 vols. 8vo. 1849-50. 1l.2s.6d. JOINT OWNERSHIP.-FOster.-Vide "Real Estate." * * All standard Law Works are kept in Stock, in law calf and other bindings. 
JOINT STOCKS.-Palmer.-Vide "Conveyancing" and "Company Law."

Thring's (Sir H.) Joint Stock Companies' Law.The Law and Practice of Joint Stock and other Public Companies, in. cluding the Statutes, with Notes, a Collection of Precedents of Memoranda and Articles of Association, and all the other Forms required in Making. Administering, and Winding-up a Company. By SrR HENRY THRING, K.C.B., The Parliamentary Counsel. Third Edition. By G. A. R. FITZGERALD, Esq., Barrister-atLaw, and Fellow of St. John's College, Oxford. 12mo. 1875. 11. "This, as the work of the original dranghtsman of the Companies" Act of 1862, and well-known Parliamentary counsel, Sir Henry Thring is naturally the highest authority on the subject." - The Times.

Jordan's Joint Stock Companies.-A Handy Book of Practical Instructions for the Formation and Management of Joint Stock Companies. Sixth Edition. 12mo. 1878. Net, 2s. 6d.

JUDGES' CHAMBERS PRACTICE.-Archibald's Forms of Summonses and Orders, with Notes for use at Judges' Chambers and in the District liegistries. By W. F. A. ARCHIBALD, M.A., of the Inner 'Temple, Barrister-at-Law. Royal $12 \mathrm{mo.}$ 1879 .

$12 s .6 d$.

"The work is done must thoronghly and yet coneisely. The practitioner will find plitin direetions how to proeeed in all the matters connected with a eommon law thetion, interpleader, attachment of debts, mandamus, injunction-indeed, the whole jurisdiction of the common law divisions, in the district registrics, and at Judges? chambers."-Lazo Times, July 26, 1879.

"A clear and well-digested vade mecum, which will no doubt be widely used by the profession." - Law Magazine, November, IS79.

JUDGMENTS,_Piggott._Vide "Foreign Judgments."

Walker's Practice on Signing Judgment in the High Court of Justice. With Forms. By H. H. WALKER, Esq., of the Judgment Department, Exchequer Division. Crown 8vo. 1879.

4s. $6 \mathrm{~d}$.

"The book undoubtedly meets a want, and furnishes inforwation available for almost every branch of practicc."

"We think that sulicitors and their clerks will flud it extremely useful."-Lau Journal.

JUD!CATURE ACTS.-Leys' Complete Time-Table to the Rules under the Supreme Court of Judicature Act, 1875. Showing all the periods fixed by the Rules within or after which any proceedings may be taken. By JOHN KIRKIVOOD LEYS, M.A., of the Middle Temple, Esq., Barristerat-Law. Royal 8vo. 1875.

Net, 1 s. $6 d$.

Lynch and Smith's Introduction to the Final Examination.-Being a collection of the questions set by the Incorporated Law Society, with the answers adapted to meet the recent extensive alterations made by the JUDICATURE AC'T, 1873. By H. FOULKS LYNCH, Solicitor, and ERNES' AUGUS'TUS SMITH, Solicitor, Clifford's Inn, Prizeman; Senior Prizeman of the Incorporated Law Society, and Brodrip Gold Medalist, 1872. Vol. I. The Principles of the Law. Post 8vo. 1874. 12s.

Lynch's Epitome of Practice in the Supreme Court of Judicature in England. With References to Acts, Tiules, and Orders. For the Use of Students. Fourth Edition. Royal 8ro. 1878.

Morgan.- Vide "Chancery."

Stephen's Judicature Acts 1873,1874, and 1875, consolidated. With Notes and an Index. By Sir JAMES TITZJAMES S'IEPHEN, one of THer Majesty's Judges. $12 \mathrm{mo}$. 1875.

4s. $6 d$.

* All standard Law Works are kept in Stock, in law calf and other bindings. 
JUDICATURE ACTS.-Continued.

Wilson's Supreme Court of Judicature Acts, Appellate Jurisdiction Act, 1876, Rules of Court and Forms. With other Acts, Orders, Rules and Regulations relating to the Supreme Court of Justice. With Practical Notes and a Copious Index, forming a CoMplete Guide to The New Practice. Second Edition. By ARTHUli IVILSON, of the Inner 'Temple, Barrister-at-Law. (Assisted by HARRY GREENWOOD, of Lincoln's Inn, Barrister-at-Law, and JOHN BIDDLE, of the Master of the Rolls Chambers.) Royal 12mo. 1878. (pp. 726.)

(In limp leather for the pocket, 22s. 6d.)

* * A large paper Eidition of the above (for marginal notes). Royal 8 vo 1875. (In limp leather or calf, 30s.) 1l.5s.

Rules of the Supreme Court, Nov., 1878, and Mal'ch, 1879. (Forming a Supplement to the above.) Each $3 d$.

"As regards Mr. Wilson's notes, we can only say that they are indispensable to the proper understanding of the new system of procedure. They treat the principles unon which the alterations are based with a clearness and breadih of view which have never been equalled or even approached by any other commentator."--Solicitors" Journal.

"Mr. Wilson has bestowed upon this edition an amount of industry and care which the Bench and the Profession will, we are sure, gratefully acknowledge. . . . . . A conspicuous and important feature in this second edition is a table of cases prepared by Mr. Biddle, iu which not only are cases given with references to two or thres reports, but every place in which the cases are reported. . . . . . Wilson's 'Judicature Acts, is now the latest, and we think it is the most convenient of the works of the same class. . . . The practitioner will find that it supplies all his wauts."-Law Times.

JURISPRUDENCE.-AmOS, LaW as a Science and as an Art.-An Introductory Lecture delivered at University College at the commencement of the session 1874-5. By SHELDON AMOS, Esq., M.A., Barrister-at-Law. 8vo. 1874. Net, 1s. $6 d$.

Phillimore's (J. G.) Jurisprudence.-An Inaugural Lecture on Jurisprudence, and a Lectrre on Canon Law, delivered at the Hall of the Inner Temple, Hilury Term, 1851. By J. G. PHILLIMORE, Esq., Q.C. 8vo. 1851. Sewed. $3 s .6 d$.

Piggott.-Vide "Foreign Judgments."

JUSTINIAN, INSTITUTES OF.-Cumin.-Vide "Civil Law."

Greene.-Vide "Roman Law."

Mears.-Vide "Roman Law."

Ruegg's Student's "Auxilium" to the Institutes of Justinian.-Being a complete synopsis thereof in the form of Question and Answer. By ALFRED HENRY RUEGG, of the Middle Temple, Barrister-at-Law. Post 8vo. 1879.

"The student will be greatly assisted in clearing and arranging his knowledge by a work of this kind."-Law Journal.

JUSTICE OF THE PEACE.-Burn's Justice of the Peace and Parish Officer.-Ldited by the following Barristers, under the General Superintendence of JOHN BLOSSETT MAULE, Esq., Q.C. The Thirtieth Edition. Vol. I. containing titles "Abatement" to "Dwellings for Artisans;" by THOS. S. PRIT. CHARD, Esq., Recorder of Wenlock. Vol. II. containing titles "Easter Offering" to "Hundred ;" by SAML. B. BRIST'OWE, Esq., Q.C., M.P. Vol. III. containing titles "Indictment" to "Promissory Notes ;" by L. W. CAVE, Esq., Q.C., Recorder of Lincoln. Vol. IV. containing the whole title "Poor ;" by J. E. DAVIS, Esq., Stipendiary Magistrate for Stoke-upon-Trent. Vol. V. containing titles "Quo Warranto" to "Wreck;" by J. B. MLAULE, Esq., Q.C., Recorder of Leeds. Five vols. 8vo. $1869 . \quad 7 l .7 s$. * * All standard Law Works are kept in Stock, in law calf and other bindings. 
JUSTICE OF THE PEACE.-Continued.

Paley.-Vide "Convictions."

Stone's Practice for Justices of the Peace, Tustices' Clerks and Solicitors at Petty and Special Sessions, in Summary Matters and Indictable Offences, with a List of Summary Convictions and of Matters not Criminal. With Forms. Eighth Edition. By 'THOMAS SIlikELl PRITCHARD, Esq., Barrister-at-Law, Recorder of Wenlock. Demy Svo. 1si . $11.10 s$.

Wiqram's The Justices' Note Book. By W. KNOX WJGRAM, Esq., Barrister-at-Law, J.P. Middlesex. Royal 12mo., $18 s 0$.

$10 s .6 \mathrm{~d}$.

Tn the first portion, or 'Preliminars Notes,' the constitution of courts of Summary Jurisdiction, together with the whole course of ordinary proeedure, as morlified by the recent Aet, are explained in a serics of short shajters, under the following heads:-

I. Justices-Jurisdietion-Divisions-Petty and Special Sessions. II. Summary Jurisdiction upon lnformation-Preliminary Proccedings. IIl. Summary Jurisdiction upon Information - the Hearing and Punishment. IV. Indictable offencesCommittal for Trial. V. Summary Jurisdiction as regards Indictable offences ; (children-young persons -and adults). VI. summary Jurisdiction upon Complaint. VII. Quarter Sessions and A pleal. VIII. Note on the Summary Jurisdietion Aet, 1879.

In the second part, entitled 'Notes of Matters and Offenees alphabetieally arranged," will be found an accomnt of most subjects whieh from time to time occury the attention of Justiees, either in Petty or Special Sessions.

'We have nothiug but praise for the book, which is a justices' royal road to knowledge, and ought to lead them to a more accurate acquaintance with their duties than many of them have hitherto possessed." - Solicitors' Journal.

"This is altogether a eapital book. Mr. Wigram is a good lawser and a good justices' lawyer."-Law Journal.

"We can thorougbly recommend the volume to magistrates." - Law Times.

LAND TAX.-Bourdin's Land Tax.-An Exposition of the Land Tax ; its Assessment and Collection, with a statement of the rights conferred by the Redemption Acts. By MAIK A. BOURDIN, of the Inland Revenue Office, Somerset House (late Registrar of Land Tax). Second Edition. Crown 8vo. $1870 . \quad 4 s$.

LANDLORD AND TENANT.-Woodfall's Law of Landlord and Tenant.-A Practical Treatise on the Law of Landlord and Tenant, with a full Collection of Precedents and Forms of Procedure. Eleventh Edition. Containing an Abstract of Leading Propositions, and Tables of certain Customs of the Country. By T. M. LELY, of the Inner Temple, Esq., Barrister-at-Jaw. Royal Sro. 1877.

11. $16 s$.

"The editor las expended elaborate industry and systematic ability in making the work as perfect as possiblc; and we doubt not that this eleventh edition will be a greater success than any of its predecessors."- Solicitors' Journal.

LAW LIST.-Law List (The).-Comprising the Judges and Officers of the different Courts of Justice, Counsel, Special Pleaders, Draftsmen, Conveyancers, Solicitors, Notaries, \&c., in England and Wales; the Circuits, Judges, Treasurers, Registrars, and High Bailiffs of the County Courts, District Registries and Registrars nnder the P'robate Act, Lords Lieutenant of Counties, Recorders, Clerks of the Peace, Town Clerks, Coroners, Colonial Judges, and Colonial I awyers having English Agents, Metropolitan and Stipendiary Magistrates, Law Agents, Law and Public Officers, Circuits of the Judges and Counsel attending Circuit and Sessions, List of Sheriff s and A gents, London Commissioners to Administer Caths in the Supreme Court of Judicature in England, Conveyancers 1'ractising in England under Certificates obtained in Scotland, \&c., \&c., and a variety of other useful matters so far as relates to Special Pleaders, Draftsmen, Conveyancers, Solicitors, Proctors and Notaries. Compiled by WILLIAM HENRY COUSINS, of the Inland Revenue Office, Somerset House, Registrar of Stamped Certificates, and of Joint Stock Companies. Published annually. By Authority. 1880.

(Net cash 9s.) 10s. 6d.

* * All standard Law Horks are kept in Stock, in law calf and other Lindings. 
LAW REPORTS.-A large Stock of second-hand Reports. Estimates on application.

LAWYER'S COMPANION.-Vide "Diary."

LEADING CASES.-Haynes' Student's Leading Cases. Being some of the Principal Decisions of the Courts in Constitutional Law, Common Law, Conreyancing and Equity, Probate, Divorce, Banliruptcy, and Criminal Law. With Notes for the use of Students. By JOHN F. HAYNES, J.L.D., Anthor of "The Practice of the Chancery Division of the High Court of Justice," "The Student's Statutes," \&c. Demy 8vo. 1878.

" We consider Nr. Haynes' book to be one of a very praiseworthy class; and we may say also that its editor appcars to be a competent man. He can express himself with clearness, precision, and terseness."-Solicitors' Journal.

"Wiil irove of great utılity, not only t, Studeuts, but Practitioncrs. The Notes are clear, nointer and concise."-Law 7 imes.

"We think that this book will supply a want . . . . the book is singularly well arranged for reference."-Lav, Journal.

"The statements of the ririous cases are fairly full and clear, and many of the notes are good."- Law Mugazine.

Shirley's Leading Cases in Common Law made Easy. By W. SHIRLEY SHIRLEY, M.A., Esq., Barrister-atLaw, North-Eastern Circuit.

LEXICON.-Vide "Dictionarp."

LIBRARIES AND MUSEUMS.--Cham bers' Public Libraries and Museums and Literary and Scientific Institutions generally, a Digest of the Law pelating to. Second Edition. By G. F. CHAMBElis, of the Inner Temple, Barrister-at-Law. Imperial Svo. 1879. Ss. $6 d$.

LICENSING.-Lely and Foulkes' Licensing Acts, $1828,1869,1872$, and 1874 ; Containing the Law of the Sale of Liquors by Retail and the Management of Licensed Houses ; with Notes to the Acts, a Summary of the Law, and an Appendix of Forms. Second Edition. By J. M. LELY and W. D. I. FOULKES, Fsqrs., Barristers-zt-Iaw. Royal 12mo. 1874. 8s.

"Messrs. Lely and Foulkes' plan is to priut in full the principal Acts, and to interplate between the sections of each of these stitutes all subsidiary enactments, distinguishing them by brackets and inarginal notes..... These notes are usually sensible and to the point and give evideuce both of care and knowledge of the subject." - Solicitors' Jousnal.

LIENS.-Cavanagh.--lide "Money Securities."

LIFE ASSURANCE.-Scratchley's Decisions in Life Assurance Lavv, collated alphabetically according to the point involved; with the Statutes. Revised Edition. By ARTHUR SCRATCHLEY, M.A., Barrister-at-Law. Demy 8 vo. 1878. $5 s$.

LICHTS.-Woolpych's Practical Treatise on the Law of Window Lights.--Second Edition. 12mo. 1864. 6s.

LOCKE KING'S ACTS.-Cavanagh._- Tide "Money Securities."

LORD MAYOR'S COURT PRACTICE.-Candy.- Vide "Mayor's Court Practice."

LUNACY.-Elmer's Practice in Lunacy.-The Practice in Lunacy under Commissions and Inquisitions, with Notes of Cases aud Recent Decisions, the Statutes and General Orders, Forms and Costs of Proceedings in Lunacy, an Index and Schedule of Cases. Sixth Edition. By JOSEPH ELMER, of the Ollice of the Masters in Lunacy. Svo. 1877.

MAGISTERIAL LAW.-Burn.-Vide "Justice of the Peace."

$21 s$.

Leeming and Cross.-Fide "Quarter Sessions."

Pritchard.-Vide "Quarter Sessions."

Stone.-Vide "Petty Sessions."

Wigram.- Tide "Justice of the Peace."

* * All standard Law Works are kept in Stock, in law calf and other bindings. 
MANDAMUS. - Tapping on Mandamus. - The Law and Practice of the High Prerogative IVrit of Mandamus as it obtains both in England and Ireland. Royal Sro. 1848. Net, 1l.1s.

MARITIME COLLISION.-LOWndes.-Marsden.-Fide "Collision."

MAYOR'S COURT PRACTICE.-Candy's MaYor's Court

Practice.-The Jurisdiction, Process, Practice, and Mode of Pleading in Ordinary Actions in the Mayor's Court, London (commonly called the "Lord Mayor's Court"). Founded on Brandon. By GEORGE CANDY, Esq., Barrister-at-Law. Demy Svo. 1879. "The 'ordinary' practice of the Court is dealt with in its natural order, and is simply and clearly stated."-Laio Journal.

MERCANTILE LAW.-BOyd.-Vide "Shipping."

Russell.-Vide "Agency."

Smith's Compendium of Mercantile Lavv.-Ninth Edition. By G. M. DOWDESWELL, of the Inner Temple, Esণ., one of Her Majesty's Counsel. Royal 8vo. 1877. 1l. 18 s.

"We can safely say that, to the practising Solieitor, few books will be found more nseful than the ninth edition of 'Smith's Mereantile Law.'" -Law Magazine.

Tudor's Selection of Leading Cases on Mercantile and Maritime Law. - With Notes. By O. D. TUDOR, Esq.. Barrister-at-Law. Second Elition. Royal 8vo. 1868. 1l. 18s. METROPOLIS BUILDING ACTS.-Woolrych's Metropolis Building Acts, with Notes, Explanatory of the Sections and of the Architectural Terms contained therein. Second Edition. By NOEL H. PATERSON, M.A., Esq., Barrister-at-Law. $12 \mathrm{mo.}$ 1877.

8s. $6 d$.

MINES.-Rogers' Law relating to Mines, Minerals, and Quarries in Great Britain and Ireland; with a Summary of the Laws of Foreign States and Practical Directions for obtaining Government Grants to work Foreign Mines. Second Edition Enlarged. By ARUNDEL ROGERis, Esq., Judge of County Courts. Svo. $1876 . \quad 1 l .11 s .6 d$. "The volume will prove iuvaluable as a work of legal reference."-The Mining Joumal. MONEY SECURITIES,-Cavanagh's Lavv of Money Secupities.-In Three Books. I. Personal Securities. II. Securities on Property. III. Miscellaneous; with an Appendix containing the Crossed Cheques Act, 1876, The Factors Acts, 1823 to 1877, Locke King's, and its Amending Acts, and the Bills of Sale Act, 1878. By CHIISTOPHER CAVANAGH,B.A.,LL.B.(Iond.), of the Middle Temple, Esq., Barrister-at-Law. In 1 vol. Demy Svo. 1879. 21 s. "We know of yo work which embraces so much that is of every-day importance, nor tho ge know of any author who shows more faniliality with his subjeet. The book is one which we sluall certainly keep near at hatd, and we belicve that it will prove u decided aequisition to the practitioner."-Liøo Times.

"The author has the gift of a pleasant stgle; there are abrudant and correct referenees to decisions of a recent date : and. in the matter of newly-enated statutes;

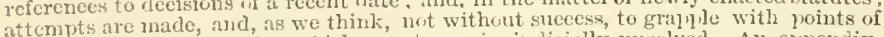
rractice and interpretation which as jet remain judieially unsolved. An aprendix, in which is embodied the fill text of several important statutes, adus to the ntility in which is embodice the work as a book of reference; and there is a good index."-Solicitors' Journal. "In the sceond look lills of sale extend over some sixty-three lages; and the treatise on tlicm seems on the whole well written, checially with reference to the alterations made by 41 \& 42 Vict. e. 31."-Law Journal.

"May be tlie means of saving enornous lubonr to thonsands of readers."-Bullionist.

MORTGACE.-CoOte's Treatise oll the Lav of Mortgage.-Third Edition. Royal 8vo. $1850 . \quad$ Net, 11.

MORTMAIN.-Ravilinson's Notes on the Mortmain Acts; shewing their operation on Gifts, Devises and Bequests for Charitable Uses. By JAMIES IA WLINSON, Solicitor. Wemy 8 vo.

187\%. Interleaved.

$N e t, 2 s .6 d$.

" All stanclard Law Works are kept in Stock, in law calf and other bindings. 

NAVY.-Thring's Criminal Law of the Navy, with an the Rules of Evidence, and an Appendix comprising the Naval Discipline Act and Practical Forms. Second Edition. By late Commissioner of Bankruptcy at Liverpool, and C. E. GIFFORD, Assistant-Paymaster, Royal Navy. 12mo. $1877 . \quad 12 s .6 \mathrm{~d}$. "A full series of forms of warrants, minutes, charges, cc., and a good Index, complete the utility of a work which should be in the hinds of all who have to deal with the regu-
lating and goveruing of the Fleet." - Low Mfagazine.

"In the new edition, the procedure, naval regulations, forms, and all matters conMr. Gifford, so that the work is in and Military Gazette.

NISI PRIUS, Ros

Rives.-Roscoe's Digest of the Law of Evidence Fdition. Trial of Actions at $\mathrm{Nisi}$ Prius.-Fourteenth MAURICE POIVE DAY, one of Her Majesty's Counsel, and (Bound in one thick volume, Barrister-at-Law. Royal 12mo. 1879. 2l. calf or circuit, $9 \mathrm{~s}$. net, extru.)

"The task of adaptiug the oll textr.)

patieut labour, careful acu the new procedure was one requiring much matter obsolete or unnecessary. and conciseness, as well as discretion in the omission of good evideuce of the possession An examination of the bulky volume before us affords that the popularity of thesiou of these qualities by the present editors, and we feel sure Law Magazine.

Selvyn's Abridgment of the Law of Nisi Prius.-Thirteenth Edition. By DAVID KEANE, Q.C. Recorder of Bedford, and CHARLES 'T. SMITH, M.A., one of the Judges of the Supreme Court of the Cape of Good Hope. 2 vols. NOTANDA.-Vide "Digests."

Net, $1 l$.

NOTARY.-Brooke's Trea eatise on the Office and Prac. tice of a Notary of England.- With a full collection of Precedents. Fourth Edition. By LEONE I.EVI, Esq., F.S.A., NUISANCES, Inn, Barrister-at-Iaw. 8vo. $1876 . \quad 1 l .48$. NUISANCES.-FitzGerald.-Vide "Public Health."

of Judicaturaite's Oaths in the Supreme Court Administer Part I, contains in the Supreme Court of Judicature in England. ment, Designation practical information respecting their Appointcollection of officially risdiction, and Powers ; Part II. comprising a Explanatory Oblally recognised Forms of Jurats and Oaths, with Record and Writ Cations. By T. W. BRAITHWAITE, of the

Record and Writ Clerks' Office. Feap. 8vo. 1876.
"Specially useful to Commissioners."-Law Magazine.

administer oaths." - Soliciton's' Journal. become the recognised guiaje of commissioners to PARTITION.-FOster.-Vide "Theal Estate."

PARTNERSHIP.-POllock's Digest of the Law of Part. nership. By FREDERICK POLLOCK, of Lincoln's Inn, Esq., Barrister-at-Law. Author of "Principles of Contract at Law and in Equity." Demy 8ro. 1877 . 8 s. $6 d$. * * The object of this work is to give the substance of the $\mathbf{L}$. $6 \mathrm{~d}$. "Of the execntion of the work, we cam speak in terms of the hishest praise. The with those of Sir James Stephen." -Law Magazizen " MIr. Pollocl's work Stephen." -Law Magazine.

in design, scholarly and compiete in execution." - Salurday Revieu".

perhaps, remove some drawbacks, and render Eurlishest of the Law of Partnership,' will, to study than it is at present." - The Examiner. Euglish law a pleasanter and easier subject * All standlod tresent. -The Exiner. 
PATENTS.-Hindmarch's Treatise on the Law relating to Patents.-Svo. 1846.

Jolnnson's Patentees' Manual; being a Treatise on the Law and Practice of Letters Patent, especially intended for the use of Patentees and Inventors.-By JAMES JOHNSON, Barrister-at-Law. and J. H. JOH NSON, Solicitor and Patent Agent. Fourth Edition. Thoroughly revised and much enlarged. Demy Svo. 1879. 10s.6d. "A very excellent manual."-Laer Times, February S, 1879.

"The anthors bave uot only a knowledge of the law, but of the working of the law. Besices the table of cases there is a copious index to subjects. - Law Journal, Warch 1, is 89.

Thompson's Handbook of Patent Law of all Countries.-Third Edition, revised. By WM. P. THOMPSON, C.E., Head of the International Patent Office, Liverpool. $12 \mathrm{mo}$. $187 \mathrm{~S}$.

PERSONAL PROPERTY.-Smith.-Fide "Real Property." Net 2 s. 6 d. PETITIONS.-Palmer.- Vide "Conveyancing."

PETTY SESSIONS.-Stone's Practice for Justices of the Peace, Justices' Clerks and Solicitors at Petty and Special Sessions, in Summary Matters and Indictable Offences, with a List of Summary Convictions and of Matters not Criminal. With Forms. Eighth Edition. By THOMAS SIRRELL PRITCHARD, of the Inner 'Temple, Esq., Barrister-at-Law, Recorder of Wenlock. In 1 vol. Demy 8io. 1877.

11. $10 s$.

"The book, as a whole, is thoroughly satisfactory, and, baving gone carefully through it, we can recommend it with confidence to the numerons hody of our readers who are daily interested in the subjects to which it relates." - Solicitors' Journal.

POOR LAW.-Davis' Treatise on the Poor Laws.-Being Vol. IV. of Burns' Justice of the Peace. 8vo. $1869 . \quad 11.11 s .6 d$.

POWERS.-Farvell on Powers.-A Concise Treatise on Powers. By GEORGE FARIVELL, B.A., of Lincoln's Inn, Esq., Barrister-at-Law. 8vo. $1874 . \quad 1 l .1 s$.

"We recommend Mr. Farwell's book as containing within a small comprss what would otherwise have to be sought out in the pages of hundreds of confusing reports, "-The Lau. FRECEDENTS.-Vide "Conveyancing."

PRINCIPAL AND AGENT.--Petgrave's Principal and Agent.-A Manual of the Law of Principal and Agent. By E. C. PETGRAVE, Solicitor. 12mo. 1857. $7 s .6 \dot{d}$.

Petgrave's Code of the Lav of Principal and Agent, with a Preface. By E. C. PETGRAVE, Solicitor. Demy $12 \mathrm{mo} .1876$.

Net, seved, 2s.

PRIVY COUNCIL. - Finlason's History, Constitution, and Character of the Judicial Committee of the Privy Council, considered as a Tudicial Tribunal, especially in Ecclesiastical Cases, with special reference to the right and duty of its members to declare their opinions. By W. F. FINLASON, Barrister-at-Law. Demy 8vo. $1878 . \quad 4 s .6 d$.

Lattey's Handy Book on the Practice and Frocedure before the Privy Courcil.-By RORERT THOMAS LATTEY, Attorney of the Court of Queen's Bench, and of the High Court of Bengal. 12mo. 1869.

PROBATE.-Browne's Probate Practice: a Treatise on the Principles and Practice of the Court of Probate, in Contentious and Non-Contentious Business, with the Statutes, Rules, Fees, and Forms relating thereto. By GEORGE BROWNE, Esq., Barristerat-Law, Recorder of Lndlow. 8vo. $1873 . \quad 1 \mathrm{l} .1 \mathrm{~s}$.

"A cursory glance through Mr. Browne's work shows that it has been compiled with more than ordinary care and intclligence. We slould consult it with every confidence." - Law Times.

Haynes.-Fide " Leading Cases."

** All slandard Law Works are hept in Stock, in law calf and other bindings. 
PUBLIC HEALTH.-Chambers' Digest of the Law relating to Public Health and Local Govern. ment.- With Notes of 1073 leading Cases. Various official documents ; precelents of By-laws and Regulations. The Statutes in full. A 'Table of Offences and Punishments, and a Copions Index. Seventh Edition, enlarged and revised, with Supplement containing new Local Government Board By-Iaws in full. Imperial 8vo. $1875-7$.

* * The Supplenent may be had separately, price $9 s$.

FitzGerald's Public Health and Rivers Pollution Prevention Acts.-The Law relating to Public Health and Local Government, as contained in the Public Health Act, 1875, with Introduction and Notes, showing all the alterations in the Existing Law, with reference to the Cases, \&c.; together witl a Supplement containing "The Rivers Pollution Prevention Act, 1876." With Explanatory Introduction, Notes, Cases, and Index. By G. A. R. FI'IZGERALD, Esq., Barrister-at-Law. Royal 8vo. 1876 .

1l. $1 s$.

"A copious and well-executed analytical index completes the work which we can confilently recommend to the officers and members of sanitary authorities, and all interested in the subject matter of the new Act."-Law MIagazine and Ileview.

"Mr. FitzGerald comes lorward with a special qualification for the task, for he was employed by the Government in the preparation of the Act of 1875; and, as he himself says, has necessirily, for some time past, devoted attention to the law relating to public health and loral government."-Law Journal.

PUBLIC MEETINGS.-Chambers' Handbook for Public Meetings, including Hints as to the Summoning and Management of them; and as to the Duties of Chairmen, Clerks, Secretaries, and other Officials; Rules of Debate, \&c., to which is added a Digest of Reported Cases. By GEORGE F. CHAMBERs, Esq., Barrister-at-Law. 12mo. 1878.

Net, $2 s .6 d$.

QUARTER SESSIONS.-Leeming \& Cross's General and Quarter Sessions of the Peace.-Their Jurisdiction and Practice in other than Criminal matters. Second Edition. By HORATIO LLOYD, Esq., Recorder of Chester, Judge of County Courts, and Deputy-Chairman of Quarter Sessions, and $H$. $F$. T'HURLOW, of the Inner 'Temple, Esq., Barrister-at-Law. 8vo. 1876. "The present editors appear to have taken the utmost pains to make the volume complete, and, from our examination of it, we can thoroughly recominend it to all interested in the practice of quarter sessions." - Law Times

Pritchard's Quarter Sessions.-The Jurisdiction, Practice and Procedure of the Quarter Sessions in Criminal, Civil, and Appellate Matters. By 'I'HOS. SIRRELL PRI'TCHARD, of the Inner Temple, Esq., Barrister-at-Law, Reeorder of Wenlock. 8ro. 1875 .

"We can confidently say that it is witten thronghout with cleamess and intellirence and that both in legislation and in case law it is carefully brought down to the must
recent dute." - Solicitors' Journal.

RAILWAYS.-Browne and Theobald's Law of Railvays. By J. H. BALFOUR BROWNE, of the Middle Temple, Registrar of the Railway Commissioners, and H. S. 'THEOBAI.D, of the Inner Temple, Esqrs., Barristers-at-Law. (In preparation.)

Lely's Railway and Canal Traffic Act, 1873.And other Railway and Canal Statutes; with the General Orders, Forms, and Table of Fees. By J. M. LELY, Esq. Post 8vo. 1873. 8s.

* * All standard Lav Jorks are kept in Stock, in law calf and other binding 
RATES AND RATING.-Castle's Practical Treatise on the Law of Rating. By EDWALD JAMES CAS'T'LE, of the Inmer 'Temple, Barrister-at-Law. Demy Svo. 1879. 11. 1s. "Mrr. Castle's book is a enrrect, exhanstire, elear and eoncise riew of the law."Lorir Times.

"The book is a useful assistant in a perplexed hranel of Law."-Lav" Journal.

Chamber's Law relating to Rates and Rating ; with especial reference to the Powers and Duties of liate-levying Local Authorities, and their Officers. Being the Statutes in full and brief Notes of 550 Cases. By G. F. CHAMBERS, Esq., Barrister-at-Iaw. Imp. Svo. 1878. $12 \mathrm{~s}$.

REAL ESTATE.-FOster's Law of Joint Ownership and Partition of Real Estate. By EDWAID JOHN lOSTER; M.A., late of lincoln's Imn, Barrister-at-Law. $8 \mathrm{ro}$. $157 \mathrm{~s}$.

10s. $6 \mathrm{~d}$.

"Mr. Foster mas lo congratulated on hasing produced a very satisfactory vade mecum on the Law of Juint Owmership and Partition. He bas taken considerable pains to make his treatise practically useful, and has combined within the fifteen chimters into which the book is divided, brevity of statement with completeness of treatment."-Law Magazine.

FEAL PROPERTY.-Greenwood's Recent Real Pro. perty Statutes. Comprising those passed during the years 1874-187T inclusive. Consolidated with the Earlier Statutes thereby Amended. With Copious Notes, and a Supplement containing the Orders under the Settled Estates Act, 1878. By HARRY GREFNWOOD, M.A., Esq., Barrister-at-Law. 8vo. 187s. $10 s$.

"To students particularly this collection, with the careful notes and references to previous legislation, will be of considerable value."-Lav Times.

"The anthor has added notes which, especially on the Vendor and Purchaser Act, "The author sates Act, are likely to be useful to the practitioner . . . so far as we have tested them, the stutements appear to be generally aceurate and careful, and the wro will be found exceedingly himdy for reference,"- Solicitors' Journal.

". I!r. Greenwood's book gives such of the provisions of the ancuded statutes as arc still in force, as well as the provisious of the new statutes, in o: der to show more clearly the cffect of the recent legislation, "-Lriv Jowmal.

Leake's Elementary Digest of the Law of Property in Land.-Containing: Introduction. Part I. The Sources of the Law.-Part II. Listates in Land. By STEPHEN MIARTIN LEAKE, Barrister-at-Law. 8ro. 1874. $11.2 s$.

"* The above forms a complete Introduction to the Study of the Law of Real Property.

Shearwood's Real Property.-A Concise Abridgment of the I,aw of lieal Property and an Introduction to Conveyancing. Designed to facilitate the subject for Sturlents preparing for Fxamination. By JOSEPH A. SHEARWOOD, of Lincoln's Inn, Isq., Barrister-at-Law. Demy 8vo. $1878 . \quad 6 s .6 d$. "The jresent law is expounded paragraphically, so that it could be actually lecimed without understanding the origin from which it las gpung, or the prineiples on which it is based."-Lavo Journal.

Shelford's Real Property Statutes.-Eighth Edition. By 'T'. H. CARSON, Esq., Barrister-at-Law. 8vo. 1874. 1l. $10 s$.

Smith's Real and Personal Property.-A Com. pendium of the Iaw of Real and I'ersonal I'roperty, primarily connected with Conveyancing. Designed as a second book for Students, and as a digest of the most useful learning for Practitioners. By JOSIAH IV. SMITH, B.C.I., Q.C. Fifth Edition. 2 rols. Demy 8 vo. 1877 . 2l. $2 s$.

"He has given to the student a book which be may read over and over again with proflt and pleasure." - Law Times.

"The work before us will, we think, be fuund of very great scrvice to the practitioner." - Solicitors' Journal.

* All standard Lavo Works are kept in Stock, in law calf and other Lindings. 
REGISTRATION.-Browne's(G.Lathom)Parliamentary and Municipal Registration Act, 1878 (41 \& 42 Vict. cap. 26); with an Introduction, Notes, and Additional Forms. By G. LATHOM BROWNE, of the Middle 'Temple, Esq., Barrister-at-Law. 12mo. $1878 . \quad 5 s .6 d$.

REGISTRATION CASES.-HOPWOOd and Coltman's Registration Cases.-Vul. I. (1868-1872). Net,2l.18s. Calt. Vol. II. (1873-1878). Net, 21. 10s. Calf.

RIVERS POLLUTION PREVENTION.-FitzGerald's Rivers Pollution Prevention Act, 1875.--With Explanatory Introduction, Notes, Cases, and Index. Royal 8vo. 1876. 3s. 6d.

ROMAN LAW.-Cumin.-Vide "Civil."

Greene's Outlines of Roman Lavv.--Consisting chiefly of an Analysis and Summary of the Institutes. For the use of Students. By T. IVHITCOIIBE GREENE, B.C.L., of Lincoln's Inn, Barrister-at-Jaw. Third Ldition. Toolscap 8vo. 1875. $7 s .6 d$.

Mears' Student's Ortolan.-An Analysis of M. Ortolan's Institutes of Justinian, including the History and Generalization of RoMan Law. By T. IAMBER' MEARS, M.A., LL.D. Lond., of the Inner Temple, Barrister-at-Law. Published by permission of the late M. Ortolan. Post 8vo. 1876. 12s.6d. Ruegg.-Vide "Justinian."

SAUNDERS' REPORTS.-Williams' (Sir E. V.) Notes to Saunders' Reports.-By the late Serjeant WILLIAMS. Continued to the present time by the Right Hon. Sir EDWARD VAUGHAN WILLIAMS. 2 vols. Royal 8 vo. 1871. 2l. $10 \mathrm{~s}$. SETTLED ESTATES.-Middleton's Settled Estates Act, 1877, and the Settled Estates Act Orders, 1878, with Introduction, Notes and Forms, and Summary of Practice. Second Fdition. By JAMES W. MIIDDLETON, B.A., of Lincoln's Inn, Barrister-at-Law. $12 \mathrm{mo} .1879 . \quad 4 s, 6 d$. "A complete work as a practical edition of the Settled Wstates Act, 1577, and will be found exceedingly usclul to legal practitioners."-Law Joumal.

" The book is a well-timed and useful manual of the Act." - Solicitors' Journal. Review.

"The book is excellently arrarged, particularly ia the summary of practice."-- Saturday

SHERIFF LAW.-Churehill's Law of the Office and Duties of the Sheriff, with the Writs and Forms relating to the Office. By CAMERON CHURCHILL, B.A., of the Inner 'Temple, Barrister-at-Law, assisted by A. CARMICHAEL BRUCE, B.A., of Lincoln's Inn, Barrister-at-Law. Demy 8vo. 1879. 18s.

"This is a work upnn a subject of large practical importance, and seems to have been compiled with exceptional care. . . . There is an appendix of forms which will be tound useful."-Law Tines.

"Under-Sheriffs, and lawyers generally, will find this a nseful book to have by them, both for perusal and reterence."-Law Magazine.

SHIPPINC, and vide "Admiralty."

Boyd's Merchant Shipping Laws; being a Consolida. tion of all the Merchant Shipping and Passenger Acts from 1854 to 1876, inclusive; with Notes of all the leading English and American Cases on the subjects affected by Legislation, and an Appendix containing the New Rules issued in October, $18 \mathbf{7} 6$; forming a com. plete Treatise on Maritime Law. By A. C. BOYD, LLB., of the Inner Temple, Esq., Barrister-at-Law, and Mlidland Circuit. Sro. 1876.

1l. $5 \mathrm{~s}$. Times.

SICNING JUDGMENTS.-Walker.-Vide "Julgments."

* * All standard Law Works are kept in Stock, in law calf and other bindings. 
SOLICITORS.-Cordery's Law relating to Solicitors of the Supreme Court of Judicature.-With an Appendix of Statutes and Iivles. By A. CORDERY, of the Inmer Temple, Esq., Barrister-at-Law. Demy $8 v 0.1878$.

"Mr. Cordery writes tersley and clearly, and displays in gencral great industry and care in the collection of crses." - Solicitors" Journal.

"The chapters on liability of solicitors and on lien may be selected as two of the best in the book."-Law Joumal.

SOLICITORS' GUIDES. - Ville " Ixamination Guides."

STAMP LAWS.-Tilsley's Treatise on the Stamp Laws.-Being an Analytical Digest of all the Statutes and Cases relating to Stamp Duties, with practical remarks thereon. Third Edition. With Tables of all the Stamp Duties payable in the United Kingdom after the 1st January, 1871, and of Former Duties, \&c., \&c. By E. H. TILSLEY, of the Inland Revenue Otfice. 8vo. 1871.

$18 s$.

STATUTES, and vide "Acts of Parliament."

Biddle's Table of Statutes.-A Table of References to unrepealed Public General Acts, arranged in the Alphabetical Order of their Short or Popular Titles. Second Edition, including References to all the Acts in Chitty's Collection of Statutes. Royal 8vo. 1570. (Published at 9s. 6d.) Net, 2s. 6d.

Chitty's Collection of Statutes, with Supplements, to 1878.-A Collection of Statutes of Practical Utility ; with Notes thereon. The 'Third Edition, containing all the Statutes of Practical Utility in the Civil and Criminal Administration of Justice to the Present Time. By W. N. WELSBY and EDTVARD BEAVAN, Esqrs., Barristers-at-Law. In 4 very thick vols. Royal 8vo. 1865. (Published at 12l. 12s.) Reduced to, net, 6l.6s.

Supplements to the above. By HORA'IO LLOYD, Esq., Judge of County Courts, and Deputy-Chairman of Quarter Sessions for Cheshire. Royal Svo. Part I., comprising the Statutes for 1873, 7s. 6d. Part II., 1874, 6s. Part III., 1875, 16s. Part IV., 1876, 6s. 6d. Part V., 1877, 4s. 6d. Part VI., 1878, 10s. Part VII., 1S79, 7s. 6d., sewed.

*** Continued Annually.

"When he (Lord Campbell) was upon the Bench he always had this work by him, and no statutes were ever referred to by the Bar which he could not find in it."

*The Revised Edition of the Statutes, A.D. 12351868 , prepared under the direction of the Statute Law Committee, miblished by the authority of Her Majesty's Government. In 15 vols. Imperial 8 vo. 1870-1878.

Vol. 1.- Henry III. to James II., 2.-Will. \& Mary to $10 \mathrm{Geo}$. III., 3.-II (reo. III. to 41 Geo. III, 4. - 41 Geo. III. to $5 I$ Geo. III., 5.-52 Geo. III. to 4 Geo. IV., 6.-5 Geo. IV. to 1 \& 2 Will. IV., 7.-2 \& 3 Will. IV. to $6 \& 7$ Will. IV., 8. - 7 Will. IV. \& I Vict. to 5 \& 6 Vict., $9 .-6$ \& 7 Vict. to 9 \& 10 Vict., $10 .-10$ \& 11 Vict. to 13 \& 14 Viet., , 11.-14 \& 15 Vict. to 16 \& 17 Vict., 12. -17 \& 18 Vict. to 19 \& 20 Vict., "13.-20 Vict. to 21 \& 25 Viet., "14.-25 \& 26 Viet. to 28 \& 29 Vict., 19l. $9 s$.

"15.-29 \& 30 Vict. to 31 \& 32 Vict., and $\} 1566-1867-S \quad I 10 \quad 6$

"15.-29 \& 30 Vict. to 31 \& 32 Vict., and
Supplement, ** 'The above Work is now completed.

1235-16S5 . 11. 1s. 0cl. $1688-1770 \cdot 1 \quad 0 \quad 0$ $1770-1800$. $017 \quad 0$ 1801-1811 * 0180 $1812-1823$. 150 1824-1831 • 1 6 0 1831-1836 $\quad-110 \quad 0$ $1837-1842 \quad 1 \quad 12 \quad 6$ $1843-1846^{\circ} \cdot 111 \quad 6$ $1847-1850$. 176 1851-1853 . 140 $1854-1856$ - 160 1857-1861 . 1100 $1862-1865$, 1100

* All standard Law Works are hept in Slock, in low calf and other lindings. 
STATUTES.-Continuel.

*Chronological Table of and Index to the Statutes to the end of the Session of 1878. Fifth Edition, imperial 8vo. 1879.

$14 s$.

* Public General Statutes, royal 8vo, issued in parts and in complete volumes, and supplied immediately on publication.

* Printed by Her Majesty's Printers, and Sold by Stevens \& Sons.

Head's Statutes by Heart; being a System of Memoria T'echnica, applied to Statutes, and embracing Common Law, Chan. cery, Bankruptcy, Criminal Law, Probate and Divorce, and Convey. ancing. By FREDERICK WILLIAM HEAD, of the Inuer Temple, Student-at-Law. Demy 8vo. $1877 . \quad \mathrm{Net}, 1 s .6 d$.

SUMMARY CONVICTIONS.-Paley's Law and Practice of Surnmary Convictions under the Summary Jurisdiction Acts, 1848 and 1879 ; including Proceedings preliminary and subsequent to Convictions, and the responsibility of convicting Magistrates and their Officers, with Forms. Sixth Edition. By W. H. MACNAMARA, Esq., Barrister-at-Law. Demy 8vo. 1879.

"We gladly welcome this good edition of a good book."- Solicitors' Journal.

Templer's Summary Jurisdiction Act, 1879.Rules and Schedules of Forms. With Notes. By FREDERIC GORDON TEMPLER, of the Inner Templer, Esc., Barrister-atLaw. Demy Svo. 1880.

"We think this edition everything that could be desired."-Sheffield Post, Feb. 7, Is80.

Wigram.-1 Vide ".Justice of the Peace."

SUMMONSES AND ORDERS.-A rehibald.-Vide "Judges' Cham. bers Practice."

TORTS.-Addison on Wrongs and their Remedies.Being a Treatise on the Law of Torts. Ey C. G. ADDISON, Esq., Author of "The Law of Contracts." Fifth Edition. Re-written. By L. W. CAVE, Esq., M.A., one of Her Majesty's Counsel, Riccorder of Lincoln. Royal 8vo. $1879 . \quad 1 \%$ 18s.

"Since the last edition of this work was published, by the operation of the Judicature Acts, great changes have heen effected in practice and pleading. . . In 1he present edition the mature of the right infringed has been taken is the bisis of the arramgenent throughont. . . . Every effort has locen made, while assimiliting this edition in form to the compranion treatise on Contrects, to maintain the repulittiun which the work has already acquired." - Listrect from Prifece.

"As new presented, this va'uable treatise must prove highly acetplable to judges and

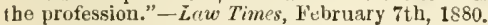

"Cave'B 'Addison on Torts' will be recognized as an indispensable addition to every lawyer's library." - Lew Ilenguzine and Review, February, 1880.

TRADE MARKS - Rules under the Trade Marks' Registration Act, 1875 (by Authority). Sewed. Net, 1s.

Sebastian on the Lav of Trade Marks.-The Law of Trade MIarks and their Registration, and matters connected there. with, including a chapter on Goodwill. 'Together with Appendices containing Precelents of Injunctions, \&c.; The Trade Marks Regis. tration Acts, 1875-7, the Rules and Instructions thereunder; The Merchandise Marks Act. 1862, and other Statutory enactments; and The United States Statute, 1870 and 1875 , and the Treaty with the United States, 1877 ; and the New Rules and Instructions issued in February, 1S78. With a copious Index. By IEWIS BOYD SLBASTIAN, P.C.L., M.A., of Lincoln's Inn, Esq., Barrister-at-Law. 8vo. 1878.

$14 s$.

"The book eanuot fail to be of service to a large class of lawyers."-Solicitors' fournal.

"Mr. Sebistian has written the fullest and most methodieal book on trade marks whieh Las appeared in England sinee the passing of the Trade Marks liegistration Acts."-Tiade Murks.

"Viewed as a eempilation, the book leaves little to be desired. Viewerl as a treatise on a suhject of growing imp rtance, it a s s strikes us as being well, aud at any rate carefully executed."-Law Journal.

"Mr. Sebristian's book is a earetul statement of the law,"-Law Times.

* All Standard Law Works are kept in Stoch, in law calf ard other bindings. 
TRADE MARKS.-Continuel.

Sebastian's Digest of Cases of Trade Mark, Trade Name, Trade Secret, Goodwill, \&c., decided in the Courts of the United Kingdom, India, the Colonies, and the United States of America. By ILWIS BOYD SEBASTIAN, 13.C.I., M.L., of Lincoln's Inn, Lsq., Barrister-at-Law, Author of "The Law of Tracle Marks." Demy Svo. $1879 . \quad 1 l .1 s$. "A digest which will be of very grent value to all practitioners who have to advise (wil matters connected with trade nilurks." - Solucitor's' Journal, Jnly 26, 1879.

Trade Marks' Journal.-4to. Sewed. (Issued fortnightly.) Nos. 1 to 1 Sti are nove ready. N'et, cach 1 s.

Index to Vol. I. (Nos. 1-47.)

Ditto, "Vol. II. (Nos, 48-97.) Net, 3 s.

Ditto, "Vol. III. (Nos. 98-123.)

Ditto, ", Vol. IV. (Nos. 124-141.) Net, $3 s$. $N e t, 3 s$. Net, $3 s$.

Wood's Law of Trade Marks.-Containing the Mer. chandise Marks' Act, 1862, and the Trade Marks' Registration Act, 1875 ; with the Rules thereunder, and Practical Directions for obtaining Registration; with Notes, full Table of Cases and Index. By J. BIGLAND WOOD, Esq., Barrister-at-Law. 12mo, 1876. $5 s$.

TRAMWAYS.-Palmer.-Vide " Conveyancing."

Sutton's Tramway Acts.-The Tramway Acts of the United Kingdom, with Notes on the Law and Practice, and an Appendix containing the Standing Orders of Parliament, Rules of the Board of Trade relating to Tramways, and Decisions of the Referees with respect to Locus Standi. By HENRY SUTTON, B.A., of Lincoln's Inn, Barrister-at-Law. Post 8vo. 1874. $12 s$.

TRUSTS AND TRUSTEES_-Godefroi's Digest of the Principles of the Law of Trusts and Trustees. - By HENRY GODEFROI, of Lincoln's Inn, Esq., Barrister-at-Law. Joint Author of "Godefroi and Shortt's Law of Railway Companies." Demy 8vo. $1879 . \quad 1 l .1$ s. "No one who refers to this book for information on a question within its range is, we think, likcly to go away" unsatisfied."-Saturlay Riview, September 6, 1870.

"ls a work of great utility to the practitioner."-Law Nagazine.

"As a digest of the law, Mr. Godefroi's work inerits commendation, for the author"s statenents are bricf and clear, and for his statements he refers to a goodly array of authoritics. In the table of cases the referenees to the several contemporaneous reports are given, and there is a very copious index to subjects."-Law Joumul.

USES.-Jones (W. Hanbury) on Uses.-8vo. 1862. 7s. VENDORS AND PURCHASERS,-Dart's Vendors and Purchasers.-A Treatise on the Law and Practice relating to Ven. dors and Purchasers of Real Estate. By J. HENRY DART, of Lincoln's Inn, Esq.. one of the Six Conveyancing Counsel of the High Court of Justice, Chancery Division. Fifth Edition. By the AUTHOR and IVILTIAM BARBER, of Lincoln's Inn, Esq., Barrister-at-Law. 2 vols. Royal 8vo. $1876 . \quad 3 l .13 s .6 d$. "A standard work like Nr. Dart's is beyond all praise."-The Law Journal.

WATERS.-W Wolrych on the Lav of Waters.-Including Rights in the Sen, Rivers, Canals, \&c. Second Edition. 8vo. 1851. Goddard.-Vide" Easements." Net, $10 s$.

WATERWORKS.-Palmer.-Vide "Conveyancing."

WILLS.-Ravilinson's Guide to Solicitors on taking Instructions for Wills.-8vo. 1874. 
WILLS.-Continued.

Theobald's Concise Treatise on the Construction of Wills.- With Table of Cases and Full Index. By

H. S. THEOBALD, of the Inner Temple, Esq., Barrister-at-Law, and Fellow of Wadham College, Oxford. 8vo. $1876 . \quad 1 l$.

"MIr. Theobald has certainly given evidence of extensive investigation, conscientious labour, and clear exposition."- Law Mlagazine.

"We desire to record our decided impression, after a somewhat careful examination, that this is a book of great ability and value. It bears on every page traces of care and sound jndgment. It is certain to prove of great practical usefulness, for it supplies a want which was be ginning to be distinctly felt."-Solicitor's' Journal.

"His arrangement being good, and his statement ot the effect of the decisions being clear, his work cannot fail to be of practical utility, and as such we can commend it to the attention of the profession." - Law Times.

"It is remarkably well arranged, and its contcnts embrace all the principal beads on the subject." - Law Journal.

WRONGS.-Vide "Torts."

EEFPOETS.-A large stodi new and second-hand. Estimates on application.

BINDING.-Executed in the best manner at moderate prices and with dispatch.

\section{The Law Reports, Law Journal, and all other Reports, bound to Office Patterns, at Office Prices.}

PRIVATE ACTS.-The Publishers of this Catalogue possess the largest known collection of Private Acts of Parliament (including Public and Local), and can supply single copies commencing from a very early period.

VAIUATIOINS.-Foi Probate, Partnership, or other purposes.

\section{STEVENS AND SONS,}

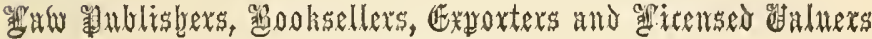

119, CHANCERY LANE, LONDON, W.C. 


\section{NEW WORKS AND NEW EDITIONS.}

\section{INT PREPARATION.}

Archibald's Handjook of the Practice in the Com. mon Lav Divisions of the High Count of Justice; with Forms for the use of Conntry Solicitors. By IV.F.A. Archibald, Esq., Barrister-at-Law, Author of "Forms of Summonses and Orders, with Notes for use at Judges' C'bambers, \&c.

Baker's Law of Highways. By Thomes Buker, of the Inner Temple, Esq., Barrister-at-Law

(In the press.)

Ball's Principles of Torts and Contracts.-A short Digest of the ('ommon Law, chiefly founded upon the works of Addison, with Illustrative Cases, for the use of Students. By IV. Eclmund Ball, LI.B., late "Ilolt Scholar" of Gray's Inn, Barrister-atLaw and Midland ('ircuit.

(In the press.)

Browne and Theobald's Law of Railways. By .J. II. Balfou Broune, of the Middle Temple, Esq., Barrister-at-Law, Registrar to the Railway Commissioners, and $I I$. S. Theobuld, of the Inner Temple, Isq., Barrister-at-Law.

Bullen and Leake's Precedents of Pleading. Fourth Edition. By T.J. Bullen, Esq., Speeial Pleader, and Cyril Dodd, of the Inner Temple, Esq, Barrister-at-Law.

(In the press.)

Daniell's Chancery Practice.--Sixth Edition,-By L. Ficld and E.C. Dunn, Esqrs., Barristers-at-Law. Assisted by W. II. Upjohn, Esq., Student and Holt Seholar of Gray's Inn, \&c., Editor of the 'Third Edition of "Daniell's Forms."

Marsden on Maritime Collision.-A Treatise on the Law relating to Collisions between Ships, C'ompulsory Pilotage, and the Rule of the Rioad at Sea. With a Summary of English and American Decisions thereon, references to Foreign Law, and an Appendix contaiming the International Tiegulations (of I863 and 1880) for preventing Collisions at Sea; the Thames, Mersey, and otber Local Rules of Narigation; and Extracts from the Merchant Shipping Acts. By Reginald G. Marselen, Esq., Barrister-at-Law.

(In the press.)

Pitt- Lewis' County Court Practice. - A complete Practice of the County Courts, including Admiralty and Bankruptcy, embodying the Act, Rules, Forms, and Costs, with 'Table of Cases and full Index. By G. Pitt-Lewis, of the Middle Temple and Western Circuit, Esq., Barrister-at-Law, sometime Holder of the Studentships of the Four Inns of Court, assisted by II. A. de Colyar, of the Niddle Temple, Esq., Barrister-at-Law, Anthor of "A Treatise on the Law of Guarantees."

(Nearly ready.)

Prentice's Proceedings in an Action in the Queen's Bench, Common Pleas, and Exchequer Divisions of the High Court of Justice. Second Edition. By Sumucl Prentice, Esq., one of Her Majesty's Counsel.

(In the press.)

Shirley's Leading Cases in Common Law made Easy. By W. Shirley Shirley, M.A., Esq., Barrister-at-Iaw, North Eastern ('irenit.

(In the press.)

Smith's Treatise on the Law of Negligence. liy IIorece Smith, of the Inner 'Temple, Esq., Barrister-at-Law, Author of "The I aw of I andlord and 'Tenant," Editor of Reseoe's "Criminal Evirlence."

(Nearly ready.)

Stone's Practice for Justices of the Peace, Justices' Clenks, and Solicitors at Petty ana Special Sessions, \&c. Ninth Edition. By $F$. $G$. Templer, of the Immer Temple, Jscl., Barrister-at-I aw, Editor of "The Summary Jurisdiction Act, 1879.'

STLVENS AND SONS, 119, (IHANCJIIY JANE, LONUON, WY (: 

Bedford's Guide to Stephen's New Commentaries on the

Laws of England. By QUESTJON AND ANSWER. 8vo. 1879. Price 12s. cloth. "Here is a book which will be of the greatest service to students."-Law Journal.

Bedford's Final Examination Digest._Containing a Digest of the Final Examination Questions in matters of Law and Procedure determined by the Chancery, Queen's Bench, Common Pleas, and Exchequer Divisions of the High Court of Justice; and on the Law of Real and Personal Property; and the Practice of Conreyancing. By EDWARD HENSLOWE BEDFORD, Solicitor. Anthor of "The Guide to Stephen's Commentaries," \&c. 82\%. 1879. Price 16s. cloth.

Haynes' Student's Leading Cases.-Being some of the Principal Decisions of the Courts in Constitutional Law, Common Law, Conveyancing and Equity, Probate and Divorce, Bankruptcy, and Criminal Law. With Notes for the use of Students. By JOHN F. HAYNES, LL.D. Demy 8vo. 1878. Price 16s. cloth.

"Will prove of great utility, not only to Students, but Practitioners. The Notes are clear, pointed and concise."-Law Times.

Foulkes' Elementary View of the Proceedings in an Action in the Supreme Court.-Founded on "Suitr's Action AT Law." By" W. 1. I. FOULKES, Esq. Second Edition. 12mo. 1879. Price 10s. 6d. cloth.

Greenwood's Manual of Conveyancing.-A Manual of the

Practice of Conveyaucing, showing the present Practice relating to the daily routine of Conreyancing in Solicitors' Offices. 'To which are added Concise Common Forms and Precedents in Conveyancing, Conditions of Sale, Conveyances, and all other Assurances in constant use. Fifth Edition. By H. N. CAPEL, B.A., LL.B., Solicitor. Demy 8\% 1877 . Price 15s. cloth.

"The information nnder these heads is just of that ordinary practical kind which is learned from experience, and is not to be gathered from treatises. A careful study of these pages would probably arm a diligent clerk with as much useful knowledue as he might otherwise take year of desultory questioning and observing to acquire. '- Soticitor's' Joumal.

Smith's Real and Personal Property.-A Compendium of the Law of Real and Personal Property, primarily connected with Conveyancing. Designed as a second book for Students, and as a digest of the most useful learning for Practitioners. By JOSIAH W. SMITH, B.C.L., Q.C. Fifth Edition. 2 vols. Demy 8vo. 1877. Price 2l. 2s. cloth.

"He has given to the student a book which he maj read over and over again with profit and

Greenwood's Recent Real Property Statutes.-Comprising those passed during the years 1874-1877 inclusive. Consolidated with the Earlier Statutes thereby Amended, and a Supplement containing the Orders under the Settled Estates Act, 1878. With Copious Notes. By HARRY GREENWOOD, M.A., of Lincoln's Inn, Esq., Barrister-at-Law. Demy 8vo. 1878. Price 10s. cloth.

"To Students particularly this collection, with the careful notes and references to previous Legislation, will be of considerable value. . . The cases are fully noted up, and the Index has

Pollock's Principles of Contract at Law and in Equity.-

Being a Treatise on the General Principles concerning the Validity of Agreements, with a special view to the comparison of Law and Equity; and with references to the Indian Contract Act, and occasionally to Roman, American, and Contineutal Law. Second Edition. By FREīERICK POLLOCK, of Lincoln's Inn, Esq., Barrister-atLaw. Demy 8vo. 1878. Price 1l.6s. cloth.

Wharton's Law Lexicon, or Dictionary of Jurisprudence, Explaining the Technical Words and Phrases employed in the several Departments of Lnglish Law; including the various Legal Terms used in Commercial Business; with an Explanatory as well as Literal translation of the Latin Maxims contained in the Writings of the Ancient and Modern Commentators. Sieth Edition. Revised in accordance with the Judicature Acts, by J. SHIRESS WILL, of the Middle Temple, Esy., Barrister-at-Law. Super-royal 8vo. 1876. Price $2 l$.2s. cloth.

" $\Delta \mathrm{s}$ a work of reference for the library, the handsoin" and elahorate edition of "Wharton's Law Lexicon' which $\$ \mathrm{r}$. Shiress Will has produced, must superselte all sormer issues of that wellknown wrik."-Lar Magazine and Reviear.

Wheaton's Elements of International Law. - Second English Edition. Edited with Notes and Appendix of Statutes and Treaties, bringing the work down to the present time. $13 \mathrm{y} \mathrm{A.C.} \mathrm{BOYD,} \mathrm{Esq.,} \mathrm{LL.B.,} \mathrm{J.P.,} \mathrm{Barrister-}$ at-Law. Author of "The Nerchant Shipping Laws." Demy 8vo. 18s0. Price 1l. I0s. cloth.

"lioth the plin and exceution of the work before us deservcs commendation. The text of Wheaton is Iresented without alteration." - Law Journal

* All Standard Law Works are kept in Stock, in law calf and other bindings. 
Churchill's Law of the Office and Duties of the Sheriff, with the Writs and Forms relating to the Ofice. By CAMERON CHURCHILL, of the Inner Temple, assisted by A. CARMICHAEL BRUCE, of Lincoln's Inn, Esqrs., Barristers-at-Law. Demy Svo. 1879. Price 18s, cloth.

"This is a work upon a subject of large practical importance, and seems to have been compiled with exceptional care. . . The effect of the decisisns and the keneral law are accurately and cuncisely stisted. There is an appendix of forms which will be found useful."-Law Times.

Dicey's Law of Domicil as a Branch of the Law of England. -Stated in the Form of Rules. By A. V. DICEY, B.C.L., Barrister-at-Law, and formerly Fellow of Trinity College, Oxford, one of the Junior Counsel to the Inland Revenue. Author of "Rules for the Selections of Parties to an Action." Demy 8vo. 1879. Price 18s. cloth.

"The practitioner will find the book a thoroughly exact and trustworthy summary of the present state of the Law,"-The Spectator.

Chitty on Bills of Exchange and Promissory Notes, with references to the Law of Scotland, France and America. Eleventh Elition. By JOHN A. RUSSELL, Esq., LL.B., one of Her Majesty's Counsel and a Judge of County Courts. Demy 8vo. 1878. Price 28s. cloth.

Archbold's Pleading and Evidence in Criminal Cases.With the Statutes, Precedents of Indictments, Sc., and the Evidence necessary to support them. Nineteenth Edition, including the Practice in Criminal Proceedings by Indictment. By WILLIADI BRUCE, Esq., Barrister-at-Law, and Stipendiary Magistrate for the Borough of Leeds. Royal 12mo. 1878. Price 1l. 11s. 6d. cloth.

Sebastian's Digest of Cases of Trade Irark, Trade Name, Trade Secret, Goodwill, \&c., decided in the Courts of th United Kingdom, India, the Colonies, and the United States of America. By LEWIS BOYD SEBASTIAN, B.C.I., M.A., of Lincoln's Inn, Esq., Barrister-at-Law, Author of "The Law of Trade Marks." Demy 8vo. 1879. Price 1l. 1s. cloth.

"A digest which will be of very great value to all practitioners who have to advise on matters connected with trade marks."-Solicutor's'Journal.

Roscoe's Digest of the Law of Evidence in Criminal Cases. -Ninth Edition. By HORACE SMITH, of the Inner Temple, Esq., Barrister-atLaw. Royal 12mo. 1878. Price 1l.11s.6d. cloth.

Goddard's Treatise on the Law of Easements.-Second Edition. By JOHN LEYBOURN GODDARD, of the Midule Temple, Esq., Bar. rister-at-Law. Demy 8i'o. 1877. Price 16s. cloth.

"Nowhere has the subject been treated so exhaustively, and wo may add, so scientifically, as by Mr. Goddard. We recommend it to the most careful study of the law studeut, as well as to the library of the Practitioner."-Law Times.

\section{Pollock's Digest of the Law of Partnership.-By}

FREDERICK POLLOCK, of Lincoln's Inn, Esq., Barrister-at-Law. Anthor of "Principles of Contract at Law and in Equity." Demy 8vo. 1877. Price 8s. 6d. cloth.

"Mr. Pollock's work appears eminently satisfactory . . the book is praiseworthy in design, scholarly and complete in execution."-Saturilay Reviero.

Roscoe's Admiralty Practice.-A Treatise on the Jurisdiction and Practice of the Admiralty Division of the High Court of Justice, and on Appeals therefrom, \&c. With an Appendix containing Statutes, Rules as to Fees and Costs, Forms, Precedents of Pleadings and Bills of Costs. By E. S. ROSCOE, Esq.,

Barrister-at-Law, and Northern Circuit. Demy Svo. 1878. Price 1l. cloth.

"Mr. Roscoe has performed his task well, supplying in the most convenient shape a clear digest of the law aud practice of the Adniralty Courts." - Liverpool Courier.

Smith's Mercantile Law.-A Compendium of Mercantile Law. By the late JOHN WILLIAM SMITH, Esq. Ninth Edition. By G. M. DOWDESWELL, of the Inner Temple, Esq., one of Her Majesty's Counsel. Royal 8vo. 1877. Price 1l. 18s. cloth.

Russell's Treatise on the Duty and Power of an Arbitrator, and the Law of Submissions and Awards; with an Appendix of Forms and of the Statutes relating to Arbitration. By FRANCIS RUSSELL, Esq., Barrister at-Law. Fifth Edition. Royal 8vo. 1878. Price 1l. 16s. cloth. 
